\title{
SELECTED HYDROLOGIC DATA FOR URBAN WATERSHEDS IN SOUTH CAROLINA, 1983-90
}

By Sarah W. Logan, Michael R. Eckenwiler, and Larry R. Bohman

U.S. GEOLOGICAL SURVEY

Open-File Report 95-351

Prepared in cooperation with the SOUTH CAROLINA DEPARTMENT OF TRANSPORTATION 


\section{U.S. DEPARTMENT OF THE INTERIOR \\ BRUCE BABBITT, Secretary}

U.S. GEOLOGICAL SURVEY

Gordon P. Eaton, Director

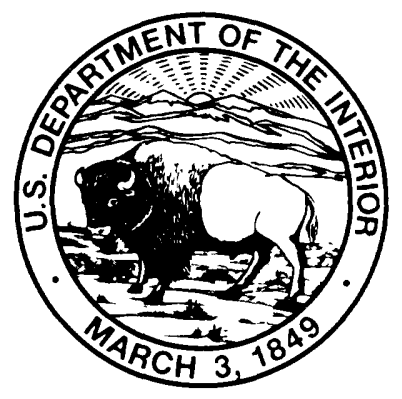

For additional information write to:

Copies of this report can be purchased from:

District Chief

U.S. Geological Survey

Stephenson Center- Suite 129

720 Gracern Road

Columbia, SC 29210-7651

U.S. Geological Survey

Earth Science Information Center

Open-File Reports Section

Box 25286, Mail Stop 517

Denver Federal Center

Denver, CO 80225 


\section{CONTENTS}

Page

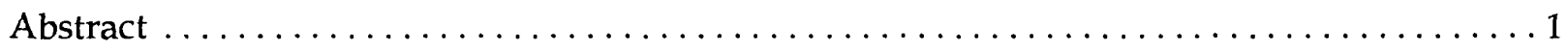

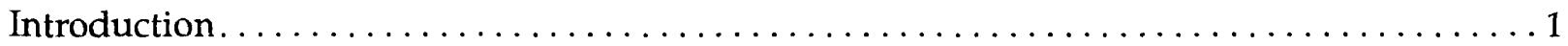

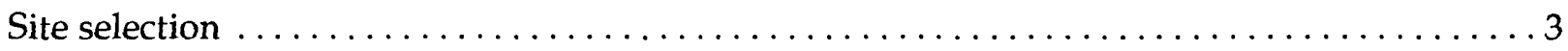

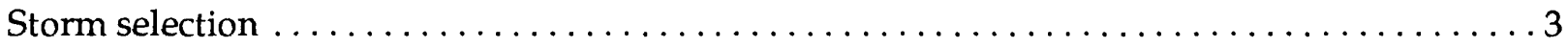

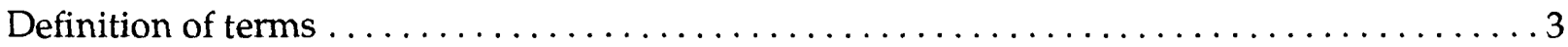

Instrumentation and hydrologic data collection $\ldots \ldots \ldots \ldots \ldots \ldots \ldots \ldots \ldots \ldots \ldots \ldots \ldots \ldots \ldots \ldots$

Station descriptions, hydrographs, and tabulated rainfall and streamflow data $\ldots \ldots \ldots 6$

References ......................................... 434 


\section{ILLUSTRATIONS}

Page

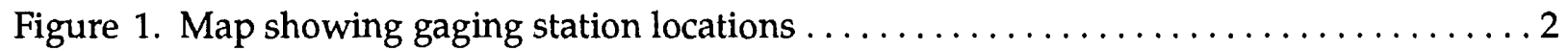

2.-162. Graphs showing streamflow and rainfall at stations:

2. 02110740, Midway Swash at Myrtle Beach, April 15-16, 1987 . . . . . . . . . 8

3. 02110740, Midway Swash at Myrtle Beach, June 24-25, 1987. . . . . . . . . 11

4. 02110740, Midway Swash at Myrtle Beach, August 24-25, 1988 . . . . . . . 13

5. 02110740, Midway Swash at Myrtle Beach, August 1-2, 1989 . . . . . . . . . 16

6. 02110740, Midway Swash at Myrtle Beach, September 16-17, 1989 . . . . . . . 19

7. 02110740, Midway Swash at Myrtle Beach, September 25-26, 1989 . . . . . . . . 21

8. 02110740, Midway Swash at Myrtle Beach, August 9, 1990............ 24

9. 02131130, Gully Branch at Florence, August 25-26, $1985 \ldots \ldots \ldots \ldots \ldots \ldots 27$

10. 02131130, Gully Branch at Florence, October 9, $1986 \ldots \ldots \ldots \ldots \ldots \ldots . \ldots 29$

11. 02131130, Gully Branch at Florence, August 1-2, $1987 \ldots \ldots \ldots \ldots \ldots \ldots$

12. 02131130, Gully Branch at Florence, August 29-30, 1987 . . . . . . . . . . 34

13. 02131130, Gully Branch at Florence, August 24-25, $1988 \ldots \ldots \ldots \ldots \ldots$

14. 02131130, Gully Branch at Florence, September 25-26, 1988 . . . . . . . . 38

15. 02131130, Gully Branch at Florence, July 19-20, $1989 \ldots \ldots \ldots \ldots \ldots \ldots \ldots$

16. 02135518, Turkey Creek at Sumter, August 28-29, $1988 \ldots \ldots \ldots \ldots \ldots \ldots \ldots 4$

17. 02135518, Turkey Creek at Sumter, June 15-16, 1989 . . . . . . . . . . . 47

18. 02135518, Turkey Creek at Sumter, June 30, 1989 . . . . . . . . . . . . . . 49

19. 02135518, Turkey Creek at Sumter, July 30-31, $1989 \ldots \ldots \ldots \ldots \ldots \ldots \ldots$

20. 02135518, Turkey Creek at Sumter, September $2-3,1989 \ldots \ldots \ldots \ldots$. . . . . . 54

21. 02135518, Turkey Creek at Sumter, September $21-22,1989 \ldots \ldots \ldots \ldots$. . . . . 56

22. 02135518, Turkey Creek at Sumter, September 13-14, 1990 . . . . . . . . . . . 59

23. 02145940, Little Dutchman Creek tributary at Rock Hill,

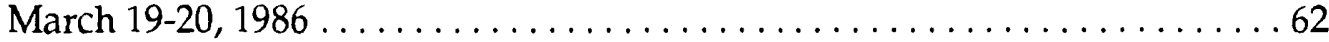

24. 02145940, Little Dutchman Creek tributary at Rock Hill, March 30, 1987 . . . . 65 25. 02145940, Little Dutchman Creek tributary at Rock Hill,

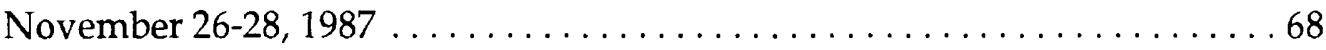




\section{ILLUSTRATIONS--Continued}

Figure 26. 02145940, Little Dutchman Creek tributary at Rock Hill,

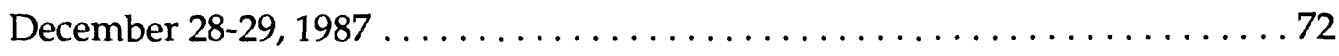

27. 02145940, Little Dutchman Creek tributary at Rock Hill,

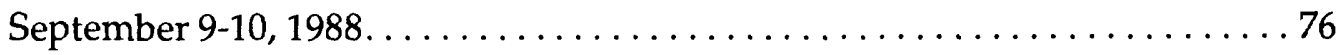

28. 02145940, Little Dutchman Creek tributary at Rock Hill,

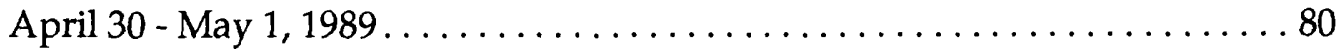

29. 02145940, Little Dutchman Creek tributary at Rock Hill,

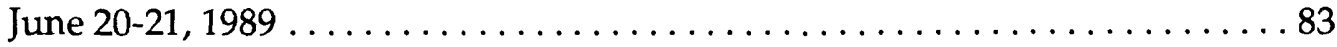

30. 02146100, Manchester Creek tributary at Rock Hill, July 8-9, 1988. . . . . . . 87

31. 02146100, Manchester Creek tributary at Rock Hill,

April 30 - May $1,1989 \ldots \ldots \ldots \ldots \ldots \ldots \ldots \ldots \ldots . \ldots \ldots$

32. 02146100, Manchester Creek tributary at Rock Hill, May 9-10, 1989 . . . . . 92

33. 02146100, Manchester Creek tributary at Rock Hill, June 16-17, 1989 . . . . . . 96

34. 02146100, Manchester Creek tributary at Rock Hill, June 20-21, 1989 . . . . . . 98

35. 02146100, Manchester Creek tributary at Rock Hill, September 26, 1989 . . . 101

36. 02146100, Manchester Creek tributary at Rock Hill,

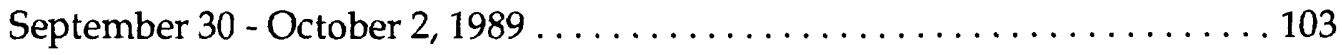

37. 02156250, Chinquapin Creek tributary at Spartanburg,

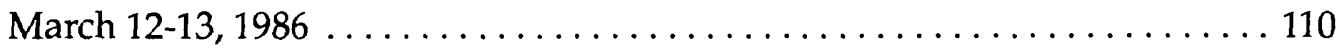

38. 02156250, Chinquapin Creek tributary at Spartanburg, May 16, 1986 . . . . . 112

39. 02156250, Chinquapin Creek tributary at Spartanburg, August 2, 1986 . . . . 114

40. 02156250, Chinquapin Creek tributary at Spartanburg, August 13, 1986 . . . 116

41. 02156250, Chinquapin Creek tributary at Spartanburg,

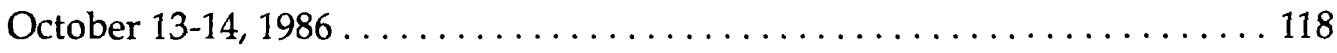

42. 02156250, Chinquapin Creek tributary at Spartanburg,

October 25-26, 1986 .

43. 02156250, Chinquapin Creek tributary at Spartanburg,

November $7,1986 \ldots \ldots \ldots \ldots \ldots \ldots \ldots \ldots \ldots \ldots \ldots \ldots \ldots \ldots \ldots \ldots$

44. 02159785, Fairforest Creek tributary at Spartanburg, June 18-19, $1987 \ldots \ldots .127$ 


\section{ILLUSTRATIONS--Continued}

Figure 45. 02159785, Fairforest Creek tributary at Spartanburg, September 4, 1988. . . . 129

46. 02159785, Fairforest Creek tributary at Spartanburg,

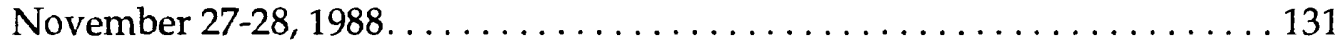

47. 02159785, Fairforest Creek tributary at Spartanburg, June 20-21, $1989 \ldots \ldots 133$

48. 02159785, Fairforest Creek tributary at Spartanburg, February 16, 1990 . . . 135

49. 02159785, Fairforest Creek tributary at Spartanburg, March 17, 1990 . . . . . 137

50. 02159785, Fairforest Creek tributary at Spartanburg, October 12-13, 1990 . . . 139

51. 02160325, Brushy Creek (Enoree River tributary) near Greenville,

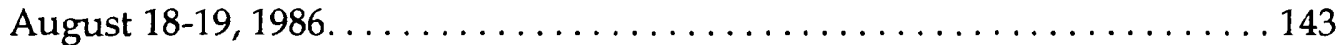

52. 02160325, Brushy Creek (Enoree River tributary) near Greenville,

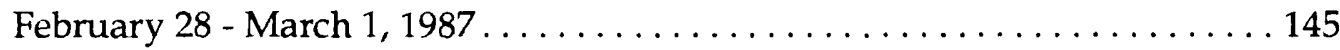

53. 02160325, Brushy Creek (Enoree River tributary) near Greenville,

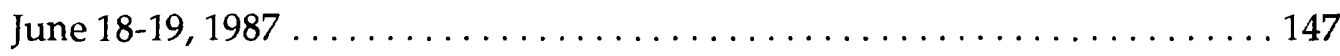

54. 02160325, Brushy Creek (Enoree River tributary) near Greenville,

September 11,1987 . . . . . . . . . . . . . . . . . . . . . . . . 149

55. 02160325, Brushy Creek (Enoree River tributary) near Greenville,

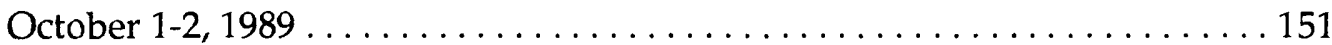

56. 02160325, Brushy Creek (Enoree River tributary) near Greenville,

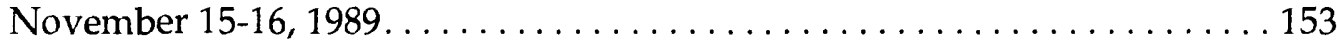

57. 02160325, Brushy Creek (Enoree River tributary) near Greenville,

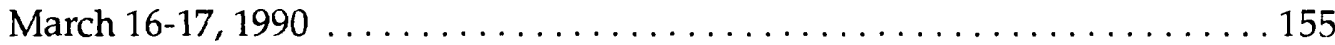

58. 02162093, Smith Branch at Columbia, August 19-20, 1984 . . . . . . . . 158

59. 02162093, Smith Branch at Columbia, July 25-26, 1986 . . . . . . . . . . 160

60. 02162093, Smith Branch at Columbia, August 19-21, 1986. . . . . . . . . . 162

61. 02162093, Smith Branch at Columbia, August 28-29, 1988 . . . . . . . . . . 164

62. 02162093, Smith Branch at Columbia, June 8-10, $1989 \ldots \ldots \ldots \ldots \ldots \ldots \ldots$

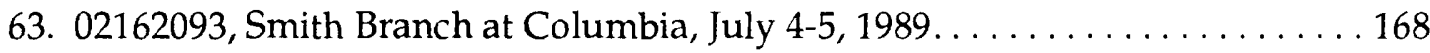

64. 02162093, Smith Branch at Columbia, September 21-23, 1989 . . . . . . . . . 170

65. 02163940, Richland Creek tributary at Greenville, March 19, 1986 . . . . . . 173 


\section{ILLUSTRATIONS--Continued}

Page

Figure $\quad 66.02163940$, Richland Creek tributary at Greenville, July 23, 1986 . . . . . . 175

67. 02163940, Richland Creek tributary at Greenville, July 27, 1986 . . . . . . . 177

68. 02163940, Richland Creek tributary at Greenville, August 18, 1986 . . . . . 179

69. 02163940, Richland Creek tributary at Greenville, May 29, $1987 \ldots \ldots \ldots \ldots 1 \varepsilon 1$

70. 02163940, Richland Creek tributary at Greenville, July 30-31, $1987 \ldots \ldots \ldots 1 \& 3$

71. 02163940, Richland Creek tributary at Greenville, August 16, 1989 . . . . . 185

72. 02164011, Brushy Creek (Reedy River tributary) at Greenville,

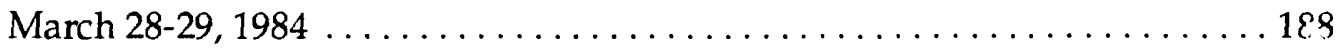

73. 02164011, Brushy Creek (Reedy River tributary) at Greenville,

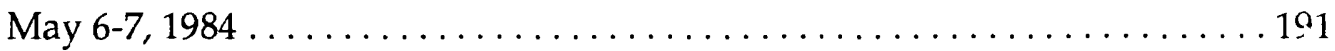

74. 02164011, Brushy Creek (Reedy River tributary) at Greenville,

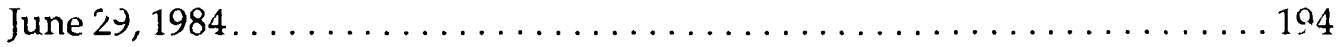

75. 02164011, Brushy Creek (Reedy River tributary) at Greenville,

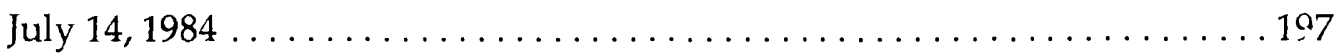

76. 02164011, Brushy Creek (Reedy River tributary) at Greenville,

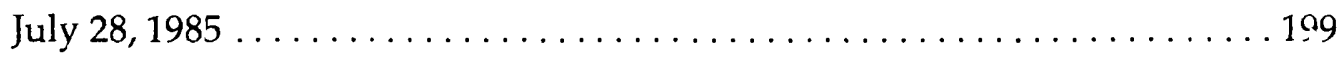

77. 02164011, Brushy Creek (Reedy River tributary) at Greenville,

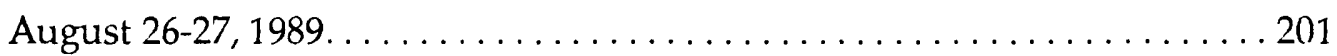

78. 02164011, Brushy Creek (Reedy River tributary) at Greenville,

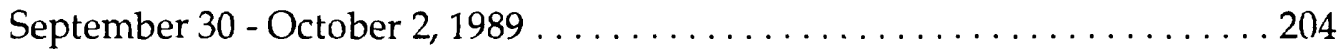

79. 02166975, Sample Branch at Greenwood, August 18, $1986 \ldots \ldots \ldots \ldots$. . . 2:0

80. 02166975, Sample Branch at Greenwood, January 20, $1988 \ldots \ldots \ldots \ldots \ldots$. . . 2

81. 02166975, Sample Branch at Greenwood, July 20, $1989 \ldots \ldots \ldots \ldots \ldots \ldots$

82. 02166975, Sample Branch at Greenwood, July 31 - August 1, 1989. . . . . . . 2:6

83. 02166975, Sample Branch at Greenwood, February 16-17, $1990 \ldots \ldots \ldots$. . . 2: 8

84. 02166975, Sample Branch at Greenwood, February 18-19, 1990 . . . . . . . . 221

85. 02166975, Sample Branch at Greenwood, May 28-29, 1990 . . . . . . . . . 224

86. 02167020, Crane Creek tributary at Columbia, March 13-14, 1986 . . . . . . 227

87. 02167020, Crane Creek tributary at Columbia, July 25-26, 1986 . . . . . . . . 229 


\section{ILLUSTRATIONS--Continued}

Page

Figure $\quad 88.02167020$, Crane Creek tributary at Columbia, May 4, $1987 \ldots \ldots \ldots \ldots$. 31

89. 02167020, Crane Creek tributary at Columbia, June $4,1987 \ldots \ldots \ldots \ldots \ldots \ldots 33$

90. 02167020, Crane Creek tributary at Columbia, June $8,1988 \ldots \ldots \ldots \ldots \ldots .35$

91. 02167020, Crane Creek tributary at Columbia, June $29,1989 \ldots \ldots \ldots \ldots \ldots .37$

92. 02167020, Crane Creek tributary at Columbia, August 15, 1989 . . . . . . 240

93. 02168845, Saluda River tributary at Columbia, August $11-12,1986 \ldots \ldots \ldots .43$

94. 02168845, Saluda River tributary at Columbia, September $9-10,1987 \ldots \ldots .45$

95. 02168845, Saluda River tributary at Columbia, August 11, 1988 . . . . . . . 247

96. 02168845, Saluda River tributary at Columbia, September 25-26, 1988 . . . . ¿ ¿49

97. 02168845, Saluda River tributary at Columbia, May $1-2,1989 \ldots \ldots \ldots \ldots .51$

98. 02168845, Saluda River tributary at Columbia, July 26, 1989 . . . . . . . . . 2.54

99. 02168845, Saluda River tributary at Columbia, September $15-16,1989 \ldots \ldots 2.56$

100. 02169505, Rocky Branch at Columbia, August 30-31, 1985 . . . . . . . . . 250

101. 02169505, Rocky Branch at Columbia, July $3-4,1987 \ldots \ldots \ldots \ldots \ldots \ldots \ldots 2$

102. 02169505, Rocky Branch at Columbia, July 28, $1987 \ldots \ldots \ldots \ldots \ldots \ldots \ldots 254$

103. 02169505, Rocky Branch at Columbia, September 9-10, 1987. . . . . . . . ¿.56

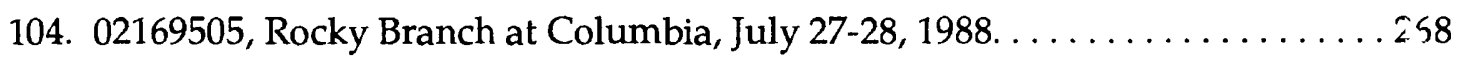

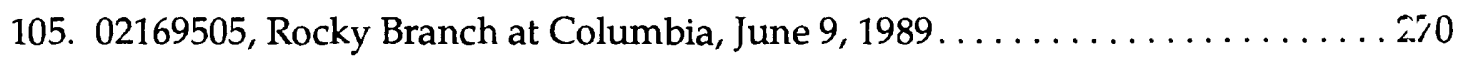

106. 02169505, Rocky Branch at Columbia, June 19-20, $1989 \ldots \ldots \ldots \ldots \ldots \ldots \ldots 2$

107. 02169568, Pen Branch at Columbia, August 11-13, 1986 . . . . . . . . . . 275

108. 02169568, Pen Branch at Columbia, August 18-19, 1986. . . . . . . . . . 2.79

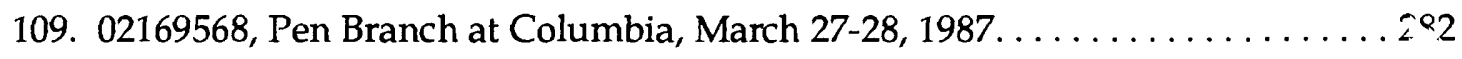

110. 02169568, Pen Branch at Columbia, July $28-29,1987 \ldots \ldots \ldots \ldots \ldots \ldots \ldots 2$

111. 02169568, Pen Branch at Columbia, July $27-28,1988 \ldots \ldots \ldots \ldots \ldots \ldots \ldots .87$

112. 02169568, Pen Branch at Columbia, June 8-9, $1989 \ldots \ldots \ldots \ldots \ldots$. . . . . . . 89

113. 02169568, Pen Branch at Columbia, September $21-23,1989 \ldots \ldots \ldots \ldots \ldots 2$

114. 0217206930, Noisette Creek at North Charleston, March 13-14, 1986 . . . . . . 297

115. 0217206930, Noisette Creek at North Charleston, September 5-6, $1986 \ldots \ldots$. . . $こ 0$

116. 0217206930, Noisette Creek at North Charleston, August 30,1987 . . . . . . . $\approx 73$ 


\section{ILLUSTRATIONS--Continued}

Page

Figure 117. 0217206930, Noisette Creek at North Charleston, September 8-9, 1988 . . . . . 305

118. 0217206930, Noisette Creek at North Charleston, June 6, 1989 . . . . . . . . . 309

119. 0217206930, Noisette Creek at North Charleston, August 30-31, 1989 ....... $\lesssim 11$

120. 0217206930, Noisette Creek at North Charleston, September 3, 1989 ....... 313

121. 02173491, Hess Branch at Orangeburg, July 12, 1987 . . . . . . . . . . . 316

122. 02173491, Hess Branch at Orangeburg, August 8-9, 1987 .............. 318

123. 02173491, Hess Branch at Orangeburg, July 22-23, 1988.............. 320

124. 02173491, Hess Branch at Orangeburg, June 22-23, 1989 . . . . . . . . . . . 322

125. 02173491, Hess Branch at Orangeburg, July 16, $1989 \ldots \ldots \ldots \ldots \ldots \ldots \ldots 324$

126. 02173491, Hess Branch at Orangeburg, July 20, $1989 \ldots \ldots \ldots \ldots \ldots \ldots . \ldots 326$

127. 02173491, Hess Branch at Orangeburg, August 15, 1989 . . . . . . . . . . 328

128. 02173495, Sunnyside Canal at Orangeburg, November 10, 1987 ......... 331

129. 02173495, Sunnyside Canal at Orangeburg, June 19, $1988 \ldots \ldots \ldots \ldots \ldots 33$

130. 02173495, Sunnyside Canal at Orangeburg, July 22, $1988 \ldots \ldots \ldots \ldots \ldots . \ldots 335$

131. 02173495, Sunnyside Canal at Orangeburg, September 9, 1988 . ......... 337

132. 02173495, Sunnyside Canal at Orangeburg, August $8,1990 \ldots \ldots \ldots \ldots . \ldots 310$

133. 02173495, Sunnyside Canal at Orangeburg, September $8,1990 \ldots \ldots \ldots \ldots 312$

134. 02173495, Sunnyside Canal at Orangeburg, October 10-11, 1990 ......... 314

135. 02174240, Middlepen Branch at Orangeburg, June 19-20, $1986 \ldots \ldots \ldots \ldots . \ldots 19$

136. 02174240, Middlepen Branch at Orangeburg, January 1, 1987 ........... 351

137. 02174240, Middlepen Branch at Orangeburg, May 4-5, 1987 ............ 354

138. 02174240, Middlepen Branch at Orangeburg, October 26-27, 1987 . . . . . . 357

139. 02174240, Middlepen Branch at Orangeburg, July 4-5, 1989 ............ 359

140. 02174240, Middlepen Branch at Orangeburg, July 8-9, 1989 ............ 362

141. 02174240, Middlepen Branch at Orangeburg, August 8-9, 1990 .......... 354

142. 02176380 , Coosawhatchie River tributary at Allendale,

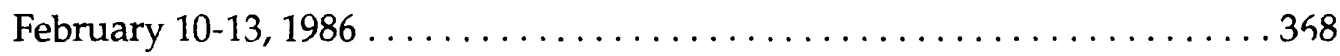

143. 02176380, Coosawhatchie River tributary at Allendale, May 12-14, 1986 . . . 374

144. 02176380, Coosawhatchie River tributary at Allendale, June 9-11, 1986 . . . . 377 


\section{ILLUSTRATIONS--Continued}

Page

Figure 145. 02176380, Coosawhatchie River tributary at Allendale, April 19, 1988 ..... 90

146. 02176380, Coosawhatchie River tributary at Allendale, August 5-6, 1988 . . . $\approx{ }^{\circ} 3$

147. 02176380, Coosawhatchie River tributary at Allendale,

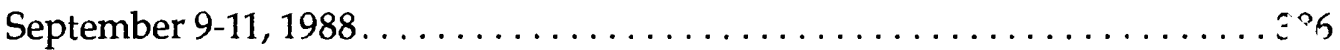

148. 02176380, Coosawhatchie River tributary at Allendale,

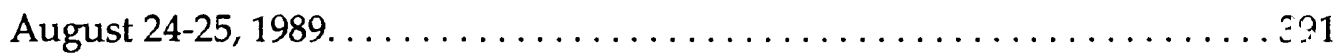

149. 02187260, Whitner Creek at Anderson, September 29, 1986. . . . . . . . . こ95

150. 02187260, Whitner Creek at Anderson, March 30, 1987 . . . . . . . . . . . . $\approx 97$

151. 02187260, Whitner Creek at Anderson, April 23, $1987 \ldots \ldots \ldots \ldots \ldots \ldots$. . . . . . .

152. 02187260, Whitner Creek at Anderson, May 4, $1987 \ldots \ldots \ldots \ldots \ldots \ldots \ldots$. . . . . . . . .

153. 02187260, Whitner Creek at Anderson, June 25-26, $1987 \ldots \ldots \ldots \ldots \ldots \ldots .444$

154. 02187260, Whitner Creek at Anderson, July 30, $1987 \ldots \ldots \ldots \ldots \ldots \ldots$. . . . . . . . .

155. 02187260, Whitner Creek at Anderson, August 2, $1987 \ldots \ldots \ldots \ldots \ldots \ldots$. . . . . . . .

156. 02187268, Dye Creek at Anderson, June $25-26,1987 \ldots \ldots \ldots \ldots \ldots \ldots \ldots .11$

157. 02187268, Dye Creek at Anderson, June 20-21, $1989 \ldots \ldots \ldots \ldots \ldots \ldots \ldots \ldots 414$

158. 02187268, Dye Creek at Anderson, January 20-21, $1990 \ldots \ldots \ldots \ldots \ldots \ldots .17$

159. 02187268, Dye Creek at Anderson, February $9-11,1990 \ldots \ldots \ldots \ldots \ldots \ldots 420$

160. 02187268, Dye Creek at Anderson, February 16-17, $1990 \ldots \ldots \ldots \ldots \ldots \ldots 424$

161. 02187268, Dye Creek at Anderson, March 16-17, $1990 \ldots \ldots \ldots \ldots \ldots \ldots$. . . . . 427

162. 02187268, Dye Creek at Anderson, October $11-13,1990 \ldots \ldots \ldots \ldots \ldots \ldots .430$ 


\section{TABLES}

Page

Tables showing streamflow and rainfall at stations:

1. 02110740, Midway Swash at Myrtle Beach, April 15-16, 1987............. 9

2. 02110740, Midway Swash at Myrtle Beach, June 24-25, 1987 ........... 12

3. 02110740, Midway Swash at Myrtle Beach, August 24-25, 1988 ........... 14

4. 02110740, Midway Swash at Myrtle Beach, August 1-2, 1989 ............ 17

5. 02110740, Midway Swash at Myrtle Beach, September 16-17, 1989 . . . . . . . 20

6. 02110740, Midway Swash at Myrtle Beach, September 25-26, 1989 . . . . . . 22

7. 02110740, Midway Swash at Myrtle Beach, August 9, 1990............. 25

8. 02131130 , Gully Branch at Florence, August 25-26, $1985 \ldots \ldots \ldots \ldots \ldots \ldots 28$

9. 02131130 , Gully Branch at Florence, October 9, $1986 \ldots \ldots \ldots \ldots \ldots \ldots \ldots$

10. 02131130, Gully Branch at Florence, August 1-2, $1987 \ldots \ldots \ldots \ldots \ldots \ldots . \ldots 32$

11. 02131130, Gully Branch at Florence, August 29-30, 1987 .............. 35

12. 02131130, Gully Branch at Florence, August 24-25, $1988 \ldots \ldots \ldots \ldots \ldots . \ldots 37$

13. 02131130, Gully Branch at Florence, September 25-26, 1988 . . . . . . . . . 39

14. 02131130, Gully Branch at Florence, July 19-20, $1989 \ldots \ldots \ldots \ldots \ldots \ldots \ldots 42$

15. 02135518, Turkey Creek at Sumter, August 28-29, $1988 \ldots \ldots \ldots \ldots \ldots \ldots . . \ldots 5$

16. 02135518 , Turkey Creek at Sumter, June $15-16,1989 \ldots \ldots \ldots \ldots \ldots \ldots \ldots 48$

17. 02135518, Turkey Creek at Sumter, June 30, $1989 \ldots \ldots \ldots \ldots \ldots \ldots \ldots \ldots . \ldots . \ldots$

18. 02135518, Turkey Creek at Sumter, July 30-31, $1989 \ldots \ldots \ldots \ldots \ldots \ldots \ldots . \ldots 5$

19. 02135518, Turkey Creek at Sumter, September 2-3, 1989 ............... 55

20. 02135518, Turkey Creek at Sumter, September 21-22, 1989 . . . . . . . . . . . 57

21. 02135518, Turkey Creek at Sumter, September 13-14, 1990 .............. 60

22. 02145940, Little Dutchman Creek tributary at Rock Hill,

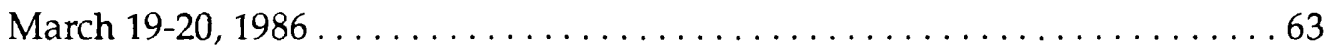

23. 02145940, Little Dutchman Creek tributary at Rock Hill,

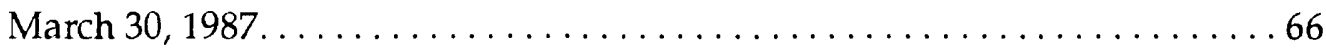

24. 02145940, Little Dutchman Creek tributary at Rock Hill,

November $26-28,1987 \ldots \ldots \ldots \ldots \ldots \ldots \ldots \ldots \ldots \ldots \ldots . \ldots \ldots$ 


\section{TABLES--Continued}

Page

25. 02145940, Little Dutchman Creek tributary at Rock Hill,

December $28-29,1987 \ldots \ldots \ldots \ldots \ldots \ldots \ldots \ldots \ldots \ldots \ldots$

26. 02145940, Little Dutchman Creek tributary at Rock Hill,

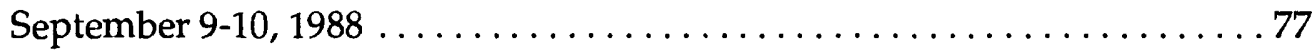

27. 02145940, Little Dutchman Creek tributary at Rock Hill,

April 30 - May 1, 1989............................ 81

28. 02145940, Little Dutchman Creek tributary at Rock Hill, June 20-21, 1989 . . 84

29. 02146100, Manchester Creek tributary at Rock Hill, July 8-9, 1988. . . . . . 88

30. 02146100, Manchester Creek tributary at Rock Hill,

April 30 - May 1, 1989......................... 90

31. 02146100, Manchester Creek tributary at Rock Hill, May 9-10, 1989 . . . . . 93

32. 02146100, Manchester Creek tributary at Rock Hill, June 16-17, 1989 . . . . . 97

33. 02146100, Manchester Creek tributary at Rock Hill, June 20-21, 1989 . . . . . . 99

34. 02146100, Manchester Creek tributary at Rock Hill, September 26, 1989 . . . 102

35. 02146100, Manchester Creek tributary at Rock Hill,

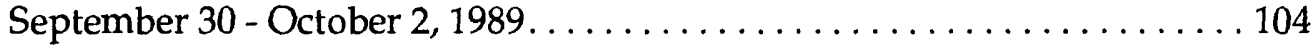

36. 02156250, Chinquapin Creek tributary at Spartanburg,

March 12-13, $1986 \ldots \ldots \ldots \ldots \ldots \ldots \ldots \ldots \ldots \ldots \ldots \ldots \ldots \ldots \ldots \ldots \ldots$

37. 02156250, Chinquapin Creek tributary at Spartanburg, May 16, 1986 . . . . 113

38. 02156250, Chinquapin Creek tributary at Spartanburg, August 2, 1986 . . . 115

39. 02156250, Chinquapin Creek tributary at Spartanburg, August 13, 1986 . . . 117

40. 02156250, Chinquapin Creek tributary at Spartanburg,

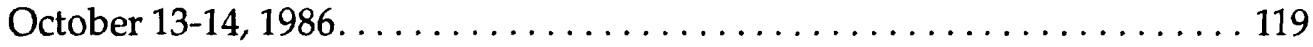

41. 02156250, Chinquapin Creek tributary at Spartanburg,

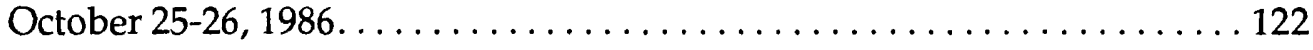

42. 02156250, Chinquapin Creek tributary at Spartanburg,

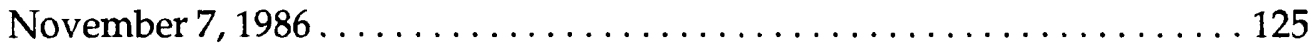

43. 02159785, Fairforest Creek tributary at Spartanburg, June 18-19, $1987 \ldots \ldots 128$

44. 02159785, Fairforest Creek tributary at Spartanburg, September 4, 1988 . . . 130 


\section{TABLES--Continued}

45. 02159785, Fairforest Creek tributary at Spartanburg,

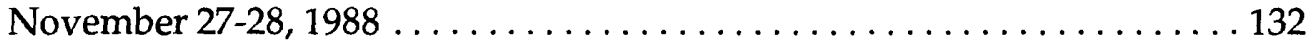

46. 02159785, Fairforest Creek tributary at Spartanburg, June 20-21, 1989 . . . . 134

47. 02159785, Fairforest Creek tributary at Spartanburg, February 16, 1990 . . . 136

48. 02159785, Fairforest Creek tributary at Spartanburg, March 17, 1990 . . . . 138

49. 02159785, Fairforest Creek tributary at Spartanburg,

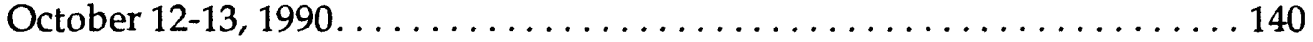

50. 02160325, Brushy Creek (Enoree River tributary) near Greenville,

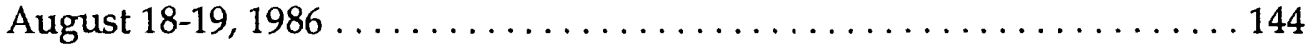

51. 02160325, Brushy Creek (Enoree River tributary) near Greenville,

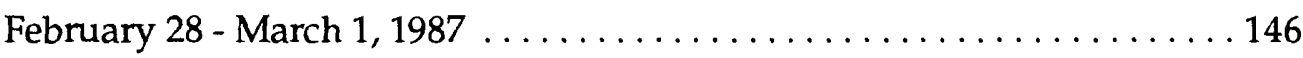

52. 02160325, Brushy Creek (Enoree River tributary) near Greenville,

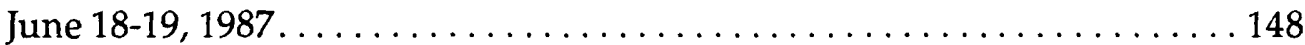

53. 02160325, Brushy Creek (Enoree River tributary) near Greenville,

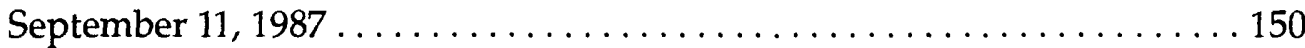

54. 02160325, Brushy Creek (Enoree River tributary) near Greenville,

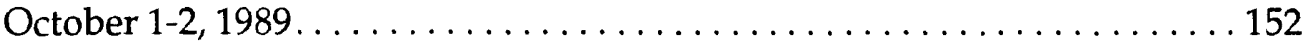

55. 02160325, Brushy Creek (Enoree River tributary) near Greenville,

November $15-16,1989 \ldots \ldots \ldots \ldots \ldots \ldots \ldots \ldots \ldots \ldots \ldots \ldots$

56. 02160325, Brushy Creek (Enoree River tributary) near Greenville,

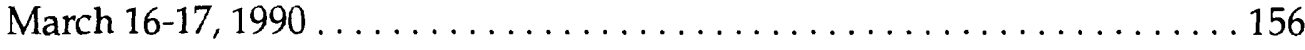

57. 02162093, Smith Branch at Columbia, August 19-20, 1984 . . . . . . . . . . . 159

58. 02162093, Smith Branch at Columbia, July 25-26, 1986. . . . . . . . . . . 161

59. 02162093, Smith Branch at Columbia, August 19-21, 1986. . . . . . . . . . 163

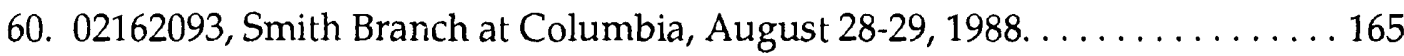

61. 02162093, Smith Branch at Columbia, June 8-10, $1989 \ldots \ldots \ldots \ldots \ldots \ldots \ldots 7$

62. 02162093, Smith Branch at Columbia, July 4-5, 1989 . . . . . . . . . . . 169

63. 02162093, Smith Branch at Columbia, September 21-23, 1989 . . . . . . . . . 171

64. 02163940, Richland Creek tributary at Greenville, March 19, 1986 . . . . . . 174 


\section{TABLES--Continued}

Page

65. 02163940, Richland Creek tributary at Greenville, July 23, 1986 . . . . . . 176

66. 02163940, Richland Creek tributary at Greenville, July 27, 1986 . . . . . . . 178

67. 02163940, Richland Creek tributary at Greenville, August 18, 1986 . . . . . . 180

68. 02163940, Richland Creek tributary at Greenville, May 29, 1987 . . . . . . . 182

69. 02163940, Richland Creek tributary at Greenville, July 30-31, 1987 . . . . . . 184

70. 02163940, Richland Creek tributary at Greenville, August 16, 1989 . . . . . 186

71. 02164011, Brushy Creek (Reedy River tributary) at Greenville,

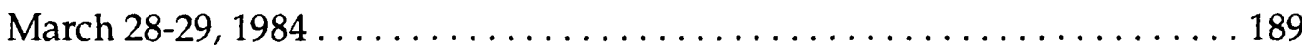

72. 02164011, Brushy Creek (Reedy River tributary) at Greenville,

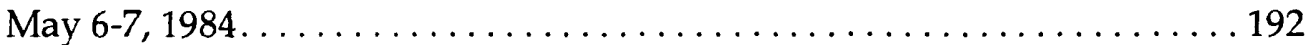

73. 02164011, Brushy Creek (Reedy River tributary) at Greenville,

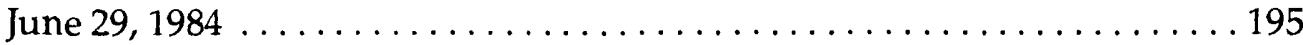

74. 02164011, Brushy Creek (Reedy River tributary) at Greenville,

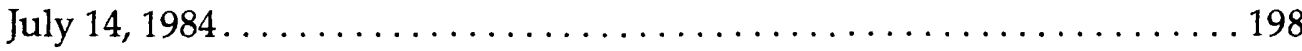

75. 02164011, Brushy Creek (Reedy River tributary) at Greenville,

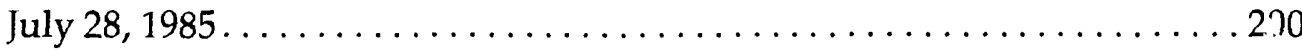

76. 02164011, Brushy Creek (Reedy River tributary) at Greenville,

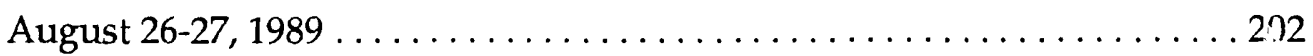

77. 02164011, Brushy Creek (Reedy River tributary) at Greenville,

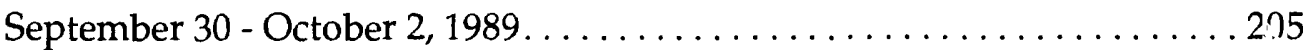

78. 02166975, Sample Branch at Greenwood, August 18, $1986 \ldots \ldots \ldots \ldots \ldots 211$

79. 02166975, Sample Branch at Greenwood, January 20,1988 . . . . . . . . . 213

80. 02166975, Sample Branch at Greenwood, July 20, 1989 . . . . . . . . . 215

81. 02166975, Sample Branch at Greenwood, July 31 - August 1, 1989 . . . . . . 217

82. 02166975, Sample Branch at Greenwood, February 16-17, 1990 . . . . . . . . 219

83. 02166975, Sample Branch at Greenwood, February 18-19, 1990 . . . . . . . 222

84. 02166975, Sample Branch at Greenwood, May 28-29, 1990 . . . . . . . . . 225

85. 02167020, Crane Creek tributary at Columbia, March 13-14, 1986 . . . . . . 228

86. 02167020, Crane Creek tributary at Columbia, July 25-26, 1986 . . . . . . . 230 


\section{TABLES--Continued}

87. 02167020, Crane Creek tributary at Columbia, May 4, 1987 . . . . . . . 232

89. 02167020, Crane Creek tributary at Columbia, June 4, 1987 . . . . . . . . 234

89. 02167020, Crane Creek tributary at Columbia, June $8,1988 \ldots \ldots \ldots \ldots \ldots 236$

90. 02167020, Crane Creek tributary at Columbia, June 29, 1989 . . . . . . . 238

91. 02167020, Crane Creek tributary at Columbia, August 15, 1989 . . . . . . . 241

92. 02168845, Saluda River tributary at Columbia, August 11-12, 1986 . . . . . . 244

93. 02168845, Saluda River tributary at Columbia, September 9-10, 1987 . . . . . 246

94. 02168845, Saluda River tributary at Columbia, August 11, 1988. . . . . . 24 \&

95. 02168845, Saluda River tributary at Columbia, September 25-26, 1988 . . . . 250

96. 02168845, Saluda River tributary at Columbia, May 1-2, 1989 . . . . . . . 252

97. 02168845, Saluda River tributary at Columbia, July 26, 1989 . . . . . . . 255

98. 02168845, Saluda River tributary at Columbia, September 15-16, 1989 . . . . 257

99. 02169505, Rocky Branch at Columbia, August 30-31, 1985 . . . . . . . . . 26?

100. 02169505, Rocky Branch at Columbia, July 3-4, 1987 . . . . . . . . . . 263

101. 02169505, Rocky Branch at Columbia, July 28, $1987 \ldots \ldots \ldots \ldots \ldots \ldots$

102. 02169505, Rocky Branch at Columbia, September 9-10, 1987 . . . . . . . 267

103. 02169505, Rocky Branch at Columbia, July 27-28, $1988 \ldots \ldots \ldots \ldots \ldots$. . . 260

104. 02169505, Rocky Branch at Columbia, June 9, 1989. . . . . . . . . . . . . 271

105. 02169505, Rocky Branch at Columbia, June 19-20, $1989 \ldots \ldots \ldots \ldots \ldots \ldots 27$ ?

106. 02169568, Pen Branch at Columbia, August 11-13, 1986. . . . . . . . . 276

107. 02169568, Pen Branch at Columbia, August 18-19, 1986. . . . . . . . . 280

108. 02169568, Pen Branch at Columbia, March $27-28,1987 \ldots \ldots \ldots \ldots \ldots \ldots$

109. 02169568, Pen Branch at Columbia, July 28-29, 1987 . . . . . . . . . . 285

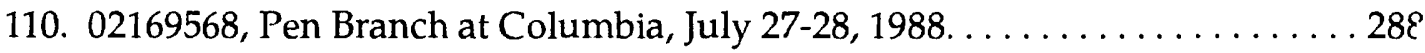

111. 02169568, Pen Branch at Columbia, June 8-9, $1989 \ldots \ldots \ldots \ldots \ldots \ldots$. . . . . .

112. 02169568, Pen Branch at Columbia, September 21-23, 1989 . . . . . . . . . 29:

113. 0217206930, Noisette Creek at North Charleston, March 13-14, 1986 . . . . . . 298

114. 0217206930, Noisette Creek at North Charleston, September 5-6, 1986 . . . . 301

115. 0217206930, Noisette Creek at North Charleston, August 30, 1987 . . . . . . 304 


\section{TABLES--Continued}

116. 0217206930, Noisette Creek at North Charleston, September 8-9, $1988 \ldots \ldots 306$

117. 0217206930, Noisette Creek at North Charleston, June 6, 1989 . . . . . . . . . 310

118. 0217206930, Noisette Creek at North Charleston, August 30-31, 1989 . . . . 312

119. 0217206930, Noisette Creek at North Charleston, September 3, 1989 . . . . . 314

120. 02173491, Hess Branch at Orangeburg, July 12, $1987 \ldots \ldots \ldots \ldots \ldots \ldots \ldots . . \ldots 17$

121. 02173491, Hess Branch at Orangeburg, August 8-9, 1987. . . . . . . . . . 319

122. 02173491, Hess Branch at Orangeburg, July 22-23, 1988 . . . . . . . . . . . . 321

123. 02173491, Hess Branch at Orangeburg, June 22-23, $1989 \ldots \ldots \ldots \ldots \ldots \ldots 323$

124. 02173491, Hess Branch at Orangeburg, July 16, $1989 \ldots \ldots \ldots \ldots \ldots \ldots \ldots$

125. 02173491, Hess Branch at Orangeburg, July 20, 1989 . . . . . . . . . . . . 327

126. 02173491, Hess Branch at Orangeburg, August 15, 1989 . . . . . . . . . . 329

127. 02173495, Sunnyside Canal at Orangeburg, November 10, 1987 . . . . . . 332

128. 02173495, Sunnyside Canal at Orangeburg, June 19, $1988 \ldots \ldots \ldots \ldots \ldots \ldots 34$

129. 02173495, Sunnyside Canal at Orangeburg, July 22, $1988 \ldots \ldots \ldots \ldots \ldots \ldots 36$

130. 02173495, Sunnyside Canal at Orangeburg, September $9,1988 \ldots \ldots \ldots . . .338$

131. 02173495, Sunnyside Canal at Orangeburg, August $8,1990 \ldots \ldots \ldots \ldots \ldots 341$

132. 02173495, Sunnyside Canal at Orangeburg, September $8,1990 \ldots \ldots \ldots . .343$

133. 02173495, Sunnyside Canal at Orangeburg, October 10-11, $1990 \ldots \ldots \ldots \ldots 345$

134. 02174240, Middlepen Branch at Orangeburg, June 19-20, 1986 . . . . . . . 350

135. 02174240, Middlepen Branch at Orangeburg, January 1, 1987 . . . . . . . 352

136. 02174240, Middlepen Branch at Orangeburg, May 4-5, 1987 . . . . . . . 355

137. 02174240, Middlepen Branch at Orangeburg, October 26-27, 1987 . . . . . 358

138. 02174240, Middlepen Branch at Orangeburg, July 4-5, 1989 . . . . . . . . 360

139. 02174240, Middlepen Branch at Orangeburg, July 8-9, $1989 \ldots \ldots \ldots \ldots \ldots 363$

140. 02174240, Middlepen Branch at Orangeburg, August 8-9, $1990 \ldots \ldots \ldots \ldots 365$

141. 02176380, Coosawhatchie River tributary at Allendale,

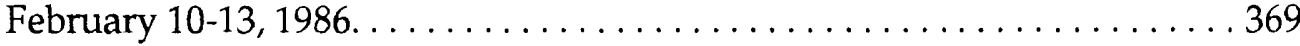

142. 02176380, Coosawhatchie River tributary at Allendale, May 12-14, 1986 . . 375

143. 02176380, Coosawhatchie River tributary at Allendale, June 9-11, 1986 . . . 378 


\section{TABLES--Continued}

144. 02176380, Coosawhatchie River tributary at Allendale, April 19, 1988 . . . . 3\&1

145. 02176380, Coosawhatchie River tributary at Allendale,

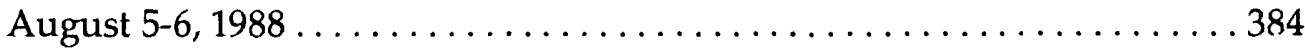

146. 02176380, Coosawhatchie River tributary at Allendale,

September $9-11,1988 \ldots \ldots \ldots \ldots \ldots \ldots \ldots \ldots \ldots \ldots \ldots \ldots \ldots \ldots$

147. 02176380, Coosawhatchie River tributary at Allendale,

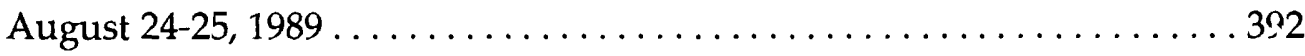

148. 02187260, Whitner Creek at Anderson, September 29, 1986 . . . . . . . . 396

149. 02187260, Whitner Creek at Anderson, March 30, 1987 . . . . . . . . . . 398

150. 02187260, Whitner Creek at Anderson, April 23, $1987 \ldots \ldots \ldots \ldots \ldots \ldots$. . . . 401

151. 02187260, Whitner Creek at Anderson, May 4, 1987 . . . . . . . . . 403

152. 02187260, Whitner Creek at Anderson, June 25-26, $1987 \ldots \ldots \ldots \ldots \ldots$

153. 02187260, Whitner Creek at Anderson, July 30, $1987 \ldots \ldots \ldots \ldots \ldots \ldots \ldots 4$

154. 02187260, Whitner Creek at Anderson, August 2, 1987 . . . . . . . . . . 409

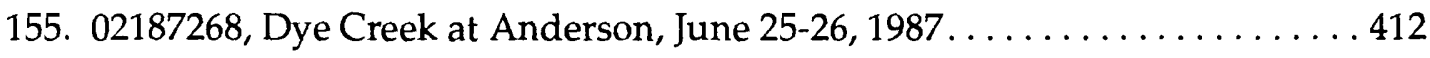

156. 02187268, Dye Creek at Anderson, June 20-21, 1989 . . . . . . . . . . . 415

157. 02187268, Dye Creek at Anderson, January 20-21, $1990 \ldots \ldots \ldots \ldots \ldots \ldots 418$

158. 02187268, Dye Creek at Anderson, February 9-11, $1990 \ldots \ldots \ldots \ldots \ldots \ldots 21$

159. 02187268, Dye Creek at Anderson, February 16-17, $1990 \ldots \ldots \ldots \ldots \ldots \ldots$

160. 02187268, Dye Creek at Anderson, March 16-17, $1990 \ldots \ldots \ldots \ldots \ldots \ldots . \ldots 28$

161. 02187268, Dye Creek at Anderson, October 11-13, 1990 . . . . . . . . . 431 


\section{CONVERSION FACTORS AND ABBREVIATIONS OF UNITS}

\begin{tabular}{|c|c|c|}
\hline Multiply & By & Ie obtain \\
\hline \multicolumn{3}{|c|}{ Length } \\
\hline inch (in.) & 2.54 & centimeter \\
\hline foot $(f t)$ & 0.3048 & meter \\
\hline mile (mi) & 1.609 & kilometer \\
\hline foot per mile $(\mathrm{ft} / \mathrm{mi})$ & 0.1894 & meter per kilometer \\
\hline \multicolumn{3}{|c|}{ Area } \\
\hline square mile $\left(\mathrm{mi}^{2}\right)$ & 2.590 & square kilometer \\
\hline \multicolumn{3}{|c|}{ Flow } \\
\hline cubic foot per second $\left(\mathrm{ft}^{3} / \mathrm{s}\right)$ & 0.02832 & cubic meter per se-ond \\
\hline
\end{tabular}




\title{
SELECTED HYDROLOGIC DATA FOR URBAN WATERSHEDS IN \\ SOUTH CAROLINA, 1983-1990
}

\author{
By Sarah W. Logan, Michael R. Eckenwiler, and Larry R. Bohman
}

\begin{abstract}
Rainfall and streamflow data were collected at 23 gaging stations located in urban watersheds in South Carolina from 1983-90. The site selection process and the instrumentation used to collect the data are described. A compilation of rainfall and streamflow data in graphic and tabular form for seven selected events at each gaging station are presented. A gaging-station description and a listing of certain streamflow and basin characteristics also are included.
\end{abstract}

\section{INTRODUCTION}

Knowledge of flood characteristics is essential for the design of highway-drainage structures, for establishing flood-insurance rates, and for many other uses by urban planners and engineers. Although abundant rural rainfall-runoff data are available, these data are not applicable to urban streams. Therefore, in the fall of 1983, the U.S. Geological Survey (USGS), in cooperation with the South Carolina Department of Transportation, began collecting rainfall-runoff data at selected urban basins in the Piedmont and Coastal Plain Provinces of South Carolina to be used in determining urban flood characteristics. Each basin was instrumented with a water-stage recorder and a cumulative-rainfall recorder. By the end of 1984, data were being collected at 7 sites in 6 cities and towns in South Carolina. In 1985, the number of data-collection sites was increased to a total of 27 sites in 14 cities; however, 4 sites were excluded because the data were not usable for modeling.

The data presented in this report were collected as part of a broader investigation to determine techniques for estimating peak streamflows, runoff volumes, and flood hydrographs for urban watersheds in South Carolina. However, only the final results from that investigation were published. The purpose of this report is to present selected concurrent rainfall and streamflow data from 1983-90 for the 23 urban data-colle-tion sites in South Carolina used by Bohman (1992) (fig. 1). Included in the report is the description of the site selection process and a detailed description of data-collention methods. For each site, a station description, rainfall data, and streamflow data for selected storm events are presented. 


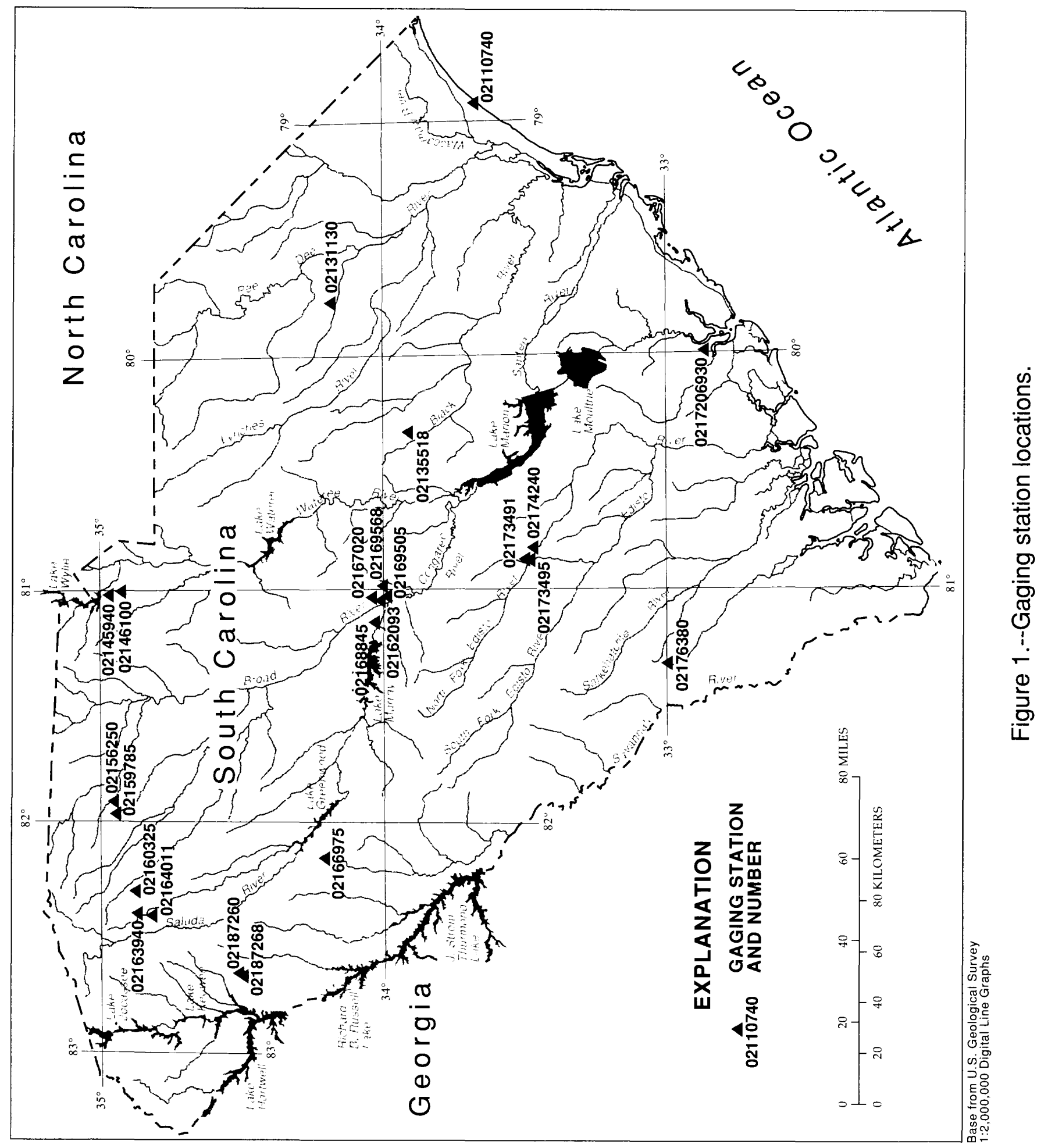




\section{SITE SELECTION}

Extensive field reconnaissance was required to select the basins to be instrumented. Approximately 500 sites were selected and inspected in the field for possible use. Some factors considered during the site inspections were 1) suitability for rain-gage location, 2) accessibility for streamflow measurements, 3) presence of a bridge or culvert with hydraulic characteristics suitable for theoretical computation of peak streamflow, 4) absence of ponds or lakes, and 5) urban land use in the basin. Basins that were likely to undergo changes in impervious area or drainage efficiency were eliminated from the selection process. Basin characteristics such as drainage area, main channel slope, and degree of development were determined to ensure a suitable distribution of basin characteristics. The final sites were equally distributed between the Piedmont and Coastal Plain physiographic provinces.

\section{STORM SELECTION}

Hydrologic data from seven storms were selected to provide sufficient data for modeling (the number of storms, seven, was arbitrarily selected). The largest singlepeak storms were used when possible to facilitate hydrograph comparison. Other criteria governing storm selection were uniform rainfall throughout the basin and that the record was complete for the entire storm. The length of the storm and the amour $t$ of rainfall were not considered in the selection process.

\section{DEFINITION OF TERMS}

Terms and symbols related to streamflow, basin characteristics, and other hydrologic data, as used in the data compilation section of this report, are defined bejow. They are not necessarily the only valid definitions for these terms. A brief description of how the basin characteristics were determined or measured also is given.

Basin development factor (BDF, dimensionless)--This parameter is an index of the efficiency of the drainage system and ranges from 0 to 12 . Four aspects of the drainage system are evaluated in order to determine the BDF, as shown below:

1. Channel modifications such as deepening, enlarging, straightening, or clearirg of vegetation and debris.

2. Channel linings made of impervious material.

3. Storm drains and storm sewers present.

4. Curb and gutter streets. 
The drainage basin is divided into three subbasins based on approximate travel times. A value of 1 is added to the BDF for each drainage improvement aspect that is prevalent in over 50 percent of a subbasin. Therefore, the maximum BDF of 12 results from 3 subbasins times 4 improvement aspects per subbasin. A value of 0 indicate: a lack of drainage system modifications, but does not necessarily mean the basin is rural. The BDF is described in more detail in a report by Sauer and others (1983).

Channel length (mi)--Computed as the distance measured along the main channel from the basin outlet to the watershed divide as determined from USGS 7.5-minute series topographic quadrangle maps or maps of equivalent accuracy.

Channel slope ( $\mathrm{ft} / \mathrm{mi}$ )--Computed between points that are 10 and 85 percent of the main channel length upstream from a specified location as determined from USGS 7.5-minute series topographic quadrangle maps or maps of equivalent accuracy.

Drainage area $\left(\mathrm{mi}^{2}\right)$--The area contributing surface runoff to a specified location on a stream, measured in a horizontal plane and enclosed by a topographic divide. The area was determined from USGS 7.5-minute series topographic quadrangle maps or maps of equivalent accuracy using a digitizer or planimeter. Storm-sewer maps obtained from city engineering or public works departments were used when available. Basin boundaries were checked in the field areas of low relief when storm-sewrer information could not be obtained.

Flood frequency data $\left(\mathrm{UQ}_{\mathrm{T}}, \mathrm{ft}^{3} / \mathrm{s}\right)$--Urban peak streamflow (UQ) corresponding to the indicated recurrence interval $(\mathrm{T})$, in years. These values were taken from a study by Bohman (1992).

Total impervious area (percentage)--The percentage of the watershed that is impervious to infiltration of rainfall. This characteristic was measured by use of the grid-overlay method using aerial photography. According to Cochran (1963), a minimum of 200 points, or grid intersections, for each area or subbasin will provide a confidence level of 0.10 . Grid intersections over points on buildings, streets, and parking lots were counted as impervious surface points. Grid intersections located over forests, lawns, unpaved industrial yards, and so on, were treated as pervious surface points. An estimate of the percentage of total impervious area was determined by dividing the impervious points by the total number of grid intersections. Three counts of at least 200 points for each subbasin (usually many more) were obtained with different orientation of the grid network and the results were averaged for the final value.

Two-year 2-hour rainfall amount (in.)--The cumulative 2-hour rainfall corresponding to the two-year recurrence interval as determined from the National Weather Service (NWS), formerly known as the U.S. Weather Bureau (1961).

Left bank, right bank--Right and left refer to the direction that would be reported by an observer facing downstream. 


\section{INSTRUMENTATION AND HYDROLOGIC DATA COLLECTION}

Rainfall and streamflow data were collected for each urban basin studied. A rain gage was located near each gaging station with the same data-collection interval. Rainfall recorders were housed in metal shelters attached to 3-in. galvanized pipe collector wells with a funnel mounted to the top. A float in the well was connected by a steel cable to a recorder that registered rainfall accumulations to the nearest 0.01 in.

Larger basins have greater probability for areal variations in rainfall amourt, intensity, timing, and distribution. The data in this report have been compared to other local USGS rain gages or daily NWS sites in the vicinity so that the amounts ard distribution given can be assumed to be reasonably uniform throughout the basin. Local NWS stations also were used to check monthly and annual rainfall amounts recorded at the USGS gages. Stage data were converted to flow data using standard rating curves that relate stage to flow. Stage elevations were recorded at 5-minute intervals for basins with drainage areas less than about $5 \mathrm{mi}^{2}$ and at 15 -minute intervals for larger basins. The stage elevations were referenced to an arbitrary datum and were recorded to the nearest $0.01 \mathrm{ft}$. Recorders were housed in metal shelters set on top of 8- or 12-in. diameter corrugated-metal pipe stilling wells. Communication between the stilling well and the stream was usually accomplished through $1 / 2$ in.-diameter holes drilled in the well at about $1-\mathrm{ft}$ intervals. Stilling wells were attached to wooden free-standirg platforms set along an upstream bank outside the hydraulic drawdown zone of the structure. In cases where the gage was attached to the headwall or a wingwall, the stilling well was sealed and an 11 /4-in.-diameter-intake pipe was extended upstream beyond the zone of influence caused by drawdown from the structure. A crest-stage indicator was installed in the vicinity of the intake to verify maximum gage-height recordings. Crest-stage indicators also were installed at the downstream end of each structure near the exit.

Rating curves and tables for each station were prepared to represent the stag?streamflow relation defined by streamflow measurements. These relations were used to convert recorded stage to flow. Extensions to rating curves, necessary to express streamflow greater than measured, were made from the results of indirect measurements of peak streamflow, or from a logarithmic extrapolation of the stage-streamflow relation.

The fall through the culverts, culvert geometry, and the surveyed approach sectic $n$ were used to compute a theoretical stage-streamflow relation from indirect methods described by Bodhaine (1968). The fall was determined from a plot of upstream and downstream stages recorded and a second plot was drawn to show the relation between the maximum stage elevation indicated by the recording gage and the upstream creststage indicator. When a difference was observed, the relation was used to adjust recorded stage to correspond with stages from the crest-stage indicator. The relatic $n$ between the stage elevation registered by the upstream crest-stage indicator and the elevation indicated by the continuous recorder also indicated any problem with the continuous-record data collection. These problems include a hanging float, a float taro that jumped the spline, or intakes clogged with sediment. 


\section{STATION DESCRIPTIONS, HYDROGRAPHS, AND TABULATED RAINFALL $A$ ND STREAMFLOW DATA}

Station locations, and selected hydrologic data for each of the 23 stations are presented in this section as listed below. For each station, a brief station description is given including 1) station name and number, 2) latitude (lat) and longitude (long), 3) general location, 4) period of record, 5) description of gages, 6) stage-streamflow rating information, and 7) selected climatic and physiographic basin characteristics. Following the station description, the data for the seven selected storm events are presented in graphic and tabular form.

Page

Station 02110740, Midway Swash at Myrtle Beach, S.C .7

Station 02131130, Gully Branch at Florence, S.C...............................................................26

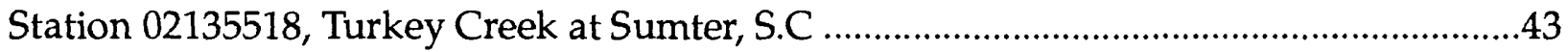

Station 02145940, Little Dutchman Creek Tributary at Rock Hill, S.C. ...............................61

Station 02146100, Manchester Creek Tributary at Rock Hill, S.C ..........................................86

Station 02156250, Chinquapin Creek Tributary at Spartanburg, S.C..................................109

Station 02159785, Fairforest Creek Tributary at Spartanburg, S.C. .....................................126

Station 02160325, Brushy Creek (Enoree River Tributary) near Greenville, S.C..............142

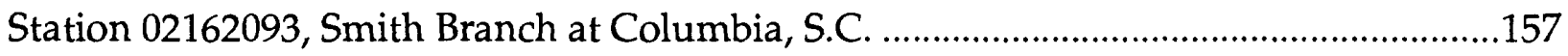

Station 02163940, Richland Creek Tributary at Greenville, S.C........................................172

Station 02164011, Brushy Creek (Reedy River Tributary) at Greenville, S.C.....................187

Station 02166975, Sample Branch at Greenwood, S.C. ......................................................209

Station 02167020, Crane Creek Tributary at Columbia, S.C...............................................226

Station 02168845, Saluda River Tributary at Columbia, S.C. ...............................................242

Station 02169505, Rocky Branch at Columbia, S.C...........................................................259

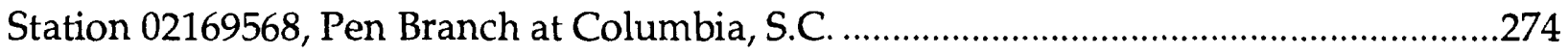

Station 0217206930, Noisette Creek at North Charleston, S.C............................................296

Station 02173491, Hess Branch at Orangeburg, S.C. ...........................................................315

Station 02173495, Sunnyside Canal at Orangeburg, S.C. ................................................330

Station 02174240, Middlepen Branch at Orangeburg, S.C. ..............................................348

Station 02176380, Coosawhatchie River Tributary at Allendale, S.C. ...............................367

Station 02187260, Whitner Creek at Anderson, S.C. ...........................................................394

Station 02187268, Dye Creek at Anderson, S.C ................................................................ 410 


\section{Station 02110740, Midway Swash at Myrtle Beach, S.C.}

Location.--Lat $33^{\circ} 39^{\prime} 44^{\prime \prime}$, long $78^{\circ} 55^{\prime} 25^{\prime \prime}$, Horry County, Hydrologic Unit 03040206 , at culvert on U.S. Highway 17, and about 1.0 mi upstream from the mouth at the Atlantic Ocean.

Period of record.-- March 4, 1987 to September 25, 1990.

Gage.--Digital stage recorder with 5-minute punch interval. The recorder is housed in a metal shelter atop a stilling well attached to a free-standing platform located on the left bank approximately $18 \mathrm{ft}$ upstream from a double $5 \mathrm{ft}$ by $10 \mathrm{ft}$ concrete box culvert. An enameled staff gage is attached to the platform. One crest-stage indicator is located in the median between the northbound and southbound roadway culverts on the left wingwall. A second crest-stage indicator is located on the right downstream culvert wingwall.

Rating.--The stage-streamflow relation is defined by current meter measurements up to $362 \mathrm{ft}^{3} / \mathrm{s}$. The stage-streamflow relation was extended to $500 \mathrm{ft}^{3} / \mathrm{s}$ using indirect computational methods.

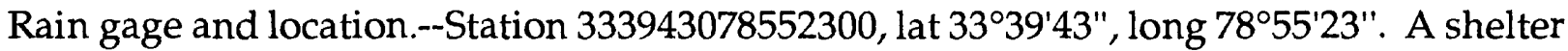
containing a digital cumulative rainfall recorder with a 5-minute punch interval attached to the right downstream wingwall, at the U.S. Highway 17 crossing of Midway Swash, and $1.0 \mathrm{mi}$ upstream from the mouth at the Atlantic Ocean.

Selected basin characteristics.--

Drainage area -- $0.80 \mathrm{mi}^{2}$

Physiographic province -- Lower Coastal Plain

Channel slope -- $9.2 \mathrm{ft} / \mathrm{mi}$

Channel length -- $1.40 \mathrm{mi}$

Total impervious area -- 23.0 percent

Basin development factor -7

2-year, 2-hour rainfall amount -- 2.24 in.

Flood frequency data: $\mathrm{UQ}_{2} \quad 296 \mathrm{ft}^{3} / \mathrm{s}$

$\mathrm{UQ}_{5} \quad 478 \mathrm{ft}^{3} / \mathrm{s}$

$\mathrm{UQ}_{10} \quad 605 \mathrm{ft}^{3} / \mathrm{s}$

$\mathrm{UQ}_{25} \quad 771 \mathrm{ft}^{3} / \mathrm{s}$

$\mathrm{UQ}_{50} \quad 897 \mathrm{ft}^{3} / \mathrm{s}$

$\mathrm{UQ}_{100} \quad 1,020 \mathrm{ft}^{3} / \mathrm{s}$

$\mathrm{UQ}_{500} \quad 1,330 \mathrm{ft}^{3} / \mathrm{s}$ 


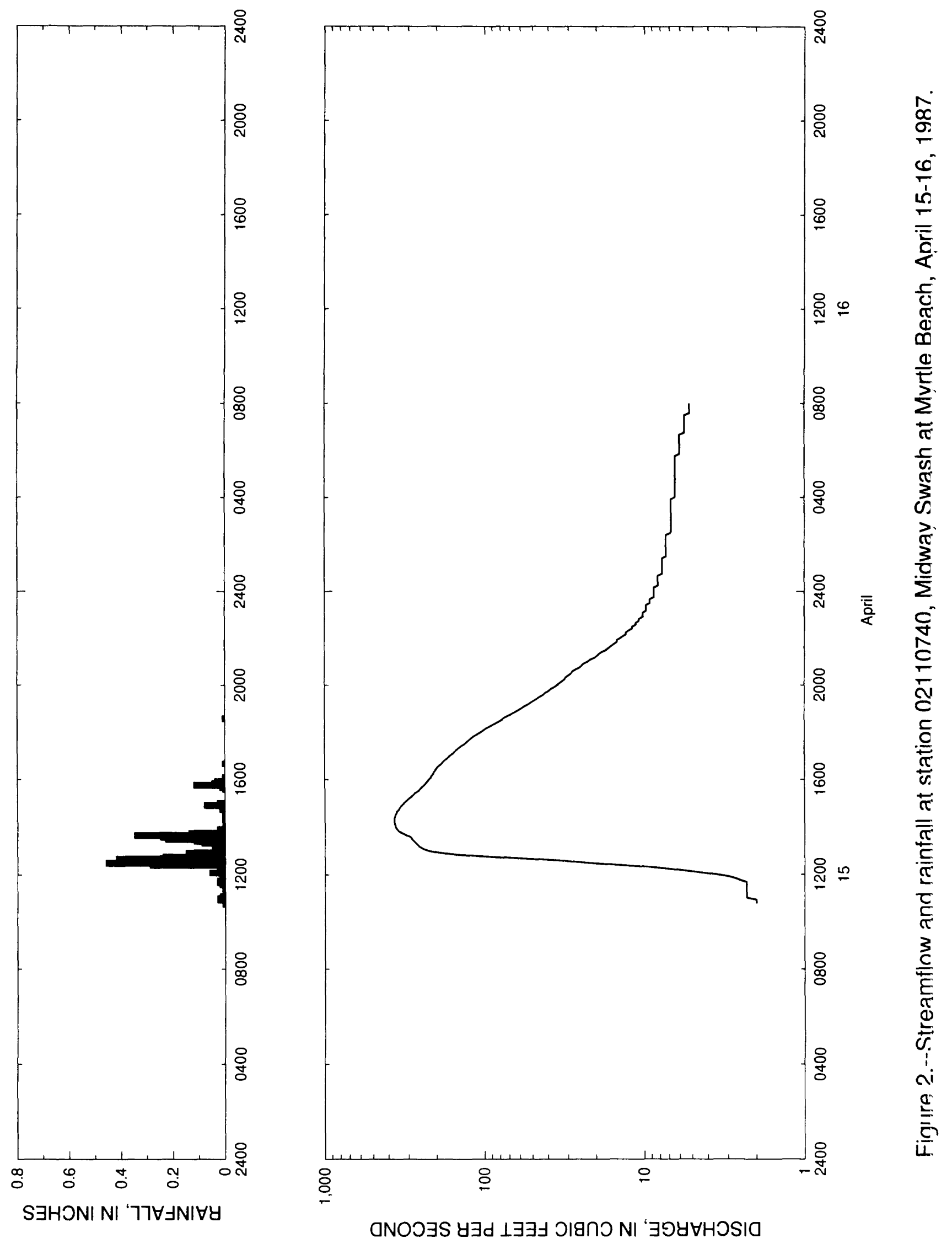


Table 1. - - Streamflow and rainfall at station 02110740, Midway Swash at Myrtle Beach, April 15-16, 1987

\begin{tabular}{|c|c|c|c|c|c|c|c|c|}
\hline $\begin{array}{l}\text { Time } \\
\text { (hours) }\end{array}$ & $\begin{array}{l}\text { Streamflow } \\
\text { (cubic feet } \\
\text { per second) }\end{array}$ & $\begin{array}{l}\text { Rain- } \\
\text { fall } \\
\text { (inches) }\end{array}$ & $\begin{array}{l}\text { Time } \\
\text { (hours) }\end{array}$ & $\begin{array}{l}\text { Streamflow } \\
\text { (cubic feet } \\
\text { per second) }\end{array}$ & $\begin{array}{l}\text { Rain- } \\
\text { fall } \\
\text { (inches) }\end{array}$ & $\begin{array}{l}\text { Time } \\
\text { (hours) }\end{array}$ & $\begin{array}{l}\text { Streamflow } \\
\text { (cubic feet } \\
\text { per second) }\end{array}$ & $\begin{array}{l}\text { Rain- } \\
\text { fall } \\
\text { (inches) }\end{array}$ \\
\hline $\begin{array}{l}\text { Apri1 } 15, \\
1045 \\
1050 \\
1055 \\
1100\end{array}$ & $\begin{array}{r}1987 \\
2.0 \\
2.0 \\
2.0 \\
2.3\end{array}$ & $\begin{array}{l}0.01 \\
0.00 \\
0.03 \\
0.03\end{array}$ & $\begin{array}{l}1605 \\
1610 \\
1615 \\
1620 \\
1625\end{array}$ & $\begin{array}{l}218.0 \\
215.0 \\
210.0 \\
207.0 \\
202.0\end{array}$ & $\begin{array}{l}0.01 \\
0.00 \\
0.00 \\
0.00 \\
0.00\end{array}$ & $\begin{array}{l}2130 \\
2135 \\
2140 \\
2145 \\
2150\end{array}$ & $\begin{array}{l}17.2 \\
16.6 \\
16.0 \\
15.4 \\
14.8\end{array}$ & $\begin{array}{l}0.00 \\
0.00 \\
0.00 \\
0.00 \\
0.00\end{array}$ \\
\hline $\begin{array}{l}1105 \\
1110 \\
1115 \\
1120 \\
1125\end{array}$ & $\begin{array}{l}2.3 \\
2.3 \\
2.3 \\
2.3 \\
2.3\end{array}$ & $\begin{array}{l}0.02 \\
0.01 \\
0.01 \\
0.01 \\
0.01\end{array}$ & $\begin{array}{l}1630 \\
1635 \\
1640 \\
1645 \\
1650\end{array}$ & $\begin{array}{l}198.0 \\
192.0 \\
186.0 \\
182.0 \\
176.0\end{array}$ & $\begin{array}{l}0.00 \\
0.00 \\
0.01 \\
0.00 \\
0.00\end{array}$ & $\begin{array}{l}2155 \\
2200 \\
2205 \\
2210 \\
2215\end{array}$ & $\begin{array}{l}14.8 \\
14.2 \\
13.6 \\
13.0 \\
13.0\end{array}$ & $\begin{array}{l}0.00 \\
0.00 \\
0.00 \\
0.00 \\
0.00\end{array}$ \\
\hline $\begin{array}{l}1130 \\
1135 \\
1140 \\
1145 \\
1150\end{array}$ & $\begin{array}{l}2.3 \\
2.3 \\
2.3 \\
2.5 \\
2.7\end{array}$ & $\begin{array}{l}0.00 \\
0.02 \\
0.03 \\
0.03 \\
0.01\end{array}$ & $\begin{array}{l}1655 \\
1700 \\
1705 \\
1710 \\
1715\end{array}$ & $\begin{array}{l}170.0 \\
166.0 \\
159.0 \\
154.0 \\
150.0\end{array}$ & $\begin{array}{l}0.00 \\
0.00 \\
0.00 \\
0.00 \\
0.00\end{array}$ & $\begin{array}{l}2220 \\
2225 \\
2230 \\
2235 \\
2240\end{array}$ & $\begin{array}{l}12.5 \\
11.9 \\
11.9 \\
11.3 \\
11.3\end{array}$ & $\begin{array}{l}0.00 \\
0.00 \\
0.00 \\
0.00 \\
0.00\end{array}$ \\
\hline $\begin{array}{l}1155 \\
1200 \\
1205 \\
1210 \\
1215\end{array}$ & $\begin{array}{l}3.0 \\
3.6 \\
4.5 \\
5.6 \\
7.3\end{array}$ & $\begin{array}{l}0.01 \\
0.02 \\
0.06 \\
0.03 \\
0.00\end{array}$ & $\begin{array}{l}1720 \\
1725 \\
1730 \\
1735 \\
1740\end{array}$ & $\begin{array}{l}145.0 \\
140.0 \\
134.0 \\
129.0 \\
124.0\end{array}$ & $\begin{array}{l}0.00 \\
0.00 \\
0.00 \\
0.00 \\
0.00\end{array}$ & $\begin{array}{l}2245 \\
2250 \\
2255 \\
2300 \\
2305\end{array}$ & $\begin{array}{l}10.8 \\
10.8 \\
10.2 \\
10.2 \\
10.2\end{array}$ & $\begin{array}{l}0.00 \\
0.00 \\
0.00 \\
0.00 \\
0.00\end{array}$ \\
\hline $\begin{array}{l}1220 \\
1225 \\
1230 \\
1235 \\
1240\end{array}$ & $\begin{array}{r}9.7 \\
14.8 \\
23.8 \\
33.3 \\
56.6\end{array}$ & $\begin{array}{l}0.01 \\
0.29 \\
0.46 \\
0.31 \\
0.42\end{array}$ & $\begin{array}{l}1745 \\
1750 \\
1755 \\
1800 \\
1805\end{array}$ & $\begin{array}{l}120.0 \\
115.0 \\
110.0 \\
105.0 \\
101.0\end{array}$ & $\begin{array}{l}0.00 \\
0.00 \\
0.00 \\
0.00 \\
0.00\end{array}$ & $\begin{array}{l}2310 \\
2315 \\
2320 \\
2325 \\
2330\end{array}$ & $\begin{array}{l}9.7 \\
9.7 \\
9.7 \\
9.7 \\
9.2\end{array}$ & $\begin{array}{l}0.00 \\
0.00 \\
0.00 \\
0.00 \\
0.00\end{array}$ \\
\hline $\begin{array}{l}1245 \\
1250 \\
1255 \\
1300 \\
1305\end{array}$ & $\begin{array}{r}98.2 \\
150.0 \\
193.0 \\
224.0 \\
243.0\end{array}$ & $\begin{array}{l}0.24 \\
0.12 \\
0.15 \\
0.05 \\
0.03\end{array}$ & $\begin{array}{l}1810 \\
1815 \\
1820 \\
1825 \\
1830\end{array}$ & $\begin{array}{l}97.3 \\
91.9 \\
87.6 \\
83.3 \\
79.1\end{array}$ & $\begin{array}{l}0.00 \\
0.00 \\
0.00 \\
0.00 \\
0.00\end{array}$ & $\begin{array}{l}2335 \\
2340 \\
2345 \\
2350 \\
2355\end{array}$ & $\begin{array}{l}9.2 \\
9.2 \\
8.7 \\
8.7 \\
8.7\end{array}$ & $\begin{array}{l}0.00 \\
0.00 \\
0.00 \\
0.00 \\
0.00\end{array}$ \\
\hline $\begin{array}{l}1310 \\
1315 \\
1320 \\
1325 \\
1330\end{array}$ & $\begin{array}{l}256.0 \\
264.0 \\
271.0 \\
278.0 \\
286.0\end{array}$ & $\begin{array}{l}0.04 \\
0.05 \\
0.09 \\
0.12 \\
0.23\end{array}$ & $\begin{array}{l}1835 \\
1840 \\
1845 \\
1850 \\
1855\end{array}$ & $\begin{array}{l}75.8 \\
72.5 \\
68.3 \\
65.1 \\
61.9\end{array}$ & $\begin{array}{l}0.01 \\
0.00 \\
0.00 \\
0.00 \\
0.00\end{array}$ & $\begin{array}{l}\text { April 16, } \\
0000 \\
0005 \\
0010 \\
0015\end{array}$ & $\begin{array}{r}1987 \\
8.7 \\
8.7 \\
8.7 \\
8.2\end{array}$ & $\begin{array}{l}0.00 \\
0.00 \\
0.00 \\
0.00\end{array}$ \\
\hline $\begin{array}{l}1335 \\
1340 \\
1345 \\
1350 \\
1355\end{array}$ & $\begin{array}{l}292.0 \\
312.0 \\
331.0 \\
346.0 \\
355.0\end{array}$ & $\begin{array}{l}0.25 \\
0.35 \\
0.14 \\
0.00 \\
0.03\end{array}$ & $\begin{array}{l}1900 \\
1905 \\
1910 \\
1915 \\
1920\end{array}$ & $\begin{array}{l}58.9 \\
56.6 \\
53.6 \\
51.4 \\
49.3\end{array}$ & $\begin{array}{l}0.00 \\
0.00 \\
0.00 \\
0.00 \\
0.00\end{array}$ & $\begin{array}{l}0020 \\
0025 \\
0030 \\
0035 \\
0040\end{array}$ & $\begin{array}{l}8.2 \\
8.2 \\
8.2 \\
8.2 \\
8.2\end{array}$ & $\begin{array}{l}0.00 \\
0.00 \\
0.00 \\
0.00 \\
0.00\end{array}$ \\
\hline $\begin{array}{l}1400 \\
1405 \\
1410 \\
1415 \\
1420\end{array}$ & $\begin{array}{l}362.0 \\
364.0 \\
368.0 \\
368.0 \\
366.0\end{array}$ & $\begin{array}{l}0.01 \\
0.01 \\
0.01 \\
0.00 \\
0.00\end{array}$ & $\begin{array}{l}1925 \\
1930 \\
1935 \\
1940 \\
1945\end{array}$ & $\begin{array}{l}47.1 \\
45.0 \\
42.9 \\
41.6 \\
39.6\end{array}$ & $\begin{array}{l}0.00 \\
0.00 \\
0.00 \\
0.00 \\
0.00\end{array}$ & $\begin{array}{l}0045 \\
0050 \\
0055 \\
0100 \\
0105\end{array}$ & $\begin{array}{l}7.7 \\
7.7 \\
7.7 \\
7.7 \\
7.7\end{array}$ & $\begin{array}{l}0.00 \\
0.00 \\
0.00 \\
0.00 \\
0.00\end{array}$ \\
\hline $\begin{array}{l}1425 \\
1430 \\
1435 \\
1440 \\
1445\end{array}$ & $\begin{array}{l}366.0 \\
362.0 \\
358.0 \\
353.0 \\
344.0\end{array}$ & $\begin{array}{l}0.01 \\
0.00 \\
0.01 \\
0.00 \\
0.02\end{array}$ & $\begin{array}{l}1950 \\
1955 \\
2000 \\
2005 \\
2010\end{array}$ & $\begin{array}{l}38.3 \\
36.4 \\
35.1 \\
33.9 \\
32.7\end{array}$ & $\begin{array}{l}0.00 \\
0.00 \\
0.00 \\
0.00 \\
0.00\end{array}$ & $\begin{array}{l}0110 \\
0115 \\
0120 \\
0125 \\
0130\end{array}$ & $\begin{array}{l}7.7 \\
7.7 \\
7.7 \\
7.7 \\
7.3\end{array}$ & $\begin{array}{l}0.00 \\
0.00 \\
0.00 \\
0.00 \\
0.00\end{array}$ \\
\hline $\begin{array}{l}1450 \\
1455 \\
1500 \\
1505 \\
1510\end{array}$ & $\begin{array}{l}338.0 \\
328.0 \\
320.0 \\
311.0 \\
301.0\end{array}$ & $\begin{array}{l}0.01 \\
0.08 \\
0.03 \\
0.00 \\
0.00\end{array}$ & $\begin{array}{l}2015 \\
2020 \\
2025 \\
2030 \\
2035\end{array}$ & $\begin{array}{l}31.5 \\
30.9 \\
29.7 \\
28.6 \\
28.0\end{array}$ & $\begin{array}{l}0.00 \\
0.00 \\
0.00 \\
0.00 \\
0.00\end{array}$ & $\begin{array}{l}0135 \\
0140 \\
0145 \\
0150 \\
0155\end{array}$ & $\begin{array}{l}7.3 \\
7.3 \\
7.3 \\
7.3 \\
7.3\end{array}$ & $\begin{array}{l}0.00 \\
0.00 \\
0.00 \\
0.00 \\
0.00\end{array}$ \\
\hline $\begin{array}{l}1515 \\
1520 \\
1525 \\
1530 \\
1535\end{array}$ & $\begin{array}{l}291.0 \\
282.0 \\
273.0 \\
2620 \\
254.0\end{array}$ & $\begin{array}{l}0.00 \\
0.00 \\
0.00 \\
0.00 \\
3.01\end{array}$ & $\begin{array}{l}2040 \\
2045 \\
2050 \\
2055 \\
2100\end{array}$ & $\begin{array}{l}26.6 \\
25.2 \\
24.5 \\
23.8 \\
22.5\end{array}$ & $\begin{array}{l}0.00 \\
0.00 \\
0.00 \\
0.00 \\
0.00\end{array}$ & $\begin{array}{l}0200 \\
0205 \\
0210 \\
0215 \\
0220\end{array}$ & $\begin{array}{ll}7 & 3 \\
7 & 3 \\
7 & 3 \\
7 & 3 \\
7 & 3 \\
7 & 3\end{array}$ & $\begin{array}{l}0.00 \\
0.00 \\
0.00 \\
0.00 \\
0.00\end{array}$ \\
\hline $\begin{array}{l}1540 \\
1545 \\
1550 \\
1555 \\
1500\end{array}$ & $\begin{array}{l}248.0 \\
240.0 \\
234.0 \\
228.0 \\
223.0\end{array}$ & $\begin{array}{l}0.02 \\
0.12 \\
0.05 \\
0.04 \\
0.00\end{array}$ & $\begin{array}{l}2105 \\
2110 \\
2115 \\
2120 \\
2125\end{array}$ & $\begin{array}{l}21.8 \\
20.4 \\
19.7 \\
19.1 \\
18.4\end{array}$ & $\begin{array}{l}0.00 \\
0.00 \\
0.00 \\
0.00 \\
0.00\end{array}$ & $\begin{array}{l}0225 \\
0230 \\
0235 \\
0240 \\
0245\end{array}$ & $\begin{array}{l}7.3 \\
6.8 \\
6.8 \\
6.8 \\
6.8\end{array}$ & $\begin{array}{l}0.00 \\
0.00 \\
0.00 \\
0.00 \\
0.00\end{array}$ \\
\hline
\end{tabular}


Table 1. - Streamflow and rainfall at station 02110740, Midway Swash $a^{+}$. Myrtle Beach, April 15-16, 1987--Continued

\begin{tabular}{|c|c|c|c|c|c|c|c|c|}
\hline $\begin{array}{l}\text { Time } \\
\text { (hours) }\end{array}$ & $\begin{array}{l}\text { Streamflow } \\
\text { (cubic feet } \\
\text { per second) }\end{array}$ & $\begin{array}{l}\text { Rain- } \\
\text { fall } \\
\text { (inches) }\end{array}$ & $\begin{array}{l}\text { Time } \\
\text { (hours) }\end{array}$ & $\begin{array}{l}\text { Streamflow } \\
\text { (cubic feet } \\
\text { per second) }\end{array}$ & $\begin{array}{l}\text { Rain- } \\
\text { fall } \\
\text { (inches) }\end{array}$ & $\begin{array}{l}\text { Time } \\
\text { (hours) }\end{array}$ & $\begin{array}{l}\text { Streamflow } \\
\text { (cubic feet } \\
\text { per second) }\end{array}$ & $\begin{array}{l}\text { Rain- } \\
\text { fall } \\
\text { (inches) }\end{array}$ \\
\hline $\begin{array}{l}0250 \\
0255 \\
0300 \\
0305 \\
0310\end{array}$ & $\begin{array}{l}6.8 \\
6.8 \\
6.8 \\
6.8 \\
6.8\end{array}$ & $\begin{array}{l}0.00 \\
0.00 \\
0.00 \\
0.00 \\
0.00\end{array}$ & $\begin{array}{l}0435 \\
0440 \\
0445 \\
0450 \\
0455\end{array}$ & $\begin{array}{l}6.4 \\
6.4 \\
6.4 \\
6.4 \\
6.4\end{array}$ & $\begin{array}{l}0.00 \\
0.00 \\
0.00 \\
0.00 \\
0.00\end{array}$ & $\begin{array}{l}0620 \\
0625 \\
0630 \\
0635 \\
0640\end{array}$ & $\begin{array}{l}6.0 \\
6.0 \\
6.0 \\
6.0 \\
6.0\end{array}$ & $\begin{array}{l}0.00 \\
0.00 \\
0.00 \\
0.00 \\
0.00\end{array}$ \\
\hline $\begin{array}{l}0315 \\
0320 \\
0325 \\
0330 \\
0335\end{array}$ & $\begin{array}{l}6.8 \\
6.8 \\
6.8 \\
6.8 \\
6.8\end{array}$ & $\begin{array}{l}0.00 \\
0.00 \\
0.00 \\
0.00 \\
0.00\end{array}$ & $\begin{array}{l}0500 \\
0505 \\
0510 \\
0515 \\
0520\end{array}$ & $\begin{array}{l}6.4 \\
6.4 \\
6.4 \\
6.4 \\
6.4\end{array}$ & $\begin{array}{l}0.00 \\
0.00 \\
0.00 \\
0.00 \\
0.00\end{array}$ & $\begin{array}{l}0645 \\
0650 \\
0655 \\
0700 \\
0705\end{array}$ & $\begin{array}{l}5.6 \\
5.6 \\
5.6 \\
5.6 \\
5.6\end{array}$ & $\begin{array}{l}0.00 \\
0.00 \\
0.00 \\
0.00 \\
0.00\end{array}$ \\
\hline $\begin{array}{l}0340 \\
0345 \\
0350 \\
0355 \\
0400\end{array}$ & $\begin{array}{l}6.8 \\
6.8 \\
6.8 \\
6.8 \\
6.4\end{array}$ & $\begin{array}{l}0.00 \\
0.00 \\
0.00 \\
0.00 \\
0.00\end{array}$ & $\begin{array}{l}0525 \\
0530 \\
0535 \\
0540 \\
0545\end{array}$ & $\begin{array}{l}6.4 \\
6.4 \\
6.4 \\
6.4 \\
6.4\end{array}$ & $\begin{array}{l}0.00 \\
0.00 \\
0.00 \\
0.00 \\
0.00\end{array}$ & $\begin{array}{l}0710 \\
0715 \\
0720 \\
0725 \\
0730\end{array}$ & $\begin{array}{l}5.6 \\
5.6 \\
5.6 \\
5.6 \\
5.6\end{array}$ & $\begin{array}{l}0.00 \\
0.00 \\
0.00 \\
0.00 \\
0.00\end{array}$ \\
\hline $\begin{array}{l}0405 \\
0410 \\
0415 \\
0420 \\
0425\end{array}$ & $\begin{array}{l}6.4 \\
6.4 \\
6.4 \\
6.4 \\
6.4\end{array}$ & $\begin{array}{l}0.00 \\
0.00 \\
0.00 \\
0.00 \\
0.00\end{array}$ & $\begin{array}{l}0550 \\
0555 \\
0600 \\
0605 \\
0610\end{array}$ & $\begin{array}{l}6.0 \\
6.0 \\
6.0 \\
6.0 \\
6.0\end{array}$ & $\begin{array}{l}0.00 \\
0.00 \\
0.00 \\
0.00 \\
0.00\end{array}$ & $\begin{array}{l}0735 \\
0740 \\
0745 \\
0750 \\
0755\end{array}$ & $\begin{array}{l}5.2 \\
5.2 \\
5.2 \\
5.2 \\
5.2\end{array}$ & $\begin{array}{l}0.00 \\
0.00 \\
0.00 \\
0.00 \\
0.00\end{array}$ \\
\hline 0430 & 6.4 & 0.00 & 0615 & 6.0 & 0.00 & 0800 & 5.2 & 0.00 \\
\hline
\end{tabular}




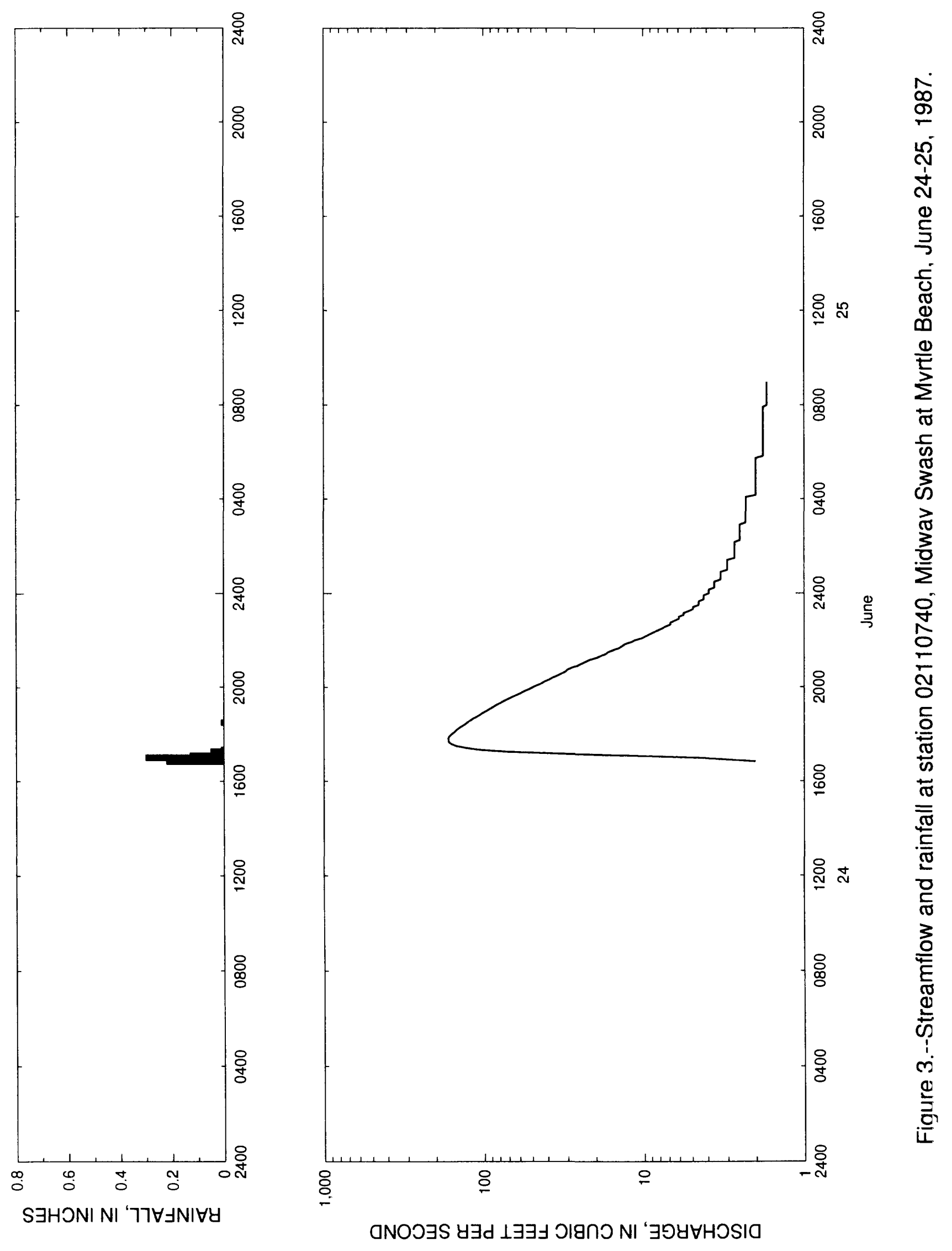


Table 2.-- Streamflow and rainfall at station 02110740, Midway Swash at Myrtle Beach, June $24-25,1987$

\begin{tabular}{|c|c|c|c|c|c|c|c|c|}
\hline $\begin{array}{l}\text { Time } \\
\text { (hours) }\end{array}$ & $\begin{array}{l}\text { Streamflow } \\
\text { (cubic feet } \\
\text { per second) }\end{array}$ & $\begin{array}{l}\text { Rain- } \\
\text { fall } \\
\text { (inches) }\end{array}$ & $\begin{array}{l}\text { Time } \\
\text { (hours) }\end{array}$ & $\begin{array}{l}\text { Streamflow } \\
\text { (cubic feet } \\
\text { per second) }\end{array}$ & $\begin{array}{l}\text { Rain- } \\
\text { fall } \\
\text { (inches) }\end{array}$ & $\begin{array}{l}\text { Time } \\
\text { (hours) }\end{array}$ & $\begin{array}{l}\text { Streamflow } \\
\text { (cubic feet } \\
\text { per second) }\end{array}$ & $\begin{array}{l}\text { Rain- } \\
\text { fall } \\
\text { (inches) }\end{array}$ \\
\hline $\begin{array}{l}\text { June } 24 \text {, } \\
1645 \\
1650 \\
1655 \\
1700\end{array}$ & $\begin{array}{r}1987 \\
1.3 \\
2.0 \\
3.0 \\
4.5\end{array}$ & $\begin{array}{l}0.08 \\
0.22 \\
0.19 \\
0.30\end{array}$ & $\begin{array}{l}2205 \\
2210 \\
2215 \\
2220 \\
2225\end{array}$ & $\begin{array}{r}10.2 \\
9.7 \\
9.2 \\
8.7 \\
8.2\end{array}$ & $\begin{array}{l}0.00 \\
0.00 \\
0.00 \\
0.00 \\
0.00\end{array}$ & $\begin{array}{l}0325 \\
0330 \\
0335 \\
0340 \\
0345\end{array}$ & $\begin{array}{l}2.3 \\
2.3 \\
2.3 \\
2.3 \\
2.3\end{array}$ & $\begin{array}{l}0.00 \\
0.00 \\
0.00 \\
0.00 \\
0.00\end{array}$ \\
\hline $\begin{array}{l}1705 \\
1710 \\
1715 \\
1720 \\
1725\end{array}$ & $\begin{array}{r}10.2 \\
32.7 \\
70.8 \\
106.0 \\
130.0\end{array}$ & $\begin{array}{l}0.13 \\
0.02 \\
0.05 \\
0.01 \\
0.00\end{array}$ & $\begin{array}{l}2230 \\
2235 \\
2240 \\
2245 \\
2250\end{array}$ & $\begin{array}{l}7.7 \\
7.3 \\
6.8 \\
6.8 \\
6.4\end{array}$ & $\begin{array}{l}0.00 \\
0.00 \\
0.00 \\
0.00 \\
0.00\end{array}$ & $\begin{array}{l}0350 \\
0355 \\
0400 \\
0405 \\
0410\end{array}$ & $\begin{array}{l}2.3 \\
2.3 \\
2.3 \\
2.3 \\
2.0\end{array}$ & $\begin{array}{l}0.00 \\
0.00 \\
0.00 \\
0.00 \\
0.00\end{array}$ \\
\hline $\begin{array}{l}1730 \\
1735 \\
1740 \\
1745 \\
1750\end{array}$ & $\begin{array}{l}149.0 \\
160.0 \\
166.0 \\
167.0 \\
167.0\end{array}$ & $\begin{array}{l}0.00 \\
0.00 \\
0.00 \\
0.00 \\
0.00\end{array}$ & $\begin{array}{l}2255 \\
2300 \\
2305 \\
2310 \\
2315\end{array}$ & $\begin{array}{l}6.0 \\
6.0 \\
5.6 \\
5.6 \\
5.2\end{array}$ & $\begin{array}{l}0.00 \\
0.00 \\
0.00 \\
0.00 \\
0.00\end{array}$ & $\begin{array}{l}0415 \\
0420 \\
0425 \\
0430 \\
0435\end{array}$ & $\begin{array}{l}2.0 \\
2.0 \\
2.0 \\
2.0 \\
2.0\end{array}$ & $\begin{array}{l}0.00 \\
0.00 \\
0.00 \\
0.00 \\
0.00\end{array}$ \\
\hline $\begin{array}{l}1755 \\
1800 \\
1805 \\
1810 \\
1815\end{array}$ & $\begin{array}{l}165.0 \\
160.0 \\
154.0 \\
150.0 \\
144.0\end{array}$ & $\begin{array}{l}0.00 \\
0.00 \\
0.00 \\
0.00 \\
0.00\end{array}$ & $\begin{array}{l}2320 \\
2325 \\
2330 \\
2335 \\
2340\end{array}$ & $\begin{array}{l}4.9 \\
4.9 \\
4.5 \\
4.5 \\
4.5\end{array}$ & $\begin{array}{l}0.00 \\
0.00 \\
0.00 \\
0.00 \\
0.00\end{array}$ & $\begin{array}{l}0440 \\
0445 \\
0450 \\
0455 \\
0500\end{array}$ & $\begin{array}{l}2.0 \\
2.0 \\
2.0 \\
2.0 \\
2.0\end{array}$ & $\begin{array}{l}0.00 \\
0.00 \\
0.00 \\
0.00 \\
0.00\end{array}$ \\
\hline $\begin{array}{l}1820 \\
1825 \\
1830 \\
1835 \\
1840\end{array}$ & $\begin{array}{l}138.0 \\
132.0 \\
127.0 \\
122.0 \\
117.0\end{array}$ & $\begin{array}{l}0.00 \\
0.00 \\
0.01 \\
0.00 \\
0.00\end{array}$ & $\begin{array}{l}2345 \\
2350 \\
2355 \\
\text { June } 25 \\
0000\end{array}$ & $\begin{array}{r}4.2 \\
4.2 \\
4.2 \\
1987 \\
\quad 3.9\end{array}$ & $\begin{array}{l}0.00 \\
0.00 \\
0.00 \\
0.00\end{array}$ & $\begin{array}{l}0505 \\
0510 \\
0515 \\
0520 \\
0525\end{array}$ & $\begin{array}{l}2.0 \\
2.0 \\
2.0 \\
2.0 \\
2.0\end{array}$ & $\begin{array}{l}0.00 \\
0.00 \\
0.00 \\
0.00 \\
0.00\end{array}$ \\
\hline $\begin{array}{l}1845 \\
1850 \\
1855 \\
1900 \\
1905\end{array}$ & $\begin{array}{r}111.0 \\
106.0 \\
102.0 \\
96.4 \\
91.9\end{array}$ & $\begin{array}{l}0.00 \\
0.00 \\
0.00 \\
0.00 \\
0.00\end{array}$ & $\begin{array}{l}0005 \\
0010 \\
0015 \\
0020 \\
0025\end{array}$ & $\begin{array}{l}3.9 \\
3.9 \\
3.6 \\
3.6 \\
3.6\end{array}$ & $\begin{array}{l}0.00 \\
0.00 \\
0.00 \\
0.00 \\
0.00\end{array}$ & $\begin{array}{l}0530 \\
0535 \\
0540 \\
0545 \\
0550\end{array}$ & $\begin{array}{l}2.0 \\
2.0 \\
2.0 \\
2.0 \\
1.8\end{array}$ & $\begin{array}{l}0.00 \\
0.00 \\
0.00 \\
0.00 \\
0.00\end{array}$ \\
\hline $\begin{array}{l}1910 \\
1915 \\
1920 \\
1925 \\
1930\end{array}$ & $\begin{array}{l}87.6 \\
83.3 \\
79.1 \\
75.0 \\
70.8\end{array}$ & $\begin{array}{l}0.00 \\
0.00 \\
0.00 \\
0.00 \\
0.00\end{array}$ & $\begin{array}{l}0030 \\
0035 \\
0040 \\
0045 \\
0050\end{array}$ & $\begin{array}{l}3.6 \\
3.3 \\
3.3 \\
3.3 \\
3.3\end{array}$ & $\begin{array}{l}0.00 \\
0.00 \\
0.00 \\
0.00 \\
0.00\end{array}$ & $\begin{array}{l}0555 \\
0600 \\
0605 \\
0610 \\
0615\end{array}$ & $\begin{array}{l}1.8 \\
1.8 \\
1.8 \\
1.8 \\
1.8\end{array}$ & $\begin{array}{l}0.00 \\
0.00 \\
0.00 \\
0.00 \\
0.00\end{array}$ \\
\hline $\begin{array}{l}1935 \\
1940 \\
1945 \\
1950 \\
1955\end{array}$ & $\begin{array}{l}66.7 \\
62.7 \\
58.9 \\
55.8 \\
52.2\end{array}$ & $\begin{array}{l}0.00 \\
0.00 \\
0.00 \\
0.00 \\
0.00\end{array}$ & $\begin{array}{l}0055 \\
0100 \\
0105 \\
0110 \\
0115\end{array}$ & $\begin{array}{l}3.3 \\
3.0 \\
3.0 \\
3.0 \\
3.0\end{array}$ & $\begin{array}{l}0.00 \\
0.00 \\
0.00 \\
0.00 \\
0.00\end{array}$ & $\begin{array}{l}0620 \\
0625 \\
0630 \\
0635 \\
0640\end{array}$ & $\begin{array}{l}1.8 \\
1.8 \\
1.8 \\
1.8 \\
1.8\end{array}$ & $\begin{array}{l}0.00 \\
0.00 \\
0.00 \\
0.00 \\
0.00\end{array}$ \\
\hline $\begin{array}{l}2000 \\
2005 \\
2010 \\
2015 \\
2020\end{array}$ & $\begin{array}{l}49.3 \\
46.4 \\
43.6 \\
41.6 \\
38.9\end{array}$ & $\begin{array}{l}0.00 \\
0.00 \\
0.00 \\
0.00 \\
0.00\end{array}$ & $\begin{array}{l}0120 \\
0125 \\
0130 \\
0135 \\
0140\end{array}$ & $\begin{array}{l}3.0 \\
3.0 \\
2.7 \\
2.7 \\
2.7\end{array}$ & $\begin{array}{l}0.00 \\
0.00 \\
0.00 \\
0.00 \\
0.00\end{array}$ & $\begin{array}{l}0645 \\
0650 \\
0655 \\
0700 \\
0705\end{array}$ & $\begin{array}{l}1.8 \\
1.8 \\
1.8 \\
1.8 \\
1.8\end{array}$ & $\begin{array}{l}0.00 \\
0.00 \\
0.00 \\
0.00 \\
0.00\end{array}$ \\
\hline $\begin{array}{l}2025 \\
2030 \\
2035 \\
2040 \\
2045\end{array}$ & $\begin{array}{l}37.0 \\
34.5 \\
32.7 \\
30.9 \\
29.7\end{array}$ & $\begin{array}{l}0.00 \\
0.00 \\
0.00 \\
0.00 \\
0.00\end{array}$ & $\begin{array}{l}0145 \\
0150 \\
0155 \\
0200 \\
0205\end{array}$ & $\begin{array}{l}2.7 \\
2.7 \\
2.7 \\
2.7 \\
2.7\end{array}$ & $\begin{array}{l}0.00 \\
0.00 \\
0.00 \\
0.00 \\
0.00\end{array}$ & $\begin{array}{l}0710 \\
0715 \\
0720 \\
0725 \\
0730\end{array}$ & $\begin{array}{l}1.8 \\
1.8 \\
1.8 \\
1.8 \\
1.8\end{array}$ & $\begin{array}{l}0.00 \\
0.00 \\
0.00 \\
0.00 \\
0.00\end{array}$ \\
\hline $\begin{array}{l}2050 \\
2055 \\
2100 \\
2105 \\
2110\end{array}$ & $\begin{array}{l}28.0 \\
25.9 \\
24.5 \\
23.1 \\
21.8\end{array}$ & $\begin{array}{l}0.00 \\
0.00 \\
0.00 \\
0.00 \\
0.00\end{array}$ & $\begin{array}{l}0210 \\
0215 \\
0220 \\
0225 \\
0230\end{array}$ & $\begin{array}{l}2.7 \\
2.5 \\
2.5 \\
2.5 \\
2.5\end{array}$ & $\begin{array}{l}0.00 \\
0.00 \\
0.00 \\
0.00 \\
0.00\end{array}$ & $\begin{array}{l}0735 \\
0740 \\
0745 \\
0750 \\
0755\end{array}$ & $\begin{array}{l}1.8 \\
1.8 \\
1.8 \\
1.8 \\
1.8\end{array}$ & $\begin{array}{l}0.00 \\
0.00 \\
0.00 \\
0.00 \\
0.00\end{array}$ \\
\hline $\begin{array}{l}2115 \\
2120 \\
2125 \\
2130 \\
2135\end{array}$ & $\begin{array}{l}19.7 \\
18.4 \\
17.2 \\
16.6 \\
15.4\end{array}$ & $\begin{array}{l}0.00 \\
0.00 \\
0.00 \\
0.00 \\
0.00\end{array}$ & $\begin{array}{l}0235 \\
0240 \\
0245 \\
0250 \\
0255\end{array}$ & $\begin{array}{l}2.5 \\
2.5 \\
2.5 \\
2.5 \\
2.5\end{array}$ & $\begin{array}{l}0.00 \\
0.00 \\
0.00 \\
0.00 \\
0.00\end{array}$ & $\begin{array}{l}0800 \\
0805 \\
0810 \\
0815 \\
0820\end{array}$ & $\begin{array}{l}1.7 \\
1.7 \\
1.7 \\
1.7 \\
1.7\end{array}$ & $\begin{array}{l}0.00 \\
0.00 \\
0.00 \\
0.00 \\
0.00\end{array}$ \\
\hline $\begin{array}{l}2140 \\
2145 \\
2150 \\
2155 \\
2200\end{array}$ & $\begin{array}{l}14.2 \\
13.6 \\
13.0 \\
11.9 \\
11.3\end{array}$ & $\begin{array}{l}0.00 \\
0.00 \\
0.00 \\
0.00 \\
0.00\end{array}$ & $\begin{array}{l}0300 \\
0305 \\
0310 \\
0315 \\
0320\end{array}$ & $\begin{array}{l}2.3 \\
2.3 \\
2.3 \\
2.3 \\
2.3\end{array}$ & $\begin{array}{l}0.00 \\
0.00 \\
0.00 \\
0.00 \\
0.00\end{array}$ & $\begin{array}{l}0825 \\
0830 \\
0835 \\
0840 \\
0845\end{array}$ & $\begin{array}{l}1.7 \\
1.7 \\
1.7 \\
1.7 \\
1.7\end{array}$ & $\begin{array}{l}0.00 \\
0.00 \\
0.00 \\
0.00 \\
0.00\end{array}$ \\
\hline $\begin{array}{l}\text { June } 25 \text {, } \\
0850\end{array}$ & $\begin{array}{ll}1987 & \\
& 1.7\end{array}$ & 0.00 & 0855 & 1.7 & 0.00 & 0900 & 1.7 & 0.00 \\
\hline
\end{tabular}




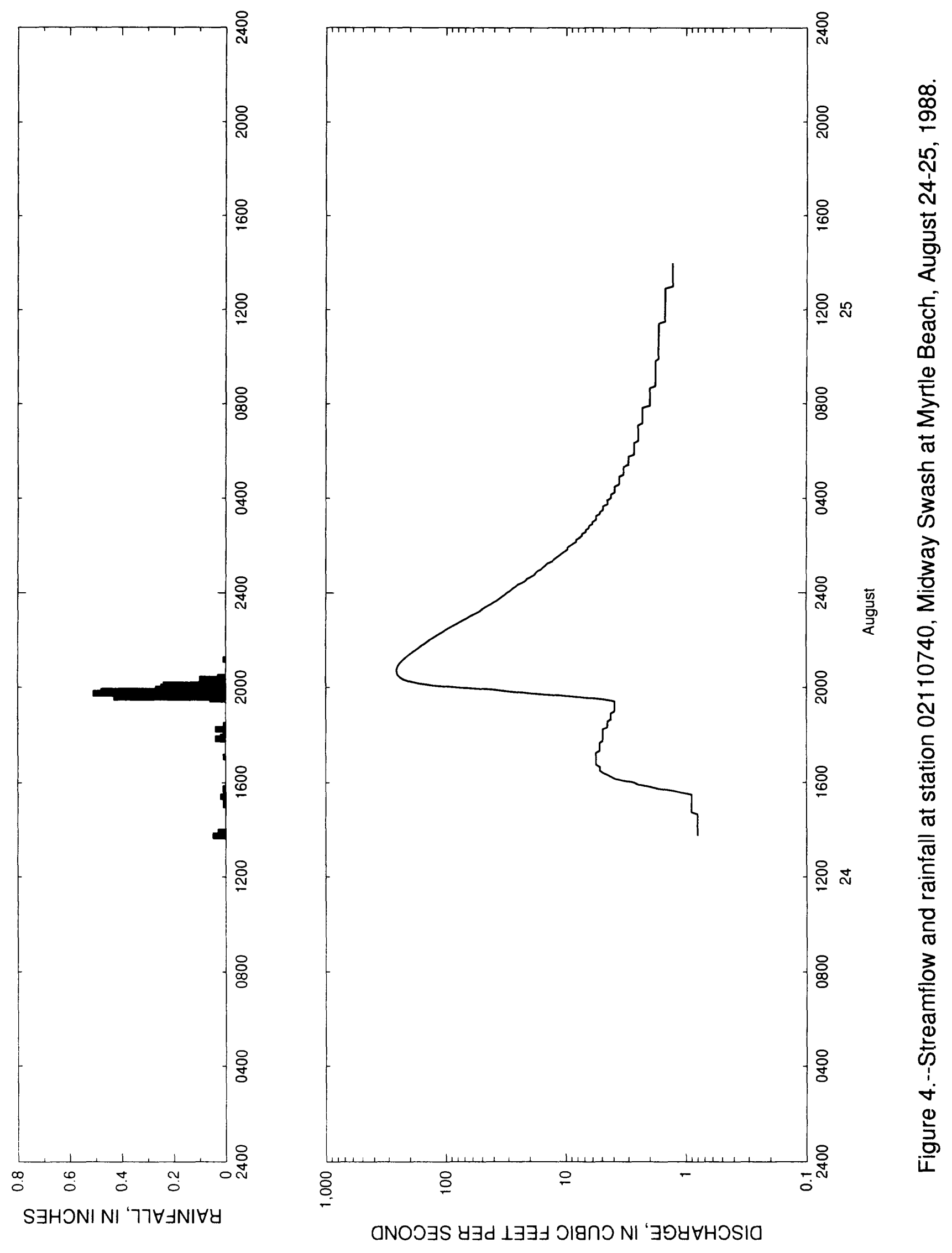


Table 3.--Streamflow and rainfall at station 02110740 . Midway Swash at Myrtle Beach, August $24-25,1988$

\begin{tabular}{|c|c|c|c|c|c|c|c|c|}
\hline $\begin{array}{l}\text { Time } \\
\text { (hours) }\end{array}$ & $\begin{array}{l}\text { Streamflow } \\
\text { (cubic feet } \\
\text { per second) }\end{array}$ & $\begin{array}{l}\text { Rain- } \\
\text { fall } \\
\text { (inches) }\end{array}$ & $\begin{array}{l}\text { Time } \\
\text { (hours) }\end{array}$ & $\begin{array}{l}\text { Streamflow } \\
\text { (cubic feet } \\
\text { per second) }\end{array}$ & $\begin{array}{l}\text { Rain- } \\
\text { fall } \\
\text { (inches) }\end{array}$ & $\begin{array}{l}\text { Time } \\
\text { (hours) }\end{array}$ & $\begin{array}{l}\text { Streamflow } \\
\text { (cubic feet } \\
\text { per second) }\end{array}$ & $\begin{array}{l}\text { Rain- } \\
\text { fall } \\
\text { (inches) }\end{array}$ \\
\hline $\begin{array}{c}\text { August } \\
1340 \\
1345 \\
1350 \\
1355\end{array}$ & $\begin{array}{r}24,1988 \\
0.8 \\
0.8 \\
0.8 \\
0.8\end{array}$ & $\begin{array}{l}0.01 \\
0.05 \\
0.03 \\
0.03\end{array}$ & $\begin{array}{l}1900 \\
1905 \\
1910 \\
1915 \\
1920\end{array}$ & $\begin{array}{l}3.9 \\
3.9 \\
3.9 \\
3.9 \\
3.9\end{array}$ & $\begin{array}{l}0.00 \\
0.00 \\
0.00 \\
0.00 \\
0.00\end{array}$ & $\begin{array}{l}0020 \\
0025 \\
0030 \\
0035 \\
0040\end{array}$ & $\begin{array}{l}25.2 \\
23.1 \\
21.8 \\
21.1 \\
19.7\end{array}$ & $\begin{array}{l}0.00 \\
0.00 \\
0.00 \\
0.00 \\
0.00\end{array}$ \\
\hline $\begin{array}{l}1400 \\
1405 \\
1410 \\
1415 \\
1420\end{array}$ & $\begin{array}{l}0.8 \\
0.8 \\
0.8 \\
0.8 \\
0.8\end{array}$ & $\begin{array}{l}0.00 \\
0.00 \\
0.00 \\
0.00 \\
0.00\end{array}$ & $\begin{array}{l}1925 \\
1930 \\
1935 \\
1940 \\
1945\end{array}$ & $\begin{array}{r}3.9 \\
4.9 \\
7.3 \\
11.3 \\
19.1\end{array}$ & $\begin{array}{l}0.00 \\
0.06 \\
0.43 \\
0.35 \\
0.51\end{array}$ & $\begin{array}{l}0045 \\
0050 \\
0055 \\
0100 \\
0105\end{array}$ & $\begin{array}{l}18.4 \\
17.8 \\
17.2 \\
16.0 \\
15.4\end{array}$ & $\begin{array}{l}0.00 \\
0.00 \\
0.00 \\
0.00 \\
0.00\end{array}$ \\
\hline $\begin{array}{l}1425 \\
1430 \\
1435 \\
1440 \\
1445\end{array}$ & $\begin{array}{l}0.8 \\
0.8 \\
0.8 \\
0.8 \\
0.9\end{array}$ & $\begin{array}{l}0.00 \\
0.00 \\
0.00 \\
0.00 \\
0.00\end{array}$ & $\begin{array}{l}1950 \\
1955 \\
2000 \\
2005 \\
2010\end{array}$ & $\begin{array}{r}29.7 \\
41.6 \\
79.9 \\
130.0 \\
172.0\end{array}$ & $\begin{array}{l}0.48 \\
0.27 \\
0.25 \\
0.24 \\
0.10\end{array}$ & $\begin{array}{l}0110 \\
0115 \\
0120 \\
0125 \\
0130\end{array}$ & $\begin{array}{l}14.8 \\
14.2 \\
13.0 \\
12.5 \\
11.9\end{array}$ & $\begin{array}{l}0.00 \\
0.00 \\
0.00 \\
0.00 \\
0.00\end{array}$ \\
\hline $\begin{array}{l}1450 \\
1455 \\
1500 \\
1505 \\
1510\end{array}$ & $\begin{array}{l}0.9 \\
0.9 \\
0.9 \\
0.9 \\
0.9\end{array}$ & $\begin{array}{l}0.00 \\
0.00 \\
0.00 \\
0.01 \\
0.01\end{array}$ & $\begin{array}{l}2015 \\
2020 \\
2025 \\
2030 \\
2035\end{array}$ & $\begin{array}{l}203.0 \\
226.0 \\
240.0 \\
250.0 \\
255.0\end{array}$ & $\begin{array}{l}0.10 \\
0.10 \\
0.03 \\
0.00 \\
0.00\end{array}$ & $\begin{array}{l}0135 \\
0140 \\
0145 \\
0150 \\
0155\end{array}$ & $\begin{array}{r}11.3 \\
10.8 \\
10.2 \\
9.7 \\
9.7\end{array}$ & $\begin{array}{l}0.00 \\
0.00 \\
0.00 \\
0.00 \\
0.00\end{array}$ \\
\hline $\begin{array}{l}1515 \\
1520 \\
1525 \\
1530 \\
1535\end{array}$ & $\begin{array}{l}0.9 \\
0.9 \\
0.9 \\
0.9 \\
1.1\end{array}$ & $\begin{array}{l}0.01 \\
0.00 \\
0.02 \\
0.01 \\
0.00\end{array}$ & $\begin{array}{l}2040 \\
2045 \\
2050 \\
2055 \\
2100\end{array}$ & $\begin{array}{l}256.0 \\
256.0 \\
254.0 \\
249.0 \\
243.0\end{array}$ & $\begin{array}{l}0.00 \\
0.00 \\
0.00 \\
0.00 \\
0.00\end{array}$ & $\begin{array}{l}0200 \\
0205 \\
0210 \\
0215 \\
0220\end{array}$ & $\begin{array}{l}9.2 \\
8.7 \\
8.2 \\
8.2 \\
7.7\end{array}$ & $\begin{array}{l}0.00 \\
0.00 \\
0.00 \\
0.00 \\
0.00\end{array}$ \\
\hline $\begin{array}{l}1540 \\
1545 \\
1550 \\
1555 \\
1600\end{array}$ & $\begin{array}{l}1.3 \\
1.7 \\
2.0 \\
2.5 \\
2.7\end{array}$ & $\begin{array}{l}0.01 \\
0.01 \\
0.00 \\
0.00 \\
0.00\end{array}$ & $\begin{array}{l}2105 \\
2110 \\
2115 \\
2120 \\
2125\end{array}$ & $\begin{array}{l}234.0 \\
226.0 \\
216.0 \\
207.0 \\
196.0\end{array}$ & $\begin{array}{l}0.00 \\
0.01 \\
0.00 \\
0.00 \\
0.00\end{array}$ & $\begin{array}{l}0225 \\
0230 \\
0235 \\
0240 \\
0245\end{array}$ & $\begin{array}{l}7.3 \\
7.3 \\
6.8 \\
6.8 \\
6.4\end{array}$ & $\begin{array}{l}0.00 \\
0.00 \\
0.00 \\
0.00 \\
0.00\end{array}$ \\
\hline $\begin{array}{l}1605 \\
1610 \\
1615 \\
1620 \\
1625\end{array}$ & $\begin{array}{l}3.3 \\
3.9 \\
4.2 \\
4.5 \\
4.9\end{array}$ & $\begin{array}{l}0.00 \\
0.00 \\
0.00 \\
0.00 \\
0.00\end{array}$ & $\begin{array}{l}2130 \\
2135 \\
2140 \\
2145 \\
2150\end{array}$ & $\begin{array}{l}186.0 \\
177.0 \\
168.0 \\
160.0 \\
150.0\end{array}$ & $\begin{array}{l}0.00 \\
0.00 \\
0.00 \\
0.00 \\
0.00\end{array}$ & $\begin{array}{l}0250 \\
0255 \\
0300 \\
0305 \\
0310\end{array}$ & $\begin{array}{l}6.4 \\
6.0 \\
6.0 \\
5.6 \\
5.6\end{array}$ & $\begin{array}{l}0.00 \\
0.00 \\
0.00 \\
0.00 \\
0.00\end{array}$ \\
\hline $\begin{array}{l}1630 \\
1635 \\
1640 \\
1645 \\
1650\end{array}$ & $\begin{array}{l}5.2 \\
5.2 \\
5.2 \\
5.6 \\
5.6\end{array}$ & $\begin{array}{l}0.00 \\
0.00 \\
0.00 \\
0.00 \\
0.00\end{array}$ & $\begin{array}{l}2155 \\
2200 \\
2205 \\
2210 \\
2215\end{array}$ & $\begin{array}{l}143.0 \\
136.0 \\
128.0 \\
121.0 \\
114.0\end{array}$ & $\begin{array}{l}0.00 \\
0.00 \\
0.00 \\
0.00 \\
0.00\end{array}$ & $\begin{array}{l}0315 \\
0320 \\
0325 \\
0330 \\
0335\end{array}$ & $\begin{array}{l}5.6 \\
5.2 \\
5.2 \\
4.9 \\
4.9\end{array}$ & $\begin{array}{l}0.00 \\
0.00 \\
0.00 \\
0.00 \\
0.00\end{array}$ \\
\hline $\begin{array}{l}1655 \\
1700 \\
1705 \\
1710 \\
1715\end{array}$ & $\begin{array}{l}5.6 \\
5.6 \\
5.6 \\
5.6 \\
5.6\end{array}$ & $\begin{array}{l}0.00 \\
0.00 \\
0.01 \\
0.00 \\
0.00\end{array}$ & $\begin{array}{l}2220 \\
2225 \\
2230 \\
2235 \\
2240\end{array}$ & $\begin{array}{r}107.0 \\
101.0 \\
94.6 \\
88.4 \\
82.4\end{array}$ & $\begin{array}{l}0.00 \\
0.00 \\
0.00 \\
0.00 \\
0.00\end{array}$ & $\begin{array}{l}0340 \\
0345 \\
0350 \\
0355 \\
0400\end{array}$ & $\begin{array}{l}4.9 \\
4.5 \\
4.5 \\
4.5 \\
4.2\end{array}$ & $\begin{array}{l}0.00 \\
0.00 \\
0.00 \\
0.00 \\
0.00\end{array}$ \\
\hline $\begin{array}{l}1720 \\
1725 \\
1730 \\
1735 \\
1740\end{array}$ & $\begin{array}{l}5.2 \\
5.2 \\
5.2 \\
5.2 \\
5.2\end{array}$ & $\begin{array}{l}0.00 \\
0.00 \\
0.00 \\
0.00 \\
0.00\end{array}$ & $\begin{array}{l}2245 \\
2250 \\
2255 \\
2300 \\
2305\end{array}$ & $\begin{array}{l}77.4 \\
72.5 \\
67.5 \\
63.5 \\
58.9\end{array}$ & $\begin{array}{l}0.00 \\
0.00 \\
0.00 \\
0.00 \\
0.00\end{array}$ & $\begin{array}{l}0405 \\
0410 \\
0415 \\
0420 \\
0425\end{array}$ & $\begin{array}{l}4.2 \\
4.2 \\
3.9 \\
3.9 \\
3.9\end{array}$ & $\begin{array}{l}0.00 \\
0.00 \\
0.00 \\
0.00 \\
0.00\end{array}$ \\
\hline $\begin{array}{l}1745 \\
1750 \\
1755 \\
1800 \\
1805\end{array}$ & $\begin{array}{l}4.9 \\
4.9 \\
4.9 \\
4.9 \\
4.9\end{array}$ & $\begin{array}{l}0.00 \\
0.04 \\
0.02 \\
0.00 \\
0.01\end{array}$ & $\begin{array}{l}2310 \\
2315 \\
2320 \\
2325 \\
2330\end{array}$ & $\begin{array}{l}55.1 \\
51.4 \\
48.5 \\
45.7 \\
42.3\end{array}$ & $\begin{array}{l}0.00 \\
0.00 \\
0.00 \\
0.00 \\
0.00\end{array}$ & $\begin{array}{l}0430 \\
0435 \\
0440 \\
0445 \\
0450\end{array}$ & $\begin{array}{l}3.9 \\
3.6 \\
3.6 \\
3.6 \\
3.6\end{array}$ & $\begin{array}{l}0.00 \\
0.00 \\
0.00 \\
0.00 \\
0.00\end{array}$ \\
\hline $\begin{array}{l}1810 \\
1815 \\
1820 \\
1825 \\
1830\end{array}$ & $\begin{array}{l}4.9 \\
4.9 \\
4.5 \\
4.5 \\
4.5\end{array}$ & $\begin{array}{l}0.00 \\
0.04 \\
0.01 \\
0.01 \\
0.00\end{array}$ & $\begin{array}{l}2335 \\
2340 \\
2345 \\
2350 \\
2355\end{array}$ & $\begin{array}{l}40.2 \\
37.6 \\
35.7 \\
33.9 \\
32.1\end{array}$ & $\begin{array}{l}0.00 \\
0.00 \\
0.00 \\
0.00 \\
0.00\end{array}$ & $\begin{array}{l}0455 \\
0500 \\
0505 \\
0510 \\
0515\end{array}$ & $\begin{array}{l}3.6 \\
3.3 \\
3.3 \\
3.3 \\
3.3\end{array}$ & $\begin{array}{l}0.00 \\
0.00 \\
0.00 \\
0.00 \\
0.00\end{array}$ \\
\hline $\begin{array}{l}1835 \\
1840 \\
1845 \\
1850 \\
1855\end{array}$ & $\begin{array}{l}4.5 \\
4.2 \\
4.2 \\
4.2 \\
4.2\end{array}$ & $\begin{array}{l}0.00 \\
0.00 \\
0.00 \\
0.00 \\
0.00\end{array}$ & $\begin{array}{l}\text { August } \\
0000 \\
0005 \\
0010 \\
0015\end{array}$ & $\begin{array}{r}1988 \\
30.9 \\
29.1 \\
28.0 \\
26.6\end{array}$ & $\begin{array}{l}0.00 \\
0.00 \\
0.00 \\
0.00\end{array}$ & $\begin{array}{l}0520 \\
0525 \\
0530 \\
0535 \\
0540\end{array}$ & $\begin{array}{l}3.3 \\
3.0 \\
3.0 \\
3.0 \\
3.0\end{array}$ & $\begin{array}{l}0.00 \\
0.00 \\
0.00 \\
0.00 \\
0.00\end{array}$ \\
\hline
\end{tabular}


Table 3.--Streamflow and rainfall at station 02110740, Midway Swash at Myrtle Beach. August $24-25,1988^{--C o n t i n u e d}$

\begin{tabular}{|c|c|c|c|c|c|c|c|c|}
\hline $\begin{array}{l}\text { Time } \\
\text { (hours) }\end{array}$ & $\begin{array}{l}\text { Streamflow } \\
\text { (cubic feet } \\
\text { per second) }\end{array}$ & $\begin{array}{l}\text { Rain- } \\
\text { fall } \\
\text { (inches) }\end{array}$ & $\begin{array}{l}\text { Time } \\
\text { (hours) }\end{array}$ & $\begin{array}{l}\text { Streamflow } \\
\text { (cubic feet } \\
\text { per second) }\end{array}$ & $\begin{array}{l}\text { Rain- } \\
\text { fall } \\
\text { (inches) }\end{array}$ & $\begin{array}{l}\text { Time } \\
\text { (hours) }\end{array}$ & $\begin{array}{l}\text { Streamflow } \\
\text { (cubic feet } \\
\text { per second) }\end{array}$ & $\begin{array}{l}\text { Rain- } \\
\text { fall } \\
\text { (inches) }\end{array}$ \\
\hline $\begin{array}{l}0545 \\
0550 \\
0555 \\
0600 \\
0605\end{array}$ & $\begin{array}{l}3.0 \\
2.7 \\
2.7 \\
2.7 \\
2.7\end{array}$ & $\begin{array}{l}0.00 \\
0.00 \\
0.00 \\
0.00 \\
0.00\end{array}$ & $\begin{array}{l}0835 \\
0840 \\
0845 \\
0850 \\
0855\end{array}$ & $\begin{array}{l}2.0 \\
2.0 \\
1.8 \\
1.8 \\
1.8\end{array}$ & $\begin{array}{l}0.00 \\
0.00 \\
0.00 \\
0.00 \\
0.00\end{array}$ & $\begin{array}{l}1125 \\
1130 \\
1135 \\
1140 \\
1145\end{array}$ & $\begin{array}{l}1.7 \\
1.5 \\
1.5 \\
1.5 \\
1.5\end{array}$ & $\begin{array}{l}0.00 \\
0.00 \\
0.00 \\
0.00 \\
0.00\end{array}$ \\
\hline $\begin{array}{l}0610 \\
0615 \\
0620 \\
0625 \\
0630\end{array}$ & $\begin{array}{l}2.7 \\
2.7 \\
2.7 \\
2.5 \\
2.5\end{array}$ & $\begin{array}{l}0.00 \\
0.00 \\
0.00 \\
0.00 \\
0.00\end{array}$ & $\begin{array}{l}0900 \\
0905 \\
0910 \\
0915 \\
0920\end{array}$ & $\begin{array}{l}1.8 \\
1.8 \\
1.8 \\
1.8 \\
1.8\end{array}$ & $\begin{array}{l}0.00 \\
0.00 \\
0.00 \\
0.00 \\
0.00\end{array}$ & $\begin{array}{l}1150 \\
1155 \\
1200 \\
1205 \\
1210\end{array}$ & $\begin{array}{l}1.5 \\
1.5 \\
1.5 \\
1.5 \\
1.5\end{array}$ & $\begin{array}{l}0.00 \\
0.00 \\
0.00 \\
0.00 \\
0.00\end{array}$ \\
\hline $\begin{array}{l}0635 \\
0640 \\
0645 \\
0650 \\
0655\end{array}$ & $\begin{array}{l}2.5 \\
2.5 \\
2.5 \\
2.5 \\
2.5\end{array}$ & $\begin{array}{l}0.00 \\
0.00 \\
0.00 \\
0.00 \\
0.00\end{array}$ & $\begin{array}{l}0925 \\
0930 \\
0935 \\
0940 \\
0945\end{array}$ & $\begin{array}{l}1.8 \\
1.8 \\
1.8 \\
1.8 \\
1.8\end{array}$ & $\begin{array}{l}0.00 \\
0.00 \\
0.00 \\
0.00 \\
0.00\end{array}$ & $\begin{array}{l}1215 \\
1220 \\
1225 \\
1230 \\
1235\end{array}$ & $\begin{array}{l}1.5 \\
1.5 \\
1.5 \\
1.5 \\
1.5\end{array}$ & $\begin{array}{l}0.00 \\
0.00 \\
0.00 \\
0.00 \\
0.00\end{array}$ \\
\hline $\begin{array}{l}0700 \\
0705 \\
0710 \\
0715 \\
0720\end{array}$ & $\begin{array}{l}2.5 \\
2.5 \\
2.3 \\
2.3 \\
2.3\end{array}$ & $\begin{array}{l}0.00 \\
0.00 \\
0.00 \\
0.00 \\
0.00\end{array}$ & $\begin{array}{l}0950 \\
0955 \\
1000 \\
1005 \\
1010\end{array}$ & $\begin{array}{l}1.8 \\
1.7 \\
1.7 \\
1.7 \\
1.7\end{array}$ & $\begin{array}{l}0.00 \\
0.00 \\
0.00 \\
0.00 \\
0.00\end{array}$ & $\begin{array}{l}1240 \\
1245 \\
1250 \\
1255 \\
1300\end{array}$ & $\begin{array}{l}1.5 \\
1.5 \\
1.5 \\
1.5 \\
1.3\end{array}$ & $\begin{array}{l}0.00 \\
0.00 \\
0.00 \\
0.00 \\
0.00\end{array}$ \\
\hline $\begin{array}{l}0725 \\
0730 \\
0735 \\
0740 \\
0745\end{array}$ & $\begin{array}{l}2.3 \\
2.3 \\
2.3 \\
2.3 \\
2.3\end{array}$ & $\begin{array}{l}0.00 \\
0.00 \\
0.00 \\
0.00 \\
0.00\end{array}$ & $\begin{array}{l}1015 \\
1020 \\
1025 \\
1030 \\
1035\end{array}$ & $\begin{array}{l}1.7 \\
1.7 \\
1.7 \\
1.7 \\
1.7\end{array}$ & $\begin{array}{l}0.00 \\
0.00 \\
0.00 \\
0.00 \\
0.00\end{array}$ & $\begin{array}{l}1305 \\
1310 \\
1315 \\
1320 \\
1325\end{array}$ & $\begin{array}{l}1.3 \\
1.3 \\
1.3 \\
1.3 \\
1.3\end{array}$ & $\begin{array}{l}0.00 \\
0.00 \\
0.00 \\
0.00 \\
0.00\end{array}$ \\
\hline $\begin{array}{l}0750 \\
0755 \\
0800 \\
0805 \\
0810\end{array}$ & $\begin{array}{l}2.3 \\
2.0 \\
2.0 \\
2.0 \\
2.0\end{array}$ & $\begin{array}{l}0.00 \\
0.00 \\
0.00 \\
0.00 \\
0.00\end{array}$ & $\begin{array}{l}1040 \\
1045 \\
1050 \\
1055 \\
1100\end{array}$ & $\begin{array}{l}1.7 \\
1.7 \\
1.7 \\
1.7 \\
1.7\end{array}$ & $\begin{array}{l}0.00 \\
0.00 \\
0.00 \\
0.00 \\
0.00\end{array}$ & $\begin{array}{l}1330 \\
1335 \\
1340 \\
1345 \\
1350\end{array}$ & $\begin{array}{l}1.3 \\
1.3 \\
1.3 \\
1.3 \\
1.3\end{array}$ & $\begin{array}{l}0.00 \\
0.00 \\
0.00 \\
0.00 \\
0.00\end{array}$ \\
\hline $\begin{array}{l}0815 \\
0820 \\
0825 \\
0830\end{array}$ & $\begin{array}{l}2.0 \\
2.0 \\
2.0 \\
2.0\end{array}$ & $\begin{array}{l}0.00 \\
0.00 \\
0.00 \\
0.00\end{array}$ & $\begin{array}{l}1105 \\
1110 \\
1115 \\
1120\end{array}$ & $\begin{array}{l}1.7 \\
1.7 \\
1.7 \\
1.7\end{array}$ & $\begin{array}{l}0.00 \\
0.00 \\
0.00 \\
0.00\end{array}$ & $\begin{array}{l}1355 \\
1400\end{array}$ & $\begin{array}{l}1.3 \\
1.3\end{array}$ & $\begin{array}{l}0.00 \\
0.00\end{array}$ \\
\hline
\end{tabular}



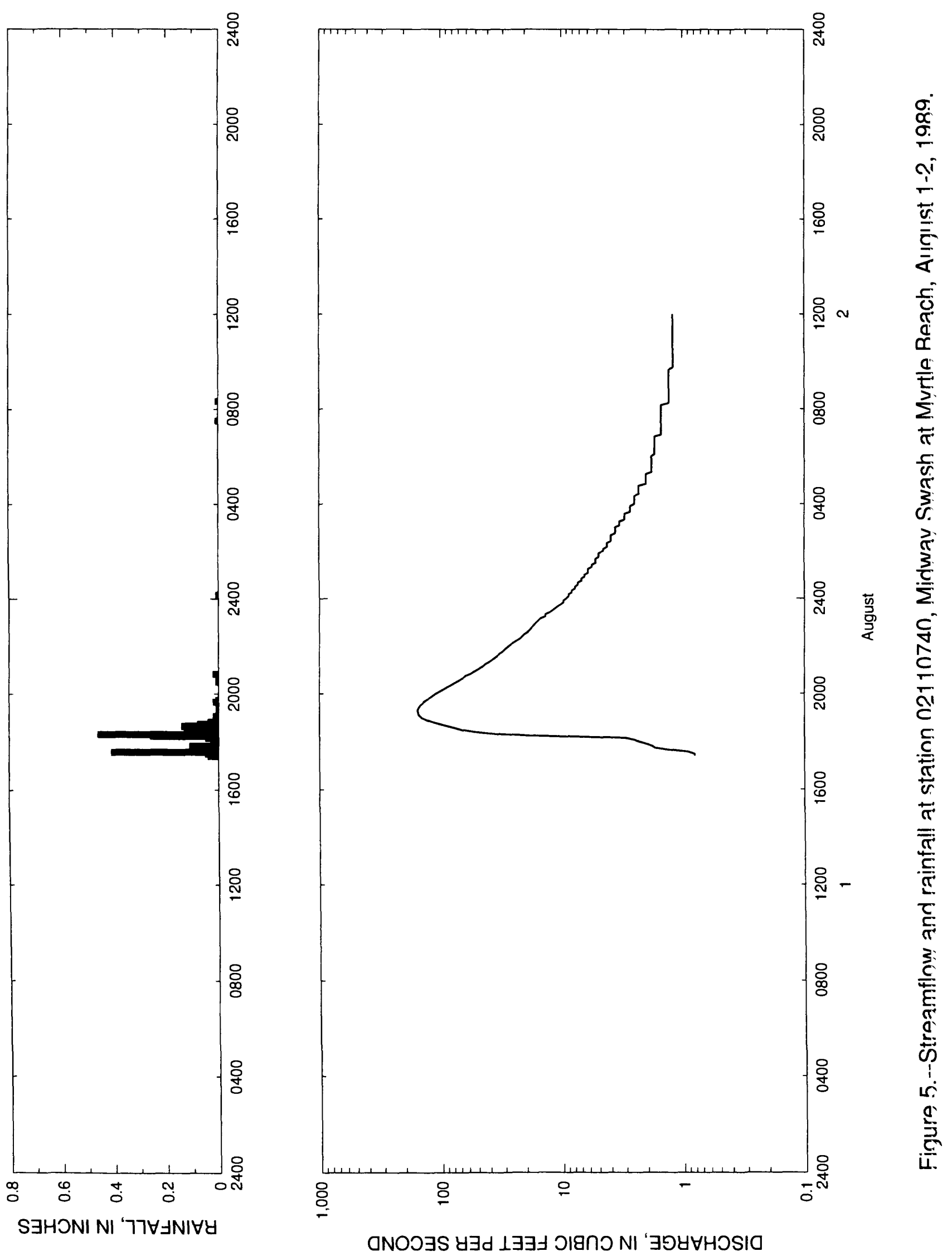
Table 4. - - Streamflow and rainfall at station 02110740, Midway Swash at Myrtle Beach, August $1-2,1989$

\begin{tabular}{|c|c|c|c|c|c|c|c|c|}
\hline $\begin{array}{l}\text { Time } \\
\text { (hours) }\end{array}$ & $\begin{array}{l}\text { Streamflow } \\
\text { (cubic feet } \\
\text { per second) }\end{array}$ & $\begin{array}{l}\text { Rain- } \\
\text { fall } \\
\text { (inches) }\end{array}$ & $\begin{array}{l}\text { Time } \\
\text { (hours) }\end{array}$ & $\begin{array}{l}\text { Streamflow } \\
\text { (cubic feet } \\
\text { per second) }\end{array}$ & $\begin{array}{l}\text { Rain- } \\
\text { fall } \\
\text { (inches) }\end{array}$ & $\begin{array}{l}\text { Time } \\
\text { (hours) }\end{array}$ & $\begin{array}{l}\text { Streamflow } \\
\text { (cubic feet } \\
\text { per second) }\end{array}$ & $\begin{array}{l}\text { Rain- } \\
\text { fall } \\
\text { (inches) }\end{array}$ \\
\hline $\begin{array}{c}\text { August } \\
1725 \\
1730 \\
1735 \\
1740\end{array}$ & $\begin{array}{r}1989 \\
0.8 \\
0.8 \\
0.9 \\
1.3\end{array}$ & $\begin{array}{l}0.04 \\
0.05 \\
0.41 \\
0.05\end{array}$ & $\begin{array}{l}2245 \\
2250 \\
2255 \\
2300 \\
2305\end{array}$ & $\begin{array}{l}17.8 \\
17.2 \\
16.6 \\
16.0 \\
15.4\end{array}$ & $\begin{array}{l}0.00 \\
0.00 \\
0.00 \\
0.00 \\
0.00\end{array}$ & $\begin{array}{l}0405 \\
0410 \\
0415 \\
0420 \\
0425\end{array}$ & $\begin{array}{l}2.5 \\
2.5 \\
2.5 \\
2.5 \\
2.3\end{array}$ & $\begin{array}{l}0.00 \\
0.00 \\
0.00 \\
0.00 \\
0.00\end{array}$ \\
\hline $\begin{array}{l}1745 \\
1750 \\
1755 \\
1800 \\
1805\end{array}$ & $\begin{array}{l}1.7 \\
1.8 \\
2.0 \\
2.3 \\
2.5\end{array}$ & $\begin{array}{l}0.09 \\
0.11 \\
0.03 \\
0.03 \\
0.03\end{array}$ & $\begin{array}{l}2310 \\
2315 \\
2320 \\
2325 \\
2330\end{array}$ & $\begin{array}{l}14.8 \\
13.6 \\
13.6 \\
12.5 \\
11.9\end{array}$ & $\begin{array}{l}0.00 \\
0.00 \\
0.00 \\
0.00 \\
0.00\end{array}$ & $\begin{array}{l}0430 \\
0435 \\
0440 \\
0445 \\
0450\end{array}$ & $\begin{array}{l}2.3 \\
2.3 \\
2.3 \\
2.3 \\
2.0\end{array}$ & $\begin{array}{l}0.00 \\
0.00 \\
0.00 \\
0.00 \\
0.00\end{array}$ \\
\hline $\begin{array}{l}1810 \\
1815 \\
1820 \\
1825 \\
1830\end{array}$ & $\begin{array}{r}3.0 \\
15.4 \\
33.3 \\
50.0 \\
65.9\end{array}$ & $\begin{array}{l}0.05 \\
0.26 \\
0.46 \\
0.06 \\
0.13\end{array}$ & $\begin{array}{l}2335 \\
2340 \\
2345 \\
2350 \\
2355\end{array}$ & $\begin{array}{r}11.3 \\
10.8 \\
10.2 \\
9.7 \\
9.7\end{array}$ & $\begin{array}{l}0.00 \\
0.00 \\
0.00 \\
0.00 \\
0.00\end{array}$ & $\begin{array}{l}0455 \\
0500 \\
0505 \\
0510 \\
0515\end{array}$ & $\begin{array}{l}2.0 \\
2.0 \\
2.0 \\
2.0 \\
2.0\end{array}$ & $\begin{array}{l}0.00 \\
0.00 \\
0.00 \\
0.00 \\
0.00\end{array}$ \\
\hline $\begin{array}{l}1835 \\
1840 \\
1845 \\
1850 \\
1855\end{array}$ & $\begin{array}{r}75.8 \\
88.4 \\
104.0 \\
119.0 \\
132.0\end{array}$ & $\begin{array}{l}0.05 \\
0.14 \\
0.08 \\
0.04 \\
0.01\end{array}$ & $\begin{array}{c}\text { August } \\
0000 \\
0005 \\
0010 \\
0015\end{array}$ & $\begin{array}{r}1989 \\
9.2 \\
8.7 \\
8.7 \\
8.2\end{array}$ & $\begin{array}{l}0.00 \\
0.00 \\
0.01 \\
0.00\end{array}$ & $\begin{array}{l}0520 \\
0525 \\
0530 \\
0535 \\
0540\end{array}$ & $\begin{array}{l}1.8 \\
1.8 \\
1.8 \\
1.8 \\
1.8\end{array}$ & $\begin{array}{l}0.00 \\
0.00 \\
0.00 \\
0.00 \\
0.00\end{array}$ \\
\hline $\begin{array}{l}1900 \\
1905 \\
1910 \\
1915 \\
1920\end{array}$ & $\begin{array}{l}144.0 \\
150.0 \\
154.0 \\
155.0 \\
156.0\end{array}$ & $\begin{array}{l}0.01 \\
0.02 \\
0.01 \\
0.01 \\
0.00\end{array}$ & $\begin{array}{l}0020 \\
0025 \\
0030 \\
0035 \\
0040\end{array}$ & $\begin{array}{l}8.2 \\
7.7 \\
7.7 \\
7.3 \\
7.3\end{array}$ & $\begin{array}{l}0.00 \\
0.00 \\
0.00 \\
0.00 \\
0.00\end{array}$ & $\begin{array}{l}0545 \\
0550 \\
0555 \\
0600 \\
0605\end{array}$ & $\begin{array}{l}1.8 \\
1.8 \\
1.8 \\
1.8 \\
1.7\end{array}$ & $\begin{array}{l}0.00 \\
0.00 \\
0.00 \\
0.00 \\
0.00\end{array}$ \\
\hline $\begin{array}{l}1925 \\
1930 \\
1935 \\
1940 \\
1945\end{array}$ & $\begin{array}{l}153.0 \\
149.0 \\
143.0 \\
138.0 \\
130.0\end{array}$ & $\begin{array}{l}0.01 \\
0.00 \\
0.01 \\
0.02 \\
0.01\end{array}$ & $\begin{array}{l}0045 \\
0050 \\
0055 \\
0100 \\
0105\end{array}$ & $\begin{array}{l}6.8 \\
6.8 \\
6.4 \\
6.4 \\
6.0\end{array}$ & $\begin{array}{l}0.00 \\
0.00 \\
0.00 \\
0.00 \\
0.00\end{array}$ & $\begin{array}{l}0610 \\
0615 \\
0620 \\
0625 \\
0630\end{array}$ & $\begin{array}{l}1.7 \\
1.7 \\
1.7 \\
1.7 \\
1.7\end{array}$ & $\begin{array}{l}0.00 \\
0.00 \\
0.00 \\
0.00 \\
0.00\end{array}$ \\
\hline $\begin{array}{l}1950 \\
1955 \\
2000 \\
2005 \\
2010\end{array}$ & $\begin{array}{r}122.0 \\
116.0 \\
110.0 \\
103.0 \\
96.4\end{array}$ & $\begin{array}{l}0.00 \\
0.00 \\
0.00 \\
0.00 \\
0.00\end{array}$ & $\begin{array}{l}0110 \\
0115 \\
0120 \\
0125 \\
0130\end{array}$ & $\begin{array}{l}6.0 \\
6.0 \\
5.6 \\
5.6 \\
5.2\end{array}$ & $\begin{array}{l}0.00 \\
0.00 \\
0.00 \\
0.00 \\
0.00\end{array}$ & $\begin{array}{l}0635 \\
0640 \\
0645 \\
0650 \\
0655\end{array}$ & $\begin{array}{l}1.7 \\
1.7 \\
1.7 \\
1.7 \\
1.5\end{array}$ & $\begin{array}{l}0.00 \\
0.00 \\
0.00 \\
0.00 \\
0.00\end{array}$ \\
\hline $\begin{array}{l}2015 \\
2020 \\
2025 \\
2030 \\
2035\end{array}$ & $\begin{array}{l}90.2 \\
84.1 \\
79.1 \\
74.2 \\
69.2\end{array}$ & $\begin{array}{l}0.00 \\
0.00 \\
0.00 \\
0.01 \\
0.01\end{array}$ & $\begin{array}{l}0135 \\
0140 \\
0145 \\
0150 \\
0155\end{array}$ & $\begin{array}{l}5.2 \\
5.2 \\
4.9 \\
4.9 \\
4.9\end{array}$ & $\begin{array}{l}0.00 \\
0.00 \\
0.00 \\
0.00 \\
0.00\end{array}$ & $\begin{array}{l}0700 \\
0705 \\
0710 \\
0715 \\
0720\end{array}$ & $\begin{array}{l}1.5 \\
1.5 \\
1.5 \\
1.5 \\
1.5\end{array}$ & $\begin{array}{l}0.00 \\
0.00 \\
0.00 \\
0.00 \\
0.00\end{array}$ \\
\hline $\begin{array}{l}2040 \\
2045 \\
2050 \\
2055 \\
2100\end{array}$ & $\begin{array}{l}65.1 \\
61.9 \\
56.6 \\
53.6 \\
50.0\end{array}$ & $\begin{array}{l}0.00 \\
0.00 \\
0.02 \\
0.00 \\
0.00\end{array}$ & $\begin{array}{l}0200 \\
0205 \\
0210 \\
0215 \\
0220\end{array}$ & $\begin{array}{l}4.5 \\
4.5 \\
4.2 \\
4.2 \\
4.2\end{array}$ & $\begin{array}{l}0.00 \\
0.00 \\
0.00 \\
0.00 \\
0.00\end{array}$ & $\begin{array}{l}0725 \\
0730 \\
0735 \\
0740 \\
0745\end{array}$ & $\begin{array}{l}1.5 \\
1.5 \\
1.5 \\
1.5 \\
1.5\end{array}$ & $\begin{array}{l}0.00 \\
0.01 \\
0.00 \\
0.00 \\
0.00\end{array}$ \\
\hline $\begin{array}{l}2105 \\
2110 \\
2115 \\
2120 \\
2125\end{array}$ & $\begin{array}{l}47.1 \\
44.3 \\
42.3 \\
39.6 \\
37.6\end{array}$ & $\begin{array}{l}0.00 \\
0.00 \\
0.00 \\
0.00 \\
0.00\end{array}$ & $\begin{array}{l}0225 \\
0230 \\
0235 \\
0240 \\
0245\end{array}$ & $\begin{array}{l}3.9 \\
3.9 \\
3.9 \\
3.9 \\
3.6\end{array}$ & $\begin{array}{l}0.00 \\
0.00 \\
0.00 \\
0.00 \\
0.00\end{array}$ & $\begin{array}{l}0750 \\
0755 \\
0800 \\
0805 \\
0810\end{array}$ & $\begin{array}{l}1.5 \\
1.5 \\
1.5 \\
1.5 \\
1.5\end{array}$ & $\begin{array}{l}0.00 \\
0.00 \\
0.00 \\
0.00 \\
0.00\end{array}$ \\
\hline $\begin{array}{l}2130 \\
2135 \\
2140 \\
2145 \\
2150\end{array}$ & $\begin{array}{l}35.7 \\
33.9 \\
32.7 \\
30.9 \\
29.7\end{array}$ & $\begin{array}{l}0.00 \\
0.00 \\
0.00 \\
0.00 \\
0.00\end{array}$ & $\begin{array}{l}0250 \\
0255 \\
0300 \\
0305 \\
0310\end{array}$ & $\begin{array}{l}3.6 \\
3.6 \\
3.6 \\
3.3 \\
3.3\end{array}$ & $\begin{array}{l}0.00 \\
0.00 \\
0.00 \\
0.00 \\
0.00\end{array}$ & $\begin{array}{l}0815 \\
0820 \\
0825 \\
0830 \\
0835\end{array}$ & $\begin{array}{l}1.3 \\
1.3 \\
1.3 \\
1.3 \\
1.3\end{array}$ & $\begin{array}{l}0.00 \\
0.01 \\
0.00 \\
0.00 \\
0.00\end{array}$ \\
\hline $\begin{array}{l}2155 \\
2200 \\
2205 \\
2210 \\
2215\end{array}$ & $\begin{array}{l}28.6 \\
27.3 \\
25.9 \\
24.5 \\
23.1\end{array}$ & $\begin{array}{l}0.00 \\
0.00 \\
0.00 \\
0.00 \\
0.00\end{array}$ & $\begin{array}{l}0315 \\
0320 \\
0325 \\
0330 \\
0335\end{array}$ & $\begin{array}{l}3.3 \\
3.0 \\
3.0 \\
3.0 \\
3.0\end{array}$ & $\begin{array}{l}0.00 \\
0.00 \\
0.00 \\
0.00 \\
0.00\end{array}$ & $\begin{array}{l}0840 \\
0845 \\
0850 \\
0855 \\
0900\end{array}$ & $\begin{array}{l}1.3 \\
1.3 \\
1.3 \\
1.3 \\
1.3\end{array}$ & $\begin{array}{l}0.00 \\
0.00 \\
0.00 \\
0.00 \\
0.00\end{array}$ \\
\hline $\begin{array}{l}2220 \\
2225 \\
2230 \\
2235 \\
2240\end{array}$ & $\begin{array}{l}21.8 \\
21.1 \\
20.4 \\
19.1 \\
18.4\end{array}$ & $\begin{array}{l}0.00 \\
0.00 \\
0.00 \\
0.00 \\
0.00\end{array}$ & $\begin{array}{l}0340 \\
0345 \\
0350 \\
0355 \\
0400\end{array}$ & $\begin{array}{l}2.7 \\
2.7 \\
2.7 \\
2.7 \\
2.5\end{array}$ & $\begin{array}{l}0.00 \\
0.00 \\
0.00 \\
0.00 \\
0.00\end{array}$ & $\begin{array}{l}0905 \\
0910 \\
0915 \\
0920 \\
0925\end{array}$ & $\begin{array}{l}1.3 \\
1.3 \\
1.3 \\
1.3 \\
1.3\end{array}$ & $\begin{array}{l}0.00 \\
0.00 \\
0.00 \\
0.00 \\
0.00\end{array}$ \\
\hline
\end{tabular}


Table 4.--Streamflow and rainfall at station 02110740. Midway Swash at Myrtle Beach, August 1-2, 1989--Continued

\begin{tabular}{|c|c|c|c|c|c|c|c|c|}
\hline $\begin{array}{l}\text { Time } \\
\text { (hours) }\end{array}$ & $\begin{array}{l}\text { Streamflow } \\
\text { (cubic feet } \\
\text { per second) }\end{array}$ & $\begin{array}{l}\text { Rain- } \\
\text { fall } \\
\text { (inches) }\end{array}$ & $\begin{array}{l}\text { Time } \\
\text { (hours) }\end{array}$ & $\begin{array}{l}\text { Streamflow } \\
\text { (cubic feet } \\
\text { per second) }\end{array}$ & $\begin{array}{l}\text { Rain- } \\
\text { fall } \\
\text { (inches) }\end{array}$ & $\begin{array}{l}\text { Time } \\
\text { (hours) }\end{array}$ & $\begin{array}{l}\text { Streamflow } \\
\text { (cubic feet } \\
\text { per second) }\end{array}$ & $\begin{array}{l}\text { Rain- } \\
\text { fall } \\
\text { (inches) }\end{array}$ \\
\hline $\begin{array}{l}0930 \\
0935 \\
0940 \\
0945 \\
0950\end{array}$ & $\begin{array}{l}1.3 \\
1.3 \\
1.3 \\
1.2 \\
1.2\end{array}$ & $\begin{array}{l}0.00 \\
0.00 \\
0.00 \\
0.00 \\
0.00\end{array}$ & $\begin{array}{l}1025 \\
1030 \\
1035 \\
1040 \\
1045\end{array}$ & $\begin{array}{l}1.2 \\
1.2 \\
1.2 \\
1.2 \\
1.2\end{array}$ & $\begin{array}{l}0.00 \\
0.00 \\
0.00 \\
0.00 \\
0.00\end{array}$ & $\begin{array}{l}1120 \\
1125 \\
1130 \\
1135 \\
1140\end{array}$ & $\begin{array}{l}1.2 \\
1.2 \\
1.2 \\
1.2 \\
1.2\end{array}$ & $\begin{array}{l}0.00 \\
0.00 \\
0.00 \\
0.00 \\
0.00\end{array}$ \\
\hline $\begin{array}{l}0955 \\
1000 \\
1005 \\
1010 \\
1015\end{array}$ & $\begin{array}{l}1.2 \\
1.2 \\
1.2 \\
1.2 \\
1.2\end{array}$ & $\begin{array}{l}0.00 \\
0.00 \\
0.00 \\
0.00 \\
0.00\end{array}$ & $\begin{array}{l}1050 \\
1055 \\
1100 \\
1105 \\
1110\end{array}$ & $\begin{array}{l}1.2 \\
1.2 \\
1.2 \\
1.2 \\
1.2\end{array}$ & $\begin{array}{l}0.00 \\
0.00 \\
0.00 \\
0.00 \\
0.00\end{array}$ & $\begin{array}{l}1145 \\
1150 \\
1155 \\
1200\end{array}$ & $\begin{array}{l}1.2 \\
1.2 \\
1.2 \\
1.2\end{array}$ & $\begin{array}{l}0.00 \\
0.00 \\
0.00 \\
0.00\end{array}$ \\
\hline 1020 & 1.2 & 0.00 & 1115 & 1.2 & 0.00 & & & \\
\hline
\end{tabular}




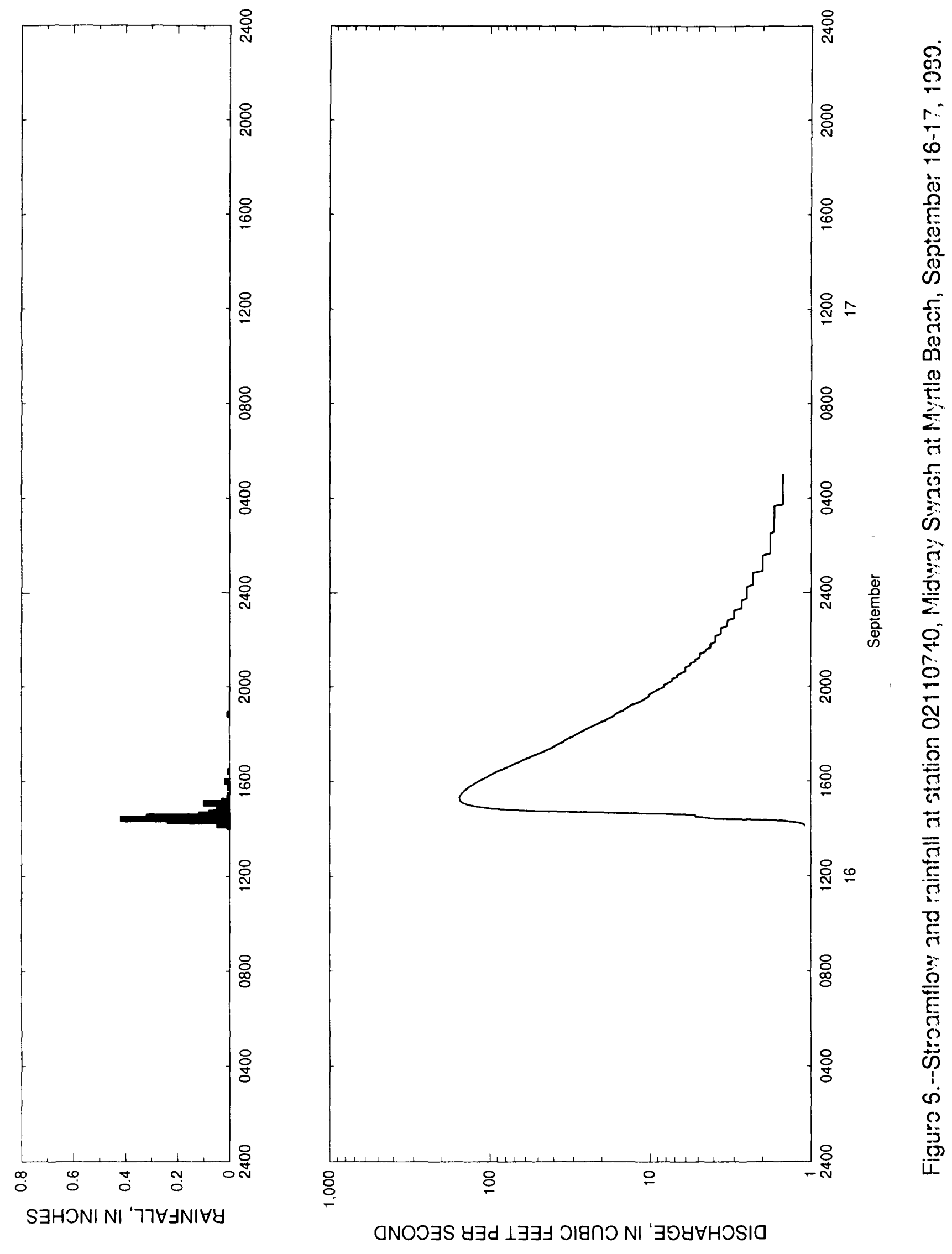


Table 5. - - Streamflow and rainfall at station 02110740, Midway Swash at Myrtle Beach, September $16-17,1989$

\begin{tabular}{|c|c|c|c|c|c|c|c|c|}
\hline $\begin{array}{l}\text { Time } \\
\text { (hours) }\end{array}$ & $\begin{array}{l}\text { Streamflow } \\
\text { (cubic feet } \\
\text { per second) }\end{array}$ & $\begin{array}{l}\text { Rain- } \\
\text { fall } \\
\text { (inches) }\end{array}$ & $\begin{array}{l}\text { Time } \\
\text { (hours) }\end{array}$ & $\begin{array}{l}\text { Streamflow } \\
\text { (cubic feet } \\
\text { per second) }\end{array}$ & $\begin{array}{l}\text { Rain- } \\
\text { fall } \\
\text { (inches) }\end{array}$ & $\begin{array}{l}\text { Time } \\
\text { (hours) }\end{array}$ & $\begin{array}{l}\text { Streamflow } \\
\text { (cubic feet } \\
\text { per second) }\end{array}$ & $\begin{array}{l}\text { Rain- } \\
\text { fall } \\
\text { (inches) }\end{array}$ \\
\hline $\begin{array}{l}\text { Sept ember } \\
1405 \\
1410 \\
1415 \\
1420\end{array}$ & 16, $\begin{array}{l}1989 \\
1.1 \\
1.1 \\
1.2 \\
1.5\end{array}$ & $\begin{array}{l}0.01 \\
0.05 \\
0.05 \\
0.24\end{array}$ & $\begin{array}{l}1905 \\
1910 \\
1915 \\
1920 \\
1925\end{array}$ & $\begin{array}{l}14.2 \\
13.6 \\
13.0 \\
11.9 \\
11.3\end{array}$ & $\begin{array}{l}0.00 \\
0.00 \\
0.00 \\
0.00 \\
0.00\end{array}$ & $\begin{array}{l}0005 \\
0010 \\
0015 \\
0020 \\
0025\end{array}$ & $\begin{array}{l}2.5 \\
2.5 \\
2.5 \\
2.3 \\
2.3\end{array}$ & $\begin{array}{l}0.00 \\
0.00 \\
0.00 \\
0.00 \\
0.00\end{array}$ \\
\hline $\begin{array}{l}1425 \\
1430 \\
1435 \\
1440 \\
1445\end{array}$ & $\begin{array}{r}3.9 \\
5.2 \\
5.2 \\
17.2 \\
58.9\end{array}$ & $\begin{array}{l}0.42 \\
0.32 \\
0.12 \\
0.08 \\
0.03\end{array}$ & $\begin{array}{l}1930 \\
1935 \\
1940 \\
1945 \\
1950\end{array}$ & $\begin{array}{r}10.8 \\
10.2 \\
10.2 \\
9.7 \\
9.2\end{array}$ & $\begin{array}{l}0.00 \\
0.00 \\
0.00 \\
0.00 \\
0.00\end{array}$ & $\begin{array}{l}0030 \\
0035 \\
0040 \\
0045 \\
0050\end{array}$ & $\begin{array}{l}2.3 \\
2.3 \\
2.3 \\
2.3 \\
2.3\end{array}$ & $\begin{array}{l}0.00 \\
0.00 \\
0.00 \\
0.00 \\
0.00\end{array}$ \\
\hline $\begin{array}{l}1450 \\
1455 \\
1500 \\
1505 \\
1510\end{array}$ & $\begin{array}{r}96.4 \\
119.0 \\
136.0 \\
148.0 \\
153.0\end{array}$ & $\begin{array}{l}0.05 \\
0.01 \\
0.03 \\
0.10 \\
0.03\end{array}$ & $\begin{array}{l}1955 \\
2000 \\
2005 \\
2010 \\
2015\end{array}$ & $\begin{array}{l}8.7 \\
8.2 \\
8.2 \\
7.7 \\
7.3\end{array}$ & $\begin{array}{l}0.00 \\
0.00 \\
0.00 \\
0.00 \\
0.00\end{array}$ & $\begin{array}{l}0055 \\
0100 \\
0105 \\
0110 \\
0115\end{array}$ & $\begin{array}{l}2.0 \\
2.0 \\
2.0 \\
2.0 \\
2.0\end{array}$ & $\begin{array}{l}0.00 \\
0.00 \\
0.00 \\
0.00 \\
0.00\end{array}$ \\
\hline $\begin{array}{l}1515 \\
1520 \\
1525 \\
1530 \\
1535\end{array}$ & $\begin{array}{l}155.0 \\
155.0 \\
153.0 \\
150.0 \\
145.0\end{array}$ & $\begin{array}{l}0.00 \\
0.01 \\
0.01 \\
0.00 \\
0.00\end{array}$ & $\begin{array}{l}2020 \\
2025 \\
2030 \\
2035 \\
2040\end{array}$ & $\begin{array}{l}7.3 \\
6.8 \\
6.8 \\
6.4 \\
6.0\end{array}$ & $\begin{array}{l}0.00 \\
0.00 \\
0.00 \\
0.00 \\
0.00\end{array}$ & $\begin{array}{l}0120 \\
0125 \\
0130 \\
0135 \\
0140\end{array}$ & $\begin{array}{l}2.0 \\
2.0 \\
2.0 \\
2.0 \\
1.8\end{array}$ & $\begin{array}{l}0.00 \\
0.00 \\
0.00 \\
0.00 \\
0.00\end{array}$ \\
\hline $\begin{array}{l}1540 \\
1545 \\
1550 \\
1555 \\
1600\end{array}$ & $\begin{array}{l}140.0 \\
136.0 \\
129.0 \\
124.0 \\
118.0\end{array}$ & $\begin{array}{l}0.00 \\
0.01 \\
0.01 \\
0.00 \\
0.02\end{array}$ & $\begin{array}{l}2045 \\
2050 \\
2055 \\
2100 \\
2105\end{array}$ & $\begin{array}{l}6.0 \\
6.0 \\
5.6 \\
5.6 \\
5.2\end{array}$ & $\begin{array}{l}0.00 \\
0.00 \\
0.00 \\
0.00 \\
0.00\end{array}$ & $\begin{array}{l}0145 \\
0150 \\
0155 \\
0200 \\
0205\end{array}$ & $\begin{array}{l}1.8 \\
1.8 \\
1.8 \\
1.8 \\
1.8\end{array}$ & $\begin{array}{l}0.00 \\
0.00 \\
0.00 \\
0.00 \\
0.00\end{array}$ \\
\hline $\begin{array}{l}1605 \\
1610 \\
1615 \\
1620 \\
1625\end{array}$ & $\begin{array}{r}112.0 \\
105.0 \\
100.0 \\
94.6 \\
89.3\end{array}$ & $\begin{array}{l}0.00 \\
0.00 \\
0.00 \\
0.00 \\
0.01\end{array}$ & $\begin{array}{l}2110 \\
2115 \\
2120 \\
2125 \\
2130\end{array}$ & $\begin{array}{l}5.2 \\
4.9 \\
4.9 \\
4.9 \\
4.5\end{array}$ & $\begin{array}{l}0.00 \\
0.00 \\
0.00 \\
0.00 \\
0.00\end{array}$ & $\begin{array}{l}0210 \\
0215 \\
0220 \\
0225 \\
0230\end{array}$ & $\begin{array}{l}1.8 \\
1.8 \\
1.8 \\
1.8 \\
1.8\end{array}$ & $\begin{array}{l}0.00 \\
0.00 \\
0.00 \\
0.00 \\
0.00\end{array}$ \\
\hline $\begin{array}{l}1630 \\
1635 \\
1640 \\
1645 \\
1650\end{array}$ & $\begin{array}{l}84.1 \\
79.1 \\
74.2 \\
70.0 \\
65.1\end{array}$ & $\begin{array}{l}0.00 \\
0.00 \\
0.00 \\
0.00 \\
0.00\end{array}$ & $\begin{array}{l}2135 \\
2140 \\
2145 \\
2150 \\
2155\end{array}$ & $\begin{array}{l}4.5 \\
4.2 \\
4.2 \\
4.2 \\
3.9\end{array}$ & $\begin{array}{l}0.00 \\
0.00 \\
0.00 \\
0.00 \\
0.00\end{array}$ & $\begin{array}{l}0235 \\
0240 \\
0245 \\
0250 \\
0255\end{array}$ & $\begin{array}{l}1.7 \\
1.7 \\
1.7 \\
1.7 \\
1.7\end{array}$ & $\begin{array}{l}0.00 \\
0.00 \\
0.00 \\
0.00 \\
0.00\end{array}$ \\
\hline $\begin{array}{l}1655 \\
1700 \\
1705 \\
1710 \\
1715\end{array}$ & $\begin{array}{l}61.9 \\
57.3 \\
53.6 \\
50.7 \\
47.1\end{array}$ & $\begin{array}{l}0.00 \\
0.00 \\
0.00 \\
0.00 \\
0.00\end{array}$ & $\begin{array}{l}2200 \\
2205 \\
2210 \\
2215 \\
2220\end{array}$ & $\begin{array}{l}3.9 \\
3.9 \\
3.9 \\
3.6 \\
3.6\end{array}$ & $\begin{array}{l}0.00 \\
0.00 \\
0.00 \\
0.00 \\
0.00\end{array}$ & $\begin{array}{l}0300 \\
0305 \\
0310 \\
0315 \\
0320\end{array}$ & $\begin{array}{l}1.7 \\
1.7 \\
1.7 \\
1.7 \\
1.7\end{array}$ & $\begin{array}{l}0.00 \\
0.00 \\
0.00 \\
0.00 \\
0.00\end{array}$ \\
\hline $\begin{array}{l}1720 \\
1725 \\
1730 \\
1735 \\
1740\end{array}$ & $\begin{array}{l}44.3 \\
41.6 \\
39.6 \\
37.6 \\
35.1\end{array}$ & $\begin{array}{l}0.00 \\
0.00 \\
0.00 \\
0.00 \\
0.00\end{array}$ & $\begin{array}{l}2225 \\
2230 \\
2235 \\
2240 \\
2245\end{array}$ & $\begin{array}{l}3.6 \\
3.6 \\
3.3 \\
3.3 \\
3.3\end{array}$ & $\begin{array}{l}0.00 \\
0.00 \\
0.00 \\
0.00 \\
0.00\end{array}$ & $\begin{array}{l}0325 \\
0330 \\
0335 \\
0340 \\
0345\end{array}$ & $\begin{array}{l}1.7 \\
1.7 \\
1.7 \\
1.7 \\
1.5\end{array}$ & $\begin{array}{l}0.00 \\
0.00 \\
0.00 \\
0.00 \\
0.00\end{array}$ \\
\hline $\begin{array}{l}1745 \\
1750 \\
1755 \\
1800 \\
1805\end{array}$ & $\begin{array}{l}33.9 \\
32.1 \\
30.3 \\
29.1 \\
27.3\end{array}$ & $\begin{array}{l}0.00 \\
0.00 \\
0.00 \\
0.00 \\
0.00\end{array}$ & $\begin{array}{l}2250 \\
2255 \\
2300 \\
2305 \\
2310\end{array}$ & $\begin{array}{l}3.3 \\
3.0 \\
3.0 \\
3.0 \\
3.0\end{array}$ & $\begin{array}{l}0.00 \\
0.00 \\
0.00 \\
0.00 \\
0.00\end{array}$ & $\begin{array}{l}0350 \\
0355 \\
0400 \\
0405 \\
0410\end{array}$ & $\begin{array}{l}1.5 \\
1.5 \\
1.5 \\
1.5 \\
1.5\end{array}$ & $\begin{array}{l}0.00 \\
0.00 \\
0.00 \\
0.00 \\
0.00\end{array}$ \\
\hline $\begin{array}{l}1810 \\
1815 \\
1820 \\
1825 \\
1830\end{array}$ & $\begin{array}{l}25.9 \\
24.5 \\
23.1 \\
21.8 \\
20.4\end{array}$ & $\begin{array}{l}0.00 \\
0.00 \\
0.00 \\
0.00 \\
0.00\end{array}$ & $\begin{array}{l}2315 \\
2320 \\
2325 \\
2330 \\
2335\end{array}$ & $\begin{array}{l}3.0 \\
2.7 \\
2.7 \\
2.7 \\
2.7\end{array}$ & $\begin{array}{l}0.00 \\
0.00 \\
0.00 \\
0.00 \\
0.00\end{array}$ & $\begin{array}{l}0415 \\
0420 \\
0425 \\
0430 \\
0435\end{array}$ & $\begin{array}{l}1.5 \\
1.5 \\
1.5 \\
1.5 \\
1.5\end{array}$ & $\begin{array}{l}0.00 \\
0.00 \\
0.00 \\
0.00 \\
0.00\end{array}$ \\
\hline $\begin{array}{l}1835 \\
1840 \\
1845 \\
1850 \\
1855\end{array}$ & $\begin{array}{l}19.1 \\
18.4 \\
17.2 \\
16.6 \\
16.0\end{array}$ & $\begin{array}{l}0.00 \\
0.00 \\
0.00 \\
0.01 \\
0.00\end{array}$ & $\begin{array}{c}2340 \\
2345 \\
2350 \\
2355 \\
\text { September }\end{array}$ & $\begin{aligned} & 2.7 \\
& 2.5 \\
& 2.5 \\
& 2.5 \\
\times \quad 17 . & 1989\end{aligned}$ & $\begin{array}{l}0.00 \\
0.00 \\
0.00 \\
0.00\end{array}$ & $\begin{array}{l}0440 \\
0445 \\
0450 \\
0455 \\
0500\end{array}$ & $\begin{array}{l}1.5 \\
1.5 \\
1.5 \\
1.5 \\
1.5\end{array}$ & $\begin{array}{l}0.00 \\
0.00 \\
0.00 \\
0.00 \\
0.00\end{array}$ \\
\hline 1900 & 14.8 & 0.00 & 0000 & 2.5 & 0.00 & & & \\
\hline
\end{tabular}




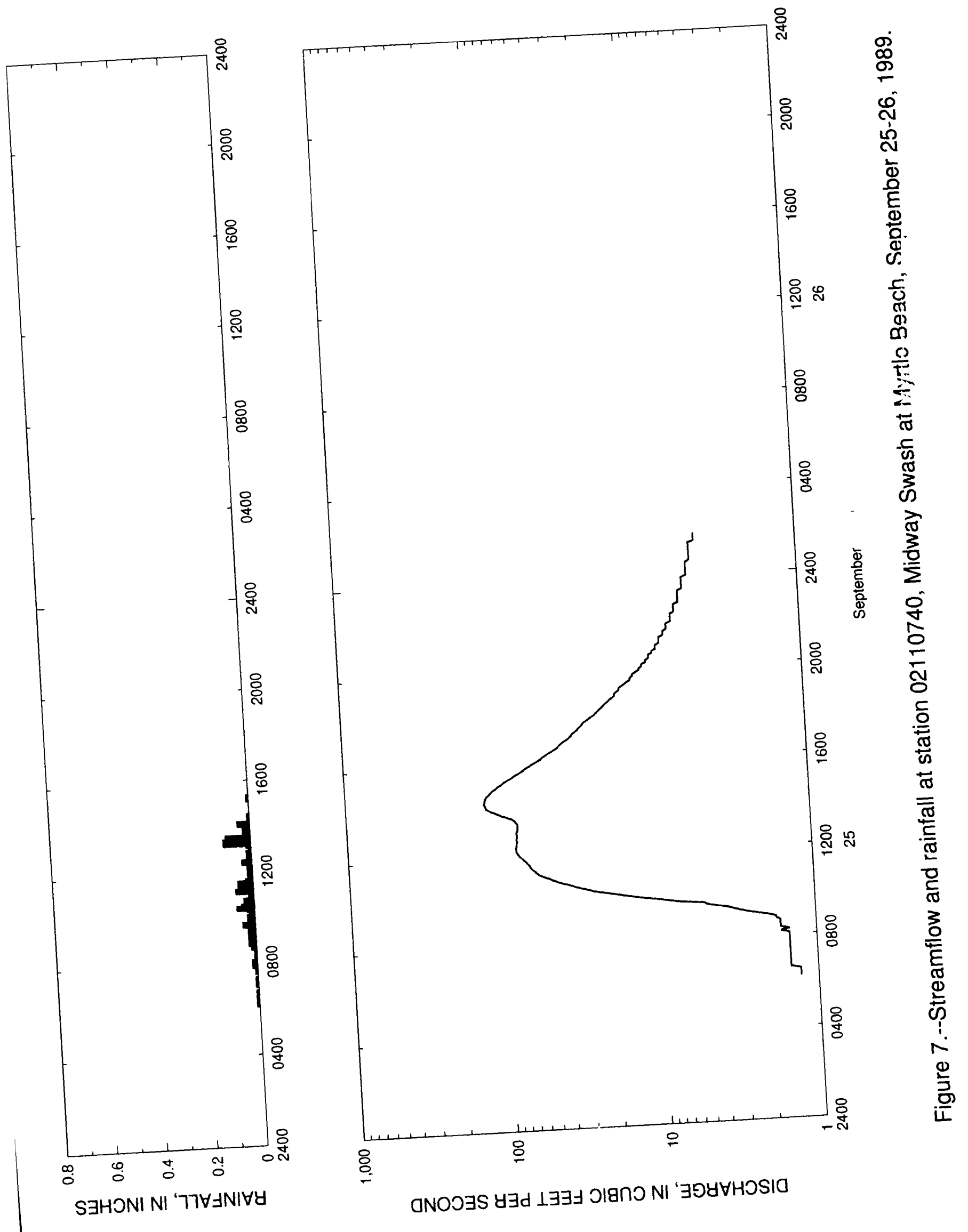


Table 6.--Streamflow and rainfall at station 02110740. Midway Swash at Myrtle Beach, September 25-26, 1989

\begin{tabular}{|c|c|c|c|c|c|c|c|c|}
\hline $\begin{array}{l}\text { Time } \\
\text { (hours) }\end{array}$ & $\begin{array}{l}\text { Streamflow } \\
\text { (cubic feet } \\
\text { per second) }\end{array}$ & $\begin{array}{l}\text { Rain- } \\
\text { fall } \\
\text { (inches) }\end{array}$ & $\begin{array}{l}\text { Time } \\
\text { (hours) }\end{array}$ & $\begin{array}{l}\text { Streamflow } \\
\text { (cubic feet } \\
\text { per second) }\end{array}$ & $\begin{array}{l}\text { Rain- } \\
\text { fall } \\
\text { (inches) }\end{array}$ & $\begin{array}{l}\text { Time } \\
\text { (hours) }\end{array}$ & $\begin{array}{l}\text { Streamflow } \\
\text { (cubic feet } \\
\text { per second) }\end{array}$ & $\begin{array}{l}\text { Rair- } \\
\text { fall } \\
\text { (incres) }\end{array}$ \\
\hline $\begin{array}{l}\text { September } \\
0610 \\
0615 \\
0620 \\
0625\end{array}$ & 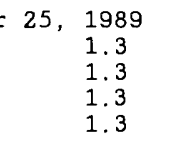 & $\begin{array}{l}0.01 \\
0.00 \\
0.00 \\
0.01\end{array}$ & $\begin{array}{l}1130 \\
1135 \\
1140 \\
1145 \\
1150\end{array}$ & $\begin{array}{l}66.7 \\
67.5 \\
69.2 \\
70.8 \\
73.3\end{array}$ & $\begin{array}{l}0.06 \\
0.03 \\
0.02 \\
0.01 \\
0.02\end{array}$ & $\begin{array}{l}1655 \\
1700 \\
1705 \\
1710 \\
1715\end{array}$ & $\begin{array}{l}37.0 \\
35.1 \\
33.9 \\
32.7 \\
32.1\end{array}$ & $\begin{array}{l}0.0 C \\
0.0 C \\
0.0 C \\
0.0 C \\
0.0 C\end{array}$ \\
\hline $\begin{array}{l}0630 \\
0635 \\
0640 \\
0645 \\
0650\end{array}$ & $\begin{array}{l}1.3 \\
1.5 \\
1.5 \\
1.5 \\
1.5\end{array}$ & $\begin{array}{l}0.00 \\
0.00 \\
0.01 \\
0.00 \\
0.00\end{array}$ & $\begin{array}{l}1155 \\
1200 \\
1205 \\
1210 \\
1215\end{array}$ & $\begin{array}{l}75.0 \\
77.4 \\
79.1 \\
80.8 \\
81.6\end{array}$ & $\begin{array}{l}0.01 \\
0.01 \\
0.02 \\
0.02 \\
0.01\end{array}$ & $\begin{array}{l}1720 \\
1725 \\
1730 \\
1735 \\
1740\end{array}$ & $\begin{array}{l}30.9 \\
29.7 \\
29.1 \\
28.0 \\
27.3\end{array}$ & $\begin{array}{l}0.0 \mathrm{C} \\
0.0 \mathrm{C} \\
0.0 \mathrm{C} \\
0.0 \mathrm{C} \\
0.0 \mathrm{C}\end{array}$ \\
\hline $\begin{array}{l}0655 \\
0700 \\
0705 \\
0710 \\
0715\end{array}$ & $\begin{array}{l}1.5 \\
1.5 \\
1.5 \\
1.5 \\
1.5\end{array}$ & $\begin{array}{l}0.00 \\
0.01 \\
0.00 \\
0.00 \\
0.01\end{array}$ & $\begin{array}{l}1220 \\
1225 \\
1230 \\
1235 \\
1240\end{array}$ & $\begin{array}{l}81.6 \\
81.6 \\
80.8 \\
80.8 \\
79.9\end{array}$ & $\begin{array}{l}0.01 \\
0.04 \\
0.02 \\
0.02 \\
0.01\end{array}$ & $\begin{array}{l}1745 \\
1750 \\
1755 \\
1800 \\
1805\end{array}$ & $\begin{array}{l}26.6 \\
25.2 \\
24.5 \\
23.1 \\
22.5\end{array}$ & $\begin{array}{l}0.0 \mathrm{C} \\
0.0 \mathrm{C} \\
0.0 \mathrm{C} \\
0.0 \mathrm{C} \\
0.0 \mathrm{C}\end{array}$ \\
\hline $\begin{array}{l}0720 \\
0725 \\
0730 \\
0735 \\
0740\end{array}$ & $\begin{array}{l}1.5 \\
1.5 \\
1.5 \\
1.5 \\
1.5\end{array}$ & $\begin{array}{l}0.00 \\
0.00 \\
0.00 \\
0.01 \\
0.00\end{array}$ & $\begin{array}{l}1245 \\
1250 \\
1255 \\
1300 \\
1305\end{array}$ & $\begin{array}{l}80.8 \\
79.9 \\
79.9 \\
79.9 \\
79.9\end{array}$ & $\begin{array}{l}0.01 \\
0.02 \\
0.01 \\
0.01 \\
0.00\end{array}$ & $\begin{array}{l}1810 \\
1815 \\
1820 \\
1825 \\
1830\end{array}$ & $\begin{array}{l}21.8 \\
21.1 \\
20.4 \\
19.7 \\
19.1\end{array}$ & $\begin{array}{l}0.0 \mathrm{C} \\
0.0 \mathrm{C} \\
0.0 \mathrm{C} \\
0.0 \mathrm{C} \\
0.0 \mathrm{C}\end{array}$ \\
\hline $\begin{array}{l}0745 \\
0750 \\
0755 \\
0800 \\
0805\end{array}$ & $\begin{array}{l}1.5 \\
1.5 \\
1.5 \\
1.5 \\
1.5\end{array}$ & $\begin{array}{l}0.01 \\
0.02 \\
0.02 \\
0.02 \\
0.01\end{array}$ & $\begin{array}{l}1310 \\
1315 \\
1320 \\
1325 \\
1330\end{array}$ & $\begin{array}{l}79.1 \\
78.3 \\
78.3 \\
78.3 \\
79.9\end{array}$ & $\begin{array}{l}0.02 \\
0.11 \\
0.11 \\
0.08 \\
0.10\end{array}$ & $\begin{array}{l}1835 \\
1840 \\
1845 \\
1850 \\
1855\end{array}$ & $\begin{array}{l}18.4 \\
17.8 \\
17.2 \\
16.6 \\
16.6\end{array}$ & $\begin{array}{l}0.0 \mathrm{C} \\
0.0 \mathrm{C} \\
0.0 \mathrm{C} \\
0.0 \mathrm{C} \\
0.0 \mathrm{C}\end{array}$ \\
\hline $\begin{array}{l}0810 \\
0815 \\
0820 \\
0825 \\
0830\end{array}$ & $\begin{array}{l}1.7 \\
1.5 \\
1.7 \\
1.7 \\
1.7\end{array}$ & $\begin{array}{l}0.01 \\
0.00 \\
0.01 \\
0.01 \\
0.01\end{array}$ & $\begin{array}{l}1335 \\
1340 \\
1345 \\
1350 \\
1355\end{array}$ & $\begin{array}{r}81.6 \\
85.0 \\
91.0 \\
99.1 \\
105.0\end{array}$ & $\begin{array}{l}0.03 \\
0.02 \\
0.03 \\
0.03 \\
0.01\end{array}$ & $\begin{array}{l}1900 \\
1905 \\
1910 \\
1915 \\
1920\end{array}$ & $\begin{array}{l}16.0 \\
15.4 \\
15.4 \\
14.8 \\
14.2\end{array}$ & $\begin{array}{l}0.0 C \\
0.0 C \\
0.0 C \\
0.0 C \\
0.0 C\end{array}$ \\
\hline $\begin{array}{l}0835 \\
0840 \\
0845 \\
0850 \\
0855\end{array}$ & $\begin{array}{l}1.7 \\
1.7 \\
1.8 \\
1.8 \\
2.0\end{array}$ & $\begin{array}{l}0.00 \\
0.02 \\
0.02 \\
0.03 \\
0.03\end{array}$ & $\begin{array}{l}1400 \\
1405 \\
1410 \\
1415 \\
1420\end{array}$ & $\begin{array}{l}113.0 \\
119.0 \\
124.0 \\
125.0 \\
127.0\end{array}$ & $\begin{array}{l}0.01 \\
0.05 \\
0.00 \\
0.01 \\
0.00\end{array}$ & $\begin{array}{l}1925 \\
1930 \\
1935 \\
1940 \\
1945\end{array}$ & $\begin{array}{l}13.6 \\
13.0 \\
13.0 \\
12.5 \\
12.5\end{array}$ & $\begin{array}{l}0.0 \mathrm{C} \\
0.0 \mathrm{C} \\
0.0 \mathrm{C} \\
0.0 \mathrm{C} \\
0.0 \mathrm{C}\end{array}$ \\
\hline $\begin{array}{l}0900 \\
0905 \\
0910 \\
0915 \\
0920\end{array}$ & $\begin{array}{l}2.3 \\
2.7 \\
3.0 \\
3.3 \\
3.6\end{array}$ & $\begin{array}{l}0.03 \\
0.03 \\
0.01 \\
0.03 \\
0.02\end{array}$ & $\begin{array}{l}1425 \\
1430 \\
1435 \\
1440 \\
1445\end{array}$ & $\begin{array}{l}126.0 \\
126.0 \\
124.0 \\
122.0 \\
118.0\end{array}$ & $\begin{array}{l}0.01 \\
0.00 \\
0.00 \\
0.00 \\
0.00\end{array}$ & $\begin{array}{l}1950 \\
1955 \\
2000 \\
2005 \\
2010\end{array}$ & $\begin{array}{l}11.9 \\
11.3 \\
11.3 \\
10.8 \\
10.8\end{array}$ & $\begin{array}{l}0.0 C \\
0.0 C \\
0.0 C \\
0.0 C \\
0.0 C\end{array}$ \\
\hline $\begin{array}{l}0925 \\
0930 \\
0935 \\
0940 \\
0945\end{array}$ & $\begin{array}{l}4.2 \\
4.9 \\
5.2 \\
7.3 \\
8.7\end{array}$ & $\begin{array}{l}0.03 \\
0.02 \\
0.02 \\
0.05 \\
0.03\end{array}$ & $\begin{array}{l}1450 \\
1455 \\
1500 \\
1505 \\
1510\end{array}$ & $\begin{array}{r}115.0 \\
111.0 \\
106.0 \\
102.0 \\
97.3\end{array}$ & $\begin{array}{l}0.00 \\
0.00 \\
0.00 \\
0.00 \\
0.01\end{array}$ & $\begin{array}{l}2015 \\
2020 \\
2025 \\
2030 \\
2035\end{array}$ & $\begin{array}{r}10.2 \\
10.2 \\
9.7 \\
9.7 \\
9.7\end{array}$ & $\begin{array}{l}0.0 C \\
0.0 C \\
0.00 \\
0.0 C \\
0.0 C\end{array}$ \\
\hline $\begin{array}{l}0950 \\
0955 \\
1000 \\
1005 \\
1010\end{array}$ & $\begin{array}{l}10.2 \\
12.5 \\
14.8 \\
17.2 \\
19.7\end{array}$ & $\begin{array}{l}0.01 \\
0.02 \\
0.03 \\
0.01 \\
0.01\end{array}$ & $\begin{array}{l}1515 \\
1520 \\
1525 \\
1530 \\
1535\end{array}$ & $\begin{array}{l}93.7 \\
89.3 \\
84.1 \\
80.8 \\
76.6\end{array}$ & $\begin{array}{l}0.01 \\
0.00 \\
0.00 \\
0.00 \\
0.00\end{array}$ & $\begin{array}{l}2040 \\
2045 \\
2050 \\
2055 \\
2100\end{array}$ & $\begin{array}{l}9.2 \\
9.2 \\
8.7 \\
8.7 \\
8.7\end{array}$ & $\begin{array}{l}0.00 \\
0.00 \\
0.00 \\
0.06 \\
0.00\end{array}$ \\
\hline $\begin{array}{l}1015 \\
1020 \\
1025 \\
1030 \\
1035\end{array}$ & $\begin{array}{l}23.1 \\
26.6 \\
29.1 \\
32.1 \\
35.1\end{array}$ & $\begin{array}{l}0.02 \\
0.03 \\
0.07 \\
0.05 \\
0.03\end{array}$ & $\begin{array}{l}1540 \\
1545 \\
1550 \\
1555 \\
1600\end{array}$ & $\begin{array}{l}72.5 \\
69.2 \\
65.9 \\
62.7 \\
59.6\end{array}$ & $\begin{array}{l}0.00 \\
0.00 \\
0.00 \\
0.00 \\
0.00\end{array}$ & $\begin{array}{l}2105 \\
2110 \\
2115 \\
2120 \\
2125\end{array}$ & $\begin{array}{l}8.2 \\
8.2 \\
8.2 \\
8.2 \\
7.7\end{array}$ & $\begin{array}{l}0.00 \\
0.00 \\
0.00 \\
0.00 \\
0.00\end{array}$ \\
\hline $\begin{array}{l}1040 \\
1045 \\
1050 \\
1055 \\
1100\end{array}$ & $\begin{array}{l}37.6 \\
41.6 \\
45.0 \\
48.5 \\
51.4\end{array}$ & $\begin{array}{l}0.03 \\
0.04 \\
0.02 \\
0.01 \\
0.01\end{array}$ & $\begin{array}{l}1605 \\
1610 \\
1615 \\
1620 \\
1625\end{array}$ & $\begin{array}{l}56.6 \\
53.6 \\
51.4 \\
49.3 \\
47.1\end{array}$ & $\begin{array}{l}0.00 \\
0.00 \\
0.00 \\
0.00 \\
0.00\end{array}$ & $\begin{array}{l}2130 \\
2135 \\
2140 \\
2145 \\
2150\end{array}$ & $\begin{array}{l}7.7 \\
7.7 \\
7.3 \\
7.3 \\
7.3\end{array}$ & $\begin{array}{l}0.00 \\
0.00 \\
0.00 \\
0.00 \\
0.00\end{array}$ \\
\hline $\begin{array}{l}1105 \\
1110 \\
1115 \\
1120 \\
1125\end{array}$ & $\begin{array}{l}55.8 \\
58.9 \\
61.2 \\
62.7 \\
65.1\end{array}$ & $\begin{array}{l}0.02 \\
0.07 \\
0.03 \\
0.06 \\
0.06\end{array}$ & $\begin{array}{l}1630 \\
1635 \\
1640 \\
1645 \\
1650\end{array}$ & $\begin{array}{l}45.0 \\
42.9 \\
40.9 \\
39.6 \\
38.3\end{array}$ & $\begin{array}{l}0.00 \\
0.00 \\
0.00 \\
0.00 \\
0.00\end{array}$ & $\begin{array}{l}2155 \\
2200 \\
2205 \\
2210 \\
2215\end{array}$ & $\begin{array}{l}7.3 \\
6.8 \\
6.8 \\
6.8 \\
6.8\end{array}$ & $\begin{array}{l}0.00 \\
0.00 \\
0.00 \\
0.00 \\
0.00\end{array}$ \\
\hline
\end{tabular}


Table 6.--Streamflow and rainfall at station 02110740, Midway Swash at Myrtle Beach, September 25-26, 1989--Continued

\begin{tabular}{|c|c|c|c|c|c|c|c|c|}
\hline $\begin{array}{l}\text { Time } \\
\text { (hours) }\end{array}$ & $\begin{array}{l}\text { Streamflow } \\
\text { (cubic feet } \\
\text { per second) }\end{array}$ & $\begin{array}{l}\text { Rain- } \\
\text { fall } \\
\text { (inches) }\end{array}$ & $\begin{array}{l}\text { Time } \\
\text { (hours) }\end{array}$ & $\begin{array}{l}\text { Streamflow } \\
\text { (cubic feet } \\
\text { per second) }\end{array}$ & $\begin{array}{l}\text { Rain- } \\
\text { fall } \\
\text { (inches) }\end{array}$ & $\begin{array}{l}\text { Time } \\
\text { (hours) }\end{array}$ & $\begin{array}{l}\text { Streamflow } \\
\text { (cubic feet } \\
\text { per second) }\end{array}$ & $\begin{array}{l}\text { Rain- } \\
\text { fall } \\
\text { (inches) }\end{array}$ \\
\hline $\begin{array}{l}2220 \\
2225 \\
2230 \\
2235 \\
2240\end{array}$ & $\begin{array}{l}6.8 \\
6.4 \\
6.4 \\
6.4 \\
6.4\end{array}$ & $\begin{array}{l}0.00 \\
0.00 \\
0.00 \\
0.00 \\
0.00\end{array}$ & $\begin{array}{c}2340 \\
2345 \\
2350 \\
2355 \\
\text { September }\end{array}$ & $\begin{array}{r}5.6 \\
5.6 \\
5.6 \\
5.6 \\
\times 26,1989\end{array}$ & $\begin{array}{l}0.00 \\
0.00 \\
0.00 \\
0.00\end{array}$ & $\begin{array}{l}0055 \\
0100 \\
0105 \\
0110 \\
0115\end{array}$ & $\begin{array}{l}4.9 \\
4.9 \\
4.9 \\
4.9 \\
4.9\end{array}$ & $\begin{array}{l}0.00 \\
0.00 \\
0.00 \\
0.00 \\
0.00\end{array}$ \\
\hline $\begin{array}{l}2245 \\
2250 \\
2255 \\
2300 \\
2305\end{array}$ & $\begin{array}{l}6.4 \\
6.0 \\
6.0 \\
6.0 \\
6.0\end{array}$ & $\begin{array}{l}0.00 \\
0.00 \\
0.00 \\
0.00 \\
0.00\end{array}$ & $\begin{array}{l}0000 \\
0005 \\
0010 \\
0015 \\
0020\end{array}$ & $\begin{array}{l}5.2 \\
5.2 \\
5.2 \\
5.2 \\
5.2\end{array}$ & $\begin{array}{l}0.00 \\
0.00 \\
0.00 \\
0.00 \\
0.00\end{array}$ & $\begin{array}{l}0120 \\
0125 \\
0130 \\
0135 \\
0140\end{array}$ & $\begin{array}{l}4.9 \\
4.9 \\
4.5 \\
4.5 \\
4.5\end{array}$ & $\begin{array}{l}0.00 \\
0.00 \\
0.00 \\
0.00 \\
0.00\end{array}$ \\
\hline $\begin{array}{l}2310 \\
2315 \\
2320 \\
2325 \\
2330\end{array}$ & $\begin{array}{l}6.0 \\
6.0 \\
6.0 \\
5.6 \\
5.6\end{array}$ & $\begin{array}{l}0.00 \\
0.00 \\
0.00 \\
0.00 \\
0.00\end{array}$ & $\begin{array}{l}0025 \\
0030 \\
0035 \\
0040 \\
0045\end{array}$ & $\begin{array}{l}5.2 \\
5.2 \\
5.2 \\
4.9 \\
4.9\end{array}$ & $\begin{array}{l}0.00 \\
0.00 \\
0.00 \\
0.00 \\
0.00\end{array}$ & $\begin{array}{l}0145 \\
0150 \\
0155 \\
0200\end{array}$ & $\begin{array}{l}4.5 \\
4.5 \\
4.5 \\
4.5\end{array}$ & $\begin{array}{l}0.00 \\
0.00 \\
0.00 \\
0.00\end{array}$ \\
\hline 2335 & 5.6 & 0.00 & 0050 & 4.9 & 0.00 & & & \\
\hline
\end{tabular}




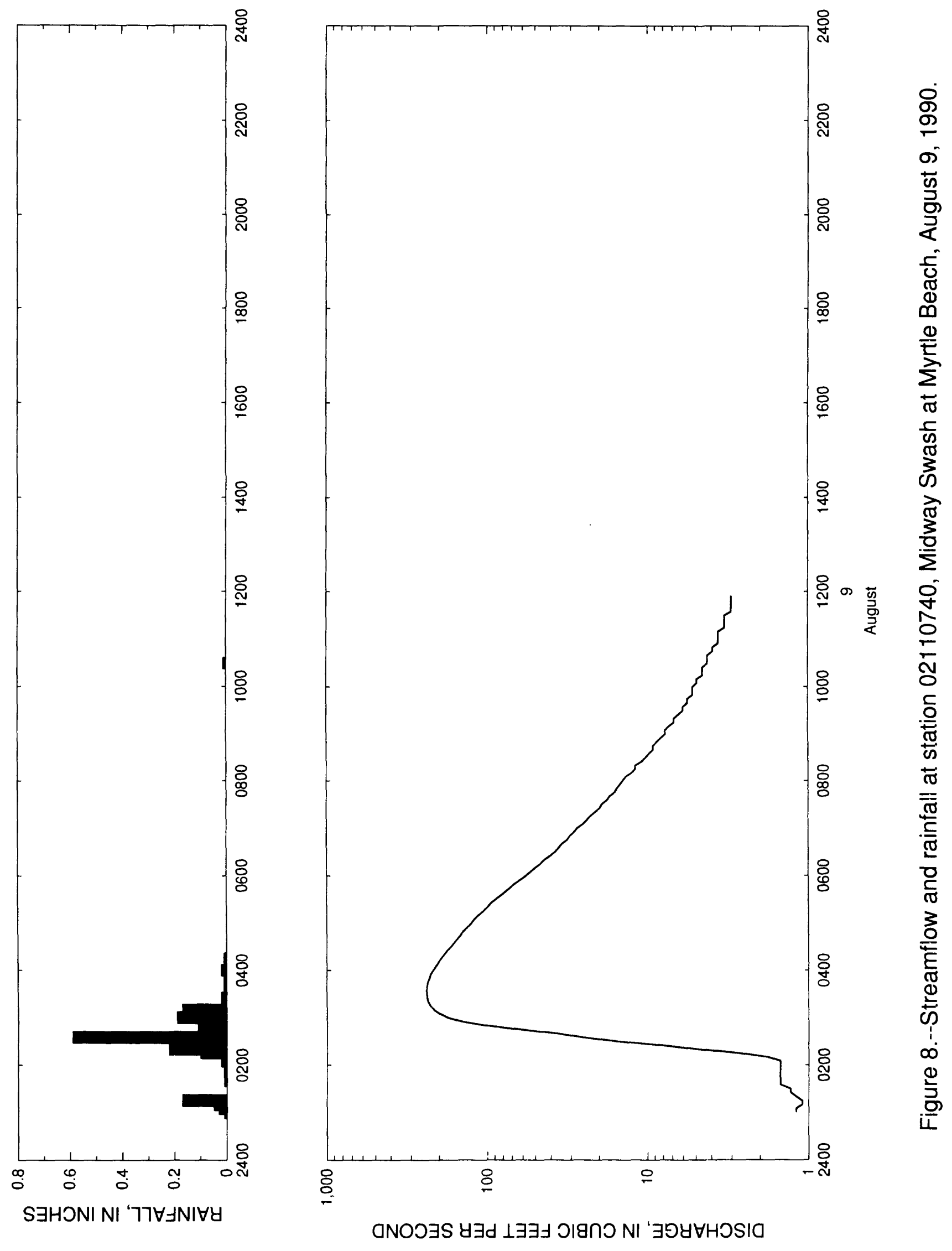


Table 7.--Streamflow and rainfall at station 02110740, Midway Swash at Myrtle Beach, August 9,1990

\begin{tabular}{|c|c|c|c|c|c|c|c|c|}
\hline $\begin{array}{l}\text { Time } \\
\text { (hours) }\end{array}$ & $\begin{array}{l}\text { Streamflow } \\
\text { (cubic feet } \\
\text { per second) }\end{array}$ & $\begin{array}{l}\text { Rain- } \\
\text { fall } \\
\text { (inches) }\end{array}$ & $\begin{array}{l}\text { Time } \\
\text { (hours) }\end{array}$ & $\begin{array}{l}\text { Streamflow } \\
\text { (cubic feet } \\
\text { per second) }\end{array}$ & $\begin{array}{l}\text { Rain- } \\
\text { fall } \\
\text { (inches) }\end{array}$ & $\begin{array}{l}\text { Time } \\
\text { (hours) }\end{array}$ & $\begin{array}{l}\text { Streamflow } \\
\text { (cubic feet } \\
\text { per second) }\end{array}$ & $\begin{array}{l}\text { Rain- } \\
\text { fall } \\
\text { (inches) }\end{array}$ \\
\hline $\begin{array}{l}\text { August } 9 \\
0100 \\
0105 \\
0110 \\
0115\end{array}$ & $\begin{array}{r}1990 \\
1.2 \\
1.2 \\
1.1 \\
1.1\end{array}$ & $\begin{array}{l}0.01 \\
0.03 \\
0.05 \\
0.17\end{array}$ & $\begin{array}{l}0440 \\
0445 \\
0450 \\
0455 \\
0500\end{array}$ & $\begin{array}{l}154.0 \\
147.0 \\
141.0 \\
133.0 \\
126.0\end{array}$ & $\begin{array}{l}0.00 \\
0.00 \\
0.00 \\
0.00 \\
0.00\end{array}$ & $\begin{array}{l}0825 \\
0830 \\
0835 \\
0840 \\
0845\end{array}$ & $\begin{array}{r}10.8 \\
10.2 \\
9.7 \\
9.2 \\
9.2\end{array}$ & $\begin{array}{l}0.00 \\
0.00 \\
0.00 \\
0.00 \\
0.00\end{array}$ \\
\hline $\begin{array}{l}0120 \\
0125 \\
0130 \\
0135 \\
0140\end{array}$ & $\begin{array}{l}1.2 \\
1.3 \\
1.3 \\
1.5 \\
1.5\end{array}$ & $\begin{array}{l}0.00 \\
0.00 \\
0.00 \\
0.00 \\
0.01\end{array}$ & $\begin{array}{l}0505 \\
0510 \\
0515 \\
0520 \\
0525\end{array}$ & $\begin{array}{r}121.0 \\
114.0 \\
106.0 \\
100.0 \\
94.6\end{array}$ & $\begin{array}{l}0.00 \\
0.00 \\
0.00 \\
0.00 \\
0.00\end{array}$ & $\begin{array}{l}0850 \\
0855 \\
0900 \\
0905 \\
0910\end{array}$ & $\begin{array}{l}8.7 \\
8.2 \\
7.7 \\
7.7 \\
7.3\end{array}$ & $\begin{array}{l}0.00 \\
0.00 \\
0.00 \\
0.00 \\
0.00\end{array}$ \\
\hline $\begin{array}{l}0145 \\
0150 \\
0155 \\
0200 \\
0205\end{array}$ & $\begin{array}{l}1.5 \\
1.5 \\
1.5 \\
1.5 \\
1.5\end{array}$ & $\begin{array}{l}0.01 \\
0.00 \\
0.00 \\
0.01 \\
0.02\end{array}$ & $\begin{array}{l}0530 \\
0535 \\
0540 \\
0545 \\
0550\end{array}$ & $\begin{array}{l}88.4 \\
82.4 \\
76.6 \\
71.6 \\
66.7\end{array}$ & $\begin{array}{l}0.00 \\
0.00 \\
0.00 \\
0.00 \\
0.00\end{array}$ & $\begin{array}{l}0915 \\
0920 \\
0925 \\
0930 \\
0935\end{array}$ & $\begin{array}{l}6.8 \\
6.8 \\
6.4 \\
6.0 \\
6.0\end{array}$ & $\begin{array}{l}0.00 \\
0.00 \\
0.00 \\
0.00 \\
0.00\end{array}$ \\
\hline $\begin{array}{l}0210 \\
0215 \\
0220 \\
0225 \\
0230\end{array}$ & $\begin{array}{r}1.8 \\
2.7 \\
4.9 \\
8.2 \\
15.4\end{array}$ & $\begin{array}{l}0.01 \\
0.10 \\
0.22 \\
0.00 \\
0.01\end{array}$ & $\begin{array}{l}0555 \\
0600 \\
0605 \\
0610 \\
0615\end{array}$ & $\begin{array}{l}61.9 \\
57.3 \\
53.6 \\
50.0 \\
46.4\end{array}$ & $\begin{array}{l}0.00 \\
0.00 \\
0.00 \\
0.00 \\
0.00\end{array}$ & $\begin{array}{l}0940 \\
0945 \\
0950 \\
0955 \\
1000\end{array}$ & $\begin{array}{l}5.6 \\
5.6 \\
5.2 \\
5.2 \\
5.2\end{array}$ & $\begin{array}{l}0.00 \\
0.00 \\
0.00 \\
0.00 \\
0.00\end{array}$ \\
\hline $\begin{array}{l}0235 \\
0240 \\
0245 \\
0250 \\
0255\end{array}$ & $\begin{array}{r}25.2 \\
36.4 \\
62.7 \\
103.0 \\
144.0\end{array}$ & $\begin{array}{l}0.59 \\
0.04 \\
0.11 \\
0.05 \\
0.06\end{array}$ & $\begin{array}{l}0620 \\
0625 \\
0630 \\
0635 \\
0640\end{array}$ & $\begin{array}{l}43.6 \\
40.2 \\
37.6 \\
35.7 \\
33.9\end{array}$ & $\begin{array}{l}0.00 \\
0.00 \\
0.00 \\
0.00 \\
0.00\end{array}$ & $\begin{array}{l}1005 \\
1010 \\
1015 \\
1020 \\
1025\end{array}$ & $\begin{array}{l}4.9 \\
4.9 \\
4.5 \\
4.5 \\
4.5\end{array}$ & $\begin{array}{l}0.00 \\
0.00 \\
0.00 \\
0.00 \\
0.00\end{array}$ \\
\hline $\begin{array}{l}0300 \\
0305 \\
0310 \\
0315 \\
0320\end{array}$ & $\begin{array}{l}177.0 \\
199.0 \\
216.0 \\
227.0 \\
234.0\end{array}$ & $\begin{array}{l}0.19 \\
0.01 \\
0.17 \\
0.01 \\
0.01\end{array}$ & $\begin{array}{l}0645 \\
0650 \\
0655 \\
0700 \\
0705\end{array}$ & $\begin{array}{l}31.5 \\
30.3 \\
28.6 \\
27.3 \\
25.2\end{array}$ & $\begin{array}{l}0.00 \\
0.00 \\
0.00 \\
0.00 \\
0.00\end{array}$ & $\begin{array}{l}1030 \\
1035 \\
1040 \\
1045 \\
1050\end{array}$ & $\begin{array}{l}4.2 \\
4.2 \\
4.2 \\
3.9 \\
3.9\end{array}$ & $\begin{array}{l}0.01 \\
0.00 \\
0.00 \\
0.00 \\
0.00\end{array}$ \\
\hline $\begin{array}{l}0325 \\
0330 \\
0335 \\
0340 \\
0345\end{array}$ & $\begin{array}{l}238.0 \\
239.0 \\
239.0 \\
238.0 \\
235.0\end{array}$ & $\begin{array}{l}0.02 \\
0.01 \\
0.01 \\
0.00 \\
0.01\end{array}$ & $\begin{array}{l}0710 \\
0715 \\
0720 \\
0725 \\
0730\end{array}$ & $\begin{array}{l}23.8 \\
22.5 \\
21.1 \\
19.7 \\
19.1\end{array}$ & $\begin{array}{l}0.00 \\
0.00 \\
0.00 \\
0.00 \\
0.00\end{array}$ & $\begin{array}{l}1055 \\
1100 \\
1105 \\
1110 \\
1115\end{array}$ & $\begin{array}{l}3.6 \\
3.6 \\
3.6 \\
3.6 \\
3.3\end{array}$ & $\begin{array}{l}0.00 \\
0.00 \\
0.00 \\
0.00 \\
0.00\end{array}$ \\
\hline $\begin{array}{l}0350 \\
0355 \\
0400 \\
0405 \\
0410\end{array}$ & $\begin{array}{l}230.0 \\
226.0 \\
218.0 \\
210.0 \\
202.0\end{array}$ & $\begin{array}{l}0.01 \\
0.01 \\
0.02 \\
0.01 \\
0.00\end{array}$ & $\begin{array}{l}0735 \\
0740 \\
0745 \\
0750 \\
0755\end{array}$ & $\begin{array}{l}17.8 \\
17.2 \\
16.0 \\
15.4 \\
14.8\end{array}$ & $\begin{array}{l}0.00 \\
0.00 \\
0.00 \\
0.00 \\
0.00\end{array}$ & $\begin{array}{l}1120 \\
1125 \\
1130 \\
1135 \\
1140\end{array}$ & $\begin{array}{l}3.3 \\
3.3 \\
3.3 \\
3.0 \\
3.0\end{array}$ & $\begin{array}{l}0.00 \\
0.00 \\
0.00 \\
0.00 \\
0.00\end{array}$ \\
\hline $\begin{array}{l}0415 \\
0420 \\
0425 \\
0430 \\
0435\end{array}$ & $\begin{array}{l}194.0 \\
186.0 \\
178.0 \\
169.0 \\
162.0\end{array}$ & $\begin{array}{l}0.01 \\
0.00 \\
0.00 \\
0.00 \\
0.00\end{array}$ & $\begin{array}{l}0800 \\
0805 \\
0810 \\
0815 \\
0820\end{array}$ & $\begin{array}{l}14.2 \\
13.6 \\
12.5 \\
11.9 \\
11.9\end{array}$ & $\begin{array}{l}0.00 \\
0.00 \\
0.00 \\
0.00 \\
0.00\end{array}$ & $\begin{array}{l}1145 \\
1150 \\
1155 \\
1200\end{array}$ & $\begin{array}{l}3.0 \\
3.0 \\
3.0 \\
3.0\end{array}$ & $\begin{array}{l}0.00 \\
0.00 \\
0.00 \\
0.00\end{array}$ \\
\hline
\end{tabular}




\section{Station 02131130, Gully Branch at Florence, S.C.}

Location.-Lat $34^{\circ} 11^{\prime} 00^{\prime \prime}$, long $79^{\circ} 46^{\prime} 12^{\prime \prime}$, Florence County, Hydrologic Unit 03040201, at culvert on Cherokee Road (State secondary road 13), $1.1 \mathrm{mi}$ south of the Florence City/County Complex, and $0.8 \mathrm{mi}$ upstream from the mouth at Jefferies Creek.

Period of record.-- August 24, 1984 to October 4, 1989.

Gage.--Digital stage recorder with 5-minute punch interval. The recorder is housed in a metal shelter atop a stilling well attached to the left upstream wingwall of a double $10 \mathrm{ft}$ by $10 \mathrm{ft}$ concrete box culvert. A sealed intake pipe extends $20 \mathrm{ft}$ upstream to a separate stilling basin (sand trap) with a removable lid. One crest-stage indicator is located opposite the recording gage intake on the upstream right bank. A second crest-stage indicator is located on the right downstream wingwall.

Rating.--The stage-streamflow relation is defined by current meter measurements up to $12 \mathrm{ft}^{3} / \mathrm{s}$. The stage-streamflow relation was extended to $700 \mathrm{ft}^{3} / \mathrm{s}$ using indirect computational methods.

Rain gage and location.--Station 341100079461200 , lat $34^{\circ} 11^{\prime} 00^{\prime \prime}$, long $79^{\circ} 46^{\prime} 12^{\prime \prime}$. A shelter containing a digital cumulative rainfall recorder with a 5-minute punch interval attached to the upstream culvert headwall at Cherokee Road (State secondary road 13), $1.1 \mathrm{mi}$ south of the Florence City/County Complex, and $0.8 \mathrm{mi}$ upstream from the mouth at Jefferies Creek.

Selected basin characteristics.--

Drainage area $-1.92 \mathrm{mi}^{2}$

Physiographic province -- Lower Coastal Plain

Channel slope -- $29.1 \mathrm{ft} / \mathrm{mi}$

Channel length -- $1.97 \mathrm{mi}$

Total impervious area -- 31.0 percent

Basin development factor --9

2-year, 2-hour rainfall amount -- 2.24 in.

Flood frequency data: $\mathrm{UQ}_{2} \quad 555 \mathrm{ft}^{3} / \mathrm{s}$

$\mathrm{UQ}_{5} \quad 951 \mathrm{ft}^{3} / \mathrm{s}$

$\mathrm{UQ}_{10} \quad 1,220 \mathrm{ft}^{3} / \mathrm{s}$

$\mathrm{UQ}_{25} \quad 1,560 \mathrm{ft}^{3} / \mathrm{s}$

$\mathrm{UQ}_{50} \quad 1,810 \mathrm{ft}^{3} / \mathrm{s}$

$\mathrm{UQ}_{100} \quad 2,050 \mathrm{ft}^{3} / \mathrm{s}$

$\mathrm{UQ}_{500} \quad 2,580 \mathrm{ft}^{3} / \mathrm{s}$ 


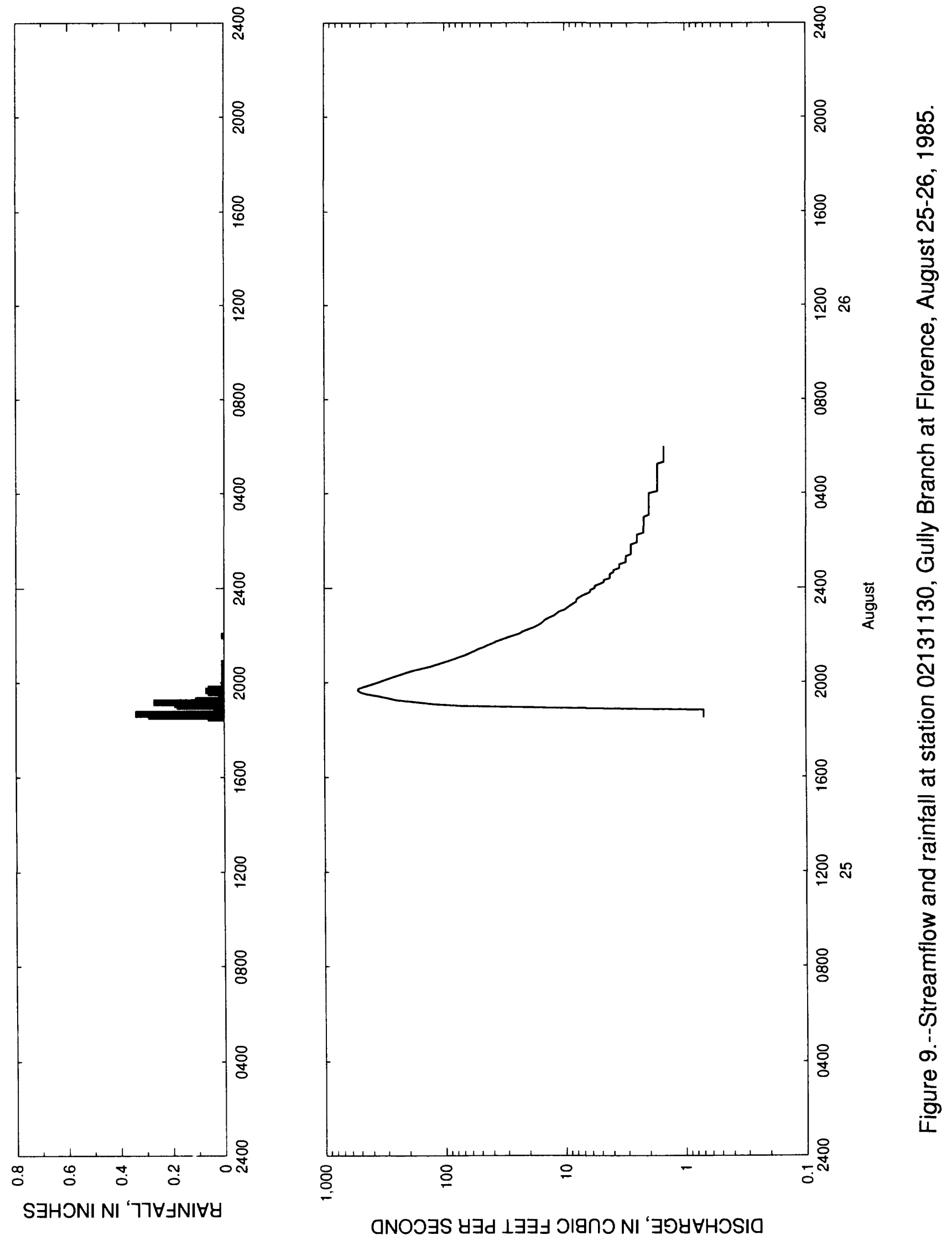


Table 8. - - Streamflow and rainfall at station 02131130 , Gully Branch at Florence, August $25-26,1985$

\begin{tabular}{|c|c|c|c|c|c|c|c|c|}
\hline $\begin{array}{l}\text { Time } \\
\text { (hours) }\end{array}$ & $\begin{array}{l}\text { Streamflow } \\
\text { (cubic feet } \\
\text { per second) }\end{array}$ & $\begin{array}{l}\text { Rain- } \\
\text { fall } \\
\text { (inches) }\end{array}$ & $\begin{array}{l}\text { Time } \\
\text { (hours) }\end{array}$ & $\begin{array}{l}\text { Streamflow } \\
\text { (cubic feet } \\
\text { per second) }\end{array}$ & $\begin{array}{l}\text { Rain- } \\
\text { fall } \\
\text { (inches) }\end{array}$ & $\begin{array}{l}\text { Time } \\
\text { (hours) }\end{array}$ & $\begin{array}{l}\text { Streamflow } \\
\text { (cubic feet } \\
\text { per second) }\end{array}$ & $\begin{array}{l}\text { Rain- } \\
\text { fall } \\
\text { (incl os) }\end{array}$ \\
\hline $\begin{array}{c}\text { August } \\
1830 \\
1835 \\
1840 \\
1845\end{array}$ & $\begin{array}{r}1985 \\
0.7 \\
0.7 \\
0.7 \\
0.7\end{array}$ & $\begin{array}{l}0.06 \\
0.29 \\
0.34 \\
0.01\end{array}$ & $\begin{array}{l}2225 \\
2230 \\
2235 \\
2240 \\
2245\end{array}$ & $\begin{array}{l}16.9 \\
15.8 \\
15.1 \\
14.5 \\
13.4\end{array}$ & $\begin{array}{l}0.00 \\
0.00 \\
0.00 \\
0.00 \\
0.00\end{array}$ & $\begin{array}{l}0220 \\
0225 \\
0230 \\
0235 \\
0240\end{array}$ & $\begin{array}{l}2.2 \\
2.2 \\
2.2 \\
2.2 \\
2.2\end{array}$ & $\begin{array}{l}0.00 \\
0.00 \\
0.00 \\
0.00 \\
0.00\end{array}$ \\
\hline $\begin{array}{l}1850 \\
1855 \\
1900 \\
1905 \\
1910\end{array}$ & $\begin{array}{r}0.7 \\
10.6 \\
71.8 \\
126.0 \\
174.0\end{array}$ & $\begin{array}{l}0.01 \\
0.04 \\
0.18 \\
0.19 \\
0.27\end{array}$ & $\begin{array}{l}2250 \\
2255 \\
2300 \\
2305 \\
2310\end{array}$ & $\begin{array}{r}12.3 \\
11.7 \\
11.1 \\
10.0 \\
9.5\end{array}$ & $\begin{array}{l}0.00 \\
0.00 \\
0.00 \\
0.00 \\
0.00\end{array}$ & $\begin{array}{l}0245 \\
0250 \\
0255 \\
0300 \\
0305\end{array}$ & $\begin{array}{l}2.2 \\
2.2 \\
2.2 \\
2.2 \\
2.0\end{array}$ & $\begin{array}{l}0.00 \\
0.00 \\
0.00 \\
0.00 \\
0.00\end{array}$ \\
\hline $\begin{array}{l}1915 \\
1920 \\
1925 \\
1930 \\
1935\end{array}$ & $\begin{array}{l}250.0 \\
294.0 \\
356.0 \\
442.0 \\
502.0\end{array}$ & $\begin{array}{l}0.11 \\
0.02 \\
0.01 \\
0.01 \\
0.06\end{array}$ & $\begin{array}{l}2315 \\
2320 \\
2325 \\
2330 \\
2335\end{array}$ & $\begin{array}{l}9.0 \\
8.5 \\
8.0 \\
8.0 \\
7.6\end{array}$ & $\begin{array}{l}0.00 \\
0.00 \\
0.00 \\
0.00 \\
0.00\end{array}$ & $\begin{array}{l}0310 \\
0315 \\
0320 \\
0325 \\
0330\end{array}$ & $\begin{array}{l}2.0 \\
2.0 \\
2.0 \\
2.0 \\
2.0\end{array}$ & $\begin{array}{l}0.00 \\
0.00 \\
0.00 \\
0.00 \\
0.00\end{array}$ \\
\hline $\begin{array}{l}1940 \\
1945 \\
1950 \\
1955 \\
2000\end{array}$ & $\begin{array}{l}530.0 \\
522.0 \\
460.0 \\
405.0 \\
358.0\end{array}$ & $\begin{array}{l}0.07 \\
0.06 \\
0.01 \\
0.01 \\
0.01\end{array}$ & $\begin{array}{c}2340 \\
2345 \\
2350 \\
2355 \\
\text { August }\end{array}$ & $\begin{array}{r}7.1 \\
6.6 \\
6.1 \\
6.1 \\
26,1985\end{array}$ & $\begin{array}{l}0.00 \\
0.00 \\
0.00 \\
0.00\end{array}$ & $\begin{array}{l}0335 \\
0340 \\
0345 \\
0350 \\
0355\end{array}$ & $\begin{array}{l}2.0 \\
2.0 \\
2.0 \\
2.0 \\
2.0\end{array}$ & $\begin{array}{l}0.0 C \\
0.0 C \\
0.0 C \\
0.0 C \\
0.0 C\end{array}$ \\
\hline $\begin{array}{l}2005 \\
2010 \\
2015 \\
2020 \\
2025\end{array}$ & $\begin{array}{l}324.0 \\
292.0 \\
261.0 \\
232.0 \\
208.0\end{array}$ & $\begin{array}{l}0.01 \\
0.01 \\
0.01 \\
0.00 \\
0.01\end{array}$ & $\begin{array}{l}0000 \\
0005 \\
0010 \\
0015 \\
0020\end{array}$ & $\begin{array}{l}5.6 \\
5.6 \\
5.1 \\
4.7 \\
4.7\end{array}$ & $\begin{array}{l}0.00 \\
0.00 \\
0.00 \\
0.00 \\
0.00\end{array}$ & $\begin{array}{l}0400 \\
0405 \\
0410 \\
0415 \\
0420\end{array}$ & $\begin{array}{l}2.0 \\
1.7 \\
1.7 \\
1.7 \\
1.7\end{array}$ & $\begin{array}{l}0.0 C \\
0.0 C \\
0.0 C \\
0.0 C \\
0.0 C\end{array}$ \\
\hline $\begin{array}{l}2030 \\
2035 \\
2040 \\
2045 \\
2050\end{array}$ & $\begin{array}{l}182.0 \\
157.0 \\
134.0 \\
118.0 \\
105.0\end{array}$ & $\begin{array}{l}0.01 \\
0.00 \\
0.01 \\
0.00 \\
0.01\end{array}$ & $\begin{array}{l}0025 \\
0030 \\
0035 \\
0040 \\
0045\end{array}$ & $\begin{array}{l}4.2 \\
4.2 \\
4.2 \\
3.9 \\
3.9\end{array}$ & $\begin{array}{l}0.00 \\
0.00 \\
0.00 \\
0.00 \\
0.00\end{array}$ & $\begin{array}{l}0425 \\
0430 \\
0435 \\
0440 \\
0445\end{array}$ & $\begin{array}{l}1.7 \\
1.7 \\
1.7 \\
1.7 \\
1.7\end{array}$ & $\begin{array}{l}0.0 C \\
0.0 C \\
0.0 C \\
0.00 \\
0.00\end{array}$ \\
\hline $\begin{array}{l}2055 \\
2100 \\
2105 \\
2110 \\
2115\end{array}$ & $\begin{array}{l}93.3 \\
83.7 \\
75.7 \\
68.0 \\
61.7\end{array}$ & $\begin{array}{l}0.00 \\
0.00 \\
0.00 \\
0.00 \\
0.00\end{array}$ & $\begin{array}{l}0050 \\
0055 \\
0100 \\
0105 \\
0110\end{array}$ & $\begin{array}{l}3.5 \\
3 \cdot 5 \\
3 \cdot 5 \\
3.1 \\
3.1\end{array}$ & $\begin{array}{l}0.00 \\
0.00 \\
0.00 \\
0.00 \\
0.00\end{array}$ & $\begin{array}{l}0450 \\
0455 \\
0500 \\
0505 \\
0510\end{array}$ & $\begin{array}{l}1.7 \\
1.7 \\
1.7 \\
1.7 \\
1.7\end{array}$ & $\begin{array}{l}0.00 \\
0.00 \\
0.00 \\
0.00 \\
0.00\end{array}$ \\
\hline $\begin{array}{l}2120 \\
2125 \\
2130 \\
2135 \\
2140\end{array}$ & $\begin{array}{l}56.5 \\
52.4 \\
47.4 \\
44.0 \\
40.0\end{array}$ & $\begin{array}{l}0.00 \\
0.00 \\
0.00 \\
0.00 \\
0.00\end{array}$ & $\begin{array}{l}0115 \\
0120 \\
0125 \\
0130 \\
0135\end{array}$ & $\begin{array}{l}3.1 \\
3.1 \\
2.8 \\
2.8 \\
2.8\end{array}$ & $\begin{array}{l}0.00 \\
0.00 \\
0.00 \\
0.00 \\
0.00\end{array}$ & $\begin{array}{l}0515 \\
0520 \\
0525 \\
0530 \\
0535\end{array}$ & $\begin{array}{l}1.7 \\
1.5 \\
1.5 \\
1.5 \\
1.5\end{array}$ & $\begin{array}{l}0.00 \\
0.00 \\
0.00 \\
0.00 \\
0.00\end{array}$ \\
\hline $\begin{array}{l}2145 \\
2150 \\
2155 \\
2200 \\
2205\end{array}$ & $\begin{array}{l}37.0 \\
33.4 \\
30.0 \\
26.7 \\
23.7\end{array}$ & $\begin{array}{l}0.00 \\
0.00 \\
0.00 \\
0.01 \\
0.00\end{array}$ & $\begin{array}{l}0140 \\
0145 \\
0150 \\
0155 \\
0200\end{array}$ & $\begin{array}{l}2.8 \\
2.8 \\
2.8 \\
2.5 \\
2.5\end{array}$ & $\begin{array}{l}0.00 \\
0.00 \\
0.00 \\
0.00 \\
0.00\end{array}$ & $\begin{array}{l}0540 \\
0545 \\
0550 \\
0555 \\
0600\end{array}$ & $\begin{array}{l}1.5 \\
1.5 \\
1.5 \\
1.5 \\
1.5\end{array}$ & $\begin{array}{l}0.00 \\
0.00 \\
0.00 \\
0.00 \\
0.00\end{array}$ \\
\hline $\begin{array}{l}2210 \\
2215 \\
2220\end{array}$ & $\begin{array}{l}22.3 \\
20.2 \\
18.2\end{array}$ & $\begin{array}{l}0.00 \\
0.00 \\
0.00\end{array}$ & $\begin{array}{l}0205 \\
0210 \\
0215\end{array}$ & $\begin{array}{l}2.5 \\
2.5 \\
2.5\end{array}$ & $\begin{array}{l}0.00 \\
0.00 \\
0.00\end{array}$ & & & \\
\hline
\end{tabular}




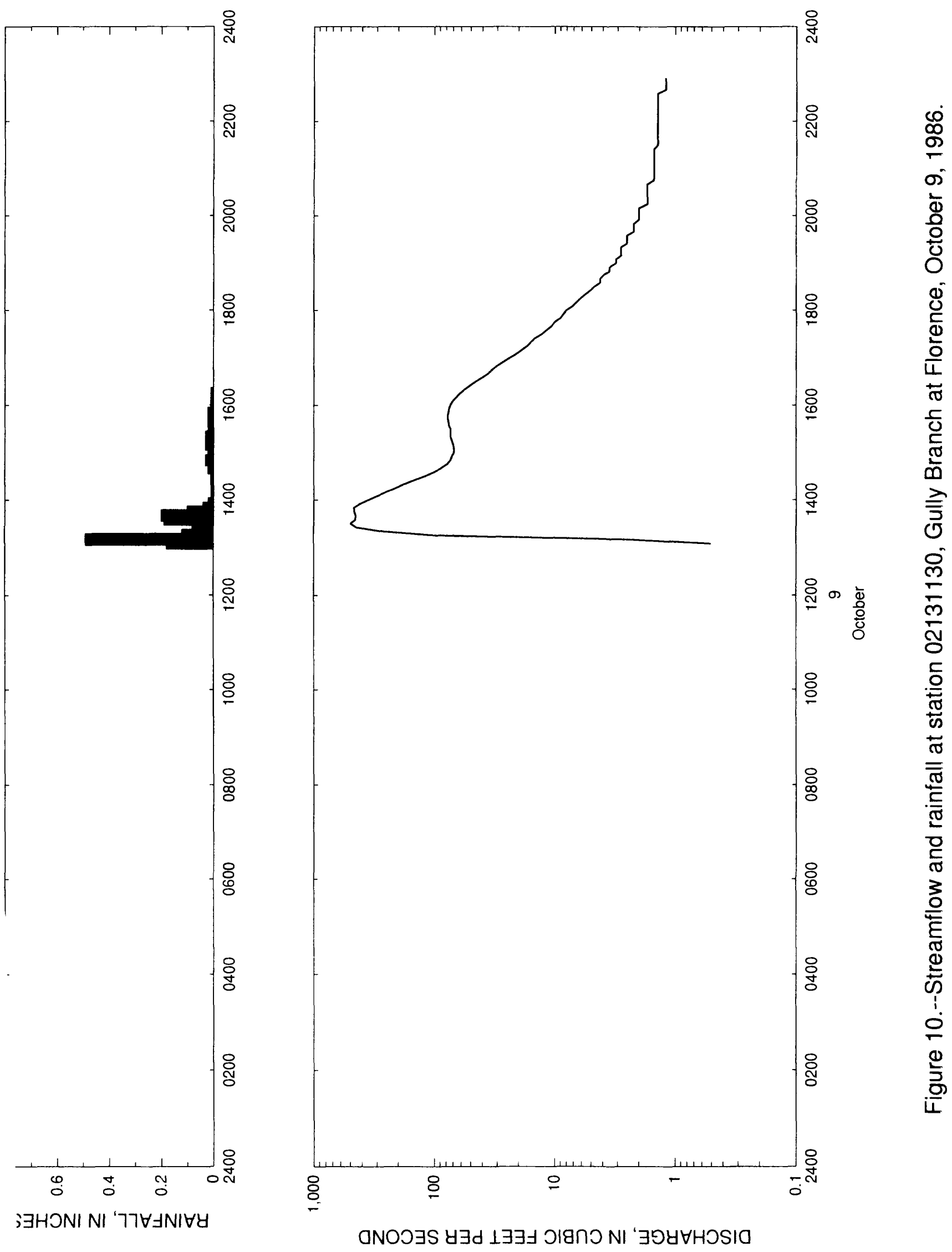


Table 9. - Streamflow and rainfal1 at station 02131130, Gully Branch at Florence. October 9,1986

\begin{tabular}{|c|c|c|c|c|c|c|c|c|}
\hline $\begin{array}{l}\text { Time } \\
\text { (hours) }\end{array}$ & $\begin{array}{l}\text { Streamflow } \\
\text { (cubic feet } \\
\text { per second) }\end{array}$ & $\begin{array}{l}\text { Rain- } \\
\text { fall } \\
\text { (inches) }\end{array}$ & $\begin{array}{l}\text { Time } \\
\text { (hours) }\end{array}$ & $\begin{array}{l}\text { Streamflow } \\
\text { (cubic feet } \\
\text { per second) }\end{array}$ & $\begin{array}{l}\text { Rain- } \\
\text { fall } \\
\text { (inches) }\end{array}$ & $\begin{array}{l}\text { Time } \\
\text { (hours) }\end{array}$ & $\begin{array}{l}\text { Streamflow } \\
\text { (cubic feet } \\
\text { per second) }\end{array}$ & $\begin{array}{l}\text { Rain- } \\
\text { fall } \\
\text { (inches) }\end{array}$ \\
\hline $\begin{array}{l}\text { October } \\
1305 \\
1310 \\
1315 \\
1320\end{array}$ & $\begin{array}{r}9, \quad 1986 \\
0.5 \\
2.5 \\
93.3 \\
264.0\end{array}$ & $\begin{array}{l}0.18 \\
0.49 \\
0.12 \\
0.02\end{array}$ & $\begin{array}{l}1625 \\
1630 \\
1635 \\
1640 \\
1645\end{array}$ & $\begin{array}{l}50.8 \\
45.7 \\
40.8 \\
36.3 \\
33.4\end{array}$ & $\begin{array}{l}0.00 \\
0.00 \\
0.00 \\
0.00 \\
0.00\end{array}$ & $\begin{array}{l}1950 \\
1955 \\
2000 \\
2005 \\
2010\end{array}$ & $\begin{array}{l}2.2 \\
2.0 \\
2.0 \\
2.0 \\
2.0\end{array}$ & $\begin{array}{l}0.00 \\
0.00 \\
0.00 \\
0.00 \\
0.00\end{array}$ \\
\hline $\begin{array}{l}1325 \\
1330 \\
1335 \\
1340 \\
1345\end{array}$ & $\begin{array}{l}442.0 \\
500.0 \\
454.0 \\
452.0 \\
463.0\end{array}$ & $\begin{array}{l}0.01 \\
0.08 \\
0.19 \\
0.20 \\
0.10\end{array}$ & $\begin{array}{l}1650 \\
1655 \\
1700 \\
1705 \\
1710\end{array}$ & $\begin{array}{l}30.0 \\
26.7 \\
23.7 \\
20.9 \\
18.8\end{array}$ & $\begin{array}{l}0.00 \\
0.00 \\
0.00 \\
0.00 \\
0.00\end{array}$ & $\begin{array}{l}2015 \\
2020 \\
2025 \\
2030 \\
2035\end{array}$ & $\begin{array}{l}1.7 \\
1.7 \\
1.7 \\
1.7 \\
1.7\end{array}$ & $\begin{array}{l}0.00 \\
0.00 \\
0.00 \\
0.00 \\
0.00\end{array}$ \\
\hline $\begin{array}{l}1350 \\
1355 \\
1400 \\
1405 \\
1410\end{array}$ & $\begin{array}{l}467.0 \\
419.0 \\
356.0 \\
300.0 \\
253.0\end{array}$ & $\begin{array}{l}0.04 \\
0.02 \\
0.01 \\
0.00 \\
0.00\end{array}$ & $\begin{array}{l}1715 \\
1720 \\
1725 \\
1730 \\
1735\end{array}$ & $\begin{array}{l}16.9 \\
15.7 \\
14.5 \\
12.8 \\
11.7\end{array}$ & $\begin{array}{l}0.00 \\
0.00 \\
0.00 \\
0.00 \\
0.00\end{array}$ & $\begin{array}{l}2040 \\
2045 \\
2050 \\
2055 \\
2100\end{array}$ & $\begin{array}{l}1.7 \\
1.5 \\
1.5 \\
1.5 \\
1.5\end{array}$ & $\begin{array}{l}0.00 \\
0.00 \\
0.00 \\
0.00 \\
0.00\end{array}$ \\
\hline $\begin{array}{l}1415 \\
1420 \\
1425 \\
1430 \\
1435\end{array}$ & $\begin{array}{l}211.0 \\
179.0 \\
147.0 \\
121.0 \\
102.0\end{array}$ & $\begin{array}{l}0.01 \\
0.00 \\
0.00 \\
0.01 \\
0.01\end{array}$ & $\begin{array}{l}1740 \\
1745 \\
1750 \\
1755 \\
1800\end{array}$ & $\begin{array}{r}10.6 \\
10.0 \\
9.0 \\
8.5 \\
8.0\end{array}$ & $\begin{array}{l}0.00 \\
0.00 \\
0.00 \\
0.00 \\
0.00\end{array}$ & $\begin{array}{l}2105 \\
2110 \\
2115 \\
2120 \\
2125\end{array}$ & $\begin{array}{l}1.5 \\
1.5 \\
1.5 \\
1.5 \\
1.5\end{array}$ & $\begin{array}{l}0.00 \\
0.00 \\
0.00 \\
0.00 \\
0.00\end{array}$ \\
\hline $\begin{array}{l}1440 \\
1445 \\
1450 \\
1455 \\
1500\end{array}$ & $\begin{array}{l}87.9 \\
78.6 \\
73.7 \\
71.8 \\
68.9\end{array}$ & $\begin{array}{l}0.02 \\
0.02 \\
0.03 \\
0.01 \\
0.02\end{array}$ & $\begin{array}{l}1805 \\
1810 \\
1815 \\
1820 \\
1825\end{array}$ & $\begin{array}{l}7.1 \\
6.6 \\
6.1 \\
5.6 \\
5.1\end{array}$ & $\begin{array}{l}0.00 \\
0.00 \\
0.00 \\
0.00 \\
0.00\end{array}$ & $\begin{array}{l}2130 \\
2135 \\
2140 \\
2145 \\
2150\end{array}$ & $\begin{array}{l}1.4 \\
1.4 \\
1.4 \\
1.4 \\
1.4\end{array}$ & $\begin{array}{l}0.00 \\
0.00 \\
0.00 \\
0.00 \\
0.00\end{array}$ \\
\hline $\begin{array}{l}1505 \\
1510 \\
1515 \\
1520 \\
1525\end{array}$ & $\begin{array}{l}68.9 \\
69.9 \\
71.8 \\
73.7 \\
73.7\end{array}$ & $\begin{array}{l}0.02 \\
0.03 \\
0.01 \\
0.03 \\
0.01\end{array}$ & $\begin{array}{l}1830 \\
1835 \\
1840 \\
1845 \\
1850\end{array}$ & $\begin{array}{l}4.7 \\
4.2 \\
4.2 \\
3.9 \\
3.5\end{array}$ & $\begin{array}{l}0.00 \\
0.00 \\
0.00 \\
0.00 \\
0.00\end{array}$ & $\begin{array}{l}2155 \\
2200 \\
2205 \\
2210 \\
2215\end{array}$ & $\begin{array}{l}1.4 \\
1.4 \\
1.4 \\
1.4 \\
1.4\end{array}$ & $\begin{array}{l}0.00 \\
0.00 \\
0.00 \\
0.00 \\
0.00\end{array}$ \\
\hline $\begin{array}{l}1530 \\
1535 \\
1540 \\
1545 \\
1550\end{array}$ & $\begin{array}{l}73.7 \\
75.7 \\
76.6 \\
77.6 \\
76.6\end{array}$ & $\begin{array}{l}0.02 \\
0.02 \\
0.01 \\
0.01 \\
0.02\end{array}$ & $\begin{array}{l}1855 \\
1900 \\
1905 \\
1910 \\
1915\end{array}$ & $\begin{array}{l}3.5 \\
3.1 \\
3.1 \\
2.8 \\
2.8\end{array}$ & $\begin{array}{l}0.00 \\
0.00 \\
0.00 \\
0.00 \\
0.00\end{array}$ & $\begin{array}{l}2220 \\
2225 \\
2230 \\
2235 \\
2240\end{array}$ & $\begin{array}{l}1.4 \\
1.4 \\
1.4 \\
1.4 \\
1.2\end{array}$ & $\begin{array}{l}0.00 \\
0.00 \\
0.00 \\
0.00 \\
0.00\end{array}$ \\
\hline $\begin{array}{l}1555 \\
1600 \\
1605 \\
1610 \\
1615\end{array}$ & $\begin{array}{l}75.7 \\
73.7 \\
70.8 \\
66.2 \\
61.7\end{array}$ & $\begin{array}{l}0.00 \\
0.01 \\
0.00 \\
0.00 \\
0.01\end{array}$ & $\begin{array}{l}1920 \\
1925 \\
1930 \\
1935 \\
1940\end{array}$ & $\begin{array}{l}2.8 \\
2.5 \\
2.5 \\
2.5 \\
2.2\end{array}$ & $\begin{array}{l}0.00 \\
0.00 \\
0.00 \\
0.00 \\
0.00\end{array}$ & $\begin{array}{l}2245 \\
2250 \\
2255 \\
2300\end{array}$ & $\begin{array}{l}1.2 \\
1.2 \\
1.2 \\
1.2\end{array}$ & $\begin{array}{l}0.00 \\
0.00 \\
0.00 \\
0.00\end{array}$ \\
\hline 1620 & 56.5 & 0.00 & 1945 & 2.2 & 0.00 & & & \\
\hline
\end{tabular}




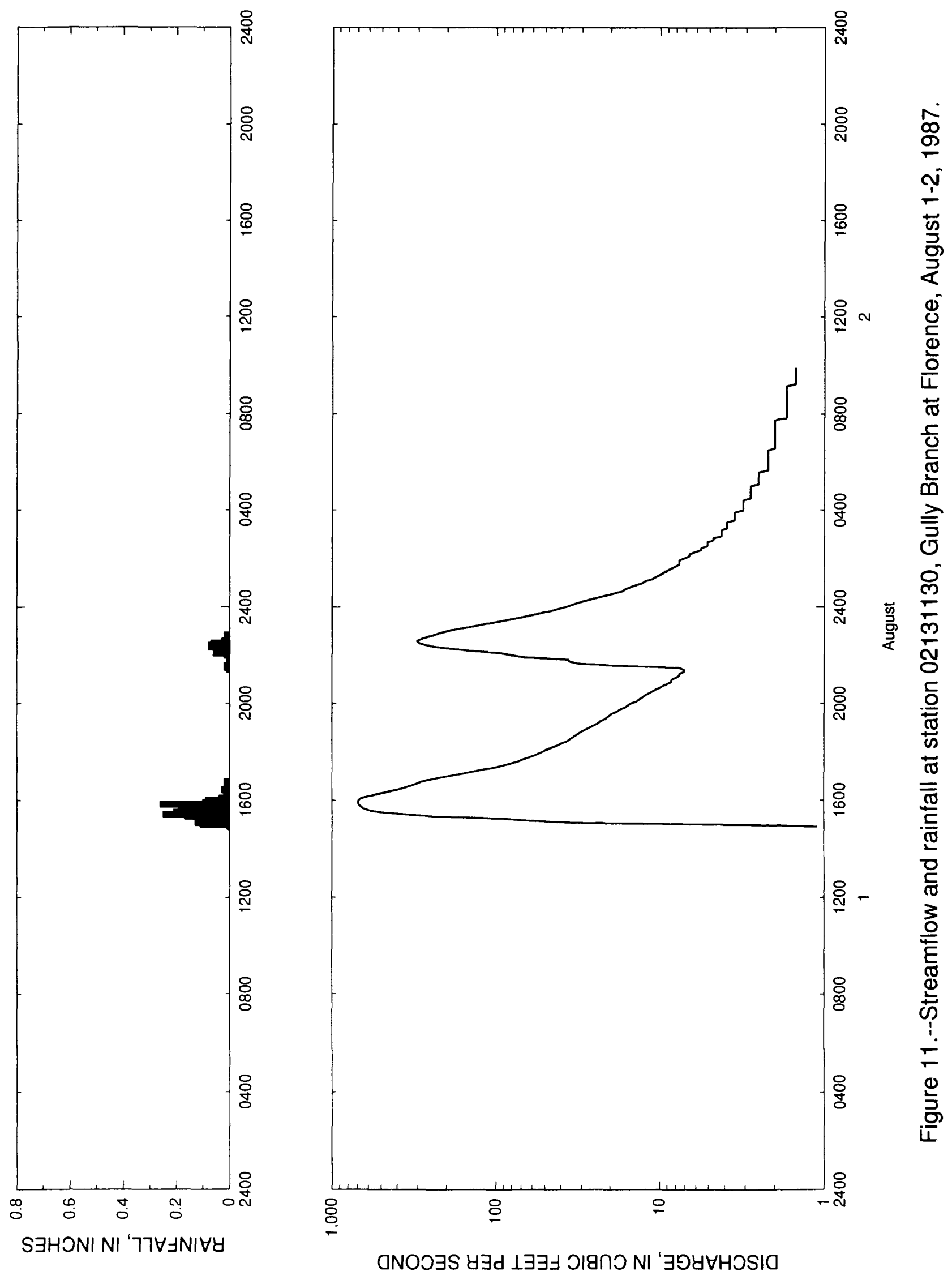


Table 10.--Streamflow and rainfall at station 02131130 , Gully Branch at Florence, August $1-2,1987$

\begin{tabular}{|c|c|c|c|c|c|c|c|c|}
\hline $\begin{array}{l}\text { Time } \\
\text { (hours) }\end{array}$ & $\begin{array}{l}\text { Streamflow } \\
\text { (cubic feet } \\
\text { per second) }\end{array}$ & $\begin{array}{l}\text { Rain- } \\
\text { fall } \\
\text { (inches) }\end{array}$ & $\begin{array}{l}\text { Time } \\
\text { (hours) }\end{array}$ & $\begin{array}{l}\text { Streamflow } \\
\text { (cubic feet } \\
\text { per second) }\end{array}$ & $\begin{array}{l}\text { Rain- } \\
\text { fall } \\
\text { (inches) }\end{array}$ & $\begin{array}{l}\text { Time } \\
\text { (hours) }\end{array}$ & $\begin{array}{l}\text { Streamflow } \\
\text { (cubic feet } \\
\text { per second) }\end{array}$ & $\begin{array}{l}\text { Rain- } \\
\text { fall } \\
\text { (inches) }\end{array}$ \\
\hline $\begin{array}{l}\text { August } 1 \text {, } \\
1455 \\
1500 \\
1505 \\
1510\end{array}$ & $\begin{array}{r}1987 \\
1.1 \\
3.1 \\
34.1 \\
62.6\end{array}$ & $\begin{array}{l}0.01 \\
0.11 \\
0.13 \\
0.12\end{array}$ & $\begin{array}{l}2015 \\
2020 \\
2025 \\
2030 \\
2035\end{array}$ & $\begin{array}{l}12.8 \\
12.3 \\
11.7 \\
11.1 \\
10.6\end{array}$ & $\begin{array}{l}0.00 \\
0.00 \\
0.00 \\
0.00 \\
0.00\end{array}$ & $\begin{array}{l}0135 \\
0140 \\
0145 \\
0150 \\
0155\end{array}$ & $\begin{array}{l}8.5 \\
8.0 \\
7.6 \\
7.6 \\
7.6\end{array}$ & $\begin{array}{l}0.00 \\
0.00 \\
0.00 \\
0.00 \\
0.00\end{array}$ \\
\hline $\begin{array}{l}1515 \\
1520 \\
1525 \\
1530 \\
1535\end{array}$ & $\begin{array}{r}91.1 \\
235.0 \\
354.0 \\
498.0 \\
602.0\end{array}$ & $\begin{array}{l}0.09 \\
0.17 \\
0.25 \\
0.21 \\
0.19\end{array}$ & $\begin{array}{l}2040 \\
2045 \\
2050 \\
2055 \\
2100\end{array}$ & $\begin{array}{r}10.0 \\
9.5 \\
9.0 \\
8.5 \\
8.5\end{array}$ & $\begin{array}{l}0.00 \\
0.00 \\
0.00 \\
0.00 \\
0.00\end{array}$ & $\begin{array}{l}0200 \\
0205 \\
0210 \\
0215 \\
0220\end{array}$ & $\begin{array}{l}7.1 \\
6.6 \\
6.6 \\
6.1 \\
5.6\end{array}$ & $\begin{array}{l}0.00 \\
0.00 \\
0.00 \\
0.00 \\
0.00\end{array}$ \\
\hline $\begin{array}{l}1540 \\
1545 \\
1550 \\
1555 \\
1600\end{array}$ & $\begin{array}{l}648.0 \\
671.0 \\
690.0 \\
696.0 \\
690.0\end{array}$ & $\begin{array}{l}0.18 \\
0.15 \\
0.26 \\
0.10 \\
0.09\end{array}$ & $\begin{array}{l}2105 \\
2110 \\
2115 \\
2120 \\
2125\end{array}$ & $\begin{array}{l}8.0 \\
7.6 \\
7.6 \\
7.1 \\
7.1\end{array}$ & $\begin{array}{l}0.00 \\
0.00 \\
0.00 \\
0.00 \\
0.01\end{array}$ & $\begin{array}{l}0225 \\
0230 \\
0235 \\
0240 \\
0245\end{array}$ & $\begin{array}{l}5.6 \\
5.1 \\
5.1 \\
5.1 \\
4.7\end{array}$ & $\begin{array}{l}0.00 \\
0.00 \\
0.00 \\
0.00 \\
0.00\end{array}$ \\
\hline $\begin{array}{l}1605 \\
1610 \\
1615 \\
1620 \\
1625\end{array}$ & $\begin{array}{l}669.0 \\
602.0 \\
528.0 \\
458.0 \\
402.0\end{array}$ & $\begin{array}{l}0.04 \\
0.02 \\
0.01 \\
0.00 \\
0.03\end{array}$ & $\begin{array}{l}2130 \\
2135 \\
2140 \\
2145 \\
2150\end{array}$ & $\begin{array}{r}7.6 \\
17.5 \\
31.3 \\
35.5 \\
36.3\end{array}$ & $\begin{array}{l}0.02 \\
0.02 \\
0.01 \\
0.01 \\
0.00\end{array}$ & $\begin{array}{l}0250 \\
0255 \\
0300 \\
0305 \\
0310\end{array}$ & $\begin{array}{l}4.7 \\
4.2 \\
4.2 \\
4.2 \\
4.2\end{array}$ & $\begin{array}{l}0.00 \\
0.00 \\
0.00 \\
0.00 \\
0.00\end{array}$ \\
\hline $\begin{array}{l}1630 \\
1635 \\
1640 \\
1645 \\
1650\end{array}$ & $\begin{array}{l}362.0 \\
333.0 \\
305.0 \\
284.0 \\
252.0\end{array}$ & $\begin{array}{l}0.02 \\
0.01 \\
0.02 \\
0.02 \\
0.00\end{array}$ & $\begin{array}{l}2155 \\
2200 \\
2205 \\
2210 \\
2215\end{array}$ & $\begin{array}{r}67.1 \\
79.6 \\
93.3 \\
134.0 \\
178.0\end{array}$ & $\begin{array}{l}0.01 \\
0.02 \\
0.06 \\
0.06 \\
0.06\end{array}$ & $\begin{array}{l}0315 \\
0320 \\
0325 \\
0330 \\
0335\end{array}$ & $\begin{array}{l}3.9 \\
3.9 \\
3.9 \\
3.9 \\
3.5\end{array}$ & $\begin{array}{l}0.00 \\
0.00 \\
0.00 \\
0.00 \\
0.00\end{array}$ \\
\hline $\begin{array}{l}1655 \\
1700 \\
1705 \\
1710 \\
1715\end{array}$ & $\begin{array}{l}219.0 \\
188.0 \\
160.0 \\
138.0 \\
119.0\end{array}$ & $\begin{array}{l}0.00 \\
0.00 \\
0.00 \\
0.00 \\
0.00\end{array}$ & $\begin{array}{l}2220 \\
2225 \\
2230 \\
2235 \\
2240\end{array}$ & $\begin{array}{l}226.0 \\
270.0 \\
294.0 \\
305.0 \\
287.0\end{array}$ & $\begin{array}{l}0.08 \\
0.08 \\
0.07 \\
0.03 \\
0.02\end{array}$ & $\begin{array}{l}0340 \\
0345 \\
0350 \\
0355 \\
0400\end{array}$ & $\begin{array}{l}3.5 \\
3.5 \\
3.5 \\
3.5 \\
3.1\end{array}$ & $\begin{array}{l}0.00 \\
0.00 \\
0.00 \\
0.00 \\
0.00\end{array}$ \\
\hline $\begin{array}{l}1720 \\
1725 \\
1730 \\
1735 \\
1740\end{array}$ & $\begin{array}{r}102.0 \\
91.1 \\
81.7 \\
73.7 \\
68.9\end{array}$ & $\begin{array}{l}0.00 \\
0.00 \\
0.00 \\
0.00 \\
0.00\end{array}$ & $\begin{array}{l}2245 \\
2250 \\
2255 \\
2300 \\
2305\end{array}$ & $\begin{array}{l}264.0 \\
242.0 \\
222.0 \\
199.0 \\
173.0\end{array}$ & $\begin{array}{l}0.02 \\
0.02 \\
0.00 \\
0.00 \\
0.00\end{array}$ & $\begin{array}{l}0405 \\
0410 \\
0415 \\
0420 \\
0425\end{array}$ & $\begin{array}{l}3.1 \\
3.1 \\
3.1 \\
3.1 \\
3.1\end{array}$ & $\begin{array}{l}0.00 \\
0.00 \\
0.00 \\
0.00 \\
0.00\end{array}$ \\
\hline $\begin{array}{l}1745 \\
1750 \\
1755 \\
1800 \\
1805\end{array}$ & $\begin{array}{l}63.5 \\
58.2 \\
54.9 \\
51.6 \\
49.1\end{array}$ & $\begin{array}{l}0.00 \\
0.00 \\
0.00 \\
0.00 \\
0.00\end{array}$ & $\begin{array}{l}2310 \\
2315 \\
2320 \\
2325 \\
2330\end{array}$ & $\begin{array}{r}147.0 \\
127.0 \\
109.0 \\
93.3 \\
79.6\end{array}$ & $\begin{array}{l}0.00 \\
0.00 \\
0.00 \\
0.00 \\
0.00\end{array}$ & $\begin{array}{l}0430 \\
0435 \\
0440 \\
0445 \\
0450\end{array}$ & $\begin{array}{l}2.8 \\
2.8 \\
2.8 \\
2.8 \\
2.8\end{array}$ & $\begin{array}{l}0.00 \\
0.00 \\
0.00 \\
0.00 \\
0.00\end{array}$ \\
\hline $\begin{array}{l}1810 \\
1815 \\
1820 \\
1825 \\
1830\end{array}$ & $\begin{array}{l}45.7 \\
42.4 \\
40.0 \\
37.0 \\
35.5\end{array}$ & $\begin{array}{l}0.00 \\
0.00 \\
0.00 \\
0.00 \\
0.00\end{array}$ & $\begin{array}{l}2335 \\
2340 \\
2345 \\
2350 \\
2355\end{array}$ & $\begin{array}{l}68.9 \\
59.9 \\
53.2 \\
46.5 \\
42.4\end{array}$ & $\begin{array}{l}0.00 \\
0.00 \\
0.00 \\
0.00 \\
0.00\end{array}$ & $\begin{array}{l}0455 \\
0500 \\
0505 \\
0510 \\
0515\end{array}$ & $\begin{array}{l}2.8 \\
2.8 \\
2.5 \\
2.5 \\
2.5\end{array}$ & $\begin{array}{l}0.00 \\
0.00 \\
0.00 \\
0.00 \\
0.00\end{array}$ \\
\hline $\begin{array}{l}1835 \\
1840 \\
1845 \\
1850 \\
1855\end{array}$ & $\begin{array}{l}34.1 \\
32.7 \\
31.3 \\
30.0 \\
28.3\end{array}$ & $\begin{array}{l}0.00 \\
0.00 \\
0.00 \\
0.00 \\
0.00\end{array}$ & $\begin{array}{l}\text { August } 2 \\
0000 \\
0005 \\
0010 \\
0015\end{array}$ & $\begin{array}{r}1987 \\
37.7 \\
34.8 \\
32.0 \\
29.2\end{array}$ & $\begin{array}{l}0.00 \\
0.00 \\
0.00 \\
0.00\end{array}$ & $\begin{array}{l}0520 \\
0525 \\
0530 \\
0535 \\
0540\end{array}$ & $\begin{array}{l}2.5 \\
2.5 \\
2.5 \\
2.5 \\
2.2\end{array}$ & $\begin{array}{l}0.00 \\
0.00 \\
0.00 \\
0.00 \\
0.00\end{array}$ \\
\hline $\begin{array}{l}1900 \\
1905 \\
1910 \\
1915 \\
1920\end{array}$ & $\begin{array}{l}26.7 \\
25.2 \\
23.7 \\
23.0 \\
21.6\end{array}$ & $\begin{array}{l}0.00 \\
0.00 \\
0.00 \\
0.00 \\
0.00\end{array}$ & $\begin{array}{l}0020 \\
0025 \\
0030 \\
0035 \\
0040\end{array}$ & $\begin{array}{l}26.0 \\
23.0 \\
20.9 \\
18.8 \\
16.9\end{array}$ & $\begin{array}{l}0.00 \\
0.00 \\
0.00 \\
0.00 \\
0.00\end{array}$ & $\begin{array}{l}0545 \\
0550 \\
0555 \\
0600 \\
0605\end{array}$ & $\begin{array}{l}2.2 \\
2.2 \\
2.2 \\
2.2 \\
2.2\end{array}$ & $\begin{array}{l}0.00 \\
0.00 \\
0.00 \\
0.00 \\
0.00\end{array}$ \\
\hline $\begin{array}{l}1925 \\
1930 \\
1935 \\
1940 \\
1945\end{array}$ & $\begin{array}{l}20.9 \\
20.2 \\
19.5 \\
18.2 \\
17.5\end{array}$ & $\begin{array}{l}0.00 \\
0.00 \\
0.00 \\
0.00 \\
0.00\end{array}$ & $\begin{array}{l}0045 \\
0050 \\
0055 \\
0100 \\
0105\end{array}$ & $\begin{array}{l}16.3 \\
15.1 \\
13.9 \\
12.8 \\
12.3\end{array}$ & $\begin{array}{l}0.00 \\
0.00 \\
0.00 \\
0.00 \\
0.00\end{array}$ & $\begin{array}{l}0610 \\
0615 \\
0620 \\
0625 \\
0630\end{array}$ & $\begin{array}{l}2.2 \\
2.2 \\
2.2 \\
2.2 \\
2.2\end{array}$ & $\begin{array}{l}0.00 \\
0.00 \\
0.00 \\
0.00 \\
0.00\end{array}$ \\
\hline $\begin{array}{l}1950 \\
1955 \\
2000 \\
2005 \\
2010\end{array}$ & $\begin{array}{l}16.3 \\
15.7 \\
15.1 \\
13.9 \\
13.4\end{array}$ & $\begin{array}{l}0.00 \\
0.00 \\
0.00 \\
0.00 \\
0.00\end{array}$ & $\begin{array}{l}0110 \\
0115 \\
0120 \\
0125 \\
0130\end{array}$ & $\begin{array}{r}11.1 \\
10.6 \\
10.0 \\
9.5 \\
9.0\end{array}$ & $\begin{array}{l}0.00 \\
0.00 \\
0.00 \\
0.00 \\
0.00\end{array}$ & $\begin{array}{l}0635 \\
0640 \\
0645 \\
0650 \\
0655\end{array}$ & $\begin{array}{l}2.0 \\
2.0 \\
2.0 \\
2.0 \\
2.0\end{array}$ & $\begin{array}{l}0.00 \\
0.00 \\
0.00 \\
0.02 \\
0.00\end{array}$ \\
\hline
\end{tabular}


Table 10.--Streamflow and rainfa11 at station 02131130, Gu11y Branch at Florence, August $1-2,1987^{--C o n t i n u e d}$

\begin{tabular}{|c|c|c|c|c|c|c|c|c|}
\hline $\begin{array}{l}\text { Time } \\
\text { (hours) }\end{array}$ & $\begin{array}{l}\text { Streamflow } \\
\text { (cubic feet } \\
\text { per second) }\end{array}$ & $\begin{array}{l}\text { Rain- } \\
\text { fall } \\
\text { (inches) }\end{array}$ & $\begin{array}{l}\text { Time } \\
\text { (hours) }\end{array}$ & $\begin{array}{l}\text { Streamflow } \\
\text { (cubic feet } \\
\text { per second) }\end{array}$ & $\begin{array}{l}\text { Rain- } \\
\text { fall } \\
\text { (inches) }\end{array}$ & $\begin{array}{l}\text { Time } \\
\text { (hours) }\end{array}$ & $\begin{array}{l}\text { Streamflow } \\
\text { (cubic feet } \\
\text { per second) }\end{array}$ & $\begin{array}{l}\text { Rain- } \\
\text { fall } \\
\text { (inches) }\end{array}$ \\
\hline $\begin{array}{l}0700 \\
0705 \\
0710 \\
0715 \\
0720\end{array}$ & $\begin{array}{l}2.0 \\
2.0 \\
2.0 \\
2.0 \\
2.0\end{array}$ & $\begin{array}{l}0.00 \\
0.00 \\
0.00 \\
0.00 \\
0.00\end{array}$ & $\begin{array}{l}0805 \\
0810 \\
0815 \\
0820 \\
0825\end{array}$ & $\begin{array}{l}1.7 \\
1.7 \\
1.7 \\
1.7 \\
1.7\end{array}$ & $\begin{array}{l}0.00 \\
0.00 \\
0.00 \\
0.00 \\
0.00\end{array}$ & $\begin{array}{l}0910 \\
0915 \\
0920 \\
0925 \\
0930\end{array}$ & $\begin{array}{l}1.7 \\
1.5 \\
1.5 \\
1.5 \\
1.5\end{array}$ & $\begin{array}{l}0.00 \\
0.00 \\
0.00 \\
0.00 \\
0.00\end{array}$ \\
\hline $\begin{array}{l}0725 \\
0730 \\
0735 \\
0740 \\
0745\end{array}$ & $\begin{array}{l}2.0 \\
2.0 \\
2.0 \\
2.0 \\
2.0\end{array}$ & $\begin{array}{l}0.00 \\
0.00 \\
0.00 \\
0.00 \\
0.00\end{array}$ & $\begin{array}{l}0830 \\
0835 \\
0840 \\
0845 \\
0850\end{array}$ & $\begin{array}{l}1.7 \\
1.7 \\
1.7 \\
1.7 \\
1.7\end{array}$ & $\begin{array}{l}0.00 \\
0.00 \\
0.00 \\
0.00 \\
0.00\end{array}$ & $\begin{array}{l}0935 \\
0940 \\
0945 \\
0950 \\
0955\end{array}$ & $\begin{array}{l}1.5 \\
1.5 \\
1.5 \\
1.5 \\
1.5\end{array}$ & $\begin{array}{l}0.00 \\
0.00 \\
0.00 \\
0.00 \\
0.00\end{array}$ \\
\hline $\begin{array}{l}0750 \\
0755 \\
0800\end{array}$ & $\begin{array}{l}1.7 \\
1.7 \\
1.7\end{array}$ & $\begin{array}{l}0.00 \\
0.00 \\
0.00\end{array}$ & $\begin{array}{l}0855 \\
0900 \\
0905\end{array}$ & $\begin{array}{l}1.7 \\
1.7 \\
1.7\end{array}$ & $\begin{array}{l}0.00 \\
0.00 \\
0.00\end{array}$ & 1000 & 1.5 & 0.00 \\
\hline
\end{tabular}




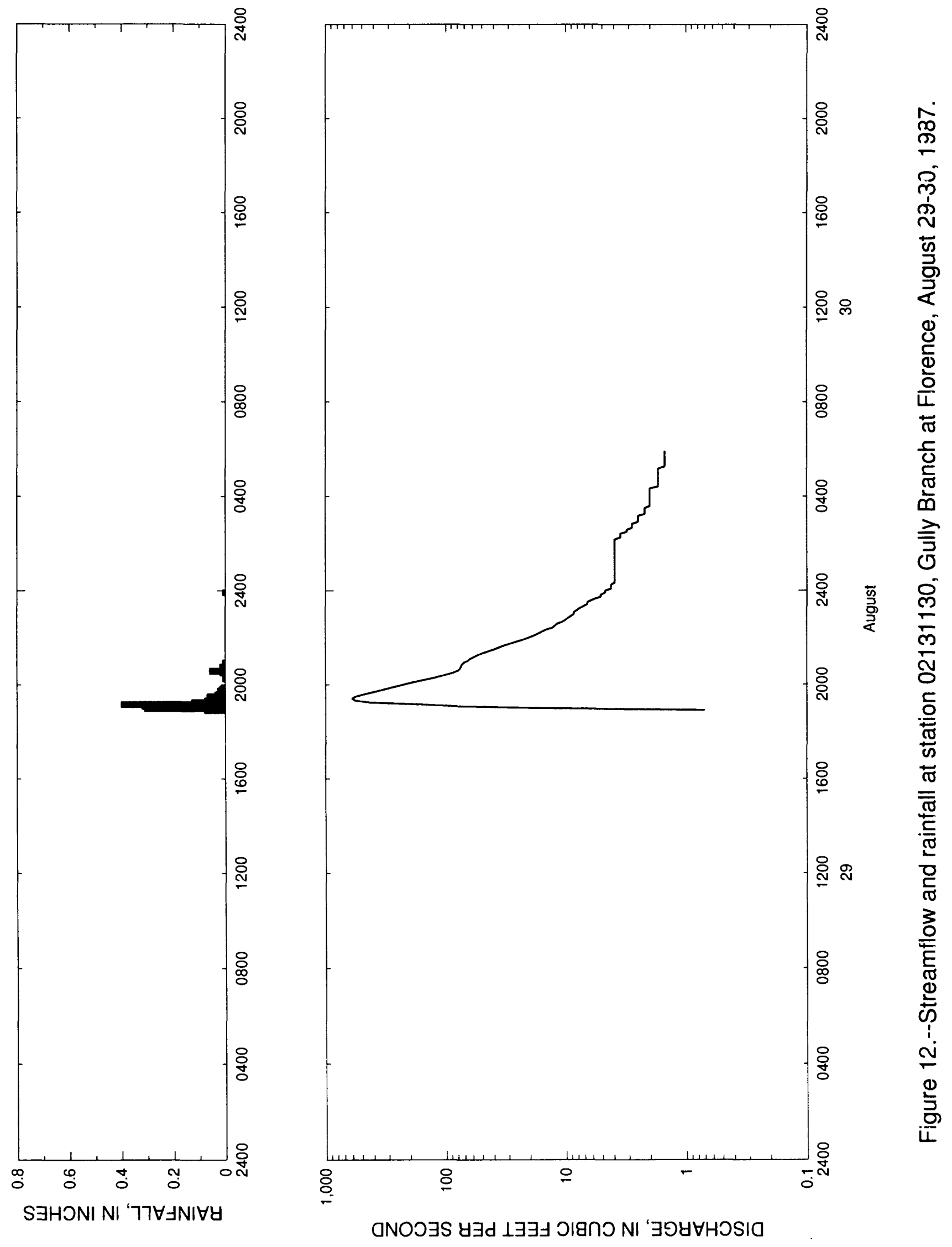


Table 11.--Streamflow and rainfall at station 02131130, Gully Branch at Florence, August $29-30,1987$

\begin{tabular}{|c|c|c|c|c|c|c|c|c|}
\hline $\begin{array}{l}\text { Time } \\
\text { (hours) }\end{array}$ & $\begin{array}{l}\text { Streamflow } \\
\text { (cubic feet } \\
\text { per second) }\end{array}$ & $\begin{array}{l}\text { Rain- } \\
\text { fall } \\
\text { (inches) }\end{array}$ & $\begin{array}{l}\text { Time } \\
\text { (hours) }\end{array}$ & $\begin{array}{l}\text { Streamflow } \\
\text { (cubic feet } \\
\text { per second) }\end{array}$ & $\begin{array}{l}\text { Rain- } \\
\text { fall } \\
\text { (inches) }\end{array}$ & $\begin{array}{l}\text { Time } \\
\text { (hours) }\end{array}$ & $\begin{array}{l}\text { Streamflow } \\
\text { (cubic feet } \\
\text { per second) }\end{array}$ & $\begin{array}{l}\text { Rain- } \\
\text { fall } \\
\text { (inches) }\end{array}$ \\
\hline $\begin{array}{l}\text { August } \\
1855 \\
1900 \\
1905 \\
1910\end{array}$ & 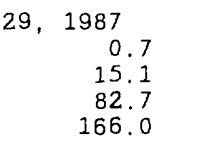 & $\begin{array}{l}0.08 \\
0.31 \\
0.32 \\
0.40\end{array}$ & $\begin{array}{l}2240 \\
2245 \\
2250 \\
2255 \\
2300\end{array}$ & $\begin{array}{r}10.6 \\
10.0 \\
9.5 \\
9.0 \\
8.5\end{array}$ & $\begin{array}{l}0.00 \\
0.00 \\
0.00 \\
0.00 \\
0.00\end{array}$ & $\begin{array}{l}0225 \\
0230 \\
0235 \\
0240 \\
0245\end{array}$ & $\begin{array}{l}3.5 \\
3.1 \\
3.1 \\
2.8 \\
2.8\end{array}$ & $\begin{array}{l}0.00 \\
0.00 \\
0.00 \\
0.00 \\
0.00\end{array}$ \\
\hline $\begin{array}{l}1915 \\
1920 \\
1925 \\
1930 \\
1935\end{array}$ & $\begin{array}{l}428.0 \\
568.0 \\
604.0 \\
566.0 \\
493.0\end{array}$ & $\begin{array}{l}0.13 \\
0.08 \\
0.06 \\
0.07 \\
0.04\end{array}$ & $\begin{array}{l}2305 \\
2310 \\
2315 \\
2320 \\
2325\end{array}$ & $\begin{array}{l}8.5 \\
8.0 \\
7.6 \\
7.1 \\
6.6\end{array}$ & $\begin{array}{l}0.00 \\
0.00 \\
0.00 \\
0.00 \\
0.00\end{array}$ & $\begin{array}{l}0250 \\
0255 \\
0300 \\
0305 \\
0310\end{array}$ & $\begin{array}{l}2.8 \\
2.5 \\
2.5 \\
2.5 \\
2.5\end{array}$ & $\begin{array}{l}0.00 \\
0.00 \\
0.00 \\
0.00 \\
0.00\end{array}$ \\
\hline $\begin{array}{l}1940 \\
1945 \\
1950 \\
1955 \\
2000\end{array}$ & $\begin{array}{l}422.0 \\
359.0 \\
308.0 \\
265.0 \\
228.0\end{array}$ & $\begin{array}{l}0.01 \\
0.03 \\
0.02 \\
0.00 \\
0.00\end{array}$ & $\begin{array}{l}2330 \\
2335 \\
2340 \\
2345 \\
2350\end{array}$ & $\begin{array}{l}6.6 \\
6.1 \\
5.6 \\
5.1 \\
5.1\end{array}$ & $\begin{array}{l}0.00 \\
0.00 \\
0.00 \\
0.00 \\
0.00\end{array}$ & $\begin{array}{l}0315 \\
0320 \\
0325 \\
0330 \\
0335\end{array}$ & $\begin{array}{l}2.2 \\
2.2 \\
2.2 \\
2.2 \\
2.0\end{array}$ & $\begin{array}{l}0.00 \\
0.00 \\
0.00 \\
0.00 \\
0.00\end{array}$ \\
\hline $\begin{array}{l}2005 \\
2010 \\
2015 \\
2020 \\
2025\end{array}$ & $\begin{array}{l}194.0 \\
164.0 \\
136.0 \\
115.0 \\
100.0\end{array}$ & $\begin{array}{l}0.00 \\
0.00 \\
0.01 \\
0.00 \\
0.01\end{array}$ & $\begin{array}{c}2355 \\
\text { August } \\
0000 \\
0005 \\
0010\end{array}$ & $\begin{array}{r}4.7 \\
30,1987 \\
4.7 \\
4.2 \\
4.2\end{array}$ & $\begin{array}{l}0.01 \\
0.00 \\
0.00 \\
0.00\end{array}$ & $\begin{array}{l}0340 \\
0345 \\
0350 \\
0355 \\
0400\end{array}$ & $\begin{array}{l}2.0 \\
2.0 \\
2.0 \\
2.0 \\
2.0\end{array}$ & $\begin{array}{l}0.00 \\
0.00 \\
0.00 \\
0.00 \\
0.00\end{array}$ \\
\hline $\begin{array}{l}2030 \\
2035 \\
2040 \\
2045 \\
2050\end{array}$ & $\begin{array}{l}86.9 \\
79.6 \\
76.6 \\
74.7 \\
73.7\end{array}$ & $\begin{array}{l}0.02 \\
0.06 \\
0.02 \\
0.02 \\
0.01\end{array}$ & $\begin{array}{l}0015 \\
0020 \\
0025 \\
0030 \\
0035\end{array}$ & $\begin{array}{l}4.2 \\
3.9 \\
3.9 \\
3.9 \\
3.9\end{array}$ & $\begin{array}{l}0.00 \\
0.00 \\
0.00 \\
0.00 \\
0.00\end{array}$ & $\begin{array}{l}0405 \\
0410 \\
0415 \\
0420 \\
0425\end{array}$ & $\begin{array}{l}2.0 \\
2.0 \\
2.0 \\
2.0 \\
1.7\end{array}$ & $\begin{array}{l}0.00 \\
0.00 \\
0.00 \\
0.00 \\
0.00\end{array}$ \\
\hline $\begin{array}{l}2055 \\
2100 \\
2105 \\
2110 \\
2115\end{array}$ & $\begin{array}{l}70.8 \\
65.3 \\
62.6 \\
58.2 \\
54.0\end{array}$ & $\begin{array}{l}0.01 \\
0.00 \\
0.00 \\
0.00 \\
0.00\end{array}$ & $\begin{array}{l}0040 \\
0045 \\
0050 \\
0055 \\
0100\end{array}$ & $\begin{array}{l}3.9 \\
3.9 \\
3.9 \\
3.9 \\
3.9\end{array}$ & $\begin{array}{l}0.00 \\
0.00 \\
0.00 \\
0.00 \\
0.00\end{array}$ & $\begin{array}{l}0430 \\
0435 \\
0440 \\
0445 \\
0450\end{array}$ & $\begin{array}{l}1.7 \\
1.7 \\
1.7 \\
1.7 \\
1.7\end{array}$ & $\begin{array}{l}0.00 \\
0.00 \\
0.00 \\
0.00 \\
0.00\end{array}$ \\
\hline $\begin{array}{l}2120 \\
2125 \\
2130 \\
2135 \\
2140\end{array}$ & $\begin{array}{l}49.1 \\
44.0 \\
39.3 \\
35.5 \\
32.0\end{array}$ & $\begin{array}{l}0.00 \\
0.00 \\
0.00 \\
0.00 \\
0.00\end{array}$ & $\begin{array}{l}0105 \\
0110 \\
0115 \\
0120 \\
0125\end{array}$ & $\begin{array}{l}3.9 \\
3.9 \\
3.9 \\
3.9 \\
3.9\end{array}$ & $\begin{array}{l}0.00 \\
0.00 \\
0.00 \\
0.00 \\
0.00\end{array}$ & $\begin{array}{l}0455 \\
0500 \\
0505 \\
0510 \\
0515\end{array}$ & $\begin{array}{l}1.7 \\
1.7 \\
1.7 \\
1.7 \\
1.5\end{array}$ & $\begin{array}{l}0.0 C \\
0.0 C \\
0.0 C \\
0.0 C \\
0.0 C\end{array}$ \\
\hline $\begin{array}{l}2145 \\
2150 \\
2155 \\
2200 \\
2205\end{array}$ & $\begin{array}{l}28.3 \\
25.2 \\
22.3 \\
20.2 \\
18.2\end{array}$ & $\begin{array}{l}0.00 \\
0.00 \\
0.00 \\
0.00 \\
0.00\end{array}$ & $\begin{array}{l}0130 \\
0135 \\
0140 \\
0145 \\
0150\end{array}$ & $\begin{array}{l}3.9 \\
3.9 \\
3.9 \\
3.9 \\
3.9\end{array}$ & $\begin{array}{l}0.00 \\
0.00 \\
0.00 \\
0.00 \\
0.00\end{array}$ & $\begin{array}{l}0520 \\
0525 \\
0530 \\
0535 \\
0540\end{array}$ & $\begin{array}{l}1.5 \\
1.5 \\
1.5 \\
1.5 \\
1.5\end{array}$ & $\begin{array}{l}0.00 \\
0.00 \\
0.00 \\
0.00 \\
0.00\end{array}$ \\
\hline $\begin{array}{l}2210 \\
2215 \\
2220 \\
2225 \\
2230\end{array}$ & $\begin{array}{l}16.9 \\
15.7 \\
14.5 \\
12.8 \\
12.3\end{array}$ & $\begin{array}{l}0.00 \\
0.00 \\
0.00 \\
0.00 \\
0.00\end{array}$ & $\begin{array}{l}0155 \\
0200 \\
0205 \\
0210 \\
0215\end{array}$ & $\begin{array}{l}3.9 \\
3.9 \\
3.9 \\
3.9 \\
3.5\end{array}$ & $\begin{array}{l}0.00 \\
0.00 \\
0.00 \\
0.00 \\
0.00\end{array}$ & $\begin{array}{l}0545 \\
0550 \\
0555 \\
0600\end{array}$ & $\begin{array}{l}1.5 \\
1.5 \\
1.5 \\
1.5\end{array}$ & $\begin{array}{l}0.00 \\
0.00 \\
0.00 \\
0.00\end{array}$ \\
\hline 2235 & 11.7 & 0.00 & 0220 & 3.5 & 0.00 & & & \\
\hline
\end{tabular}




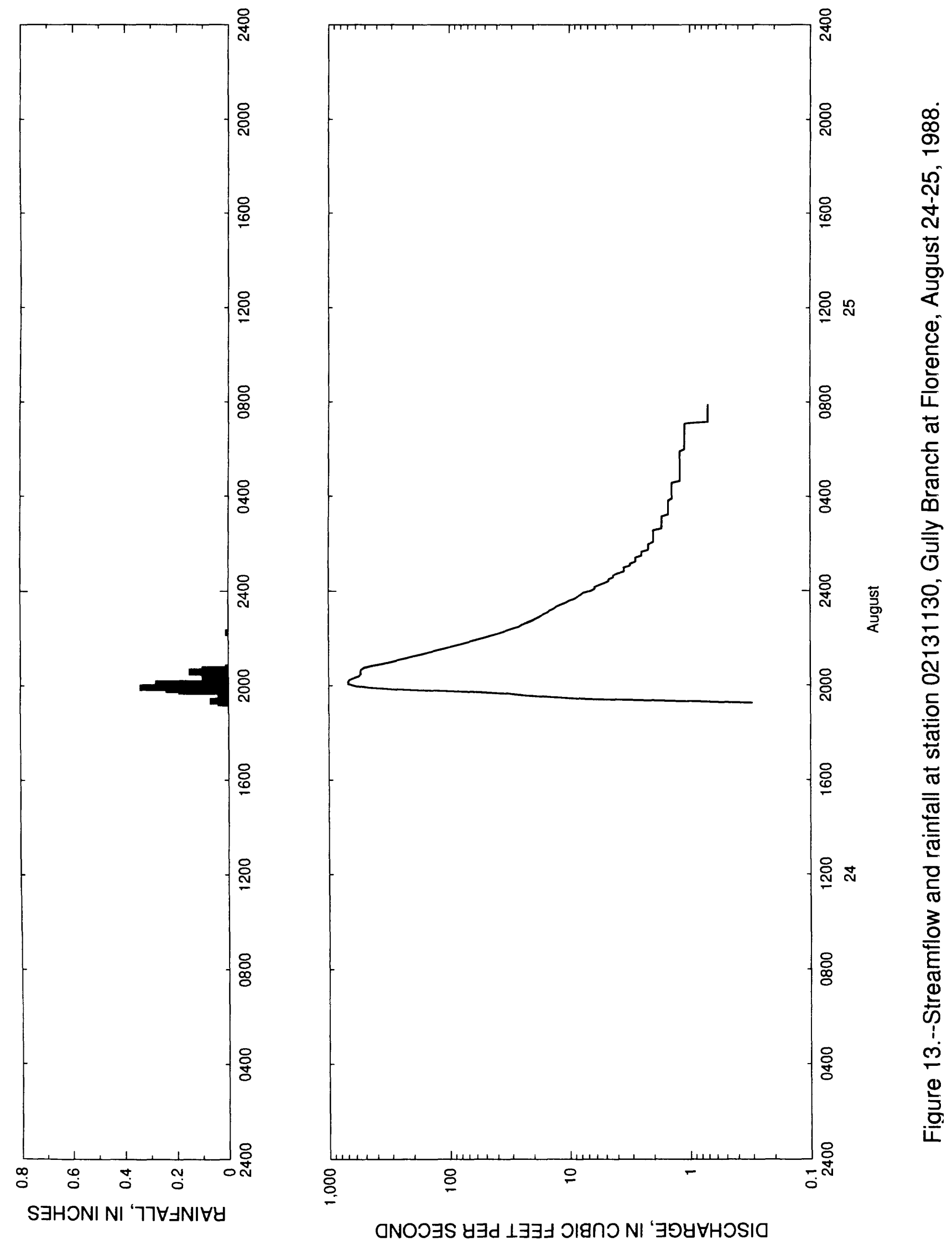


Table 12.- - Streamflow and rainfall at station 02131130, Gully Branch at Florence, August $24-25,1988$

\begin{tabular}{|c|c|c|c|c|c|c|c|c|}
\hline $\begin{array}{l}\text { Time } \\
\text { (hours) }\end{array}$ & $\begin{array}{l}\text { Streamflow } \\
\text { (cubic feet } \\
\text { per second) }\end{array}$ & $\begin{array}{l}\text { Rain- } \\
\text { fall } \\
\text { (inches) }\end{array}$ & $\begin{array}{l}\text { Time } \\
\text { (hours) }\end{array}$ & $\begin{array}{l}\text { Streamflow } \\
\text { (cubic feet } \\
\text { per second) }\end{array}$ & $\begin{array}{l}\text { Rain- } \\
\text { fall } \\
\text { (inches) }\end{array}$ & $\begin{array}{l}\text { Time } \\
\text { (hours) }\end{array}$ & $\begin{array}{l}\text { Streamflow } \\
\text { (cubic feet } \\
\text { per second) }\end{array}$ & $\begin{array}{l}\text { Rain- } \\
\text { fa11 } \\
\text { (inches) }\end{array}$ \\
\hline $\begin{array}{l}\text { August } 2 \\
1915 \\
1920 \\
1925 \\
1930\end{array}$ & 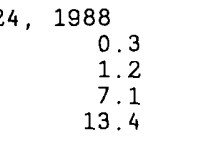 & $\begin{array}{l}0.04 \\
0.07 \\
0.03 \\
0.04\end{array}$ & $\begin{array}{l}2330 \\
2335 \\
2340 \\
2345 \\
2350\end{array}$ & $\begin{array}{r}10.6 \\
10.0 \\
9.0 \\
8.5 \\
8.0\end{array}$ & $\begin{array}{l}0.00 \\
0.00 \\
0.00 \\
0.00 \\
0.00\end{array}$ & $\begin{array}{l}0345 \\
0350 \\
0355 \\
0400 \\
0405\end{array}$ & $\begin{array}{l}1.5 \\
1.5 \\
1.4 \\
1.4 \\
1.4\end{array}$ & $\begin{array}{l}0.00 \\
0.00 \\
0.00 \\
0.00 \\
0.00\end{array}$ \\
\hline $\begin{array}{l}1935 \\
1940 \\
1945 \\
1950 \\
1955\end{array}$ & $\begin{array}{r}23.7 \\
33.4 \\
73.7 \\
258.0 \\
458.0\end{array}$ & $\begin{array}{l}0.04 \\
0.04 \\
0.19 \\
0.24 \\
0.34\end{array}$ & $\begin{array}{c}2355 \\
\text { August } \\
0000 \\
0005 \\
0010\end{array}$ & $\begin{array}{r}7.6 \\
25,1988 \\
6.6 \\
6.1 \\
6.1\end{array}$ & $\begin{array}{l}0.00 \\
0.00 \\
0.00 \\
0.00\end{array}$ & $\begin{array}{l}0410 \\
0415 \\
0420 \\
0425 \\
0430\end{array}$ & $\begin{array}{l}1.4 \\
1.4 \\
1.4 \\
1.4 \\
1.4\end{array}$ & $\begin{array}{l}0.00 \\
0.00 \\
0.00 \\
0.00 \\
0.00\end{array}$ \\
\hline $\begin{array}{l}2000 \\
2005 \\
2010 \\
2015 \\
2020\end{array}$ & $\begin{array}{l}610.0 \\
692.0 \\
694.0 \\
675.0 \\
618.0\end{array}$ & $\begin{array}{l}0.19 \\
0.28 \\
0.09 \\
0.08 \\
0.10\end{array}$ & $\begin{array}{l}0015 \\
0020 \\
0025 \\
0030 \\
0035\end{array}$ & $\begin{array}{l}5.6 \\
5.1 \\
4.7 \\
4.7 \\
4.3\end{array}$ & $\begin{array}{l}0.00 \\
0.00 \\
0.00 \\
0.00 \\
0.00\end{array}$ & $\begin{array}{l}0435 \\
0440 \\
0445 \\
0450 \\
0455\end{array}$ & $\begin{array}{l}1.4 \\
1.2 \\
1.2 \\
1.2 \\
1.2\end{array}$ & $\begin{array}{l}0.00 \\
0.00 \\
0.00 \\
0.00 \\
0.00\end{array}$ \\
\hline $\begin{array}{l}2025 \\
2030 \\
2035 \\
2040 \\
2045\end{array}$ & $\begin{array}{l}561.0 \\
538.0 \\
547.0 \\
541.0 \\
507.0\end{array}$ & $\begin{array}{l}0.01 \\
0.09 \\
0.15 \\
0.10 \\
0.01\end{array}$ & $\begin{array}{l}0040 \\
0045 \\
0050 \\
0055 \\
0100\end{array}$ & $\begin{array}{l}4.3 \\
3.9 \\
3.5 \\
3.5 \\
3.5\end{array}$ & $\begin{array}{l}0.00 \\
0.00 \\
0.00 \\
0.00 \\
0.00\end{array}$ & $\begin{array}{l}0500 \\
0505 \\
0510 \\
0515 \\
0520\end{array}$ & $\begin{array}{l}1.2 \\
1.2 \\
1.2 \\
1.2 \\
1.2\end{array}$ & $\begin{array}{l}0.00 \\
0.00 \\
0.00 \\
0.00 \\
0.00\end{array}$ \\
\hline $\begin{array}{l}2050 \\
2055 \\
2100 \\
2105 \\
2110\end{array}$ & $\begin{array}{l}433.0 \\
354.0 \\
300.0 \\
261.0 \\
225.0\end{array}$ & $\begin{array}{l}0.00 \\
0.00 \\
0.00 \\
0.00 \\
0.00\end{array}$ & $\begin{array}{l}0105 \\
0110 \\
0115 \\
0120 \\
0125\end{array}$ & $\begin{array}{l}3.1 \\
3.1 \\
2.8 \\
2.8 \\
2.8\end{array}$ & $\begin{array}{l}0.00 \\
0.00 \\
0.00 \\
0.00 \\
0.00\end{array}$ & $\begin{array}{l}0525 \\
0530 \\
0535 \\
0540 \\
0545\end{array}$ & $\begin{array}{l}1.2 \\
1.2 \\
1.2 \\
1.2 \\
1.2\end{array}$ & $\begin{array}{l}0.00 \\
0.00 \\
0.00 \\
0.00 \\
0.00\end{array}$ \\
\hline $\begin{array}{l}2115 \\
2120 \\
2125 \\
2130 \\
2135\end{array}$ & $\begin{array}{l}196.0 \\
166.0 \\
145.0 \\
125.0 \\
107.0\end{array}$ & $\begin{array}{l}0.00 \\
0.00 \\
0.00 \\
0.00 \\
0.00\end{array}$ & $\begin{array}{l}0130 \\
0135 \\
0140 \\
0145 \\
0150\end{array}$ & $\begin{array}{l}2.5 \\
2.5 \\
2.5 \\
2.2 \\
2.2\end{array}$ & $\begin{array}{l}0.00 \\
0.00 \\
0.00 \\
0.00 \\
0.00\end{array}$ & $\begin{array}{l}0550 \\
0555 \\
0600 \\
0605 \\
0610\end{array}$ & $\begin{array}{l}1.2 \\
1.2 \\
1.1 \\
1.1 \\
1.1\end{array}$ & $\begin{array}{l}0.00 \\
0.00 \\
0.00 \\
0.00 \\
0.00\end{array}$ \\
\hline $\begin{array}{l}2140 \\
2145 \\
2150 \\
2155 \\
2200\end{array}$ & $\begin{array}{l}93.3 \\
80.6 \\
70.8 \\
61.7 \\
53.2\end{array}$ & $\begin{array}{l}0.00 \\
0.00 \\
0.00 \\
0.00 \\
0.00\end{array}$ & $\begin{array}{l}0155 \\
0200 \\
0205 \\
0210 \\
0215\end{array}$ & $\begin{array}{l}2.2 \\
2.2 \\
2.0 \\
2.0 \\
2.0\end{array}$ & $\begin{array}{l}0.00 \\
0.00 \\
0.00 \\
0.00 \\
0.00\end{array}$ & $\begin{array}{l}0615 \\
0620 \\
0625 \\
0630 \\
0635\end{array}$ & $\begin{array}{l}1.1 \\
1.1 \\
1.1 \\
1.1 \\
1.1\end{array}$ & $\begin{array}{l}0.00 \\
0.00 \\
0.00 \\
0.00 \\
0.00\end{array}$ \\
\hline $\begin{array}{l}2205 \\
2210 \\
2215 \\
2220 \\
2225\end{array}$ & $\begin{array}{l}46.5 \\
40.8 \\
36.3 \\
32.7 \\
29.2\end{array}$ & $\begin{array}{l}0.00 \\
0.00 \\
0.01 \\
0.00 \\
0.00\end{array}$ & $\begin{array}{l}0220 \\
0225 \\
0230 \\
0235 \\
0240\end{array}$ & $\begin{array}{l}2.0 \\
2.0 \\
2.0 \\
2.0 \\
1.7\end{array}$ & $\begin{array}{l}0.00 \\
0.00 \\
0.00 \\
0.00 \\
0.00\end{array}$ & $\begin{array}{l}0640 \\
0645 \\
0650 \\
0655 \\
0700\end{array}$ & $\begin{array}{l}1.1 \\
1.1 \\
1.1 \\
1.1 \\
1.1\end{array}$ & $\begin{array}{l}0.00 \\
0.00 \\
0.00 \\
0.00 \\
0.00\end{array}$ \\
\hline $\begin{array}{l}2230 \\
2235 \\
2240 \\
2245 \\
2250\end{array}$ & $\begin{array}{l}26.0 \\
24.5 \\
22.3 \\
20.2 \\
18.8\end{array}$ & $\begin{array}{l}0.00 \\
0.00 \\
0.00 \\
0.00 \\
0.00\end{array}$ & $\begin{array}{l}0245 \\
0250 \\
0255 \\
0300 \\
0305\end{array}$ & $\begin{array}{l}1.7 \\
1.7 \\
1.7 \\
1.7 \\
1.7\end{array}$ & $\begin{array}{l}0.00 \\
0.00 \\
0.00 \\
0.00 \\
0.00\end{array}$ & $\begin{array}{l}0705 \\
0710 \\
0715 \\
0720 \\
0725\end{array}$ & $\begin{array}{l}1.1 \\
0.7 \\
0.7 \\
0.7 \\
0.7\end{array}$ & $\begin{array}{l}0.00 \\
0.00 \\
0.00 \\
0.00 \\
0.00\end{array}$ \\
\hline $\begin{array}{l}2255 \\
2300 \\
2305 \\
2310 \\
2315\end{array}$ & $\begin{array}{l}17.5 \\
16.3 \\
15.1 \\
14.5 \\
13.4\end{array}$ & $\begin{array}{l}0.00 \\
0.00 \\
0.00 \\
0.00 \\
0.00\end{array}$ & $\begin{array}{l}0310 \\
0315 \\
0320 \\
0325 \\
0330\end{array}$ & $\begin{array}{l}1.7 \\
1.5 \\
1.5 \\
1.5 \\
1.5\end{array}$ & $\begin{array}{l}0.00 \\
0.00 \\
0.00 \\
0.00 \\
0.00\end{array}$ & $\begin{array}{l}0730 \\
0735 \\
0740 \\
0745 \\
0750\end{array}$ & $\begin{array}{l}0.7 \\
0.7 \\
0.7 \\
0.7 \\
0.7\end{array}$ & $\begin{array}{l}0.00 \\
0.00 \\
0.00 \\
0.00 \\
0.00\end{array}$ \\
\hline $\begin{array}{l}2320 \\
2325\end{array}$ & $\begin{array}{l}12.8 \\
11.7\end{array}$ & $\begin{array}{l}0.00 \\
0.00\end{array}$ & $\begin{array}{l}0335 \\
0340\end{array}$ & $\begin{array}{l}1.5 \\
1.5\end{array}$ & $\begin{array}{l}0.00 \\
0.00\end{array}$ & $\begin{array}{l}0755 \\
0800\end{array}$ & $\begin{array}{l}0.7 \\
0.7\end{array}$ & $\begin{array}{l}0.00 \\
0.00\end{array}$ \\
\hline
\end{tabular}




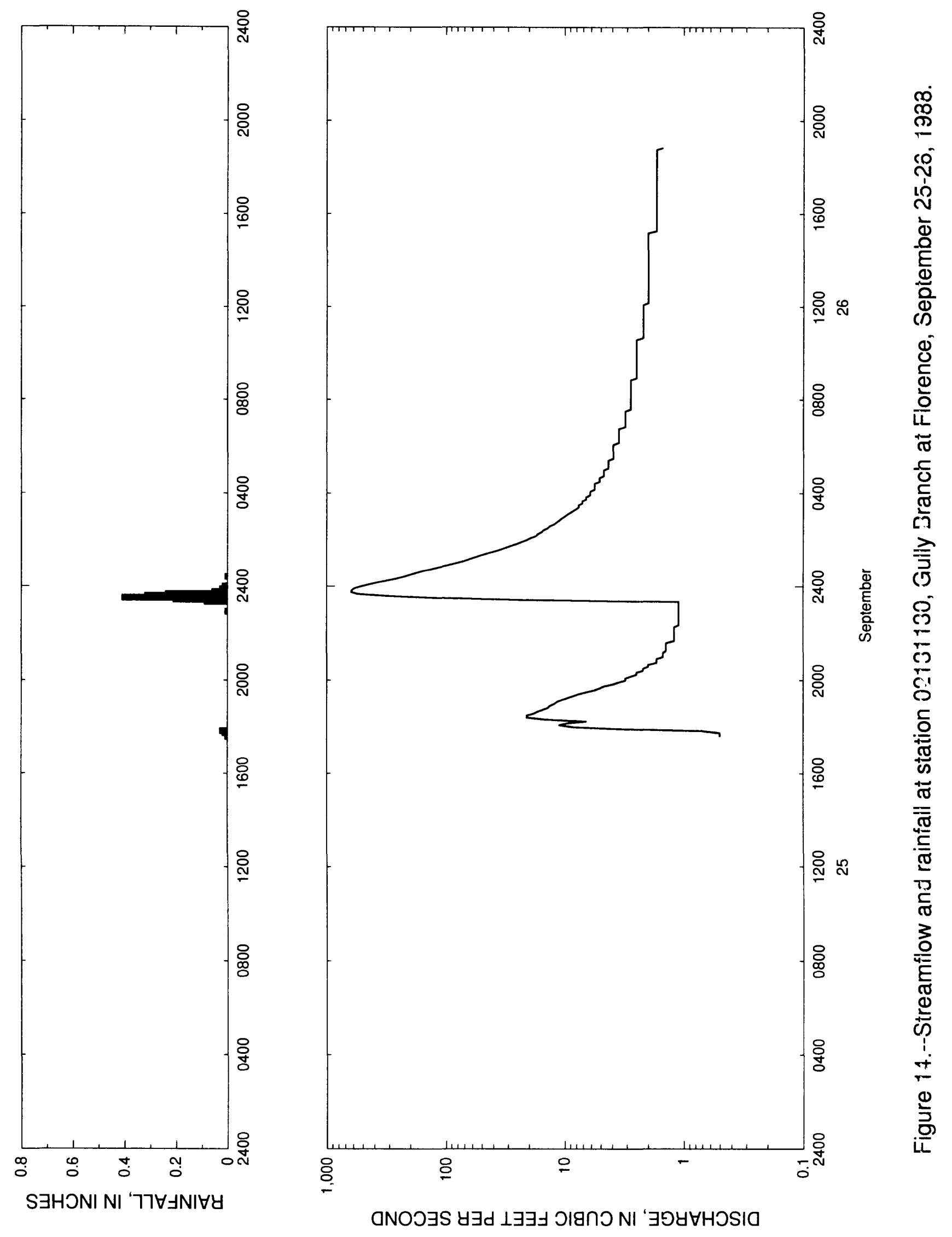


Table 13.--Streamflow and rainfall at station 02131130, Gully Branch at Florence, September $25-26,1988$

\begin{tabular}{|c|c|c|c|c|c|c|c|c|}
\hline $\begin{array}{l}\text { Time } \\
\text { (hours) }\end{array}$ & $\begin{array}{l}\text { Streamflow } \\
\text { (cubic feet } \\
\text { per second) }\end{array}$ & $\begin{array}{l}\text { Rain- } \\
\text { fall } \\
\text { (inches) }\end{array}$ & $\begin{array}{l}\text { Time } \\
\text { (hours) }\end{array}$ & $\begin{array}{l}\text { Streamflow } \\
\text { (cubic feet } \\
\text { per second) }\end{array}$ & $\begin{array}{l}\text { Rain- } \\
\text { fall } \\
\text { (inches) }\end{array}$ & $\begin{array}{l}\text { Time } \\
\text { (hours) }\end{array}$ & $\begin{array}{l}\text { Streamflow } \\
\text { (cubic feet } \\
\text { per second) }\end{array}$ & $\begin{array}{l}\text { Rain- } \\
\text { fall } \\
\text { (inches) }\end{array}$ \\
\hline $\begin{array}{l}\text { September } \\
1735 \\
1740 \\
1745 \\
1750\end{array}$ & $\begin{array}{ll}25, & 1988 \\
0.5 \\
0.5 \\
0.5 \\
0.7\end{array}$ & $\begin{array}{l}0.01 \\
0.01 \\
0.02 \\
0.03\end{array}$ & $\begin{array}{l}2255 \\
2300 \\
2305 \\
2310 \\
2315\end{array}$ & $\begin{array}{l}1.1 \\
1.1 \\
1.1 \\
1.1 \\
1.1\end{array}$ & $\begin{array}{l}0.01 \\
0.00 \\
0.00 \\
0.00 \\
0.00\end{array}$ & $\begin{array}{l}0415 \\
0420 \\
0425 \\
0430 \\
0435\end{array}$ & $\begin{array}{l}5.6 \\
5.6 \\
5.6 \\
5.1 \\
5.1\end{array}$ & $\begin{array}{l}0.00 \\
0.00 \\
0.00 \\
0.00 \\
0.00\end{array}$ \\
\hline $\begin{array}{l}1755 \\
1800 \\
1805 \\
1810 \\
1815\end{array}$ & $\begin{array}{r}3.5 \\
8.5 \\
11.1 \\
9.5 \\
6.6\end{array}$ & $\begin{array}{l}0.00 \\
0.00 \\
0.00 \\
0.00 \\
0.00\end{array}$ & $\begin{array}{l}2320 \\
2325 \\
2330 \\
2335 \\
2340\end{array}$ & $\begin{array}{r}1.1 \\
24.5 \\
113.0 \\
298.0 \\
549.0\end{array}$ & $\begin{array}{l}0.09 \\
0.21 \\
0.41 \\
0.32 \\
0.24\end{array}$ & $\begin{array}{l}0440 \\
0445 \\
0450 \\
0455 \\
0500\end{array}$ & $\begin{array}{l}5.1 \\
4.7 \\
4.7 \\
4.7 \\
4.7\end{array}$ & $\begin{array}{l}0.00 \\
0.00 \\
0.00 \\
0.00 \\
0.00\end{array}$ \\
\hline $\begin{array}{l}1820 \\
1825 \\
1830 \\
1835 \\
1840\end{array}$ & $\begin{array}{l}14.5 \\
20.9 \\
20.9 \\
18.2 \\
16.9\end{array}$ & $\begin{array}{l}0.00 \\
0.00 \\
0.00 \\
0.00 \\
0.00\end{array}$ & $\begin{array}{c}2345 \\
2350 \\
2355 \\
\text { Septembe } \\
0000\end{array}$ & $\begin{array}{c}624.0 \\
618.0 \\
582.0 \\
\times 26,1988 \\
515.0\end{array}$ & $\begin{array}{l}0.06 \\
0.03 \\
0.00 \\
0.02\end{array}$ & $\begin{array}{l}0505 \\
0510 \\
0515 \\
0520 \\
0525\end{array}$ & $\begin{array}{l}4.3 \\
4.3 \\
4.3 \\
4.3 \\
4.3\end{array}$ & $\begin{array}{l}0.00 \\
0.00 \\
0.00 \\
0.00 \\
0.00\end{array}$ \\
\hline $\begin{array}{l}1845 \\
1850 \\
1855 \\
1900 \\
1905\end{array}$ & $\begin{array}{l}15.3 \\
13.9 \\
13.4 \\
12.3 \\
11.7\end{array}$ & $\begin{array}{l}0.00 \\
0.00 \\
0.00 \\
0.00 \\
0.00\end{array}$ & $\begin{array}{l}0005 \\
0010 \\
0015 \\
0020 \\
0025\end{array}$ & $\begin{array}{l}442.0 \\
379.0 \\
317.0 \\
261.0 \\
226.0\end{array}$ & $\begin{array}{l}0.00 \\
0.00 \\
0.00 \\
0.00 \\
0.01\end{array}$ & $\begin{array}{l}0530 \\
0535 \\
0540 \\
0545 \\
0550\end{array}$ & $\begin{array}{l}3.9 \\
3.9 \\
3.9 \\
3.9 \\
3.9\end{array}$ & $\begin{array}{l}0.00 \\
0.00 \\
0.00 \\
0.00 \\
0.00\end{array}$ \\
\hline $\begin{array}{l}1910 \\
1915 \\
1920 \\
1925 \\
1930\end{array}$ & $\begin{array}{r}10.6 \\
9.5 \\
8.5 \\
7.6 \\
6.6\end{array}$ & $\begin{array}{l}0.00 \\
0.00 \\
0.00 \\
0.00 \\
0.00\end{array}$ & $\begin{array}{l}0030 \\
0035 \\
0040 \\
0045 \\
0050\end{array}$ & $\begin{array}{l}200.0 \\
177.0 \\
155.0 \\
130.0 \\
112.0\end{array}$ & $\begin{array}{l}0.00 \\
0.00 \\
0.00 \\
0.00 \\
0.00\end{array}$ & $\begin{array}{l}0555 \\
0600 \\
0605 \\
0610 \\
0615\end{array}$ & $\begin{array}{l}3.9 \\
3.9 \\
3.9 \\
3.5 \\
3.5\end{array}$ & $\begin{array}{l}0.00 \\
0.00 \\
0.00 \\
0.00 \\
0.00\end{array}$ \\
\hline $\begin{array}{l}1935 \\
1940 \\
1945 \\
1950 \\
1955\end{array}$ & $\begin{array}{l}5.6 \\
5.1 \\
4.7 \\
3.9 \\
3.5\end{array}$ & $\begin{array}{l}0.00 \\
0.00 \\
0.00 \\
0.00 \\
0.00\end{array}$ & $\begin{array}{l}0055 \\
0100 \\
0105 \\
0110 \\
0115\end{array}$ & $\begin{array}{l}95.5 \\
81.7 \\
70.8 \\
63.5 \\
56.5\end{array}$ & $\begin{array}{l}0.00 \\
0.00 \\
0.00 \\
0.00 \\
0.00\end{array}$ & $\begin{array}{l}0620 \\
0625 \\
0630 \\
0635 \\
0640\end{array}$ & $\begin{array}{l}3.5 \\
3.5 \\
3.5 \\
3.5 \\
3.5\end{array}$ & $\begin{array}{l}0.00 \\
0.00 \\
0.00 \\
0.00 \\
0.00\end{array}$ \\
\hline $\begin{array}{l}2000 \\
2005 \\
2010 \\
2015 \\
2020\end{array}$ & $\begin{array}{l}3.1 \\
3.1 \\
2.8 \\
2.5 \\
2.5\end{array}$ & $\begin{array}{l}0.00 \\
0.00 \\
0.00 \\
0.00 \\
0.00\end{array}$ & $\begin{array}{l}0120 \\
0125 \\
0130 \\
0135 \\
0140\end{array}$ & $\begin{array}{l}50.8 \\
44.9 \\
39.3 \\
34.8 \\
31.3\end{array}$ & $\begin{array}{l}0.00 \\
0.00 \\
0.00 \\
0.00 \\
0.00\end{array}$ & $\begin{array}{l}0645 \\
0650 \\
0655 \\
0700 \\
0705\end{array}$ & $\begin{array}{l}3.5 \\
3.1 \\
3.1 \\
3.1 \\
3.1\end{array}$ & $\begin{array}{l}0.00 \\
0.00 \\
0.00 \\
0.00 \\
0.00\end{array}$ \\
\hline $\begin{array}{l}2025 \\
2030 \\
2035 \\
2040 \\
2045\end{array}$ & $\begin{array}{l}2.2 \\
2.2 \\
2.0 \\
2.0 \\
1.7\end{array}$ & $\begin{array}{l}0.00 \\
0.00 \\
0.00 \\
0.00 \\
0.00\end{array}$ & $\begin{array}{l}0145 \\
0150 \\
0155 \\
0200 \\
0205\end{array}$ & $\begin{array}{l}28.3 \\
25.2 \\
23.0 \\
20.9 \\
19.5\end{array}$ & $\begin{array}{l}0.00 \\
0.00 \\
0.00 \\
0.00 \\
0.00\end{array}$ & $\begin{array}{l}0710 \\
0715 \\
0720 \\
0725 \\
0730\end{array}$ & $\begin{array}{l}3.1 \\
3.1 \\
3.1 \\
3.1 \\
3.1\end{array}$ & $\begin{array}{l}0.00 \\
0.00 \\
0.00 \\
0.00 \\
0.00\end{array}$ \\
\hline $\begin{array}{l}2050 \\
2055 \\
2100 \\
2105 \\
2110\end{array}$ & $\begin{array}{l}1.7 \\
1.7 \\
1.5 \\
1.5 \\
1.5\end{array}$ & $\begin{array}{l}0.00 \\
0.00 \\
0.00 \\
0.00 \\
0.00\end{array}$ & $\begin{array}{l}0210 \\
0215 \\
0220 \\
0225 \\
0230\end{array}$ & $\begin{array}{l}17.5 \\
16.9 \\
15.7 \\
15.1 \\
13.9\end{array}$ & $\begin{array}{l}0.00 \\
0.00 \\
0.00 \\
0.00 \\
0.00\end{array}$ & $\begin{array}{l}0735 \\
0740 \\
0745 \\
0750 \\
0755\end{array}$ & $\begin{array}{l}2.8 \\
2.8 \\
2.8 \\
2.8 \\
2.8\end{array}$ & $\begin{array}{l}0.00 \\
0.00 \\
0.00 \\
0.00 \\
0.00\end{array}$ \\
\hline $\begin{array}{l}2115 \\
2120 \\
2125 \\
2130 \\
2135\end{array}$ & $\begin{array}{l}1.4 \\
1.4 \\
1.4 \\
1.4 \\
1.4\end{array}$ & $\begin{array}{l}0.00 \\
0.00 \\
0.00 \\
0.00 \\
0.00\end{array}$ & $\begin{array}{l}0235 \\
0240 \\
0245 \\
0250 \\
0255\end{array}$ & $\begin{array}{l}13.4 \\
12.3 \\
11.7 \\
11.1 \\
10.6\end{array}$ & $\begin{array}{l}0.00 \\
0.00 \\
0.00 \\
0.00 \\
0.00\end{array}$ & $\begin{array}{l}0800 \\
0805 \\
0810 \\
0815 \\
0820\end{array}$ & $\begin{array}{l}2.8 \\
2.8 \\
2.8 \\
2.8 \\
2.8\end{array}$ & $\begin{array}{l}0.00 \\
0.00 \\
0.00 \\
0.00 \\
0.00\end{array}$ \\
\hline $\begin{array}{l}2140 \\
2145 \\
2150 \\
2155 \\
2200\end{array}$ & $\begin{array}{l}1.2 \\
1.2 \\
1.2 \\
1.2 \\
1.2\end{array}$ & $\begin{array}{l}0.00 \\
0.00 \\
0.00 \\
0.00 \\
0.00\end{array}$ & $\begin{array}{l}0300 \\
0305 \\
0310 \\
0315 \\
0320\end{array}$ & $\begin{array}{r}10.0 \\
9.5 \\
9.0 \\
8.5 \\
8.0\end{array}$ & $\begin{array}{l}0.00 \\
0.00 \\
0.00 \\
0.00 \\
0.00\end{array}$ & $\begin{array}{l}0825 \\
0830 \\
0835 \\
0840 \\
0845\end{array}$ & $\begin{array}{l}2.8 \\
2.8 \\
2.8 \\
2.8 \\
2.8\end{array}$ & $\begin{array}{l}0.00 \\
0.00 \\
0.00 \\
0.00 \\
0.00\end{array}$ \\
\hline $\begin{array}{l}2205 \\
2210 \\
2215 \\
2220 \\
2225\end{array}$ & $\begin{array}{l}1.2 \\
1.2 \\
1.2 \\
1.1 \\
1.1\end{array}$ & $\begin{array}{l}0.00 \\
0.00 \\
0.00 \\
0.00 \\
0.00\end{array}$ & $\begin{array}{l}0325 \\
0330 \\
0335 \\
0340 \\
0345\end{array}$ & $\begin{array}{l}7.6 \\
7.6 \\
7.1 \\
7.1 \\
6.6\end{array}$ & $\begin{array}{l}0.00 \\
0.00 \\
0.00 \\
0.00 \\
0.00\end{array}$ & $\begin{array}{l}0850 \\
0855 \\
0900 \\
0905 \\
0910\end{array}$ & $\begin{array}{l}2.8 \\
2.5 \\
2.5 \\
2.5 \\
2.5\end{array}$ & $\begin{array}{l}0.00 \\
0.00 \\
0.00 \\
0.00 \\
0.00\end{array}$ \\
\hline $\begin{array}{l}2230 \\
2235 \\
2240 \\
2245 \\
2250\end{array}$ & $\begin{array}{l}1.1 \\
1.1 \\
1.1 \\
1.1 \\
1.1\end{array}$ & $\begin{array}{l}0.00 \\
0.00 \\
0.00 \\
0.00 \\
0.00\end{array}$ & $\begin{array}{l}0350 \\
0355 \\
0400 \\
0405 \\
0410\end{array}$ & $\begin{array}{l}6.6 \\
6.1 \\
6.1 \\
6.1 \\
5.6\end{array}$ & $\begin{array}{l}0.00 \\
0.00 \\
0.00 \\
0.00 \\
0.00\end{array}$ & $\begin{array}{l}0915 \\
0920 \\
0925 \\
0930 \\
0935\end{array}$ & $\begin{array}{l}2.5 \\
2.5 \\
2.5 \\
2.5 \\
2.5\end{array}$ & $\begin{array}{l}0.00 \\
0.00 \\
0.00 \\
0.00 \\
0.00\end{array}$ \\
\hline
\end{tabular}


Table 13.--Streamflow and rainfall at station 02131130, Gully Branch at Florence, September 25-26, 1988--Continued

\begin{tabular}{|c|c|c|c|c|c|c|c|c|}
\hline $\begin{array}{l}\text { Time } \\
\text { (hours) }\end{array}$ & $\begin{array}{l}\text { Streamflow } \\
\text { (cubic feet } \\
\text { per second) }\end{array}$ & $\begin{array}{l}\text { Rain- } \\
\text { fall } \\
\text { (inches) }\end{array}$ & $\begin{array}{l}\text { Time } \\
\text { (hours) }\end{array}$ & $\begin{array}{l}\text { Streamf1ow } \\
\text { (cubic feet } \\
\text { per second) }\end{array}$ & $\begin{array}{l}\text { Rain- } \\
\text { fall } \\
\text { (inches) }\end{array}$ & $\begin{array}{l}\text { Time } \\
\text { (hours) }\end{array}$ & $\begin{array}{l}\text { Streamflow } \\
\text { (cubic feet } \\
\text { per second) }\end{array}$ & $\begin{array}{l}\text { Rain- } \\
\text { fall } \\
\text { (inches) }\end{array}$ \\
\hline $\begin{array}{l}0940 \\
0945 \\
0950 \\
0955 \\
1000\end{array}$ & $\begin{array}{l}2.5 \\
2.5 \\
2.5 \\
2.5 \\
2.5\end{array}$ & $\begin{array}{l}0.00 \\
0.00 \\
0.00 \\
0.00 \\
0.00\end{array}$ & $\begin{array}{l}1250 \\
1255 \\
1300 \\
1305 \\
1310\end{array}$ & $\begin{array}{l}2.0 \\
2.0 \\
2.0 \\
2.0 \\
2.0\end{array}$ & $\begin{array}{l}0.00 \\
0.00 \\
0.00 \\
0.00 \\
0.00\end{array}$ & $\begin{array}{l}1600 \\
1605 \\
1610 \\
1615 \\
1620\end{array}$ & $\begin{array}{l}1.7 \\
1.7 \\
1.7 \\
1.7 \\
1.7\end{array}$ & $\begin{array}{l}0.00 \\
0.00 \\
0.00 \\
0.00 \\
0.00\end{array}$ \\
\hline $\begin{array}{l}1005 \\
1010 \\
1015 \\
1020 \\
1025\end{array}$ & $\begin{array}{l}2.5 \\
2.5 \\
2.5 \\
2.5 \\
2.5\end{array}$ & $\begin{array}{l}0.00 \\
0.00 \\
0.00 \\
0.00 \\
0.00\end{array}$ & $\begin{array}{l}1315 \\
1320 \\
1325 \\
1330 \\
1335\end{array}$ & $\begin{array}{l}2.0 \\
2.0 \\
2.0 \\
2.0 \\
2.0\end{array}$ & $\begin{array}{l}0.00 \\
0.00 \\
0.00 \\
0.00 \\
0.00\end{array}$ & $\begin{array}{l}1625 \\
1630 \\
1635 \\
1640 \\
1645\end{array}$ & $\begin{array}{l}1.7 \\
1.7 \\
1.7 \\
1.7 \\
1.7\end{array}$ & $\begin{array}{l}0.00 \\
0.00 \\
0.00 \\
0.00 \\
0.00\end{array}$ \\
\hline $\begin{array}{l}1030 \\
1035 \\
1040 \\
1045 \\
1050\end{array}$ & $\begin{array}{l}2.5 \\
2.5 \\
2.2 \\
2.2 \\
2.2\end{array}$ & $\begin{array}{l}0.00 \\
0.00 \\
0.00 \\
0.00 \\
0.00\end{array}$ & $\begin{array}{l}1340 \\
1345 \\
1350 \\
1355 \\
1400\end{array}$ & $\begin{array}{l}2.0 \\
2.0 \\
2.0 \\
2.0 \\
2.0\end{array}$ & $\begin{array}{l}0.00 \\
0.00 \\
0.00 \\
0.00 \\
0.00\end{array}$ & $\begin{array}{l}1650 \\
1655 \\
1700 \\
1705 \\
1710\end{array}$ & $\begin{array}{l}1.7 \\
1.7 \\
1.7 \\
1.7 \\
1.7\end{array}$ & $\begin{array}{l}0.00 \\
0.00 \\
0.00 \\
0.00 \\
0.00\end{array}$ \\
\hline $\begin{array}{l}1055 \\
1100 \\
1105 \\
1110 \\
1115\end{array}$ & $\begin{array}{l}2.2 \\
2.2 \\
2.2 \\
2.2 \\
2.2\end{array}$ & $\begin{array}{l}0.00 \\
0.00 \\
0.00 \\
0.00 \\
0.00\end{array}$ & $\begin{array}{l}1405 \\
1410 \\
1415 \\
1420 \\
1425\end{array}$ & $\begin{array}{l}2.0 \\
2.0 \\
2.0 \\
2.0 \\
2.0\end{array}$ & $\begin{array}{l}0.00 \\
0.00 \\
0.00 \\
0.00 \\
0.00\end{array}$ & $\begin{array}{l}1715 \\
1720 \\
1725 \\
1730 \\
1735\end{array}$ & $\begin{array}{l}1.7 \\
1.7 \\
1.7 \\
1.7 \\
1.7\end{array}$ & $\begin{array}{l}0.00 \\
0.00 \\
0.00 \\
0.00 \\
0.00\end{array}$ \\
\hline $\begin{array}{l}1120 \\
1125 \\
1130 \\
1135 \\
1140\end{array}$ & $\begin{array}{l}2.2 \\
2.2 \\
2.2 \\
2.2 \\
2.2\end{array}$ & $\begin{array}{l}0.00 \\
0.00 \\
0.00 \\
0.00 \\
0.00\end{array}$ & $\begin{array}{l}1430 \\
1435 \\
1440 \\
1445 \\
1450\end{array}$ & $\begin{array}{l}2.0 \\
2.0 \\
2.0 \\
2.0 \\
2.0\end{array}$ & $\begin{array}{l}0.00 \\
0.00 \\
0.00 \\
0.00 \\
0.00\end{array}$ & $\begin{array}{l}1740 \\
1745 \\
1750 \\
1755 \\
1800\end{array}$ & $\begin{array}{l}1.7 \\
1.7 \\
1.7 \\
1.7 \\
1.7\end{array}$ & $\begin{array}{l}0.00 \\
0.00 \\
0.00 \\
0.00 \\
0.00\end{array}$ \\
\hline $\begin{array}{l}1145 \\
1150 \\
1155 \\
1200 \\
1205\end{array}$ & $\begin{array}{l}2.2 \\
2.2 \\
2.2 \\
2.2 \\
2.2\end{array}$ & $\begin{array}{l}0.00 \\
0.00 \\
0.00 \\
0.00 \\
0.00\end{array}$ & $\begin{array}{l}1455 \\
1500 \\
1505 \\
1510 \\
1515\end{array}$ & $\begin{array}{l}2.0 \\
2.0 \\
2.0 \\
2.0 \\
1.7\end{array}$ & $\begin{array}{l}0.00 \\
0.00 \\
0.00 \\
0.00 \\
0.00\end{array}$ & $\begin{array}{l}1805 \\
1810 \\
1815 \\
1820 \\
1825\end{array}$ & $\begin{array}{l}1.7 \\
1.7 \\
1.7 \\
1.7 \\
1.7\end{array}$ & $\begin{array}{l}0.00 \\
0.00 \\
0.00 \\
0.00 \\
0.00\end{array}$ \\
\hline $\begin{array}{l}1210 \\
1215 \\
1220 \\
1225 \\
1230\end{array}$ & $\begin{array}{l}2.0 \\
2.0 \\
2.0 \\
2.0 \\
2.0\end{array}$ & $\begin{array}{l}0.00 \\
0.00 \\
0.00 \\
0.00 \\
0.00\end{array}$ & $\begin{array}{l}1520 \\
1525 \\
1530 \\
1535 \\
1540\end{array}$ & $\begin{array}{l}1.7 \\
1.7 \\
1.7 \\
1.7 \\
1.7\end{array}$ & $\begin{array}{l}0.00 \\
0.00 \\
0.00 \\
0.00 \\
0.00\end{array}$ & $\begin{array}{l}1830 \\
1835 \\
1840 \\
1845 \\
1850\end{array}$ & $\begin{array}{l}1.7 \\
1.7 \\
1.7 \\
1.7 \\
1.5\end{array}$ & $\begin{array}{l}0.00 \\
0.00 \\
0.00 \\
0.00 \\
0.00\end{array}$ \\
\hline $\begin{array}{l}1235 \\
1240 \\
1245\end{array}$ & $\begin{array}{l}2.0 \\
2.0 \\
2.0\end{array}$ & $\begin{array}{l}0.00 \\
0.00 \\
0.00\end{array}$ & $\begin{array}{l}1545 \\
1550 \\
1555\end{array}$ & $\begin{array}{l}1.7 \\
1.7 \\
1.7\end{array}$ & $\begin{array}{l}0.00 \\
0.00 \\
0.00\end{array}$ & $\begin{array}{l}1855 \\
1900\end{array}$ & $\begin{array}{l}1.5 \\
1.5\end{array}$ & $\begin{array}{l}0.00 \\
0.00\end{array}$ \\
\hline
\end{tabular}




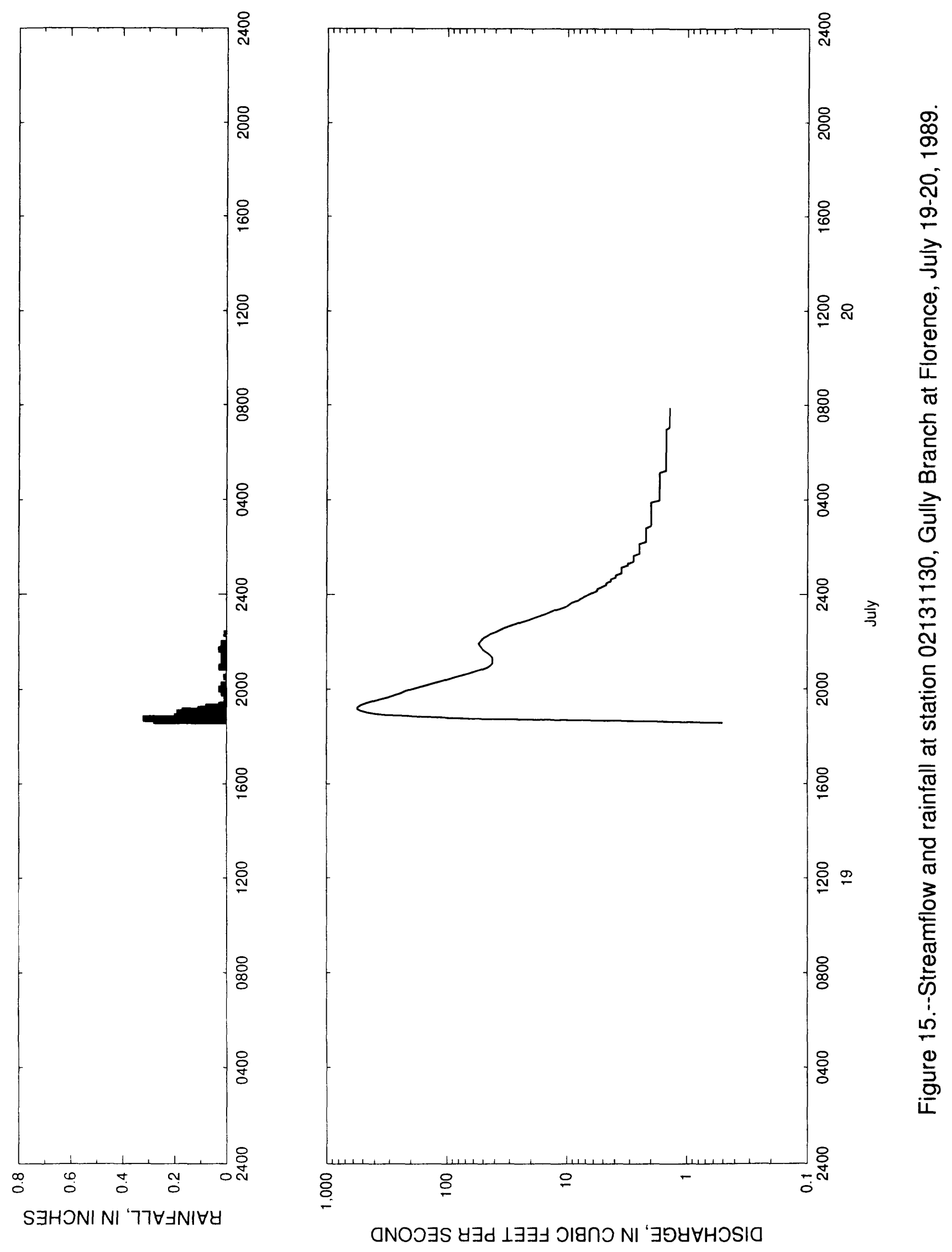


Table 14.--Streamflow and rainfall at station 02131130 , Gu11y Branch at Elorence, July $19-20,1989$

\begin{tabular}{|c|c|c|c|c|c|c|c|c|}
\hline $\begin{array}{l}\text { Time } \\
\text { (hours) }\end{array}$ & $\begin{array}{l}\text { Streamflow } \\
\text { (cubic feet } \\
\text { per second) }\end{array}$ & $\begin{array}{l}\text { Rain- } \\
\text { fall } \\
\text { (inches) }\end{array}$ & $\begin{array}{l}\text { Time } \\
\text { (hours) }\end{array}$ & $\begin{array}{l}\text { Streamflow } \\
\text { (cubic feet } \\
\text { per second) }\end{array}$ & $\begin{array}{l}\text { Rain- } \\
\text { fall } \\
\text { (inches) }\end{array}$ & $\begin{array}{l}\text { Time } \\
\text { (hours) }\end{array}$ & $\begin{array}{l}\text { Streamflow } \\
\text { (cubic feet } \\
\text { per second) }\end{array}$ & $\begin{array}{l}\text { Rain- } \\
\text { fall } \\
\text { (inchos) }\end{array}$ \\
\hline $\begin{array}{l}\text { July } 19, \\
1835 \\
1840 \\
1845 \\
1850\end{array}$ & $\begin{array}{r}1989 \\
0.5 \\
3.5 \\
62.6 \\
148.0\end{array}$ & $\begin{array}{l}0.00 \\
0.28 \\
0.32 \\
0.20\end{array}$ & $\begin{array}{l}2305 \\
2310 \\
2315 \\
2320 \\
2325\end{array}$ & $\begin{array}{l}16.9 \\
15.1 \\
13.9 \\
12.8 \\
11.1\end{array}$ & $\begin{array}{l}0.00 \\
0.00 \\
0.00 \\
0.00 \\
0.00\end{array}$ & $\begin{array}{l}0335 \\
0340 \\
0345 \\
0350 \\
0355\end{array}$ & $\begin{array}{l}2.0 \\
2.0 \\
2.0 \\
2.0 \\
2.0\end{array}$ & $\begin{array}{l}0.00 \\
0.00 \\
0.00 \\
0.00 \\
0.00\end{array}$ \\
\hline $\begin{array}{l}1855 \\
1900 \\
1905 \\
1910 \\
1915\end{array}$ & $\begin{array}{l}322.0 \\
452.0 \\
515.0 \\
555.0 \\
551.0\end{array}$ & $\begin{array}{l}0.19 \\
0.19 \\
0.17 \\
0.11 \\
0.08\end{array}$ & $\begin{array}{l}2330 \\
2335 \\
2340 \\
2345 \\
2350\end{array}$ & $\begin{array}{r}10.0 \\
9.5 \\
9.0 \\
8.0 \\
7.6\end{array}$ & $\begin{array}{l}0.00 \\
0.00 \\
0.00 \\
0.00 \\
0.00\end{array}$ & $\begin{array}{l}0400 \\
0405 \\
0410 \\
0415 \\
0420\end{array}$ & $\begin{array}{l}1.7 \\
1.7 \\
1.7 \\
1.7 \\
1.7\end{array}$ & $\begin{array}{l}0.00 \\
0.00 \\
0.00 \\
0.00 \\
0.00\end{array}$ \\
\hline $\begin{array}{l}1920 \\
1925 \\
1930 \\
1935 \\
1940\end{array}$ & $\begin{array}{l}519.0 \\
467.0 \\
409.0 \\
358.0 \\
306.0\end{array}$ & $\begin{array}{l}0.03 \\
0.00 \\
0.01 \\
0.01 \\
0.01\end{array}$ & $\begin{array}{l}2355 \\
\text { July } 20 \\
0000 \\
0005 \\
0010\end{array}$ & $1989 \begin{array}{l}7.1 \\
6.6 \\
6.1 \\
5.6\end{array}$ & $\begin{array}{l}0.00 \\
0.00 \\
0.00 \\
0.00\end{array}$ & $\begin{array}{l}0425 \\
0430 \\
0435 \\
0440 \\
0445\end{array}$ & $\begin{array}{l}1.7 \\
1.7 \\
1.7 \\
1.7 \\
1.7\end{array}$ & $\begin{array}{l}0.00 \\
0.00 \\
0.00 \\
0.00 \\
0.00\end{array}$ \\
\hline $\begin{array}{l}1945 \\
1950 \\
1955 \\
2000 \\
2005\end{array}$ & $\begin{array}{l}274.0 \\
242.0 \\
222.0 \\
197.0 \\
171.0\end{array}$ & $\begin{array}{l}0.01 \\
0.02 \\
0.00 \\
0.03 \\
0.00\end{array}$ & $\begin{array}{l}0015 \\
0020 \\
0025 \\
0030 \\
0035\end{array}$ & $\begin{array}{l}5.6 \\
5.1 \\
4.7 \\
4.7 \\
4.3\end{array}$ & $\begin{array}{l}0.00 \\
0.00 \\
0.00 \\
0.00 \\
0.00\end{array}$ & $\begin{array}{l}0450 \\
0455 \\
0500 \\
0505 \\
0510\end{array}$ & $\begin{array}{l}1.7 \\
1.7 \\
1.7 \\
1.7 \\
1.7\end{array}$ & $\begin{array}{l}0.00 \\
0.00 \\
0.00 \\
0.00 \\
0.00\end{array}$ \\
\hline $\begin{array}{l}2010 \\
2015 \\
2020 \\
2025 \\
2030\end{array}$ & $\begin{array}{r}147.0 \\
128.0 \\
110.0 \\
96.6 \\
84.8\end{array}$ & $\begin{array}{l}0.02 \\
0.00 \\
0.00 \\
0.00 \\
0.01\end{array}$ & $\begin{array}{l}0040 \\
0045 \\
0050 \\
0055 \\
0100\end{array}$ & $\begin{array}{l}4.3 \\
3.9 \\
3.9 \\
3.5 \\
3.5\end{array}$ & $\begin{array}{l}0.00 \\
0.00 \\
0.00 \\
0.00 \\
0.00\end{array}$ & $\begin{array}{l}0515 \\
0520 \\
0525 \\
0530 \\
0535\end{array}$ & $\begin{array}{l}1.5 \\
1.5 \\
1.5 \\
1.5 \\
1.5\end{array}$ & $\begin{array}{l}0.00 \\
0.00 \\
0.00 \\
0.00 \\
0.00\end{array}$ \\
\hline $\begin{array}{l}2035 \\
2040 \\
2045 \\
2050 \\
2055\end{array}$ & $\begin{array}{l}73.7 \\
64.4 \\
57.4 \\
50.8 \\
45.7\end{array}$ & $\begin{array}{l}0.00 \\
0.00 \\
0.00 \\
0.00 \\
0.03\end{array}$ & $\begin{array}{l}0105 \\
0110 \\
0115 \\
0120 \\
0125\end{array}$ & $\begin{array}{l}3.5 \\
3.5 \\
3.1 \\
3.1 \\
2.8\end{array}$ & $\begin{array}{l}0.00 \\
0.00 \\
0.00 \\
0.00 \\
0.00\end{array}$ & $\begin{array}{l}0540 \\
0545 \\
0550 \\
0555 \\
0600\end{array}$ & $\begin{array}{l}1.5 \\
1.5 \\
1.5 \\
1.5 \\
1.5\end{array}$ & $\begin{array}{l}0.00 \\
0.00 \\
0.00 \\
0.00 \\
0.00\end{array}$ \\
\hline $\begin{array}{l}2100 \\
2105 \\
2110 \\
2115 \\
2120\end{array}$ & $\begin{array}{l}43.2 \\
41.6 \\
41.6 \\
41.6 \\
41.6\end{array}$ & $\begin{array}{l}0.02 \\
0.00 \\
0.02 \\
0.01 \\
0.02\end{array}$ & $\begin{array}{l}0130 \\
0135 \\
0140 \\
0145 \\
0150\end{array}$ & $\begin{array}{l}2.8 \\
2.8 \\
2.8 \\
2.5 \\
2.5\end{array}$ & $\begin{array}{l}0.00 \\
0.00 \\
0.00 \\
0.00 \\
0.00\end{array}$ & $\begin{array}{l}0605 \\
0610 \\
0615 \\
0620 \\
0625\end{array}$ & $\begin{array}{l}1.5 \\
1.5 \\
1.5 \\
1.5 \\
1.5\end{array}$ & $\begin{array}{l}0.00 \\
0.00 \\
0.00 \\
0.00 \\
0.00\end{array}$ \\
\hline $\begin{array}{l}2125 \\
2130 \\
2135 \\
2140 \\
2145\end{array}$ & $\begin{array}{l}43.2 \\
44.9 \\
47.4 \\
50.0 \\
51.6\end{array}$ & $\begin{array}{l}0.01 \\
0.00 \\
0.02 \\
0.03 \\
0.01\end{array}$ & $\begin{array}{l}0155 \\
0200 \\
0205 \\
0210 \\
0215\end{array}$ & $\begin{array}{l}2.5 \\
2.5 \\
2.5 \\
2.5 \\
2.2\end{array}$ & $\begin{array}{l}0.00 \\
0.00 \\
0.00 \\
0.00 \\
0.00\end{array}$ & $\begin{array}{l}0630 \\
0635 \\
0640 \\
0645 \\
0650\end{array}$ & $\begin{array}{l}1.5 \\
1.5 \\
1.5 \\
1.5 \\
1.5\end{array}$ & $\begin{array}{l}0.00 \\
0.00 \\
0.00 \\
0.00 \\
0.00\end{array}$ \\
\hline $\begin{array}{l}2150 \\
2155 \\
2200 \\
2205 \\
2210\end{array}$ & $\begin{array}{l}53.2 \\
54.0 \\
52.4 \\
50.8 \\
49.1\end{array}$ & $\begin{array}{l}0.00 \\
0.02 \\
0.00 \\
0.00 \\
0.00\end{array}$ & $\begin{array}{l}0220 \\
0225 \\
0230 \\
0235 \\
0240\end{array}$ & $\begin{array}{l}2.2 \\
2.2 \\
2.2 \\
2.2 \\
2.2\end{array}$ & $\begin{array}{l}0.00 \\
0.00 \\
0.00 \\
0.00 \\
0.00\end{array}$ & $\begin{array}{l}0655 \\
0700 \\
0705 \\
0710 \\
0715\end{array}$ & $\begin{array}{l}1.5 \\
1.5 \\
1.4 \\
1.4 \\
1.4\end{array}$ & $\begin{array}{l}0.00 \\
0.00 \\
0.00 \\
0.00 \\
0.00\end{array}$ \\
\hline $\begin{array}{l}2215 \\
2220 \\
2225 \\
2230 \\
2235\end{array}$ & $\begin{array}{l}45.7 \\
43.2 \\
39.2 \\
36.3 \\
33.4\end{array}$ & $\begin{array}{l}0.00 \\
0.01 \\
0.00 \\
0.00 \\
0.00\end{array}$ & $\begin{array}{l}0245 \\
0250 \\
0255 \\
0300 \\
0305\end{array}$ & $\begin{array}{l}2.2 \\
2.2 \\
2.0 \\
2.0 \\
2.0\end{array}$ & $\begin{array}{l}0.00 \\
0.00 \\
0.00 \\
0.00 \\
0.00\end{array}$ & $\begin{array}{l}0720 \\
0725 \\
0730 \\
0735 \\
0740\end{array}$ & $\begin{array}{l}1.4 \\
1.4 \\
1.4 \\
1.4 \\
1.4\end{array}$ & $\begin{array}{l}0.00 \\
0.00 \\
0.00 \\
0.00 \\
0.00\end{array}$ \\
\hline $\begin{array}{l}2240 \\
2245 \\
2250 \\
2255 \\
2300\end{array}$ & $\begin{array}{l}30.0 \\
26.7 \\
23.7 \\
20.9 \\
18.8\end{array}$ & $\begin{array}{l}0.00 \\
0.00 \\
0.00 \\
0.00 \\
0.00\end{array}$ & $\begin{array}{l}0310 \\
0315 \\
0320 \\
0325 \\
0330\end{array}$ & $\begin{array}{l}2.0 \\
2.0 \\
2.0 \\
2.0 \\
2.0\end{array}$ & $\begin{array}{l}0.00 \\
0.00 \\
0.00 \\
0.00 \\
0.00\end{array}$ & $\begin{array}{l}0745 \\
0750 \\
0755 \\
0800\end{array}$ & $\begin{array}{l}1.4 \\
1.4 \\
1.4 \\
1.4\end{array}$ & $\begin{array}{l}0.00 \\
0.00 \\
0.00 \\
0.00\end{array}$ \\
\hline
\end{tabular}




\section{Station 02135518, Turkey Creek at Sumter, S.C.}

Location.--Lat $33^{\circ} 55^{\prime} 13^{\prime \prime}$, long $80^{\circ} 19^{\prime} 43^{\prime \prime}$, Sumter County Hydrologic Unit 03040205, at culvert on East Liberty Street (U.S. Highway 76), 0.65 mi east of Sumter City Hall, and $4.0 \mathrm{mi}$ upstream from the mouth at the Pocotaligo River.

Period of record.-- November 8, 1985 to November 16, 1990.

Gage.--Digital stage recorder with 5-minute punch interval. The recorder is housed in a metal shelter atop a stilling well attached to the headwall at the center web of the double $10 \mathrm{ft}$ by $8.1 \mathrm{ft}$ concrete box culvert. A sealed intake pipe extends $20 \mathrm{ft}$ upstream to a separate stilling basin (sand trap) with a removable lid. One creststage indicator is located opposite the recording gage intake on the upstream left. bank. A second crest-stage indicator is located on the left downstream wingwall.

Rating.--The stage-streamflow relation is defined by current meter measurements up to $286 \mathrm{ft}^{3} / \mathrm{s}$. The stage-streamflow relation was extended to $660 \mathrm{ft}^{3} / \mathrm{s}$ graphically $\mathrm{cn}$ logarithmic paper.

Rain gage and location.--Station 335513080194300 , lat $33^{\circ} 5^{\prime} 13^{\prime \prime}$, long $80^{\circ} 19^{\prime} 43^{\prime \prime}$. A shelter containing a digital cumulative rainfall recorder with a 5-minute punch interval attached to the left upstream wingwall at the East Liberty Street (U.S. Highway 76) crossing of Turkey Creek, 0.65 mi east of Sumter City Hall.

Selected basin characteristics.--

Drainage area $-2.20 \mathrm{mi}^{2}$

Physiographic province -- Lower Coastal Plain

Channel slope -- $20.2 \mathrm{ft} / \mathrm{mi}$

Channel length -- $1.79 \mathrm{mi}$

Total impervious area --25.0 percent

Basin development factor -- 8

2-year, 2-hour rainfall amount -- 2.19 in.

\begin{tabular}{|c|c|c|}
\hline Flood frequency data: & $\mathrm{UQ}_{2}$ & $334 \mathrm{ft}^{3} / \mathrm{s}$ \\
\hline & $\mathrm{UQ}_{5}$ & $595 \mathrm{ft}^{3} / \mathrm{s}$ \\
\hline & $\mathrm{UQ}_{10}$ & $792 \mathrm{ft}^{3} / \mathrm{s}$ \\
\hline & $\mathrm{UQ}_{25}$ & $1,060 \mathrm{ft}^{3} / \mathrm{s}$ \\
\hline & $\mathrm{UQ}_{50}$ & $1,270 \mathrm{ft}^{3} / \mathrm{s}$ \\
\hline & $\mathrm{UQ}_{100}$ & $1,490 \mathrm{ft}^{3} / \mathrm{s}$ \\
\hline & $\mathrm{UQ}_{500}$ & $2,020 \mathrm{ft}^{3} / \mathrm{s}$ \\
\hline
\end{tabular}




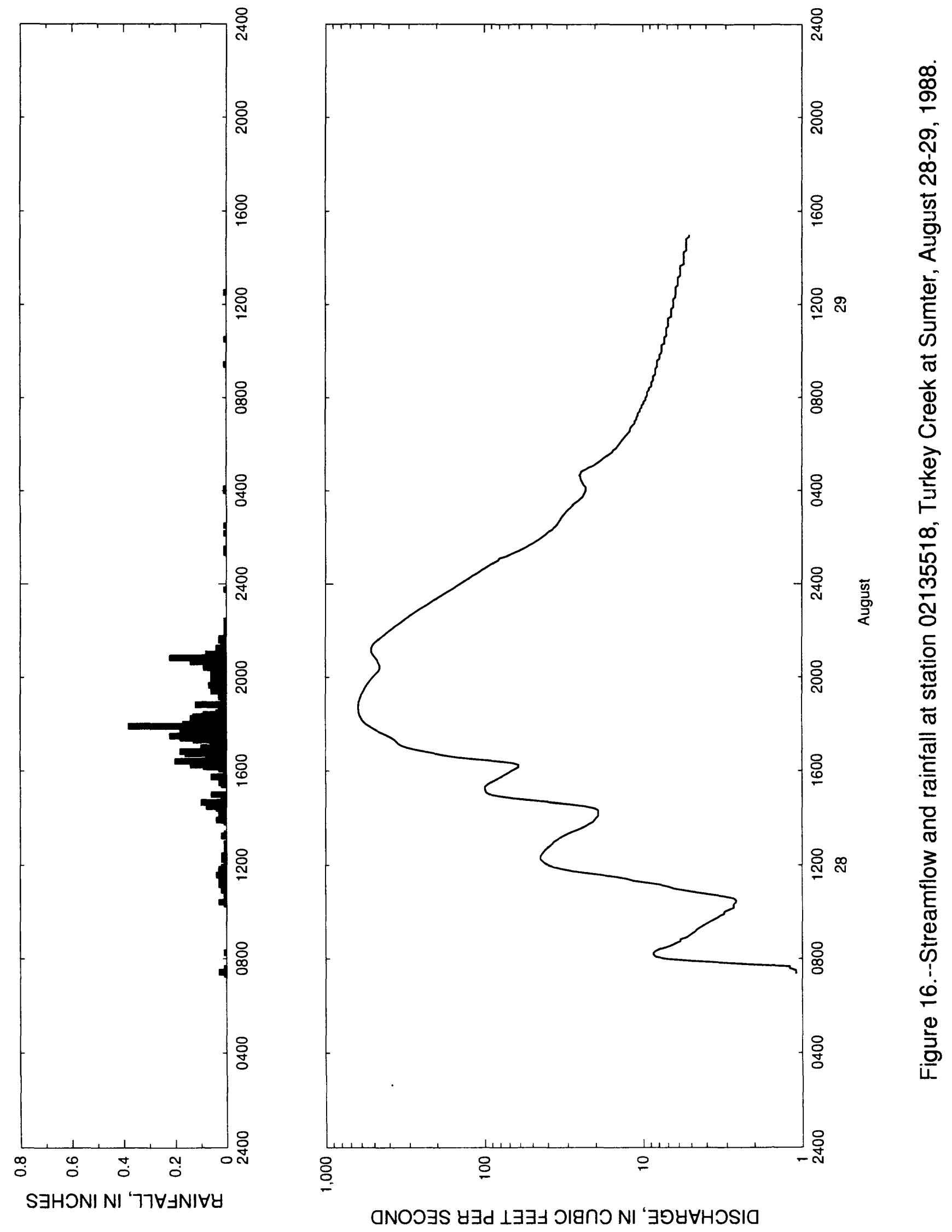


Table 15. - Streamflow and rainfall at station 02135518. Turkey Creek at Sumter, August $28-29,1988$

\begin{tabular}{|c|c|c|c|c|c|c|c|c|}
\hline $\begin{array}{l}\text { Time } \\
\text { (hours) }\end{array}$ & $\begin{array}{l}\text { Streamflow } \\
\text { (cubic feet } \\
\text { per second) }\end{array}$ & $\begin{array}{l}\text { Rain- } \\
\text { fall } \\
\text { (inches) }\end{array}$ & $\begin{array}{l}\text { Time } \\
\text { (hours) }\end{array}$ & $\begin{array}{l}\text { Streamflow } \\
\text { (cubic feet } \\
\text { per second) }\end{array}$ & $\begin{array}{l}\text { Rain- } \\
\text { fall } \\
\text { (inches) }\end{array}$ & $\begin{array}{l}\text { Time } \\
\text { (hours) }\end{array}$ & $\begin{array}{l}\text { Streamflow } \\
\text { (cubic feet } \\
\text { per second) }\end{array}$ & $\begin{array}{l}\text { Rair- } \\
\text { fall } \\
\text { (incles) }\end{array}$ \\
\hline $\begin{array}{c}\text { August } \\
0720 \\
0725 \\
0730 \\
0735\end{array}$ & $\begin{array}{r}28,1988 \\
1.1 \\
1.1 \\
1.1 \\
1.2\end{array}$ & $\begin{array}{l}0.01 \\
0.03 \\
0.01 \\
0.01\end{array}$ & $\begin{array}{l}1240 \\
1245 \\
1250 \\
1255 \\
1300\end{array}$ & $\begin{array}{l}40.9 \\
39.7 \\
38.4 \\
37.2 \\
36.4\end{array}$ & $\begin{array}{l}0.01 \\
0.00 \\
0.01 \\
0.01 \\
0.00\end{array}$ & $\begin{array}{l}1805 \\
1810 \\
1815 \\
1820 \\
1825\end{array}$ & $\begin{array}{l}576.0 \\
591.0 \\
599.0 \\
608.0 \\
616.0\end{array}$ & $\begin{array}{l}0.08 \\
0.0 z \\
0.14 \\
0.12 \\
0.09\end{array}$ \\
\hline $\begin{array}{l}0740 \\
0745 \\
0750 \\
0755 \\
0800\end{array}$ & $\begin{array}{l}1.2 \\
2.1 \\
3.3 \\
5.1 \\
7.1\end{array}$ & $\begin{array}{l}0.00 \\
0.00 \\
0.00 \\
0.00 \\
0.00\end{array}$ & $\begin{array}{l}1305 \\
1310 \\
1315 \\
1320 \\
1325\end{array}$ & $\begin{array}{l}34.8 \\
33.3 \\
31.7 \\
29.9 \\
28.0\end{array}$ & $\begin{array}{l}0.00 \\
0.00 \\
0.02 \\
0.01 \\
0.00\end{array}$ & $\begin{array}{l}1830 \\
1835 \\
1840 \\
1845 \\
1850\end{array}$ & $\begin{array}{l}620.0 \\
621.0 \\
623.0 \\
623.0 \\
621.0\end{array}$ & $\begin{array}{l}0.04 \\
0.03 \\
0.01 \\
0.06 \\
0.12 .\end{array}$ \\
\hline $\begin{array}{l}0805 \\
0810 \\
0815 \\
0820 \\
0825\end{array}$ & $\begin{array}{l}8.3 \\
8.6 \\
8.6 \\
8.3 \\
7.8\end{array}$ & $\begin{array}{l}0.00 \\
0.00 \\
0.01 \\
0.00 \\
0.00\end{array}$ & $\begin{array}{l}1330 \\
1335 \\
1340 \\
1345 \\
1350\end{array}$ & $\begin{array}{l}25.9 \\
24.2 \\
22.8 \\
21.8 \\
20.7\end{array}$ & $\begin{array}{l}0.00 \\
0.00 \\
0.00 \\
0.00 \\
0.01\end{array}$ & $\begin{array}{l}1855 \\
1900 \\
1905 \\
1910 \\
1915\end{array}$ & $\begin{array}{l}620.0 \\
615.0 \\
609.0 \\
603.0 \\
597.0\end{array}$ & $\begin{array}{l}0.01 \\
0.02 \\
0.02 \\
0.02 \\
0.01\end{array}$ \\
\hline $\begin{array}{l}0830 \\
0835 \\
0840 \\
0845 \\
0850\end{array}$ & $\begin{array}{l}7.1 \\
6.6 \\
6.2 \\
5.8 \\
5.8\end{array}$ & $\begin{array}{l}0.00 \\
0.00 \\
0.00 \\
0.00 \\
0.00\end{array}$ & $\begin{array}{l}1355 \\
1400 \\
1405 \\
1410 \\
1415\end{array}$ & $\begin{array}{l}20.1 \\
19.7 \\
19.1 \\
19.1 \\
19.1\end{array}$ & $\begin{array}{l}0.04 \\
0.00 \\
0.00 \\
0.03 \\
0.01\end{array}$ & $\begin{array}{l}1920 \\
1925 \\
1930 \\
1935 \\
1940\end{array}$ & $\begin{array}{l}591.0 \\
580.0 \\
572.0 \\
564.0 \\
554.0\end{array}$ & $\begin{array}{l}0.06 \\
0.0 E \\
0.01 \\
0.02 . \\
0.07\end{array}$ \\
\hline $\begin{array}{l}0855 \\
0900 \\
0905 \\
0910 \\
0915\end{array}$ & $\begin{array}{l}5.3 \\
5.1 \\
4.9 \\
4.7 \\
4.6\end{array}$ & $\begin{array}{l}0.00 \\
0.00 \\
0.00 \\
0.00 \\
0.00\end{array}$ & $\begin{array}{l}1420 \\
1425 \\
1430 \\
1435 \\
1440\end{array}$ & $\begin{array}{l}19.1 \\
20.1 \\
23.1 \\
28.4 \\
37.6\end{array}$ & $\begin{array}{l}0.01 \\
0.04 \\
0.08 \\
0.07 \\
0.10\end{array}$ & $\begin{array}{l}1945 \\
1950 \\
1955 \\
2000 \\
2005\end{array}$ & $\begin{array}{l}543.0 \\
532.0 \\
520.0 \\
507.0 \\
493.0\end{array}$ & $\begin{array}{l}0.0 \Xi \\
0.0 E \\
0.0 \Xi \\
0.0 z \\
0.06\end{array}$ \\
\hline $\begin{array}{l}0920 \\
0925 \\
0930 \\
0935 \\
0940\end{array}$ & $\begin{array}{l}4.4 \\
4.2 \\
4.0 \\
3.8 \\
3.6\end{array}$ & $\begin{array}{l}0.00 \\
0.00 \\
0.00 \\
0.00 \\
0.00\end{array}$ & $\begin{array}{l}1445 \\
1450 \\
1455 \\
1500 \\
1505\end{array}$ & $\begin{array}{l}49.8 \\
65.4 \\
80.5 \\
93.3 \\
97.6\end{array}$ & $\begin{array}{l}0.02 \\
0.02 \\
0.00 \\
0.06 \\
0.00\end{array}$ & $\begin{array}{l}2010 \\
2015 \\
2020 \\
2025 \\
2030\end{array}$ & $\begin{array}{l}479.0 \\
468.0 \\
460.0 \\
458.0 \\
459.0\end{array}$ & $\begin{array}{l}0.02 \\
0.02 \\
0.06 \\
0.09 \\
0.06\end{array}$ \\
\hline $\begin{array}{l}0945 \\
0950 \\
0955 \\
1000 \\
1005\end{array}$ & $\begin{array}{l}3.4 \\
3.3 \\
3.1 \\
3.1 \\
2.9\end{array}$ & $\begin{array}{l}0.00 \\
0.00 \\
0.00 \\
0.00 \\
0.00\end{array}$ & $\begin{array}{l}1510 \\
1515 \\
1520 \\
1525 \\
1530\end{array}$ & $\begin{array}{l}98.8 \\
99.4 \\
99.4 \\
95.7 \\
91.5\end{array}$ & $\begin{array}{l}0.00 \\
0.00 \\
0.00 \\
0.02 \\
0.03\end{array}$ & $\begin{array}{l}2035 \\
2040 \\
2045 \\
2050 \\
2055\end{array}$ & $\begin{array}{l}465.0 \\
471.0 \\
479.0 \\
490.0 \\
500.0\end{array}$ & $\begin{array}{l}0.02 . \\
0.14 \\
0.08 \\
0.22 . \\
0.0 C\end{array}$ \\
\hline $\begin{array}{l}1010 \\
1015 \\
1020 \\
1025 \\
1030\end{array}$ & $\begin{array}{l}2.7 \\
2.7 \\
2.7 \\
2.6 \\
2.6\end{array}$ & $\begin{array}{l}0.00 \\
0.00 \\
0.01 \\
0.03 \\
0.00\end{array}$ & $\begin{array}{l}1535 \\
1540 \\
1545 \\
1550 \\
1555\end{array}$ & $\begin{array}{l}86.8 \\
82.2 \\
77.7 \\
74.4 \\
70.6\end{array}$ & $\begin{array}{l}0.00 \\
0.00 \\
0.06 \\
0.00 \\
0.00\end{array}$ & $\begin{array}{l}2100 \\
2105 \\
2110 \\
2115 \\
2120\end{array}$ & $\begin{array}{l}510.0 \\
516.0 \\
517.0 \\
516.0 \\
510.0\end{array}$ & $\begin{array}{l}0.08 \\
0.02 . \\
0.06 \\
0.02 \\
0.02 .\end{array}$ \\
\hline $\begin{array}{l}1035 \\
1040 \\
1045 \\
1050 \\
1055\end{array}$ & $\begin{array}{l}2.7 \\
3.1 \\
3.8 \\
4.6 \\
5.5\end{array}$ & $\begin{array}{l}0.01 \\
0.00 \\
0.00 \\
0.01 \\
0.02\end{array}$ & $\begin{array}{l}1600 \\
1605 \\
1610 \\
1615 \\
1620\end{array}$ & $\begin{array}{l}67.5 \\
63.8 \\
60.8 \\
60.8 \\
66.4\end{array}$ & $\begin{array}{l}0.01 \\
0.03 \\
0.09 \\
0.14 \\
0.08\end{array}$ & $\begin{array}{l}2125 \\
2130 \\
2135 \\
2140 \\
2145\end{array}$ & $\begin{array}{l}501.0 \\
486.0 \\
471.0 \\
454.0 \\
440.0\end{array}$ & $\begin{array}{l}0.01 \\
0.02 . \\
0.02 \\
0.02 \\
0.01\end{array}$ \\
\hline $\begin{array}{l}1100 \\
1105 \\
1110 \\
1115 \\
1120\end{array}$ & $\begin{array}{r}6.4 \\
6.9 \\
7.8 \\
9.4 \\
11.5\end{array}$ & $\begin{array}{l}0.01 \\
0.02 \\
0.03 \\
0.02 \\
0.01\end{array}$ & $\begin{array}{l}1625 \\
1630 \\
1635 \\
1640 \\
1645\end{array}$ & $\begin{array}{r}83.9 \\
115.0 \\
149.0 \\
180.0 \\
208.0\end{array}$ & $\begin{array}{l}0.20 \\
0.02 \\
0.04 \\
0.08 \\
0.16\end{array}$ & $\begin{array}{l}2150 \\
2155 \\
2200 \\
2205 \\
2210\end{array}$ & $\begin{array}{l}426.0 \\
412.0 \\
398.0 \\
383.0 \\
369.0\end{array}$ & $\begin{array}{l}0.0 C \\
0.01 \\
0.01 \\
0.0 C \\
0.0 C\end{array}$ \\
\hline $\begin{array}{l}1125 \\
1130 \\
1135 \\
1140 \\
1145\end{array}$ & $\begin{array}{l}12.5 \\
14.7 \\
18.1 \\
22.8 \\
27.7\end{array}$ & $\begin{array}{l}0.03 \\
0.03 \\
0.04 \\
0.02 \\
0.01\end{array}$ & $\begin{array}{l}1650 \\
1655 \\
1700 \\
1705 \\
1710\end{array}$ & $\begin{array}{l}242.0 \\
279.0 \\
311.0 \\
335.0 \\
351.0\end{array}$ & $\begin{array}{l}0.18 \\
0.02 \\
0.10 \\
0.02 \\
0.02\end{array}$ & $\begin{array}{l}2215 \\
2220 \\
2225 \\
2230 \\
2235\end{array}$ & $\begin{array}{l}354.0 \\
340.0 \\
328.0 \\
315.0 \\
303.0\end{array}$ & $\begin{array}{l}0.01 \\
0.00 \\
0.01 \\
0.00 \\
0.00\end{array}$ \\
\hline $\begin{array}{l}1150 \\
1155 \\
1200 \\
1205 \\
1210\end{array}$ & $\begin{array}{l}32.1 \\
36.0 \\
39.3 \\
41.8 \\
43.1\end{array}$ & $\begin{array}{l}0.03 \\
0.02 \\
0.01 \\
0.01 \\
0.01\end{array}$ & $\begin{array}{l}1715 \\
1720 \\
1725 \\
1730 \\
1735\end{array}$ & $\begin{array}{l}361.0 \\
371.0 \\
387.0 \\
409.0 \\
435.0\end{array}$ & $\begin{array}{l}0.06 \\
0.13 \\
0.18 \\
0.22 \\
0.10\end{array}$ & $\begin{array}{l}2240 \\
2245 \\
2250 \\
2255 \\
2300\end{array}$ & $\begin{array}{l}291.0 \\
278.0 \\
267.0 \\
256.0 \\
244.0\end{array}$ & $\begin{array}{l}0.00 \\
0.00 \\
0.00 \\
0.00 \\
0.00\end{array}$ \\
\hline $\begin{array}{l}1215 \\
i 220 \\
-225 \\
: 230 \\
1235\end{array}$ & $\begin{array}{l}44.4 \\
44.4 \\
44.0 \\
43.1 \\
42.2\end{array}$ & $\begin{array}{ll}0 & 02 \\
0.00 \\
0.02 \\
0.01 \\
0.01\end{array}$ & $\begin{array}{l}1740 \\
1745 \\
1750 \\
1755 \\
1800\end{array}$ & $\begin{array}{l}464.0 \\
488.0 \\
5110 \\
532.0 \\
558.0\end{array}$ & $\begin{array}{l}0.18 \\
0.10 \\
0.00 \\
0.38 \\
0.17\end{array}$ & $\begin{array}{l}2305 \\
2310 \\
2315 \\
2320 \\
2325\end{array}$ & $\begin{array}{l}233.0 \\
223.0 \\
214.0 \\
204.0 \\
195.0\end{array}$ & $\begin{array}{l}0.00 \\
0.00 \\
0.00 \\
0.00 \\
0.00\end{array}$ \\
\hline
\end{tabular}


Table 15. - Streamflow and rainfall at station 02135518. Turkey Creek at. Sumter, August $28-29,1988^{--C o n t i n u e d}$

\begin{tabular}{|c|c|c|c|c|c|c|c|c|}
\hline $\begin{array}{l}\text { Time } \\
\text { (hours) }\end{array}$ & $\begin{array}{l}\text { Streamflow } \\
\text { (cubic feet } \\
\text { per second) }\end{array}$ & $\begin{array}{l}\text { Rain- } \\
\text { fall } \\
\text { (inches) }\end{array}$ & $\begin{array}{l}\text { Time } \\
\text { (hours) }\end{array}$ & $\begin{array}{l}\text { Streamflow } \\
\text { (cubic feet } \\
\text { per second) }\end{array}$ & $\begin{array}{l}\text { Rain- } \\
\text { fall } \\
\text { (inches) }\end{array}$ & $\begin{array}{l}\text { Time } \\
\text { (hours) }\end{array}$ & $\begin{array}{l}\text { Streamflow } \\
\text { (cubic feet } \\
\text { per second) }\end{array}$ & $\begin{array}{l}\text { Rain- } \\
\text { fall } \\
\text { (inches) }\end{array}$ \\
\hline $\begin{array}{l}2330 \\
2335 \\
2340 \\
2345 \\
2350\end{array}$ & $\begin{array}{l}186.0 \\
178.0 \\
170.0 \\
162.0 \\
155.0\end{array}$ & $\begin{array}{l}0.00 \\
0.00 \\
0.00 \\
0.01 \\
0.00\end{array}$ & $\begin{array}{l}0440 \\
0445 \\
0450 \\
0455 \\
0500\end{array}$ & $\begin{array}{l}24.9 \\
24.5 \\
24.2 \\
22.8 \\
21.8\end{array}$ & $\begin{array}{l}0.00 \\
0.00 \\
0.00 \\
0.00 \\
0.00\end{array}$ & $\begin{array}{l}0955 \\
1000 \\
1005 \\
1010 \\
1015\end{array}$ & $\begin{array}{l}7.6 \\
7.6 \\
7.6 \\
7.6 \\
7.6\end{array}$ & $\begin{array}{l}0.00 \\
0.00 \\
0.00 \\
0.00 \\
0.00\end{array}$ \\
\hline $\begin{array}{l}2355 \\
\text { August } 2 \\
0000 \\
0005 \\
0010\end{array}$ & $\begin{array}{r}149.0 \\
1988 \\
142.0 \\
136.0 \\
130.0\end{array}$ & $\begin{array}{l}0.00 \\
0.00 \\
0.00 \\
0.00\end{array}$ & $\begin{array}{l}0505 \\
0510 \\
0515 \\
0520 \\
0525\end{array}$ & $\begin{array}{l}20.4 \\
19.7 \\
18.8 \\
18.1 \\
17.5\end{array}$ & $\begin{array}{l}0.00 \\
0.00 \\
0.00 \\
0.00 \\
0.00\end{array}$ & $\begin{array}{l}1020 \\
1025 \\
1030 \\
1035 \\
1040\end{array}$ & $\begin{array}{l}7.3 \\
7.3 \\
7.3 \\
7.3 \\
7.1\end{array}$ & $\begin{array}{l}0.00 \\
0.00 \\
0.01 \\
0.00 \\
0.00\end{array}$ \\
\hline $\begin{array}{l}0015 \\
0020 \\
0025 \\
0030 \\
0035\end{array}$ & $\begin{array}{l}124.0 \\
119.0 \\
113.0 \\
108.0 \\
104.0\end{array}$ & $\begin{array}{l}0.00 \\
0.00 \\
0.00 \\
0.00 \\
0.00\end{array}$ & $\begin{array}{l}0530 \\
0535 \\
0540 \\
0545 \\
0550\end{array}$ & $\begin{array}{l}16.8 \\
16.2 \\
15.6 \\
15.3 \\
14.7\end{array}$ & $\begin{array}{l}0.00 \\
0.00 \\
0.00 \\
0.00 \\
0.00\end{array}$ & $\begin{array}{l}1045 \\
1050 \\
1055 \\
1100 \\
1105\end{array}$ & $\begin{array}{l}7.1 \\
7.1 \\
7.1 \\
7.1 \\
6.9\end{array}$ & $\begin{array}{l}0.00 \\
0.00 \\
0.00 \\
0.00 \\
0.00\end{array}$ \\
\hline $\begin{array}{l}0040 \\
0045 \\
0050 \\
0055 \\
0100\end{array}$ & $\begin{array}{l}98.8 \\
94.5 \\
90.3 \\
86.2 \\
81.6\end{array}$ & $\begin{array}{l}0.00 \\
0.00 \\
0.00 \\
0.00 \\
0.00\end{array}$ & $\begin{array}{l}0555 \\
0600 \\
0605 \\
0610 \\
0615\end{array}$ & $\begin{array}{l}14.4 \\
14.1 \\
13.8 \\
13.5 \\
13.2\end{array}$ & $\begin{array}{l}0.00 \\
0.00 \\
0.00 \\
0.00 \\
0.00\end{array}$ & $\begin{array}{l}1110 \\
1115 \\
1120 \\
1125 \\
1130\end{array}$ & $\begin{array}{l}6.9 \\
6.9 \\
6.9 \\
6.9 \\
6.6\end{array}$ & $\begin{array}{l}0.00 \\
0.00 \\
0.00 \\
0.00 \\
0.00\end{array}$ \\
\hline $\begin{array}{l}0105 \\
0110 \\
0115 \\
0120 \\
0125\end{array}$ & $\begin{array}{l}80.5 \\
72.8 \\
68.5 \\
64.4 \\
60.3\end{array}$ & $\begin{array}{l}0.00 \\
0.00 \\
0.00 \\
0.01 \\
0.00\end{array}$ & $\begin{array}{l}0620 \\
0625 \\
0630 \\
0635 \\
0640\end{array}$ & $\begin{array}{l}12.9 \\
12.6 \\
12.3 \\
12.0 \\
12.0\end{array}$ & $\begin{array}{l}0.00 \\
0.00 \\
0.00 \\
0.00 \\
0.00\end{array}$ & $\begin{array}{l}1135 \\
1140 \\
1145 \\
1150 \\
1155\end{array}$ & $\begin{array}{l}6.6 \\
6.6 \\
6.6 \\
6.6 \\
6.4\end{array}$ & $\begin{array}{l}0.00 \\
0.00 \\
0.00 \\
0.00 \\
0.00\end{array}$ \\
\hline $\begin{array}{l}0130 \\
0135 \\
0140 \\
0145 \\
0150\end{array}$ & $\begin{array}{l}56.9 \\
54.0 \\
51.6 \\
48.9 \\
47.0\end{array}$ & $\begin{array}{l}0.01 \\
0.00 \\
0.00 \\
0.00 \\
0.00\end{array}$ & $\begin{array}{l}0645 \\
0650 \\
0655 \\
0700 \\
0705\end{array}$ & $\begin{array}{l}11.8 \\
11.5 \\
11.2 \\
11.2 \\
10.9\end{array}$ & $\begin{array}{l}0.00 \\
0.00 \\
0.00 \\
0.00 \\
0.00\end{array}$ & $\begin{array}{l}1200 \\
1205 \\
1210 \\
1215 \\
1220\end{array}$ & $\begin{array}{l}6.4 \\
6.4 \\
6.4 \\
6.4 \\
6.2\end{array}$ & $\begin{array}{l}0.00 \\
0.00 \\
0.00 \\
0.00 \\
0.00\end{array}$ \\
\hline $\begin{array}{l}0155 \\
0200 \\
0205 \\
0210 \\
0215\end{array}$ & $\begin{array}{l}44.8 \\
43.1 \\
41.4 \\
40.1 \\
38.9\end{array}$ & $\begin{array}{l}0.00 \\
0.00 \\
0.00 \\
0.01 \\
0.00\end{array}$ & $\begin{array}{l}0710 \\
0715 \\
0720 \\
0725 \\
0730\end{array}$ & $\begin{array}{l}10.9 \\
10.7 \\
10.7 \\
10.4 \\
10.4\end{array}$ & $\begin{array}{l}0.00 \\
0.00 \\
0.00 \\
0.00 \\
0.00\end{array}$ & $\begin{array}{l}1225 \\
1230 \\
1235 \\
1240 \\
1245\end{array}$ & $\begin{array}{l}6.2 \\
6.2 \\
6.2 \\
6.2 \\
6.2\end{array}$ & $\begin{array}{l}0.00 \\
0.01 \\
0.00 \\
0.00 \\
0.00\end{array}$ \\
\hline $\begin{array}{l}0220 \\
0225 \\
0230 \\
0235 \\
0240\end{array}$ & $\begin{array}{l}37.2 \\
36.4 \\
35.2 \\
34.4 \\
34.0\end{array}$ & $\begin{array}{l}0.00 \\
0.00 \\
0.01 \\
0.00 \\
0.00\end{array}$ & $\begin{array}{l}0735 \\
0740 \\
0745 \\
0750 \\
0755\end{array}$ & $\begin{array}{r}10.2 \\
10.2 \\
9.9 \\
9.9 \\
9.6\end{array}$ & $\begin{array}{l}0.00 \\
0.00 \\
0.00 \\
0.00 \\
0.00\end{array}$ & $\begin{array}{l}1250 \\
1255 \\
1300 \\
1305 \\
1310\end{array}$ & $\begin{array}{l}6.0 \\
6.0 \\
6.0 \\
6.0 \\
6.0\end{array}$ & $\begin{array}{l}0.00 \\
0.00 \\
0.00 \\
0.00 \\
0.00\end{array}$ \\
\hline $\begin{array}{l}0245 \\
0250 \\
0255 \\
0300 \\
0305\end{array}$ & $\begin{array}{l}33.3 \\
32.9 \\
32.1 \\
31.3 \\
30.6\end{array}$ & $\begin{array}{l}0.00 \\
0.00 \\
0.00 \\
0.00 \\
0.00\end{array}$ & $\begin{array}{l}0800 \\
0805 \\
0810 \\
0815 \\
0820\end{array}$ & $\begin{array}{l}9.6 \\
9.4 \\
9.4 \\
9.4 \\
9.1\end{array}$ & $\begin{array}{l}0.00 \\
0.00 \\
0.00 \\
0.00 \\
0.00\end{array}$ & $\begin{array}{l}1315 \\
1320 \\
1325 \\
1330 \\
1335\end{array}$ & $\begin{array}{l}5.8 \\
5.8 \\
5.8 \\
5.8 \\
5.8\end{array}$ & $\begin{array}{l}0.00 \\
0.00 \\
0.00 \\
0.00 \\
0.00\end{array}$ \\
\hline $\begin{array}{l}0310 \\
0315 \\
0320 \\
0325 \\
0330\end{array}$ & $\begin{array}{l}29.9 \\
28.8 \\
28.0 \\
27.3 \\
26.3\end{array}$ & $\begin{array}{l}0.00 \\
0.00 \\
0.00 \\
0.00 \\
0.00\end{array}$ & $\begin{array}{l}0825 \\
0830 \\
0835 \\
0840 \\
0845\end{array}$ & $\begin{array}{l}9.1 \\
8.8 \\
8.8 \\
8.8 \\
8.6\end{array}$ & $\begin{array}{l}0.00 \\
0.00 \\
0.00 \\
0.00 \\
0.00\end{array}$ & $\begin{array}{l}1340 \\
1345 \\
1350 \\
1355 \\
1400\end{array}$ & $\begin{array}{l}5.8 \\
5.5 \\
5.5 \\
5.5 \\
5.5\end{array}$ & $\begin{array}{l}0.00 \\
0.00 \\
0.00 \\
0.00 \\
0.00\end{array}$ \\
\hline $\begin{array}{l}0335 \\
0340 \\
0345 \\
0350 \\
0355\end{array}$ & $\begin{array}{l}25.2 \\
24.5 \\
23.8 \\
23.5 \\
23.1\end{array}$ & $\begin{array}{l}0.00 \\
0.00 \\
0.00 \\
0.00 \\
0.00\end{array}$ & $\begin{array}{l}0850 \\
0855 \\
0900 \\
0905 \\
0910\end{array}$ & $\begin{array}{l}8.6 \\
8.6 \\
8.3 \\
8.3 \\
8.3\end{array}$ & $\begin{array}{l}0.00 \\
0.00 \\
0.00 \\
0.00 \\
0.00\end{array}$ & $\begin{array}{l}1405 \\
1410 \\
1415 \\
1420 \\
1425\end{array}$ & $\begin{array}{l}5.5 \\
5.5 \\
5.5 \\
5.3 \\
5.3\end{array}$ & $\begin{array}{l}0.00 \\
0.00 \\
0.00 \\
0.00 \\
0.00\end{array}$ \\
\hline $\begin{array}{l}0400 \\
0405 \\
0410 \\
0415 \\
0420\end{array}$ & $\begin{array}{l}22.8 \\
22.8 \\
22.8 \\
23.5 \\
23.8\end{array}$ & $\begin{array}{l}0.01 \\
0.01 \\
0.00 \\
0.00 \\
0.00\end{array}$ & $\begin{array}{l}0915 \\
0920 \\
0925 \\
0930 \\
0935\end{array}$ & $\begin{array}{l}8.3 \\
8.1 \\
8.1 \\
8.1 \\
8.1\end{array}$ & $\begin{array}{l}0.00 \\
0.00 \\
0.01 \\
0.00 \\
0.00\end{array}$ & $\begin{array}{l}1430 \\
1435 \\
1440 \\
1445 \\
1450\end{array}$ & $\begin{array}{l}5.3 \\
5.3 \\
5.3 \\
5.3 \\
5.3\end{array}$ & $\begin{array}{l}0.00 \\
0.00 \\
0.00 \\
0.00 \\
0.00\end{array}$ \\
\hline $\begin{array}{l}0425 \\
0430 \\
0435\end{array}$ & $\begin{array}{l}24.2 \\
24.5 \\
24.5\end{array}$ & $\begin{array}{l}0.00 \\
0.00 \\
0.00\end{array}$ & $\begin{array}{l}0940 \\
0945 \\
0950\end{array}$ & $\begin{array}{l}7.8 \\
7.8 \\
7.8\end{array}$ & $\begin{array}{l}0.00 \\
0.00 \\
0.00\end{array}$ & $\begin{array}{l}1455 \\
1500\end{array}$ & $\begin{array}{l}5.1 \\
5.1\end{array}$ & $\begin{array}{l}0.00 \\
0.00\end{array}$ \\
\hline
\end{tabular}




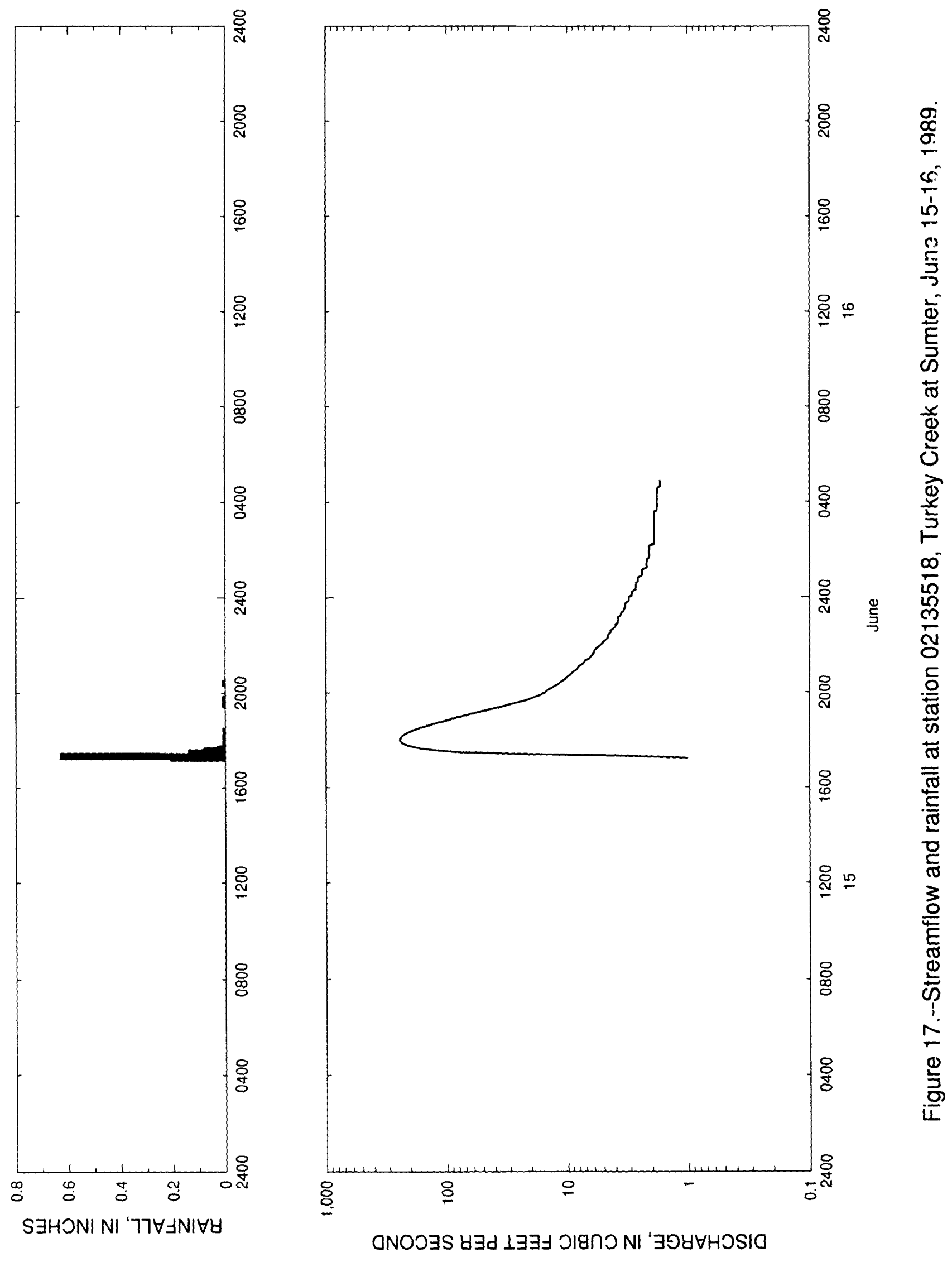


Table 16. - Streamflow and rainfall at station 02135518, Turkey Creek at Sumter, June $15-16,1989$

\begin{tabular}{|c|c|c|c|c|c|c|c|c|}
\hline $\begin{array}{l}\text { Time } \\
\text { (hours) }\end{array}$ & $\begin{array}{l}\text { Streamflow } \\
\text { (cubic feet } \\
\text { per second) }\end{array}$ & $\begin{array}{l}\text { Rain- } \\
\text { fall } \\
\text { (inches) }\end{array}$ & $\begin{array}{l}\text { Time } \\
\text { (hours) }\end{array}$ & $\begin{array}{l}\text { Streamflow } \\
\text { (cubic feet } \\
\text { per second) }\end{array}$ & $\begin{array}{l}\text { Rain- } \\
\text { fall } \\
\text { (inches) }\end{array}$ & $\begin{array}{l}\text { Time } \\
\text { (hours) }\end{array}$ & $\begin{array}{l}\text { Streamflow } \\
\text { (cubic feet } \\
\text { per second) }\end{array}$ & $\begin{array}{l}\text { Rain- } \\
\text { fall } \\
\text { (inches) }\end{array}$ \\
\hline $\begin{array}{l}\text { June 15, } \\
1715 \\
1720 \\
1725 \\
1730\end{array}$ & $\begin{array}{r}1989 \\
1.0 \\
3.3 \\
27.0 \\
82.2\end{array}$ & $\begin{array}{l}0.21 \\
0.63 \\
0.02 \\
0.14\end{array}$ & $\begin{array}{l}2115 \\
2120 \\
2125 \\
2130 \\
2135\end{array}$ & $\begin{array}{l}7.3 \\
7.1 \\
6.6 \\
6.4 \\
6.2\end{array}$ & $\begin{array}{l}0.00 \\
0.00 \\
0.00 \\
0.00 \\
0.00\end{array}$ & $\begin{array}{l}0115 \\
0120 \\
0125 \\
0130 \\
0135\end{array}$ & $\begin{array}{l}2.2 \\
2.2 \\
2.2 \\
2.2 \\
2.2\end{array}$ & $\begin{array}{l}0.00 \\
0.00 \\
0.00 \\
0.00 \\
0.00\end{array}$ \\
\hline $\begin{array}{l}1735 \\
1740 \\
1745 \\
1750 \\
1755\end{array}$ & $\begin{array}{l}125.0 \\
167.0 \\
196.0 \\
222.0 \\
237.0\end{array}$ & $\begin{array}{l}0.08 \\
0.03 \\
0.00 \\
0.01 \\
0.00\end{array}$ & $\begin{array}{l}2140 \\
2145 \\
2150 \\
2155 \\
2200\end{array}$ & $\begin{array}{l}6.0 \\
6.0 \\
5.8 \\
5.5 \\
5.3\end{array}$ & $\begin{array}{l}0.00 \\
0.00 \\
0.00 \\
0.00 \\
0.00\end{array}$ & $\begin{array}{l}0140 \\
0145 \\
0150 \\
0155 \\
0200\end{array}$ & $\begin{array}{l}2.1 \\
2.1 \\
2.1 \\
2.1 \\
2.1\end{array}$ & $\begin{array}{l}0.00 \\
0.00 \\
0.00 \\
0.00 \\
0.00\end{array}$ \\
\hline $\begin{array}{l}1800 \\
1805 \\
1810 \\
1815 \\
1820\end{array}$ & $\begin{array}{l}243.0 \\
243.0 \\
237.0 \\
226.0 \\
212.0\end{array}$ & $\begin{array}{l}0.00 \\
0.01 \\
0.00 \\
0.00 \\
0.01\end{array}$ & $\begin{array}{l}2205 \\
2210 \\
2215 \\
2220 \\
2225\end{array}$ & $\begin{array}{l}5.1 \\
4.9 \\
4.7 \\
4.6 \\
4.6\end{array}$ & $\begin{array}{l}0.00 \\
0.00 \\
0.00 \\
0.00 \\
0.00\end{array}$ & $\begin{array}{l}0205 \\
0210 \\
0215 \\
0220 \\
0225\end{array}$ & $\begin{array}{l}2.1 \\
2.1 \\
1.9 \\
1.9 \\
1.9\end{array}$ & $\begin{array}{l}0.00 \\
0.00 \\
0.00 \\
0.00 \\
0.00\end{array}$ \\
\hline $\begin{array}{l}1825 \\
1830 \\
1835 \\
1840 \\
1845\end{array}$ & $\begin{array}{l}195.0 \\
175.0 \\
155.0 \\
137.0 \\
120.0\end{array}$ & $\begin{array}{l}0.01 \\
0.00 \\
0.00 \\
0.00 \\
0.00\end{array}$ & $\begin{array}{l}2230 \\
2235 \\
2240 \\
2245 \\
2250\end{array}$ & $\begin{array}{l}4.4 \\
4.4 \\
4.2 \\
4.0 \\
4.0\end{array}$ & $\begin{array}{l}0.00 \\
0.00 \\
0.00 \\
0.00 \\
0.00\end{array}$ & $\begin{array}{l}0230 \\
0235 \\
0240 \\
0245 \\
0250\end{array}$ & $\begin{array}{l}1.9 \\
1.9 \\
1.9 \\
1.9 \\
1.9\end{array}$ & $\begin{array}{l}0.00 \\
0.00 \\
0.00 \\
0.00 \\
0.00\end{array}$ \\
\hline $\begin{array}{l}1850 \\
1855 \\
1900 \\
1905 \\
1910\end{array}$ & $\begin{array}{r}104.0 \\
90.3 \\
77.7 \\
66.4 \\
56.4\end{array}$ & $\begin{array}{l}0.00 \\
0.00 \\
0.00 \\
0.00 \\
0.00\end{array}$ & $\begin{array}{l}2255 \\
2300 \\
2305 \\
2310 \\
2315\end{array}$ & $\begin{array}{l}3.8 \\
3.8 \\
3.8 \\
3.8 \\
3.6\end{array}$ & $\begin{array}{l}0.00 \\
0.00 \\
0.00 \\
0.00 \\
0.00\end{array}$ & $\begin{array}{l}0255 \\
0300 \\
0305 \\
0310 \\
0315\end{array}$ & $\begin{array}{l}1.9 \\
1.9 \\
1.9 \\
1.9 \\
1.9\end{array}$ & $\begin{array}{l}0.00 \\
0.00 \\
0.00 \\
0.00 \\
0.00\end{array}$ \\
\hline $\begin{array}{l}1915 \\
1920 \\
1925 \\
1930 \\
1935\end{array}$ & $\begin{array}{l}47.9 \\
40.9 \\
34.4 \\
29.9 \\
25.9\end{array}$ & $\begin{array}{l}0.00 \\
0.00 \\
0.00 \\
0.01 \\
0.00\end{array}$ & $\begin{array}{l}2320 \\
2325 \\
2330 \\
2335 \\
2340\end{array}$ & $\begin{array}{l}3.6 \\
3.4 \\
3.4 \\
3.3 \\
3.3\end{array}$ & $\begin{array}{l}0.00 \\
0.00 \\
0.00 \\
0.00 \\
0.00\end{array}$ & $\begin{array}{l}0320 \\
0325 \\
0330 \\
0335 \\
0340\end{array}$ & $\begin{array}{l}1.9 \\
1.9 \\
1.9 \\
1.9 \\
1.8\end{array}$ & $\begin{array}{l}0.00 \\
0.00 \\
0.00 \\
0.00 \\
0.00\end{array}$ \\
\hline $\begin{array}{l}1940 \\
1945 \\
1950 \\
1955 \\
2000\end{array}$ & $\begin{array}{l}22.4 \\
20.1 \\
18.1 \\
16.5 \\
15.3\end{array}$ & $\begin{array}{l}0.00 \\
0.01 \\
0.00 \\
0.00 \\
0.00\end{array}$ & $\begin{array}{l}2345 \\
2350 \\
2355 \\
\text { June } 16 \text {, } \\
0000\end{array}$ & $\begin{array}{r}3.3 \\
3.1 \\
3.1 \\
3989 \\
3.1\end{array}$ & $\begin{array}{l}0.00 \\
0.00 \\
0.00 \\
0.00\end{array}$ & $\begin{array}{l}0345 \\
0350 \\
0355 \\
0400 \\
0405\end{array}$ & $\begin{array}{l}1.8 \\
1.8 \\
1.8 \\
1.8 \\
1.8\end{array}$ & $\begin{array}{l}0.00 \\
0.00 \\
0.00 \\
0.00 \\
0.00\end{array}$ \\
\hline $\begin{array}{l}2005 \\
2010 \\
2015 \\
2020 \\
2025\end{array}$ & $\begin{array}{l}14.7 \\
13.8 \\
12.9 \\
12.0 \\
11.5\end{array}$ & $\begin{array}{l}0.00 \\
0.00 \\
0.00 \\
0.00 \\
0.01\end{array}$ & $\begin{array}{l}0005 \\
0010 \\
0015 \\
0020 \\
0025\end{array}$ & $\begin{array}{l}2.9 \\
2.9 \\
2.9 \\
2.7 \\
2.7\end{array}$ & $\begin{array}{l}0.00 \\
0.00 \\
0.00 \\
0.00 \\
0.00\end{array}$ & $\begin{array}{l}0410 \\
0415 \\
0420 \\
0425 \\
0430\end{array}$ & $\begin{array}{l}1.8 \\
1.8 \\
1.8 \\
1.8 \\
1.8\end{array}$ & $\begin{array}{l}0.00 \\
0.00 \\
0.00 \\
0.00 \\
0.00\end{array}$ \\
\hline $\begin{array}{l}2030 \\
2035 \\
2040 \\
2045 \\
2050\end{array}$ & $\begin{array}{r}10.9 \\
10.4 \\
9.9 \\
9.4 \\
9.1\end{array}$ & $\begin{array}{l}0.00 \\
0.00 \\
0.00 \\
0.00 \\
0.00\end{array}$ & $\begin{array}{l}0030 \\
0035 \\
0040 \\
0045 \\
0050\end{array}$ & $\begin{array}{l}2.7 \\
2.7 \\
2.6 \\
2.6 \\
2.6\end{array}$ & $\begin{array}{l}0.00 \\
0.00 \\
0.00 \\
0.00 \\
0.00\end{array}$ & $\begin{array}{l}0435 \\
0440 \\
0445 \\
0450 \\
0455\end{array}$ & $\begin{array}{l}1.8 \\
1.7 \\
1.7 \\
1.7 \\
1.7\end{array}$ & $\begin{array}{l}0.00 \\
0.00 \\
0.00 \\
0.00 \\
0.00\end{array}$ \\
\hline $\begin{array}{l}2055 \\
2100 \\
2105 \\
2110\end{array}$ & $\begin{array}{l}8.6 \\
8.3 \\
8.1 \\
7.6\end{array}$ & $\begin{array}{l}0.00 \\
0.00 \\
0.00 \\
0.00\end{array}$ & $\begin{array}{l}0055 \\
0100 \\
0105 \\
0110\end{array}$ & $\begin{array}{l}2.4 \\
2.4 \\
2.4 \\
2.4\end{array}$ & $\begin{array}{l}0.00 \\
0.00 \\
0.00 \\
0.00\end{array}$ & 0500 & 1.7 & 0.00 \\
\hline
\end{tabular}




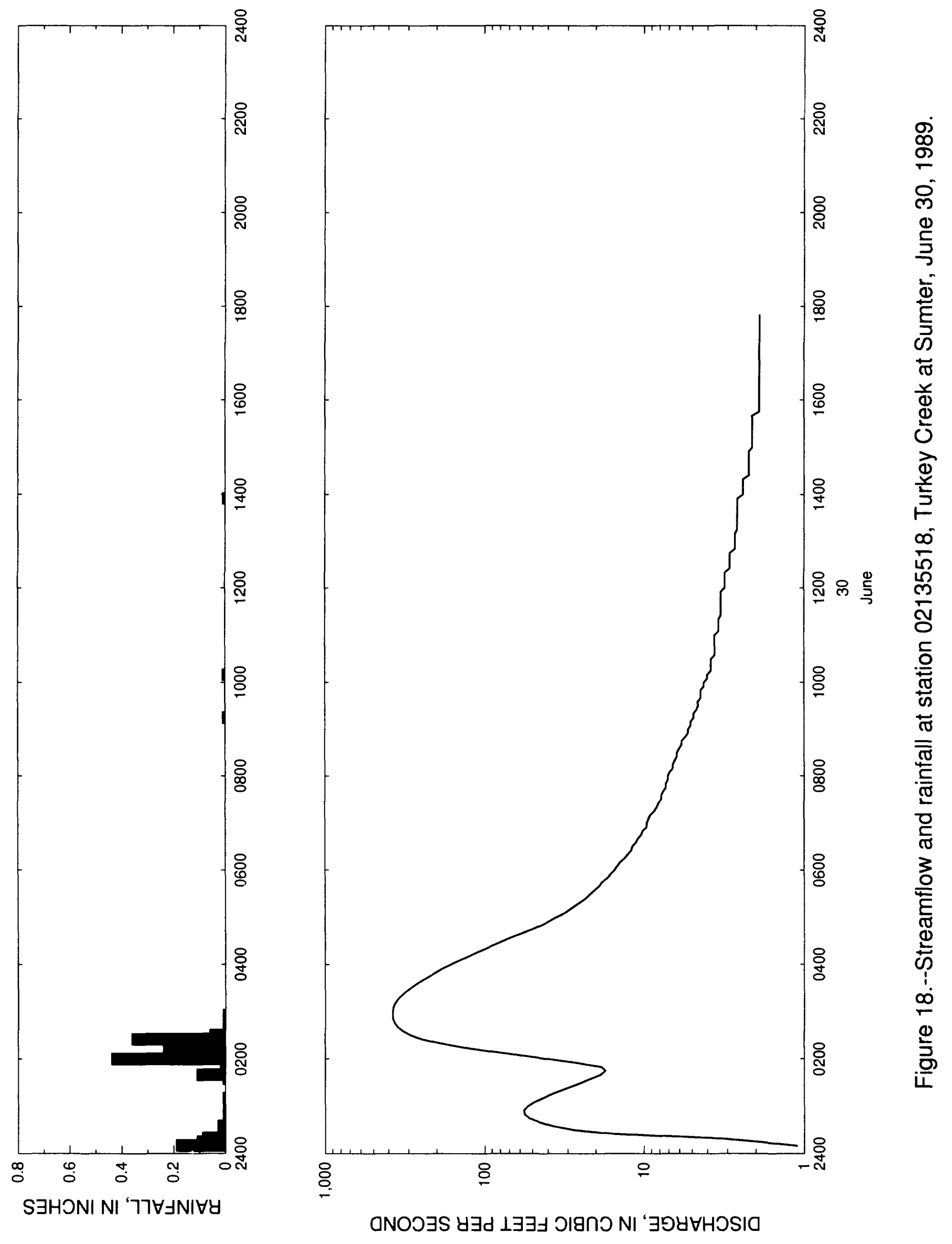


Table 17. - Streamflow and rainfall at station 02135518. Turkey Creek at Sumter, June 30,1989

\begin{tabular}{|c|c|c|c|c|c|c|c|c|}
\hline $\begin{array}{l}\text { Time } \\
\text { (hours) }\end{array}$ & $\begin{array}{l}\text { Streamflow } \\
\text { (cubic feet } \\
\text { per second) }\end{array}$ & $\begin{array}{l}\text { Rain- } \\
\text { fall } \\
\text { (inches) }\end{array}$ & $\begin{array}{l}\text { Time } \\
\text { (hours) }\end{array}$ & $\begin{array}{l}\text { Streamflow } \\
\text { (cubic feet } \\
\text { per second) }\end{array}$ & $\begin{array}{l}\text { Rain- } \\
\text { fall } \\
\text { (inches) }\end{array}$ & $\begin{array}{l}\text { Time } \\
\text { (hours) }\end{array}$ & $\begin{array}{l}\text { Streamflow } \\
\text { (cubic feet } \\
\text { per second) }\end{array}$ & $\begin{array}{l}\text { Rain- } \\
\text { fall } \\
\text { (inches) }\end{array}$ \\
\hline $\begin{array}{l}\text { June } 30 \\
0010 \\
0015 \\
0020 \\
0025\end{array}$ & $\begin{array}{r}1989 \\
1.1 \\
1.9 \\
3.8 \\
15.3\end{array}$ & $\begin{array}{l}0.19 \\
0.11 \\
0.09 \\
0.01\end{array}$ & $\begin{array}{l}0530 \\
0535 \\
0540 \\
0545 \\
0550\end{array}$ & $\begin{array}{l}21.8 \\
20.4 \\
19.1 \\
18.4 \\
17.1\end{array}$ & $\begin{array}{l}0.00 \\
0.00 \\
0.00 \\
0.00 \\
0.00\end{array}$ & $\begin{array}{l}1055 \\
1100 \\
1105 \\
1110 \\
1115\end{array}$ & $\begin{array}{l}3.6 \\
3.6 \\
3.4 \\
3.4 \\
3.4\end{array}$ & $\begin{array}{l}0.00 \\
0.00 \\
0.00 \\
0.00 \\
0.00\end{array}$ \\
\hline $\begin{array}{l}0030 \\
0035 \\
0040 \\
0045 \\
0050\end{array}$ & $\begin{array}{l}27.7 \\
37.6 \\
45.7 \\
52.6 \\
56.4\end{array}$ & $\begin{array}{l}0.00 \\
0.03 \\
0.00 \\
0.01 \\
0.00\end{array}$ & $\begin{array}{l}0555 \\
0600 \\
0605 \\
0610 \\
0615\end{array}$ & $\begin{array}{l}16.2 \\
15.3 \\
14.7 \\
14.1 \\
13.2\end{array}$ & $\begin{array}{l}0.00 \\
0.00 \\
0.00 \\
0.00 \\
0.00\end{array}$ & $\begin{array}{l}1120 \\
1125 \\
1130 \\
1135 \\
1140\end{array}$ & $\begin{array}{l}3.4 \\
3.3 \\
3.3 \\
3.3 \\
3.3\end{array}$ & $\begin{array}{l}0.00 \\
0.00 \\
0.00 \\
0.00 \\
0.00\end{array}$ \\
\hline $\begin{array}{l}0055 \\
0100 \\
0105 \\
0110 \\
0115\end{array}$ & $\begin{array}{l}56.9 \\
54.0 \\
49.3 \\
44.0 \\
38.4\end{array}$ & $\begin{array}{l}0.01 \\
0.00 \\
0.00 \\
0.01 \\
0.00\end{array}$ & $\begin{array}{l}0620 \\
0625 \\
0630 \\
0635 \\
0640\end{array}$ & $\begin{array}{l}12.6 \\
12.0 \\
11.8 \\
11.2 \\
10.9\end{array}$ & $\begin{array}{l}0.00 \\
0.00 \\
0.00 \\
0.00 \\
0.00\end{array}$ & $\begin{array}{l}1145 \\
1150 \\
1155 \\
1200 \\
1205\end{array}$ & $\begin{array}{l}3.3 \\
3.3 \\
3.3 \\
3.1 \\
3.1\end{array}$ & $\begin{array}{l}0.00 \\
0.00 \\
0.00 \\
0.00 \\
0.00\end{array}$ \\
\hline $\begin{array}{l}0120 \\
0125 \\
0130 \\
0135 \\
0140\end{array}$ & $\begin{array}{l}33.3 \\
28.8 \\
24.9 \\
21.8 \\
18.8\end{array}$ & $\begin{array}{l}0.00 \\
0.00 \\
0.00 \\
0.01 \\
0.11\end{array}$ & $\begin{array}{l}0645 \\
0650 \\
0655 \\
0700 \\
0705\end{array}$ & $\begin{array}{r}10.4 \\
10.2 \\
9.6 \\
9.6 \\
9.4\end{array}$ & $\begin{array}{l}0.00 \\
0.00 \\
0.00 \\
0.00 \\
0.00\end{array}$ & $\begin{array}{l}1210 \\
1215 \\
1220 \\
1225 \\
1230\end{array}$ & $\begin{array}{l}3.1 \\
3.1 \\
3.1 \\
2.9 \\
2.9\end{array}$ & $\begin{array}{l}0.00 \\
0.00 \\
0.00 \\
0.00 \\
0.00\end{array}$ \\
\hline $\begin{array}{l}0145 \\
0150 \\
0155 \\
0200 \\
0205\end{array}$ & $\begin{array}{l}17.5 \\
18.4 \\
26.3 \\
40.1 \\
62.8\end{array}$ & $\begin{array}{l}0.02 \\
0.01 \\
0.01 \\
0.44 \\
0.20\end{array}$ & $\begin{array}{l}0710 \\
0715 \\
0720 \\
0725 \\
0730\end{array}$ & $\begin{array}{l}9.1 \\
8.6 \\
8.3 \\
8.1 \\
7.8\end{array}$ & $\begin{array}{l}0.00 \\
0.00 \\
0.00 \\
0.00 \\
0.00\end{array}$ & $\begin{array}{l}1235 \\
1240 \\
1245 \\
1250 \\
1255\end{array}$ & $\begin{array}{l}2.9 \\
2.9 \\
2.9 \\
2.7 \\
2.7\end{array}$ & $\begin{array}{l}0.00 \\
0.00 \\
0.00 \\
0.00 \\
0.00\end{array}$ \\
\hline $\begin{array}{l}0210 \\
0215 \\
0220 \\
0225 \\
0230\end{array}$ & $\begin{array}{r}96.3 \\
141.0 \\
193.0 \\
248.0 \\
291.0\end{array}$ & $\begin{array}{l}0.21 \\
0.24 \\
0.00 \\
0.36 \\
0.06\end{array}$ & $\begin{array}{l}0735 \\
0740 \\
0745 \\
0750 \\
0755\end{array}$ & $\begin{array}{l}7.8 \\
7.6 \\
7.3 \\
7.3 \\
7.1\end{array}$ & $\begin{array}{l}0.00 \\
0.00 \\
0.00 \\
0.00 \\
0.00\end{array}$ & $\begin{array}{l}1300 \\
1305 \\
1310 \\
1315 \\
1320\end{array}$ & $\begin{array}{l}2.7 \\
2.7 \\
2.7 \\
2.6 \\
2.6\end{array}$ & $\begin{array}{l}0.00 \\
0.00 \\
0.00 \\
0.00 \\
0.00\end{array}$ \\
\hline $\begin{array}{l}0235 \\
0240 \\
0245 \\
0250 \\
0255\end{array}$ & $\begin{array}{l}324.0 \\
351.0 \\
367.0 \\
376.0 \\
379.0\end{array}$ & $\begin{array}{l}0.01 \\
0.01 \\
0.00 \\
0.00 \\
0.01\end{array}$ & $\begin{array}{l}0800 \\
0805 \\
0810 \\
0815 \\
0820\end{array}$ & $\begin{array}{l}7.1 \\
6.9 \\
6.6 \\
6.6 \\
6.4\end{array}$ & $\begin{array}{l}0.00 \\
0.00 \\
0.00 \\
0.00 \\
0.00\end{array}$ & $\begin{array}{l}1325 \\
1330 \\
1335 \\
1340 \\
1345\end{array}$ & $\begin{array}{l}2.6 \\
2.6 \\
2.6 \\
2.6 \\
2.6\end{array}$ & $\begin{array}{l}0.00 \\
0.00 \\
0.00 \\
0.00 \\
0.00\end{array}$ \\
\hline $\begin{array}{l}0300 \\
0305 \\
0310 \\
0315 \\
0320\end{array}$ & $\begin{array}{l}378.0 \\
376.0 \\
367.0 \\
353.0 \\
335.0\end{array}$ & $\begin{array}{l}0.00 \\
0.00 \\
0.00 \\
0.00 \\
0.00\end{array}$ & $\begin{array}{l}0825 \\
0830 \\
0835 \\
0840 \\
0845\end{array}$ & $\begin{array}{l}6.2 \\
6.2 \\
6.0 \\
5.8 \\
5.8\end{array}$ & $\begin{array}{l}0.00 \\
0.00 \\
0.00 \\
0.00 \\
0.00\end{array}$ & $\begin{array}{l}1350 \\
1355 \\
1400 \\
1405 \\
1410\end{array}$ & $\begin{array}{l}2.6 \\
2.6 \\
2.4 \\
2.4 \\
2.4\end{array}$ & $\begin{array}{l}0.00 \\
0.01 \\
0.00 \\
0.00 \\
0.00\end{array}$ \\
\hline $\begin{array}{l}0325 \\
0330 \\
0335 \\
0340 \\
0345\end{array}$ & $\begin{array}{l}314.0 \\
291.0 \\
268.0 \\
245.0 \\
223.0\end{array}$ & $\begin{array}{l}0.00 \\
0.00 \\
0.00 \\
0.00 \\
0.00\end{array}$ & $\begin{array}{l}0850 \\
0855 \\
0900 \\
0905 \\
0910\end{array}$ & $\begin{array}{l}5.5 \\
5.3 \\
5.3 \\
5.1 \\
5.1\end{array}$ & $\begin{array}{l}0.00 \\
0.00 \\
0.00 \\
0.00 \\
0.00\end{array}$ & $\begin{array}{l}1415 \\
1420 \\
1425 \\
1430 \\
1435\end{array}$ & $\begin{array}{l}2.4 \\
2.4 \\
2.2 \\
2.2 \\
2.2\end{array}$ & $\begin{array}{l}0.00 \\
0.00 \\
0.00 \\
0.00 \\
0.00\end{array}$ \\
\hline $\begin{array}{l}0350 \\
0355 \\
0400 \\
0405 \\
0410\end{array}$ & $\begin{array}{l}202.0 \\
182.0 \\
163.0 \\
144.0 \\
127.0\end{array}$ & $\begin{array}{l}0.00 \\
0.00 \\
0.00 \\
0.00 \\
0.00\end{array}$ & $\begin{array}{l}0915 \\
0920 \\
0925 \\
0930 \\
0935\end{array}$ & $\begin{array}{l}4.9 \\
4.9 \\
4.7 \\
4.6 \\
4.6\end{array}$ & $\begin{array}{l}0.01 \\
0.00 \\
0.00 \\
0.00 \\
0.00\end{array}$ & $\begin{array}{l}1440 \\
1445 \\
1450 \\
1455 \\
1500\end{array}$ & $\begin{array}{l}2.2 \\
2.2 \\
2.2 \\
2.2 \\
2.1\end{array}$ & $\begin{array}{l}0.00 \\
0.00 \\
0.00 \\
0.00 \\
0.00\end{array}$ \\
\hline $\begin{array}{l}0415 \\
0420 \\
0425 \\
0430 \\
0435\end{array}$ & $\begin{array}{r}113.0 \\
98.8 \\
87.4 \\
77.1 \\
67.5\end{array}$ & $\begin{array}{l}0.00 \\
0.00 \\
0.00 \\
0.00 \\
0.00\end{array}$ & $\begin{array}{l}0940 \\
0945 \\
0950 \\
0955 \\
1000\end{array}$ & $\begin{array}{l}4.4 \\
4.4 \\
4.4 \\
4.2 \\
4.2\end{array}$ & $\begin{array}{l}0.00 \\
0.00 \\
0.00 \\
0.00 \\
0.00\end{array}$ & $\begin{array}{l}1505 \\
1510 \\
1515 \\
1520 \\
1525\end{array}$ & $\begin{array}{l}2.1 \\
2.1 \\
2.1 \\
2.1 \\
2.1\end{array}$ & $\begin{array}{l}0.00 \\
0.00 \\
0.00 \\
0.00 \\
0.00\end{array}$ \\
\hline $\begin{array}{l}0440 \\
0445 \\
0450 \\
0455 \\
0500\end{array}$ & $\begin{array}{l}58.3 \\
50.7 \\
44.4 \\
39.7 \\
36.0\end{array}$ & $\begin{array}{l}0.00 \\
0.00 \\
0.00 \\
0.00 \\
0.00\end{array}$ & $\begin{array}{l}1005 \\
1010 \\
1015 \\
1020 \\
1025\end{array}$ & $\begin{array}{l}4.0 \\
4.0 \\
3.8 \\
3.8 \\
3.8\end{array}$ & $\begin{array}{l}0.00 \\
0.01 \\
0.00 \\
0.00 \\
0.00\end{array}$ & $\begin{array}{l}1530 \\
1535 \\
1540 \\
1545 \\
1550\end{array}$ & $\begin{array}{l}2.1 \\
2.1 \\
2.1 \\
1.9 \\
1.9\end{array}$ & $\begin{array}{l}0.00 \\
0.00 \\
0.00 \\
0.00 \\
0.00\end{array}$ \\
\hline $\begin{array}{l}0505 \\
0510 \\
0515 \\
0520 \\
0525\end{array}$ & $\begin{array}{l}32.1 \\
29.5 \\
27.0 \\
24.9 \\
23.1\end{array}$ & $\begin{array}{l}0.00 \\
0.00 \\
0.00 \\
0.00 \\
0.00\end{array}$ & $\begin{array}{l}1030 \\
1035 \\
1040 \\
1045 \\
1050\end{array}$ & $\begin{array}{l}3.8 \\
3.6 \\
3.6 \\
3.6 \\
3.6\end{array}$ & $\begin{array}{l}0.00 \\
0.00 \\
0.00 \\
0.00 \\
0.00\end{array}$ & $\begin{array}{l}1555 \\
1600 \\
1605 \\
1610 \\
1615\end{array}$ & $\begin{array}{l}1.9 \\
1.9 \\
1.9 \\
1.9 \\
1.9\end{array}$ & $\begin{array}{l}0.00 \\
0.00 \\
0.00 \\
0.00 \\
0.00\end{array}$ \\
\hline
\end{tabular}


Table 17. - - Streamflow and rainfall at station 02135518. Turkey Creek at Sumter, June $30,1989--$ Continued

\begin{tabular}{|c|c|c|c|c|c|c|c|c|}
\hline $\begin{array}{l}\text { Time } \\
\text { (hours) }\end{array}$ & $\begin{array}{l}\text { Streamflow } \\
\text { (cubic feet } \\
\text { per second) }\end{array}$ & $\begin{array}{l}\text { Rain- } \\
\text { fall } \\
\text { (inches) }\end{array}$ & $\begin{array}{l}\text { Time } \\
\text { (hours) }\end{array}$ & $\begin{array}{l}\text { Streamflow } \\
\text { (cubic feet } \\
\text { per second) }\end{array}$ & $\begin{array}{l}\text { Rain- } \\
\text { fall } \\
\text { (inches) }\end{array}$ & $\begin{array}{l}\text { Time } \\
\text { (hours) }\end{array}$ & $\begin{array}{l}\text { Streamflow } \\
\text { (cubic feet } \\
\text { per second) }\end{array}$ & $\begin{array}{l}\text { Rain- } \\
\text { fall } \\
\text { (inches) }\end{array}$ \\
\hline $\begin{array}{l}1620 \\
1625 \\
1630 \\
1635 \\
1640\end{array}$ & $\begin{array}{l}1.9 \\
1.9 \\
1.9 \\
1.9 \\
1.9\end{array}$ & $\begin{array}{l}0.00 \\
0.00 \\
0.00 \\
0.00 \\
0.00\end{array}$ & $\begin{array}{l}1655 \\
1700 \\
1705 \\
1710 \\
1715\end{array}$ & $\begin{array}{l}1.9 \\
1.9 \\
1.9 \\
1.9 \\
1.9\end{array}$ & $\begin{array}{l}0.00 \\
0.00 \\
0.00 \\
0.00 \\
0.00\end{array}$ & $\begin{array}{l}1730 \\
1735 \\
1740 \\
1745 \\
1750\end{array}$ & $\begin{array}{l}1.9 \\
1.9 \\
1.9 \\
1.9 \\
1.9\end{array}$ & $\begin{array}{l}0.00 \\
0.00 \\
0.00 \\
0.00 \\
0.00\end{array}$ \\
\hline $\begin{array}{l}1645 \\
1650\end{array}$ & $\begin{array}{l}1.9 \\
1.9\end{array}$ & $\begin{array}{l}0.00 \\
0.00\end{array}$ & $\begin{array}{l}1720 \\
1725\end{array}$ & $\begin{array}{l}1.9 \\
1.9\end{array}$ & $\begin{array}{l}0.00 \\
0.00\end{array}$ & $\begin{array}{l}1755 \\
1800\end{array}$ & $\begin{array}{l}1.9 \\
1.9\end{array}$ & $\begin{array}{l}0.00 \\
0.00\end{array}$ \\
\hline
\end{tabular}




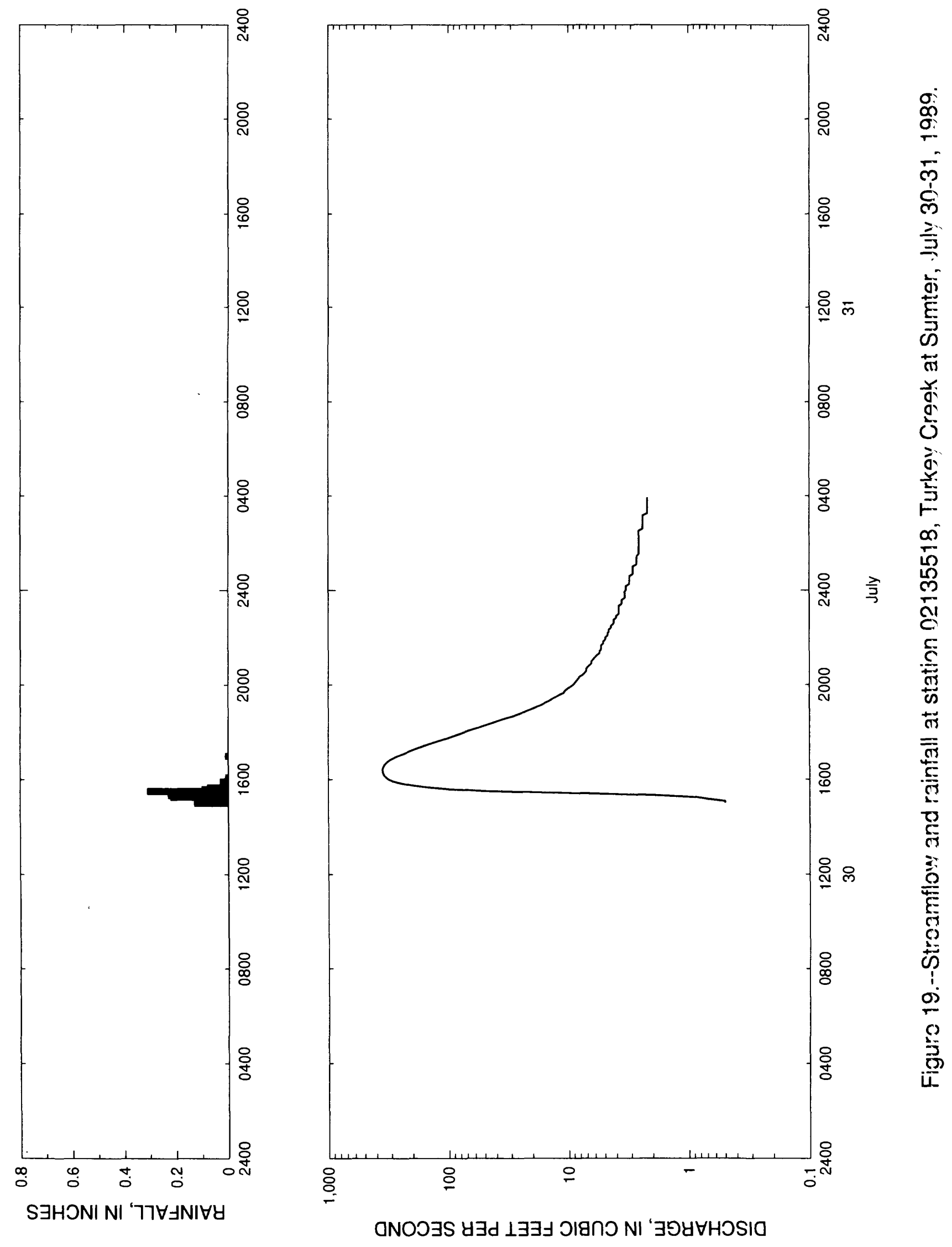


Table 18. - Streamflow and rainfall at station 02135518, Turkey Creek at Sumter, July $30-31,1989$

\begin{tabular}{|c|c|c|c|c|c|c|c|c|}
\hline $\begin{array}{l}\text { Time } \\
\text { (hours) }\end{array}$ & $\begin{array}{l}\text { Streamflow } \\
\text { (cubic feet } \\
\text { per second) }\end{array}$ & $\begin{array}{l}\text { Rain- } \\
\text { fall } \\
\text { (inches) }\end{array}$ & $\begin{array}{l}\text { Time } \\
\text { (hours) }\end{array}$ & $\begin{array}{l}\text { Streamflow } \\
\text { (cubic feet } \\
\text { per second) }\end{array}$ & $\begin{array}{l}\text { Rain- } \\
\text { fall } \\
\text { (inches) }\end{array}$ & $\begin{array}{l}\text { Time } \\
\text { (hours) }\end{array}$ & $\begin{array}{l}\text { Streamflow } \\
\text { (cubic feet } \\
\text { per second) }\end{array}$ & $\begin{array}{l}\text { Rain- } \\
\text { fall } \\
\text { (inches) }\end{array}$ \\
\hline $\begin{array}{l}\text { July } 30, \\
1500 \\
1505 \\
1510 \\
1515\end{array}$ & $\begin{array}{l}1989 \\
0.5 \\
0.5 \\
0.7 \\
0.9\end{array}$ & $\begin{array}{l}0.13 \\
0.11 \\
0.12 \\
0.22\end{array}$ & $\begin{array}{l}1925 \\
1930 \\
1935 \\
1940 \\
1945\end{array}$ & $\begin{array}{l}13.5 \\
12.6 \\
11.8 \\
10.9 \\
10.7\end{array}$ & $\begin{array}{l}0.00 \\
0.00 \\
0.00 \\
0.00 \\
0.00\end{array}$ & $\begin{array}{l}2355 \\
\text { July } 31 \\
0000 \\
0005 \\
0010\end{array}$ & $1989 \begin{array}{l}3.4 \\
3.3 \\
3.3 \\
3.3\end{array}$ & $\begin{array}{l}0.00 \\
0.00 \\
0.00 \\
0.00\end{array}$ \\
\hline $\begin{array}{l}1520 \\
1525 \\
1530 \\
1535 \\
1540\end{array}$ & $\begin{array}{r}1.9 \\
9.6 \\
47.5 \\
100.0 \\
153.0\end{array}$ & $\begin{array}{l}0.23 \\
0.08 \\
0.31 \\
0.10 \\
0.08\end{array}$ & $\begin{array}{l}1950 \\
1955 \\
2000 \\
2005 \\
2010\end{array}$ & $\begin{array}{r}10.2 \\
9.6 \\
9.1 \\
8.8 \\
8.6\end{array}$ & $\begin{array}{l}0.00 \\
0.00 \\
0.00 \\
0.00 \\
0.00\end{array}$ & $\begin{array}{l}0015 \\
0020 \\
0025 \\
0030 \\
0035\end{array}$ & $\begin{array}{l}3 \cdot 1 \\
3 \cdot 1 \\
3 \cdot 1 \\
3 \cdot 1 \\
3 \cdot 1\end{array}$ & $\begin{array}{l}0.00 \\
0.00 \\
0.00 \\
0.00 \\
0.00\end{array}$ \\
\hline $\begin{array}{l}1545 \\
1550 \\
1555 \\
1600 \\
1605\end{array}$ & $\begin{array}{l}204.0 \\
250.0 \\
291.0 \\
316.0 \\
333.0\end{array}$ & $\begin{array}{l}0.03 \\
0.02 \\
0.03 \\
0.01 \\
0.01\end{array}$ & $\begin{array}{l}2015 \\
2020 \\
2025 \\
2030 \\
2035\end{array}$ & $\begin{array}{l}8.3 \\
8.1 \\
7.6 \\
7.3 \\
7.1\end{array}$ & $\begin{array}{l}0.00 \\
0.00 \\
0.00 \\
0.00 \\
0.00\end{array}$ & $\begin{array}{l}0040 \\
0045 \\
0050 \\
0055 \\
0100\end{array}$ & $\begin{array}{l}2.9 \\
2.9 \\
2.9 \\
2.9 \\
2.9\end{array}$ & $\begin{array}{l}0.00 \\
0.00 \\
0.00 \\
0.00 \\
0.00\end{array}$ \\
\hline $\begin{array}{l}1610 \\
1615 \\
1620 \\
1625 \\
1630\end{array}$ & $\begin{array}{l}346.0 \\
352.0 \\
357.0 \\
357.0 \\
354.0\end{array}$ & $\begin{array}{l}0.00 \\
0.00 \\
0.00 \\
0.00 \\
0.00\end{array}$ & $\begin{array}{l}2040 \\
2045 \\
2050 \\
2055 \\
2100\end{array}$ & $\begin{array}{l}7.1 \\
6.9 \\
6.6 \\
6.4 \\
6.4\end{array}$ & $\begin{array}{l}0.00 \\
0.00 \\
0.00 \\
0.00 \\
0.00\end{array}$ & $\begin{array}{l}0105 \\
0110 \\
0115 \\
0120 \\
0125\end{array}$ & $\begin{array}{l}2.7 \\
2.7 \\
2.7 \\
2.7 \\
2.7\end{array}$ & $\begin{array}{l}0.00 \\
0.00 \\
0.00 \\
0.00 \\
0.00\end{array}$ \\
\hline $\begin{array}{l}1635 \\
1640 \\
1645 \\
1650 \\
1655\end{array}$ & $\begin{array}{l}345.0 \\
333.0 \\
321.0 \\
305.0 \\
284.0\end{array}$ & $\begin{array}{l}0.00 \\
0.00 \\
0.00 \\
0.00 \\
0.00\end{array}$ & $\begin{array}{l}2105 \\
2110 \\
2115 \\
2120 \\
2125\end{array}$ & $\begin{array}{l}6.2 \\
6.0 \\
5.8 \\
5.5 \\
5.5\end{array}$ & $\begin{array}{l}0.00 \\
0.00 \\
0.00 \\
0.00 \\
0.00\end{array}$ & $\begin{array}{l}0130 \\
0135 \\
0140 \\
0145 \\
0150\end{array}$ & $\begin{array}{l}2.6 \\
2.6 \\
2.6 \\
2.6 \\
2.6\end{array}$ & $\begin{array}{l}0.00 \\
0.00 \\
0.00 \\
0.00 \\
0.00\end{array}$ \\
\hline $\begin{array}{l}1700 \\
1705 \\
1710 \\
1715 \\
1720\end{array}$ & $\begin{array}{l}262.0 \\
238.0 \\
217.0 \\
198.0 \\
179.0\end{array}$ & $\begin{array}{l}0.01 \\
0.00 \\
0.00 \\
0.00 \\
0.00\end{array}$ & $\begin{array}{l}2130 \\
2135 \\
2140 \\
2145 \\
2150\end{array}$ & $\begin{array}{l}5.3 \\
5.3 \\
5.3 \\
5.1 \\
5.1\end{array}$ & $\begin{array}{l}0.00 \\
0.00 \\
0.00 \\
0.00 \\
0.00\end{array}$ & $\begin{array}{l}0155 \\
0200 \\
0205 \\
0210 \\
0215\end{array}$ & $\begin{array}{l}2.6 \\
2.6 \\
2.6 \\
2.6 \\
2.6\end{array}$ & $\begin{array}{l}0.00 \\
0.00 \\
0.00 \\
0.00 \\
0.00\end{array}$ \\
\hline $\begin{array}{l}1725 \\
1730 \\
1735 \\
1740 \\
1745\end{array}$ & $\begin{array}{l}161.0 \\
144.0 \\
129.0 \\
115.0 \\
102.0\end{array}$ & $\begin{array}{l}0.00 \\
0.00 \\
0.00 \\
0.00 \\
0.00\end{array}$ & $\begin{array}{l}2155 \\
2200 \\
2205 \\
2210 \\
2215\end{array}$ & $\begin{array}{l}4.9 \\
4.9 \\
4.7 \\
4.7 \\
4.6\end{array}$ & $\begin{array}{l}0.00 \\
0.00 \\
0.00 \\
0.00 \\
0.00\end{array}$ & $\begin{array}{l}0220 \\
0225 \\
0230 \\
0235 \\
0240\end{array}$ & $\begin{array}{l}2.6 \\
2.6 \\
2.6 \\
2.4 \\
2.4\end{array}$ & $\begin{array}{l}0.00 \\
0.00 \\
0.00 \\
0.00 \\
0.00\end{array}$ \\
\hline $\begin{array}{l}1750 \\
1755 \\
1800 \\
1805 \\
1810\end{array}$ & $\begin{array}{l}92.1 \\
82.8 \\
73.9 \\
65.9 \\
58.3\end{array}$ & $\begin{array}{l}0.00 \\
0.00 \\
0.00 \\
0.00 \\
0.00\end{array}$ & $\begin{array}{l}2220 \\
2225 \\
2230 \\
2235 \\
2240\end{array}$ & $\begin{array}{l}4.6 \\
4.4 \\
4.4 \\
4.2 \\
4.2\end{array}$ & $\begin{array}{l}0.00 \\
0.00 \\
0.00 \\
0.00 \\
0.00\end{array}$ & $\begin{array}{l}0245 \\
0250 \\
0255 \\
0300 \\
0305\end{array}$ & $\begin{array}{l}2.4 \\
2.4 \\
2.4 \\
2.4 \\
2.4\end{array}$ & $\begin{array}{l}0.00 \\
0.00 \\
0.00 \\
0.00 \\
0.00\end{array}$ \\
\hline $\begin{array}{l}1815 \\
1820 \\
1825 \\
1830 \\
1835\end{array}$ & $\begin{array}{l}52.6 \\
47.0 \\
42.2 \\
37.6 \\
33.6\end{array}$ & $\begin{array}{l}0.00 \\
0.00 \\
0.00 \\
0.00 \\
0.00\end{array}$ & $\begin{array}{l}2245 \\
2250 \\
2255 \\
2300 \\
2305\end{array}$ & $\begin{array}{l}4.2 \\
4.0 \\
4.0 \\
3.8 \\
3.8\end{array}$ & $\begin{array}{l}0.00 \\
0.00 \\
0.00 \\
0.00 \\
0.00\end{array}$ & $\begin{array}{l}0310 \\
0315 \\
0320 \\
0325 \\
0330\end{array}$ & $\begin{array}{l}2.4 \\
2.2 \\
2.2 \\
2.2 \\
2.2\end{array}$ & $\begin{array}{l}0.00 \\
0.00 \\
0.00 \\
0.00 \\
0.00\end{array}$ \\
\hline $\begin{array}{l}1840 \\
1845 \\
1850 \\
1855 \\
1900\end{array}$ & $\begin{array}{l}29.5 \\
26.6 \\
23.8 \\
21.8 \\
19.7\end{array}$ & $\begin{array}{l}0.00 \\
0.00 \\
0.00 \\
0.00 \\
0.00\end{array}$ & $\begin{array}{l}2310 \\
2315 \\
2320 \\
2325 \\
2330\end{array}$ & $\begin{array}{l}3.8 \\
3.8 \\
3.8 \\
3.6 \\
3.6\end{array}$ & $\begin{array}{l}0.00 \\
0.00 \\
0.00 \\
0.00 \\
0.00\end{array}$ & $\begin{array}{l}0335 \\
0340 \\
0345 \\
0350 \\
0355\end{array}$ & $\begin{array}{l}2.2 \\
2.2 \\
2.2 \\
2.2 \\
2.2\end{array}$ & $\begin{array}{l}0.00 \\
0.00 \\
0.00 \\
0.00 \\
0.00\end{array}$ \\
\hline $\begin{array}{l}1905 \\
1910 \\
1915 \\
1920\end{array}$ & $\begin{array}{l}18.1 \\
16.5 \\
15.6 \\
14.4\end{array}$ & $\begin{array}{l}0.00 \\
0.00 \\
0.00 \\
0.00\end{array}$ & $\begin{array}{l}2335 \\
2340 \\
2345 \\
2350\end{array}$ & $\begin{array}{l}3.6 \\
3.4 \\
3.4 \\
3.4\end{array}$ & $\begin{array}{l}0.00 \\
0.00 \\
0.00 \\
0.00\end{array}$ & 0400 & 2.1 & 0.00 \\
\hline
\end{tabular}




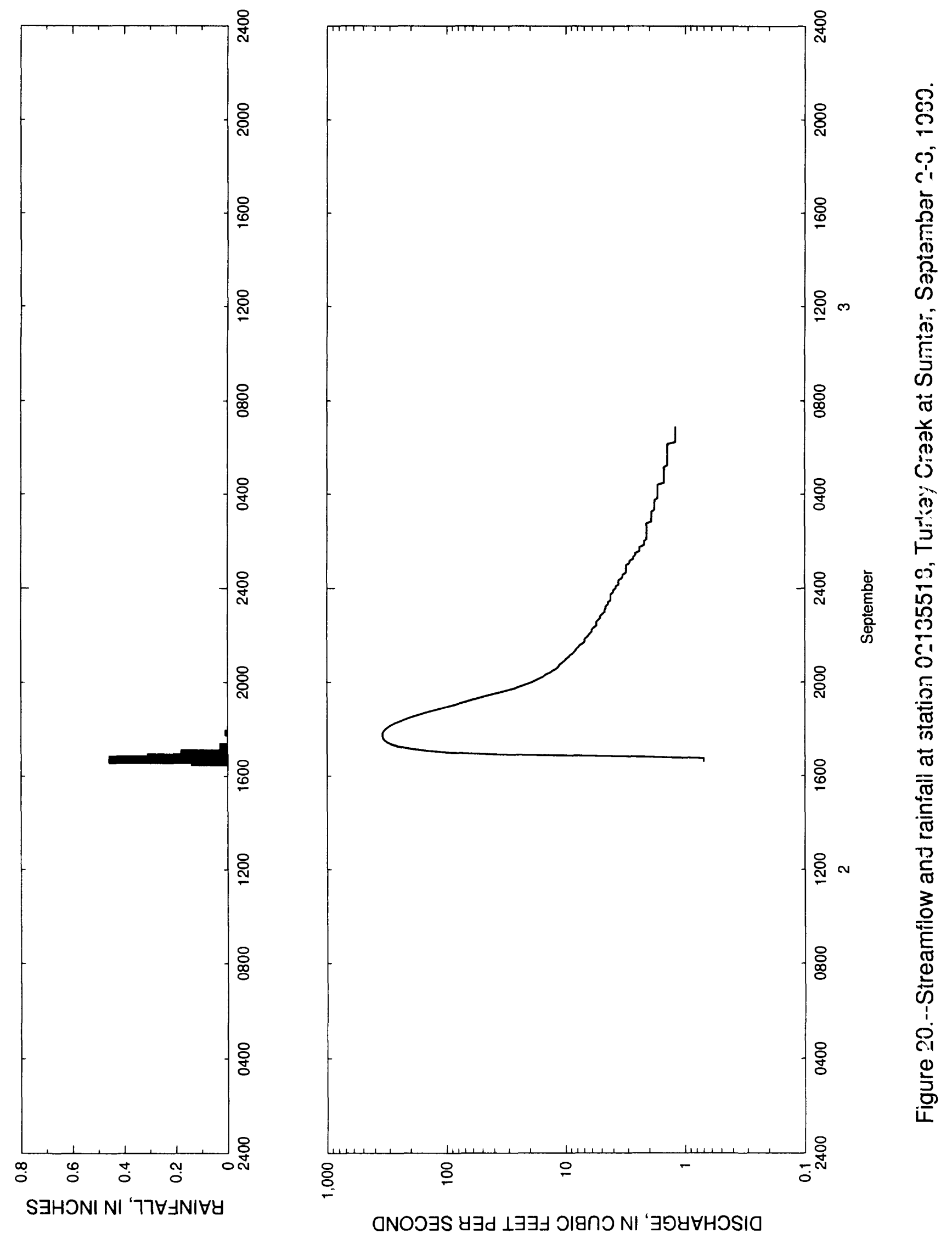


Table 19. - - Streamflow and rainfall at station 02135518, Turkey Creek at Sumter, September 2-3, 1989

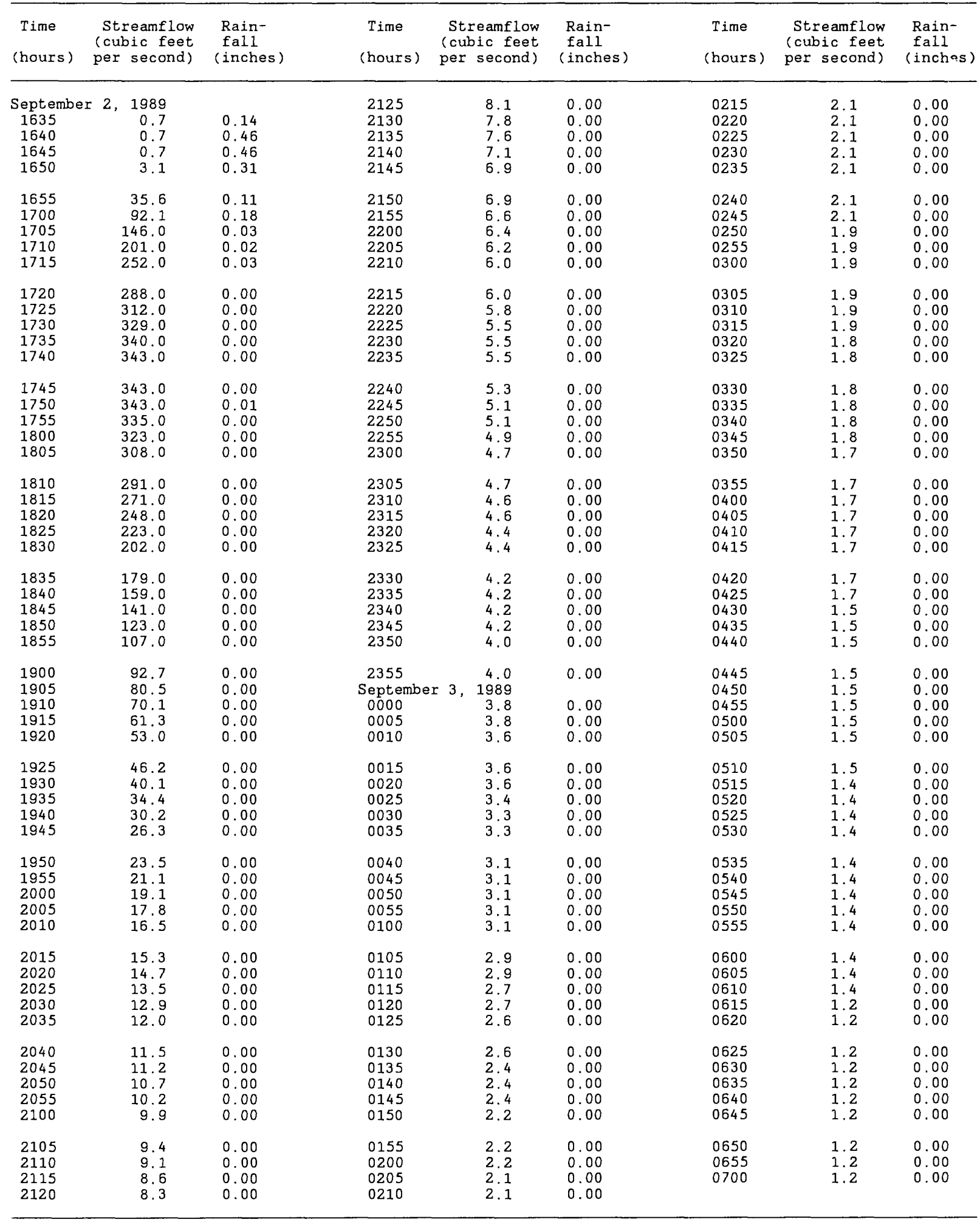



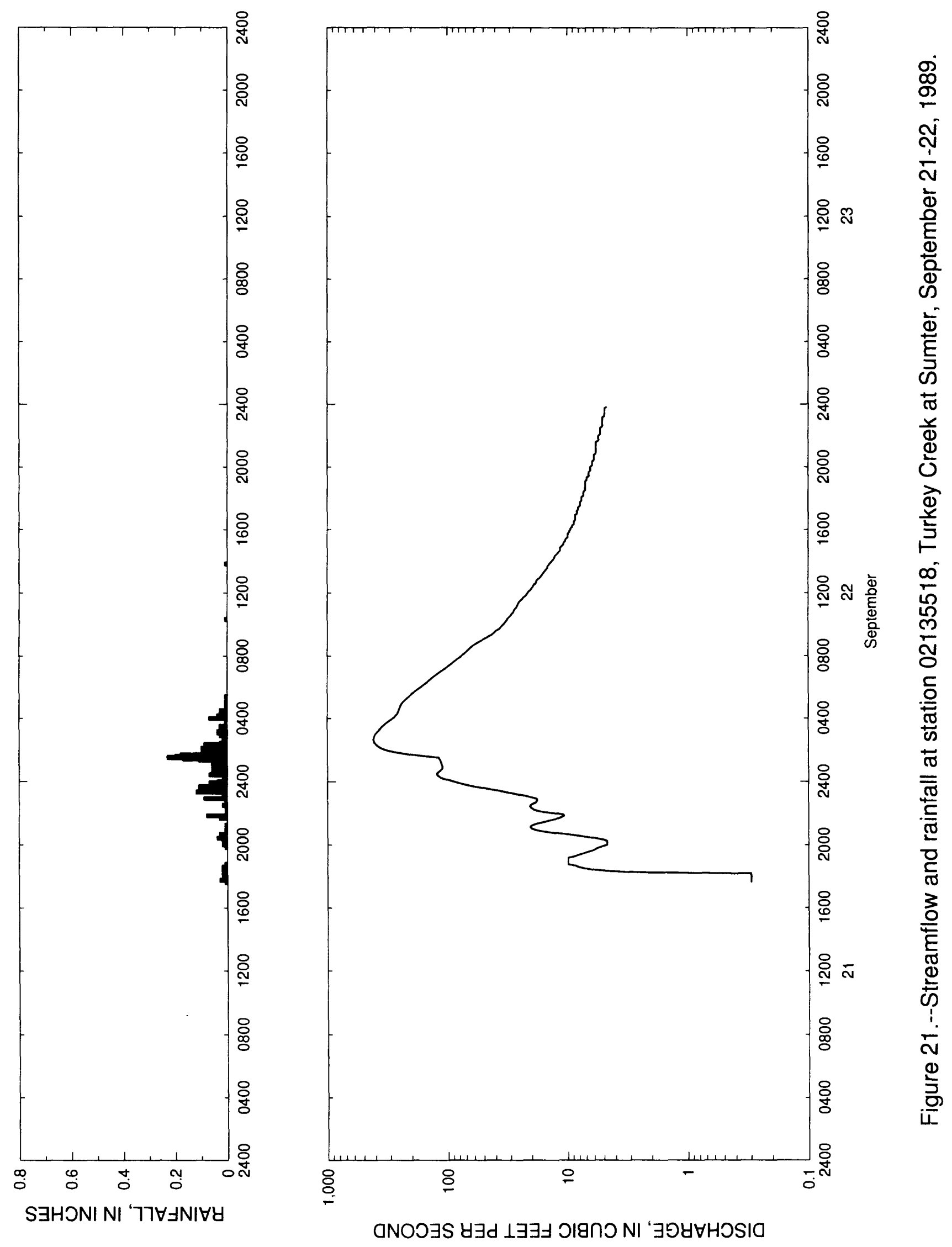
Table 20.--Streamflow and rainfall at station 02135518. Turkey Creek at Sumter, September 21-22, 1989

\begin{tabular}{|c|c|c|c|c|c|c|c|c|}
\hline $\begin{array}{l}\text { Time } \\
\text { (hours) }\end{array}$ & $\begin{array}{l}\text { Streamflow } \\
\text { (cubic feet } \\
\text { per second) }\end{array}$ & $\begin{array}{l}\text { Rain- } \\
\text { fall } \\
\text { (inches) }\end{array}$ & $\begin{array}{l}\text { Time } \\
\text { (hours) }\end{array}$ & $\begin{array}{l}\text { Streamflow } \\
\text { (cubic feet } \\
\text { per second) }\end{array}$ & $\begin{array}{l}\text { Rain- } \\
\text { fall } \\
\text { (inches) }\end{array}$ & $\begin{array}{l}\text { Time } \\
\text { (hours) }\end{array}$ & $\begin{array}{l}\text { Streamflow } \\
\text { (cubic feet } \\
\text { per second) }\end{array}$ & $\begin{array}{l}\text { Rain- } \\
\text { fall } \\
\text { (inctes) }\end{array}$ \\
\hline $\begin{array}{l}\text { September } \\
1735 \\
1740 \\
1745 \\
1750\end{array}$ & $\begin{aligned} & 2.1, 1989 \\
& 0.3 \\
& 0.3 \\
& 0.3 \\
& 0.3\end{aligned}$ & $\begin{array}{l}0.01 \\
0.00 \\
0.03 \\
0.02\end{array}$ & $\begin{array}{l}2255 \\
2300 \\
2305 \\
2310 \\
2315\end{array}$ & $\begin{array}{l}18.1 \\
20.1 \\
22.1 \\
25.2 \\
28.4\end{array}$ & $\begin{array}{l}0.09 \\
0.02 \\
0.00 \\
0.00 \\
0.00\end{array}$ & $\begin{array}{l}0415 \\
0420 \\
0425 \\
0430 \\
0435\end{array}$ & $\begin{array}{l}265.0 \\
261.0 \\
258.0 \\
256.0 \\
254.0\end{array}$ & $\begin{array}{l}0.02 . \\
0.03 \\
0.03 \\
0.03 \\
0.01\end{array}$ \\
\hline $\begin{array}{l}1755 \\
1800 \\
1805 \\
1810 \\
1815\end{array}$ & $\begin{array}{l}0.3 \\
0.3 \\
0.3 \\
0.3 \\
2.7\end{array}$ & $\begin{array}{l}0.01 \\
0.00 \\
0.02 \\
0.01 \\
0.01\end{array}$ & $\begin{array}{l}2320 \\
2325 \\
2330 \\
2335 \\
2340\end{array}$ & $\begin{array}{l}32.9 \\
37.2 \\
43.5 \\
50.2 \\
58.3\end{array}$ & $\begin{array}{l}0.12 \\
0.09 \\
0.01 \\
0.00 \\
0.11\end{array}$ & $\begin{array}{l}0440 \\
0445 \\
0450 \\
0455 \\
0500\end{array}$ & $\begin{array}{l}251.0 \\
249.0 \\
247.0 \\
243.0 \\
239.0\end{array}$ & $\begin{array}{l}0.01 \\
0.01 \\
0.00 \\
0.01 \\
0.00\end{array}$ \\
\hline $\begin{array}{l}1820 \\
1825 \\
1830 \\
1835 \\
1840\end{array}$ & $\begin{array}{l}4.7 \\
6.2 \\
7.3 \\
8.1 \\
8.6\end{array}$ & $\begin{array}{l}0.00 \\
0.02 \\
0.00 \\
0.02 \\
0.00\end{array}$ & $\begin{array}{l}2345 \\
2350 \\
2355 \\
\text { September } \\
0000\end{array}$ & $\begin{array}{c}66.4 \\
73.9 \\
81.6 \\
222,1989 \\
89.1\end{array}$ & $\begin{array}{l}0.00 \\
0.07 \\
0.07 \\
0.04\end{array}$ & $\begin{array}{l}0505 \\
0510 \\
0515 \\
0520 \\
0525\end{array}$ & $\begin{array}{l}234.0 \\
228.0 \\
222.0 \\
216.0 \\
210.0\end{array}$ & $\begin{array}{l}0.01 \\
0.00 \\
0.00 \\
0.00 \\
0.01\end{array}$ \\
\hline $\begin{array}{l}1845 \\
1850 \\
1855 \\
1900 \\
1905\end{array}$ & $\begin{array}{l}9.9 \\
9.9 \\
9.9 \\
9.9 \\
9.9\end{array}$ & $\begin{array}{l}0.01 \\
0.00 \\
0.00 \\
0.00 \\
0.00\end{array}$ & $\begin{array}{l}0005 \\
0010 \\
0015 \\
0020 \\
0025\end{array}$ & $\begin{array}{r}96.9 \\
106.0 \\
114.0 \\
119.0 \\
123.0\end{array}$ & $\begin{array}{l}0.02 \\
0.01 \\
0.01 \\
0.00 \\
0.07\end{array}$ & $\begin{array}{l}0530 \\
0535 \\
0540 \\
0545 \\
0550\end{array}$ & $\begin{array}{l}204.0 \\
198.0 \\
191.0 \\
186.0 \\
180.0\end{array}$ & $\begin{array}{l}0.00 \\
0.00 \\
0.00 \\
0.00 \\
0.00\end{array}$ \\
\hline $\begin{array}{l}1910 \\
1915 \\
1920 \\
1925 \\
1930\end{array}$ & $\begin{array}{l}9.9 \\
8.8 \\
8.3 \\
7.6 \\
7.1\end{array}$ & $\begin{array}{l}0.00 \\
0.00 \\
0.00 \\
0.00 \\
0.00\end{array}$ & $\begin{array}{l}0030 \\
0035 \\
0040 \\
0045 \\
0050\end{array}$ & $\begin{array}{l}123.0 \\
120.0 \\
116.0 \\
113.0 \\
111.0\end{array}$ & $\begin{array}{l}0.02 \\
0.03 \\
0.06 \\
0.04 \\
0.06\end{array}$ & $\begin{array}{l}0555 \\
0600 \\
0605 \\
0610 \\
0615\end{array}$ & $\begin{array}{l}174.0 \\
168.0 \\
163.0 \\
157.0 \\
152.0\end{array}$ & $\begin{array}{l}0.00 \\
0.00 \\
0.00 \\
0.00 \\
0.00\end{array}$ \\
\hline $\begin{array}{l}1935 \\
1940 \\
1945 \\
1950 \\
1955\end{array}$ & $\begin{array}{l}6.6 \\
6.0 \\
5.8 \\
5.5 \\
5.1\end{array}$ & $\begin{array}{l}1.00 \\
0.00 \\
0.00 \\
0.01 \\
0.00\end{array}$ & $\begin{array}{l}0055 \\
0100 \\
0105 \\
0110 \\
0115\end{array}$ & $\begin{array}{l}111.0 \\
111.0 \\
112.0 \\
113.0 \\
114.0\end{array}$ & $\begin{array}{l}0.06 \\
0.06 \\
0.03 \\
0.04 \\
0.03\end{array}$ & $\begin{array}{l}0620 \\
0625 \\
0630 \\
0635 \\
0640\end{array}$ & $\begin{array}{l}147.0 \\
144.0 \\
139.0 \\
135.0 \\
131.0\end{array}$ & $\begin{array}{l}0.00 \\
0.00 \\
0.00 \\
0.00 \\
0.00\end{array}$ \\
\hline $\begin{array}{l}2000 \\
2005 \\
2010 \\
2015 \\
2020\end{array}$ & $\begin{array}{l}4.7 \\
4.7 \\
4.7 \\
4.7 \\
5.1\end{array}$ & $\begin{array}{l}0.02 \\
0.00 \\
0.02 \\
0.00 \\
0.01\end{array}$ & $\begin{array}{l}0120 \\
0125 \\
0130 \\
0135 \\
0140\end{array}$ & $\begin{array}{l}115.0 \\
117.0 \\
119.0 \\
156.0 \\
198.0\end{array}$ & $\begin{array}{l}0.11 \\
0.17 \\
0.23 \\
0.20 \\
0.18\end{array}$ & $\begin{array}{l}0645 \\
0650 \\
0655 \\
0700 \\
0705\end{array}$ & $\begin{array}{l}127.0 \\
123.0 \\
119.0 \\
115.0 \\
111.0\end{array}$ & $\begin{array}{l}0.00 \\
0.00 \\
0.00 \\
0.00 \\
0.00\end{array}$ \\
\hline $\begin{array}{l}2025 \\
2030 \\
2035 \\
2040 \\
2045\end{array}$ & $\begin{array}{r}5.8 \\
6.9 \\
8.3 \\
10.2 \\
12.9\end{array}$ & $\begin{array}{l}0.04 \\
0.03 \\
0.00 \\
0.03 \\
0.01\end{array}$ & $\begin{array}{l}0145 \\
0150 \\
0155 \\
0200 \\
0205\end{array}$ & $\begin{array}{l}233.0 \\
273.0 \\
308.0 \\
336.0 \\
358.0\end{array}$ & $\begin{array}{l}0.10 \\
0.06 \\
0.04 \\
0.04 \\
0.10\end{array}$ & $\begin{array}{l}0710 \\
0715 \\
0720 \\
0725 \\
0730\end{array}$ & $\begin{array}{r}107.0 \\
102.0 \\
99.4 \\
95.7 \\
92.7\end{array}$ & $\begin{array}{l}0.00 \\
0.00 \\
0.00 \\
0.00 \\
0.00\end{array}$ \\
\hline $\begin{array}{l}2050 \\
2055 \\
2100 \\
2105 \\
2110\end{array}$ & $\begin{array}{l}15.9 \\
18.1 \\
19.7 \\
20.4 \\
20.4\end{array}$ & $\begin{array}{l}0.00 \\
0.00 \\
0.01 \\
0.00 \\
0.00\end{array}$ & $\begin{array}{l}0210 \\
0215 \\
0220 \\
0225 \\
0230\end{array}$ & $\begin{array}{l}374.0 \\
387.0 \\
398.0 \\
406.0 \\
411.0\end{array}$ & $\begin{array}{l}0.07 \\
0.08 \\
0.09 \\
0.03 \\
0.02\end{array}$ & $\begin{array}{l}0735 \\
0740 \\
0745 \\
0750 \\
0755\end{array}$ & $\begin{array}{l}89.7 \\
86.8 \\
84.5 \\
81.6 \\
78.8\end{array}$ & $\begin{array}{l}0.00 \\
0.00 \\
0.00 \\
0.00 \\
0.00\end{array}$ \\
\hline $\begin{array}{l}2115 \\
2120 \\
2125 \\
2130 \\
2135\end{array}$ & $\begin{array}{l}19.4 \\
18.1 \\
16.2 \\
14.7 \\
13.2\end{array}$ & $\begin{array}{l}0.01 \\
0.00 \\
0.00 \\
0.00 \\
0.00\end{array}$ & $\begin{array}{l}0235 \\
0240 \\
0245 \\
0250 \\
0255\end{array}$ & $\begin{array}{l}415.0 \\
415.0 \\
412.0 \\
410.0 \\
407.0\end{array}$ & $\begin{array}{l}0.00 \\
0.02 \\
0.02 \\
0.02 \\
0.03\end{array}$ & $\begin{array}{l}0800 \\
0805 \\
0810 \\
0815 \\
0820\end{array}$ & $\begin{array}{l}76.6 \\
74.4 \\
72.2 \\
70.1 \\
68.5\end{array}$ & $\begin{array}{l}0.00 \\
0.00 \\
0.00 \\
0.00 \\
0.00\end{array}$ \\
\hline $\begin{array}{l}2140 \\
2145 \\
2150 \\
2155 \\
2200\end{array}$ & $\begin{array}{l}12.0 \\
11.2 \\
10.7 \\
10.9 \\
12.9\end{array}$ & $\begin{array}{l}0.03 \\
0.00 \\
0.08 \\
0.00 \\
0.00\end{array}$ & $\begin{array}{l}0300 \\
0305 \\
0310 \\
0315 \\
0320\end{array}$ & $\begin{array}{l}401.0 \\
392.0 \\
382.0 \\
374.0 \\
364.0\end{array}$ & $\begin{array}{l}0.02 \\
0.04 \\
0.04 \\
0.03 \\
0.02\end{array}$ & $\begin{array}{l}0825 \\
0830 \\
0835 \\
0840 \\
0845\end{array}$ & $\begin{array}{l}66.4 \\
64.9 \\
62.8 \\
60.8 \\
58.8\end{array}$ & $\begin{array}{l}0.00 \\
0.00 \\
0.00 \\
0.00 \\
0.00\end{array}$ \\
\hline $\begin{array}{l}2205 \\
2210 \\
2215 \\
2220 \\
2225\end{array}$ & $\begin{array}{l}15.9 \\
18.1 \\
19.4 \\
20.1 \\
20.7\end{array}$ & $\begin{array}{l}0.00 \\
0.01 \\
0.00 \\
0.00 \\
0.01\end{array}$ & $\begin{array}{l}0325 \\
0330 \\
0335 \\
0340 \\
0345\end{array}$ & $\begin{array}{l}355.0 \\
345.0 \\
336.0 \\
327.0 \\
316.0\end{array}$ & $\begin{array}{l}0.02 \\
0.03 \\
0.01 \\
0.01 \\
0.01\end{array}$ & $\begin{array}{l}0850 \\
0855 \\
0900 \\
0905 \\
0910\end{array}$ & $\begin{array}{l}56.4 \\
54.0 \\
51.6 \\
49.3 \\
47.0\end{array}$ & $\begin{array}{l}0.00 \\
0.00 \\
0.00 \\
0.00 \\
0.00\end{array}$ \\
\hline $\begin{array}{l}2230 \\
2235 \\
2240 \\
2245 \\
2250\end{array}$ & $\begin{array}{l}20.4 \\
19.7 \\
18.4 \\
18.1 \\
17.8\end{array}$ & $\begin{array}{l}0.02 \\
0.00 \\
0.01 \\
0.01 \\
0.00\end{array}$ & $\begin{array}{l}0350 \\
0355 \\
0400 \\
0405 \\
0410\end{array}$ & $\begin{array}{l}306.0 \\
296.0 \\
286.0 \\
277.0 \\
271.0\end{array}$ & $\begin{array}{l}0.01 \\
0.01 \\
0.07 \\
0.04 \\
0.04\end{array}$ & $\begin{array}{l}0915 \\
0920 \\
0925 \\
0930 \\
0935\end{array}$ & $\begin{array}{l}45.3 \\
43.1 \\
41.8 \\
40.5 \\
39.7\end{array}$ & $\begin{array}{l}0.00 \\
0.00 \\
0.00 \\
0.00 \\
0.00\end{array}$ \\
\hline
\end{tabular}


Table 20.--Streamflow and rainfall at station 02135518. Turkey Creek at Sumter, September 21-22, 1989--Continued

\begin{tabular}{|c|c|c|c|c|c|c|c|c|}
\hline $\begin{array}{l}\text { Time } \\
\text { (hours) }\end{array}$ & $\begin{array}{l}\text { Streamflow } \\
\text { (cubic feet } \\
\text { per second) }\end{array}$ & $\begin{array}{l}\text { Rain- } \\
\text { fall } \\
\text { (inches) }\end{array}$ & $\begin{array}{l}\text { Time } \\
\text { (hours) }\end{array}$ & $\begin{array}{l}\text { Streamflow } \\
\text { (cubic feet } \\
\text { per second) }\end{array}$ & $\begin{array}{l}\text { Rain- } \\
\text { fall } \\
\text { (inches) }\end{array}$ & $\begin{array}{l}\text { Time } \\
\text { (hours) }\end{array}$ & $\begin{array}{l}\text { Streamflow } \\
\text { (cubic feet } \\
\text { per second) }\end{array}$ & $\begin{array}{l}\text { Rain- } \\
\text { fall } \\
\text { (inches) }\end{array}$ \\
\hline $\begin{array}{l}0940 \\
0945 \\
0950 \\
0955 \\
1000\end{array}$ & $\begin{array}{l}38.0 \\
36.8 \\
36.0 \\
35.2 \\
34.4\end{array}$ & $\begin{array}{l}0.00 \\
0.00 \\
0.00 \\
0.00 \\
0.00\end{array}$ & $\begin{array}{l}1430 \\
1435 \\
1440 \\
1445 \\
1450\end{array}$ & $\begin{array}{l}12.0 \\
11.8 \\
11.5 \\
11.5 \\
11.5\end{array}$ & $\begin{array}{l}0.00 \\
0.00 \\
0.00 \\
0.00 \\
0.00\end{array}$ & $\begin{array}{l}1920 \\
1925 \\
1930 \\
1935 \\
1940\end{array}$ & $\begin{array}{l}6.9 \\
6.6 \\
6.6 \\
6.6 \\
6.6\end{array}$ & $\begin{array}{l}0.00 \\
0.00 \\
0.00 \\
0.00 \\
0.00\end{array}$ \\
\hline $\begin{array}{l}1005 \\
1010 \\
1015 \\
1020 \\
1025\end{array}$ & $\begin{array}{l}33.6 \\
32.9 \\
32.1 \\
31.7 \\
31.0\end{array}$ & $\begin{array}{l}0.00 \\
0.00 \\
0.00 \\
0.01 \\
0.00\end{array}$ & $\begin{array}{l}1455 \\
1500 \\
1505 \\
1510 \\
1515\end{array}$ & $\begin{array}{l}11.2 \\
10.9 \\
10.7 \\
10.7 \\
10.4\end{array}$ & $\begin{array}{l}0.00 \\
0.00 \\
0.00 \\
0.00 \\
0.00\end{array}$ & $\begin{array}{l}1945 \\
1950 \\
1955 \\
2000 \\
2005\end{array}$ & $\begin{array}{l}6.4 \\
6.4 \\
6.4 \\
6.4 \\
6.2\end{array}$ & $\begin{array}{l}0.00 \\
0.00 \\
0.00 \\
0.00 \\
0.00\end{array}$ \\
\hline $\begin{array}{l}1030 \\
1035 \\
1040 \\
1045 \\
1050\end{array}$ & $\begin{array}{l}30.2 \\
29.5 \\
29.1 \\
28.4 \\
28.0\end{array}$ & $\begin{array}{l}0.00 \\
0.00 \\
0.00 \\
0.00 \\
0.00\end{array}$ & $\begin{array}{l}1520 \\
1525 \\
1530 \\
1535 \\
1540\end{array}$ & $\begin{array}{r}10.4 \\
10.2 \\
9.9 \\
9.9 \\
9.9\end{array}$ & $\begin{array}{l}0.00 \\
0.00 \\
0.00 \\
0.00 \\
0.00\end{array}$ & $\begin{array}{l}2010 \\
2015 \\
2020 \\
2025 \\
2030\end{array}$ & $\begin{array}{l}6.2 \\
6.2 \\
6.2 \\
6.0 \\
6.0\end{array}$ & $\begin{array}{l}0.00 \\
0.00 \\
0.00 \\
0.00 \\
0.00\end{array}$ \\
\hline $\begin{array}{l}1055 \\
1100 \\
1105 \\
1110 \\
1115\end{array}$ & $\begin{array}{l}27.7 \\
27.3 \\
26.6 \\
26.3 \\
25.9\end{array}$ & $\begin{array}{l}0.00 \\
0.00 \\
0.00 \\
0.00 \\
0.00\end{array}$ & $\begin{array}{l}1545 \\
1550 \\
1555 \\
1600 \\
1605\end{array}$ & $\begin{array}{l}9.9 \\
9.6 \\
9.6 \\
9.4 \\
9.4\end{array}$ & $\begin{array}{l}0.00 \\
0.00 \\
0.00 \\
0.00 \\
0.00\end{array}$ & $\begin{array}{l}2035 \\
2040 \\
2045 \\
2050 \\
2055\end{array}$ & $\begin{array}{l}6.0 \\
6.0 \\
6.0 \\
5.8 \\
5.8\end{array}$ & $\begin{array}{l}0.00 \\
0.00 \\
0.00 \\
0.00 \\
0.00\end{array}$ \\
\hline $\begin{array}{l}1120 \\
1125 \\
1130 \\
1135 \\
1140\end{array}$ & $\begin{array}{l}25.5 \\
25.2 \\
24.5 \\
23.8 \\
23.5\end{array}$ & $\begin{array}{l}0.00 \\
0.00 \\
0.00 \\
0.00 \\
0.00\end{array}$ & $\begin{array}{l}1610 \\
1615 \\
1620 \\
1625 \\
1630\end{array}$ & $\begin{array}{l}9.1 \\
9.1 \\
8.8 \\
8.8 \\
8.8\end{array}$ & $\begin{array}{l}0.00 \\
0.00 \\
0.00 \\
0.00 \\
0.00\end{array}$ & $\begin{array}{l}2100 \\
2105 \\
2110 \\
2115 \\
2120\end{array}$ & $\begin{array}{l}5.8 \\
5.8 \\
5.8 \\
5.8 \\
5.8\end{array}$ & $\begin{array}{l}0.00 \\
0.00 \\
0.00 \\
0.00 \\
0.00\end{array}$ \\
\hline $\begin{array}{l}1145 \\
1150 \\
1155 \\
1200 \\
1205\end{array}$ & $\begin{array}{l}22.8 \\
22.1 \\
21.8 \\
21.4 \\
21.1\end{array}$ & $\begin{array}{l}0.00 \\
0.00 \\
0.00 \\
0.00 \\
0.00\end{array}$ & $\begin{array}{l}1635 \\
1640 \\
1645 \\
1650 \\
1655\end{array}$ & $\begin{array}{l}8.6 \\
8.6 \\
8.6 \\
8.6 \\
8.6\end{array}$ & $\begin{array}{l}0.00 \\
0.00 \\
0.00 \\
0.00 \\
0.00\end{array}$ & $\begin{array}{l}2125 \\
2130 \\
2135 \\
2140 \\
2145\end{array}$ & $\begin{array}{l}5.8 \\
5.8 \\
5.8 \\
5.5 \\
5.5\end{array}$ & $\begin{array}{l}0.00 \\
0.00 \\
0.00 \\
0.00 \\
0.00\end{array}$ \\
\hline $\begin{array}{l}1210 \\
1215 \\
1220 \\
1225 \\
1230\end{array}$ & $\begin{array}{l}20.4 \\
20.1 \\
19.7 \\
19.4 \\
19.1\end{array}$ & $\begin{array}{l}0.00 \\
0.00 \\
0.00 \\
0.00 \\
0.00\end{array}$ & $\begin{array}{l}1700 \\
1705 \\
1710 \\
1715 \\
1720\end{array}$ & $\begin{array}{l}8.3 \\
8.3 \\
8.3 \\
8.1 \\
8.1\end{array}$ & $\begin{array}{l}0.00 \\
0.00 \\
0.00 \\
0.00 \\
0.00\end{array}$ & $\begin{array}{l}2150 \\
2155 \\
2200 \\
2205 \\
2210\end{array}$ & $\begin{array}{l}5.5 \\
5.5 \\
5.5 \\
5.3 \\
5.3\end{array}$ & $\begin{array}{l}0.00 \\
0.00 \\
0.00 \\
0.00 \\
0.00\end{array}$ \\
\hline $\begin{array}{l}1235 \\
1240 \\
1245 \\
1250 \\
1255\end{array}$ & $\begin{array}{l}18.4 \\
18.1 \\
18.1 \\
17.8 \\
17.1\end{array}$ & $\begin{array}{l}0.00 \\
0.00 \\
0.00 \\
0.00 \\
0.00\end{array}$ & $\begin{array}{l}1725 \\
1730 \\
1735 \\
1740 \\
1745\end{array}$ & $\begin{array}{l}8.1 \\
7.8 \\
7.8 \\
7.8 \\
7.8\end{array}$ & $\begin{array}{l}0.00 \\
0.00 \\
0.00 \\
0.00 \\
0.00\end{array}$ & $\begin{array}{l}2215 \\
2220 \\
2225 \\
2230 \\
2235\end{array}$ & $\begin{array}{l}5.3 \\
5.3 \\
5.3 \\
5.3 \\
5.1\end{array}$ & $\begin{array}{l}0.00 \\
0.00 \\
0.0 C \\
0.0 C \\
0.0 C\end{array}$ \\
\hline $\begin{array}{l}1300 \\
1305 \\
1310 \\
1315 \\
1320\end{array}$ & $\begin{array}{l}16.8 \\
16.5 \\
16.2 \\
15.9 \\
15.6\end{array}$ & $\begin{array}{l}0.00 \\
0.00 \\
0.00 \\
0.00 \\
0.00\end{array}$ & $\begin{array}{l}1750 \\
1755 \\
1800 \\
1805 \\
1810\end{array}$ & $\begin{array}{l}7.6 \\
7.6 \\
7.6 \\
7.6 \\
7.6\end{array}$ & $\begin{array}{l}0.00 \\
0.00 \\
0.00 \\
0.00 \\
0.00\end{array}$ & $\begin{array}{l}2240 \\
2245 \\
2250 \\
2255 \\
2300\end{array}$ & $\begin{array}{l}5.1 \\
5.1 \\
5.1 \\
5.1 \\
5.1\end{array}$ & $\begin{array}{l}0.0 C \\
0.0 C \\
0.0 C \\
0.0 C \\
0.0 C\end{array}$ \\
\hline $\begin{array}{l}1325 \\
1330 \\
1335 \\
1340 \\
1345\end{array}$ & $\begin{array}{l}15.3 \\
15.0 \\
14.7 \\
14.7 \\
14.4\end{array}$ & $\begin{array}{l}0.00 \\
0.00 \\
0.00 \\
0.00 \\
0.00\end{array}$ & $\begin{array}{l}1815 \\
1820 \\
1825 \\
1830 \\
1835\end{array}$ & $\begin{array}{l}7.3 \\
7.3 \\
7.3 \\
7.1 \\
7.1\end{array}$ & $\begin{array}{l}0.00 \\
0.00 \\
0.00 \\
0.00 \\
0.00\end{array}$ & $\begin{array}{l}2305 \\
2310 \\
2315 \\
2320 \\
2325\end{array}$ & $\begin{array}{l}5.1 \\
5.1 \\
4.9 \\
4.9 \\
4.9\end{array}$ & $\begin{array}{l}0.0 C \\
0.0 C \\
0.0 C \\
0.0 C \\
0.0 C\end{array}$ \\
\hline $\begin{array}{l}1350 \\
1355 \\
1400 \\
1405 \\
1410\end{array}$ & $\begin{array}{l}14.1 \\
13.8 \\
13.5 \\
13.2 \\
12.9\end{array}$ & $\begin{array}{l}0.01 \\
0.00 \\
0.00 \\
0.00 \\
0.00\end{array}$ & $\begin{array}{l}1840 \\
1845 \\
1850 \\
1855 \\
1900\end{array}$ & $\begin{array}{l}7.1 \\
7.1 \\
7.1 \\
7.1 \\
7.1\end{array}$ & $\begin{array}{l}0.00 \\
0.00 \\
0.00 \\
0.00 \\
0.00\end{array}$ & $\begin{array}{l}2330 \\
2335 \\
2340 \\
2345 \\
2350\end{array}$ & $\begin{array}{l}4.9 \\
4.9 \\
4.9 \\
4.9 \\
4.7\end{array}$ & $\begin{array}{l}0.0 C \\
0.0 C \\
0.0 C \\
0.0 C \\
0.0 C\end{array}$ \\
\hline $\begin{array}{l}1415 \\
1420 \\
1425\end{array}$ & $\begin{array}{l}12.9 \\
12.6 \\
12.3\end{array}$ & $\begin{array}{l}0.00 \\
0.00 \\
0.00\end{array}$ & $\begin{array}{l}1905 \\
1910 \\
1915\end{array}$ & $\begin{array}{l}7.1 \\
6.9 \\
6.9\end{array}$ & $\begin{array}{l}0.00 \\
0.00 \\
0.00\end{array}$ & 2355 & 4.7 & $0.0 \mathrm{C}$ \\
\hline
\end{tabular}




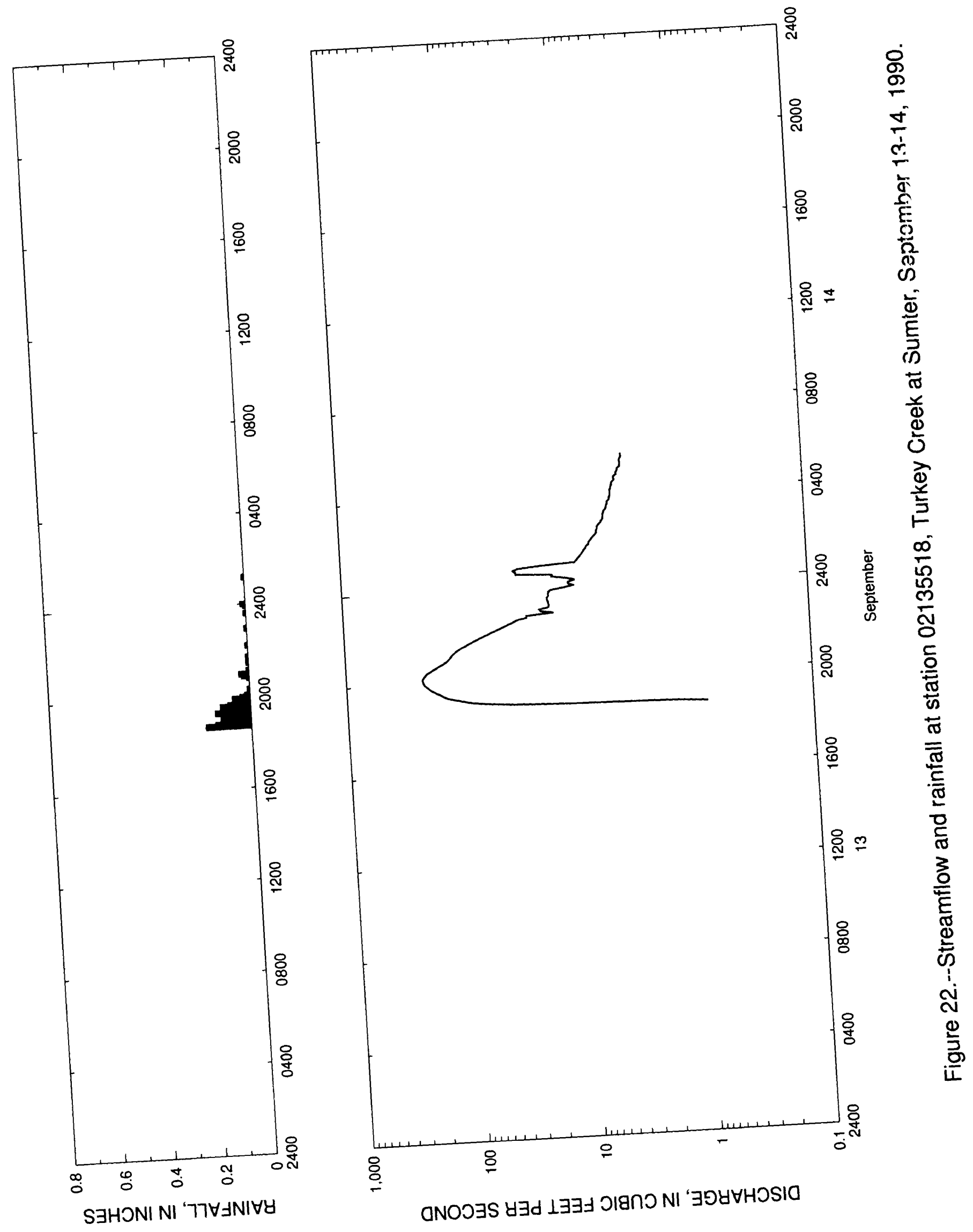


Table 21. - Streamflow and rainfall at station 02135518. Turkey Creek at Sumter, September $13-14,1990$

\begin{tabular}{|c|c|c|c|c|c|c|c|c|}
\hline $\begin{array}{l}\text { Time } \\
\text { (hours) }\end{array}$ & $\begin{array}{l}\text { Streamflow } \\
\text { (cubic feet } \\
\text { per second) }\end{array}$ & $\begin{array}{l}\text { Rain- } \\
\text { fall } \\
\text { (inches) }\end{array}$ & $\begin{array}{l}\text { Time } \\
\text { (hours) }\end{array}$ & $\begin{array}{l}\text { Streamflow } \\
\text { (cubic feet } \\
\text { per second) }\end{array}$ & $\begin{array}{l}\text { Rain- } \\
\text { fall } \\
\text { (inches) }\end{array}$ & $\begin{array}{l}\text { Time } \\
\text { (hours) }\end{array}$ & $\begin{array}{l}\text { Streamflow } \\
\text { (cubic feet } \\
\text { per second) }\end{array}$ & $\begin{array}{l}\text { Rain- } \\
\text { fall } \\
\text { (irohes) }\end{array}$ \\
\hline $\begin{array}{l}\text { September } \\
1840 \\
1845 \\
1850 \\
1855\end{array}$ & $\begin{array}{c}13,1990 \\
0.8 \\
1.6 \\
12.2 \\
36.9\end{array}$ & $\begin{array}{l}0.18 \\
0.14 \\
0.09 \\
0.12\end{array}$ & $\begin{array}{l}2230 \\
2235 \\
2240 \\
2245 \\
2250\end{array}$ & $\begin{array}{l}34.6 \\
31.9 \\
26.6 \\
26.6 \\
15.4\end{array}$ & $\begin{array}{l}0.00 \\
0.00 \\
0.00 \\
0.00 \\
0.00\end{array}$ & $\begin{array}{l}0220 \\
0225 \\
0230 \\
0235 \\
0240\end{array}$ & $\begin{array}{l}6.1 \\
6.0 \\
6.0 \\
5.8 \\
5.6\end{array}$ & $\begin{array}{l}0.00 \\
0.00 \\
0.00 \\
0.00 \\
0.00\end{array}$ \\
\hline $\begin{array}{l}1900 \\
1905 \\
1910 \\
1915 \\
1920\end{array}$ & $\begin{array}{r}63.1 \\
85.7 \\
102.0 \\
120.0 \\
138.0\end{array}$ & $\begin{array}{l}0.12 \\
0.10 \\
0.10 \\
0.14 \\
0.07\end{array}$ & $\begin{array}{l}2255 \\
2300 \\
2305 \\
2310 \\
2315\end{array}$ & $\begin{array}{l}20.0 \\
20.6 \\
17.0 \\
16.9 \\
17.0\end{array}$ & $\begin{array}{l}0.01 \\
0.00 \\
0.00 \\
0.00 \\
0.00\end{array}$ & $\begin{array}{l}0245 \\
0250 \\
0255 \\
0300 \\
0305\end{array}$ & $\begin{array}{l}5.5 \\
5.3 \\
5.3 \\
5.3 \\
5.2\end{array}$ & $\begin{array}{l}0.00 \\
0.00 \\
0.00 \\
0.00 \\
0.00\end{array}$ \\
\hline $\begin{array}{l}1925 \\
1930 \\
1935 \\
1940 \\
1945\end{array}$ & $\begin{array}{l}150.0 \\
160.0 \\
173.0 \\
185.0 \\
195.0\end{array}$ & $\begin{array}{l}0.04 \\
0.12 \\
0.09 \\
0.04 \\
0.07\end{array}$ & $\begin{array}{l}2320 \\
2325 \\
2330 \\
2335 \\
2340\end{array}$ & $\begin{array}{l}17.1 \\
17.4 \\
17.5 \\
16.9 \\
17.0\end{array}$ & $\begin{array}{l}0.00 \\
0.00 \\
0.00 \\
0.01 \\
0.00\end{array}$ & $\begin{array}{l}0310 \\
0315 \\
0320 \\
0325 \\
0330\end{array}$ & $\begin{array}{l}5.2 \\
5.0 \\
4.9 \\
4.9 \\
4.8\end{array}$ & $\begin{array}{l}0.00 \\
0.00 \\
0.00 \\
0.00 \\
0.00\end{array}$ \\
\hline $\begin{array}{l}1950 \\
1955 \\
2000 \\
2005 \\
2010\end{array}$ & $\begin{array}{l}204.0 \\
212.0 \\
218.0 \\
221.0 \\
222.0\end{array}$ & $\begin{array}{l}0.07 \\
0.04 \\
0.02 \\
0.00 \\
0.00\end{array}$ & $\begin{array}{l}2345 \\
2350 \\
2355 \\
\text { September } \\
0000\end{array}$ & $\begin{array}{r}16.8 \\
16.1 \\
12.4 \\
1 \quad 14.1990 \\
10.1\end{array}$ & $\begin{array}{l}0.00 \\
0.00 \\
0.01 \\
0.02\end{array}$ & $\begin{array}{l}0335 \\
0340 \\
0345 \\
0350 \\
0355\end{array}$ & $\begin{array}{l}4.8 \\
4.6 \\
4.6 \\
4.5 \\
4.5\end{array}$ & $\begin{array}{l}0.00 \\
0.00 \\
0.00 \\
0.00 \\
0.00\end{array}$ \\
\hline $\begin{array}{l}2015 \\
2020 \\
2025 \\
2030 \\
2035\end{array}$ & $\begin{array}{l}219.0 \\
212.0 \\
204.0 \\
192.0 \\
180.0\end{array}$ & $\begin{array}{l}0.01 \\
0.00 \\
0.00 \\
0.00 \\
0.00\end{array}$ & $\begin{array}{l}0005 \\
0010 \\
0015 \\
0020 \\
0025\end{array}$ & $\begin{array}{r}11.3 \\
11.3 \\
9.9 \\
12.0 \\
15.6\end{array}$ & $\begin{array}{l}0.00 \\
0.00 \\
0.00 \\
0.00 \\
0.00\end{array}$ & $\begin{array}{l}0400 \\
0405 \\
0410 \\
0415 \\
0420\end{array}$ & $\begin{array}{l}4.5 \\
4.5 \\
4.4 \\
4.4 \\
4.3\end{array}$ & $\begin{array}{l}0.00 \\
0.00 \\
0.00 \\
0.00 \\
0.00\end{array}$ \\
\hline $\begin{array}{l}2040 \\
2045 \\
2050 \\
2055 \\
2100\end{array}$ & $\begin{array}{l}168.0 \\
156.0 \\
145.0 \\
136.0 \\
130.0\end{array}$ & $\begin{array}{l}0.00 \\
0.01 \\
0.03 \\
0.04 \\
0.01\end{array}$ & $\begin{array}{l}0030 \\
0035 \\
0040 \\
0045 \\
0050\end{array}$ & $\begin{array}{l}15.4 \\
31.6 \\
31.6 \\
33.4 \\
30.1\end{array}$ & $\begin{array}{l}0.00 \\
0.00 \\
0.00 \\
0.00 \\
0.00\end{array}$ & $\begin{array}{l}0425 \\
0430 \\
0435 \\
0440 \\
0445\end{array}$ & $\begin{array}{l}4.3 \\
4.1 \\
4.1 \\
4.1 \\
3.9\end{array}$ & $\begin{array}{l}0.00 \\
0.00 \\
0.00 \\
0.00 \\
0.00\end{array}$ \\
\hline $\begin{array}{l}2105 \\
2110 \\
2115 \\
2120 \\
2125\end{array}$ & $\begin{array}{l}126.0 \\
122.0 \\
118.0 \\
112.0 \\
106.0\end{array}$ & $\begin{array}{l}0.01 \\
0.00 \\
0.00 \\
0.00 \\
0.01\end{array}$ & $\begin{array}{l}0055 \\
0100 \\
0105 \\
0110 \\
0115\end{array}$ & $\begin{array}{r}19.5 \\
9.7 \\
9.3 \\
9.1 \\
8.7\end{array}$ & $\begin{array}{l}0.00 \\
0.00 \\
0.00 \\
0.01 \\
0.00\end{array}$ & $\begin{array}{l}0450 \\
0455 \\
0500 \\
0505 \\
0510\end{array}$ & $\begin{array}{l}3.9 \\
3.8 \\
3.8 \\
3.6 \\
3.6\end{array}$ & $\begin{array}{l}0.00 \\
0.00 \\
0.00 \\
0.00 \\
0.00\end{array}$ \\
\hline $\begin{array}{l}2130 \\
2135 \\
2140 \\
2145 \\
2150\end{array}$ & $\begin{array}{l}98.9 \\
91.2 \\
84.3 \\
77.8 \\
71.5\end{array}$ & $\begin{array}{l}0.01 \\
0.01 \\
0.01 \\
0.00 \\
0.00\end{array}$ & $\begin{array}{l}0120 \\
0125 \\
0130 \\
0135 \\
0140\end{array}$ & $\begin{array}{l}8.4 \\
8.2 \\
8.0 \\
7.7 \\
7.6\end{array}$ & $\begin{array}{l}0.00 \\
0.00 \\
0.00 \\
0.00 \\
0.00\end{array}$ & $\begin{array}{l}0515 \\
0520 \\
0525 \\
0530 \\
0535\end{array}$ & $\begin{array}{l}3.6 \\
3.6 \\
3.6 \\
3.5 \\
3.5\end{array}$ & $\begin{array}{l}0.00 \\
0.00 \\
0.00 \\
0.00 \\
0.00\end{array}$ \\
\hline $\begin{array}{l}2155 \\
2200 \\
2205 \\
2210 \\
2215\end{array}$ & $\begin{array}{l}65.5 \\
59.4 \\
54.6 \\
49.6 \\
45.3\end{array}$ & $\begin{array}{l}0.00 \\
0.00 \\
0.00 \\
0.01 \\
0.00\end{array}$ & $\begin{array}{l}0145 \\
0150 \\
0155 \\
0200 \\
0205\end{array}$ & $\begin{array}{l}7.2 \\
7.2 \\
7.0 \\
6.8 \\
6.5\end{array}$ & $\begin{array}{l}0.00 \\
0.00 \\
0.00 \\
0.00 \\
0.00\end{array}$ & $\begin{array}{l}0540 \\
0545 \\
0550 \\
0555 \\
0600\end{array}$ & $\begin{array}{l}3.5 \\
3.4 \\
3.4 \\
3.4 \\
3.4\end{array}$ & $\begin{array}{l}0.00 \\
0.00 \\
0.00 \\
0.00 \\
0.00\end{array}$ \\
\hline $\begin{array}{l}2220 \\
2225\end{array}$ & $\begin{array}{l}41.3 \\
37.9\end{array}$ & $\begin{array}{l}0.00 \\
0.00\end{array}$ & $\begin{array}{l}0210 \\
0215\end{array}$ & $\begin{array}{l}6.3 \\
6.1\end{array}$ & $\begin{array}{l}0.00 \\
0.00\end{array}$ & & & \\
\hline
\end{tabular}




\section{Station 02145940, Little Dutchman Creek Tributary at Rock Hill, S.C.}

Location.--Lat $34^{\circ} 58^{\prime} 34^{\prime \prime}$, long $81^{\circ} 01^{\prime} 02^{\prime \prime}$, York County, Hydrologic Unit 03050103 , at culvert on Celanese Road (S.C. Highway 161), $0.2 \mathrm{mi}$ upstream from the mouth at Little Dutchman Creek.

Period of record.-- October 25, 1985 to October 3, 1989.

Gage.--Digital stage recorder with 5-minute punch interval. The recorder is housed ir a metal shelter atop a stilling well attached to a free-standing platform located on tho left bank approximately $50 \mathrm{ft}$ upstream from the single $10.1 \mathrm{ft}$ by $12 \mathrm{ft}$ concrete box culvert. An enameled staff gage is attached to the wooden platform. A crest-stage indicator is located on the right downstream wingwall.

Rating.--The stage-streamflow relation is defined by current meter measurements up to $112 \mathrm{ft}^{3} / \mathrm{s}$. The stage-streamflow relation was extended for streamflows greater than $1,200 \mathrm{ft}^{3} / \mathrm{s}$ using indirect computational methods.

Rain gage and location.--Station 345734081003000 , lat $34^{\circ} 57^{\prime} 34^{\prime \prime}$, long $81^{\circ} 00^{\prime} 30^{\prime \prime}$. A shelter containing a digital cumulative rainfall recorder with a 5-minute punch interval at the Rock Hill Telephone Company facility on Ebinport Road (State secondary road 904) near the intersection with U.S. Highway 21 , and $2.7 \mathrm{mi}$ northeast of the Rock Hill Post Office.

Selected basin characteristics.--

Drainage area $-3.50 \mathrm{mi}^{2}$

Physiographic province -- Piedmont

Channel slope -- $46.8 \mathrm{ft} / \mathrm{mi}$

Channel length -- $2.90 \mathrm{mi}$

Total impervious area -- 19.0 percent

Basin development factor -- 6

2-year, 2-hour rainfall amount -- 1.95 in.

\begin{tabular}{|c|c|c|}
\hline \multirow[t]{7}{*}{ Flood frequency data: } & $\mathrm{UQ}_{2}$ & $966 \mathrm{ft}^{3} / \mathrm{s}$ \\
\hline & $\mathrm{UQ}_{5}$ & $1,410 \mathrm{ft}^{3} / \mathrm{s}$ \\
\hline & $\mathrm{UQ}_{10}$ & $1,690 \mathrm{ft}^{3} / \mathrm{s}$ \\
\hline & $\mathrm{UQ}_{25}$ & $2,020 \mathrm{ft}^{3} / \mathrm{s}$ \\
\hline & $\mathrm{UQ}_{50}$ & $2,240 \mathrm{ft}^{3} / \mathrm{s}$ \\
\hline & $\mathrm{UQ}_{100}$ & $2,450 \mathrm{ft}^{3} / \mathrm{s}$ \\
\hline & $\mathrm{UQ}_{500}$ & $2,890 \mathrm{ft}^{3} / \mathrm{s}$ \\
\hline
\end{tabular}




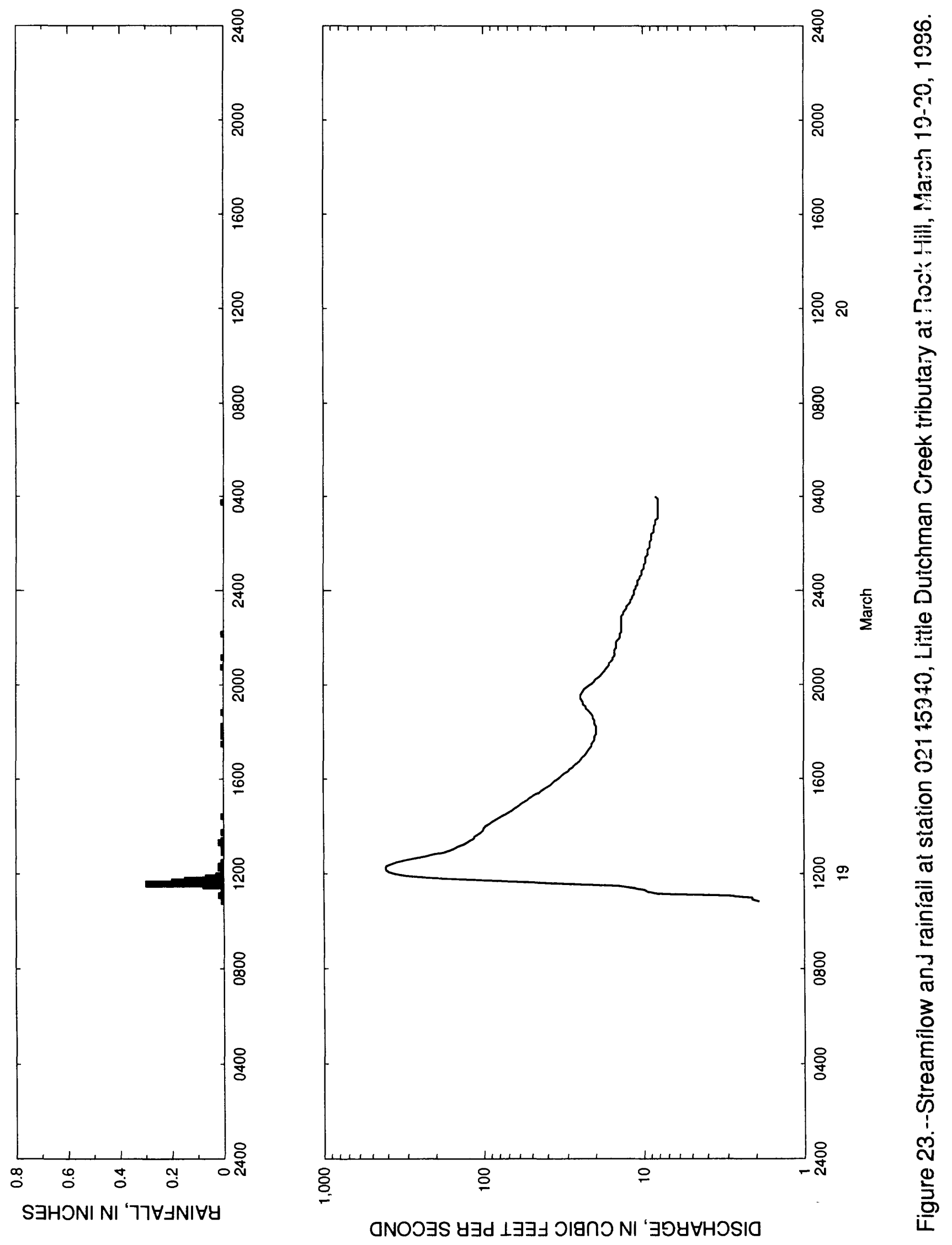


Table 22. - - Streamflow and rainfal1 at station 02145940 , Little Dutchman Creek tributary at Rock Hi11, March $19-20,1986$

\begin{tabular}{|c|c|c|c|c|c|c|c|c|}
\hline $\begin{array}{l}\text { Time } \\
\text { (hours) }\end{array}$ & $\begin{array}{l}\text { Streamflow } \\
\text { (cubic feet } \\
\text { per second) }\end{array}$ & $\begin{array}{l}\text { Rain- } \\
\text { fall } \\
\text { (inches) }\end{array}$ & $\begin{array}{l}\text { Time } \\
\text { (hours) }\end{array}$ & $\begin{array}{l}\text { Streamflow } \\
\text { (cubic feet } \\
\text { per second) }\end{array}$ & $\begin{array}{l}\text { Rain- } \\
\text { fall } \\
\text { (inches) }\end{array}$ & $\begin{array}{l}\text { Time } \\
\text { (hours) }\end{array}$ & $\begin{array}{l}\text { Streamflow } \\
\text { (cubic feet } \\
\text { per second) }\end{array}$ & $\begin{array}{l}\text { Rain- } \\
\text { fal1 } \\
\text { (inches) }\end{array}$ \\
\hline $\begin{array}{l}\text { March 19, } \\
1050 \\
1055 \\
1100 \\
1105\end{array}$ & $\begin{array}{r}1986 \\
1.9 \\
2.1 \\
2.1 \\
3.0\end{array}$ & $\begin{array}{l}0.01 \\
0.01 \\
0.00 \\
0.02\end{array}$ & $\begin{array}{l}1610 \\
1615 \\
1620 \\
1625 \\
1630\end{array}$ & $\begin{array}{l}31.9 \\
30.8 \\
29.3 \\
28.8 \\
27.4\end{array}$ & $\begin{array}{l}0.00 \\
0.00 \\
0.00 \\
0.00 \\
0.00\end{array}$ & $\begin{array}{l}2135 \\
2140 \\
2145 \\
2150 \\
2155\end{array}$ & $\begin{array}{l}14.8 \\
14.8 \\
14.8 \\
14.8 \\
14.4\end{array}$ & $\begin{array}{l}0.00 \\
0.00 \\
0.00 \\
0.00 \\
0.00\end{array}$ \\
\hline $\begin{array}{l}1110 \\
1115 \\
1120 \\
1125 \\
1130\end{array}$ & $\begin{array}{r}8.1 \\
9.4 \\
9.9 \\
12.0 \\
14.4\end{array}$ & $\begin{array}{l}0.01 \\
0.01 \\
0.01 \\
0.01 \\
0.08\end{array}$ & $\begin{array}{l}1635 \\
1640 \\
1645 \\
1650 \\
1655\end{array}$ & $\begin{array}{l}26.9 \\
25.9 \\
25.0 \\
24.6 \\
24.1\end{array}$ & $\begin{array}{l}0.00 \\
0.00 \\
0.00 \\
0.00 \\
0.00\end{array}$ & $\begin{array}{l}2200 \\
2205 \\
2210 \\
2215 \\
2220\end{array}$ & $\begin{array}{l}14.0 \\
14.0 \\
14.0 \\
13.7 \\
13.7\end{array}$ & $\begin{array}{l}0.00 \\
0.00 \\
0.01 \\
0.00 \\
0.00\end{array}$ \\
\hline $\begin{array}{l}1135 \\
1140 \\
1145 \\
1150 \\
1155\end{array}$ & $\begin{array}{r}30.8 \\
61.6 \\
115.0 \\
219.0 \\
306.0\end{array}$ & $\begin{array}{l}0.30 \\
0.20 \\
0.15 \\
0.07 \\
0.03\end{array}$ & $\begin{array}{l}1700 \\
1705 \\
1710 \\
1715 \\
1720\end{array}$ & $\begin{array}{l}23.3 \\
22.8 \\
22.4 \\
22.0 \\
21.5\end{array}$ & $\begin{array}{l}0.00 \\
0.00 \\
0.00 \\
0.00 \\
0.00\end{array}$ & $\begin{array}{l}2225 \\
2230 \\
2235 \\
2240 \\
2245\end{array}$ & $\begin{array}{l}13.7 \\
13.7 \\
13.7 \\
13.7 \\
13.7\end{array}$ & $\begin{array}{l}0.00 \\
0.00 \\
0.00 \\
0.00 \\
0.00\end{array}$ \\
\hline $\begin{array}{l}1200 \\
1205 \\
1210 \\
1215 \\
1220\end{array}$ & $\begin{array}{l}359.0 \\
393.0 \\
408.0 \\
411.0 \\
406.0\end{array}$ & $\begin{array}{l}0.00 \\
0.01 \\
0.01 \\
0.02 \\
0.02\end{array}$ & $\begin{array}{l}1725 \\
1730 \\
1735 \\
1740 \\
1745\end{array}$ & $\begin{array}{l}21.0 \\
21.0 \\
20.6 \\
20.1 \\
20.1\end{array}$ & $\begin{array}{l}0.00 \\
0.01 \\
0.00 \\
0.00 \\
0.00\end{array}$ & $\begin{array}{l}2250 \\
2255 \\
2300 \\
2305 \\
2310\end{array}$ & $\begin{array}{l}13.7 \\
13.7 \\
13.3 \\
13.3 \\
13.0\end{array}$ & $\begin{array}{l}0.00 \\
0.00 \\
0.00 \\
0.00 \\
0.00\end{array}$ \\
\hline $\begin{array}{l}1225 \\
1230 \\
1235 \\
1240 \\
1245\end{array}$ & $\begin{array}{l}378.0 \\
350.0 \\
312.0 \\
270.0 \\
233.0\end{array}$ & $\begin{array}{l}0.00 \\
0.01 \\
0.00 \\
0.00 \\
0.00\end{array}$ & $\begin{array}{l}1750 \\
1755 \\
1800 \\
1805 \\
1810\end{array}$ & $\begin{array}{l}20.1 \\
19.7 \\
19.7 \\
19.7 \\
19.7\end{array}$ & $\begin{array}{l}0.01 \\
0.00 \\
0.00 \\
0.01 \\
0.01\end{array}$ & $\begin{array}{l}2315 \\
2320 \\
2325 \\
2330 \\
2335\end{array}$ & $\begin{array}{l}12.7 \\
12.7 \\
12.3 \\
12.0 \\
12.0\end{array}$ & $\begin{array}{l}0.00 \\
0.00 \\
0.00 \\
0.00 \\
0.00\end{array}$ \\
\hline $\begin{array}{l}1250 \\
1255 \\
1300 \\
1305 \\
1310\end{array}$ & $\begin{array}{l}209.0 \\
180.0 \\
164.0 \\
153.0 \\
145.0\end{array}$ & $\begin{array}{l}0.00 \\
0.01 \\
0.01 \\
0.01 \\
0.01\end{array}$ & $\begin{array}{l}1815 \\
1820 \\
1825 \\
1830 \\
1835\end{array}$ & $\begin{array}{l}19.7 \\
20.1 \\
20.1 \\
20.1 \\
20.6\end{array}$ & $\begin{array}{l}0.01 \\
0.00 \\
0.00 \\
0.00 \\
0.00\end{array}$ & $\begin{array}{r}2340 \\
2345 \\
2350 \\
2355 \\
\text { March 20, }\end{array}$ & $\begin{array}{r}11.7 \\
11.7 \\
11.4 \\
11.4 \\
1986\end{array}$ & $\begin{array}{l}0.00 \\
0.00 \\
0.00 \\
0.00\end{array}$ \\
\hline $\begin{array}{l}1315 \\
1320 \\
1325 \\
1330 \\
1335\end{array}$ & $\begin{array}{l}134.0 \\
127.0 \\
122.0 \\
115.0 \\
114.0\end{array}$ & $\begin{array}{l}0.00 \\
0.02 \\
0.01 \\
0.00 \\
0.00\end{array}$ & $\begin{array}{l}1840 \\
1845 \\
1850 \\
1855 \\
1900\end{array}$ & $\begin{array}{l}20.6 \\
21.0 \\
21.5 \\
22.0 \\
22.8\end{array}$ & $\begin{array}{l}0.00 \\
0.00 \\
0.01 \\
0.00 \\
0.00\end{array}$ & $\begin{array}{l}0000 \\
0005 \\
0010 \\
0015 \\
0020\end{array}$ & $\begin{array}{l}11.4 \\
11.1 \\
11.1 \\
10.8 \\
10.8\end{array}$ & $\begin{array}{l}0.00 \\
0.00 \\
0.00 \\
0.00 \\
0.00\end{array}$ \\
\hline $\begin{array}{l}1340 \\
1345 \\
1350 \\
1355 \\
1400\end{array}$ & $\begin{array}{r}109.0 \\
104.0 \\
101.0 \\
100.0 \\
97.2\end{array}$ & $\begin{array}{l}0.00 \\
0.01 \\
0.00 \\
0.00 \\
0.00\end{array}$ & $\begin{array}{l}1905 \\
1910 \\
1915 \\
1920 \\
1925\end{array}$ & $\begin{array}{l}22.8 \\
23.7 \\
23.7 \\
24.1 \\
24.6\end{array}$ & $\begin{array}{l}0.00 \\
0.00 \\
0.00 \\
0.00 \\
0.00\end{array}$ & $\begin{array}{l}0025 \\
0030 \\
0035 \\
0040 \\
0045\end{array}$ & $\begin{array}{l}10.8 \\
10.5 \\
10.5 \\
10.2 \\
10.2\end{array}$ & $\begin{array}{l}0.00 \\
0.00 \\
0.00 \\
0.00 \\
0.00\end{array}$ \\
\hline $\begin{array}{l}1405 \\
1410 \\
1415 \\
1420 \\
1425\end{array}$ & $\begin{array}{l}92.4 \\
89.1 \\
85.1 \\
81.2 \\
77.5\end{array}$ & $\begin{array}{l}0.00 \\
0.00 \\
0.00 \\
0.00 \\
0.01\end{array}$ & $\begin{array}{l}1930 \\
1935 \\
1940 \\
1945 \\
1950\end{array}$ & $\begin{array}{l}24.6 \\
24.6 \\
24.1 \\
23.7 \\
23.3\end{array}$ & $\begin{array}{l}0.00 \\
0.00 \\
0.00 \\
0.00 \\
0.00\end{array}$ & $\begin{array}{l}0050 \\
0055 \\
0100 \\
0105 \\
0110\end{array}$ & $\begin{array}{r}10.2 \\
9.9 \\
9.9 \\
9.9 \\
9.7\end{array}$ & $\begin{array}{l}0.00 \\
0.00 \\
0.00 \\
0.00 \\
0.00\end{array}$ \\
\hline $\begin{array}{l}1430 \\
1435 \\
1440 \\
1445 \\
1450\end{array}$ & $\begin{array}{l}73.1 \\
69.4 \\
66.3 \\
63.9 \\
61.0\end{array}$ & $\begin{array}{l}0.00 \\
0.00 \\
0.00 \\
0.00 \\
0.00\end{array}$ & $\begin{array}{l}1955 \\
2000 \\
2005 \\
2010 \\
2015\end{array}$ & $\begin{array}{l}22.4 \\
21.5 \\
20.6 \\
20.1 \\
19.7\end{array}$ & $\begin{array}{l}0.00 \\
0.00 \\
0.00 \\
0.00 \\
0.00\end{array}$ & $\begin{array}{l}0115 \\
0120 \\
0125 \\
0130 \\
0135\end{array}$ & $\begin{array}{l}9.7 \\
9.7 \\
9.7 \\
9.4 \\
9.4\end{array}$ & $\begin{array}{l}0.00 \\
0.00 \\
0.00 \\
0.00 \\
0.00\end{array}$ \\
\hline $\begin{array}{l}1455 \\
1500 \\
1505 \\
1510 \\
1515\end{array}$ & $\begin{array}{l}58.7 \\
56.5 \\
53.7 \\
52.1 \\
50.0\end{array}$ & $\begin{array}{l}0.00 \\
0.00 \\
0.00 \\
0.00 \\
0.00\end{array}$ & $\begin{array}{l}2020 \\
2025 \\
2030 \\
2035 \\
2040\end{array}$ & $\begin{array}{l}18.8 \\
18.3 \\
17.9 \\
17.5 \\
17.1\end{array}$ & $\begin{array}{l}0.00 \\
0.00 \\
0.00 \\
0.00 \\
0.00\end{array}$ & $\begin{array}{l}0140 \\
0145 \\
0150 \\
0155 \\
0200\end{array}$ & $\begin{array}{l}9.4 \\
9.4 \\
9.1 \\
9.1 \\
9.1\end{array}$ & $\begin{array}{l}0.00 \\
0.00 \\
0.00 \\
0.00 \\
0.00\end{array}$ \\
\hline $\begin{array}{l}1520 \\
1525 \\
1530 \\
1535 \\
1540\end{array}$ & $\begin{array}{l}48.0 \\
44.7 \\
43.4 \\
41.5 \\
39.7\end{array}$ & $\begin{array}{l}0.00 \\
0.00 \\
0.00 \\
0.00 \\
0.00\end{array}$ & $\begin{array}{l}2045 \\
2050 \\
2055 \\
2100 \\
2105\end{array}$ & $\begin{array}{l}16.7 \\
16.3 \\
16.3 \\
15.9 \\
15.5\end{array}$ & $\begin{array}{l}0.01 \\
0.00 \\
0.00 \\
0.00 \\
0.00\end{array}$ & $\begin{array}{l}0205 \\
0210 \\
0215 \\
0220 \\
0225\end{array}$ & $\begin{array}{l}9.1 \\
8.9 \\
8.9 \\
8.9 \\
8.9\end{array}$ & $\begin{array}{l}0.00 \\
0.00 \\
0.00 \\
0.00 \\
0.00\end{array}$ \\
\hline $\begin{array}{l}1545 \\
1550 \\
1555 \\
i 600 \\
1605\end{array}$ & 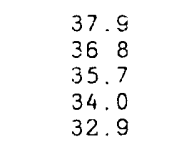 & $\begin{array}{l}0.00 \\
0.00 \\
0.00 \\
0.00 \\
0.00\end{array}$ & $\begin{array}{l}2110 \\
2115 \\
2120 \\
2125 \\
2130\end{array}$ & $\begin{array}{l}15.5 \\
15.1 \\
15.1 \\
15.1 \\
15.1\end{array}$ & $\begin{array}{l}0.01 \\
0.00 \\
0.00 \\
0.00 \\
0.00\end{array}$ & $\begin{array}{l}0230 \\
0235 \\
0240 \\
0245 \\
0250\end{array}$ & $\begin{array}{l}8.6 \\
8.6 \\
8.6 \\
8.6 \\
8.4\end{array}$ & $\begin{array}{l}0.00 \\
0.00 \\
0.00 \\
0.00 \\
0.00\end{array}$ \\
\hline
\end{tabular}


Table 22.--Streamflow and rainfall at station 02145940 , Little Dutchman Creek tributary at Rock Hill, March 19-20, 1986--Continued

\begin{tabular}{|c|c|c|c|c|c|c|c|c|}
\hline $\begin{array}{l}\text { Time } \\
\text { (hours) }\end{array}$ & $\begin{array}{l}\text { Streamflow } \\
\text { (cubic feet } \\
\text { per second) }\end{array}$ & $\begin{array}{l}\text { Rain- } \\
\text { fall } \\
\text { (inches) }\end{array}$ & $\begin{array}{l}\text { Time } \\
\text { (hours) }\end{array}$ & $\begin{array}{l}\text { Streamflow } \\
\text { (cubic feet } \\
\text { per second) }\end{array}$ & $\begin{array}{l}\text { Rain- } \\
\text { fall } \\
\text { (inches) }\end{array}$ & $\begin{array}{l}\text { Time } \\
\text { (hours) }\end{array}$ & $\begin{array}{l}\text { Streamflow } \\
\text { (cubic feet } \\
\text { per second) }\end{array}$ & $\begin{array}{l}\text { Rain- } \\
\text { fall } \\
\text { (inches) }\end{array}$ \\
\hline $\begin{array}{l}0255 \\
0300 \\
0305 \\
0310 \\
0315\end{array}$ & $\begin{array}{l}8.4 \\
8.4 \\
8.1 \\
8.1 \\
8.1\end{array}$ & $\begin{array}{l}0.00 \\
0.00 \\
0.00 \\
0.00 \\
0.00\end{array}$ & $\begin{array}{l}0320 \\
0325 \\
0330 \\
0335 \\
0340\end{array}$ & $\begin{array}{l}8.1 \\
8.1 \\
8.1 \\
8.1 \\
8.1\end{array}$ & $\begin{array}{l}0.00 \\
0.00 \\
0.00 \\
0.00 \\
0.00\end{array}$ & $\begin{array}{l}0345 \\
0350 \\
0355 \\
0400\end{array}$ & $\begin{array}{l}8.1 \\
8.1 \\
8.1 \\
8.4\end{array}$ & $\begin{array}{l}0.01 \\
0.00 \\
0.00 \\
0.00\end{array}$ \\
\hline
\end{tabular}




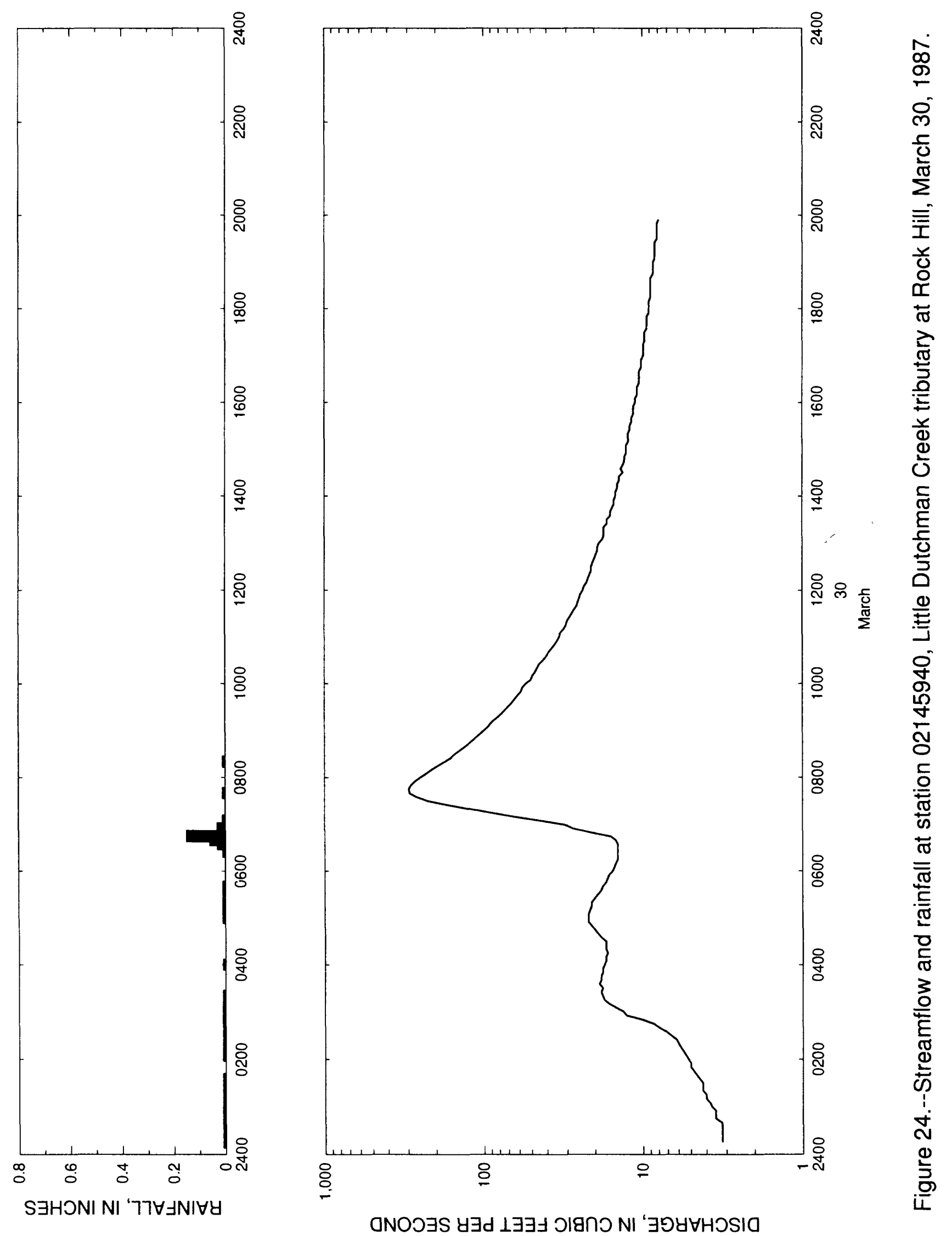


Table 23.--Streamflow and rainfall at station 02145940 , Little Dutchman Creek tributary at Rock Hill, March 30,1987

\begin{tabular}{|c|c|c|c|c|c|c|c|c|}
\hline $\begin{array}{l}\text { Time } \\
\text { (hours) }\end{array}$ & $\begin{array}{l}\text { Streamflow } \\
\text { (cubic feet } \\
\text { per second) }\end{array}$ & $\begin{array}{l}\text { Rain- } \\
\text { fall } \\
\text { (inches) }\end{array}$ & $\begin{array}{l}\text { Time } \\
\text { (hours) }\end{array}$ & $\begin{array}{l}\text { Streamflow } \\
\text { (cubic feet } \\
\text { per second) }\end{array}$ & $\begin{array}{l}\text { Rain- } \\
\text { fall } \\
\text { (inches) }\end{array}$ & $\begin{array}{l}\text { Time } \\
\text { (hours) }\end{array}$ & $\begin{array}{l}\text { Streamflow } \\
\text { (cubic feet } \\
\text { per second) }\end{array}$ & $\begin{array}{l}\text { Rain- } \\
\text { fall } \\
\text { (inshes) }\end{array}$ \\
\hline $\begin{array}{c}\text { March } 30, \\
0015 \\
0020 \\
0025 \\
0030\end{array}$ & $\begin{array}{r}1987 \\
3.2 \\
3.2 \\
3.2 \\
3.2\end{array}$ & $\begin{array}{l}0.01 \\
0.00 \\
0.00 \\
0.01\end{array}$ & $\begin{array}{l}0535 \\
0540 \\
0545 \\
0550 \\
0555\end{array}$ & $\begin{array}{l}18.3 \\
17.9 \\
17.1 \\
16.7 \\
16.3\end{array}$ & $\begin{array}{l}0.00 \\
0.01 \\
0.00 \\
0.00 \\
0.00\end{array}$ & $\begin{array}{l}1100 \\
1105 \\
1110 \\
1115 \\
1120\end{array}$ & $\begin{array}{l}33.5 \\
32.9 \\
31.3 \\
30.3 \\
29.8\end{array}$ & $\begin{array}{l}0.00 \\
0.00 \\
0.00 \\
0.00 \\
0.00\end{array}$ \\
\hline $\begin{array}{l}0035 \\
0040 \\
0045 \\
0050 \\
0055\end{array}$ & $\begin{array}{l}3.2 \\
3.2 \\
3.5 \\
3.5 \\
3.5\end{array}$ & $\begin{array}{l}0.00 \\
0.01 \\
0.01 \\
0.01 \\
0.01\end{array}$ & $\begin{array}{l}0600 \\
0605 \\
0610 \\
0615 \\
0620\end{array}$ & $\begin{array}{l}15.5 \\
15.1 \\
14.8 \\
14.4 \\
14.4\end{array}$ & $\begin{array}{l}0.00 \\
0.00 \\
0.00 \\
0.00 \\
0.00\end{array}$ & $\begin{array}{l}1125 \\
1130 \\
1135 \\
1140 \\
1145\end{array}$ & $\begin{array}{l}28.8 \\
27.8 \\
26.9 \\
25.9 \\
25.5\end{array}$ & $\begin{array}{l}0.00 \\
0.00 \\
0.00 \\
0.00 \\
0.00\end{array}$ \\
\hline $\begin{array}{l}0100 \\
0105 \\
0110 \\
0115 \\
0120\end{array}$ & $\begin{array}{l}3.7 \\
3.8 \\
4.0 \\
4.0 \\
4.2\end{array}$ & $\begin{array}{l}0.00 \\
0.01 \\
0.01 \\
0.01 \\
0.01\end{array}$ & $\begin{array}{l}0625 \\
0630 \\
0635 \\
0640 \\
0645\end{array}$ & $\begin{array}{l}14.4 \\
14.4 \\
14.4 \\
14.8 \\
15.9\end{array}$ & $\begin{array}{l}0.01 \\
0.01 \\
0.03 \\
0.06 \\
0.15\end{array}$ & $\begin{array}{l}1150 \\
1155 \\
1200 \\
1205 \\
1210\end{array}$ & $\begin{array}{l}25.0 \\
24.6 \\
23.7 \\
23.3 \\
22.4\end{array}$ & $\begin{array}{l}0.00 \\
0.00 \\
0.00 \\
0.00 \\
0.00\end{array}$ \\
\hline $\begin{array}{l}0125 \\
0130 \\
0135 \\
0140 \\
0145\end{array}$ & $\begin{array}{l}4.2 \\
4.2 \\
4.4 \\
4.6 \\
4.8\end{array}$ & $\begin{array}{l}0.01 \\
0.00 \\
0.01 \\
0.00 \\
0.00\end{array}$ & $\begin{array}{l}0650 \\
0655 \\
0700 \\
0705 \\
0710\end{array}$ & $\begin{array}{l}21.5 \\
27.4 \\
30.8 \\
44.0 \\
64.5\end{array}$ & $\begin{array}{l}0.03 \\
0.03 \\
0.00 \\
0.01 \\
0.00\end{array}$ & $\begin{array}{l}1215 \\
1220 \\
1225 \\
1230 \\
1235\end{array}$ & $\begin{array}{l}22.0 \\
21.5 \\
21.0 \\
21.0 \\
20.6\end{array}$ & $\begin{array}{l}0.00 \\
0.00 \\
0.00 \\
0.00 \\
0.00\end{array}$ \\
\hline $\begin{array}{l}0150 \\
0155 \\
0200 \\
0205 \\
0210\end{array}$ & $\begin{array}{l}5.0 \\
5.0 \\
5.2 \\
5.4 \\
5.6\end{array}$ & $\begin{array}{l}0.00 \\
0.00 \\
0.00 \\
0.01 \\
0.00\end{array}$ & $\begin{array}{l}0715 \\
0720 \\
0725 \\
0730 \\
0735\end{array}$ & $\begin{array}{r}89.7 \\
123.0 \\
168.0 \\
225.0 \\
263.0\end{array}$ & $\begin{array}{l}0.00 \\
0.00 \\
0.00 \\
0.00 \\
0.00\end{array}$ & $\begin{array}{l}1240 \\
1245 \\
1250 \\
1255 \\
1300\end{array}$ & $\begin{array}{l}20.1 \\
19.7 \\
19.2 \\
19.2 \\
18.8\end{array}$ & $\begin{array}{l}0.00 \\
0.00 \\
0.00 \\
0.00 \\
0.00\end{array}$ \\
\hline $\begin{array}{l}0215 \\
0220 \\
0225 \\
0230 \\
0235\end{array}$ & $\begin{array}{l}5.8 \\
6.0 \\
6.2 \\
6.7 \\
7.2\end{array}$ & $\begin{array}{l}0.00 \\
0.01 \\
0.00 \\
0.01 \\
0.00\end{array}$ & $\begin{array}{l}0740 \\
0745 \\
0750 \\
0755 \\
0800\end{array}$ & $\begin{array}{l}292.0 \\
296.0 \\
287.0 \\
271.0 \\
251.0\end{array}$ & $\begin{array}{l}0.01 \\
0.00 \\
0.00 \\
0.00 \\
0.00\end{array}$ & $\begin{array}{l}1305 \\
1310 \\
1315 \\
1320 \\
1325\end{array}$ & $\begin{array}{l}17.9 \\
17.5 \\
17.5 \\
17.5 \\
16.7\end{array}$ & $\begin{array}{l}0.00 \\
0.00 \\
0.00 \\
0.00 \\
0.00\end{array}$ \\
\hline $\begin{array}{l}0240 \\
0245 \\
0250 \\
0255 \\
0300\end{array}$ & $\begin{array}{r}7.9 \\
8.6 \\
10.2 \\
12.7 \\
13.3\end{array}$ & $\begin{array}{l}0.01 \\
0.00 \\
0.01 \\
0.01 \\
0.00\end{array}$ & $\begin{array}{l}0805 \\
0810 \\
0815 \\
0820 \\
0825\end{array}$ & $\begin{array}{l}230.0 \\
212.0 \\
194.0 \\
177.0 \\
161.0\end{array}$ & $\begin{array}{l}0.00 \\
0.00 \\
0.00 \\
0.01 \\
0.00\end{array}$ & $\begin{array}{l}1330 \\
1335 \\
1340 \\
1345 \\
1350\end{array}$ & $\begin{array}{l}16.7 \\
15.9 \\
15.9 \\
15.5 \\
15.1\end{array}$ & $\begin{array}{l}0.00 \\
0.00 \\
0.00 \\
0.00 \\
0.00\end{array}$ \\
\hline $\begin{array}{l}0305 \\
0310 \\
0315 \\
0320 \\
0325\end{array}$ & $\begin{array}{l}14.8 \\
16.3 \\
17.5 \\
17.9 \\
18.3\end{array}$ & $\begin{array}{l}0.00 \\
0.01 \\
0.00 \\
0.01 \\
0.00\end{array}$ & $\begin{array}{l}0830 \\
0835 \\
0840 \\
0845 \\
0850\end{array}$ & $\begin{array}{l}152.0 \\
141.0 \\
131.0 \\
122.0 \\
114.0\end{array}$ & $\begin{array}{l}0.00 \\
0.00 \\
0.00 \\
0.00 \\
0.00\end{array}$ & $\begin{array}{l}1355 \\
1400 \\
1405 \\
1410 \\
1415\end{array}$ & $\begin{array}{l}15.1 \\
14.8 \\
14.8 \\
14.4 \\
14.4\end{array}$ & $\begin{array}{l}0.00 \\
0.00 \\
0.00 \\
0.00 \\
0.00\end{array}$ \\
\hline $\begin{array}{l}0330 \\
0335 \\
0340 \\
0345 \\
0350\end{array}$ & $\begin{array}{l}17.9 \\
18.8 \\
18.3 \\
18.3 \\
17.9\end{array}$ & $\begin{array}{l}0.00 \\
0.00 \\
0.00 \\
0.00 \\
0.00\end{array}$ & $\begin{array}{l}0855 \\
0900 \\
0905 \\
0910 \\
0915\end{array}$ & $\begin{array}{r}107.0 \\
100.0 \\
93.8 \\
89.7 \\
83.8\end{array}$ & $\begin{array}{l}0.00 \\
0.00 \\
0.00 \\
0.00 \\
0.00\end{array}$ & $\begin{array}{l}1420 \\
1425 \\
1430 \\
1435 \\
1440\end{array}$ & $\begin{array}{l}14.0 \\
14.0 \\
13.3 \\
13.7 \\
13.3\end{array}$ & $\begin{array}{l}0.00 \\
0.00 \\
0.00 \\
0.00 \\
0.00\end{array}$ \\
\hline $\begin{array}{l}0355 \\
0400 \\
0405 \\
0410 \\
0415\end{array}$ & $\begin{array}{l}17.9 \\
17.5 \\
17.1 \\
17.1 \\
16.7\end{array}$ & $\begin{array}{l}0.00 \\
0.01 \\
0.00 \\
0.00 \\
0.00\end{array}$ & $\begin{array}{l}0920 \\
0925 \\
0930 \\
0935 \\
0940\end{array}$ & $\begin{array}{l}78.7 \\
74.4 \\
70.6 \\
66.9 \\
63.9\end{array}$ & $\begin{array}{l}0.00 \\
0.00 \\
0.00 \\
0.00 \\
0.00\end{array}$ & $\begin{array}{l}1445 \\
1450 \\
1455 \\
1500 \\
1505\end{array}$ & $\begin{array}{l}13.0 \\
13.0 \\
12.7 \\
12.7 \\
12.7\end{array}$ & $\begin{array}{l}0.00 \\
0.00 \\
0.00 \\
0.00 \\
0.00\end{array}$ \\
\hline $\begin{array}{l}0420 \\
0425 \\
0430 \\
0435 \\
0440\end{array}$ & $\begin{array}{l}17.1 \\
17.1 \\
17.1 \\
18.3 \\
19.2\end{array}$ & $\begin{array}{l}0.00 \\
0.00 \\
0.00 \\
0.00 \\
0.00\end{array}$ & $\begin{array}{l}0945 \\
0950 \\
0955 \\
1000 \\
1005\end{array}$ & $\begin{array}{l}61.0 \\
58.1 \\
57.0 \\
54.3 \\
50.5\end{array}$ & $\begin{array}{l}0.00 \\
0.00 \\
0.00 \\
0.00 \\
0.00\end{array}$ & $\begin{array}{l}1510 \\
1515 \\
1520 \\
1525 \\
1530\end{array}$ & $\begin{array}{l}12.3 \\
12.3 \\
12.3 \\
12.0 \\
12.0\end{array}$ & $\begin{array}{l}0.00 \\
0.00 \\
0.00 \\
0.00 \\
0.00\end{array}$ \\
\hline $\begin{array}{l}0445 \\
0450 \\
0455 \\
0500 \\
0505\end{array}$ & $\begin{array}{l}20.1 \\
21.0 \\
22.0 \\
22.0 \\
22.0\end{array}$ & $\begin{array}{l}0.00 \\
0.00 \\
0.00 \\
0.01 \\
0.00\end{array}$ & $\begin{array}{l}1010 \\
1015 \\
1020 \\
1025 \\
1030\end{array}$ & $\begin{array}{l}49.3 \\
47.3 \\
46.0 \\
44.7 \\
42.1\end{array}$ & $\begin{array}{l}0.00 \\
0.00 \\
0.00 \\
0.00 \\
0.00\end{array}$ & $\begin{array}{l}1535 \\
1540 \\
1545 \\
1550 \\
1555\end{array}$ & $\begin{array}{l}11.7 \\
11.7 \\
11.4 \\
11.4 \\
11.4\end{array}$ & $\begin{array}{l}0.00 \\
0.00 \\
0.00 \\
0.00 \\
0.00\end{array}$ \\
\hline $\begin{array}{l}0510 \\
0515 \\
0520 \\
0525 \\
0530\end{array}$ & $\begin{array}{l}21.5 \\
21.0 \\
21.0 \\
20.1 \\
19.2\end{array}$ & $\begin{array}{l}0.00 \\
0.01 \\
0.01 \\
0.00 \\
0.01\end{array}$ & $\begin{array}{l}1035 \\
1040 \\
1045 \\
1050 \\
1055\end{array}$ & $\begin{array}{l}40.3 \\
39.1 \\
37.4 \\
35.7 \\
34.5\end{array}$ & $\begin{array}{l}0.00 \\
0.00 \\
0.00 \\
0.00 \\
0.00\end{array}$ & $\begin{array}{l}1600 \\
1605 \\
1610 \\
1615 \\
1620\end{array}$ & $\begin{array}{l}11.1 \\
11.1 \\
10.8 \\
10.8 \\
10.8\end{array}$ & $\begin{array}{l}0.00 \\
0.00 \\
0.00 \\
0.00 \\
0.00\end{array}$ \\
\hline
\end{tabular}


Table 23.--Streamflow and rainfall at station 02145940, Little Dutchman Creek tributary at Rock Hi1l, March 30,1987--Continued

\begin{tabular}{|c|c|c|c|c|c|c|c|c|}
\hline $\begin{array}{l}\text { Time } \\
\text { (hours) }\end{array}$ & $\begin{array}{l}\text { Streamflow } \\
\text { (cubic feet } \\
\text { per second) }\end{array}$ & $\begin{array}{l}\text { Rain- } \\
\text { fall } \\
\text { (inches) }\end{array}$ & $\begin{array}{l}\text { Time } \\
\text { (hours) }\end{array}$ & $\begin{array}{l}\text { Streamflow } \\
\text { (cubic feet } \\
\text { per second) }\end{array}$ & $\begin{array}{l}\text { Rain- } \\
\text { fall } \\
\text { (inches) }\end{array}$ & $\begin{array}{l}\text { Time } \\
\text { (hours) }\end{array}$ & $\begin{array}{l}\text { Streamflow } \\
\text { (cubic feet } \\
\text { per second) }\end{array}$ & $\begin{array}{l}\text { Rain- } \\
\text { fall } \\
\text { (inches) }\end{array}$ \\
\hline $\begin{array}{l}1625 \\
1630 \\
1635 \\
1640 \\
1645\end{array}$ & $\begin{array}{l}10.5 \\
10.5 \\
10.5 \\
10.5 \\
10.2\end{array}$ & $\begin{array}{l}0.00 \\
0.00 \\
0.00 \\
0.00 \\
0.00\end{array}$ & $\begin{array}{l}1740 \\
1745 \\
1750 \\
1755 \\
1800\end{array}$ & $\begin{array}{l}9.4 \\
9.4 \\
9.4 \\
9.1 \\
9.1\end{array}$ & $\begin{array}{l}0.00 \\
0.00 \\
0.00 \\
0.00 \\
0.00\end{array}$ & $\begin{array}{l}1855 \\
1900 \\
1905 \\
1910 \\
1915\end{array}$ & $\begin{array}{l}8.6 \\
8.6 \\
8.4 \\
8.4 \\
8.4\end{array}$ & $\begin{array}{l}0.00 \\
0.00 \\
0.00 \\
0.00 \\
0.00\end{array}$ \\
\hline $\begin{array}{l}1650 \\
1655 \\
1700 \\
1705 \\
1710\end{array}$ & $\begin{array}{r}10.2 \\
10.2 \\
9.9 \\
9.9 \\
9.9\end{array}$ & $\begin{array}{l}0.00 \\
0.00 \\
0.00 \\
0.00 \\
0.00\end{array}$ & $\begin{array}{l}1805 \\
1810 \\
1815 \\
1820 \\
1825\end{array}$ & $\begin{array}{l}9.1 \\
9.1 \\
8.9 \\
8.9 \\
8.9\end{array}$ & $\begin{array}{l}0.00 \\
0.00 \\
0.00 \\
0.00 \\
0.00\end{array}$ & $\begin{array}{l}1920 \\
1925 \\
1930 \\
1935 \\
1940\end{array}$ & $\begin{array}{l}8.4 \\
8.4 \\
8.1 \\
8.1 \\
8.1\end{array}$ & $\begin{array}{l}0.00 \\
0.00 \\
0.00 \\
0.00 \\
0.00\end{array}$ \\
\hline $\begin{array}{l}1715 \\
1720 \\
1725 \\
1730 \\
1735\end{array}$ & $\begin{array}{l}9.9 \\
9.7 \\
9.7 \\
9.7 \\
9.4\end{array}$ & $\begin{array}{l}0.00 \\
0.00 \\
0.00 \\
0.00 \\
0.00\end{array}$ & $\begin{array}{l}1830 \\
1835 \\
1840 \\
1845 \\
1850\end{array}$ & $\begin{array}{l}8.9 \\
8.9 \\
8.9 \\
8.6 \\
8.6\end{array}$ & $\begin{array}{l}0.00 \\
0.00 \\
0.00 \\
0.00 \\
0.00\end{array}$ & $\begin{array}{l}1945 \\
1950 \\
1955 \\
2000\end{array}$ & $\begin{array}{l}8.1 \\
8.1 \\
7.9 \\
7.9\end{array}$ & $\begin{array}{l}0.00 \\
0.00 \\
0.00 \\
0.00\end{array}$ \\
\hline
\end{tabular}



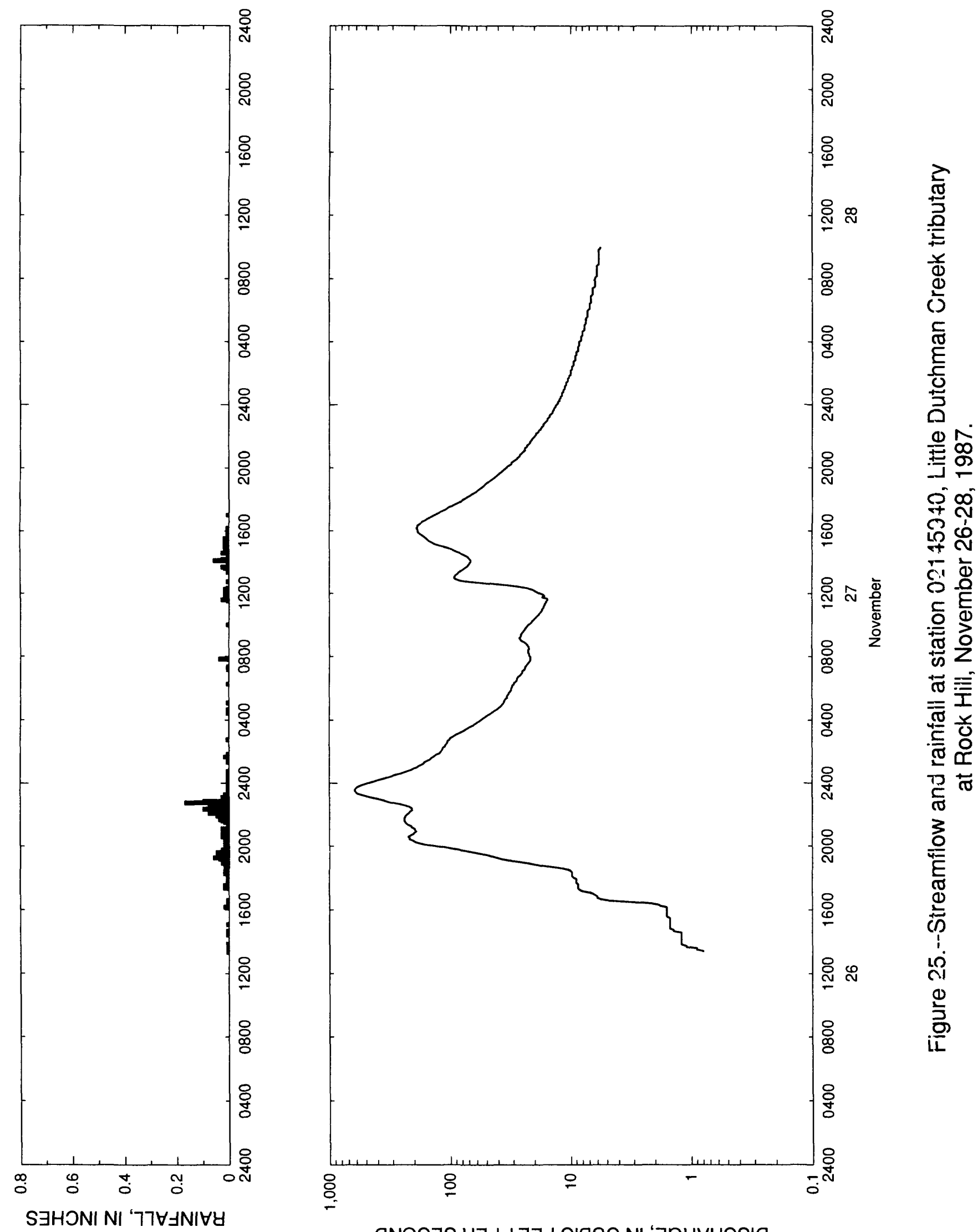

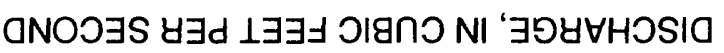


Table 24.--Streamflow and rainfall at station 02145940, Little Dutchman Creek tributary at Rock Hill, November $26-28,1987$

\begin{tabular}{|c|c|c|c|c|c|c|c|c|}
\hline $\begin{array}{l}\text { Time } \\
\text { (hours) }\end{array}$ & $\begin{array}{l}\text { Streamflow } \\
\text { (cubic feet } \\
\text { per second) }\end{array}$ & $\begin{array}{l}\text { Rain- } \\
\text { fall } \\
\text { (inches) }\end{array}$ & $\begin{array}{l}\text { Time } \\
\text { (hours) }\end{array}$ & $\begin{array}{l}\text { Streamflow } \\
\text { (cubic feet } \\
\text { per second) }\end{array}$ & $\begin{array}{l}\text { Rain- } \\
\text { fall } \\
\text { (inches) }\end{array}$ & $\begin{array}{l}\text { Time } \\
\text { (hours) }\end{array}$ & $\begin{array}{l}\text { Streamflow } \\
\text { (cubic. feet } \\
\text { per second) }\end{array}$ & $\begin{array}{l}\text { Rain- } \\
\text { fall } \\
\text { (inches) }\end{array}$ \\
\hline $\begin{array}{l}\text { November } \\
1320 \\
1325 \\
1330 \\
1335\end{array}$ & $\begin{array}{r}1987 \\
0.8 \\
0.8 \\
0.9 \\
0.9\end{array}$ & $\begin{array}{l}0.01 \\
0.00 \\
0.01 \\
0.01\end{array}$ & $\begin{array}{l}1840 \\
1845 \\
1850 \\
1855 \\
1900\end{array}$ & $\begin{array}{l}14.0 \\
17.1 \\
19.7 \\
22.4 \\
26.9\end{array}$ & $\begin{array}{l}0.01 \\
0.02 \\
0.01 \\
0.03 \\
0.02\end{array}$ & $\begin{array}{l}0000 \\
0005 \\
0010 \\
0015 \\
0020\end{array}$ & $\begin{array}{l}479.0 \\
439.0 \\
404.0 \\
371.0 \\
338.0\end{array}$ & $\begin{array}{l}0.00 \\
0.00 \\
0.01 \\
0.01 \\
0.01\end{array}$ \\
\hline $\begin{array}{l}1340 \\
1345 \\
1350 \\
1355 \\
1400\end{array}$ & $\begin{array}{l}1.1 \\
1.1 \\
1.2 \\
1.2 \\
1.2\end{array}$ & $\begin{array}{l}0.00 \\
0.00 \\
0.01 \\
0.00 \\
0.00\end{array}$ & $\begin{array}{l}1905 \\
1910 \\
1915 \\
1920 \\
1925\end{array}$ & $\begin{array}{l}32.4 \\
37.4 \\
40.9 \\
44.7 \\
48.0\end{array}$ & $\begin{array}{l}0.00 \\
0.04 \\
0.06 \\
0.04 \\
0.02\end{array}$ & $\begin{array}{l}0025 \\
0030 \\
0035 \\
0040 \\
0045\end{array}$ & $\begin{array}{l}310.0 \\
288.0 \\
260.0 \\
242.0 \\
227.0\end{array}$ & $\begin{array}{l}0.00 \\
0.01 \\
0.01 \\
0.00 \\
0.01\end{array}$ \\
\hline $\begin{array}{l}1405 \\
1410 \\
1415 \\
1420 \\
1425\end{array}$ & $\begin{array}{l}1.2 \\
1.2 \\
1.2 \\
1.2 \\
1.2\end{array}$ & $\begin{array}{l}0.00 \\
0.00 \\
0.00 \\
0.00 \\
0.01\end{array}$ & $\begin{array}{l}1930 \\
1935 \\
1940 \\
1945 \\
1950\end{array}$ & $\begin{array}{l}54.8 \\
62.7 \\
71.8 \\
83.8 \\
98.6\end{array}$ & $\begin{array}{l}0.02 \\
0.05 \\
0.03 \\
0.03 \\
0.02\end{array}$ & $\begin{array}{l}0050 \\
0055 \\
0100 \\
0105 \\
0110\end{array}$ & $\begin{array}{l}211.0 \\
202.0 \\
189.0 \\
183.0 \\
174.0\end{array}$ & $\begin{array}{l}0.00 \\
0.00 \\
0.00 \\
0.00 \\
0.00\end{array}$ \\
\hline $\begin{array}{l}1430 \\
1435 \\
1440 \\
1445 \\
1450\end{array}$ & $\begin{array}{l}1.2 \\
1.2 \\
1.4 \\
1.4 \\
1.5\end{array}$ & $\begin{array}{l}0.01 \\
0.01 \\
0.01 \\
0.00 \\
0.00\end{array}$ & $\begin{array}{l}1955 \\
2000 \\
2005 \\
2010 \\
2015\end{array}$ & $\begin{array}{l}113.0 \\
133.0 \\
162.0 \\
181.0 \\
196.0\end{array}$ & $\begin{array}{l}0.02 \\
0.01 \\
0.02 \\
0.02 \\
0.02\end{array}$ & $\begin{array}{l}0115 \\
0120 \\
0125 \\
0130 \\
0135\end{array}$ & $\begin{array}{l}166.0 \\
164.0 \\
155.0 \\
148.0 \\
144.0\end{array}$ & $\begin{array}{l}0.00 \\
0.01 \\
0.01 \\
0.01 \\
0.01\end{array}$ \\
\hline $\begin{array}{l}1455 \\
1500 \\
1505 \\
1510 \\
1515\end{array}$ & $\begin{array}{l}1.5 \\
1.5 \\
1.5 \\
1.5 \\
1.5\end{array}$ & $\begin{array}{l}0.00 \\
0.00 \\
0.01 \\
0.00 \\
0.00\end{array}$ & $\begin{array}{l}2020 \\
2025 \\
2030 \\
2035 \\
2040\end{array}$ & $\begin{array}{l}204.0 \\
219.0 \\
217.0 \\
223.0 \\
212.0\end{array}$ & $\begin{array}{l}0.02 \\
0.02 \\
0.02 \\
0.03 \\
0.02\end{array}$ & $\begin{array}{l}0140 \\
0145 \\
0150 \\
0155 \\
0200\end{array}$ & $\begin{array}{l}139.0 \\
134.0 \\
130.0 \\
122.0 \\
120.0\end{array}$ & $\begin{array}{l}0.02 \\
0.01 \\
0.01 \\
0.00 \\
0.00\end{array}$ \\
\hline $\begin{array}{l}1520 \\
1525 \\
1530 \\
1535 \\
1540\end{array}$ & $\begin{array}{l}1.5 \\
1.5 \\
1.5 \\
1.6 \\
1.6\end{array}$ & $\begin{array}{l}0.00 \\
0.00 \\
0.00 \\
0.00 \\
0.00\end{array}$ & $\begin{array}{l}2045 \\
2050 \\
2055 \\
2100 \\
2105\end{array}$ & $\begin{array}{l}202.0 \\
199.0 \\
191.0 \\
196.0 \\
197.0\end{array}$ & $\begin{array}{l}0.03 \\
0.01 \\
0.02 \\
0.01 \\
0.03\end{array}$ & $\begin{array}{l}0205 \\
0210 \\
0215 \\
0220 \\
0225\end{array}$ & $\begin{array}{l}117.0 \\
116.0 \\
114.0 \\
110.0 \\
109.0\end{array}$ & $\begin{array}{l}0.00 \\
0.00 \\
0.00 \\
0.00 \\
0.00\end{array}$ \\
\hline $\begin{array}{l}1545 \\
1550 \\
1555 \\
1600 \\
1605\end{array}$ & $\begin{array}{l}1.6 \\
1.6 \\
1.6 \\
1.6 \\
1.6\end{array}$ & $\begin{array}{l}0.00 \\
0.00 \\
0.00 \\
0.00 \\
0.00\end{array}$ & $\begin{array}{l}2110 \\
2115 \\
2120 \\
2125 \\
2130\end{array}$ & $\begin{array}{l}208.0 \\
211.0 \\
224.0 \\
232.0 \\
237.0\end{array}$ & $\begin{array}{l}0.01 \\
0.00 \\
0.00 \\
0.00 \\
0.02\end{array}$ & $\begin{array}{l}0230 \\
0235 \\
0240 \\
0245 \\
0250\end{array}$ & $\begin{array}{l}106.0 \\
105.0 \\
105.0 \\
101.0 \\
100.0\end{array}$ & $\begin{array}{l}0.00 \\
0.00 \\
0.00 \\
0.01 \\
0.00\end{array}$ \\
\hline $\begin{array}{l}1610 \\
1615 \\
1620 \\
1625 \\
1630\end{array}$ & $\begin{array}{l}1.6 \\
1.8 \\
1.9 \\
2.2 \\
3.2\end{array}$ & $\begin{array}{l}0.02 \\
0.01 \\
0.01 \\
0.01 \\
0.01\end{array}$ & $\begin{array}{l}2135 \\
2140 \\
2145 \\
2150 \\
2155\end{array}$ & $\begin{array}{l}239.0 \\
241.0 \\
240.0 \\
238.0 \\
234.0\end{array}$ & $\begin{array}{l}0.03 \\
0.04 \\
0.02 \\
0.02 \\
0.05\end{array}$ & $\begin{array}{l}0255 \\
0300 \\
0305 \\
0310 \\
0315\end{array}$ & $\begin{array}{l}95.8 \\
92.4 \\
88.4 \\
83.8 \\
80.6\end{array}$ & $\begin{array}{l}0.00 \\
0.00 \\
0.00 \\
0.00 \\
0.00\end{array}$ \\
\hline $\begin{array}{l}1635 \\
1640 \\
1645 \\
1650 \\
1655\end{array}$ & $\begin{array}{l}4.8 \\
5.6 \\
6.0 \\
6.0 \\
6.2\end{array}$ & $\begin{array}{l}0.01 \\
0.00 \\
0.00 \\
0.00 \\
0.00\end{array}$ & $\begin{array}{l}2200 \\
2205 \\
2210 \\
2215 \\
2220\end{array}$ & $\begin{array}{l}228.0 \\
220.0 \\
217.0 \\
208.0 \\
208.0\end{array}$ & $\begin{array}{l}0.01 \\
0.08 \\
0.05 \\
0.06 \\
0.10\end{array}$ & $\begin{array}{l}0320 \\
0325 \\
0330 \\
0335 \\
0340\end{array}$ & $\begin{array}{l}76.2 \\
73.1 \\
70.6 \\
67.5 \\
63.9\end{array}$ & $\begin{array}{l}0.00 \\
0.00 \\
0.00 \\
0.00 \\
0.00\end{array}$ \\
\hline $\begin{array}{l}1700 \\
1705 \\
1710 \\
1715 \\
1720\end{array}$ & $\begin{array}{l}6.5 \\
6.9 \\
7.9 \\
8.4 \\
8.6\end{array}$ & $\begin{array}{l}0.00 \\
0.00 \\
0.00 \\
0.00 \\
0.02\end{array}$ & $\begin{array}{l}2225 \\
2230 \\
2235 \\
2240 \\
2245\end{array}$ & $\begin{array}{l}211.0 \\
221.0 \\
241.0 \\
269.0 \\
305.0\end{array}$ & $\begin{array}{l}0.02 \\
0.01 \\
0.01 \\
0.08 \\
0.17\end{array}$ & $\begin{array}{l}0345 \\
0350 \\
0355 \\
0400 \\
0405\end{array}$ & $\begin{array}{l}62.2 \\
59.9 \\
57.6 \\
55.4 \\
53.7\end{array}$ & $\begin{array}{l}0.00 \\
0.00 \\
0.00 \\
0.00 \\
0.00\end{array}$ \\
\hline $\begin{array}{l}1725 \\
1730 \\
1735 \\
1740 \\
1745\end{array}$ & $\begin{array}{l}8.6 \\
8.6 \\
8.6 \\
8.9 \\
8.9\end{array}$ & $\begin{array}{l}0.02 \\
0.02 \\
0.01 \\
0.01 \\
0.00\end{array}$ & $\begin{array}{l}2250 \\
2255 \\
2300 \\
2305 \\
2310\end{array}$ & $\begin{array}{l}336.0 \\
361.0 \\
400.0 \\
456.0 \\
501.0\end{array}$ & $\begin{array}{l}0.10 \\
0.03 \\
0.02 \\
0.03 \\
0.01\end{array}$ & $\begin{array}{l}0410 \\
0415 \\
0420 \\
0425 \\
0430\end{array}$ & $\begin{array}{l}51.6 \\
50.0 \\
48.0 \\
46.0 \\
44.0\end{array}$ & $\begin{array}{l}0.00 \\
0.00 \\
0.00 \\
0.01 \\
0.01\end{array}$ \\
\hline $\begin{array}{l}1750 \\
1755 \\
1800 \\
1805 \\
1810\end{array}$ & $\begin{array}{l}8.9 \\
8.9 \\
9.4 \\
9.7 \\
9.7\end{array}$ & $\begin{array}{l}0.01 \\
0.00 \\
0.01 \\
0.01 \\
0.01\end{array}$ & $\begin{array}{l}2315 \\
2320 \\
2325 \\
2330 \\
2335\end{array}$ & $\begin{array}{l}551.0 \\
591.0 \\
604.0 \\
618.0 \\
616.0\end{array}$ & $\begin{array}{l}0.02 \\
0.01 \\
0.00 \\
0.01 \\
0.00\end{array}$ & $\begin{array}{l}0435 \\
0440 \\
0445 \\
0450 \\
0455\end{array}$ & $\begin{array}{l}42.8 \\
40.9 \\
39.7 \\
38.5 \\
37.4\end{array}$ & $\begin{array}{l}0.00 \\
0.01 \\
0.00 \\
0.00 \\
0.00\end{array}$ \\
\hline $\begin{array}{l}1815 \\
1820 \\
1825 \\
1830 \\
1835\end{array}$ & $\begin{array}{r}9.7 \\
9.7 \\
9.9 \\
10.5 \\
11.7\end{array}$ & $\begin{array}{l}0.02 \\
0.02 \\
0.01 \\
0.02 \\
0.02\end{array}$ & $\begin{array}{c}2340 \\
2345 \\
2350 \\
2355 \\
\text { November }\end{array}$ & $\begin{array}{r}604.0 \\
585.0 \\
556.0 \\
516.0 \\
27 . \quad 1987\end{array}$ & $\begin{array}{l}0.01 \\
0.01 \\
0.01 \\
0.01\end{array}$ & $\begin{array}{l}0500 \\
0505 \\
0510 \\
0515 \\
0520\end{array}$ & $\begin{array}{l}36.8 \\
35.7 \\
35.7 \\
35.1 \\
34.5\end{array}$ & $\begin{array}{l}0.00 \\
0.01 \\
0.00 \\
0.00 \\
0.00\end{array}$ \\
\hline
\end{tabular}



November 26-28, 1987--Continued

\begin{tabular}{|c|c|c|c|c|c|c|c|c|}
\hline $\begin{array}{l}\text { Time } \\
\text { (hours) }\end{array}$ & $\begin{array}{l}\text { Streamflow } \\
\text { (cubic feet } \\
\text { per second) }\end{array}$ & $\begin{array}{l}\text { Rain- } \\
\text { fall } \\
\text { (inches) }\end{array}$ & $\begin{array}{l}\text { Time } \\
\text { (hours) }\end{array}$ & $\begin{array}{l}\text { Streamflow } \\
\text { (cubic feet } \\
\text { per second) }\end{array}$ & $\begin{array}{l}\text { Rain- } \\
\text { fall } \\
\text { (inches) }\end{array}$ & $\begin{array}{l}\text { Time } \\
\text { (hours) }\end{array}$ & $\begin{array}{l}\text { Streamflow } \\
\text { (cubic feet } \\
\text { per second) }\end{array}$ & $\begin{array}{l}\text { Rain- } \\
\text { fall } \\
\text { (inches) }\end{array}$ \\
\hline $\begin{array}{l}0525 \\
0530 \\
0535 \\
0540 \\
0545\end{array}$ & $\begin{array}{l}33.5 \\
33.5 \\
32.9 \\
32.4 \\
31.9\end{array}$ & $\begin{array}{l}0.00 \\
0.00 \\
0.00 \\
0.00 \\
0.00\end{array}$ & $\begin{array}{l}1050 \\
1055 \\
1100 \\
1105 \\
1110\end{array}$ & $\begin{array}{l}17.5 \\
17.1 \\
17.1 \\
16.7 \\
16.7\end{array}$ & $\begin{array}{l}0.00 \\
0.00 \\
0.00 \\
0.00 \\
0.00\end{array}$ & $\begin{array}{l}1615 \\
1620 \\
1625 \\
1630 \\
1635\end{array}$ & $\begin{array}{l}186.0 \\
186.0 \\
179.0 \\
174.0 \\
171.0\end{array}$ & $\begin{array}{l}0.07 \\
0.07 \\
0.07 \\
0.07 \\
0.07\end{array}$ \\
\hline $\begin{array}{l}0550 \\
0555 \\
0600 \\
0605 \\
0610\end{array}$ & $\begin{array}{l}31.3 \\
30.8 \\
30.8 \\
30.3 \\
30.3\end{array}$ & $\begin{array}{l}0.00 \\
0.00 \\
0.00 \\
0.00 \\
0.00\end{array}$ & $\begin{array}{l}1115 \\
1120 \\
1125 \\
1130 \\
1135\end{array}$ & $\begin{array}{l}16.3 \\
16.3 \\
15.9 \\
15.9 \\
15.5\end{array}$ & $\begin{array}{l}0.00 \\
0.00 \\
0.00 \\
0.01 \\
0.03\end{array}$ & $\begin{array}{l}1640 \\
1645 \\
1650 \\
1655 \\
1700\end{array}$ & $\begin{array}{l}162.0 \\
156.0 \\
149.0 \\
142.0 \\
136.0\end{array}$ & $\begin{array}{l}0.07 \\
0.07 \\
0.07 \\
0.07 \\
0.01\end{array}$ \\
\hline $\begin{array}{l}0615 \\
0620 \\
0625 \\
0630 \\
0635\end{array}$ & $\begin{array}{l}29.3 \\
29.3 \\
28.3 \\
27.8 \\
27.8\end{array}$ & $\begin{array}{l}0.01 \\
0.00 \\
0.00 \\
0.00 \\
0.00\end{array}$ & $\begin{array}{l}1140 \\
1145 \\
1150 \\
1155 \\
1200\end{array}$ & $\begin{array}{l}15.5 \\
17.1 \\
16.3 \\
16.7 \\
17.9\end{array}$ & $\begin{array}{l}0.01 \\
0.01 \\
0.02 \\
0.02 \\
0.02\end{array}$ & $\begin{array}{l}1705 \\
1710 \\
1715 \\
1720 \\
1725\end{array}$ & $\begin{array}{l}129.0 \\
123.0 \\
117.0 \\
110.0 \\
106.0\end{array}$ & $\begin{array}{l}0.07 \\
0.07 \\
0.00 \\
0.00 \\
0.00\end{array}$ \\
\hline $\begin{array}{l}0640 \\
0645 \\
0650 \\
0655 \\
0700\end{array}$ & $\begin{array}{l}27.4 \\
26.9 \\
25.9 \\
25.5 \\
25.0\end{array}$ & $\begin{array}{l}0.00 \\
0.00 \\
0.00 \\
0.00 \\
0.00\end{array}$ & $\begin{array}{l}1205 \\
1210 \\
1215 \\
1220 \\
1225\end{array}$ & $\begin{array}{l}18.8 \\
19.7 \\
20.6 \\
22.4 \\
25.5\end{array}$ & $\begin{array}{l}0.00 \\
0.01 \\
0.02 \\
0.01 \\
0.00\end{array}$ & $\begin{array}{l}1730 \\
1735 \\
1740 \\
1745 \\
1750\end{array}$ & $\begin{array}{r}103.0 \\
96.5 \\
92.4 \\
87.7 \\
83.2\end{array}$ & $\begin{array}{l}0.00 \\
0.00 \\
0.00 \\
0.00 \\
0.00\end{array}$ \\
\hline $\begin{array}{l}0705 \\
0710 \\
0715 \\
0720 \\
0725\end{array}$ & $\begin{array}{l}25.0 \\
24.1 \\
23.7 \\
23.7 \\
23.3\end{array}$ & $\begin{array}{l}0.00 \\
0.01 \\
0.00 \\
0.01 \\
0.00\end{array}$ & $\begin{array}{l}1230 \\
1235 \\
1240 \\
1245 \\
1250\end{array}$ & $\begin{array}{l}30.8 \\
39.1 \\
51.6 \\
68.1 \\
83.8\end{array}$ & $\begin{array}{l}0.00 \\
0.00 \\
0.00 \\
0.01 \\
0.00\end{array}$ & $\begin{array}{l}1755 \\
1800 \\
1805 \\
1810 \\
1815\end{array}$ & $\begin{array}{l}80.6 \\
77.5 \\
73.7 \\
71.2 \\
68.2\end{array}$ & $\begin{array}{l}0.00 \\
0.00 \\
0.00 \\
0.00 \\
0.00\end{array}$ \\
\hline $\begin{array}{l}0730 \\
0735 \\
0740 \\
0745 \\
0750\end{array}$ & $\begin{array}{l}22.8 \\
22.4 \\
22.0 \\
21.5 \\
21.5\end{array}$ & $\begin{array}{l}0.00 \\
0.00 \\
0.00 \\
0.00 \\
0.04\end{array}$ & $\begin{array}{l}1255 \\
1300 \\
1305 \\
1310 \\
1315\end{array}$ & $\begin{array}{l}91.1 \\
92.4 \\
91.9 \\
89.7 \\
86.4\end{array}$ & $\begin{array}{l}0.00 \\
0.00 \\
0.00 \\
0.00 \\
0.00\end{array}$ & $\begin{array}{l}1820 \\
1825 \\
1830 \\
1835 \\
1840\end{array}$ & $\begin{array}{l}65.7 \\
62.7 \\
60.4 \\
58.7 \\
57.0\end{array}$ & $\begin{array}{l}0.00 \\
0.00 \\
0.00 \\
0.00 \\
0.00\end{array}$ \\
\hline $\begin{array}{l}0755 \\
0800 \\
0805 \\
0810 \\
0815\end{array}$ & $\begin{array}{l}21.5 \\
21.5 \\
22.0 \\
22.0 \\
22.4\end{array}$ & $\begin{array}{l}0.00 \\
0.00 \\
0.00 \\
0.00 \\
0.00\end{array}$ & $\begin{array}{l}1320 \\
1325 \\
1330 \\
1335 \\
1340\end{array}$ & $\begin{array}{l}85.1 \\
81.9 \\
79.3 \\
76.2 \\
73.7\end{array}$ & $\begin{array}{l}0.01 \\
0.01 \\
0.01 \\
0.02 \\
0.03\end{array}$ & $\begin{array}{l}1845 \\
1850 \\
1855 \\
1900 \\
1905\end{array}$ & $\begin{array}{l}54.8 \\
53.2 \\
51.6 \\
50.5 \\
48.6\end{array}$ & $\begin{array}{l}0.00 \\
0.00 \\
0.00 \\
0.00 \\
0.00\end{array}$ \\
\hline $\begin{array}{l}0820 \\
0825 \\
0830 \\
0835 \\
0840\end{array}$ & $\begin{array}{l}22.4 \\
22.4 \\
22.0 \\
22.0 \\
22.4\end{array}$ & $\begin{array}{l}0.00 \\
0.00 \\
0.00 \\
0.00 \\
0.00\end{array}$ & $\begin{array}{l}1345 \\
1350 \\
1355 \\
1400 \\
1405\end{array}$ & $\begin{array}{l}71.2 \\
70.0 \\
68.7 \\
67.5 \\
66.9\end{array}$ & $\begin{array}{l}0.01 \\
0.01 \\
0.00 \\
0.01 \\
0.06\end{array}$ & $\begin{array}{l}1910 \\
1915 \\
1920 \\
1925 \\
1930\end{array}$ & $\begin{array}{l}46.6 \\
44.7 \\
43.4 \\
42.1 \\
40.9\end{array}$ & $\begin{array}{l}0.00 \\
0.00 \\
0.00 \\
0.00 \\
0.00\end{array}$ \\
\hline $\begin{array}{l}0845 \\
0850 \\
0855 \\
0900 \\
0905\end{array}$ & $\begin{array}{l}22.8 \\
23.3 \\
24.1 \\
25.5 \\
25.9\end{array}$ & $\begin{array}{l}0.00 \\
0.00 \\
0.00 \\
0.00 \\
0.00\end{array}$ & $\begin{array}{l}1410 \\
1415 \\
1420 \\
1425 \\
1430\end{array}$ & $\begin{array}{l}68.1 \\
70.0 \\
71.2 \\
74.4 \\
78.7\end{array}$ & $\begin{array}{l}0.03 \\
0.01 \\
0.01 \\
0.01 \\
0.01\end{array}$ & $\begin{array}{l}1935 \\
1940 \\
1945 \\
1950 \\
1955\end{array}$ & $\begin{array}{l}39.7 \\
38.5 \\
37.4 \\
36.2 \\
35.1\end{array}$ & $\begin{array}{l}0.00 \\
0.00 \\
0.00 \\
0.00 \\
0.00\end{array}$ \\
\hline $\begin{array}{l}0910 \\
0915 \\
0920 \\
0925 \\
0930\end{array}$ & $\begin{array}{l}26.4 \\
25.9 \\
25.5 \\
25.5 \\
25.0\end{array}$ & $\begin{array}{l}0.00 \\
0.00 \\
0.00 \\
0.00 \\
0.00\end{array}$ & $\begin{array}{l}1435 \\
1440 \\
1445 \\
1450 \\
1455\end{array}$ & $\begin{array}{r}83.2 \\
88.4 \\
93.8 \\
97.9 \\
107.0\end{array}$ & $\begin{array}{l}0.03 \\
0.01 \\
0.02 \\
0.02 \\
0.01\end{array}$ & $\begin{array}{l}2000 \\
2005 \\
2010 \\
2015 \\
2020\end{array}$ & $\begin{array}{l}34.0 \\
33.5 \\
31.9 \\
30.8 \\
30.8\end{array}$ & $\begin{array}{l}0.00 \\
0.00 \\
0.00 \\
0.00 \\
0 . C 0\end{array}$ \\
\hline $\begin{array}{l}0935 \\
0940 \\
0945 \\
0950 \\
0955\end{array}$ & $\begin{array}{l}24.6 \\
24.1 \\
23.7 \\
23.3 \\
22.8\end{array}$ & $\begin{array}{l}0.00 \\
0.00 \\
0.00 \\
0.00 \\
0.00\end{array}$ & $\begin{array}{l}1500 \\
1505 \\
1510 \\
1515 \\
1520\end{array}$ & $\begin{array}{l}117.0 \\
125.0 \\
135.0 \\
141.0 \\
149.0\end{array}$ & $\begin{array}{l}0.02 \\
0.01 \\
0.01 \\
0.02 \\
0.01\end{array}$ & $\begin{array}{l}2025 \\
2030 \\
2035 \\
2040 \\
2045\end{array}$ & $\begin{array}{l}29.8 \\
28.8 \\
27.8 \\
27.4 \\
26.4\end{array}$ & $\begin{array}{l}0 . C 0 \\
0 . C 0 \\
0 . C 0 \\
0 . C 0 \\
0 . C 0\end{array}$ \\
\hline $\begin{array}{l}1000 \\
1005 \\
1010 \\
1015 \\
1020\end{array}$ & $\begin{array}{l}22.4 \\
21.5 \\
21.0 \\
20.6 \\
20.1\end{array}$ & $\begin{array}{l}0.01 \\
0.00 \\
0.00 \\
0.00 \\
0.00\end{array}$ & $\begin{array}{l}1525 \\
1530 \\
1535 \\
1540 \\
1545\end{array}$ & $\begin{array}{l}153.0 \\
157.0 \\
162.0 \\
168.0 \\
174.0\end{array}$ & $\begin{array}{l}0.01 \\
0.02 \\
0.00 \\
0.00 \\
0.00\end{array}$ & $\begin{array}{l}2050 \\
2055 \\
2100 \\
2105 \\
2110\end{array}$ & $\begin{array}{l}26.4 \\
25.5 \\
25.0 \\
24.1 \\
23.7\end{array}$ & $\begin{array}{l}0 . C 0 \\
0 . C 0 \\
0 . C 0 \\
0 . C 0 \\
0 . C 0\end{array}$ \\
\hline $\begin{array}{l}1025 \\
1030 \\
1035 \\
1040 \\
1045\end{array}$ & $\begin{array}{l}19.7 \\
19.2 \\
18.8 \\
18.3 \\
17.9\end{array}$ & $\begin{array}{l}0.00 \\
0.00 \\
0.00 \\
0.00 \\
0.00\end{array}$ & $\begin{array}{l}1550 \\
1555 \\
1600 \\
1605 \\
1610\end{array}$ & $\begin{array}{l}181.0 \\
185.0 \\
185.0 \\
186.0 \\
190.0\end{array}$ & $\begin{array}{l}0.01 \\
0.01 \\
0.00 \\
0.00 \\
0.01\end{array}$ & $\begin{array}{l}2115 \\
2120 \\
2125 \\
2130 \\
2135\end{array}$ & $\begin{array}{l}23.7 \\
22.8 \\
22.8 \\
22.0 \\
21.5\end{array}$ & $\begin{array}{l}0.00 \\
0.00 \\
0.00 \\
0.00 \\
0.00\end{array}$ \\
\hline
\end{tabular}


Table 24.--Streamflow and rainfa11 at station 02145940, Little Dutchman Creek tributary at Rock Hi11. November 26-28, 1987--Continued

\begin{tabular}{|c|c|c|c|c|c|c|c|c|}
\hline $\begin{array}{l}\text { Time } \\
\text { (hours) }\end{array}$ & $\begin{array}{l}\text { Streamflow } \\
\text { (cubic feet } \\
\text { per second) }\end{array}$ & $\begin{array}{l}\text { Rain- } \\
\text { fall } \\
\text { (inches) }\end{array}$ & $\begin{array}{l}\text { Time } \\
\text { (hours) }\end{array}$ & $\begin{array}{l}\text { Streamflow } \\
\text { (cubic feet } \\
\text { per second) }\end{array}$ & $\begin{array}{l}\text { Rain- } \\
\text { fall } \\
\text { (inches) }\end{array}$ & $\begin{array}{l}\text { Time } \\
\text { (hours) }\end{array}$ & $\begin{array}{l}\text { Streamflow } \\
\text { (cubic feet } \\
\text { per second) }\end{array}$ & $\begin{array}{l}\text { Rain- } \\
\text { fall } \\
\text { (inches) }\end{array}$ \\
\hline $\begin{array}{l}2140 \\
2145 \\
2150 \\
2155 \\
2200\end{array}$ & $\begin{array}{l}21.5 \\
21.0 \\
20.6 \\
20.1 \\
19.7\end{array}$ & $\begin{array}{l}0.00 \\
0.00 \\
0.00 \\
0.00 \\
0.00\end{array}$ & $\begin{array}{l}0145 \\
0150 \\
0155 \\
0200 \\
0205\end{array}$ & $\begin{array}{r}10.2 \\
10.2 \\
9.9 \\
9.9 \\
9.9\end{array}$ & $\begin{array}{l}0.00 \\
0.00 \\
0.00 \\
0.00 \\
0.00\end{array}$ & $\begin{array}{l}0555 \\
0600 \\
0605 \\
0610 \\
0615\end{array}$ & $\begin{array}{l}7.2 \\
7.2 \\
6.9 \\
6.9 \\
6.9\end{array}$ & $\begin{array}{l}0.00 \\
0.0 \mathrm{C} \\
0.0 \mathrm{C} \\
0.0 \mathrm{C} \\
0.00\end{array}$ \\
\hline $\begin{array}{l}2205 \\
2210 \\
2215 \\
2220 \\
2225\end{array}$ & $\begin{array}{l}19.2 \\
19.2 \\
18.3 \\
18.3 \\
17.5\end{array}$ & $\begin{array}{l}0.00 \\
0.00 \\
0.00 \\
0.00 \\
0.00\end{array}$ & $\begin{array}{l}0210 \\
0215 \\
0220 \\
0225 \\
0230\end{array}$ & $\begin{array}{l}9.9 \\
9.7 \\
9.7 \\
9.7 \\
9.4\end{array}$ & $\begin{array}{l}0.00 \\
0.00 \\
0.00 \\
0.00 \\
0.00\end{array}$ & $\begin{array}{l}0620 \\
0625 \\
0630 \\
0635 \\
0640\end{array}$ & $\begin{array}{l}6.9 \\
6.9 \\
6.7 \\
6.7 \\
6.7\end{array}$ & $\begin{array}{l}0.0 \mathrm{C} \\
0.0 \mathrm{C} \\
0.0 \mathrm{C} \\
0.0 \mathrm{C} \\
0.0 \mathrm{C}\end{array}$ \\
\hline $\begin{array}{l}2230 \\
2235 \\
2240 \\
2245 \\
2250\end{array}$ & $\begin{array}{l}17.5 \\
17.1 \\
16.7 \\
16.7 \\
16.3\end{array}$ & $\begin{array}{l}0.00 \\
0.00 \\
0.00 \\
0.00 \\
0.00\end{array}$ & $\begin{array}{l}0235 \\
0240 \\
0245 \\
0250 \\
0255\end{array}$ & $\begin{array}{l}9.4 \\
9.4 \\
9.4 \\
9.1 \\
9.1\end{array}$ & $\begin{array}{l}0.00 \\
0.00 \\
0.00 \\
0.00 \\
0.00\end{array}$ & $\begin{array}{l}0645 \\
0650 \\
0655 \\
0700 \\
0705\end{array}$ & $\begin{array}{l}6.7 \\
6.7 \\
6.7 \\
6.5 \\
6.5\end{array}$ & $\begin{array}{l}0.0 C \\
0.0 C \\
0.0 C \\
0.0 C \\
0.0 C\end{array}$ \\
\hline $\begin{array}{l}2255 \\
2300 \\
2305 \\
2310 \\
2315\end{array}$ & $\begin{array}{l}15.9 \\
15.5 \\
15.5 \\
15.1 \\
14.8\end{array}$ & $\begin{array}{l}0.00 \\
0.00 \\
0.00 \\
0.00 \\
0.00\end{array}$ & $\begin{array}{l}0300 \\
0305 \\
0310 \\
0315 \\
0320\end{array}$ & $\begin{array}{l}9.1 \\
9.1 \\
8.9 \\
8.9 \\
8.9\end{array}$ & $\begin{array}{l}0.00 \\
0.00 \\
0.00 \\
0.00 \\
0.00\end{array}$ & $\begin{array}{l}0710 \\
0715 \\
0720 \\
0725 \\
0730\end{array}$ & $\begin{array}{l}6.5 \\
6.5 \\
6.5 \\
6.5 \\
6.2\end{array}$ & $\begin{array}{l}0.0 C \\
0.0 C \\
0.0 C \\
0.0 C \\
0.0 C\end{array}$ \\
\hline $\begin{array}{l}2320 \\
2325 \\
2330 \\
2335 \\
2340\end{array}$ & $\begin{array}{l}14.8 \\
14.4 \\
14.0 \\
14.0 \\
13.7\end{array}$ & $\begin{array}{l}0.00 \\
0.00 \\
0.00 \\
0.00 \\
0.00\end{array}$ & $\begin{array}{l}0325 \\
0330 \\
0335 \\
0340 \\
0345\end{array}$ & $\begin{array}{l}8.6 \\
8.6 \\
8.6 \\
8.6 \\
8.4\end{array}$ & $\begin{array}{l}0.00 \\
0.00 \\
0.00 \\
0.00 \\
0.00\end{array}$ & $\begin{array}{l}0735 \\
0740 \\
0745 \\
0750 \\
0755\end{array}$ & $\begin{array}{l}6.2 \\
6.2 \\
6.2 \\
6.2 \\
6.3\end{array}$ & $\begin{array}{l}0.0 C \\
0.0 C \\
0.0 C \\
0.0 C \\
0.0 C\end{array}$ \\
\hline $\begin{array}{c}2345 \\
2350 \\
2355 \\
\text { November } \\
0000\end{array}$ & $\begin{array}{r}13.7 \\
13.3 \\
13.3 \\
1987 \\
13.0\end{array}$ & $\begin{array}{l}0.00 \\
0.00 \\
0.00 \\
0.00\end{array}$ & $\begin{array}{l}0350 \\
0355 \\
0400 \\
0405 \\
0410\end{array}$ & $\begin{array}{l}8.4 \\
8.4 \\
8.4 \\
8.1 \\
8.1\end{array}$ & $\begin{array}{l}0.00 \\
0.00 \\
0.00 \\
0.00 \\
0.00\end{array}$ & $\begin{array}{l}0800 \\
0805 \\
0810 \\
0815 \\
0820\end{array}$ & $\begin{array}{l}6.2 \\
6.2 \\
6.0 \\
6.0 \\
6.0\end{array}$ & $\begin{array}{l}0.0 C \\
0.0 C \\
0.0 C \\
0.0 C \\
0.0 C\end{array}$ \\
\hline $\begin{array}{l}0005 \\
0010 \\
0015 \\
0020 \\
0025\end{array}$ & $\begin{array}{l}12.7 \\
12.7 \\
12.3 \\
12.3 \\
12.0\end{array}$ & $\begin{array}{l}0.00 \\
0.00 \\
0.00 \\
0.00 \\
0.00\end{array}$ & $\begin{array}{l}0415 \\
0420 \\
0425 \\
0430 \\
0435\end{array}$ & $\begin{array}{l}8.1 \\
8.1 \\
7.9 \\
7.9 \\
7.9\end{array}$ & $\begin{array}{l}0.00 \\
0.00 \\
0.00 \\
0.00 \\
0.00\end{array}$ & $\begin{array}{l}0825 \\
0830 \\
0835 \\
0840 \\
0845\end{array}$ & $\begin{array}{l}6.0 \\
6.0 \\
6.0 \\
6.0 \\
6.0\end{array}$ & $\begin{array}{l}0.0 C \\
0.0 C \\
0.0 C \\
0.0 C \\
0.00\end{array}$ \\
\hline $\begin{array}{l}0030 \\
0035 \\
0040 \\
0045 \\
0050\end{array}$ & $\begin{array}{l}12.0 \\
11.7 \\
11.7 \\
11.7 \\
11.4\end{array}$ & $\begin{array}{l}0.00 \\
0.00 \\
0.00 \\
0.00 \\
0.00\end{array}$ & $\begin{array}{l}0440 \\
0445 \\
0450 \\
0455 \\
0500\end{array}$ & $\begin{array}{l}7.9 \\
7.6 \\
7.6 \\
7.6 \\
7.6\end{array}$ & $\begin{array}{l}0.00 \\
0.00 \\
0.00 \\
0.00 \\
0.00\end{array}$ & $\begin{array}{l}0850 \\
0855 \\
0900 \\
0905 \\
0910\end{array}$ & $\begin{array}{l}6.0 \\
5.8 \\
5.8 \\
5.8 \\
5.8\end{array}$ & $\begin{array}{l}0.0 C \\
0.0 C \\
0.00 \\
0.05 \\
0.00\end{array}$ \\
\hline $\begin{array}{l}0055 \\
0100 \\
0105 \\
0110 \\
0115\end{array}$ & $\begin{array}{l}11.4 \\
11.1 \\
11.1 \\
11.1 \\
10.8\end{array}$ & $\begin{array}{l}0.00 \\
0.00 \\
0.00 \\
0.00 \\
0.00\end{array}$ & $\begin{array}{l}0505 \\
0510 \\
0515 \\
0520 \\
0525\end{array}$ & $\begin{array}{l}7.6 \\
7.4 \\
7.4 \\
7.4 \\
7.4\end{array}$ & $\begin{array}{l}0.00 \\
0.00 \\
0.00 \\
0.00 \\
0.00\end{array}$ & $\begin{array}{l}0915 \\
0920 \\
0925 \\
0930 \\
0935\end{array}$ & $\begin{array}{l}5.8 \\
5.8 \\
5.8 \\
5.8 \\
5.8\end{array}$ & $\begin{array}{l}0.00 \\
0.00 \\
0.00 \\
0.00 \\
0.00\end{array}$ \\
\hline $\begin{array}{l}0120 \\
0125 \\
0130 \\
0135 \\
0140\end{array}$ & $\begin{array}{l}10.8 \\
10.8 \\
10.5 \\
10.5 \\
10.5\end{array}$ & $\begin{array}{l}0.00 \\
0.00 \\
0.00 \\
0.00 \\
0.00\end{array}$ & $\begin{array}{l}0530 \\
0535 \\
0540 \\
0545 \\
0550\end{array}$ & $\begin{array}{l}7.4 \\
7.2 \\
7.2 \\
7.2 \\
7.2\end{array}$ & $\begin{array}{l}0.00 \\
0.00 \\
0.00 \\
0.00 \\
0.00\end{array}$ & $\begin{array}{l}0940 \\
0945 \\
0950 \\
0955 \\
1000\end{array}$ & $\begin{array}{l}5.8 \\
5.8 \\
5.8 \\
5.6 \\
5.6\end{array}$ & $\begin{array}{l}0.00 \\
0.00 \\
0.00 \\
0.00 \\
0.00\end{array}$ \\
\hline
\end{tabular}




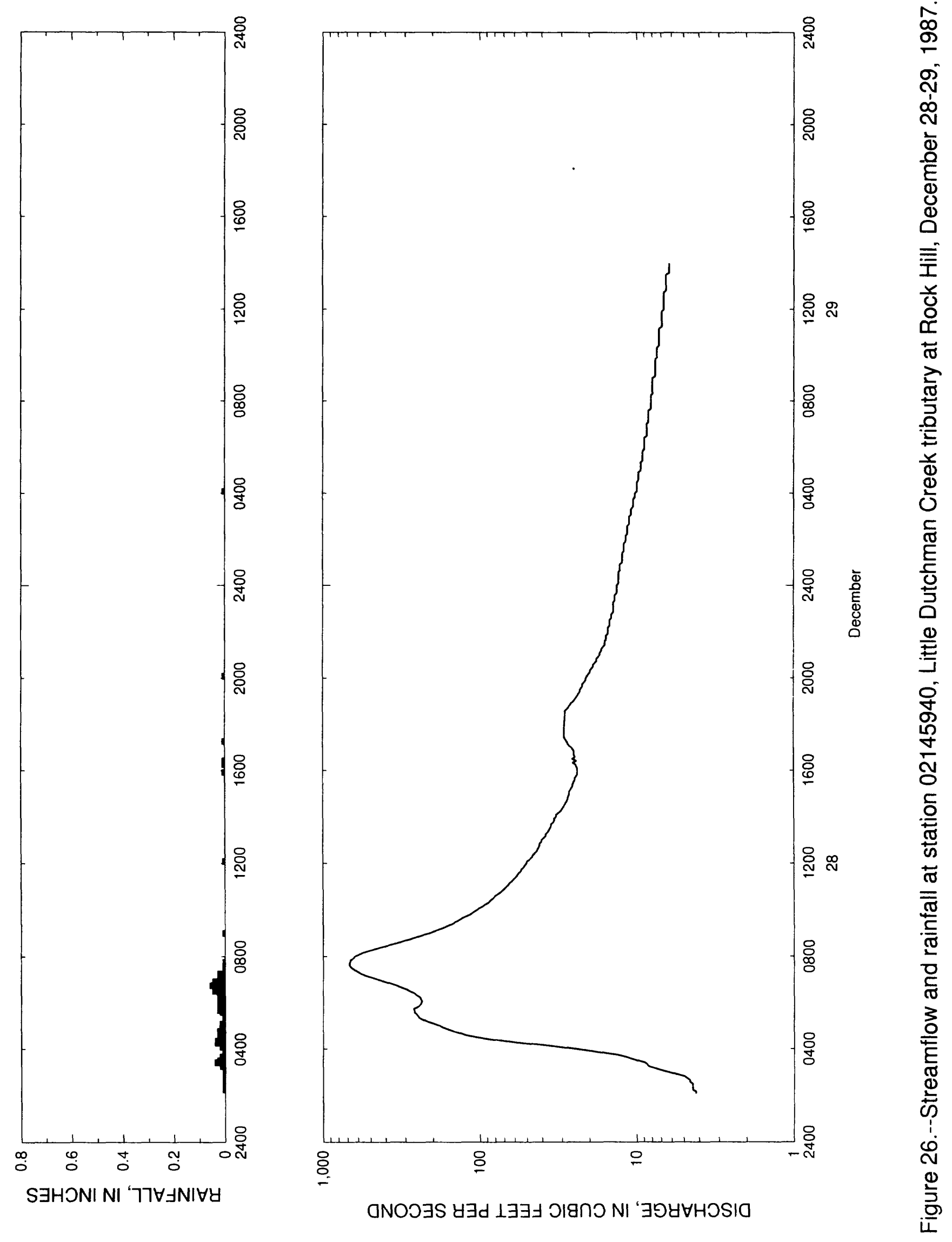


Table 25. - Streamflow and rainfall at station 02145940, Little Dutchman Creek tributary at Rock Hil1, December 28-29, 1987

\begin{tabular}{|c|c|c|c|c|c|c|c|c|}
\hline $\begin{array}{l}\text { Time } \\
\text { (hours) }\end{array}$ & $\begin{array}{l}\text { Streamflow } \\
\text { (cubic feet } \\
\text { per second) }\end{array}$ & $\begin{array}{l}\text { Rain- } \\
\text { fall } \\
\text { (inches) }\end{array}$ & $\begin{array}{l}\text { Time } \\
\text { (hours) }\end{array}$ & $\begin{array}{l}\text { Streamflow } \\
\text { (cubic feet } \\
\text { per second) }\end{array}$ & $\begin{array}{l}\text { Rain- } \\
\text { fall } \\
\text { (inches) }\end{array}$ & $\begin{array}{l}\text { Time } \\
\text { (hours) }\end{array}$ & $\begin{array}{l}\text { Streamflow } \\
\text { (cubic feet } \\
\text { per second) }\end{array}$ & $\begin{array}{l}\text { Rain- } \\
\text { fall } \\
\text { (inches) }\end{array}$ \\
\hline $\begin{array}{l}\text { December } \\
0200 \\
0205 \\
0210 \\
0215\end{array}$ & $\begin{array}{r}28, \quad 1987 \\
4.0 \\
4.2 \\
4.2 \\
4.4\end{array}$ & $\begin{array}{l}0.01 \\
0.00 \\
0.00 \\
0.01\end{array}$ & $\begin{array}{l}0720 \\
0725 \\
0730 \\
0735 \\
0740\end{array}$ & $\begin{array}{l}604.0 \\
637.0 \\
659.0 \\
678.0 \\
685.0\end{array}$ & $\begin{array}{l}0.01 \\
0.01 \\
0.00 \\
0.01 \\
0.00\end{array}$ & $\begin{array}{l}1245 \\
1250 \\
1255 \\
1300 \\
1305\end{array}$ & $\begin{array}{l}41.5 \\
41.5 \\
40.3 \\
40.3 \\
39.1\end{array}$ & $\begin{array}{l}0.00 \\
0.00 \\
0.00 \\
0.00 \\
0.00\end{array}$ \\
\hline $\begin{array}{l}0220 \\
0225 \\
0230 \\
0235 \\
0240\end{array}$ & $\begin{array}{l}4.4 \\
4.4 \\
4.4 \\
4.6 \\
4.6\end{array}$ & $\begin{array}{l}0.00 \\
0.01 \\
0.00 \\
0.01 \\
0.01\end{array}$ & $\begin{array}{l}0745 \\
0750 \\
0755 \\
0800 \\
0805\end{array}$ & $\begin{array}{l}681.0 \\
674.0 \\
643.0 \\
627.0 \\
591.0\end{array}$ & $\begin{array}{l}0.01 \\
0.00 \\
0.00 \\
0.00 \\
0.00\end{array}$ & $\begin{array}{l}1310 \\
1315 \\
1320 \\
1325 \\
1330\end{array}$ & $\begin{array}{l}37.9 \\
37.9 \\
36.8 \\
36.2 \\
35.7\end{array}$ & $\begin{array}{l}0.00 \\
0.00 \\
0.00 \\
0.00 \\
0.00\end{array}$ \\
\hline $\begin{array}{l}0245 \\
0250 \\
0255 \\
0300 \\
0305\end{array}$ & $\begin{array}{l}4.8 \\
5.0 \\
5.6 \\
6.2 \\
6.9\end{array}$ & $\begin{array}{l}0.00 \\
0.01 \\
0.00 \\
0.01 \\
0.01\end{array}$ & $\begin{array}{l}0810 \\
0815 \\
0820 \\
0825 \\
0830\end{array}$ & $\begin{array}{l}553.0 \\
507.0 \\
462.0 \\
420.0 \\
377.0\end{array}$ & $\begin{array}{l}0.00 \\
0.00 \\
0.00 \\
0.00 \\
0.00\end{array}$ & $\begin{array}{l}1335 \\
1340 \\
1345 \\
1350 \\
1355\end{array}$ & $\begin{array}{l}35.1 \\
35.1 \\
34.0 \\
33.5 \\
33.5\end{array}$ & $\begin{array}{l}0.00 \\
0.00 \\
0.00 \\
0.00 \\
0.00\end{array}$ \\
\hline $\begin{array}{l}0310 \\
0315 \\
0320 \\
0325 \\
0330\end{array}$ & $\begin{array}{l}7.6 \\
8.4 \\
8.6 \\
8.9 \\
9.9\end{array}$ & $\begin{array}{l}0.01 \\
0.02 \\
0.02 \\
0.04 \\
0.03\end{array}$ & $\begin{array}{l}0835 \\
0840 \\
0845 \\
0850 \\
0855\end{array}$ & $\begin{array}{l}339.0 \\
308.0 \\
278.0 \\
257.0 \\
235.0\end{array}$ & $\begin{array}{l}0.00 \\
0.00 \\
0.00 \\
0.00 \\
0.00\end{array}$ & $\begin{array}{l}1400 \\
1405 \\
1410 \\
1415 \\
1420\end{array}$ & $\begin{array}{l}32.4 \\
32.4 \\
31.3 \\
30.3 \\
29.8\end{array}$ & $\begin{array}{l}0.00 \\
0.00 \\
0.00 \\
0.00 \\
0.00\end{array}$ \\
\hline $\begin{array}{l}0335 \\
0340 \\
0345 \\
0350 \\
0355\end{array}$ & $\begin{array}{l}10.8 \\
11.7 \\
13.3 \\
16.3 \\
19.7\end{array}$ & $\begin{array}{l}0.02 \\
0.02 \\
0.01 \\
0.01 \\
0.01\end{array}$ & $\begin{array}{l}0900 \\
0905 \\
0910 \\
0915 \\
0920\end{array}$ & $\begin{array}{l}211.0 \\
196.0 \\
184.0 \\
170.0 \\
160.0\end{array}$ & $\begin{array}{l}0.01 \\
0.00 \\
0.00 \\
0.00 \\
0.00\end{array}$ & $\begin{array}{l}1425 \\
1430 \\
1435 \\
1440 \\
1445\end{array}$ & $\begin{array}{l}29.3 \\
28.8 \\
28.3 \\
27.8 \\
27.4\end{array}$ & $\begin{array}{l}0.00 \\
0.00 \\
0.00 \\
0.00 \\
0.00\end{array}$ \\
\hline $\begin{array}{l}0400 \\
0405 \\
0410 \\
0415 \\
0420\end{array}$ & $\begin{array}{l}24.6 \\
31.3 \\
40.3 \\
54.8 \\
70.6\end{array}$ & $\begin{array}{l}0.01 \\
0.02 \\
0.02 \\
0.04 \\
0.04\end{array}$ & $\begin{array}{l}0925 \\
0930 \\
0935 \\
0940 \\
0945\end{array}$ & $\begin{array}{l}149.0 \\
144.0 \\
135.0 \\
129.0 \\
121.0\end{array}$ & $\begin{array}{l}0.00 \\
0.00 \\
0.00 \\
0.00 \\
0.00\end{array}$ & $\begin{array}{l}1450 \\
1455 \\
1500 \\
1505 \\
1510\end{array}$ & $\begin{array}{l}27.4 \\
27.0 \\
26.9 \\
26.9 \\
26.4\end{array}$ & $\begin{array}{l}0.00 \\
0.00 \\
0.00 \\
0.00 \\
0.00\end{array}$ \\
\hline $\begin{array}{l}0425 \\
0430 \\
0435 \\
0440 \\
0445\end{array}$ & $\begin{array}{r}87.7 \\
105.0 \\
124.0 \\
134.0 \\
148.0\end{array}$ & $\begin{array}{l}0.03 \\
0.02 \\
0.03 \\
0.03 \\
0.03\end{array}$ & $\begin{array}{l}0950 \\
0955 \\
1000 \\
1005 \\
1010\end{array}$ & $\begin{array}{r}114.0 \\
110.0 \\
105.0 \\
101.0 \\
95.8\end{array}$ & $\begin{array}{l}0.00 \\
0.00 \\
0.00 \\
0.00 \\
0.00\end{array}$ & $\begin{array}{l}1515 \\
1520 \\
1525 \\
1530 \\
1535\end{array}$ & $\begin{array}{l}25.9 \\
25.5 \\
25.5 \\
25.0 \\
24.6\end{array}$ & $\begin{array}{l}0.00 \\
0.00 \\
0.00 \\
0.00 \\
0.00\end{array}$ \\
\hline $\begin{array}{l}0450 \\
0455 \\
0500 \\
0505 \\
0510\end{array}$ & $\begin{array}{l}160.0 \\
173.0 \\
182.0 \\
197.0 \\
215.0\end{array}$ & $\begin{array}{l}0.02 \\
0.01 \\
0.01 \\
0.02 \\
0.01\end{array}$ & $\begin{array}{l}1015 \\
1020 \\
1025 \\
1030 \\
1035\end{array}$ & $\begin{array}{l}92.4 \\
87.7 \\
85.8 \\
82.5 \\
80.6\end{array}$ & $\begin{array}{l}0.00 \\
0.00 \\
0.00 \\
0.00 \\
0.00\end{array}$ & $\begin{array}{l}1540 \\
1545 \\
1550 \\
1555 \\
1600\end{array}$ & $\begin{array}{l}24.6 \\
24.1 \\
23.7 \\
23.7 \\
23.7\end{array}$ & $\begin{array}{l}0.00 \\
0.00 \\
0.00 \\
0.01 \\
0.00\end{array}$ \\
\hline $\begin{array}{l}0515 \\
0520 \\
0525 \\
0530 \\
0535\end{array}$ & $\begin{array}{l}228.0 \\
243.0 \\
249.0 \\
254.0 \\
262.0\end{array}$ & $\begin{array}{l}0.01 \\
0.00 \\
0.01 \\
0.00 \\
0.02\end{array}$ & $\begin{array}{l}1040 \\
1045 \\
1050 \\
1055 \\
1100\end{array}$ & $\begin{array}{l}77.5 \\
74.4 \\
71.8 \\
69.4 \\
67.5\end{array}$ & $\begin{array}{l}0.00 \\
0.00 \\
0.00 \\
0.00 \\
0.00\end{array}$ & $\begin{array}{l}1605 \\
1610 \\
1615 \\
1620 \\
1625\end{array}$ & $\begin{array}{l}23.7 \\
24.1 \\
24.4 \\
25.4 \\
24.1\end{array}$ & $\begin{array}{l}0.00 \\
0.00 \\
0.01 \\
0.01 \\
0.01\end{array}$ \\
\hline $\begin{array}{l}0540 \\
0545 \\
0550 \\
0555 \\
0600\end{array}$ & $\begin{array}{l}263.0 \\
266.0 \\
250.0 \\
242.0 \\
238.0\end{array}$ & $\begin{array}{l}0.03 \\
0.03 \\
0.03 \\
0.03 \\
0.03\end{array}$ & $\begin{array}{l}1105 \\
1110 \\
1115 \\
1120 \\
1125\end{array}$ & $\begin{array}{l}65.7 \\
64.5 \\
62.2 \\
60.4 \\
58.7\end{array}$ & $\begin{array}{l}0.00 \\
0.00 \\
0.00 \\
0.00 \\
0.00\end{array}$ & $\begin{array}{l}1630 \\
1635 \\
1640 \\
1645 \\
1650\end{array}$ & $\begin{array}{l}25.6 \\
24.6 \\
25.0 \\
25.0 \\
25.0\end{array}$ & $\begin{array}{l}0.00 \\
0.00 \\
0.00 \\
0.00 \\
0.00\end{array}$ \\
\hline $\begin{array}{l}0605 \\
0610 \\
0615 \\
0620 \\
0625\end{array}$ & $\begin{array}{l}236.0 \\
240.0 \\
243.0 \\
254.0 \\
263.0\end{array}$ & $\begin{array}{l}0.02 \\
0.03 \\
0.03 \\
0.03 \\
0.03\end{array}$ & $\begin{array}{l}1130 \\
1135 \\
1140 \\
1145 \\
1150\end{array}$ & $\begin{array}{l}57.6 \\
56.5 \\
54.8 \\
54.3 \\
52.6\end{array}$ & $\begin{array}{l}0.00 \\
0.00 \\
0.00 \\
0.00 \\
0.00\end{array}$ & $\begin{array}{l}1655 \\
1700 \\
1705 \\
1710 \\
1715\end{array}$ & $\begin{array}{l}25.5 \\
25.9 \\
26.9 \\
27.4 \\
27.8\end{array}$ & $\begin{array}{l}0.00 \\
0.00 \\
0.00 \\
0.00 \\
0.01\end{array}$ \\
\hline $\begin{array}{l}0630 \\
0635 \\
0640 \\
0645 \\
0650\end{array}$ & $\begin{array}{l}280.0 \\
295.0 \\
319.0 \\
341.0 \\
371.0\end{array}$ & $\begin{array}{l}0.05 \\
0.04 \\
0.05 \\
0.06 \\
0.04\end{array}$ & $\begin{array}{l}1155 \\
1200 \\
1205 \\
1210 \\
1215\end{array}$ & $\begin{array}{l}51.6 \\
50.5 \\
50.0 \\
48.0 \\
46.6\end{array}$ & $\begin{array}{l}0.00 \\
0.00 \\
0.01 \\
0.00 \\
0.00\end{array}$ & $\begin{array}{l}1720 \\
1725 \\
1730 \\
1735 \\
1740\end{array}$ & $\begin{array}{l}28.3 \\
28.8 \\
28.8 \\
28.8 \\
28.8\end{array}$ & $\begin{array}{l}0.00 \\
0.00 \\
0.00 \\
0.00 \\
0.00\end{array}$ \\
\hline $\begin{array}{l}0655 \\
0700 \\
0705 \\
0710 \\
0715\end{array}$ & $\begin{array}{l}408.0 \\
445.0 \\
486.0 \\
533.0 \\
5750\end{array}$ & $\begin{array}{ll}0.05 \\
0 & 03 \\
0 & 02 \\
0 & 02 \\
0.03\end{array}$ & $\begin{array}{l}1220 \\
1225 \\
1230 \\
1235 \\
1240\end{array}$ & $\begin{array}{l}46.0 \\
44.7 \\
43.4 \\
42.8 \\
42.2\end{array}$ & $\begin{array}{l}0.00 \\
0.00 \\
0.00 \\
0.00 \\
0.00\end{array}$ & $\begin{array}{l}1745 \\
1750 \\
1755 \\
1800 \\
1805\end{array}$ & $\begin{array}{l}28.8 \\
28.8 \\
28.8 \\
28.8 \\
28.7\end{array}$ & $\begin{array}{l}0.00 \\
0.00 \\
0.00 \\
0.00 \\
0.00\end{array}$ \\
\hline
\end{tabular}


Table 25.-- Streamflow and rainfall at station 02145940, Little Dutchmar Creek tributary at Rock Hill, December 28-29, 1987--Continued

\begin{tabular}{|c|c|c|c|c|c|c|c|c|}
\hline $\begin{array}{l}\text { Time } \\
\text { (hours) }\end{array}$ & $\begin{array}{l}\text { Streamflow } \\
\text { (cubic feet } \\
\text { per second) }\end{array}$ & $\begin{array}{l}\text { Rain- } \\
\text { fall } \\
\text { (inches) }\end{array}$ & $\begin{array}{l}\text { Time } \\
\text { (hours) }\end{array}$ & $\begin{array}{l}\text { Streamflow } \\
\text { (cubic feet } \\
\text { per second) }\end{array}$ & $\begin{array}{l}\text { Rain- } \\
\text { fall } \\
\text { (inches) }\end{array}$ & $\begin{array}{l}\text { Time } \\
\text { (hours) }\end{array}$ & $\begin{array}{l}\text { Streamflow } \\
\text { (cubic feet } \\
\text { per second) }\end{array}$ & $\begin{array}{l}\text { Rain- } \\
\text { fall } \\
\text { (incles) }\end{array}$ \\
\hline $\begin{array}{l}1810 \\
1815 \\
1820 \\
1825 \\
1830\end{array}$ & $\begin{array}{l}28.7 \\
28.6 \\
28.6 \\
28.5 \\
28.5\end{array}$ & $\begin{array}{l}0.00 \\
0.00 \\
0.00 \\
0.00 \\
0.00\end{array}$ & $\begin{array}{l}2335 \\
2340 \\
2345 \\
2350 \\
2355\end{array}$ & $\begin{array}{l}13.7 \\
13.3 \\
13.3 \\
13.3 \\
13.3\end{array}$ & $\begin{array}{l}0.00 \\
0.00 \\
0.00 \\
0.00 \\
0.00\end{array}$ & $\begin{array}{l}0455 \\
0500 \\
0505 \\
0510 \\
0515\end{array}$ & $\begin{array}{l}9.7 \\
9.4 \\
9.4 \\
9.4 \\
9.4\end{array}$ & $\begin{array}{l}0.00 \\
0.00 \\
0.00 \\
0.00 \\
0.00\end{array}$ \\
\hline $\begin{array}{l}1835 \\
1840 \\
1845 \\
1850 \\
1855\end{array}$ & $\begin{array}{l}28.3 \\
27.4 \\
26.9 \\
26.4 \\
25.9\end{array}$ & $\begin{array}{l}0.00 \\
0.00 \\
0.00 \\
0.00 \\
0.00\end{array}$ & $\begin{array}{c}\text { December } \\
0000 \\
0005 \\
0010 \\
0015\end{array}$ & $29, \begin{array}{l}1987 \\
13.3 \\
13.0 \\
13.0 \\
13.0\end{array}$ & $\begin{array}{l}0.00 \\
0.00 \\
0.00 \\
0.00\end{array}$ & $\begin{array}{l}0520 \\
0525 \\
0530 \\
0535 \\
0540\end{array}$ & $\begin{array}{l}9.4 \\
9.1 \\
9.1 \\
9.1 \\
9.1\end{array}$ & $\begin{array}{l}0.00 \\
0.00 \\
0.00 \\
0.00 \\
0.00\end{array}$ \\
\hline $\begin{array}{l}1900 \\
1905 \\
1910 \\
1915 \\
1920\end{array}$ & $\begin{array}{l}25.0 \\
24.6 \\
24.1 \\
23.7 \\
23.3\end{array}$ & $\begin{array}{l}0.00 \\
0.00 \\
0.00 \\
0.00 \\
0.00\end{array}$ & $\begin{array}{l}0020 \\
0025 \\
0030 \\
0035 \\
0040\end{array}$ & $\begin{array}{l}13.0 \\
13.0 \\
13.0 \\
13.0 \\
12.7\end{array}$ & $\begin{array}{l}0.00 \\
0.00 \\
0.00 \\
0.00 \\
0.00\end{array}$ & $\begin{array}{l}0545 \\
0550 \\
0555 \\
0600 \\
0605\end{array}$ & $\begin{array}{l}9.1 \\
9.1 \\
8.9 \\
8.9 \\
8.9\end{array}$ & $\begin{array}{l}0.00 \\
0.00 \\
0.00 \\
0.00 \\
0.00\end{array}$ \\
\hline $\begin{array}{l}1925 \\
1930 \\
1935 \\
1940 \\
1945\end{array}$ & $\begin{array}{l}22.8 \\
22.8 \\
22.4 \\
22.0 \\
22.0\end{array}$ & $\begin{array}{l}0.00 \\
0.00 \\
0.00 \\
0.00 \\
0.00\end{array}$ & $\begin{array}{l}0045 \\
0050 \\
0055 \\
0100 \\
0105\end{array}$ & $\begin{array}{l}12.7 \\
12.7 \\
12.7 \\
12.3 \\
12.3\end{array}$ & $\begin{array}{l}0.00 \\
0.00 \\
0.00 \\
0.00 \\
0.00\end{array}$ & $\begin{array}{l}0610 \\
0615 \\
0620 \\
0625 \\
0630\end{array}$ & $\begin{array}{l}8.9 \\
8.9 \\
8.9 \\
8.9 \\
8.6\end{array}$ & $\begin{array}{l}0.00 \\
0.00 \\
0.00 \\
0.00 \\
0.00\end{array}$ \\
\hline $\begin{array}{l}1950 \\
1955 \\
2000 \\
2005 \\
2010\end{array}$ & $\begin{array}{l}21.5 \\
21.0 \\
21.0 \\
20.6 \\
20.1\end{array}$ & $\begin{array}{l}0.00 \\
0.00 \\
0.00 \\
0.01 \\
0.00\end{array}$ & $\begin{array}{l}0110 \\
0115 \\
0120 \\
0125 \\
0130\end{array}$ & $\begin{array}{l}12.3 \\
12.3 \\
12.3 \\
12.3 \\
12.0\end{array}$ & $\begin{array}{l}0.00 \\
0.00 \\
0.00 \\
0.00 \\
0.00\end{array}$ & $\begin{array}{l}0635 \\
0640 \\
0645 \\
0650 \\
0655\end{array}$ & $\begin{array}{l}8.6 \\
8.6 \\
8.6 \\
8.6 \\
8.6\end{array}$ & $\begin{array}{l}0.00 \\
0.00 \\
0.00 \\
0.00 \\
0.00\end{array}$ \\
\hline $\begin{array}{l}2015 \\
2020 \\
2025 \\
2030 \\
2035\end{array}$ & $\begin{array}{l}19.7 \\
19.7 \\
19.2 \\
18.8 \\
18.8\end{array}$ & $\begin{array}{l}0.00 \\
0.00 \\
0.00 \\
0.00 \\
0.00\end{array}$ & $\begin{array}{l}0135 \\
0140 \\
0145 \\
0150 \\
0155\end{array}$ & $\begin{array}{l}12.0 \\
12.0 \\
12.0 \\
12.0 \\
11.7\end{array}$ & $\begin{array}{l}0.00 \\
0.00 \\
0.00 \\
0.00 \\
0.00\end{array}$ & $\begin{array}{l}0700 \\
0705 \\
0710 \\
0715 \\
0720\end{array}$ & $\begin{array}{l}8.6 \\
8.4 \\
8.4 \\
8.4 \\
8.4\end{array}$ & $\begin{array}{l}0.00 \\
0.00 \\
0.00 \\
0.00 \\
0.00\end{array}$ \\
\hline $\begin{array}{l}2040 \\
2045 \\
2050 \\
2055 \\
2100\end{array}$ & $\begin{array}{l}18.3 \\
17.9 \\
17.9 \\
17.5 \\
17.1\end{array}$ & $\begin{array}{l}0.00 \\
0.00 \\
0.00 \\
0.00 \\
0.00\end{array}$ & $\begin{array}{l}0200 \\
0205 \\
0210 \\
0215 \\
0220\end{array}$ & $\begin{array}{l}11.7 \\
11.7 \\
11.7 \\
11.4 \\
11.4\end{array}$ & $\begin{array}{l}0.00 \\
0.00 \\
0.00 \\
0.00 \\
0.00\end{array}$ & $\begin{array}{l}0725 \\
0730 \\
0735 \\
0740 \\
0745\end{array}$ & $\begin{array}{l}8.4 \\
8.4 \\
8.4 \\
8.1 \\
8.1\end{array}$ & $\begin{array}{l}0.00 \\
0.00 \\
0.00 \\
0.00 \\
0.00\end{array}$ \\
\hline $\begin{array}{l}2105 \\
2110 \\
2115 \\
2120 \\
2125\end{array}$ & $\begin{array}{l}17.1 \\
16.7 \\
16.7 \\
16.3 \\
15.9\end{array}$ & $\begin{array}{l}0.00 \\
0.00 \\
0.00 \\
0.00 \\
0.00\end{array}$ & $\begin{array}{l}0225 \\
0230 \\
0235 \\
0240 \\
0245\end{array}$ & $\begin{array}{l}11.4 \\
11.4 \\
11.4 \\
11.1 \\
11.1\end{array}$ & $\begin{array}{l}0.00 \\
0.00 \\
0.00 \\
0.00 \\
0.00\end{array}$ & $\begin{array}{l}0750 \\
0755 \\
0800 \\
0805 \\
0810\end{array}$ & $\begin{array}{l}8.1 \\
8.1 \\
8.1 \\
8.1 \\
8.1\end{array}$ & $\begin{array}{l}0.00 \\
0.00 \\
0.00 \\
0.00 \\
0.00\end{array}$ \\
\hline $\begin{array}{l}2130 \\
2135 \\
2140 \\
2145 \\
2150\end{array}$ & $\begin{array}{l}15.9 \\
15.9 \\
15.5 \\
15.5 \\
15.5\end{array}$ & $\begin{array}{l}0.00 \\
0.00 \\
0.00 \\
0.00 \\
0.00\end{array}$ & $\begin{array}{l}0250 \\
0255 \\
0300 \\
0305 \\
0310\end{array}$ & $\begin{array}{l}11.1 \\
11.1 \\
11.1 \\
10.8 \\
10.8\end{array}$ & $\begin{array}{l}0.00 \\
0.00 \\
0.00 \\
0.00 \\
0.00\end{array}$ & $\begin{array}{l}0815 \\
0820 \\
0825 \\
0830 \\
0835\end{array}$ & $\begin{array}{l}8.1 \\
7.9 \\
7.9 \\
7.9 \\
7.9\end{array}$ & $\begin{array}{l}0.00 \\
0.00 \\
0.00 \\
0.00 \\
0.00\end{array}$ \\
\hline $\begin{array}{l}2155 \\
2200 \\
2205 \\
2210 \\
2215\end{array}$ & $\begin{array}{l}15.1 \\
15.1 \\
15.1 \\
15.1 \\
14.8\end{array}$ & $\begin{array}{l}0.00 \\
0.00 \\
0.00 \\
0.00 \\
0.00\end{array}$ & $\begin{array}{l}0315 \\
0320 \\
0325 \\
0330 \\
0335\end{array}$ & $\begin{array}{l}10.8 \\
10.8 \\
10.5 \\
10.5 \\
10.5\end{array}$ & $\begin{array}{l}0.00 \\
0.00 \\
0.00 \\
0.00 \\
0.00\end{array}$ & $\begin{array}{l}0840 \\
0845 \\
0850 \\
0855 \\
0900\end{array}$ & $\begin{array}{l}7.9 \\
7.9 \\
7.9 \\
7.9 \\
7.9\end{array}$ & $\begin{array}{l}0.00 \\
0.00 \\
0.00 \\
0.00 \\
0.00\end{array}$ \\
\hline $\begin{array}{l}2220 \\
2225 \\
2230 \\
2235 \\
2240\end{array}$ & $\begin{array}{l}14.8 \\
14.8 \\
14.8 \\
14.4 \\
14.4\end{array}$ & $\begin{array}{l}0.00 \\
0.00 \\
0.00 \\
0.00 \\
0.00\end{array}$ & $\begin{array}{l}0340 \\
0345 \\
0350 \\
0355 \\
0400\end{array}$ & $\begin{array}{l}10.5 \\
10.5 \\
10.2 \\
10.2 \\
10.2\end{array}$ & $\begin{array}{l}0.00 \\
0.00 \\
0.00 \\
0.00 \\
0.00\end{array}$ & $\begin{array}{l}0905 \\
0910 \\
0915 \\
0920 \\
0925\end{array}$ & $\begin{array}{l}7.6 \\
7.6 \\
7.6 \\
7.6 \\
7.6\end{array}$ & $\begin{array}{l}0.00 \\
0.00 \\
0.00 \\
0.00 \\
0.00\end{array}$ \\
\hline $\begin{array}{l}2245 \\
2250 \\
2255 \\
2300 \\
2305\end{array}$ & $\begin{array}{l}14.4 \\
14.0 \\
14.0 \\
14.0 \\
14.0\end{array}$ & $\begin{array}{l}0.00 \\
0.00 \\
0.00 \\
0.00 \\
0.00\end{array}$ & $\begin{array}{l}0405 \\
0410 \\
0415 \\
0420 \\
0425\end{array}$ & $\begin{array}{l}9.9 \\
9.9 \\
9.9 \\
9.9 \\
9.9\end{array}$ & $\begin{array}{l}0.01 \\
0.00 \\
0.00 \\
0.00 \\
0.00\end{array}$ & $\begin{array}{l}0930 \\
0935 \\
0940 \\
0945 \\
0950\end{array}$ & $\begin{array}{l}7.6 \\
7.6 \\
7.6 \\
7.6 \\
7.6\end{array}$ & $\begin{array}{l}0.00 \\
0.00 \\
0.00 \\
0.00 \\
0.00\end{array}$ \\
\hline $\begin{array}{l}2310 \\
2315 \\
2320 \\
2325 \\
2330\end{array}$ & $\begin{array}{l}14.0 \\
14.0 \\
13.7 \\
13.7 \\
13.7\end{array}$ & $\begin{array}{l}0.00 \\
0.00 \\
0.00 \\
0.00 \\
0.00\end{array}$ & $\begin{array}{l}0430 \\
0435 \\
0440 \\
0445 \\
0450\end{array}$ & $\begin{array}{l}9.9 \\
9.7 \\
9.7 \\
9.7 \\
9.7\end{array}$ & $\begin{array}{l}0.00 \\
0.00 \\
0.00 \\
0.00 \\
0.00\end{array}$ & $\begin{array}{l}0955 \\
1000 \\
1005 \\
1010 \\
1015\end{array}$ & $\begin{array}{l}7.4 \\
7.4 \\
7.4 \\
7.4 \\
7.4\end{array}$ & $\begin{array}{l}0.00 \\
0.00 \\
0.00 \\
0.00 \\
0.00\end{array}$ \\
\hline
\end{tabular}


Table 25. - Streamflow and rainfall at station 02145940, Little Dutchman Creek tributary at Rock Hill, December 28-29,1987--Continued

\begin{tabular}{|c|c|c|c|c|c|c|c|c|}
\hline $\begin{array}{l}\text { Time } \\
\text { (hours) }\end{array}$ & $\begin{array}{l}\text { Streamflow } \\
\text { (cubic feet } \\
\text { per second) }\end{array}$ & $\begin{array}{l}\text { Rain- } \\
\text { fal1 } \\
\text { (inches) }\end{array}$ & $\begin{array}{l}\text { Time } \\
\text { (hours) }\end{array}$ & $\begin{array}{l}\text { Streamflow } \\
\text { (cubic feet } \\
\text { per second) }\end{array}$ & $\begin{array}{l}\text { Rain- } \\
\text { fall } \\
\text { (inches) }\end{array}$ & $\begin{array}{l}\text { Time } \\
\text { (hours) }\end{array}$ & $\begin{array}{l}\text { Streamflow } \\
\text { (cubic feet } \\
\text { per second) }\end{array}$ & $\begin{array}{l}\text { Rain- } \\
\text { fall } \\
\text { (inches) }\end{array}$ \\
\hline $\begin{array}{l}1020 \\
1025 \\
1030 \\
1035 \\
1040\end{array}$ & $\begin{array}{l}7.4 \\
7.2 \\
7.2 \\
7.2 \\
7.2\end{array}$ & $\begin{array}{l}0.00 \\
0.00 \\
0.00 \\
0.00 \\
0.00\end{array}$ & $\begin{array}{l}1140 \\
1145 \\
1150 \\
1155 \\
1200\end{array}$ & $\begin{array}{l}6.9 \\
6.9 \\
6.9 \\
6.9 \\
6.7\end{array}$ & $\begin{array}{l}0.00 \\
0.00 \\
0.00 \\
0.00 \\
0.00\end{array}$ & $\begin{array}{l}1300 \\
1305 \\
1310 \\
1315 \\
1320\end{array}$ & $\begin{array}{l}6.5 \\
6.5 \\
6.5 \\
6.5 \\
6.5\end{array}$ & $\begin{array}{l}0.00 \\
0.00 \\
0.00 \\
0.00 \\
0.00\end{array}$ \\
\hline $\begin{array}{l}1045 \\
1050 \\
1055 \\
1100 \\
1105\end{array}$ & $\begin{array}{l}7.2 \\
7.2 \\
7.2 \\
7.2 \\
7.2\end{array}$ & $\begin{array}{l}0.00 \\
0.00 \\
0.00 \\
0.00 \\
0.00\end{array}$ & $\begin{array}{l}1205 \\
1210 \\
1215 \\
1220 \\
1225\end{array}$ & $\begin{array}{l}6.7 \\
6.7 \\
6.7 \\
6.7 \\
6.7\end{array}$ & $\begin{array}{l}0.00 \\
0.00 \\
0.00 \\
0.00 \\
0.00\end{array}$ & $\begin{array}{l}1325 \\
1330 \\
1335 \\
1340 \\
1345\end{array}$ & $\begin{array}{l}6.5 \\
6.5 \\
6.2 \\
6.2 \\
6.2\end{array}$ & $\begin{array}{l}0.00 \\
0.00 \\
0.00 \\
0.00 \\
0.00\end{array}$ \\
\hline $\begin{array}{l}1110 \\
1115 \\
1120 \\
1125 \\
1130\end{array}$ & $\begin{array}{l}7.2 \\
6.9 \\
6.9 \\
6.9 \\
6.9\end{array}$ & $\begin{array}{l}0.00 \\
0.00 \\
0.00 \\
0.00 \\
0.00\end{array}$ & $\begin{array}{l}1230 \\
1235 \\
1240 \\
1245 \\
1250\end{array}$ & $\begin{array}{l}6.7 \\
6.7 \\
6.7 \\
6.7 \\
6.5\end{array}$ & $\begin{array}{l}0.00 \\
0.00 \\
0.00 \\
0.00 \\
0.00\end{array}$ & $\begin{array}{l}1350 \\
1355 \\
1400\end{array}$ & $\begin{array}{l}6.2 \\
6.2 \\
6.2\end{array}$ & $\begin{array}{l}0.00 \\
0.00 \\
0.00\end{array}$ \\
\hline 1135 & 6.9 & 0.00 & 1255 & 6.5 & 0.00 & & & \\
\hline
\end{tabular}



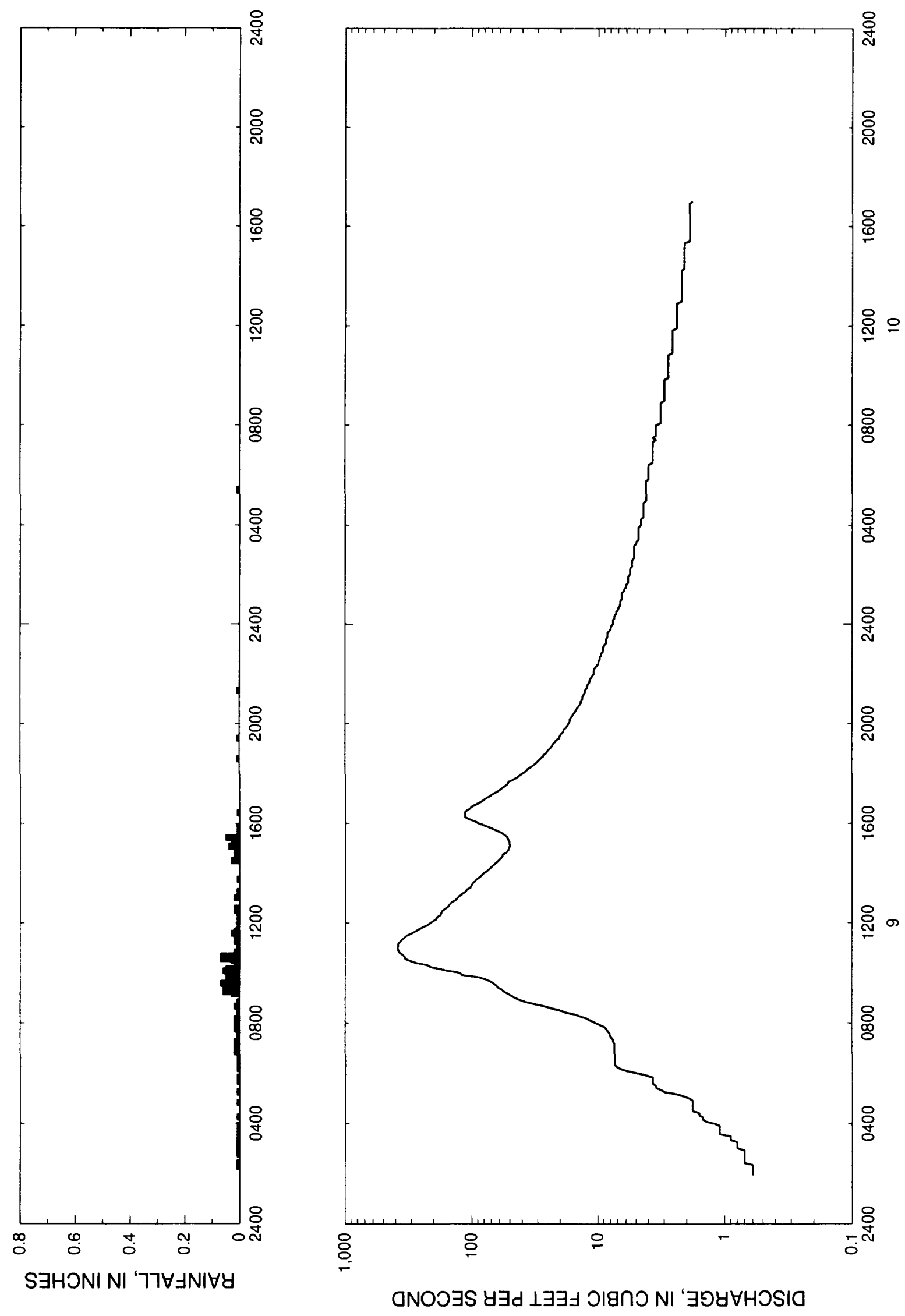

ㅇํำ

o

है

帚

है

$\sigma^{-}$

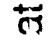

ज

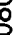

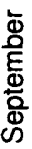

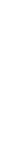

$+$

王

बi

$+$

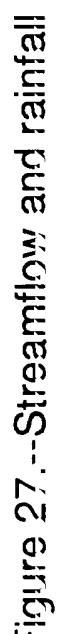


Table 26. - Streamflow and rainfall at station 02145940, Little Dutchman Creek tributary at Rock Hi11, September 9-10, 1988

\begin{tabular}{|c|c|c|c|c|c|c|c|c|}
\hline $\begin{array}{l}\text { Time } \\
\text { (hours) }\end{array}$ & $\begin{array}{l}\text { Streamflow } \\
\text { (cubic feet } \\
\text { per second) }\end{array}$ & $\begin{array}{l}\text { Rain- } \\
\text { fall } \\
\text { (inches) }\end{array}$ & $\begin{array}{l}\text { Time } \\
\text { (hours) }\end{array}$ & $\begin{array}{l}\text { Streamflow } \\
\text { (cubic feet } \\
\text { per second) }\end{array}$ & $\begin{array}{l}\text { Rain- } \\
\text { fall } \\
\text { (inches) }\end{array}$ & $\begin{array}{l}\text { Time } \\
\text { (hours) }\end{array}$ & $\begin{array}{l}\text { Streamflow } \\
\text { (cubic feet } \\
\text { per second) }\end{array}$ & $\begin{array}{l}\text { Rain- } \\
\text { fall } \\
\text { (inches) }\end{array}$ \\
\hline $\begin{array}{l}\text { September } \\
0150 \\
0155 \\
0200 \\
0205\end{array}$ & $\begin{array}{c}9, \\
1988 \\
0.6 \\
0.6 \\
0.6 \\
0.6\end{array}$ & $\begin{array}{l}0.01 \\
0.00 \\
0.00 \\
0.00\end{array}$ & $\begin{array}{l}0710 \\
0715 \\
0720 \\
0725 \\
0730\end{array}$ & $\begin{array}{l}7.4 \\
7.6 \\
7.6 \\
7.9 \\
8.1\end{array}$ & $\begin{array}{l}0.01 \\
0.02 \\
0.00 \\
0.01 \\
0.01\end{array}$ & $\begin{array}{l}1235 \\
1240 \\
1245 \\
1250 \\
1255\end{array}$ & $\begin{array}{l}163.0 \\
154.0 \\
150.0 \\
144.0 \\
134.0\end{array}$ & $\begin{array}{l}0.02 \\
0.00 \\
0.00 \\
0.00 \\
0.00\end{array}$ \\
\hline $\begin{array}{l}0210 \\
0215 \\
0220 \\
0225 \\
0230\end{array}$ & $\begin{array}{l}0.6 \\
0.6 \\
0.6 \\
0.7 \\
0.7\end{array}$ & $\begin{array}{l}0.00 \\
0.01 \\
0.00 \\
0.01 \\
0.00\end{array}$ & $\begin{array}{l}0735 \\
0740 \\
0745 \\
0750 \\
0755\end{array}$ & $\begin{array}{l}8.1 \\
8.4 \\
8.6 \\
8.9 \\
9.7\end{array}$ & $\begin{array}{l}0.01 \\
0.01 \\
0.02 \\
0.02 \\
0.02\end{array}$ & $\begin{array}{l}1300 \\
1305 \\
1310 \\
1315 \\
1320\end{array}$ & $\begin{array}{l}131.0 \\
126.0 \\
119.0 \\
112.0 \\
110.0\end{array}$ & $\begin{array}{l}0.02 \\
0.00 \\
0.00 \\
0.01 \\
0.00\end{array}$ \\
\hline $\begin{array}{l}0235 \\
0240 \\
0245 \\
0250 \\
0255\end{array}$ & $\begin{array}{l}0.7 \\
0.7 \\
0.7 \\
0.7 \\
0.7\end{array}$ & $\begin{array}{l}0.00 \\
0.00 \\
0.01 \\
0.00 \\
0.00\end{array}$ & $\begin{array}{l}0800 \\
0805 \\
0810 \\
0815 \\
0820\end{array}$ & $\begin{array}{l}10.5 \\
11.4 \\
12.3 \\
13.7 \\
15.1\end{array}$ & $\begin{array}{l}0.02 \\
0.02 \\
0.02 \\
0.01 \\
0.00\end{array}$ & $\begin{array}{l}1325 \\
1330 \\
1335 \\
1340 \\
1345\end{array}$ & $\begin{array}{r}103.0 \\
101.0 \\
99.3 \\
95.1 \\
92.4\end{array}$ & $\begin{array}{l}0.00 \\
0.00 \\
0.00 \\
0.00 \\
0.01\end{array}$ \\
\hline $\begin{array}{l}0300 \\
0305 \\
0310 \\
0315 \\
0320\end{array}$ & $\begin{array}{l}0.8 \\
0.8 \\
0.8 \\
0.8 \\
0.9\end{array}$ & $\begin{array}{l}0.01 \\
0.00 \\
0.01 \\
0.01 \\
0.00\end{array}$ & $\begin{array}{l}0825 \\
0830 \\
0835 \\
0840 \\
0845\end{array}$ & $\begin{array}{l}17.9 \\
20.1 \\
23.3 \\
26.9 \\
31.9\end{array}$ & $\begin{array}{l}0.01 \\
0.01 \\
0.01 \\
0.02 \\
0.01\end{array}$ & $\begin{array}{l}1350 \\
1355 \\
1400 \\
1405 \\
1410\end{array}$ & $\begin{array}{l}87.8 \\
83.8 \\
80.0 \\
75.6 \\
72.5\end{array}$ & $\begin{array}{l}0.00 \\
0.00 \\
0.00 \\
0.00 \\
0.00\end{array}$ \\
\hline $\begin{array}{l}0325 \\
0330 \\
0335 \\
0340 \\
0345\end{array}$ & $\begin{array}{l}0.9 \\
0.9 \\
1.1 \\
1.1 \\
1.1\end{array}$ & $\begin{array}{l}0.00 \\
0.01 \\
0.00 \\
0.01 \\
0.00\end{array}$ & $\begin{array}{l}0850 \\
0855 \\
0900 \\
0905 \\
0910\end{array}$ & $\begin{array}{l}37.4 \\
41.5 \\
45.3 \\
48.6 \\
51.6\end{array}$ & $\begin{array}{l}0.01 \\
0.00 \\
0.00 \\
0.00 \\
0.03\end{array}$ & $\begin{array}{l}1415 \\
1420 \\
1425 \\
1430 \\
1435\end{array}$ & $\begin{array}{l}70.0 \\
66.9 \\
64.5 \\
61.6 \\
59.3\end{array}$ & $\begin{array}{l}0.00 \\
0.00 \\
0.00 \\
0.03 \\
0.00\end{array}$ \\
\hline $\begin{array}{l}0350 \\
0355 \\
0400 \\
0405 \\
0410\end{array}$ & $\begin{array}{l}1.1 \\
1.1 \\
1.2 \\
1.4 \\
1.5\end{array}$ & $\begin{array}{l}0.01 \\
0.01 \\
0.00 \\
0.00 \\
0.00\end{array}$ & $\begin{array}{l}0915 \\
0920 \\
0925 \\
0930 \\
0935\end{array}$ & $\begin{array}{l}55.4 \\
58.1 \\
62.2 \\
63.9 \\
67.5\end{array}$ & $\begin{array}{l}0.06 \\
0.05 \\
0.03 \\
0.06 \\
0.07\end{array}$ & $\begin{array}{l}1440 \\
1445 \\
1450 \\
1455 \\
1500\end{array}$ & $\begin{array}{l}57.6 \\
57.0 \\
53.2 \\
51.6 \\
51.1\end{array}$ & $\begin{array}{l}0.00 \\
0.02 \\
0.00 \\
0.02 \\
0.01\end{array}$ \\
\hline $\begin{array}{l}0415 \\
0420 \\
0425 \\
0430 \\
0435\end{array}$ & $\begin{array}{l}1.5 \\
1.6 \\
1.6 \\
1.8 \\
1.8\end{array}$ & $\begin{array}{l}0.01 \\
0.00 \\
0.00 \\
0.00 \\
0.00\end{array}$ & $\begin{array}{l}0940 \\
0945 \\
0950 \\
0955 \\
1000\end{array}$ & $\begin{array}{r}71.2 \\
78.1 \\
88.4 \\
120.0 \\
124.0\end{array}$ & $\begin{array}{l}0.05 \\
0.04 \\
0.04 \\
0.05 \\
0.04\end{array}$ & $\begin{array}{l}1505 \\
1510 \\
1515 \\
1520 \\
1525\end{array}$ & $\begin{array}{l}50.0 \\
50.5 \\
50.5 \\
51.6 \\
52.1\end{array}$ & $\begin{array}{l}0.04 \\
0.03 \\
0.02 \\
0.02 \\
0.05\end{array}$ \\
\hline $\begin{array}{l}0440 \\
0445 \\
0450 \\
0455 \\
0500\end{array}$ & $\begin{array}{l}1.8 \\
1.8 \\
1.8 \\
1.8 \\
1.9\end{array}$ & $\begin{array}{l}0.00 \\
0.00 \\
0.01 \\
0.00 \\
0.00\end{array}$ & $\begin{array}{l}1005 \\
1010 \\
1015 \\
1020 \\
1025\end{array}$ & $\begin{array}{l}149.0 \\
175.0 \\
210.0 \\
224.0 \\
275.0\end{array}$ & $\begin{array}{l}0.06 \\
0.05 \\
0.01 \\
0.01 \\
0.02\end{array}$ & $\begin{array}{l}1530 \\
1535 \\
1540 \\
1545 \\
1550\end{array}$ & $\begin{array}{l}54.3 \\
57.0 \\
61.0 \\
66.3 \\
72.5\end{array}$ & $\begin{array}{l}0.00 \\
0.01 \\
0.00 \\
0.00 \\
0.01\end{array}$ \\
\hline $\begin{array}{l}0505 \\
0510 \\
0515 \\
0520 \\
0525\end{array}$ & $\begin{array}{l}2.1 \\
2.4 \\
3.0 \\
3.2 \\
3.5\end{array}$ & $\begin{array}{l}0.00 \\
0.00 \\
0.01 \\
0.00 \\
0.00\end{array}$ & $\begin{array}{l}1030 \\
1035 \\
1040 \\
1045 \\
1050\end{array}$ & $\begin{array}{l}308.0 \\
336.0 \\
341.0 \\
354.0 \\
376.0\end{array}$ & $\begin{array}{l}0.03 \\
0.07 \\
0.07 \\
0.02 \\
0.02\end{array}$ & $\begin{array}{l}1555 \\
1600 \\
1605 \\
1610 \\
1615\end{array}$ & $\begin{array}{r}80.0 \\
89.1 \\
95.8 \\
105.0 \\
114.0\end{array}$ & $\begin{array}{l}0.00 \\
0.00 \\
0.00 \\
0.00 \\
0.00\end{array}$ \\
\hline $\begin{array}{l}0530 \\
0535 \\
0540 \\
0545 \\
0550\end{array}$ & $\begin{array}{l}3.5 \\
3.7 \\
3.7 \\
3.7 \\
3.7\end{array}$ & $\begin{array}{l}0.00 \\
0.00 \\
0.01 \\
0.00 \\
0.01\end{array}$ & $\begin{array}{l}1055 \\
1100 \\
1105 \\
1110 \\
1115\end{array}$ & $\begin{array}{l}382.0 \\
385.0 \\
382.0 \\
382.0 \\
370.0\end{array}$ & $\begin{array}{l}0.00 \\
0.01 \\
0.01 \\
0.00 \\
0.02\end{array}$ & $\begin{array}{l}1620 \\
1625 \\
1630 \\
1635 \\
1640\end{array}$ & $\begin{array}{l}113.0 \\
114.0 \\
112.0 \\
105.0 \\
101.0\end{array}$ & $\begin{array}{l}0.00 \\
0.01 \\
0.00 \\
0.00 \\
0.00\end{array}$ \\
\hline $\begin{array}{l}0555 \\
0600 \\
0605 \\
0610 \\
0615\end{array}$ & $\begin{array}{l}4.2 \\
5.0 \\
6.0 \\
6.7 \\
7.2\end{array}$ & $\begin{array}{l}0.00 \\
0.00 \\
0.00 \\
0.01 \\
0.00\end{array}$ & $\begin{array}{l}1120 \\
1125 \\
1130 \\
1135 \\
1140\end{array}$ & $\begin{array}{l}355.0 \\
340.0 \\
327.0 \\
302.0 \\
281.0\end{array}$ & $\begin{array}{l}0.02 \\
0.02 \\
0.02 \\
0.03 \\
0.02\end{array}$ & $\begin{array}{l}1645 \\
1650 \\
1655 \\
1700 \\
1705\end{array}$ & $\begin{array}{l}93.8 \\
86.4 \\
81.2 \\
77.5 \\
72.5\end{array}$ & $\begin{array}{l}0.00 \\
0.00 \\
0.00 \\
0.00 \\
0.00\end{array}$ \\
\hline $\begin{array}{l}0620 \\
0625 \\
0630 \\
0635 \\
0640\end{array}$ & $\begin{array}{l}7.4 \\
7.4 \\
7.4 \\
7.4 \\
7.4\end{array}$ & $\begin{array}{l}0.00 \\
0.01 \\
0.00 \\
0.00 \\
0.01\end{array}$ & $\begin{array}{l}1145 \\
1150 \\
1155 \\
1200 \\
1205\end{array}$ & $\begin{array}{l}265.0 \\
245.0 \\
224.0 \\
214.0 \\
203.0\end{array}$ & $\begin{array}{l}0.00 \\
0.01 \\
0.01 \\
0.00 \\
0.01\end{array}$ & $\begin{array}{l}1710 \\
1715 \\
1720 \\
1725 \\
1730\end{array}$ & $\begin{array}{l}68.7 \\
63.9 \\
60.4 \\
57.6 \\
54.8\end{array}$ & $\begin{array}{l}0.00 \\
0.00 \\
0.00 \\
0.00 \\
0.00\end{array}$ \\
\hline $\begin{array}{l}0645 \\
0650 \\
0655 \\
0700 \\
0705\end{array}$ & $\begin{array}{ll}7 & 4 \\
7 & 4 \\
7 & 4 \\
7 & 4 \\
7 & 4\end{array}$ & $\begin{array}{l}0.01 \\
0.02 \\
0.00 \\
0.02 \\
0.02\end{array}$ & $\begin{array}{l}1210 \\
1215 \\
1220 \\
1225 \\
1230\end{array}$ & $\begin{array}{l}191.0 \\
188.0 \\
177.0 \\
175.0 \\
171.0\end{array}$ & $\begin{array}{l}0.01 \\
0.00 \\
0.00 \\
0.01 \\
0.02\end{array}$ & $\begin{array}{l}1735 \\
1740 \\
1745 \\
1750 \\
1755\end{array}$ & $\begin{array}{l}52.1 \\
51.6 \\
47.3 \\
44.0 \\
42.1\end{array}$ & $\begin{array}{l}0.00 \\
0.00 \\
0.00 \\
0.00 \\
0.00\end{array}$ \\
\hline
\end{tabular}


Table 26. - Streamflow and rainfall at station 02145940, Little Dutchman Creek tributary at Rock Hill, September $9-10,1988--$ Continued

\begin{tabular}{|c|c|c|c|c|c|c|c|c|}
\hline $\begin{array}{l}\text { Time } \\
\text { (hours) }\end{array}$ & $\begin{array}{l}\text { Streamflow } \\
\text { (cubic feet } \\
\text { per second) }\end{array}$ & $\begin{array}{l}\text { Rain- } \\
\text { fall } \\
\text { (inches) }\end{array}$ & $\begin{array}{l}\text { Time } \\
\text { (hours) }\end{array}$ & $\begin{array}{l}\text { Streamflow } \\
\text { (cubic feet } \\
\text { per second) }\end{array}$ & $\begin{array}{l}\text { Rain- } \\
\text { fall } \\
\text { (inches) }\end{array}$ & $\begin{array}{l}\text { Time } \\
\text { (hours) }\end{array}$ & $\begin{array}{l}\text { Streamflow } \\
\text { (cubic feet } \\
\text { per second) }\end{array}$ & $\begin{array}{l}\text { Rain- } \\
\text { fall } \\
\text { (inches) }\end{array}$ \\
\hline $\begin{array}{l}1800 \\
1805 \\
1810 \\
1815 \\
1820\end{array}$ & $\begin{array}{l}39.7 \\
37.4 \\
36.2 \\
34.0 \\
32.4\end{array}$ & $\begin{array}{l}0.00 \\
0.00 \\
0.00 \\
0.00 \\
0.00\end{array}$ & $\begin{array}{l}2325 \\
2330 \\
2335 \\
2340 \\
2345\end{array}$ & $\begin{array}{l}8.6 \\
8.4 \\
8.4 \\
8.4 \\
8.1\end{array}$ & $\begin{array}{l}0.00 \\
0.00 \\
0.00 \\
0.00 \\
0.00\end{array}$ & $\begin{array}{l}0445 \\
0450 \\
0455 \\
0500 \\
0505\end{array}$ & $\begin{array}{l}4.4 \\
4.4 \\
4.4 \\
4.2 \\
4.2\end{array}$ & $\begin{array}{l}0.00 \\
0.00 \\
0.00 \\
0.00 \\
0.00\end{array}$ \\
\hline $\begin{array}{l}1825 \\
1830 \\
1835 \\
1840 \\
1845\end{array}$ & $\begin{array}{l}30.8 \\
29.8 \\
28.8 \\
27.4 \\
26.9\end{array}$ & $\begin{array}{l}0.00 \\
0.00 \\
0.01 \\
0.00 \\
0.00\end{array}$ & $\begin{array}{l}2350 \\
2355 \\
\text { September } \\
0000 \\
0005\end{array}$ & $\begin{aligned} 7.9 \\
7.9 \\
10, \\
1988 \\
7.6 \\
7.6\end{aligned}$ & $\begin{array}{l}0.00 \\
0.00 \\
0.00 \\
0.00\end{array}$ & $\begin{array}{l}0510 \\
0515 \\
0520 \\
0525 \\
0530\end{array}$ & $\begin{array}{l}4.2 \\
4.2 \\
4.2 \\
4.2 \\
4.2\end{array}$ & $\begin{array}{l}0.00 \\
0.00 \\
0.00 \\
0.01 \\
0.00\end{array}$ \\
\hline $\begin{array}{l}1850 \\
1855 \\
1900 \\
1905 \\
1910\end{array}$ & $\begin{array}{l}25.5 \\
25.0 \\
24.1 \\
23.3 \\
22.8\end{array}$ & $\begin{array}{l}0.00 \\
0.00 \\
0.00 \\
0.00 \\
0.00\end{array}$ & $\begin{array}{l}0010 \\
0015 \\
0020 \\
0025 \\
0030\end{array}$ & $\begin{array}{l}7.6 \\
7.4 \\
7.4 \\
7.2 \\
7.2\end{array}$ & $\begin{array}{l}0.00 \\
0.00 \\
0.00 \\
0.00 \\
0.00\end{array}$ & $\begin{array}{l}0535 \\
0540 \\
0545 \\
0550 \\
0555\end{array}$ & $\begin{array}{l}4.2 \\
4.2 \\
4.2 \\
4.0 \\
4.0\end{array}$ & $\begin{array}{l}0.00 \\
0.00 \\
0.00 \\
0.00 \\
0.00\end{array}$ \\
\hline $\begin{array}{l}1915 \\
1920 \\
1925 \\
1930 \\
1935\end{array}$ & $\begin{array}{l}22.0 \\
21.5 \\
20.1 \\
20.1 \\
19.7\end{array}$ & $\begin{array}{l}0.00 \\
0.00 \\
0.01 \\
0.00 \\
0.00\end{array}$ & $\begin{array}{l}0035 \\
0040 \\
0045 \\
0050 \\
0055\end{array}$ & $\begin{array}{l}6.9 \\
5.9 \\
6.7 \\
6.7 \\
6.7\end{array}$ & $\begin{array}{l}0.00 \\
0.00 \\
0.00 \\
0.00 \\
0.00\end{array}$ & $\begin{array}{l}0600 \\
0605 \\
0610 \\
0615 \\
0620\end{array}$ & $\begin{array}{l}4.0 \\
4.0 \\
4.0 \\
4.0 \\
4.0\end{array}$ & $\begin{array}{l}0.00 \\
0.00 \\
0.00 \\
0.00 \\
0.00\end{array}$ \\
\hline $\begin{array}{l}1940 \\
1945 \\
1950 \\
1955 \\
2000\end{array}$ & $\begin{array}{l}18.8 \\
18.8 \\
17.9 \\
17.5 \\
17.1\end{array}$ & $\begin{array}{l}0.00 \\
0.00 \\
0.00 \\
0.00 \\
0.00\end{array}$ & $\begin{array}{l}0100 \\
0105 \\
0110 \\
0115 \\
0120\end{array}$ & $\begin{array}{l}6.5 \\
6.5 \\
6.5 \\
6.5 \\
6.2\end{array}$ & $\begin{array}{l}0.00 \\
0.00 \\
0.00 \\
0.00 \\
0.00\end{array}$ & $\begin{array}{l}0625 \\
0630 \\
0635 \\
0640 \\
0645\end{array}$ & $\begin{array}{l}4.0 \\
3.7 \\
3.7 \\
3.7 \\
3.7\end{array}$ & $\begin{array}{l}0.00 \\
0.00 \\
0.00 \\
0.00 \\
0.00\end{array}$ \\
\hline $\begin{array}{l}2005 \\
2010 \\
2015 \\
2020 \\
2025\end{array}$ & $\begin{array}{l}16.7 \\
16.7 \\
16.3 \\
15.9 \\
15.5\end{array}$ & $\begin{array}{l}0.00 \\
0.00 \\
0.00 \\
0.00 \\
0.00\end{array}$ & $\begin{array}{l}0125 \\
0130 \\
0135 \\
0140 \\
0145\end{array}$ & $\begin{array}{l}6.2 \\
6.0 \\
6.0 \\
5.8 \\
5.8\end{array}$ & $\begin{array}{l}0.00 \\
0.00 \\
0.00 \\
0.00 \\
0.00\end{array}$ & $\begin{array}{l}0650 \\
0655 \\
0700 \\
0705 \\
0710\end{array}$ & $\begin{array}{l}3.7 \\
3.7 \\
3.7 \\
3.7 \\
3.7\end{array}$ & $\begin{array}{l}0.00 \\
0.00 \\
0.00 \\
0.00 \\
0.00\end{array}$ \\
\hline $\begin{array}{l}2030 \\
2035 \\
2040 \\
2045 \\
2050\end{array}$ & $\begin{array}{l}15.1 \\
14.8 \\
14.4 \\
14.0 \\
13.7\end{array}$ & $\begin{array}{l}0.00 \\
0.00 \\
0.00 \\
0.00 \\
0.00\end{array}$ & $\begin{array}{l}0150 \\
0155 \\
0200 \\
0205 \\
0210\end{array}$ & $\begin{array}{l}5.8 \\
5.8 \\
5.6 \\
5.6 \\
5.6\end{array}$ & $\begin{array}{l}0.00 \\
0.00 \\
0.00 \\
0.00 \\
0.00\end{array}$ & $\begin{array}{l}0715 \\
0720 \\
0725 \\
0730 \\
0735\end{array}$ & $\begin{array}{l}3.7 \\
3.7 \\
3.5 \\
3.7 \\
3.5\end{array}$ & $\begin{array}{l}0.00 \\
0.00 \\
0.00 \\
0.00 \\
0.00\end{array}$ \\
\hline $\begin{array}{l}2055 \\
2100 \\
2105 \\
2110 \\
2115\end{array}$ & $\begin{array}{l}13.7 \\
13.3 \\
13.3 \\
13.0 \\
12.7\end{array}$ & $\begin{array}{l}0.00 \\
0.00 \\
0.00 \\
0.00 \\
0.00\end{array}$ & $\begin{array}{l}0215 \\
0220 \\
0225 \\
0230 \\
0235\end{array}$ & $\begin{array}{l}5.6 \\
5.4 \\
5.4 \\
5.4 \\
5.4\end{array}$ & $\begin{array}{l}0.00 \\
0.00 \\
0.00 \\
0.00 \\
0.00\end{array}$ & $\begin{array}{l}0740 \\
0745 \\
0750 \\
0755 \\
0800\end{array}$ & $\begin{array}{l}3.5 \\
3.5 \\
3.5 \\
3.5 \\
3.5\end{array}$ & $\begin{array}{l}0.00 \\
0.00 \\
0.00 \\
0.00 \\
0.00\end{array}$ \\
\hline $\begin{array}{l}2120 \\
2125 \\
2130 \\
2135 \\
2140\end{array}$ & $\begin{array}{l}12.7 \\
12.3 \\
12.3 \\
12.0 \\
11.7\end{array}$ & $\begin{array}{l}0.01 \\
0.00 \\
0.00 \\
0.00 \\
0.00\end{array}$ & $\begin{array}{l}0240 \\
0245 \\
0250 \\
0255 \\
0300\end{array}$ & $\begin{array}{l}5.2 \\
5.2 \\
5.2 \\
5.2 \\
5.2\end{array}$ & $\begin{array}{l}0.00 \\
0.00 \\
0.00 \\
0.00 \\
0.00\end{array}$ & $\begin{array}{l}0805 \\
0810 \\
0815 \\
0820 \\
0825\end{array}$ & $\begin{array}{l}3.2 \\
3.2 \\
3.2 \\
3.2 \\
3.2\end{array}$ & $\begin{array}{l}0.00 \\
0.00 \\
0.00 \\
0.00 \\
0.00\end{array}$ \\
\hline $\begin{array}{l}2145 \\
2150 \\
2155 \\
2200 \\
2205\end{array}$ & $\begin{array}{l}11.7 \\
11.4 \\
11.1 \\
10.8 \\
10.8\end{array}$ & $\begin{array}{l}0.00 \\
0.00 \\
0.00 \\
0.00 \\
0.00\end{array}$ & $\begin{array}{l}0305 \\
0310 \\
0315 \\
0320 \\
0325\end{array}$ & $\begin{array}{l}5.2 \\
5.2 \\
5.0 \\
5.0 \\
4.8\end{array}$ & $\begin{array}{l}0.00 \\
0.00 \\
0.00 \\
0.00 \\
0.00\end{array}$ & $\begin{array}{l}0830 \\
0835 \\
0840 \\
0845 \\
0850\end{array}$ & $\begin{array}{l}3.2 \\
3.2 \\
3.2 \\
3.2 \\
3.2\end{array}$ & $\begin{array}{l}0.00 \\
0.00 \\
0.00 \\
0.00 \\
0.00\end{array}$ \\
\hline $\begin{array}{l}2210 \\
2215 \\
2220 \\
2225 \\
2230\end{array}$ & $\begin{array}{r}10.8 \\
10.5 \\
10.2 \\
9.9 \\
9.9\end{array}$ & $\begin{array}{l}0.00 \\
0.00 \\
0.00 \\
0.00 \\
0.00\end{array}$ & $\begin{array}{l}0330 \\
0335 \\
0340 \\
0345 \\
0350\end{array}$ & $\begin{array}{l}4.8 \\
4.8 \\
4.8 \\
4.8 \\
4.8\end{array}$ & $\begin{array}{l}0.00 \\
0.00 \\
0.00 \\
0.00 \\
0.00\end{array}$ & $\begin{array}{l}0855 \\
0900 \\
0905 \\
0910 \\
0915\end{array}$ & $\begin{array}{l}3.2 \\
3.0 \\
3.0 \\
3.0 \\
3.0\end{array}$ & $\begin{array}{l}0.00 \\
0.00 \\
0.00 \\
0.00 \\
0.00\end{array}$ \\
\hline $\begin{array}{l}2235 \\
2240 \\
2245 \\
2250 \\
2255\end{array}$ & $\begin{array}{l}9.7 \\
9.7 \\
9.4 \\
9.4 \\
9.1\end{array}$ & $\begin{array}{l}0.00 \\
0.00 \\
0.00 \\
0.00 \\
0.00\end{array}$ & $\begin{array}{l}0355 \\
0400 \\
0405 \\
0410 \\
0415\end{array}$ & $\begin{array}{l}4.8 \\
4.6 \\
4.6 \\
4.6 \\
4.6\end{array}$ & $\begin{array}{l}0.00 \\
0.00 \\
0.00 \\
0.00 \\
0.00\end{array}$ & $\begin{array}{l}0920 \\
0925 \\
0930 \\
0935 \\
0940\end{array}$ & $\begin{array}{l}3.0 \\
3.0 \\
3.0 \\
3.0 \\
3.0\end{array}$ & $\begin{array}{l}0.00 \\
0.00 \\
0.00 \\
0.00 \\
0.00\end{array}$ \\
\hline $\begin{array}{l}2300 \\
2305 \\
2310 \\
2315 \\
2320\end{array}$ & $\begin{array}{l}9.1 \\
9.1 \\
8.9 \\
8.6 \\
8.6\end{array}$ & $\begin{array}{l}0.00 \\
0.00 \\
0.00 \\
0.00 \\
0.00\end{array}$ & $\begin{array}{l}0420 \\
0425 \\
0430 \\
0435 \\
0440\end{array}$ & $\begin{array}{l}4.4 \\
4.4 \\
4.4 \\
4.4 \\
4.4\end{array}$ & $\begin{array}{l}0.00 \\
0.00 \\
0.00 \\
0.00 \\
0.00\end{array}$ & $\begin{array}{l}0945 \\
0950 \\
0955 \\
1000 \\
1005\end{array}$ & $\begin{array}{l}3.0 \\
3.0 \\
2.8 \\
2.8 \\
2.8\end{array}$ & $\begin{array}{l}0.00 \\
0.00 \\
0.00 \\
0.00 \\
0.00\end{array}$ \\
\hline
\end{tabular}


Table 26.--Streamflow and rainfall at station 02145940, Little Dutchman Creek tributary at Rock Hill, September $9-10,1988^{--C o n t i n u e d ~}$

\begin{tabular}{|c|c|c|c|c|c|c|c|c|}
\hline $\begin{array}{l}\text { Time } \\
\text { (hours) }\end{array}$ & $\begin{array}{l}\text { Streamflow } \\
\text { (cubic feet } \\
\text { per second) }\end{array}$ & $\begin{array}{l}\text { Rain- } \\
\text { fall } \\
\text { (inches) }\end{array}$ & $\begin{array}{l}\text { Time } \\
\text { (hours) }\end{array}$ & $\begin{array}{l}\text { Streamflow } \\
\text { (cubic feet } \\
\text { per second) }\end{array}$ & $\begin{array}{l}\text { Rain- } \\
\text { fall } \\
\text { (inches) }\end{array}$ & $\begin{array}{l}\text { Time } \\
\text { (hours) }\end{array}$ & $\begin{array}{l}\text { Streamflow } \\
\text { (cubic feet } \\
\text { per second) }\end{array}$ & $\begin{array}{l}\text { Rain- } \\
\text { fall } \\
\text { (inches) }\end{array}$ \\
\hline $\begin{array}{l}1010 \\
1015 \\
1020 \\
1025 \\
1030\end{array}$ & $\begin{array}{l}2.8 \\
2.8 \\
2.8 \\
2.8 \\
2.8\end{array}$ & $\begin{array}{l}0.00 \\
0.00 \\
0.00 \\
0.00 \\
0.00\end{array}$ & $\begin{array}{l}1230 \\
1235 \\
1240 \\
1245 \\
1250\end{array}$ & $\begin{array}{l}2.4 \\
2.4 \\
2.4 \\
2.4 \\
2.4\end{array}$ & $\begin{array}{l}0.00 \\
0.00 \\
0.00 \\
0.00 \\
0.00\end{array}$ & $\begin{array}{l}1450 \\
1455 \\
1500 \\
1505 \\
1510\end{array}$ & $\begin{array}{l}2.1 \\
2.1 \\
2.1 \\
2.1 \\
2.1\end{array}$ & $\begin{array}{l}0.00 \\
0.00 \\
0.00 \\
0.00 \\
0.00\end{array}$ \\
\hline $\begin{array}{l}1035 \\
1040 \\
1045 \\
1050 \\
1055\end{array}$ & $\begin{array}{l}2.8 \\
2.8 \\
2.8 \\
2.8 \\
2.6\end{array}$ & $\begin{array}{l}0.00 \\
0.00 \\
0.00 \\
0.00 \\
0.00\end{array}$ & $\begin{array}{l}1255 \\
1300 \\
1305 \\
1310 \\
1315\end{array}$ & $\begin{array}{l}2.4 \\
2.2 \\
2.2 \\
2.2 \\
2.2\end{array}$ & $\begin{array}{l}0.00 \\
0.00 \\
0.00 \\
0.00 \\
0.00\end{array}$ & $\begin{array}{l}1515 \\
1520 \\
1525 \\
1530 \\
1535\end{array}$ & $\begin{array}{l}2.1 \\
2.1 \\
1.9 \\
1.9 \\
1.9\end{array}$ & $\begin{array}{l}0.00 \\
0.00 \\
0.00 \\
0.00 \\
0.00\end{array}$ \\
\hline $\begin{array}{l}1100 \\
1105 \\
1110 \\
1115 \\
1120\end{array}$ & $\begin{array}{l}2.6 \\
2.6 \\
2.6 \\
2.6 \\
2.6\end{array}$ & $\begin{array}{l}0.00 \\
0.00 \\
0.00 \\
0.00 \\
0.00\end{array}$ & $\begin{array}{l}1320 \\
1325 \\
1330 \\
1335 \\
1340\end{array}$ & $\begin{array}{l}2.2 \\
2.2 \\
2.2 \\
2.2 \\
2.2\end{array}$ & $\begin{array}{l}0.00 \\
0.00 \\
0.00 \\
0.00 \\
0.00\end{array}$ & $\begin{array}{l}1540 \\
1545 \\
1550 \\
1555 \\
1600\end{array}$ & $\begin{array}{l}1.9 \\
1.9 \\
1.9 \\
1.9 \\
1.9\end{array}$ & $\begin{array}{l}0.00 \\
0.00 \\
0.00 \\
0.00 \\
0.00\end{array}$ \\
\hline $\begin{array}{l}1125 \\
1130 \\
1135 \\
1140 \\
1145\end{array}$ & $\begin{array}{l}2.6 \\
2.6 \\
2.6 \\
2.6 \\
2.6\end{array}$ & $\begin{array}{l}0.00 \\
0.00 \\
0.00 \\
0.00 \\
0.00\end{array}$ & $\begin{array}{l}1345 \\
1350 \\
1355 \\
1400 \\
1405\end{array}$ & $\begin{array}{l}2.2 \\
2.2 \\
2.2 \\
2.2 \\
2.2\end{array}$ & $\begin{array}{l}0.00 \\
0.00 \\
0.00 \\
0.00 \\
0.00\end{array}$ & $\begin{array}{l}1605 \\
1610 \\
1615 \\
1620 \\
1625\end{array}$ & $\begin{array}{l}1.9 \\
1.9 \\
1.9 \\
1.9 \\
1.9\end{array}$ & $\begin{array}{l}0.00 \\
0.00 \\
0.00 \\
0.00 \\
0.00\end{array}$ \\
\hline $\begin{array}{l}1150 \\
1155 \\
1200 \\
1205 \\
1210\end{array}$ & $\begin{array}{l}2.6 \\
2.4 \\
2.4 \\
2.4 \\
2.4\end{array}$ & $\begin{array}{l}0.00 \\
0.00 \\
0.00 \\
0.00 \\
0.00\end{array}$ & $\begin{array}{l}1410 \\
1415 \\
1420 \\
1425 \\
1430\end{array}$ & $\begin{array}{l}2.2 \\
2.2 \\
2.1 \\
2.1 \\
2.1\end{array}$ & $\begin{array}{l}0.00 \\
0.00 \\
0.00 \\
0.00 \\
0.00\end{array}$ & $\begin{array}{l}1630 \\
1635 \\
1640 \\
1645 \\
1650\end{array}$ & $\begin{array}{l}1.9 \\
1.9 \\
1.9 \\
1.9 \\
1.9\end{array}$ & $\begin{array}{l}0.00 \\
0.00 \\
0.00 \\
0.00 \\
0.00\end{array}$ \\
\hline $\begin{array}{l}1215 \\
1220 \\
1225\end{array}$ & $\begin{array}{l}2.4 \\
2.4 \\
2.4\end{array}$ & $\begin{array}{l}0.00 \\
0.00 \\
0.00\end{array}$ & $\begin{array}{l}1435 \\
1440 \\
1445\end{array}$ & $\begin{array}{l}2.1 \\
2.1 \\
2.1\end{array}$ & $\begin{array}{l}0.00 \\
0.00 \\
0.00\end{array}$ & $\begin{array}{l}1655 \\
1700\end{array}$ & $\begin{array}{l}1.9 \\
1.8\end{array}$ & $\begin{array}{l}0.00 \\
0.00\end{array}$ \\
\hline
\end{tabular}




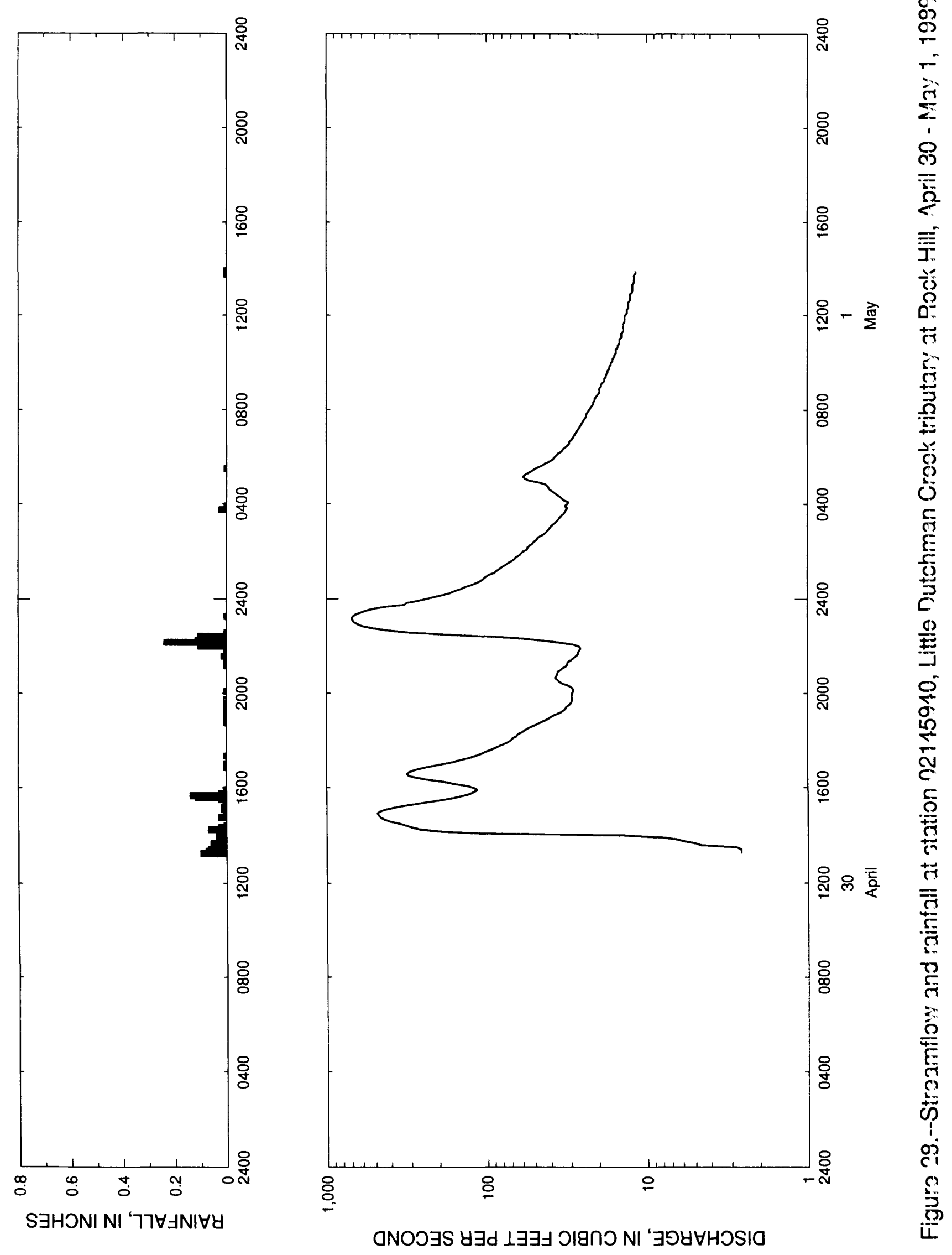


Table 27. - Streamflow and rainfall at station 02145940, Little Dutchman Creek tributary at Rock Hill, April 30 - May 1, 1989

\begin{tabular}{|c|c|c|c|c|c|c|c|c|}
\hline $\begin{array}{l}\text { Time } \\
\text { (hours) }\end{array}$ & $\begin{array}{l}\text { Streamflow } \\
\text { (cubic feet } \\
\text { per second) }\end{array}$ & $\begin{array}{l}\text { Rain- } \\
\text { fall } \\
\text { (inches) }\end{array}$ & $\begin{array}{l}\text { Time } \\
\text { (hours) }\end{array}$ & $\begin{array}{l}\text { Streamflow } \\
\text { (cubic feet } \\
\text { per second) }\end{array}$ & $\begin{array}{l}\text { Rain- } \\
\text { fall } \\
\text { (inches) }\end{array}$ & $\begin{array}{l}\text { Time } \\
\text { (hours) }\end{array}$ & $\begin{array}{l}\text { Streamflow } \\
\text { (cubic feet } \\
\text { per second) }\end{array}$ & $\begin{array}{l}\text { Rain- } \\
\text { fall } \\
\text { (inches) }\end{array}$ \\
\hline $\begin{array}{l}\text { Apri1 } 30, \\
1315 \\
1320 \\
1325 \\
1330\end{array}$ & $\begin{array}{r}1989 \\
2.6 \\
2.6 \\
2.6 \\
2.8\end{array}$ & $\begin{array}{l}0.10 \\
0.08 \\
0.07 \\
0.03\end{array}$ & $\begin{array}{l}1835 \\
1840 \\
1845 \\
1850 \\
1855\end{array}$ & $\begin{array}{l}52.6 \\
49.3 \\
46.6 \\
44.0 \\
41.5\end{array}$ & $\begin{array}{l}0.00 \\
0.00 \\
0.01 \\
0.01 \\
0.00\end{array}$ & $\begin{array}{c}\text { May 1, } 1 \\
0000 \\
0005 \\
0010 \\
0015\end{array}$ & $\begin{array}{r}241.0 \\
214.0 \\
190.0 \\
170.0\end{array}$ & $\begin{array}{l}0.00 \\
0.00 \\
0.00 \\
0.00\end{array}$ \\
\hline $\begin{array}{l}1335 \\
1340 \\
1345 \\
1350 \\
1355\end{array}$ & $\begin{array}{l}4.6 \\
5.0 \\
5.8 \\
6.5 \\
8.1\end{array}$ & $\begin{array}{l}0.01 \\
0.06 \\
0.04 \\
0.02 \\
0.03\end{array}$ & $\begin{array}{l}1900 \\
1905 \\
1910 \\
1915 \\
1920\end{array}$ & $\begin{array}{l}39.7 \\
37.9 \\
35.1 \\
33.5 \\
32.4\end{array}$ & $\begin{array}{l}0.01 \\
0.00 \\
0.01 \\
0.01 \\
0.00\end{array}$ & $\begin{array}{l}0020 \\
0025 \\
0030 \\
0035 \\
0040\end{array}$ & $\begin{array}{l}159.0 \\
145.0 \\
137.0 \\
125.0 \\
117.0\end{array}$ & $\begin{array}{l}0.00 \\
0.00 \\
0.00 \\
0.00 \\
0.00\end{array}$ \\
\hline $\begin{array}{l}1400 \\
1405 \\
1410 \\
1415 \\
1420\end{array}$ & $\begin{array}{r}13.7 \\
99.3 \\
192.0 \\
261.0 \\
295.0\end{array}$ & $\begin{array}{l}0.04 \\
0.03 \\
0.02 \\
0.07 \\
0.03\end{array}$ & $\begin{array}{l}1925 \\
1930 \\
1935 \\
1940 \\
1945\end{array}$ & $\begin{array}{l}31.9 \\
30.8 \\
29.8 \\
29.3 \\
29.3\end{array}$ & $\begin{array}{l}0.00 \\
0.01 \\
0.00 \\
0.01 \\
0.01\end{array}$ & $\begin{array}{l}0045 \\
0050 \\
0055 \\
0100 \\
0105\end{array}$ & $\begin{array}{r}110.0 \\
105.0 \\
101.0 \\
97.2 \\
89.7\end{array}$ & $\begin{array}{l}0.00 \\
0.00 \\
0.00 \\
0.00 \\
0.00\end{array}$ \\
\hline $\begin{array}{l}1425 \\
1430 \\
1435 \\
1440 \\
1445\end{array}$ & $\begin{array}{l}322.0 \\
356.0 \\
403.0 \\
436.0 \\
461.0\end{array}$ & $\begin{array}{l}0.01 \\
0.00 \\
0.00 \\
0.00 \\
0.03\end{array}$ & $\begin{array}{l}1950 \\
1955 \\
2000 \\
2005 \\
2010\end{array}$ & $\begin{array}{l}29.3 \\
29.3 \\
29.3 \\
28.8 \\
28.8\end{array}$ & $\begin{array}{l}0.00 \\
0.00 \\
0.00 \\
0.01 \\
0.00\end{array}$ & $\begin{array}{l}0110 \\
0115 \\
0120 \\
0125 \\
0130\end{array}$ & $\begin{array}{l}87.1 \\
83.2 \\
80.0 \\
76.2 \\
73.7\end{array}$ & $\begin{array}{l}0.00 \\
0.00 \\
0.00 \\
0.00 \\
0.00\end{array}$ \\
\hline $\begin{array}{l}1450 \\
1455 \\
1500 \\
1505 \\
1510\end{array}$ & $\begin{array}{l}474.0 \\
485.0 \\
466.0 \\
430.0 \\
382.0\end{array}$ & $\begin{array}{l}0.01 \\
0.00 \\
0.00 \\
0.02 \\
0.02\end{array}$ & $\begin{array}{l}2015 \\
2020 \\
2025 \\
2030 \\
2035\end{array}$ & $\begin{array}{l}29.3 \\
30.8 \\
33.5 \\
35.1 \\
36.2\end{array}$ & $\begin{array}{l}0.00 \\
0.00 \\
0.00 \\
0.00 \\
0.00\end{array}$ & $\begin{array}{l}0135 \\
0140 \\
0145 \\
0150 \\
0155\end{array}$ & $\begin{array}{l}70.0 \\
66.9 \\
65.7 \\
62.7 \\
61.0\end{array}$ & $\begin{array}{l}0.00 \\
0.00 \\
0.00 \\
0.00 \\
0.00\end{array}$ \\
\hline $\begin{array}{l}1515 \\
1520 \\
1525 \\
1530 \\
1535\end{array}$ & $\begin{array}{l}331.0 \\
276.0 \\
228.0 \\
191.0 \\
161.0\end{array}$ & $\begin{array}{l}0.00 \\
0.00 \\
0.01 \\
0.03 \\
0.12\end{array}$ & $\begin{array}{l}2040 \\
2045 \\
2050 \\
2055 \\
2100\end{array}$ & $\begin{array}{l}37.4 \\
36.8 \\
36.2 \\
36.2 \\
34.5\end{array}$ & $\begin{array}{l}0.00 \\
0.00 \\
0.00 \\
0.00 \\
0.00\end{array}$ & $\begin{array}{l}0200 \\
0205 \\
0210 \\
0215 \\
0220\end{array}$ & $\begin{array}{l}59.3 \\
55.9 \\
55.4 \\
53.7 \\
51.6\end{array}$ & $\begin{array}{l}0.00 \\
0.00 \\
0.00 \\
0.00 \\
0.00\end{array}$ \\
\hline $\begin{array}{l}1540 \\
1545 \\
1550 \\
1555 \\
1600\end{array}$ & $\begin{array}{l}142.0 \\
128.0 \\
120.0 \\
114.0 \\
120.0\end{array}$ & $\begin{array}{l}0.14 \\
0.03 \\
0.00 \\
0.01 \\
0.00\end{array}$ & $\begin{array}{l}2105 \\
2110 \\
2115 \\
2120 \\
2125\end{array}$ & $\begin{array}{l}33.5 \\
31.9 \\
31.3 \\
31.3 \\
29.8\end{array}$ & $\begin{array}{l}0.00 \\
0.01 \\
0.01 \\
0.00 \\
0.01\end{array}$ & $\begin{array}{l}0225 \\
0230 \\
0235 \\
0240 \\
0245\end{array}$ & $\begin{array}{l}50.5 \\
48.6 \\
48.0 \\
45.3 \\
43.4\end{array}$ & $\begin{array}{l}0.00 \\
0.00 \\
0.00 \\
0.00 \\
0.00\end{array}$ \\
\hline $\begin{array}{l}1605 \\
1610 \\
1615 \\
1620 \\
1625\end{array}$ & $\begin{array}{l}132.0 \\
159.0 \\
186.0 \\
233.0 \\
276.0\end{array}$ & $\begin{array}{l}0.00 \\
0.00 \\
0.00 \\
0.00 \\
0.00\end{array}$ & $\begin{array}{l}2130 \\
2135 \\
2140 \\
2145 \\
2150\end{array}$ & $\begin{array}{l}28.8 \\
27.8 \\
26.9 \\
26.9 \\
26.4\end{array}$ & $\begin{array}{l}0.00 \\
0.02 \\
0.01 \\
0.01 \\
0.00\end{array}$ & $\begin{array}{l}0250 \\
0255 \\
0300 \\
0305 \\
0310\end{array}$ & $\begin{array}{l}42.1 \\
40.9 \\
40.3 \\
39.1 \\
37.9\end{array}$ & $\begin{array}{l}0.00 \\
0.00 \\
0.00 \\
0.00 \\
0.00\end{array}$ \\
\hline $\begin{array}{l}1630 \\
1635 \\
1640 \\
1645 \\
1650\end{array}$ & $\begin{array}{l}308.0 \\
315.0 \\
305.0 \\
280.0 \\
249.0\end{array}$ & $\begin{array}{l}0.00 \\
0.00 \\
0.00 \\
0.00 \\
0.01\end{array}$ & $\begin{array}{l}2155 \\
2200 \\
2205 \\
2210 \\
2215\end{array}$ & $\begin{array}{l}25.9 \\
26.4 \\
28.8 \\
35.1 \\
44.7\end{array}$ & $\begin{array}{l}0.01 \\
0.11 \\
0.11 \\
0.24 \\
0.12\end{array}$ & $\begin{array}{l}0315 \\
0320 \\
0325 \\
0330 \\
0335\end{array}$ & $\begin{array}{l}36.8 \\
35.7 \\
35.1 \\
34.0 \\
32.9\end{array}$ & $\begin{array}{l}0.00 \\
0.00 \\
0.00 \\
0.00 \\
0.00\end{array}$ \\
\hline $\begin{array}{l}1655 \\
1700 \\
1705 \\
1710 \\
1715\end{array}$ & $\begin{array}{l}216.0 \\
188.0 \\
162.0 \\
146.0 \\
130.0\end{array}$ & $\begin{array}{l}0.00 \\
0.01 \\
0.00 \\
0.00 \\
0.00\end{array}$ & $\begin{array}{l}2220 \\
2225 \\
2230 \\
2235 \\
2240\end{array}$ & $\begin{array}{r}60.4 \\
95.8 \\
181.0 \\
307.0 \\
417.0\end{array}$ & $\begin{array}{l}0.05 \\
0.11 \\
0.01 \\
0.01 \\
0.00\end{array}$ & $\begin{array}{l}0340 \\
0345 \\
0350 \\
0355 \\
0400\end{array}$ & $\begin{array}{l}32.4 \\
31.9 \\
31.3 \\
32.4 \\
31.3\end{array}$ & $\begin{array}{l}0.00 \\
0.03 \\
0.00 \\
0.01 \\
0.00\end{array}$ \\
\hline $\begin{array}{l}1720 \\
1725 \\
1730 \\
1735 \\
1740\end{array}$ & $\begin{array}{r}119.0 \\
110.0 \\
103.0 \\
94.5 \\
88.4\end{array}$ & $\begin{array}{l}0.01 \\
0.00 \\
0.00 \\
0.00 \\
0.00\end{array}$ & $\begin{array}{l}2245 \\
2250 \\
2255 \\
2300 \\
2305\end{array}$ & $\begin{array}{l}514.0 \\
599.0 \\
639.0 \\
676.0 \\
691.0\end{array}$ & $\begin{array}{l}0.00 \\
0.00 \\
0.00 \\
0.00 \\
0.00\end{array}$ & $\begin{array}{l}0405 \\
0410 \\
0415 \\
0420 \\
0425\end{array}$ & $\begin{array}{l}30.8 \\
32.9 \\
34.0 \\
35.1 \\
36.8\end{array}$ & $\begin{array}{l}0.00 \\
0.00 \\
0.00 \\
0.00 \\
0.00\end{array}$ \\
\hline $\begin{array}{l}1745 \\
1750 \\
1755 \\
1800 \\
1805\end{array}$ & $\begin{array}{l}83.2 \\
78.1 \\
73.7 \\
70.6 \\
68.7\end{array}$ & $\begin{array}{l}0.00 \\
0.00 \\
0.00 \\
0.00 \\
0.00\end{array}$ & $\begin{array}{l}2310 \\
2315 \\
2320 \\
2325 \\
2330\end{array}$ & $\begin{array}{l}700.0 \\
687.0 \\
662.0 \\
613.0 \\
567.0\end{array}$ & $\begin{array}{l}0.00 \\
0.01 \\
0.00 \\
0.00 \\
0.00\end{array}$ & $\begin{array}{l}0430 \\
0435 \\
0440 \\
0445 \\
0450\end{array}$ & $\begin{array}{l}37.9 \\
39.7 \\
40.9 \\
41.5 \\
42.8\end{array}$ & $\begin{array}{l}0.00 \\
0.00 \\
0.00 \\
0.00 \\
0.00\end{array}$ \\
\hline $\begin{array}{l}1810 \\
1815 \\
1820 \\
1825 \\
1830\end{array}$ & $\begin{array}{l}65.1 \\
63.9 \\
60.4 \\
58.1 \\
55.4\end{array}$ & $\begin{array}{l}0.00 \\
0.00 \\
0.00 \\
0.00 \\
0.00\end{array}$ & $\begin{array}{l}2335 \\
2340 \\
2345 \\
2350 \\
2355\end{array}$ & $\begin{array}{l}505.0 \\
431.0 \\
327.0 \\
318.0 \\
271.0\end{array}$ & $\begin{array}{l}0.00 \\
0.00 \\
0.00 \\
0.00 \\
0.00\end{array}$ & $\begin{array}{l}0455 \\
0500 \\
0505 \\
0510 \\
0515\end{array}$ & $\begin{array}{l}46.6 \\
54.3 \\
57.6 \\
59.3 \\
57.6\end{array}$ & $\begin{array}{l}0.00 \\
0.00 \\
0.00 \\
0.00 \\
0.00\end{array}$ \\
\hline
\end{tabular}


Table 27. - Streamflow and rainfall at station 02145940 , Little Dutchman Creek tributary at Rock Hil1, April 30 - May 1, 1989--Continued

\begin{tabular}{|c|c|c|c|c|c|c|c|c|}
\hline $\begin{array}{l}\text { Time } \\
\text { (hours) }\end{array}$ & $\begin{array}{l}\text { Streamflow } \\
\text { (cubic feet } \\
\text { per second) }\end{array}$ & $\begin{array}{l}\text { Rain- } \\
\text { fall } \\
\text { (inches) }\end{array}$ & $\begin{array}{l}\text { Time } \\
\text { (hours) }\end{array}$ & $\begin{array}{l}\text { Streamflow } \\
\text { (cubic feet } \\
\text { per second) }\end{array}$ & $\begin{array}{l}\text { Rain- } \\
\text { fall } \\
\text { (inches) }\end{array}$ & $\begin{array}{l}\text { Time } \\
\text { (hours) }\end{array}$ & $\begin{array}{l}\text { Streamflow } \\
\text { (cubic feet } \\
\text { per second) }\end{array}$ & $\begin{array}{l}\text { Rain- } \\
\text { fall } \\
\text { (inches) }\end{array}$ \\
\hline $\begin{array}{l}0520 \\
0525 \\
0530 \\
0535 \\
0540\end{array}$ & $\begin{array}{l}54.8 \\
52.1 \\
50.0 \\
47.3 \\
44.7\end{array}$ & $\begin{array}{l}0.00 \\
0.00 \\
0.01 \\
0.00 \\
0.00\end{array}$ & $\begin{array}{l}0815 \\
0820 \\
0825 \\
0830 \\
0835\end{array}$ & $\begin{array}{l}21.5 \\
21.5 \\
21.0 \\
21.0 \\
20.6\end{array}$ & $\begin{array}{l}0.00 \\
0.00 \\
0.00 \\
0.00 \\
0.00\end{array}$ & $\begin{array}{l}1110 \\
1115 \\
1120 \\
1125 \\
1130\end{array}$ & $\begin{array}{l}14.4 \\
14.4 \\
14.0 \\
14.0 \\
14.0\end{array}$ & $\begin{array}{l}0.00 \\
0.0 ? \\
0.0 ? \\
0.0 ? \\
0.0 ?\end{array}$ \\
\hline $\begin{array}{l}0545 \\
0550 \\
0555 \\
0600 \\
0605\end{array}$ & $\begin{array}{l}42.8 \\
40.3 \\
38.5 \\
37.9 \\
36.8\end{array}$ & $\begin{array}{l}0.00 \\
0.00 \\
0.00 \\
0.00 \\
0.00\end{array}$ & $\begin{array}{l}0840 \\
0845 \\
0850 \\
0855 \\
0900\end{array}$ & $\begin{array}{l}20.1 \\
19.7 \\
19.7 \\
19.7 \\
19.2\end{array}$ & $\begin{array}{l}0.00 \\
0.00 \\
0.00 \\
0.00 \\
0.00\end{array}$ & $\begin{array}{l}1135 \\
1140 \\
1145 \\
1150 \\
1155\end{array}$ & $\begin{array}{l}14.0 \\
14.0 \\
13.7 \\
13.7 \\
13.7\end{array}$ & $\begin{array}{l}0.00 \\
0.00 \\
0.07 \\
0.07 \\
0.07\end{array}$ \\
\hline $\begin{array}{l}0610 \\
0615 \\
0620 \\
0625 \\
0630\end{array}$ & $\begin{array}{l}35.7 \\
34.0 \\
33.5 \\
32.4 \\
31.3\end{array}$ & $\begin{array}{l}0.00 \\
0.00 \\
0.00 \\
0.00 \\
0.00\end{array}$ & $\begin{array}{l}0905 \\
0910 \\
0915 \\
0920 \\
0925\end{array}$ & $\begin{array}{l}19.2 \\
18.8 \\
18.3 \\
18.3 \\
17.9\end{array}$ & $\begin{array}{l}0.00 \\
0.00 \\
0.00 \\
0.00 \\
0.00\end{array}$ & $\begin{array}{l}1200 \\
1205 \\
1210 \\
1215 \\
1220\end{array}$ & $\begin{array}{l}13.7 \\
13.3 \\
13.3 \\
13.3 \\
13.0\end{array}$ & $\begin{array}{l}0.0 ? \\
0.07 \\
0.07 \\
0.07 \\
0.00\end{array}$ \\
\hline $\begin{array}{l}0635 \\
0640 \\
0645 \\
0650 \\
0655\end{array}$ & $\begin{array}{l}30.3 \\
30.3 \\
29.3 \\
28.8 \\
28.3\end{array}$ & $\begin{array}{l}0.00 \\
0.00 \\
0.00 \\
0.00 \\
0.00\end{array}$ & $\begin{array}{l}0930 \\
0935 \\
0940 \\
0945 \\
0950\end{array}$ & $\begin{array}{l}17.9 \\
17.5 \\
17.5 \\
17.1 \\
17.1\end{array}$ & $\begin{array}{l}0.00 \\
0.00 \\
0.00 \\
0.00 \\
0.00\end{array}$ & $\begin{array}{l}1225 \\
1230 \\
1235 \\
1240 \\
1245\end{array}$ & $\begin{array}{l}13.0 \\
13.0 \\
13.0 \\
12.7 \\
12.7\end{array}$ & $\begin{array}{l}0.0 n \\
0.0 n \\
0.07 \\
0.07 \\
0.00\end{array}$ \\
\hline $\begin{array}{l}0700 \\
0705 \\
0710 \\
0715 \\
0720\end{array}$ & $\begin{array}{l}27.8 \\
27.4 \\
26.9 \\
26.4 \\
25.9\end{array}$ & $\begin{array}{l}0.00 \\
0.00 \\
0.00 \\
0.00 \\
0.00\end{array}$ & $\begin{array}{l}0955 \\
1000 \\
1005 \\
1010 \\
1015\end{array}$ & $\begin{array}{l}16.7 \\
16.7 \\
16.3 \\
16.3 \\
15.9\end{array}$ & $\begin{array}{l}0.00 \\
0.00 \\
0.00 \\
0.00 \\
0.00\end{array}$ & $\begin{array}{l}1250 \\
1255 \\
1300 \\
1305 \\
1310\end{array}$ & $\begin{array}{l}12.7 \\
12.7 \\
12.3 \\
12.3 \\
12.3\end{array}$ & $\begin{array}{l}0.00 \\
0.00 \\
0.00 \\
0.00 \\
0.00\end{array}$ \\
\hline $\begin{array}{l}0725 \\
0730 \\
0735 \\
0740 \\
0745\end{array}$ & $\begin{array}{l}25.5 \\
25.0 \\
24.6 \\
24.1 \\
23.7\end{array}$ & $\begin{array}{l}0.00 \\
0.00 \\
0.00 \\
0.00 \\
0.00\end{array}$ & $\begin{array}{l}1020 \\
1025 \\
1030 \\
1035 \\
1040\end{array}$ & $\begin{array}{l}15.9 \\
15.5 \\
15.5 \\
15.5 \\
15.1\end{array}$ & $\begin{array}{l}0.00 \\
0.00 \\
0.00 \\
0.00 \\
0.00\end{array}$ & $\begin{array}{l}1315 \\
1320 \\
1325 \\
1330 \\
1335\end{array}$ & $\begin{array}{l}12.3 \\
12.3 \\
12.0 \\
12.0 \\
12.0\end{array}$ & $\begin{array}{l}0.00 \\
0.00 \\
0.00 \\
0.00 \\
0.00\end{array}$ \\
\hline $\begin{array}{l}0750 \\
0755 \\
0800 \\
0805 \\
0810\end{array}$ & $\begin{array}{l}23.7 \\
23.3 \\
22.8 \\
22.4 \\
22.0\end{array}$ & $\begin{array}{l}0.00 \\
0.00 \\
0.00 \\
0.00 \\
0.00\end{array}$ & $\begin{array}{l}1045 \\
1050 \\
1055 \\
1100 \\
1105\end{array}$ & $\begin{array}{l}15.1 \\
14.8 \\
14.8 \\
14.8 \\
14.4\end{array}$ & $\begin{array}{l}0.00 \\
0.00 \\
0.00 \\
0.00 \\
0.00\end{array}$ & $\begin{array}{l}1340 \\
1345 \\
1350 \\
1355 \\
1400\end{array}$ & $\begin{array}{l}12.0 \\
12.0 \\
11.7 \\
11.7 \\
11.7\end{array}$ & $\begin{array}{l}0.00 \\
0.01 \\
0.00 \\
0.01 \\
0.03\end{array}$ \\
\hline
\end{tabular}



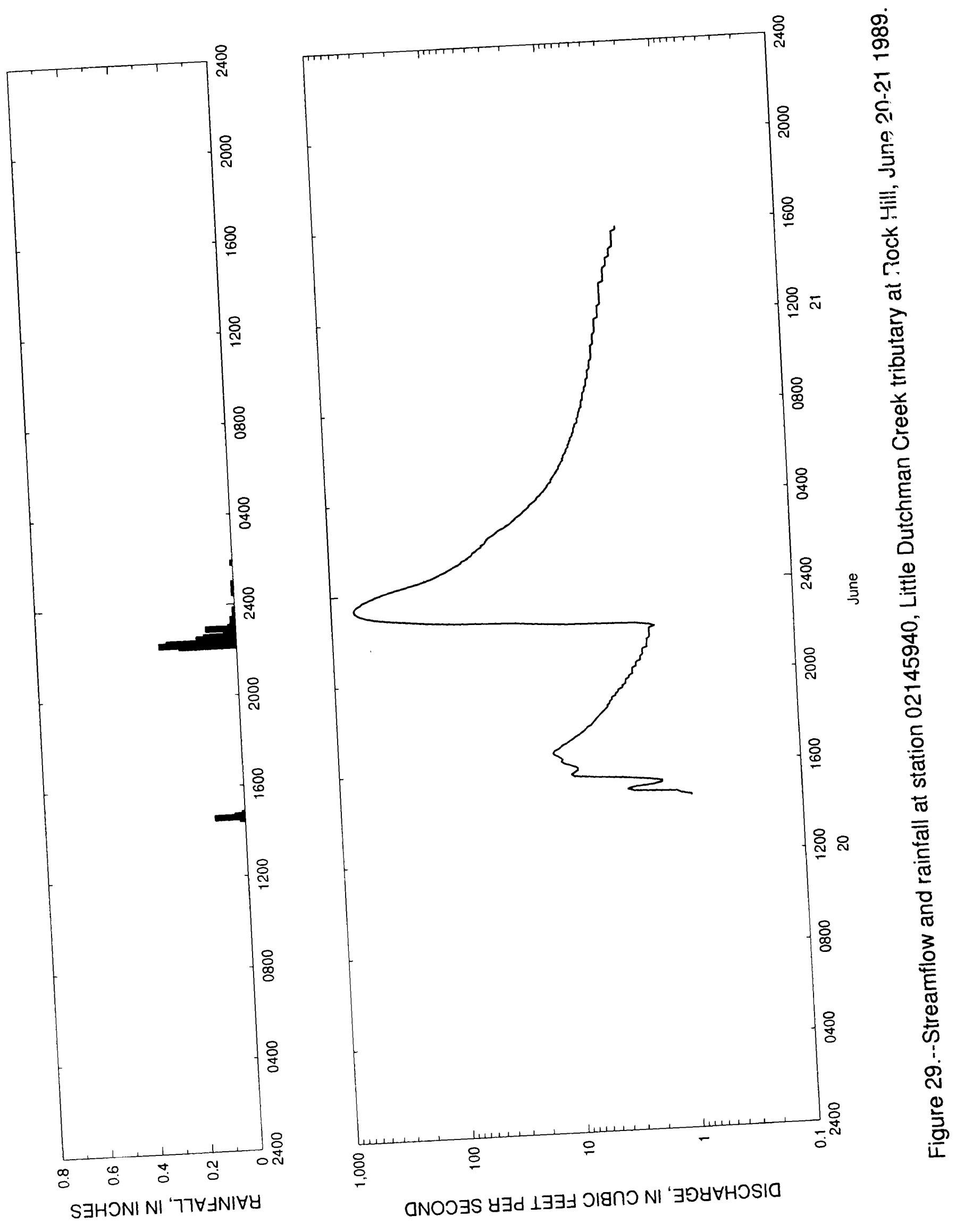
Table 28.--Streamflow and rainfall at station 02145940, Little Dutchman Creek tributary at Rock Hi11, June $20-21,1989$

\begin{tabular}{|c|c|c|c|c|c|c|c|c|}
\hline $\begin{array}{l}\text { Time } \\
\text { (hours) }\end{array}$ & $\begin{array}{l}\text { Streamflow } \\
\text { (cubic feet } \\
\text { per second) }\end{array}$ & $\begin{array}{l}\text { Rain- } \\
\text { fall } \\
\text { (inches) }\end{array}$ & $\begin{array}{l}\text { Time } \\
\text { (hours) }\end{array}$ & $\begin{array}{l}\text { Streamflow } \\
\text { (cubic feet } \\
\text { per second) }\end{array}$ & $\begin{array}{l}\text { Rain- } \\
\text { fall } \\
\text { (inches) }\end{array}$ & $\begin{array}{l}\text { Time } \\
\text { (hours) }\end{array}$ & $\begin{array}{l}\text { Streamflow } \\
\text { (cubic feet } \\
\text { per second) }\end{array}$ & $\begin{array}{l}\text { Rain- } \\
\text { fall } \\
\text { (inches) }\end{array}$ \\
\hline $\begin{array}{l}\text { June } 20 \\
1430 \\
1435 \\
1440 \\
1445\end{array}$ & $\begin{array}{r}1989 \\
0.9 \\
0.9 \\
1.1 \\
1.2\end{array}$ & $\begin{array}{l}0.02 \\
0.12 \\
0.04 \\
0.01\end{array}$ & $\begin{array}{l}1950 \\
1955 \\
2000 \\
2005 \\
2010\end{array}$ & $\begin{array}{l}2.8 \\
2.8 \\
2.6 \\
2.6 \\
2.6\end{array}$ & $\begin{array}{l}0.00 \\
0.00 \\
0.00 \\
0.00 \\
0.00\end{array}$ & $\begin{array}{l}0110 \\
0115 \\
0120 \\
0125 \\
0130\end{array}$ & $\begin{array}{l}78.7 \\
72.5 \\
71.2 \\
64.5 \\
61.6\end{array}$ & $\begin{array}{l}0.00 \\
0.00 \\
0.00 \\
0.00 \\
0.00\end{array}$ \\
\hline $\begin{array}{l}1450 \\
1455 \\
1500 \\
1505 \\
1510\end{array}$ & $\begin{array}{l}2.8 \\
3.2 \\
2.8 \\
1.9 \\
1.6\end{array}$ & $\begin{array}{l}0.00 \\
0.00 \\
0.00 \\
0.00 \\
0.00\end{array}$ & $\begin{array}{l}2015 \\
2020 \\
2025 \\
2030 \\
2035\end{array}$ & $\begin{array}{l}2.6 \\
2.4 \\
2.4 \\
2.4 \\
2.2\end{array}$ & $\begin{array}{l}0.00 \\
0.00 \\
0.00 \\
0.00 \\
0.00\end{array}$ & $\begin{array}{l}0135 \\
0140 \\
0145 \\
0150 \\
0155\end{array}$ & $\begin{array}{l}58.1 \\
57.0 \\
53.2 \\
51.6 \\
48.0\end{array}$ & $\begin{array}{l}0.00 \\
0.00 \\
0.00 \\
0.01 \\
0.00\end{array}$ \\
\hline $\begin{array}{l}1515 \\
1520 \\
1525 \\
1530 \\
1535\end{array}$ & $\begin{array}{l}1.6 \\
2.1 \\
3.2 \\
5.8 \\
9.1\end{array}$ & $\begin{array}{l}0.00 \\
0.00 \\
0.00 \\
0.00 \\
0.00\end{array}$ & $\begin{array}{l}2040 \\
2045 \\
2050 \\
2055 \\
2100\end{array}$ & $\begin{array}{l}2.2 \\
2.2 \\
2.1 \\
2.1 \\
2.1\end{array}$ & $\begin{array}{l}0.00 \\
0.00 \\
0.00 \\
0.00 \\
0.00\end{array}$ & $\begin{array}{l}0200 \\
0205 \\
0210 \\
0215 \\
0220\end{array}$ & $\begin{array}{l}47.3 \\
44.0 \\
43.4 \\
42.1 \\
40.3\end{array}$ & $\begin{array}{l}0.00 \\
0.00 \\
0.00 \\
0.00 \\
0.00\end{array}$ \\
\hline $\begin{array}{l}1540 \\
1545 \\
1550 \\
1555 \\
1600\end{array}$ & $\begin{array}{l}9.7 \\
9.1 \\
8.4 \\
8.4 \\
8.9\end{array}$ & $\begin{array}{l}0.00 \\
0.00 \\
0.00 \\
0.00 \\
0.00\end{array}$ & $\begin{array}{l}2105 \\
2110 \\
2115 \\
2120 \\
2125\end{array}$ & $\begin{array}{l}2.1 \\
1.9 \\
1.9 \\
1.9 \\
1.9\end{array}$ & $\begin{array}{l}0.00 \\
0.00 \\
0.00 \\
0.00 \\
0.00\end{array}$ & $\begin{array}{l}0225 \\
0230 \\
0235 \\
0240 \\
0245\end{array}$ & $\begin{array}{l}37.4 \\
35.7 \\
34.0 \\
31.9 \\
29.3\end{array}$ & $\begin{array}{l}0.00 \\
0.00 \\
0.00 \\
0.00 \\
0.00\end{array}$ \\
\hline $\begin{array}{l}1605 \\
1610 \\
1615 \\
1620 \\
1625\end{array}$ & $\begin{array}{r}9.9 \\
11.1 \\
11.7 \\
11.4 \\
11.7\end{array}$ & $\begin{array}{l}0.00 \\
0.00 \\
0.00 \\
0.00 \\
0.00\end{array}$ & $\begin{array}{l}2130 \\
2135 \\
2140 \\
2145 \\
2150\end{array}$ & $\begin{array}{l}1.9 \\
1.8 \\
1.8 \\
1.8 \\
1.8\end{array}$ & $\begin{array}{l}0.00 \\
0.00 \\
0.00 \\
0.00 \\
0.00\end{array}$ & $\begin{array}{l}0250 \\
0255 \\
0300 \\
0305 \\
0310\end{array}$ & $\begin{array}{l}27.8 \\
25.9 \\
25.0 \\
23.7 \\
22.8\end{array}$ & $\begin{array}{l}0.00 \\
0.00 \\
0.00 \\
0.00 \\
0.00\end{array}$ \\
\hline $\begin{array}{l}1630 \\
1635 \\
1640 \\
1645 \\
1650\end{array}$ & $\begin{array}{l}12.3 \\
13.3 \\
13.7 \\
13.3 \\
12.3\end{array}$ & $\begin{array}{l}0.00 \\
0.00 \\
0.00 \\
0.00 \\
0.00\end{array}$ & $\begin{array}{l}2155 \\
2200 \\
2205 \\
2210 \\
2215\end{array}$ & $\begin{array}{l}1.8 \\
1.8 \\
1.6 \\
1.8 \\
2.4\end{array}$ & $\begin{array}{l}0.00 \\
0.00 \\
0.00 \\
0.23 \\
0.31\end{array}$ & $\begin{array}{l}0315 \\
0320 \\
0325 \\
0330 \\
0335\end{array}$ & $\begin{array}{l}21.5 \\
20.6 \\
19.7 \\
18.8 \\
17.9\end{array}$ & $\begin{array}{l}0.00 \\
0.00 \\
0.00 \\
0.00 \\
0.00\end{array}$ \\
\hline $\begin{array}{l}1655 \\
1700 \\
1705 \\
1710 \\
1715\end{array}$ & $\begin{array}{r}11.7 \\
11.1 \\
10.2 \\
9.7 \\
9.1\end{array}$ & $\begin{array}{l}0.00 \\
0.00 \\
0.00 \\
0.00 \\
0.00\end{array}$ & $\begin{array}{l}2220 \\
2225 \\
2230 \\
2235 \\
2240\end{array}$ & $\begin{array}{r}9.7 \\
17.1 \\
26.4 \\
82.5 \\
150.0\end{array}$ & $\begin{array}{l}0.28 \\
0.14 \\
0.16 \\
0.13 \\
0.05\end{array}$ & $\begin{array}{l}0340 \\
0345 \\
0350 \\
0355 \\
0400\end{array}$ & $\begin{array}{l}17.5 \\
16.7 \\
15.9 \\
15.1 \\
14.8\end{array}$ & $\begin{array}{l}0.00 \\
0.00 \\
0.00 \\
0.00 \\
0.00\end{array}$ \\
\hline $\begin{array}{l}1720 \\
1725 \\
1730 \\
1735 \\
1740\end{array}$ & $\begin{array}{l}8.6 \\
8.1 \\
7.6 \\
7.2 \\
6.9\end{array}$ & $\begin{array}{l}0.00 \\
0.00 \\
0.00 \\
0.00 \\
0.00\end{array}$ & $\begin{array}{l}2245 \\
2250 \\
2255 \\
2300 \\
2305\end{array}$ & $\begin{array}{l}220.0 \\
323.0 \\
425.0 \\
506.0 \\
563.0\end{array}$ & $\begin{array}{l}0.01 \\
0.02 \\
0.12 \\
0.03 \\
0.02\end{array}$ & $\begin{array}{l}0405 \\
0410 \\
0415 \\
0420 \\
0425\end{array}$ & $\begin{array}{l}14.0 \\
13.7 \\
13.0 \\
12.7 \\
12.3\end{array}$ & $\begin{array}{l}0.00 \\
0.00 \\
0.00 \\
0.00 \\
0.00\end{array}$ \\
\hline $\begin{array}{l}1745 \\
1750 \\
1755 \\
1800 \\
1805\end{array}$ & $\begin{array}{l}6.7 \\
6.2 \\
6.0 \\
5.8 \\
5.6\end{array}$ & $\begin{array}{l}0.00 \\
0.00 \\
0.00 \\
0.00 \\
0.00\end{array}$ & $\begin{array}{l}2310 \\
2315 \\
2320 \\
2325 \\
2330\end{array}$ & $\begin{array}{l}605.0 \\
633.0 \\
641.0 \\
631.0 \\
610.0\end{array}$ & $\begin{array}{l}0.01 \\
0.02 \\
0.02 \\
0.00 \\
0.01\end{array}$ & $\begin{array}{l}0430 \\
0435 \\
0440 \\
0445 \\
0450\end{array}$ & $\begin{array}{l}12.0 \\
11.7 \\
11.1 \\
11.1 \\
10.8\end{array}$ & $\begin{array}{l}0.00 \\
0.00 \\
0.00 \\
0.00 \\
0.00\end{array}$ \\
\hline $\begin{array}{l}1810 \\
1815 \\
1820 \\
1825 \\
1830\end{array}$ & $\begin{array}{l}5.4 \\
5.2 \\
5.0 \\
4.8 \\
4.6\end{array}$ & $\begin{array}{l}0.00 \\
0.00 \\
0.00 \\
0.00 \\
0.00\end{array}$ & $\begin{array}{l}2335 \\
2340 \\
2345 \\
2350 \\
2355\end{array}$ & $\begin{array}{l}570.0 \\
539.0 \\
493.0 \\
448.0 \\
404.0\end{array}$ & $\begin{array}{l}0.01 \\
0.01 \\
0.01 \\
0.00 \\
0.00\end{array}$ & $\begin{array}{l}0455 \\
0500 \\
0505 \\
0510 \\
0515\end{array}$ & $\begin{array}{r}10.5 \\
10.2 \\
9.9 \\
9.7 \\
9.4\end{array}$ & $\begin{array}{l}0.00 \\
0.00 \\
0.00 \\
0.00 \\
0.00\end{array}$ \\
\hline $\begin{array}{l}1835 \\
1840 \\
1845 \\
1850 \\
1855\end{array}$ & $\begin{array}{l}4.4 \\
4.4 \\
4.2 \\
4.2 \\
4.0\end{array}$ & $\begin{array}{l}0.00 \\
0.00 \\
0.00 \\
0.00 \\
0.00\end{array}$ & $\begin{array}{l}\text { June } 21 \\
0000 \\
0005 \\
0010 \\
0015\end{array}$ & $\begin{array}{l}1989 \\
360.0 \\
321.0 \\
281.0 \\
237.0\end{array}$ & $\begin{array}{l}0.00 \\
0.00 \\
0.00 \\
0.00\end{array}$ & $\begin{array}{l}0520 \\
0525 \\
0530 \\
0535 \\
0540\end{array}$ & $\begin{array}{l}9.4 \\
9.1 \\
8.9 \\
8.6 \\
8.6\end{array}$ & $\begin{array}{l}0.00 \\
0.00 \\
0.00 \\
0.00 \\
0.00\end{array}$ \\
\hline $\begin{array}{l}1900 \\
1905 \\
1910 \\
1915 \\
1920\end{array}$ & $\begin{array}{l}4.0 \\
3.7 \\
3.7 \\
3.5 \\
3.5\end{array}$ & $\begin{array}{l}0.00 \\
0.00 \\
0.00 \\
0.00 \\
0.00\end{array}$ & $\begin{array}{l}0020 \\
0025 \\
0030 \\
0035 \\
0040\end{array}$ & $\begin{array}{l}207.0 \\
176.0 \\
155.0 \\
139.0 \\
125.0\end{array}$ & $\begin{array}{l}0.00 \\
0.00 \\
0.01 \\
0.01 \\
0.01\end{array}$ & $\begin{array}{l}0545 \\
0550 \\
0555 \\
0600 \\
0605\end{array}$ & $\begin{array}{l}8.4 \\
8.4 \\
8.1 \\
7.9 \\
7.9\end{array}$ & $\begin{array}{l}0.00 \\
0.00 \\
0.00 \\
0.00 \\
0.00\end{array}$ \\
\hline $\begin{array}{l}1925 \\
1930 \\
1935 \\
1940 \\
1945\end{array}$ & $\begin{array}{l}3.2 \\
3.2 \\
3.0 \\
3.0 \\
3.0\end{array}$ & $\begin{array}{l}0.00 \\
0.00 \\
0.00 \\
0.00 \\
0.00\end{array}$ & $\begin{array}{l}0045 \\
0050 \\
0055 \\
0100 \\
0105\end{array}$ & $\begin{array}{r}116.0 \\
106.0 \\
97.2 \\
90.4 \\
85.1\end{array}$ & $\begin{array}{l}0.00 \\
0.00 \\
0.01 \\
0.00 \\
0.00\end{array}$ & $\begin{array}{l}0610 \\
0615 \\
0620 \\
0625 \\
0630\end{array}$ & $\begin{array}{l}7.6 \\
7.6 \\
7.4 \\
7.4 \\
7.2\end{array}$ & $\begin{array}{l}0.00 \\
0.00 \\
0.00 \\
0.00 \\
0.00\end{array}$ \\
\hline
\end{tabular}


Table 28.--Streamflow and rainfall at station 02145940, Little Dutchman Creek tributary at Rock Hill, June 20-21, 1989--Cont inued

\begin{tabular}{|c|c|c|c|c|c|c|c|c|}
\hline $\begin{array}{l}\text { Time } \\
\text { (hours) }\end{array}$ & $\begin{array}{l}\text { Streamflow } \\
\text { (cubic feet } \\
\text { per second) }\end{array}$ & $\begin{array}{l}\text { Rain- } \\
\text { fall } \\
\text { (inches) }\end{array}$ & $\begin{array}{l}\text { Time } \\
\text { (hours) }\end{array}$ & $\begin{array}{l}\text { Streamflow } \\
\text { (cubic feet } \\
\text { per second) }\end{array}$ & $\begin{array}{l}\text { Rain- } \\
\text { fall } \\
\text { (inches) }\end{array}$ & $\begin{array}{l}\text { Time } \\
\text { (hours) }\end{array}$ & $\begin{array}{l}\text { Streamflow } \\
\text { (cubic feet } \\
\text { per second) }\end{array}$ & $\begin{array}{l}\text { Rain- } \\
\text { fall } \\
\text { (inches) }\end{array}$ \\
\hline $\begin{array}{l}0635 \\
0640 \\
0645 \\
0650 \\
0655\end{array}$ & $\begin{array}{l}7.2 \\
6.9 \\
6.9 \\
6.7 \\
6.7\end{array}$ & $\begin{array}{l}0.00 \\
0.00 \\
0.00 \\
0.00 \\
0.00\end{array}$ & $\begin{array}{l}0945 \\
0950 \\
0955 \\
1000 \\
1005\end{array}$ & $\begin{array}{l}4.6 \\
4.6 \\
4.6 \\
4.4 \\
4.4\end{array}$ & $\begin{array}{l}0.00 \\
0.00 \\
0.00 \\
0.00 \\
0.00\end{array}$ & $\begin{array}{l}1255 \\
1300 \\
1305 \\
1310 \\
1315\end{array}$ & $\begin{array}{l}3.5 \\
3.5 \\
3.5 \\
3.5 \\
3.5\end{array}$ & $\begin{array}{l}0.00 \\
0.00 \\
0.00 \\
0.00 \\
0.00\end{array}$ \\
\hline $\begin{array}{l}0700 \\
0705 \\
0710 \\
0715 \\
0720\end{array}$ & $\begin{array}{l}6.7 \\
6.5 \\
6.5 \\
6.2 \\
6.2\end{array}$ & $\begin{array}{l}0.00 \\
0.00 \\
0.00 \\
0.00 \\
0.00\end{array}$ & $\begin{array}{l}1010 \\
1015 \\
1020 \\
1025 \\
1030\end{array}$ & $\begin{array}{l}4.4 \\
4.4 \\
4.4 \\
4.4 \\
4.4\end{array}$ & $\begin{array}{l}0.00 \\
0.00 \\
0.00 \\
0.00 \\
0.00\end{array}$ & $\begin{array}{l}1320 \\
1325 \\
1330 \\
1335 \\
1340\end{array}$ & $\begin{array}{l}3.5 \\
3.2 \\
3.2 \\
3.2 \\
3.2\end{array}$ & $\begin{array}{l}0.00 \\
0.00 \\
0.00 \\
0.00 \\
0.00\end{array}$ \\
\hline $\begin{array}{l}0725 \\
0730 \\
0735 \\
0740 \\
0745\end{array}$ & $\begin{array}{l}6.2 \\
6.0 \\
6.0 \\
6.0 \\
5.8\end{array}$ & $\begin{array}{l}0.00 \\
0.00 \\
0.00 \\
0.00 \\
0.00\end{array}$ & $\begin{array}{l}1035 \\
1040 \\
1045 \\
1050 \\
1055\end{array}$ & $\begin{array}{l}4.4 \\
4.2 \\
4.2 \\
4.2 \\
4.2\end{array}$ & $\begin{array}{l}0.00 \\
0.00 \\
0.00 \\
0.00 \\
0.00\end{array}$ & $\begin{array}{l}1345 \\
1350 \\
1355 \\
1400 \\
1405\end{array}$ & $\begin{array}{l}3.2 \\
3.2 \\
3.2 \\
3.2 \\
3.0\end{array}$ & $\begin{array}{l}0.00 \\
0.00 \\
0.00 \\
0.00 \\
0.00\end{array}$ \\
\hline $\begin{array}{l}0750 \\
0755 \\
0800 \\
0805 \\
0810\end{array}$ & $\begin{array}{l}5.8 \\
5.6 \\
5.6 \\
5.6 \\
5.6\end{array}$ & $\begin{array}{l}0.00 \\
0.00 \\
0.00 \\
0.00 \\
0.00\end{array}$ & $\begin{array}{l}1100 \\
1105 \\
1110 \\
1115 \\
1120\end{array}$ & $\begin{array}{l}4.2 \\
4.2 \\
4.0 \\
4.0 \\
4.0\end{array}$ & $\begin{array}{l}0.00 \\
0.00 \\
0.00 \\
0.00 \\
0.00\end{array}$ & $\begin{array}{l}1410 \\
1415 \\
1420 \\
1425 \\
1430\end{array}$ & $\begin{array}{l}3.0 \\
3.0 \\
3.0 \\
3.0 \\
2.8\end{array}$ & $\begin{array}{l}0.00 \\
0.00 \\
0.00 \\
0.00 \\
0.00\end{array}$ \\
\hline $\begin{array}{l}0815 \\
0820 \\
0825 \\
0830 \\
0835\end{array}$ & $\begin{array}{l}5.4 \\
5.4 \\
5.4 \\
5.4 \\
5.2\end{array}$ & $\begin{array}{l}0.00 \\
0.00 \\
0.00 \\
0.00 \\
0.00\end{array}$ & $\begin{array}{l}1125 \\
1130 \\
1135 \\
1140 \\
1145\end{array}$ & $\begin{array}{l}4.0 \\
4.0 \\
4.0 \\
4.0 \\
4.0\end{array}$ & $\begin{array}{l}0.00 \\
0.00 \\
0.00 \\
0.00 \\
0.00\end{array}$ & $\begin{array}{l}1435 \\
1440 \\
1445 \\
1450 \\
1455\end{array}$ & $\begin{array}{l}2.8 \\
2.8 \\
2.8 \\
2.8 \\
2.6\end{array}$ & $\begin{array}{l}0.00 \\
0.00 \\
0.00 \\
0.00 \\
0.00\end{array}$ \\
\hline $\begin{array}{l}0840 \\
0845 \\
0850 \\
0855 \\
0900\end{array}$ & $\begin{array}{l}5.2 \\
5.2 \\
5.0 \\
5.0 \\
5.0\end{array}$ & $\begin{array}{l}0.00 \\
0.00 \\
0.00 \\
0.00 \\
0.00\end{array}$ & $\begin{array}{l}1150 \\
1155 \\
1200 \\
1205 \\
1210\end{array}$ & $\begin{array}{l}3.7 \\
3.7 \\
3.7 \\
3.7 \\
3.7\end{array}$ & $\begin{array}{l}0.00 \\
0.00 \\
0.00 \\
0.00 \\
0.00\end{array}$ & $\begin{array}{l}1500 \\
1505 \\
1510 \\
1515 \\
1520\end{array}$ & $\begin{array}{l}2.6 \\
2.6 \\
2.6 \\
2.6 \\
2.6\end{array}$ & $\begin{array}{l}0.00 \\
0.00 \\
0.00 \\
0.00 \\
0.00\end{array}$ \\
\hline $\begin{array}{l}0905 \\
0910 \\
0915 \\
0920 \\
0925\end{array}$ & $\begin{array}{l}5.0 \\
4.8 \\
4.8 \\
4.8 \\
4.8\end{array}$ & $\begin{array}{l}0.00 \\
0.00 \\
0.00 \\
0.00 \\
0.00\end{array}$ & $\begin{array}{l}1215 \\
1220 \\
1225 \\
1230 \\
1235\end{array}$ & $\begin{array}{l}3.7 \\
3.7 \\
3.5 \\
3.5 \\
3.5\end{array}$ & $\begin{array}{l}0.00 \\
0.00 \\
0.00 \\
0.00 \\
0.00\end{array}$ & $\begin{array}{l}1525 \\
1530 \\
1535 \\
1540 \\
1545\end{array}$ & $\begin{array}{l}2.6 \\
2.6 \\
2.6 \\
2.4 \\
2.4\end{array}$ & $\begin{array}{l}0.00 \\
0.00 \\
0.00 \\
0.00 \\
0.00\end{array}$ \\
\hline $\begin{array}{l}0930 \\
0935 \\
0940\end{array}$ & $\begin{array}{l}4.8 \\
4.6 \\
4.6\end{array}$ & $\begin{array}{l}0.00 \\
0.00 \\
0.00\end{array}$ & $\begin{array}{l}1240 \\
1245 \\
1250\end{array}$ & $\begin{array}{l}3.5 \\
3.5 \\
3.5\end{array}$ & $\begin{array}{l}0.00 \\
0.00 \\
0.00\end{array}$ & $\begin{array}{l}1550 \\
1555 \\
1600\end{array}$ & $\begin{array}{l}2.4 \\
2.4 \\
2.4\end{array}$ & $\begin{array}{l}0.00 \\
0.00 \\
0.00\end{array}$ \\
\hline
\end{tabular}




\section{Station 02146100, Manchester Creek Tributary at Rock Hill, S.C.}

Location.--Lat $34^{\circ} 56^{\prime} 03^{\prime \prime}$, long $81^{\circ} 00^{\prime} 11^{\prime \prime}$, York County, Hydrologic Unit 03050103, at culvert on State secondary road 579, $1.2 \mathrm{mi}$ east of Winthrop College, and $0.7 \mathrm{mi}$ upstream from the mouth at Manchester Creek.

Period of record.-- December 12, 1985 to October 3, 1989.

Gage.--Digital stage recorder with 5-minute punch interval. The recorder is house in a metal shelter atop a stilling well attached to the headwall at the center web of the double $9.3 \mathrm{ft}$ by $8 \mathrm{ft}$ concrete box culvert. A sealed intake pipe extends $20 \mathrm{ft}$ upstream to a separate stilling basin (sand trap) with a removable lid. One crest-stage indicator is located opposite the recording gage intake on the upstream left bank. A seccnd crest-stage indicator is located on the right downstream wingwall.

Rating.--The stage-streamflow relation is defined by current meter measurements up to $110 \mathrm{ft}^{3} / \mathrm{s}$. The stage-streamflow relation was extended to $518 \mathrm{ft}^{3} / \mathrm{s}$ using indire $\mathrm{t}$ computational methods.

Rain gage and location.--Station 345607081001400 , lat $34^{\circ} 56^{\prime} 07^{\prime \prime}$, long $81^{\circ} 00^{\prime} 14^{\prime \prime}$. A shelter containing a digital cumulative rainfall recorder with a 5-minute punch interval attached to the right downstream wingwall at the State secondary road 579 crossing, $1.2 \mathrm{mi}$ east of Winthrop College, and $0.7 \mathrm{mi}$ upstream from the mouth at Manch oster Creek.

Selected basin characteristics.--

Drainage area $-1.29 \mathrm{mi}^{2}$

Physiographic province - Piedmont

Channel slope $-61.0 \mathrm{ft} / \mathrm{mi}$

Channel length -- $1.81 \mathrm{mi}$

Total impervious area -- 31.0 percent

Basin development factor -- 6

2-year, 2-hour rainfall amount -- 1.95 in.

\begin{tabular}{|c|c|c|}
\hline Flood frequency data: & $\mathrm{UQ}_{2}$ & $530 \mathrm{ft}^{3} / \mathrm{s}$ \\
\hline & $\mathrm{UQ}_{5}$ & $788 \mathrm{ft}^{3} / \mathrm{s}$ \\
\hline & $\mathrm{UQ}_{10}$ & $955 \mathrm{ft}^{3} / \mathrm{s}$ \\
\hline & $\mathrm{UQ}_{25}$ & $1,160 \mathrm{ft}^{3} / \mathrm{s}$ \\
\hline & $\mathrm{UQ}_{50}$ & $1,310 \mathrm{ft}^{3} / \mathrm{s}$ \\
\hline & $\mathrm{UQ}_{100}$ & $1,450 \mathrm{ft}^{3} / \mathrm{s}$ \\
\hline & $\mathrm{UQ}_{500}$ & $1,770 \mathrm{ft}^{3} / \mathrm{s}$ \\
\hline
\end{tabular}




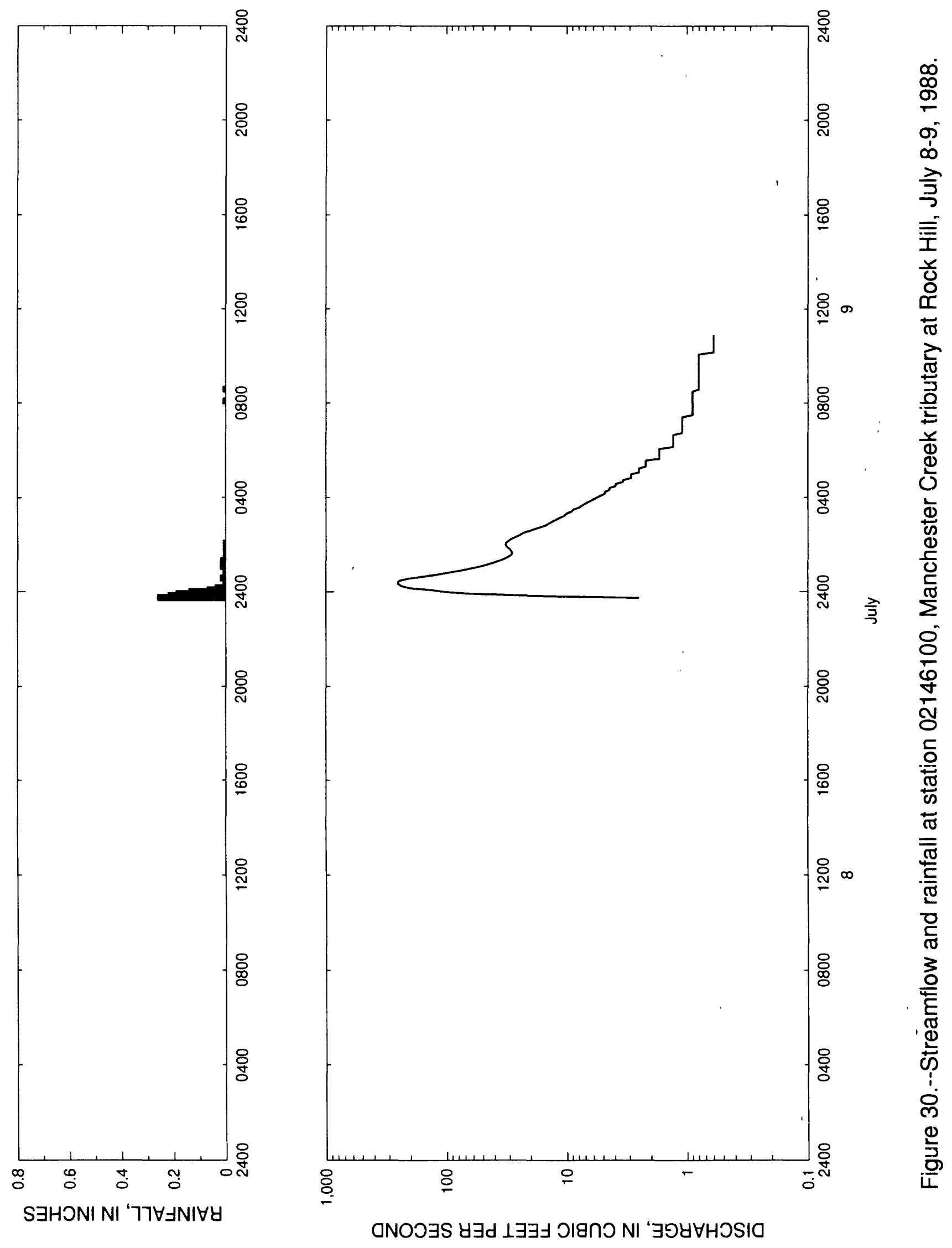


Table 29. - - Streamflow and rainfall at station 02146100 , Manchester Creek tributary at Rock Hill, July $8-9,1988$

\begin{tabular}{|c|c|c|c|c|c|c|c|c|}
\hline $\begin{array}{l}\text { Time } \\
\text { (hours) }\end{array}$ & $\begin{array}{l}\text { Streamflow } \\
\text { (cubic feet } \\
\text { per second) }\end{array}$ & $\begin{array}{l}\text { Rain- } \\
\text { fall } \\
\text { (inches) }\end{array}$ & $\begin{array}{l}\text { Time } \\
\text { (hours) }\end{array}$ & $\begin{array}{l}\text { Streamflow } \\
\text { (cubic feet } \\
\text { per second) }\end{array}$ & $\begin{array}{l}\text { Rain- } \\
\text { fall } \\
\text { (inches) }\end{array}$ & $\begin{array}{l}\text { Time } \\
\text { (hours) }\end{array}$ & $\begin{array}{l}\text { Streamflow } \\
\text { (cubic feet } \\
\text { per second) }\end{array}$ & $\begin{array}{l}\text { Rain- } \\
\text { fall } \\
\text { (inches) }\end{array}$ \\
\hline $\begin{array}{l}\text { July } 8, \\
2345 \\
2350 \\
2355 \\
\text { July 9, }\end{array}$ & $\begin{array}{rr}1988 & 2.5 \\
& 17.5 \\
& 62.7 \\
1988 & \end{array}$ & $\begin{array}{l}0.26 \\
0.22 \\
0.19\end{array}$ & $\begin{array}{l}0325 \\
0330 \\
0335 \\
0340 \\
0345\end{array}$ & $\begin{array}{l}9.1 \\
8.7 \\
7.8 \\
7.4 \\
7.0\end{array}$ & $\begin{array}{l}0.00 \\
0.00 \\
0.00 \\
0.00 \\
0.00\end{array}$ & $\begin{array}{l}0715 \\
0720 \\
0725 \\
0730 \\
0735\end{array}$ & $\begin{array}{l}1.1 \\
1.1 \\
1.1 \\
0.9 \\
0.9\end{array}$ & $\begin{array}{l}0.00 \\
0.00 \\
0.00 \\
0.00 \\
0.00\end{array}$ \\
\hline $\begin{array}{l}0000 \\
0005 \\
0010 \\
0015 \\
0020\end{array}$ & $\begin{array}{l}104.0 \\
133.0 \\
202.0 \\
233.0 \\
252.0\end{array}$ & $\begin{array}{l}0.14 \\
0.07 \\
0.04 \\
0.01 \\
0.01\end{array}$ & $\begin{array}{l}0350 \\
0355 \\
0400 \\
0405 \\
0410\end{array}$ & $\begin{array}{l}6.5 \\
6.0 \\
5.6 \\
5.2 \\
4.8\end{array}$ & $\begin{array}{l}0.00 \\
0.00 \\
0.00 \\
0.00 \\
0.00\end{array}$ & $\begin{array}{l}0740 \\
0745 \\
0750 \\
0755 \\
0800\end{array}$ & $\begin{array}{l}0.9 \\
0.9 \\
0.9 \\
0.9 \\
0.9\end{array}$ & $\begin{array}{l}0.00 \\
0.00 \\
0.00 \\
0.00 \\
0.00\end{array}$ \\
\hline $\begin{array}{l}0025 \\
0030 \\
0035 \\
0040 \\
0045\end{array}$ & $\begin{array}{l}252.0 \\
240.0 \\
202.0 \\
154.0 \\
118.0\end{array}$ & $\begin{array}{l}0.01 \\
0.01 \\
0.02 \\
0.00 \\
0.01\end{array}$ & $\begin{array}{l}0415 \\
0420 \\
0425 \\
0430 \\
0435\end{array}$ & $\begin{array}{l}4.8 \\
4.4 \\
4.4 \\
3.9 \\
3.9\end{array}$ & $\begin{array}{l}0.00 \\
0.00 \\
0.00 \\
0.00 \\
0.00\end{array}$ & $\begin{array}{l}0805 \\
0810 \\
0815 \\
0820 \\
0825\end{array}$ & $\begin{array}{l}0.9 \\
0.9 \\
0.9 \\
0.9 \\
0.9\end{array}$ & $\begin{array}{l}0.01 \\
0.00 \\
0.00 \\
0.00 \\
0.00\end{array}$ \\
\hline $\begin{array}{l}0050 \\
0055 \\
0100 \\
0105 \\
0110\end{array}$ & $\begin{array}{l}94.2 \\
75.6 \\
62.7 \\
52.6 \\
45.8\end{array}$ & $\begin{array}{l}0.00 \\
0.00 \\
0.01 \\
0.02 \\
0.01\end{array}$ & $\begin{array}{l}0440 \\
0445 \\
0450 \\
0455 \\
0500\end{array}$ & $\begin{array}{l}3.4 \\
3.4 \\
2.9 \\
2.9 \\
2.9\end{array}$ & $\begin{array}{l}0.00 \\
0.00 \\
0.00 \\
0.00 \\
0.00\end{array}$ & $\begin{array}{l}0830 \\
0835 \\
0840 \\
0845 \\
0850\end{array}$ & $\begin{array}{l}0.9 \\
0.8 \\
0.8 \\
0.8 \\
0.8\end{array}$ & $\begin{array}{l}0.00 \\
0.01 \\
0.00 \\
0.00 \\
0.00\end{array}$ \\
\hline $\begin{array}{l}0115 \\
0120 \\
0125 \\
0130 \\
0135\end{array}$ & $\begin{array}{l}40.2 \\
36.1 \\
33.0 \\
30.6 \\
29.1\end{array}$ & $\begin{array}{l}0.01 \\
0.02 \\
0.01 \\
0.01 \\
0.01\end{array}$ & $\begin{array}{l}0505 \\
0510 \\
0515 \\
0520 \\
0525\end{array}$ & $\begin{array}{l}2.5 \\
2.5 \\
2.5 \\
2.2 \\
2.2\end{array}$ & $\begin{array}{l}0.00 \\
0.00 \\
0.00 \\
0.00 \\
0.00\end{array}$ & $\begin{array}{l}0855 \\
0900 \\
0905 \\
0910 \\
0915\end{array}$ & $\begin{array}{l}0.8 \\
0.8 \\
0.8 \\
0.8 \\
0.8\end{array}$ & $\begin{array}{l}0.00 \\
0.00 \\
0.00 \\
0.00 \\
0.00\end{array}$ \\
\hline $\begin{array}{l}0140 \\
0145 \\
0150 \\
0155 \\
0200\end{array}$ & $\begin{array}{l}28.3 \\
29.1 \\
29.8 \\
31.4 \\
32.2\end{array}$ & $\begin{array}{l}0.01 \\
0.00 \\
0.01 \\
0.00 \\
0.00\end{array}$ & $\begin{array}{l}0530 \\
0535 \\
0540 \\
0545 \\
0550\end{array}$ & $\begin{array}{l}2.2 \\
2.2 \\
1.7 \\
1.7 \\
1.7\end{array}$ & $\begin{array}{l}0.00 \\
0.00 \\
0.00 \\
0.00 \\
0.00\end{array}$ & $\begin{array}{l}0920 \\
0925 \\
0930 \\
0935 \\
0940\end{array}$ & $\begin{array}{l}0.8 \\
0.8 \\
0.8 \\
0.8 \\
0.8\end{array}$ & $\begin{array}{l}0.00 \\
0.00 \\
0.00 \\
0.00 \\
0.00\end{array}$ \\
\hline $\begin{array}{l}0205 \\
0210 \\
0215 \\
0220 \\
0225\end{array}$ & $\begin{array}{l}32.2 \\
30.6 \\
29.1 \\
26.8 \\
24.7\end{array}$ & $\begin{array}{l}0.01 \\
0.00 \\
0.00 \\
0.00 \\
0.00\end{array}$ & $\begin{array}{l}0555 \\
0600 \\
0605 \\
0610 \\
0615\end{array}$ & $\begin{array}{l}1.7 \\
1.7 \\
1.7 \\
1.3 \\
1.3\end{array}$ & $\begin{array}{l}0.00 \\
0.00 \\
0.00 \\
0.00 \\
0.00\end{array}$ & $\begin{array}{l}0945 \\
0950 \\
0955 \\
1000 \\
1005\end{array}$ & $\begin{array}{l}0.8 \\
0.8 \\
0.8 \\
0.8 \\
0.8\end{array}$ & $\begin{array}{l}0.00 \\
0.00 \\
0.00 \\
0.00 \\
0.00\end{array}$ \\
\hline $\begin{array}{l}0230 \\
0235 \\
0240 \\
0245 \\
0250\end{array}$ & $\begin{array}{l}23.2 \\
21.0 \\
18.8 \\
16.8 \\
15.0\end{array}$ & $\begin{array}{l}0.00 \\
0.00 \\
0.00 \\
0.00 \\
0.00\end{array}$ & $\begin{array}{l}0620 \\
0625 \\
0630 \\
0635 \\
0640\end{array}$ & $\begin{array}{l}1.3 \\
1.3 \\
1.3 \\
1.3 \\
1.3\end{array}$ & $\begin{array}{l}0.00 \\
0.00 \\
0.00 \\
0.00 \\
0.00\end{array}$ & $\begin{array}{l}1010 \\
1015 \\
1020 \\
1025 \\
1030\end{array}$ & $\begin{array}{l}0.6 \\
0.6 \\
0.6 \\
0.6 \\
0.6\end{array}$ & $\begin{array}{l}0.00 \\
0.00 \\
0.00 \\
0.00 \\
0.00\end{array}$ \\
\hline $\begin{array}{l}0255 \\
0300 \\
0305 \\
0310 \\
0315\end{array}$ & $\begin{array}{l}14.1 \\
13.2 \\
12.3 \\
11.4 \\
10.5\end{array}$ & $\begin{array}{l}0.00 \\
0.00 \\
0.00 \\
0.00 \\
0.00\end{array}$ & $\begin{array}{l}0645 \\
0650 \\
0655 \\
0700 \\
0705\end{array}$ & $\begin{array}{l}1.1 \\
1.1 \\
1.1 \\
1.1 \\
1.1\end{array}$ & $\begin{array}{l}0.00 \\
0.00 \\
0.00 \\
0.00 \\
0.00\end{array}$ & $\begin{array}{l}1035 \\
1040 \\
1045 \\
1050 \\
1055\end{array}$ & $\begin{array}{l}0.6 \\
0.6 \\
0.6 \\
0.6 \\
0.6\end{array}$ & $\begin{array}{l}0.00 \\
0.00 \\
0.00 \\
0.00 \\
0.00\end{array}$ \\
\hline 0320 & 10.1 & 0.00 & 0710 & 1.1 & 0.00 & 1100 & 0.6 & 0.00 \\
\hline
\end{tabular}




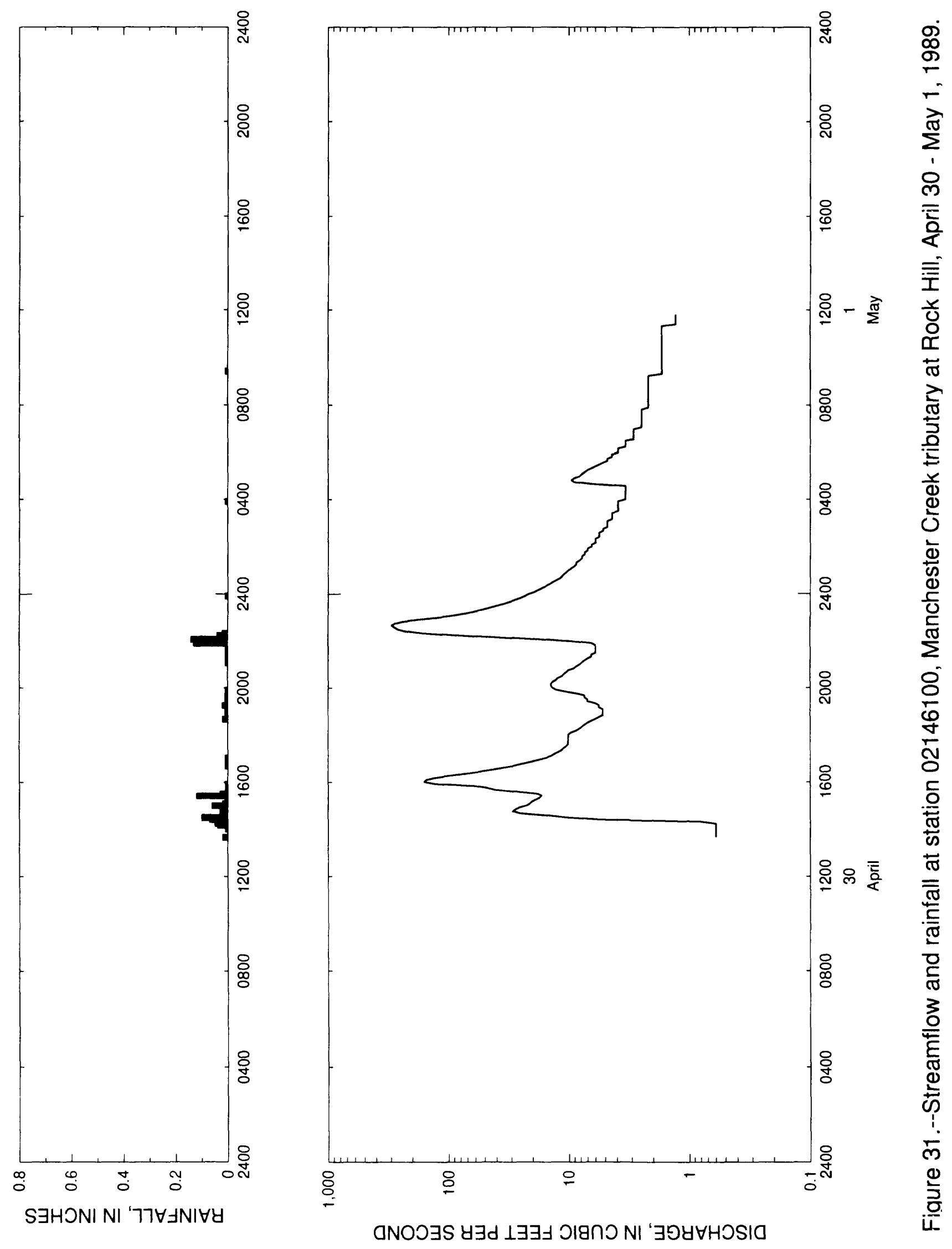


Table 30.--Streamflow and rainfall at station 02146100, Manchester Creek tributary at Rock Hil1, April $30-$ May 1,1989

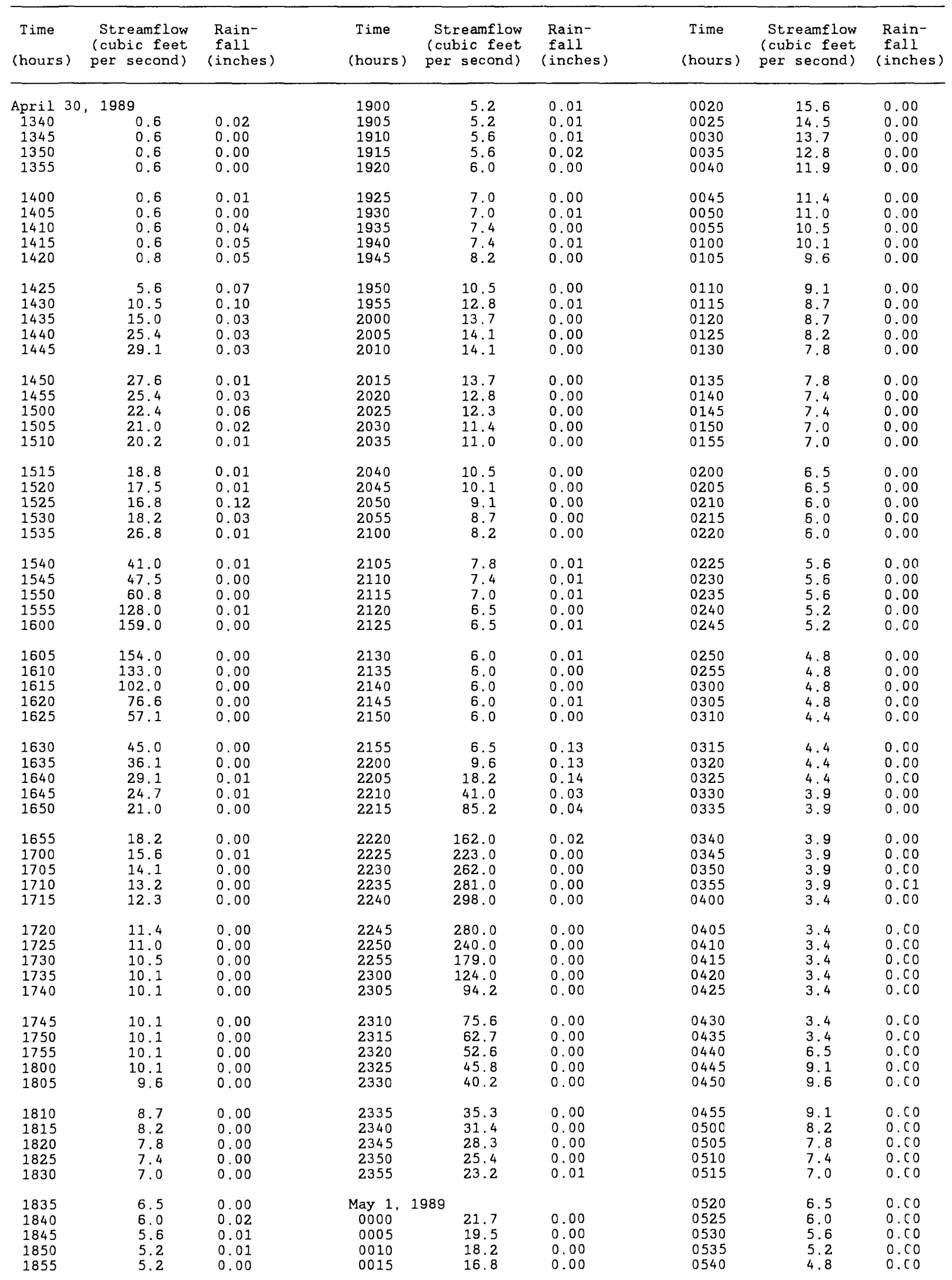


Table 30. - Streamflow and rainfall at station 02146100, Manchester Creek tributary at Rock Hill, April $30-$ May 1, 1989--Continued

\begin{tabular}{|c|c|c|c|c|c|c|c|c|}
\hline $\begin{array}{l}\text { Time } \\
\text { (hours) }\end{array}$ & $\begin{array}{l}\text { Streamflow } \\
\text { (cubic feet } \\
\text { per second) }\end{array}$ & $\begin{array}{l}\text { Rain- } \\
\text { fall } \\
\text { (inches) }\end{array}$ & $\begin{array}{l}\text { Time } \\
\text { (hours) }\end{array}$ & $\begin{array}{l}\text { Streamflow } \\
\text { (cubic feet } \\
\text { per second) }\end{array}$ & $\begin{array}{l}\text { Rain- } \\
\text { fall } \\
\text { (inches) }\end{array}$ & $\begin{array}{l}\text { Time } \\
\text { (hours) }\end{array}$ & $\begin{array}{l}\text { Streamflow } \\
\text { (cubic feet } \\
\text { per second) }\end{array}$ & $\begin{array}{l}\text { Rain- } \\
\text { fall } \\
\text { (inches) }\end{array}$ \\
\hline $\begin{array}{l}0545 \\
0550 \\
0555 \\
0600 \\
0605\end{array}$ & $\begin{array}{l}4.8 \\
4.4 \\
4.4 \\
3.9 \\
3.9\end{array}$ & $\begin{array}{l}0.00 \\
0.00 \\
0.00 \\
0.00 \\
0.00\end{array}$ & $\begin{array}{l}0755 \\
0800 \\
0805 \\
0810 \\
0815\end{array}$ & $\begin{array}{l}2.2 \\
2.2 \\
2.2 \\
2.2 \\
2.2\end{array}$ & $\begin{array}{l}0.00 \\
0.00 \\
0.00 \\
0.00 \\
0.00\end{array}$ & $\begin{array}{l}1005 \\
1010 \\
1015 \\
1020 \\
1025\end{array}$ & $\begin{array}{l}1.7 \\
1.7 \\
1.7 \\
1.7 \\
1.7\end{array}$ & $\begin{array}{l}0.00 \\
0.00 \\
0.00 \\
0.00 \\
0.00\end{array}$ \\
\hline $\begin{array}{l}0610 \\
0615 \\
0620 \\
0625 \\
0630\end{array}$ & $\begin{array}{l}3.9 \\
3.4 \\
3.4 \\
3.4 \\
3.4\end{array}$ & $\begin{array}{l}0.00 \\
0.00 \\
0.00 \\
0.00 \\
0.00\end{array}$ & $\begin{array}{l}0820 \\
0825 \\
0830 \\
0835 \\
0840\end{array}$ & $\begin{array}{l}2.2 \\
2.2 \\
2.2 \\
2.2 \\
2.2\end{array}$ & $\begin{array}{l}0.00 \\
0.00 \\
0.00 \\
0.00 \\
0.00\end{array}$ & $\begin{array}{l}1030 \\
1035 \\
1040 \\
1045 \\
1050\end{array}$ & $\begin{array}{l}1.7 \\
1.7 \\
1.7 \\
1.7 \\
1.7\end{array}$ & $\begin{array}{l}0.00 \\
0.00 \\
0.00 \\
0.00 \\
0.00\end{array}$ \\
\hline $\begin{array}{l}0635 \\
0640 \\
0645 \\
0650 \\
0655\end{array}$ & $\begin{array}{l}2.9 \\
2.9 \\
2.9 \\
2.9 \\
2.9\end{array}$ & $\begin{array}{l}0.00 \\
0.00 \\
0.00 \\
0.00 \\
0.00\end{array}$ & $\begin{array}{l}0845 \\
0850 \\
0855 \\
0900 \\
0905\end{array}$ & $\begin{array}{l}2.2 \\
2.2 \\
2.2 \\
2.2 \\
2.2\end{array}$ & $\begin{array}{l}0.00 \\
0.00 \\
0.00 \\
0.00 \\
0.00\end{array}$ & $\begin{array}{l}1055 \\
1100 \\
1105 \\
1110 \\
1115\end{array}$ & $\begin{array}{l}1.7 \\
1.7 \\
1.7 \\
1.7 \\
1.7\end{array}$ & $\begin{array}{l}0.00 \\
0.00 \\
0.00 \\
0.00 \\
0.00\end{array}$ \\
\hline $\begin{array}{l}0700 \\
0705 \\
0710 \\
0715 \\
0>20\end{array}$ & $\begin{array}{l}2.9 \\
2.5 \\
2.5 \\
2.5 \\
2.5\end{array}$ & $\begin{array}{l}0.00 \\
0.00 \\
0.00 \\
0.00 \\
0.00\end{array}$ & $\begin{array}{l}0910 \\
0915 \\
0920 \\
0925 \\
0930\end{array}$ & $\begin{array}{l}2.2 \\
2.2 \\
1.7 \\
1.7 \\
1.7\end{array}$ & $\begin{array}{l}0.00 \\
0.00 \\
0.00 \\
0.01 \\
0.00\end{array}$ & $\begin{array}{l}1120 \\
1125 \\
1130 \\
1135 \\
1140\end{array}$ & $\begin{array}{l}1.7 \\
1.3 \\
1.3 \\
1.3 \\
1.3\end{array}$ & $\begin{array}{l}0.00 \\
0.00 \\
0.00 \\
0.00 \\
0.00\end{array}$ \\
\hline $\begin{array}{l}0725 \\
0730 \\
0735 \\
0740 \\
0745\end{array}$ & $\begin{array}{l}2.5 \\
2.5 \\
2.5 \\
2.5 \\
2.5\end{array}$ & $\begin{array}{l}0.00 \\
0.00 \\
0.00 \\
0.00 \\
0.00\end{array}$ & $\begin{array}{l}0935 \\
0940 \\
0945 \\
0950 \\
0955\end{array}$ & $\begin{array}{l}1.7 \\
1.7 \\
1.7 \\
1.7 \\
1.7\end{array}$ & $\begin{array}{l}0.00 \\
0.00 \\
0.00 \\
0.00 \\
0.00\end{array}$ & $\begin{array}{l}1145 \\
1150 \\
1155 \\
1200\end{array}$ & $\begin{array}{l}1.3 \\
1.3 \\
1.3 \\
1.3\end{array}$ & $\begin{array}{l}0.00 \\
0.00 \\
0.00 \\
0.00\end{array}$ \\
\hline 0750 & 2.5 & 0.00 & 1000 & 1.7 & 0.00 & & & \\
\hline
\end{tabular}




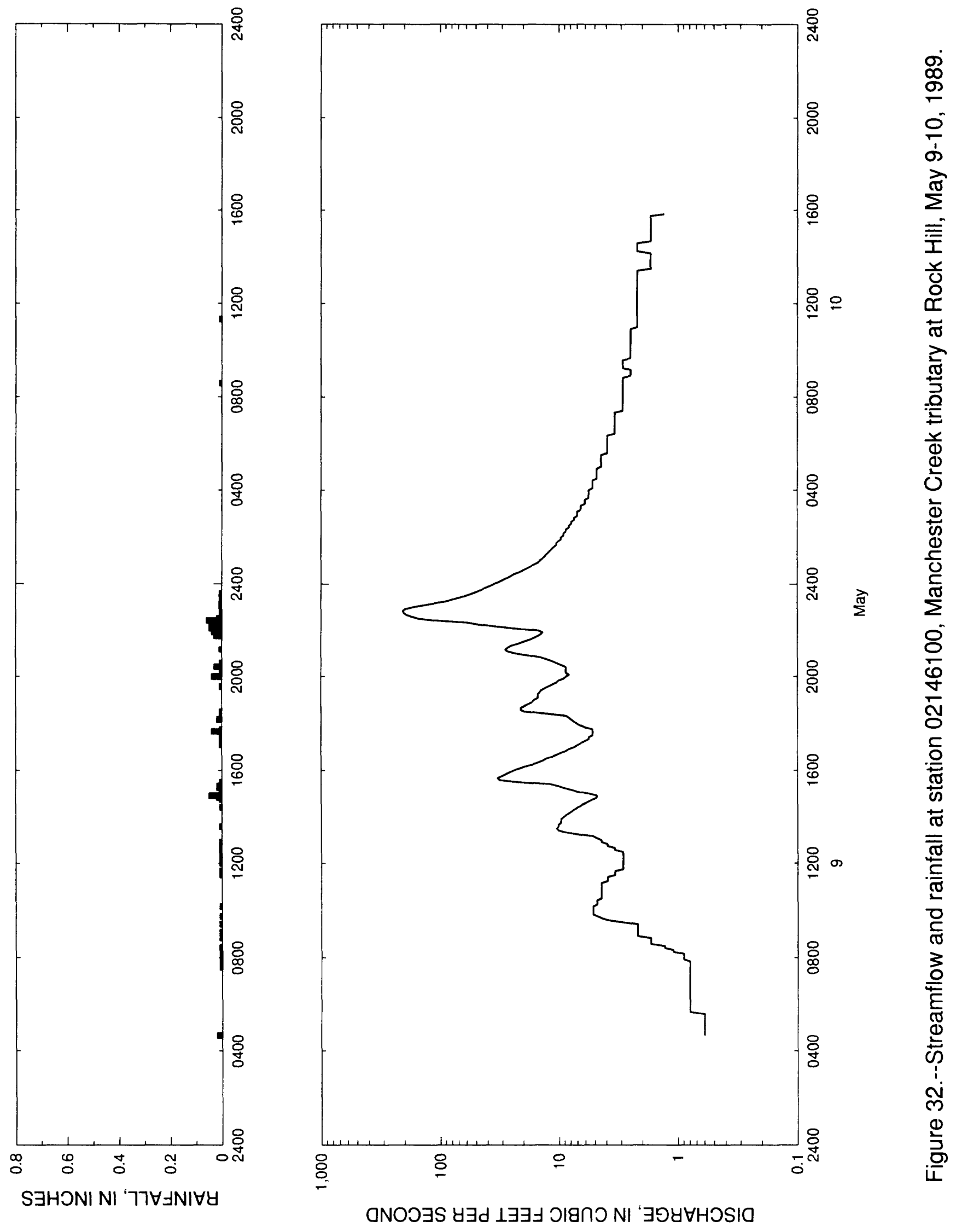


Table 31.--Streamflow and rainfa11 at station 02146100, Manchester Creek tributary at Rock Hil1, May $9-10,1989$

\begin{tabular}{|c|c|c|c|c|c|c|c|c|c|}
\hline $\begin{array}{l}\text { Time } \\
\text { (hours) }\end{array}$ & $\begin{array}{l}\text { Str } \\
\text { (cub } \\
\text { per }\end{array}$ & $\begin{array}{l}\text { reamflow } \\
\text { oic feet } \\
\text { second) }\end{array}$ & $\begin{array}{l}\text { Rain- } \\
\text { fall } \\
\text { (inches) }\end{array}$ & $\begin{array}{l}\text { Time } \\
\text { (hours) }\end{array}$ & $\begin{array}{l}\text { Streamflow } \\
\text { (cubic feet } \\
\text { per second) }\end{array}$ & $\begin{array}{l}\text { Rain- } \\
\text { fall } \\
\text { (inches) }\end{array}$ & $\begin{array}{l}\text { Time } \\
\text { (hours) }\end{array}$ & $\begin{array}{l}\text { Streamflow } \\
\text { (cubic feet } \\
\text { per second) }\end{array}$ & $\begin{array}{l}\text { Rain- } \\
\text { fall } \\
\text { (inches) }\end{array}$ \\
\hline $\begin{array}{c}\text { May 09, } \\
0440 \\
0445 \\
0450 \\
0455\end{array}$ & 1989 & $\begin{array}{l}0.6 \\
0.6 \\
0.6 \\
0.6\end{array}$ & $\begin{array}{l}0.02 \\
0.00 \\
0.00 \\
0.00\end{array}$ & $\begin{array}{l}1000 \\
1005 \\
1010 \\
1015 \\
1020\end{array}$ & $\begin{array}{l}5.2 \\
5.2 \\
5.2 \\
4.8 \\
4.8\end{array}$ & $\begin{array}{l}0.00 \\
0.00 \\
0.01 \\
0.00 \\
0.00\end{array}$ & $\begin{array}{l}1525 \\
1530 \\
1535 \\
1540 \\
1545\end{array}$ & $\begin{array}{l}11.9 \\
21.7 \\
31.4 \\
33.0 \\
30.6\end{array}$ & $\begin{array}{l}0.00 \\
0.01 \\
0.00 \\
0.00 \\
0.00\end{array}$ \\
\hline $\begin{array}{l}0500 \\
0505 \\
0510 \\
0515 \\
0520\end{array}$ & & $\begin{array}{l}0.6 \\
0.6 \\
0.6 \\
0.6 \\
0.6\end{array}$ & $\begin{array}{l}0.00 \\
0.00 \\
0.00 \\
0.00 \\
0.00\end{array}$ & $\begin{array}{l}1025 \\
1030 \\
1035 \\
1040 \\
1045\end{array}$ & $\begin{array}{l}4.8 \\
4.4 \\
4.4 \\
4.4 \\
4.4\end{array}$ & $\begin{array}{l}0.00 \\
0.00 \\
0.00 \\
0.00 \\
0.00\end{array}$ & $\begin{array}{l}1550 \\
1555 \\
1600 \\
1605 \\
1610\end{array}$ & $\begin{array}{l}28.3 \\
26.1 \\
24.0 \\
21.7 \\
19.5\end{array}$ & $\begin{array}{l}0.00 \\
0.00 \\
0.00 \\
0.00 \\
0.00\end{array}$ \\
\hline $\begin{array}{l}0525 \\
0530 \\
0535 \\
0540 \\
0545\end{array}$ & & $\begin{array}{l}0.6 \\
0.6 \\
0.6 \\
0.8 \\
0.8\end{array}$ & $\begin{array}{l}0.00 \\
0.00 \\
0.00 \\
0.00 \\
0.00\end{array}$ & $\begin{array}{l}1050 \\
1055 \\
1100 \\
1105 \\
1110\end{array}$ & $\begin{array}{l}4.4 \\
4.4 \\
4.4 \\
4.4 \\
4.4\end{array}$ & $\begin{array}{l}0.00 \\
0.00 \\
0.00 \\
0.00 \\
0.00\end{array}$ & $\begin{array}{l}1615 \\
1620 \\
1625 \\
1630 \\
1635\end{array}$ & $\begin{array}{l}16.8 \\
15.0 \\
13.7 \\
12.8 \\
11.4\end{array}$ & $\begin{array}{l}0.00 \\
0.00 \\
0.00 \\
0.00 \\
0.00\end{array}$ \\
\hline $\begin{array}{l}0550 \\
0555 \\
0600 \\
0605 \\
0610\end{array}$ & & $\begin{array}{l}0.8 \\
0.8 \\
0.8 \\
0.8 \\
0.8\end{array}$ & $\begin{array}{l}0.00 \\
0.00 \\
0.00 \\
0.00 \\
0.00\end{array}$ & $\begin{array}{l}1115 \\
1120 \\
1125 \\
1130 \\
1135\end{array}$ & $\begin{array}{l}3.9 \\
3.9 \\
3.9 \\
3.4 \\
3.4\end{array}$ & $\begin{array}{l}0.00 \\
0.00 \\
0.00 \\
0.01 \\
0.01\end{array}$ & $\begin{array}{l}1640 \\
1645 \\
1650 \\
1655 \\
1700\end{array}$ & $\begin{array}{r}10.5 \\
9.6 \\
8.7 \\
8.2 \\
7.4\end{array}$ & $\begin{array}{l}0.00 \\
0.00 \\
0.00 \\
0.00 \\
0.00\end{array}$ \\
\hline $\begin{array}{l}0615 \\
0620 \\
0625 \\
0630 \\
0635\end{array}$ & & $\begin{array}{l}0.8 \\
0.8 \\
0.8 \\
0.8 \\
0.8\end{array}$ & $\begin{array}{l}0.00 \\
0.00 \\
0.00 \\
0.00 \\
0.00\end{array}$ & $\begin{array}{l}1140 \\
1145 \\
1150 \\
1155 \\
1200\end{array}$ & $\begin{array}{l}3.4 \\
2.9 \\
2.9 \\
2.9 \\
2.9\end{array}$ & $\begin{array}{l}0.01 \\
0.00 \\
0.00 \\
0.00 \\
0.01\end{array}$ & $\begin{array}{l}1705 \\
1710 \\
1715 \\
1720 \\
1725\end{array}$ & $\begin{array}{l}7.0 \\
6.5 \\
6.0 \\
5.6 \\
5.6\end{array}$ & $\begin{array}{l}0.01 \\
0.00 \\
0.00 \\
0.01 \\
0.01\end{array}$ \\
\hline $\begin{array}{l}0640 \\
0645 \\
0650 \\
0655 \\
0700\end{array}$ & & $\begin{array}{l}0.8 \\
0.8 \\
0.8 \\
0.8 \\
0.8\end{array}$ & $\begin{array}{l}0.00 \\
0.00 \\
0.00 \\
0.00 \\
0.00\end{array}$ & $\begin{array}{l}1205 \\
1210 \\
1215 \\
1220 \\
1225\end{array}$ & $\begin{array}{l}2.9 \\
2.9 \\
2.9 \\
2.9 \\
2.9\end{array}$ & $\begin{array}{l}0.00 \\
0.01 \\
0.01 \\
0.01 \\
0.00\end{array}$ & $\begin{array}{l}1730 \\
1735 \\
1740 \\
1745 \\
1750\end{array}$ & $\begin{array}{l}5.2 \\
5.2 \\
5.2 \\
5.2 \\
6.0\end{array}$ & $\begin{array}{l}0.01 \\
0.00 \\
0.04 \\
0.01 \\
0.00\end{array}$ \\
\hline $\begin{array}{l}0705 \\
0710 \\
0715 \\
0720 \\
0725\end{array}$ & & $\begin{array}{l}0.8 \\
0.8 \\
0.8 \\
0.8 \\
0.8\end{array}$ & $\begin{array}{l}0.00 \\
0.00 \\
0.00 \\
0.00 \\
0.00\end{array}$ & $\begin{array}{l}1230 \\
1235 \\
1240 \\
1245 \\
1250\end{array}$ & $\begin{array}{l}2.9 \\
3.4 \\
3.4 \\
3.9 \\
3.9\end{array}$ & $\begin{array}{l}0.01 \\
0.00 \\
0.00 \\
0.01 \\
0.01\end{array}$ & $\begin{array}{l}1755 \\
1800 \\
1805 \\
1810 \\
1815\end{array}$ & $\begin{array}{l}6.5 \\
7.0 \\
7.4 \\
7.8 \\
8.2\end{array}$ & $\begin{array}{l}0.00 \\
0.00 \\
0.00 \\
0.02 \\
0.00\end{array}$ \\
\hline $\begin{array}{l}0730 \\
0735 \\
0740 \\
0745 \\
0750\end{array}$ & & $\begin{array}{l}0.8 \\
0.8 \\
0.8 \\
0.8 \\
0.8\end{array}$ & $\begin{array}{l}0.00 \\
0.01 \\
0.00 \\
0.00 \\
0.01\end{array}$ & $\begin{array}{l}1255 \\
1300 \\
1305 \\
1310 \\
1315\end{array}$ & $\begin{array}{l}4.4 \\
4.4 \\
4.8 \\
5.2 \\
7.0\end{array}$ & $\begin{array}{l}0.01 \\
0.00 \\
0.00 \\
0.00 \\
0.00\end{array}$ & $\begin{array}{l}1820 \\
1825 \\
1830 \\
1835 \\
1840\end{array}$ & $\begin{array}{r}8.7 \\
12.8 \\
19.5 \\
21.0 \\
21.0\end{array}$ & $\begin{array}{l}0.01 \\
0.01 \\
0.01 \\
0.00 \\
0.00\end{array}$ \\
\hline $\begin{array}{l}0755 \\
0800 \\
0805 \\
0810 \\
0815\end{array}$ & & $\begin{array}{l}0.9 \\
0.9 \\
0.9 \\
0.9 \\
1.1\end{array}$ & $\begin{array}{l}0.00 \\
0.01 \\
0.00 \\
0.01 \\
0.01\end{array}$ & $\begin{array}{l}1320 \\
1325 \\
1330 \\
1335 \\
1340\end{array}$ & $\begin{array}{r}8.7 \\
10.1 \\
10.5 \\
10.1 \\
10.1\end{array}$ & $\begin{array}{l}0.00 \\
0.00 \\
0.00 \\
0.01 \\
0.00\end{array}$ & $\begin{array}{l}1845 \\
1850 \\
1855 \\
1900 \\
1905\end{array}$ & $\begin{array}{l}19.5 \\
18.2 \\
16.8 \\
16.2 \\
15.0\end{array}$ & $\begin{array}{l}0.00 \\
0.00 \\
0.00 \\
0.00 \\
0.00\end{array}$ \\
\hline $\begin{array}{l}0820 \\
0825 \\
0830 \\
0835 \\
0840\end{array}$ & & $\begin{array}{l}1.1 \\
1.3 \\
1.3 \\
1.7 \\
1.7\end{array}$ & $\begin{array}{l}0.00 \\
0.01 \\
0.00 \\
0.00 \\
0.00\end{array}$ & $\begin{array}{l}1345 \\
1350 \\
1355 \\
1400 \\
1405\end{array}$ & $\begin{array}{l}9.6 \\
9.6 \\
9.6 \\
9.1 \\
8.7\end{array}$ & $\begin{array}{l}0.00 \\
0.00 \\
0.00 \\
0.00 \\
0.00\end{array}$ & $\begin{array}{l}1910 \\
1915 \\
1920 \\
1925 \\
1930\end{array}$ & $\begin{array}{l}15.0 \\
15.0 \\
14.5 \\
14.1 \\
13.2\end{array}$ & $\begin{array}{l}0.00 \\
0.00 \\
0.00 \\
0.00 \\
0.00\end{array}$ \\
\hline $\begin{array}{l}0845 \\
0850 \\
0855 \\
0900 \\
0905\end{array}$ & & $\begin{array}{l}1.7 \\
1.7 \\
2.2 \\
2.2 \\
2.2\end{array}$ & $\begin{array}{l}0.00 \\
0.01 \\
0.00 \\
0.00 \\
0.01\end{array}$ & $\begin{array}{l}1410 \\
1415 \\
1420 \\
1425 \\
1430\end{array}$ & $\begin{array}{l}8.2 \\
7.8 \\
7.4 \\
7.0 \\
6.5\end{array}$ & $\begin{array}{l}0.00 \\
0.00 \\
0.00 \\
0.01 \\
0.00\end{array}$ & $\begin{array}{l}1935 \\
1940 \\
1945 \\
1950 \\
1955\end{array}$ & $\begin{array}{r}12.3 \\
11.4 \\
10.5 \\
10.1 \\
9.1\end{array}$ & $\begin{array}{l}0.01 \\
0.00 \\
0.00 \\
0.00 \\
0.00\end{array}$ \\
\hline $\begin{array}{l}0910 \\
0915 \\
0920 \\
0925 \\
0930\end{array}$ & & $\begin{array}{l}2.2 \\
2.2 \\
2.2 \\
2.2 \\
2.9\end{array}$ & $\begin{array}{l}0.00 \\
0.00 \\
0.00 \\
0.01 \\
0.00\end{array}$ & $\begin{array}{l}1435 \\
1440 \\
1445 \\
1450 \\
1455\end{array}$ & $\begin{array}{l}6.0 \\
5.6 \\
5.2 \\
4.8 \\
4.8\end{array}$ & $\begin{array}{l}0.00 \\
0.00 \\
0.01 \\
0.02 \\
0.05\end{array}$ & $\begin{array}{l}2000 \\
2005 \\
2010 \\
2015 \\
2020\end{array}$ & $\begin{array}{l}8.7 \\
8.2 \\
8.7 \\
8.7 \\
8.7\end{array}$ & $\begin{array}{l}0.04 \\
0.00 \\
0.01 \\
0.01 \\
0.01\end{array}$ \\
\hline $\begin{array}{l}0935 \\
0940 \\
0945 \\
0950 \\
0955\end{array}$ & & $\begin{array}{l}3.9 \\
4.4 \\
4.8 \\
5.2 \\
5.2\end{array}$ & $\begin{array}{l}0.00 \\
0.00 \\
0.01 \\
0.00 \\
0.00\end{array}$ & $\begin{array}{l}1500 \\
1505 \\
1510 \\
1515 \\
1520\end{array}$ & $\begin{array}{r}5.6 \\
7.0 \\
7.8 \\
9.1 \\
10.1\end{array}$ & $\begin{array}{l}0.01 \\
0.00 \\
0.01 \\
0.02 \\
0.02\end{array}$ & $\begin{array}{l}2025 \\
2030 \\
2035 \\
2040 \\
2045\end{array}$ & $\begin{array}{r}8.7 \\
9.6 \\
10.5 \\
11.4 \\
12.8\end{array}$ & $\begin{array}{l}0.03 \\
0.01 \\
0.01 \\
0.00 \\
0.00\end{array}$ \\
\hline
\end{tabular}


Table 31.--Streamflow and rainfall at station 02146100, Manchester Creok tributary at Rock Hill, May $9-10,1989--$ Continued

\begin{tabular}{|c|c|c|c|c|c|c|c|c|}
\hline $\begin{array}{l}\text { Time } \\
\text { (hours) }\end{array}$ & $\begin{array}{l}\text { Streamflow } \\
\text { (cubic feet } \\
\text { per second) }\end{array}$ & $\begin{array}{l}\text { Rain- } \\
\text { fall } \\
\text { (inches) }\end{array}$ & $\begin{array}{l}\text { Time } \\
\text { (hours) }\end{array}$ & $\begin{array}{l}\text { Streamflow } \\
\text { (cubic feet } \\
\text { per second) }\end{array}$ & $\begin{array}{l}\text { Rain- } \\
\text { fall } \\
\text { (inches) }\end{array}$ & $\begin{array}{l}\text { Time } \\
\text { (hours) }\end{array}$ & $\begin{array}{l}\text { Streamflow } \\
\text { (cubic feet } \\
\text { per second) }\end{array}$ & $\begin{array}{l}\text { Rain- } \\
\text { fall } \\
\text { (inches) }\end{array}$ \\
\hline $\begin{array}{l}2050 \\
2055 \\
2100 \\
2105 \\
2110\end{array}$ & $\begin{array}{l}14.5 \\
18.2 \\
23.2 \\
26.8 \\
28.3\end{array}$ & $\begin{array}{l}0.00 \\
0.00 \\
0.00 \\
0.00 \\
0.01\end{array}$ & $\begin{array}{l}0210 \\
0215 \\
0220 \\
0225 \\
0230\end{array}$ & $\begin{array}{l}9.1 \\
8.7 \\
8.7 \\
8.2 \\
8.2\end{array}$ & $\begin{array}{l}0.00 \\
0.00 \\
0.00 \\
0.00 \\
0.00\end{array}$ & $\begin{array}{l}0735 \\
0740 \\
0745 \\
0750 \\
0755\end{array}$ & $\begin{array}{l}2.9 \\
2.9 \\
2.9 \\
2.9 \\
2.9\end{array}$ & $\begin{array}{l}0.00 \\
0.00 \\
0.00 \\
0.00 \\
0.00\end{array}$ \\
\hline $\begin{array}{l}2115 \\
2120 \\
2125 \\
2130 \\
2135\end{array}$ & $\begin{array}{l}26.8 \\
25.4 \\
22.4 \\
20.2 \\
18.2\end{array}$ & $\begin{array}{l}0.00 \\
0.00 \\
0.00 \\
0.00 \\
0.00\end{array}$ & $\begin{array}{l}0235 \\
0240 \\
0245 \\
0250 \\
0255\end{array}$ & $\begin{array}{l}7.8 \\
7.8 \\
7.4 \\
7.4 \\
7.0\end{array}$ & $\begin{array}{l}0.00 \\
0.00 \\
0.00 \\
0.00 \\
0.00\end{array}$ & $\begin{array}{l}0800 \\
0805 \\
0810 \\
0815 \\
0820\end{array}$ & $\begin{array}{l}2.9 \\
2.9 \\
2.9 \\
2.9 \\
2.9\end{array}$ & $\begin{array}{l}0.00 \\
0.00 \\
0.00 \\
0.00 \\
0.00\end{array}$ \\
\hline $\begin{array}{l}2140 \\
2145 \\
2150 \\
2155 \\
2200\end{array}$ & $\begin{array}{l}16.2 \\
15.0 \\
14.1 \\
13.7 \\
15.0\end{array}$ & $\begin{array}{l}0.00 \\
0.03 \\
0.02 \\
0.04 \\
0.01\end{array}$ & $\begin{array}{l}0300 \\
0305 \\
0310 \\
0315 \\
0320\end{array}$ & $\begin{array}{l}7.0 \\
7.0 \\
6.5 \\
6.5 \\
6.5\end{array}$ & $\begin{array}{l}0.00 \\
0.00 \\
0.00 \\
0.00 \\
0.00\end{array}$ & $\begin{array}{l}0825 \\
0830 \\
0835 \\
0840 \\
0845\end{array}$ & $\begin{array}{l}2.9 \\
2.9 \\
2.9 \\
2.9 \\
2.9\end{array}$ & $\begin{array}{l}0.00 \\
0.00 \\
0.01 \\
0.00 \\
0.00\end{array}$ \\
\hline $\begin{array}{l}2205 \\
2210 \\
2215 \\
2220 \\
2225\end{array}$ & $\begin{array}{r}24.0 \\
34.5 \\
47.5 \\
58.9 \\
109.0\end{array}$ & $\begin{array}{l}0.05 \\
0.05 \\
0.01 \\
0.01 \\
0.06\end{array}$ & $\begin{array}{l}0325 \\
0330 \\
0335 \\
0340 \\
0345\end{array}$ & $\begin{array}{l}6.0 \\
6.0 \\
6.0 \\
5.6 \\
5.6\end{array}$ & $\begin{array}{l}0.00 \\
0.00 \\
0.00 \\
0.00 \\
0.00\end{array}$ & $\begin{array}{l}0850 \\
0855 \\
0900 \\
0905 \\
0910\end{array}$ & $\begin{array}{l}2.9 \\
2.5 \\
2.5 \\
2.5 \\
2.5\end{array}$ & $\begin{array}{l}0.00 \\
0.00 \\
0.00 \\
0.00 \\
0.00\end{array}$ \\
\hline $\begin{array}{l}2230 \\
2235 \\
2240 \\
2245 \\
2250\end{array}$ & $\begin{array}{l}151.0 \\
175.0 \\
194.0 \\
203.0 \\
207.0\end{array}$ & $\begin{array}{l}0.02 \\
0.00 \\
0.01 \\
0.01 \\
0.01\end{array}$ & $\begin{array}{l}0350 \\
0355 \\
0400 \\
0405 \\
0410\end{array}$ & $\begin{array}{l}5.6 \\
5.6 \\
5.6 \\
5.2 \\
5.2\end{array}$ & $\begin{array}{l}0.00 \\
0.00 \\
0.00 \\
0.00 \\
0.00\end{array}$ & $\begin{array}{l}0915 \\
0920 \\
0925 \\
0930 \\
0935\end{array}$ & $\begin{array}{l}2.9 \\
2.9 \\
2.9 \\
2.9 \\
2.9\end{array}$ & $\begin{array}{l}0.00 \\
0.00 \\
0.00 \\
0.00 \\
0.00\end{array}$ \\
\hline $\begin{array}{l}2255 \\
2300 \\
2305 \\
2310 \\
2315\end{array}$ & $\begin{array}{r}196.0 \\
167.0 \\
137.0 \\
112.0 \\
89.6\end{array}$ & $\begin{array}{l}0.00 \\
0.00 \\
0.01 \\
0.00 \\
0.00\end{array}$ & $\begin{array}{l}0415 \\
0420 \\
0425 \\
0430 \\
0435\end{array}$ & $\begin{array}{l}5.2 \\
5.2 \\
5.2 \\
4.8 \\
4.8\end{array}$ & $\begin{array}{l}0.00 \\
0.00 \\
0.00 \\
0.00 \\
0.00\end{array}$ & $\begin{array}{l}0940 \\
0945 \\
0950 \\
0955 \\
1000\end{array}$ & $\begin{array}{l}2.5 \\
2.5 \\
2.5 \\
2.5 \\
2.5\end{array}$ & $\begin{array}{l}0.00 \\
0.00 \\
0.00 \\
0.00 \\
0.00\end{array}$ \\
\hline $\begin{array}{l}2320 \\
2325 \\
2330 \\
2335 \\
2340\end{array}$ & $\begin{array}{l}79.8 \\
68.5 \\
60.8 \\
54.4 \\
49.2\end{array}$ & $\begin{array}{l}0.01 \\
0.00 \\
0.00 \\
0.01 \\
0.00\end{array}$ & $\begin{array}{l}0440 \\
0445 \\
0450 \\
0455 \\
0500\end{array}$ & $\begin{array}{l}4.8 \\
4.8 \\
4.8 \\
4.8 \\
4.4\end{array}$ & $\begin{array}{l}0.00 \\
0.00 \\
0.00 \\
0.00 \\
0.00\end{array}$ & $\begin{array}{l}1005 \\
1010 \\
1015 \\
1020 \\
1025\end{array}$ & $\begin{array}{l}2.5 \\
2.5 \\
2.5 \\
2.5 \\
2.5\end{array}$ & $\begin{array}{l}0.00 \\
0.00 \\
0.00 \\
0.00 \\
0.00\end{array}$ \\
\hline $\begin{array}{l}2345 \\
2350 \\
2355 \\
\\
0000\end{array}$ & $\begin{array}{c}45.0 \\
41.8 \\
37.7 \\
\text { May } 10 \\
35.3\end{array}$ & $\begin{array}{r}0.00 \\
0.00 \\
0.00 \\
1989 \\
0.00\end{array}$ & $\begin{array}{l}0505 \\
0510 \\
0515 \\
0520 \\
0525\end{array}$ & $\begin{array}{l}4.4 \\
4.4 \\
4.4 \\
4.4 \\
4.4\end{array}$ & $\begin{array}{l}0.00 \\
0.00 \\
0.00 \\
0.00 \\
0.00\end{array}$ & $\begin{array}{l}1030 \\
1035 \\
1040 \\
1045 \\
1050\end{array}$ & $\begin{array}{l}2.5 \\
2.5 \\
2.5 \\
2.5 \\
2.5\end{array}$ & $\begin{array}{l}0.00 \\
0.00 \\
0.00 \\
0.00 \\
0.00\end{array}$ \\
\hline $\begin{array}{l}0005 \\
0010 \\
0015 \\
0020 \\
0025\end{array}$ & $\begin{array}{l}32.2 \\
29.8 \\
27.6 \\
25.4 \\
24.0\end{array}$ & $\begin{array}{l}0.00 \\
0.00 \\
0.00 \\
0.00 \\
0.00\end{array}$ & $\begin{array}{l}0530 \\
0535 \\
0540 \\
0545 \\
0550\end{array}$ & $\begin{array}{l}4.4 \\
3.9 \\
3.9 \\
3.9 \\
3.9\end{array}$ & $\begin{array}{l}0.00 \\
0.00 \\
0.00 \\
0.00 \\
0.00\end{array}$ & $\begin{array}{l}1055 \\
1100 \\
1105 \\
1110 \\
1115\end{array}$ & $\begin{array}{l}2.5 \\
2.2 \\
2.2 \\
2.2 \\
2.2\end{array}$ & $\begin{array}{l}0.00 \\
0.00 \\
0.00 \\
0.00 \\
0.00\end{array}$ \\
\hline $\begin{array}{l}0030 \\
0035 \\
0040 \\
0045 \\
0050\end{array}$ & $\begin{array}{l}21.7 \\
20.2 \\
18.8 \\
17.5 \\
16.2\end{array}$ & $\begin{array}{l}0.00 \\
0.00 \\
0.00 \\
0.00 \\
0.00\end{array}$ & $\begin{array}{l}0555 \\
0600 \\
0605 \\
0610 \\
0615\end{array}$ & $\begin{array}{l}3.9 \\
3.9 \\
3.9 \\
3.9 \\
3.9\end{array}$ & $\begin{array}{l}0.00 \\
0.00 \\
0.00 \\
0.00 \\
0.00\end{array}$ & $\begin{array}{l}1120 \\
1125 \\
1130 \\
1135 \\
1140\end{array}$ & $\begin{array}{l}2.2 \\
2.2 \\
2.2 \\
2.2 \\
2.2\end{array}$ & $\begin{array}{l}0.01 \\
0.00 \\
0.00 \\
0.00 \\
0.00\end{array}$ \\
\hline $\begin{array}{l}0055 \\
0100 \\
0105 \\
0110 \\
0115\end{array}$ & $\begin{array}{l}15.0 \\
14.5 \\
13.7 \\
13.2 \\
12.8\end{array}$ & $\begin{array}{l}0.00 \\
0.00 \\
0.00 \\
0.00 \\
0.00\end{array}$ & $\begin{array}{l}0620 \\
0625 \\
0630 \\
0635 \\
0640\end{array}$ & $\begin{array}{l}3.9 \\
3.4 \\
3.4 \\
3.4 \\
3.4\end{array}$ & $\begin{array}{l}0.00 \\
0.00 \\
0.00 \\
0.00 \\
0.00\end{array}$ & $\begin{array}{l}1145 \\
1150 \\
1155 \\
1200 \\
1205\end{array}$ & $\begin{array}{l}2.2 \\
2.2 \\
2.2 \\
2.2 \\
2.2\end{array}$ & $\begin{array}{l}0.07 \\
0.07 \\
0.03 \\
0.00 \\
0.07\end{array}$ \\
\hline $\begin{array}{l}0120 \\
0125 \\
0130 \\
0135 \\
0140\end{array}$ & $\begin{array}{l}12.3 \\
11.9 \\
11.4 \\
11.0 \\
10.5\end{array}$ & $\begin{array}{l}0.00 \\
0.00 \\
0.00 \\
0.00 \\
0.00\end{array}$ & $\begin{array}{l}0645 \\
0650 \\
0655 \\
0700 \\
0705\end{array}$ & $\begin{array}{l}3.4 \\
3.4 \\
3.4 \\
3.4 \\
3.4\end{array}$ & $\begin{array}{l}0.00 \\
0.00 \\
0.00 \\
0.00 \\
0.00\end{array}$ & $\begin{array}{l}1210 \\
1215 \\
1220 \\
1225 \\
1230\end{array}$ & $\begin{array}{l}2.2 \\
2.2 \\
2.2 \\
2.2 \\
2.2\end{array}$ & $\begin{array}{l}0.07 \\
0.07 \\
0.07 \\
0.07 \\
0.07\end{array}$ \\
\hline $\begin{array}{l}0145 \\
0150 \\
0155 \\
0200 \\
0205\end{array}$ & $\begin{array}{r}10.5 \\
10.1 \\
9.6 \\
9.6 \\
9.1\end{array}$ & $\begin{array}{l}0.00 \\
0.00 \\
0.00 \\
0.00 \\
0.00\end{array}$ & $\begin{array}{l}0710 \\
0715 \\
0720 \\
0725 \\
0730\end{array}$ & $\begin{array}{l}3.4 \\
3.4 \\
3.4 \\
2.9 \\
2.9\end{array}$ & $\begin{array}{l}0.00 \\
0.00 \\
0.00 \\
0.00 \\
0.00\end{array}$ & $\begin{array}{l}1235 \\
1240 \\
1245 \\
1250 \\
1255\end{array}$ & $\begin{array}{l}2.2 \\
2.2 \\
2.2 \\
2.2 \\
2.2\end{array}$ & $\begin{array}{l}0.0 ? \\
0.0 ? \\
0.0 ? \\
0.0 ? \\
0.0 ?\end{array}$ \\
\hline
\end{tabular}


Table 31. - Streamflow and rainfall at station 02146100, Manchester Creek tributary at Rock Hill, May 9-10, 1989--Continued

\begin{tabular}{|c|c|c|c|c|c|c|c|c|}
\hline $\begin{array}{l}\text { Time } \\
\text { (hours) }\end{array}$ & $\begin{array}{l}\text { Streamflow } \\
\text { (cubic feet } \\
\text { per second) }\end{array}$ & $\begin{array}{l}\text { Rain- } \\
\text { fall } \\
\text { (inches) }\end{array}$ & $\begin{array}{l}\text { Time } \\
\text { (hours) }\end{array}$ & $\begin{array}{l}\text { Streamflow } \\
\text { (cubic feet } \\
\text { per second) }\end{array}$ & $\begin{array}{l}\text { Rain- } \\
\text { fall } \\
\text { (inches) }\end{array}$ & $\begin{array}{l}\text { Time } \\
\text { (hours) }\end{array}$ & $\begin{array}{l}\text { Streamflow } \\
\text { (cubic feet } \\
\text { per second) }\end{array}$ & $\begin{array}{l}\text { Rain- } \\
\text { fall } \\
\text { (inches) }\end{array}$ \\
\hline $\begin{array}{l}1300 \\
1305 \\
1310 \\
1315 \\
1320\end{array}$ & $\begin{array}{l}2.2 \\
2.2 \\
2.2 \\
2.2 \\
2.2\end{array}$ & $\begin{array}{l}0.00 \\
0.00 \\
0.00 \\
0.00 \\
0.00\end{array}$ & $\begin{array}{l}1405 \\
1410 \\
1415 \\
1420 \\
1425\end{array}$ & $\begin{array}{l}1.7 \\
1.7 \\
2.2 \\
2.2 \\
2.2\end{array}$ & $\begin{array}{l}0.00 \\
0.00 \\
0.00 \\
0.00 \\
0.00\end{array}$ & $\begin{array}{l}1510 \\
1515 \\
1520 \\
1525 \\
1530\end{array}$ & $\begin{array}{l}1.7 \\
1.7 \\
1.7 \\
1.7 \\
1.7\end{array}$ & $\begin{array}{l}0.00 \\
0.00 \\
0.00 \\
0.00 \\
0.00\end{array}$ \\
\hline $\begin{array}{l}1325 \\
1330 \\
1335 \\
1340 \\
1345\end{array}$ & $\begin{array}{l}2.2 \\
1.7 \\
1.7 \\
1.7 \\
1.7\end{array}$ & $\begin{array}{l}0.00 \\
0.00 \\
0.00 \\
0.00 \\
0.00\end{array}$ & $\begin{array}{l}1430 \\
1435 \\
1440 \\
1445 \\
1450\end{array}$ & $\begin{array}{l}2.2 \\
2.2 \\
1.7 \\
1.7 \\
1.7\end{array}$ & $\begin{array}{l}0.00 \\
0.00 \\
0.00 \\
0.00 \\
0.00\end{array}$ & $\begin{array}{l}1535 \\
1540 \\
1545 \\
1550 \\
1555\end{array}$ & $\begin{array}{l}1.7 \\
1.7 \\
1.7 \\
1.3 \\
1.3\end{array}$ & $\begin{array}{l}0.00 \\
0.00 \\
0.00 \\
0.00 \\
0.00\end{array}$ \\
\hline $\begin{array}{l}1350 \\
1355 \\
1400\end{array}$ & $\begin{array}{l}1.7 \\
1.7 \\
1.7\end{array}$ & $\begin{array}{l}0.00 \\
0.00 \\
0.00\end{array}$ & $\begin{array}{l}1455 \\
1500 \\
1505\end{array}$ & $\begin{array}{l}1.7 \\
1.7 \\
1.7\end{array}$ & $\begin{array}{l}0.00 \\
0.00 \\
0.00\end{array}$ & 1600 & 1.3 & 0.00 \\
\hline
\end{tabular}




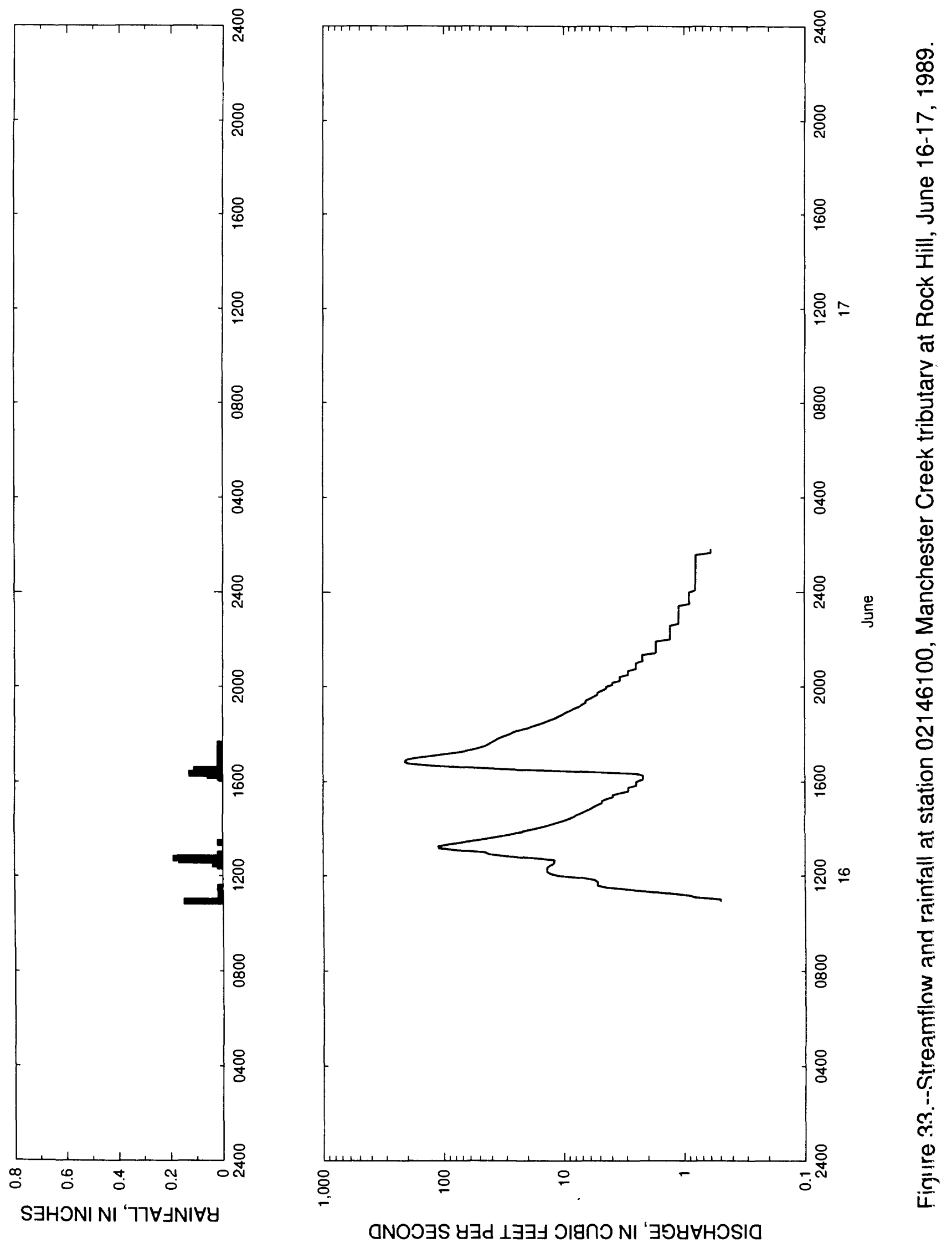


Table 32. - Streamflow and rainfall at station 02146100, Manchester Creek tributary at Rock Hill, June $16-17,1989$

\begin{tabular}{|c|c|c|c|c|c|c|c|c|}
\hline $\begin{array}{l}\text { Time } \\
\text { (hours) }\end{array}$ & $\begin{array}{l}\text { Streamflow } \\
\text { (cubic feet } \\
\text { per second) }\end{array}$ & $\begin{array}{l}\text { Rain- } \\
\text { fall } \\
\text { (inches) }\end{array}$ & $\begin{array}{l}\text { Time } \\
\text { (hours) }\end{array}$ & $\begin{array}{l}\text { Streamflow } \\
\text { (cubic feet } \\
\text { per second) }\end{array}$ & $\begin{array}{l}\text { Rain- } \\
\text { fall } \\
\text { (inches) }\end{array}$ & $\begin{array}{l}\text { Time } \\
\text { (hours) }\end{array}$ & $\begin{array}{l}\text { Streamflow } \\
\text { (cubic feet } \\
\text { per second) }\end{array}$ & $\begin{array}{l}\text { Rain- } \\
\text { fall } \\
\text { (inches) }\end{array}$ \\
\hline $\begin{array}{l}\text { June } 16 \\
1055 \\
1100 \\
1105 \\
1110\end{array}$ & $\begin{array}{r}1989 \\
0.5 \\
0.5 \\
0.8 \\
0.9\end{array}$ & $\begin{array}{l}0.15 \\
0.02 \\
0.02 \\
0.00\end{array}$ & $\begin{array}{l}1600 \\
1605 \\
1610 \\
1615 \\
1620\end{array}$ & $\begin{array}{l}2.5 \\
2.2 \\
2.2 \\
2.2 \\
2.5\end{array}$ & $\begin{array}{l}0.00 \\
0.00 \\
0.02 \\
0.06 \\
0.13\end{array}$ & $\begin{array}{l}2110 \\
2115 \\
2120 \\
2125 \\
2130\end{array}$ & $\begin{array}{l}2.2 \\
2.2 \\
2.2 \\
1.7 \\
1.7\end{array}$ & $\begin{array}{l}0.00 \\
0.00 \\
0.00 \\
0.00 \\
0.00\end{array}$ \\
\hline $\begin{array}{l}1115 \\
1120 \\
1125 \\
1130 \\
1135\end{array}$ & $\begin{array}{l}1.3 \\
2.2 \\
2.9 \\
4.4 \\
5.2\end{array}$ & $\begin{array}{l}0.02 \\
0.02 \\
0.00 \\
0.02 \\
0.00\end{array}$ & $\begin{array}{l}1625 \\
1630 \\
1635 \\
1640 \\
1645\end{array}$ & $\begin{array}{r}7.0 \\
24.0 \\
56.2 \\
123.0 \\
196.0\end{array}$ & $\begin{array}{l}0.03 \\
0.11 \\
0.02 \\
0.02 \\
0.02\end{array}$ & $\begin{array}{l}2135 \\
2140 \\
2145 \\
2150 \\
2155\end{array}$ & $\begin{array}{l}1.7 \\
1.7 \\
1.7 \\
1.7 \\
1.7\end{array}$ & $\begin{array}{l}0.00 \\
0.00 \\
0.00 \\
0.00 \\
0.00\end{array}$ \\
\hline $\begin{array}{l}1140 \\
1145 \\
1150 \\
1155 \\
1200\end{array}$ & $\begin{array}{r}5.2 \\
5.2 \\
5.6 \\
7.0 \\
11.0\end{array}$ & $\begin{array}{l}0.00 \\
0.00 \\
0.00 \\
0.00 \\
0.00\end{array}$ & $\begin{array}{l}1650 \\
1655 \\
1700 \\
1705 \\
1710\end{array}$ & $\begin{array}{r}209.0 \\
205.0 \\
169.0 \\
128.0 \\
95.3\end{array}$ & $\begin{array}{l}0.00 \\
0.02 \\
0.02 \\
0.00 \\
0.02\end{array}$ & $\begin{array}{l}2200 \\
2205 \\
2210 \\
2215 \\
2220\end{array}$ & $\begin{array}{l}1 \cdot 3 \\
1 \cdot 3 \\
1 \cdot 3 \\
1 \cdot 3 \\
1 \cdot 3\end{array}$ & $\begin{array}{l}0.00 \\
0.00 \\
0.00 \\
0.00 \\
0.00\end{array}$ \\
\hline $\begin{array}{l}1205 \\
1210 \\
1215 \\
1220 \\
1225\end{array}$ & $\begin{array}{l}12.8 \\
13.7 \\
13.7 \\
13.7 \\
13.2\end{array}$ & $\begin{array}{l}0.00 \\
0.00 \\
0.00 \\
0.00 \\
0.02\end{array}$ & $\begin{array}{l}1715 \\
1720 \\
1725 \\
1730 \\
1735\end{array}$ & $\begin{array}{l}72.5 \\
58.9 \\
50.9 \\
45.0 \\
41.8\end{array}$ & $\begin{array}{l}0.00 \\
0.02 \\
0.00 \\
0.00 \\
0.02\end{array}$ & $\begin{array}{l}2225 \\
2230 \\
2235 \\
2240 \\
2245\end{array}$ & $\begin{array}{l}1 \cdot 3 \\
1 \cdot 3 \\
1 \cdot 3 \\
1 \cdot 1 \\
1 \cdot 1\end{array}$ & $\begin{array}{l}0.00 \\
0.00 \\
0.00 \\
0.00 \\
0.00\end{array}$ \\
\hline $\begin{array}{l}1230 \\
1235 \\
1240 \\
1245 \\
1250\end{array}$ & $\begin{array}{l}12.3 \\
11.9 \\
11.9 \\
17.5 \\
30.6\end{array}$ & $\begin{array}{l}0.04 \\
0.02 \\
0.17 \\
0.19 \\
0.02\end{array}$ & $\begin{array}{l}1740 \\
1745 \\
1750 \\
1755 \\
1800\end{array}$ & $\begin{array}{l}39.3 \\
36.9 \\
34.5 \\
31.4 \\
28.3\end{array}$ & $\begin{array}{l}0.00 \\
0.00 \\
0.00 \\
0.00 \\
0.00\end{array}$ & $\begin{array}{l}2250 \\
2255 \\
2300 \\
2305 \\
2310\end{array}$ & $\begin{array}{l}1 \cdot 1 \\
1 \cdot 1 \\
1 \cdot 1 \\
1 \cdot 1 \\
1.1\end{array}$ & $\begin{array}{l}0.00 \\
0.00 \\
0.00 \\
0.00 \\
0.00\end{array}$ \\
\hline $\begin{array}{l}1255 \\
1300 \\
1305 \\
1310 \\
1315\end{array}$ & $\begin{array}{r}41.8 \\
45.0 \\
75.6 \\
109.0 \\
111.0\end{array}$ & $\begin{array}{l}0.02 \\
0.00 \\
0.00 \\
0.00 \\
0.00\end{array}$ & $\begin{array}{l}1805 \\
1810 \\
1815 \\
1820 \\
1825\end{array}$ & $\begin{array}{l}26.1 \\
24.0 \\
20.0 \\
18.2 \\
16.2\end{array}$ & $\begin{array}{l}0.00 \\
0.00 \\
0.00 \\
0.00 \\
0.00\end{array}$ & $\begin{array}{l}2315 \\
2320 \\
2325 \\
2330 \\
2335\end{array}$ & $\begin{array}{l}1.1 \\
1.1 \\
1.1 \\
0.9 \\
0.9\end{array}$ & $\begin{array}{l}0.00 \\
0.00 \\
0.00 \\
0.00 \\
0.00\end{array}$ \\
\hline $\begin{array}{l}1320 \\
1325 \\
1330 \\
1335 \\
1340\end{array}$ & $\begin{array}{l}90.7 \\
70.5 \\
53.5 \\
42.6 \\
34.5\end{array}$ & $\begin{array}{l}0.00 \\
0.02 \\
0.00 \\
0.00 \\
0.00\end{array}$ & $\begin{array}{l}1830 \\
1835 \\
1840 \\
1845 \\
1850\end{array}$ & $\begin{array}{l}14.5 \\
13.2 \\
11.9 \\
11.0 \\
10.1\end{array}$ & $\begin{array}{l}0.00 \\
0.00 \\
0.00 \\
0.00 \\
0.00\end{array}$ & $\begin{array}{c}2340 \\
2345 \\
2350 \\
2355 \\
\text { June } 17\end{array}$ & $\begin{array}{r}0.9 \\
0.9 \\
0.9 \\
1989 \\
0.9\end{array}$ & $\begin{array}{l}0.00 \\
0.00 \\
0.00 \\
0.00\end{array}$ \\
\hline $\begin{array}{l}1345 \\
1350 \\
1355 \\
1400 \\
1405\end{array}$ & $\begin{array}{l}28.3 \\
24.0 \\
20.2 \\
16.8 \\
14.5\end{array}$ & $\begin{array}{l}0.00 \\
0.00 \\
0.00 \\
0.00 \\
0.00\end{array}$ & $\begin{array}{l}1855 \\
1900 \\
1905 \\
1910 \\
1915\end{array}$ & $\begin{array}{l}9.6 \\
8.7 \\
8.2 \\
7.4 \\
7.0\end{array}$ & $\begin{array}{l}0.00 \\
0.00 \\
0.00 \\
0.00 \\
0.00\end{array}$ & $\begin{array}{l}0000 \\
0005 \\
0010 \\
0015 \\
0020\end{array}$ & $\begin{array}{l}0.9 \\
0.8 \\
0.8 \\
0.8 \\
0.8\end{array}$ & $\begin{array}{l}0.00 \\
0.00 \\
0.00 \\
0.00 \\
0.00\end{array}$ \\
\hline $\begin{array}{l}1410 \\
1415 \\
1420 \\
1425 \\
1430\end{array}$ & $\begin{array}{r}12.8 \\
11.4 \\
10.1 \\
9.1 \\
8.2\end{array}$ & $\begin{array}{l}0.00 \\
0.00 \\
0.00 \\
0.00 \\
0.00\end{array}$ & $\begin{array}{l}1920 \\
1925 \\
1930 \\
1935 \\
1940\end{array}$ & $\begin{array}{l}6.5 \\
6.5 \\
6.0 \\
5.6 \\
5.2\end{array}$ & $\begin{array}{l}0.00 \\
0.00 \\
0.00 \\
0.00 \\
0.00\end{array}$ & $\begin{array}{l}0025 \\
0030 \\
0035 \\
0040 \\
0045\end{array}$ & $\begin{array}{l}0.8 \\
0.8 \\
0.8 \\
0.8 \\
0.8\end{array}$ & $\begin{array}{l}0.00 \\
0.00 \\
0.00 \\
0.00 \\
0.00\end{array}$ \\
\hline $\begin{array}{l}1435 \\
1440 \\
1445 \\
1450 \\
1455\end{array}$ & $\begin{array}{l}7.8 \\
7.0 \\
6.5 \\
6.0 \\
5.6\end{array}$ & $\begin{array}{l}0.00 \\
0.00 \\
0.00 \\
0.00 \\
0.00\end{array}$ & $\begin{array}{l}1945 \\
1950 \\
1955 \\
2000 \\
2005\end{array}$ & $\begin{array}{l}5.2 \\
4.8 \\
4.4 \\
4.4 \\
3.9\end{array}$ & $\begin{array}{l}0.00 \\
0.00 \\
0.00 \\
0.00 \\
0.00\end{array}$ & $\begin{array}{l}0050 \\
0055 \\
0100 \\
0105 \\
0110\end{array}$ & $\begin{array}{l}0.8 \\
0.8 \\
0.8 \\
0.8 \\
0.8\end{array}$ & $\begin{array}{l}0.00 \\
0.00 \\
0.00 \\
0.00 \\
0.00\end{array}$ \\
\hline $\begin{array}{l}1500 \\
1505 \\
1510 \\
1515 \\
1520\end{array}$ & $\begin{array}{l}5.2 \\
4.8 \\
4.8 \\
4.4 \\
3.9\end{array}$ & $\begin{array}{l}0.00 \\
0.00 \\
0.00 \\
0.00 \\
0.00\end{array}$ & $\begin{array}{l}2010 \\
2015 \\
2020 \\
2025 \\
2030\end{array}$ & $\begin{array}{l}3.9 \\
3.4 \\
3.4 \\
3.4 \\
2.9\end{array}$ & $\begin{array}{l}0.00 \\
0.00 \\
0.00 \\
0.00 \\
0.00\end{array}$ & $\begin{array}{l}0115 \\
0120 \\
0125 \\
0130 \\
0135\end{array}$ & $\begin{array}{l}0.8 \\
0.8 \\
0.8 \\
0.8 \\
0.8\end{array}$ & $\begin{array}{l}0.00 \\
0.00 \\
0.00 \\
0.00 \\
0.00\end{array}$ \\
\hline $\begin{array}{l}1525 \\
1530 \\
1535 \\
1540 \\
1545\end{array}$ & $\begin{array}{l}3.9 \\
3.4 \\
2.9 \\
2.9 \\
2.9\end{array}$ & $\begin{array}{l}0.00 \\
0.00 \\
0.00 \\
0.00 \\
0.00\end{array}$ & $\begin{array}{l}2035 \\
2040 \\
2045 \\
2050 \\
2055\end{array}$ & $\begin{array}{l}2.9 \\
2.9 \\
2.5 \\
2.5 \\
2.5\end{array}$ & $\begin{array}{l}0.00 \\
0.00 \\
0.00 \\
0.00 \\
0.00\end{array}$ & $\begin{array}{l}0140 \\
0145 \\
0150 \\
0155 \\
0200\end{array}$ & $\begin{array}{l}0.6 \\
0.6 \\
0.6 \\
0.6 \\
0.6\end{array}$ & $\begin{array}{l}0.00 \\
0.00 \\
0.00 \\
0.00 \\
0.00\end{array}$ \\
\hline $\begin{array}{l}1550 \\
1555\end{array}$ & $\begin{array}{l}2.5 \\
2.5\end{array}$ & $\begin{array}{l}0.00 \\
0.00\end{array}$ & $\begin{array}{l}2100 \\
2105\end{array}$ & $\begin{array}{l}2.5 \\
2.2\end{array}$ & $\begin{array}{l}0.00 \\
0.00\end{array}$ & & & \\
\hline
\end{tabular}




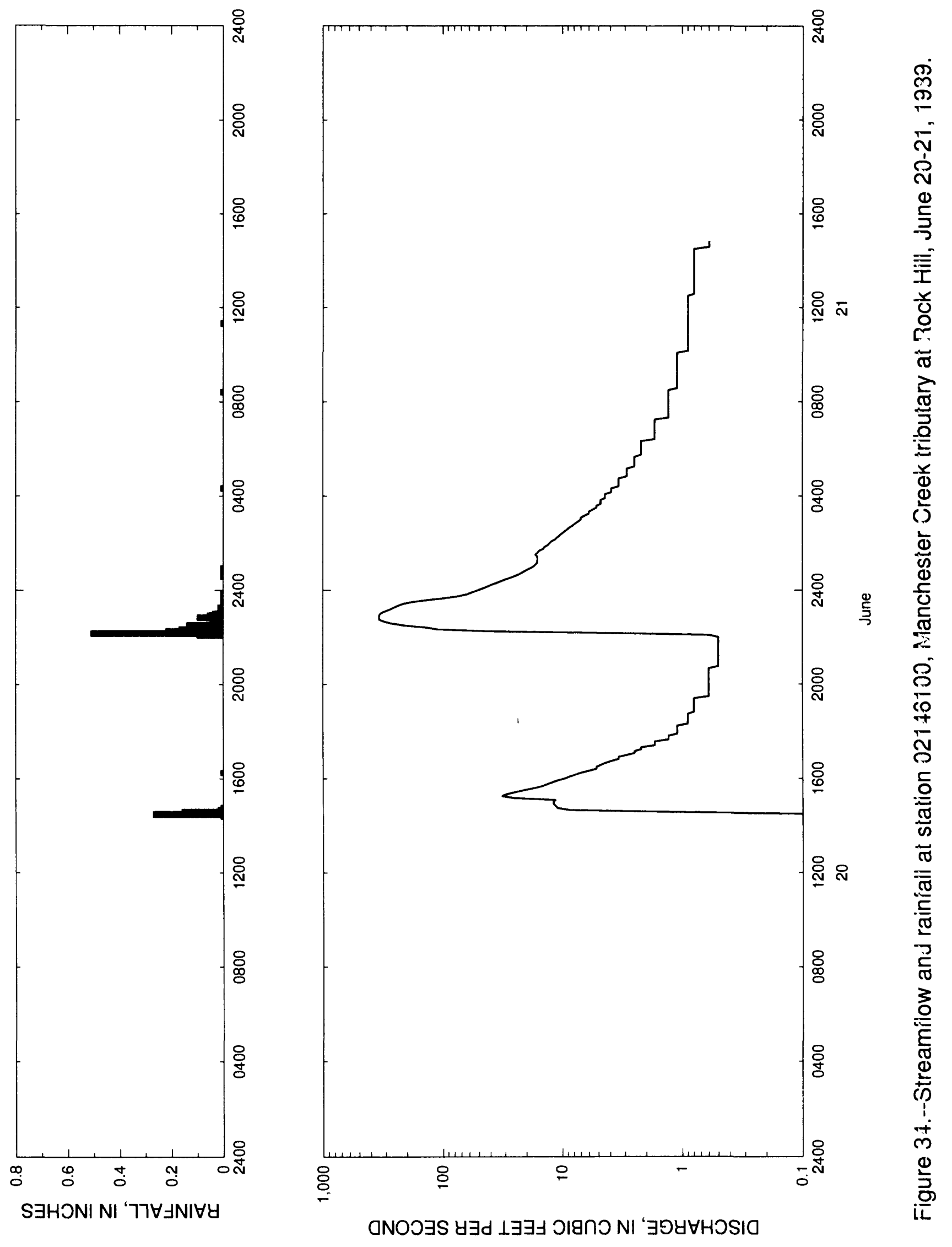


Table 33. - Streamflow and rainfall at station 02146100, Manchester Creek tributary at Rock Hill, June $20-21,1989$

\begin{tabular}{|c|c|c|c|c|c|c|c|c|}
\hline $\begin{array}{l}\text { Time } \\
\text { (hours) }\end{array}$ & $\begin{array}{l}\text { Streamflow } \\
\text { (cubic feet } \\
\text { per second) }\end{array}$ & $\begin{array}{l}\text { Rain- } \\
\text { fall } \\
\text { (inches) }\end{array}$ & $\begin{array}{l}\text { Time } \\
\text { (hours) }\end{array}$ & $\begin{array}{l}\text { Streamflow } \\
\text { (cubic feet } \\
\text { per second) }\end{array}$ & $\begin{array}{l}\text { Rain- } \\
\text { fall } \\
\text { (inches) }\end{array}$ & $\begin{array}{l}\text { Time } \\
\text { (hours) }\end{array}$ & $\begin{array}{l}\text { Streamflow } \\
\text { (cubic feet } \\
\text { per second) }\end{array}$ & $\begin{array}{l}\text { Rain- } \\
\text { fall } \\
\text { (inches) }\end{array}$ \\
\hline $\begin{array}{l}\text { June } 20 \text {, } \\
1425 \\
1430 \\
1435 \\
1440\end{array}$ & $\begin{array}{l}1989 \\
0.1 \\
0.1 \\
1.3 \\
8.7\end{array}$ & $\begin{array}{l}0.01 \\
0.27 \\
0.16 \\
0.02\end{array}$ & $\begin{array}{l}1945 \\
1950 \\
1955 \\
2000 \\
2005\end{array}$ & $\begin{array}{l}0.6 \\
0.6 \\
0.6 \\
0.6 \\
0.6\end{array}$ & $\begin{array}{l}0.00 \\
0.00 \\
0.00 \\
0.00 \\
0.00\end{array}$ & $\begin{array}{l}0105 \\
0110 \\
0115 \\
0120 \\
0125\end{array}$ & $\begin{array}{l}16.8 \\
16.2 \\
16.2 \\
16.2 \\
16.2\end{array}$ & $\begin{array}{l}0.00 \\
0.00 \\
0.00 \\
0.00 \\
0.00\end{array}$ \\
\hline $\begin{array}{l}1445 \\
1450 \\
1455 \\
1500 \\
1505\end{array}$ & $\begin{array}{l}11.0 \\
11.4 \\
11.9 \\
11.9 \\
11.4\end{array}$ & $\begin{array}{l}0.01 \\
0.00 \\
0.00 \\
0.00 \\
0.00\end{array}$ & $\begin{array}{l}2010 \\
2015 \\
2020 \\
2025 \\
2030\end{array}$ & $\begin{array}{l}0.6 \\
0.6 \\
0.6 \\
0.6 \\
0.6\end{array}$ & $\begin{array}{l}0.00 \\
0.00 \\
0.00 \\
0.00 \\
0.00\end{array}$ & $\begin{array}{l}0130 \\
0135 \\
0140 \\
0145 \\
0150\end{array}$ & $\begin{array}{l}16.8 \\
16.2 \\
15.6 \\
14.5 \\
14.1\end{array}$ & $\begin{array}{l}0.00 \\
0.00 \\
0.00 \\
0.00 \\
0.00\end{array}$ \\
\hline $\begin{array}{l}1510 \\
1515 \\
1520 \\
1525 \\
1530\end{array}$ & $\begin{array}{l}25.4 \\
32.2 \\
29.1 \\
24.7 \\
21.0\end{array}$ & $\begin{array}{l}0.00 \\
0.00 \\
0.00 \\
0.00 \\
0.00\end{array}$ & $\begin{array}{l}2035 \\
2040 \\
2045 \\
2050 \\
2055\end{array}$ & $\begin{array}{l}0.6 \\
0.6 \\
0.5 \\
0.5 \\
0.5\end{array}$ & $\begin{array}{l}0.00 \\
0.00 \\
0.00 \\
0.00 \\
0.00\end{array}$ & $\begin{array}{l}0155 \\
0200 \\
0205 \\
0210 \\
0215\end{array}$ & $\begin{array}{l}13.2 \\
12.8 \\
12.3 \\
11.4 \\
11.0\end{array}$ & $\begin{array}{l}0.00 \\
0.00 \\
0.00 \\
0.00 \\
0.00\end{array}$ \\
\hline $\begin{array}{l}1535 \\
1540 \\
1545 \\
1550 \\
1555\end{array}$ & $\begin{array}{l}17.5 \\
15.0 \\
13.7 \\
12.3 \\
11.0\end{array}$ & $\begin{array}{l}0.00 \\
0.00 \\
0.00 \\
0.00 \\
0.00\end{array}$ & $\begin{array}{l}2100 \\
2105 \\
2110 \\
2115 \\
2120\end{array}$ & $\begin{array}{l}0.5 \\
0.5 \\
0.5 \\
0.5 \\
0.5\end{array}$ & $\begin{array}{l}0.00 \\
0.00 \\
0.00 \\
0.00 \\
0.00\end{array}$ & $\begin{array}{l}0220 \\
0225 \\
0230 \\
0235 \\
0240\end{array}$ & $\begin{array}{r}10.5 \\
10.1 \\
9.6 \\
9.1 \\
8.7\end{array}$ & $\begin{array}{l}0.00 \\
0.00 \\
0.00 \\
0.00 \\
0.00\end{array}$ \\
\hline $\begin{array}{l}1600 \\
1605 \\
1610 \\
1615 \\
1620\end{array}$ & $\begin{array}{l}9.6 \\
8.7 \\
7.8 \\
7.0 \\
6.0\end{array}$ & $\begin{array}{l}0.00 \\
0.00 \\
0.00 \\
0.01 \\
0.00\end{array}$ & $\begin{array}{l}2125 \\
2130 \\
2135 \\
2140 \\
2145\end{array}$ & $\begin{array}{l}0.5 \\
0.5 \\
0.5 \\
0.5 \\
0.5\end{array}$ & $\begin{array}{l}0.00 \\
0.00 \\
0.00 \\
0.00 \\
0.00\end{array}$ & $\begin{array}{l}0245 \\
0250 \\
0255 \\
0300 \\
0305\end{array}$ & $\begin{array}{l}8.2 \\
7.8 \\
7.4 \\
7.0 \\
7.0\end{array}$ & $\begin{array}{l}0.00 \\
0.00 \\
0.00 \\
0.00 \\
0.00\end{array}$ \\
\hline $\begin{array}{l}1625 \\
1630 \\
1635 \\
1640 \\
1645\end{array}$ & $\begin{array}{l}5.2 \\
5.2 \\
4.8 \\
4.4 \\
3.9\end{array}$ & $\begin{array}{l}0.00 \\
0.00 \\
0.00 \\
0.00 \\
0.00\end{array}$ & $\begin{array}{l}2150 \\
2155 \\
2200 \\
2205 \\
2210\end{array}$ & $\begin{array}{l}0.5 \\
0.5 \\
0.5 \\
0.6 \\
3.9\end{array}$ & $\begin{array}{l}0.00 \\
0.00 \\
0.00 \\
0.10 \\
0.51\end{array}$ & $\begin{array}{l}0310 \\
0315 \\
0320 \\
0325 \\
0330\end{array}$ & $\begin{array}{l}6.5 \\
6.0 \\
6.0 \\
5.6 \\
5.2\end{array}$ & $\begin{array}{l}0.00 \\
0.00 \\
0.00 \\
0.00 \\
0.00\end{array}$ \\
\hline $\begin{array}{l}1650 \\
1655 \\
1700 \\
1705 \\
1710\end{array}$ & $\begin{array}{l}3.4 \\
3.4 \\
2.9 \\
2.5 \\
2.5\end{array}$ & $\begin{array}{l}0.00 \\
0.00 \\
0.00 \\
0.00 \\
0.00\end{array}$ & $\begin{array}{l}2215 \\
2220 \\
2225 \\
2230 \\
2235\end{array}$ & $\begin{array}{r}42.6 \\
111.0 \\
139.0 \\
207.0 \\
269.0\end{array}$ & $\begin{array}{l}0.22 \\
0.17 \\
0.14 \\
0.14 \\
0.05\end{array}$ & $\begin{array}{l}0335 \\
0340 \\
0345 \\
0350 \\
0355\end{array}$ & $\begin{array}{l}5.2 \\
4.8 \\
4.8 \\
4.8 \\
4.4\end{array}$ & $\begin{array}{l}0.00 \\
0.00 \\
0.00 \\
0.00 \\
0.00\end{array}$ \\
\hline $\begin{array}{l}1715 \\
1720 \\
1725 \\
1730 \\
1735\end{array}$ & $\begin{array}{l}2.2 \\
2.2 \\
1.7 \\
1.7 \\
1.7\end{array}$ & $\begin{array}{l}0.00 \\
0.00 \\
0.00 \\
0.00 \\
0.00\end{array}$ & $\begin{array}{l}2240 \\
2245 \\
2250 \\
2255 \\
2300\end{array}$ & $\begin{array}{l}312.0 \\
339.0 \\
340.0 \\
341.0 \\
332.0\end{array}$ & $\begin{array}{l}0.02 \\
0.02 \\
0.10 \\
0.06 \\
0.04\end{array}$ & $\begin{array}{l}0400 \\
0405 \\
0410 \\
0415 \\
0420\end{array}$ & $\begin{array}{l}4.4 \\
4.4 \\
3.9 \\
3.9 \\
3.9\end{array}$ & $\begin{array}{l}0.00 \\
0.00 \\
0.00 \\
0.00 \\
0.01\end{array}$ \\
\hline $\begin{array}{l}1740 \\
1745 \\
1750 \\
1755 \\
1800\end{array}$ & $\begin{array}{l}1.3 \\
1.3 \\
1.3 \\
1.1 \\
1.1\end{array}$ & $\begin{array}{l}0.00 \\
0.00 \\
0.00 \\
0.00 \\
0.00\end{array}$ & $\begin{array}{l}2305 \\
2310 \\
2315 \\
2320 \\
2325\end{array}$ & $\begin{array}{l}310.0 \\
281.0 \\
260.0 \\
240.0 \\
215.0\end{array}$ & $\begin{array}{l}0.01 \\
0.01 \\
0.02 \\
0.01 \\
0.01\end{array}$ & $\begin{array}{l}0425 \\
0430 \\
0435 \\
0440 \\
0445\end{array}$ & $\begin{array}{l}3.4 \\
3.4 \\
3.4 \\
3.4 \\
3.4\end{array}$ & $\begin{array}{l}0.00 \\
0.00 \\
0.00 \\
0.00 \\
0.00\end{array}$ \\
\hline $\begin{array}{l}1805 \\
1810 \\
1815 \\
1820 \\
1825\end{array}$ & $\begin{array}{l}1.1 \\
1.1 \\
1.1 \\
0.9 \\
0.9\end{array}$ & $\begin{array}{l}0.00 \\
0.00 \\
0.00 \\
0.00 \\
0.00\end{array}$ & $\begin{array}{l}2330 \\
2335 \\
2340 \\
2345 \\
2350\end{array}$ & $\begin{array}{r}179.0 \\
133.0 \\
95.3 \\
73.5 \\
62.7\end{array}$ & $\begin{array}{l}0.01 \\
0.01 \\
0.01 \\
0.00 \\
0.01\end{array}$ & $\begin{array}{l}0450 \\
0455 \\
0500 \\
0505 \\
0510\end{array}$ & $\begin{array}{l}2.9 \\
2.9 \\
2.9 \\
2.9 \\
2.9\end{array}$ & $\begin{array}{l}0.00 \\
0.00 \\
0.00 \\
0.00 \\
0.00\end{array}$ \\
\hline $\begin{array}{l}1830 \\
1835 \\
1840 \\
1845 \\
1850\end{array}$ & $\begin{array}{l}0.9 \\
0.9 \\
0.9 \\
0.9 \\
0.8\end{array}$ & $\begin{array}{l}0.00 \\
0.00 \\
0.00 \\
0.00 \\
0.00\end{array}$ & $\begin{array}{l}2355 \\
\text { June } 21 \text {, } \\
0000 \\
0005 \\
0010\end{array}$ & $\begin{array}{r}198956.2 \\
50.9 \\
45.8 \\
41.8\end{array}$ & $\begin{array}{l}0.00 \\
0.00 \\
0.00 \\
0.00\end{array}$ & $\begin{array}{l}0515 \\
0520 \\
0525 \\
0530 \\
0535\end{array}$ & $\begin{array}{l}2.5 \\
2.5 \\
2.5 \\
2.5 \\
2.5\end{array}$ & $\begin{array}{l}0.00 \\
0.00 \\
0.00 \\
0.00 \\
0.00\end{array}$ \\
\hline $\begin{array}{l}1855 \\
1900 \\
1905 \\
1910 \\
1915\end{array}$ & $\begin{array}{l}0.8 \\
0.8 \\
0.8 \\
0.8 \\
0.8\end{array}$ & $\begin{array}{l}0.00 \\
0.00 \\
0.00 \\
0.00 \\
0.00\end{array}$ & $\begin{array}{l}0015 \\
0020 \\
0025 \\
0030 \\
0035\end{array}$ & $\begin{array}{l}38.5 \\
34.5 \\
31.4 \\
28.3 \\
25.4\end{array}$ & $\begin{array}{l}0.00 \\
0.00 \\
0.00 \\
0.00 \\
0.01\end{array}$ & $\begin{array}{l}0540 \\
0545 \\
0550 \\
0555 \\
0600\end{array}$ & $\begin{array}{l}2.5 \\
2.2 \\
2.2 \\
2.2 \\
2.2\end{array}$ & $\begin{array}{l}0.00 \\
0.00 \\
0.00 \\
0.00 \\
0.00\end{array}$ \\
\hline $\begin{array}{l}1920 \\
1925 \\
1930 \\
1935 \\
1940\end{array}$ & $\begin{array}{l}0.8 \\
0.8 \\
0.6 \\
0.6 \\
0.6\end{array}$ & $\begin{array}{l}0.00 \\
0.00 \\
0.00 \\
0.00 \\
0.00\end{array}$ & $\begin{array}{l}0040 \\
0045 \\
0050 \\
0055 \\
0100\end{array}$ & $\begin{array}{l}23.2 \\
21.7 \\
20.2 \\
18.8 \\
17.5\end{array}$ & $\begin{array}{l}0.01 \\
0.00 \\
0.00 \\
0.01 \\
0.00\end{array}$ & $\begin{array}{l}0605 \\
0610 \\
0615 \\
0620 \\
0625\end{array}$ & $\begin{array}{l}2.2 \\
2.2 \\
2.2 \\
2.2 \\
1.7\end{array}$ & $\begin{array}{l}0.00 \\
0.00 \\
0.00 \\
0.00 \\
0.00\end{array}$ \\
\hline
\end{tabular}


Table 33.--Streamflow and rainfall at station 02146100, Manchester Creek tributary at Rock Hill, June $20-21,1989--$ Continued

\begin{tabular}{|c|c|c|c|c|c|c|c|c|}
\hline $\begin{array}{l}\text { Time } \\
\text { (hours) }\end{array}$ & $\begin{array}{l}\text { Streamflow } \\
\text { (cubic feet } \\
\text { per second) }\end{array}$ & $\begin{array}{l}\text { Rain- } \\
\text { fal1 } \\
\text { (inches) }\end{array}$ & $\begin{array}{l}\text { Time } \\
\text { (hours) }\end{array}$ & $\begin{array}{l}\text { Streamflow } \\
\text { (cubic feet } \\
\text { per second) }\end{array}$ & $\begin{array}{l}\text { Rain- } \\
\text { fall } \\
\text { (inches) }\end{array}$ & $\begin{array}{l}\text { Time } \\
\text { (hours) }\end{array}$ & $\begin{array}{l}\text { Streamflow } \\
\text { (cubic feet } \\
\text { per second) }\end{array}$ & $\begin{array}{l}\text { Rair- } \\
\text { fall } \\
\text { (incres) }\end{array}$ \\
\hline $\begin{array}{l}0630 \\
0635 \\
0640 \\
0645 \\
0650\end{array}$ & $\begin{array}{l}1.7 \\
1.7 \\
1.7 \\
1.7 \\
1.7\end{array}$ & $\begin{array}{l}0.00 \\
0.00 \\
0.00 \\
0.00 \\
0.00\end{array}$ & $\begin{array}{l}0925 \\
0930 \\
0935 \\
0940 \\
0945\end{array}$ & $\begin{array}{l}1.1 \\
1.1 \\
1.1 \\
1.1 \\
1.1\end{array}$ & $\begin{array}{l}0.00 \\
0.00 \\
0.00 \\
0.00 \\
0.00\end{array}$ & $\begin{array}{l}1220 \\
1225 \\
1230 \\
1235 \\
1240\end{array}$ & $\begin{array}{l}0.9 \\
0.9 \\
0.9 \\
0.8 \\
0.8\end{array}$ & $\begin{array}{l}0 . O C \\
0.0 C \\
0.0 C \\
0.0 C \\
0.0 C\end{array}$ \\
\hline $\begin{array}{l}0655 \\
0700 \\
0705 \\
0710 \\
0715\end{array}$ & $\begin{array}{l}1.7 \\
1.7 \\
1.7 \\
1.7 \\
1.7\end{array}$ & $\begin{array}{l}0.00 \\
0.00 \\
0.00 \\
0.00 \\
0.00\end{array}$ & $\begin{array}{l}0950 \\
0955 \\
1000 \\
1005 \\
1010\end{array}$ & $\begin{array}{l}1.1 \\
1.1 \\
1.1 \\
1.1 \\
0.9\end{array}$ & $\begin{array}{l}0.00 \\
0.00 \\
0.00 \\
0.00 \\
0.00\end{array}$ & $\begin{array}{l}1245 \\
1250 \\
1255 \\
1300 \\
1305\end{array}$ & $\begin{array}{l}0.8 \\
0.8 \\
0.8 \\
0.8 \\
0.8\end{array}$ & $\begin{array}{l}0.0 C \\
0.0 C \\
0.0 C \\
0.0 C \\
0.00\end{array}$ \\
\hline $\begin{array}{l}0720 \\
0725 \\
0730 \\
0735 \\
0740\end{array}$ & $\begin{array}{l}1.3 \\
1.3 \\
1.3 \\
1.3 \\
1.3\end{array}$ & $\begin{array}{l}0.00 \\
0.00 \\
0.00 \\
0.00 \\
0.00\end{array}$ & $\begin{array}{l}1015 \\
1020 \\
1025 \\
1030 \\
1035\end{array}$ & $\begin{array}{l}0.9 \\
0.9 \\
0.9 \\
0.9 \\
0.9\end{array}$ & $\begin{array}{l}0.00 \\
0.00 \\
0.00 \\
0.00 \\
0.00\end{array}$ & $\begin{array}{l}1310 \\
1315 \\
1320 \\
1325 \\
1330\end{array}$ & $\begin{array}{l}0.8 \\
0.8 \\
0.8 \\
0.8 \\
0.8\end{array}$ & $\begin{array}{l}0.00 \\
0.00 \\
0.00 \\
0.00 \\
0.00\end{array}$ \\
\hline $\begin{array}{l}0745 \\
0750 \\
0755 \\
0800 \\
0805\end{array}$ & $\begin{array}{l}1.3 \\
1.3 \\
1.3 \\
1.3 \\
1.3\end{array}$ & $\begin{array}{l}0.00 \\
0.00 \\
0.00 \\
0.00 \\
0.00\end{array}$ & $\begin{array}{l}1040 \\
1045 \\
1050 \\
1055 \\
1100\end{array}$ & $\begin{array}{l}0.9 \\
0.9 \\
0.9 \\
0.9 \\
0.9\end{array}$ & $\begin{array}{l}0.00 \\
0.00 \\
0.00 \\
0.00 \\
0.00\end{array}$ & $\begin{array}{l}1335 \\
1340 \\
1345 \\
1350 \\
1355\end{array}$ & $\begin{array}{l}0.8 \\
0.8 \\
0.8 \\
0.8 \\
0.8\end{array}$ & $\begin{array}{l}0.00 \\
0.00 \\
0.00 \\
0.00 \\
0.00\end{array}$ \\
\hline $\begin{array}{l}0810 \\
0815 \\
0820 \\
0825 \\
0830\end{array}$ & $\begin{array}{l}1.3 \\
1.3 \\
1.3 \\
1.3 \\
1.3\end{array}$ & $\begin{array}{l}0.00 \\
0.00 \\
0.00 \\
0.01 \\
0.00\end{array}$ & $\begin{array}{l}1105 \\
1110 \\
1115 \\
1120 \\
1125\end{array}$ & $\begin{array}{l}0.9 \\
0.9 \\
0.9 \\
0.9 \\
0.9\end{array}$ & $\begin{array}{l}0.00 \\
0.00 \\
0.00 \\
0.01 \\
0.00\end{array}$ & $\begin{array}{l}1400 \\
1405 \\
1410 \\
1415 \\
1420\end{array}$ & $\begin{array}{l}0.8 \\
0.8 \\
0.8 \\
0.8 \\
0.8\end{array}$ & $\begin{array}{l}0.00 \\
0.00 \\
0.00 \\
0.00 \\
0.00\end{array}$ \\
\hline $\begin{array}{l}0835 \\
0840 \\
0845 \\
0850 \\
0855\end{array}$ & $\begin{array}{l}1.1 \\
1.1 \\
1.1 \\
1.1 \\
1.1\end{array}$ & $\begin{array}{l}0.00 \\
0.00 \\
0.00 \\
0.00 \\
0.00\end{array}$ & $\begin{array}{l}1130 \\
1135 \\
1140 \\
1145 \\
1150\end{array}$ & $\begin{array}{l}0.9 \\
0.9 \\
0.9 \\
0.9 \\
0.9\end{array}$ & $\begin{array}{l}0.00 \\
0.00 \\
0.00 \\
0.00 \\
0.00\end{array}$ & $\begin{array}{l}1425 \\
1430 \\
1435 \\
1440 \\
1445\end{array}$ & $\begin{array}{l}0.8 \\
0.8 \\
0.6 \\
0.6 \\
0.6\end{array}$ & $\begin{array}{l}0.00 \\
0.00 \\
0.00 \\
0.00 \\
0.00\end{array}$ \\
\hline $\begin{array}{l}0900 \\
0905 \\
0910 \\
0915 \\
0920\end{array}$ & $\begin{array}{l}1.1 \\
1.1 \\
1.1 \\
1.1 \\
1.1\end{array}$ & $\begin{array}{l}0.00 \\
0.00 \\
0.00 \\
0.00 \\
0.00\end{array}$ & $\begin{array}{l}1155 \\
1200 \\
1205 \\
1210 \\
1215\end{array}$ & $\begin{array}{l}0.9 \\
0.9 \\
0.9 \\
0.9 \\
0.9\end{array}$ & $\begin{array}{l}0.00 \\
0.00 \\
0.00 \\
0.00 \\
0.00\end{array}$ & $\begin{array}{l}1450 \\
1455 \\
1500\end{array}$ & $\begin{array}{l}0.6 \\
0.6 \\
0.6\end{array}$ & $\begin{array}{l}0.00 \\
0.00 \\
0.00\end{array}$ \\
\hline
\end{tabular}



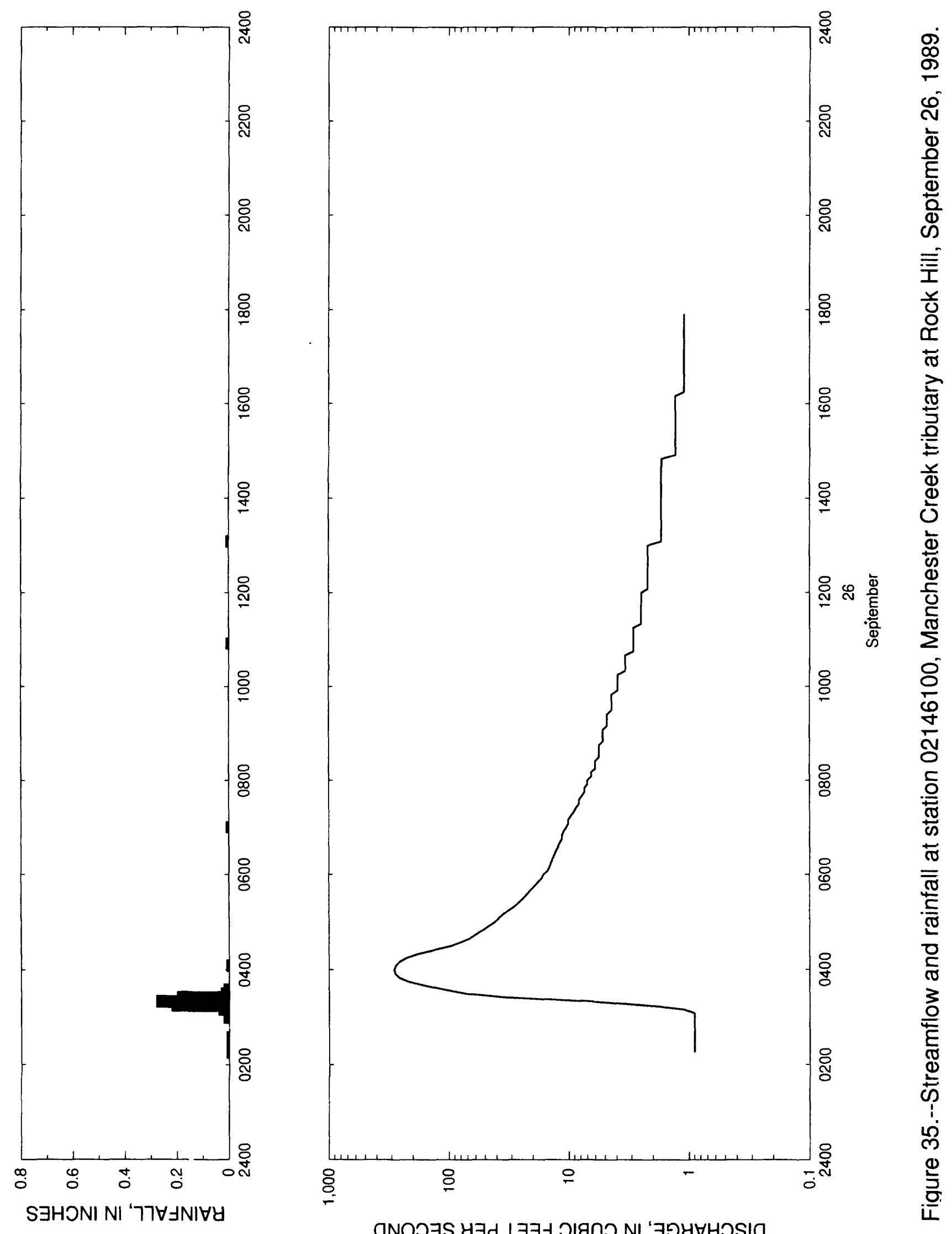
Table 34.--Streamflow and rainfall at station 02146100, Manchester Creek tributary at Rock Hil1, September 26,1989

\begin{tabular}{|c|c|c|c|c|c|c|c|c|}
\hline $\begin{array}{l}\text { Time } \\
\text { (hours) }\end{array}$ & $\begin{array}{l}\text { Streamflow } \\
\text { (cubic feet } \\
\text { per second) }\end{array}$ & $\begin{array}{l}\text { Rain- } \\
\text { fall } \\
\text { (inches) }\end{array}$ & $\begin{array}{l}\text { Time } \\
\text { (hours) }\end{array}$ & $\begin{array}{l}\text { Streamflow } \\
\text { (cubic feet } \\
\text { per second) }\end{array}$ & $\begin{array}{l}\text { Rain- } \\
\text { fall } \\
\text { (inches) }\end{array}$ & $\begin{array}{l}\text { Time } \\
\text { (hours) }\end{array}$ & $\begin{array}{l}\text { Streamflow } \\
\text { (cubic feet } \\
\text { per second) }\end{array}$ & $\begin{array}{l}\text { Rain- } \\
\text { fall } \\
\text { (inches) }\end{array}$ \\
\hline $\begin{array}{l}\text { September } \\
0215 \\
0220 \\
0225 \\
0230\end{array}$ & 26, $\begin{array}{l}1989 \\
0.9 \\
0.9 \\
0.9 \\
0.9\end{array}$ & $\begin{array}{l}0.01 \\
0.00 \\
0.00 \\
0.01\end{array}$ & $\begin{array}{l}0730 \\
0735 \\
0740 \\
0745 \\
0750\end{array}$ & $\begin{array}{l}8.2 \\
8.2 \\
7.8 \\
7.4 \\
7.4\end{array}$ & $\begin{array}{l}0.00 \\
0.00 \\
0.00 \\
0.00 \\
0.00\end{array}$ & $\begin{array}{l}1250 \\
1255 \\
1300 \\
1305 \\
1310\end{array}$ & $\begin{array}{l}2.2 \\
2.2 \\
2.2 \\
1.7 \\
1.7\end{array}$ & $\begin{array}{l}0.00 \\
0.00 \\
0.00 \\
0.01 \\
0.00\end{array}$ \\
\hline $\begin{array}{l}0235 \\
0240 \\
0245 \\
0250 \\
0255\end{array}$ & $\begin{array}{l}0.9 \\
0.9 \\
0.9 \\
0.9 \\
0.9\end{array}$ & $\begin{array}{l}0.01 \\
0.00 \\
0.00 \\
0.00 \\
0.00\end{array}$ & $\begin{array}{l}0755 \\
0800 \\
0805 \\
0810 \\
0815\end{array}$ & $\begin{array}{l}7.0 \\
7.0 \\
6.5 \\
6.5 \\
6.0\end{array}$ & $\begin{array}{l}0.00 \\
0.00 \\
0.00 \\
0.00 \\
0.00\end{array}$ & $\begin{array}{l}1315 \\
1320 \\
1325 \\
1330 \\
1335\end{array}$ & $\begin{array}{l}1.7 \\
1.7 \\
1.7 \\
1.7 \\
1.7\end{array}$ & $\begin{array}{l}0.00 \\
0.00 \\
0.00 \\
0.00 \\
0.00\end{array}$ \\
\hline $\begin{array}{l}0300 \\
0305 \\
0310 \\
0315 \\
0320\end{array}$ & $\begin{array}{l}0.9 \\
0.9 \\
1.1 \\
2.2 \\
6.5\end{array}$ & $\begin{array}{l}0.02 \\
0.01 \\
0.04 \\
0.22 \\
0.28\end{array}$ & $\begin{array}{l}0820 \\
0825 \\
0830 \\
0835 \\
0840\end{array}$ & $\begin{array}{l}6.0 \\
6.0 \\
5.6 \\
5.6 \\
5.6\end{array}$ & $\begin{array}{l}0.00 \\
0.00 \\
0.00 \\
0.00 \\
0.00\end{array}$ & $\begin{array}{l}1340 \\
1345 \\
1350 \\
1355 \\
1400\end{array}$ & $\begin{array}{l}1.7 \\
1.7 \\
1.7 \\
1.7 \\
1.7\end{array}$ & $\begin{array}{l}0.00 \\
0.00 \\
0.00 \\
0.00 \\
0.00\end{array}$ \\
\hline $\begin{array}{l}0325 \\
0330 \\
0335 \\
0340 \\
0345\end{array}$ & $\begin{array}{r}32.2 \\
72.5 \\
109.0 \\
156.0 \\
215.0\end{array}$ & $\begin{array}{l}0.20 \\
0.03 \\
0.02 \\
0.00 \\
0.00\end{array}$ & $\begin{array}{l}0845 \\
0850 \\
0855 \\
0900 \\
0905\end{array}$ & $\begin{array}{l}5.6 \\
5.2 \\
5.2 \\
5.2 \\
5.2\end{array}$ & $\begin{array}{l}0.00 \\
0.00 \\
0.00 \\
0.00 \\
0.00\end{array}$ & $\begin{array}{l}1405 \\
1410 \\
1415 \\
1420 \\
1425\end{array}$ & $\begin{array}{l}1.7 \\
1.7 \\
1.7 \\
1.7 \\
1.7\end{array}$ & $\begin{array}{l}0.00 \\
0.00 \\
0.00 \\
0.00 \\
0.00\end{array}$ \\
\hline $\begin{array}{l}0350 \\
0355 \\
0400 \\
0405 \\
0410\end{array}$ & $\begin{array}{l}261.0 \\
281.0 \\
288.0 \\
279.0 \\
259.0\end{array}$ & $\begin{array}{l}0.00 \\
0.00 \\
0.00 \\
0.01 \\
0.00\end{array}$ & $\begin{array}{l}0910 \\
0915 \\
0920 \\
0925 \\
0930\end{array}$ & $\begin{array}{l}4.8 \\
4.8 \\
4.8 \\
4.8 \\
4.4\end{array}$ & $\begin{array}{l}0.00 \\
0.00 \\
0.00 \\
0.00 \\
0.00\end{array}$ & $\begin{array}{l}1430 \\
1435 \\
1440 \\
1445 \\
1450\end{array}$ & $\begin{array}{l}1.7 \\
1.7 \\
1.7 \\
1.7 \\
1.7\end{array}$ & $\begin{array}{l}0.00 \\
0.00 \\
0.00 \\
0.00 \\
0.00\end{array}$ \\
\hline $\begin{array}{l}0415 \\
0420 \\
0425 \\
0430 \\
0435\end{array}$ & $\begin{array}{r}226.0 \\
182.0 \\
132.0 \\
95.3 \\
78.7\end{array}$ & $\begin{array}{l}0.00 \\
0.00 \\
0.00 \\
0.00 \\
0.00\end{array}$ & $\begin{array}{l}0935 \\
0940 \\
0945 \\
0950 \\
0955\end{array}$ & $\begin{array}{l}4.4 \\
4.4 \\
4.4 \\
4.4 \\
3.9\end{array}$ & $\begin{array}{l}0.00 \\
0.00 \\
0.00 \\
0.00 \\
0.00\end{array}$ & $\begin{array}{l}1455 \\
1500 \\
1505 \\
1510 \\
1515\end{array}$ & $\begin{array}{l}1.3 \\
1.3 \\
1.3 \\
1.3 \\
1.3\end{array}$ & $\begin{array}{l}0.00 \\
0.00 \\
0.00 \\
0.00 \\
0.00\end{array}$ \\
\hline $\begin{array}{l}0440 \\
0445 \\
0450 \\
0455 \\
0500\end{array}$ & $\begin{array}{l}66.5 \\
58.9 \\
51.7 \\
46.6 \\
41.8\end{array}$ & $\begin{array}{l}0.00 \\
0.00 \\
0.00 \\
0.00 \\
0.00\end{array}$ & $\begin{array}{l}1000 \\
1005 \\
1010 \\
1015 \\
1020\end{array}$ & $\begin{array}{l}3.9 \\
3.9 \\
3.9 \\
3.9 \\
3.4\end{array}$ & $\begin{array}{l}0.00 \\
0.00 \\
0.00 \\
0.00 \\
0.00\end{array}$ & $\begin{array}{l}1520 \\
1525 \\
1530 \\
1535 \\
1540\end{array}$ & $\begin{array}{l}1.3 \\
1.3 \\
1.3 \\
1.3 \\
1.3\end{array}$ & $\begin{array}{l}0.00 \\
0.00 \\
0.00 \\
0.00 \\
0.00\end{array}$ \\
\hline $\begin{array}{l}0505 \\
0510 \\
0515 \\
0520 \\
0525\end{array}$ & $\begin{array}{l}38.5 \\
35.6 \\
31.4 \\
28.3 \\
26.1\end{array}$ & $\begin{array}{l}0.00 \\
0.00 \\
0.00 \\
0.00 \\
0.00\end{array}$ & $\begin{array}{l}1025 \\
1030 \\
1035 \\
1040 \\
1045\end{array}$ & $\begin{array}{l}3.4 \\
3.4 \\
3.4 \\
3.4 \\
2.9\end{array}$ & $\begin{array}{l}0.00 \\
0.00 \\
0.00 \\
0.00 \\
0.00\end{array}$ & $\begin{array}{l}1545 \\
1550 \\
1555 \\
1600 \\
1605\end{array}$ & $\begin{array}{l}1.3 \\
1.3 \\
1.3 \\
1.3 \\
1.3\end{array}$ & $\begin{array}{l}0.00 \\
0.00 \\
0.00 \\
0.00 \\
0.00\end{array}$ \\
\hline $\begin{array}{l}0530 \\
0535 \\
0540 \\
0545 \\
0550\end{array}$ & $\begin{array}{l}24.0 \\
22.4 \\
21.0 \\
19.5 \\
18.2\end{array}$ & $\begin{array}{l}0.00 \\
0.00 \\
0.00 \\
0.00 \\
0.00\end{array}$ & $\begin{array}{l}1050 \\
1055 \\
1100 \\
1105 \\
1110\end{array}$ & $\begin{array}{l}2.9 \\
2.9 \\
2.9 \\
2.9 \\
2.9\end{array}$ & $\begin{array}{l}0.00 \\
0.01 \\
0.00 \\
0.00 \\
0.00\end{array}$ & $\begin{array}{l}1610 \\
1615 \\
1620 \\
1625 \\
1630\end{array}$ & $\begin{array}{l}1.3 \\
1.1 \\
1.1 \\
1.1 \\
1.1\end{array}$ & $\begin{array}{l}0.00 \\
0.00 \\
0.00 \\
0.00 \\
0.00\end{array}$ \\
\hline $\begin{array}{l}0555 \\
0600 \\
0605 \\
0610 \\
0615\end{array}$ & $\begin{array}{l}16.8 \\
16.2 \\
15.0 \\
14.5 \\
14.1\end{array}$ & $\begin{array}{l}0.00 \\
0.00 \\
0.00 \\
0.00 \\
0.00\end{array}$ & $\begin{array}{l}1115 \\
1120 \\
1125 \\
1130 \\
1135\end{array}$ & $\begin{array}{l}2.9 \\
2.5 \\
2.5 \\
2.5 \\
2.5\end{array}$ & $\begin{array}{l}0.00 \\
0.00 \\
0.00 \\
0.00 \\
0.00\end{array}$ & $\begin{array}{l}1635 \\
1640 \\
1645 \\
1650 \\
1655\end{array}$ & $\begin{array}{l}1.1 \\
1.1 \\
1.1 \\
1.1 \\
1.1\end{array}$ & $\begin{array}{l}0.00 \\
0.00 \\
0.00 \\
0.00 \\
0.00\end{array}$ \\
\hline $\begin{array}{l}0620 \\
0625 \\
0630 \\
0635 \\
0640\end{array}$ & $\begin{array}{l}13.7 \\
13.2 \\
12.8 \\
12.3 \\
11.9\end{array}$ & $\begin{array}{l}0.00 \\
0.00 \\
0.00 \\
0.00 \\
0.00\end{array}$ & $\begin{array}{l}1140 \\
1145 \\
1150 \\
1155 \\
1200\end{array}$ & $\begin{array}{l}2.5 \\
2.5 \\
2.5 \\
2.5 \\
2.5\end{array}$ & $\begin{array}{l}0.00 \\
0.00 \\
0.00 \\
0.00 \\
0.00\end{array}$ & $\begin{array}{l}1700 \\
1705 \\
1710 \\
1715 \\
1720\end{array}$ & $\begin{array}{l}1.1 \\
1.1 \\
1.1 \\
1.1 \\
1.1\end{array}$ & $\begin{array}{l}0.00 \\
0.00 \\
0.00 \\
0.00 \\
0.00\end{array}$ \\
\hline $\begin{array}{l}0645 \\
0650 \\
0655 \\
0700 \\
0705\end{array}$ & $\begin{array}{l}11.4 \\
11.4 \\
11.0 \\
10.5 \\
10.1\end{array}$ & $\begin{array}{l}0.00 \\
0.00 \\
0.00 \\
0.01 \\
0.00\end{array}$ & $\begin{array}{l}1205 \\
1210 \\
1215 \\
1220 \\
1225\end{array}$ & $\begin{array}{l}2.2 \\
2.2 \\
2.2 \\
2.2 \\
2.2\end{array}$ & $\begin{array}{l}0.00 \\
0.00 \\
0.00 \\
0.00 \\
0.00\end{array}$ & $\begin{array}{l}1725 \\
1730 \\
1735 \\
1740 \\
1745\end{array}$ & $\begin{array}{l}1.1 \\
1.1 \\
1.1 \\
1.1 \\
1.1\end{array}$ & $\begin{array}{l}0.00 \\
0.00 \\
0.00 \\
0.00 \\
0.00\end{array}$ \\
\hline $\begin{array}{l}0710 \\
0715 \\
0720 \\
0725\end{array}$ & $\begin{array}{r}10.1 \\
9.6 \\
9.1 \\
8.7\end{array}$ & $\begin{array}{l}0.00 \\
0.00 \\
0.00 \\
0.00\end{array}$ & $\begin{array}{l}1230 \\
1235 \\
1240 \\
1245\end{array}$ & $\begin{array}{l}2.2 \\
2.2 \\
2.2 \\
2.2\end{array}$ & $\begin{array}{l}0.00 \\
0.00 \\
0.00 \\
0.00\end{array}$ & $\begin{array}{l}1750 \\
1755 \\
1800 \\
1805\end{array}$ & $\begin{array}{l}1.1 \\
1.1 \\
1.1 \\
1.1\end{array}$ & $\begin{array}{l}0.00 \\
0.00 \\
0.00 \\
0.00\end{array}$ \\
\hline
\end{tabular}




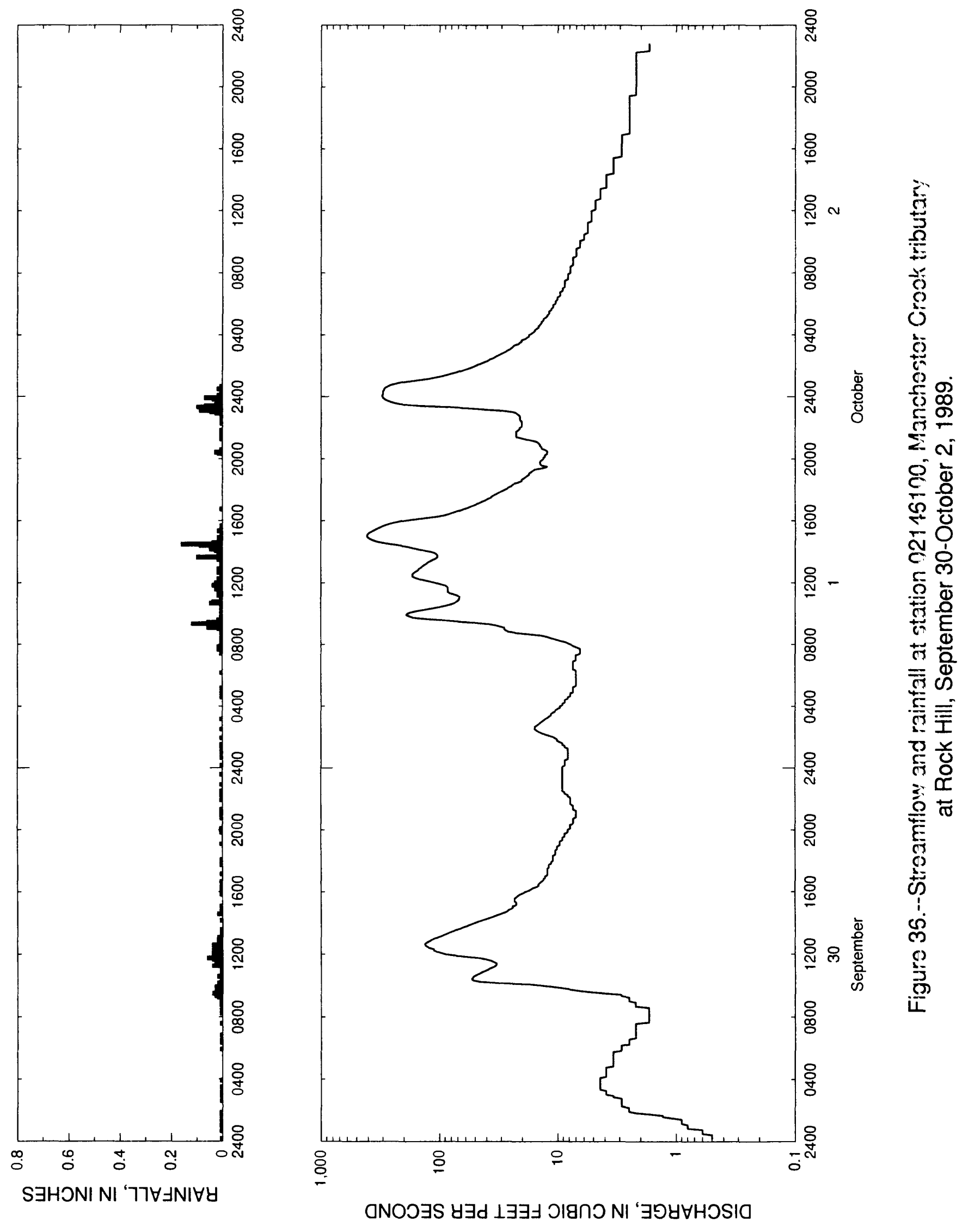


Table 35. - Streamflow and rainfall at station 02146100, Manchester Creek tributary at Rock Hi11, September 30 - October 2, 1989

\begin{tabular}{|c|c|c|c|c|c|c|c|c|}
\hline $\begin{array}{l}\text { Time } \\
\text { (hours) }\end{array}$ & $\begin{array}{l}\text { Streamflow } \\
\text { (cubic feet } \\
\text { per second) }\end{array}$ & $\begin{array}{l}\text { Rain- } \\
\text { fall } \\
\text { (inches) }\end{array}$ & $\begin{array}{l}\text { Time } \\
\text { (hours) }\end{array}$ & $\begin{array}{l}\text { Streamflow } \\
\text { (cubic feet } \\
\text { per second) }\end{array}$ & $\begin{array}{l}\text { Rain- } \\
\text { fall } \\
\text { (inches) }\end{array}$ & $\begin{array}{l}\text { Time } \\
\text { (hours) }\end{array}$ & $\begin{array}{l}\text { Streamflow } \\
\text { (cubic feet } \\
\text { per second) }\end{array}$ & $\begin{array}{l}\text { Rain- } \\
\text { fall } \\
\text { (inches) }\end{array}$ \\
\hline $\begin{array}{l}\text { September } \\
0010 \\
0015 \\
0020 \\
0025\end{array}$ & $\begin{array}{r}30,1989 \\
0.5 \\
0.5 \\
0.5 \\
0.5\end{array}$ & $\begin{array}{l}0.01 \\
0.00 \\
0.00 \\
0.00\end{array}$ & $\begin{array}{l}0530 \\
0535 \\
0540 \\
0545 \\
0550\end{array}$ & $\begin{array}{l}3.4 \\
3.4 \\
3.4 \\
3.4 \\
2.9\end{array}$ & $\begin{array}{l}0.00 \\
0.00 \\
0.00 \\
0.00 \\
0.00\end{array}$ & $\begin{array}{l}1055 \\
1100 \\
1105 \\
1110 \\
1115\end{array}$ & $\begin{array}{l}41.8 \\
39.3 \\
37.7 \\
35.3 \\
33.8\end{array}$ & $\begin{array}{l}0.00 \\
0.00 \\
0.01 \\
0.01 \\
0.04\end{array}$ \\
\hline $\begin{array}{l}0030 \\
0035 \\
0040 \\
0045 \\
0050\end{array}$ & $\begin{array}{l}0.6 \\
0.6 \\
0.6 \\
0.6 \\
0.8\end{array}$ & $\begin{array}{l}0.00 \\
0.00 \\
0.01 \\
0.00 \\
0.00\end{array}$ & $\begin{array}{l}0555 \\
0600 \\
0605 \\
0610 \\
0615\end{array}$ & $\begin{array}{l}2.9 \\
2.9 \\
2.9 \\
2.9 \\
2.5\end{array}$ & $\begin{array}{l}0.01 \\
0.00 \\
0.00 \\
0.00 \\
0.00\end{array}$ & $\begin{array}{l}1120 \\
1125 \\
1130 \\
1135 \\
1140\end{array}$ & $\begin{array}{l}33.0 \\
33.0 \\
34.5 \\
36.9 \\
40.2\end{array}$ & $\begin{array}{l}0.02 \\
0.03 \\
0.03 \\
0.02 \\
0.04\end{array}$ \\
\hline $\begin{array}{l}0055 \\
0100 \\
0105 \\
0110 \\
0115\end{array}$ & $\begin{array}{l}0.8 \\
0.8 \\
0.8 \\
0.9 \\
0.9\end{array}$ & $\begin{array}{l}0.00 \\
0.01 \\
0.01 \\
0.00 \\
0.00\end{array}$ & $\begin{array}{l}0620 \\
0625 \\
0630 \\
0635 \\
0640\end{array}$ & $\begin{array}{l}2.5 \\
2.5 \\
2.5 \\
2.5 \\
2.2\end{array}$ & $\begin{array}{l}0.01 \\
0.00 \\
0.01 \\
0.00 \\
0.00\end{array}$ & $\begin{array}{l}1145 \\
1150 \\
1155 \\
1200 \\
1205\end{array}$ & $\begin{array}{l}45.8 \\
58.9 \\
75.6 \\
89.6 \\
97.6\end{array}$ & $\begin{array}{l}0.06 \\
0.04 \\
0.02 \\
0.04 \\
0.03\end{array}$ \\
\hline $\begin{array}{l}0120 \\
0125 \\
0130 \\
0135 \\
0140\end{array}$ & $\begin{array}{l}0.9 \\
0.9 \\
1.1 \\
1.3 \\
1.3\end{array}$ & $\begin{array}{l}0.01 \\
0.00 \\
0.00 \\
0.01 \\
0.00\end{array}$ & $\begin{array}{l}0645 \\
0650 \\
0655 \\
0700 \\
0705\end{array}$ & $\begin{array}{l}2.2 \\
2.2 \\
2.2 \\
2.2 \\
2.2\end{array}$ & $\begin{array}{l}0.00 \\
0.01 \\
0.00 \\
0.00 \\
0.00\end{array}$ & $\begin{array}{l}1210 \\
1215 \\
1220 \\
1225 \\
1230\end{array}$ & $\begin{array}{l}106.0 \\
112.0 \\
112.0 \\
123.0 \\
128.0\end{array}$ & $\begin{array}{l}0.03 \\
0.04 \\
0.00 \\
0.02 \\
0.02\end{array}$ \\
\hline $\begin{array}{l}0145 \\
0150 \\
0155 \\
0200 \\
0205\end{array}$ & $\begin{array}{l}1.7 \\
2.2 \\
2.5 \\
2.5 \\
2.5\end{array}$ & $\begin{array}{l}0.00 \\
0.01 \\
0.00 \\
0.00 \\
0.00\end{array}$ & $\begin{array}{l}0710 \\
0715 \\
0720 \\
0725 \\
0730\end{array}$ & $\begin{array}{l}2.2 \\
2.2 \\
2.2 \\
2.2 \\
2.2\end{array}$ & $\begin{array}{l}0.00 \\
0.00 \\
0.00 \\
0.00 \\
0.00\end{array}$ & $\begin{array}{l}1235 \\
1240 \\
1245 \\
1250 \\
1255\end{array}$ & $\begin{array}{l}132.0 \\
133.0 \\
129.0 \\
122.0 \\
117.0\end{array}$ & $\begin{array}{l}0.04 \\
0.00 \\
0.02 \\
0.02 \\
0.02\end{array}$ \\
\hline $\begin{array}{l}0210 \\
0215 \\
0220 \\
0225 \\
0230\end{array}$ & $\begin{array}{l}2.5 \\
2.9 \\
2.9 \\
2.9 \\
2.9\end{array}$ & $\begin{array}{l}0.00 \\
0.00 \\
0.00 \\
0.00 \\
0.00\end{array}$ & $\begin{array}{l}0735 \\
0740 \\
0745 \\
0750 \\
0755\end{array}$ & $\begin{array}{l}2.2 \\
1.7 \\
1.7 \\
1.7 \\
1.7\end{array}$ & $\begin{array}{l}0.01 \\
0.00 \\
0.00 \\
0.00 \\
0.00\end{array}$ & $\begin{array}{l}1300 \\
1305 \\
1310 \\
1315 \\
1320\end{array}$ & $\begin{array}{r}111.0 \\
104.0 \\
96.5 \\
91.9 \\
86.3\end{array}$ & $\begin{array}{l}0.00 \\
0.02 \\
0.01 \\
0.01 \\
0.01\end{array}$ \\
\hline $\begin{array}{l}0235 \\
0240 \\
0245 \\
0250 \\
0255\end{array}$ & $\begin{array}{l}2.9 \\
2.9 \\
2.9 \\
3.4 \\
3.4\end{array}$ & $\begin{array}{l}0.01 \\
0.00 \\
0.00 \\
0.00 \\
0.01\end{array}$ & $\begin{array}{l}0800 \\
0805 \\
0810 \\
0815 \\
0820\end{array}$ & $\begin{array}{l}1.7 \\
1.7 \\
1.7 \\
1.7 \\
1.7\end{array}$ & $\begin{array}{l}0.00 \\
0.00 \\
0.00 \\
0.01 \\
0.00\end{array}$ & $\begin{array}{l}1325 \\
1330 \\
1335 \\
1340 \\
1345\end{array}$ & $\begin{array}{l}81.9 \\
76.6 \\
71.5 \\
66.5 \\
62.7\end{array}$ & $\begin{array}{l}0.00 \\
0.01 \\
0.01 \\
0.00 \\
0.00\end{array}$ \\
\hline $\begin{array}{l}0300 \\
0305 \\
0310 \\
0315 \\
0320\end{array}$ & $\begin{array}{l}3.9 \\
3.9 \\
3.9 \\
3.9 \\
4.4\end{array}$ & $\begin{array}{l}0.00 \\
0.00 \\
0.01 \\
0.00 \\
0.00\end{array}$ & $\begin{array}{l}0825 \\
0830 \\
0835 \\
0840 \\
0845\end{array}$ & $\begin{array}{l}1.7 \\
1.7 \\
1.7 \\
2.2 \\
2.2\end{array}$ & $\begin{array}{l}0.01 \\
0.00 \\
0.00 \\
0.00 \\
0.01\end{array}$ & $\begin{array}{l}1350 \\
1355 \\
1400 \\
1405 \\
1410\end{array}$ & $\begin{array}{l}58.0 \\
54.4 \\
50.9 \\
47.5 \\
44.2\end{array}$ & $\begin{array}{l}0.00 \\
0.00 \\
0.00 \\
0.00 \\
0.01\end{array}$ \\
\hline $\begin{array}{l}0325 \\
0330 \\
0335 \\
0340 \\
0345\end{array}$ & $\begin{array}{l}4.4 \\
4.4 \\
4.4 \\
4.4 \\
4.4\end{array}$ & $\begin{array}{l}0.00 \\
0.01 \\
0.00 \\
0.00 \\
0.00\end{array}$ & $\begin{array}{l}0850 \\
0855 \\
0900 \\
0905 \\
0910\end{array}$ & $\begin{array}{l}2.2 \\
2.2 \\
2.5 \\
2.5 \\
2.5\end{array}$ & $\begin{array}{l}0.00 \\
0.01 \\
0.00 \\
0.00 \\
0.00\end{array}$ & $\begin{array}{l}1415 \\
1420 \\
1425 \\
1430 \\
1435\end{array}$ & $\begin{array}{l}41.0 \\
37.7 \\
35.3 \\
33.0 \\
30.6\end{array}$ & $\begin{array}{l}0.00 \\
0.00 \\
0.00 \\
0.00 \\
0.02\end{array}$ \\
\hline $\begin{array}{l}0350 \\
0355 \\
0400 \\
0405 \\
0410\end{array}$ & $\begin{array}{l}4.4 \\
4.4 \\
4.4 \\
4.4 \\
3.9\end{array}$ & $\begin{array}{l}0.00 \\
0.01 \\
0.00 \\
0.00 \\
0.00\end{array}$ & $\begin{array}{l}0915 \\
0920 \\
0925 \\
0930 \\
0935\end{array}$ & $\begin{array}{l}2.5 \\
2.9 \\
2.9 \\
3.9 \\
5.2\end{array}$ & $\begin{array}{l}0.02 \\
0.03 \\
0.03 \\
0.04 \\
0.02\end{array}$ & $\begin{array}{l}1440 \\
1445 \\
1450 \\
1455 \\
1500\end{array}$ & $\begin{array}{l}28.3 \\
26.8 \\
26.1 \\
24.7 \\
24.0\end{array}$ & $\begin{array}{l}0.00 \\
0.01 \\
0.00 \\
0.00 \\
0.00\end{array}$ \\
\hline $\begin{array}{l}0415 \\
0420 \\
0425 \\
0430 \\
0435\end{array}$ & $\begin{array}{l}3.9 \\
3.9 \\
3.9 \\
3.9 \\
3.9\end{array}$ & $\begin{array}{l}0.00 \\
0.00 \\
0.00 \\
0.00 \\
0.00\end{array}$ & $\begin{array}{l}0940 \\
0945 \\
0950 \\
0955 \\
1000\end{array}$ & $\begin{array}{r}6.5 \\
7.8 \\
9.1 \\
11.0 \\
13.7\end{array}$ & $\begin{array}{l}0.03 \\
0.02 \\
0.01 \\
0.03 \\
0.01\end{array}$ & $\begin{array}{l}1505 \\
1510 \\
1515 \\
1520 \\
1525\end{array}$ & $\begin{array}{l}24.0 \\
22.4 \\
22.4 \\
22.4 \\
23.2\end{array}$ & $\begin{array}{l}0.01 \\
0.00 \\
0.00 \\
0.00 \\
0.00\end{array}$ \\
\hline $\begin{array}{l}0440 \\
0445 \\
0450 \\
0455 \\
0500\end{array}$ & $\begin{array}{l}3.9 \\
3.9 \\
3.4 \\
3.4 \\
3.4\end{array}$ & $\begin{array}{l}0.00 \\
0.00 \\
0.00 \\
0.00 \\
0.00\end{array}$ & $\begin{array}{l}1005 \\
1010 \\
1015 \\
1020 \\
1025\end{array}$ & $\begin{array}{l}17.5 \\
32.2 \\
45.8 \\
51.7 \\
53.5\end{array}$ & $\begin{array}{l}0.01 \\
0.02 \\
0.01 \\
0.01 \\
0.01\end{array}$ & $\begin{array}{l}1530 \\
1535 \\
1540 \\
1545 \\
1550\end{array}$ & $\begin{array}{l}23.2 \\
23.2 \\
22.4 \\
21.7 \\
21.0\end{array}$ & $\begin{array}{l}0.00 \\
0.00 \\
0.00 \\
0.00 \\
0.01\end{array}$ \\
\hline $\begin{array}{l}0505 \\
0510 \\
0515 \\
0520 \\
0525\end{array}$ & $\begin{array}{l}3.4 \\
3.4 \\
3.4 \\
3.4 \\
3.4\end{array}$ & $\begin{array}{l}0.00 \\
0.00 \\
0.00 \\
0.00 \\
0.00\end{array}$ & $\begin{array}{l}1030 \\
1035 \\
1040 \\
1045 \\
1050\end{array}$ & $\begin{array}{l}52.6 \\
51.7 \\
49.2 \\
46.6 \\
44.2\end{array}$ & $\begin{array}{l}0.00 \\
0.02 \\
0.00 \\
0.01 \\
0.01\end{array}$ & $\begin{array}{l}1555 \\
1600 \\
1605 \\
1610 \\
1615\end{array}$ & $\begin{array}{l}19.5 \\
18.8 \\
17.5 \\
16.8 \\
16.2\end{array}$ & $\begin{array}{l}0.00 \\
0.00 \\
0.01 \\
0.00 \\
0.00\end{array}$ \\
\hline
\end{tabular}


Table 35.--Streamflow and rainfall at station 02146100, Manchester Creek tributary at Rock Hill, September 30 - October 2 , 1989--Continued

\begin{tabular}{|c|c|c|c|c|c|c|c|c|}
\hline $\begin{array}{l}\text { Time } \\
\text { (hours) }\end{array}$ & $\begin{array}{l}\text { Streamflow } \\
\text { (cubic feet } \\
\text { per second) }\end{array}$ & $\begin{array}{l}\text { Rain- } \\
\text { fall } \\
\text { (inches) }\end{array}$ & $\begin{array}{l}\text { Time } \\
\text { (hours) }\end{array}$ & $\begin{array}{l}\text { Streamflow } \\
\text { (cubic feet } \\
\text { per second) }\end{array}$ & $\begin{array}{l}\text { Rain- } \\
\text { fall } \\
\text { (inches) }\end{array}$ & $\begin{array}{l}\text { Time } \\
\text { (hours) }\end{array}$ & $\begin{array}{l}\text { Streamflow } \\
\text { (cubic feet } \\
\text { per second) }\end{array}$ & $\begin{array}{l}\text { Rain- } \\
\text { fall } \\
\text { (inches) }\end{array}$ \\
\hline $\begin{array}{l}1620 \\
1625 \\
1630 \\
1635 \\
1640\end{array}$ & $\begin{array}{l}15.0 \\
14.5 \\
14.5 \\
14.1 \\
13.7\end{array}$ & $\begin{array}{l}0.01 \\
0.00 \\
0.00 \\
0.00 \\
0.01\end{array}$ & $\begin{array}{l}2145 \\
2150 \\
2155 \\
2200 \\
2205\end{array}$ & $\begin{array}{l}7.8 \\
7.8 \\
7.8 \\
7.8 \\
7.8\end{array}$ & $\begin{array}{l}0.00 \\
0.00 \\
0.01 \\
0.00 \\
0.00\end{array}$ & $\begin{array}{l}0305 \\
0310 \\
0315 \\
0320 \\
0325\end{array}$ & $\begin{array}{l}13.2 \\
12.8 \\
12.3 \\
11.9 \\
11.4\end{array}$ & $\begin{array}{l}0.00 \\
0.01 \\
0.00 \\
0.00 \\
0.00\end{array}$ \\
\hline $\begin{array}{l}1645 \\
1650 \\
1655 \\
1700 \\
1705\end{array}$ & $\begin{array}{l}13.2 \\
13.2 \\
12.8 \\
12.8 \\
12.3\end{array}$ & $\begin{array}{l}0.00 \\
0.00 \\
0.00 \\
0.00 \\
0.00\end{array}$ & $\begin{array}{l}2210 \\
2215 \\
2220 \\
2225 \\
2230\end{array}$ & $\begin{array}{l}8.2 \\
8.2 \\
8.7 \\
8.7 \\
9.1\end{array}$ & $\begin{array}{l}0.00 \\
0.01 \\
0.00 \\
0.00 \\
0.01\end{array}$ & $\begin{array}{l}0330 \\
0335 \\
0340 \\
0345 \\
0350\end{array}$ & $\begin{array}{l}11.4 \\
11.0 \\
10.5 \\
10.5 \\
10.1\end{array}$ & $\begin{array}{l}0.00 \\
0.00 \\
0.00 \\
0.00 \\
0.00\end{array}$ \\
\hline $\begin{array}{l}1710 \\
1715 \\
1720 \\
1725 \\
1730\end{array}$ & $\begin{array}{l}12.3 \\
12.3 \\
12.3 \\
12.3 \\
12.3\end{array}$ & $\begin{array}{l}0.01 \\
0.00 \\
0.00 \\
0.00 \\
0.00\end{array}$ & $\begin{array}{l}2235 \\
2240 \\
2245 \\
2250 \\
2255\end{array}$ & $\begin{array}{l}9.1 \\
9.1 \\
9.1 \\
9.1 \\
9.1\end{array}$ & $\begin{array}{l}0.00 \\
0.00 \\
0.00 \\
0.00 \\
0.01\end{array}$ & $\begin{array}{l}0355 \\
0400 \\
0405 \\
0410 \\
0415\end{array}$ & $\begin{array}{l}9.6 \\
9.6 \\
9.1 \\
9.1 \\
8.7\end{array}$ & $\begin{array}{l}0.00 \\
0.00 \\
0.00 \\
0.00 \\
0.00\end{array}$ \\
\hline $\begin{array}{l}1735 \\
1740 \\
1745 \\
1750 \\
1755\end{array}$ & $\begin{array}{l}11.9 \\
11.9 \\
11.9 \\
11.4 \\
11.4\end{array}$ & $\begin{array}{l}0.00 \\
0.00 \\
0.01 \\
0.00 \\
0.00\end{array}$ & $\begin{array}{l}2300 \\
2305 \\
2310 \\
2315 \\
2320\end{array}$ & $\begin{array}{l}9.1 \\
9.1 \\
9.1 \\
9.1 \\
9.1\end{array}$ & $\begin{array}{l}0.00 \\
0.00 \\
0.00 \\
0.00 \\
0.00\end{array}$ & $\begin{array}{l}0420 \\
0425 \\
0430 \\
0435 \\
0440\end{array}$ & $\begin{array}{l}8.7 \\
8.7 \\
8.2 \\
8.2 \\
7.8\end{array}$ & $\begin{array}{l}0.00 \\
0.00 \\
0.00 \\
0.01 \\
0.00\end{array}$ \\
\hline $\begin{array}{l}1800 \\
1805 \\
1810 \\
1815 \\
1820\end{array}$ & $\begin{array}{l}11.0 \\
11.0 \\
11.0 \\
11.0 \\
11.0\end{array}$ & $\begin{array}{l}0.00 \\
0.01 \\
0.00 \\
0.00 \\
0.00\end{array}$ & $\begin{array}{l}2325 \\
2330 \\
2335 \\
2340 \\
2345\end{array}$ & $\begin{array}{l}9.1 \\
9.1 \\
9.1 \\
9.1 \\
9.1\end{array}$ & $\begin{array}{l}0.00 \\
0.00 \\
0.01 \\
0.00 \\
0.00\end{array}$ & $\begin{array}{l}0445 \\
0450 \\
0455 \\
0500 \\
0505\end{array}$ & $\begin{array}{l}7.8 \\
7.8 \\
7.4 \\
7.4 \\
7.4\end{array}$ & $\begin{array}{l}0.00 \\
0.01 \\
0.00 \\
0.00 \\
0.00\end{array}$ \\
\hline $\begin{array}{l}1825 \\
1830 \\
1835 \\
1840 \\
1845\end{array}$ & $\begin{array}{l}10.5 \\
10.5 \\
10.5 \\
10.5 \\
10.1\end{array}$ & $\begin{array}{l}0.00 \\
0.00 \\
0.00 \\
0.00 \\
0.00\end{array}$ & $\begin{array}{l}2350 \\
2355 \\
\text { October } \\
0000 \\
0005\end{array}$ & $\begin{array}{r}9.1 \\
9.1 \\
01, \quad 1989 \\
9.1 \\
9.1\end{array}$ & $\begin{array}{l}0.00 \\
0.00 \\
0.00 \\
0.00\end{array}$ & $\begin{array}{l}0510 \\
0515 \\
0520 \\
0525 \\
0530\end{array}$ & $\begin{array}{l}7.4 \\
7.4 \\
7.0 \\
7.0 \\
7.0\end{array}$ & $\begin{array}{l}0.01 \\
0.00 \\
0.00 \\
0.00 \\
0.00\end{array}$ \\
\hline $\begin{array}{l}1850 \\
1855 \\
1900 \\
1905 \\
1910\end{array}$ & $\begin{array}{r}10.1 \\
10.1 \\
9.6 \\
9.6 \\
9.6\end{array}$ & $\begin{array}{l}0.00 \\
0.00 \\
0.00 \\
0.01 \\
0.00\end{array}$ & $\begin{array}{l}0010 \\
0015 \\
0020 \\
0025 \\
0030\end{array}$ & $\begin{array}{l}8.7 \\
8.7 \\
8.7 \\
8.7 \\
8.7\end{array}$ & $\begin{array}{l}0.01 \\
0.00 \\
0.00 \\
0.00 \\
0.00\end{array}$ & $\begin{array}{l}0535 \\
0540 \\
0545 \\
0550 \\
0555\end{array}$ & $\begin{array}{l}7.0 \\
7.0 \\
7.0 \\
7.0 \\
7.0\end{array}$ & $\begin{array}{l}0.00 \\
0.00 \\
0.00 \\
0.00 \\
0.00\end{array}$ \\
\hline $\begin{array}{l}1915 \\
1920 \\
1925 \\
1930 \\
1935\end{array}$ & $\begin{array}{l}9.6 \\
9.1 \\
9.1 \\
9.1 \\
8.7\end{array}$ & $\begin{array}{l}0.00 \\
0.00 \\
0.00 \\
0.00 \\
0.00\end{array}$ & $\begin{array}{l}0035 \\
0040 \\
0045 \\
0050 \\
0055\end{array}$ & $\begin{array}{l}8.2 \\
8.2 \\
8.2 \\
8.2 \\
8.2\end{array}$ & $\begin{array}{l}0.00 \\
0.01 \\
0.00 \\
0.01 \\
0.00\end{array}$ & $\begin{array}{l}0600 \\
0605 \\
0610 \\
0615 \\
0620\end{array}$ & $\begin{array}{l}7.0 \\
7.0 \\
7.0 \\
7.0 \\
7.0\end{array}$ & $\begin{array}{l}0.00 \\
0.00 \\
0.01 \\
0.00 \\
0.00\end{array}$ \\
\hline $\begin{array}{l}1940 \\
1945 \\
1950 \\
1955 \\
2000\end{array}$ & $\begin{array}{l}8.7 \\
8.7 \\
8.2 \\
8.2 \\
8.2\end{array}$ & $\begin{array}{l}0.00 \\
0.00 \\
0.01 \\
0.00 \\
0.00\end{array}$ & $\begin{array}{l}0100 \\
0105 \\
0110 \\
0115 \\
0120\end{array}$ & $\begin{array}{l}8.2 \\
8.2 \\
8.2 \\
8.2 \\
8.7\end{array}$ & $\begin{array}{l}0.01 \\
0.01 \\
0.00 \\
0.01 \\
0.01\end{array}$ & $\begin{array}{l}0625 \\
0630 \\
0635 \\
0640 \\
0645\end{array}$ & $\begin{array}{l}7.4 \\
7.4 \\
7.4 \\
7.4 \\
7.4\end{array}$ & $\begin{array}{l}0.00 \\
0.00 \\
0.00 \\
0.00 \\
0.00\end{array}$ \\
\hline $\begin{array}{l}2005 \\
2010 \\
2015 \\
2020 \\
2025\end{array}$ & $\begin{array}{l}7.8 \\
7.8 \\
7.8 \\
7.8 \\
7.4\end{array}$ & $\begin{array}{l}0.01 \\
0.00 \\
0.00 \\
0.00 \\
0.00\end{array}$ & $\begin{array}{l}0125 \\
0130 \\
0135 \\
0140 \\
0145\end{array}$ & $\begin{array}{r}8.7 \\
9.1 \\
9.1 \\
9.6 \\
10.1\end{array}$ & $\begin{array}{l}0.00 \\
0.01 \\
0.00 \\
0.00 \\
0.00\end{array}$ & $\begin{array}{l}0650 \\
0655 \\
0700 \\
0705 \\
0710\end{array}$ & $\begin{array}{l}7.4 \\
7.4 \\
7.0 \\
7.0 \\
7.0\end{array}$ & $\begin{array}{l}0.00 \\
0.00 \\
0.00 \\
0.00 \\
0.00\end{array}$ \\
\hline $\begin{array}{l}2030 \\
2035 \\
2040 \\
2045 \\
2050\end{array}$ & $\begin{array}{l}7.4 \\
7.4 \\
7.4 \\
7.4 \\
7.0\end{array}$ & $\begin{array}{l}0.00 \\
0.00 \\
0.00 \\
0.01 \\
0.00\end{array}$ & $\begin{array}{l}0150 \\
0155 \\
0200 \\
0205 \\
021 C\end{array}$ & $\begin{array}{l}10.1 \\
10.5 \\
11.0 \\
11.9 \\
12.8\end{array}$ & $\begin{array}{l}0.00 \\
0.01 \\
0.00 \\
0.00 \\
0.00\end{array}$ & $\begin{array}{l}0715 \\
0720 \\
0725 \\
0730 \\
0735\end{array}$ & $\begin{array}{l}7.0 \\
7.0 \\
6.5 \\
6.5 \\
6.5\end{array}$ & $\begin{array}{l}0.00 \\
0.00 \\
0.01 \\
0.00 \\
0.01\end{array}$ \\
\hline $\begin{array}{l}2055 \\
2100 \\
2105 \\
2110 \\
2115\end{array}$ & $\begin{array}{l}7.0 \\
7.0 \\
7.0 \\
7.0 \\
7.0\end{array}$ & $\begin{array}{l}0.00 \\
0.01 \\
0.01 \\
0.00 \\
0.00\end{array}$ & $\begin{array}{l}0215 \\
0220 \\
0225 \\
0230 \\
0235\end{array}$ & $\begin{array}{l}13.7 \\
14.5 \\
15.0 \\
15.6 \\
15.6\end{array}$ & $\begin{array}{l}0.00 \\
0.00 \\
0.00 \\
0.01 \\
0.00\end{array}$ & $\begin{array}{l}0740 \\
0745 \\
0750 \\
0755 \\
0800\end{array}$ & $\begin{array}{l}6.5 \\
6.5 \\
7.0 \\
7.4 \\
7.8\end{array}$ & $\begin{array}{l}0.02 \\
0.01 \\
0.02 \\
0.01 \\
0.01\end{array}$ \\
\hline $\begin{array}{l}2120 \\
2125 \\
2130 \\
2135 \\
2140\end{array}$ & $\begin{array}{ll}7 & 4 \\
7 & 4 \\
7 & 4 \\
7 & 4 \\
7 & 8\end{array}$ & 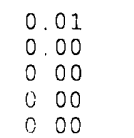 & $\begin{array}{l}0240 \\
0245 \\
0250 \\
0255 \\
0300\end{array}$ & $\begin{array}{l}15.6 \\
15.0 \\
14.5 \\
14.1 \\
13.7\end{array}$ & $\begin{array}{l}0.00 \\
0.00 \\
0.00 \\
0.00 \\
0.00\end{array}$ & $\begin{array}{l}0805 \\
0810 \\
0815 \\
0820 \\
0825\end{array}$ & $\begin{array}{r}8.2 \\
8.7 \\
9.6 \\
10.5 \\
11.4\end{array}$ & $\begin{array}{l}0.01 \\
0.01 \\
0.00 \\
0.00 \\
0.01\end{array}$ \\
\hline
\end{tabular}


Table 35. - Streamflow and rainfall at station 02146100, Manchester Cresk tributary at Rock Hill, September 30 - October 2 , 1989--Continued

\begin{tabular}{|c|c|c|c|c|c|c|c|c|}
\hline $\begin{array}{l}\text { Time } \\
\text { (hours) }\end{array}$ & $\begin{array}{l}\text { Streamflow } \\
\text { (cubic feet } \\
\text { per second) }\end{array}$ & $\begin{array}{l}\text { Rain- } \\
\text { fa11 } \\
\text { (inches) }\end{array}$ & $\begin{array}{l}\text { Time } \\
\text { (hours) }\end{array}$ & $\begin{array}{l}\text { Streamflow } \\
\text { (cubic feet } \\
\text { per second) }\end{array}$ & $\begin{array}{l}\text { Rain- } \\
\text { fal1 } \\
\text { (inches) }\end{array}$ & $\begin{array}{l}\text { Time } \\
\text { (hours) }\end{array}$ & $\begin{array}{l}\text { Streamflow } \\
\text { (cubic feet } \\
\text { per second) }\end{array}$ & $\begin{array}{l}\text { Rain- } \\
\text { fa11 } \\
\text { (incres) }\end{array}$ \\
\hline $\begin{array}{l}0830 \\
0835 \\
0840 \\
0845 \\
0850\end{array}$ & $\begin{array}{l}12.3 \\
13.7 \\
17.5 \\
22.4 \\
26.1\end{array}$ & $\begin{array}{l}0.00 \\
0.00 \\
0.00 \\
0.01 \\
0.00\end{array}$ & $\begin{array}{l}1355 \\
1400 \\
1405 \\
1410 \\
1415\end{array}$ & $\begin{array}{l}108.0 \\
116.0 \\
131.0 \\
149.0 \\
166.0\end{array}$ & $\begin{array}{l}0.02 \\
0.02 \\
0.03 \\
0.05 \\
0.05\end{array}$ & $\begin{array}{l}1920 \\
1925 \\
1930 \\
1935 \\
1940\end{array}$ & $\begin{array}{l}15.6 \\
13.2 \\
12.3 \\
13.7 \\
14.1\end{array}$ & $\begin{array}{l}0.00 \\
0.00 \\
0.00 \\
0.00 \\
0.00\end{array}$ \\
\hline $\begin{array}{l}0855 \\
0900 \\
0905 \\
0910 \\
0915\end{array}$ & $\begin{array}{l}27.6 \\
28.3 \\
28.3 \\
30.6 \\
33.8\end{array}$ & $\begin{array}{l}0.01 \\
0.02 \\
0.06 \\
0.04 \\
0.04\end{array}$ & $\begin{array}{l}1420 \\
1425 \\
1430 \\
1435 \\
1440\end{array}$ & $\begin{array}{l}186.0 \\
214.0 \\
258.0 \\
300.0 \\
338.0\end{array}$ & $\begin{array}{l}0.03 \\
0.09 \\
0.16 \\
0.04 \\
0.02\end{array}$ & $\begin{array}{l}1945 \\
1950 \\
1955 \\
2000 \\
2005\end{array}$ & $\begin{array}{l}14.1 \\
14.1 \\
13.7 \\
13.2 \\
13.2\end{array}$ & $\begin{array}{l}0.00 \\
0.00 \\
0.00 \\
0.00 \\
0.00\end{array}$ \\
\hline $\begin{array}{l}0920 \\
0925 \\
0930 \\
0935 \\
0940\end{array}$ & $\begin{array}{r}38.5 \\
50.9 \\
70.5 \\
94.2 \\
133.0\end{array}$ & $\begin{array}{l}0.12 \\
0.06 \\
0.01 \\
0.02 \\
0.00\end{array}$ & $\begin{array}{l}1445 \\
1450 \\
1455 \\
1500 \\
1505\end{array}$ & $\begin{array}{l}366.0 \\
388.0 \\
403.0 \\
410.0 \\
409.0\end{array}$ & $\begin{array}{l}0.02 \\
0.02 \\
0.02 \\
0.01 \\
0.01\end{array}$ & $\begin{array}{l}2010 \\
2015 \\
2020 \\
2025 \\
2030\end{array}$ & $\begin{array}{l}12.8 \\
12.8 \\
12.3 \\
12.3 \\
12.3\end{array}$ & $\begin{array}{l}0.00 \\
0.00 \\
0.02 \\
0.03 \\
0.01\end{array}$ \\
\hline $\begin{array}{l}0945 \\
0950 \\
0955 \\
1000 \\
1005\end{array}$ & $\begin{array}{l}167.0 \\
179.0 \\
190.0 \\
187.0 \\
176.0\end{array}$ & $\begin{array}{l}0.01 \\
0.00 \\
0.01 \\
0.01 \\
0.00\end{array}$ & $\begin{array}{l}1510 \\
1515 \\
1520 \\
1525 \\
1530\end{array}$ & $\begin{array}{l}401.0 \\
387.0 \\
371.0 \\
353.0 \\
334.0\end{array}$ & $\begin{array}{l}0.01 \\
0.00 \\
0.02 \\
0.00 \\
0.01\end{array}$ & $\begin{array}{l}2035 \\
2040 \\
2045 \\
2050 \\
2055\end{array}$ & $\begin{array}{l}12.8 \\
13.7 \\
13.7 \\
14.1 \\
14.1\end{array}$ & $\begin{array}{l}0.01 \\
0.00 \\
0.00 \\
0.00 \\
0.00\end{array}$ \\
\hline $\begin{array}{l}1010 \\
1015 \\
1020 \\
1025 \\
1030\end{array}$ & $\begin{array}{r}156.0 \\
135.0 \\
117.0 \\
102.0 \\
90.7\end{array}$ & $\begin{array}{l}0.01 \\
0.00 \\
0.01 \\
0.00 \\
0.00\end{array}$ & $\begin{array}{l}1535 \\
1540 \\
1545 \\
1550 \\
1555\end{array}$ & $\begin{array}{l}316.0 \\
298.0 \\
278.0 \\
255.0 \\
229.0\end{array}$ & $\begin{array}{l}0.00 \\
0.01 \\
0.00 \\
0.00 \\
0.00\end{array}$ & $\begin{array}{l}2100 \\
2105 \\
2110 \\
2115 \\
2120\end{array}$ & $\begin{array}{l}14.5 \\
15.0 \\
16.2 \\
18.6 \\
20.2\end{array}$ & $\begin{array}{l}0.00 \\
0.00 \\
0.00 \\
0.01 \\
0.01\end{array}$ \\
\hline $\begin{array}{l}1035 \\
1040 \\
1045 \\
1050 \\
1055\end{array}$ & $\begin{array}{l}81.9 \\
75.6 \\
72.5 \\
69.5 \\
68.5\end{array}$ & $\begin{array}{l}0.01 \\
0.05 \\
0.04 \\
0.01 \\
0.00\end{array}$ & $\begin{array}{l}1600 \\
1605 \\
1610 \\
1615 \\
1620\end{array}$ & $\begin{array}{r}200.0 \\
166.0 \\
133.0 \\
109.0 \\
93.0\end{array}$ & $\begin{array}{l}0.00 \\
0.00 \\
0.00 \\
0.00 \\
0.00\end{array}$ & $\begin{array}{l}2125 \\
2130 \\
2135 \\
2140 \\
2145\end{array}$ & $\begin{array}{l}22.4 \\
22.4 \\
22.4 \\
22.4 \\
22.4\end{array}$ & $\begin{array}{l}0.00 \\
0.01 \\
0.00 \\
0.01 \\
0.00\end{array}$ \\
\hline $\begin{array}{l}1100 \\
1105 \\
1110 \\
1115 \\
1120\end{array}$ & $\begin{array}{l}67.5 \\
67.5 \\
70.5 \\
75.6 \\
81.9\end{array}$ & $\begin{array}{l}0.01 \\
0.01 \\
0.02 \\
0.02 \\
0.01\end{array}$ & $\begin{array}{l}1625 \\
1630 \\
1635 \\
1640 \\
1645\end{array}$ & $\begin{array}{l}84.1 \\
78.7 \\
73.5 \\
67.5 \\
62.7\end{array}$ & $\begin{array}{l}0.00 \\
0.00 \\
0.00 \\
0.00 \\
0.01\end{array}$ & $\begin{array}{l}2150 \\
2155 \\
2200 \\
2205 \\
2210\end{array}$ & $\begin{array}{l}21.7 \\
21.0 \\
21.0 \\
20.2 \\
20.2\end{array}$ & $\begin{array}{l}0.01 \\
0.00 \\
0.00 \\
0.00 \\
0.00\end{array}$ \\
\hline $\begin{array}{l}1125 \\
1130 \\
1135 \\
1140 \\
1145\end{array}$ & $\begin{array}{l}85.2 \\
85.2 \\
85.2 \\
85.2 \\
86.3\end{array}$ & $\begin{array}{l}0.01 \\
0.02 \\
0.03 \\
0.02 \\
0.03\end{array}$ & $\begin{array}{l}1650 \\
1655 \\
1700 \\
1705 \\
1710\end{array}$ & $\begin{array}{l}58.0 \\
54.4 \\
50.9 \\
48.3 \\
45.8\end{array}$ & $\begin{array}{l}0.00 \\
0.00 \\
0.00 \\
0.00 \\
0.00\end{array}$ & $\begin{array}{l}2215 \\
2220 \\
2225 \\
2230 \\
2235\end{array}$ & $\begin{array}{l}20.2 \\
20.2 \\
20.2 \\
21.0 \\
21.0\end{array}$ & $\begin{array}{l}0.01 \\
0.00 \\
0.01 \\
0.00 \\
0.01\end{array}$ \\
\hline $\begin{array}{l}1150 \\
1155 \\
1200 \\
1205 \\
1210\end{array}$ & $\begin{array}{r}89.6 \\
97.6 \\
108.0 \\
119.0 \\
132.0\end{array}$ & $\begin{array}{l}0.04 \\
0.03 \\
0.03 \\
0.02 \\
0.02\end{array}$ & $\begin{array}{l}1715 \\
1720 \\
1725 \\
1730 \\
1735\end{array}$ & $\begin{array}{l}43.4 \\
41.0 \\
39.3 \\
36.9 \\
36.1\end{array}$ & $\begin{array}{l}0.00 \\
0.00 \\
0.00 \\
0.00 \\
0.00\end{array}$ & $\begin{array}{l}2240 \\
2245 \\
2250 \\
2255 \\
2300\end{array}$ & $\begin{array}{l}21.0 \\
21.0 \\
21.7 \\
22.4 \\
24.0\end{array}$ & $\begin{array}{l}0.01 \\
0.01 \\
0.01 \\
0.03 \\
0.05\end{array}$ \\
\hline $\begin{array}{l}1215 \\
1220 \\
1225 \\
1230 \\
1235\end{array}$ & $\begin{array}{l}148.0 \\
159.0 \\
169.0 \\
170.0 \\
169.0\end{array}$ & $\begin{array}{l}0.02 \\
0.01 \\
0.01 \\
0.01 \\
0.01\end{array}$ & $\begin{array}{l}1740 \\
1745 \\
1750 \\
1755 \\
1800\end{array}$ & $\begin{array}{l}34.5 \\
33.0 \\
31.4 \\
29.8 \\
28.3\end{array}$ & $\begin{array}{l}0.00 \\
0.00 \\
0.00 \\
0.00 \\
0.00\end{array}$ & $\begin{array}{l}2305 \\
2310 \\
2315 \\
2320 \\
2325\end{array}$ & $\begin{array}{r}29.1 \\
41.0 \\
55.3 \\
80.8 \\
143.0\end{array}$ & $\begin{array}{l}0.09 \\
0.02 \\
0.06 \\
0.10 \\
0.07\end{array}$ \\
\hline $\begin{array}{l}1240 \\
1245 \\
1250 \\
1255 \\
1300\end{array}$ & $\begin{array}{l}165.0 \\
159.0 \\
152.0 \\
149.0 \\
144.0\end{array}$ & $\begin{array}{l}0.02 \\
0.00 \\
0.02 \\
0.02 \\
0.00\end{array}$ & $\begin{array}{l}1805 \\
1810 \\
1815 \\
1820 \\
1825\end{array}$ & $\begin{array}{l}26.8 \\
26.1 \\
24.7 \\
24.0 \\
23.2\end{array}$ & $\begin{array}{l}0.00 \\
0.00 \\
0.00 \\
0.00 \\
0.00\end{array}$ & $\begin{array}{l}2330 \\
2335 \\
2340 \\
2345 \\
2350\end{array}$ & $\begin{array}{l}205.0 \\
235.0 \\
258.0 \\
275.0 \\
290.0\end{array}$ & $\begin{array}{l}0.03 \\
0.09 \\
0.02 \\
0.01 \\
0.04\end{array}$ \\
\hline $\begin{array}{l}1305 \\
1310 \\
1315 \\
1320 \\
1325\end{array}$ & $\begin{array}{l}140.0 \\
135.0 \\
129.0 \\
126.0 \\
120.0\end{array}$ & $\begin{array}{l}0.01 \\
0.00 \\
0.00 \\
0.01 \\
0.00\end{array}$ & $\begin{array}{l}1830 \\
1835 \\
1840 \\
1845 \\
1850\end{array}$ & $\begin{array}{l}21.7 \\
20.2 \\
20.2 \\
19.5 \\
18.8\end{array}$ & $\begin{array}{l}0.00 \\
0.00 \\
0.00 \\
0.00 \\
0.00\end{array}$ & $\begin{aligned} & 2355 \\
& \text { October } 02, \\
& 0000 \\
& 0005 \\
& 0010\end{aligned}$ & $\begin{array}{r}299.0 \\
1989 \\
305.0 \\
305.0 \\
300.0\end{array}$ & $\begin{array}{l}0.07 \\
0.02 \\
0.02 \\
0.0 ?\end{array}$ \\
\hline $\begin{array}{l}1330 \\
1335 \\
1340 \\
1345 \\
1350\end{array}$ & $\begin{array}{l}114.0 \\
108.0 \\
104.0 \\
104.0 \\
105.0\end{array}$ & $\begin{array}{l}0.02 \\
0.02 \\
0.10 \\
0.02 \\
0.02\end{array}$ & $\begin{array}{l}1855 \\
1900 \\
1905 \\
1910 \\
1915\end{array}$ & $\begin{array}{l}18.2 \\
17.5 \\
17.5 \\
16.8 \\
16.2\end{array}$ & $\begin{array}{l}0.00 \\
0.00 \\
0.00 \\
0.00 \\
0.00\end{array}$ & $\begin{array}{l}0015 \\
0020 \\
0025 \\
0030 \\
0035\end{array}$ & $\begin{array}{l}300.0 \\
300.0 \\
296.0 \\
293.0 \\
287.0\end{array}$ & $\begin{array}{l}0.01 \\
0.00 \\
0.00 \\
0.02 \\
0.03\end{array}$ \\
\hline
\end{tabular}


Table 35.--Streamflow and rainfal1 at station 02146100, Manchester Creek tributary at Rock Hill, September $30-$ October 2, 1989--Continued

\begin{tabular}{|c|c|c|c|c|c|c|c|c|}
\hline $\begin{array}{l}\text { Time } \\
\text { (hours) }\end{array}$ & $\begin{array}{l}\text { Streamflow } \\
\text { (cubic feet } \\
\text { per second) }\end{array}$ & $\begin{array}{l}\text { Rain- } \\
\text { fall } \\
\text { (inches) }\end{array}$ & $\begin{array}{l}\text { Time } \\
\text { (hours) }\end{array}$ & $\begin{array}{l}\text { Streamflow } \\
\text { (cubic feet } \\
\text { per second) }\end{array}$ & $\begin{array}{l}\text { Rain- } \\
\text { fall } \\
\text { (inches) }\end{array}$ & $\begin{array}{l}\text { Time } \\
\text { (hours) }\end{array}$ & $\begin{array}{l}\text { Streamflow } \\
\text { (cubic feet } \\
\text { per second) }\end{array}$ & $\begin{array}{l}\text { Rain- } \\
\text { fall } \\
\text { (incl os) }\end{array}$ \\
\hline $\begin{array}{l}0040 \\
0045 \\
0050 \\
0055 \\
0100\end{array}$ & $\begin{array}{l}275.0 \\
261.0 \\
238.0 \\
213.0 \\
180.0\end{array}$ & $\begin{array}{l}0.01 \\
0.00 \\
0.00 \\
0.00 \\
0.00\end{array}$ & $\begin{array}{l}0605 \\
0610 \\
0615 \\
0620 \\
0625\end{array}$ & $\begin{array}{l}10.5 \\
10.5 \\
10.1 \\
10.1 \\
10.1\end{array}$ & $\begin{array}{l}0.00 \\
0.00 \\
0.00 \\
0.00 \\
0.00\end{array}$ & $\begin{array}{l}1130 \\
1135 \\
1140 \\
1145 \\
1150\end{array}$ & $\begin{array}{l}5.2 \\
5.2 \\
5.2 \\
5.2 \\
5.2\end{array}$ & $\begin{array}{l}0.00 \\
0.00 \\
0.00 \\
0.00 \\
0.00\end{array}$ \\
\hline $\begin{array}{l}0105 \\
0110 \\
0115 \\
0120 \\
0125\end{array}$ & $\begin{array}{r}148.0 \\
124.0 \\
108.0 \\
96.5 \\
87.4\end{array}$ & $\begin{array}{l}0.00 \\
0.00 \\
0.00 \\
0.00 \\
0.00\end{array}$ & $\begin{array}{l}0630 \\
0635 \\
0640 \\
0645 \\
0650\end{array}$ & $\begin{array}{l}9.6 \\
9.6 \\
9.6 \\
9.6 \\
9.1\end{array}$ & $\begin{array}{l}0.00 \\
0.00 \\
0.00 \\
0.00 \\
0.00\end{array}$ & $\begin{array}{l}1155 \\
1200 \\
1205 \\
1210 \\
1215\end{array}$ & $\begin{array}{l}5.2 \\
5.2 \\
4.8 \\
4.8 \\
4.8\end{array}$ & $\begin{array}{l}0.00 \\
0.00 \\
0.00 \\
0.00 \\
0.00\end{array}$ \\
\hline $\begin{array}{l}0130 \\
0135 \\
0140 \\
0145 \\
0150\end{array}$ & $\begin{array}{l}79.8 \\
72.5 \\
66.5 \\
61.7 \\
57.1\end{array}$ & $\begin{array}{l}0.00 \\
0.00 \\
0.00 \\
0.00 \\
0.00\end{array}$ & $\begin{array}{l}0655 \\
0700 \\
0705 \\
0710 \\
0715\end{array}$ & $\begin{array}{l}9.1 \\
9.1 \\
8.7 \\
8.7 \\
8.7\end{array}$ & $\begin{array}{l}0.00 \\
0.00 \\
0.00 \\
0.00 \\
0.00\end{array}$ & $\begin{array}{l}1220 \\
1225 \\
1230 \\
1235 \\
1240\end{array}$ & $\begin{array}{l}4.8 \\
4.8 \\
4.8 \\
4.8 \\
4.8\end{array}$ & $\begin{array}{l}0.00 \\
0.00 \\
0.00 \\
0.00 \\
0.00\end{array}$ \\
\hline $\begin{array}{l}0155 \\
0200 \\
0205 \\
0210 \\
0215\end{array}$ & $\begin{array}{l}53.5 \\
50.0 \\
47.5 \\
44.2 \\
41.8\end{array}$ & $\begin{array}{l}0.00 \\
0.00 \\
0.00 \\
0.00 \\
0.00\end{array}$ & $\begin{array}{l}0720 \\
0725 \\
0730 \\
0735 \\
0740\end{array}$ & $\begin{array}{l}8.7 \\
8.7 \\
8.7 \\
8.2 \\
8.2\end{array}$ & $\begin{array}{l}0.00 \\
0.00 \\
0.00 \\
0.00 \\
0.00\end{array}$ & $\begin{array}{l}1245 \\
1250 \\
1255 \\
1300 \\
1305\end{array}$ & $\begin{array}{l}4.4 \\
4.4 \\
4.4 \\
4.4 \\
4.4\end{array}$ & $\begin{array}{l}0.00 \\
0.00 \\
0.00 \\
0.00 \\
0.00\end{array}$ \\
\hline $\begin{array}{l}0220 \\
0225 \\
0230 \\
0235 \\
0240\end{array}$ & $\begin{array}{l}39.3 \\
37.7 \\
35.3 \\
33.8 \\
32.2\end{array}$ & $\begin{array}{l}0.00 \\
0.00 \\
0.00 \\
0.00 \\
0.00\end{array}$ & $\begin{array}{l}0745 \\
0750 \\
0755 \\
0800 \\
0805\end{array}$ & $\begin{array}{l}8.2 \\
8.2 \\
8.2 \\
7.8 \\
7.8\end{array}$ & $\begin{array}{l}0.00 \\
0.00 \\
0.00 \\
0.00 \\
0.00\end{array}$ & $\begin{array}{l}1310 \\
1315 \\
1320 \\
1325 \\
1330\end{array}$ & $\begin{array}{l}4.4 \\
4.4 \\
4.4 \\
4.4 \\
3.9\end{array}$ & $\begin{array}{l}0.00 \\
0.00 \\
0.00 \\
0.00 \\
0.00\end{array}$ \\
\hline $\begin{array}{l}0245 \\
0250 \\
0255 \\
0300 \\
0305\end{array}$ & $\begin{array}{l}30.6 \\
29.1 \\
27.6 \\
26.8 \\
25.4\end{array}$ & $\begin{array}{l}0.00 \\
0.00 \\
0.00 \\
0.00 \\
0.00\end{array}$ & $\begin{array}{l}0810 \\
0815 \\
0820 \\
0825 \\
0830\end{array}$ & $\begin{array}{l}7.8 \\
7.8 \\
7.8 \\
7.8 \\
7.4\end{array}$ & $\begin{array}{l}0.00 \\
0.00 \\
0.00 \\
0.00 \\
0.00\end{array}$ & $\begin{array}{l}1335 \\
1340 \\
1345 \\
1350 \\
1355\end{array}$ & $\begin{array}{l}3.9 \\
3.9 \\
3.9 \\
3.9 \\
3.9\end{array}$ & $\begin{array}{l}0.00 \\
0.00 \\
0.00 \\
0.00 \\
0.00\end{array}$ \\
\hline $\begin{array}{l}0310 \\
0315 \\
0320 \\
0325 \\
0330\end{array}$ & $\begin{array}{l}24.7 \\
24.0 \\
23.2 \\
21.7 \\
21.0\end{array}$ & $\begin{array}{l}0.00 \\
0.00 \\
0.00 \\
0.00 \\
0.00\end{array}$ & $\begin{array}{l}0835 \\
0840 \\
0845 \\
0850 \\
0855\end{array}$ & $\begin{array}{l}7.4 \\
7.4 \\
7.4 \\
7.4 \\
7.4\end{array}$ & $\begin{array}{l}0.00 \\
0.00 \\
0.00 \\
0.00 \\
0.00\end{array}$ & $\begin{array}{l}1400 \\
1405 \\
1410 \\
1415 \\
1420\end{array}$ & $\begin{array}{l}3.9 \\
3.9 \\
3.9 \\
3.9 \\
3.9\end{array}$ & $\begin{array}{l}0.00 \\
0.00 \\
0.00 \\
0.00 \\
0.00\end{array}$ \\
\hline $\begin{array}{l}0335 \\
0340 \\
0345 \\
0350 \\
0355\end{array}$ & $\begin{array}{l}20.2 \\
20.2 \\
18.8 \\
18.2 \\
17.5\end{array}$ & $\begin{array}{l}0.00 \\
0.00 \\
0.00 \\
0.00 \\
0.00\end{array}$ & $\begin{array}{l}0900 \\
0905 \\
0910 \\
0915 \\
0920\end{array}$ & $\begin{array}{l}7.4 \\
7.0 \\
7.0 \\
7.0 \\
7.0\end{array}$ & $\begin{array}{l}0.00 \\
0.00 \\
0.00 \\
0.00 \\
0.00\end{array}$ & $\begin{array}{l}1425 \\
1430 \\
1435 \\
1440 \\
1445\end{array}$ & $\begin{array}{l}3.4 \\
3.4 \\
3.4 \\
3.4 \\
3.4\end{array}$ & $\begin{array}{l}0.00 \\
0.00 \\
0.00 \\
0.00 \\
0.00\end{array}$ \\
\hline $\begin{array}{l}0400 \\
0405 \\
0410 \\
0415 \\
0420\end{array}$ & $\begin{array}{l}17.5 \\
16.8 \\
16.2 \\
15.6 \\
15.6\end{array}$ & $\begin{array}{l}0.00 \\
0.00 \\
0.00 \\
0.00 \\
0.00\end{array}$ & $\begin{array}{l}0925 \\
0930 \\
0935 \\
0940 \\
0945\end{array}$ & $\begin{array}{l}7.0 \\
7.0 \\
7.0 \\
6.5 \\
6.5\end{array}$ & $\begin{array}{l}0.00 \\
0.00 \\
0.00 \\
0.00 \\
0.00\end{array}$ & $\begin{array}{l}1450 \\
1455 \\
1500 \\
1505 \\
1510\end{array}$ & $\begin{array}{l}3.4 \\
3.4 \\
3.4 \\
3.4 \\
3.4\end{array}$ & $\begin{array}{l}0.00 \\
0.00 \\
0.00 \\
0.00 \\
0.00\end{array}$ \\
\hline $\begin{array}{l}0425 \\
0430 \\
0435 \\
0440 \\
0445\end{array}$ & $\begin{array}{l}15.0 \\
14.5 \\
14.5 \\
14.1 \\
13.7\end{array}$ & $\begin{array}{l}0.00 \\
0.00 \\
0.00 \\
0.00 \\
0.00\end{array}$ & $\begin{array}{l}0950 \\
0955 \\
1000 \\
1005 \\
1010\end{array}$ & $\begin{array}{l}6.5 \\
6.5 \\
6.5 \\
6.5 \\
6.0\end{array}$ & $\begin{array}{l}0.00 \\
0.00 \\
0.00 \\
0.00 \\
0.00\end{array}$ & $\begin{array}{l}1515 \\
1520 \\
1525 \\
1530 \\
1535\end{array}$ & $\begin{array}{l}3.4 \\
3.4 \\
3.4 \\
2.9 \\
2.9\end{array}$ & $\begin{array}{l}0.00 \\
0.07 \\
0.00 \\
0.00 \\
0.03\end{array}$ \\
\hline $\begin{array}{l}0450 \\
0455 \\
0500 \\
0505 \\
0510\end{array}$ & $\begin{array}{l}13.7 \\
13.2 \\
13.2 \\
12.8 \\
12.3\end{array}$ & $\begin{array}{l}0.00 \\
0.00 \\
0.00 \\
0.00 \\
0.00\end{array}$ & $\begin{array}{l}1015 \\
1020 \\
1025 \\
1030 \\
1035\end{array}$ & $\begin{array}{l}6.0 \\
6.0 \\
6.0 \\
6.0 \\
5.6\end{array}$ & $\begin{array}{l}0.00 \\
0.00 \\
0.00 \\
0.00 \\
0.00\end{array}$ & $\begin{array}{l}1540 \\
1545 \\
1550 \\
1555 \\
1600\end{array}$ & $\begin{array}{l}2.9 \\
2.9 \\
2.9 \\
2.9 \\
2.9\end{array}$ & $\begin{array}{l}0.03 \\
0.07 \\
0.07 \\
0.07 \\
0.07\end{array}$ \\
\hline $\begin{array}{l}0515 \\
0520 \\
0525 \\
0530 \\
0535\end{array}$ & $\begin{array}{l}12.3 \\
11.9 \\
11.9 \\
11.9 \\
11.4\end{array}$ & $\begin{array}{l}0.00 \\
0.00 \\
0.00 \\
0.00 \\
0.00\end{array}$ & $\begin{array}{l}1040 \\
1045 \\
1050 \\
1055 \\
1100\end{array}$ & $\begin{array}{l}5.6 \\
5.6 \\
5.6 \\
5.6 \\
5.6\end{array}$ & $\begin{array}{l}0.00 \\
0.00 \\
0.00 \\
0.00 \\
0.00\end{array}$ & $\begin{array}{l}1605 \\
1610 \\
1615 \\
1620 \\
1625\end{array}$ & $\begin{array}{l}2.9 \\
2.9 \\
2.9 \\
2.9 \\
2.9\end{array}$ & $\begin{array}{l}0.03 \\
0.03 \\
0.00 \\
0.03 \\
0.07\end{array}$ \\
\hline $\begin{array}{l}0540 \\
0545 \\
0550 \\
0555 \\
0600\end{array}$ & $\begin{array}{l}11.4 \\
11.0 \\
11.0 \\
11.0 \\
10.5\end{array}$ & $\begin{array}{l}0.00 \\
0.00 \\
0.00 \\
0.00 \\
0.00\end{array}$ & $\begin{array}{l}1105 \\
1110 \\
1115 \\
1120 \\
1125\end{array}$ & $\begin{array}{l}5.6 \\
5.6 \\
5.6 \\
5.2 \\
5.2\end{array}$ & $\begin{array}{l}0.00 \\
0.00 \\
0.00 \\
0.00 \\
0.00\end{array}$ & $\begin{array}{l}1630 \\
1635 \\
1640 \\
1645 \\
1650\end{array}$ & $\begin{array}{l}2.9 \\
2.9 \\
2.9 \\
2.9 \\
2.9\end{array}$ & $\begin{array}{l}0.00 \\
0.07 \\
0.00 \\
0.00 \\
0.03\end{array}$ \\
\hline
\end{tabular}


Table 35. - Streanflow and rainfall at station 02146100, Manchester Creek tributary at Rock Hill, September 30 - October 2 , 1989--Continued

\begin{tabular}{|c|c|c|c|c|c|c|c|c|}
\hline $\begin{array}{l}\text { Time } \\
\text { (hours) }\end{array}$ & $\begin{array}{l}\text { Streamflow } \\
\text { (cubic feet } \\
\text { per second) }\end{array}$ & $\begin{array}{l}\text { Rain- } \\
\text { fall } \\
\text { (inches) }\end{array}$ & $\begin{array}{l}\text { Time } \\
\text { (hours) }\end{array}$ & $\begin{array}{l}\text { Streamflow } \\
\text { (cubic feet } \\
\text { per second) }\end{array}$ & $\begin{array}{l}\text { Rain- } \\
\text { fall } \\
\text { (inches) }\end{array}$ & $\begin{array}{l}\text { Time } \\
\text { (hours) }\end{array}$ & $\begin{array}{l}\text { Streamflow } \\
\text { (cubic feet } \\
\text { per second) }\end{array}$ & $\begin{array}{l}\text { Rain- } \\
\text { fall } \\
\text { (inchos) }\end{array}$ \\
\hline $\begin{array}{l}1655 \\
1700 \\
1705 \\
1710 \\
1715\end{array}$ & $\begin{array}{l}2.9 \\
2.5 \\
2.5 \\
2.5 \\
2.5\end{array}$ & $\begin{array}{l}0.00 \\
0.00 \\
0.00 \\
0.00 \\
0.00\end{array}$ & $\begin{array}{l}1900 \\
1905 \\
1910 \\
1915 \\
1920\end{array}$ & $\begin{array}{l}2.5 \\
2.5 \\
2.5 \\
2.5 \\
2.5\end{array}$ & $\begin{array}{l}0.00 \\
0.00 \\
0.00 \\
0.00 \\
0.00\end{array}$ & $\begin{array}{l}2105 \\
2110 \\
2115 \\
2120 \\
2125\end{array}$ & $\begin{array}{l}2.2 \\
2.2 \\
2.2 \\
2.2 \\
2.2\end{array}$ & $\begin{array}{l}0.00 \\
0.00 \\
0.00 \\
0.00 \\
0.00\end{array}$ \\
\hline $\begin{array}{l}1720 \\
1725 \\
1730 \\
1735 \\
1740\end{array}$ & $\begin{array}{l}2.5 \\
2.5 \\
2.5 \\
2.5 \\
2.5\end{array}$ & $\begin{array}{l}0.00 \\
0.00 \\
0.00 \\
0.00 \\
0.00\end{array}$ & $\begin{array}{l}1925 \\
1930 \\
1935 \\
1940 \\
1945\end{array}$ & $\begin{array}{l}2.5 \\
2.2 \\
2.2 \\
2.2 \\
2.2\end{array}$ & $\begin{array}{l}0.00 \\
0.00 \\
0.00 \\
0.00 \\
0.00\end{array}$ & $\begin{array}{l}2130 \\
2135 \\
2140 \\
2145 \\
2150\end{array}$ & $\begin{array}{l}2.2 \\
2.2 \\
2.2 \\
2.2 \\
2.2\end{array}$ & $\begin{array}{l}0.00 \\
0.00 \\
0.00 \\
0.00 \\
0.00\end{array}$ \\
\hline $\begin{array}{l}1745 \\
1750 \\
1755 \\
1800 \\
1805\end{array}$ & $\begin{array}{l}2.5 \\
2.5 \\
2.5 \\
2.5 \\
2.5\end{array}$ & $\begin{array}{l}0.00 \\
0.00 \\
0.00 \\
0.00 \\
0.00\end{array}$ & $\begin{array}{l}1950 \\
1955 \\
2000 \\
2005 \\
2010\end{array}$ & $\begin{array}{l}2.2 \\
2.2 \\
2.2 \\
2.2 \\
2.2\end{array}$ & $\begin{array}{l}0.00 \\
0.00 \\
0.00 \\
0.00 \\
0.00\end{array}$ & $\begin{array}{l}2155 \\
2200 \\
2205 \\
2210 \\
2215\end{array}$ & $\begin{array}{l}2.2 \\
2.2 \\
2.2 \\
2.2 \\
2.2\end{array}$ & $\begin{array}{l}0.00 \\
0.00 \\
0.00 \\
0.00 \\
0.00\end{array}$ \\
\hline $\begin{array}{l}1810 \\
1815 \\
1820 \\
1825 \\
1830\end{array}$ & $\begin{array}{l}2.5 \\
2.5 \\
2.5 \\
2.5 \\
2.5\end{array}$ & $\begin{array}{l}0.00 \\
0.00 \\
0.00 \\
0.00 \\
0.00\end{array}$ & $\begin{array}{l}2015 \\
2020 \\
2025 \\
2030 \\
2035\end{array}$ & $\begin{array}{l}2.2 \\
2.2 \\
2.2 \\
2.2 \\
2.2\end{array}$ & $\begin{array}{l}0.00 \\
0.00 \\
0.00 \\
0.00 \\
0.00\end{array}$ & $\begin{array}{l}2220 \\
2225 \\
2230 \\
2235 \\
2240\end{array}$ & $\begin{array}{l}1.7 \\
1.7 \\
1.7 \\
1.7 \\
1.7\end{array}$ & $\begin{array}{l}0.00 \\
0.00 \\
0.00 \\
0.00 \\
0.00\end{array}$ \\
\hline $\begin{array}{l}1835 \\
1840 \\
1845 \\
1850 \\
1855\end{array}$ & $\begin{array}{l}2.5 \\
2.5 \\
2.5 \\
2.5 \\
2.5\end{array}$ & $\begin{array}{l}0.00 \\
0.00 \\
0.00 \\
0.00 \\
0.00\end{array}$ & $\begin{array}{l}2040 \\
2045 \\
2050 \\
2055 \\
2100\end{array}$ & $\begin{array}{l}2.2 \\
2.2 \\
2.2 \\
2.2 \\
2.2\end{array}$ & $\begin{array}{l}0.00 \\
0.00 \\
0.00 \\
0.00 \\
0.00\end{array}$ & $\begin{array}{l}2245 \\
2250 \\
2255 \\
2300\end{array}$ & $\begin{array}{l}1.7 \\
1.7 \\
1.7 \\
1.7\end{array}$ & $\begin{array}{l}0.00 \\
0.00 \\
0.00 \\
0.00\end{array}$ \\
\hline
\end{tabular}




\section{Station 02156250, Chinquapin Creek Tributary at Spartanburg, S.C.}

Location.--Lat 34'57'34', long 81'55'29", Spartanburg County, Hydrologic Unit 030501C 5 , at culvert on Pine Street (U.S. Highway 176), about $0.8 \mathrm{mi}$ east of Rutledge College, and $0.9 \mathrm{mi}$ northeast of Spartanburg City Hall, and $0.1 \mathrm{mi}$ upstream from the mouth at Chinquapin Creek.

Period of record.-- December 17, 1985 to March 6, 1987

Gage.--Digital stage recorder with 5-minute punch interval. The recorder is housed in a metal shelter atop a stilling well attached to a free-standing platform on the left bark $20 \mathrm{ft}$ upstream of a double $7 \mathrm{ft}$ by $7 \mathrm{ft}$ concrete box culvert. A crest-stage indicator is located on the downstream left wingwall.

Rating.--The stage-streamflow relation is defined by current meter measurements up to $0.5 \mathrm{ft}^{3} / \mathrm{s}$. The stage-streamflow relation was extended to $600 \mathrm{ft}^{3} / \mathrm{s}$ using indirect computational methods.

Rain gage and location.--Station 345736081552500, lat $34^{\circ} 57^{\prime} 36^{\prime \prime}$, long $81^{\circ} 55^{\prime 2} 25^{\prime \prime}$. A shelter containing a digital cumulative rainfall recorder with a 5-minute punch interval on a lot belonging to the Piedmont Gas Company on U.S. Highway 176, about $0.8 \mathrm{mi}$ east of Rutledge College, and 0.9 mi northeast of Spartanburg City Hall.

Selected basin characteristics.--

Drainage area -- $0.52 \mathrm{mi}^{2}$

Physiographic province -- Piedmont

Channel slope -- $139.0 \mathrm{ft} / \mathrm{mi}$

Channel length -- $1.15 \mathrm{mi}$

Total impervious area -- 47.0 percent

Basin development factor -- 10

2-year, 2-hour rainfall amount -- 2.00 in.

Flood frequency data: $\begin{array}{lr}\mathrm{UQ}_{2} & 567 \mathrm{ft}^{3} / \mathrm{s} \\ \mathrm{UQ}_{5} & 831 \mathrm{ft}^{3} / \mathrm{s} \\ \mathrm{UQ}_{10} & 1,000 \mathrm{ft}^{3} / \mathrm{s} \\ \mathrm{UQ}_{25} & 1,210 \mathrm{ft}^{3} / \mathrm{s} \\ \mathrm{UQ}_{50} & 1,360 \mathrm{ft}^{3} / \mathrm{s} \\ \mathrm{UQ}_{100} & 1,500 \mathrm{ft}^{3} / \mathrm{s} \\ \mathrm{UQ}_{500} & 1,810 \mathrm{ft}^{3} / \mathrm{s}\end{array}$




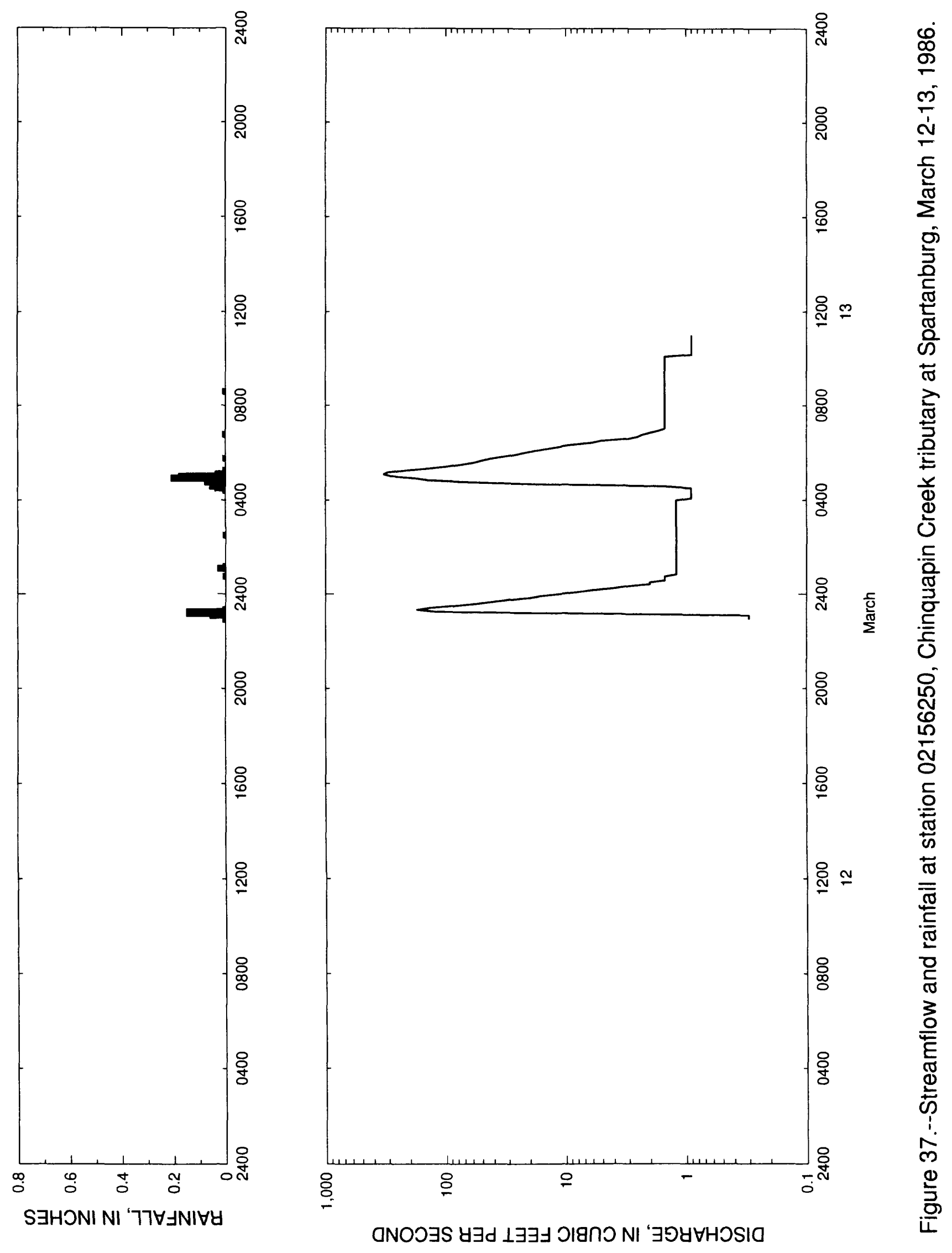


Table 36.--Streamflow and rainfall at station 02156250, Chinquapin Creek tributary at Spartanburg, March 12-13, 1986

\begin{tabular}{|c|c|c|c|c|c|c|c|c|}
\hline $\begin{array}{l}\text { Time } \\
\text { (hours) }\end{array}$ & $\begin{array}{l}\text { Streamflow } \\
\text { (cubic feet } \\
\text { per second) }\end{array}$ & $\begin{array}{l}\text { Rain- } \\
\text { fall } \\
\text { (inches) }\end{array}$ & $\begin{array}{l}\text { Time } \\
\text { (hours) }\end{array}$ & $\begin{array}{l}\text { Streamflow } \\
\text { (cubic feet } \\
\text { per second) }\end{array}$ & $\begin{array}{l}\text { Rain- } \\
\text { fall } \\
\text { (inches) }\end{array}$ & $\begin{array}{l}\text { Time } \\
\text { (hours) }\end{array}$ & $\begin{array}{l}\text { Streamflow } \\
\text { (cubic feet } \\
\text { per second) }\end{array}$ & $\begin{array}{l}\text { Rain- } \\
\text { fall } \\
\text { (inclos) }\end{array}$ \\
\hline $\begin{array}{r}\text { March } 12, \\
2255 \\
2300 \\
2305 \\
2310\end{array}$ & $\begin{array}{r}1986 \\
0.3 \\
0.3 \\
0.3 \\
7.2\end{array}$ & $\begin{array}{l}0.01 \\
0.01 \\
0.06 \\
0.15\end{array}$ & $\begin{array}{l}0255 \\
0300 \\
0305 \\
0310 \\
0315\end{array}$ & $\begin{array}{l}1.2 \\
1.2 \\
1.2 \\
1.2 \\
1.2\end{array}$ & $\begin{array}{l}0.00 \\
0.00 \\
0.00 \\
0.00 \\
0.00\end{array}$ & $\begin{array}{l}0705 \\
0710 \\
0715 \\
0720 \\
0725\end{array}$ & $\begin{array}{l}1.5 \\
1.5 \\
1.5 \\
1.5 \\
1.5\end{array}$ & $\begin{array}{l}0.00 \\
0.00 \\
0.00 \\
0.00 \\
0.00\end{array}$ \\
\hline $\begin{array}{l}2315 \\
2320 \\
2325 \\
2330 \\
2335\end{array}$ & $\begin{array}{r}121.0 \\
174.0 \\
135.0 \\
83.5 \\
56.0\end{array}$ & $\begin{array}{l}0.15 \\
0.01 \\
0.00 \\
0.00 \\
0.00\end{array}$ & $\begin{array}{l}0320 \\
0325 \\
0330 \\
0335 \\
0340\end{array}$ & $\begin{array}{l}1.2 \\
1.2 \\
1.2 \\
1.2 \\
1.2\end{array}$ & $\begin{array}{l}0.00 \\
0.00 \\
0.00 \\
0.00 \\
0.00\end{array}$ & $\begin{array}{l}0730 \\
0735 \\
0740 \\
0745 \\
0750\end{array}$ & $\begin{array}{l}1.5 \\
1.5 \\
1.5 \\
1.5 \\
1.5\end{array}$ & $\begin{array}{l}0.00 \\
0.00 \\
0.00 \\
0.00 \\
0.00\end{array}$ \\
\hline $\begin{array}{r}2340 \\
2345 \\
2350 \\
2355 \\
\text { March 13, }\end{array}$ & $\begin{array}{r}41.0 \\
30.0 \\
20.0 \\
16.0 \\
1986\end{array}$ & $\begin{array}{l}0.00 \\
0.00 \\
0.00 \\
0.00\end{array}$ & $\begin{array}{l}0345 \\
0350 \\
0355 \\
0400 \\
0405\end{array}$ & $\begin{array}{l}1.2 \\
1.2 \\
1.2 \\
1.2 \\
0.9\end{array}$ & $\begin{array}{l}0.00 \\
0.00 \\
0.00 \\
0.00 \\
0.00\end{array}$ & $\begin{array}{l}0755 \\
0800 \\
0805 \\
0810 \\
0815\end{array}$ & $\begin{array}{l}1 \cdot 5 \\
1.5 \\
1.5 \\
1.5 \\
1.5\end{array}$ & $\begin{array}{l}0.00 \\
0.00 \\
0.00 \\
0.00 \\
0.00\end{array}$ \\
\hline $\begin{array}{l}0000 \\
0005 \\
0010 \\
0015 \\
0020\end{array}$ & $\begin{array}{r}11.0 \\
8.0 \\
6.0 \\
4.0 \\
3.0\end{array}$ & $\begin{array}{l}0.00 \\
0.00 \\
0.00 \\
0.00 \\
0.00\end{array}$ & $\begin{array}{l}0410 \\
0415 \\
0420 \\
0425 \\
0430\end{array}$ & $\begin{array}{l}0.9 \\
0.9 \\
0.9 \\
0.9 \\
0.9\end{array}$ & $\begin{array}{l}0.00 \\
0.00 \\
0.00 \\
0.01 \\
0.04\end{array}$ & $\begin{array}{l}0820 \\
0825 \\
0830 \\
0835 \\
0840\end{array}$ & $\begin{array}{l}1.5 \\
1.5 \\
1.5 \\
1.5 \\
1.5\end{array}$ & $\begin{array}{l}0.0 C \\
0.0 C \\
0.0 C \\
0.01 \\
0.0 C\end{array}$ \\
\hline $\begin{array}{l}0025 \\
0030 \\
0035 \\
0040 \\
0045\end{array}$ & $\begin{array}{l}2.0 \\
2.0 \\
1.5 \\
1.5 \\
1.5\end{array}$ & $\begin{array}{l}0.00 \\
0.00 \\
0.00 \\
0.00 \\
0.01\end{array}$ & $\begin{array}{l}0435 \\
0440 \\
0445 \\
0450 \\
0455\end{array}$ & $\begin{array}{r}1.5 \\
15.1 \\
56.0 \\
140.0 \\
181.0\end{array}$ & $\begin{array}{l}0.06 \\
0.06 \\
0.08 \\
0.06 \\
0.21\end{array}$ & $\begin{array}{l}0845 \\
0850 \\
0855 \\
0900 \\
0905\end{array}$ & $\begin{array}{l}1.5 \\
1.5 \\
1.5 \\
1.5 \\
1.5\end{array}$ & $\begin{array}{l}0.0 C \\
0.0 C \\
0.0 C \\
0.0 C \\
0.0 C\end{array}$ \\
\hline $\begin{array}{l}0050 \\
0055 \\
0100 \\
0105 \\
0110\end{array}$ & $\begin{array}{l}1.2 \\
1.2 \\
1.2 \\
1.2 \\
1.2\end{array}$ & $\begin{array}{l}0.00 \\
0.00 \\
0.00 \\
0.03 \\
0.01\end{array}$ & $\begin{array}{l}0500 \\
0505 \\
0510 \\
0515 \\
0520\end{array}$ & $\begin{array}{l}289.0 \\
328.0 \\
304.0 \\
213.0 \\
139.0\end{array}$ & $\begin{array}{l}0.18 \\
0.04 \\
0.00 \\
0.01 \\
0.00\end{array}$ & $\begin{array}{l}0910 \\
0915 \\
0920 \\
0925 \\
0930\end{array}$ & $\begin{array}{l}1.5 \\
1.5 \\
1.5 \\
1.5 \\
1.5\end{array}$ & $\begin{array}{l}0.0 C \\
0.0 C \\
0.0 C \\
0.0 C \\
0.0 C\end{array}$ \\
\hline $\begin{array}{l}0115 \\
0120 \\
0125 \\
0130 \\
0135\end{array}$ & $\begin{array}{l}1.2 \\
1.2 \\
1.2 \\
1.2 \\
1.2\end{array}$ & $\begin{array}{l}0.00 \\
0.00 \\
0.00 \\
0.00 \\
0.00\end{array}$ & $\begin{array}{l}0525 \\
0530 \\
0535 \\
0540 \\
0545\end{array}$ & $\begin{array}{l}97.8 \\
73.5 \\
58.2 \\
50.5 \\
42.0\end{array}$ & $\begin{array}{l}0.00 \\
0.00 \\
0.00 \\
0.00 \\
0.01\end{array}$ & $\begin{array}{l}0935 \\
0940 \\
0945 \\
0950 \\
0955\end{array}$ & $\begin{array}{l}1.5 \\
1.5 \\
1.5 \\
1.5 \\
1.5\end{array}$ & $\begin{array}{l}0.0 \mathrm{C} \\
0.0 \mathrm{C} \\
0.0 \mathrm{C} \\
0.0 \mathrm{C} \\
0.0 \mathrm{C}\end{array}$ \\
\hline $\begin{array}{l}0140 \\
0145 \\
0150 \\
0155 \\
0200\end{array}$ & $\begin{array}{l}1.2 \\
1.2 \\
1.2 \\
1.2 \\
1.2\end{array}$ & $\begin{array}{l}0.00 \\
0.00 \\
0.00 \\
0.00 \\
0.00\end{array}$ & $\begin{array}{l}0550 \\
0555 \\
0600 \\
0605 \\
0610\end{array}$ & $\begin{array}{l}33.0 \\
26.0 \\
22.0 \\
18.0 \\
14.0\end{array}$ & $\begin{array}{l}0.00 \\
0.00 \\
0.00 \\
0.00 \\
0.00\end{array}$ & $\begin{array}{l}1000 \\
1005 \\
1010 \\
1015 \\
1020\end{array}$ & $\begin{array}{l}1.5 \\
1.5 \\
0.9 \\
0.9 \\
0.9\end{array}$ & $\begin{array}{l}0.0 \mathrm{C} \\
0.0 \mathrm{C} \\
0.0 \mathrm{C} \\
0.0 \mathrm{C} \\
0.00\end{array}$ \\
\hline $\begin{array}{l}0205 \\
0210 \\
0215 \\
0220 \\
0225\end{array}$ & $\begin{array}{l}1.2 \\
1.2 \\
1.2 \\
1.2 \\
1.2\end{array}$ & $\begin{array}{l}0.00 \\
0.00 \\
0.00 \\
0.00 \\
0.00\end{array}$ & $\begin{array}{l}0615 \\
0620 \\
0625 \\
0630 \\
0635\end{array}$ & $\begin{array}{r}11.0 \\
9.0 \\
6.0 \\
5.0 \\
3.0\end{array}$ & $\begin{array}{l}0.00 \\
0.00 \\
0.00 \\
0.00 \\
0.00\end{array}$ & $\begin{array}{l}1025 \\
1030 \\
1035 \\
1040 \\
1045\end{array}$ & $\begin{array}{l}0.9 \\
0.9 \\
0.9 \\
0.9 \\
0.9\end{array}$ & $\begin{array}{l}0.00 \\
0.00 \\
0.00 \\
0.00 \\
0.00\end{array}$ \\
\hline $\begin{array}{l}0230 \\
0235 \\
0240 \\
0245 \\
0250\end{array}$ & $\begin{array}{l}1.2 \\
1.2 \\
1.2 \\
1.2 \\
1.2\end{array}$ & $\begin{array}{l}0.01 \\
0.00 \\
0.00 \\
0.00 \\
0.00\end{array}$ & $\begin{array}{l}0640 \\
0645 \\
0650 \\
0655 \\
0700\end{array}$ & $\begin{array}{l}2.5 \\
2.3 \\
2.0 \\
1.7 \\
1.5\end{array}$ & $\begin{array}{l}0.00 \\
0.01 \\
0.00 \\
0.00 \\
0.00\end{array}$ & $\begin{array}{l}1050 \\
1055 \\
1100 \\
1105\end{array}$ & $\begin{array}{l}0.9 \\
0.9 \\
0.9 \\
0.9\end{array}$ & $\begin{array}{l}0.00 \\
0.00 \\
0.00 \\
0.00\end{array}$ \\
\hline
\end{tabular}



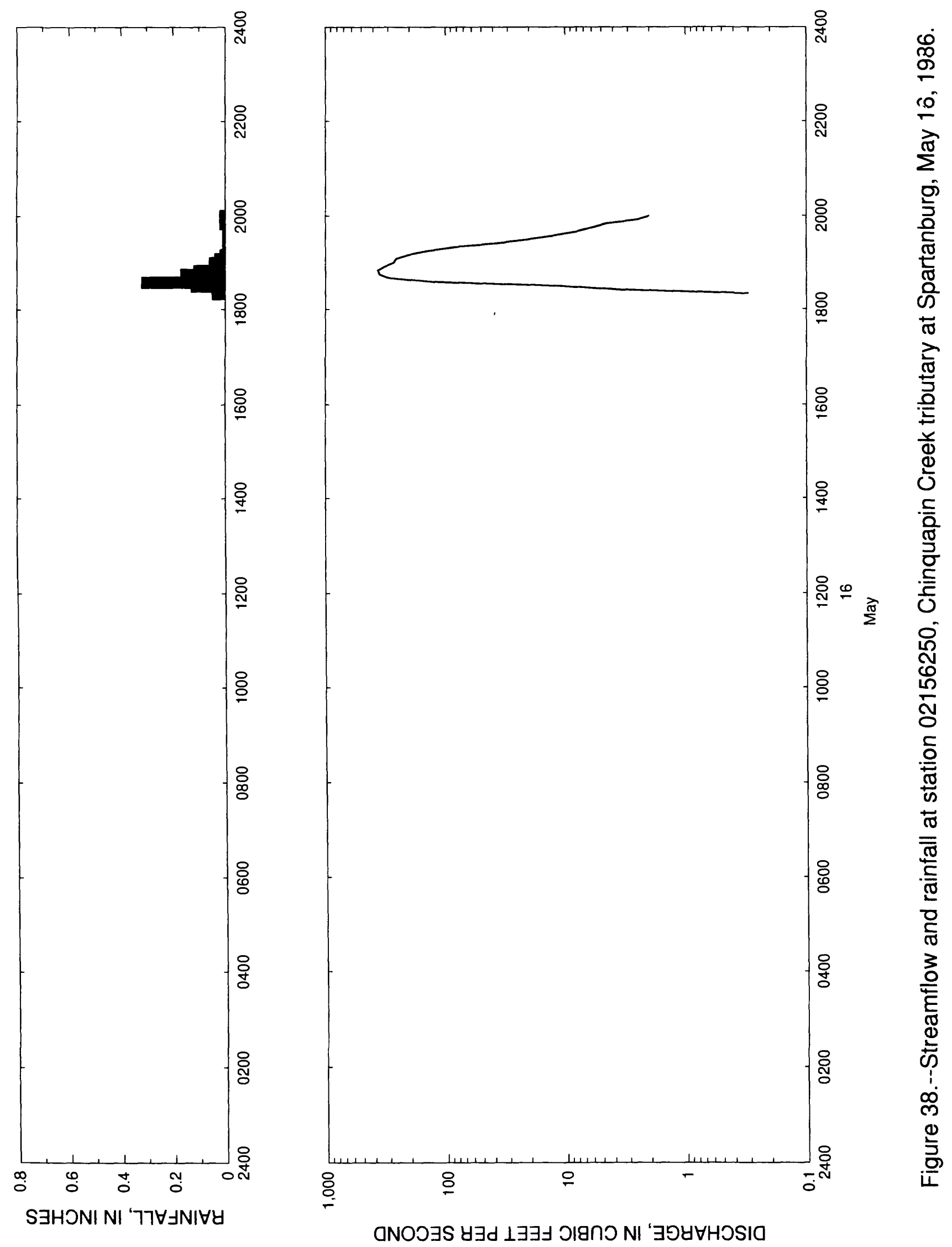
Table 37.- - Streamflow and rainfall at station 02156250. Chinquapin Creek tributary at Spartanburg, May 16, 1986

\begin{tabular}{|c|c|c|c|c|c|c|c|c|}
\hline $\begin{array}{l}\text { Time } \\
\text { (hours) }\end{array}$ & $\begin{array}{l}\text { Streamflow } \\
\text { (cubic feet } \\
\text { per second) }\end{array}$ & $\begin{array}{l}\text { Rain- } \\
\text { fall } \\
\text { (inches) }\end{array}$ & $\begin{array}{l}\text { Time } \\
\text { (hours) }\end{array}$ & $\begin{array}{l}\text { Streamflow } \\
\text { (cubic feet } \\
\text { per second) }\end{array}$ & $\begin{array}{l}\text { Rain- } \\
\text { fall } \\
\text { (inches) }\end{array}$ & $\begin{array}{c}\text { Time } \\
\text { (hours) }\end{array}$ & $\begin{array}{l}\text { Streamflow } \\
\text { (cubic feet } \\
\text { per second) }\end{array}$ & $\begin{array}{l}\text { Rain- } \\
\text { fall } \\
\text { (inches) }\end{array}$ \\
\hline $\begin{array}{l}\text { May 16, } \\
1820 \\
1825 \\
1830 \\
1835\end{array}$ & $\begin{array}{r}1986 \quad 0.3 \\
3.5 \\
12.9 \\
124.0\end{array}$ & $\begin{array}{l}0.05 \\
0.03 \\
0.13 \\
0.32\end{array}$ & $\begin{array}{l}1855 \\
1900 \\
1905 \\
1910 \\
1915\end{array}$ & $\begin{array}{l}324.0 \\
272.0 \\
259.0 \\
205.0 \\
144.0\end{array}$ & $\begin{array}{l}0.06 \\
0.06 \\
0.04 \\
0.02 \\
0.01\end{array}$ & $\begin{array}{l}1935 \\
1940 \\
1945 \\
1950 \\
1955\end{array}$ & $\begin{array}{r}12.0 \\
8.0 \\
6.0 \\
4.5 \\
2.5\end{array}$ & $\begin{array}{l}0.01 \\
0.01 \\
0.01 \\
0.02 \\
0.02\end{array}$ \\
\hline $\begin{array}{l}1840 \\
1845 \\
1850\end{array}$ & $\begin{array}{l}295.0 \\
357.0 \\
368.0\end{array}$ & $\begin{array}{l}0.15 \\
0.17 \\
0.12\end{array}$ & $\begin{array}{l}1920 \\
1925 \\
1930\end{array}$ & $\begin{array}{l}83.0 \\
36.0 \\
20.0\end{array}$ & $\begin{array}{l}0.01 \\
0.01 \\
0.01\end{array}$ & 2000 & 2.0 & 0.02 \\
\hline
\end{tabular}




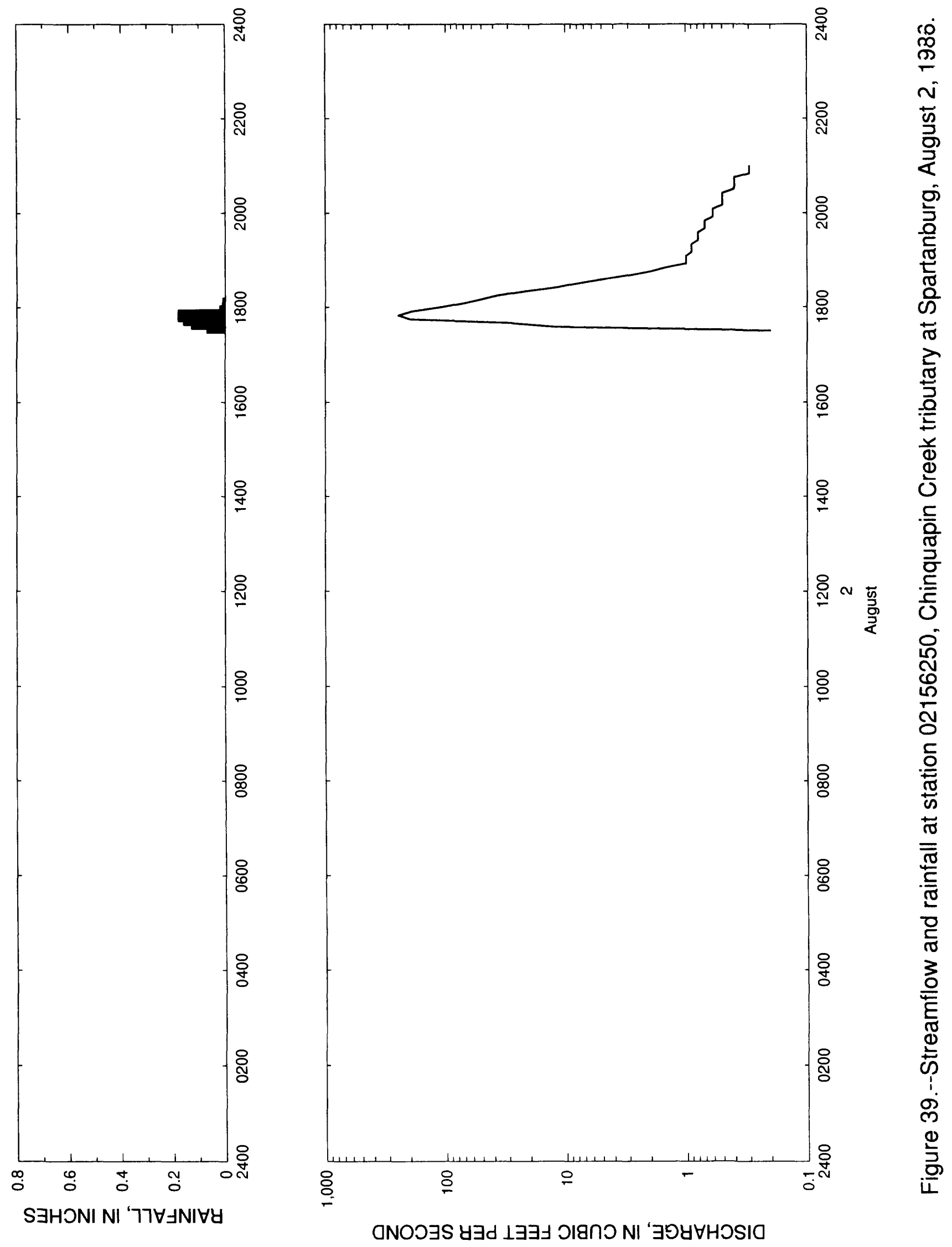


Table 38. - - Streamflow and rainfall at station 02156250, Chinquapin Creek tributary at Spartanburg. August 2,1986

\begin{tabular}{|c|c|c|c|c|c|c|c|c|}
\hline $\begin{array}{l}\text { Time } \\
\text { (hours) }\end{array}$ & $\begin{array}{l}\text { Streamflow } \\
\text { (cubic feet } \\
\text { per second) }\end{array}$ & $\begin{array}{l}\text { Rain- } \\
\text { fall } \\
\text { (inches) }\end{array}$ & $\begin{array}{l}\text { Time } \\
\text { (hours) }\end{array}$ & $\begin{array}{l}\text { Streamflow } \\
\text { (cubic feet } \\
\text { per second) }\end{array}$ & $\begin{array}{l}\text { Rain- } \\
\text { fall } \\
\text { (inches) }\end{array}$ & $\begin{array}{l}\text { Time } \\
\text { (hours) }\end{array}$ & $\begin{array}{l}\text { Streamflow } \\
\text { (cubic feet } \\
\text { per second) }\end{array}$ & $\begin{array}{l}\text { Rain- } \\
\text { fali } \\
\text { (inches) }\end{array}$ \\
\hline $\begin{array}{c}\text { August } 2 \text {, } \\
1730 \\
1735 \\
1740 \\
1745\end{array}$ & $\begin{array}{r}1986 \\
0.2 \\
12.3 \\
29.2 \\
198.0\end{array}$ & $\begin{array}{l}0.00 \\
0.07 \\
0.13 \\
0.16\end{array}$ & $\begin{array}{l}1840 \\
1845 \\
1850 \\
1855 \\
1900\end{array}$ & $\begin{array}{l}3.0 \\
2.0 \\
1.5 \\
1.0 \\
1.0\end{array}$ & $\begin{array}{l}0.00 \\
0.00 \\
0.00 \\
0.00 \\
0.00\end{array}$ & $\begin{array}{l}1955 \\
2000 \\
2005 \\
2010 \\
2015\end{array}$ & $\begin{array}{l}0.6 \\
0.6 \\
0.6 \\
0.5 \\
0.5\end{array}$ & $\begin{array}{l}0.00 \\
0.00 \\
0.00 \\
0.00 \\
0.00\end{array}$ \\
\hline $\begin{array}{l}1750 \\
1755 \\
1800 \\
1805 \\
1810\end{array}$ & $\begin{array}{r}248.0 \\
191.0 \\
110.0 \\
71.1 \\
51.5\end{array}$ & $\begin{array}{l}0.18 \\
0.02 \\
0.00 \\
0.01 \\
0.00\end{array}$ & $\begin{array}{l}1905 \\
1910 \\
1915 \\
1920 \\
1925\end{array}$ & $\begin{array}{l}1.0 \\
0.9 \\
0.9 \\
0.9 \\
0.8\end{array}$ & $\begin{array}{l}0.00 \\
0.00 \\
0.00 \\
0.00 \\
0.00\end{array}$ & $\begin{array}{l}2020 \\
2025 \\
2030 \\
2035 \\
2040\end{array}$ & $\begin{array}{l}0.5 \\
0.5 \\
0.4 \\
0.4 \\
0.4\end{array}$ & $\begin{array}{l}0.00 \\
0.00 \\
0.00 \\
0.00 \\
0.00\end{array}$ \\
\hline $\begin{array}{l}1815 \\
1820 \\
1825 \\
1830 \\
1835\end{array}$ & $\begin{array}{r}37.2 \\
22.0 \\
12.0 \\
8.0 \\
5.0\end{array}$ & $\begin{array}{l}0.00 \\
0.00 \\
0.00 \\
0.00 \\
0.00\end{array}$ & $\begin{array}{l}1930 \\
1935 \\
1940 \\
1945 \\
1950\end{array}$ & $\begin{array}{l}0.8 \\
0.8 \\
0.7 \\
0.7 \\
0.7\end{array}$ & $\begin{array}{l}0.00 \\
0.00 \\
0.00 \\
0.00 \\
0.00\end{array}$ & $\begin{array}{l}2045 \\
2050 \\
2055 \\
2100\end{array}$ & $\begin{array}{l}0.4 \\
0.3 \\
0.3 \\
0.3\end{array}$ & $\begin{array}{l}0.00 \\
0.00 \\
0.00 \\
0.00\end{array}$ \\
\hline
\end{tabular}



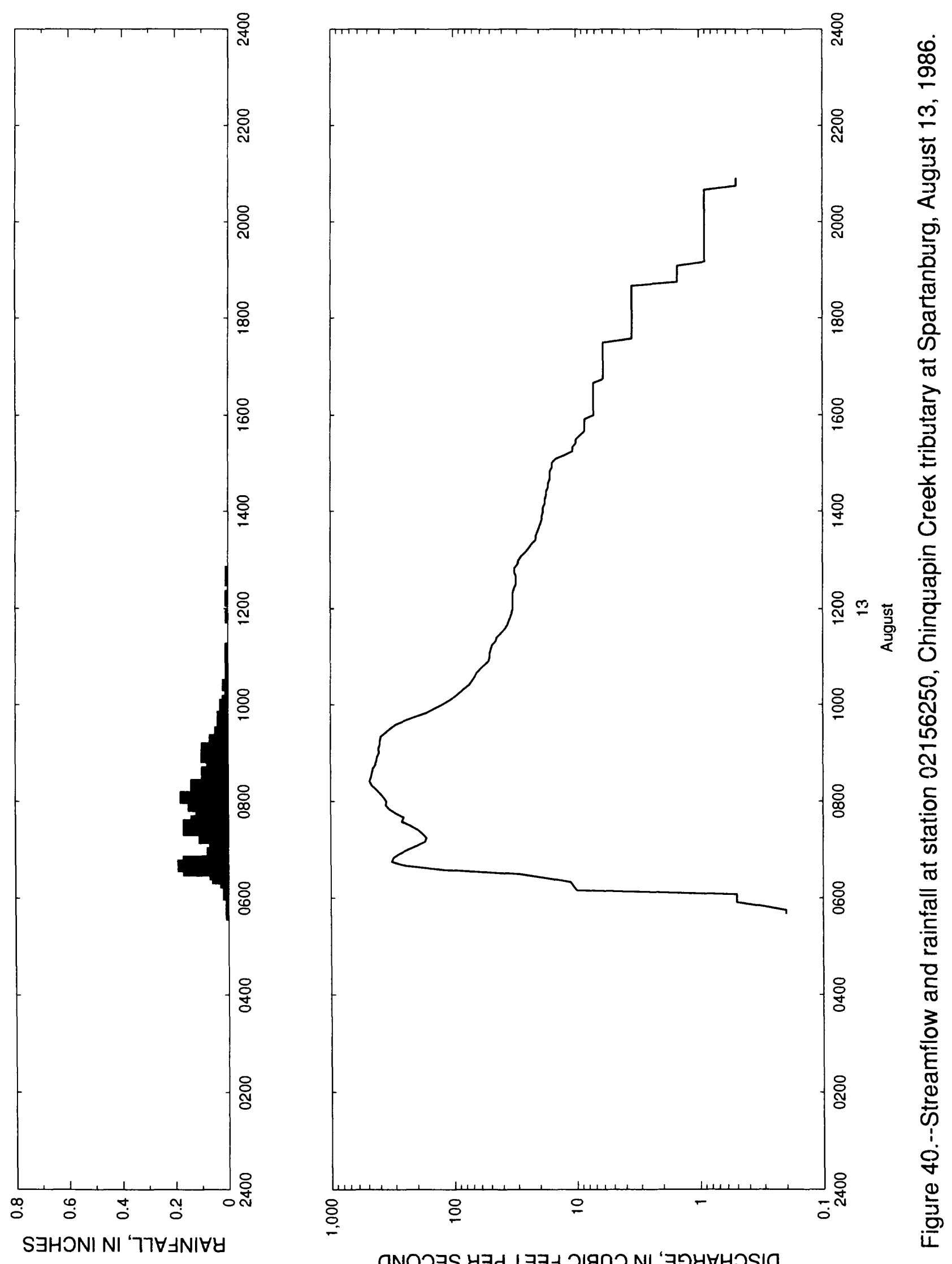
Table 39.--Streamflow and rainfall at station 02156250, Chinquapin Creek tributary at Spartanburg, August 13,1986

\begin{tabular}{|c|c|c|c|c|c|c|c|c|}
\hline $\begin{array}{l}\text { Time } \\
\text { (hours) }\end{array}$ & $\begin{array}{l}\text { Streamflow } \\
\text { (cubic feet } \\
\text { per second) }\end{array}$ & $\begin{array}{l}\text { Rain- } \\
\text { fall } \\
\text { (inches) }\end{array}$ & $\begin{array}{l}\text { Time } \\
\text { (hours) }\end{array}$ & $\begin{array}{l}\text { Streamflow } \\
\text { (cubic feet } \\
\text { per second) }\end{array}$ & $\begin{array}{l}\text { Rain- } \\
\text { fall } \\
\text { (inches) }\end{array}$ & $\begin{array}{l}\text { Time } \\
\text { (hours) }\end{array}$ & $\begin{array}{l}\text { Streamflow } \\
\text { (cubic feet } \\
\text { per second) }\end{array}$ & $\begin{array}{l}\text { Rain- } \\
\text { fall } \\
\text { (inches) }\end{array}$ \\
\hline $\begin{array}{c}\text { August } \\
0540 \\
0545 \\
0550 \\
0555\end{array}$ & $\begin{array}{r}13,1986 \\
0.2 \\
0.2 \\
0.3 \\
0.5\end{array}$ & $\begin{array}{l}0.01 \\
0.00 \\
0.00 \\
0.01\end{array}$ & $\begin{array}{l}1045 \\
1050 \\
1055 \\
1100 \\
1105\end{array}$ & $\begin{array}{l}60.5 \\
56.0 \\
51.5 \\
50.5 \\
50.5\end{array}$ & $\begin{array}{l}0.01 \\
0.00 \\
0.01 \\
0.01 \\
0.00\end{array}$ & $\begin{array}{l}1555 \\
1600 \\
1605 \\
1610 \\
1615\end{array}$ & $\begin{array}{l}8.5 \\
7.2 \\
7.2 \\
7.2 \\
7.2\end{array}$ & $\begin{array}{l}0.00 \\
0.00 \\
0.00 \\
0.00 \\
0.00\end{array}$ \\
\hline $\begin{array}{l}0600 \\
0605 \\
0610 \\
0615 \\
0620\end{array}$ & $\begin{array}{r}0.5 \\
0.5 \\
10.0 \\
10.6 \\
11.2\end{array}$ & $\begin{array}{l}0.00 \\
0.02 \\
0.00 \\
0.01 \\
0.03\end{array}$ & $\begin{array}{l}1110 \\
1115 \\
1120 \\
1125 \\
1130\end{array}$ & $\begin{array}{l}49.4 \\
48.3 \\
45.1 \\
44.1 \\
41.0\end{array}$ & $\begin{array}{l}0.01 \\
0.00 \\
0.00 \\
0.00 \\
0.00\end{array}$ & $\begin{array}{l}1620 \\
1625 \\
1630 \\
1635 \\
1640\end{array}$ & $\begin{array}{l}7.2 \\
7.2 \\
7.2 \\
7.2 \\
7.2\end{array}$ & $\begin{array}{l}0.00 \\
0.00 \\
0.00 \\
0.00 \\
0.00\end{array}$ \\
\hline $\begin{array}{l}0625 \\
0630 \\
0635 \\
0640 \\
0645\end{array}$ & $\begin{array}{r}17.4 \\
29.2 \\
122.0 \\
245.0 \\
320.0\end{array}$ & $\begin{array}{l}0.06 \\
0.07 \\
0.17 \\
0.19 \\
0.17\end{array}$ & $\begin{array}{l}1135 \\
1140 \\
1145 \\
1150 \\
1155\end{array}$ & $\begin{array}{l}38.1 \\
36.3 \\
35.4 \\
34.4 \\
33.5\end{array}$ & $\begin{array}{l}0.00 \\
0.00 \\
0.00 \\
0.01 \\
0.00\end{array}$ & $\begin{array}{l}1645 \\
1650 \\
1655 \\
1700 \\
1705\end{array}$ & $\begin{array}{l}6.0 \\
6.0 \\
6.0 \\
6.0 \\
6.0\end{array}$ & $\begin{array}{l}0.00 \\
0.00 \\
0.00 \\
0.00 \\
0.00\end{array}$ \\
\hline $\begin{array}{l}0650 \\
0655 \\
0700 \\
0705 \\
0710\end{array}$ & $\begin{array}{l}310.0 \\
276.0 \\
236.0 \\
200.0 \\
172.0\end{array}$ & $\begin{array}{l}0.08 \\
0.08 \\
0.05 \\
0.06 \\
0.07\end{array}$ & $\begin{array}{l}1200 \\
1205 \\
1210 \\
1215 \\
1220\end{array}$ & $\begin{array}{l}32.7 \\
32.7 \\
32.7 \\
32.7 \\
32.7\end{array}$ & $\begin{array}{l}0.00 \\
0.00 \\
0.01 \\
0.01 \\
0.00\end{array}$ & $\begin{array}{l}1710 \\
1715 \\
1720 \\
1725 \\
1730\end{array}$ & $\begin{array}{l}6.0 \\
6.0 \\
6.0 \\
6.0 \\
6.0\end{array}$ & $\begin{array}{l}0.00 \\
0.00 \\
0.00 \\
0.00 \\
0.00\end{array}$ \\
\hline $\begin{array}{l}0715 \\
0720 \\
0725 \\
0730 \\
0735\end{array}$ & $\begin{array}{l}168.0 \\
181.0 \\
198.0 \\
227.0 \\
266.0\end{array}$ & $\begin{array}{l}0.11 \\
0.05 \\
0.17 \\
0.17 \\
0.14\end{array}$ & $\begin{array}{l}1225 \\
1230 \\
1235 \\
1240 \\
1245\end{array}$ & $\begin{array}{l}31.8 \\
30.9 \\
30.9 \\
30.9 \\
31.8\end{array}$ & $\begin{array}{l}0.00 \\
0.00 \\
0.01 \\
0.01 \\
0.01\end{array}$ & $\begin{array}{l}1735 \\
1740 \\
1745 \\
1750 \\
1755\end{array}$ & $\begin{array}{l}3.5 \\
3.5 \\
3.5 \\
3.5 \\
3.5\end{array}$ & $\begin{array}{l}0.00 \\
0.00 \\
0.00 \\
0.00 \\
0.00\end{array}$ \\
\hline $\begin{array}{l}0740 \\
0745 \\
0750 \\
0755 \\
0800\end{array}$ & $\begin{array}{l}256.0 \\
296.0 \\
333.0 \\
357.0 \\
354.0\end{array}$ & $\begin{array}{l}0.08 \\
0.07 \\
0.12 \\
0.15 \\
0.13\end{array}$ & $\begin{array}{l}1250 \\
1255 \\
1300 \\
1305 \\
1310\end{array}$ & $\begin{array}{l}31.8 \\
30.0 \\
29.2 \\
27.7 \\
25.6\end{array}$ & $\begin{array}{l}0.00 \\
0.00 \\
0.00 \\
0.00 \\
0.00\end{array}$ & $\begin{array}{l}1800 \\
1805 \\
1810 \\
1815 \\
1820\end{array}$ & $\begin{array}{l}3.5 \\
3.5 \\
3.5 \\
3.5 \\
3.5\end{array}$ & $\begin{array}{l}0.00 \\
0.00 \\
0.00 \\
0.00 \\
0.00\end{array}$ \\
\hline $\begin{array}{l}0805 \\
0810 \\
0815 \\
0820 \\
0825\end{array}$ & $\begin{array}{l}373.0 \\
399.0 \\
428.0 \\
466.0 \\
484.0\end{array}$ & $\begin{array}{l}0.18 \\
0.14 \\
0.13 \\
0.14 \\
0.10\end{array}$ & $\begin{array}{l}1315 \\
1320 \\
1325 \\
1330 \\
1335\end{array}$ & $\begin{array}{l}24.2 \\
22.9 \\
21.2 \\
21.2 \\
20.6\end{array}$ & $\begin{array}{l}0.00 \\
0.00 \\
0.00 \\
0.00 \\
0.00\end{array}$ & $\begin{array}{l}1825 \\
1830 \\
1835 \\
1840 \\
1845\end{array}$ & $\begin{array}{l}3.5 \\
3.5 \\
3.5 \\
3.5 \\
1.5\end{array}$ & $\begin{array}{l}0.00 \\
0.00 \\
0.00 \\
0.00 \\
0.00\end{array}$ \\
\hline $\begin{array}{l}0830 \\
0835 \\
0840 \\
0845 \\
0850\end{array}$ & $\begin{array}{l}473.0 \\
464.0 \\
457.0 \\
435.0 \\
424.0\end{array}$ & $\begin{array}{l}0.10 \\
0.10 \\
0.07 \\
0.06 \\
0.08\end{array}$ & $\begin{array}{l}1340 \\
1345 \\
1350 \\
1355 \\
1400\end{array}$ & $\begin{array}{l}20.0 \\
19.5 \\
19.0 \\
19.0 \\
18.5\end{array}$ & $\begin{array}{l}0.00 \\
0.00 \\
0.00 \\
0.00 \\
0.00\end{array}$ & $\begin{array}{l}1850 \\
1855 \\
1900 \\
1905 \\
1910\end{array}$ & $\begin{array}{l}1.5 \\
1.5 \\
1.5 \\
1.5 \\
0.9\end{array}$ & $\begin{array}{l}0.00 \\
0.00 \\
0.00 \\
0.00 \\
0.00\end{array}$ \\
\hline $\begin{array}{l}0855 \\
0900 \\
0905 \\
0910 \\
0915\end{array}$ & $\begin{array}{l}419.0 \\
404.0 \\
409.0 \\
400.0 \\
397.0\end{array}$ & $\begin{array}{l}0.10 \\
0.10 \\
0.10 \\
0.05 \\
0.07\end{array}$ & $\begin{array}{l}1405 \\
1410 \\
1415 \\
1420 \\
1425\end{array}$ & $\begin{array}{l}18.5 \\
17.9 \\
17.9 \\
17.4 \\
17.4\end{array}$ & $\begin{array}{l}0.00 \\
0.00 \\
0.00 \\
0.00 \\
0.00\end{array}$ & $\begin{array}{l}1915 \\
1920 \\
1925 \\
1930 \\
1935\end{array}$ & $\begin{array}{l}0.9 \\
0.9 \\
0.9 \\
0.9 \\
0.9\end{array}$ & $\begin{array}{l}0.00 \\
0.00 \\
0.00 \\
0.00 \\
0.00\end{array}$ \\
\hline $\begin{array}{l}0920 \\
0925 \\
0930 \\
0935 \\
0940\end{array}$ & $\begin{array}{l}392.0 \\
358.0 \\
328.0 \\
296.0 \\
250.0\end{array}$ & $\begin{array}{l}0.05 \\
0.05 \\
0.03 \\
0.03 \\
0.04\end{array}$ & $\begin{array}{l}1430 \\
1435 \\
1440 \\
1445 \\
1450\end{array}$ & $\begin{array}{l}16.8 \\
16.8 \\
16.3 \\
16.3 \\
16.3\end{array}$ & $\begin{array}{l}0.00 \\
0.00 \\
0.00 \\
0.00 \\
0.00\end{array}$ & $\begin{array}{l}1940 \\
1945 \\
1950 \\
1955 \\
2000\end{array}$ & $\begin{array}{l}0.9 \\
0.9 \\
0.9 \\
0.9 \\
0.9\end{array}$ & $\begin{array}{l}0.00 \\
0.00 \\
0.00 \\
0.00 \\
0.00\end{array}$ \\
\hline $\begin{array}{l}0945 \\
0950 \\
0955 \\
1000 \\
1005\end{array}$ & $\begin{array}{l}206.0 \\
166.0 \\
144.0 \\
124.0 \\
110.0\end{array}$ & $\begin{array}{l}0.04 \\
0.02 \\
0.02 \\
0.03 \\
0.02\end{array}$ & $\begin{array}{l}1455 \\
1500 \\
1505 \\
1510 \\
1515\end{array}$ & $\begin{array}{l}15.7 \\
15.7 \\
14.6 \\
12.3 \\
10.6\end{array}$ & $\begin{array}{l}0.00 \\
0.00 \\
0.00 \\
0.00 \\
0.00\end{array}$ & $\begin{array}{l}2005 \\
2010 \\
2015 \\
2020 \\
2025\end{array}$ & $\begin{array}{l}0.9 \\
0.9 \\
0.9 \\
0.9 \\
0.9\end{array}$ & $\begin{array}{l}0.00 \\
0.00 \\
0.00 \\
0.00 \\
0.00\end{array}$ \\
\hline $\begin{array}{l}1010 \\
1015 \\
1020 \\
1025 \\
1030\end{array}$ & $\begin{array}{l}97.8 \\
89.9 \\
82.2 \\
74.7 \\
71.1\end{array}$ & $\begin{array}{l}0.01 \\
0.01 \\
0.01 \\
0.02 \\
0.00\end{array}$ & $\begin{array}{l}1520 \\
1525 \\
1530 \\
1535 \\
1540\end{array}$ & $\begin{array}{r}10.6 \\
10.0 \\
10.0 \\
9.2 \\
8.5\end{array}$ & $\begin{array}{l}0.00 \\
0.00 \\
0.00 \\
0.00 \\
0.00\end{array}$ & $\begin{array}{l}2030 \\
2035 \\
2040 \\
2045 \\
2050\end{array}$ & $\begin{array}{l}0.9 \\
0.9 \\
0.9 \\
0.5 \\
0.5\end{array}$ & $\begin{array}{l}0.00 \\
0.00 \\
0.00 \\
0.00 \\
0.00\end{array}$ \\
\hline $\begin{array}{l}1035 \\
1040\end{array}$ & $\begin{array}{l}67.5 \\
65.1\end{array}$ & $\begin{array}{l}0.01 \\
0.00\end{array}$ & $\begin{array}{l}1545 \\
1550\end{array}$ & $\begin{array}{l}8.5 \\
8.5\end{array}$ & $\begin{array}{l}0.00 \\
0.00\end{array}$ & $\begin{array}{l}2055 \\
2100\end{array}$ & $\begin{array}{l}0.5 \\
0.5\end{array}$ & $\begin{array}{l}0.00 \\
0.00\end{array}$ \\
\hline
\end{tabular}




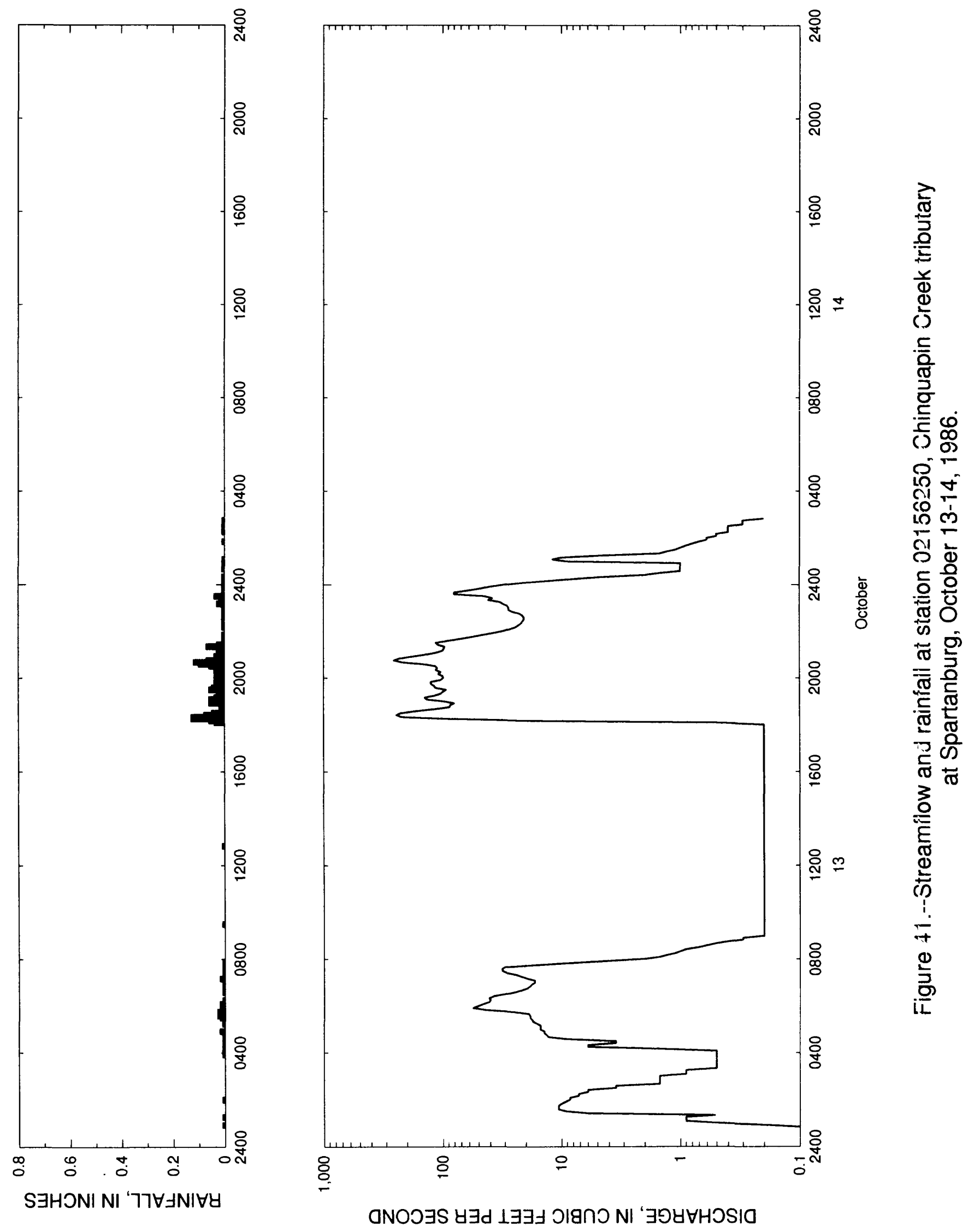


Table 40.--Streamflow and rainfall at station 02156250. Chinquapin Creek tributary at Spartanburg, October $13-14,1986$

\begin{tabular}{|c|c|c|c|c|c|c|c|c|}
\hline $\begin{array}{l}\text { Time } \\
\text { (hours) }\end{array}$ & $\begin{array}{l}\text { Streamflow } \\
\text { (cubic feet } \\
\text { per second) }\end{array}$ & $\begin{array}{l}\text { Rain- } \\
\text { fall } \\
\text { (inches) }\end{array}$ & $\begin{array}{l}\text { Time } \\
\text { (hours) }\end{array}$ & $\begin{array}{l}\text { Streamflow } \\
\text { (cubic feet } \\
\text { per second) }\end{array}$ & $\begin{array}{l}\text { Rain- } \\
\text { fall } \\
\text { (inches) }\end{array}$ & $\begin{array}{l}\text { Time } \\
\text { (hours) }\end{array}$ & $\begin{array}{l}\text { Streamflow } \\
\text { (cubic feet } \\
\text { per second) }\end{array}$ & $\begin{array}{l}\text { Rain- } \\
\text { fall } \\
\text { (irohes) }\end{array}$ \\
\hline $\begin{array}{l}\text { October } \\
0050 \\
0055 \\
0100 \\
0105\end{array}$ & $\begin{array}{r}13,1986 \\
0.1 \\
0.2 \\
0.5 \\
0.9\end{array}$ & $\begin{array}{l}0.00 \\
0.01 \\
0.00 \\
0.00\end{array}$ & $\begin{array}{l}0610 \\
0615 \\
0620 \\
0625 \\
0630\end{array}$ & $\begin{array}{l}41.0 \\
40.0 \\
41.0 \\
37.2 \\
30.0\end{array}$ & $\begin{array}{l}0.00 \\
0.01 \\
0.00 \\
0.00 \\
0.00\end{array}$ & $\begin{array}{l}1135 \\
1140 \\
1145 \\
1150 \\
1155\end{array}$ & $\begin{array}{l}0.2 \\
0.2 \\
0.2 \\
0.2 \\
0.2\end{array}$ & $\begin{array}{l}0.00 \\
0.00 \\
0.00 \\
0.00 \\
0.00\end{array}$ \\
\hline $\begin{array}{l}0110 \\
0115 \\
0120 \\
0125 \\
0130\end{array}$ & $\begin{array}{l}0.9 \\
0.9 \\
0.5 \\
6.0 \\
9.2\end{array}$ & $\begin{array}{l}0.00 \\
0.01 \\
0.00 \\
0.00 \\
0.00\end{array}$ & $\begin{array}{l}0635 \\
0640 \\
0645 \\
0650 \\
0655\end{array}$ & $\begin{array}{l}24.9 \\
21.8 \\
19.5 \\
18.5 \\
17.9\end{array}$ & $\begin{array}{l}0.01 \\
0.00 \\
0.01 \\
0.01 \\
0.00\end{array}$ & $\begin{array}{l}1200 \\
1205 \\
1210 \\
1215 \\
1220\end{array}$ & $\begin{array}{l}0.2 \\
0.2 \\
0.2 \\
0.2 \\
0.2\end{array}$ & $\begin{array}{l}0.00 \\
0.00 \\
0.00 \\
0.00 \\
0.00\end{array}$ \\
\hline $\begin{array}{l}0135 \\
0140 \\
0145 \\
0150 \\
0155\end{array}$ & $\begin{array}{r}10.6 \\
10.6 \\
10.6 \\
10.0 \\
9.2\end{array}$ & $\begin{array}{l}0.00 \\
0.00 \\
0.00 \\
0.00 \\
0.00\end{array}$ & $\begin{array}{l}0700 \\
0705 \\
0710 \\
0715 \\
0720\end{array}$ & $\begin{array}{l}16.8 \\
16.8 \\
19.5 \\
21.8 \\
24.2\end{array}$ & $\begin{array}{l}0.01 \\
0.01 \\
0.02 \\
0.01 \\
0.01\end{array}$ & $\begin{array}{l}1225 \\
1230 \\
1235 \\
1240 \\
1245\end{array}$ & $\begin{array}{l}0.2 \\
0.2 \\
0.2 \\
0.2 \\
0.2\end{array}$ & $\begin{array}{l}0.00 \\
0.00 \\
0.00 \\
0.00 \\
0.00\end{array}$ \\
\hline $\begin{array}{l}0200 \\
0205 \\
0210 \\
0215 \\
0220\end{array}$ & $\begin{array}{l}8.5 \\
8.5 \\
7.2 \\
7.2 \\
6.0\end{array}$ & $\begin{array}{l}0.01 \\
0.00 \\
0.00 \\
0.00 \\
0.00\end{array}$ & $\begin{array}{l}0725 \\
0730 \\
0735 \\
0740 \\
0745\end{array}$ & $\begin{array}{l}29.2 \\
31.8 \\
31.8 \\
30.0 \\
16.0\end{array}$ & $\begin{array}{l}0.01 \\
0.01 \\
0.00 \\
0.01 \\
0.00\end{array}$ & $\begin{array}{l}1250 \\
1255 \\
1300 \\
1305 \\
1310\end{array}$ & $\begin{array}{l}0.2 \\
0.2 \\
0.2 \\
0.2 \\
0.2\end{array}$ & $\begin{array}{l}0.01 \\
0.00 \\
0.00 \\
0.00 \\
0.00\end{array}$ \\
\hline $\begin{array}{l}0225 \\
0230 \\
0235 \\
0240 \\
0245\end{array}$ & $\begin{array}{l}6.0 \\
3.5 \\
3.5 \\
1.5 \\
1.5\end{array}$ & $\begin{array}{l}0.00 \\
0.00 \\
0.00 \\
0.00 \\
0.00\end{array}$ & $\begin{array}{l}0750 \\
0755 \\
0800 \\
0805 \\
0810\end{array}$ & $\begin{array}{l}8.0 \\
4.0 \\
2.0 \\
1.5 \\
1.3\end{array}$ & $\begin{array}{l}0.01 \\
0.00 \\
0.00 \\
0.00 \\
0.00\end{array}$ & $\begin{array}{l}1315 \\
1320 \\
1325 \\
1330 \\
1335\end{array}$ & $\begin{array}{l}0.2 \\
0.2 \\
0.2 \\
0.2 \\
0.2\end{array}$ & $\begin{array}{l}0.00 \\
0.00 \\
0.00 \\
0.00 \\
0.00\end{array}$ \\
\hline $\begin{array}{l}0250 \\
0255 \\
0300 \\
0305 \\
0310\end{array}$ & $\begin{array}{l}1.5 \\
1.5 \\
1.5 \\
0.9 \\
0.9\end{array}$ & $\begin{array}{l}0.00 \\
0.00 \\
0.00 \\
0.00 \\
0.00\end{array}$ & $\begin{array}{l}0815 \\
0820 \\
0825 \\
0830 \\
0835\end{array}$ & $\begin{array}{l}1.1 \\
1.0 \\
0.9 \\
0.7 \\
0.6\end{array}$ & $\begin{array}{l}0.00 \\
0.00 \\
0.00 \\
0.00 \\
0.00\end{array}$ & $\begin{array}{l}1340 \\
1345 \\
1350 \\
1355 \\
1400\end{array}$ & $\begin{array}{l}0.2 \\
0.2 \\
0.2 \\
0.2 \\
0.2\end{array}$ & $\begin{array}{l}0.00 \\
0.00 \\
0.00 \\
0.00 \\
0.00\end{array}$ \\
\hline $\begin{array}{l}0315 \\
0320 \\
0325 \\
0330 \\
0335\end{array}$ & $\begin{array}{l}0.9 \\
0.5 \\
0.5 \\
0.5 \\
0.5\end{array}$ & $\begin{array}{l}0.00 \\
0.00 \\
0.00 \\
0.00 \\
0.00\end{array}$ & $\begin{array}{l}0840 \\
0845 \\
0850 \\
0855 \\
0900\end{array}$ & $\begin{array}{l}0.5 \\
0.4 \\
0.3 \\
0.3 \\
0.2\end{array}$ & $\begin{array}{l}0.00 \\
0.00 \\
0.00 \\
0.00 \\
0.00\end{array}$ & $\begin{array}{l}1405 \\
1410 \\
1415 \\
1420 \\
1425\end{array}$ & $\begin{array}{l}0.2 \\
0.2 \\
0.2 \\
0.2 \\
0.2\end{array}$ & $\begin{array}{l}0.00 \\
0.00 \\
0.00 \\
0.00 \\
0.00\end{array}$ \\
\hline $\begin{array}{l}0340 \\
0345 \\
0350 \\
0355 \\
0400\end{array}$ & $\begin{array}{l}0.5 \\
0.5 \\
0.5 \\
0.5 \\
0.5\end{array}$ & $\begin{array}{l}0.00 \\
0.00 \\
0.00 \\
0.01 \\
0.00\end{array}$ & $\begin{array}{l}0905 \\
0910 \\
0915 \\
0920 \\
0925\end{array}$ & $\begin{array}{l}0.2 \\
0.2 \\
0.2 \\
0.2 \\
0.2\end{array}$ & $\begin{array}{l}0.00 \\
0.00 \\
0.00 \\
0.00 \\
0.00\end{array}$ & $\begin{array}{l}1430 \\
1435 \\
1440 \\
1445 \\
1450\end{array}$ & $\begin{array}{l}0.2 \\
0.2 \\
0.2 \\
0.2 \\
0.2\end{array}$ & $\begin{array}{l}0.00 \\
0.00 \\
0.00 \\
0.00 \\
0.00\end{array}$ \\
\hline $\begin{array}{l}0405 \\
0410 \\
0415 \\
0420 \\
0425\end{array}$ & $\begin{array}{l}0.5 \\
1.5 \\
6.0 \\
6.0 \\
3.5\end{array}$ & $\begin{array}{l}0.01 \\
0.01 \\
0.00 \\
0.00 \\
0.01\end{array}$ & $\begin{array}{l}0930 \\
0935 \\
0940 \\
0945 \\
0950\end{array}$ & $\begin{array}{l}0.2 \\
0.2 \\
0.2 \\
0.2 \\
0.2\end{array}$ & $\begin{array}{l}0.01 \\
0.00 \\
0.00 \\
0.00 \\
0.00\end{array}$ & $\begin{array}{l}1455 \\
1500 \\
1505 \\
1510 \\
1515\end{array}$ & $\begin{array}{l}0.2 \\
0.2 \\
0.2 \\
0.2 \\
0.2\end{array}$ & $\begin{array}{l}0.00 \\
0.00 \\
0.00 \\
0.00 \\
0.00\end{array}$ \\
\hline $\begin{array}{l}0430 \\
0435 \\
0440 \\
0445 \\
0450\end{array}$ & $\begin{array}{r}3.5 \\
9.2 \\
12.9 \\
13.4 \\
14.0\end{array}$ & $\begin{array}{l}0.00 \\
0.01 \\
0.00 \\
0.01 \\
0.00\end{array}$ & $\begin{array}{l}0955 \\
1000 \\
1005 \\
1010 \\
1015\end{array}$ & $\begin{array}{l}0.2 \\
0.2 \\
0.2 \\
0.2 \\
0.2\end{array}$ & $\begin{array}{l}0.00 \\
0.00 \\
0.00 \\
0.00 \\
0.00\end{array}$ & $\begin{array}{l}1520 \\
1525 \\
1530 \\
1535 \\
1540\end{array}$ & $\begin{array}{l}0.2 \\
0.2 \\
0.2 \\
0.2 \\
0.2\end{array}$ & $\begin{array}{l}0.00 \\
0.00 \\
0.00 \\
0.00 \\
0.00\end{array}$ \\
\hline $\begin{array}{l}0455 \\
0500 \\
0505 \\
0510 \\
0515\end{array}$ & $\begin{array}{l}14.0 \\
15.1 \\
15.1 \\
15.1 \\
16.3\end{array}$ & $\begin{array}{l}0.02 \\
0.00 \\
0.00 \\
0.00 \\
0.01\end{array}$ & $\begin{array}{l}1020 \\
1025 \\
1030 \\
1035 \\
1040\end{array}$ & $\begin{array}{l}0.2 \\
0.2 \\
0.2 \\
0.2 \\
0.2\end{array}$ & $\begin{array}{l}0.00 \\
0.00 \\
0.00 \\
0.00 \\
0.00\end{array}$ & $\begin{array}{l}1545 \\
1550 \\
1555 \\
1600 \\
1605\end{array}$ & $\begin{array}{l}0.2 \\
0.2 \\
0.2 \\
0.2 \\
0.2\end{array}$ & $\begin{array}{l}0.00 \\
0.00 \\
0.00 \\
0.00 \\
0.00\end{array}$ \\
\hline $\begin{array}{l}0520 \\
0525 \\
0530 \\
0535 \\
0540\end{array}$ & $\begin{array}{l}17.4 \\
17.9 \\
18.5 \\
18.5 \\
19.0\end{array}$ & $\begin{array}{l}0.01 \\
0.01 \\
0.02 \\
0.03 \\
0.03\end{array}$ & $\begin{array}{l}1045 \\
1050 \\
1055 \\
1100 \\
1105\end{array}$ & $\begin{array}{l}0.2 \\
0.2 \\
0.2 \\
0.2 \\
0.2\end{array}$ & $\begin{array}{l}0.00 \\
0.00 \\
0.00 \\
0.00 \\
0.00\end{array}$ & $\begin{array}{l}1610 \\
1615 \\
1620 \\
1625 \\
1630\end{array}$ & $\begin{array}{l}0.2 \\
0.2 \\
0.2 \\
0.2 \\
0.2\end{array}$ & $\begin{array}{l}0.00 \\
0.00 \\
0.00 \\
0.00 \\
0.00\end{array}$ \\
\hline $\begin{array}{l}0545 \\
0550 \\
0555 \\
0600 \\
0605\end{array}$ & $\begin{array}{l}25.6 \\
44.1 \\
56.0 \\
50.5 \\
46.2\end{array}$ & $\begin{array}{l}0.03 \\
0.01 \\
0.00 \\
0.02 \\
0.02\end{array}$ & $\begin{array}{l}1110 \\
1115 \\
1120 \\
1125 \\
1130\end{array}$ & $\begin{array}{l}0.2 \\
0.2 \\
0.2 \\
0.2 \\
0.2\end{array}$ & $\begin{array}{l}0.00 \\
0.00 \\
0.00 \\
0.00 \\
0.00\end{array}$ & $\begin{array}{l}1635 \\
1640 \\
1645 \\
1650 \\
1655\end{array}$ & $\begin{array}{l}0.2 \\
0.2 \\
0.2 \\
0.2 \\
0.2\end{array}$ & $\begin{array}{l}0.00 \\
0.00 \\
0.00 \\
0.00 \\
0.00\end{array}$ \\
\hline
\end{tabular}


Table 40.-- Streamflow and rainfall at station 02156250 , Chinquapin Creek tributary at Spartanburg. October 13-14,1986--Continued

\begin{tabular}{|c|c|c|c|c|c|c|c|c|}
\hline $\begin{array}{l}\text { Time } \\
\text { (hours) }\end{array}$ & $\begin{array}{l}\text { Streamflow } \\
\text { (cubic feet } \\
\text { per second) }\end{array}$ & $\begin{array}{l}\text { Rain- } \\
\text { fall } \\
\text { (inches) }\end{array}$ & $\begin{array}{l}\text { Time } \\
\text { (hours) }\end{array}$ & $\begin{array}{l}\text { Streamflow } \\
\text { (cubic feet } \\
\text { per second) }\end{array}$ & $\begin{array}{l}\text { Rain- } \\
\text { fall } \\
\text { (inches) }\end{array}$ & $\begin{array}{l}\text { Time } \\
\text { (hours) }\end{array}$ & $\begin{array}{l}\text { Streamflow } \\
\text { (cubic feet } \\
\text { per second) }\end{array}$ & $\begin{array}{l}\text { Rain- } \\
\text { fall } \\
\text { (inches) }\end{array}$ \\
\hline $\begin{array}{l}1700 \\
1705 \\
1710 \\
1715 \\
1720\end{array}$ & $\begin{array}{l}0.2 \\
0.2 \\
0.2 \\
0.2 \\
0.2\end{array}$ & $\begin{array}{l}0.00 \\
0.00 \\
0.00 \\
0.00 \\
0.00\end{array}$ & $\begin{array}{l}2025 \\
2030 \\
2035 \\
2040 \\
2045\end{array}$ & $\begin{array}{l}111.0 \\
115.0 \\
143.0 \\
220.0 \\
257.0\end{array}$ & $\begin{array}{l}0.04 \\
0.06 \\
0.10 \\
0.12 \\
0.07\end{array}$ & $\begin{array}{l}2350 \\
2355 \\
\text { October } \\
0000 \\
0005\end{array}$ & $\begin{array}{r}48.3 \\
39.1 \\
14, \quad 1986 \\
30.0 \\
21.0\end{array}$ & $\begin{array}{l}0.00 \\
0.01 \\
0.00 \\
0.01\end{array}$ \\
\hline $\begin{array}{l}1725 \\
1730 \\
1735 \\
1740 \\
1745\end{array}$ & $\begin{array}{l}0.2 \\
0.2 \\
0.2 \\
0.2 \\
0.2\end{array}$ & $\begin{array}{l}0.00 \\
0.00 \\
0.00 \\
0.00 \\
0.00\end{array}$ & $\begin{array}{l}2050 \\
2055 \\
2100 \\
2105 \\
2110\end{array}$ & $\begin{array}{l}232.0 \\
181.0 \\
140.0 \\
113.0 \\
100.0\end{array}$ & $\begin{array}{l}0.04 \\
0.04 \\
0.02 \\
0.02 \\
0.03\end{array}$ & $\begin{array}{l}0010 \\
0015 \\
0020 \\
0025 \\
0030\end{array}$ & $\begin{array}{r}13.0 \\
8.0 \\
4.5 \\
2.0 \\
1.5\end{array}$ & $\begin{array}{l}0.00 \\
0.00 \\
0.01 \\
0.00 \\
0.00\end{array}$ \\
\hline $\begin{array}{l}1750 \\
1755 \\
1800 \\
1805 \\
1810\end{array}$ & $\begin{array}{r}0.2 \\
0.2 \\
0.2 \\
0.5 \\
17.9\end{array}$ & $\begin{array}{l}0.00 \\
0.00 \\
0.00 \\
0.04 \\
0.06\end{array}$ & $\begin{array}{l}2115 \\
2120 \\
2125 \\
2130 \\
2135\end{array}$ & $\begin{array}{r}97.8 \\
96.4 \\
110.0 \\
114.0 \\
91.2\end{array}$ & $\begin{array}{l}0.01 \\
0.07 \\
0.03 \\
0.01 \\
0.01\end{array}$ & $\begin{array}{l}0035 \\
0040 \\
0045 \\
0050 \\
0055\end{array}$ & $\begin{array}{l}1.0 \\
1.0 \\
1.0 \\
1.0 \\
1.0\end{array}$ & $\begin{array}{l}0.00 \\
0.01 \\
0.01 \\
0.01 \\
0.00\end{array}$ \\
\hline $\begin{array}{l}1815 \\
1820 \\
1825 \\
1830 \\
1835\end{array}$ & $\begin{array}{r}89.9 \\
222.0 \\
244.0 \\
226.0 \\
166.0\end{array}$ & $\begin{array}{l}0.13 \\
0.13 \\
0.08 \\
0.05 \\
0.02\end{array}$ & $\begin{array}{l}2140 \\
2145 \\
2150 \\
2155 \\
2200\end{array}$ & $\begin{array}{l}69.9 \\
56.0 \\
46.2 \\
37.2 \\
30.9\end{array}$ & $\begin{array}{l}0.00 \\
0.00 \\
0.01 \\
0.00 \\
0.00\end{array}$ & $\begin{array}{l}0100 \\
0105 \\
0110 \\
0115 \\
0120\end{array}$ & $\begin{array}{r}9.0 \\
12.0 \\
10.0 \\
4.5 \\
1.5\end{array}$ & $\begin{array}{l}0.00 \\
0.01 \\
0.00 \\
0.00 \\
0.00\end{array}$ \\
\hline $\begin{array}{l}1840 \\
1845 \\
1850 \\
1855 \\
1900\end{array}$ & $\begin{array}{r}115.0 \\
87.3 \\
86.0 \\
79.7 \\
97.8\end{array}$ & $\begin{array}{l}0.02 \\
0.02 \\
0.01 \\
0.06 \\
0.06\end{array}$ & $\begin{array}{l}2205 \\
2210 \\
2215 \\
2220 \\
2225\end{array}$ & $\begin{array}{l}27.0 \\
24.2 \\
22.9 \\
21.8 \\
21.2\end{array}$ & $\begin{array}{l}0.00 \\
0.01 \\
0.00 \\
0.00 \\
0.01\end{array}$ & $\begin{array}{l}0125 \\
0130 \\
0135 \\
0140 \\
0145\end{array}$ & $\begin{array}{l}1.3 \\
1.1 \\
1.0 \\
0.9 \\
0.8\end{array}$ & $\begin{array}{l}0.00 \\
0.00 \\
0.00 \\
0.00 \\
0.00\end{array}$ \\
\hline $\begin{array}{l}1905 \\
1910 \\
1915 \\
1920 \\
1925\end{array}$ & $\begin{array}{r}136.0 \\
142.0 \\
117.0 \\
104.0 \\
99.1\end{array}$ & $\begin{array}{l}0.06 \\
0.04 \\
0.02 \\
0.03 \\
0.03\end{array}$ & $\begin{array}{l}2230 \\
2235 \\
2240 \\
2245 \\
2250\end{array}$ & $\begin{array}{l}20.6 \\
20.6 \\
21.2 \\
22.3 \\
25.6\end{array}$ & $\begin{array}{l}0.01 \\
0.01 \\
0.01 \\
0.01 \\
0.01\end{array}$ & $\begin{array}{l}0150 \\
0155 \\
0200 \\
0205 \\
0210\end{array}$ & $\begin{array}{l}0.7 \\
0.6 \\
0.6 \\
0.5 \\
0.5\end{array}$ & $\begin{array}{l}0.01 \\
0.00 \\
0.00 \\
0.00 \\
0.00\end{array}$ \\
\hline $\begin{array}{l}1930 \\
1935 \\
1940 \\
1945 \\
1950\end{array}$ & $\begin{array}{r}93.8 \\
115.0 \\
118.0 \\
125.0 \\
126.0\end{array}$ & $\begin{array}{l}0.06 \\
0.05 \\
0.04 \\
0.04 \\
0.03\end{array}$ & $\begin{array}{l}2255 \\
2300 \\
2305 \\
2310 \\
2315\end{array}$ & $\begin{array}{l}27.7 \\
27.7 \\
28.5 \\
30.9 \\
32.7\end{array}$ & $\begin{array}{l}0.00 \\
0.01 \\
0.01 \\
0.03 \\
0.01\end{array}$ & $\begin{array}{l}0215 \\
0220 \\
0225 \\
0230 \\
0235\end{array}$ & $\begin{array}{l}0.4 \\
0.4 \\
0.4 \\
0.4 \\
0.3\end{array}$ & $\begin{array}{l}0.01 \\
0.00 \\
0.00 \\
0.01 \\
0.00\end{array}$ \\
\hline $\begin{array}{l}1955 \\
2000 \\
2005 \\
2010 \\
2015\end{array}$ & $\begin{array}{r}104.0 \\
99.1 \\
100.0 \\
109.0 \\
104.0\end{array}$ & $\begin{array}{l}0.04 \\
0.04 \\
0.04 \\
0.03 \\
0.04\end{array}$ & $\begin{array}{l}2320 \\
2325 \\
2330 \\
2335 \\
2340\end{array}$ & $\begin{array}{l}41.0 \\
38.1 \\
44.1 \\
79.7 \\
79.7\end{array}$ & $\begin{array}{l}0.01 \\
0.02 \\
0.04 \\
0.01 \\
0.01\end{array}$ & $\begin{array}{l}0240 \\
0245 \\
0250 \\
0255 \\
0300\end{array}$ & $\begin{array}{l}0.3 \\
0.3 \\
0.2 \\
0.2 \\
0.2\end{array}$ & $\begin{array}{l}0.00 \\
0.01 \\
0.00 \\
0.00 \\
0.01\end{array}$ \\
\hline 2020 & 114.0 & 0.04 & 2345 & 61.6 & 0.00 & & & \\
\hline
\end{tabular}




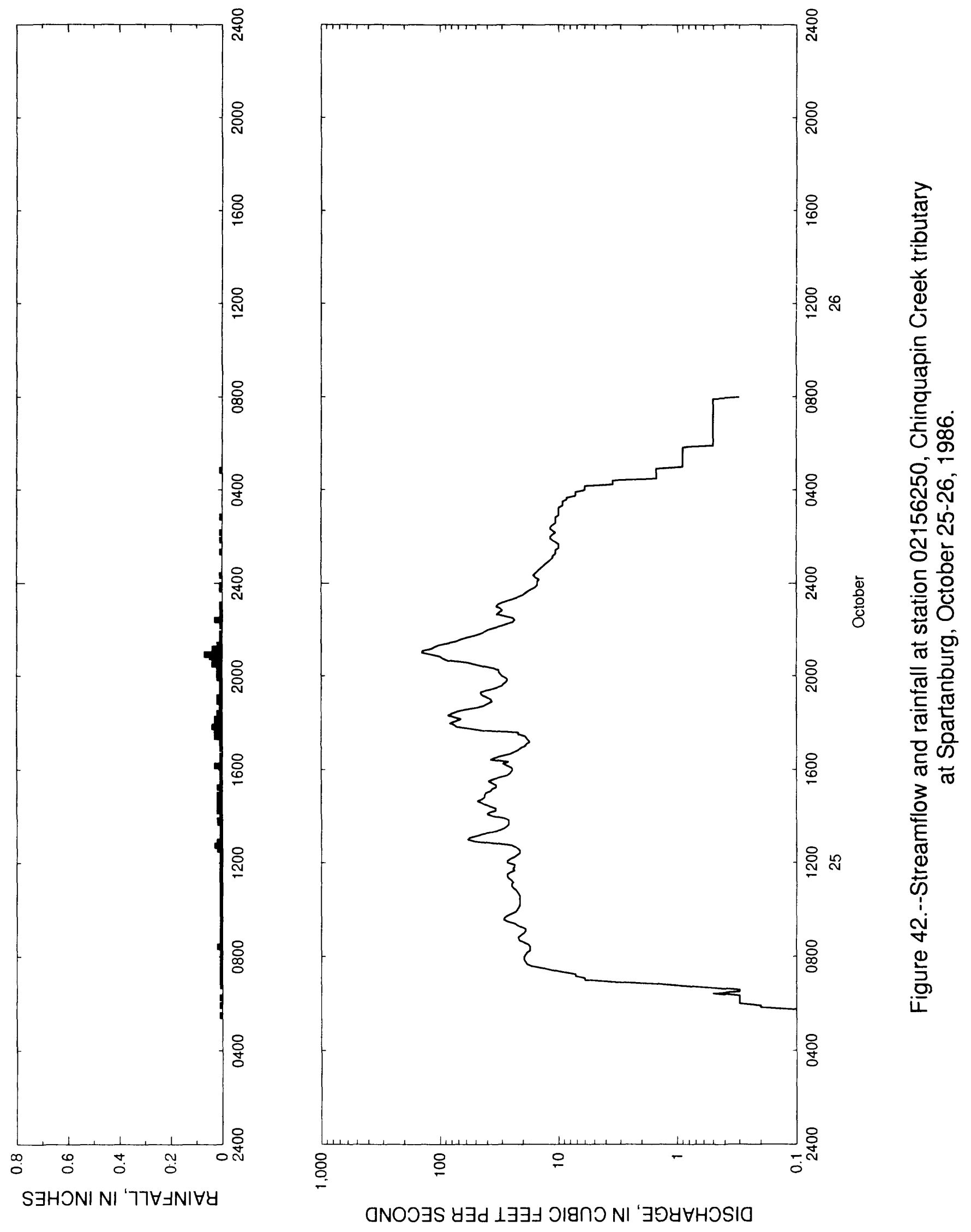


Table 41.--Streamflow and rainfal1 at station 02156250. Chinguapin Creek tributary at Spartanburg. October $25-26,1986$

\begin{tabular}{|c|c|c|c|c|c|c|c|c|}
\hline $\begin{array}{l}\text { Time } \\
\text { (hours) }\end{array}$ & $\begin{array}{l}\text { Streamflow } \\
\text { (cubic feet } \\
\text { per second) }\end{array}$ & $\begin{array}{l}\text { Rain - } \\
\text { fall } \\
\text { (inches) }\end{array}$ & $\begin{array}{l}\text { Time } \\
\text { (hours) }\end{array}$ & $\begin{array}{l}\text { Streamflow } \\
\text { (cubic feet } \\
\text { per second) }\end{array}$ & $\begin{array}{l}\text { Rain- } \\
\text { fall } \\
\text { (inches) }\end{array}$ & $\begin{array}{l}\text { Time } \\
\text { (hours) }\end{array}$ & $\begin{array}{l}\text { Streamflow } \\
\text { (cubic feet } \\
\text { per second) }\end{array}$ & $\begin{array}{l}\text { Rain- } \\
\text { fall } \\
\text { (inches) }\end{array}$ \\
\hline $\begin{array}{l}\text { October } \\
0530 \\
0535 \\
0540 \\
0545\end{array}$ & $\begin{array}{r}1986 \\
0.1 \\
0.1 \\
0.1 \\
0.1\end{array}$ & $\begin{array}{l}0.01 \\
0.00 \\
0.00 \\
0.00\end{array}$ & $\begin{array}{l}1050 \\
1055 \\
1100 \\
1105 \\
1110\end{array}$ & $\begin{array}{l}22.9 \\
24.2 \\
24.9 \\
24.9 \\
24.2\end{array}$ & $\begin{array}{l}0.01 \\
0.01 \\
0.01 \\
0.01 \\
0.01\end{array}$ & $\begin{array}{l}1615 \\
1620 \\
1625 \\
1630 \\
1635\end{array}$ & $\begin{array}{l}29.2 \\
26.3 \\
37.2 \\
34.4 \\
30.0\end{array}$ & $\begin{array}{l}0.01 \\
0.00 \\
0.01 \\
0.00 \\
0.01\end{array}$ \\
\hline $\begin{array}{l}0550 \\
0555 \\
0600 \\
0605 \\
0610\end{array}$ & $\begin{array}{l}0.2 \\
0.2 \\
0.3 \\
0.3 \\
0.3\end{array}$ & $\begin{array}{l}0.00 \\
0.01 \\
0.00 \\
0.00 \\
0.00\end{array}$ & $\begin{array}{l}1115 \\
1120 \\
1125 \\
1130 \\
1135\end{array}$ & $\begin{array}{l}24.9 \\
26.3 \\
27.0 \\
27.0 \\
25.6\end{array}$ & $\begin{array}{l}0.01 \\
0.01 \\
0.00 \\
0.01 \\
0.01\end{array}$ & $\begin{array}{l}1640 \\
1645 \\
1650 \\
1655 \\
1700\end{array}$ & $\begin{array}{l}25.6 \\
23.5 \\
21.8 \\
20.6 \\
19.0\end{array}$ & $\begin{array}{l}0.00 \\
0.00 \\
0.00 \\
0.01 \\
0.00\end{array}$ \\
\hline $\begin{array}{l}0615 \\
0620 \\
0625 \\
0630 \\
0635\end{array}$ & $\begin{array}{l}0.3 \\
0.3 \\
0.5 \\
0.3 \\
0.3\end{array}$ & $\begin{array}{l}0.01 \\
0.00 \\
0.00 \\
0.00 \\
0.00\end{array}$ & $\begin{array}{l}1140 \\
1145 \\
1150 \\
1155 \\
1200\end{array}$ & $\begin{array}{l}23.5 \\
24.2 \\
23.5 \\
23.5 \\
27.0\end{array}$ & $\begin{array}{l}0.01 \\
0.01 \\
0.01 \\
0.01 \\
0.00\end{array}$ & $\begin{array}{l}1705 \\
1710 \\
1715 \\
1720 \\
1725\end{array}$ & $\begin{array}{l}18.5 \\
17.4 \\
17.9 \\
18.5 \\
19.0\end{array}$ & $\begin{array}{l}0.00 \\
0.01 \\
0.00 \\
0.01 \\
0.03\end{array}$ \\
\hline $\begin{array}{l}0640 \\
0645 \\
0650 \\
0655 \\
0700\end{array}$ & $\begin{array}{l}0.5 \\
0.9 \\
1.5 \\
3.5 \\
6.0\end{array}$ & $\begin{array}{l}0.00 \\
0.01 \\
0.00 \\
0.01 \\
0.00\end{array}$ & $\begin{array}{l}1205 \\
1210 \\
1215 \\
1220 \\
1225\end{array}$ & $\begin{array}{l}27.0 \\
25.6 \\
23.5 \\
22.3 \\
21.2\end{array}$ & $\begin{array}{l}0.01 \\
0.00 \\
0.01 \\
0.01 \\
0.01\end{array}$ & $\begin{array}{l}1730 \\
1735 \\
1740 \\
1745 \\
1750\end{array}$ & $\begin{array}{l}21.8 \\
21.8 \\
43.1 \\
54.8 \\
72.3\end{array}$ & $\begin{array}{l}0.03 \\
0.02 \\
0.03 \\
0.03 \\
0.04\end{array}$ \\
\hline $\begin{array}{l}0705 \\
0710 \\
0715 \\
0720 \\
0725\end{array}$ & $\begin{array}{r}6.0 \\
7.2 \\
7.2 \\
9.2 \\
11.2\end{array}$ & $\begin{array}{l}0.01 \\
0.01 \\
0.01 \\
0.01 \\
0.00\end{array}$ & $\begin{array}{l}1230 \\
1235 \\
1240 \\
1245 \\
1250\end{array}$ & $\begin{array}{l}21.2 \\
21.8 \\
22.9 \\
24.9 \\
34.4\end{array}$ & $\begin{array}{l}0.00 \\
0.02 \\
0.02 \\
0.03 \\
0.02\end{array}$ & $\begin{array}{l}1755 \\
1800 \\
1805 \\
1810 \\
1815\end{array}$ & $\begin{array}{l}76.0 \\
82.2 \\
73.5 \\
66.3 \\
76.0\end{array}$ & $\begin{array}{l}0.02 \\
0.02 \\
0.03 \\
0.03 \\
0.02\end{array}$ \\
\hline $\begin{array}{l}0730 \\
0735 \\
0740 \\
0745 \\
0750\end{array}$ & $\begin{array}{l}13.4 \\
16.8 \\
18.5 \\
19.0 \\
19.5\end{array}$ & $\begin{array}{l}0.01 \\
0.00 \\
0.01 \\
0.01 \\
0.00\end{array}$ & $\begin{array}{l}1255 \\
1300 \\
1305 \\
1310 \\
1315\end{array}$ & $\begin{array}{l}50.5 \\
58.2 \\
56.0 \\
48.3 \\
43.1\end{array}$ & $\begin{array}{l}0.02 \\
0.01 \\
0.01 \\
0.01 \\
0.00\end{array}$ & $\begin{array}{l}1820 \\
1825 \\
1830 \\
1835 \\
1840\end{array}$ & $\begin{array}{l}86.0 \\
78.4 \\
69.9 \\
59.3 \\
48.3\end{array}$ & $\begin{array}{l}0.02 \\
0.02 \\
0.01 \\
0.00 \\
0.01\end{array}$ \\
\hline $\begin{array}{l}0755 \\
0800 \\
0805 \\
0810 \\
0815\end{array}$ & $\begin{array}{l}19.5 \\
19.5 \\
19.0 \\
18.5 \\
17.4\end{array}$ & $\begin{array}{l}0.01 \\
0.00 \\
0.01 \\
0.00 \\
0.01\end{array}$ & $\begin{array}{l}1320 \\
1325 \\
1330 \\
1335 \\
1340\end{array}$ & $\begin{array}{l}35.4 \\
30.9 \\
28.5 \\
27.0 \\
26.3\end{array}$ & $\begin{array}{l}0.01 \\
0.01 \\
0.01 \\
0.00 \\
0.01\end{array}$ & $\begin{array}{l}1845 \\
1850 \\
1855 \\
1900 \\
1905\end{array}$ & $\begin{array}{l}42.0 \\
39.1 \\
36.3 \\
37.2 \\
40.0\end{array}$ & $\begin{array}{l}0.01 \\
0.01 \\
0.02 \\
0.01 \\
0.02\end{array}$ \\
\hline $\begin{array}{l}0820 \\
0825 \\
0830 \\
0835 \\
0840\end{array}$ & $\begin{array}{l}17.4 \\
17.4 \\
17.9 \\
19.5 \\
21.2\end{array}$ & $\begin{array}{l}0.01 \\
0.02 \\
0.01 \\
0.00 \\
0.01\end{array}$ & $\begin{array}{l}1345 \\
1350 \\
1355 \\
1400 \\
1405\end{array}$ & $\begin{array}{l}26.3 \\
26.3 \\
28.5 \\
35.4 \\
40.0\end{array}$ & $\begin{array}{l}0.02 \\
0.02 \\
0.01 \\
0.01 \\
0.01\end{array}$ & $\begin{array}{l}1910 \\
1915 \\
1920 \\
1925 \\
1930\end{array}$ & $\begin{array}{l}43.1 \\
45.1 \\
45.1 \\
38.1 \\
33.5\end{array}$ & $\begin{array}{l}0.01 \\
0.01 \\
0.01 \\
0.00 \\
0.00\end{array}$ \\
\hline $\begin{array}{l}0845 \\
0850 \\
0855 \\
0900 \\
0905\end{array}$ & $\begin{array}{l}21.8 \\
21.8 \\
20.6 \\
19.5 \\
19.0\end{array}$ & $\begin{array}{l}0.00 \\
0.01 \\
0.01 \\
0.01 \\
0.01\end{array}$ & $\begin{array}{l}1410 \\
1415 \\
1420 \\
1425 \\
1430\end{array}$ & $\begin{array}{l}38.1 \\
33.5 \\
33.5 \\
37.2 \\
41.0\end{array}$ & $\begin{array}{l}0.01 \\
0.02 \\
0.01 \\
0.02 \\
0.02\end{array}$ & $\begin{array}{l}1935 \\
1940 \\
1945 \\
1950 \\
1955\end{array}$ & $\begin{array}{l}30.0 \\
29.2 \\
27.7 \\
27.0 \\
27.7\end{array}$ & $\begin{array}{l}0.01 \\
0.01 \\
0.01 \\
0.01 \\
0.02\end{array}$ \\
\hline $\begin{array}{l}0910 \\
0915 \\
0920 \\
0925 \\
0930\end{array}$ & $\begin{array}{l}19.0 \\
20.5 \\
22.3 \\
23.5 \\
27.0\end{array}$ & $\begin{array}{l}0.01 \\
0.01 \\
0.01 \\
0.01 \\
0.01\end{array}$ & $\begin{array}{l}1435 \\
1440 \\
1445 \\
1450 \\
1455\end{array}$ & $\begin{array}{l}44.1 \\
48.3 \\
44.1 \\
42.0 \\
42.0\end{array}$ & $\begin{array}{l}0.01 \\
0.02 \\
0.01 \\
0.01 \\
0.02\end{array}$ & $\begin{array}{l}2000 \\
2005 \\
2010 \\
2015 \\
2020\end{array}$ & $\begin{array}{l}29.9 \\
30.9 \\
31.8 \\
31.8 \\
35.4\end{array}$ & $\begin{array}{l}0.00 \\
0.01 \\
0.02 \\
0.01 \\
0.01\end{array}$ \\
\hline $\begin{array}{l}0935 \\
0940 \\
0945 \\
0950 \\
0955\end{array}$ & $\begin{array}{l}29.2 \\
28.5 \\
27.0 \\
24.9 \\
22.9\end{array}$ & $\begin{array}{l}0.00 \\
0.01 \\
0.01 \\
0.00 \\
0.01\end{array}$ & $\begin{array}{l}1500 \\
1505 \\
1510 \\
1515 \\
1520\end{array}$ & $\begin{array}{l}41.0 \\
37.2 \\
36.3 \\
33.5 \\
33.5\end{array}$ & $\begin{array}{l}0.00 \\
0.01 \\
0.01 \\
0.02 \\
0.01\end{array}$ & $\begin{array}{l}2025 \\
2030 \\
2035 \\
2040 \\
2045\end{array}$ & $\begin{array}{l}43.1 \\
50.5 \\
59.3 \\
86.0 \\
95.1\end{array}$ & $\begin{array}{l}0.02 \\
0.04 \\
0.03 \\
0.04 \\
0.04\end{array}$ \\
\hline $\begin{array}{l}1000 \\
1005 \\
1010 \\
1015 \\
1020\end{array}$ & $\begin{array}{l}22.3 \\
21.8 \\
21.2 \\
21.2 \\
21.2\end{array}$ & $\begin{array}{l}0.01 \\
0.01 \\
0.00 \\
0.01 \\
0.00\end{array}$ & $\begin{array}{l}1525 \\
1530 \\
1535 \\
1540 \\
1545\end{array}$ & $\begin{array}{l}36.3 \\
39.1 \\
35.4 \\
30.9 \\
27.0\end{array}$ & $\begin{array}{l}0.00 \\
0.01 \\
0.00 \\
0.01 \\
0.01\end{array}$ & $\begin{array}{l}2050 \\
2055 \\
2100 \\
2105 \\
2110\end{array}$ & $\begin{array}{l}100.0 \\
118.0 \\
142.0 \\
140.0 \\
119.0\end{array}$ & $\begin{array}{l}0.05 \\
0.07 \\
0.04 \\
0.03 \\
0.04\end{array}$ \\
\hline $\begin{array}{l}1025 \\
1030 \\
1035 \\
1040 \\
1045\end{array}$ & $\begin{array}{l}21.2 \\
21.2 \\
21.2 \\
21.8 \\
22.3\end{array}$ & $\begin{array}{l}0.01 \\
0.01 \\
0.01 \\
0.00 \\
0.01\end{array}$ & $\begin{array}{l}1550 \\
1555 \\
1600 \\
1605 \\
1610\end{array}$ & $\begin{array}{l}25.6 \\
24.9 \\
24.2 \\
24.9 \\
27.0\end{array}$ & $\begin{array}{l}0.00 \\
0.01 \\
0.00 \\
0.00 \\
0.03\end{array}$ & $\begin{array}{l}2115 \\
2120 \\
2125 \\
2130 \\
2135\end{array}$ & $\begin{array}{r}111.0 \\
102.0 \\
86.0 \\
72.3 \\
66.3\end{array}$ & $\begin{array}{l}0.01 \\
0.02 \\
0.01 \\
0.01 \\
0.01\end{array}$ \\
\hline
\end{tabular}


Table 41.--Streamflow and rainfall at station 02156250 , Chinquapin Creek tributary at Spartanburg. October 25-26, 1986--Continued

\begin{tabular}{|c|c|c|c|c|c|c|c|c|}
\hline $\begin{array}{l}\text { Time } \\
\text { (hours) }\end{array}$ & $\begin{array}{l}\text { Streamflow } \\
\text { (cubic feet } \\
\text { per second) }\end{array}$ & $\begin{array}{l}\text { Rain- } \\
\text { fall } \\
\text { (inches) }\end{array}$ & $\begin{array}{l}\text { Time } \\
\text { (hours) }\end{array}$ & $\begin{array}{l}\text { Streamflow } \\
\text { (cubic feet } \\
\text { per second) }\end{array}$ & $\begin{array}{l}\text { Rain- } \\
\text { fall } \\
\text { (inches) }\end{array}$ & $\begin{array}{l}\text { Time } \\
\text { (hours) }\end{array}$ & $\begin{array}{l}\text { Streamflow } \\
\text { (cubic feet } \\
\text { per second) }\end{array}$ & $\begin{array}{l}\text { Rain- } \\
\text { fall } \\
\text { (inches) }\end{array}$ \\
\hline $\begin{array}{l}2140 \\
2145 \\
2150 \\
2155 \\
2200\end{array}$ & $\begin{array}{l}58.2 \\
50.5 \\
45.1 \\
42.0 \\
39.1\end{array}$ & $\begin{array}{l}0.00 \\
0.01 \\
0.01 \\
0.00 \\
0.00\end{array}$ & $\begin{array}{l}0105 \\
0110 \\
0115 \\
0120 \\
0125\end{array}$ & $\begin{array}{l}11.2 \\
11.2 \\
10.6 \\
10.6 \\
10.6\end{array}$ & $\begin{array}{l}0.00 \\
0.00 \\
0.00 \\
0.01 \\
0.00\end{array}$ & $\begin{array}{l}0435 \\
0440 \\
0445 \\
0450 \\
0455\end{array}$ & $\begin{array}{l}1.5 \\
1.5 \\
1.5 \\
1.5 \\
1.5\end{array}$ & $\begin{array}{l}0.00 \\
0.00 \\
0.00 \\
0.01 \\
0.00\end{array}$ \\
\hline $\begin{array}{l}2205 \\
2210 \\
2215 \\
2220 \\
2225\end{array}$ & $\begin{array}{l}34.4 \\
30.0 \\
27.0 \\
24.2 \\
23.5\end{array}$ & $\begin{array}{l}0.00 \\
0.01 \\
0.00 \\
0.01 \\
0.03\end{array}$ & $\begin{array}{l}0130 \\
0135 \\
0140 \\
0145 \\
0150\end{array}$ & $\begin{array}{l}10.0 \\
10.0 \\
10.0 \\
10.6 \\
11.2\end{array}$ & $\begin{array}{l}0.00 \\
0.00 \\
0.00 \\
0.00 \\
0.01\end{array}$ & $\begin{array}{l}0500 \\
0505 \\
0510 \\
0515 \\
0520\end{array}$ & $\begin{array}{l}0.9 \\
0.9 \\
0.9 \\
0.9 \\
0.9\end{array}$ & $\begin{array}{l}0.00 \\
0.00 \\
0.00 \\
0.00 \\
0.00\end{array}$ \\
\hline $\begin{array}{l}2230 \\
2235 \\
2240 \\
2245 \\
2250\end{array}$ & $\begin{array}{l}24.2 \\
28.5 \\
33.5 \\
31.8 \\
30.0\end{array}$ & $\begin{array}{l}0.01 \\
0.00 \\
0.01 \\
0.01 \\
0.01\end{array}$ & $\begin{array}{l}0155 \\
0200 \\
0205 \\
0210 \\
0215\end{array}$ & $\begin{array}{l}11.7 \\
11.7 \\
11.2 \\
10.6 \\
11.2\end{array}$ & $\begin{array}{l}0.00 \\
0.00 \\
0.00 \\
0.01 \\
0.00\end{array}$ & $\begin{array}{l}0525 \\
0530 \\
0535 \\
0540 \\
0545\end{array}$ & $\begin{array}{l}0.9 \\
0.9 \\
0.9 \\
0.9 \\
0.9\end{array}$ & $\begin{array}{l}0.00 \\
0.00 \\
0.00 \\
0.00 \\
0.00\end{array}$ \\
\hline $\begin{array}{l}2255 \\
2300 \\
2305 \\
2310 \\
2315\end{array}$ & $\begin{array}{l}30.9 \\
33.5 \\
32.7 \\
30.0 \\
27.0\end{array}$ & $\begin{array}{l}0.01 \\
0.00 \\
0.01 \\
0.00 \\
0.00\end{array}$ & $\begin{array}{l}0220 \\
0225 \\
0230 \\
0235 \\
0240\end{array}$ & $\begin{array}{l}11.7 \\
11.7 \\
11.2 \\
10.6 \\
10.6\end{array}$ & $\begin{array}{l}0.00 \\
0.00 \\
0.00 \\
0.00 \\
0.00\end{array}$ & $\begin{array}{l}0550 \\
0555 \\
0600 \\
0605 \\
0610\end{array}$ & $\begin{array}{l}0.9 \\
0.5 \\
0.5 \\
0.5 \\
0.5\end{array}$ & $\begin{array}{l}0.00 \\
0.00 \\
0.00 \\
0.00 \\
0.00\end{array}$ \\
\hline $\begin{array}{l}2320 \\
2325 \\
2330 \\
2335 \\
2340\end{array}$ & $\begin{array}{l}24.2 \\
21.8 \\
20.0 \\
19.0 \\
17.9\end{array}$ & $\begin{array}{l}0.00 \\
0.00 \\
0.00 \\
0.00 \\
0.00\end{array}$ & $\begin{array}{l}0245 \\
0250 \\
0255 \\
0300 \\
0305\end{array}$ & $\begin{array}{l}10.6 \\
10.6 \\
10.0 \\
10.0 \\
10.0\end{array}$ & $\begin{array}{l}0.00 \\
0.01 \\
0.00 \\
0.00 \\
0.00\end{array}$ & $\begin{array}{l}0615 \\
0620 \\
0625 \\
0630 \\
0635\end{array}$ & $\begin{array}{l}0.5 \\
0.5 \\
0.5 \\
0.5 \\
0.5\end{array}$ & $\begin{array}{l}0.00 \\
0.00 \\
0.00 \\
0.00 \\
0.00\end{array}$ \\
\hline $\begin{array}{l}2345 \\
2350 \\
2355 \\
\text { October } \\
0000\end{array}$ & $\begin{array}{r}16.8 \\
15.7 \\
15.1 \\
26, \quad 1986 \\
15.1\end{array}$ & $\begin{array}{l}0.01 \\
0.00 \\
0.01 \\
0.00\end{array}$ & $\begin{array}{l}0310 \\
0315 \\
0320 \\
0325 \\
0330\end{array}$ & $\begin{array}{r}10.0 \\
10.0 \\
9.2 \\
9.2 \\
9.2\end{array}$ & $\begin{array}{l}0.00 \\
0.00 \\
0.00 \\
0.00 \\
0.00\end{array}$ & $\begin{array}{l}0640 \\
0645 \\
0650 \\
0655 \\
0700\end{array}$ & $\begin{array}{l}0.5 \\
0.5 \\
0.5 \\
0.5 \\
0.5\end{array}$ & $\begin{array}{l}0.00 \\
0.00 \\
0.00 \\
0.00 \\
0.00\end{array}$ \\
\hline $\begin{array}{l}0005 \\
0010 \\
0015 \\
0020 \\
0025\end{array}$ & $\begin{array}{l}15.1 \\
14.6 \\
15.7 \\
16.3 \\
15.7\end{array}$ & $\begin{array}{l}0.00 \\
0.00 \\
0.00 \\
0.01 \\
0.00\end{array}$ & $\begin{array}{l}0335 \\
0340 \\
0345 \\
0350 \\
0355\end{array}$ & $\begin{array}{l}8.5 \\
8.5 \\
7.2 \\
7.2 \\
7.2\end{array}$ & $\begin{array}{l}0.00 \\
0.00 \\
0.00 \\
0.00 \\
0.00\end{array}$ & $\begin{array}{l}0705 \\
0710 \\
0715 \\
0720 \\
0725\end{array}$ & $\begin{array}{l}0.5 \\
0.5 \\
0.5 \\
0.5 \\
0.5\end{array}$ & $\begin{array}{l}0.00 \\
0.00 \\
0.00 \\
0.00 \\
0.00\end{array}$ \\
\hline $\begin{array}{l}0030 \\
0035 \\
0040 \\
0045 \\
0050\end{array}$ & $\begin{array}{l}15.1 \\
14.6 \\
14.0 \\
13.4 \\
12.9\end{array}$ & $\begin{array}{l}0.00 \\
0.00 \\
0.00 \\
0.00 \\
0.00\end{array}$ & $\begin{array}{l}0400 \\
0405 \\
0410 \\
0415 \\
0420\end{array}$ & $\begin{array}{l}6.0 \\
6.0 \\
6.0 \\
3.5 \\
3.5\end{array}$ & $\begin{array}{l}0.00 \\
0.00 \\
0.00 \\
0.00 \\
0.00\end{array}$ & $\begin{array}{l}0730 \\
0735 \\
0740 \\
0745 \\
0750\end{array}$ & $\begin{array}{l}0.5 \\
0.5 \\
0.5 \\
0.5 \\
0.5\end{array}$ & $\begin{array}{l}0.00 \\
0.00 \\
0.00 \\
0.00 \\
0.00\end{array}$ \\
\hline $\begin{array}{l}0055 \\
0100\end{array}$ & $\begin{array}{l}12.3 \\
11.7\end{array}$ & $\begin{array}{l}0.00 \\
0.00\end{array}$ & $\begin{array}{l}0425 \\
0430\end{array}$ & $\begin{array}{l}3.5 \\
1.5\end{array}$ & $\begin{array}{l}0.00 \\
0.00\end{array}$ & $\begin{array}{l}0755 \\
0800\end{array}$ & $\begin{array}{l}0.5 \\
0.3\end{array}$ & $\begin{array}{l}0.00 \\
0.00\end{array}$ \\
\hline
\end{tabular}




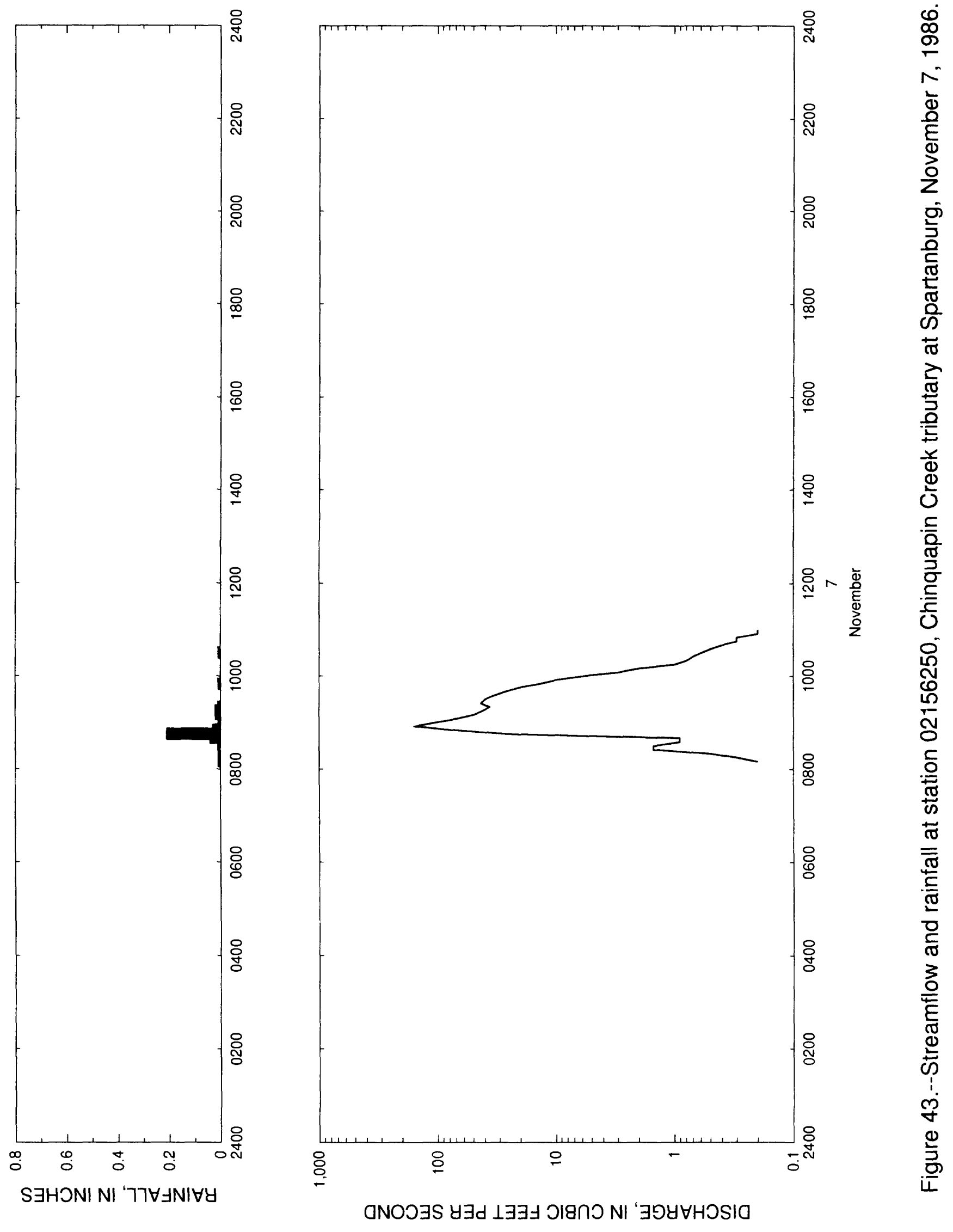


Table 42.--Streamflow and rainfall at station 02156250, Chinquapin Creek tributary at Spartanburg. November 7, 1986

\begin{tabular}{|c|c|c|c|c|c|c|c|c|}
\hline $\begin{array}{l}\text { Time } \\
\text { (hours) }\end{array}$ & $\begin{array}{l}\text { Streamflow } \\
\text { (cubic feet } \\
\text { per second) }\end{array}$ & $\begin{array}{l}\text { Rain- } \\
\text { fall } \\
\text { (inches) }\end{array}$ & $\begin{array}{l}\text { Time } \\
\text { (hours) }\end{array}$ & $\begin{array}{l}\text { Streamflow } \\
\text { (cubic feet } \\
\text { per second) }\end{array}$ & $\begin{array}{l}\text { Rain- } \\
\text { fall } \\
\text { (inches) }\end{array}$ & $\begin{array}{l}\text { Time } \\
\text { (hours) }\end{array}$ & $\begin{array}{l}\text { Streamflow } \\
\text { (cubic feet } \\
\text { per second) }\end{array}$ & $\begin{array}{l}\text { Rain- } \\
\text { fall } \\
\text { (inches) }\end{array}$ \\
\hline $\begin{array}{l}\text { November } \\
0805 \\
0810 \\
0815 \\
0820\end{array}$ & $\begin{array}{r}7, \quad 1986 \\
0.2 \\
0.2 \\
0.3 \\
0.5\end{array}$ & $\begin{array}{l}0.01 \\
0.01 \\
0.00 \\
0.01\end{array}$ & $\begin{array}{l}0905 \\
0910 \\
0915 \\
0920 \\
0925\end{array}$ & $\begin{array}{l}67.5 \\
49.4 \\
42.0 \\
36.3 \\
43.1\end{array}$ & $\begin{array}{l}0.01 \\
0.02 \\
0.02 \\
0.01 \\
0.00\end{array}$ & $\begin{array}{l}1010 \\
1015 \\
1020 \\
1025 \\
1030\end{array}$ & $\begin{array}{l}2.0 \\
1.0 \\
0.8 \\
0.7 \\
0.6\end{array}$ & $\begin{array}{l}0.00 \\
0.00 \\
0.00 \\
0.00 \\
0.01\end{array}$ \\
\hline $\begin{array}{l}0825 \\
0830 \\
0835 \\
0840 \\
0845\end{array}$ & $\begin{array}{r}1.5 \\
1.5 \\
0.9 \\
0.9 \\
22.9\end{array}$ & $\begin{array}{l}0.00 \\
0.00 \\
0.01 \\
0.04 \\
0.21\end{array}$ & $\begin{array}{l}0930 \\
0935 \\
0940 \\
0945 \\
0950\end{array}$ & $\begin{array}{l}40.0 \\
33.5 \\
27.0 \\
21.0 \\
14.0\end{array}$ & $\begin{array}{l}0.00 \\
0.00 \\
0.00 \\
0.00 \\
0.01\end{array}$ & $\begin{array}{l}1035 \\
1040 \\
1045 \\
1050 \\
1055\end{array}$ & $\begin{array}{l}0.5 \\
0.4 \\
0.3 \\
0.3 \\
0.2\end{array}$ & $\begin{array}{l}0.00 \\
0.00 \\
0.00 \\
0.00 \\
0.00\end{array}$ \\
\hline $\begin{array}{l}0850 \\
0855 \\
0900\end{array}$ & $\begin{array}{r}71.1 \\
159.0 \\
104.0\end{array}$ & $\begin{array}{l}0.03 \\
0.01 \\
0.01\end{array}$ & $\begin{array}{l}0955 \\
1000 \\
1005\end{array}$ & $\begin{array}{r}10.0 \\
6.0 \\
3.0\end{array}$ & $\begin{array}{l}0.00 \\
0.00 \\
0.00\end{array}$ & 1100 & 0.2 & $0 . C 0$ \\
\hline
\end{tabular}




\section{Station 02159785, Fairforest Creek Tributary at Spartanburg, S.C.}

Location.--Lat $34^{\circ} 57^{\prime} 10^{\prime \prime}$, long $81^{\circ} 57^{\prime} 57^{\prime \prime}$, Spartanburg County, Hydrologic Unit 03050107, at culvert on Textile Road (State secondary road 485), $1.8 \mathrm{mi}$ west of the Spartanburg courthouse, and $0.5 \mathrm{mi}$ upstream from the mouth at Fairforest Creek.

Period of record.-- March 13, 1987 to November 2, 1990.

Gage.--Digital stage recorder with 5-minute punch interval. The recorder is housed in a metal shelter atop a stilling well attached to a free-standing platform located on the right bank approximately $12 \mathrm{ft}$ upstream from the single $6 \mathrm{ft}$ by $8.2 \mathrm{ft}$ concrete bo: culvert. An enameled staff gage is attached to the platform. A crest-stage indicator is located on the right downstream wingwall.

Rating.--The stage-streamflow relation is defined by current meter measurements up to $4.1 \mathrm{ft}^{3} / \mathrm{s}$. The stage-streamflow relation was extended to $200 \mathrm{ft}^{3} / \mathrm{s}$ using indirect computational methods.

Rain gage and location.--Station 345738081572900, lat 34 ${ }^{\circ} 57^{\prime} 38^{\prime \prime}$, long 81 ${ }^{\circ} 57^{\prime 2} 29^{\prime \prime}$. A shelter containing a digital cumulative rainfall recorder with a 5-minute punch interval at the back lot of property located on Hayne Street (State secondary road 78), and $1.4 \mathrm{mi}$ northwest of Spartanburg City Hall.

Selected basin characteristics.--

Drainage area $-0.52 \mathrm{mi}^{2}$

Physiographic province - Piedmont

Channel slope -- $112.0 \mathrm{ft} / \mathrm{mi}$

Channel length -- $1.75 \mathrm{mi}$

Total impervious area -14.0 percent

Basin development factor - 0

2-year, 2-hour rainfall amount -- $2.00 \mathrm{in.}$

Flood frequency data: $\mathrm{UQ}_{2} \quad 154 \mathrm{ft}^{3} / \mathrm{s}$

$\mathrm{UQ}_{5} \quad 266 \mathrm{ft}^{3} / \mathrm{s}$

$\mathrm{UQ}_{10} \quad 349 \mathrm{ft}^{3} / \mathrm{s}$

$\mathrm{UQ}_{25} \quad 460 \mathrm{ft}^{3} / \mathrm{s}$

$\mathrm{UQ}_{50} \quad 545 \mathrm{ft}^{3} / \mathrm{s}$

$\mathrm{UQ}_{100} \quad 635 \mathrm{ft}^{3} / \mathrm{s}$

$\mathrm{UQ}_{500} \quad 852 \mathrm{ft}^{3} / \mathrm{s}$ 


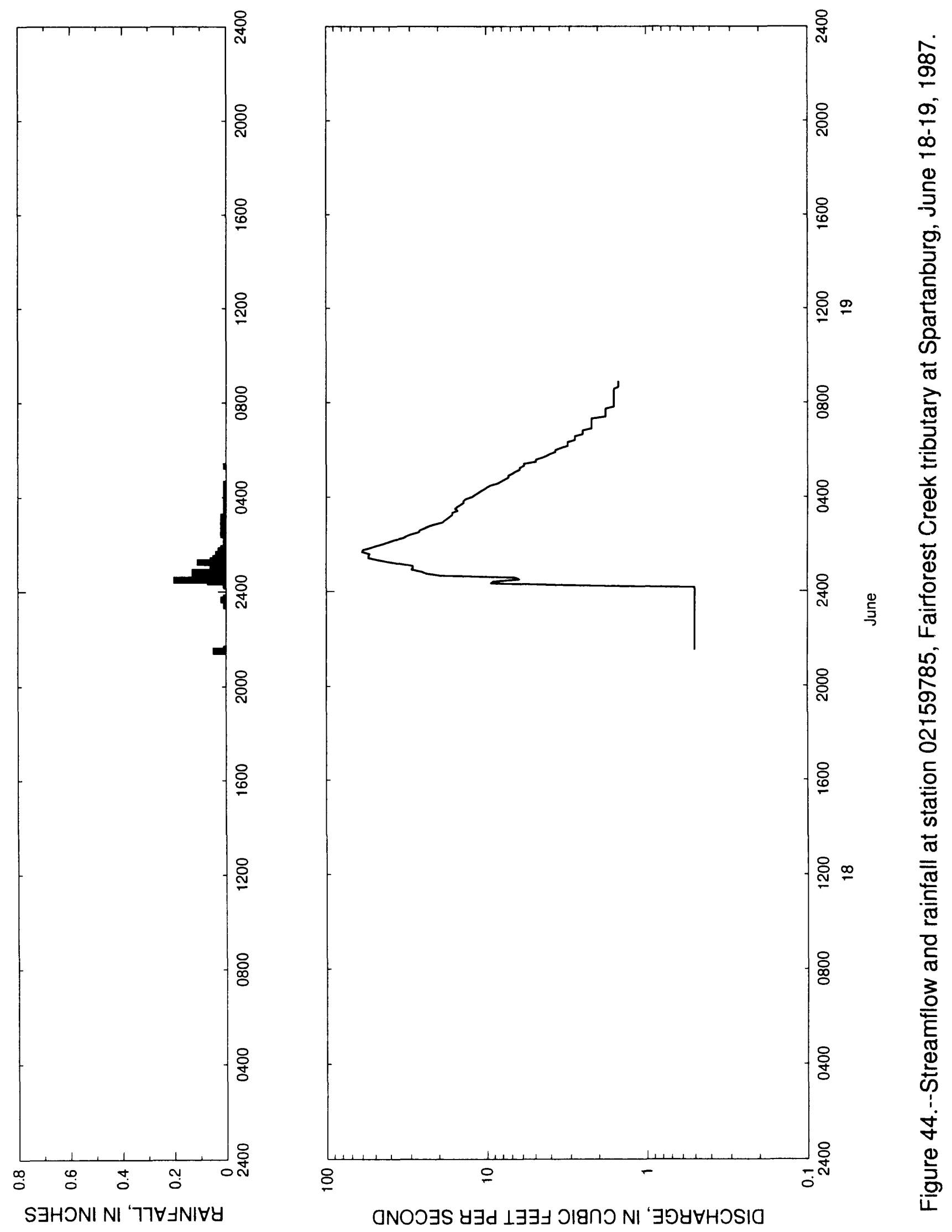


Table 43.- Streamflow and rainfall at station 02159785, Fairforest Croek tributary at Spartanburg, June $18-19,1987$

\begin{tabular}{|c|c|c|c|c|c|c|c|c|c|}
\hline $\begin{array}{l}\text { Time } \\
\text { (hours) }\end{array}$ & $\begin{array}{l}\text { Str } \\
\text { (cub } \\
\text { per }\end{array}$ & $\begin{array}{l}\text { eamflow } \\
\text { ic feet } \\
\text { second) }\end{array}$ & $\begin{array}{l}\text { Rain- } \\
\text { fall } \\
\text { (inches) }\end{array}$ & $\begin{array}{l}\text { Time } \\
\text { (hours) }\end{array}$ & $\begin{array}{l}\text { Streamflow } \\
\text { (cubic feet } \\
\text { per second) }\end{array}$ & $\begin{array}{l}\text { Rain- } \\
\text { fall } \\
\text { (inches) }\end{array}$ & $\begin{array}{l}\text { Time } \\
\text { (hours) }\end{array}$ & $\begin{array}{l}\text { Streamflow } \\
\text { (cubic feet } \\
\text { per second) }\end{array}$ & $\begin{array}{l}\text { Rain- } \\
\text { fall } \\
\text { (inches) }\end{array}$ \\
\hline $\begin{array}{l}\text { June } 18, \\
2130 \\
2135 \\
2140 \\
2145\end{array}$ & 1987 & $\begin{array}{l}0.5 \\
0.5 \\
0.5 \\
0.5\end{array}$ & $\begin{array}{l}0.05 \\
0.01 \\
0.00 \\
0.00\end{array}$ & $\begin{array}{l}0115 \\
0120 \\
0125 \\
0130 \\
0135\end{array}$ & $\begin{array}{l}41.3 \\
47.9 \\
54.3 \\
54.3 \\
53.5\end{array}$ & $\begin{array}{l}0.11 \\
0.06 \\
0.05 \\
0.03 \\
0.04\end{array}$ & $\begin{array}{l}0510 \\
0515 \\
0520 \\
0525 \\
0530\end{array}$ & $\begin{array}{l}6.2 \\
6.2 \\
5.8 \\
5.8 \\
4.9\end{array}$ & $\begin{array}{l}0.00 \\
0.00 \\
0.01 \\
0.00 \\
0.00\end{array}$ \\
\hline $\begin{array}{l}2150 \\
2155 \\
2200 \\
2205 \\
2210\end{array}$ & & $\begin{array}{l}0.5 \\
0.5 \\
0.5 \\
0.5 \\
0.5\end{array}$ & $\begin{array}{l}0.00 \\
0.00 \\
0.00 \\
0.00 \\
0.00\end{array}$ & $\begin{array}{l}0140 \\
0145 \\
0150 \\
0155 \\
0200\end{array}$ & $\begin{array}{l}59.6 \\
58.8 \\
53.1 \\
49.1 \\
44.3\end{array}$ & $\begin{array}{l}0.02 \\
0.03 \\
0.02 \\
0.01 \\
0.01\end{array}$ & $\begin{array}{l}0535 \\
0540 \\
0545 \\
0550 \\
0555\end{array}$ & $\begin{array}{l}4.9 \\
4.5 \\
4.2 \\
4.0 \\
3.7\end{array}$ & $\begin{array}{l}0.00 \\
0.00 \\
0.00 \\
0.00 \\
0.00\end{array}$ \\
\hline $\begin{array}{l}2215 \\
2220 \\
2225 \\
2230 \\
2235\end{array}$ & & $\begin{array}{l}0.5 \\
0.5 \\
0.5 \\
0.5 \\
0.5\end{array}$ & $\begin{array}{l}0.00 \\
0.00 \\
0.00 \\
0.00 \\
0.00\end{array}$ & $\begin{array}{l}0205 \\
0210 \\
0215 \\
0220 \\
0225\end{array}$ & $\begin{array}{l}40.9 \\
37.3 \\
33.0 \\
31.5 \\
29.3\end{array}$ & $\begin{array}{l}0.00 \\
0.01 \\
0.01 \\
0.01 \\
0.02\end{array}$ & $\begin{array}{l}0600 \\
0605 \\
0610 \\
0615 \\
0620\end{array}$ & $\begin{array}{l}3.7 \\
3.4 \\
3.1 \\
3.1 \\
3.1\end{array}$ & $\begin{array}{l}0.00 \\
0.00 \\
0.00 \\
0.00 \\
0.00\end{array}$ \\
\hline $\begin{array}{l}2240 \\
2245 \\
2250 \\
2255 \\
2300\end{array}$ & & $\begin{array}{l}0.5 \\
0.5 \\
0.5 \\
0.5 \\
0.5\end{array}$ & $\begin{array}{l}0.00 \\
0.00 \\
0.00 \\
0.00 \\
0.00\end{array}$ & $\begin{array}{l}0230 \\
0235 \\
0240 \\
0245 \\
0250\end{array}$ & $\begin{array}{l}26.5 \\
26.0 \\
24.3 \\
22.9 \\
20.9\end{array}$ & $\begin{array}{l}0.02 \\
0.02 \\
0.01 \\
0.02 \\
0.01\end{array}$ & $\begin{array}{l}0625 \\
0630 \\
0635 \\
0640 \\
0645\end{array}$ & $\begin{array}{l}2.8 \\
2.8 \\
2.8 \\
2.5 \\
2.5\end{array}$ & $\begin{array}{l}0.00 \\
0.00 \\
0.00 \\
0.00 \\
0.00\end{array}$ \\
\hline $\begin{array}{l}2305 \\
2310 \\
2315 \\
2320 \\
2325\end{array}$ & & $\begin{array}{l}0.5 \\
0.5 \\
0.5 \\
0.5 \\
0.5\end{array}$ & $\begin{array}{l}0.00 \\
0.00 \\
0.00 \\
0.00 \\
0.01\end{array}$ & $\begin{array}{l}0255 \\
0300 \\
0305 \\
0310 \\
0315\end{array}$ & $\begin{array}{l}18.8 \\
18.2 \\
17.5 \\
16.9 \\
16.3\end{array}$ & $\begin{array}{l}0.02 \\
0.02 \\
0.02 \\
0.02 \\
0.01\end{array}$ & $\begin{array}{l}0650 \\
0655 \\
0700 \\
0705 \\
0710\end{array}$ & $\begin{array}{l}2.5 \\
2.2 \\
2.2 \\
2.2 \\
2.2\end{array}$ & $\begin{array}{l}0.00 \\
0.00 \\
0.00 \\
0.00 \\
0.00\end{array}$ \\
\hline $\begin{array}{l}2330 \\
2335 \\
2340 \\
2345 \\
2350\end{array}$ & & $\begin{array}{l}0.5 \\
0.5 \\
0.5 \\
0.5 \\
0.5\end{array}$ & $\begin{array}{l}0.00 \\
0.01 \\
0.02 \\
0.01 \\
0.00\end{array}$ & $\begin{array}{l}0320 \\
0325 \\
0330 \\
0335 \\
0340\end{array}$ & $\begin{array}{l}16.3 \\
15.1 \\
15.7 \\
15.1 \\
14.5\end{array}$ & $\begin{array}{l}0.01 \\
0.01 \\
0.01 \\
0.01 \\
0.01\end{array}$ & $\begin{array}{l}0715 \\
0720 \\
0725 \\
0730 \\
0735\end{array}$ & $\begin{array}{l}2.2 \\
2.2 \\
1.8 \\
1.8 \\
1.8\end{array}$ & $\begin{array}{l}0.00 \\
0.00 \\
0.00 \\
0.00 \\
0.00\end{array}$ \\
\hline $\begin{array}{l}2355 \\
\text { June } 19 \\
0000 \\
0005 \\
0010\end{array}$ & 1987 & $\begin{array}{l}0.5 \\
0.5 \\
0.5 \\
0.5\end{array}$ & $\begin{array}{l}0.00 \\
0.00 \\
0.00 \\
0.00\end{array}$ & $\begin{array}{l}0345 \\
0350 \\
0355 \\
0400 \\
0405\end{array}$ & $\begin{array}{l}13.9 \\
13.9 \\
13.4 \\
12.3 \\
11.8\end{array}$ & $\begin{array}{l}0.01 \\
0.00 \\
0.01 \\
0.00 \\
0.01\end{array}$ & $\begin{array}{l}0740 \\
0745 \\
0750 \\
0755 \\
0800\end{array}$ & $\begin{array}{l}1.8 \\
1.8 \\
1.6 \\
1.6 \\
1.6\end{array}$ & $\begin{array}{l}0.00 \\
0.00 \\
0.00 \\
0.00 \\
0.00\end{array}$ \\
\hline $\begin{array}{l}0015 \\
0020 \\
0025 \\
0030 \\
0035\end{array}$ & & $\begin{array}{l}3.1 \\
9.4 \\
9.0 \\
6.2 \\
6.6\end{array}$ & $\begin{array}{l}0.01 \\
0.00 \\
0.07 \\
0.20 \\
0.10\end{array}$ & $\begin{array}{l}0410 \\
0415 \\
0420 \\
0425 \\
0430\end{array}$ & $\begin{array}{r}11.3 \\
10.8 \\
10.3 \\
9.9 \\
9.4\end{array}$ & $\begin{array}{l}0.01 \\
0.00 \\
0.01 \\
0.00 \\
0.00\end{array}$ & $\begin{array}{l}0805 \\
0810 \\
0815 \\
0820 \\
0825\end{array}$ & $\begin{array}{l}1.6 \\
1.6 \\
1.6 \\
1.6 \\
1.6\end{array}$ & $\begin{array}{l}0.00 \\
0.00 \\
0.00 \\
0.00 \\
0.00\end{array}$ \\
\hline $\begin{array}{l}0040 \\
0045 \\
0050 \\
0055 \\
0100\end{array}$ & & $\begin{array}{l}19.5 \\
23.6 \\
25.4 \\
29.3 \\
28.8\end{array}$ & $\begin{array}{l}0.12 \\
0.13 \\
0.13 \\
0.06 \\
0.06\end{array}$ & $\begin{array}{l}0435 \\
0440 \\
0445 \\
0450 \\
0455\end{array}$ & $\begin{array}{l}8.5 \\
8.1 \\
7.7 \\
7.3 \\
7.3\end{array}$ & $\begin{array}{l}0.01 \\
0.00 \\
0.00 \\
0.00 \\
0.00\end{array}$ & $\begin{array}{l}0830 \\
0835 \\
0840 \\
0845 \\
0850\end{array}$ & $\begin{array}{l}1.6 \\
1.6 \\
1.5 \\
1.5 \\
1.5\end{array}$ & $\begin{array}{l}0.00 \\
0.00 \\
0.00 \\
0.00 \\
0.00\end{array}$ \\
\hline $\begin{array}{l}0105 \\
0110\end{array}$ & & $\begin{array}{l}28.8 \\
34.5\end{array}$ & $\begin{array}{l}0.06 \\
0.06\end{array}$ & $\begin{array}{l}0500 \\
0505\end{array}$ & $\begin{array}{l}6.9 \\
6.6\end{array}$ & $\begin{array}{l}0.00 \\
0.00\end{array}$ & $\begin{array}{l}0855 \\
0900\end{array}$ & $\begin{array}{l}1.5 \\
1.5\end{array}$ & $\begin{array}{l}0.00 \\
0.00\end{array}$ \\
\hline
\end{tabular}




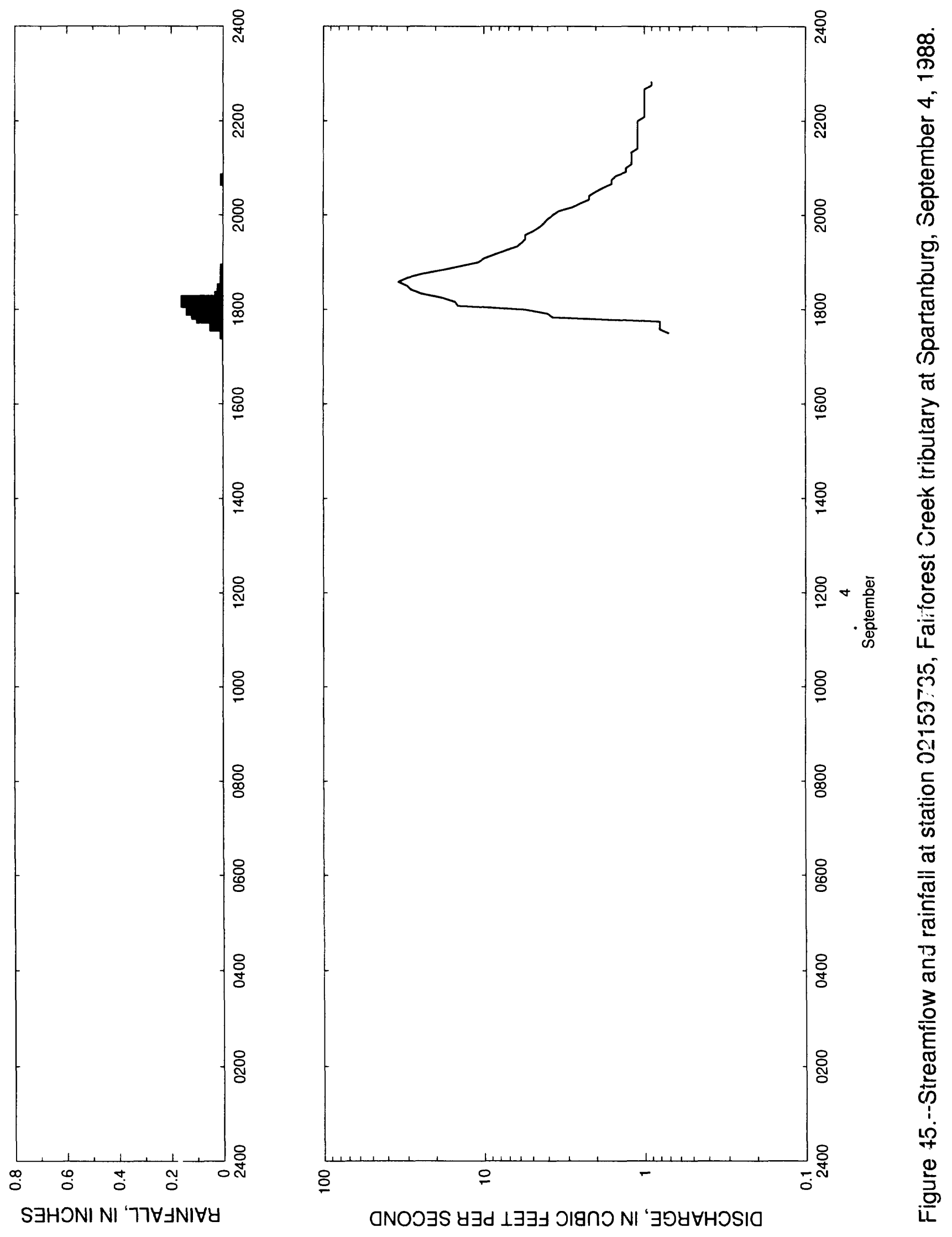


Table 44.--Streamflow and rainfall at station 02159785 , Fairforest Creek tributary at Spartanburg, September 4,1988

\begin{tabular}{|c|c|c|c|c|c|c|c|c|}
\hline $\begin{array}{l}\text { Time } \\
\text { (hours) }\end{array}$ & $\begin{array}{l}\text { Streamflow } \\
\text { (cubic feet } \\
\text { per second) }\end{array}$ & $\begin{array}{l}\text { Rain- } \\
\text { fall } \\
\text { (inches) }\end{array}$ & $\begin{array}{l}\text { Time } \\
\text { (hours) }\end{array}$ & $\begin{array}{l}\text { Streamflow } \\
\text { (cubic feet } \\
\text { per second) }\end{array}$ & $\begin{array}{l}\text { Rain- } \\
\text { fall } \\
\text { (inches) }\end{array}$ & $\begin{array}{l}\text { Time } \\
\text { (hours) }\end{array}$ & $\begin{array}{l}\text { Streamflow } \\
\text { (cubic feet } \\
\text { per second) }\end{array}$ & $\begin{array}{l}\text { Rain- } \\
\text { fall } \\
\text { (inches) }\end{array}$ \\
\hline $\begin{array}{c}\text { September } \\
1730 \\
1735 \\
1740 \\
1745\end{array}$ & $\begin{array}{r}1988 \\
0.7 \\
0.8 \\
0.8 \\
0.8\end{array}$ & $\begin{array}{l}0.01 \\
0.01 \\
0.05 \\
0.02\end{array}$ & $\begin{array}{l}1920 \\
1925 \\
1930 \\
1935 \\
1940\end{array}$ & $\begin{array}{l}6.2 \\
5.8 \\
5.5 \\
5.5 \\
4.9\end{array}$ & $\begin{array}{l}0.00 \\
0.00 \\
0.00 \\
0.00 \\
0.00\end{array}$ & $\begin{array}{l}2115 \\
2120 \\
2125 \\
2130 \\
2135\end{array}$ & $\begin{array}{l}1.2 \\
1.2 \\
1.1 \\
1.1 \\
1.1\end{array}$ & $\begin{array}{l}0.00 \\
0.00 \\
0.00 \\
0.00 \\
0.00\end{array}$ \\
\hline $\begin{array}{l}1750 \\
1755 \\
1800 \\
1805 \\
1810\end{array}$ & $\begin{array}{r}3.7 \\
4.0 \\
5.5 \\
14.5 \\
15.1\end{array}$ & $\begin{array}{l}0.10 \\
0.12 \\
0.14 \\
0.14 \\
0.16\end{array}$ & $\begin{array}{l}1945 \\
1950 \\
1955 \\
2000 \\
2005\end{array}$ & $\begin{array}{l}4.5 \\
4.2 \\
4.0 \\
3.7 \\
3.4\end{array}$ & $\begin{array}{l}0.00 \\
0.00 \\
0.00 \\
0.00 \\
0.00\end{array}$ & $\begin{array}{l}2140 \\
2145 \\
2150 \\
2155 \\
2200\end{array}$ & $\begin{array}{l}1.1 \\
1.1 \\
1.1 \\
1.1 \\
1.1\end{array}$ & $\begin{array}{l}0.00 \\
0.00 \\
0.00 \\
0.00 \\
0.00\end{array}$ \\
\hline $\begin{array}{l}1815 \\
1820 \\
1825 \\
1830 \\
1835\end{array}$ & $\begin{array}{l}18.2 \\
24.3 \\
28.2 \\
29.9 \\
34.0\end{array}$ & $\begin{array}{l}0.03 \\
0.02 \\
0.02 \\
0.00 \\
0.01\end{array}$ & $\begin{array}{l}2010 \\
2015 \\
2020 \\
2025 \\
2030\end{array}$ & $\begin{array}{l}2.8 \\
2.5 \\
2.2 \\
2.2 \\
2.0\end{array}$ & $\begin{array}{l}0.00 \\
0.00 \\
0.00 \\
0.00 \\
0.00\end{array}$ & $\begin{array}{l}2205 \\
2210 \\
2215 \\
2220 \\
2225\end{array}$ & $\begin{array}{l}1.0 \\
1.0 \\
1.0 \\
1.0 \\
1.0\end{array}$ & $\begin{array}{l}0.00 \\
0.00 \\
0.00 \\
0.00 \\
0.00\end{array}$ \\
\hline $\begin{array}{l}1840 \\
1845 \\
1850 \\
1855 \\
1900\end{array}$ & $\begin{array}{l}29.9 \\
24.3 \\
18.2 \\
13.9 \\
10.8\end{array}$ & $\begin{array}{l}0.00 \\
0.00 \\
0.01 \\
0.00 \\
0.00\end{array}$ & $\begin{array}{l}2035 \\
2040 \\
2045 \\
2050 \\
2055\end{array}$ & $\begin{array}{l}1.8 \\
1.6 \\
1.6 \\
1.5 \\
1.3\end{array}$ & $\begin{array}{l}0.00 \\
0.00 \\
0.01 \\
0.00 \\
0.00\end{array}$ & $\begin{array}{l}2230 \\
2235 \\
2240 \\
2245 \\
2250\end{array}$ & $\begin{array}{l}1.0 \\
1.0 \\
1.0 \\
0.9 \\
0.9\end{array}$ & $\begin{array}{l}0.00 \\
0.00 \\
0.00 \\
0.00 \\
0.00\end{array}$ \\
\hline $\begin{array}{l}1905 \\
1910 \\
1915\end{array}$ & $\begin{array}{l}9.9 \\
8.5 \\
7.3\end{array}$ & $\begin{array}{l}0.00 \\
0.00 \\
0.00\end{array}$ & $\begin{array}{l}2100 \\
2105 \\
2110\end{array}$ & $\begin{array}{l}1.3 \\
1.2 \\
1.2\end{array}$ & $\begin{array}{l}0.00 \\
0.00 \\
0.00\end{array}$ & $\begin{array}{l}2255 \\
2300\end{array}$ & $\begin{array}{l}0.9 \\
0.9\end{array}$ & $\begin{array}{l}0.00 \\
0.00\end{array}$ \\
\hline
\end{tabular}



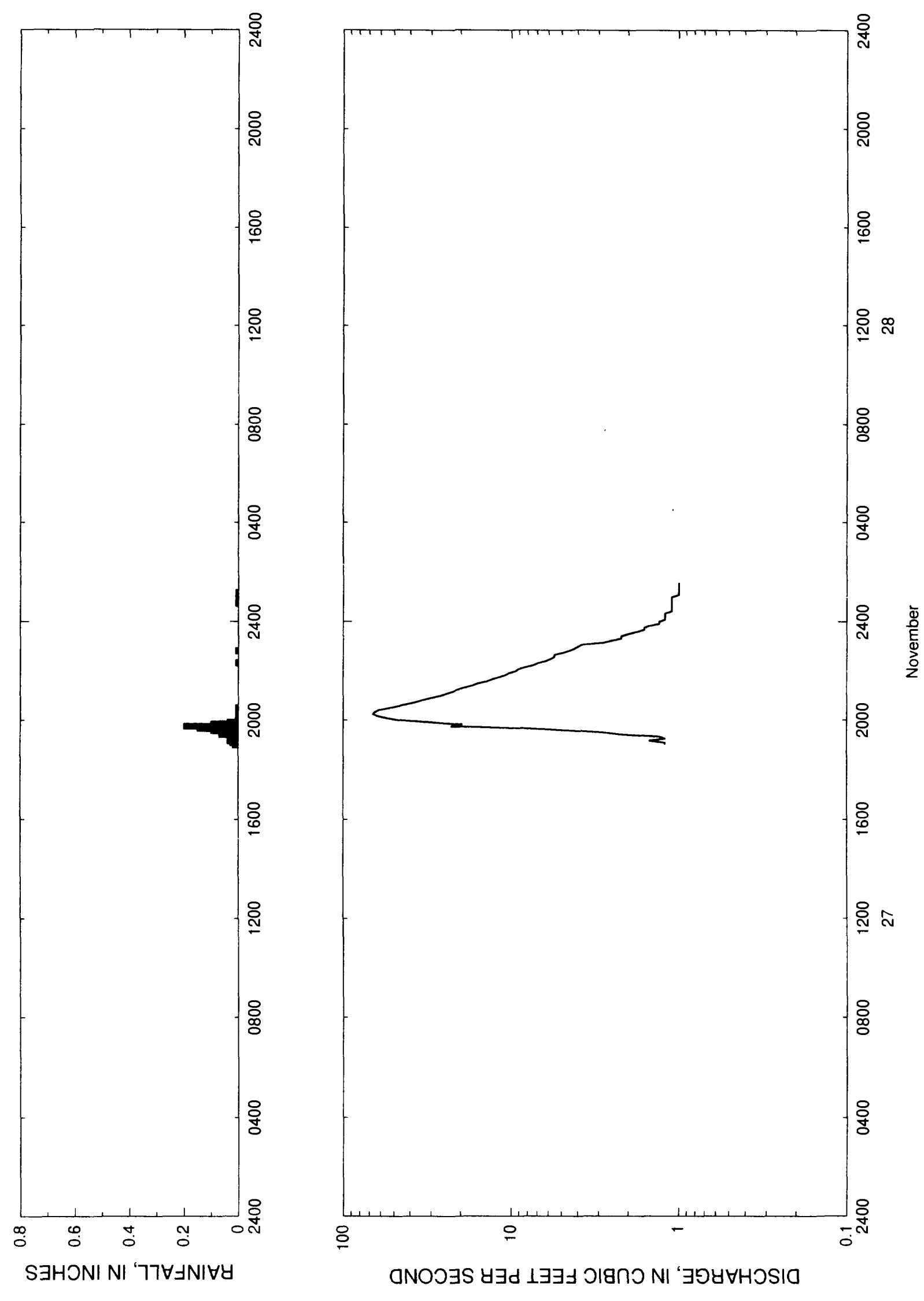

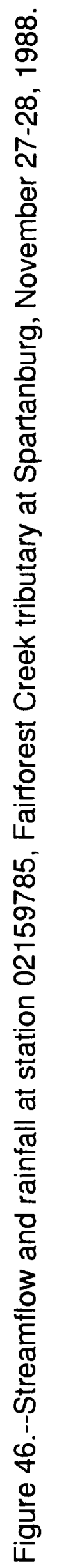


Table 45. - Streamflow and rainfa11 at station 02159785, Fairforest Creek tributary at Spartanburg, November $27-28,1988$

\begin{tabular}{|c|c|c|c|c|c|c|c|c|c|c|}
\hline $\begin{array}{l}\text { Time } \\
\text { (hours) }\end{array}$ & $\begin{array}{l}\text { Str } \\
\text { (cub } \\
\text { per }\end{array}$ & $\begin{array}{l}\text { reamflow } \\
\text { bic feet } \\
\text { second) }\end{array}$ & $\begin{array}{l}\text { Rain- } \\
\text { fall } \\
\text { (inches) }\end{array}$ & $\begin{array}{l}\text { Time } \\
\text { (hours) }\end{array}$ & $\begin{array}{l}\text { Streamflow } \\
\text { (cubic feet } \\
\text { per second) }\end{array}$ & $\begin{array}{l}\text { Rain- } \\
\text { fall } \\
\text { (inches) }\end{array}$ & $\begin{array}{l}\text { Time } \\
\text { (hours) }\end{array}$ & $\begin{array}{l}\text { Str } \\
\text { (cub } \\
\text { per }\end{array}$ & $\begin{array}{l}\text { reamflow } \\
\text { bic feet } \\
\text { second) }\end{array}$ & $\begin{array}{l}\text { Rain- } \\
\text { fall } \\
\text { (inches) }\end{array}$ \\
\hline $\begin{array}{l}\text { November } \\
1900 \\
1905 \\
1910 \\
1915\end{array}$ & 27 & $\begin{array}{r}1988 \\
1.2 \\
1.2 \\
1.5 \\
1.2\end{array}$ & $\begin{array}{l}0.02 \\
0.03 \\
0.04 \\
0.02\end{array}$ & $\begin{array}{l}2120 \\
2125 \\
2130 \\
2135 \\
2140\end{array}$ & $\begin{array}{l}18.8 \\
16.9 \\
15.7 \\
13.9 \\
12.9\end{array}$ & $\begin{array}{l}0.00 \\
0.00 \\
0.00 \\
0.00 \\
0.00\end{array}$ & $\begin{array}{c}2345 \\
2350 \\
2355 \\
\text { November } \\
0000\end{array}$ & 28 & $\begin{array}{r}1.6 \\
1.5 \\
1.3 \\
1988 \\
1.3\end{array}$ & $\begin{array}{l}0.00 \\
0.00 \\
0.00 \\
0.00\end{array}$ \\
\hline $\begin{array}{l}1920 \\
1925 \\
1930 \\
1935 \\
1940\end{array}$ & & $\begin{array}{l}1.3 \\
2.2 \\
2.8 \\
4.5 \\
8.1\end{array}$ & $\begin{array}{l}0.02 \\
0.07 \\
0.05 \\
0.10 \\
0.15\end{array}$ & $\begin{array}{l}2145 \\
2150 \\
2155 \\
2200 \\
2205\end{array}$ & $\begin{array}{r}11.8 \\
10.8 \\
10.3 \\
9.4 \\
9.0\end{array}$ & $\begin{array}{l}0.00 \\
0.00 \\
0.00 \\
0.00 \\
0.00\end{array}$ & $\begin{array}{l}0005 \\
0010 \\
0015 \\
0020 \\
0025\end{array}$ & & $\begin{array}{l}1.2 \\
1.2 \\
1.2 \\
1.2 \\
1.1\end{array}$ & $\begin{array}{l}0.00 \\
0.00 \\
0.00 \\
0.00 \\
0.00\end{array}$ \\
\hline $\begin{array}{l}1945 \\
1950 \\
1955 \\
2000 \\
2005\end{array}$ & & $\begin{array}{l}22.9 \\
19.5 \\
29.3 \\
45.9 \\
54.5\end{array}$ & $\begin{array}{l}0.20 \\
0.10 \\
0.04 \\
0.00 \\
0.01\end{array}$ & $\begin{array}{l}2210 \\
2215 \\
2220 \\
2225 \\
2230\end{array}$ & $\begin{array}{l}8.1 \\
7.3 \\
6.9 \\
6.2 \\
5.8\end{array}$ & $\begin{array}{l}0.00 \\
0.00 \\
0.01 \\
0.00 \\
0.00\end{array}$ & $\begin{array}{l}0030 \\
0035 \\
0040 \\
0045 \\
0050\end{array}$ & & $\begin{array}{l}1.1 \\
1.1 \\
1.1 \\
1.1 \\
1.1\end{array}$ & $\begin{array}{l}0.00 \\
0.00 \\
0.00 \\
0.01 \\
0.01\end{array}$ \\
\hline $\begin{array}{l}2010 \\
2015 \\
2020 \\
2025 \\
2030\end{array}$ & & $\begin{array}{l}62.3 \\
66.5 \\
64.8 \\
61.5 \\
53.3\end{array}$ & $\begin{array}{l}0.00 \\
0.00 \\
0.01 \\
0.01 \\
0.01\end{array}$ & $\begin{array}{l}2235 \\
2240 \\
2245 \\
2250 \\
2255\end{array}$ & $\begin{array}{l}5.5 \\
5.5 \\
4.9 \\
4.5 \\
4.2\end{array}$ & $\begin{array}{l}0.00 \\
0.00 \\
0.00 \\
0.01 \\
0.00\end{array}$ & $\begin{array}{l}0055 \\
0100 \\
0105 \\
0110 \\
0115\end{array}$ & & $\begin{array}{l}1.1 \\
1.1 \\
1.0 \\
1.0 \\
1.0\end{array}$ & $\begin{array}{l}0.01 \\
0.01 \\
0.01 \\
0.01 \\
0.00\end{array}$ \\
\hline $\begin{array}{l}2035 \\
2040 \\
2045 \\
2050 \\
2055\end{array}$ & & $\begin{array}{l}47.1 \\
41.3 \\
36.4 \\
33.5 \\
29.9\end{array}$ & $\begin{array}{l}0.00 \\
0.00 \\
0.00 \\
0.00 \\
0.00\end{array}$ & $\begin{array}{l}2300 \\
2305 \\
2310 \\
2315 \\
2320\end{array}$ & $\begin{array}{l}4.0 \\
3.7 \\
2.8 \\
2.5 \\
2.2\end{array}$ & $\begin{array}{l}0.00 \\
0.00 \\
0.00 \\
0.00 \\
0.00\end{array}$ & $\begin{array}{l}0120 \\
0125 \\
0130 \\
0135 \\
0140\end{array}$ & & $\begin{array}{l}1.0 \\
1.0 \\
1.0 \\
1.0 \\
1.0\end{array}$ & $\begin{array}{l}0.00 \\
0.00 \\
0.00 \\
0.00 \\
0.00\end{array}$ \\
\hline $\begin{array}{l}2100 \\
2105 \\
2110 \\
2115\end{array}$ & & $\begin{array}{l}26.5 \\
24.3 \\
22.3 \\
20.9\end{array}$ & $\begin{array}{l}0.00 \\
0.00 \\
0.00 \\
0.00\end{array}$ & $\begin{array}{l}2325 \\
2330 \\
2335 \\
2340\end{array}$ & $\begin{array}{l}2.2 \\
2.0 \\
1.8 \\
1.6\end{array}$ & $\begin{array}{l}0.00 \\
0.00 \\
0.00 \\
0.00\end{array}$ & 0145 & & 0.9 & 0.00 \\
\hline
\end{tabular}




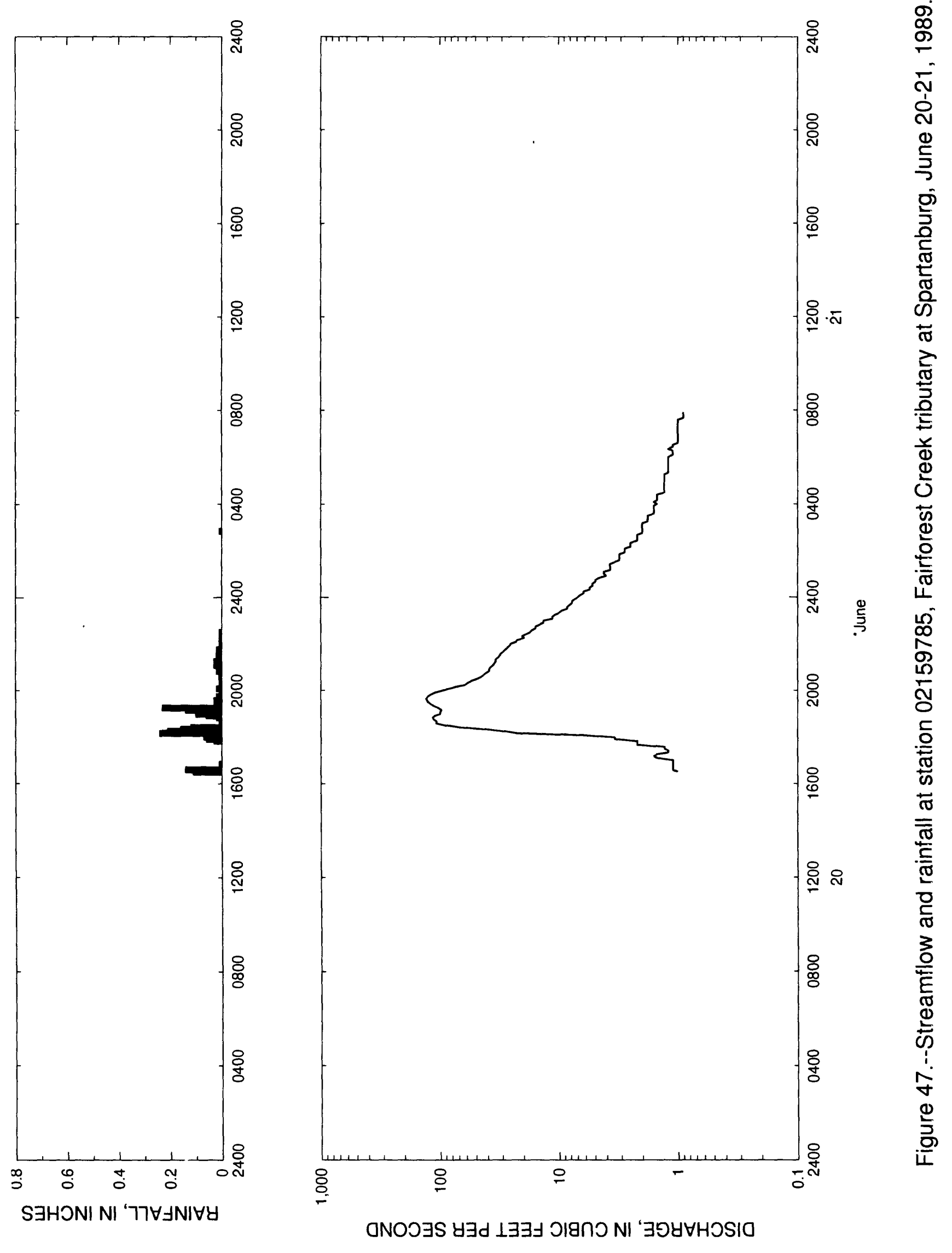


Table 46.--Streamflow and rainfall at station 02159785, Fairforest Creek tributary at Spartanburg. June $20-21,1989$

\begin{tabular}{|c|c|c|c|c|c|c|c|c|}
\hline $\begin{array}{l}\text { Time } \\
\text { (hours) }\end{array}$ & $\begin{array}{l}\text { Streamflow } \\
\text { (cubic feet } \\
\text { per second) }\end{array}$ & $\begin{array}{l}\text { Rain- } \\
\text { fall } \\
\text { (inches) }\end{array}$ & $\begin{array}{l}\text { Time } \\
\text { (hours) }\end{array}$ & $\begin{array}{l}\text { Streamflow } \\
\text { (cubic feet } \\
\text { per second) }\end{array}$ & $\begin{array}{l}\text { Rain- } \\
\text { fall } \\
\text { (inches) }\end{array}$ & $\begin{array}{l}\text { Time } \\
\text { (hours) }\end{array}$ & $\begin{array}{l}\text { Streamflow } \\
\text { (cubic feet } \\
\text { per second) }\end{array}$ & $\begin{array}{l}\text { Rain- } \\
\text { fall } \\
\text { (inches) }\end{array}$ \\
\hline $\begin{array}{l}\text { June } 20 \\
1630 \\
1635 \\
1640 \\
1645\end{array}$ & $\begin{array}{l}1989 \\
\begin{array}{l}1.0 \\
1.1 \\
1.1 \\
1.1\end{array}\end{array}$ & $\begin{array}{l}0.11 \\
0.14 \\
0.01 \\
0.00\end{array}$ & $\begin{array}{l}2140 \\
2145 \\
2150 \\
2155 \\
2200\end{array}$ & $\begin{array}{l}29.3 \\
28.2 \\
27.1 \\
26.0 \\
25.4\end{array}$ & $\begin{array}{l}0.00 \\
0.02 \\
0.00 \\
0.01 \\
0.00\end{array}$ & $\begin{array}{l}0250 \\
0255 \\
0300 \\
0305 \\
0310\end{array}$ & $\begin{array}{l}2.0 \\
2.0 \\
2.0 \\
2.0 \\
2.0\end{array}$ & $\begin{array}{l}0.01 \\
0.00 \\
0.00 \\
0.00 \\
0.00\end{array}$ \\
\hline $\begin{array}{l}1650 \\
1655 \\
1700 \\
1705 \\
1710\end{array}$ & $\begin{array}{l}1.1 \\
1 \cdot 1 \\
1.1 \\
1.5 \\
1.6\end{array}$ & $\begin{array}{l}0.01 \\
0.00 \\
0.00 \\
0.00 \\
0.00\end{array}$ & $\begin{array}{l}2205 \\
2210 \\
2215 \\
2220 \\
2225\end{array}$ & $\begin{array}{l}22.9 \\
22.3 \\
19.5 \\
20.2 \\
18.8\end{array}$ & $\begin{array}{l}0.01 \\
0.00 \\
0.01 \\
0.00 \\
0.00\end{array}$ & $\begin{array}{l}0315 \\
0320 \\
0325 \\
0330 \\
0335\end{array}$ & $\begin{array}{l}1.8 \\
1.8 \\
1.8 \\
1.8 \\
1.6\end{array}$ & $\begin{array}{l}0.00 \\
0.00 \\
0.00 \\
0.00 \\
0.00\end{array}$ \\
\hline $\begin{array}{l}1715 \\
1720 \\
1725 \\
1730 \\
1735\end{array}$ & $\begin{array}{l}1.5 \\
1.2 \\
1.2 \\
1.3 \\
1.3\end{array}$ & $\begin{array}{l}0.00 \\
0.00 \\
0.00 \\
0.00 \\
0.00\end{array}$ & $\begin{array}{l}2230 \\
2235 \\
2240 \\
2245 \\
2250\end{array}$ & $\begin{array}{l}17.5 \\
16.9 \\
15.7 \\
15.7 \\
14.5\end{array}$ & $\begin{array}{l}0.01 \\
0.00 \\
0.00 \\
0.00 \\
0.00\end{array}$ & $\begin{array}{l}0340 \\
0345 \\
0350 \\
0355 \\
0400\end{array}$ & $\begin{array}{l}1.6 \\
1.6 \\
1.6 \\
1.6 \\
1.5\end{array}$ & $\begin{array}{l}0.00 \\
0.00 \\
0.00 \\
0.00 \\
0.00\end{array}$ \\
\hline $\begin{array}{l}1740 \\
1745 \\
1750 \\
1755 \\
1800\end{array}$ & $\begin{array}{l}2.2 \\
2.2 \\
2.2 \\
3.4 \\
3.4\end{array}$ & $\begin{array}{l}0.00 \\
0.00 \\
0.03 \\
0.06 \\
0.07\end{array}$ & $\begin{array}{l}2255 \\
2300 \\
2305 \\
2310 \\
2315\end{array}$ & $\begin{array}{l}13.4 \\
13.4 \\
11.3 \\
11.3 \\
10.8\end{array}$ & $\begin{array}{l}0.00 \\
0.00 \\
0.00 \\
0.00 \\
0.00\end{array}$ & $\begin{array}{l}0405 \\
0410 \\
0415 \\
0420 \\
0425\end{array}$ & $\begin{array}{l}1.6 \\
1.5 \\
1.5 \\
1.5 \\
1.5\end{array}$ & $\begin{array}{l}0.00 \\
0.00 \\
0.00 \\
0.00 \\
0.00\end{array}$ \\
\hline $\begin{array}{l}1805 \\
1810 \\
1815 \\
1820 \\
1825\end{array}$ & $\begin{array}{r}6.2 \\
22.3 \\
28.8 \\
40.4 \\
66.1\end{array}$ & $\begin{array}{l}0.04 \\
0.24 \\
0.21 \\
0.16 \\
0.12\end{array}$ & $\begin{array}{l}2320 \\
2325 \\
2330 \\
2335 \\
2340\end{array}$ & $\begin{array}{l}9.9 \\
9.4 \\
8.5 \\
8.5 \\
8.1\end{array}$ & $\begin{array}{l}0.00 \\
0.00 \\
0.00 \\
0.00 \\
0.00\end{array}$ & $\begin{array}{l}0430 \\
0435 \\
0440 \\
0445 \\
0450\end{array}$ & $\begin{array}{l}1 \cdot 3 \\
1 \cdot 3 \\
1 \cdot 3 \\
1 \cdot 3 \\
1 \cdot 3\end{array}$ & $\begin{array}{l}0.00 \\
0.00 \\
0.00 \\
0.00 \\
0.00\end{array}$ \\
\hline $\begin{array}{l}1830 \\
1835 \\
1840 \\
1845 \\
1850\end{array}$ & $\begin{array}{r}90.7 \\
108.0 \\
107.0 \\
113.0 \\
115.0\end{array}$ & $\begin{array}{l}0.01 \\
0.01 \\
0.00 \\
0.01 \\
0.02\end{array}$ & $\begin{array}{l}2345 \\
2350 \\
2355 \\
\text { June } 21 \\
0000\end{array}$ & $\begin{array}{r}7.7 \\
7.7 \\
7.3 \\
1989 \\
\quad 6.9\end{array}$ & $\begin{array}{l}0.00 \\
0.00 \\
0.00 \\
0.00\end{array}$ & $\begin{array}{l}0455 \\
0500 \\
0505 \\
0510 \\
0515\end{array}$ & $\begin{array}{l}1 \cdot 3 \\
1 \cdot 3 \\
1 \cdot 3 \\
1 \cdot 3 \\
1 \cdot 3\end{array}$ & $\begin{array}{l}0.00 \\
0.00 \\
0.00 \\
0.00 \\
0.00\end{array}$ \\
\hline $\begin{array}{l}1855 \\
1900 \\
1905 \\
1910 \\
1915\end{array}$ & $\begin{array}{r}111.0 \\
99.6 \\
99.6 \\
97.0 \\
103.0\end{array}$ & $\begin{array}{l}0.06 \\
0.10 \\
0.07 \\
0.14 \\
0.23\end{array}$ & $\begin{array}{l}0005 \\
0010 \\
0015 \\
0020 \\
0025\end{array}$ & $\begin{array}{l}6.6 \\
6.2 \\
6.2 \\
5.5 \\
5.5\end{array}$ & $\begin{array}{l}0.00 \\
0.00 \\
0.00 \\
0.00 \\
0.00\end{array}$ & $\begin{array}{l}0520 \\
0525 \\
0530 \\
0535 \\
0540\end{array}$ & $\begin{array}{l}1.2 \\
1.2 \\
1.2 \\
1.2 \\
1.2\end{array}$ & $\begin{array}{l}0.00 \\
0.00 \\
0.00 \\
0.00 \\
0.00\end{array}$ \\
\hline $\begin{array}{l}1920 \\
1925 \\
1930 \\
1935 \\
1940\end{array}$ & $\begin{array}{l}112.0 \\
120.0 \\
126.0 \\
129.0 \\
130.0\end{array}$ & $\begin{array}{l}0.01 \\
0.03 \\
0.00 \\
0.03 \\
0.02\end{array}$ & $\begin{array}{l}0030 \\
0035 \\
0040 \\
0045 \\
0050\end{array}$ & $\begin{array}{l}5.2 \\
5.2 \\
4.9 \\
4.9 \\
4.5\end{array}$ & $\begin{array}{l}0.00 \\
0.00 \\
0.00 \\
0.00 \\
0.00\end{array}$ & $\begin{array}{l}0545 \\
0550 \\
0555 \\
0600 \\
0605\end{array}$ & $\begin{array}{l}1.2 \\
1.2 \\
1.2 \\
1.2 \\
1.1\end{array}$ & $\begin{array}{l}0.00 \\
0.00 \\
0.00 \\
0.00 \\
0.00\end{array}$ \\
\hline $\begin{array}{l}1945 \\
1950 \\
1955 \\
2000 \\
2005\end{array}$ & $\begin{array}{r}126.0 \\
119.0 \\
110.0 \\
96.6 \\
82.7\end{array}$ & $\begin{array}{l}0.02 \\
0.01 \\
0.01 \\
0.01 \\
0.02\end{array}$ & $\begin{array}{l}0055 \\
0100 \\
0105 \\
0110 \\
0115\end{array}$ & $\begin{array}{l}4.0 \\
4.2 \\
4.2 \\
3.7 \\
3.7\end{array}$ & $\begin{array}{l}0.00 \\
0.00 \\
0.00 \\
0.00 \\
0.00\end{array}$ & $\begin{array}{l}0610 \\
0615 \\
0620 \\
0625 \\
0630\end{array}$ & $\begin{array}{l}1.1 \\
1.1 \\
1.2 \\
1.1 \\
1.1\end{array}$ & $\begin{array}{l}0.00 \\
0.00 \\
0.00 \\
0.00 \\
0.00\end{array}$ \\
\hline $\begin{array}{l}2010 \\
2015 \\
2020 \\
2025 \\
2030\end{array}$ & $\begin{array}{l}73.1 \\
61.5 \\
57.8 \\
54.1 \\
48.8\end{array}$ & $\begin{array}{l}0.00 \\
0.01 \\
0.01 \\
0.00 \\
0.01\end{array}$ & $\begin{array}{l}0120 \\
0125 \\
0130 \\
0135 \\
0140\end{array}$ & $\begin{array}{l}3.7 \\
3.7 \\
3.4 \\
3.1 \\
3.1\end{array}$ & $\begin{array}{l}0.00 \\
0.00 \\
0.00 \\
0.00 \\
0.00\end{array}$ & $\begin{array}{l}0635 \\
0640 \\
0645 \\
0650 \\
0655\end{array}$ & $\begin{array}{l}1.0 \\
1.0 \\
1.0 \\
1.0 \\
1.0\end{array}$ & $\begin{array}{l}0.00 \\
0.00 \\
0.00 \\
0.00 \\
0.00\end{array}$ \\
\hline $\begin{array}{l}2035 \\
2040 \\
2045 \\
2050 \\
2055\end{array}$ & $\begin{array}{l}45.1 \\
43.0 \\
40.9 \\
38.6 \\
38.6\end{array}$ & $\begin{array}{l}0.00 \\
0.01 \\
0.00 \\
0.02 \\
0.01\end{array}$ & $\begin{array}{l}0145 \\
0150 \\
0155 \\
0200 \\
0205\end{array}$ & $\begin{array}{l}3.1 \\
3.1 \\
2.8 \\
2.8 \\
2.8\end{array}$ & $\begin{array}{l}0.00 \\
0.00 \\
0.00 \\
0.00 \\
0.00\end{array}$ & $\begin{array}{l}0700 \\
0705 \\
0710 \\
0715 \\
0720\end{array}$ & $\begin{array}{l}1.0 \\
1.0 \\
1.0 \\
1.0 \\
1.0\end{array}$ & $\begin{array}{l}0.00 \\
0.00 \\
0.00 \\
0.00 \\
0.00\end{array}$ \\
\hline $\begin{array}{l}2100 \\
2105 \\
2110 \\
2115 \\
2120\end{array}$ & $\begin{array}{l}37.7 \\
35.9 \\
35.0 \\
34.0 \\
34.0\end{array}$ & $\begin{array}{l}0.02 \\
0.03 \\
0.01 \\
0.03 \\
0.01\end{array}$ & $\begin{array}{l}0210 \\
0215 \\
0220 \\
0225 \\
0230\end{array}$ & $\begin{array}{l}2.5 \\
2.5 \\
2.5 \\
2.2 \\
2.2\end{array}$ & $\begin{array}{l}0.00 \\
0.00 \\
0.00 \\
0.00 \\
0.00\end{array}$ & $\begin{array}{l}0725 \\
0730 \\
0735 \\
0740 \\
0745\end{array}$ & $\begin{array}{l}1.0 \\
1.0 \\
1.0 \\
0.9 \\
0.9\end{array}$ & $\begin{array}{l}0.00 \\
0.00 \\
0.00 \\
0.00 \\
0.00\end{array}$ \\
\hline $\begin{array}{l}2125 \\
2130 \\
2135\end{array}$ & $\begin{array}{l}32.5 \\
31.5 \\
31.0\end{array}$ & $\begin{array}{l}0.01 \\
0.02 \\
0.02\end{array}$ & $\begin{array}{l}0235 \\
0240 \\
0245\end{array}$ & $\begin{array}{l}2.2 \\
2.2 \\
2.0\end{array}$ & $\begin{array}{l}0.00 \\
0.00 \\
0.00\end{array}$ & $\begin{array}{l}0750 \\
0755 \\
0800\end{array}$ & $\begin{array}{l}0.9 \\
0.9 \\
0.9\end{array}$ & $\begin{array}{l}0.00 \\
0.00 \\
0.00\end{array}$ \\
\hline
\end{tabular}




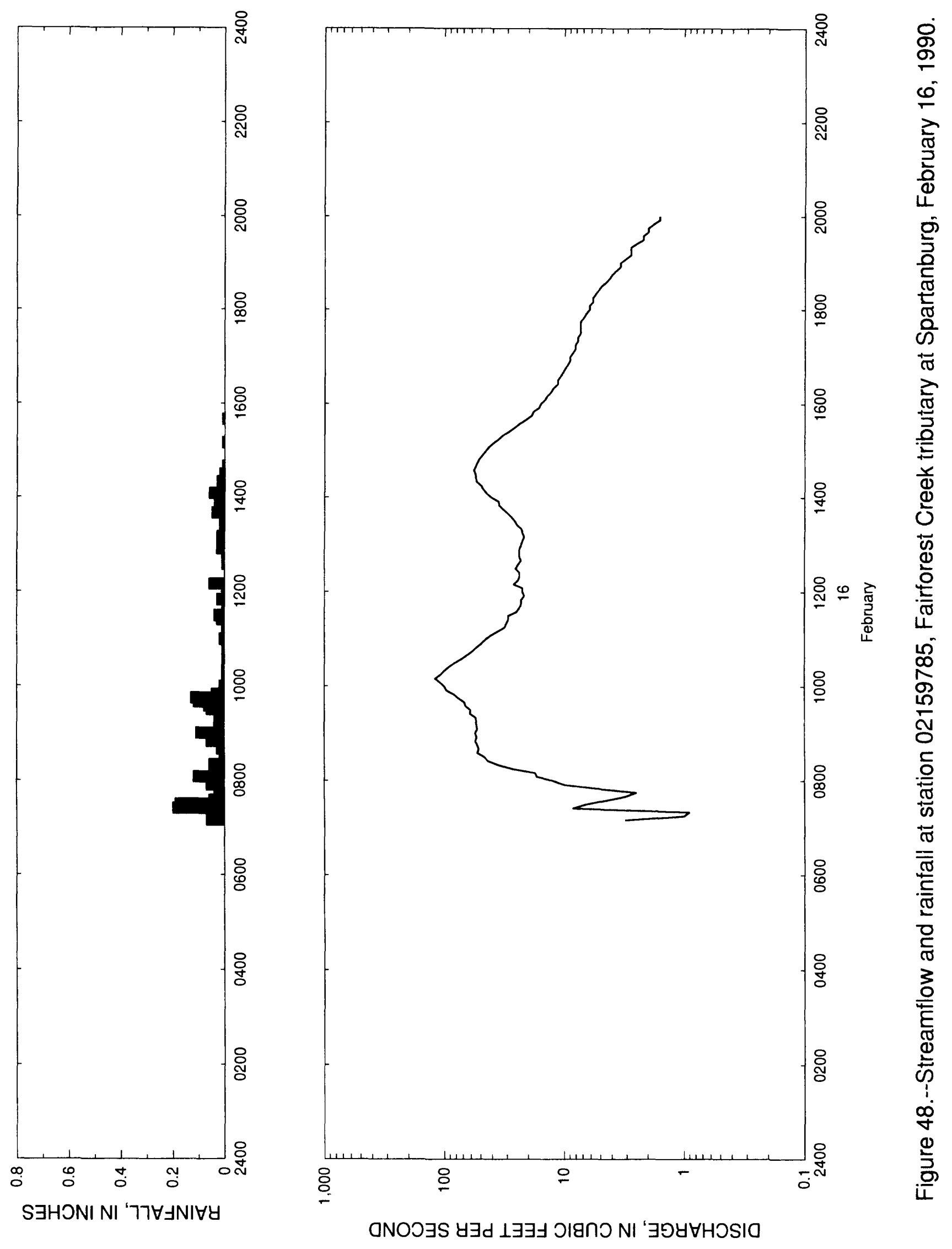


Table 47. - Streamflow and rainfall at station 02159785, Fairforest Creek tributary at Spartanburg, February 16, 1990

\begin{tabular}{|c|c|c|c|c|c|c|c|c|}
\hline $\begin{array}{l}\text { Time } \\
\text { (hours) }\end{array}$ & $\begin{array}{l}\text { Streamflow } \\
\text { (cubic feet } \\
\text { per second) }\end{array}$ & $\begin{array}{l}\text { Rain- } \\
\text { fall } \\
\text { (inches) }\end{array}$ & $\begin{array}{l}\text { Time } \\
\text { (hours) }\end{array}$ & $\begin{array}{l}\text { Streamflow } \\
\text { (cubic feet } \\
\text { per second) }\end{array}$ & $\begin{array}{l}\text { Rain- } \\
\text { fall } \\
\text { (inches) }\end{array}$ & $\begin{array}{l}\text { Time } \\
\text { (hours) }\end{array}$ & $\begin{array}{l}\text { Streamflow } \\
\text { (cubic feet } \\
\text { per second) }\end{array}$ & $\begin{array}{l}\text { Rain- } \\
\text { fall } \\
\text { (inches) }\end{array}$ \\
\hline $\begin{array}{c}\text { February } \\
0710 \\
0715 \\
0720 \\
0725\end{array}$ & $\begin{array}{r}16, \quad 990 \\
3.1 \\
1.0 \\
0.9 \\
8.5\end{array}$ & $\begin{array}{l}0.07 \\
0.04 \\
0.02 \\
0.20\end{array}$ & $\begin{array}{l}1130 \\
1135 \\
1140 \\
1145 \\
1150\end{array}$ & $\begin{array}{l}29.3 \\
24.9 \\
23.6 \\
22.9 \\
22.9\end{array}$ & $\begin{array}{l}0.04 \\
0.00 \\
0.01 \\
0.01 \\
0.03\end{array}$ & $\begin{array}{l}1555 \\
1600 \\
1605 \\
1610 \\
1615\end{array}$ & $\begin{array}{l}16.3 \\
15.7 \\
14.5 \\
13.9 \\
12.9\end{array}$ & $\begin{array}{l}0.00 \\
0.00 \\
0.00 \\
0.00 \\
0.00\end{array}$ \\
\hline $\begin{array}{l}0730 \\
0735 \\
0740 \\
0745 \\
0750\end{array}$ & $\begin{array}{l}6.6 \\
4.5 \\
3.1 \\
2.5 \\
5.2\end{array}$ & $\begin{array}{l}0.19 \\
0.06 \\
0.04 \\
0.01 \\
0.02\end{array}$ & $\begin{array}{l}1155 \\
1200 \\
1205 \\
1210 \\
1215\end{array}$ & $\begin{array}{l}21.6 \\
22.3 \\
22.3 \\
26.5 \\
24.3\end{array}$ & $\begin{array}{l}0.01 \\
0.00 \\
0.01 \\
0.06 \\
0.00\end{array}$ & $\begin{array}{l}1620 \\
1625 \\
1630 \\
1635 \\
1640\end{array}$ & $\begin{array}{l}12.3 \\
11.3 \\
11.3 \\
10.8 \\
10.3\end{array}$ & $\begin{array}{l}0.00 \\
0.00 \\
0.00 \\
0.00 \\
0.00\end{array}$ \\
\hline $\begin{array}{l}0755 \\
0800 \\
0805 \\
0810 \\
0815\end{array}$ & $\begin{array}{r}9.9 \\
12.3 \\
16.9 \\
17.5 \\
26.5\end{array}$ & $\begin{array}{l}0.07 \\
0.05 \\
0.12 \\
0.05 \\
0.02\end{array}$ & $\begin{array}{l}1220 \\
1225 \\
1230 \\
1235 \\
1240\end{array}$ & $\begin{array}{l}23.6 \\
23.6 \\
25.4 \\
24.3 \\
22.9\end{array}$ & $\begin{array}{l}0.00 \\
0.00 \\
0.00 \\
0.01 \\
0.01\end{array}$ & $\begin{array}{l}1645 \\
1650 \\
1655 \\
1700 \\
1705\end{array}$ & $\begin{array}{l}9.9 \\
9.4 \\
9.0 \\
9.0 \\
8.5\end{array}$ & $\begin{array}{l}0.00 \\
0.00 \\
0.00 \\
0.00 \\
0.00\end{array}$ \\
\hline $\begin{array}{l}0820 \\
0825 \\
0830 \\
0835 \\
0840\end{array}$ & $\begin{array}{l}35.4 \\
43.0 \\
46.3 \\
52.9 \\
51.6\end{array}$ & $\begin{array}{l}0.06 \\
0.02 \\
0.01 \\
0.01 \\
0.03\end{array}$ & $\begin{array}{l}1245 \\
1250 \\
1255 \\
1300 \\
1305\end{array}$ & $\begin{array}{l}23.6 \\
23.6 \\
23.6 \\
22.9 \\
22.3\end{array}$ & $\begin{array}{l}0.01 \\
0.00 \\
0.03 \\
0.03 \\
0.03\end{array}$ & $\begin{array}{l}1710 \\
1715 \\
1720 \\
1725 \\
1730\end{array}$ & $\begin{array}{l}8.1 \\
8.1 \\
7.7 \\
7.7 \\
7.3\end{array}$ & $\begin{array}{l}0.00 \\
0.00 \\
0.00 \\
0.00 \\
0.00\end{array}$ \\
\hline $\begin{array}{l}0845 \\
0850 \\
0855 \\
0900 \\
0905\end{array}$ & $\begin{array}{l}52.9 \\
54.9 \\
53.7 \\
54.9 \\
52.9\end{array}$ & $\begin{array}{l}0.02 \\
0.07 \\
0.00 \\
0.11 \\
0.00\end{array}$ & $\begin{array}{l}1310 \\
1315 \\
1320 \\
1325 \\
1330\end{array}$ & $\begin{array}{l}21.6 \\
22.3 \\
22.9 \\
24.9 \\
26.0\end{array}$ & $\begin{array}{l}0.03 \\
0.01 \\
0.02 \\
0.02 \\
0.02\end{array}$ & $\begin{array}{l}1735 \\
1740 \\
1745 \\
1750 \\
1755\end{array}$ & $\begin{array}{l}7.3 \\
7.3 \\
7.3 \\
6.9 \\
6.6\end{array}$ & $\begin{array}{l}0.00 \\
0.00 \\
0.00 \\
0.00 \\
0.00\end{array}$ \\
\hline $\begin{array}{l}0910 \\
0915 \\
0920 \\
0925 \\
0930\end{array}$ & $\begin{array}{l}53.7 \\
54.1 \\
54.9 \\
61.1 \\
60.7\end{array}$ & $\begin{array}{l}0.04 \\
0.01 \\
0.03 \\
0.04 \\
0.07\end{array}$ & $\begin{array}{l}1335 \\
1340 \\
1345 \\
1350 \\
1355\end{array}$ & $\begin{array}{l}27.7 \\
29.9 \\
32.5 \\
35.0 \\
35.4\end{array}$ & $\begin{array}{l}0.01 \\
0.05 \\
0.01 \\
0.04 \\
0.01\end{array}$ & $\begin{array}{l}1800 \\
1805 \\
1810 \\
1815 \\
1820\end{array}$ & $\begin{array}{l}6.2 \\
6.2 \\
5.8 \\
5.8 \\
5.5\end{array}$ & $\begin{array}{l}0.00 \\
0.00 \\
0.00 \\
0.00 \\
0.00\end{array}$ \\
\hline $\begin{array}{l}0935 \\
0940 \\
0945 \\
0950 \\
0955\end{array}$ & $\begin{array}{l}66.5 \\
68.1 \\
76.5 \\
83.2 \\
95.8\end{array}$ & $\begin{array}{l}0.08 \\
0.12 \\
0.13 \\
0.05 \\
0.02\end{array}$ & $\begin{array}{l}1400 \\
1405 \\
1410 \\
1415 \\
1420\end{array}$ & $\begin{array}{l}40.4 \\
44.3 \\
47.6 \\
49.6 \\
54.1\end{array}$ & $\begin{array}{l}0.00 \\
0.06 \\
0.02 \\
0.00 \\
0.03\end{array}$ & $\begin{array}{l}1825 \\
1830 \\
1835 \\
1840 \\
1845\end{array}$ & $\begin{array}{l}5.2 \\
4.9 \\
4.5 \\
4.2 \\
4.0\end{array}$ & $\begin{array}{l}0.00 \\
0.00 \\
0.00 \\
0.00 \\
0.00\end{array}$ \\
\hline $\begin{array}{l}1000 \\
1005 \\
1010 \\
1015 \\
1020\end{array}$ & $\begin{array}{r}99.6 \\
108.0 \\
119.0 \\
107.0 \\
100.0\end{array}$ & $\begin{array}{l}0.02 \\
0.00 \\
0.00 \\
0.01 \\
0.01\end{array}$ & $\begin{array}{l}1425 \\
1430 \\
1435 \\
1440 \\
1445\end{array}$ & $\begin{array}{l}54.9 \\
55.3 \\
57.0 \\
54.9 \\
53.3\end{array}$ & $\begin{array}{l}0.02 \\
0.02 \\
0.01 \\
0.01 \\
0.00\end{array}$ & $\begin{array}{l}1850 \\
1855 \\
1900 \\
1905 \\
1910\end{array}$ & $\begin{array}{l}3.7 \\
3.4 \\
3.4 \\
3.1 \\
2.8\end{array}$ & $\begin{array}{l}0.00 \\
0.00 \\
0.00 \\
0.00 \\
0.00\end{array}$ \\
\hline $\begin{array}{l}1025 \\
1030 \\
1035 \\
1040 \\
1045\end{array}$ & $\begin{array}{l}91.1 \\
82.3 \\
72.3 \\
64.4 \\
58.2\end{array}$ & $\begin{array}{l}0.00 \\
0.01 \\
0.01 \\
0.01 \\
0.01\end{array}$ & $\begin{array}{l}1450 \\
1455 \\
1500 \\
1505 \\
1510\end{array}$ & $\begin{array}{l}51.2 \\
48.0 \\
45.1 \\
42.6 \\
39.1\end{array}$ & $\begin{array}{l}0.00 \\
0.00 \\
0.00 \\
0.00 \\
0.01\end{array}$ & $\begin{array}{l}1915 \\
1920 \\
1925 \\
1930 \\
1935\end{array}$ & $\begin{array}{l}2.8 \\
2.8 \\
2.5 \\
2.2 \\
2.2\end{array}$ & $\begin{array}{l}0.00 \\
0.00 \\
0.00 \\
0.00 \\
0.00\end{array}$ \\
\hline $\begin{array}{l}1050 \\
1055 \\
1100 \\
1105 \\
1110\end{array}$ & $\begin{array}{l}53.7 \\
48.8 \\
45.1 \\
40.9 \\
35.9\end{array}$ & $\begin{array}{l}0.01 \\
0.00 \\
0.02 \\
0.00 \\
0.00\end{array}$ & $\begin{array}{l}1515 \\
1520 \\
1525 \\
1530 \\
1535\end{array}$ & $\begin{array}{l}35.4 \\
32.5 \\
28.8 \\
26.0 \\
23.6\end{array}$ & $\begin{array}{l}0.00 \\
0.00 \\
0.00 \\
0.00 \\
0.00\end{array}$ & $\begin{array}{l}1940 \\
1945 \\
1950 \\
1955 \\
2000\end{array}$ & $\begin{array}{l}2.0 \\
2.0 \\
1.8 \\
1.6 \\
1.6\end{array}$ & $\begin{array}{l}0.00 \\
0.00 \\
0.00 \\
0.00 \\
0.00\end{array}$ \\
\hline $\begin{array}{l}1115 \\
1120 \\
1125\end{array}$ & $\begin{array}{l}31.5 \\
30.4 \\
29.3\end{array}$ & $\begin{array}{l}0.01 \\
0.01 \\
0.03\end{array}$ & $\begin{array}{l}1540 \\
1545 \\
1550\end{array}$ & $\begin{array}{l}20.9 \\
18.8 \\
18.2\end{array}$ & $\begin{array}{l}0.01 \\
0.00 \\
0.00\end{array}$ & & & \\
\hline
\end{tabular}



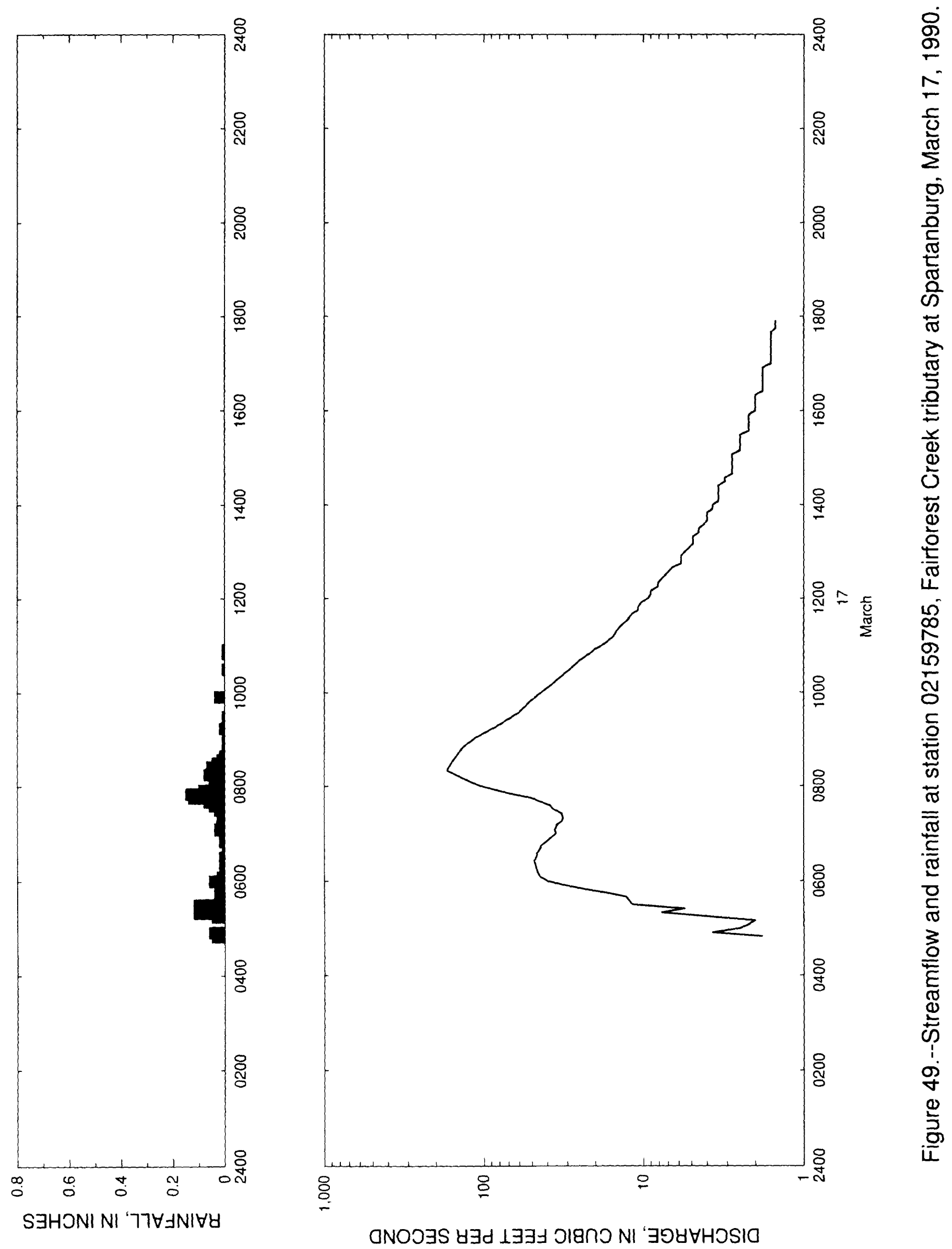
Table 48. - Streamflow and rainfall at station 02159785, Fairforest Cret tributary at Spartanburg. March 17,1990

\begin{tabular}{|c|c|c|c|c|c|c|c|c|}
\hline $\begin{array}{l}\text { Time } \\
\text { (hours) }\end{array}$ & $\begin{array}{l}\text { Streamflow } \\
\text { (cubic feet } \\
\text { per second) }\end{array}$ & $\begin{array}{l}\text { Rain- } \\
\text { fal1 } \\
\text { (inches) }\end{array}$ & $\begin{array}{l}\text { Time } \\
\text { (hours) }\end{array}$ & $\begin{array}{l}\text { Streamflow } \\
\text { (cubic feet } \\
\text { per second) }\end{array}$ & $\begin{array}{l}\text { Rain- } \\
\text { fall } \\
\text { (inches) }\end{array}$ & $\begin{array}{l}\text { Time } \\
\text { (hours) }\end{array}$ & $\begin{array}{l}\text { Streamflow } \\
\text { (cubic feet } \\
\text { per second) }\end{array}$ & $\begin{array}{l}\text { Rain- } \\
\text { fall } \\
\text { (inches) }\end{array}$ \\
\hline $\begin{array}{l}\text { March } 17 \text {, } \\
0450 \\
0455 \\
0500 \\
0505\end{array}$ & $\begin{array}{r}1990 \\
1.8 \\
3.7 \\
2.5 \\
2.2\end{array}$ & $\begin{array}{l}0.05 \\
0.06 \\
0.00 \\
0.00\end{array}$ & $\begin{array}{l}0915 \\
0920 \\
0925 \\
0930 \\
0935\end{array}$ & $\begin{array}{l}87.5 \\
79.0 \\
73.1 \\
66.1 \\
60.7\end{array}$ & $\begin{array}{l}0.02 \\
0.00 \\
0.01 \\
0.01 \\
0.00\end{array}$ & $\begin{array}{l}1345 \\
1350 \\
1355 \\
1400 \\
1405\end{array}$ & $\begin{array}{l}4.0 \\
4.0 \\
3.7 \\
3.7 \\
3.4\end{array}$ & $\begin{array}{l}0.00 \\
0.00 \\
0.00 \\
0.00 \\
0.00\end{array}$ \\
\hline $\begin{array}{l}0510 \\
0515 \\
0520 \\
0525 \\
0530\end{array}$ & $\begin{array}{r}2.0 \\
4.0 \\
7.7 \\
5.5 \\
11.8\end{array}$ & $\begin{array}{l}0.00 \\
0.05 \\
0.12 \\
0.02 \\
0.12\end{array}$ & $\begin{array}{l}0940 \\
0945 \\
0950 \\
0955 \\
1000\end{array}$ & $\begin{array}{l}57.0 \\
54.1 \\
50.8 \\
47.1 \\
43.9\end{array}$ & $\begin{array}{l}0.00 \\
0.00 \\
0.00 \\
0.04 \\
0.00\end{array}$ & $\begin{array}{l}1410 \\
1415 \\
1420 \\
1425 \\
1430\end{array}$ & $\begin{array}{l}3.4 \\
3.4 \\
3.4 \\
3.4 \\
3.1\end{array}$ & $\begin{array}{l}0.00 \\
0.00 \\
0.00 \\
0.00 \\
0.00\end{array}$ \\
\hline $\begin{array}{l}0535 \\
0540 \\
0545 \\
0550 \\
0555\end{array}$ & $\begin{array}{l}12.3 \\
12.9 \\
16.9 \\
23.6 \\
31.5\end{array}$ & $\begin{array}{l}0.01 \\
0.01 \\
0.04 \\
0.03 \\
0.04\end{array}$ & $\begin{array}{l}1005 \\
1010 \\
1015 \\
1020 \\
1025\end{array}$ & $\begin{array}{l}40.9 \\
37.7 \\
35.4 \\
33.0 \\
31.0\end{array}$ & $\begin{array}{l}0.00 \\
0.00 \\
0.00 \\
0.00 \\
0.00\end{array}$ & $\begin{array}{l}1435 \\
1440 \\
1445 \\
1450 \\
1455\end{array}$ & $\begin{array}{l}3.1 \\
2.8 \\
2.8 \\
2.8 \\
2.8\end{array}$ & $\begin{array}{l}0.00 \\
0.00 \\
0.00 \\
0.00 \\
0.00\end{array}$ \\
\hline $\begin{array}{l}0600 \\
0605 \\
0610 \\
0615 \\
0620\end{array}$ & $\begin{array}{l}40.0 \\
43.9 \\
45.9 \\
46.7 \\
47.6\end{array}$ & $\begin{array}{l}0.06 \\
0.03 \\
0.01 \\
0.01 \\
0.02\end{array}$ & $\begin{array}{l}1030 \\
1035 \\
1040 \\
1045 \\
1050\end{array}$ & $\begin{array}{l}28.8 \\
27.1 \\
25.4 \\
23.6 \\
21.6\end{array}$ & $\begin{array}{l}0.01 \\
0.00 \\
0.00 \\
0.00 \\
0.01\end{array}$ & $\begin{array}{l}1500 \\
1505 \\
1510 \\
1515 \\
1520\end{array}$ & $\begin{array}{l}2.8 \\
2.8 \\
2.5 \\
2.5 \\
2.5\end{array}$ & $\begin{array}{l}0.00 \\
0.00 \\
0.00 \\
0.00 \\
0.00\end{array}$ \\
\hline $\begin{array}{l}0625 \\
0630 \\
0635 \\
0640 \\
0645\end{array}$ & $\begin{array}{l}48.4 \\
47.1 \\
46.3 \\
44.7 \\
43.4\end{array}$ & $\begin{array}{l}0.01 \\
0.02 \\
0.00 \\
0.01 \\
0.01\end{array}$ & $\begin{array}{l}1055 \\
1100 \\
1105 \\
1110 \\
1115\end{array}$ & $\begin{array}{l}20.2 \\
18.2 \\
16.9 \\
15.7 \\
15.1\end{array}$ & $\begin{array}{l}0.01 \\
0.00 \\
0.00 \\
0.00 \\
0.00\end{array}$ & $\begin{array}{l}1525 \\
1530 \\
1535 \\
1540 \\
1545\end{array}$ & $\begin{array}{l}2.5 \\
2.5 \\
2.2 \\
2.2 \\
2.2\end{array}$ & $\begin{array}{l}0.00 \\
0.00 \\
0.00 \\
0.00 \\
0.00\end{array}$ \\
\hline $\begin{array}{l}0650 \\
0655 \\
0700 \\
0705 \\
0710\end{array}$ & $\begin{array}{l}40.4 \\
37.7 \\
35.4 \\
35.9 \\
35.0\end{array}$ & $\begin{array}{l}0.02 \\
0.01 \\
0.00 \\
0.04 \\
0.02\end{array}$ & $\begin{array}{l}1120 \\
1125 \\
1130 \\
1135 \\
1140\end{array}$ & $\begin{array}{l}14.5 \\
13.9 \\
12.9 \\
12.3 \\
11.8\end{array}$ & $\begin{array}{l}0.00 \\
0.00 \\
0.00 \\
0.00 \\
0.00\end{array}$ & $\begin{array}{l}1550 \\
1555 \\
1600 \\
1605 \\
1610\end{array}$ & $\begin{array}{l}2.2 \\
2.2 \\
2.0 \\
2.0 \\
2.0\end{array}$ & $\begin{array}{l}0.00 \\
0.00 \\
0.00 \\
0.00 \\
0.00\end{array}$ \\
\hline $\begin{array}{l}0715 \\
0720 \\
0725 \\
0730 \\
0735\end{array}$ & $\begin{array}{l}32.5 \\
32.0 \\
32.5 \\
36.4 \\
38.6\end{array}$ & $\begin{array}{l}0.03 \\
0.01 \\
0.01 \\
0.04 \\
0.06\end{array}$ & $\begin{array}{l}1145 \\
1150 \\
1155 \\
1200 \\
1205\end{array}$ & $\begin{array}{r}10.8 \\
10.8 \\
10.3 \\
9.4 \\
9.0\end{array}$ & $\begin{array}{l}0.00 \\
0.00 \\
0.00 \\
0.00 \\
0.00\end{array}$ & $\begin{array}{l}1615 \\
1620 \\
1625 \\
1630 \\
1635\end{array}$ & $\begin{array}{l}2.0 \\
2.0 \\
1.8 \\
1.8 \\
1.8\end{array}$ & $\begin{array}{l}0.00 \\
0.00 \\
0.00 \\
0.00 \\
0.00\end{array}$ \\
\hline $\begin{array}{l}0740 \\
0745 \\
0750 \\
0755 \\
0800\end{array}$ & $\begin{array}{r}44.3 \\
50.8 \\
68.1 \\
85.2 \\
105.0\end{array}$ & $\begin{array}{l}0.08 \\
0.14 \\
0.15 \\
0.10 \\
0.00\end{array}$ & $\begin{array}{l}1210 \\
1215 \\
1220 \\
1225 \\
1230\end{array}$ & $\begin{array}{l}9.0 \\
8.1 \\
8.1 \\
7.7 \\
7.3\end{array}$ & $\begin{array}{l}0.00 \\
0.00 \\
0.00 \\
0.00 \\
0.00\end{array}$ & $\begin{array}{l}1640 \\
1645 \\
1650 \\
1655 \\
1700\end{array}$ & $\begin{array}{l}1.8 \\
1.8 \\
1.8 \\
1.8 \\
1.6\end{array}$ & $\begin{array}{l}0.00 \\
0.00 \\
0.00 \\
0.00 \\
0.00\end{array}$ \\
\hline $\begin{array}{l}0805 \\
0810 \\
0815 \\
0820 \\
0825\end{array}$ & $\begin{array}{l}120.0 \\
136.0 \\
152.0 \\
170.0 \\
166.0\end{array}$ & $\begin{array}{l}0.01 \\
0.06 \\
0.08 \\
0.02 \\
0.07\end{array}$ & $\begin{array}{l}1235 \\
1240 \\
1245 \\
1250 \\
1255\end{array}$ & $\begin{array}{l}6.9 \\
6.6 \\
5.8 \\
5.8 \\
5.8\end{array}$ & $\begin{array}{l}0.00 \\
0.00 \\
0.00 \\
0.00 \\
0.00\end{array}$ & $\begin{array}{l}1705 \\
1710 \\
1715 \\
1720 \\
1725\end{array}$ & $\begin{array}{l}1.6 \\
1.6 \\
1.6 \\
1.6 \\
1.6\end{array}$ & $\begin{array}{l}0.00 \\
0.00 \\
0.00 \\
0.00 \\
0.00\end{array}$ \\
\hline $\begin{array}{l}0830 \\
0835 \\
0840 \\
0845 \\
0850\end{array}$ & $\begin{array}{l}160.0 \\
154.0 \\
148.0 \\
142.0 \\
136.0\end{array}$ & $\begin{array}{l}0.05 \\
0.03 \\
0.02 \\
0.00 \\
0.01\end{array}$ & $\begin{array}{l}1300 \\
1305 \\
1310 \\
1315 \\
1320\end{array}$ & $\begin{array}{l}5.5 \\
5.2 \\
4.9 \\
4.9 \\
4.9\end{array}$ & $\begin{array}{l}0.00 \\
0.00 \\
0.00 \\
0.00 \\
0.00\end{array}$ & $\begin{array}{l}1730 \\
1735 \\
1740 \\
1745 \\
1750\end{array}$ & $\begin{array}{l}1.6 \\
1.6 \\
1.6 \\
1.5 \\
1.5\end{array}$ & $\begin{array}{l}0.00 \\
0.00 \\
0.00 \\
0.00 \\
0.00\end{array}$ \\
\hline $\begin{array}{l}0855 \\
0900 \\
0905 \\
0910\end{array}$ & $\begin{array}{r}127.0 \\
118.0 \\
108.0 \\
97.5\end{array}$ & $\begin{array}{l}0.01 \\
0.00 \\
0.01 \\
0.00\end{array}$ & $\begin{array}{l}1325 \\
1330 \\
1335 \\
1340\end{array}$ & $\begin{array}{l}4.5 \\
4.5 \\
4.2 \\
4.0\end{array}$ & $\begin{array}{l}0.00 \\
0.00 \\
0.00 \\
0.00\end{array}$ & $\begin{array}{l}1755 \\
1800\end{array}$ & $\begin{array}{l}1.5 \\
1.5\end{array}$ & $\begin{array}{l}0.00 \\
0.00\end{array}$ \\
\hline
\end{tabular}



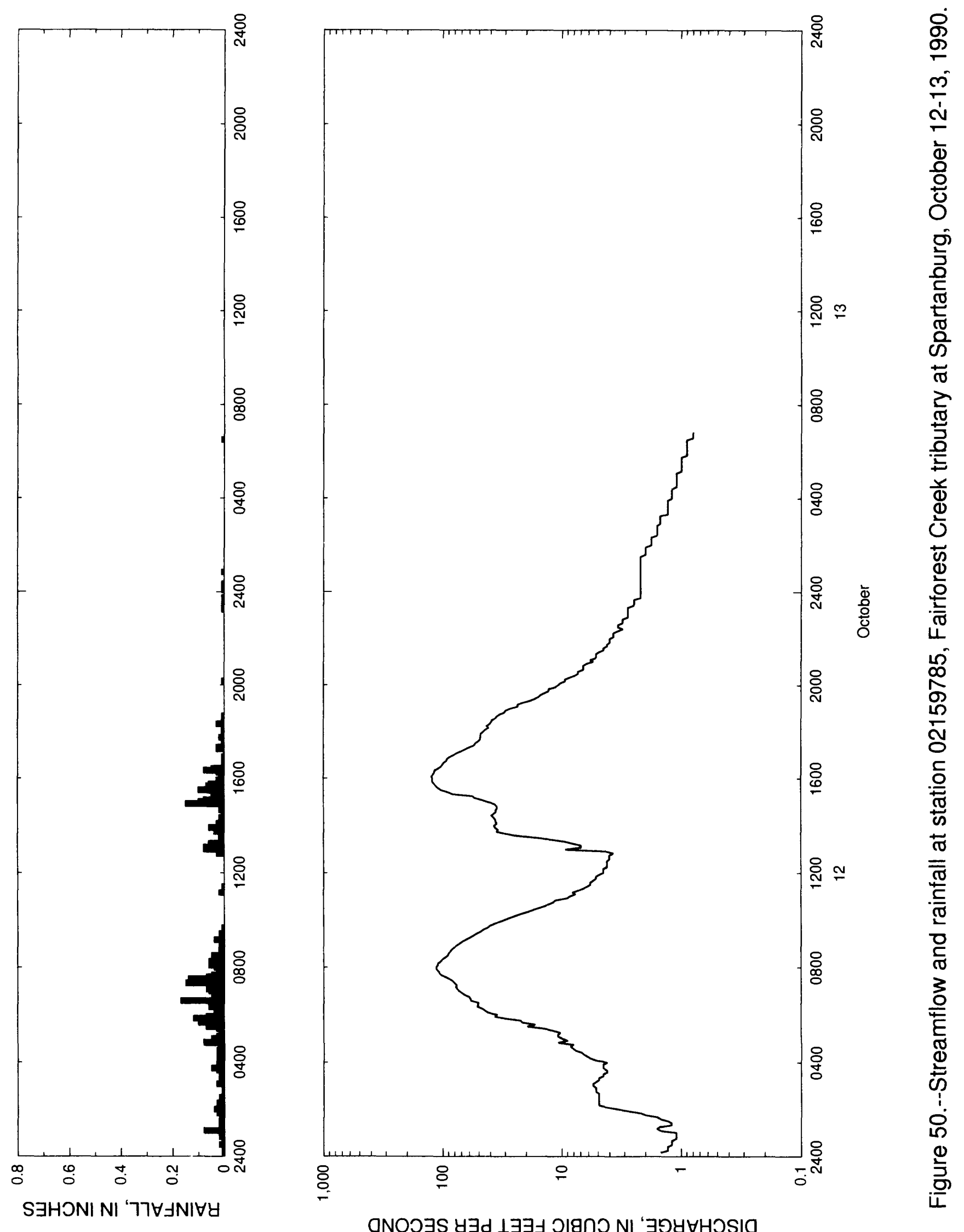
Table 49.--Streamflow and rainfa11 at station 02159785, Fairforest Creek tributary at Spartanburg, Octobex $12-13,1990$

\begin{tabular}{|c|c|c|c|c|c|c|c|c|}
\hline $\begin{array}{l}\text { Time } \\
\text { (hours) }\end{array}$ & $\begin{array}{l}\text { Streamflow } \\
\text { (cubic feet } \\
\text { per second) }\end{array}$ & $\begin{array}{l}\text { Rain- } \\
\text { fal1 } \\
\text { (inches) }\end{array}$ & $\begin{array}{l}\text { Time } \\
\text { (hours) }\end{array}$ & $\begin{array}{l}\text { Streamflow } \\
\text { (cubic feet } \\
\text { per second) }\end{array}$ & $\begin{array}{l}\text { Rain- } \\
\text { fall } \\
\text { (inches) }\end{array}$ & $\begin{array}{l}\text { Time } \\
\text { (hours) }\end{array}$ & $\begin{array}{l}\text { Streamflow } \\
\text { (cubic feet } \\
\text { per second) }\end{array}$ & $\begin{array}{l}\text { Rain- } \\
\text { fa11 } \\
\text { (inches) }\end{array}$ \\
\hline $\begin{array}{l}\text { October } \\
0010 \\
0015 \\
0020 \\
0025\end{array}$ & $\begin{array}{r}12,1990 \\
1.5 \\
1.3 \\
1.3 \\
1.3\end{array}$ & $\begin{array}{l}0.01 \\
0.00 \\
0.01 \\
0.00\end{array}$ & $\begin{array}{l}0530 \\
0535 \\
0540 \\
0545 \\
0550\end{array}$ & $\begin{array}{l}19.5 \\
16.9 \\
21.6 \\
22.3 \\
29.9\end{array}$ & $\begin{array}{l}0.07 \\
0.02 \\
0.10 \\
0.03 \\
0.12\end{array}$ & $\begin{array}{l}1055 \\
1100 \\
1105 \\
1110 \\
1115\end{array}$ & $\begin{array}{l}9.0 \\
8.5 \\
7.7 \\
8.1 \\
7.3\end{array}$ & $\begin{array}{l}0.00 \\
0.00 \\
0.00 \\
0.02 \\
0.00\end{array}$ \\
\hline $\begin{array}{l}0030 \\
0035 \\
0040 \\
0045 \\
0050\end{array}$ & $\begin{array}{l}1.2 \\
1.2 \\
1.2 \\
1.1 \\
1.1\end{array}$ & $\begin{array}{l}0.02 \\
0.01 \\
0.00 \\
0.01 \\
0.02\end{array}$ & $\begin{array}{l}0555 \\
0600 \\
0605 \\
0610 \\
0615\end{array}$ & $\begin{array}{l}36.4 \\
35.0 \\
42.1 \\
44.3 \\
46.7\end{array}$ & $\begin{array}{l}0.07 \\
0.04 \\
0.02 \\
0.01 \\
0.04\end{array}$ & $\begin{array}{l}1120 \\
1125 \\
1130 \\
1135 \\
1140\end{array}$ & $\begin{array}{l}6.6 \\
6.2 \\
5.8 \\
5.8 \\
5.5\end{array}$ & $\begin{array}{l}0.00 \\
0.01 \\
0.00 \\
0.00 \\
0.00\end{array}$ \\
\hline $\begin{array}{l}0055 \\
0100 \\
0105 \\
0110 \\
0115\end{array}$ & $\begin{array}{l}1.1 \\
1.1 \\
1.5 \\
1.6 \\
1.5\end{array}$ & $\begin{array}{l}0.02 \\
0.02 \\
0.08 \\
0.02 \\
0.01\end{array}$ & $\begin{array}{l}0620 \\
0625 \\
0630 \\
0635 \\
0640\end{array}$ & $\begin{array}{l}51.2 \\
50.4 \\
50.8 \\
58.2 \\
59.0\end{array}$ & $\begin{array}{l}0.06 \\
0.03 \\
0.06 \\
0.17 \\
0.04\end{array}$ & $\begin{array}{l}1145 \\
1150 \\
1155 \\
1200 \\
1205\end{array}$ & $\begin{array}{l}5.2 \\
5.2 \\
4.9 \\
4.5 \\
4.5\end{array}$ & $\begin{array}{l}0.00 \\
0.00 \\
0.00 \\
0.00 \\
0.00\end{array}$ \\
\hline $\begin{array}{l}0120 \\
0125 \\
0130 \\
0135 \\
0140\end{array}$ & $\begin{array}{l}1.2 \\
1.2 \\
1.3 \\
1.5 \\
1.6\end{array}$ & $\begin{array}{l}0.02 \\
0.02 \\
0.02 \\
0.02 \\
0.02\end{array}$ & $\begin{array}{l}0645 \\
0650 \\
0655 \\
0700 \\
0705\end{array}$ & $\begin{array}{l}60.3 \\
66.1 \\
69.8 \\
73.5 \\
76.0\end{array}$ & $\begin{array}{l}0.02 \\
0.05 \\
0.02 \\
0.06 \\
0.07\end{array}$ & $\begin{array}{l}1210 \\
1215 \\
1220 \\
1225 \\
1230\end{array}$ & $\begin{array}{l}4.5 \\
4.2 \\
4.2 \\
4.2 \\
4.2\end{array}$ & $\begin{array}{l}0.00 \\
0.00 \\
0.00 \\
0.00 \\
0.00\end{array}$ \\
\hline $\begin{array}{l}0145 \\
0150 \\
0155 \\
0200 \\
0205\end{array}$ & $\begin{array}{l}2.0 \\
2.2 \\
2.8 \\
3.4 \\
4.2\end{array}$ & $\begin{array}{l}0.01 \\
0.03 \\
0.01 \\
0.04 \\
0.02\end{array}$ & $\begin{array}{l}0710 \\
0715 \\
0720 \\
0725 \\
0730\end{array}$ & $\begin{array}{l}77.7 \\
76.9 \\
79.8 \\
82.7 \\
87.8\end{array}$ & $\begin{array}{l}0.03 \\
0.03 \\
0.15 \\
0.07 \\
0.14\end{array}$ & $\begin{array}{l}1235 \\
1240 \\
1245 \\
1250 \\
1255\end{array}$ & $\begin{array}{l}4.0 \\
4.0 \\
4.0 \\
3.7 \\
4.2\end{array}$ & $\begin{array}{l}0.00 \\
0.00 \\
0.00 \\
0.03 \\
0.03\end{array}$ \\
\hline $\begin{array}{l}0210 \\
0215 \\
0220 \\
0225 \\
0230\end{array}$ & $\begin{array}{l}4.9 \\
4.9 \\
4.9 \\
4.9 \\
4.9\end{array}$ & $\begin{array}{l}0.01 \\
0.03 \\
0.00 \\
0.01 \\
0.02\end{array}$ & $\begin{array}{l}0735 \\
0740 \\
0745 \\
0750 \\
0755\end{array}$ & $\begin{array}{r}94.5 \\
103.0 \\
107.0 \\
109.0 \\
113.0\end{array}$ & $\begin{array}{l}0.07 \\
0.05 \\
0.03 \\
0.03 \\
0.02\end{array}$ & $\begin{array}{l}1300 \\
1305 \\
1310 \\
1315 \\
1320\end{array}$ & $\begin{array}{l}9.4 \\
6.9 \\
6.9 \\
8.1 \\
9.4\end{array}$ & $\begin{array}{l}0.08 \\
0.08 \\
0.06 \\
0.06 \\
0.02\end{array}$ \\
\hline $\begin{array}{l}0235 \\
0240 \\
0245 \\
0250 \\
0255\end{array}$ & $\begin{array}{l}4.9 \\
4.9 \\
5.2 \\
5.2 \\
5.2\end{array}$ & $\begin{array}{l}0.01 \\
0.00 \\
0.01 \\
0.01 \\
0.00\end{array}$ & $\begin{array}{l}0800 \\
0805 \\
0810 \\
0815 \\
0820\end{array}$ & $\begin{array}{l}114.0 \\
111.0 \\
110.0 \\
104.0 \\
101.0\end{array}$ & $\begin{array}{l}0.04 \\
0.06 \\
0.02 \\
0.06 \\
0.05\end{array}$ & $\begin{array}{l}1325 \\
1330 \\
1335 \\
1340 \\
1345\end{array}$ & $\begin{array}{l}12.3 \\
16.3 \\
24.9 \\
29.9 \\
35.4\end{array}$ & $\begin{array}{l}0.02 \\
0.02 \\
0.02 \\
0.01 \\
0.04\end{array}$ \\
\hline $\begin{array}{l}0300 \\
0305 \\
0310 \\
0315 \\
0320\end{array}$ & $\begin{array}{l}5.5 \\
5.5 \\
5.2 \\
4.9 \\
4.9\end{array}$ & $\begin{array}{l}0.01 \\
0.03 \\
0.02 \\
0.02 \\
0.01\end{array}$ & $\begin{array}{l}0825 \\
0830 \\
0835 \\
0840 \\
0845\end{array}$ & $\begin{array}{l}95.4 \\
90.7 \\
89.5 \\
86.5 \\
84.0\end{array}$ & $\begin{array}{l}0.02 \\
0.05 \\
0.00 \\
0.02 \\
0.02\end{array}$ & $\begin{array}{l}1350 \\
1355 \\
1400 \\
1405 \\
1410\end{array}$ & $\begin{array}{l}34.5 \\
36.4 \\
37.3 \\
35.4 \\
35.9\end{array}$ & $\begin{array}{l}0.01 \\
0.06 \\
0.02 \\
0.03 \\
0.01\end{array}$ \\
\hline $\begin{array}{l}0325 \\
0330 \\
0335 \\
0340 \\
0345\end{array}$ & $\begin{array}{l}4.5 \\
4.5 \\
4.2 \\
4.2 \\
4.5\end{array}$ & $\begin{array}{l}0.02 \\
0.01 \\
0.02 \\
0.03 \\
0.05\end{array}$ & $\begin{array}{l}0850 \\
0855 \\
0900 \\
0905 \\
0910\end{array}$ & $\begin{array}{l}80.2 \\
76.9 \\
72.7 \\
68.5 \\
64.0\end{array}$ & $\begin{array}{l}0.02 \\
0.01 \\
0.02 \\
0.01 \\
0.04\end{array}$ & $\begin{array}{l}1415 \\
1420 \\
1425 \\
1430 \\
1435\end{array}$ & $\begin{array}{l}36.4 \\
37.3 \\
39.1 \\
37.7 \\
35.9\end{array}$ & $\begin{array}{l}0.01 \\
0.02 \\
0.01 \\
0.01 \\
0.00\end{array}$ \\
\hline $\begin{array}{l}0350 \\
0355 \\
0400 \\
0405 \\
0410\end{array}$ & $\begin{array}{l}4.5 \\
4.5 \\
4.2 \\
5.2 \\
5.8\end{array}$ & $\begin{array}{l}0.02 \\
0.03 \\
0.01 \\
0.01 \\
0.03\end{array}$ & $\begin{array}{l}0915 \\
0920 \\
0925 \\
0930 \\
0935\end{array}$ & $\begin{array}{l}59.4 \\
55.7 \\
52.5 \\
48.4 \\
45.9\end{array}$ & $\begin{array}{l}0.01 \\
0.01 \\
0.02 \\
0.00 \\
0.00\end{array}$ & $\begin{array}{l}1440 \\
1445 \\
1450 \\
1455 \\
1500\end{array}$ & $\begin{array}{l}35.9 \\
35.0 \\
35.4 \\
36.8 \\
42.1\end{array}$ & $\begin{array}{l}0.02 \\
0.02 \\
0.02 \\
0.15 \\
0.10\end{array}$ \\
\hline $\begin{array}{l}0415 \\
0420 \\
0425 \\
0430 \\
0435\end{array}$ & $\begin{array}{l}6.2 \\
6.6 \\
6.9 \\
7.7 \\
8.1\end{array}$ & $\begin{array}{l}0.01 \\
0.03 \\
0.01 \\
0.03 \\
0.01\end{array}$ & $\begin{array}{l}0940 \\
0945 \\
0950 \\
0955 \\
1000\end{array}$ & $\begin{array}{l}42.1 \\
40.4 \\
37.3 \\
34.0 \\
30.4\end{array}$ & $\begin{array}{l}0.01 \\
0.00 \\
0.00 \\
0.00 \\
0.00\end{array}$ & $\begin{array}{l}1505 \\
1510 \\
1515 \\
1520 \\
1525\end{array}$ & $\begin{array}{l}47.1 \\
54.1 \\
56.1 \\
82.3 \\
90.7\end{array}$ & $\begin{array}{l}0.08 \\
0.00 \\
0.05 \\
0.04 \\
0.04\end{array}$ \\
\hline $\begin{array}{l}0440 \\
0445 \\
0450 \\
0455 \\
0500\end{array}$ & $\begin{array}{r}8.5 \\
8.1 \\
10.8 \\
9.0 \\
9.9\end{array}$ & $\begin{array}{l}0.02 \\
0.02 \\
0.08 \\
0.01 \\
0.05\end{array}$ & $\begin{array}{l}1005 \\
1010 \\
1015 \\
1020 \\
1025\end{array}$ & $\begin{array}{l}27.7 \\
24.9 \\
22.3 \\
19.5 \\
17.5\end{array}$ & $\begin{array}{l}0.00 \\
0.00 \\
0.00 \\
0.00 \\
0.00\end{array}$ & $\begin{array}{l}1530 \\
1535 \\
1540 \\
1545 \\
1550\end{array}$ & $\begin{array}{l}103.0 \\
109.0 \\
114.0 \\
118.0 \\
122.0\end{array}$ & $\begin{array}{l}0.10 \\
0.07 \\
0.07 \\
0.06 \\
0.02\end{array}$ \\
\hline $\begin{array}{l}0505 \\
0510 \\
0515 \\
0520 \\
0525\end{array}$ & $\begin{array}{l}10.8 \\
10.8 \\
10.3 \\
11.8 \\
13.9\end{array}$ & $\begin{array}{l}0.03 \\
0.01 \\
0.01 \\
0.02 \\
0.03\end{array}$ & $\begin{array}{l}1030 \\
1035 \\
1040 \\
1045 \\
1050\end{array}$ & $\begin{array}{l}15.7 \\
13.9 \\
12.9 \\
11.8 \\
11.3\end{array}$ & $\begin{array}{l}0.00 \\
0.00 \\
0.00 \\
0.00 \\
0.00\end{array}$ & $\begin{array}{l}1555 \\
1600 \\
1605 \\
1610 \\
1615\end{array}$ & $\begin{array}{l}122.0 \\
123.0 \\
124.0 \\
121.0 \\
118.0\end{array}$ & $\begin{array}{l}0.03 \\
0.02 \\
0.01 \\
0.00 \\
0.03\end{array}$ \\
\hline
\end{tabular}


Table 49.--Streamflow and rainfall at station 02159785 . Fairforest Creek tributary at Spartanburg, October 12-13,1990--Continued

\begin{tabular}{|c|c|c|c|c|c|c|c|c|}
\hline $\begin{array}{l}\text { Time } \\
\text { (hours) }\end{array}$ & $\begin{array}{l}\text { Streamflow } \\
\text { (cubic feet } \\
\text { per second) }\end{array}$ & $\begin{array}{l}\text { Rain- } \\
\text { fall } \\
\text { (inches) }\end{array}$ & $\begin{array}{l}\text { Time } \\
\text { (hours) }\end{array}$ & $\begin{array}{l}\text { Streamflow } \\
\text { (cubic feet } \\
\text { per second) }\end{array}$ & $\begin{array}{l}\text { Rain- } \\
\text { fall } \\
\text { (inches) }\end{array}$ & $\begin{array}{l}\text { Time } \\
\text { (hours) }\end{array}$ & $\begin{array}{l}\text { Streamflow } \\
\text { (cubic feet } \\
\text { per second) }\end{array}$ & $\begin{array}{l}\text { Rain- } \\
\text { fall } \\
\text { (inches) }\end{array}$ \\
\hline $\begin{array}{l}1620 \\
1625 \\
1630 \\
1635 \\
1640\end{array}$ & $\begin{array}{r}117.0 \\
110.0 \\
104.0 \\
101.0 \\
98.7\end{array}$ & $\begin{array}{l}0.08 \\
0.05 \\
0.01 \\
0.01 \\
0.01\end{array}$ & $\begin{array}{l}2120 \\
2125 \\
2130 \\
2135 \\
2140\end{array}$ & $\begin{array}{l}5.2 \\
4.9 \\
4.5 \\
4.5 \\
4.2\end{array}$ & $\begin{array}{l}0.00 \\
0.00 \\
0.00 \\
0.00 \\
0.00\end{array}$ & $\begin{array}{l}0215 \\
0220 \\
0225 \\
0230 \\
0235\end{array}$ & $\begin{array}{l}1.8 \\
1.8 \\
1.6 \\
1.6 \\
1.6\end{array}$ & $\begin{array}{l}0.00 \\
0.00 \\
0.00 \\
0.00 \\
0.00\end{array}$ \\
\hline $\begin{array}{l}1645 \\
1650 \\
1655 \\
1700 \\
1705\end{array}$ & $\begin{array}{l}93.2 \\
92.0 \\
87.4 \\
81.1 \\
76.5\end{array}$ & $\begin{array}{l}0.00 \\
0.01 \\
0.01 \\
0.00 \\
0.00\end{array}$ & $\begin{array}{l}2145 \\
2150 \\
2155 \\
2200 \\
2205\end{array}$ & $\begin{array}{l}4.2 \\
4.0 \\
4.0 \\
4.0 \\
3.7\end{array}$ & $\begin{array}{l}0.00 \\
0.00 \\
0.00 \\
0.00 \\
0.00\end{array}$ & $\begin{array}{l}0240 \\
0245 \\
0250 \\
0255 \\
0300\end{array}$ & $\begin{array}{l}1.6 \\
1.6 \\
1.6 \\
1.5 \\
1.5\end{array}$ & $\begin{array}{l}0.00 \\
0.00 \\
0.00 \\
0.00 \\
0.00\end{array}$ \\
\hline $\begin{array}{l}1710 \\
1715 \\
1720 \\
1725 \\
1730\end{array}$ & $\begin{array}{l}69.4 \\
64.4 \\
59.9 \\
54.5 \\
53.3\end{array}$ & $\begin{array}{l}0.00 \\
0.03 \\
0.03 \\
0.01 \\
0.00\end{array}$ & $\begin{array}{l}2210 \\
2215 \\
2220 \\
2225 \\
2230\end{array}$ & $\begin{array}{l}3.7 \\
3.7 \\
3.4 \\
3.1 \\
3.4\end{array}$ & $\begin{array}{l}0.00 \\
0.00 \\
0.00 \\
0.00 \\
0.00\end{array}$ & $\begin{array}{l}0305 \\
0310 \\
0315 \\
0320 \\
0325\end{array}$ & $\begin{array}{l}1.5 \\
1.5 \\
1.5 \\
1.3 \\
1.3\end{array}$ & $\begin{array}{l}0.00 \\
0.00 \\
0.00 \\
0.00 \\
0.00\end{array}$ \\
\hline $\begin{array}{l}1735 \\
1740 \\
1745 \\
1750 \\
1755\end{array}$ & $\begin{array}{l}50.4 \\
48.4 \\
48.4 \\
48.0 \\
48.0\end{array}$ & $\begin{array}{l}0.01 \\
0.00 \\
0.02 \\
0.01 \\
0.00\end{array}$ & $\begin{array}{l}2235 \\
2240 \\
2245 \\
2250 \\
2255\end{array}$ & $\begin{array}{l}3.4 \\
3.1 \\
3.1 \\
3.1 \\
2.8\end{array}$ & $\begin{array}{l}0.00 \\
0.00 \\
0.00 \\
0.00 \\
0.00\end{array}$ & $\begin{array}{l}0330 \\
0335 \\
0340 \\
0345 \\
0350\end{array}$ & $\begin{array}{l}1.3 \\
1.3 \\
1.3 \\
1.3 \\
1.3\end{array}$ & $\begin{array}{l}0.00 \\
0.00 \\
0.00 \\
0.00 \\
0.00\end{array}$ \\
\hline $\begin{array}{l}1800 \\
1805 \\
1810 \\
1815 \\
1820\end{array}$ & $\begin{array}{l}45.9 \\
43.9 \\
41.3 \\
42.6 \\
40.4\end{array}$ & $\begin{array}{l}0.00 \\
0.01 \\
0.00 \\
0.01 \\
0.03\end{array}$ & $\begin{array}{l}2300 \\
2305 \\
2310 \\
2315 \\
2320\end{array}$ & $\begin{array}{l}2.8 \\
2.8 \\
2.8 \\
2.8 \\
2.8\end{array}$ & $\begin{array}{l}0.00 \\
0.00 \\
0.00 \\
0.01 \\
0.00\end{array}$ & $\begin{array}{l}0355 \\
0400 \\
0405 \\
0410 \\
0415\end{array}$ & $\begin{array}{l}1.3 \\
1.2 \\
1.2 \\
1.2 \\
1.2\end{array}$ & $\begin{array}{l}0.00 \\
0.00 \\
0.00 \\
0.00 \\
0.00\end{array}$ \\
\hline $\begin{array}{l}1825 \\
1830 \\
1835 \\
1840 \\
1845\end{array}$ & $\begin{array}{l}39.1 \\
38.6 \\
36.4 \\
35.4 \\
33.5\end{array}$ & $\begin{array}{l}0.01 \\
0.00 \\
0.00 \\
0.01 \\
0.00\end{array}$ & $\begin{array}{l}2325 \\
2330 \\
2335 \\
2340 \\
2345\end{array}$ & $\begin{array}{l}2.5 \\
2.5 \\
2.5 \\
2.5 \\
2.2\end{array}$ & $\begin{array}{l}0.00 \\
0.01 \\
0.00 \\
0.00 \\
0.01\end{array}$ & $\begin{array}{l}0420 \\
0425 \\
0430 \\
0435 \\
0440\end{array}$ & $\begin{array}{l}1.2 \\
1.2 \\
1.1 \\
1.1 \\
1.1\end{array}$ & $\begin{array}{l}0.00 \\
0.00 \\
0.00 \\
0.00 \\
0.00\end{array}$ \\
\hline $\begin{array}{l}1850 \\
1855 \\
1900 \\
1905 \\
1910\end{array}$ & $\begin{array}{l}30.4 \\
29.9 \\
27.1 \\
23.6 \\
23.6\end{array}$ & $\begin{array}{l}0.00 \\
0.00 \\
0.00 \\
0.00 \\
0.00\end{array}$ & $\begin{array}{l}2350 \\
2355 \\
\text { October } \\
0000 \\
0005\end{array}$ & $\begin{array}{r}2.2 \\
2.2 \\
13,1990 \\
2.2 \\
2.2\end{array}$ & $\begin{array}{l}0.00 \\
0.00 \\
0.00 \\
0.01\end{array}$ & $\begin{array}{l}0445 \\
0450 \\
0455 \\
0500 \\
0505\end{array}$ & $\begin{array}{l}1.1 \\
1.1 \\
1.1 \\
1.1 \\
1.1\end{array}$ & $\begin{array}{l}0.00 \\
0.00 \\
0.00 \\
0.00 \\
0.00\end{array}$ \\
\hline $\begin{array}{l}1915 \\
1920 \\
1925 \\
1930 \\
1935\end{array}$ & $\begin{array}{l}21.6 \\
18.8 \\
16.9 \\
15.7 \\
15.1\end{array}$ & $\begin{array}{l}0.00 \\
0.00 \\
0.00 \\
0.00 \\
0.00\end{array}$ & $\begin{array}{l}0010 \\
0015 \\
0020 \\
0025 \\
0030\end{array}$ & $\begin{array}{l}2.2 \\
2.2 \\
2.2 \\
2.2 \\
2.2\end{array}$ & $\begin{array}{l}0.00 \\
0.00 \\
0.01 \\
0.00 \\
0.00\end{array}$ & $\begin{array}{l}0510 \\
0515 \\
0520 \\
0525 \\
0530\end{array}$ & $\begin{array}{l}1.0 \\
1.0 \\
1.0 \\
1.0 \\
1.0\end{array}$ & $\begin{array}{l}0.00 \\
0.00 \\
0.00 \\
0.00 \\
0.00\end{array}$ \\
\hline $\begin{array}{l}1940 \\
1945 \\
1950 \\
1955 \\
2000\end{array}$ & $\begin{array}{l}13.9 \\
12.9 \\
12.9 \\
11.3 \\
10.8\end{array}$ & $\begin{array}{l}0.00 \\
0.00 \\
0.00 \\
0.00 \\
0.00\end{array}$ & $\begin{array}{l}0035 \\
0040 \\
0045 \\
0050 \\
0055\end{array}$ & $\begin{array}{l}2.2 \\
2.2 \\
2.2 \\
2.2 \\
2.2\end{array}$ & $\begin{array}{l}0.00 \\
0.00 \\
0.00 \\
0.01 \\
0.00\end{array}$ & $\begin{array}{l}0535 \\
0540 \\
0545 \\
0550 \\
0555\end{array}$ & $\begin{array}{l}1.0 \\
1.0 \\
1.0 \\
0.9 \\
0.9\end{array}$ & $\begin{array}{l}0.00 \\
0.00 \\
0.00 \\
0.00 \\
0.00\end{array}$ \\
\hline $\begin{array}{l}2005 \\
2010 \\
2015 \\
2020 \\
2025\end{array}$ & $\begin{array}{r}10.3 \\
9.4 \\
9.4 \\
8.5 \\
7.7\end{array}$ & $\begin{array}{l}0.00 \\
0.01 \\
0.00 \\
0.00 \\
0.00\end{array}$ & $\begin{array}{l}0100 \\
0105 \\
0110 \\
0115 \\
0120\end{array}$ & $\begin{array}{l}2.2 \\
2.2 \\
2.2 \\
2.2 \\
2.2\end{array}$ & $\begin{array}{l}0.00 \\
0.00 \\
0.00 \\
0.00 \\
0.00\end{array}$ & $\begin{array}{l}0600 \\
0605 \\
0610 \\
0615 \\
0620\end{array}$ & $\begin{array}{l}0.9 \\
0.9 \\
0.9 \\
0.9 \\
0.9\end{array}$ & $\begin{array}{l}0.00 \\
0.00 \\
0.00 \\
0.00 \\
0.00\end{array}$ \\
\hline $\begin{array}{l}2030 \\
2035 \\
2040 \\
2045 \\
2050\end{array}$ & $\begin{array}{l}7.3 \\
7.3 \\
6.6 \\
6.6 \\
6.6\end{array}$ & $\begin{array}{l}0.00 \\
0.00 \\
0.00 \\
0.00 \\
0.00\end{array}$ & $\begin{array}{l}0125 \\
0130 \\
0135 \\
0140 \\
0145\end{array}$ & $\begin{array}{l}2.2 \\
2.2 \\
2.0 \\
2.0 \\
2.0\end{array}$ & $\begin{array}{l}0.00 \\
0.00 \\
0.00 \\
0.00 \\
0.00\end{array}$ & $\begin{array}{l}0625 \\
0630 \\
0635 \\
0640 \\
0645\end{array}$ & $\begin{array}{l}0.9 \\
0.9 \\
0.8 \\
0.8 \\
0.8\end{array}$ & $\begin{array}{l}0.00 \\
0.01 \\
0.00 \\
0.00 \\
0.00\end{array}$ \\
\hline $\begin{array}{l}2055 \\
2100 \\
2105 \\
2110 \\
2115\end{array}$ & $\begin{array}{l}6.2 \\
5.5 \\
5.8 \\
5.2 \\
5.2\end{array}$ & $\begin{array}{l}0.00 \\
0.00 \\
0.00 \\
0.00 \\
0.00\end{array}$ & $\begin{array}{l}0150 \\
0155 \\
0200 \\
0205 \\
0210\end{array}$ & $\begin{array}{l}2.0 \\
2.0 \\
1.8 \\
1.8 \\
1.8\end{array}$ & $\begin{array}{l}0.00 \\
0.00 \\
0.00 \\
0.00 \\
0.00\end{array}$ & $\begin{array}{l}0650 \\
0655 \\
0700\end{array}$ & $\begin{array}{l}0.8 \\
0.8 \\
0.8\end{array}$ & $\begin{array}{l}0.00 \\
0.00 \\
0.00\end{array}$ \\
\hline
\end{tabular}




\section{Station 02160325, Brushy Creek (Enoree River Tributary) near Greenville, S.C.}

Location.--Lat $34^{\circ} 53^{\prime} 00^{\prime \prime}$, long $82^{\circ} 18^{\prime} 05^{\prime \prime}$, Greenville County, Hydrologic Unit 03050108 , at bridge on Marchant Road (secondary road J-180), 0.7 mi south of Eastside High School, $0.5 \mathrm{mi}$ southeast of St. Luke Church, and $5.0 \mathrm{mi}$ upstream from the mouth at Enoree River.

Period of record.-- December 18, 1985 to November 13, 1990.

Gage.--Digital stage recorder with 15-minute punch interval. The recorder is housed in a metal shelter atop a stilling well attached to the left upstream wingwall. An enameled staff gage is also attached to the left upstream wingwall.

Rating.--The stage-streamflow relation is defined by current meter measurements up to $376 \mathrm{ft}^{3} / \mathrm{s}$. The stage-streamflow relation was extended to $1,150 \mathrm{ft}^{3} / \mathrm{s}$ graphically $\mathrm{b}$ :r logarithmic plotting.

Rain gage and location.--Station 345243082194800 , lat $34^{\circ} 52^{\prime} 43^{\prime \prime}$, long $82^{\circ} 19^{\prime} 48^{\prime \prime}$. A shelter containing a digital cumulative rainfall recorder with a 15-minute punch interval attached to the downstream side of the Howell Road (State secondary road 273) bridge over Brushy Creek, $1.9 \mathrm{mi}$ southwest of Eastside High School, and approximately $1.7 \mathrm{mi}$ west of gaging station 02160325 .

Selected basin characteristics.--

Drainage area -- $9.05 \mathrm{mi}^{2}$

Physiographic province -- Piedmont

Channel slope -- $41.0 \mathrm{ft} / \mathrm{mi}$

Channel length -- $5.60 \mathrm{mi}$

Total impervious area -- 24.0 percent

Basin development factor -6

2-year, 2-hour rainfall amount -- 2.15 in.

Flood frequency data: $\mathrm{UQ}_{2} \quad 2,050 \mathrm{ft}^{3} / \mathrm{s}$

$\begin{array}{lr}\mathrm{UQ}_{5} & 3,210 \mathrm{ft}^{3} / \mathrm{s} \\ \mathrm{UQ}_{10} & 4,110 \mathrm{ft}^{3} / \mathrm{s} \\ \mathrm{UQ}_{25} & 5,370 \mathrm{ft}^{3} / \mathrm{s} \\ \mathrm{UQ}_{50} & 6,410 \mathrm{ft}^{3} / \mathrm{s} \\ \mathrm{UQ}_{100} & 7,540 \mathrm{ft}^{3} / \mathrm{s} \\ \mathrm{UQ}_{500} & 10,500 \mathrm{ft}^{3} / \mathrm{s}\end{array}$




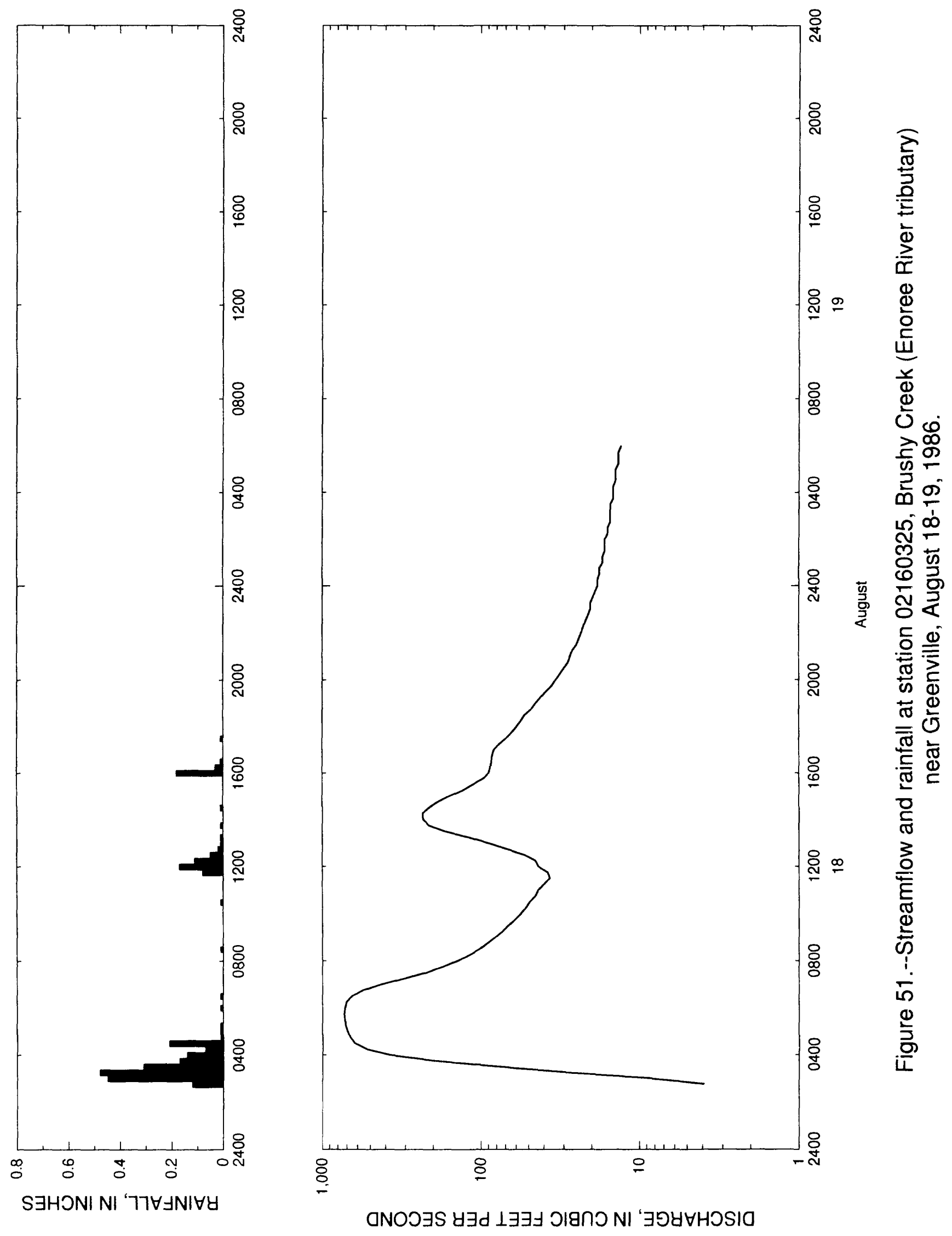


Table 50.- - Streamflow and rainfall at station 02160325 Brushy Creek (Enoree River tributary) near Greenville, August 18-19, 1986

\begin{tabular}{|c|c|c|c|c|c|c|c|c|}
\hline $\begin{array}{l}\text { Time } \\
\text { (hours) }\end{array}$ & $\begin{array}{l}\text { Streamflow } \\
\text { (cubic feet } \\
\text { per second) }\end{array}$ & $\begin{array}{l}\text { Rain - } \\
\text { fall } \\
\text { (inches) }\end{array}$ & $\begin{array}{l}\text { Time } \\
\text { (hours) }\end{array}$ & $\begin{array}{l}\text { Streamflow } \\
\text { (cubic feet } \\
\text { per second) }\end{array}$ & $\begin{array}{l}\text { Rain- } \\
\text { fal1 } \\
\text { (inches) }\end{array}$ & $\begin{array}{l}\text { Time } \\
\text { (hours) }\end{array}$ & $\begin{array}{l}\text { Streamflow } \\
\text { (cubic feet } \\
\text { per second) }\end{array}$ & $\begin{array}{l}\text { Rain- } \\
\text { fa11 } \\
\text { (inches) }\end{array}$ \\
\hline $\begin{array}{l}\text { August } 1 \\
0245 \\
0300 \\
0315 \\
0330\end{array}$ & 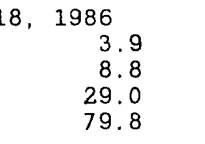 & $\begin{array}{l}0.12 \\
0.45 \\
0.48 \\
0.31\end{array}$ & $\begin{array}{l}1200 \\
1215 \\
1230 \\
1245 \\
1300\end{array}$ & $\begin{array}{l}43.5 \\
45.4 \\
53.3 \\
69.5 \\
90.2\end{array}$ & $\begin{array}{l}0.17 \\
0.11 \\
0.05 \\
0.02 \\
0.01\end{array}$ & $\begin{array}{l}2130 \\
2145 \\
2200 \\
2215 \\
2230\end{array}$ & $\begin{array}{l}24.9 \\
24.1 \\
23.3 \\
22.6 \\
21.9\end{array}$ & $\begin{array}{l}0.00 \\
0.00 \\
0.00 \\
0.00 \\
0.00\end{array}$ \\
\hline $\begin{array}{l}0345 \\
0400 \\
0415 \\
0430 \\
0445\end{array}$ & $\begin{array}{l}198.0 \\
376.0 \\
533.0 \\
627.0 \\
670.0\end{array}$ & $\begin{array}{l}0.17 \\
0.14 \\
0.07 \\
0.21 \\
0.01\end{array}$ & $\begin{array}{l}1315 \\
1330 \\
1345 \\
1400 \\
1415\end{array}$ & $\begin{array}{l}120.0 \\
169.0 \\
212.0 \\
232.0 \\
234.0\end{array}$ & $\begin{array}{l}0.01 \\
0.00 \\
0.01 \\
0.00 \\
0.00\end{array}$ & $\begin{array}{l}2245 \\
2300 \\
2315 \\
2330 \\
2345\end{array}$ & $\begin{array}{l}21.1 \\
20.4 \\
20.4 \\
19.7 \\
19.1\end{array}$ & $\begin{array}{l}0.00 \\
0.00 \\
0.00 \\
0.00 \\
0.00\end{array}$ \\
\hline $\begin{array}{l}0500 \\
0515 \\
0530 \\
0545 \\
0600\end{array}$ & $\begin{array}{l}692.0 \\
710.0 \\
724.0 \\
729.0 \\
720.0\end{array}$ & $\begin{array}{l}0.01 \\
0.01 \\
0.00 \\
0.00 \\
0.01\end{array}$ & $\begin{array}{l}1430 \\
1445 \\
1500 \\
1515 \\
1530\end{array}$ & $\begin{array}{l}214.0 \\
187.0 \\
158.0 \\
131.0 \\
113.0\end{array}$ & $\begin{array}{l}0.01 \\
0.00 \\
0.00 \\
0.00 \\
0.00\end{array}$ & $\begin{array}{c}\text { August } \\
0000 \\
0015 \\
0030 \\
0045\end{array}$ & $\begin{array}{r}19,1986 \\
18.4 \\
18.4 \\
17.8 \\
17.8\end{array}$ & $\begin{array}{l}0.00 \\
0.00 \\
0.00 \\
0.00\end{array}$ \\
\hline $\begin{array}{l}0615 \\
0630 \\
0645 \\
0700 \\
0715\end{array}$ & $\begin{array}{l}704.0 \\
650.0 \\
559.0 \\
429.0 \\
310.0\end{array}$ & $\begin{array}{l}0.00 \\
0.01 \\
0.00 \\
0.00 \\
0.00\end{array}$ & $\begin{array}{l}1545 \\
1600 \\
1615 \\
1630 \\
1645\end{array}$ & $\begin{array}{l}96.6 \\
89.2 \\
87.1 \\
86.0 \\
85.0\end{array}$ & $\begin{array}{l}0.00 \\
0.18 \\
0.03 \\
0.01 \\
0.00\end{array}$ & $\begin{array}{l}0100 \\
0115 \\
0130 \\
0145 \\
0200\end{array}$ & $\begin{array}{l}17.1 \\
17.1 \\
16.5 \\
16.5 \\
16.5\end{array}$ & $\begin{array}{l}0.00 \\
0.00 \\
0.00 \\
0.00 \\
0.00\end{array}$ \\
\hline $\begin{array}{l}0730 \\
0745 \\
0800 \\
0815 \\
0830\end{array}$ & $\begin{array}{l}222.0 \\
174.0 \\
142.0 \\
118.0 \\
103.0\end{array}$ & $\begin{array}{l}0.00 \\
0.00 \\
0.00 \\
0.00 \\
0.01\end{array}$ & $\begin{array}{l}1700 \\
1715 \\
1730 \\
1745 \\
1800\end{array}$ & $\begin{array}{l}82.9 \\
76.7 \\
69.5 \\
64.4 \\
60.3\end{array}$ & $\begin{array}{l}0.00 \\
0.00 \\
0.01 \\
0.00 \\
0.00\end{array}$ & $\begin{array}{l}0215 \\
0230 \\
0245 \\
0300 \\
0315\end{array}$ & $\begin{array}{l}15.9 \\
15.9 \\
15.3 \\
15.3 \\
15.3\end{array}$ & $\begin{array}{l}0.00 \\
0.00 \\
0.00 \\
0.00 \\
0.00\end{array}$ \\
\hline $\begin{array}{l}0845 \\
0900 \\
0915 \\
0930 \\
0945\end{array}$ & $\begin{array}{l}91.3 \\
81.8 \\
73.6 \\
67.4 \\
61.3\end{array}$ & $\begin{array}{l}0.00 \\
0.00 \\
0.00 \\
0.00 \\
0.00\end{array}$ & $\begin{array}{l}1815 \\
1830 \\
1845 \\
1900 \\
1915\end{array}$ & $\begin{array}{l}56.3 \\
53.3 \\
48.4 \\
45.4 \\
42.3\end{array}$ & $\begin{array}{l}0.00 \\
0.00 \\
0.00 \\
0.00 \\
0.00\end{array}$ & $\begin{array}{l}0330 \\
0345 \\
0400 \\
0415 \\
0430\end{array}$ & $\begin{array}{l}15.3 \\
14.7 \\
14.7 \\
14.7 \\
14.2\end{array}$ & $\begin{array}{l}0.00 \\
0.00 \\
0.00 \\
0.00 \\
0.00\end{array}$ \\
\hline $\begin{array}{l}1000 \\
1015 \\
1030 \\
1045 \\
1100\end{array}$ & $\begin{array}{l}56.3 \\
52.3 \\
49.4 \\
45.4 \\
43.5\end{array}$ & $\begin{array}{l}0.00 \\
0.00 \\
0.01 \\
0.00 \\
0.00\end{array}$ & $\begin{array}{l}1930 \\
1945 \\
2000 \\
2015 \\
2030\end{array}$ & $\begin{array}{l}39.0 \\
35.8 \\
33.8 \\
31.8 \\
29.9\end{array}$ & $\begin{array}{l}0.00 \\
0.00 \\
0.00 \\
0.00 \\
0.00\end{array}$ & $\begin{array}{l}0445 \\
0500 \\
0515 \\
0530 \\
0545\end{array}$ & $\begin{array}{l}14.2 \\
14.2 \\
13.6 \\
13.6 \\
13.6\end{array}$ & $\begin{array}{l}0.00 \\
0.00 \\
0.00 \\
0.00 \\
0.00\end{array}$ \\
\hline $\begin{array}{l}1115 \\
1130 \\
1145\end{array}$ & $\begin{array}{l}40.1 \\
36.8 \\
37.9\end{array}$ & $\begin{array}{l}0.00 \\
0.00 \\
0.08\end{array}$ & $\begin{array}{l}2045 \\
2100 \\
2115\end{array}$ & $\begin{array}{l}28.1 \\
27.3 \\
26.5\end{array}$ & $\begin{array}{l}0.00 \\
0.00 \\
0.00\end{array}$ & 0600 & 13.1 & 0.00 \\
\hline
\end{tabular}




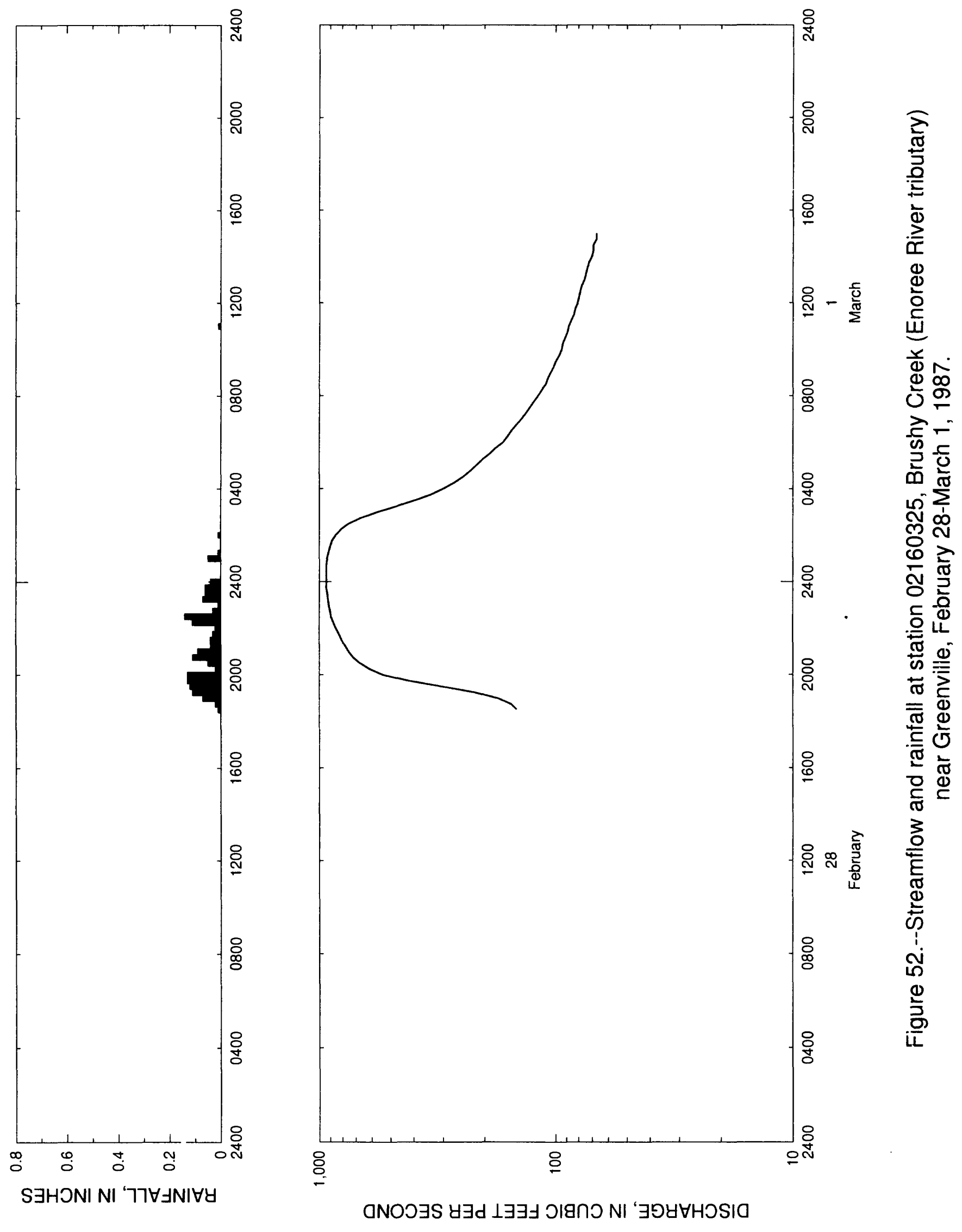


Table 51.--Streamflow and rainfall at station 02160325 , Brushy Creek (Enoree River tributary) near Greenville, February $28-$ March 1,1987

\begin{tabular}{|c|c|c|c|c|c|c|c|c|}
\hline $\begin{array}{l}\text { Time } \\
\text { (hours) }\end{array}$ & $\begin{array}{l}\text { Streamflow } \\
\text { (cubic feet } \\
\text { per second) }\end{array}$ & $\begin{array}{l}\text { Rain- } \\
\text { fal1 } \\
\text { (inches) }\end{array}$ & $\begin{array}{l}\text { Time } \\
\text { (hours) }\end{array}$ & $\begin{array}{l}\text { Streamflow } \\
\text { (cubic feet } \\
\text { per second) }\end{array}$ & $\begin{array}{l}\text { Rain- } \\
\text { fall } \\
\text { (inches) }\end{array}$ & $\begin{array}{l}\text { Time } \\
\text { (hours) }\end{array}$ & $\begin{array}{l}\text { Streamflow } \\
\text { (cubic feet } \\
\text { per second) }\end{array}$ & $\begin{array}{l}\text { Rain- } \\
\text { fall } \\
\text { (inches) }\end{array}$ \\
\hline $\begin{array}{c}\text { February } \\
1830 \\
1845 \\
1900 \\
1915\end{array}$ & $28, \begin{array}{r}1987 \\
146.0 \\
154.0 \\
176.0 \\
219.0\end{array}$ & $\begin{array}{l}0.01 \\
0.02 \\
0.07 \\
0.11\end{array}$ & $\begin{array}{l}0115 \\
0130 \\
0145 \\
0200 \\
0215\end{array}$ & $\begin{array}{l}915.0 \\
901.0 \\
885.0 \\
853.0 \\
810.0\end{array}$ & $\begin{array}{l}0.01 \\
0.00 \\
0.00 \\
0.01 \\
0.00\end{array}$ & $\begin{array}{l}0830 \\
0845 \\
0900 \\
0915 \\
0930\end{array}$ & $\begin{array}{r}110.0 \\
108.0 \\
105.0 \\
102.0 \\
99.8\end{array}$ & $\begin{array}{l}0.00 \\
0.00 \\
0.00 \\
0.00 \\
0.00\end{array}$ \\
\hline $\begin{array}{l}1930 \\
1945 \\
2000 \\
2015 \\
2030\end{array}$ & $\begin{array}{l}304.0 \\
419.0 \\
539.0 \\
611.0 \\
673.0\end{array}$ & $\begin{array}{l}0.12 \\
0.13 \\
0.13 \\
0.02 \\
0.05\end{array}$ & $\begin{array}{l}0230 \\
0245 \\
0300 \\
0315 \\
0330\end{array}$ & $\begin{array}{l}750.0 \\
668.0 \\
569.0 \\
474.0 \\
397.0\end{array}$ & $\begin{array}{l}0.00 \\
0.00 \\
0.00 \\
0.00 \\
0.00\end{array}$ & $\begin{array}{l}0945 \\
1000 \\
1015 \\
1030 \\
1045\end{array}$ & $\begin{array}{l}96.6 \\
94.4 \\
93.4 \\
91.3 \\
89.2\end{array}$ & $\begin{array}{l}0.00 \\
0.00 \\
0.00 \\
0.00 \\
0.00\end{array}$ \\
\hline $\begin{array}{l}2045 \\
2100 \\
2115 \\
2130 \\
2145\end{array}$ & $\begin{array}{l}721.0 \\
753.0 \\
780.0 \\
806.0 \\
827.0\end{array}$ & $\begin{array}{l}0.11 \\
0.09 \\
0.04 \\
0.04 \\
0.03\end{array}$ & $\begin{array}{l}0345 \\
0400 \\
0415 \\
0430 \\
0445\end{array}$ & $\begin{array}{l}340.0 \\
301.0 \\
272.0 \\
249.0 \\
232.0\end{array}$ & $\begin{array}{l}0.00 \\
0.00 \\
0.00 \\
0.00 \\
0.00\end{array}$ & $\begin{array}{l}1100 \\
1115 \\
1130 \\
1145 \\
1200\end{array}$ & $\begin{array}{l}88.1 \\
86.0 \\
83.9 \\
82.9 \\
80.8\end{array}$ & $\begin{array}{l}0.01 \\
0.00 \\
0.00 \\
0.00 \\
0.00\end{array}$ \\
\hline $\begin{array}{l}2200 \\
2215 \\
2230 \\
2245 \\
2300\end{array}$ & $\begin{array}{l}852.0 \\
874.0 \\
893.0 \\
902.0 \\
913.0\end{array}$ & $\begin{array}{l}0.02 \\
0.11 \\
0.14 \\
0.03 \\
0.01\end{array}$ & $\begin{array}{l}0500 \\
0515 \\
0530 \\
0545 \\
0600\end{array}$ & $\begin{array}{l}218.0 \\
205.0 \\
191.0 \\
180.0 \\
167.0\end{array}$ & $\begin{array}{l}0.00 \\
0.00 \\
0.00 \\
0.00 \\
0.00\end{array}$ & $\begin{array}{l}1215 \\
1230 \\
1245 \\
1300 \\
1315\end{array}$ & $\begin{array}{l}79.8 \\
78.7 \\
77.7 \\
75.6 \\
74.6\end{array}$ & $\begin{array}{l}0.00 \\
0.00 \\
0.00 \\
0.00 \\
0.00\end{array}$ \\
\hline $\begin{array}{r}2315 \\
2330 \\
2345 \\
\text { March 1, } \\
0000\end{array}$ & $\begin{array}{r}920.0 \\
926.0 \\
937.0 \\
1987 \\
934.0\end{array}$ & $\begin{array}{l}0.07 \\
0.06 \\
0.06 \\
0.04\end{array}$ & $\begin{array}{l}0615 \\
0630 \\
0645 \\
0700 \\
0715\end{array}$ & $\begin{array}{l}160.0 \\
154.0 \\
147.0 \\
140.0 \\
134.0\end{array}$ & $\begin{array}{l}0.00 \\
0.00 \\
0.00 \\
0.00 \\
0.00\end{array}$ & $\begin{array}{l}1330 \\
1345 \\
1400 \\
1415 \\
1430\end{array}$ & $\begin{array}{l}73.6 \\
72.5 \\
70.5 \\
69.5 \\
69.5\end{array}$ & $\begin{array}{l}0.00 \\
0.00 \\
0.00 \\
0.00 \\
0.00\end{array}$ \\
\hline $\begin{array}{l}0015 \\
0030 \\
0045 \\
0100\end{array}$ & $\begin{array}{l}935.0 \\
937.0 \\
935.0 \\
927.0\end{array}$ & $\begin{array}{l}0.00 \\
0.00 \\
0.00 \\
0.05\end{array}$ & $\begin{array}{l}0730 \\
0745 \\
0800 \\
0815\end{array}$ & $\begin{array}{l}129.0 \\
124.0 \\
119.0 \\
115.0\end{array}$ & $\begin{array}{l}0.00 \\
0.00 \\
0.00 \\
0.00\end{array}$ & $\begin{array}{l}1445 \\
1500\end{array}$ & $\begin{array}{l}67.4 \\
67.4\end{array}$ & $\begin{array}{l}0.00 \\
0.00\end{array}$ \\
\hline
\end{tabular}



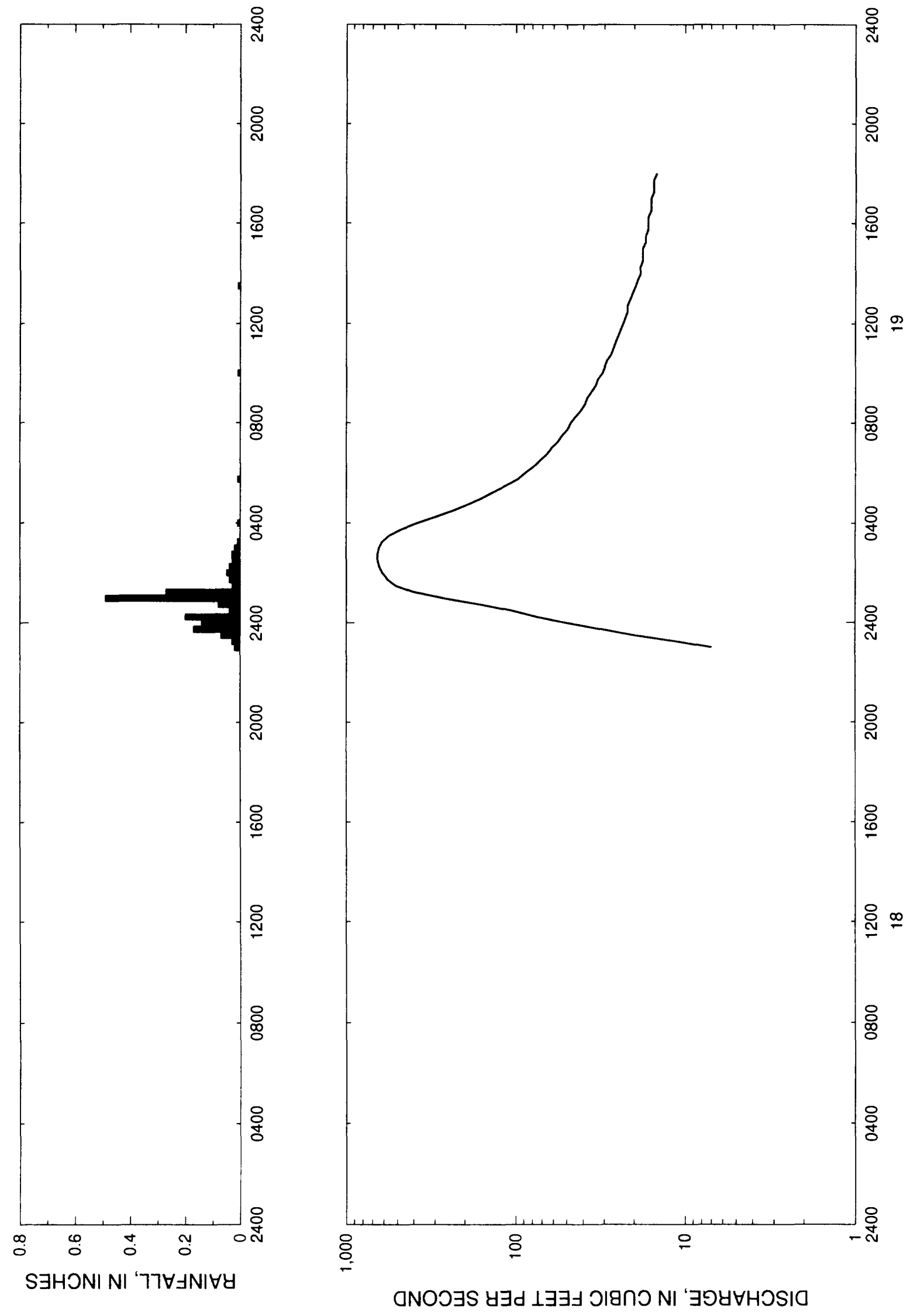

’’

क.

岕

क

$\Phi$

융 으

8

\&

济

$\Phi$

잉

뜨

$\stackrel{Ð}{5}$

音

ఏํํ

촐

స్ల్ర

등

$\pm$

$\overline{\bar{\sigma}}$

高

듬

के

लึ

造 
Table 52.--Streamflow and rainfall at station 02160325, Brushy Creek (Enoree River tributary) near Greenville, June 18-19, 1987

\begin{tabular}{|c|c|c|c|c|c|c|c|c|}
\hline $\begin{array}{l}\text { Time } \\
\text { (hours) }\end{array}$ & $\begin{array}{l}\text { Streamflow } \\
\text { (cubic feet } \\
\text { per second) }\end{array}$ & $\begin{array}{l}\text { Rain- } \\
\text { fall } \\
\text { (inches) }\end{array}$ & $\begin{array}{l}\text { Time } \\
\text { (hours) }\end{array}$ & $\begin{array}{l}\text { Streamflow } \\
\text { (cubic feet } \\
\text { per second) }\end{array}$ & $\begin{array}{l}\text { Rain- } \\
\text { fall } \\
\text { (inches) }\end{array}$ & $\begin{array}{l}\text { Time } \\
\text { (hours) }\end{array}$ & $\begin{array}{l}\text { Streamflow } \\
\text { (cubic feet } \\
\text { per second) }\end{array}$ & $\begin{array}{l}\text { Rain- } \\
\text { fall } \\
\text { (inches) }\end{array}$ \\
\hline $\begin{array}{l}\text { June } 18, \\
2300 \\
2315 \\
2330 \\
2345\end{array}$ & $\begin{array}{r}1987 \\
6.9 \\
11.5 \\
20.4 \\
31.8\end{array}$ & $\begin{array}{l}0.02 \\
0.03 \\
0.07 \\
0.17\end{array}$ & $\begin{array}{l}0515 \\
0530 \\
0545 \\
0600 \\
0615\end{array}$ & $\begin{array}{r}134.0 \\
114.0 \\
97.6 \\
88.1 \\
78.7\end{array}$ & $\begin{array}{l}0.00 \\
0.00 \\
0.01 \\
0.00 \\
0.00\end{array}$ & $\begin{array}{l}1200 \\
1215 \\
1230 \\
1245 \\
1300\end{array}$ & $\begin{array}{l}23.3 \\
22.6 \\
21.9 \\
21.9 \\
21.1\end{array}$ & $\begin{array}{l}0.00 \\
0.00 \\
0.00 \\
0.00 \\
0.00\end{array}$ \\
\hline $\begin{array}{l}\text { June } 19 \\
0000 \\
0015 \\
0030 \\
0045\end{array}$ & $\begin{array}{r}1987 \\
50.4 \\
75.6 \\
106.0 \\
162.0\end{array}$ & $\begin{array}{l}0.14 \\
0.20 \\
0.04 \\
0.08\end{array}$ & $\begin{array}{l}0630 \\
0645 \\
0700 \\
0715 \\
0730\end{array}$ & $\begin{array}{l}71.5 \\
65.4 \\
61.3 \\
56.3 \\
53.3\end{array}$ & $\begin{array}{l}0.00 \\
0.00 \\
0.00 \\
0.00 \\
0.00\end{array}$ & $\begin{array}{l}1315 \\
1330 \\
1345 \\
1400 \\
1415\end{array}$ & $\begin{array}{l}20.4 \\
19.7 \\
19.1 \\
18.4 \\
18.4\end{array}$ & $\begin{array}{l}0.00 \\
0.01 \\
0.00 \\
0.00 \\
0.00\end{array}$ \\
\hline $\begin{array}{l}0100 \\
0115 \\
0130 \\
0145 \\
0200\end{array}$ & $\begin{array}{l}265.0 \\
403.0 \\
510.0 \\
573.0 \\
614.0\end{array}$ & $\begin{array}{l}0.49 \\
0.27 \\
0.03 \\
0.04 \\
0.05\end{array}$ & $\begin{array}{l}0745 \\
0800 \\
0815 \\
0830 \\
0845\end{array}$ & $\begin{array}{l}49.4 \\
47.4 \\
44.5 \\
41.2 \\
39.0\end{array}$ & $\begin{array}{l}0.00 \\
0.00 \\
0.00 \\
0.00 \\
0.00\end{array}$ & $\begin{array}{l}1430 \\
1445 \\
1500 \\
1515 \\
1530\end{array}$ & $\begin{array}{l}17.8 \\
17.8 \\
17.8 \\
17.1 \\
17.1\end{array}$ & $\begin{array}{l}0.00 \\
0.00 \\
0.00 \\
0.00 \\
0.00\end{array}$ \\
\hline $\begin{array}{l}0215 \\
0230 \\
0245 \\
0300 \\
0315\end{array}$ & $\begin{array}{l}639.0 \\
654.0 \\
652.0 \\
641.0 \\
614.0\end{array}$ & $\begin{array}{l}0.04 \\
0.03 \\
0.03 \\
0.02 \\
0.01\end{array}$ & $\begin{array}{l}0900 \\
0915 \\
0930 \\
0945 \\
1000\end{array}$ & $\begin{array}{l}37.9 \\
35.8 \\
33.8 \\
32.8 \\
30.8\end{array}$ & $\begin{array}{l}0.00 \\
0.00 \\
0.00 \\
0.00 \\
0.01\end{array}$ & $\begin{array}{l}1545 \\
1600 \\
1615 \\
1630 \\
1645\end{array}$ & $\begin{array}{l}16.5 \\
16.5 \\
16.5 \\
15.9 \\
15.9\end{array}$ & $\begin{array}{l}0.00 \\
0.00 \\
0.00 \\
0.00 \\
0.00\end{array}$ \\
\hline $\begin{array}{l}0330 \\
0345 \\
0400 \\
0415 \\
0430\end{array}$ & $\begin{array}{l}559.0 \\
474.0 \\
382.0 \\
298.0 \\
235.0\end{array}$ & $\begin{array}{l}0.00 \\
0.00 \\
0.01 \\
0.00 \\
0.00\end{array}$ & $\begin{array}{l}1015 \\
1030 \\
1045 \\
1100 \\
1115\end{array}$ & $\begin{array}{l}29.9 \\
29.0 \\
27.3 \\
26.5 \\
25.7\end{array}$ & $\begin{array}{l}0.00 \\
0.00 \\
0.00 \\
0.00 \\
0.00\end{array}$ & $\begin{array}{l}1700 \\
1715 \\
1730 \\
1745 \\
1800\end{array}$ & $\begin{array}{l}15.9 \\
15.3 \\
15.3 \\
15.3 \\
14.7\end{array}$ & $\begin{array}{l}0.00 \\
0.00 \\
0.00 \\
0.00 \\
0.00\end{array}$ \\
\hline $\begin{array}{l}0445 \\
0500\end{array}$ & $\begin{array}{l}192.0 \\
159.0\end{array}$ & $\begin{array}{l}0.00 \\
0.00\end{array}$ & $\begin{array}{l}1130 \\
1145\end{array}$ & $\begin{array}{l}24.9 \\
24.1\end{array}$ & $\begin{array}{l}0.00 \\
0.00\end{array}$ & & & \\
\hline
\end{tabular}




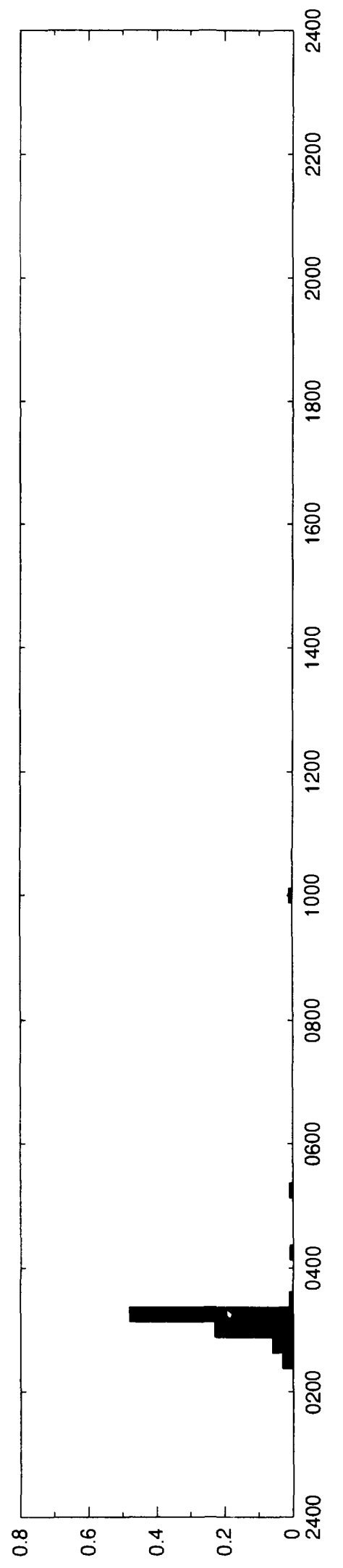

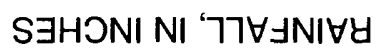

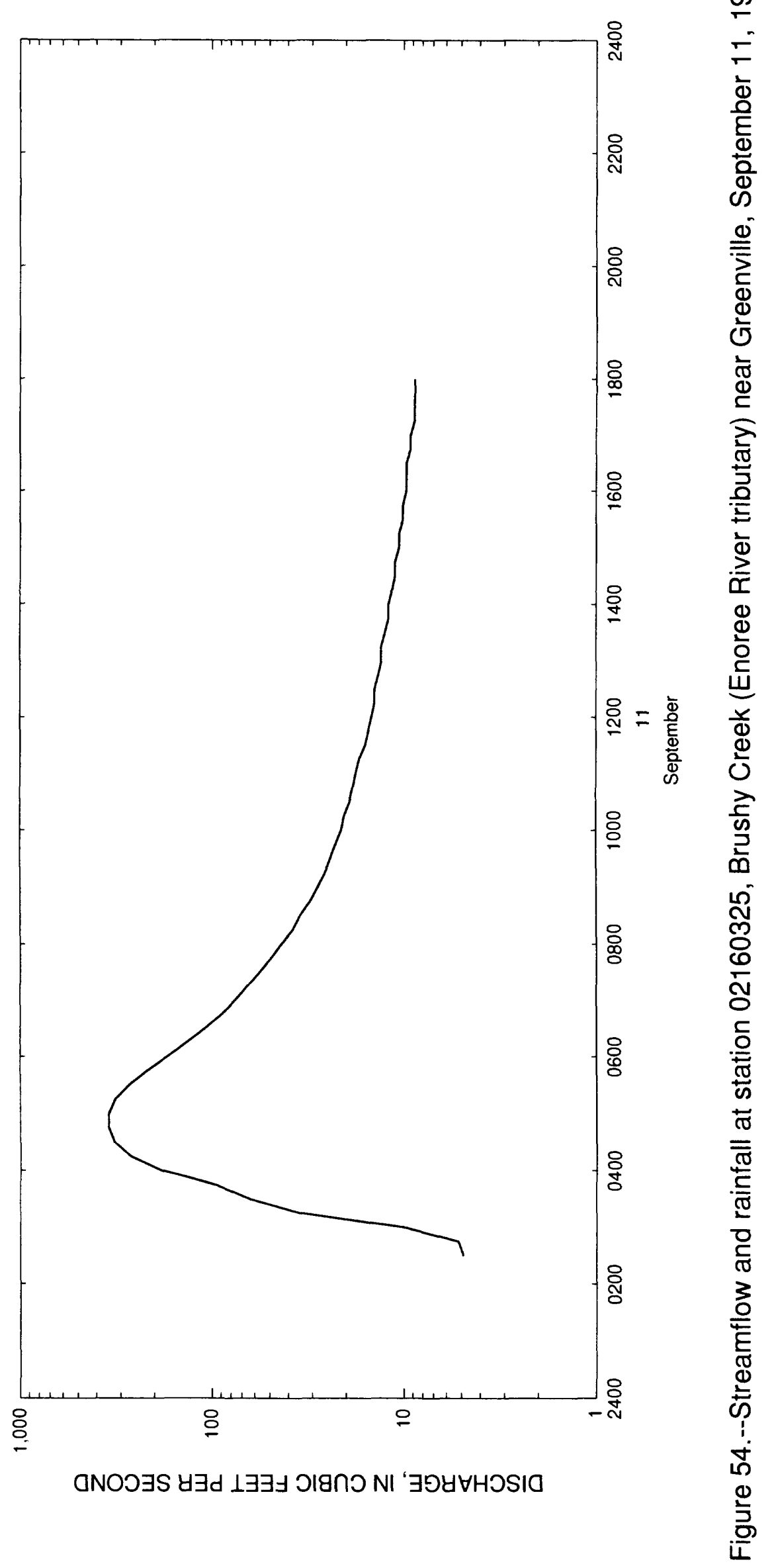

149 
Table 53.--Streamflow and rainfal1 at station 02160325, Brushy Creek (Enoree River tributary) near Greenville, September 11, 1987

\begin{tabular}{|c|c|c|c|c|c|c|c|c|}
\hline $\begin{array}{l}\text { Time } \\
\text { (hours) }\end{array}$ & $\begin{array}{l}\text { Streamflow } \\
\text { (cubic feet } \\
\text { per second) }\end{array}$ & $\begin{array}{l}\text { Rain- } \\
\text { fall } \\
\text { (inches) }\end{array}$ & $\begin{array}{l}\text { Time } \\
\text { (hours) }\end{array}$ & $\begin{array}{l}\text { Streamflow } \\
\text { (cubic feet } \\
\text { per second) }\end{array}$ & $\begin{array}{l}\text { Rain- } \\
\text { fall } \\
\text { (inches) }\end{array}$ & $\begin{array}{l}\text { Time } \\
\text { (hours) }\end{array}$ & $\begin{array}{l}\text { Streamflow } \\
\text { (cubic feet } \\
\text { per second) }\end{array}$ & $\begin{array}{l}\text { Rain- } \\
\text { fall } \\
\text { (inches) }\end{array}$ \\
\hline $\begin{array}{l}\text { Sept ember } \\
0230 \\
0245 \\
0300 \\
0315\end{array}$ & 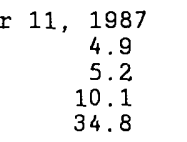 & $\begin{array}{l}0.03 \\
0.06 \\
0.23 \\
0.48\end{array}$ & $\begin{array}{l}0745 \\
0800 \\
0815 \\
0830 \\
0845\end{array}$ & $\begin{array}{l}49.4 \\
43.5 \\
37.9 \\
34.8 \\
30.8\end{array}$ & $\begin{array}{l}0.00 \\
0.00 \\
0.00 \\
0.00 \\
0.00\end{array}$ & $\begin{array}{l}1315 \\
1330 \\
1345 \\
1400 \\
1415\end{array}$ & $\begin{array}{l}13.1 \\
12.5 \\
12.0 \\
12.0 \\
11.5\end{array}$ & $\begin{array}{l}0.00 \\
0.00 \\
0.00 \\
0.00 \\
0.00\end{array}$ \\
\hline $\begin{array}{l}0330 \\
0345 \\
0400 \\
0415 \\
0430\end{array}$ & $\begin{array}{r}63.4 \\
95.5 \\
184.0 \\
267.0 \\
323.0\end{array}$ & $\begin{array}{l}0.01 \\
0.00 \\
0.00 \\
0.01 \\
0.00\end{array}$ & $\begin{array}{l}0900 \\
0915 \\
0930 \\
0945 \\
1000\end{array}$ & $\begin{array}{l}28.1 \\
25.7 \\
24.1 \\
22.6 \\
21.1\end{array}$ & $\begin{array}{l}0.00 \\
0.00 \\
0.00 \\
0.00 \\
0.01\end{array}$ & $\begin{array}{l}1430 \\
1445 \\
1500 \\
1515 \\
1530\end{array}$ & $\begin{array}{l}11.1 \\
11.1 \\
10.6 \\
10.6 \\
10.1\end{array}$ & $\begin{array}{l}0.00 \\
0.00 \\
0.00 \\
0.00 \\
0.00\end{array}$ \\
\hline $\begin{array}{l}0445 \\
0500 \\
0515 \\
0530 \\
0545\end{array}$ & $\begin{array}{l}346.0 \\
346.0 \\
321.0 \\
273.0 \\
220.0\end{array}$ & $\begin{array}{l}0.00 \\
0.00 \\
0.01 \\
0.00 \\
0.00\end{array}$ & $\begin{array}{l}1015 \\
1030 \\
1045 \\
1100 \\
1115\end{array}$ & $\begin{array}{l}20.4 \\
19.1 \\
18.4 \\
17.8 \\
17.1\end{array}$ & $\begin{array}{l}0.00 \\
0.00 \\
0.00 \\
0.00 \\
0.00\end{array}$ & $\begin{array}{l}1545 \\
1600 \\
1615 \\
1630 \\
1645\end{array}$ & $\begin{array}{r}10.1 \\
9.7 \\
9.7 \\
9.7 \\
9.2\end{array}$ & $\begin{array}{l}0.00 \\
0.00 \\
0.00 \\
0.00 \\
0.00\end{array}$ \\
\hline $\begin{array}{l}0600 \\
0615 \\
0630 \\
0645 \\
0700\end{array}$ & $\begin{array}{r}172.0 \\
136.0 \\
109.0 \\
89.2 \\
75.6\end{array}$ & $\begin{array}{l}0.00 \\
0.00 \\
0.00 \\
0.00 \\
0.00\end{array}$ & $\begin{array}{l}1130 \\
1145 \\
1200 \\
1215 \\
1230\end{array}$ & $\begin{array}{l}15.9 \\
15.3 \\
14.7 \\
14.2 \\
14.2\end{array}$ & $\begin{array}{l}0.00 \\
0.00 \\
0.00 \\
0.00 \\
0.00\end{array}$ & $\begin{array}{l}1700 \\
1715 \\
1730 \\
1745 \\
1800\end{array}$ & $\begin{array}{l}9.2 \\
8.8 \\
8.8 \\
8.8 \\
8.8\end{array}$ & $\begin{array}{l}0.00 \\
0.00 \\
0.00 \\
0.00 \\
0.00\end{array}$ \\
\hline $\begin{array}{l}0715 \\
0730\end{array}$ & $\begin{array}{l}65.4 \\
56.3\end{array}$ & $\begin{array}{l}0.00 \\
0.00\end{array}$ & $\begin{array}{l}1245 \\
1300\end{array}$ & $\begin{array}{l}13.6 \\
13.1\end{array}$ & $\begin{array}{l}0.00 \\
0.00\end{array}$ & & & \\
\hline
\end{tabular}




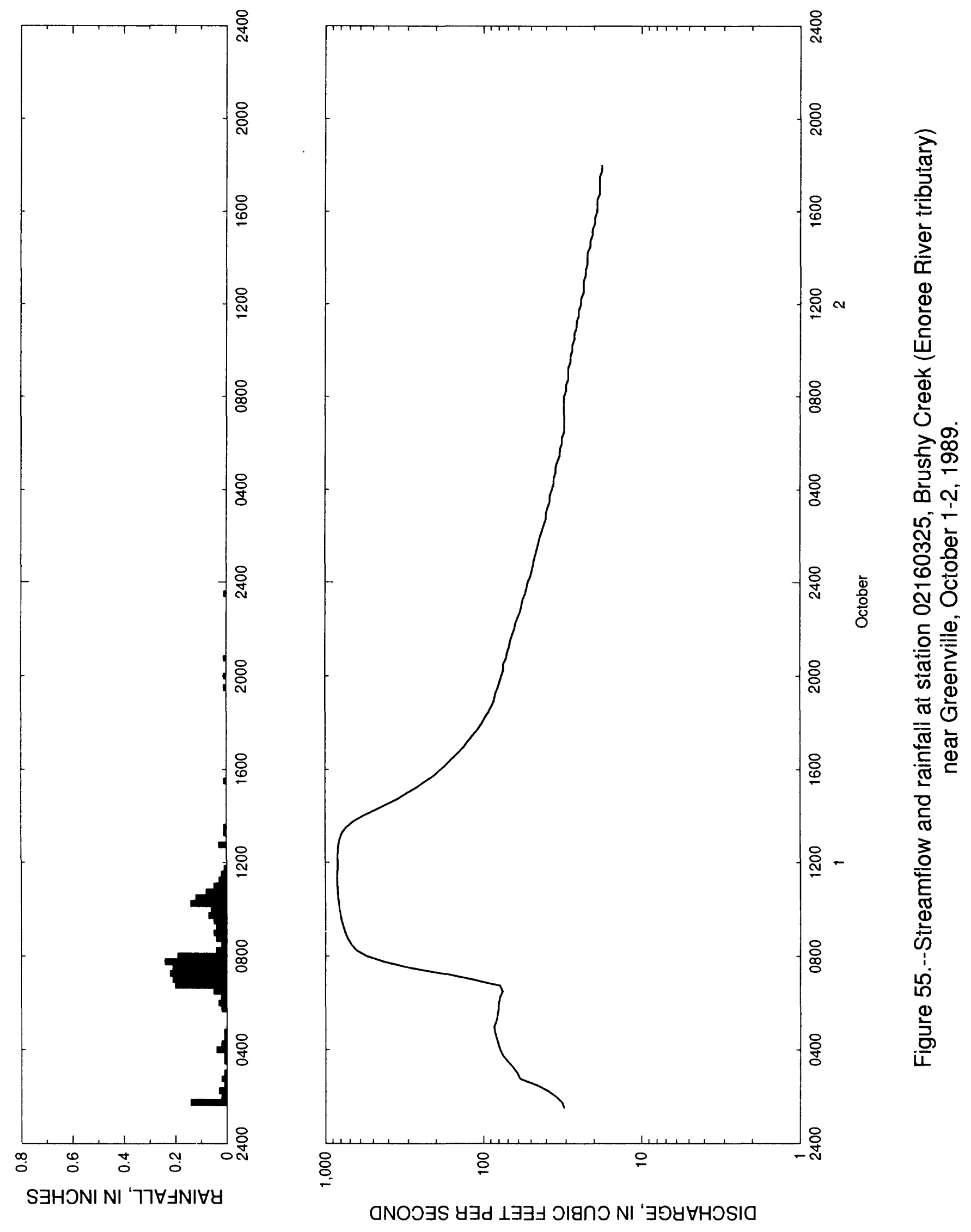


Table 54.--Streamflow and rainfall at station 02160325, Brushy Creek (Enoree River tributary) near

\section{Greenville, October 1-2, 1989}

\begin{tabular}{|c|c|c|c|c|c|c|c|c|}
\hline $\begin{array}{l}\text { Time } \\
\text { (hours) }\end{array}$ & $\begin{array}{l}\text { Streamflow } \\
\text { (cubic feet } \\
\text { per second) }\end{array}$ & $\begin{array}{l}\text { Rain- } \\
\text { fall } \\
\text { (inches) }\end{array}$ & $\begin{array}{l}\text { Time } \\
\text { (hours) }\end{array}$ & $\begin{array}{l}\text { Streamflow } \\
\text { (cubic feet } \\
\text { per second) }\end{array}$ & $\begin{array}{l}\text { Rain- } \\
\text { fall } \\
\text { (inches) }\end{array}$ & $\begin{array}{l}\text { Time } \\
\text { (hours) }\end{array}$ & $\begin{array}{l}\text { Streamflow } \\
\text { (cubic feet } \\
\text { per second) }\end{array}$ & $\begin{array}{l}\text { Rain- } \\
\text { fall } \\
\text { (inches) }\end{array}$ \\
\hline $\begin{array}{l}\text { October } \\
0130 \\
0145 \\
0200 \\
0215\end{array}$ & $\begin{array}{r}1.1989 \\
30.8 \\
31.8 \\
34.8 \\
39.0\end{array}$ & $\begin{array}{l}0.00 \\
0.14 \\
0.02 \\
0.03\end{array}$ & $\begin{array}{l}1500 \\
1515 \\
1530 \\
1545 \\
1600\end{array}$ & $\begin{array}{l}301.0 \\
261.0 \\
233.0 \\
205.0 \\
187.0\end{array}$ & $\begin{array}{l}0.00 \\
0.00 \\
0.01 \\
0.00 \\
0.00\end{array}$ & $\begin{array}{l}0430 \\
0445 \\
0500 \\
0515 \\
0530\end{array}$ & $\begin{array}{l}35.8 \\
34.8 \\
34.8 \\
33.8 \\
32.8\end{array}$ & $\begin{array}{l}0.00 \\
0.00 \\
0.00 \\
0.00 \\
0.00\end{array}$ \\
\hline $\begin{array}{l}0230 \\
0245 \\
0300 \\
0315 \\
0330\end{array}$ & $\begin{array}{l}46.4 \\
58.5 \\
61.3 \\
65.4 \\
70.5\end{array}$ & $\begin{array}{l}0.01 \\
0.02 \\
0.01 \\
0.00 \\
0.01\end{array}$ & $\begin{array}{l}1615 \\
1630 \\
1645 \\
1700 \\
1715\end{array}$ & $\begin{array}{l}170.0 \\
156.0 \\
143.0 \\
132.0 \\
124.0\end{array}$ & $\begin{array}{l}0.00 \\
0.00 \\
0.00 \\
0.00 \\
0.00\end{array}$ & $\begin{array}{l}0545 \\
0600 \\
0615 \\
0630 \\
0645\end{array}$ & $\begin{array}{l}32.8 \\
31.8 \\
31.8 \\
30.8 \\
30.8\end{array}$ & $\begin{array}{l}0.00 \\
0.00 \\
0.00 \\
0.00 \\
0.00\end{array}$ \\
\hline $\begin{array}{l}0345 \\
0400 \\
0415 \\
0430 \\
0445\end{array}$ & $\begin{array}{l}75.6 \\
78.7 \\
80.8 \\
82.9 \\
85.0\end{array}$ & $\begin{array}{l}0.01 \\
0.04 \\
0.02 \\
0.01 \\
0.01\end{array}$ & $\begin{array}{l}1730 \\
1745 \\
1800 \\
1815 \\
1830\end{array}$ & $\begin{array}{r}116.0 \\
108.0 \\
102.0 \\
97.6 \\
92.3\end{array}$ & $\begin{array}{l}0.00 \\
0.00 \\
0.00 \\
0.00 \\
0.00\end{array}$ & $\begin{array}{l}0700 \\
0715 \\
0730 \\
0745 \\
0800\end{array}$ & $\begin{array}{l}30.8 \\
30.8 \\
30.8 \\
30.8 \\
30.8\end{array}$ & $\begin{array}{l}0.00 \\
0.00 \\
0.00 \\
0.00 \\
0.00\end{array}$ \\
\hline $\begin{array}{l}0500 \\
0515 \\
0530 \\
0545 \\
0600\end{array}$ & $\begin{array}{l}86.0 \\
82.9 \\
81.8 \\
80.8 \\
79.8\end{array}$ & $\begin{array}{l}0.00 \\
0.00 \\
0.00 \\
0.02 \\
0.03\end{array}$ & $\begin{array}{l}1845 \\
1900 \\
1915 \\
1930 \\
1945\end{array}$ & $\begin{array}{l}88.1 \\
85.0 \\
83.9 \\
80.8 \\
78.7\end{array}$ & $\begin{array}{l}0.00 \\
0.00 \\
0.00 \\
0.01 \\
0.00\end{array}$ & $\begin{array}{l}0815 \\
0830 \\
0845 \\
0900 \\
0915\end{array}$ & $\begin{array}{l}29.9 \\
29.9 \\
29.0 \\
29.0 \\
29.0\end{array}$ & $\begin{array}{l}0.00 \\
0.00 \\
0.00 \\
0.00 \\
0.00\end{array}$ \\
\hline $\begin{array}{l}0615 \\
0630 \\
0645 \\
0700 \\
0715\end{array}$ & $\begin{array}{r}78.7 \\
75.6 \\
78.7 \\
115.0 \\
174.0\end{array}$ & $\begin{array}{l}0.02 \\
0.05 \\
0.20 \\
0.21 \\
0.22\end{array}$ & $\begin{array}{l}2000 \\
2015 \\
2030 \\
2045 \\
2100\end{array}$ & $\begin{array}{l}76.7 \\
74.6 \\
74.6 \\
71.5 \\
70.5\end{array}$ & $\begin{array}{l}0.01 \\
0.00 \\
0.00 \\
0.01 \\
0.00\end{array}$ & $\begin{array}{l}0930 \\
0945 \\
1000 \\
1015 \\
1030\end{array}$ & $\begin{array}{l}28.1 \\
28.1 \\
27.3 \\
27.3 \\
26.5\end{array}$ & $\begin{array}{l}0.00 \\
0.00 \\
0.00 \\
0.00 \\
0.00\end{array}$ \\
\hline $\begin{array}{l}0730 \\
0745 \\
0800 \\
0815 \\
0830\end{array}$ & $\begin{array}{l}287.0 \\
419.0 \\
546.0 \\
636.0 \\
686.0\end{array}$ & $\begin{array}{l}0.21 \\
0.24 \\
0.19 \\
0.04 \\
0.02\end{array}$ & $\begin{array}{l}2115 \\
2130 \\
2145 \\
2200 \\
2215\end{array}$ & $\begin{array}{l}68.4 \\
67.4 \\
65.4 \\
63.4 \\
62.4\end{array}$ & $\begin{array}{l}0.00 \\
0.00 \\
0.00 \\
0.00 \\
0.00\end{array}$ & $\begin{array}{l}1045 \\
1100 \\
1115 \\
1130 \\
1145\end{array}$ & $\begin{array}{l}26.5 \\
25.7 \\
25.7 \\
24.9 \\
24.9\end{array}$ & $\begin{array}{l}0.00 \\
0.00 \\
0.00 \\
0.00 \\
0.00\end{array}$ \\
\hline $\begin{array}{l}0845 \\
0900 \\
0915 \\
0930 \\
0945\end{array}$ & $\begin{array}{l}722.0 \\
748.0 \\
768.0 \\
787.0 \\
803.0\end{array}$ & $\begin{array}{l}0.04 \\
0.05 \\
0.04 \\
0.05 \\
0.07\end{array}$ & $\begin{array}{l}2230 \\
2245 \\
2300 \\
2315 \\
2330\end{array}$ & $\begin{array}{l}60.3 \\
58.3 \\
57.3 \\
56.3 \\
54.3\end{array}$ & $\begin{array}{l}0.00 \\
0.00 \\
0.00 \\
0.00 \\
0.01\end{array}$ & $\begin{array}{l}1200 \\
1215 \\
1230 \\
1245 \\
1300\end{array}$ & $\begin{array}{l}24.1 \\
24.1 \\
23.3 \\
23.3 \\
23.3\end{array}$ & $\begin{array}{l}0.00 \\
0.00 \\
0.00 \\
0.00 \\
0.00\end{array}$ \\
\hline $\begin{array}{l}1000 \\
1015 \\
1030 \\
1045 \\
1100\end{array}$ & $\begin{array}{l}814.0 \\
822.0 \\
833.0 \\
838.0 \\
841.0\end{array}$ & $\begin{array}{l}0.06 \\
0.14 \\
0.12 \\
0.08 \\
0.05\end{array}$ & $\begin{array}{l}2345 \\
\text { October } \\
0000 \\
0015 \\
0030\end{array}$ & $\begin{array}{r}53.3 \\
2,1989 \\
52.3 \\
50.4 \\
49.4\end{array}$ & $\begin{array}{l}0.00 \\
0.00 \\
0.00 \\
0.00\end{array}$ & $\begin{array}{l}1315 \\
1330 \\
1345 \\
1400 \\
1415\end{array}$ & $\begin{array}{l}22.6 \\
22.6 \\
21.9 \\
21.9 \\
21.9\end{array}$ & $\begin{array}{l}0.00 \\
0.00 \\
0.00 \\
0.00 \\
0.00\end{array}$ \\
\hline $\begin{array}{l}1115 \\
1130 \\
1145 \\
1200 \\
1215\end{array}$ & $\begin{array}{l}846.0 \\
844.0 \\
840.0 \\
841.0 \\
837.0\end{array}$ & $\begin{array}{l}0.03 \\
0.02 \\
0.01 \\
0.00 \\
0.00\end{array}$ & $\begin{array}{l}0045 \\
0100 \\
0115 \\
0130 \\
0145\end{array}$ & $\begin{array}{l}48.4 \\
47.4 \\
46.4 \\
45.4 \\
44.5\end{array}$ & $\begin{array}{l}0.00 \\
0.00 \\
0.00 \\
0.00 \\
0.00\end{array}$ & $\begin{array}{l}1430 \\
1445 \\
1500 \\
1515 \\
1530\end{array}$ & $\begin{array}{l}21.1 \\
21.1 \\
20.4 \\
20.4 \\
19.7\end{array}$ & $\begin{array}{l}0.00 \\
0.00 \\
0.00 \\
0.00 \\
0.00\end{array}$ \\
\hline $\begin{array}{l}1230 \\
1245 \\
1300 \\
1315 \\
1330\end{array}$ & $\begin{array}{l}834.0 \\
826.0 \\
810.0 \\
783.0 \\
738.0\end{array}$ & $\begin{array}{l}0.00 \\
0.03 \\
0.00 \\
0.01 \\
0.01\end{array}$ & $\begin{array}{l}0200 \\
0215 \\
0230 \\
0245 \\
0300\end{array}$ & $\begin{array}{l}43.5 \\
42.3 \\
41.2 \\
40.1 \\
40.1\end{array}$ & $\begin{array}{l}0.00 \\
0.00 \\
0.00 \\
0.00 \\
0.00\end{array}$ & $\begin{array}{l}1545 \\
1600 \\
1615 \\
1630 \\
1645\end{array}$ & $\begin{array}{l}19.7 \\
19.1 \\
19.1 \\
19.1 \\
18.4\end{array}$ & $\begin{array}{l}0.00 \\
0.00 \\
0.00 \\
0.00 \\
0.00\end{array}$ \\
\hline $\begin{array}{l}1345 \\
1400 \\
1415 \\
1430 \\
1445\end{array}$ & $\begin{array}{l}665.0 \\
574.0 \\
483.0 \\
407.0 \\
345.0\end{array}$ & $\begin{array}{l}0.00 \\
0.00 \\
0.00 \\
0.00 \\
0.00\end{array}$ & $\begin{array}{l}0315 \\
0330 \\
0345 \\
0400 \\
0415\end{array}$ & $\begin{array}{l}39.0 \\
37.9 \\
37.9 \\
36.8 \\
35.8\end{array}$ & $\begin{array}{l}0.00 \\
0.00 \\
0.00 \\
0.00 \\
0.00\end{array}$ & $\begin{array}{l}1700 \\
1715 \\
1730 \\
1745 \\
1800\end{array}$ & $\begin{array}{l}18.4 \\
18.4 \\
18.4 \\
17.8 \\
17.8\end{array}$ & $\begin{array}{l}0.00 \\
0.00 \\
0.00 \\
0.00 \\
0.00\end{array}$ \\
\hline
\end{tabular}




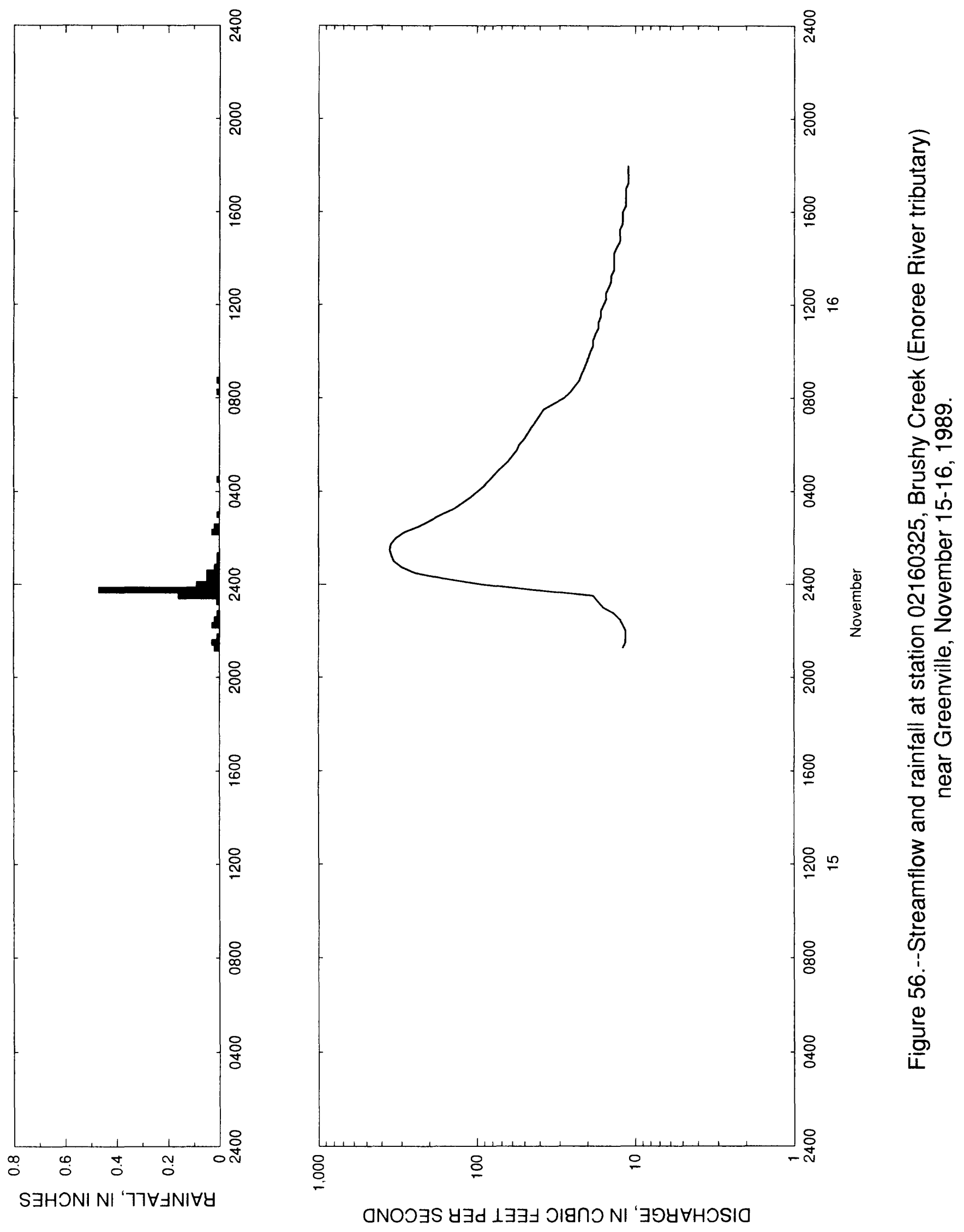


Table 55. - Streamflow and rainfal1 at station 02160325, Brushy Creek (Enoree River tributary) near Greenville, November 15-16, 1989

\begin{tabular}{|c|c|c|c|c|c|c|c|c|}
\hline $\begin{array}{l}\text { Time } \\
\text { (hours) }\end{array}$ & $\begin{array}{l}\text { Streamflow } \\
\text { (cubic feet } \\
\text { per second) }\end{array}$ & $\begin{array}{l}\text { Rain- } \\
\text { fall } \\
\text { (inches) }\end{array}$ & $\begin{array}{l}\text { Time } \\
\text { (hours) }\end{array}$ & $\begin{array}{l}\text { Streamflow } \\
\text { (cubic feet } \\
\text { per second) }\end{array}$ & $\begin{array}{l}\text { Rain- } \\
\text { fall } \\
\text { (inches) }\end{array}$ & $\begin{array}{l}\text { Time } \\
\text { (hours) }\end{array}$ & $\begin{array}{l}\text { Streamflow } \\
\text { (cubic feet } \\
\text { per second) }\end{array}$ & $\begin{array}{l}\text { Rain- } \\
\text { fall } \\
\text { (inches) }\end{array}$ \\
\hline $\begin{array}{l}\text { November } \\
2115 \\
2130 \\
2145 \\
2200\end{array}$ & $\begin{array}{r}15, \quad 1989 \\
12.0 \\
11.5 \\
11.5 \\
11.5\end{array}$ & $\begin{array}{l}0.02 \\
0.03 \\
0.01 \\
0.00\end{array}$ & $\begin{array}{l}0400 \\
0415 \\
0430 \\
0445 \\
0500\end{array}$ & $\begin{array}{l}99.8 \\
90.2 \\
82.9 \\
76.7 \\
70.5\end{array}$ & $\begin{array}{l}0.00 \\
0.00 \\
0.01 \\
0.00 \\
0.00\end{array}$ & $\begin{array}{l}1115 \\
1130 \\
1145 \\
1200 \\
1215\end{array}$ & $\begin{array}{l}17.1 \\
16.5 \\
16.5 \\
15.9 \\
15.3\end{array}$ & $\begin{array}{l}0.00 \\
0.00 \\
0.00 \\
0.00 \\
0.00\end{array}$ \\
\hline $\begin{array}{l}2215 \\
2230 \\
2245 \\
2300 \\
2315\end{array}$ & $\begin{array}{l}12.0 \\
12.5 \\
13.6 \\
15.9 \\
17.1\end{array}$ & $\begin{array}{l}0.03 \\
0.02 \\
0.01 \\
0.00 \\
0.01\end{array}$ & $\begin{array}{l}0515 \\
0530 \\
0545 \\
0600 \\
0615\end{array}$ & $\begin{array}{l}64.4 \\
60.3 \\
56.3 \\
54.3 \\
50.4\end{array}$ & $\begin{array}{l}0.00 \\
0.00 \\
0.00 \\
0.00 \\
0.00\end{array}$ & $\begin{array}{l}1230 \\
1245 \\
1300 \\
1315 \\
1330\end{array}$ & $\begin{array}{l}15.3 \\
14.7 \\
14.2 \\
14.2 \\
13.6\end{array}$ & $\begin{array}{l}0.00 \\
0.00 \\
0.00 \\
0.00 \\
0.00\end{array}$ \\
\hline $\begin{array}{c}2330 \\
2345 \\
\text { November } \\
0000 \\
0015\end{array}$ & $\begin{array}{r}18.4 \\
42.3 \\
16, \quad 1989 \\
93.4 \\
160.0\end{array}$ & $\begin{array}{l}0.16 \\
0.47 \\
0.09 \\
0.05\end{array}$ & $\begin{array}{l}0630 \\
0645 \\
0700 \\
0715 \\
0730\end{array}$ & $\begin{array}{l}47.7 \\
45.4 \\
42.3 \\
40.1 \\
37.9\end{array}$ & $\begin{array}{l}0.00 \\
0.00 \\
0.00 \\
0.00 \\
0.00\end{array}$ & $\begin{array}{l}1345 \\
1400 \\
1415 \\
1430 \\
1445\end{array}$ & $\begin{array}{l}13.6 \\
13.6 \\
13.6 \\
13.1 \\
12.5\end{array}$ & $\begin{array}{l}0.00 \\
0.00 \\
0.00 \\
0.00 \\
0.00\end{array}$ \\
\hline $\begin{array}{l}0030 \\
0045 \\
0100 \\
0115 \\
0130\end{array}$ & $\begin{array}{l}247.0 \\
300.0 \\
336.0 \\
348.0 \\
357.0\end{array}$ & $\begin{array}{l}0.05 \\
0.02 \\
0.01 \\
0.01 \\
0.00\end{array}$ & $\begin{array}{l}0745 \\
0800 \\
0815 \\
0830 \\
0845\end{array}$ & $\begin{array}{l}32.8 \\
28.1 \\
25.7 \\
24.1 \\
22.6\end{array}$ & $\begin{array}{l}0.00 \\
0.00 \\
0.01 \\
0.00 \\
0.01\end{array}$ & $\begin{array}{l}1500 \\
1515 \\
1530 \\
1545 \\
1600\end{array}$ & $\begin{array}{l}12.5 \\
12.5 \\
12.0 \\
12.0 \\
12.0\end{array}$ & $\begin{array}{l}0.00 \\
0.00 \\
0.00 \\
0.00 \\
0.00\end{array}$ \\
\hline $\begin{array}{l}0145 \\
0200 \\
0215 \\
0230 \\
0245\end{array}$ & $\begin{array}{l}348.0 \\
325.0 \\
287.0 \\
234.0 \\
198.0\end{array}$ & $\begin{array}{l}0.00 \\
0.00 \\
0.03 \\
0.02 \\
0.00\end{array}$ & $\begin{array}{l}0900 \\
0915 \\
0930 \\
0945 \\
1000\end{array}$ & $\begin{array}{l}21.9 \\
21.1 \\
20.4 \\
19.7 \\
19.1\end{array}$ & $\begin{array}{l}0.00 \\
0.00 \\
0.00 \\
0.00 \\
0.00\end{array}$ & $\begin{array}{l}1615 \\
1630 \\
1645 \\
1700 \\
1715\end{array}$ & $\begin{array}{l}11.5 \\
11.5 \\
11.5 \\
11.5 \\
11.1\end{array}$ & $\begin{array}{l}0.00 \\
0.00 \\
0.00 \\
0.00 \\
0.00\end{array}$ \\
\hline $\begin{array}{l}0300 \\
0315 \\
0330 \\
0345\end{array}$ & $\begin{array}{l}168.0 \\
140.0 \\
124.0 \\
110.0\end{array}$ & $\begin{array}{l}0.01 \\
0.00 \\
0.00 \\
0.00\end{array}$ & $\begin{array}{l}1015 \\
1030 \\
1045 \\
1100\end{array}$ & $\begin{array}{l}18.4 \\
18.4 \\
17.8 \\
17.1\end{array}$ & $\begin{array}{l}0.00 \\
0.00 \\
0.00 \\
0.00\end{array}$ & $\begin{array}{l}1730 \\
1745 \\
1800\end{array}$ & $\begin{array}{l}11.1 \\
11.1 \\
11.1\end{array}$ & $\begin{array}{l}0.00 \\
0.00 \\
0.00\end{array}$ \\
\hline
\end{tabular}




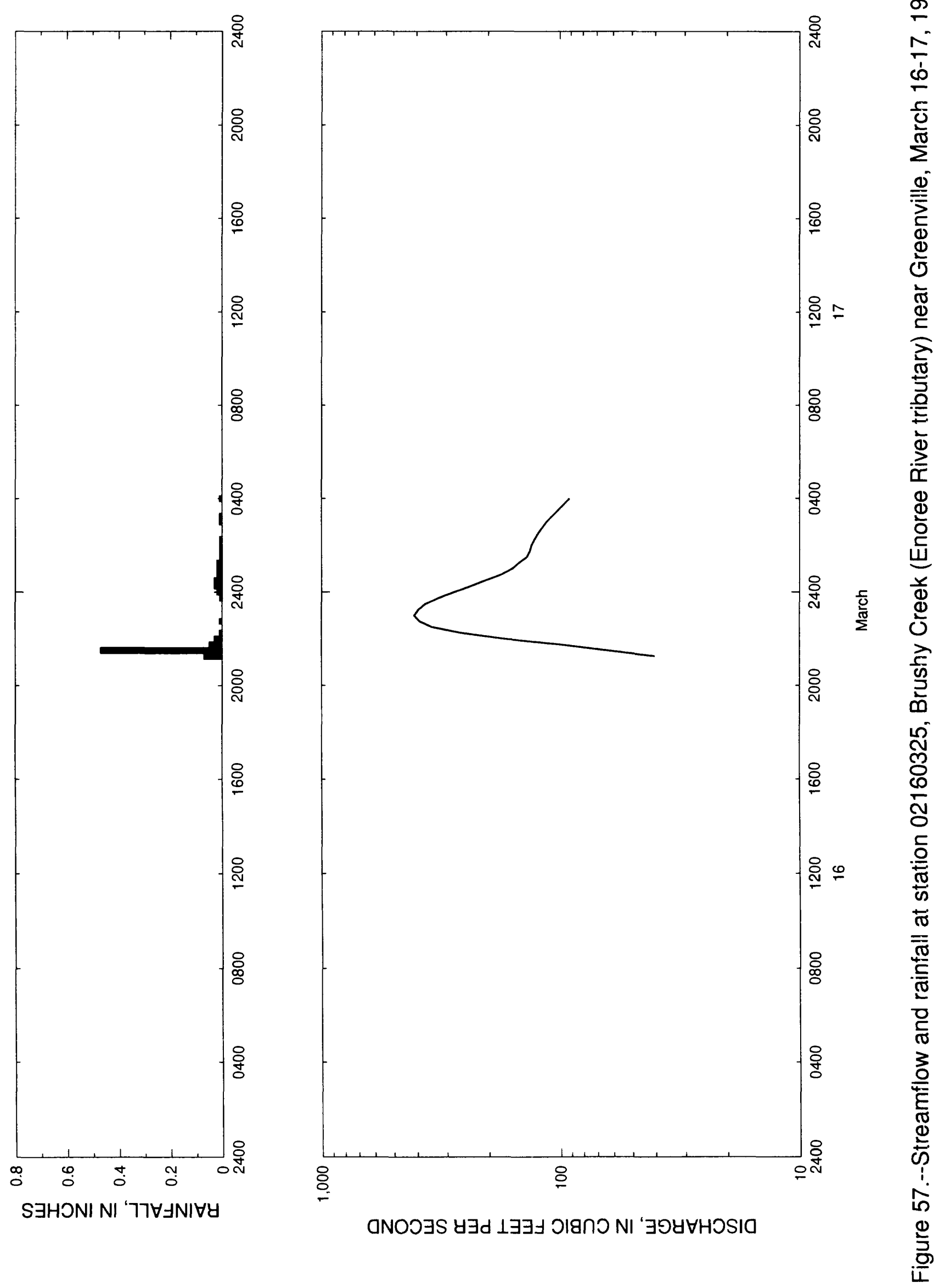


Table 56. - - Streamflow and rainfall at station 02160325, Brushy Creek (Enoree River tributary) near Greenville, March 16-17, 1990

\begin{tabular}{|c|c|c|c|c|c|c|c|c|}
\hline $\begin{array}{l}\text { Time } \\
\text { (hours) }\end{array}$ & $\begin{array}{l}\text { Streamflow } \\
\text { (cubic feet } \\
\text { per second) }\end{array}$ & $\begin{array}{l}\text { Rain- } \\
\text { fall } \\
\text { (inches) }\end{array}$ & $\begin{array}{l}\text { Time } \\
\text { (hours) }\end{array}$ & $\begin{array}{l}\text { Streamflow } \\
\text { (cubic feet } \\
\text { per second) }\end{array}$ & $\begin{array}{l}\text { Rain- } \\
\text { fall } \\
\text { (inches) }\end{array}$ & $\begin{array}{l}\text { Time } \\
\text { (hours) }\end{array}$ & $\begin{array}{l}\text { Streamflow } \\
\text { (cubic feet } \\
\text { per second) }\end{array}$ & $\begin{array}{l}\text { Rain- } \\
\text { fall } \\
\text { (inches) }\end{array}$ \\
\hline $\begin{array}{rr}\text { March } 16, \\
2115 \\
2130 \\
2145 \\
2200\end{array}$ & $\begin{array}{r}1990 \\
40.1 \\
63.4 \\
99.8 \\
172.0\end{array}$ & $\begin{array}{l}0.07 \\
0.47 \\
0.05 \\
0.03\end{array}$ & $\begin{array}{r}2330 \\
2345 \\
\text { March } 17 . \\
0000 \\
0015\end{array}$ & $\begin{array}{r}368.0 \\
325.0 \\
1990 \\
278.0 \\
237.0\end{array}$ & $\begin{array}{l}0.00 \\
0.01 \\
0.02 \\
0.03\end{array}$ & $\begin{array}{l}0145 \\
0200 \\
0215 \\
0230 \\
0245\end{array}$ & $\begin{array}{l}134.0 \\
132.0 \\
128.0 \\
124.0 \\
119.0\end{array}$ & $\begin{array}{l}0.01 \\
0.01 \\
0.01 \\
0.00 \\
0.00\end{array}$ \\
\hline $\begin{array}{l}2215 \\
2230 \\
2245 \\
2300 \\
2315\end{array}$ & $\begin{array}{l}262.0 \\
345.0 \\
389.0 \\
409.0 \\
394.0\end{array}$ & $\begin{array}{l}0.01 \\
0.00 \\
0.01 \\
0.00 \\
0.00\end{array}$ & $\begin{array}{l}0030 \\
0045 \\
0100 \\
0115 \\
0130\end{array}$ & $\begin{array}{l}205.0 \\
177.0 \\
159.0 \\
149.0 \\
138.0\end{array}$ & $\begin{array}{l}0.03 \\
0.02 \\
0.02 \\
0.02 \\
0.01\end{array}$ & $\begin{array}{l}0300 \\
0315 \\
0330 \\
0345 \\
0400\end{array}$ & $\begin{array}{r}114.0 \\
108.0 \\
102.0 \\
96.6 \\
91.3\end{array}$ & $\begin{array}{l}0.01 \\
0.01 \\
0.00 \\
0.00 \\
0.01\end{array}$ \\
\hline
\end{tabular}




\section{Station 02162093, Smith Branch at Columbia, S.C.}

Location.--Lat $34^{\circ} 01^{\prime} 38^{\prime \prime}$, long $81^{\circ} 02^{\prime} 31^{\prime \prime}$, Richland County, Hydrologic Unit 03050106, at culvert on North Main Street (U.S. Highway 21), $0.5 \mathrm{mi}$ west of Richland Memorial Hospital, $1.0 \mathrm{mi}$ northwest of the State Hospital, and $2.1 \mathrm{mi}$ upstream from the mouth at the Broad River.

Period of record.-- July 12, 1976, to present (1994). Data from 1983 to 1990 were used in this report.

Gage.--Digital stage recorder with 15-minute punch interval. The recorder is housed in a metal shelter atop a stilling well attached to the left upstream wingwall of the archtype culvert. The outside gage is an enameled staff gage attached to the wingwall at the gage.

Rating.--The stage-streamflow relation is defined by current meter measurements up to approximately $960 \mathrm{ft}^{3} / \mathrm{s}$. The stage-streamflow relation was extended to $2,200 \mathrm{ft}^{3} / \mathrm{s}$ graphically on logarithmic paper.

Rain gage and location.--Station 340138081023400 , lat $34^{\circ} 01^{\prime} 38^{\prime \prime}$, long $81^{\circ} 02^{\prime} 34^{\prime \prime}$. A she'ter containing a digital cumulative rainfall recorder with a 15-minute punch interval attached to the downstream side of a bridge in Earlewood Park, and $200 \mathrm{ft}$ downstream from the streamflow gage.

Selected basin characteristics.--

Drainage area -- $5.49 \mathrm{mi}^{2}$

Physiographic province -- Inner Coastal Plain

Channel slope -- $30.6 \mathrm{ft} / \mathrm{mi}$

Channel length -- $3.37 \mathrm{mi}$

Total impervious area -- 34.0 percent

Basin development factor --8

2-year, 2-hour rainfall amount -- 2.10 in.

Flood frequency data: $\mathrm{UQ}_{2} \quad 1,400 \mathrm{ft}^{3} / \mathrm{s}$

$\mathrm{UQ}_{5} \quad 2,090 \mathrm{ft}^{3} / \mathrm{s}$

$\mathrm{UQ}_{10} \quad 2,510 \mathrm{ft}^{3} / \mathrm{s}$

$\mathrm{UQ}_{25} \quad 3,010 \mathrm{ft}^{3} / \mathrm{s}$

$\mathrm{UQ}_{50} \quad 3,340 \mathrm{ft}^{3} / \mathrm{s}$

$\mathrm{UQ}_{100} \quad 3,660 \mathrm{ft}^{3} / \mathrm{s}$

$\mathrm{UQ}_{500} \quad 4,310 \mathrm{ft}^{3} / \mathrm{s}$ 


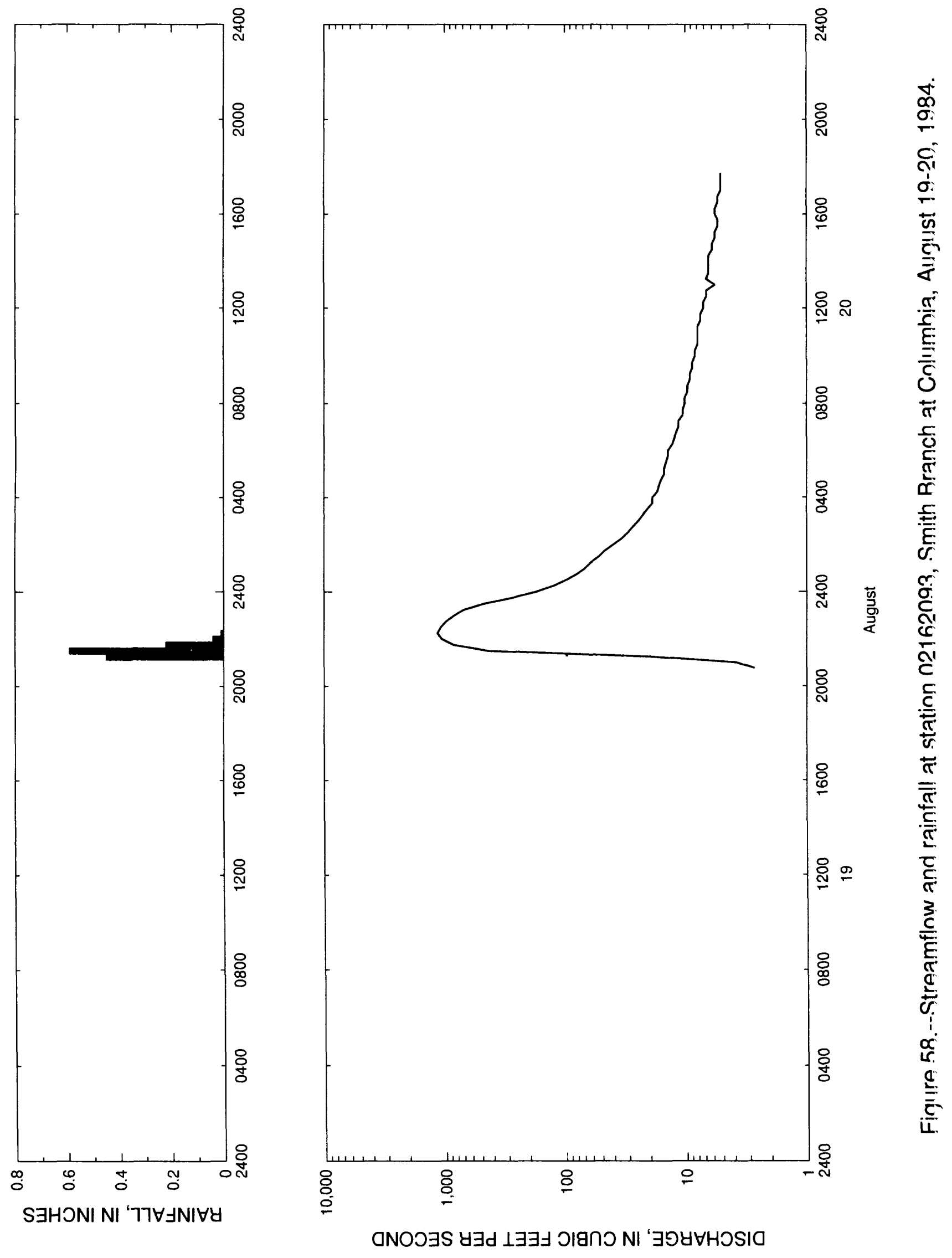


Table 57.--Streamflow and rainfall at station 02162093, Smith Branch at Columbia, August 19-20, 1984

\begin{tabular}{|c|c|c|c|c|c|c|c|c|}
\hline $\begin{array}{l}\text { Time } \\
\text { (hours) }\end{array}$ & $\begin{array}{l}\text { Streamflow } \\
\text { (cubic feet } \\
\text { per second) }\end{array}$ & $\begin{array}{l}\text { Rain- } \\
\text { fall } \\
\text { (inches) }\end{array}$ & $\begin{array}{l}\text { Time } \\
\text { (hours) }\end{array}$ & $\begin{array}{l}\text { Streamflow } \\
\text { (cubic feet } \\
\text { per second) }\end{array}$ & $\begin{array}{l}\text { Rain- } \\
\text { fall } \\
\text { (inches) }\end{array}$ & $\begin{array}{l}\text { Time } \\
\text { (hours) }\end{array}$ & $\begin{array}{l}\text { Streamflow } \\
\text { (cubic feet } \\
\text { per second) }\end{array}$ & $\begin{array}{l}\text { Rain- } \\
\text { fall } \\
\text { (inches) }\end{array}$ \\
\hline $\begin{array}{l}\text { August } \\
2045 \\
2100 \\
2115 \\
2130\end{array}$ & $\begin{array}{r}19, \quad 1984 \\
2.7 \\
3.8 \\
20.0 \\
435.0\end{array}$ & $\begin{array}{l}0.00 \\
0.00 \\
0.45 \\
0.59\end{array}$ & $\begin{array}{l}0345 \\
0400 \\
0415 \\
0430 \\
0445\end{array}$ & $\begin{array}{l}18.8 \\
18.8 \\
17.1 \\
16.6 \\
16.0\end{array}$ & $\begin{array}{l}0.00 \\
0.00 \\
0.00 \\
0.00 \\
0.00\end{array}$ & $\begin{array}{l}1115 \\
1130 \\
1145 \\
1200 \\
1215\end{array}$ & $\begin{array}{l}7.9 \\
7.5 \\
7.5 \\
7.1 \\
7.1\end{array}$ & $\begin{array}{l}0.00 \\
0.00 \\
0.00 \\
0.00 \\
0.00\end{array}$ \\
\hline $\begin{array}{l}2145 \\
2200 \\
2215 \\
2230 \\
2245\end{array}$ & $\begin{array}{r}839.0 \\
1060.0 \\
1150.0 \\
1080.0 \\
975.0\end{array}$ & $\begin{array}{l}0.22 \\
0.04 \\
0.01 \\
0.00 \\
0.00\end{array}$ & $\begin{array}{l}0500 \\
0515 \\
0530 \\
0545 \\
0600\end{array}$ & $\begin{array}{l}15.0 \\
15.0 \\
14.5 \\
14.0 \\
14.0\end{array}$ & $\begin{array}{l}0.00 \\
0.00 \\
0.00 \\
0.00 \\
0.00\end{array}$ & $\begin{array}{l}1230 \\
1245 \\
1300 \\
1315 \\
1330\end{array}$ & $\begin{array}{l}6.7 \\
6.7 \\
5.7 \\
6.7 \\
6.4\end{array}$ & $\begin{array}{l}0.00 \\
0.00 \\
0.00 \\
0.00 \\
0.00\end{array}$ \\
\hline $\begin{array}{c}2300 \\
2315 \\
2330 \\
2345 \\
\text { August }\end{array}$ & $\begin{array}{r}839.0 \\
693.0 \\
473.0 \\
278.0 \\
20,1984\end{array}$ & $\begin{array}{l}0.00 \\
0.00 \\
0.00 \\
0.00\end{array}$ & $\begin{array}{l}0615 \\
0630 \\
0645 \\
0700 \\
0715\end{array}$ & $\begin{array}{l}12.9 \\
12.4 \\
11.9 \\
11.4 \\
11.4\end{array}$ & $\begin{array}{l}0.00 \\
0.00 \\
0.00 \\
0.00 \\
0.00\end{array}$ & $\begin{array}{l}1345 \\
1400 \\
1415 \\
1430 \\
1445\end{array}$ & $\begin{array}{l}6.4 \\
6.4 \\
6.4 \\
6.0 \\
6.0\end{array}$ & $\begin{array}{l}0.00 \\
0.00 \\
0.00 \\
0.00 \\
0.00\end{array}$ \\
\hline $\begin{array}{l}0000 \\
0015 \\
0030 \\
0045 \\
0100\end{array}$ & $\begin{array}{r}173.0 \\
124.0 \\
97.5 \\
79.4 \\
67.8\end{array}$ & $\begin{array}{l}0.00 \\
0.00 \\
0.00 \\
0.00 \\
0.00\end{array}$ & $\begin{array}{l}0730 \\
0745 \\
0800 \\
0815 \\
0830\end{array}$ & $\begin{array}{r}10.5 \\
10.5 \\
10.1 \\
10.1 \\
9.6\end{array}$ & $\begin{array}{l}0.00 \\
0.00 \\
0.00 \\
0.00 \\
0.00\end{array}$ & $\begin{array}{l}1500 \\
1515 \\
1530 \\
1545 \\
1600\end{array}$ & $\begin{array}{l}5.7 \\
5.7 \\
5.4 \\
5.4 \\
5.7\end{array}$ & $\begin{array}{l}0.00 \\
0.00 \\
0.00 \\
0.00 \\
0.00\end{array}$ \\
\hline $\begin{array}{l}0115 \\
0130 \\
0145 \\
0200 \\
0215\end{array}$ & $\begin{array}{l}60.5 \\
51.8 \\
46.3 \\
39.3 \\
33.7\end{array}$ & $\begin{array}{l}0.00 \\
0.00 \\
0.00 \\
0.00 \\
0.00\end{array}$ & $\begin{array}{l}0845 \\
0900 \\
0915 \\
0930 \\
0945\end{array}$ & $\begin{array}{l}9.6 \\
9.2 \\
9.2 \\
8.8 \\
8.8\end{array}$ & $\begin{array}{l}0.00 \\
0.00 \\
0.00 \\
0.00 \\
0.00\end{array}$ & $\begin{array}{l}1615 \\
1630 \\
1645 \\
1700 \\
1715\end{array}$ & $\begin{array}{l}5.7 \\
5.4 \\
5.4 \\
5.1 \\
5.1\end{array}$ & $\begin{array}{l}0.00 \\
0.00 \\
0.00 \\
0.00 \\
0.00\end{array}$ \\
\hline $\begin{array}{l}0230 \\
0245 \\
0300 \\
0315 \\
0330\end{array}$ & $\begin{array}{l}30.1 \\
27.3 \\
24.6 \\
22.6 \\
20.6\end{array}$ & $\begin{array}{l}0.00 \\
0.00 \\
0.00 \\
0.00 \\
0.00\end{array}$ & $\begin{array}{l}1000 \\
1015 \\
1030 \\
1045 \\
1100\end{array}$ & $\begin{array}{l}8.3 \\
8.3 \\
7.9 \\
7.9 \\
7.9\end{array}$ & $\begin{array}{l}0.00 \\
0.00 \\
0.00 \\
0.00 \\
0.00\end{array}$ & $\begin{array}{l}1730 \\
1745 \\
1800\end{array}$ & $\begin{array}{l}5.1 \\
5.1 \\
4.8\end{array}$ & $\begin{array}{l}0.00 \\
0.00 \\
0.00\end{array}$ \\
\hline
\end{tabular}



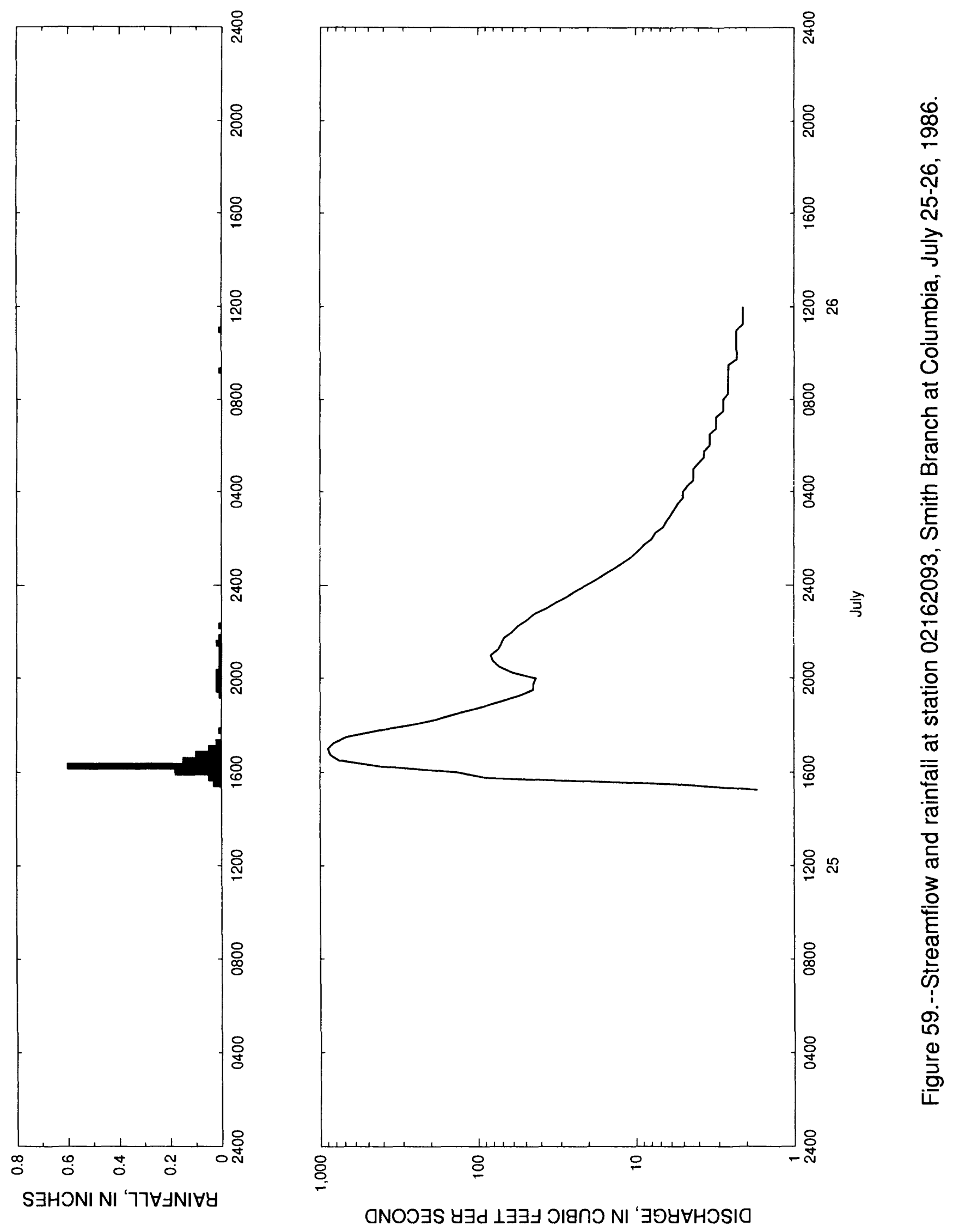
Table 58.--Streamflow and rainfall at station 02162093, Smith Branch at Columbia, July $25-26,1986$

\begin{tabular}{|c|c|c|c|c|c|c|c|c|}
\hline $\begin{array}{l}\text { Time } \\
\text { (hours) }\end{array}$ & $\begin{array}{l}\text { Streamflow } \\
\text { (cubic feet } \\
\text { per second) }\end{array}$ & $\begin{array}{l}\text { Rain- } \\
\text { fall } \\
\text { (inches) }\end{array}$ & $\begin{array}{l}\text { Time } \\
\text { (hours) }\end{array}$ & $\begin{array}{l}\text { Streamflow } \\
\text { (cubic feet } \\
\text { per second) }\end{array}$ & $\begin{array}{l}\text { Rain- } \\
\text { fall } \\
\text { (inches) }\end{array}$ & $\begin{array}{l}\text { Time } \\
\text { (hours) }\end{array}$ & $\begin{array}{l}\text { Streamflow } \\
\text { (cubic feet } \\
\text { per second) }\end{array}$ & $\begin{array}{l}\text { Rain- } \\
\text { fall } \\
\text { (inches) }\end{array}$ \\
\hline $\begin{array}{l}\text { July 25, } \\
1515 \\
1530 \\
1545 \\
1600\end{array}$ & $\begin{array}{r}1986 \\
1.7 \\
5.7 \\
84.8 \\
135.0\end{array}$ & $\begin{array}{l}0.00 \\
0.03 \\
0.05 \\
0.18\end{array}$ & $\begin{array}{l}2230 \\
2245 \\
2300 \\
2315 \\
2330\end{array}$ & $\begin{array}{l}49.0 \\
44.4 \\
36.8 \\
32.2 \\
27.3\end{array}$ & $\begin{array}{l}0.00 \\
0.00 \\
0.00 \\
0.00 \\
0.00\end{array}$ & $\begin{array}{l}0600 \\
0615 \\
0630 \\
0645 \\
0700\end{array}$ & $\begin{array}{l}3.4 \\
3.4 \\
3.4 \\
3.1 \\
3.1\end{array}$ & $\begin{array}{l}0.00 \\
0.00 \\
0.00 \\
0.00 \\
0.00\end{array}$ \\
\hline $\begin{array}{l}1615 \\
1630 \\
1645 \\
1700 \\
1715\end{array}$ & $\begin{array}{l}412.0 \\
756.0 \\
866.0 \\
895.0 \\
821.0\end{array}$ & $\begin{array}{l}0.60 \\
0.15 \\
0.10 \\
0.05 \\
0.02\end{array}$ & $\begin{array}{l}2345 \\
\text { July } 26 \\
0015 \\
0030 \\
0045\end{array}$ & $\begin{array}{r}1986.9 \\
17.7 \\
15.5 \\
13.5\end{array}$ & $\begin{array}{l}0.00 \\
0.00 \\
0.00 \\
0.00\end{array}$ & $\begin{array}{l}0715 \\
0730 \\
0745 \\
0800 \\
0815\end{array}$ & $\begin{array}{l}3.1 \\
2.8 \\
2.8 \\
2.8 \\
2.6\end{array}$ & $\begin{array}{l}0.00 \\
0.00 \\
0.00 \\
0.00 \\
0.00\end{array}$ \\
\hline $\begin{array}{l}1730 \\
1745 \\
1800 \\
1815 \\
1830\end{array}$ & $\begin{array}{l}674.0 \\
436.0 \\
266.0 \\
178.0 \\
131.0\end{array}$ & $\begin{array}{l}0.00 \\
0.01 \\
0.00 \\
0.00 \\
0.00\end{array}$ & $\begin{array}{l}0100 \\
0115 \\
0130 \\
0145 \\
0200\end{array}$ & $\begin{array}{r}11.9 \\
10.5 \\
9.6 \\
8.8 \\
7.9\end{array}$ & $\begin{array}{l}0.00 \\
0.00 \\
0.00 \\
0.00 \\
0.00\end{array}$ & $\begin{array}{l}0830 \\
0845 \\
0900 \\
0915 \\
0930\end{array}$ & $\begin{array}{l}2.6 \\
2.6 \\
2.6 \\
2.6 \\
2.6\end{array}$ & $\begin{array}{l}0.00 \\
0.00 \\
0.00 \\
0.01 \\
0.00\end{array}$ \\
\hline $\begin{array}{l}1845 \\
1900 \\
1915 \\
1930 \\
1945\end{array}$ & $\begin{array}{l}95.2 \\
71.0 \\
54.6 \\
44.4 \\
44.4\end{array}$ & $\begin{array}{l}0.00 \\
0.00 \\
0.01 \\
0.02 \\
0.02\end{array}$ & $\begin{array}{l}0215 \\
0230 \\
0245 \\
0300 \\
0315\end{array}$ & $\begin{array}{l}7.5 \\
6.7 \\
6.4 \\
6.0 \\
5.7\end{array}$ & $\begin{array}{l}0.00 \\
0.00 \\
0.00 \\
0.00 \\
0.00\end{array}$ & $\begin{array}{l}0945 \\
1000 \\
1015 \\
1030 \\
1045\end{array}$ & $\begin{array}{l}2.3 \\
2.3 \\
2.3 \\
2.3 \\
2.3\end{array}$ & $\begin{array}{l}0.00 \\
0.00 \\
0.00 \\
0.00 \\
0.00\end{array}$ \\
\hline $\begin{array}{l}2000 \\
2015 \\
2030 \\
2045 \\
2100\end{array}$ & $\begin{array}{l}42.7 \\
60.5 \\
73.0 \\
80.4 \\
82.6\end{array}$ & $\begin{array}{l}0.02 \\
0.02 \\
0.01 \\
0.01 \\
0.01\end{array}$ & $\begin{array}{l}0330 \\
0345 \\
0400 \\
0415 \\
0430\end{array}$ & $\begin{array}{l}5.4 \\
5.0 \\
5.0 \\
4.7 \\
4.3\end{array}$ & $\begin{array}{l}0.00 \\
0.00 \\
0.00 \\
0.00 \\
0.00\end{array}$ & $\begin{array}{l}1100 \\
1115 \\
1130 \\
1145 \\
1200\end{array}$ & $\begin{array}{l}2.3 \\
2.1 \\
2.1 \\
2.1 \\
2.1\end{array}$ & $\begin{array}{l}0.01 \\
0.00 \\
0.00 \\
0.00 \\
0.00\end{array}$ \\
\hline $\begin{array}{l}2115 \\
2130 \\
2145 \\
2200 \\
2215\end{array}$ & $\begin{array}{l}74.1 \\
71.0 \\
67.8 \\
60.5 \\
55.6\end{array}$ & $\begin{array}{l}0.01 \\
0.02 \\
0.01 \\
0.00 \\
0.01\end{array}$ & $\begin{array}{l}0445 \\
0500 \\
0515 \\
0530 \\
0545\end{array}$ & $\begin{array}{l}4.3 \\
4.3 \\
4.0 \\
3.7 \\
3.7\end{array}$ & $\begin{array}{l}0.00 \\
0.00 \\
0.00 \\
0.00 \\
0.00\end{array}$ & & & \\
\hline
\end{tabular}



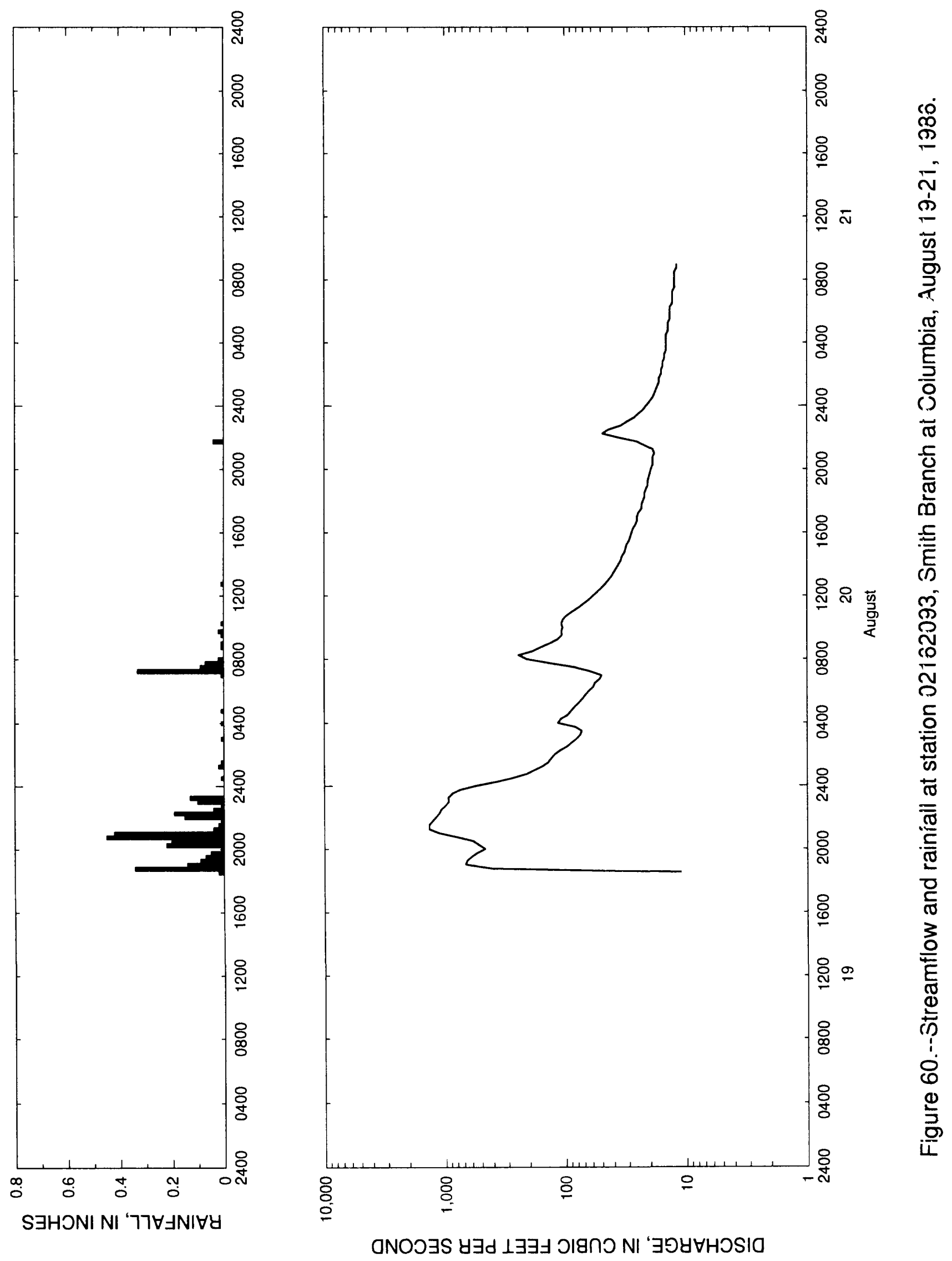
Table 59. - - Streamflow and rainfall at station 02162093, Smith Branch at Columbia, August $19-21,1986$

\begin{tabular}{|c|c|c|c|c|c|c|c|c|}
\hline $\begin{array}{c}\text { Time } \\
\text { (hours) }\end{array}$ & $\begin{array}{l}\text { Streamflow } \\
\text { (cubic feet } \\
\text { per second) }\end{array}$ & $\begin{array}{l}\text { Rain- } \\
\text { fall } \\
\text { (inches) }\end{array}$ & $\begin{array}{l}\text { Time } \\
\text { (hours) }\end{array}$ & $\begin{array}{l}\text { Streamflow } \\
\text { (cubic feet } \\
\text { per second) }\end{array}$ & $\begin{array}{l}\text { Rain- } \\
\text { fall } \\
\text { (inches) }\end{array}$ & $\begin{array}{l}\text { Time } \\
\text { (hours) }\end{array}$ & $\begin{array}{l}\text { Streamflow } \\
\text { (cubic feet } \\
\text { per second) }\end{array}$ & $\begin{array}{l}\text { Rain- } \\
\text { fall } \\
\text { (inches) }\end{array}$ \\
\hline $\begin{array}{c}\text { August } \\
1815 \\
1830 \\
1845 \\
1900\end{array}$ & $\begin{array}{r}1986 \\
3.0 \\
11.0 \\
410.0 \\
679.0\end{array}$ & $\begin{array}{l}0.00 \\
0.02 \\
0.34 \\
0.14\end{array}$ & $\begin{array}{l}0645 \\
0700 \\
0715 \\
0730 \\
0745\end{array}$ & $\begin{array}{r}51.8 \\
50.0 \\
62.6 \\
84.8 \\
136.0\end{array}$ & $\begin{array}{l}0.00 \\
0.01 \\
0.33 \\
0.09 \\
0.07\end{array}$ & $\begin{array}{l}2045 \\
2100 \\
2115 \\
2145 \\
2200\end{array}$ & $\begin{array}{l}18.8 \\
18.2 \\
18.8 \\
25.3 \\
36.0\end{array}$ & $\begin{array}{l}0.00 \\
0.00 \\
0.00 \\
0.04 \\
0.00\end{array}$ \\
\hline $\begin{array}{l}1915 \\
1930 \\
1945 \\
2000 \\
2015\end{array}$ & $\begin{array}{l}656.0 \\
601.0 \\
539.0 \\
466.0 \\
523.0\end{array}$ & $\begin{array}{l}0.09 \\
0.07 \\
0.05 \\
0.01 \\
0.22\end{array}$ & $\begin{array}{l}0800 \\
0815 \\
0830 \\
0845 \\
0900\end{array}$ & $\begin{array}{l}209.0 \\
243.0 \\
185.0 \\
160.0 \\
135.0\end{array}$ & $\begin{array}{l}0.02 \\
0.00 \\
0.00 \\
0.01 \\
0.01\end{array}$ & $\begin{array}{l}2215 \\
2230 \\
2245 \\
2300 \\
2315\end{array}$ & $\begin{array}{l}49.0 \\
43.6 \\
34.5 \\
30.8 \\
26.7\end{array}$ & $\begin{array}{l}0.00 \\
0.00 \\
0.00 \\
0.00 \\
0.00\end{array}$ \\
\hline $\begin{array}{l}2030 \\
2045 \\
2100 \\
2115 \\
2130\end{array}$ & $\begin{array}{r}589.0 \\
808.0 \\
1130.0 \\
1360.0 \\
1360.0\end{array}$ & $\begin{array}{l}0.20 \\
0.45 \\
0.42 \\
0.04 \\
0.02\end{array}$ & $\begin{array}{l}0915 \\
0930 \\
0945 \\
1000 \\
1015\end{array}$ & $\begin{array}{l}115.0 \\
106.0 \\
107.0 \\
105.0 \\
107.0\end{array}$ & $\begin{array}{l}0.00 \\
0.01 \\
0.02 \\
0.00 \\
0.01\end{array}$ & $\begin{array}{c}2330 \\
2345 \\
\text { August } \\
0000 \\
0030\end{array}$ & $\begin{array}{r}24.6 \\
22.6 \\
21,1986 \\
21.3 \\
18.8\end{array}$ & $\begin{array}{l}0.00 \\
0.00 \\
0.00 \\
0.00\end{array}$ \\
\hline $\begin{array}{l}2145 \\
2200 \\
2215 \\
2230 \\
2245\end{array}$ & $\begin{array}{r}1270.0 \\
1190.0 \\
1120.0 \\
1080.0 \\
989.0\end{array}$ & $\begin{array}{l}0.01 \\
0.15 \\
0.19 \\
0.04 \\
0.01\end{array}$ & $\begin{array}{l}1030 \\
1045 \\
1100 \\
1115 \\
1145\end{array}$ & $\begin{array}{r}104.0 \\
96.3 \\
87.1 \\
77.2 \\
63.6\end{array}$ & $\begin{array}{l}0.00 \\
0.00 \\
0.00 \\
0.00 \\
0.00\end{array}$ & $\begin{array}{l}0045 \\
0100 \\
0115 \\
0130 \\
0145\end{array}$ & $\begin{array}{l}18.2 \\
17.7 \\
17.1 \\
16.6 \\
16.6\end{array}$ & $\begin{array}{l}0.00 \\
0.00 \\
0.00 \\
0.00 \\
0.00\end{array}$ \\
\hline $\begin{array}{r}2300 \\
2315 \\
2330 \\
2345 \\
\text { August }\end{array}$ & $\begin{array}{r}931.0 \\
943.0 \\
868.0 \\
744.0 \\
20,1986\end{array}$ & $\begin{array}{l}0.10 \\
0.13 \\
0.00 \\
0.00\end{array}$ & $\begin{array}{l}1200 \\
1215 \\
1245 \\
1300 \\
1315\end{array}$ & $\begin{array}{l}58.5 \\
53.7 \\
46.3 \\
43.6 \\
41.0\end{array}$ & $\begin{array}{l}0.00 \\
0.00 \\
0.01 \\
0.00 \\
0.00\end{array}$ & $\begin{array}{l}0200 \\
0215 \\
0230 \\
0245 \\
0300\end{array}$ & $\begin{array}{l}16.0 \\
16.0 \\
15.5 \\
15.5 \\
15.0\end{array}$ & $\begin{array}{l}0.00 \\
0.00 \\
0.00 \\
0.00 \\
0.00\end{array}$ \\
\hline $\begin{array}{l}0000 \\
0015 \\
0030 \\
0045 \\
0100\end{array}$ & $\begin{array}{l}557.0 \\
376.0 \\
273.0 \\
212.0 \\
182.0\end{array}$ & $\begin{array}{l}0.00 \\
0.00 \\
0.01 \\
0.00 \\
0.00\end{array}$ & $\begin{array}{l}1330 \\
1345 \\
1400 \\
1415 \\
1430\end{array}$ & $\begin{array}{l}39.3 \\
37.6 \\
36.0 \\
34.5 \\
33.7\end{array}$ & $\begin{array}{l}0.00 \\
0.00 \\
0.00 \\
0.00 \\
0.00\end{array}$ & $\begin{array}{l}0315 \\
0330 \\
0345 \\
0400 \\
0415\end{array}$ & $\begin{array}{l}15.0 \\
14.5 \\
14.5 \\
14.5 \\
14.5\end{array}$ & $\begin{array}{l}0.00 \\
0.00 \\
0.00 \\
0.00 \\
0.00\end{array}$ \\
\hline $\begin{array}{l}0115 \\
0130 \\
0145 \\
0200 \\
0215\end{array}$ & $\begin{array}{l}156.0 \\
139.0 \\
131.0 \\
123.0 \\
110.0\end{array}$ & $\begin{array}{l}0.02 \\
0.01 \\
0.00 \\
0.00 \\
0.00\end{array}$ & $\begin{array}{l}1445 \\
1500 \\
1515 \\
1530 \\
1545\end{array}$ & $\begin{array}{l}32.2 \\
31.5 \\
30.8 \\
29.4 \\
28.7\end{array}$ & $\begin{array}{l}0.00 \\
0.00 \\
0.00 \\
0.00 \\
0.00\end{array}$ & $\begin{array}{l}0430 \\
0445 \\
0500 \\
0515 \\
0530\end{array}$ & $\begin{array}{l}14.5 \\
14.0 \\
14.0 \\
14.0 \\
13.5\end{array}$ & $\begin{array}{l}0.00 \\
0.00 \\
0.00 \\
0.00 \\
0.00\end{array}$ \\
\hline $\begin{array}{l}0230 \\
0245 \\
0300 \\
0315 \\
0330\end{array}$ & $\begin{array}{l}96.3 \\
88.2 \\
80.4 \\
75.1 \\
73.0\end{array}$ & $\begin{array}{l}0.00 \\
0.00 \\
0.01 \\
0.00 \\
0.00\end{array}$ & $\begin{array}{l}1600 \\
1615 \\
1630 \\
1645 \\
1700\end{array}$ & $\begin{array}{l}28.0 \\
27.3 \\
26.0 \\
25.3 \\
25.3\end{array}$ & $\begin{array}{l}0.00 \\
0.00 \\
0.00 \\
0.00 \\
0.00\end{array}$ & $\begin{array}{l}0545 \\
0600 \\
0615 \\
0630 \\
0645\end{array}$ & $\begin{array}{l}13.5 \\
13.5 \\
13.5 \\
12.9 \\
12.9\end{array}$ & $\begin{array}{l}0.00 \\
0.00 \\
0.00 \\
0.00 \\
0.00\end{array}$ \\
\hline $\begin{array}{l}0345 \\
0400 \\
0415 \\
0430 \\
0445\end{array}$ & $\begin{array}{r}82.6 \\
115.0 \\
109.0 \\
95.2 \\
89.3\end{array}$ & $\begin{array}{l}0.00 \\
0.01 \\
0.00 \\
0.00 \\
0.01\end{array}$ & $\begin{array}{l}1715 \\
1730 \\
1745 \\
1800 \\
1815\end{array}$ & $\begin{array}{l}24.6 \\
23.2 \\
23.2 \\
22.6 \\
21.9\end{array}$ & $\begin{array}{l}0.00 \\
0.00 \\
0.00 \\
0.00 \\
0.00\end{array}$ & $\begin{array}{l}0700 \\
0715 \\
0730 \\
0745 \\
0800\end{array}$ & $\begin{array}{l}12.9 \\
12.9 \\
12.4 \\
12.4 \\
12.4\end{array}$ & $\begin{array}{l}0.00 \\
0.00 \\
0.00 \\
0.00 \\
0.00\end{array}$ \\
\hline $\begin{array}{l}0500 \\
0515 \\
0530 \\
0545 \\
0600\end{array}$ & $\begin{array}{l}83.7 \\
77.2 \\
72.0 \\
67.8 \\
63.6\end{array}$ & $\begin{array}{l}0.00 \\
0.00 \\
0.00 \\
0.00 \\
0.00\end{array}$ & $\begin{array}{l}1830 \\
1845 \\
1900 \\
1915 \\
2000\end{array}$ & $\begin{array}{l}21.9 \\
21.3 \\
20.6 \\
20.6 \\
19.4\end{array}$ & $\begin{array}{l}0.00 \\
0.00 \\
0.00 \\
0.00 \\
0.00\end{array}$ & $\begin{array}{l}0815 \\
0830 \\
0845 \\
0850 \\
0855\end{array}$ & $\begin{array}{l}12.4 \\
12.4 \\
11.9 \\
11.9 \\
11.9\end{array}$ & $\begin{array}{l}0.00 \\
0.00 \\
0.00 \\
0.00 \\
0.00\end{array}$ \\
\hline $\begin{array}{l}0615 \\
0630\end{array}$ & $\begin{array}{l}58.5 \\
56.6\end{array}$ & $\begin{array}{l}0.00 \\
0.00\end{array}$ & $\begin{array}{l}2015 \\
2030\end{array}$ & $\begin{array}{l}188 \\
18.8\end{array}$ & $\begin{array}{l}0.00 \\
0.00\end{array}$ & 0900 & 11.9 & 0.00 \\
\hline
\end{tabular}




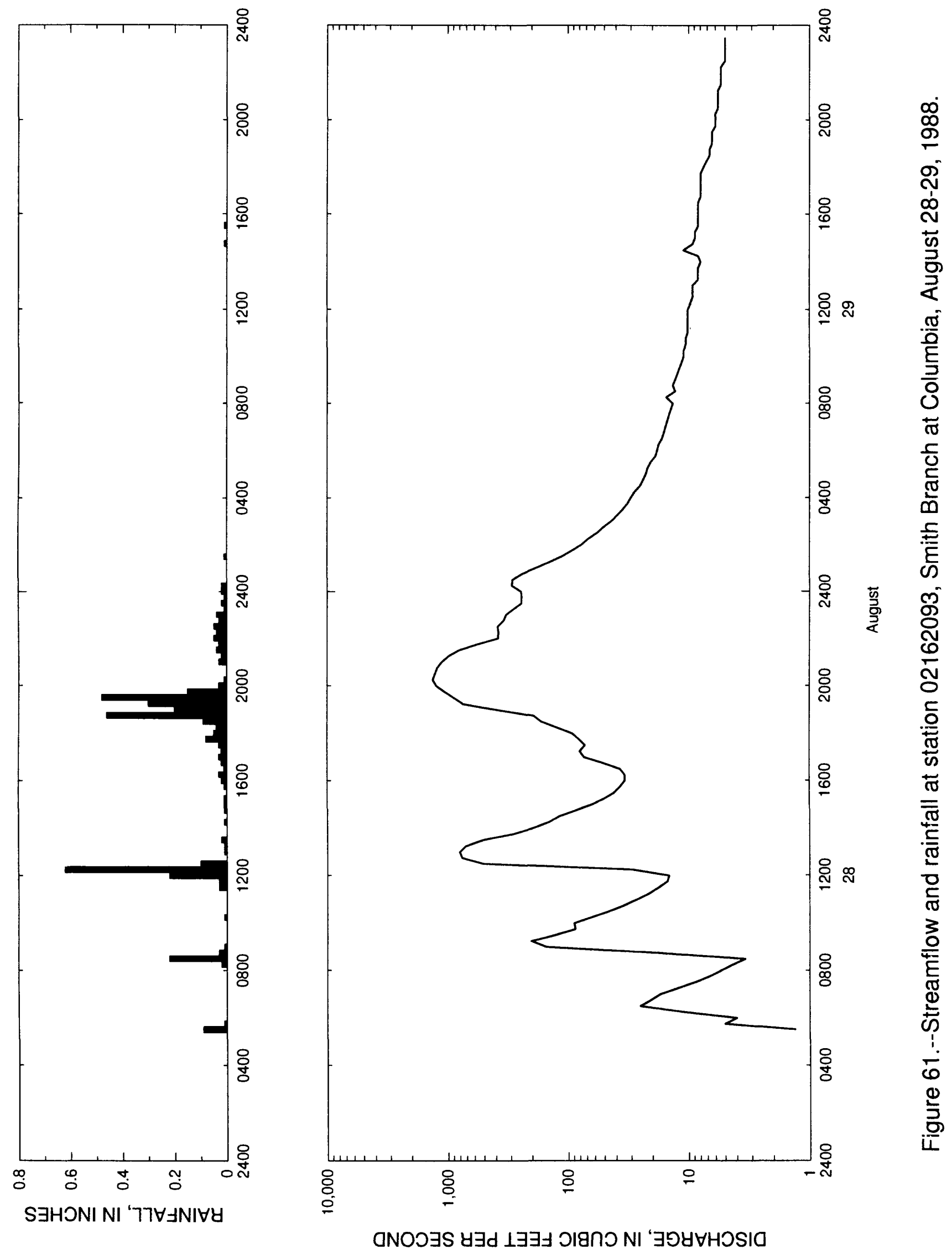


Table 60.--Streamflow and rainfall at station 02162093, Smith Branch at Columbia, August $28-29,1988$

\begin{tabular}{|c|c|c|c|c|c|c|c|c|}
\hline $\begin{array}{l}\text { Time } \\
\text { (hours) }\end{array}$ & $\begin{array}{l}\text { Streamflow } \\
\text { (cubic feet } \\
\text { per second) }\end{array}$ & $\begin{array}{l}\text { Rain- } \\
\text { fall } \\
\text { (inches) }\end{array}$ & $\begin{array}{l}\text { Time } \\
\text { (hours) }\end{array}$ & $\begin{array}{l}\text { Streamflow } \\
\text { (cubic feet } \\
\text { per second) }\end{array}$ & $\begin{array}{l}\text { Rain- } \\
\text { fall } \\
\text { (inches) }\end{array}$ & $\begin{array}{l}\text { Time } \\
\text { (hours) }\end{array}$ & $\begin{array}{l}\text { Streamflow } \\
\text { (cubic feet } \\
\text { per second) }\end{array}$ & $\begin{array}{l}\text { Rain- } \\
\text { fall } \\
\text { (inches) }\end{array}$ \\
\hline $\begin{array}{c}\text { August } \\
0530 \\
0545 \\
0600 \\
0615\end{array}$ & $\begin{array}{r}1988 \\
1.3 \\
5.0 \\
4.0 \\
11.0\end{array}$ & $\begin{array}{l}0.09 \\
0.01 \\
0.00 \\
0.00\end{array}$ & $\begin{array}{l}1945 \\
2000 \\
2015 \\
2045 \\
2100\end{array}$ & $\begin{array}{l}1050.0 \\
1240.0 \\
1330.0 \\
1220.0 \\
1120.0\end{array}$ & $\begin{array}{l}0.15 \\
0.03 \\
0.01 \\
0.00 \\
0.03\end{array}$ & $\begin{array}{l}1015 \\
1030 \\
1045 \\
1100 \\
1115\end{array}$ & $\begin{array}{l}11.0 \\
10.5 \\
10.5 \\
10.1 \\
10.1\end{array}$ & $\begin{array}{l}0.00 \\
0.00 \\
0.00 \\
0.00 \\
0.00\end{array}$ \\
\hline $\begin{array}{l}0630 \\
0645 \\
0700 \\
0715 \\
0730\end{array}$ & $\begin{array}{r}25.3 \\
20.6 \\
17.1 \\
12.4 \\
8.8\end{array}$ & $\begin{array}{l}0.00 \\
0.00 \\
0.00 \\
0.00 \\
0.00\end{array}$ & $\begin{array}{l}2115 \\
2130 \\
2145 \\
2200 \\
2215\end{array}$ & $\begin{array}{l}981.0 \\
802.0 \\
559.0 \\
380.0 \\
378.0\end{array}$ & $\begin{array}{l}0.02 \\
0.04 \\
0.03 \\
0.05 \\
0.04\end{array}$ & $\begin{array}{l}1130 \\
1145 \\
1200 \\
1215 \\
1230\end{array}$ & $\begin{array}{r}10.1 \\
10.1 \\
10.1 \\
9.6 \\
9.2\end{array}$ & $\begin{array}{l}0.00 \\
0.00 \\
0.00 \\
0.00 \\
0.00\end{array}$ \\
\hline $\begin{array}{l}0745 \\
0800 \\
0815 \\
0830 \\
0845\end{array}$ & $\begin{array}{r}6.7 \\
5.4 \\
4.3 \\
3.4 \\
18.2\end{array}$ & $\begin{array}{l}0.00 \\
0.00 \\
0.02 \\
0.22 \\
0.03\end{array}$ & $\begin{array}{l}2230 \\
2245 \\
2300 \\
2315 \\
2330\end{array}$ & $\begin{array}{l}384.0 \\
342.0 \\
327.0 \\
283.0 \\
243.0\end{array}$ & $\begin{array}{l}0.05 \\
0.03 \\
0.04 \\
0.01 \\
0.02\end{array}$ & $\begin{array}{l}1245 \\
1300 \\
1315 \\
1330 \\
1345\end{array}$ & $\begin{array}{l}9.2 \\
9.2 \\
8.3 \\
8.3 \\
8.3\end{array}$ & $\begin{array}{l}0.00 \\
0.00 \\
0.00 \\
0.00 \\
0.00\end{array}$ \\
\hline $\begin{array}{l}0900 \\
0915 \\
0930 \\
0945 \\
1000\end{array}$ & $\begin{array}{r}152.0 \\
202.0 \\
129.0 \\
87.1 \\
89.3\end{array}$ & $\begin{array}{l}0.01 \\
0.00 \\
0.00 \\
0.00 \\
0.00\end{array}$ & $\begin{array}{c}2345 \\
\text { August } \\
0000 \\
0015 \\
0030\end{array}$ & $\begin{array}{r}243.0 \\
29,1988 \\
246.0 \\
293.0 \\
291.0\end{array}$ & $\begin{array}{l}0.01 \\
0.02 \\
0.02 \\
0.00\end{array}$ & $\begin{array}{l}1400 \\
1415 \\
1430 \\
1445 \\
1500\end{array}$ & $\begin{array}{r}7.9 \\
8.3 \\
11.0 \\
9.2 \\
8.8\end{array}$ & $\begin{array}{l}0.00 \\
0.00 \\
0.00 \\
0.01 \\
0.00\end{array}$ \\
\hline $\begin{array}{l}1015 \\
1030 \\
1045 \\
1100 \\
1115\end{array}$ & $\begin{array}{l}64.6 \\
46.3 \\
34.5 \\
26.7 \\
21.3\end{array}$ & $\begin{array}{l}0.01 \\
0.00 \\
0.00 \\
0.00 \\
0.00\end{array}$ & $\begin{array}{l}0045 \\
0100 \\
0115 \\
0130 \\
0145\end{array}$ & $\begin{array}{r}240.0 \\
185.0 \\
143.0 \\
112.0 \\
92.8\end{array}$ & $\begin{array}{l}0.00 \\
0.00 \\
0.00 \\
0.01 \\
0.00\end{array}$ & $\begin{array}{l}1515 \\
1530 \\
1545 \\
1600 \\
1615\end{array}$ & $\begin{array}{l}8.8 \\
8.3 \\
8.3 \\
8.3 \\
8.3\end{array}$ & $\begin{array}{l}0.00 \\
0.01 \\
0.00 \\
0.00 \\
0.00\end{array}$ \\
\hline $\begin{array}{l}1130 \\
1145 \\
1200 \\
1215 \\
1230\end{array}$ & $\begin{array}{r}17.7 \\
15.0 \\
14.5 \\
29.4 \\
506.0\end{array}$ & $\begin{array}{l}0.03 \\
0.03 \\
0.22 \\
0.62 \\
0.10\end{array}$ & $\begin{array}{l}0200 \\
0215 \\
0230 \\
0245 \\
0300\end{array}$ & $\begin{array}{l}77.2 \\
67.8 \\
57.5 \\
50.9 \\
43.6\end{array}$ & $\begin{array}{l}0.00 \\
0.00 \\
0.00 \\
0.00 \\
0.00\end{array}$ & $\begin{array}{l}1630 \\
1645 \\
1700 \\
1715 \\
1730\end{array}$ & $\begin{array}{l}8.3 \\
7.9 \\
7.9 \\
7.9 \\
7.9\end{array}$ & $\begin{array}{l}0.00 \\
0.00 \\
0.00 \\
0.00 \\
0.00\end{array}$ \\
\hline $\begin{array}{l}1245 \\
1300 \\
1315 \\
1330 \\
1345\end{array}$ & $\begin{array}{l}766.0 \\
800.0 \\
710.0 \\
506.0 \\
285.0\end{array}$ & $\begin{array}{l}0.00 \\
0.01 \\
0.01 \\
0.02 \\
0.00\end{array}$ & $\begin{array}{l}0315 \\
0330 \\
0345 \\
0400 \\
0415\end{array}$ & $\begin{array}{l}39.3 \\
35.3 \\
32.2 \\
30.1 \\
28.0\end{array}$ & $\begin{array}{l}0.00 \\
0.00 \\
0.00 \\
0.00 \\
0.00\end{array}$ & $\begin{array}{l}1745 \\
1800 \\
1815 \\
1830 \\
1845\end{array}$ & $\begin{array}{l}7.9 \\
7.5 \\
7.1 \\
6.7 \\
6.7\end{array}$ & $\begin{array}{l}0.00 \\
0.00 \\
0.00 \\
0.00 \\
0.00\end{array}$ \\
\hline $\begin{array}{l}1400 \\
1415 \\
1430 \\
1445 \\
1500\end{array}$ & $\begin{array}{r}195.0 \\
144.0 \\
119.0 \\
87.1 \\
62.6\end{array}$ & $\begin{array}{l}0.00 \\
0.01 \\
0.00 \\
0.01 \\
0.01\end{array}$ & $\begin{array}{l}0430 \\
0445 \\
0500 \\
0515 \\
0530\end{array}$ & $\begin{array}{l}25.3 \\
23.9 \\
22.6 \\
21.9 \\
20.6\end{array}$ & $\begin{array}{l}0.00 \\
0.00 \\
0.00 \\
0.00 \\
0.00\end{array}$ & $\begin{array}{l}1900 \\
1915 \\
1930 \\
1945 \\
2000\end{array}$ & $\begin{array}{l}6.4 \\
6.4 \\
6.4 \\
6.0 \\
6.0\end{array}$ & $\begin{array}{l}0.00 \\
0.00 \\
0.00 \\
0.00 \\
0.00\end{array}$ \\
\hline $\begin{array}{l}1515 \\
1530 \\
1545 \\
1600 \\
1615\end{array}$ & $\begin{array}{l}50.0 \\
41.0 \\
36.8 \\
33.7 \\
33.7\end{array}$ & $\begin{array}{l}0.01 \\
0.00 \\
0.01 \\
0.02 \\
0.03\end{array}$ & $\begin{array}{l}0545 \\
0600 \\
0615 \\
0630 \\
0645\end{array}$ & $\begin{array}{l}18.8 \\
18.2 \\
17.7 \\
16.6 \\
16.0\end{array}$ & $\begin{array}{l}0.00 \\
0.00 \\
0.00 \\
0.00 \\
0.00\end{array}$ & $\begin{array}{l}2015 \\
2030 \\
2045 \\
2100 \\
2115\end{array}$ & $\begin{array}{l}6.0 \\
5.7 \\
5.7 \\
5.7 \\
5.7\end{array}$ & $\begin{array}{l}0.00 \\
0.00 \\
0.00 \\
0.00 \\
0.00\end{array}$ \\
\hline $\begin{array}{l}1630 \\
1645 \\
1700 \\
1715 \\
1730\end{array}$ & $\begin{array}{l}36.8 \\
50.9 \\
73.0 \\
79.4 \\
72.0\end{array}$ & $\begin{array}{l}0.01 \\
0.02 \\
0.03 \\
0.02 \\
0.03\end{array}$ & $\begin{array}{l}0700 \\
0715 \\
0730 \\
0745 \\
0800\end{array}$ & $\begin{array}{l}15.5 \\
15.0 \\
14.5 \\
14.0 \\
13.5\end{array}$ & $\begin{array}{l}0.00 \\
0.00 \\
0.00 \\
0.00 \\
0.00\end{array}$ & $\begin{array}{l}2130 \\
2145 \\
2200 \\
2215 \\
2230\end{array}$ & $\begin{array}{l}5.4 \\
5.4 \\
5.4 \\
5.4 \\
5.0\end{array}$ & $\begin{array}{l}0.00 \\
0.00 \\
0.00 \\
0.00 \\
0.00\end{array}$ \\
\hline $\begin{array}{l}1745 \\
1800 \\
1815 \\
1830 \\
1845\end{array}$ & $\begin{array}{r}80.4 \\
91.6 \\
123.0 \\
166.0 \\
192.0\end{array}$ & $\begin{array}{l}0.08 \\
0.05 \\
0.04 \\
0.09 \\
0.46\end{array}$ & $\begin{array}{l}0815 \\
0830 \\
0845 \\
0900 \\
0915\end{array}$ & $\begin{array}{l}15.3 \\
12.9 \\
13.5 \\
12.9 \\
12.4\end{array}$ & $\begin{array}{l}0.00 \\
0.00 \\
0.00 \\
0.00 \\
0.00\end{array}$ & $\begin{array}{l}2245 \\
2300 \\
2315 \\
2330 \\
2345\end{array}$ & $\begin{array}{l}5.0 \\
5.0 \\
5.0 \\
5.0 \\
4.7\end{array}$ & $\begin{array}{l}0.00 \\
0.00 \\
0.00 \\
0.00 \\
0.00\end{array}$ \\
\hline $\begin{array}{l}1900 \\
1915 \\
1930\end{array}$ & $\begin{array}{l}387.0 \\
744.0 \\
887.0\end{array}$ & $\begin{array}{l}0.20 \\
0.30 \\
0.48\end{array}$ & $\begin{array}{l}0930 \\
0945 \\
1000\end{array}$ & $\begin{array}{l}11.9 \\
11.4 \\
11.0\end{array}$ & $\begin{array}{l}0.00 \\
0.00 \\
0.00\end{array}$ & & & \\
\hline
\end{tabular}




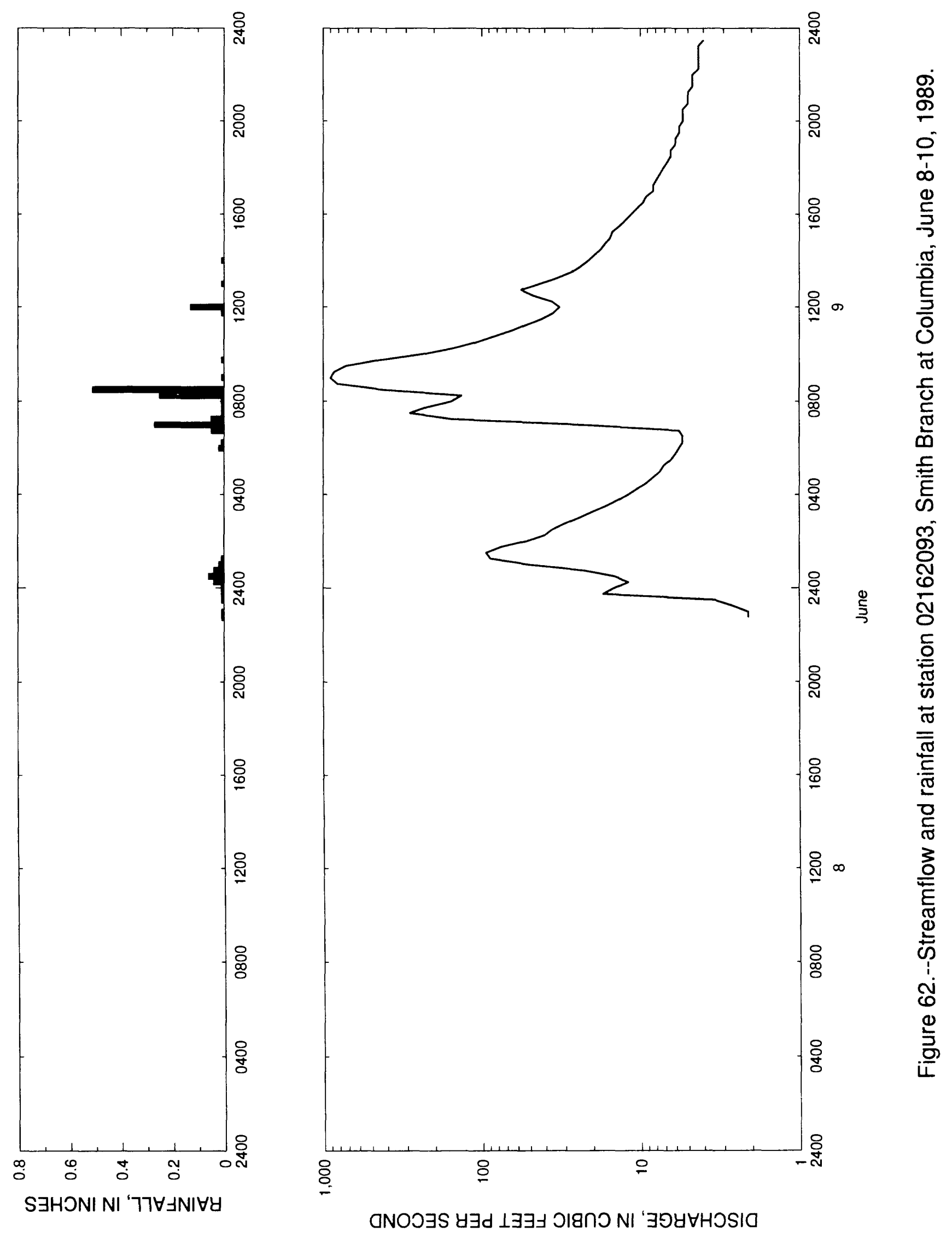


Table 61. - Streamflow and rainfall at station 02162093, Smith Branch at Columbia, June $8-10,1989$

\begin{tabular}{|c|c|c|c|c|c|c|c|c|c|}
\hline $\begin{array}{l}\text { Time } \\
\text { (hours) }\end{array}$ & $\begin{array}{l}\text { Str } \\
\text { (cub. } \\
\text { per }\end{array}$ & $\begin{array}{l}\text { eamflow } \\
\text { second) }\end{array}$ & $\begin{array}{l}\text { Rain- } \\
\text { fall } \\
\text { (inches) }\end{array}$ & $\begin{array}{l}\text { Time } \\
\text { (hours) }\end{array}$ & $\begin{array}{l}\text { Streamflow } \\
\text { (cubic feet } \\
\text { per second) }\end{array}$ & $\begin{array}{l}\text { Rain- } \\
\text { fall } \\
\text { (inches) }\end{array}$ & $\begin{array}{l}\text { Time } \\
\text { (hours) }\end{array}$ & $\begin{array}{l}\text { Streamflow } \\
\text { (cubic feet } \\
\text { per second) }\end{array}$ & $\begin{array}{l}\text { Rain- } \\
\text { fall } \\
\text { (inches) }\end{array}$ \\
\hline $\begin{array}{c}\text { June } 8 \\
2245 \\
2300 \\
2315 \\
2330\end{array}$ & 1989 & $\begin{array}{l}2.1 \\
2.1 \\
2.6 \\
3.4\end{array}$ & $\begin{array}{l}0.01 \\
0.01 \\
0.00 \\
0.01\end{array}$ & $\begin{array}{l}0715 \\
0730 \\
0745 \\
0800 \\
0815\end{array}$ & $\begin{array}{l}156.0 \\
285.0 \\
224.0 \\
156.0 \\
134.0\end{array}$ & $\begin{array}{l}0.05 \\
0.01 \\
0.01 \\
0.01 \\
0.25\end{array}$ & $\begin{array}{l}1600 \\
1615 \\
1630 \\
1645 \\
1700\end{array}$ & $\begin{array}{r}11.4 \\
10.5 \\
9.6 \\
9.2 \\
8.3\end{array}$ & $\begin{array}{l}0.00 \\
0.00 \\
0.00 \\
0.00 \\
0.00\end{array}$ \\
\hline $\begin{array}{c}2345 \\
\text { June } 9 \\
0000 \\
0015 \\
0030\end{array}$ & 1989 & $\begin{array}{l}17.1 \\
14.5 \\
11.9 \\
14.5\end{array}$ & $\begin{array}{l}0.01 \\
0.01 \\
0.04 \\
0.06\end{array}$ & $\begin{array}{l}0830 \\
0845 \\
0900 \\
0915 \\
0930\end{array}$ & $\begin{array}{l}431.0 \\
817.0 \\
903.0 \\
856.0 \\
720.0\end{array}$ & $\begin{array}{l}0.51 \\
0.00 \\
0.01 \\
0.00 \\
0.00\end{array}$ & $\begin{array}{l}1715 \\
1730 \\
1745 \\
1800 \\
1815\end{array}$ & $\begin{array}{l}8.3 \\
7.9 \\
7.5 \\
7.1 \\
6.7\end{array}$ & $\begin{array}{l}0.00 \\
0.00 \\
0.00 \\
0.00 \\
0.00\end{array}$ \\
\hline $\begin{array}{l}0045 \\
0100 \\
0115 \\
0130 \\
0145\end{array}$ & & $\begin{array}{l}22.6 \\
50.0 \\
88.2 \\
94.0 \\
75.1\end{array}$ & $\begin{array}{l}0.04 \\
0.02 \\
0.01 \\
0.00 \\
0.00\end{array}$ & $\begin{array}{l}0945 \\
1000 \\
1015 \\
1030 \\
1045\end{array}$ & $\begin{array}{r}444.0 \\
237.0 \\
151.0 \\
109.0 \\
83.7\end{array}$ & $\begin{array}{l}0.01 \\
0.00 \\
0.00 \\
0.00 \\
0.00\end{array}$ & $\begin{array}{l}1830 \\
1845 \\
1900 \\
1915 \\
1930\end{array}$ & $\begin{array}{l}6.4 \\
6.4 \\
6.0 \\
6.0 \\
5.7\end{array}$ & $\begin{array}{l}0.00 \\
0.00 \\
0.00 \\
0.00 \\
0.00\end{array}$ \\
\hline $\begin{array}{l}0200 \\
0215 \\
0230 \\
0245 \\
0300\end{array}$ & & $\begin{array}{l}51.8 \\
40.1 \\
36.0 \\
30.1 \\
24.6\end{array}$ & $\begin{array}{l}0.00 \\
0.00 \\
0.00 \\
0.00 \\
0.00\end{array}$ & $\begin{array}{l}1100 \\
1115 \\
1130 \\
1145 \\
1200\end{array}$ & $\begin{array}{l}64.6 \\
51.8 \\
41.8 \\
35.3 \\
32.2\end{array}$ & $\begin{array}{l}0.00 \\
0.00 \\
0.00 \\
0.01 \\
0.13\end{array}$ & $\begin{array}{l}1945 \\
2000 \\
2015 \\
2030 \\
2045\end{array}$ & $\begin{array}{l}5.7 \\
5.4 \\
5.4 \\
5.4 \\
5.0\end{array}$ & $\begin{array}{l}0.00 \\
0.00 \\
0.00 \\
0.00 \\
0.00\end{array}$ \\
\hline $\begin{array}{l}0330 \\
0345 \\
0400 \\
0415 \\
0430\end{array}$ & & $\begin{array}{r}16.6 \\
14.0 \\
11.9 \\
10.5 \\
9.2\end{array}$ & $\begin{array}{l}0.00 \\
0.00 \\
0.00 \\
0.00 \\
0.00\end{array}$ & $\begin{array}{l}1215 \\
1230 \\
1245 \\
1300 \\
1315\end{array}$ & $\begin{array}{l}36.0 \\
47.2 \\
56.6 \\
43.6 \\
33.7\end{array}$ & $\begin{array}{l}0.00 \\
0.00 \\
0.00 \\
0.01 \\
0.00\end{array}$ & $\begin{array}{l}2100 \\
2115 \\
2130 \\
2145 \\
2200\end{array}$ & $\begin{array}{l}5.0 \\
5.0 \\
4.7 \\
4.7 \\
4.7\end{array}$ & $\begin{array}{l}0.00 \\
0.00 \\
0.00 \\
0.00 \\
0.00\end{array}$ \\
\hline $\begin{array}{l}0445 \\
0500 \\
0515 \\
0530 \\
0545\end{array}$ & & $\begin{array}{l}8.3 \\
7.5 \\
7.1 \\
6.4 \\
6.0\end{array}$ & $\begin{array}{l}0.00 \\
0.00 \\
0.00 \\
0.00 \\
0.00\end{array}$ & $\begin{array}{l}1330 \\
1345 \\
1400 \\
1415 \\
1430\end{array}$ & $\begin{array}{l}27.3 \\
23.9 \\
21.3 \\
19.4 \\
17.7\end{array}$ & $\begin{array}{l}0.00 \\
0.00 \\
0.01 \\
0.00 \\
0.00\end{array}$ & $\begin{array}{l}2215 \\
2230 \\
2245 \\
2300 \\
2315\end{array}$ & $\begin{array}{l}4.3 \\
4.3 \\
4.3 \\
4.3 \\
4.3\end{array}$ & $\begin{array}{l}0.00 \\
0.00 \\
0.00 \\
0.00 \\
0.00\end{array}$ \\
\hline $\begin{array}{l}0600 \\
0615 \\
0630 \\
0645 \\
0700\end{array}$ & & $\begin{array}{r}5.7 \\
5.4 \\
5.4 \\
5.7 \\
21.9\end{array}$ & $\begin{array}{l}0.02 \\
0.01 \\
0.00 \\
0.05 \\
0.27\end{array}$ & $\begin{array}{l}1445 \\
1500 \\
1515 \\
1530 \\
1545\end{array}$ & $\begin{array}{l}16.6 \\
15.5 \\
15.0 \\
13.5 \\
12.4\end{array}$ & $\begin{array}{l}0.00 \\
0.00 \\
0.00 \\
0.00 \\
0.00\end{array}$ & $\begin{array}{l}2330 \\
2345 \\
\text { June } 10 \\
0000\end{array}$ & $1989 \begin{array}{l}4.0 \\
4.0 \\
4.0\end{array}$ & $\begin{array}{l}0.00 \\
0.00 \\
0.00\end{array}$ \\
\hline
\end{tabular}




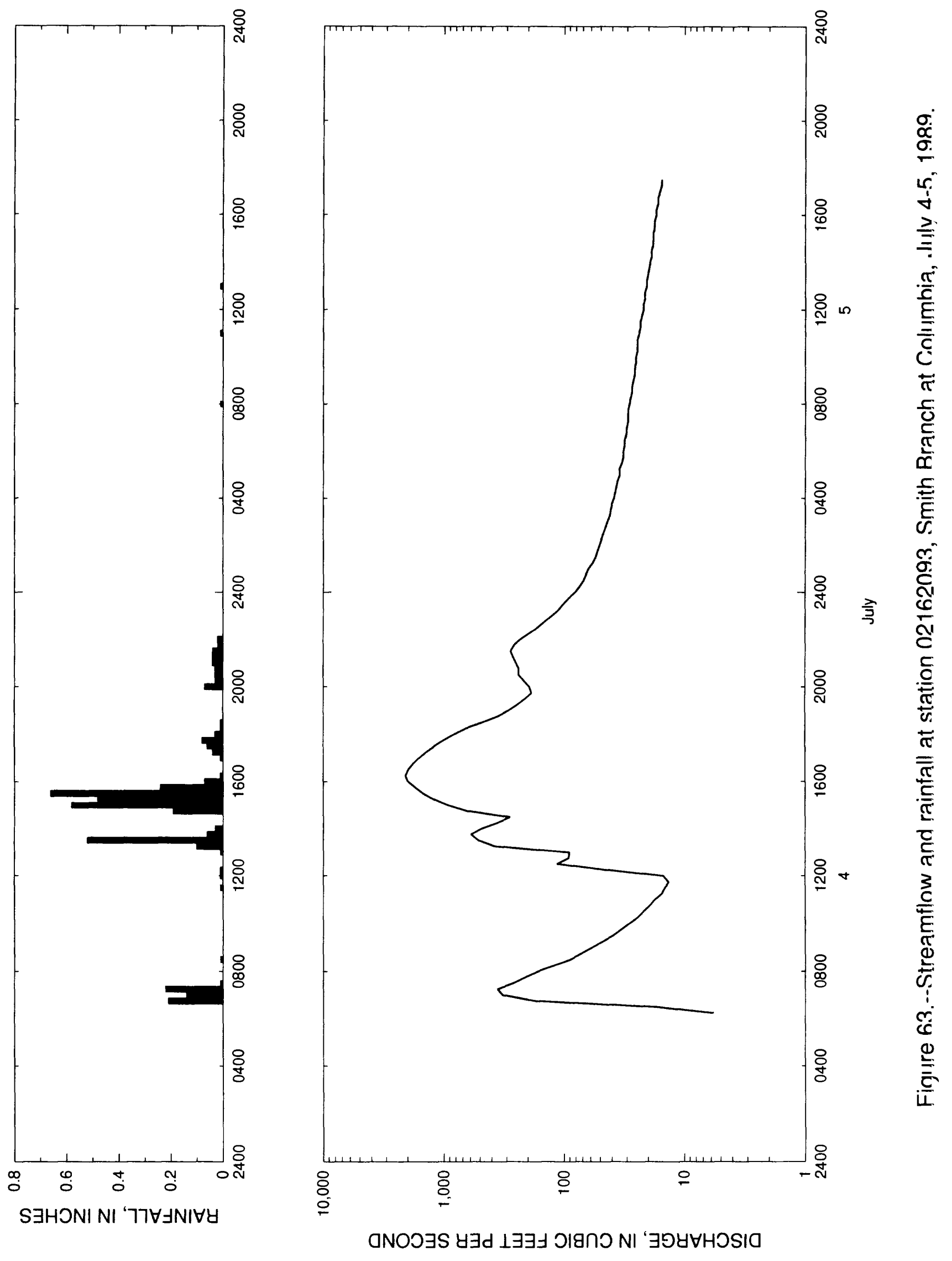


Table 62.--Streamflow and rainfali at station 02162093, Smith Branch at Columbia, July $4-5,1989$

\begin{tabular}{|c|c|c|c|c|c|c|c|c|}
\hline $\begin{array}{l}\text { Time } \\
\text { (hours) }\end{array}$ & $\begin{array}{l}\text { Streamflow } \\
\text { (cubic feet } \\
\text { per second) }\end{array}$ & $\begin{array}{l}\text { Rain- } \\
\text { fall } \\
\text { (inches) }\end{array}$ & $\begin{array}{l}\text { Time } \\
\text { (hr'1us) }\end{array}$ & $\begin{array}{l}\text { Streamflow } \\
\text { (cubic feet } \\
\text { per second) }\end{array}$ & $\begin{array}{l}\text { Rain- } \\
\text { fall } \\
\text { (inches) }\end{array}$ & $\begin{array}{l}\text { Time } \\
\text { (hours) }\end{array}$ & $\begin{array}{l}\text { Streamflow } \\
\text { (cubic feet } \\
\text { per second) }\end{array}$ & $\begin{array}{l}\text { Rair- } \\
\text { fall } \\
\text { (incres) }\end{array}$ \\
\hline $\begin{array}{l}\text { July } 4 \text {, } \\
0615 \\
0630 \\
0645 \\
0700\end{array}$ & $\begin{array}{r}1989 \quad 5.7 \\
17.1 \\
172.0 \\
325.0\end{array}$ & $\begin{array}{l}0.00 \\
0.00 \\
0.21 \\
0.14\end{array}$ & $\begin{array}{l}1815 \\
1830 \\
1845 \\
1900 \\
1915\end{array}$ & $\begin{array}{l}660.0 \\
4.5 .0 \\
358.0 \\
288.0 \\
243.0\end{array}$ & $\begin{array}{l}0.01 \\
0.01 \\
0.00 \\
0.00 \\
0.00\end{array}$ & $\begin{array}{l}0615 \\
0630 \\
0645 \\
0700 \\
0715\end{array}$ & $\begin{array}{l}31.5 \\
31.5 \\
30.1 \\
30.1 \\
29.4\end{array}$ & $\begin{array}{l}0.0 C \\
0.0 C \\
0.0 C \\
0.0 C \\
0.0 C\end{array}$ \\
\hline $\begin{array}{l}0715 \\
0730 \\
0745 \\
0800 \\
0815\end{array}$ & $\begin{array}{l}358.0 \\
266.0 \\
212.0 \\
165.0 \\
120.0\end{array}$ & $\begin{array}{l}0.22 \\
0.01 \\
0.00 \\
0.00 \\
0.00\end{array}$ & $\begin{array}{l}1930 \\
1945 \\
2000 \\
2015 \\
2030\end{array}$ & $\begin{array}{l}210.0 \\
186.0 \\
194.0 \\
215.0 \\
237.0\end{array}$ & $\begin{array}{l}0.00 \\
0.00 \\
0.07 \\
0.03 \\
0.03\end{array}$ & $\begin{array}{l}0730 \\
0745 \\
0800 \\
0815 \\
0830\end{array}$ & $\begin{array}{l}29.4 \\
29.4 \\
28.7 \\
28.0 \\
27.3\end{array}$ & $\begin{array}{l}0.0 \mathrm{C} \\
0.0 \mathrm{C} \\
0.01 \\
0.0 \mathrm{C} \\
0.0 \mathrm{C}\end{array}$ \\
\hline $\begin{array}{l}0830 \\
0845 \\
0900 \\
0915 \\
0930\end{array}$ & $\begin{array}{l}88.2 \\
71.0 \\
58.5 \\
48.1 \\
39.3\end{array}$ & $\begin{array}{l}0.01 \\
0.00 \\
0.00 \\
0.00 \\
0.00\end{array}$ & $\begin{array}{l}2045 \\
2100 \\
2115 \\
2130 \\
2145\end{array}$ & $\begin{array}{l}237.0 \\
250.0 \\
265.0 \\
278.0 \\
261.0\end{array}$ & $\begin{array}{l}0.03 \\
0.04 \\
0.04 \\
0.04 \\
0.02\end{array}$ & $\begin{array}{l}0845 \\
0900 \\
0915 \\
0930 \\
0945\end{array}$ & $\begin{array}{l}27.3 \\
26.7 \\
26.0 \\
26.0 \\
25.3\end{array}$ & $\begin{array}{l}0.00 \\
0.00 \\
0.00 \\
0.00 \\
0.00\end{array}$ \\
\hline $\begin{array}{l}0945 \\
1000 \\
1015 \\
1030 \\
1045\end{array}$ & $\begin{array}{l}33.7 \\
28.7 \\
24.6 \\
21.9 \\
19.4\end{array}$ & $\begin{array}{l}0.00 \\
0.00 \\
0.00 \\
0.00 \\
0.00\end{array}$ & $\begin{array}{l}2200 \\
2215 \\
2230 \\
2245 \\
2300\end{array}$ & $\begin{array}{l}230.0 \\
195.0 \\
165.0 \\
144.0 \\
126.0\end{array}$ & $\begin{array}{l}0.02 \\
0.00 \\
0.00 \\
0.00 \\
0.00\end{array}$ & $\begin{array}{l}1000 \\
1015 \\
1030 \\
1045 \\
1100\end{array}$ & $\begin{array}{l}25.3 \\
24.6 \\
24.6 \\
24.6 \\
23.9\end{array}$ & $\begin{array}{l}0.00 \\
0.00 \\
0.00 \\
0.00 \\
0.01\end{array}$ \\
\hline $\begin{array}{l}1100 \\
1115 \\
1130 \\
1145 \\
1200\end{array}$ & $\begin{array}{l}17.7 \\
15.5 \\
14.5 \\
13.5 \\
15.0\end{array}$ & $\begin{array}{l}0.00 \\
0.00 \\
0.01 \\
0.00 \\
0.01\end{array}$ & $\begin{array}{l}2315 \\
2330 \\
2345 \\
\text { July } 5 \\
0000\end{array}$ & $\begin{array}{r}111.0 \\
101.0 \\
91.6 \\
1989 \\
80.4\end{array}$ & $\begin{array}{l}0.00 \\
0.00 \\
0.00 \\
0.00\end{array}$ & $\begin{array}{l}1115 \\
1130 \\
1145 \\
1200 \\
1215\end{array}$ & $\begin{array}{l}23.2 \\
23.2 \\
22.6 \\
21.9 \\
21.9\end{array}$ & $\begin{array}{l}0.00 \\
0.00 \\
0.00 \\
0.00 \\
0.00\end{array}$ \\
\hline $\begin{array}{l}1215 \\
1230 \\
1245 \\
1300 \\
1315\end{array}$ & $\begin{array}{r}45.3 \\
114.0 \\
91.6 \\
90.5 \\
378.0\end{array}$ & $\begin{array}{l}0.01 \\
0.00 \\
0.00 \\
0.01 \\
0.10\end{array}$ & $\begin{array}{l}0015 \\
0030 \\
0045 \\
0100 \\
0115\end{array}$ & $\begin{array}{l}74.1 \\
68.9 \\
65.7 \\
62.6 \\
57.5\end{array}$ & $\begin{array}{l}0.00 \\
0.00 \\
0.00 \\
0.00 \\
0.00\end{array}$ & $\begin{array}{l}1230 \\
1245 \\
1300 \\
1315 \\
1400\end{array}$ & $\begin{array}{l}21.3 \\
21.3 \\
20.6 \\
20.6 \\
19.4\end{array}$ & $\begin{array}{l}0.00 \\
0.00 \\
0.01 \\
0.00 \\
0.00\end{array}$ \\
\hline $\begin{array}{l}1330 \\
1345 \\
1400 \\
1415 \\
1430\end{array}$ & $\begin{array}{l}515.0 \\
590.0 \\
484.0 \\
358.0 \\
283.0\end{array}$ & $\begin{array}{l}0.52 \\
0.06 \\
0.03 \\
0.00 \\
0.00\end{array}$ & $\begin{array}{l}0130 \\
0145 \\
0200 \\
0215 \\
0230\end{array}$ & $\begin{array}{l}54.6 \\
52.8 \\
50.9 \\
49.0 \\
47.2\end{array}$ & $\begin{array}{l}0.00 \\
0.00 \\
0.00 \\
0.00 \\
0.00\end{array}$ & $\begin{array}{l}1415 \\
1430 \\
1445 \\
1500 \\
1515\end{array}$ & $\begin{array}{l}18.8 \\
18.8 \\
18.2 \\
18.2 \\
18.2\end{array}$ & $\begin{array}{l}0.00 \\
0.00 \\
0.00 \\
0.00 \\
0.00\end{array}$ \\
\hline $\begin{array}{l}1445 \\
1500 \\
1515 \\
1530 \\
1545\end{array}$ & $\begin{array}{r}635.0 \\
925.0 \\
1210.0 \\
1490.0 \\
1730.0\end{array}$ & $\begin{array}{l}0.19 \\
0.58 \\
0.48 \\
0.66 \\
0.24\end{array}$ & $\begin{array}{l}0245 \\
0300 \\
0315 \\
0330 \\
0345\end{array}$ & $\begin{array}{l}45.3 \\
43.6 \\
41.8 \\
41.0 \\
40.1\end{array}$ & $\begin{array}{l}0.00 \\
0.00 \\
0.00 \\
0.00 \\
0.00\end{array}$ & $\begin{array}{l}1530 \\
1545 \\
1600 \\
1615 \\
1630\end{array}$ & $\begin{array}{l}17.7 \\
17.7 \\
17.1 \\
17.1 \\
16.6\end{array}$ & $\begin{array}{l}0.00 \\
0.00 \\
0.00 \\
0.00 \\
0.00\end{array}$ \\
\hline $\begin{array}{l}1600 \\
1615 \\
1630 \\
1645 \\
1700\end{array}$ & $\begin{array}{l}1990.0 \\
2080.0 \\
1980.0 \\
1800.0 \\
1610.0\end{array}$ & $\begin{array}{l}0.07 \\
0.01 \\
0.00 \\
0.00 \\
0.01\end{array}$ & $\begin{array}{l}0400 \\
0415 \\
0430 \\
0445 \\
0500\end{array}$ & $\begin{array}{l}38.5 \\
37.6 \\
36.8 \\
36.0 \\
34.5\end{array}$ & $\begin{array}{l}0.00 \\
0.00 \\
0.00 \\
0.00 \\
0.00\end{array}$ & $\begin{array}{l}1645 \\
1700 \\
1715 \\
1730 \\
1745\end{array}$ & $\begin{array}{l}16.6 \\
16.0 \\
15.5 \\
15.5 \\
15.5\end{array}$ & $\begin{array}{l}0.00 \\
0.00 \\
0.00 \\
0.00 \\
0.00\end{array}$ \\
\hline $\begin{array}{l}1715 \\
1730 \\
1745 \\
1800\end{array}$ & $\begin{array}{r}1410.0 \\
1200.0 \\
1010.0 \\
827.0\end{array}$ & $\begin{array}{l}0.04 \\
0.06 \\
0.08 \\
0.03\end{array}$ & $\begin{array}{l}0515 \\
0530 \\
0545 \\
0600\end{array}$ & $\begin{array}{l}34.5 \\
33.0 \\
32.2 \\
32.2\end{array}$ & $\begin{array}{l}0.00 \\
0.00 \\
0.00 \\
0.00\end{array}$ & 1800 & 15.5 & 0.00 \\
\hline
\end{tabular}



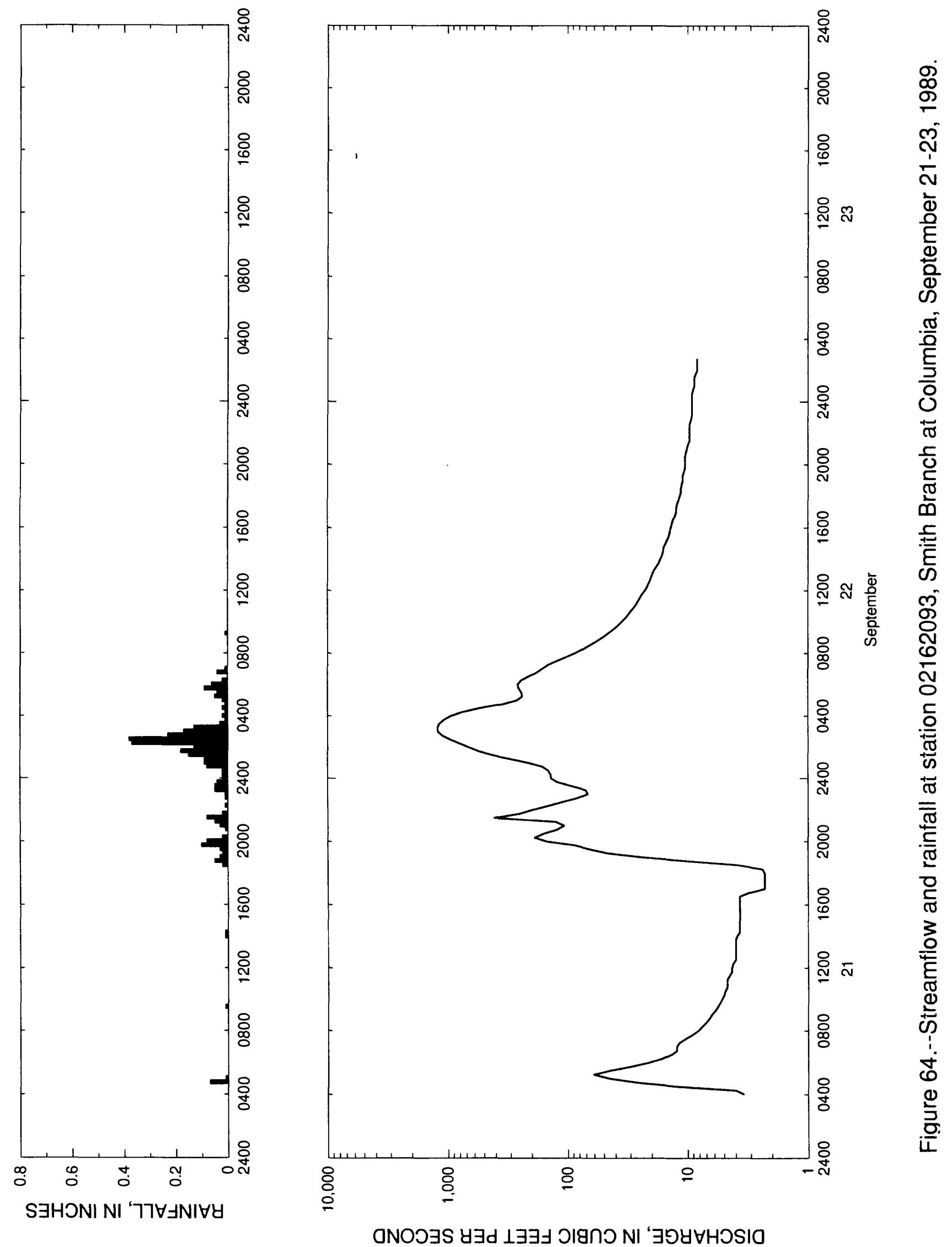
Table 63.--Streamflow and rainfall at station 02162093, Smith Branch at Columbia,

September 21-23, 1989

\begin{tabular}{|c|c|c|c|c|c|c|c|c|}
\hline $\begin{array}{l}\text { Time } \\
\text { (hours) }\end{array}$ & $\begin{array}{l}\text { Streamflow } \\
\text { (cubic feet } \\
\text { per second) }\end{array}$ & $\begin{array}{l}\text { Rain- } \\
\text { fall } \\
\text { (inches) }\end{array}$ & $\begin{array}{l}\text { Time } \\
\text { (hours) }\end{array}$ & $\begin{array}{l}\text { Streamflow } \\
\text { (cubic feet } \\
\text { per second) }\end{array}$ & $\begin{array}{l}\text { Rain- } \\
\text { fall } \\
\text { (inches) }\end{array}$ & $\begin{array}{l}\text { Time } \\
\text { (hours) }\end{array}$ & $\begin{array}{l}\text { Streamflow } \\
\text { (cubic feet } \\
\text { per second) }\end{array}$ & $\begin{array}{l}\text { Rain- } \\
\text { fall } \\
\text { (inches) }\end{array}$ \\
\hline $\begin{array}{l}\text { Sept ember } \\
0400 \\
0415 \\
0430 \\
0445\end{array}$ & 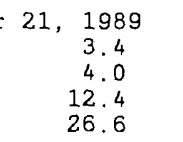 & $\begin{array}{l}0.00 \\
0.00 \\
0.00 \\
0.07\end{array}$ & $\begin{array}{l}2000 \\
2015 \\
2030 \\
2045 \\
2100\end{array}$ & $\begin{array}{l}148.0 \\
188.0 \\
158.0 \\
123.0 \\
107.0\end{array}$ & $\begin{array}{l}0.08 \\
0.02 \\
0.00 \\
0.01 \\
0.03\end{array}$ & $\begin{array}{l}1200 \\
1215 \\
1230 \\
1245 \\
1300\end{array}$ & $\begin{array}{l}22.6 \\
21.6 \\
21.0 \\
20.4 \\
19.8\end{array}$ & $\begin{array}{l}0.07 \\
0.00 \\
0.09 \\
0.07 \\
0.00\end{array}$ \\
\hline $\begin{array}{l}0500 \\
0515 \\
0530 \\
0545 \\
0600\end{array}$ & $\begin{array}{l}44.9 \\
60.9 \\
44.7 \\
29.8 \\
21.4\end{array}$ & $\begin{array}{l}0.01 \\
0.00 \\
0.00 \\
0.00 \\
0.00\end{array}$ & $\begin{array}{l}2115 \\
2130 \\
2145 \\
2200 \\
2215\end{array}$ & $\begin{array}{l}126.0 \\
409.0 \\
252.0 \\
196.0 \\
145.0\end{array}$ & $\begin{array}{l}0.05 \\
0.08 \\
0.02 \\
0.00 \\
0.01\end{array}$ & $\begin{array}{l}1315 \\
1330 \\
1345 \\
1400 \\
1415\end{array}$ & $\begin{array}{l}19.2 \\
18.3 \\
17.4 \\
16.9 \\
16.3\end{array}$ & $\begin{array}{l}0.02 \\
0.02 \\
0.02 \\
0.00 \\
0.02\end{array}$ \\
\hline $\begin{array}{l}0615 \\
0630 \\
0645 \\
0700 \\
0715\end{array}$ & $\begin{array}{l}16.4 \\
13.7 \\
12.4 \\
12.4 \\
11.8\end{array}$ & $\begin{array}{l}0.00 \\
0.00 \\
0.00 \\
0.00 \\
0.00\end{array}$ & $\begin{array}{l}2230 \\
2245 \\
2300 \\
2315 \\
2330\end{array}$ & $\begin{array}{r}108.0 \\
81.7 \\
67.9 \\
70.6 \\
92.2\end{array}$ & $\begin{array}{l}0.00 \\
0.01 \\
0.01 \\
0.05 \\
0.05\end{array}$ & $\begin{array}{l}1430 \\
1445 \\
1500 \\
1515 \\
1530\end{array}$ & $\begin{array}{l}16.0 \\
15.8 \\
15.3 \\
14.8 \\
14.3\end{array}$ & $\begin{array}{l}0.00 \\
0.07 \\
0.07 \\
0.07 \\
0.07\end{array}$ \\
\hline $\begin{array}{l}0730 \\
0745 \\
0800 \\
0815 \\
0830\end{array}$ & $\begin{array}{r}10.4 \\
9.1 \\
8.2 \\
7.6 \\
7.0\end{array}$ & $\begin{array}{l}0.00 \\
0.00 \\
0.00 \\
0.00 \\
0.00\end{array}$ & $\begin{array}{l}2345 \\
\text { September } \\
0000 \\
0015 \\
0030\end{array}$ & $\begin{array}{c}121.0 \\
22,1989 \\
137.0 \\
138.0 \\
145.0\end{array}$ & $\begin{array}{l}0.04 \\
0.02 \\
0.02 \\
0.02\end{array}$ & $\begin{array}{l}1545 \\
1600 \\
1615 \\
1630 \\
1645\end{array}$ & $\begin{array}{l}14.0 \\
13.8 \\
13.5 \\
13.2 \\
12.7\end{array}$ & $\begin{array}{l}0.07 \\
0.07 \\
0.07 \\
0.07 \\
0.00\end{array}$ \\
\hline $\begin{array}{l}0845 \\
0900 \\
0915 \\
0930 \\
0945\end{array}$ & $\begin{array}{l}6.6 \\
6.3 \\
5.9 \\
5.6 \\
5.4\end{array}$ & $\begin{array}{l}0.00 \\
0.00 \\
0.00 \\
0.01 \\
0.00\end{array}$ & $\begin{array}{l}0045 \\
0100 \\
0115 \\
0130 \\
0145\end{array}$ & $\begin{array}{l}161.0 \\
209.0 \\
301.0 \\
426.0 \\
554.0\end{array}$ & $\begin{array}{l}0.08 \\
0.09 \\
0.09 \\
0.15 \\
0.18\end{array}$ & $\begin{array}{l}1700 \\
1715 \\
1730 \\
1745 \\
1800\end{array}$ & $\begin{array}{l}12.4 \\
12.4 \\
12.2 \\
11.9 \\
11.7\end{array}$ & $\begin{array}{l}0.03 \\
0.00 \\
0.0 ? \\
0.07 \\
0.07\end{array}$ \\
\hline $\begin{array}{l}1000 \\
1015 \\
1030 \\
1045 \\
1100\end{array}$ & $\begin{array}{l}5.2 \\
5.0 \\
4.9 \\
4.7 \\
4.7\end{array}$ & $\begin{array}{l}0.00 \\
0.00 \\
0.00 \\
0.00 \\
0.00\end{array}$ & $\begin{array}{l}0200 \\
0215 \\
0230 \\
0245 \\
0300\end{array}$ & $\begin{array}{r}665.0 \\
799.0 \\
958.0 \\
1110.0 \\
1210.0\end{array}$ & $\begin{array}{l}0.13 \\
0.37 \\
0.38 \\
0.23 \\
0.17\end{array}$ & $\begin{array}{l}1815 \\
1830 \\
1845 \\
1900 \\
1915\end{array}$ & $\begin{array}{l}11.4 \\
11.4 \\
11.2 \\
11.0 \\
11.0\end{array}$ & $\begin{array}{l}0.07 \\
0.09 \\
0.00 \\
0.07 \\
0.07\end{array}$ \\
\hline $\begin{array}{l}1115 \\
1130 \\
1145 \\
1200 \\
1215\end{array}$ & $\begin{array}{l}4.7 \\
4.5 \\
4.3 \\
4.3 \\
4.2\end{array}$ & $\begin{array}{l}0.00 \\
0.00 \\
0.00 \\
0.00 \\
0.00\end{array}$ & $\begin{array}{l}0315 \\
0330 \\
0345 \\
0400 \\
0415\end{array}$ & $\begin{array}{r}1220.0 \\
1180.0 \\
1080.0 \\
944.0 \\
754.0\end{array}$ & $\begin{array}{l}0.13 \\
0.03 \\
0.01 \\
0.02 \\
0.01\end{array}$ & $\begin{array}{l}1930 \\
1945 \\
2000 \\
2015 \\
2030\end{array}$ & $\begin{array}{l}10.8 \\
10.5 \\
10.5 \\
10.5 \\
10.5\end{array}$ & $\begin{array}{l}0.02 \\
0.00 \\
0.02 \\
0.00 \\
0.02\end{array}$ \\
\hline $\begin{array}{l}1230 \\
1245 \\
1300 \\
1315 \\
1330\end{array}$ & $\begin{array}{l}4.0 \\
4.0 \\
4.0 \\
4.0 \\
4.0\end{array}$ & $\begin{array}{l}0.00 \\
0.00 \\
0.00 \\
0.00 \\
0.00\end{array}$ & $\begin{array}{l}0430 \\
0445 \\
0500 \\
0515 \\
0530\end{array}$ & $\begin{array}{l}529.0 \\
349.0 \\
265.0 \\
238.0 \\
242.0\end{array}$ & $\begin{array}{l}0.02 \\
0.01 \\
0.02 \\
0.05 \\
0.04\end{array}$ & $\begin{array}{l}2045 \\
2100 \\
2115 \\
2130 \\
2145\end{array}$ & $\begin{array}{r}10.3 \\
10.1 \\
9.9 \\
9.6 \\
9.6\end{array}$ & $\begin{array}{l}0.00 \\
0.00 \\
0.00 \\
0.07 \\
0.00\end{array}$ \\
\hline $\begin{array}{l}1345 \\
1400 \\
1415 \\
1430 \\
1445\end{array}$ & $\begin{array}{l}4.0 \\
3.9 \\
3.7 \\
3.7 \\
3.7\end{array}$ & $\begin{array}{l}0.00 \\
0.01 \\
0.01 \\
0.00 \\
0.00\end{array}$ & $\begin{array}{l}0545 \\
0600 \\
0615 \\
0630 \\
0645\end{array}$ & $\begin{array}{l}255.0 \\
260.0 \\
244.0 \\
210.0 \\
180.0\end{array}$ & $\begin{array}{l}0.09 \\
0.06 \\
0.02 \\
0.00 \\
0.04\end{array}$ & $\begin{array}{l}2200 \\
2215 \\
2230 \\
2245 \\
2300\end{array}$ & $\begin{array}{l}9.6 \\
9.6 \\
9.6 \\
9.4 \\
9.2\end{array}$ & $\begin{array}{l}0.07 \\
0.00 \\
0.07 \\
0.00 \\
0.00\end{array}$ \\
\hline $\begin{array}{l}1500 \\
1515 \\
1530 \\
1545 \\
1600\end{array}$ & $\begin{array}{l}3.7 \\
3.7 \\
3.7 \\
3.7 \\
3.7\end{array}$ & $\begin{array}{l}0.00 \\
0.00 \\
0.00 \\
0.00 \\
0.00\end{array}$ & $\begin{array}{l}0700 \\
0715 \\
0730 \\
0745 \\
0800\end{array}$ & $\begin{array}{r}162.0 \\
145.0 \\
123.0 \\
103.0 \\
87.0\end{array}$ & $\begin{array}{l}0.01 \\
0.00 \\
0.00 \\
0.00 \\
0.00\end{array}$ & $\begin{array}{l}2315 \\
2330 \\
2345 \\
\text { September } \\
0000\end{array}$ & $\begin{aligned} & 9.2 \\
& 9.2 \\
& 9.2 \\
& 923, \\
& 1989 \\
& 9.2\end{aligned}$ & $\begin{array}{l}0.00 \\
0.07 \\
0.07 \\
0.07\end{array}$ \\
\hline $\begin{array}{l}1615 \\
1630 \\
1645 \\
1700 \\
1715\end{array}$ & $\begin{array}{l}3.7 \\
3.7 \\
3.1 \\
2.3 \\
2.3\end{array}$ & $\begin{array}{l}0.00 \\
0.00 \\
0.00 \\
0.00 \\
0.00\end{array}$ & $\begin{array}{l}0815 \\
0830 \\
0845 \\
0900 \\
0915\end{array}$ & $\begin{array}{l}74.9 \\
65.3 \\
57.6 \\
51.3 \\
46.1\end{array}$ & $\begin{array}{l}0.00 \\
0.00 \\
0.00 \\
0.00 \\
0.01\end{array}$ & $\begin{array}{l}0015 \\
0030 \\
0045 \\
0100 \\
0115\end{array}$ & $\begin{array}{l}9.2 \\
9.2 \\
9.0 \\
8.8 \\
8.8\end{array}$ & $\begin{array}{l}0.02 \\
0.00 \\
0.02 \\
0.00 \\
0.00\end{array}$ \\
\hline $\begin{array}{l}1730 \\
1745 \\
1800 \\
1815 \\
1830\end{array}$ & $\begin{array}{l}2.3 \\
2.3 \\
2.3 \\
2.4 \\
3.9\end{array}$ & $\begin{array}{l}0.00 \\
0.00 \\
0.00 \\
0.00 \\
0.02\end{array}$ & $\begin{array}{l}0930 \\
0945 \\
1000 \\
1015 \\
1030\end{array}$ & $\begin{array}{l}41.7 \\
38.2 \\
35.5 \\
32.8 \\
30.9\end{array}$ & $\begin{array}{l}0.00 \\
0.00 \\
0.00 \\
0.00 \\
0.00\end{array}$ & $\begin{array}{l}0130 \\
0145 \\
0200 \\
0215 \\
0230\end{array}$ & $\begin{array}{l}8.8 \\
8.6 \\
8.3 \\
8.3 \\
8.3\end{array}$ & $\begin{array}{l}0.00 \\
0.00 \\
0.02 \\
0.02 \\
0.00\end{array}$ \\
\hline $\begin{array}{l}1845 \\
1900 \\
1915 \\
1930 \\
1945\end{array}$ & $\begin{array}{r}9.8 \\
23.4 \\
45.7 \\
64.6 \\
87.5\end{array}$ & $\begin{array}{l}0.05 \\
0.03 \\
0.02 \\
0.03 \\
0.10\end{array}$ & $\begin{array}{l}1045 \\
1100 \\
1115 \\
1130 \\
1145\end{array}$ & $\begin{array}{l}29.2 \\
27.4 \\
26.1 \\
25.0 \\
24.0\end{array}$ & $\begin{array}{l}0.00 \\
0.00 \\
0.00 \\
0.00 \\
0.00\end{array}$ & $\begin{array}{l}0245 \\
0300\end{array}$ & $\begin{array}{l}8.3 \\
8.3\end{array}$ & $\begin{array}{l}0.00 \\
0.00\end{array}$ \\
\hline
\end{tabular}




\section{Station 02163940, Richland Creek Tributary at Greenville, S.C.}

Location.--Lat $34^{\circ} 52^{\prime} 42^{\prime \prime}$, long 82²3'52", Greenville County, Hydrologic Unit 03050109, at culvert on Southern Railroad crossing, 0.4 mi upstream of Rutherford Road (State secondary road 21), $1.9 \mathrm{mi}$ north of the Federal Building, and $0.7 \mathrm{mi}$ upstream from the mouth at Richland Creek (a tributary of the Reedy River).

Period of record.-- November 20, 1985 to October 18, 1989.

Gage.--Digital stage recorder with 5-minute punch interval. The recorder is housed in a metal shelter atop a stilling well attached to a free-standing platform on the right bank, approximately $8 \mathrm{ft}$ upstream from the $9.1-\mathrm{ft}$ corrugated metal pipe culvert. A crest-stage indicator is located on the left downstream bank near the culvert exit.

Rating.--The stage-streamflow relation is defined by current meter measurements up to $21.6 \mathrm{ft}^{3} / \mathrm{s}$. The stage-streamflow relation was extended to $500 \mathrm{ft}^{3} / \mathrm{s}$ using indirect computational methods.

Rain gage and location.--Station 345230082234000 , lat $34^{\circ} 52^{\prime} 30^{\prime \prime}$, long $82^{\circ} 23^{\prime} 40^{\prime \prime}$. A she'ter containing a digital cumulative rainfall recorder with a 5-minute punch interval attached to the left upstream wingwall at the Rutherford Road (State secondary rcad 21) crossing of the Richland Creek tributary, and approximately $1.7 \mathrm{mi}$ north of the Federal Building.

Selected basin characteristics.--

Drainage area $-0.78 \mathrm{mi}^{2}$

Physiographic province -- Piedmont

Channel slope -- $152.0 \mathrm{ft} / \mathrm{mi}$

Channel length -- $1.27 \mathrm{mi}$

Total impervious area -- 27.0 percent

Basin development factor -- 5

2-year, 2-hour rainfall amount -- 2.15 in.

Flood frequency data: $\mathrm{UQ}_{2} \quad 315 \mathrm{ft}^{3} / \mathrm{s}$

$\mathrm{UQ}_{5} \quad 539 \mathrm{ft}^{3} / \mathrm{s}$

$\mathrm{UQ}_{10} \quad 698 \mathrm{ft}^{3} / \mathrm{s}$

$\mathrm{UQ}_{25} \quad 905 \mathrm{ft}^{3} / \mathrm{s}$

$\mathrm{UQ}_{50} \quad 1,060 \mathrm{ft}^{3} / \mathrm{s}$

$\mathrm{UQ}_{100} \quad 1,220 \mathrm{ft}^{3} / \mathrm{s}$

$\mathrm{UQ}_{500} \quad 1,580 \mathrm{ft}^{3} / \mathrm{s}$ 


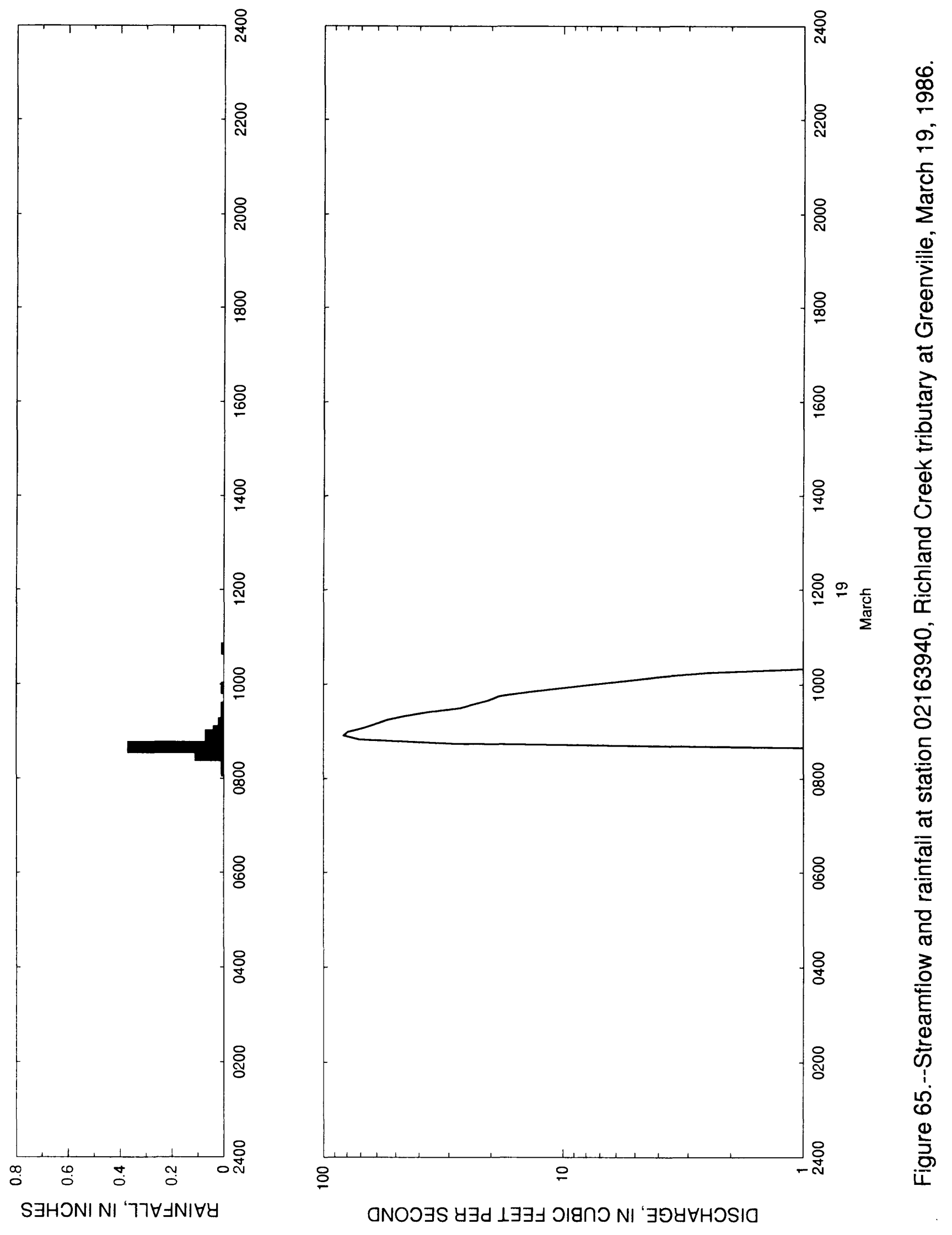


Table 64.--Streamflow and rainfall at station 02163940, Richland Creek tributary at Greenville, March 19,1986

\begin{tabular}{|c|c|c|c|c|c|c|c|c|}
\hline $\begin{array}{l}\text { Time } \\
\text { (hours) }\end{array}$ & $\begin{array}{l}\text { Streamflow } \\
\text { (cubic feet } \\
\text { per second) }\end{array}$ & $\begin{array}{l}\text { Rain- } \\
\text { fall } \\
\text { (inches) }\end{array}$ & $\begin{array}{l}\text { Time } \\
\text { (hours) }\end{array}$ & $\begin{array}{l}\text { Streamflow } \\
\text { (cubic feet } \\
\text { per second) }\end{array}$ & $\begin{array}{l}\text { Rain- } \\
\text { fall } \\
\text { (inches) }\end{array}$ & $\begin{array}{l}\text { Time } \\
\text { (hours) }\end{array}$ & $\begin{array}{l}\text { Streamflow } \\
\text { (cubic feet } \\
\text { per second) }\end{array}$ & $\begin{array}{l}\text { Rain- } \\
\text { fall } \\
\text { (incles) }\end{array}$ \\
\hline $\begin{array}{l}\text { March } 19 \text {, } \\
0810 \\
0815 \\
0820 \\
0825\end{array}$ & $\begin{array}{r}1986 \\
1.0 \\
1.0 \\
1.0 \\
1.0\end{array}$ & $\begin{array}{l}0.01 \\
0.01 \\
0.00 \\
0.01\end{array}$ & $\begin{array}{l}0905 \\
0910 \\
0915 \\
0920 \\
0925\end{array}$ & $\begin{array}{l}67.6 \\
60.5 \\
54.1 \\
45.9 \\
36.8\end{array}$ & $\begin{array}{l}0.02 \\
0.02 \\
0.01 \\
0.00 \\
0.00\end{array}$ & $\begin{array}{l}1005 \\
1010 \\
1015 \\
1020 \\
1025\end{array}$ & $\begin{array}{l}5.4 \\
3.9 \\
2.5 \\
1.0 \\
1.0\end{array}$ & $\begin{array}{l}0.00 \\
0.00 \\
0.00 \\
0.00 \\
0.00\end{array}$ \\
\hline $\begin{array}{l}0830 \\
0835 \\
0840 \\
0845 \\
0850\end{array}$ & $\begin{array}{r}1.0 \\
1.0 \\
1.0 \\
28.6 \\
70.9\end{array}$ & $\begin{array}{l}0.11 \\
0.04 \\
0.37 \\
0.06 \\
0.04\end{array}$ & $\begin{array}{l}0930 \\
0935 \\
0940 \\
0945 \\
0950\end{array}$ & $\begin{array}{l}26.9 \\
23.6 \\
20.5 \\
18.6 \\
14.2\end{array}$ & $\begin{array}{l}0.01 \\
0.00 \\
0.00 \\
0.00 \\
0.00\end{array}$ & $\begin{array}{l}1030 \\
1035 \\
1040 \\
1045 \\
1050\end{array}$ & $\begin{array}{l}1.0 \\
1.0 \\
1.0 \\
1.0 \\
1.0\end{array}$ & $\begin{array}{l}0.00 \\
0.00 \\
0.00 \\
0.01 \\
0.00\end{array}$ \\
\hline $\begin{array}{l}0855 \\
0900\end{array}$ & $\begin{array}{l}82.6 \\
79.0\end{array}$ & $\begin{array}{l}0.07 \\
0.04\end{array}$ & $\begin{array}{l}0955 \\
1000\end{array}$ & $\begin{array}{r}10.4 \\
7.6\end{array}$ & $\begin{array}{l}0.01 \\
0.00\end{array}$ & $\begin{array}{l}1055 \\
1100\end{array}$ & $\begin{array}{l}1.0 \\
1.0\end{array}$ & $\begin{array}{l}0.00 \\
0.00\end{array}$ \\
\hline
\end{tabular}




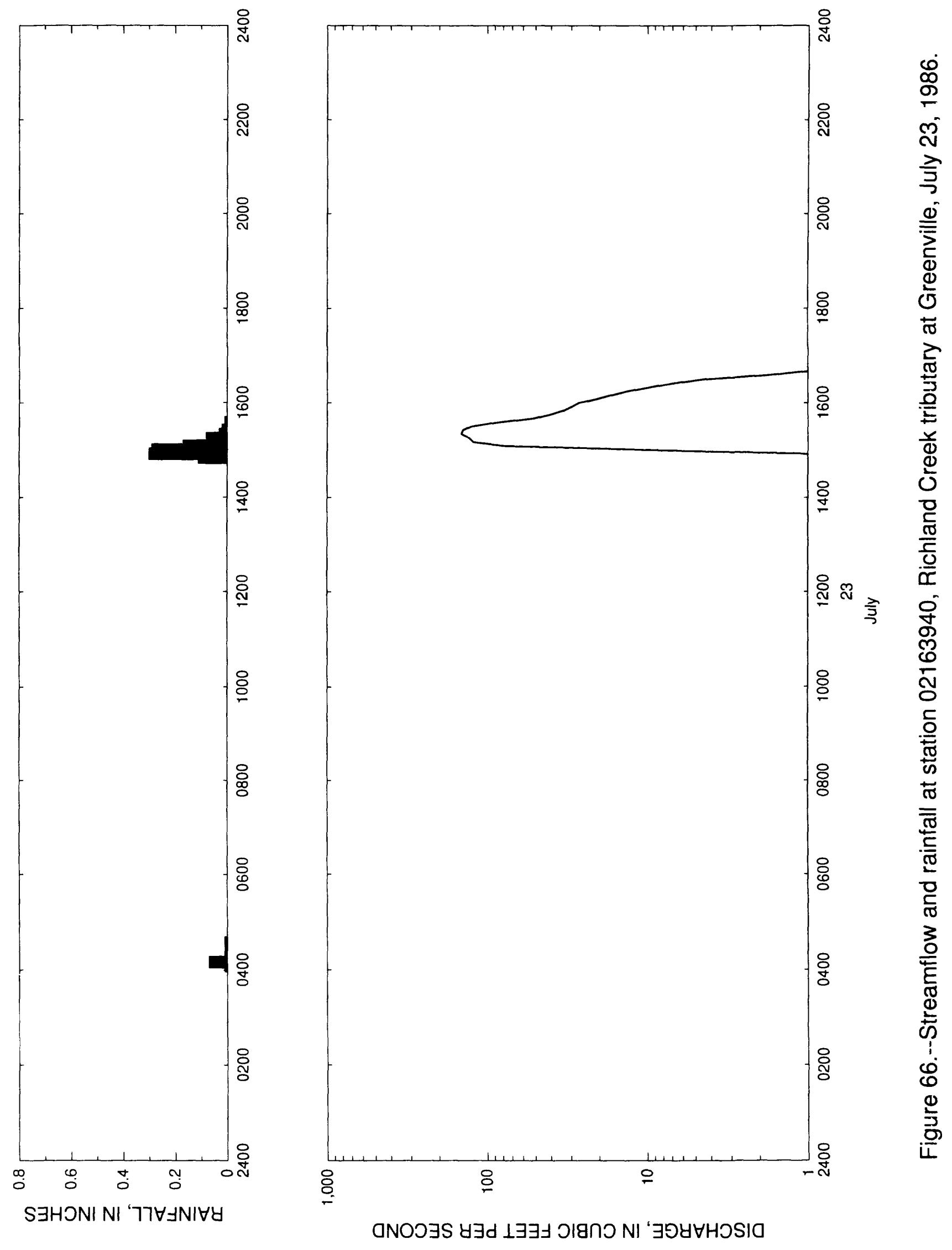


Table 65. - - Streamflow and rainfall at station 02163940, Richland Creek tributary at Greenville, July 23,1986

\begin{tabular}{|c|c|c|c|c|c|c|c|c|}
\hline $\begin{array}{l}\text { Time } \\
\text { (hours) }\end{array}$ & $\begin{array}{l}\text { Streamflow } \\
\text { (cubic feet } \\
\text { per second) }\end{array}$ & $\begin{array}{l}\text { Rain- } \\
\text { fall } \\
\text { (inches) }\end{array}$ & $\begin{array}{l}\text { Time } \\
\text { (hours) }\end{array}$ & $\begin{array}{l}\text { Streamflow } \\
\text { (cubic feet } \\
\text { per second) }\end{array}$ & $\begin{array}{l}\text { Rain- } \\
\text { fall } \\
\text { (inches) }\end{array}$ & $\begin{array}{l}\text { Time } \\
\text { (hours) }\end{array}$ & $\begin{array}{l}\text { Streamflow } \\
\text { (cubic feet } \\
\text { per second) }\end{array}$ & $\begin{array}{l}\text { Rain- } \\
\text { fall } \\
\text { (inchos) }\end{array}$ \\
\hline $\begin{array}{l}\text { July } 23 \text {, } \\
0405 \\
0410 \\
0415 \\
0420\end{array}$ & $\begin{array}{r}1986 \\
1.0 \\
1.0 \\
1.0 \\
1.0\end{array}$ & $\begin{array}{l}0.01 \\
0.07 \\
0.01 \\
0.01\end{array}$ & $\begin{array}{l}0825 \\
0830 \\
0835 \\
0840 \\
0845\end{array}$ & $\begin{array}{l}1.0 \\
1.0 \\
1.0 \\
1.0 \\
1.0\end{array}$ & $\begin{array}{l}0.00 \\
0.00 \\
0.00 \\
0.00 \\
0.00\end{array}$ & $\begin{array}{l}1250 \\
1255 \\
1300 \\
1305 \\
1310\end{array}$ & $\begin{array}{l}1.0 \\
1.0 \\
1.0 \\
1.0 \\
1.0\end{array}$ & $\begin{array}{l}0.00 \\
0.00 \\
0.00 \\
0.00 \\
0.00\end{array}$ \\
\hline $\begin{array}{l}0425 \\
0430 \\
0435 \\
0440 \\
0445\end{array}$ & $\begin{array}{l}1.0 \\
1.0 \\
1.0 \\
1.0 \\
1.0\end{array}$ & $\begin{array}{l}0.00 \\
0.00 \\
0.01 \\
0.00 \\
0.00\end{array}$ & $\begin{array}{l}0850 \\
0855 \\
0900 \\
0905 \\
0910\end{array}$ & $\begin{array}{l}1.0 \\
1.0 \\
1.0 \\
1.0 \\
1.0\end{array}$ & $\begin{array}{l}0.00 \\
0.00 \\
0.00 \\
0.00 \\
0.00\end{array}$ & $\begin{array}{l}1315 \\
1320 \\
1325 \\
1330 \\
1335\end{array}$ & $\begin{array}{l}1.0 \\
1.0 \\
1.0 \\
1.0 \\
1.0\end{array}$ & $\begin{array}{l}0.00 \\
0.00 \\
0.00 \\
0.00 \\
0.00\end{array}$ \\
\hline $\begin{array}{l}0450 \\
0455 \\
0500 \\
0505 \\
0510\end{array}$ & $\begin{array}{l}1.0 \\
1.0 \\
1.0 \\
1.0 \\
1.0\end{array}$ & $\begin{array}{l}0.00 \\
0.00 \\
0.00 \\
0.00 \\
0.00\end{array}$ & $\begin{array}{l}0915 \\
0920 \\
0925 \\
0930 \\
0935\end{array}$ & $\begin{array}{l}1.0 \\
1.0 \\
1.0 \\
1.0 \\
1.0\end{array}$ & $\begin{array}{l}0.00 \\
0.00 \\
0.00 \\
0.00 \\
0.00\end{array}$ & $\begin{array}{l}1340 \\
1345 \\
1350 \\
1355 \\
1400\end{array}$ & $\begin{array}{l}1.0 \\
1.0 \\
1.0 \\
1.0 \\
1.0\end{array}$ & $\begin{array}{l}0.00 \\
0.00 \\
0.00 \\
0.00 \\
0.00\end{array}$ \\
\hline $\begin{array}{l}0515 \\
0520 \\
0525 \\
0530 \\
0535\end{array}$ & $\begin{array}{l}1.0 \\
1.0 \\
1.0 \\
1.0 \\
1.0\end{array}$ & $\begin{array}{l}0.00 \\
0.00 \\
0.00 \\
0.00 \\
0.00\end{array}$ & $\begin{array}{l}0940 \\
0945 \\
0950 \\
0955 \\
1000\end{array}$ & $\begin{array}{l}1.0 \\
1.0 \\
1.0 \\
1.0 \\
1.0\end{array}$ & $\begin{array}{l}0.00 \\
0.00 \\
0.00 \\
0.00 \\
0.00\end{array}$ & $\begin{array}{l}1405 \\
1410 \\
1415 \\
1420 \\
1425\end{array}$ & $\begin{array}{l}1.0 \\
1.0 \\
1.0 \\
1.0 \\
1.0\end{array}$ & $\begin{array}{l}0.00 \\
0.00 \\
0.00 \\
0.00 \\
0.00\end{array}$ \\
\hline $\begin{array}{l}0540 \\
0545 \\
0550 \\
0555 \\
0600\end{array}$ & $\begin{array}{l}1.0 \\
1.0 \\
1.0 \\
1.0 \\
1.0\end{array}$ & $\begin{array}{l}0.00 \\
0.00 \\
0.00 \\
0.00 \\
0.00\end{array}$ & $\begin{array}{l}1005 \\
1010 \\
1015 \\
1020 \\
1025\end{array}$ & $\begin{array}{l}1.0 \\
1.0 \\
1.0 \\
1.0 \\
1.0\end{array}$ & $\begin{array}{l}0.00 \\
0.00 \\
0.00 \\
0.00 \\
0.00\end{array}$ & $\begin{array}{l}1430 \\
1435 \\
1440 \\
1445 \\
1450\end{array}$ & $\begin{array}{l}1.0 \\
1.0 \\
1.0 \\
1.0 \\
1.0\end{array}$ & $\begin{array}{l}0.00 \\
0.00 \\
0.00 \\
0.00 \\
0.11\end{array}$ \\
\hline $\begin{array}{l}0605 \\
0610 \\
0615 \\
0620 \\
0625\end{array}$ & $\begin{array}{l}1.0 \\
1.0 \\
1.0 \\
1.0 \\
1.0\end{array}$ & $\begin{array}{l}0.00 \\
0.00 \\
0.00 \\
0.00 \\
0.00\end{array}$ & $\begin{array}{l}1030 \\
1035 \\
1040 \\
1045 \\
1050\end{array}$ & $\begin{array}{l}1.0 \\
1.0 \\
1.0 \\
1.0 \\
1.0\end{array}$ & $\begin{array}{l}0.00 \\
0.00 \\
0.00 \\
0.00 \\
0.00\end{array}$ & $\begin{array}{l}1455 \\
1500 \\
1505 \\
1510 \\
1515\end{array}$ & $\begin{array}{r}1.0 \\
9.0 \\
77.6 \\
122.0 \\
129.0\end{array}$ & $\begin{array}{l}0.30 \\
0.29 \\
0.17 \\
0.08 \\
0.08\end{array}$ \\
\hline $\begin{array}{l}0630 \\
0635 \\
0640 \\
0645 \\
0650\end{array}$ & $\begin{array}{l}1.0 \\
1.0 \\
1.0 \\
1.0 \\
1.0\end{array}$ & $\begin{array}{l}0.00 \\
0.00 \\
0.00 \\
0.00 \\
0.00\end{array}$ & $\begin{array}{l}1055 \\
1100 \\
1105 \\
1110 \\
1115\end{array}$ & $\begin{array}{l}1.0 \\
1.0 \\
1.0 \\
1.0 \\
1.0\end{array}$ & $\begin{array}{l}0.00 \\
0.00 \\
0.00 \\
0.00 \\
0.00\end{array}$ & $\begin{array}{l}1520 \\
1525 \\
1530 \\
1535 \\
1540\end{array}$ & $\begin{array}{r}145.0 \\
142.0 \\
125.0 \\
86.3 \\
51.6\end{array}$ & $\begin{array}{l}0.03 \\
0.02 \\
0.01 \\
0.01 \\
0.00\end{array}$ \\
\hline $\begin{array}{l}0655 \\
0700 \\
0705 \\
0710 \\
0715\end{array}$ & $\begin{array}{l}1.0 \\
1.0 \\
1.0 \\
1.0 \\
1.0\end{array}$ & $\begin{array}{l}0.00 \\
0.00 \\
0.00 \\
0.00 \\
0.00\end{array}$ & $\begin{array}{l}1120 \\
1125 \\
1130 \\
1135 \\
1140\end{array}$ & $\begin{array}{l}1.0 \\
1.0 \\
1.0 \\
1.0 \\
1.0\end{array}$ & $\begin{array}{l}0.00 \\
0.00 \\
0.00 \\
0.00 \\
0.00\end{array}$ & $\begin{array}{l}1545 \\
1550 \\
1555 \\
1600 \\
1605\end{array}$ & $\begin{array}{l}40.0 \\
33.3 \\
29.5 \\
26.5 \\
20.5\end{array}$ & $\begin{array}{l}0.00 \\
0.00 \\
0.00 \\
0.00 \\
0.00\end{array}$ \\
\hline $\begin{array}{l}0720 \\
0725 \\
0730 \\
0735 \\
0740\end{array}$ & $\begin{array}{l}1.0 \\
1.0 \\
1.0 \\
1.0 \\
1.0\end{array}$ & $\begin{array}{l}0.00 \\
0.00 \\
0.00 \\
0.00 \\
0.00\end{array}$ & $\begin{array}{l}1145 \\
1150 \\
1155 \\
1200 \\
1205\end{array}$ & $\begin{array}{l}1.0 \\
1.0 \\
1.0 \\
1.0 \\
1.0\end{array}$ & $\begin{array}{l}0.00 \\
0.00 \\
0.00 \\
0.00 \\
0.00\end{array}$ & $\begin{array}{l}1610 \\
1615 \\
1620 \\
1625 \\
1630\end{array}$ & $\begin{array}{r}16.5 \\
13.0 \\
9.5 \\
6.8 \\
4.4\end{array}$ & $\begin{array}{l}0.00 \\
0.00 \\
0.00 \\
0.00 \\
0.00\end{array}$ \\
\hline $\begin{array}{l}0745 \\
0750 \\
0755 \\
0800 \\
0805\end{array}$ & $\begin{array}{l}1.0 \\
1.0 \\
1.0 \\
1.0 \\
1.0\end{array}$ & $\begin{array}{l}0.00 \\
0.00 \\
0.00 \\
0.00 \\
0.00\end{array}$ & $\begin{array}{l}1210 \\
1215 \\
1220 \\
1225 \\
1230\end{array}$ & $\begin{array}{l}1.0 \\
1.0 \\
1.0 \\
1.0 \\
1.0\end{array}$ & $\begin{array}{l}0.00 \\
0.00 \\
0.00 \\
0.00 \\
0.00\end{array}$ & $\begin{array}{l}1635 \\
1640 \\
1645 \\
1650 \\
1655\end{array}$ & $\begin{array}{l}1.8 \\
1.0 \\
1.0 \\
1.0 \\
1.0\end{array}$ & $\begin{array}{l}0.00 \\
0.00 \\
0.00 \\
0.00 \\
0.00\end{array}$ \\
\hline $\begin{array}{l}0810 \\
0815 \\
0820\end{array}$ & $\begin{array}{l}1.0 \\
1.0 \\
1.0\end{array}$ & $\begin{array}{l}0.00 \\
0.00 \\
0.00\end{array}$ & $\begin{array}{l}1235 \\
1240 \\
1245\end{array}$ & $\begin{array}{l}1.0 \\
1.0 \\
1.0\end{array}$ & $\begin{array}{l}0.00 \\
0.00 \\
0.00\end{array}$ & 1700 & 1.0 & 0.00 \\
\hline
\end{tabular}




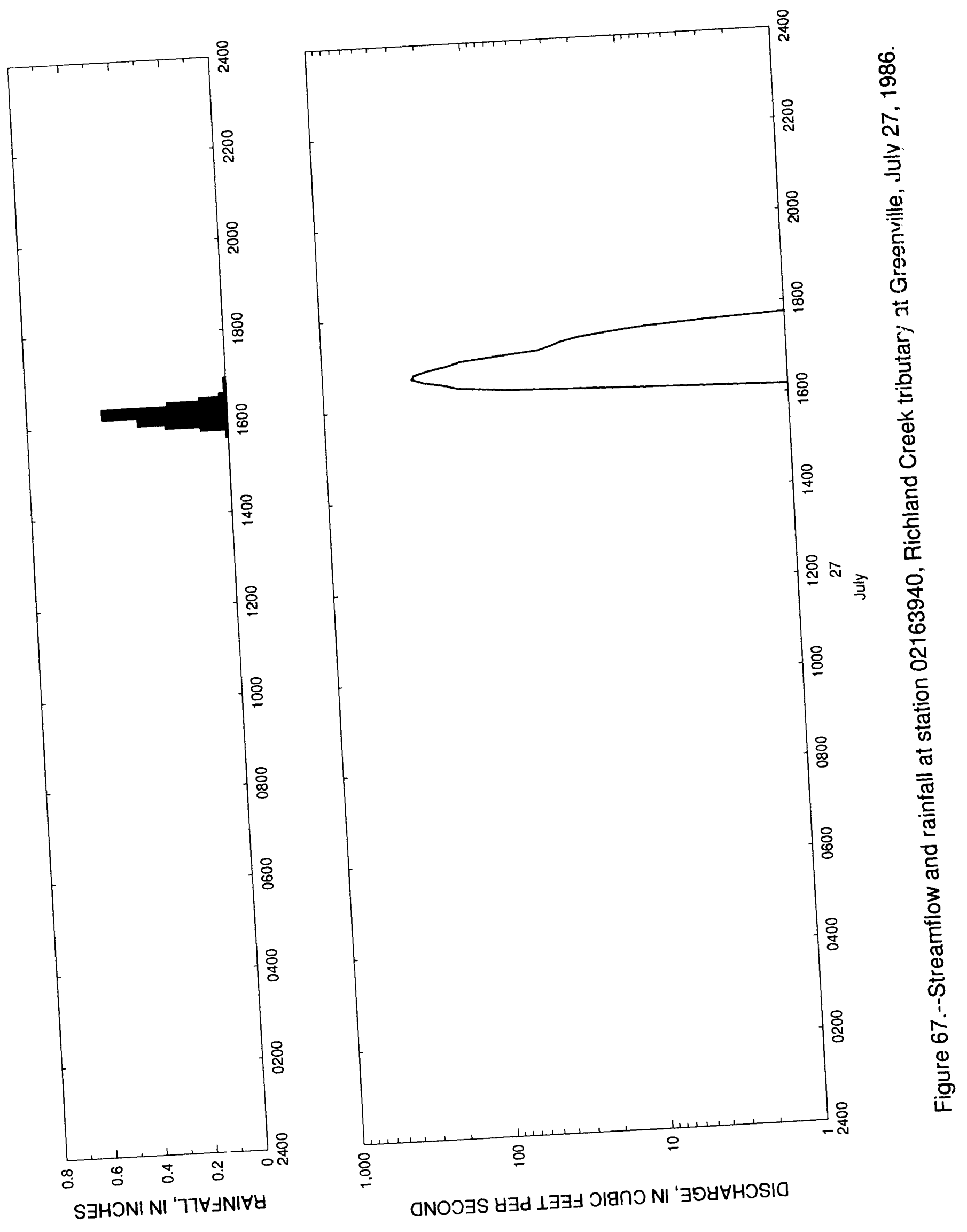


Table 66.--Streamflow and rainfall at station 02163940 , Richland Creek tributary at Greenville, July 27,1986

\begin{tabular}{|c|c|c|c|c|c|c|c|c|}
\hline $\begin{array}{l}\text { Time } \\
\text { (hours) }\end{array}$ & $\begin{array}{l}\text { Streamflow } \\
\text { (cubic feet } \\
\text { per second) }\end{array}$ & $\begin{array}{l}\text { Rain- } \\
\text { fall } \\
\text { (inches) }\end{array}$ & $\begin{array}{l}\text { Time } \\
\text { (hours) }\end{array}$ & $\begin{array}{l}\text { Streamflow } \\
\text { (cubic feet } \\
\text { per second) }\end{array}$ & $\begin{array}{l}\text { Rain- } \\
\text { fall } \\
\text { (inches) }\end{array}$ & $\begin{array}{l}\text { Time } \\
\text { (hours) }\end{array}$ & $\begin{array}{l}\text { Streamflow } \\
\text { (cubic feet } \\
\text { per second) }\end{array}$ & $\begin{array}{l}\text { Rain- } \\
\text { fall } \\
\text { (inches) }\end{array}$ \\
\hline $\begin{array}{l}\text { July } 27, \\
1545 \\
1550 \\
1555 \\
1600\end{array}$ & $\begin{array}{r}1986 \\
1.0 \\
1.0 \\
1.0 \\
1.0\end{array}$ & $\begin{array}{l}0.01 \\
0.00 \\
0.11 \\
0.25\end{array}$ & $\begin{array}{l}1630 \\
1635 \\
1640 \\
1645 \\
1650\end{array}$ & $\begin{array}{l}164.0 \\
224.0 \\
266.0 \\
258.0 \\
211.0\end{array}$ & $\begin{array}{l}0.03 \\
0.01 \\
0.00 \\
0.00 \\
0.01\end{array}$ & $\begin{array}{l}1720 \\
1725 \\
1730 \\
1735 \\
1740\end{array}$ & $\begin{array}{r}28.6 \\
22.0 \\
13.9 \\
8.0 \\
3.3\end{array}$ & $\begin{array}{l}0 . c 0 \\
0 . c 0 \\
0 . c 0 \\
0 . c 0 \\
0.10\end{array}$ \\
\hline $\begin{array}{l}1605 \\
1610 \\
1615 \\
1620 \\
1625\end{array}$ & $\begin{array}{r}1.0 \\
1.0 \\
9.0 \\
64.2 \\
134.0\end{array}$ & $\begin{array}{l}0.36 \\
0.28 \\
0.50 \\
0.24 \\
0.11\end{array}$ & $\begin{array}{l}1655 \\
1700 \\
1705 \\
1710 \\
1715\end{array}$ & $\begin{array}{r}156.0 \\
129.0 \\
74.7 \\
39.6 \\
33.3\end{array}$ & $\begin{array}{l}0.00 \\
0.00 \\
0.00 \\
0.00 \\
0.00\end{array}$ & $\begin{array}{l}1745 \\
1750 \\
1755 \\
1800\end{array}$ & $\begin{array}{l}1.0 \\
1.0 \\
1.0 \\
1.0\end{array}$ & $\begin{array}{l}0 . C 0 \\
0 . C 0 \\
0 . C 0 \\
0 . C 0\end{array}$ \\
\hline
\end{tabular}




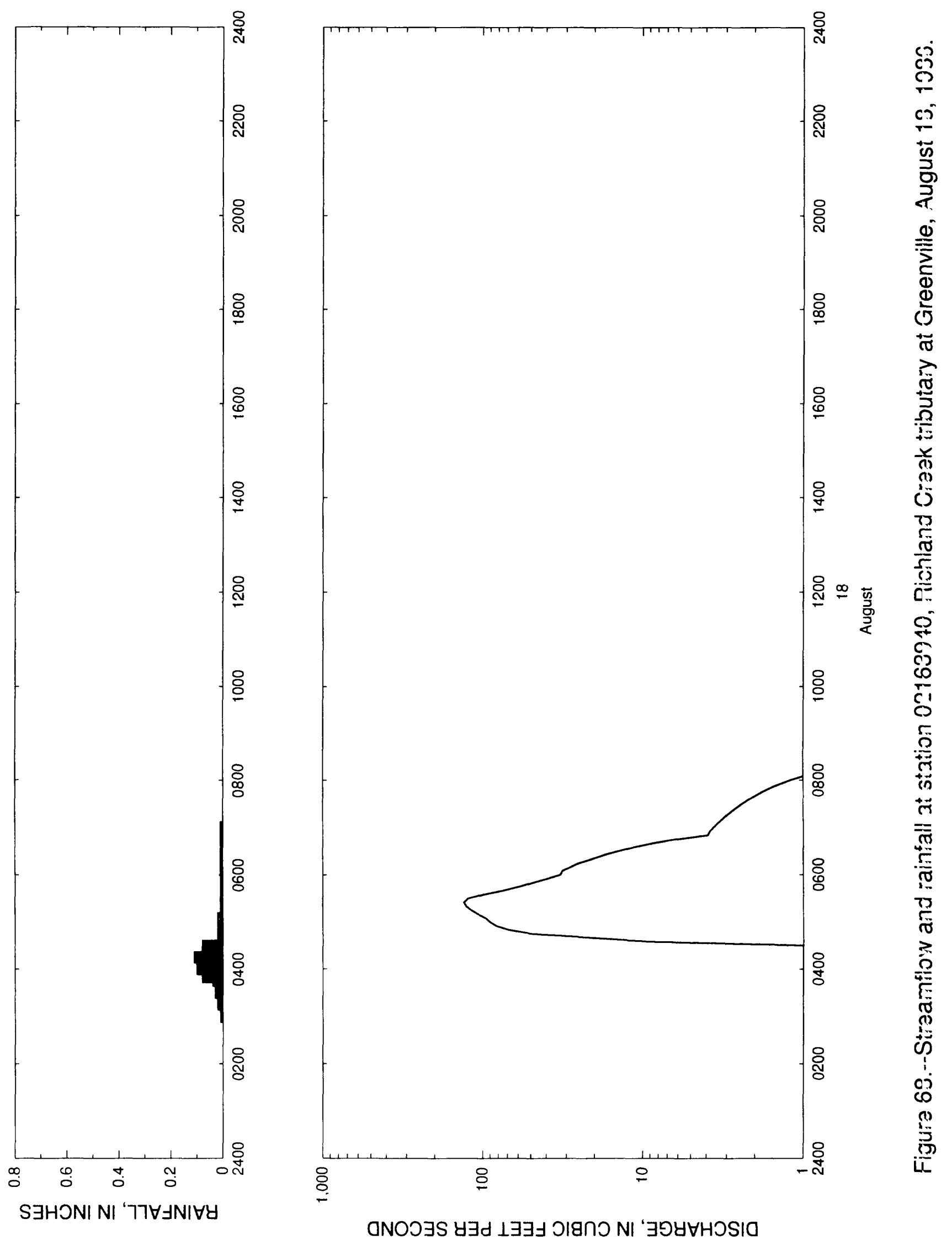


Table 67. - - Streamflow and rainfall at station 02163940, Richland Creek tributary at Greenville, August 18,1986

\begin{tabular}{|c|c|c|c|c|c|c|c|c|}
\hline $\begin{array}{l}\text { Time } \\
\text { (hours) }\end{array}$ & $\begin{array}{l}\text { Streamflow } \\
\text { (cubic feet } \\
\text { per second) }\end{array}$ & $\begin{array}{l}\text { Rain- } \\
\text { fall } \\
\text { (inches) }\end{array}$ & $\begin{array}{l}\text { Time } \\
\text { (hours) }\end{array}$ & $\begin{array}{l}\text { Streamflow } \\
\text { (cubic feet } \\
\text { per second) }\end{array}$ & $\begin{array}{l}\text { Rain- } \\
\text { fall } \\
\text { (inches) }\end{array}$ & $\begin{array}{l}\text { Time } \\
\text { (hours) }\end{array}$ & $\begin{array}{l}\text { Streamflow } \\
\text { (cubic feet } \\
\text { per second) }\end{array}$ & $\begin{array}{l}\text { Rain- } \\
\text { fall } \\
\text { (inches) }\end{array}$ \\
\hline $\begin{array}{c}\text { August } 1 \\
0300 \\
0305 \\
0310 \\
0315\end{array}$ & $\begin{array}{r}18,1986 \\
1.0 \\
1.0 \\
1.0 \\
1.0\end{array}$ & $\begin{array}{l}0.01 \\
0.01 \\
0.01 \\
0.02\end{array}$ & $\begin{array}{l}0500 \\
0505 \\
0510 \\
0515 \\
0520\end{array}$ & $\begin{array}{r}90.0 \\
96.1 \\
107.0 \\
118.0 \\
127.0\end{array}$ & $\begin{array}{l}0.02 \\
0.02 \\
0.01 \\
0.00 \\
0.00\end{array}$ & $\begin{array}{l}0705 \\
0710 \\
0715 \\
0720 \\
0725\end{array}$ & $\begin{array}{l}3.4 \\
3.2 \\
3.0 \\
2.8 \\
2.6\end{array}$ & $\begin{array}{l}0.00 \\
0.00 \\
0.00 \\
0.00 \\
0.00\end{array}$ \\
\hline $\begin{array}{l}0320 \\
0325 \\
0330 \\
0335 \\
0340\end{array}$ & $\begin{array}{l}1.0 \\
1.0 \\
1.0 \\
1.0 \\
1.0\end{array}$ & $\begin{array}{l}0.01 \\
0.02 \\
0.03 \\
0.02 \\
0.03\end{array}$ & $\begin{array}{l}0525 \\
0530 \\
0535 \\
0540 \\
0545\end{array}$ & $\begin{array}{r}131.0 \\
123.0 \\
99.4 \\
73.7 \\
58.3\end{array}$ & $\begin{array}{l}0.01 \\
0.00 \\
0.01 \\
0.01 \\
0.01\end{array}$ & $\begin{array}{l}0730 \\
0735 \\
0740 \\
0745 \\
0750\end{array}$ & $\begin{array}{l}2.4 \\
2.2 \\
2.0 \\
1.8 \\
1.6\end{array}$ & $\begin{array}{l}0.00 \\
0.00 \\
0.00 \\
0.00 \\
0.00\end{array}$ \\
\hline $\begin{array}{l}0345 \\
0350 \\
0355 \\
0400 \\
0405\end{array}$ & $\begin{array}{l}1.0 \\
1.0 \\
1.0 \\
1.0 \\
1.0\end{array}$ & $\begin{array}{l}0.04 \\
0.08 \\
0.08 \\
0.10 \\
0.06\end{array}$ & $\begin{array}{l}0550 \\
0555 \\
0600 \\
0605 \\
0610\end{array}$ & $\begin{array}{l}48.3 \\
39.3 \\
32.6 \\
31.6 \\
27.8\end{array}$ & $\begin{array}{l}0.01 \\
0.01 \\
0.01 \\
0.00 \\
0.01\end{array}$ & $\begin{array}{l}0755 \\
0800 \\
0805 \\
0810 \\
0815\end{array}$ & $\begin{array}{l}1.4 \\
1.2 \\
1.0 \\
1.0 \\
1.0\end{array}$ & $\begin{array}{l}0.00 \\
0.00 \\
0.00 \\
0.00 \\
0.00\end{array}$ \\
\hline $\begin{array}{l}0410 \\
0415 \\
0420 \\
0425 \\
0430\end{array}$ & $\begin{array}{l}1.0 \\
1.0 \\
1.0 \\
1.0 \\
1.0\end{array}$ & $\begin{array}{l}0.03 \\
0.11 \\
0.03 \\
0.03 \\
0.08\end{array}$ & $\begin{array}{l}0615 \\
0620 \\
0625 \\
0630 \\
0635\end{array}$ & $\begin{array}{l}24.8 \\
20.5 \\
17.3 \\
13.9 \\
11.2\end{array}$ & $\begin{array}{l}0.00 \\
0.01 \\
0.01 \\
0.00 \\
0.01\end{array}$ & $\begin{array}{l}0820 \\
0825 \\
0830 \\
0835 \\
0840\end{array}$ & $\begin{array}{l}1.0 \\
1.0 \\
1.0 \\
1.0 \\
1.0\end{array}$ & $\begin{array}{l}0.00 \\
0.00 \\
0.00 \\
0.00 \\
0.00\end{array}$ \\
\hline $\begin{array}{l}0435 \\
0440 \\
0445 \\
0450 \\
0455\end{array}$ & $\begin{array}{r}9.0 \\
21.2 \\
49.2 \\
69.0 \\
82.1\end{array}$ & $\begin{array}{l}0.02 \\
0.01 \\
0.02 \\
0.02 \\
0.02\end{array}$ & $\begin{array}{l}0640 \\
0645 \\
0650 \\
0655 \\
0700\end{array}$ & $\begin{array}{l}8.6 \\
6.1 \\
3.9 \\
3.8 \\
3.6\end{array}$ & $\begin{array}{l}0.00 \\
0.01 \\
0.00 \\
0.00 \\
0.01\end{array}$ & $\begin{array}{l}0845 \\
0850 \\
0855 \\
0900\end{array}$ & $\begin{array}{l}1.0 \\
1.0 \\
1.0 \\
1.0\end{array}$ & $\begin{array}{l}0.00 \\
0.00 \\
0.00 \\
0.00\end{array}$ \\
\hline
\end{tabular}




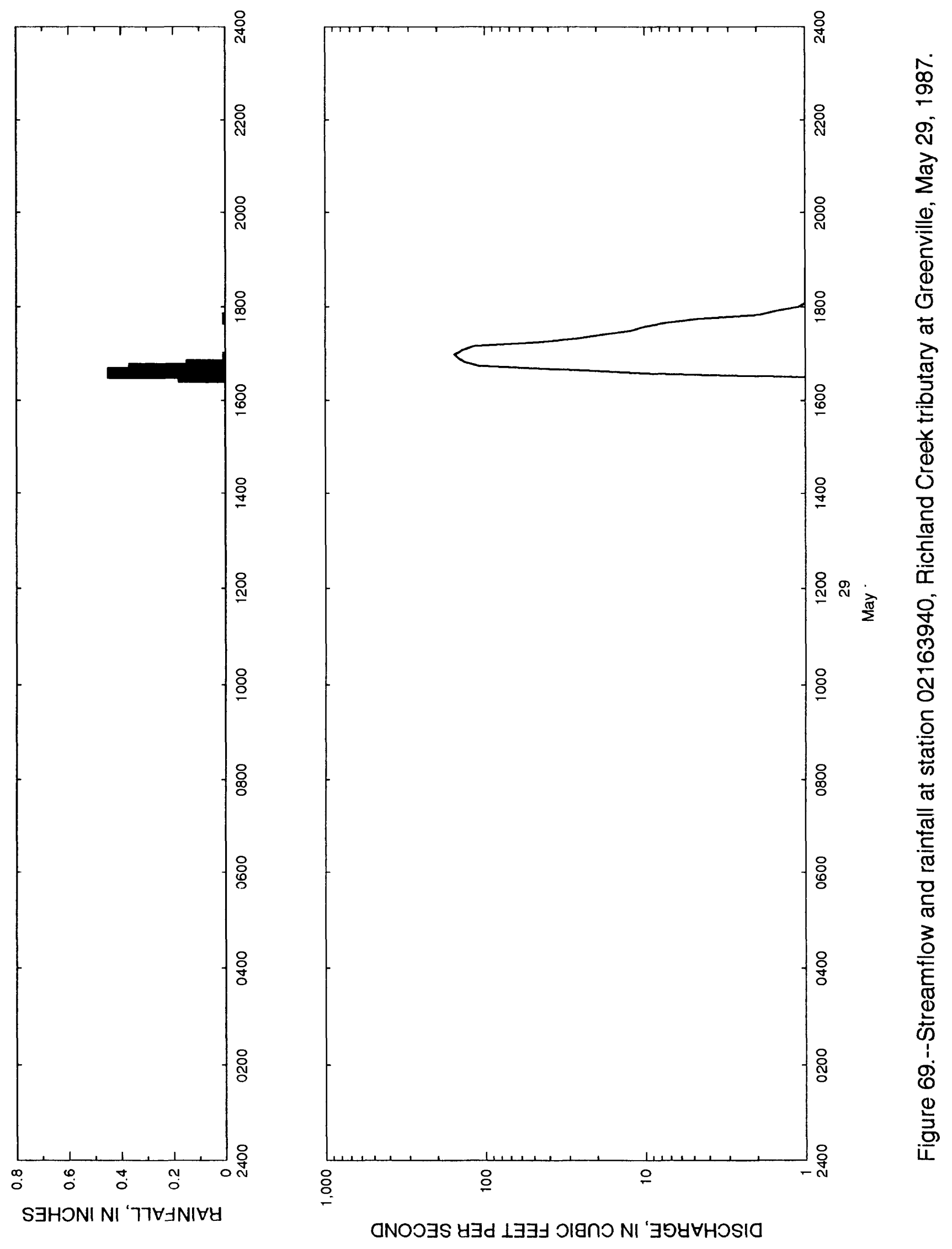


Table 68. - Streamflow and rainfall at station 02163940, Richland Creek tributary at Greenville, May 29,1987

\begin{tabular}{|c|c|c|c|c|c|c|c|c|}
\hline $\begin{array}{l}\text { Time } \\
\text { (hours) }\end{array}$ & $\begin{array}{l}\text { Streamflow } \\
\text { (cubic feet } \\
\text { per second) }\end{array}$ & $\begin{array}{l}\text { Rain- } \\
\text { fall } \\
\text { (inches) }\end{array}$ & $\begin{array}{l}\text { Time } \\
\text { (hours) }\end{array}$ & $\begin{array}{l}\text { Streamflow } \\
\text { (cubic feet } \\
\text { per second) }\end{array}$ & $\begin{array}{l}\text { Rain- } \\
\text { fall } \\
\text { (inches) }\end{array}$ & $\begin{array}{l}\text { Time } \\
\text { (hours) }\end{array}$ & $\begin{array}{l}\text { Streamflow } \\
\text { (cubic feet } \\
\text { per second) }\end{array}$ & $\begin{array}{l}\text { Rain- } \\
\text { fall } \\
\text { (inches) }\end{array}$ \\
\hline $\begin{array}{l}\text { May 29, } \\
1630 \\
1635 \\
1640 \\
1645\end{array}$ & $\begin{array}{r}1987 \quad 1.0 \\
9.0 \\
32.0 \\
110.0\end{array}$ & $\begin{array}{l}0.18 \\
0.45 \\
0.37 \\
0.15\end{array}$ & $\begin{array}{l}1720 \\
1725 \\
1730 \\
1735 \\
1740\end{array}$ & $\begin{array}{r}26.0 \\
17.7 \\
12.1 \\
10.0 \\
7.3\end{array}$ & $\begin{array}{l}0.00 \\
0.00 \\
0.00 \\
0.00 \\
0.00\end{array}$ & $\begin{array}{l}1815 \\
1820 \\
1825 \\
1830 \\
1835\end{array}$ & $\begin{array}{l}1.0 \\
1.0 \\
1.0 \\
1.0 \\
1.0\end{array}$ & $\begin{array}{l}0.00 \\
0.00 \\
0.00 \\
0.00 \\
0.00\end{array}$ \\
\hline $\begin{array}{l}1650 \\
1655 \\
1700 \\
1705 \\
1710\end{array}$ & $\begin{array}{l}136.0 \\
148.0 \\
156.0 \\
140.0 \\
116.0\end{array}$ & $\begin{array}{l}0.01 \\
0.01 \\
0.00 \\
0.00 \\
0.00\end{array}$ & $\begin{array}{l}1745 \\
1750 \\
1755 \\
1800 \\
1805\end{array}$ & $\begin{array}{l}4.7 \\
1.9 \\
1.5 \\
1.1 \\
1.0\end{array}$ & $\begin{array}{l}0.01 \\
0.00 \\
0.00 \\
0.00 \\
0.00\end{array}$ & $\begin{array}{l}1840 \\
1845 \\
1850 \\
1855 \\
1900\end{array}$ & $\begin{array}{l}1.0 \\
1.0 \\
1.0 \\
1.0 \\
1.0\end{array}$ & $\begin{array}{l}0.10 \\
0 . C 0 \\
0 . C 0 \\
0.10 \\
0.10\end{array}$ \\
\hline 1715 & 47.5 & 0.00 & 1810 & 1.0 & 0.00 & & & \\
\hline
\end{tabular}




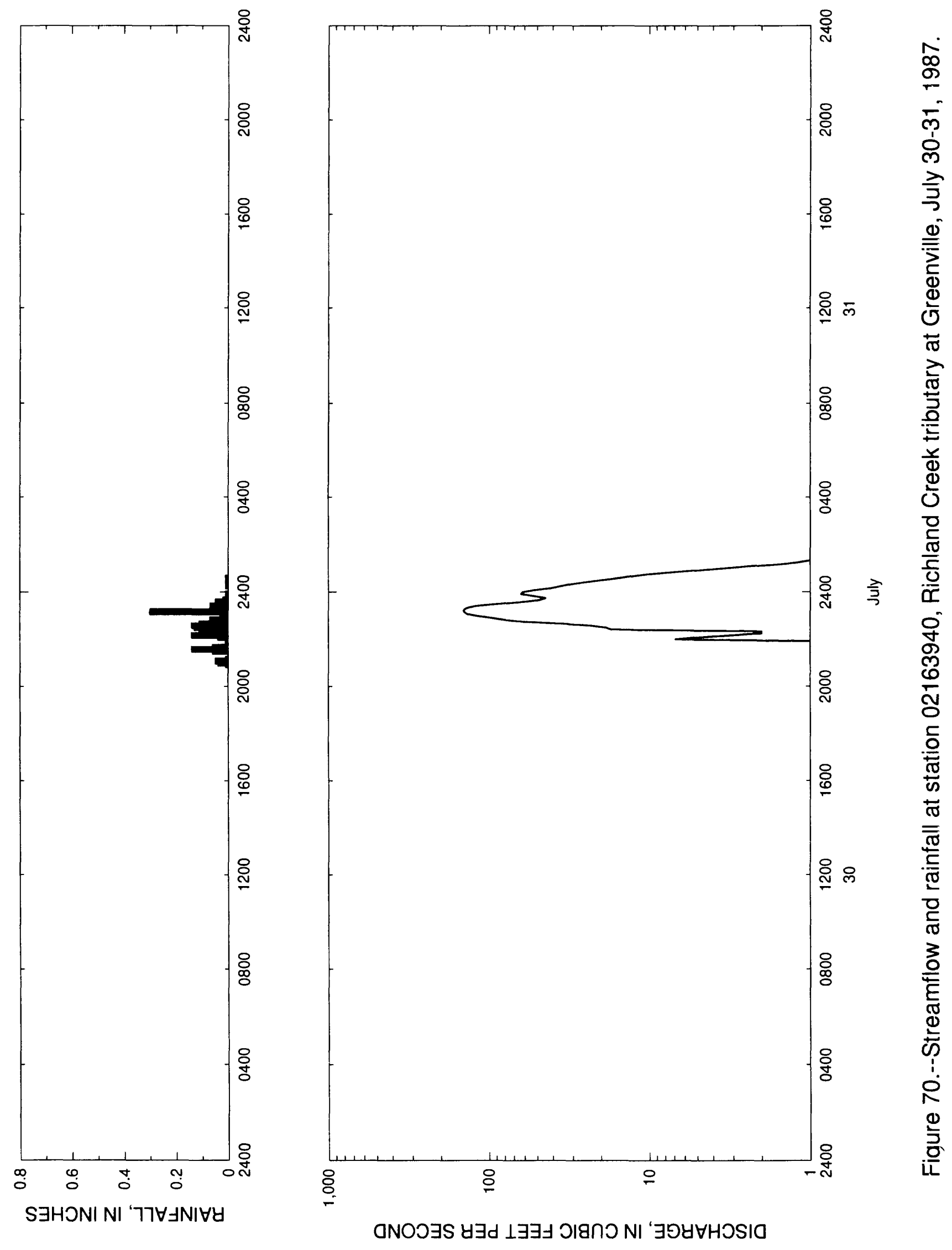


Table 69.--Streamflow and rainfall at station 02163940, Richland Creek tributary at Greenville, July $30-31,1987$

\begin{tabular}{|c|c|c|c|c|c|c|c|c|}
\hline $\begin{array}{l}\text { Time } \\
\text { (hours) }\end{array}$ & $\begin{array}{l}\text { Streamflow } \\
\text { (cubic feet } \\
\text { per second) }\end{array}$ & $\begin{array}{l}\text { Rain- } \\
\text { fall } \\
\text { (inches) }\end{array}$ & $\begin{array}{l}\text { Time } \\
\text { (hours) }\end{array}$ & $\begin{array}{l}\text { Streamflow } \\
\text { (cubic feet } \\
\text { per second) }\end{array}$ & $\begin{array}{l}\text { Rain- } \\
\text { fall } \\
\text { (inches) }\end{array}$ & $\begin{array}{l}\text { Time } \\
\text { (hours) }\end{array}$ & $\begin{array}{l}\text { Streamflow } \\
\text { (cubic feet } \\
\text { per second) }\end{array}$ & $\begin{array}{l}\text { Rain- } \\
\text { fall } \\
\text { (inches) }\end{array}$ \\
\hline $\begin{array}{l}\text { July } 30 \\
2055 \\
2100 \\
2105 \\
2110\end{array}$ & $\begin{array}{r}1987 \\
1.0 \\
1.0 \\
1.0 \\
1.0\end{array}$ & $\begin{array}{l}0.01 \\
0.04 \\
0.05 \\
0.01\end{array}$ & $\begin{array}{l}2240 \\
2245 \\
2250 \\
2255 \\
2300\end{array}$ & $\begin{array}{r}35.0 \\
60.9 \\
81.0 \\
96.1 \\
119.0\end{array}$ & $\begin{array}{l}0.11 \\
0.06 \\
0.07 \\
0.03 \\
0.00\end{array}$ & $\begin{array}{l}0025 \\
0030 \\
0035 \\
0040 \\
0045\end{array}$ & $\begin{array}{l}25.2 \\
20.1 \\
15.8 \\
13.0 \\
10.4\end{array}$ & $\begin{array}{l}0.01 \\
0.07 \\
0.01 \\
0.07 \\
0.07\end{array}$ \\
\hline $\begin{array}{l}2115 \\
2120 \\
2125 \\
2130 \\
2135\end{array}$ & $\begin{array}{l}1.0 \\
1.0 \\
1.0 \\
1.0 \\
1.0\end{array}$ & $\begin{array}{l}0.00 \\
0.00 \\
0.00 \\
0.06 \\
0.14\end{array}$ & $\begin{array}{l}2305 \\
2310 \\
2315 \\
2320 \\
2325\end{array}$ & $\begin{array}{l}137.0 \\
142.0 \\
144.0 \\
138.0 \\
121.0\end{array}$ & $\begin{array}{l}0.00 \\
0.30 \\
0.04 \\
0.05 \\
0.07\end{array}$ & $\begin{array}{l}0050 \\
0055 \\
0100 \\
0 \div 05 \\
0110\end{array}$ & $\begin{array}{l}7.3 \\
5.1 \\
3.5 \\
2.5 \\
1.6\end{array}$ & $\begin{array}{l}0.00 \\
0.07 \\
0.07 \\
0.00 \\
0.07\end{array}$ \\
\hline $\begin{array}{l}2140 \\
2145 \\
2150 \\
2155 \\
2200\end{array}$ & $\begin{array}{l}1.0 \\
1.0 \\
1.0 \\
1.0 \\
7.0\end{array}$ & $\begin{array}{l}0.06 \\
0.01 \\
0.00 \\
0.00 \\
0.01\end{array}$ & $\begin{array}{l}2330 \\
2335 \\
2340 \\
2345 \\
2350\end{array}$ & $\begin{array}{l}87.9 \\
63.3 \\
48.7 \\
44.3 \\
52.4\end{array}$ & $\begin{array}{l}0.05 \\
0.05 \\
0.02 \\
0.01 \\
0.00\end{array}$ & $\begin{array}{l}0115 \\
0120 \\
0125 \\
0130 \\
0135\end{array}$ & $\begin{array}{l}1.2 \\
1.0 \\
1.0 \\
1.0 \\
1.0\end{array}$ & $\begin{array}{l}0.00 \\
0.07 \\
0.07 \\
0.00 \\
0.07\end{array}$ \\
\hline $\begin{array}{l}2205 \\
2210 \\
2215 \\
2220 \\
2225\end{array}$ & $\begin{array}{r}5.0 \\
3.0 \\
2.0 \\
2.0 \\
17.3\end{array}$ & $\begin{array}{l}0.04 \\
0.14 \\
0.07 \\
0.07 \\
0.11\end{array}$ & $\begin{array}{l}2355 \\
\text { July } 31 \\
0000 \\
0005 \\
0010\end{array}$ & $\begin{array}{r}1987 \\
63.3 \\
61.4 \\
52.0 \\
40.8\end{array}$ & $\begin{array}{l}0.01 \\
0.00 \\
0.00 \\
0.00\end{array}$ & $\begin{array}{l}0140 \\
0145 \\
0150 \\
0155 \\
0200\end{array}$ & $\begin{array}{l}1.0 \\
1.0 \\
1.0 \\
1.0 \\
1.0\end{array}$ & $\begin{array}{l}0.00 \\
0.00 \\
0.07 \\
0.01 \\
0.07\end{array}$ \\
\hline $\begin{array}{l}2230 \\
2235\end{array}$ & $\begin{array}{l}18.6 \\
23.2\end{array}$ & $\begin{array}{l}0.13 \\
0.14\end{array}$ & $\begin{array}{l}0015 \\
0020\end{array}$ & $\begin{array}{l}35.7 \\
30.7\end{array}$ & $\begin{array}{l}0.01 \\
0.00\end{array}$ & & & \\
\hline
\end{tabular}




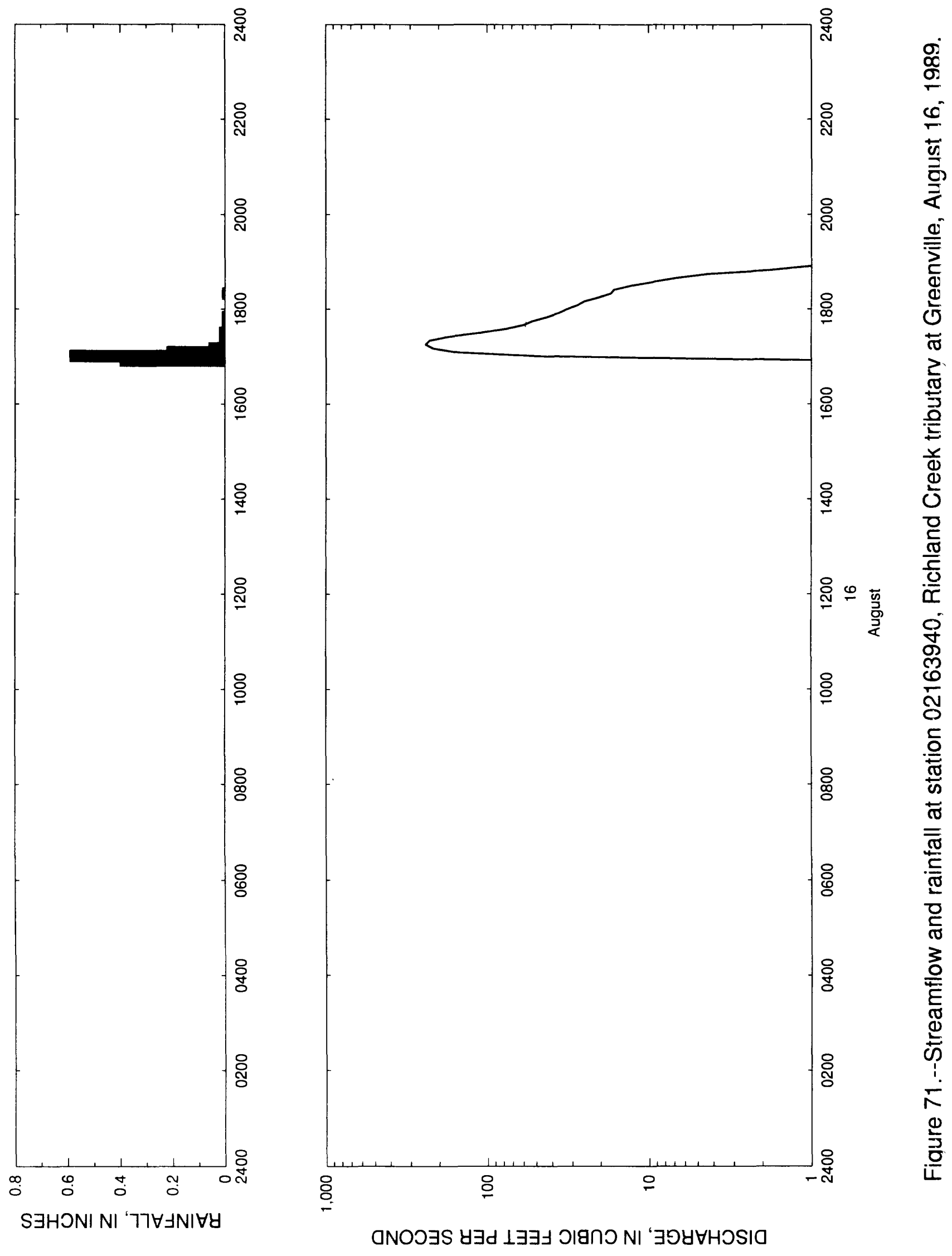


Table 70.--Streamflow and rainfall at station 02163940, Richland Creek tributary at Greenville, August 16, 1989

\begin{tabular}{|c|c|c|c|c|c|c|c|c|}
\hline $\begin{array}{l}\text { Time } \\
\text { (hours) }\end{array}$ & $\begin{array}{l}\text { Streamflow } \\
\text { (cubic feet } \\
\text { per second) }\end{array}$ & $\begin{array}{l}\text { Rain- } \\
\text { fall } \\
\text { (inches) }\end{array}$ & $\begin{array}{l}\text { Time } \\
\text { (hours) }\end{array}$ & $\begin{array}{l}\text { Streamflow } \\
\text { (cubic feet } \\
\text { per second) }\end{array}$ & $\begin{array}{l}\text { Rain- } \\
\text { fall } \\
\text { (inches) }\end{array}$ & $\begin{array}{l}\text { Time } \\
\text { (hours) }\end{array}$ & $\begin{array}{l}\text { Streamflow } \\
\text { (cubic feet } \\
\text { per second) }\end{array}$ & $\begin{array}{l}\text { Rain- } \\
\text { fall } \\
\text { (inches) }\end{array}$ \\
\hline $\begin{array}{c}\text { August } \\
1655 \\
1700 \\
1705 \\
1710\end{array}$ & 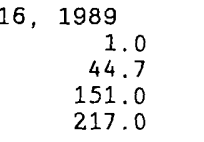 & $\begin{array}{l}0.40 \\
0.59 \\
0.22 \\
0.06\end{array}$ & $\begin{array}{l}1735 \\
1740 \\
1745 \\
1750 \\
1755\end{array}$ & $\begin{array}{l}77.1 \\
60.0 \\
52.8 \\
43.1 \\
36.4\end{array}$ & $\begin{array}{l}0.01 \\
0.00 \\
0.00 \\
0.01 \\
0.00\end{array}$ & $\begin{array}{l}1820 \\
1825 \\
1830 \\
1835 \\
1840\end{array}$ & $\begin{array}{r}17.3 \\
16.5 \\
13.0 \\
9.5 \\
6.8\end{array}$ & $\begin{array}{l}0.01 \\
0.0 C \\
0.0 C \\
0.0 C \\
0.0 C\end{array}$ \\
\hline $\begin{array}{l}1715 \\
1720 \\
1725 \\
1730\end{array}$ & $\begin{array}{l}242.0 \\
228.0 \\
175.0 \\
112.0\end{array}$ & $\begin{array}{l}0.02 \\
0.01 \\
0.02 \\
0.02\end{array}$ & $\begin{array}{l}1800 \\
1805 \\
1810 \\
1815\end{array}$ & $\begin{array}{l}32.3 \\
27.8 \\
25.2 \\
20.5\end{array}$ & $\begin{array}{l}0.00 \\
0.00 \\
0.00 \\
0.00\end{array}$ & $\begin{array}{l}1845 \\
1850 \\
1855 \\
1900\end{array}$ & $\begin{array}{l}4.4 \\
1.8 \\
1.0 \\
1.0\end{array}$ & $\begin{array}{l}0.06 \\
0.00 \\
0.00 \\
0.00\end{array}$ \\
\hline
\end{tabular}


Station 02164011, Brushy Creek (Reedy River Tributary) at Greenville, S.C.

Location.--Lat $34^{\circ} 49^{\prime} 25^{\prime \prime}$, long $82^{\circ} 24^{\prime} 26^{\prime \prime}$, Greenville County, Hydrologic Unit 03050109, at culvert on Grove Road (State secondary road 20), $1.7 \mathrm{mi}$ south of Greenville City Hall, and 3.9 mi upstream from the mouth at Reedy River.

Period of record.-- August 18, 1983 to October 18, 1989.

Gage.--Digital stage recorder with 5-minute punch interval. The recorder is housed in a metal shelter atop a stilling well attached to the right downstream wingwall of a double $8 \mathrm{ft}$ by $10 \mathrm{ft}$ concrete box culvert. One crest-stage indicator is located approximately $24 \mathrm{ft}$ upstream from the upstream end of the culvert and is attached to an extension of the left wingwall just downstream from a sewage pipe. A second crest-stage indicator is located on the left downstream wingwall.

Rating.--The stage-streamflow relation is defined by current meter measurements up to $23.4 \mathrm{ft}^{3} / \mathrm{s}$. The stage-streamflow relation was extended to $1,500 \mathrm{ft}^{3} / \mathrm{s}$ using indirect computational methods.

Rain gage and location.-Station 344949082250600 , lat $34^{\circ} 49^{\prime} 49^{\prime \prime}$, long $82^{\circ} 25^{\prime} 06^{\prime \prime}$. A shelter containing a digital cumulative rainfall recorder with a 5-minute punch interval at the Allen Street (State secondary road 5) crossing of Brushy Creek, and 0.7 mi southeast of St. Francis Hospital.

Selected basin characteristics.--

Drainage area -- $3.02 \mathrm{mi}^{2}$

Physiographic province - Piedmont

Channel slope -- $48.7 \mathrm{ft} / \mathrm{mi}$

Channel length -- $3.01 \mathrm{mi}$

Total impervious area --34.0 percent

Basin development factor -- 6

2-year, 2-hour rainfall amount -- 2.15 in.

\begin{tabular}{|c|c|c|}
\hline Flood frequency data: & $\mathrm{UQ}_{2}$ & $1,050 \mathrm{ft}^{3} / \mathrm{s}$ \\
\hline & $\mathrm{UQ}_{5}$ & $1,700 \mathrm{ft}^{3} / \mathrm{s}$ \\
\hline & $\mathrm{UQ}_{10}$ & $2,170 \mathrm{ft}^{3} / \mathrm{s}$ \\
\hline & $\mathrm{UQ}_{25}$ & $2,820 \mathrm{ft}^{3} / \mathrm{s}$ \\
\hline & $\mathrm{UQ}_{50}$ & $3,330 \mathrm{ft}^{3} / \mathrm{s}$ \\
\hline & $\mathrm{UQ}_{100}$ & $3,860 \mathrm{ft}^{3} / \mathrm{s}$ \\
\hline & $\mathrm{UQ}_{500}$ & $5,210 \mathrm{ft}^{3} / \mathrm{s}$ \\
\hline
\end{tabular}




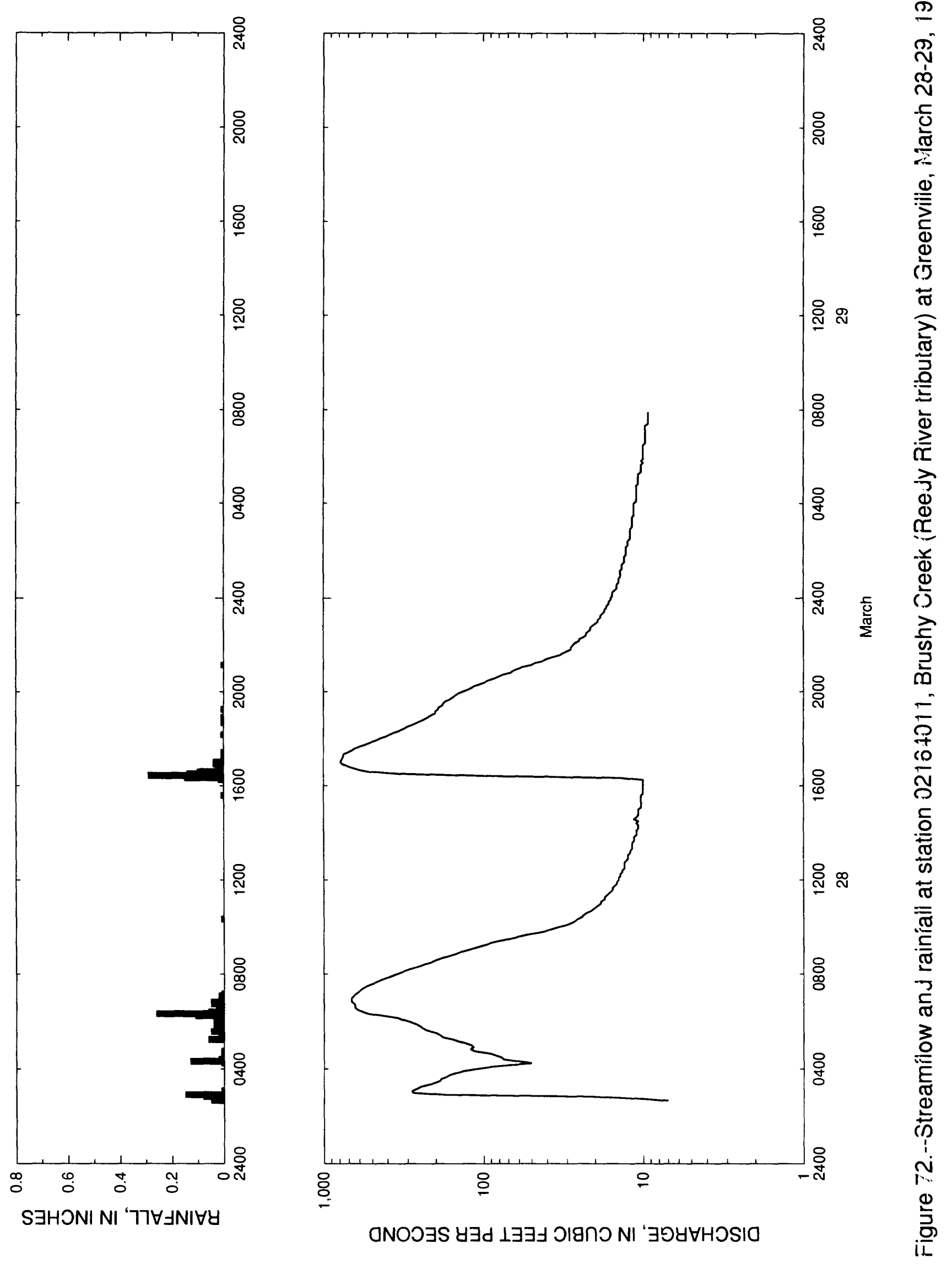


Table 71.--Streanflow and rainfall at station 02164011, Brushy Creek (Reedy River tributary) at Greenvi11e, March 28-29, 1984

\begin{tabular}{|c|c|c|c|c|c|c|c|c|}
\hline $\begin{array}{l}\text { Time } \\
\text { (hours) }\end{array}$ & $\begin{array}{l}\text { Streamflow } \\
\text { (cubic feet } \\
\text { per second) }\end{array}$ & $\begin{array}{l}\text { Rain- } \\
\text { fall } \\
\text { (inches) }\end{array}$ & $\begin{array}{l}\text { Time } \\
\text { (hours) }\end{array}$ & $\begin{array}{l}\text { Streamflow } \\
\text { (cubic feet } \\
\text { per second) }\end{array}$ & $\begin{array}{l}\text { Rain- } \\
\text { fall } \\
\text { (inches) }\end{array}$ & $\begin{array}{l}\text { Time } \\
\text { (hours) }\end{array}$ & $\begin{array}{l}\text { Streamflow } \\
\text { (cubic feet } \\
\text { per second) }\end{array}$ & $\begin{array}{l}\text { Rair- } \\
\text { fall } \\
\text { (incles) }\end{array}$ \\
\hline $\begin{array}{l}\text { March 28, } \\
0240 \\
0245 \\
0250 \\
0255\end{array}$ & $\begin{array}{r}1984 \\
7.0 \\
10.7 \\
21.2 \\
177.0\end{array}$ & $\begin{array}{l}0.05 \\
0.03 \\
0.08 \\
0.15\end{array}$ & $\begin{array}{l}0800 \\
0805 \\
0810 \\
0815 \\
0820\end{array}$ & $\begin{array}{l}351.0 \\
324.0 \\
300.0 \\
276.0 \\
252.0\end{array}$ & $\begin{array}{l}0.00 \\
0.00 \\
0.00 \\
0.00 \\
0.00\end{array}$ & $\begin{array}{l}1325 \\
1330 \\
1335 \\
1340 \\
1345\end{array}$ & $\begin{array}{l}11.7 \\
11.7 \\
11.7 \\
11.4 \\
11.4\end{array}$ & $\begin{array}{l}0.0 C \\
0.0 C \\
0.0 C \\
0.0 C \\
0.0 C\end{array}$ \\
\hline $\begin{array}{l}0300 \\
0305 \\
0310 \\
0315 \\
0320\end{array}$ & $\begin{array}{l}280.0 \\
283.0 \\
265.0 \\
250.0 \\
224.0\end{array}$ & $\begin{array}{l}0.01 \\
0.01 \\
0.00 \\
0.00 \\
0.00\end{array}$ & $\begin{array}{l}0825 \\
0830 \\
0835 \\
0840 \\
0845\end{array}$ & $\begin{array}{l}235.0 \\
213.0 \\
200.0 \\
184.0 \\
167.0\end{array}$ & $\begin{array}{l}0.00 \\
0.00 \\
0.00 \\
0.00 \\
0.00\end{array}$ & $\begin{array}{l}1350 \\
1355 \\
1400 \\
1405 \\
1410\end{array}$ & $\begin{array}{l}11.4 \\
11.0 \\
11.0 \\
11.0 \\
10.7\end{array}$ & $\begin{array}{l}0.0 C \\
0.0 C \\
0.0 C \\
0.0 C \\
0.0 C\end{array}$ \\
\hline $\begin{array}{l}0325 \\
0330 \\
0335 \\
0340 \\
0345\end{array}$ & $\begin{array}{l}202.0 \\
188.0 \\
186.0 \\
172.0 \\
165.0\end{array}$ & $\begin{array}{l}0.00 \\
0.00 \\
0.00 \\
0.00 \\
0.00\end{array}$ & $\begin{array}{l}0850 \\
0855 \\
0900 \\
0905 \\
0910\end{array}$ & $\begin{array}{l}154.0 \\
142.0 \\
128.0 \\
116.0 \\
105.0\end{array}$ & $\begin{array}{l}0.00 \\
0.00 \\
0.00 \\
0.00 \\
0.00\end{array}$ & $\begin{array}{l}1415 \\
1420 \\
1425 \\
1430 \\
1435\end{array}$ & $\begin{array}{l}10.7 \\
10.7 \\
11.0 \\
10.7 \\
11.4\end{array}$ & $\begin{array}{l}0.00 \\
0.00 \\
0.00 \\
0.00 \\
0.00\end{array}$ \\
\hline $\begin{array}{l}0350 \\
0355 \\
0400 \\
0405 \\
0410\end{array}$ & $\begin{array}{r}151.0 \\
133.0 \\
112.0 \\
92.5 \\
70.0\end{array}$ & $\begin{array}{l}0.00 \\
0.00 \\
0.00 \\
0.00 \\
0.00\end{array}$ & $\begin{array}{l}0915 \\
0920 \\
0925 \\
0930 \\
0935\end{array}$ & $\begin{array}{l}95.0 \\
87.5 \\
77.5 \\
67.5 \\
60.0\end{array}$ & $\begin{array}{l}0.00 \\
0.00 \\
0.00 \\
0.00 \\
0.00\end{array}$ & $\begin{array}{l}1440 \\
1445 \\
1450 \\
1455 \\
1500\end{array}$ & $\begin{array}{l}11.0 \\
10.7 \\
10.7 \\
10.7 \\
10.7\end{array}$ & $\begin{array}{l}0.00 \\
0.00 \\
0.00 \\
0.00 \\
0.00\end{array}$ \\
\hline $\begin{array}{l}0415 \\
0420 \\
0425 \\
0430 \\
0435\end{array}$ & $\begin{array}{l}50.0 \\
60.0 \\
75.0 \\
77.5 \\
85.0\end{array}$ & $\begin{array}{l}0.01 \\
0.13 \\
0.02 \\
0.00 \\
0.01\end{array}$ & $\begin{array}{l}0940 \\
0945 \\
0950 \\
0955 \\
1000\end{array}$ & $\begin{array}{l}53.3 \\
45.0 \\
40.0 \\
36.7 \\
33.3\end{array}$ & $\begin{array}{l}0.00 \\
0.00 \\
0.00 \\
0.00 \\
0.00\end{array}$ & $\begin{array}{l}1505 \\
1510 \\
1515 \\
1520 \\
1525\end{array}$ & $\begin{array}{l}10.3 \\
10.3 \\
10.3 \\
10.3 \\
10.3\end{array}$ & $\begin{array}{l}0.00 \\
0.00 \\
0.00 \\
0.00 \\
0.00\end{array}$ \\
\hline $\begin{array}{l}0440 \\
0445 \\
0450 \\
0455 \\
0500\end{array}$ & $\begin{array}{r}92.5 \\
114.0 \\
121.0 \\
116.0 \\
119.0\end{array}$ & $\begin{array}{l}0.00 \\
0.01 \\
0.00 \\
0.00 \\
0.00\end{array}$ & $\begin{array}{l}1005 \\
1010 \\
1015 \\
1020 \\
1025\end{array}$ & $\begin{array}{l}30.0 \\
28.2 \\
26.6 \\
25.8 \\
24.2\end{array}$ & $\begin{array}{l}0.00 \\
0.00 \\
0.00 \\
0.01 \\
0.00\end{array}$ & $\begin{array}{l}1530 \\
1535 \\
1540 \\
1545 \\
1550\end{array}$ & $\begin{array}{l}10.3 \\
10.3 \\
10.0 \\
10.0 \\
10.0\end{array}$ & $\begin{array}{l}0.00 \\
0.01 \\
0.00 \\
0.00 \\
0.00\end{array}$ \\
\hline $\begin{array}{l}0505 \\
0510 \\
0515 \\
0520 \\
0525\end{array}$ & $\begin{array}{l}130.0 \\
144.0 \\
158.0 \\
181.0 \\
188.0\end{array}$ & $\begin{array}{l}0.00 \\
0.00 \\
0.06 \\
0.02 \\
0.02\end{array}$ & $\begin{array}{l}1030 \\
1035 \\
1040 \\
1045 \\
1050\end{array}$ & $\begin{array}{l}23.5 \\
22.7 \\
21.2 \\
20.5 \\
19.8\end{array}$ & $\begin{array}{l}0.00 \\
0.00 \\
0.00 \\
0.00 \\
0.00\end{array}$ & $\begin{array}{l}1555 \\
1600 \\
1605 \\
1610 \\
1615\end{array}$ & $\begin{array}{l}10.0 \\
10.0 \\
10.0 \\
10.0 \\
10.0\end{array}$ & $\begin{array}{l}0.00 \\
0.00 \\
0.00 \\
0.00 \\
0.02\end{array}$ \\
\hline $\begin{array}{l}0530 \\
0535 \\
0540 \\
0545 \\
0550\end{array}$ & $\begin{array}{l}198.0 \\
215.0 \\
233.0 \\
244.0 \\
254.0\end{array}$ & $\begin{array}{l}0.02 \\
0.05 \\
0.01 \\
0.02 \\
0.04\end{array}$ & $\begin{array}{l}1055 \\
1100 \\
1105 \\
1110 \\
1115\end{array}$ & $\begin{array}{l}19.1 \\
18.4 \\
18.4 \\
17.4 \\
17.4\end{array}$ & $\begin{array}{l}0.00 \\
0.00 \\
0.00 \\
0.00 \\
0.00\end{array}$ & $\begin{array}{l}1620 \\
1625 \\
1630 \\
1635 \\
1640\end{array}$ & $\begin{array}{r}13.9 \\
95.0 \\
331.0 \\
517.0 \\
600.0\end{array}$ & $\begin{array}{l}0.15 \\
0.29 \\
0.14 \\
0.10 \\
0.03\end{array}$ \\
\hline $\begin{array}{l}0555 \\
0600 \\
0605 \\
0610 \\
0615\end{array}$ & $\begin{array}{l}270.0 \\
294.0 \\
324.0 \\
349.0 \\
433.0\end{array}$ & $\begin{array}{l}0.04 \\
0.04 \\
0.04 \\
0.03 \\
0.11\end{array}$ & $\begin{array}{l}1120 \\
1125 \\
1130 \\
1135 \\
1140\end{array}$ & $\begin{array}{l}16.9 \\
16.4 \\
15.9 \\
15.5 \\
15.5\end{array}$ & $\begin{array}{l}0.00 \\
0.00 \\
0.00 \\
0.00 \\
0.00\end{array}$ & $\begin{array}{l}1645 \\
1650 \\
1655 \\
1700 \\
1705\end{array}$ & $\begin{array}{l}665.0 \\
718.0 \\
762.0 \\
784.0 \\
776.0\end{array}$ & $\begin{array}{l}0.01 \\
0.01 \\
0.04 \\
0.04 \\
0.01\end{array}$ \\
\hline $\begin{array}{l}0620 \\
0625 \\
0630 \\
0635 \\
0640\end{array}$ & $\begin{array}{l}527.0 \\
575.0 \\
617.0 \\
638.0 \\
640.0\end{array}$ & $\begin{array}{l}0.26 \\
0.06 \\
0.03 \\
0.03 \\
0.01\end{array}$ & $\begin{array}{l}1145 \\
1150 \\
1155 \\
1200 \\
1205\end{array}$ & $\begin{array}{l}15.0 \\
14.6 \\
14.6 \\
14.2 \\
14.2\end{array}$ & $\begin{array}{l}0.00 \\
0.00 \\
0.00 \\
0.00 \\
0.00\end{array}$ & $\begin{array}{l}1710 \\
1715 \\
1720 \\
1725 \\
1730\end{array}$ & $\begin{array}{l}764.0 \\
753.0 \\
753.0 \\
702.0 \\
665.0\end{array}$ & $\begin{array}{l}0.01 \\
0.00 \\
0.00 \\
0.01 \\
0.00\end{array}$ \\
\hline $\begin{array}{l}0645 \\
0650 \\
0655 \\
0700 \\
0705\end{array}$ & $\begin{array}{l}646.0 \\
669.0 \\
675.0 \\
669.0 \\
652.0\end{array}$ & $\begin{array}{l}0.05 \\
0.05 \\
0.01 \\
0.01 \\
0.02\end{array}$ & $\begin{array}{l}1210 \\
1215 \\
1220 \\
1225 \\
1230\end{array}$ & $\begin{array}{l}13.9 \\
13.9 \\
13.5 \\
13.5 \\
13.1\end{array}$ & $\begin{array}{l}0.00 \\
0.00 \\
0.00 \\
0.00 \\
0.00\end{array}$ & $\begin{array}{l}1735 \\
1740 \\
1745 \\
1750 \\
1755\end{array}$ & $\begin{array}{l}635.0 \\
594.0 \\
548.0 \\
512.0 \\
471.0\end{array}$ & $\begin{array}{l}0.00 \\
0.00 \\
0.00 \\
0.00 \\
0.00\end{array}$ \\
\hline $\begin{array}{l}0710 \\
0715 \\
0720 \\
0725 \\
0730\end{array}$ & $\begin{array}{l}631.0 \\
608.0 \\
590.0 \\
567.0 \\
540.0\end{array}$ & $\begin{array}{l}0.01 \\
0.00 \\
0.00 \\
0.00 \\
0.00\end{array}$ & $\begin{array}{l}1235 \\
1240 \\
1245 \\
1250 \\
1255\end{array}$ & $\begin{array}{l}13.1 \\
13.1 \\
13.1 \\
12.8 \\
12.4\end{array}$ & $\begin{array}{l}0.00 \\
0.00 \\
0.00 \\
0.00 \\
0.00\end{array}$ & $\begin{array}{l}1800 \\
1805 \\
1810 \\
1815 \\
1820\end{array}$ & $\begin{array}{l}445.0 \\
410.0 \\
388.0 \\
365.0 \\
337.0\end{array}$ & $\begin{array}{l}0.00 \\
0.00 \\
0.01 \\
0.00 \\
0.00\end{array}$ \\
\hline $\begin{array}{l}0735 \\
0740 \\
0745 \\
0750 \\
0755\end{array}$ & $\begin{array}{l}504.0 \\
469.0 \\
441.0 \\
410.0 \\
378.0\end{array}$ & $\begin{array}{l}0.00 \\
0.00 \\
0.00 \\
0.00 \\
0.00\end{array}$ & $\begin{array}{l}1300 \\
1305 \\
1310 \\
1315 \\
1320\end{array}$ & $\begin{array}{l}12.4 \\
12.4 \\
12.0 \\
12.0 \\
11.7\end{array}$ & $\begin{array}{l}0.00 \\
0.00 \\
0.00 \\
0.00 \\
0.00\end{array}$ & $\begin{array}{l}1825 \\
1830 \\
1835 \\
1840 \\
1845\end{array}$ & $\begin{array}{l}314.0 \\
300.0 \\
278.0 \\
263.0 \\
248.0\end{array}$ & $\begin{array}{l}0.00 \\
0.00 \\
0.00 \\
0.01 \\
0.01\end{array}$ \\
\hline
\end{tabular}


Table 71.--Streamflow and rainfall at station 02164011 , Brushy Creek (Reedy River tributary) at Greenville, March $28-29,1984^{--C o n t i n u e d}$

\begin{tabular}{|c|c|c|c|c|c|c|c|c|}
\hline $\begin{array}{l}\text { Time } \\
\text { (hours) }\end{array}$ & $\begin{array}{l}\text { Streamflow } \\
\text { (cubic feet } \\
\text { per second) }\end{array}$ & $\begin{array}{l}\text { Rain- } \\
\text { fal1 } \\
\text { (inches) }\end{array}$ & $\begin{array}{l}\text { Time } \\
\text { (hours) }\end{array}$ & $\begin{array}{l}\text { Streamflow } \\
\text { (cubic feet } \\
\text { per second) }\end{array}$ & $\begin{array}{l}\text { Rain- } \\
\text { fall } \\
\text { (inches) }\end{array}$ & $\begin{array}{l}\text { Time } \\
\text { (hours) }\end{array}$ & $\begin{array}{l}\text { Streamflow } \\
\text { (cubic feet } \\
\text { per second) }\end{array}$ & $\begin{array}{l}\text { Rain- } \\
\text { fall } \\
\text { (inches) }\end{array}$ \\
\hline $\begin{array}{l}1850 \\
1855 \\
1900 \\
1905 \\
1910\end{array}$ & $\begin{array}{l}235.0 \\
224.0 \\
211.0 \\
200.0 \\
200.0\end{array}$ & $\begin{array}{l}0.01 \\
0.01 \\
0.00 \\
0.00 \\
0.00\end{array}$ & $\begin{array}{l}2320 \\
2325 \\
2330 \\
2335 \\
2340\end{array}$ & $\begin{array}{l}17.9 \\
17.4 \\
17.4 \\
16.9 \\
16.9\end{array}$ & $\begin{array}{l}0.00 \\
0.00 \\
0.00 \\
0.00 \\
0.00\end{array}$ & $\begin{array}{l}0345 \\
0350 \\
0355 \\
0400 \\
0405\end{array}$ & $\begin{array}{l}11.4 \\
11.4 \\
11.4 \\
11.4 \\
11.0\end{array}$ & $\begin{array}{l}0.00 \\
0.00 \\
0.00 \\
0.00 \\
0.00\end{array}$ \\
\hline $\begin{array}{l}1915 \\
1920 \\
1925 \\
1930 \\
1935\end{array}$ & $\begin{array}{l}193.0 \\
191.0 \\
181.0 \\
179.0 \\
174.0\end{array}$ & $\begin{array}{l}0.01 \\
0.00 \\
0.00 \\
0.00 \\
0.00\end{array}$ & $\begin{array}{r}2345 \\
2350 \\
2355 \\
\text { March 29, } \\
0000\end{array}$ & $\begin{array}{r}16.4 \\
16.4 \\
15.9 \\
1984 \\
15.9\end{array}$ & $\begin{array}{l}0.00 \\
0.00 \\
0.00 \\
0.00\end{array}$ & $\begin{array}{l}0410 \\
0415 \\
0420 \\
0425 \\
0430\end{array}$ & $\begin{array}{l}11.0 \\
11.0 \\
11.0 \\
11.0 \\
11.0\end{array}$ & $\begin{array}{l}0.00 \\
0.00 \\
0.00 \\
0.00 \\
0.00\end{array}$ \\
\hline $\begin{array}{l}1940 \\
1945 \\
1950 \\
1955 \\
2000\end{array}$ & $\begin{array}{l}165.0 \\
158.0 \\
151.0 \\
144.0 \\
135.0\end{array}$ & $\begin{array}{l}0.00 \\
0.00 \\
0.00 \\
0.00 \\
0.00\end{array}$ & $\begin{array}{l}0005 \\
0010 \\
0015 \\
0020 \\
0025\end{array}$ & $\begin{array}{l}15.5 \\
15.5 \\
15.5 \\
15.0 \\
14.6\end{array}$ & $\begin{array}{l}0.00 \\
0.00 \\
0.00 \\
0.00 \\
0.00\end{array}$ & $\begin{array}{l}0435 \\
0440 \\
0445 \\
0450 \\
0455\end{array}$ & $\begin{array}{l}11.0 \\
11.0 \\
11.0 \\
10.7 \\
10.7\end{array}$ & $\begin{array}{l}0.00 \\
C .00 \\
0.00 \\
0.00 \\
0.00\end{array}$ \\
\hline $\begin{array}{l}2005 \\
2010 \\
2015 \\
2020 \\
2025\end{array}$ & $\begin{array}{r}126.0 \\
119.0 \\
114.0 \\
105.0 \\
97.5\end{array}$ & $\begin{array}{l}0.00 \\
0.00 \\
0.00 \\
0.00 \\
0.00\end{array}$ & $\begin{array}{l}0030 \\
0035 \\
0040 \\
0045 \\
0050\end{array}$ & $\begin{array}{l}14.6 \\
14.6 \\
14.2 \\
14.2 \\
14.2\end{array}$ & $\begin{array}{l}0.00 \\
0.00 \\
0.00 \\
0.00 \\
0.00\end{array}$ & $\begin{array}{l}0500 \\
0505 \\
0510 \\
0515 \\
0520\end{array}$ & $\begin{array}{l}10.7 \\
10.7 \\
10.7 \\
10.7 \\
10.3\end{array}$ & $\begin{array}{l}0.00 \\
0.00 \\
0.00 \\
0.00 \\
0.00\end{array}$ \\
\hline $\begin{array}{l}2030 \\
2035 \\
2040 \\
2045 \\
2050\end{array}$ & $\begin{array}{l}92.5 \\
85.0 \\
80.0 \\
75.0 \\
67.5\end{array}$ & $\begin{array}{l}0.00 \\
0.00 \\
0.00 \\
0.00 \\
0.00\end{array}$ & $\begin{array}{l}0055 \\
0100 \\
0105 \\
0110 \\
0115\end{array}$ & $\begin{array}{l}13.9 \\
13.9 \\
13.9 \\
13.9 \\
13.5\end{array}$ & $\begin{array}{l}0.00 \\
0.00 \\
0.00 \\
0.00 \\
0.00\end{array}$ & $\begin{array}{l}0525 \\
0530 \\
0535 \\
0540 \\
0545\end{array}$ & $\begin{array}{l}10.3 \\
10.3 \\
10.3 \\
10.3 \\
10.0\end{array}$ & $\begin{array}{l}0.00 \\
0.00 \\
0.00 \\
0.00 \\
0.00\end{array}$ \\
\hline $\begin{array}{l}2055 \\
2100 \\
2105 \\
2110 \\
2115\end{array}$ & $\begin{array}{l}65.0 \\
60.0 \\
56.7 \\
50.0 \\
47.5\end{array}$ & $\begin{array}{l}0.00 \\
0.00 \\
0.00 \\
0.01 \\
0.00\end{array}$ & $\begin{array}{l}0120 \\
0125 \\
0130 \\
0135 \\
0140\end{array}$ & $\begin{array}{l}13.5 \\
13.5 \\
13.1 \\
13.1 \\
13.1\end{array}$ & $\begin{array}{l}0.00 \\
0.00 \\
0.00 \\
0.00 \\
0.00\end{array}$ & $\begin{array}{l}0550 \\
0555 \\
0600 \\
0605 \\
0610\end{array}$ & $\begin{array}{l}10.3 \\
10.0 \\
10.0 \\
10.0 \\
10.0\end{array}$ & $\begin{array}{l}0.00 \\
0.00 \\
0.00 \\
0.00 \\
0.00\end{array}$ \\
\hline $\begin{array}{l}2120 \\
2125 \\
2130 \\
2135 \\
2140\end{array}$ & $\begin{array}{l}42.5 \\
40.0 \\
36.7 \\
33.3 \\
31.7\end{array}$ & $\begin{array}{l}0.00 \\
0.00 \\
0.00 \\
0.00 \\
0.00\end{array}$ & $\begin{array}{l}0145 \\
0150 \\
0155 \\
0200 \\
0205\end{array}$ & $\begin{array}{l}13.1 \\
12.8 \\
12.8 \\
12.8 \\
12.8\end{array}$ & $\begin{array}{l}0.00 \\
0.00 \\
0.00 \\
0.00 \\
0.00\end{array}$ & $\begin{array}{l}0615 \\
0620 \\
0625 \\
0630 \\
0635\end{array}$ & $\begin{array}{r}10.0 \\
10.0 \\
10.0 \\
10.0 \\
9.7\end{array}$ & $\begin{array}{l}0.00 \\
0.00 \\
0.00 \\
0.00 \\
0.00\end{array}$ \\
\hline $\begin{array}{l}2145 \\
2150 \\
2155 \\
2200 \\
2205\end{array}$ & $\begin{array}{l}30.0 \\
28.2 \\
28.2 \\
27.4 \\
26.6\end{array}$ & $\begin{array}{l}0.00 \\
0.00 \\
0.00 \\
0.00 \\
0.00\end{array}$ & $\begin{array}{l}0210 \\
0215 \\
0220 \\
0225 \\
0230\end{array}$ & $\begin{array}{l}12.8 \\
12.4 \\
12.4 \\
12.4 \\
12.0\end{array}$ & $\begin{array}{l}0.00 \\
0.00 \\
0.00 \\
0.00 \\
0.00\end{array}$ & $\begin{array}{l}0640 \\
0645 \\
0650 \\
0655 \\
0700\end{array}$ & $\begin{array}{l}9.7 \\
9.7 \\
9.7 \\
9.7 \\
9.7\end{array}$ & $\begin{array}{l}0.00 \\
0.00 \\
0.00 \\
0.00 \\
0.00\end{array}$ \\
\hline $\begin{array}{l}2210 \\
2215 \\
2220 \\
2225 \\
2230\end{array}$ & $\begin{array}{l}25.0 \\
25.0 \\
23.5 \\
22.7 \\
22.7\end{array}$ & $\begin{array}{l}0.00 \\
0.00 \\
0.00 \\
0.00 \\
0.00\end{array}$ & $\begin{array}{l}0235 \\
0240 \\
0245 \\
0250 \\
0255\end{array}$ & $\begin{array}{l}12.0 \\
12.0 \\
12.0 \\
12.0 \\
12.0\end{array}$ & $\begin{array}{l}0.00 \\
0.00 \\
0.00 \\
0.00 \\
0.00\end{array}$ & $\begin{array}{l}0705 \\
0710 \\
0715 \\
0720 \\
0725\end{array}$ & $\begin{array}{l}9.7 \\
9.7 \\
9.7 \\
9.7 \\
9.3\end{array}$ & $\begin{array}{l}0.00 \\
0.00 \\
0.00 \\
0.00 \\
0.00\end{array}$ \\
\hline $\begin{array}{l}2235 \\
2240 \\
2245 \\
2250 \\
2255\end{array}$ & $\begin{array}{l}21.9 \\
21.2 \\
21.2 \\
20.5 \\
19.8\end{array}$ & $\begin{array}{l}0.00 \\
0.00 \\
0.00 \\
0.00 \\
0.00\end{array}$ & $\begin{array}{l}0300 \\
0305 \\
0310 \\
0315 \\
0320\end{array}$ & $\begin{array}{l}11.7 \\
11.7 \\
11.7 \\
11.7 \\
11.7\end{array}$ & $\begin{array}{l}0.00 \\
0.00 \\
0.00 \\
0.00 \\
0.00\end{array}$ & $\begin{array}{l}0730 \\
0735 \\
0740 \\
0745 \\
0750\end{array}$ & $\begin{array}{l}9.3 \\
9.3 \\
9.3 \\
9.3 \\
9.3\end{array}$ & $\begin{array}{l}0.00 \\
0.00 \\
0.00 \\
0.00 \\
0.00\end{array}$ \\
\hline $\begin{array}{l}2300 \\
2305 \\
2310 \\
2315\end{array}$ & $\begin{array}{l}19.1 \\
19.1 \\
18.4 \\
18.4\end{array}$ & $\begin{array}{l}0.00 \\
0.00 \\
0.00 \\
0.00\end{array}$ & $\begin{array}{l}0325 \\
0330 \\
0335 \\
0340\end{array}$ & $\begin{array}{l}11.7 \\
11.4 \\
11.4 \\
11.4\end{array}$ & $\begin{array}{l}0.00 \\
0.00 \\
0.00 \\
0.00\end{array}$ & $\begin{array}{l}0755 \\
0800\end{array}$ & $\begin{array}{l}9.3 \\
9.3\end{array}$ & $\begin{array}{l}0.00 \\
0.00\end{array}$ \\
\hline
\end{tabular}



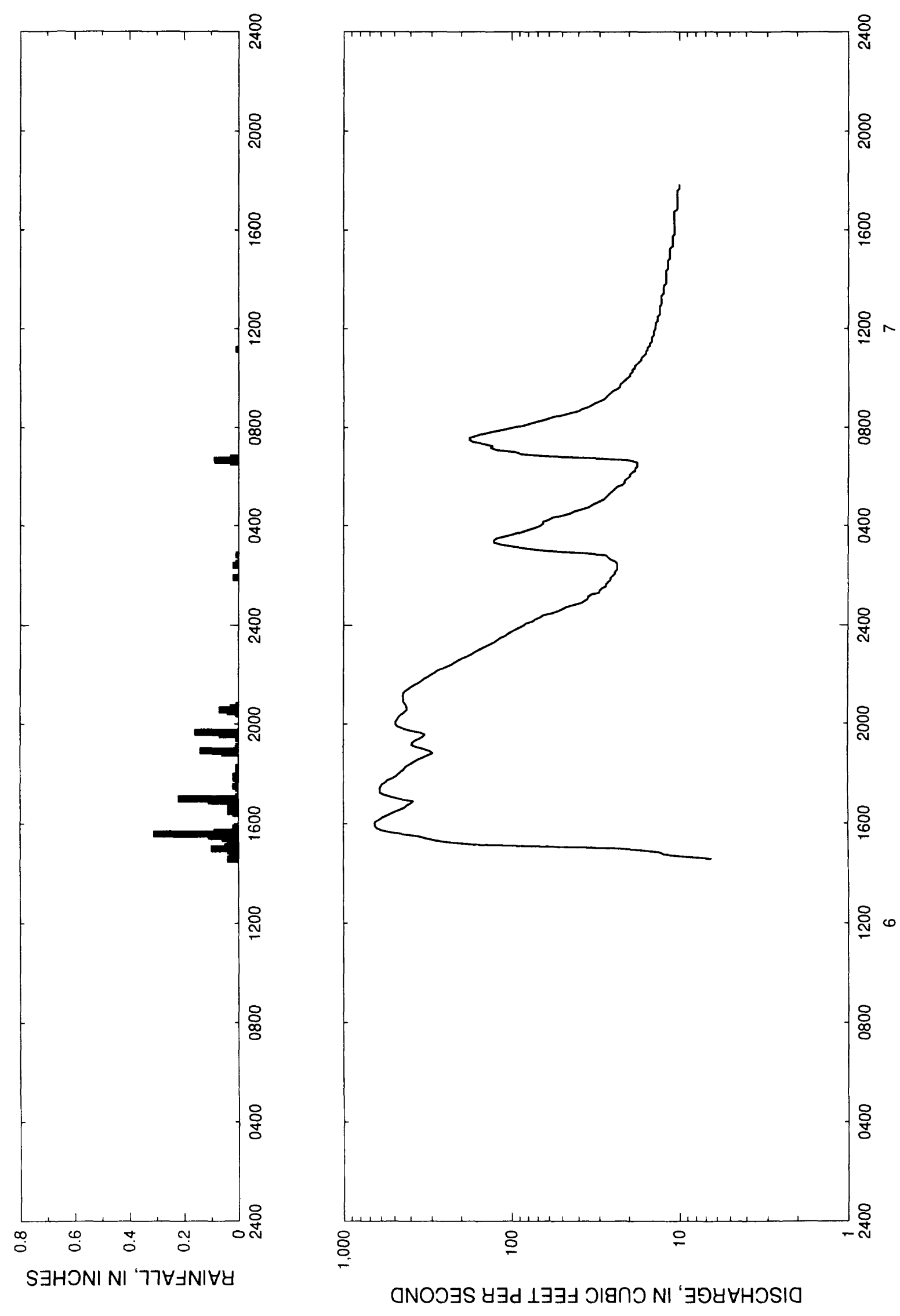

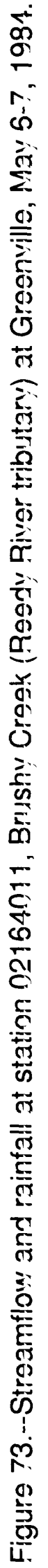


Table 72. - Streamflow and rainfall at station 02164011 , Brushy Creek (Peedy River tributary) at Greenvil1e, May $6-\overline{7,1984}$

\begin{tabular}{|c|c|c|c|c|c|c|c|c|}
\hline $\begin{array}{l}\text { Time } \\
\text { (hours) }\end{array}$ & $\begin{array}{l}\text { Streamflow } \\
\text { (cubic feet } \\
\text { per second) }\end{array}$ & $\begin{array}{l}\text { Rain- } \\
\text { fall } \\
\text { (inches) }\end{array}$ & $\begin{array}{l}\text { Time } \\
\text { (hours) }\end{array}$ & $\begin{array}{l}\text { Streamflow } \\
\text { (cubic feet } \\
\text { per second) }\end{array}$ & $\begin{array}{l}\text { Rain- } \\
\text { fall } \\
\text { (inches) }\end{array}$ & $\begin{array}{l}\text { Time } \\
\text { (hours) }\end{array}$ & $\begin{array}{l}\text { Streamflow } \\
\text { (cubic feet } \\
\text { per second) }\end{array}$ & $\begin{array}{l}\text { Rain- } \\
\text { fall } \\
\text { (inchos) }\end{array}$ \\
\hline $\begin{array}{c}\text { May 6, } 1 \\
1435 \\
1440 \\
1445 \\
1450\end{array}$ & $\begin{array}{r}1984 \quad 6.4 \\
9.3 \\
12.4 \\
13.1\end{array}$ & $\begin{array}{l}0.04 \\
0.03 \\
0.01 \\
0.00\end{array}$ & $\begin{array}{l}1955 \\
2000 \\
2005 \\
2010 \\
2015\end{array}$ & $\begin{array}{l}480.0 \\
490.0 \\
490.0 \\
482.0 \\
474.0\end{array}$ & $\begin{array}{l}0.00 \\
0.00 \\
0.00 \\
0.00 \\
0.00\end{array}$ & $\begin{array}{l}0115 \\
0120 \\
0125 \\
0130 \\
0135\end{array}$ & $\begin{array}{l}33.3 \\
30.0 \\
30.0 \\
29.1 \\
27.4\end{array}$ & $\begin{array}{l}0.00 \\
0.00 \\
0.00 \\
0.00 \\
0.00\end{array}$ \\
\hline $\begin{array}{l}1455 \\
1500 \\
1505 \\
1510 \\
1515\end{array}$ & $\begin{array}{r}16.9 \\
24.2 \\
72.5 \\
170.0 \\
226.0\end{array}$ & $\begin{array}{l}0.04 \\
0.10 \\
0.05 \\
0.03 \\
0.04\end{array}$ & $\begin{array}{l}2020 \\
2025 \\
2030 \\
2035 \\
2040\end{array}$ & $\begin{array}{l}463.0 \\
447.0 \\
433.0 \\
420.0 \\
420.0\end{array}$ & $\begin{array}{l}0.00 \\
0.01 \\
0.04 \\
0.07 \\
0.03\end{array}$ & $\begin{array}{l}0140 \\
0145 \\
0150 \\
0155 \\
0200\end{array}$ & $\begin{array}{l}27.4 \\
26.6 \\
25.8 \\
25.8 \\
25.0\end{array}$ & $\begin{array}{l}0.00 \\
0.00 \\
0.00 \\
0.02 \\
0.00\end{array}$ \\
\hline $\begin{array}{l}1520 \\
1525 \\
1530 \\
1535 \\
1540\end{array}$ & $\begin{array}{l}283.0 \\
324.0 \\
359.0 \\
439.0 \\
527.0\end{array}$ & $\begin{array}{l}0.01 \\
0.06 \\
0.11 \\
0.31 \\
0.09\end{array}$ & $\begin{array}{l}2045 \\
2050 \\
2055 \\
2100 \\
2105\end{array}$ & $\begin{array}{l}426.0 \\
433.0 \\
443.0 \\
441.0 \\
443.0\end{array}$ & $\begin{array}{l}0.01 \\
0.00 \\
0.00 \\
0.00 \\
0.00\end{array}$ & $\begin{array}{l}0205 \\
0210 \\
0215 \\
0220 \\
0225\end{array}$ & $\begin{array}{l}24.2 \\
24.2 \\
23.5 \\
23.5 \\
23.5\end{array}$ & $\begin{array}{l}0.00 \\
0.00 \\
0.00 \\
0.00 \\
0.02\end{array}$ \\
\hline $\begin{array}{l}1545 \\
1550 \\
1555 \\
1600 \\
1605\end{array}$ & $\begin{array}{l}594.0 \\
633.0 \\
648.0 \\
650.0 \\
648.0\end{array}$ & $\begin{array}{l}0.02 \\
0.02 \\
0.00 \\
0.00 \\
0.00\end{array}$ & $\begin{array}{l}2110 \\
2115 \\
2120 \\
2125 \\
2130\end{array}$ & $\begin{array}{l}443.0 \\
441.0 \\
431.0 \\
414.0 \\
398.0\end{array}$ & $\begin{array}{l}0.00 \\
0.00 \\
0.00 \\
0.00 \\
0.00\end{array}$ & $\begin{array}{l}0230 \\
0235 \\
0240 \\
0245 \\
0250\end{array}$ & $\begin{array}{l}23.5 \\
24.2 \\
25.8 \\
26.6 \\
27.4\end{array}$ & $\begin{array}{l}0.01 \\
0.00 \\
0.00 \\
0.00 \\
0.01\end{array}$ \\
\hline $\begin{array}{l}1610 \\
1615 \\
1620 \\
1625 \\
1630\end{array}$ & $\begin{array}{l}615.0 \\
590.0 \\
554.0 \\
521.0 \\
490.0\end{array}$ & $\begin{array}{l}0.00 \\
0.00 \\
0.00 \\
0.02 \\
0.04\end{array}$ & $\begin{array}{l}2135 \\
2140 \\
2145 \\
2150 \\
2155\end{array}$ & $\begin{array}{l}380.0 \\
359.0 \\
345.0 \\
333.0 \\
316.0\end{array}$ & $\begin{array}{l}0.00 \\
0.00 \\
0.00 \\
0.00 \\
0.00\end{array}$ & $\begin{array}{l}0255 \\
0300 \\
0305 \\
0310 \\
0315\end{array}$ & $\begin{array}{r}36.7 \\
62.5 \\
80.0 \\
97.5 \\
116.0\end{array}$ & $\begin{array}{l}0.00 \\
0.00 \\
0.00 \\
0.00 \\
0.00\end{array}$ \\
\hline $\begin{array}{l}1635 \\
1640 \\
1645 \\
1650 \\
1655\end{array}$ & $\begin{array}{l}455.0 \\
433.0 \\
418.0 \\
396.0 \\
384.0\end{array}$ & $\begin{array}{l}0.02 \\
0.04 \\
0.01 \\
0.00 \\
0.11\end{array}$ & $\begin{array}{l}2200 \\
2205 \\
2210 \\
2215 \\
2220\end{array}$ & $\begin{array}{l}302.0 \\
287.0 \\
276.0 \\
261.0 \\
246.0\end{array}$ & $\begin{array}{l}0.00 \\
0.00 \\
0.00 \\
0.00 \\
0.00\end{array}$ & $\begin{array}{l}0320 \\
0325 \\
0330 \\
0335 \\
0340\end{array}$ & $\begin{array}{r}128.0 \\
128.0 \\
123.0 \\
109.0 \\
97.5\end{array}$ & $\begin{array}{l}0.00 \\
0.00 \\
0.00 \\
0.00 \\
0.00\end{array}$ \\
\hline $\begin{array}{l}1700 \\
1705 \\
1710 \\
1715 \\
1720\end{array}$ & $\begin{array}{l}463.0 \\
517.0 \\
573.0 \\
606.0 \\
604.0\end{array}$ & $\begin{array}{l}0.22 \\
0.01 \\
0.00 \\
0.00 \\
0.00\end{array}$ & $\begin{array}{l}2225 \\
2230 \\
2235 \\
2240 \\
2245\end{array}$ & $\begin{array}{l}230.0 \\
220.0 \\
209.0 \\
198.0 \\
184.0\end{array}$ & $\begin{array}{l}0.00 \\
0.00 \\
0.00 \\
0.00 \\
0.00\end{array}$ & $\begin{array}{l}0345 \\
0350 \\
0355 \\
0400 \\
0405\end{array}$ & $\begin{array}{l}87.5 \\
80.0 \\
72.5 \\
67.5 \\
65.0\end{array}$ & $\begin{array}{l}0.00 \\
0.00 \\
0.00 \\
0.00 \\
0.00\end{array}$ \\
\hline $\begin{array}{l}1725 \\
1730 \\
1735 \\
1740 \\
1745\end{array}$ & $\begin{array}{l}608.0 \\
600.0 \\
590.0 \\
565.0 \\
552.0\end{array}$ & $\begin{array}{l}0.01 \\
0.02 \\
0.00 \\
0.00 \\
0.01\end{array}$ & $\begin{array}{l}2250 \\
2255 \\
2300 \\
2305 \\
2310\end{array}$ & $\begin{array}{l}174.0 \\
167.0 \\
158.0 \\
151.0 \\
142.0\end{array}$ & $\begin{array}{l}0.00 \\
0.00 \\
0.00 \\
0.00 \\
0.00\end{array}$ & $\begin{array}{l}0410 \\
0415 \\
0420 \\
0425 \\
0430\end{array}$ & $\begin{array}{l}65.0 \\
60.0 \\
56.7 \\
50.0 \\
45.0\end{array}$ & $\begin{array}{l}0.00 \\
0.00 \\
0.00 \\
0.00 \\
0.00\end{array}$ \\
\hline $\begin{array}{l}1750 \\
1755 \\
1800 \\
1805 \\
1810\end{array}$ & $\begin{array}{l}515.0 \\
490.0 \\
474.0 \\
457.0 \\
441.0\end{array}$ & $\begin{array}{l}0.02 \\
0.02 \\
0.01 \\
0.00 \\
0.00\end{array}$ & $\begin{array}{l}2315 \\
2320 \\
2325 \\
2330 \\
2335\end{array}$ & $\begin{array}{l}133.0 \\
126.0 \\
121.0 \\
116.0 \\
109.0\end{array}$ & $\begin{array}{l}0.00 \\
0.00 \\
0.00 \\
0.00 \\
0.00\end{array}$ & $\begin{array}{l}0435 \\
0440 \\
0445 \\
0450 \\
0455\end{array}$ & $\begin{array}{l}42.5 \\
38.3 \\
35.0 \\
33.3 \\
31.7\end{array}$ & $\begin{array}{l}0.00 \\
0.00 \\
0.00 \\
0.00 \\
0.00\end{array}$ \\
\hline $\begin{array}{l}1815 \\
1820 \\
1825 \\
1830 \\
1835\end{array}$ & $\begin{array}{l}433.0 \\
418.0 \\
398.0 \\
378.0 \\
359.0\end{array}$ & $\begin{array}{l}0.01 \\
0.00 \\
0.00 \\
0.00 \\
0.00\end{array}$ & $\begin{array}{r}2340 \\
2345 \\
2350 \\
2355 \\
\text { May 7, }\end{array}$ & $\begin{array}{r}105.0 \\
100.0 \\
95.0 \\
90.0 \\
1984 \quad\end{array}$ & $\begin{array}{l}0.00 \\
0.00 \\
0.00 \\
0.00\end{array}$ & $\begin{array}{l}0500 \\
0505 \\
0510 \\
0515 \\
0520\end{array}$ & $\begin{array}{l}30.0 \\
28.2 \\
27.4 \\
26.6 \\
25.8\end{array}$ & $\begin{array}{l}0.00 \\
0.00 \\
0.00 \\
0.00 \\
0.00\end{array}$ \\
\hline $\begin{array}{l}1840 \\
1845 \\
1850 \\
1855 \\
1900\end{array}$ & $\begin{array}{l}335.0 \\
314.0 \\
294.0 \\
306.0 \\
333.0\end{array}$ & $\begin{array}{l}0.00 \\
0.00 \\
0.06 \\
0.14 \\
0.01\end{array}$ & $\begin{array}{l}0000 \\
0005 \\
0010 \\
0015 \\
0020\end{array}$ & $\begin{array}{l}85.0 \\
82.5 \\
75.0 \\
72.5 \\
67.5\end{array}$ & $\begin{array}{l}0.00 \\
0.00 \\
0.00 \\
0.00 \\
0.00\end{array}$ & $\begin{array}{l}0525 \\
0530 \\
0535 \\
0540 \\
0545\end{array}$ & $\begin{array}{l}25.0 \\
24.2 \\
23.5 \\
21.9 \\
21.2\end{array}$ & $\begin{array}{l}0.00 \\
0.00 \\
0.00 \\
0.00 \\
0.00\end{array}$ \\
\hline $\begin{array}{l}1905 \\
1910 \\
1915 \\
1920 \\
1925\end{array}$ & $\begin{array}{l}369.0 \\
394.0 \\
392.0 \\
378.0 \\
355.0\end{array}$ & $\begin{array}{l}0.01 \\
0.00 \\
0.00 \\
0.00 \\
0.01\end{array}$ & $\begin{array}{l}0025 \\
0030 \\
0035 \\
0040 \\
0045\end{array}$ & $\begin{array}{l}65.0 \\
56.7 \\
53.3 \\
50.0 \\
47.5\end{array}$ & $\begin{array}{l}0.00 \\
0.00 \\
0.00 \\
0.00 \\
0.00\end{array}$ & $\begin{array}{l}0550 \\
0555 \\
0600 \\
0605 \\
0610\end{array}$ & $\begin{array}{l}21.2 \\
20.5 \\
19.8 \\
19.8 \\
19.1\end{array}$ & $\begin{array}{l}0.00 \\
0.00 \\
0.00 \\
0.00 \\
0.00\end{array}$ \\
\hline $\begin{array}{l}1930 \\
1935 \\
1940 \\
1945 \\
1950\end{array}$ & $\begin{array}{l}337.0 \\
329.0 \\
351.0 \\
404.0 \\
447.0\end{array}$ & $\begin{array}{l}0.01 \\
0.07 \\
0.16 \\
0.00 \\
0.00\end{array}$ & $\begin{array}{l}0050 \\
0055 \\
0100 \\
0105 \\
0110\end{array}$ & $\begin{array}{l}42.5 \\
38.3 \\
36.7 \\
35.0 \\
35.0\end{array}$ & $\begin{array}{l}0.00 \\
0.00 \\
0.00 \\
0.00 \\
0.00\end{array}$ & $\begin{array}{l}0615 \\
0620 \\
0625 \\
0630 \\
0635\end{array}$ & $\begin{array}{l}18.4 \\
18.4 \\
17.9 \\
17.9 \\
17.9\end{array}$ & $\begin{array}{l}0.00 \\
0.00 \\
0.00 \\
0.00 \\
0.03\end{array}$ \\
\hline
\end{tabular}


Table 72. - Streamflow and rainfall at station 02164011 , Brushy Creek (Reedy River tributary) at Greenville, May 6-7, 1984--Continued

\begin{tabular}{|c|c|c|c|c|c|c|c|c|}
\hline $\begin{array}{l}\text { Time } \\
\text { (hours) }\end{array}$ & $\begin{array}{l}\text { Streamflow } \\
\text { (cubic feet } \\
\text { per second) }\end{array}$ & $\begin{array}{l}\text { Rain- } \\
\text { fall } \\
\text { (inches) }\end{array}$ & $\begin{array}{l}\text { Time } \\
\text { (hours) }\end{array}$ & $\begin{array}{l}\text { Streamflow } \\
\text { (cubic feet } \\
\text { per second) }\end{array}$ & $\begin{array}{l}\text { Rain- } \\
\text { fall } \\
\text { (inches) }\end{array}$ & $\begin{array}{l}\text { Time } \\
\text { (hours) }\end{array}$ & $\begin{array}{l}\text { Streamflow } \\
\text { (cubic feet } \\
\text { per second) }\end{array}$ & $\begin{array}{l}\text { Rain- } \\
\text { fall } \\
\text { (inches) }\end{array}$ \\
\hline $\begin{array}{l}0640 \\
0645 \\
0650 \\
0655 \\
0700\end{array}$ & $\begin{array}{l}20.5 \\
31.7 \\
62.5 \\
87.5 \\
95.0\end{array}$ & $\begin{array}{l}0.09 \\
0.03 \\
0.00 \\
0.00 \\
0.00\end{array}$ & $\begin{array}{l}1030 \\
1035 \\
1040 \\
1045 \\
1050\end{array}$ & $\begin{array}{l}18.4 \\
17.9 \\
17.4 \\
16.9 \\
16.9\end{array}$ & $\begin{array}{l}0.00 \\
0.00 \\
0.00 \\
0.00 \\
0.00\end{array}$ & $\begin{array}{l}1420 \\
1425 \\
1430 \\
1435 \\
1440\end{array}$ & $\begin{array}{l}12.0 \\
11.7 \\
11.7 \\
11.7 \\
11.7\end{array}$ & $\begin{array}{l}0.00 \\
0.00 \\
0.00 \\
0.00 \\
0.00\end{array}$ \\
\hline $\begin{array}{l}0705 \\
0710 \\
0715 \\
0720 \\
0725\end{array}$ & $\begin{array}{l}123.0 \\
133.0 \\
130.0 \\
146.0 \\
170.0\end{array}$ & $\begin{array}{l}0.00 \\
0.00 \\
0.00 \\
0.00 \\
0.00\end{array}$ & $\begin{array}{l}1055 \\
1100 \\
1105 \\
1110 \\
1115\end{array}$ & $\begin{array}{l}16.4 \\
15.9 \\
15.9 \\
15.5 \\
15.5\end{array}$ & $\begin{array}{l}0.00 \\
0.00 \\
0.00 \\
0.01 \\
0.00\end{array}$ & $\begin{array}{l}1445 \\
1450 \\
1455 \\
1500 \\
1505\end{array}$ & $\begin{array}{l}11.7 \\
11.4 \\
11.4 \\
11.4 \\
11.4\end{array}$ & $\begin{array}{l}0.00 \\
0.00 \\
0.00 \\
0.00 \\
0.00\end{array}$ \\
\hline $\begin{array}{l}0730 \\
0735 \\
0740 \\
0745 \\
0750\end{array}$ & $\begin{array}{l}179.0 \\
179.0 \\
163.0 \\
149.0 \\
130.0\end{array}$ & $\begin{array}{l}0.00 \\
0.00 \\
0.00 \\
0.00 \\
0.00\end{array}$ & $\begin{array}{l}1120 \\
1125 \\
1130 \\
1135 \\
1140\end{array}$ & $\begin{array}{l}15.0 \\
15.0 \\
14.6 \\
14.6 \\
14.6\end{array}$ & $\begin{array}{l}0.00 \\
0.00 \\
0.00 \\
0.00 \\
0.00\end{array}$ & $\begin{array}{l}1510 \\
1515 \\
1520 \\
1525 \\
1530\end{array}$ & $\begin{array}{l}11.4 \\
11.4 \\
11.0 \\
11.0 \\
11.0\end{array}$ & $\begin{array}{l}0.00 \\
0.00 \\
0.00 \\
0.00 \\
0.00\end{array}$ \\
\hline $\begin{array}{l}0755 \\
0800 \\
0805 \\
0810 \\
0815\end{array}$ & $\begin{array}{r}112.0 \\
97.5 \\
85.0 \\
77.5 \\
70.0\end{array}$ & $\begin{array}{l}0.00 \\
0.00 \\
0.00 \\
0.00 \\
0.00\end{array}$ & $\begin{array}{l}1145 \\
1150 \\
1155 \\
1200 \\
1205\end{array}$ & $\begin{array}{l}14.2 \\
14.2 \\
14.2 \\
13.9 \\
13.9\end{array}$ & $\begin{array}{l}0.00 \\
0.00 \\
0.00 \\
0.00 \\
0.00\end{array}$ & $\begin{array}{l}1535 \\
1540 \\
1545 \\
1550 \\
1555\end{array}$ & $\begin{array}{l}11.0 \\
11.0 \\
11.0 \\
10.7 \\
10.7\end{array}$ & $\begin{array}{l}0.00 \\
0.00 \\
0.00 \\
0.00 \\
0.00\end{array}$ \\
\hline $\begin{array}{l}0820 \\
0825 \\
0830 \\
0835 \\
0840\end{array}$ & $\begin{array}{l}62.5 \\
56.7 \\
50.0 \\
45.0 \\
40.0\end{array}$ & $\begin{array}{l}0.00 \\
0.00 \\
0.00 \\
0.00 \\
0.00\end{array}$ & $\begin{array}{l}1210 \\
1215 \\
1220 \\
1225 \\
1230\end{array}$ & $\begin{array}{l}13.9 \\
13.9 \\
13.5 \\
13.5 \\
13.5\end{array}$ & $\begin{array}{l}0.00 \\
0.00 \\
0.00 \\
0.00 \\
0.00\end{array}$ & $\begin{array}{l}1600 \\
1605 \\
1610 \\
1615 \\
1620\end{array}$ & $\begin{array}{l}10.7 \\
10.7 \\
10.7 \\
10.7 \\
10.7\end{array}$ & $\begin{array}{l}0.00 \\
0.00 \\
0.00 \\
0.00 \\
0.00\end{array}$ \\
\hline $\begin{array}{l}0845 \\
0850 \\
0855 \\
0900 \\
0905\end{array}$ & $\begin{array}{l}38.3 \\
35.0 \\
33.3 \\
31.7 \\
30.0\end{array}$ & $\begin{array}{l}0.00 \\
0.00 \\
0.00 \\
0.00 \\
0.00\end{array}$ & $\begin{array}{l}1235 \\
1240 \\
1245 \\
1250 \\
1255\end{array}$ & $\begin{array}{l}13.1 \\
13.1 \\
13.1 \\
13.1 \\
13.1\end{array}$ & $\begin{array}{l}0.00 \\
0.00 \\
0.00 \\
0.00 \\
0.00\end{array}$ & $\begin{array}{l}1625 \\
1630 \\
1635 \\
1640 \\
1645\end{array}$ & $\begin{array}{l}10.7 \\
10.7 \\
10.7 \\
10.7 \\
10.7\end{array}$ & $\begin{array}{l}0.00 \\
0.00 \\
0.00 \\
0.00 \\
0.00\end{array}$ \\
\hline $\begin{array}{l}0910 \\
0915 \\
0920 \\
0925 \\
0930\end{array}$ & $\begin{array}{l}28.2 \\
27.4 \\
26.6 \\
25.8 \\
25.0\end{array}$ & $\begin{array}{l}0.00 \\
0.00 \\
0.00 \\
0.00 \\
0.00\end{array}$ & $\begin{array}{l}1300 \\
1305 \\
1310 \\
1315 \\
1320\end{array}$ & $\begin{array}{l}12.8 \\
12.8 \\
12.8 \\
12.8 \\
12.8\end{array}$ & $\begin{array}{l}0.00 \\
0.00 \\
0.00 \\
0.00 \\
0.00\end{array}$ & $\begin{array}{l}1650 \\
1655 \\
1700 \\
1705 \\
1710\end{array}$ & $\begin{array}{l}10.3 \\
10.3 \\
10.3 \\
10.3 \\
10.3\end{array}$ & $\begin{array}{l}0.00 \\
0.00 \\
0.00 \\
0.00 \\
0.00\end{array}$ \\
\hline $\begin{array}{l}0935 \\
0940 \\
0945 \\
0950 \\
0955\end{array}$ & $\begin{array}{l}23.5 \\
22.7 \\
22.7 \\
21.9 \\
21.2\end{array}$ & $\begin{array}{l}0.00 \\
0.00 \\
0.00 \\
0.00 \\
0.00\end{array}$ & $\begin{array}{l}1325 \\
1330 \\
1335 \\
1340 \\
1345\end{array}$ & $\begin{array}{l}12.4 \\
12.4 \\
12.4 \\
12.4 \\
12.4\end{array}$ & $\begin{array}{l}0.00 \\
0.00 \\
0.00 \\
0.00 \\
0.00\end{array}$ & $\begin{array}{l}1715 \\
1720 \\
1725 \\
1730 \\
1735\end{array}$ & $\begin{array}{l}10.3 \\
10.3 \\
10.3 \\
10.3 \\
10.3\end{array}$ & $\begin{array}{l}0.00 \\
0.00 \\
0.00 \\
0.00 \\
0.00\end{array}$ \\
\hline $\begin{array}{l}1000 \\
1005 \\
1010 \\
1015 \\
1020\end{array}$ & $\begin{array}{l}20.5 \\
19.8 \\
19.8 \\
19.1 \\
19.1\end{array}$ & $\begin{array}{l}0.00 \\
0.00 \\
0.00 \\
0.00 \\
0.00\end{array}$ & $\begin{array}{l}1350 \\
1355 \\
1400 \\
1405 \\
1410\end{array}$ & $\begin{array}{l}12.0 \\
12.0 \\
12.0 \\
12.0 \\
12.0\end{array}$ & $\begin{array}{l}0.00 \\
0.00 \\
0.00 \\
0.00 \\
0.00\end{array}$ & $\begin{array}{l}1740 \\
1745 \\
1750 \\
1755 \\
1800\end{array}$ & $\begin{array}{l}10.0 \\
10.0 \\
10.0 \\
10.0 \\
10.0\end{array}$ & $\begin{array}{l}0.00 \\
0.00 \\
0.00 \\
0.00 \\
0.00\end{array}$ \\
\hline 1025 & 18.4 & 0.00 & 1415 & 12.0 & 0.00 & & & \\
\hline
\end{tabular}



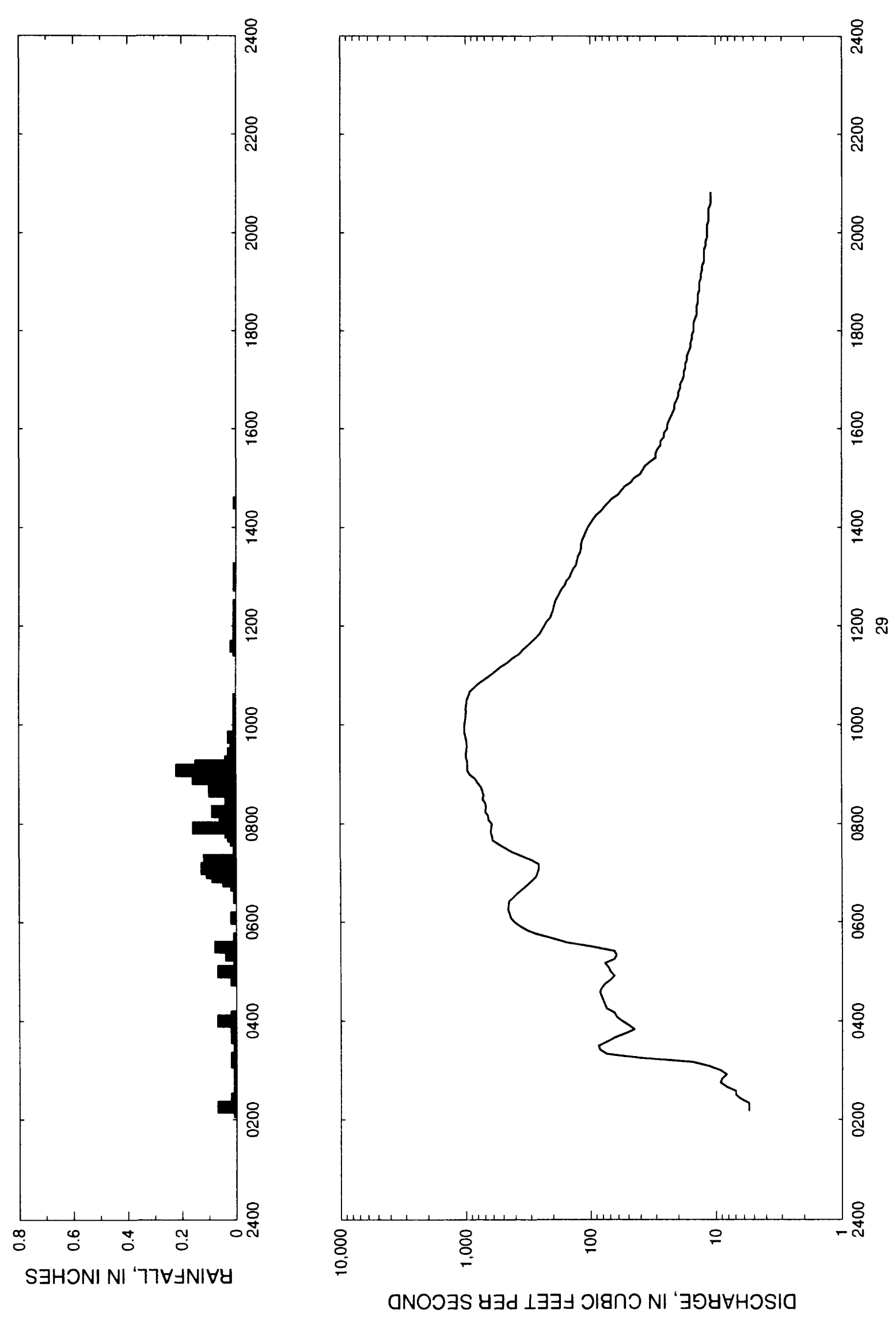

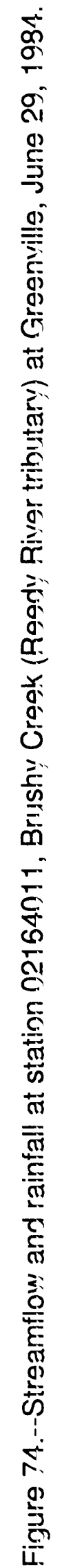


Table 73. - - Streamflow and rainfall at station 02164011, Brushy Creek (Reedy River tributary) at Greenville, June 29,1984

\begin{tabular}{|c|c|c|c|c|c|c|c|c|}
\hline $\begin{array}{l}\text { Time } \\
\text { (hours) }\end{array}$ & $\begin{array}{l}\text { Streamflow } \\
\text { (cubic feet } \\
\text { per second) }\end{array}$ & $\begin{array}{l}\text { Rain- } \\
\text { fall } \\
\text { (inches) }\end{array}$ & $\begin{array}{l}\text { Time } \\
\text { (hours) }\end{array}$ & $\begin{array}{l}\text { Streamflow } \\
\text { (cubic feet } \\
\text { per second) }\end{array}$ & $\begin{array}{l}\text { Rain- } \\
\text { fall } \\
\text { (inches) }\end{array}$ & $\begin{array}{l}\text { Time } \\
\text { (hours) }\end{array}$ & $\begin{array}{l}\text { Streamflow } \\
\text { (cubic feet } \\
\text { per second) }\end{array}$ & $\begin{array}{l}\text { Rain- } \\
\text { fall } \\
\text { (inches) }\end{array}$ \\
\hline $\begin{array}{l}\text { June } 29 \text {, } \\
0210 \\
0215 \\
0220 \\
0225\end{array}$ & $\begin{array}{r}1984 \\
5.5 \\
5.5 \\
5.5 \\
6.4\end{array}$ & $\begin{array}{l}0.01 \\
0.07 \\
0.02 \\
0.02\end{array}$ & $\begin{array}{l}0730 \\
0735 \\
0740 \\
0745 \\
0750\end{array}$ & $\begin{array}{l}480.0 \\
544.0 \\
608.0 \\
615.0 \\
629.0\end{array}$ & $\begin{array}{l}0.00 \\
0.01 \\
0.02 \\
0.03 \\
0.04\end{array}$ & $\begin{array}{l}1255 \\
1300 \\
1305 \\
1310 \\
1315\end{array}$ & $\begin{array}{l}156.0 \\
146.0 \\
142.0 \\
137.0 \\
130.0\end{array}$ & $\begin{array}{l}0.01 \\
0.00 \\
0.00 \\
0.01 \\
0.00\end{array}$ \\
\hline $\begin{array}{l}0230 \\
0235 \\
0240 \\
0245 \\
0250\end{array}$ & $\begin{array}{l}7.0 \\
7.0 \\
8.3 \\
9.3 \\
9.0\end{array}$ & $\begin{array}{l}0.00 \\
0.01 \\
0.01 \\
0.00 \\
0.00\end{array}$ & $\begin{array}{l}0755 \\
0800 \\
0805 \\
0810 \\
0815\end{array}$ & $\begin{array}{l}621.0 \\
617.0 \\
656.0 \\
660.0 \\
696.0\end{array}$ & $\begin{array}{l}0.16 \\
0.06 \\
0.04 \\
0.01 \\
0.09\end{array}$ & $\begin{array}{l}1320 \\
1325 \\
1330 \\
1335 \\
1340\end{array}$ & $\begin{array}{l}128.0 \\
126.0 \\
121.0 \\
119.0 \\
119.0\end{array}$ & $\begin{array}{l}0.00 \\
0.00 \\
0.00 \\
0.00 \\
0.00\end{array}$ \\
\hline $\begin{array}{l}0255 \\
0300 \\
0305 \\
0310 \\
0315\end{array}$ & $\begin{array}{r}8.3 \\
9.3 \\
11.4 \\
15.5 \\
40.0\end{array}$ & $\begin{array}{l}0.01 \\
0.01 \\
0.01 \\
0.02 \\
0.02\end{array}$ & $\begin{array}{l}0820 \\
0825 \\
0830 \\
0835 \\
0840\end{array}$ & $\begin{array}{l}685.0 \\
694.0 \\
727.0 \\
716.0 \\
731.0\end{array}$ & $\begin{array}{l}0.04 \\
0.03 \\
0.01 \\
0.04 \\
0.10\end{array}$ & $\begin{array}{l}1345 \\
1350 \\
1355 \\
1400 \\
1405\end{array}$ & $\begin{array}{l}116.0 \\
112.0 \\
109.0 \\
105.0 \\
100.0\end{array}$ & $\begin{array}{l}0.00 \\
0.00 \\
0.00 \\
0.00 \\
0.00\end{array}$ \\
\hline $\begin{array}{l}0320 \\
0325 \\
0330 \\
0335 \\
0340\end{array}$ & $\begin{array}{l}75.0 \\
85.0 \\
87.5 \\
75.0 \\
65.0\end{array}$ & $\begin{array}{l}0.00 \\
0.00 \\
0.01 \\
0.00 \\
0.02\end{array}$ & $\begin{array}{l}0845 \\
0850 \\
0855 \\
0900 \\
0905\end{array}$ & $\begin{array}{l}751.0 \\
798.0 \\
839.0 \\
924.0 \\
972.0\end{array}$ & $\begin{array}{l}0.00 \\
0.04 \\
0.16 \\
0.13 \\
0.22\end{array}$ & $\begin{array}{l}1410 \\
1415 \\
1420 \\
1425 \\
1430\end{array}$ & $\begin{array}{l}95.0 \\
90.0 \\
82.5 \\
77.5 \\
72.5\end{array}$ & $\begin{array}{l}0.00 \\
0.00 \\
0.00 \\
0.00 \\
0.01\end{array}$ \\
\hline $\begin{array}{l}0345 \\
0350 \\
0355 \\
0400 \\
0405\end{array}$ & $\begin{array}{l}53.3 \\
45.0 \\
50.0 \\
56.7 \\
62.5\end{array}$ & $\begin{array}{l}0.00 \\
0.02 \\
0.02 \\
0.07 \\
0.02\end{array}$ & $\begin{array}{l}0910 \\
0915 \\
0920 \\
0925 \\
0930\end{array}$ & $\begin{array}{l}967.0 \\
967.0 \\
991.0 \\
993.0 \\
983.0\end{array}$ & $\begin{array}{l}0.15 \\
0.04 \\
0.01 \\
0.03 \\
0.01\end{array}$ & $\begin{array}{l}1435 \\
1440 \\
1445 \\
1450 \\
1455\end{array}$ & $\begin{array}{l}67.5 \\
60.0 \\
56.7 \\
53.3 \\
47.5\end{array}$ & $\begin{array}{l}0.00 \\
0.00 \\
0.00 \\
0.00 \\
0.00\end{array}$ \\
\hline $\begin{array}{l}0410 \\
0415 \\
0420 \\
0425 \\
0430\end{array}$ & $\begin{array}{l}65.0 \\
75.0 \\
77.5 \\
80.0 \\
82.5\end{array}$ & $\begin{array}{l}0.00 \\
0.00 \\
0.00 \\
0.00 \\
0.00\end{array}$ & $\begin{array}{l}0935 \\
0940 \\
0945 \\
0950 \\
0955\end{array}$ & $\begin{array}{r}976.0 \\
985.0 \\
1000.0 \\
1020.0 \\
1020.0\end{array}$ & $\begin{array}{l}0.02 \\
0.00 \\
0.03 \\
0.01 \\
0.01\end{array}$ & $\begin{array}{l}1500 \\
1505 \\
1510 \\
1515 \\
1520\end{array}$ & $\begin{array}{l}45.0 \\
40.0 \\
38.3 \\
36.7 \\
33.3\end{array}$ & $\begin{array}{l}0.00 \\
0.00 \\
0.00 \\
0.00 \\
0.00\end{array}$ \\
\hline $\begin{array}{l}0435 \\
0440 \\
0445 \\
0450 \\
0455\end{array}$ & $\begin{array}{l}85.0 \\
82.5 \\
77.5 \\
70.0 \\
65.0\end{array}$ & $\begin{array}{l}0.00 \\
0.00 \\
0.00 \\
0.02 \\
0.02\end{array}$ & $\begin{array}{l}1000 \\
1005 \\
1010 \\
1015 \\
1020\end{array}$ & $\begin{array}{r}1020.0 \\
1010.0 \\
998.0 \\
991.0 \\
996.0\end{array}$ & $\begin{array}{l}0.00 \\
0.01 \\
0.01 \\
0.01 \\
0.00\end{array}$ & $\begin{array}{l}1525 \\
1530 \\
1535 \\
1540 \\
1545\end{array}$ & $\begin{array}{l}30.0 \\
30.0 \\
29.1 \\
27.4 \\
27.4\end{array}$ & $\begin{array}{l}0.00 \\
0.00 \\
0.00 \\
0.00 \\
0.00\end{array}$ \\
\hline $\begin{array}{l}0500 \\
0505 \\
0510 \\
0515 \\
0520\end{array}$ & $\begin{array}{l}70.0 \\
72.5 \\
77.5 \\
65.0 \\
62.5\end{array}$ & $\begin{array}{l}0.07 \\
0.01 \\
0.00 \\
0.01 \\
0.04\end{array}$ & $\begin{array}{l}1025 \\
1030 \\
1035 \\
1040 \\
1045\end{array}$ & $\begin{array}{l}985.0 \\
976.0 \\
946.0 \\
922.0 \\
851.0\end{array}$ & $\begin{array}{l}0.00 \\
0.01 \\
0.00 \\
0.00 \\
0.00\end{array}$ & $\begin{array}{l}1550 \\
1555 \\
1600 \\
1605 \\
1610\end{array}$ & $\begin{array}{l}25.8 \\
25.8 \\
24.2 \\
24.2 \\
23.5\end{array}$ & $\begin{array}{l}0.00 \\
0.00 \\
0.00 \\
0.00 \\
0.00\end{array}$ \\
\hline $\begin{array}{l}0525 \\
0530 \\
0535 \\
0540 \\
0545\end{array}$ & $\begin{array}{r}65.0 \\
97.5 \\
154.0 \\
200.0 \\
263.0\end{array}$ & $\begin{array}{l}0.01 \\
0.08 \\
0.01 \\
0.01 \\
0.00\end{array}$ & $\begin{array}{l}1050 \\
1055 \\
1100 \\
1105 \\
1110\end{array}$ & $\begin{array}{l}778.0 \\
698.0 \\
629.0 \\
571.0 \\
519.0\end{array}$ & $\begin{array}{l}0.00 \\
0.00 \\
0.00 \\
0.00 \\
0.00\end{array}$ & $\begin{array}{l}1615 \\
1620 \\
1625 \\
1630 \\
1635\end{array}$ & $\begin{array}{l}22.7 \\
21.9 \\
21.2 \\
21.2 \\
20.5\end{array}$ & $\begin{array}{l}0.00 \\
0.00 \\
0.00 \\
0.00 \\
0.00\end{array}$ \\
\hline $\begin{array}{l}0550 \\
0555 \\
0600 \\
0605 \\
0610\end{array}$ & $\begin{array}{l}320.0 \\
369.0 \\
406.0 \\
437.0 \\
447.0\end{array}$ & $\begin{array}{l}0.00 \\
0.00 \\
0.00 \\
0.02 \\
0.00\end{array}$ & $\begin{array}{l}1115 \\
1120 \\
1125 \\
1130 \\
1135\end{array}$ & $\begin{array}{l}461.0 \\
422.0 \\
374.0 \\
349.0 \\
322.0\end{array}$ & $\begin{array}{l}0.00 \\
0.00 \\
0.00 \\
0.01 \\
0.02\end{array}$ & $\begin{array}{l}1640 \\
1645 \\
1650 \\
1655 \\
1700\end{array}$ & $\begin{array}{l}19.8 \\
19.8 \\
19.1 \\
19.1 \\
18.4\end{array}$ & $\begin{array}{l}0.00 \\
0.00 \\
0.00 \\
0.00 \\
0.00\end{array}$ \\
\hline $\begin{array}{l}0615 \\
0620 \\
0625 \\
0630 \\
0635\end{array}$ & $\begin{array}{l}459.0 \\
455.0 \\
451.0 \\
416.0 \\
386.0\end{array}$ & $\begin{array}{l}0.00 \\
0.00 \\
0.00 \\
0.01 \\
0.00\end{array}$ & $\begin{array}{l}1140 \\
1145 \\
1150 \\
1155 \\
1200\end{array}$ & $\begin{array}{l}298.0 \\
274.0 \\
254.0 \\
244.0 \\
233.0\end{array}$ & $\begin{array}{l}0.01 \\
0.01 \\
0.00 \\
0.00 \\
0.01\end{array}$ & $\begin{array}{l}1705 \\
1710 \\
1715 \\
1720 \\
1725\end{array}$ & $\begin{array}{l}17.9 \\
17.9 \\
17.4 \\
17.4 \\
16.9\end{array}$ & $\begin{array}{l}0.00 \\
0.00 \\
0.00 \\
0.00 \\
0.00\end{array}$ \\
\hline $\begin{array}{l}0640 \\
0645 \\
0650 \\
0655 \\
3700\end{array}$ & $\begin{array}{l}353.0 \\
324.0 \\
296.0 \\
274.0 \\
267.0\end{array}$ & $\begin{array}{l}0.00 \\
0.02 \\
0.05 \\
0.09 \\
0.11\end{array}$ & $\begin{array}{l}1205 \\
1210 \\
1215 \\
1220 \\
1225\end{array}$ & $\begin{array}{l}224.0 \\
209.0 \\
204.0 \\
198.0 \\
195.0\end{array}$ & $\begin{array}{l}0.00 \\
0.00 \\
0.01 \\
0.00 \\
0.01\end{array}$ & $\begin{array}{l}1730 \\
1735 \\
1740 \\
1745 \\
1750\end{array}$ & $\begin{array}{l}16.9 \\
16.4 \\
15.9 \\
15.9 \\
15.5\end{array}$ & $\begin{array}{l}0.00 \\
0.00 \\
0.00 \\
0.00 \\
0.00\end{array}$ \\
\hline $\begin{array}{l}0705 \\
0710 \\
0715 \\
0720 \\
0725\end{array}$ & $\begin{array}{l}261.0 \\
261.0 \\
294.0 \\
353.0 \\
422.0\end{array}$ & $\begin{array}{l}0.13 \\
0.12 \\
0.12 \\
0.01 \\
0.00\end{array}$ & $\begin{array}{l}1230 \\
1235 \\
1240 \\
1245 \\
1250\end{array}$ & $\begin{array}{l}191.0 \\
184.0 \\
177.0 \\
170.0 \\
160.0\end{array}$ & $\begin{array}{l}0.00 \\
0.00 \\
0.00 \\
0.00 \\
0.01\end{array}$ & $\begin{array}{l}1755 \\
1800 \\
1805 \\
1810 \\
1815\end{array}$ & $\begin{array}{l}15.5 \\
15.0 \\
15.0 \\
15.0 \\
14.6\end{array}$ & $\begin{array}{l}0.00 \\
0.00 \\
0.00 \\
0.00 \\
0.00\end{array}$ \\
\hline
\end{tabular}


Table 73.--Streamflow and rainfall at station 02164011, Brushy Creek (Peedy River tributary) at Greenville, June $29,1984--$ Continued

\begin{tabular}{|c|c|c|c|c|c|c|c|c|}
\hline $\begin{array}{l}\text { Time } \\
\text { (hours) }\end{array}$ & $\begin{array}{l}\text { Streamflow } \\
\text { (cubic feet } \\
\text { per second) }\end{array}$ & $\begin{array}{l}\text { Rain- } \\
\text { fall } \\
\text { (inches) }\end{array}$ & $\begin{array}{l}\text { Time } \\
\text { (hours) }\end{array}$ & $\begin{array}{l}\text { Streamflow } \\
\text { (cubic feet } \\
\text { per second) }\end{array}$ & $\begin{array}{l}\text { Rain- } \\
\text { fall } \\
\text { (inches) }\end{array}$ & $\begin{array}{l}\text { Time } \\
\text { (hours) }\end{array}$ & $\begin{array}{l}\text { Streamflow } \\
\text { (cubic feet } \\
\text { per second) }\end{array}$ & $\begin{array}{l}\text { Rain- } \\
\text { fall } \\
\text { (inches) }\end{array}$ \\
\hline $\begin{array}{l}1820 \\
1825 \\
1830 \\
1835 \\
1840\end{array}$ & $\begin{array}{l}14.2 \\
14.2 \\
14.2 \\
13.9 \\
13.9\end{array}$ & $\begin{array}{l}0.00 \\
0.00 \\
0.00 \\
0.00 \\
0.00\end{array}$ & $\begin{array}{l}1915 \\
1920 \\
1925 \\
1930 \\
1935\end{array}$ & $\begin{array}{l}12.8 \\
12.8 \\
12.4 \\
12.4 \\
12.4\end{array}$ & $\begin{array}{l}0.00 \\
0.00 \\
0.00 \\
0.00 \\
0.00\end{array}$ & $\begin{array}{l}2010 \\
2015 \\
2020 \\
2025 \\
2030\end{array}$ & $\begin{array}{l}11.7 \\
11.4 \\
11.4 \\
11.4 \\
11.4\end{array}$ & $\begin{array}{l}0.00 \\
0.00 \\
0.00 \\
0.00 \\
0.00\end{array}$ \\
\hline $\begin{array}{l}1845 \\
1850 \\
1855 \\
1900 \\
1905\end{array}$ & $\begin{array}{l}13.9 \\
13.5 \\
13.5 \\
13.5 \\
13.1\end{array}$ & $\begin{array}{l}0.00 \\
0.00 \\
0.00 \\
0.00 \\
0.00\end{array}$ & $\begin{array}{l}1940 \\
1945 \\
1950 \\
1955 \\
2000\end{array}$ & $\begin{array}{l}12.4 \\
12.0 \\
12.0 \\
11.7 \\
11.7\end{array}$ & $\begin{array}{l}0.00 \\
0.00 \\
0.00 \\
0.00 \\
0.00\end{array}$ & $\begin{array}{l}2035 \\
2040 \\
2045 \\
2050 \\
2055\end{array}$ & $\begin{array}{l}11.0 \\
11.0 \\
11.0 \\
11.0 \\
10.7\end{array}$ & $\begin{array}{l}0.00 \\
0.00 \\
0.00 \\
0.00 \\
0.00\end{array}$ \\
\hline 1910 & 13.1 & 0.00 & 2005 & 11.7 & 0.00 & 2100 & 10.7 & 0.00 \\
\hline
\end{tabular}




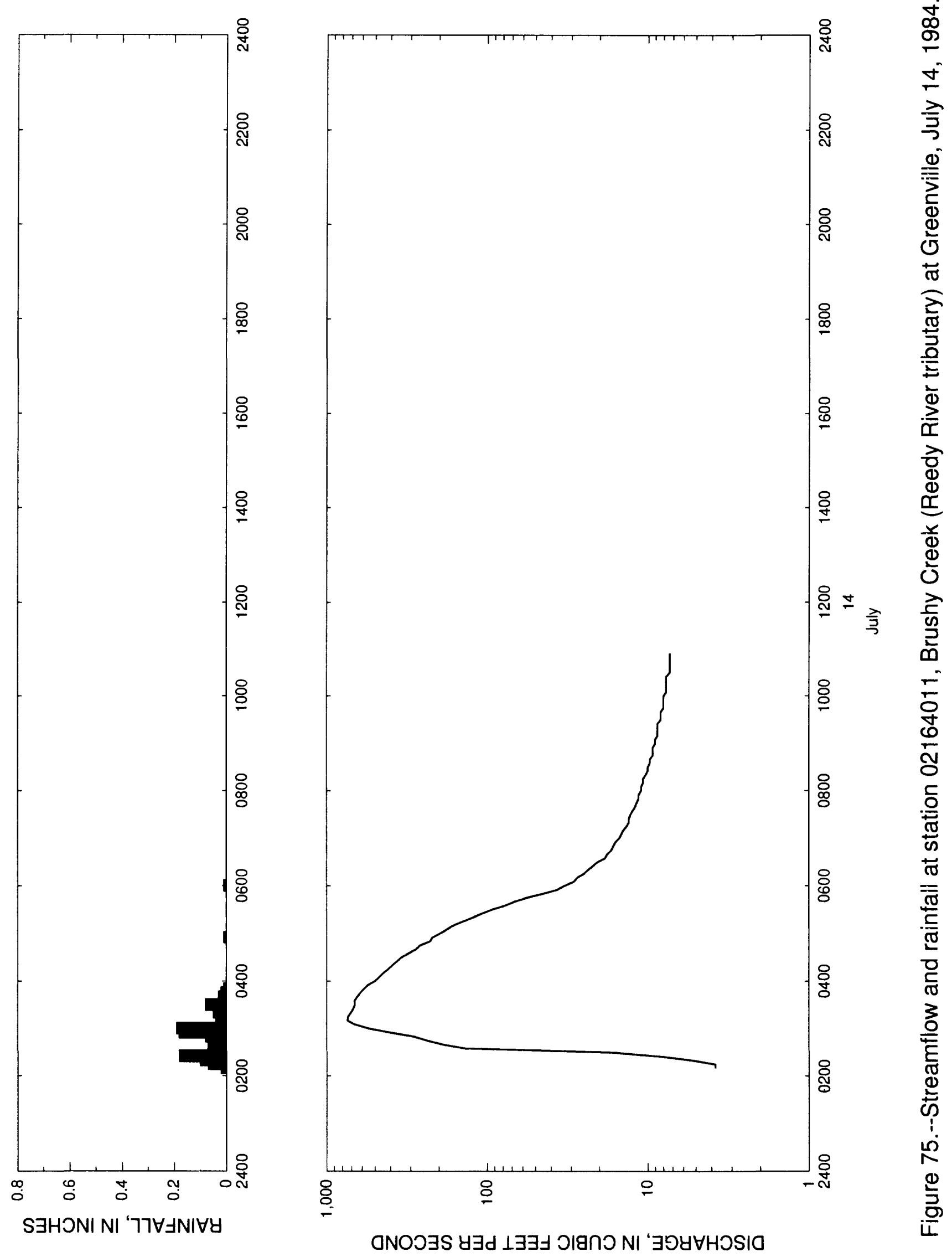


Table 74.- - Streamflow and rainfa11 at station 02164011, Brushy Creek (Reedy River tributary) at Greenville, July 14,1984

\begin{tabular}{|c|c|c|c|c|c|c|c|c|}
\hline $\begin{array}{l}\text { Time } \\
\text { (hours) }\end{array}$ & $\begin{array}{l}\text { Streamflow } \\
\text { (cubic feet } \\
\text { per second) }\end{array}$ & $\begin{array}{l}\text { Rain- } \\
\text { fall } \\
\text { (inches) }\end{array}$ & $\begin{array}{l}\text { Time } \\
\text { (hours) }\end{array}$ & $\begin{array}{l}\text { Streamflow } \\
\text { (cubic feet } \\
\text { per second) }\end{array}$ & $\begin{array}{l}\text { Rain- } \\
\text { fall } \\
\text { (inches) }\end{array}$ & $\begin{array}{l}\text { Time } \\
\text { (hours) }\end{array}$ & $\begin{array}{l}\text { Streamflow } \\
\text { (cubic feet } \\
\text { per second) }\end{array}$ & $\begin{array}{l}\text { Rain- } \\
\text { fall } \\
\text { (inches) }\end{array}$ \\
\hline $\begin{array}{l}\text { July } 14, \\
0210 \\
0215 \\
0220 \\
0225\end{array}$ & $\begin{array}{r}1984 \quad \\
3.8 \\
3.8 \\
5.2 \\
8.3\end{array}$ & $\begin{array}{l}0.02 \\
0.07 \\
0.10 \\
0.18\end{array}$ & $\begin{array}{l}0505 \\
0510 \\
0515 \\
0520 \\
0525\end{array}$ & $\begin{array}{l}179.0 \\
163.0 \\
142.0 \\
123.0 \\
107.0\end{array}$ & $\begin{array}{l}0.00 \\
0.00 \\
0.00 \\
0.00 \\
0.00\end{array}$ & $\begin{array}{l}0805 \\
0810 \\
0815 \\
0820 \\
0825\end{array}$ & $\begin{array}{l}11.0 \\
10.7 \\
10.7 \\
10.3 \\
10.0\end{array}$ & $\begin{array}{l}0.07 \\
0.07 \\
0.07 \\
0.07 \\
0.07\end{array}$ \\
\hline $\begin{array}{l}0230 \\
0235 \\
0240 \\
0245 \\
0250\end{array}$ & $\begin{array}{r}16.4 \\
137.0 \\
188.0 \\
237.0 \\
287.0\end{array}$ & $\begin{array}{l}0.07 \\
0.04 \\
0.07 \\
0.05 \\
0.08\end{array}$ & $\begin{array}{l}0530 \\
0535 \\
0540 \\
0545 \\
0550\end{array}$ & $\begin{array}{l}92.5 \\
77.5 \\
67.5 \\
56.7 \\
45.0\end{array}$ & $\begin{array}{l}0.00 \\
0.00 \\
0.00 \\
0.00 \\
0.00\end{array}$ & $\begin{array}{l}0830 \\
0835 \\
0840 \\
0845 \\
0850\end{array}$ & $\begin{array}{r}10.0 \\
9.7 \\
9.7 \\
9.3 \\
9.3\end{array}$ & $\begin{array}{l}0.0 n \\
0.00 \\
0.00 \\
0.00 \\
0.00\end{array}$ \\
\hline $\begin{array}{l}0255 \\
0300 \\
0305 \\
0310 \\
0315\end{array}$ & $\begin{array}{l}404.0 \\
548.0 \\
667.0 \\
744.0 \\
738.0\end{array}$ & $\begin{array}{l}0.18 \\
0.19 \\
0.03 \\
0.04 \\
0.01\end{array}$ & $\begin{array}{l}0555 \\
0600 \\
0605 \\
0610 \\
0615\end{array}$ & $\begin{array}{l}36.7 \\
33.3 \\
29.1 \\
27.4 \\
25.0\end{array}$ & $\begin{array}{l}0.00 \\
0.01 \\
0.00 \\
0.00 \\
0.00\end{array}$ & $\begin{array}{l}0855 \\
0900 \\
0905 \\
0910 \\
0915\end{array}$ & $\begin{array}{l}9.3 \\
9.0 \\
9.0 \\
8.7 \\
8.7\end{array}$ & $\begin{array}{l}0.00 \\
0.00 \\
0.00 \\
0.00 \\
0 . C 0\end{array}$ \\
\hline $\begin{array}{l}0320 \\
0325 \\
0330 \\
0335 \\
0340\end{array}$ & $\begin{array}{l}709.0 \\
685.0 \\
669.0 \\
673.0 \\
648.0\end{array}$ & $\begin{array}{l}0.05 \\
0.04 \\
0.08 \\
0.03 \\
0.03\end{array}$ & $\begin{array}{l}0620 \\
0625 \\
0630 \\
0635 \\
0640\end{array}$ & $\begin{array}{l}23.5 \\
21.9 \\
20.5 \\
18.4 \\
17.9\end{array}$ & $\begin{array}{l}0.00 \\
0.00 \\
0.00 \\
0.00 \\
0.00\end{array}$ & $\begin{array}{l}0920 \\
0925 \\
0930 \\
0935 \\
0940\end{array}$ & $\begin{array}{l}8.7 \\
8.7 \\
8.3 \\
8.3 \\
8.3\end{array}$ & $\begin{array}{l}0.60 \\
0.00 \\
0.50 \\
0.00 \\
0.00\end{array}$ \\
\hline $\begin{array}{l}0345 \\
0350 \\
0355 \\
0400 \\
0405\end{array}$ & $\begin{array}{l}619.0 \\
585.0 \\
552.0 \\
502.0 \\
471.0\end{array}$ & $\begin{array}{l}0.02 \\
0.01 \\
0.00 \\
0.00 \\
0.00\end{array}$ & $\begin{array}{l}0645 \\
0650 \\
0655 \\
0700 \\
0705\end{array}$ & $\begin{array}{l}16.9 \\
16.4 \\
15.9 \\
15.0 \\
14.6\end{array}$ & $\begin{array}{l}0.00 \\
0.00 \\
0.00 \\
0.00 \\
0.00\end{array}$ & $\begin{array}{l}0945 \\
0950 \\
0955 \\
1000 \\
1005\end{array}$ & $\begin{array}{l}8.0 \\
8.0 \\
8.0 \\
8.0 \\
7.7\end{array}$ & $\begin{array}{l}0.00 \\
0.00 \\
0.00 \\
0.00 \\
0.00\end{array}$ \\
\hline $\begin{array}{l}0410 \\
0415 \\
0420 \\
0425 \\
0430\end{array}$ & $\begin{array}{l}447.0 \\
416.0 \\
392.0 \\
367.0 \\
345.0\end{array}$ & $\begin{array}{l}0.00 \\
0.00 \\
0.00 \\
0.00 \\
0.00\end{array}$ & $\begin{array}{l}0710 \\
0715 \\
0720 \\
0725 \\
0730\end{array}$ & $\begin{array}{l}14.2 \\
13.5 \\
13.1 \\
13.1 \\
12.8\end{array}$ & $\begin{array}{l}0.00 \\
0.00 \\
0.00 \\
0.00 \\
0.00\end{array}$ & $\begin{array}{l}1010 \\
1015 \\
1020 \\
1025 \\
1030\end{array}$ & $\begin{array}{l}7.7 \\
7.7 \\
7.7 \\
7.7 \\
7.3\end{array}$ & $\begin{array}{l}0.00 \\
0.00 \\
0.00 \\
0.00 \\
0.00\end{array}$ \\
\hline $\begin{array}{l}0435 \\
0440 \\
0445 \\
0450 \\
0455\end{array}$ & $\begin{array}{l}312.0 \\
280.0 \\
263.0 \\
228.0 \\
220.0\end{array}$ & $\begin{array}{l}0.00 \\
0.00 \\
0.00 \\
0.00 \\
0.01\end{array}$ & $\begin{array}{l}0735 \\
0740 \\
0745 \\
0750 \\
0755\end{array}$ & $\begin{array}{l}12.4 \\
12.0 \\
11.7 \\
11.4 \\
11.4\end{array}$ & $\begin{array}{l}0.00 \\
0.00 \\
0.00 \\
0.00 \\
0.00\end{array}$ & $\begin{array}{l}1035 \\
1040 \\
1045 \\
1050 \\
1055\end{array}$ & $\begin{array}{l}7.3 \\
7.3 \\
7.3 \\
7.3 \\
7.3\end{array}$ & $\begin{array}{l}0.00 \\
0.00 \\
0.00 \\
0.00 \\
0.00\end{array}$ \\
\hline 0500 & 198.0 & 0.00 & 0800 & 11.0 & 0.00 & 1100 & 7.3 & 0.00 \\
\hline
\end{tabular}




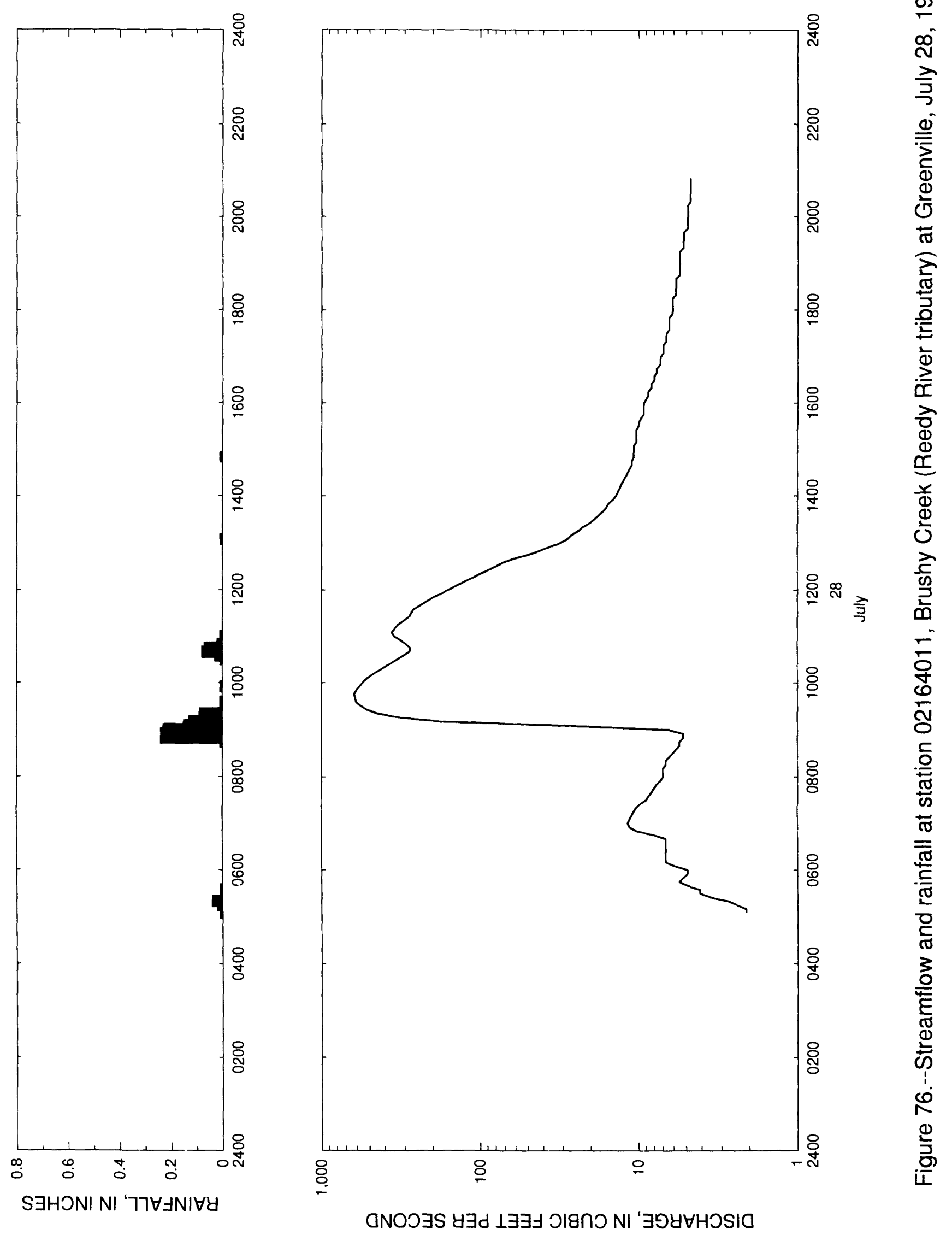


Table 75.--Streanflow and rainfall at station 02164011 , Brushy Creek (Reedy River tributary) at Greenville, July 28,1985

\begin{tabular}{|c|c|c|c|c|c|c|c|c|}
\hline $\begin{array}{l}\text { Time } \\
\text { (hours) }\end{array}$ & $\begin{array}{l}\text { Streamflow } \\
\text { (cubic feet } \\
\text { per second) }\end{array}$ & $\begin{array}{l}\text { Rain- } \\
\text { fall } \\
\text { (inches) }\end{array}$ & $\begin{array}{l}\text { Time } \\
\text { (hours) }\end{array}$ & $\begin{array}{l}\text { Streamflow } \\
\text { (cubic feet } \\
\text { per second) }\end{array}$ & $\begin{array}{l}\text { Rain- } \\
\text { fall } \\
\text { (inches) }\end{array}$ & $\begin{array}{l}\text { Time } \\
\text { (hours) }\end{array}$ & $\begin{array}{l}\text { Streamflow } \\
\text { (cubic feet } \\
\text { per second) }\end{array}$ & $\begin{array}{l}\text { Rain- } \\
\text { fall } \\
\text { (inches) }\end{array}$ \\
\hline $\begin{array}{l}\text { July } 28, \\
0505 \\
0510 \\
0515 \\
0520\end{array}$ & $\begin{array}{l}1985 \\
2.1 \\
2.1 \\
2.4 \\
2.7\end{array}$ & $\begin{array}{l}0.01 \\
0.01 \\
0.02 \\
0.04\end{array}$ & $\begin{array}{l}1025 \\
1030 \\
1035 \\
1040 \\
1045\end{array}$ & $\begin{array}{l}367.0 \\
335.0 \\
306.0 \\
278.0 \\
276.0\end{array}$ & $\begin{array}{l}0.00 \\
0.01 \\
0.03 \\
0.08 \\
0.07\end{array}$ & $\begin{array}{l}1550 \\
1555 \\
1600 \\
1605 \\
1610\end{array}$ & $\begin{array}{l}9.3 \\
9.3 \\
9.3 \\
9.0 \\
8.7\end{array}$ & $\begin{array}{l}0.00 \\
0.00 \\
0.00 \\
0.00 \\
0.00\end{array}$ \\
\hline $\begin{array}{l}0525 \\
0530 \\
0535 \\
0540 \\
0545\end{array}$ & $\begin{array}{l}3.5 \\
4.1 \\
4.1 \\
4.9 \\
5.5\end{array}$ & $\begin{array}{l}0.01 \\
0.00 \\
0.01 \\
0.00 \\
0.00\end{array}$ & $\begin{array}{l}1050 \\
1055 \\
1100 \\
1105 \\
1110\end{array}$ & $\begin{array}{l}294.0 \\
318.0 \\
349.0 \\
361.0 \\
345.0\end{array}$ & $\begin{array}{l}0.02 \\
0.00 \\
0.01 \\
0.00 \\
0.00\end{array}$ & $\begin{array}{l}1615 \\
1620 \\
1625 \\
1630 \\
1635\end{array}$ & $\begin{array}{l}8.7 \\
8.3 \\
8.3 \\
8.0 \\
8.0\end{array}$ & $\begin{array}{l}0.00 \\
0.00 \\
0.00 \\
0.00 \\
0.00\end{array}$ \\
\hline $\begin{array}{l}0550 \\
0555 \\
0600 \\
0605 \\
0610\end{array}$ & $\begin{array}{l}5.2 \\
4.9 \\
4.9 \\
5.8 \\
6.7\end{array}$ & $\begin{array}{l}0.00 \\
0.00 \\
0.00 \\
0.00 \\
0.00\end{array}$ & $\begin{array}{l}1115 \\
1120 \\
1125 \\
1130 \\
1135\end{array}$ & $\begin{array}{l}329.0 \\
302.0 \\
280.0 \\
272.0 \\
263.0\end{array}$ & $\begin{array}{l}0.00 \\
0.00 \\
0.00 \\
0.00 \\
0.00\end{array}$ & $\begin{array}{l}1640 \\
1645 \\
1650 \\
1655 \\
1700\end{array}$ & $\begin{array}{l}7.7 \\
7.7 \\
7.3 \\
7.3 \\
7.3\end{array}$ & $\begin{array}{l}0.00 \\
0.00 \\
0.00 \\
0.00 \\
0.00\end{array}$ \\
\hline $\begin{array}{l}0615 \\
0620 \\
0625 \\
0630 \\
0635\end{array}$ & $\begin{array}{l}6.7 \\
6.7 \\
6.7 \\
6.7 \\
6.7\end{array}$ & $\begin{array}{l}0.00 \\
0.00 \\
0.00 \\
0.00 \\
0.00\end{array}$ & $\begin{array}{l}1140 \\
1145 \\
1150 \\
1155 \\
1200\end{array}$ & $\begin{array}{l}239.0 \\
217.0 \\
198.0 \\
177.0 \\
160.0\end{array}$ & $\begin{array}{l}0.00 \\
0.00 \\
0.00 \\
0.00 \\
0.00\end{array}$ & $\begin{array}{l}1705 \\
1710 \\
1715 \\
1720 \\
1725\end{array}$ & $\begin{array}{l}7.0 \\
7.0 \\
7.0 \\
6.7 \\
6.7\end{array}$ & $\begin{array}{l}0.00 \\
0.00 \\
0.00 \\
0.00 \\
0.00\end{array}$ \\
\hline $\begin{array}{l}0640 \\
0645 \\
0650 \\
0655 \\
0700\end{array}$ & $\begin{array}{r}6.7 \\
8.0 \\
10.3 \\
11.4 \\
11.7\end{array}$ & $\begin{array}{l}0.00 \\
0.00 \\
0.00 \\
0.00 \\
0.00\end{array}$ & $\begin{array}{l}1205 \\
1210 \\
1215 \\
1220 \\
1225\end{array}$ & $\begin{array}{r}142.0 \\
128.0 \\
114.0 \\
102.0 \\
90.0\end{array}$ & $\begin{array}{l}0.00 \\
0.00 \\
0.00 \\
0.00 \\
0.00\end{array}$ & $\begin{array}{l}1730 \\
1735 \\
1740 \\
1745 \\
1750\end{array}$ & $\begin{array}{l}6.7 \\
6.4 \\
6.4 \\
6.4 \\
6.4\end{array}$ & $\begin{array}{l}0.00 \\
0.00 \\
0.00 \\
0.00 \\
0.00\end{array}$ \\
\hline $\begin{array}{l}0705 \\
0710 \\
0715 \\
0720 \\
0725\end{array}$ & $\begin{array}{r}11.4 \\
11.0 \\
10.7 \\
10.3 \\
9.7\end{array}$ & $\begin{array}{l}0.00 \\
0.00 \\
0.00 \\
0.00 \\
0.00\end{array}$ & $\begin{array}{l}1230 \\
1235 \\
1240 \\
1245 \\
1250\end{array}$ & $\begin{array}{l}80.0 \\
72.5 \\
62.5 \\
50.0 \\
42.5\end{array}$ & $\begin{array}{l}0.00 \\
0.00 \\
0.00 \\
0.00 \\
0.00\end{array}$ & $\begin{array}{l}1755 \\
1800 \\
1805 \\
1810 \\
1815\end{array}$ & $\begin{array}{l}6.1 \\
6.1 \\
6.1 \\
6.1 \\
6.1\end{array}$ & $\begin{array}{l}0.00 \\
0.00 \\
0.00 \\
0.00 \\
0.00\end{array}$ \\
\hline $\begin{array}{l}0730 \\
0735 \\
0740 \\
0745 \\
0750\end{array}$ & $\begin{array}{l}9.0 \\
8.7 \\
8.3 \\
8.0 \\
7.7\end{array}$ & $\begin{array}{l}0.00 \\
0.00 \\
0.00 \\
0.00 \\
0.00\end{array}$ & $\begin{array}{l}1255 \\
1300 \\
1305 \\
1310 \\
1315\end{array}$ & $\begin{array}{l}36.7 \\
31.7 \\
28.2 \\
26.6 \\
24.2\end{array}$ & $\begin{array}{l}0.00 \\
0.00 \\
0.01 \\
0.00 \\
0.00\end{array}$ & $\begin{array}{l}1820 \\
1825 \\
1830 \\
1835 \\
1840\end{array}$ & $\begin{array}{l}5.8 \\
5.8 \\
5.8 \\
5.8 \\
5.8\end{array}$ & $\begin{array}{l}0.00 \\
0.00 \\
0.00 \\
0.00 \\
0.00\end{array}$ \\
\hline $\begin{array}{l}0755 \\
0800 \\
0805 \\
0810 \\
0815\end{array}$ & $\begin{array}{l}7.3 \\
7.0 \\
7.0 \\
7.0 \\
6.7\end{array}$ & $\begin{array}{l}0.00 \\
0.00 \\
0.00 \\
0.00 \\
0.00\end{array}$ & $\begin{array}{l}1320 \\
1325 \\
1330 \\
1335 \\
1340\end{array}$ & $\begin{array}{l}22.7 \\
20.5 \\
19.1 \\
17.9 \\
16.9\end{array}$ & $\begin{array}{l}0.00 \\
0.00 \\
0.00 \\
0.00 \\
0.00\end{array}$ & $\begin{array}{l}1845 \\
1850 \\
1855 \\
1900 \\
1905\end{array}$ & $\begin{array}{l}5.5 \\
5.5 \\
5.5 \\
5.5 \\
5.5\end{array}$ & $\begin{array}{l}0.00 \\
0.00 \\
0.00 \\
0.00 \\
0.00\end{array}$ \\
\hline $\begin{array}{l}0820 \\
0825 \\
0830 \\
0835 \\
0840\end{array}$ & $\begin{array}{l}6.7 \\
6.4 \\
6.1 \\
5.8 \\
5.5\end{array}$ & $\begin{array}{l}0.00 \\
0.00 \\
0.00 \\
0.00 \\
0.00\end{array}$ & $\begin{array}{l}1345 \\
1350 \\
1355 \\
1400 \\
1405\end{array}$ & $\begin{array}{l}16.0 \\
15.5 \\
14.6 \\
13.9 \\
13.5\end{array}$ & $\begin{array}{l}0.00 \\
0.00 \\
0.00 \\
0.00 \\
0.00\end{array}$ & $\begin{array}{l}1910 \\
1915 \\
1920 \\
1925 \\
1930\end{array}$ & $\begin{array}{l}5.5 \\
5.5 \\
5.2 \\
5.2 \\
5.2\end{array}$ & $\begin{array}{l}0.00 \\
0.00 \\
0.00 \\
0.00 \\
0.00\end{array}$ \\
\hline $\begin{array}{l}0845 \\
0850 \\
0855 \\
0900 \\
0905\end{array}$ & $\begin{array}{r}5.5 \\
5.2 \\
5.2 \\
6.4 \\
27.4\end{array}$ & $\begin{array}{l}0.01 \\
0.24 \\
0.24 \\
0.23 \\
0.15\end{array}$ & $\begin{array}{l}1410 \\
1415 \\
1420 \\
1425 \\
1430\end{array}$ & $\begin{array}{l}13.1 \\
12.8 \\
12.4 \\
12.0 \\
11.7\end{array}$ & $\begin{array}{l}0.00 \\
0.00 \\
0.00 \\
0.00 \\
0.00\end{array}$ & $\begin{array}{l}1935 \\
1940 \\
1945 \\
1950 \\
1955\end{array}$ & $\begin{array}{l}5.2 \\
5.2 \\
4.9 \\
4.9 \\
4.9\end{array}$ & $\begin{array}{l}0.00 \\
0.00 \\
0.00 \\
0.00 \\
0.00\end{array}$ \\
\hline $\begin{array}{l}0910 \\
0915 \\
0920 \\
0925 \\
0930\end{array}$ & $\begin{array}{l}174.0 \\
316.0 \\
437.0 \\
515.0 \\
567.0\end{array}$ & $\begin{array}{l}0.13 \\
0.07 \\
0.09 \\
0.01 \\
0.00\end{array}$ & $\begin{array}{l}1435 \\
1440 \\
1445 \\
1450 \\
1455\end{array}$ & $\begin{array}{l}11.4 \\
11.0 \\
11.0 \\
10.7 \\
10.7\end{array}$ & $\begin{array}{l}0.00 \\
0.00 \\
0.00 \\
0.01 \\
0.00\end{array}$ & $\begin{array}{l}2000 \\
2005 \\
2010 \\
2015 \\
2020\end{array}$ & $\begin{array}{l}4.9 \\
4.9 \\
4.9 \\
4.9 \\
4.7\end{array}$ & $\begin{array}{l}0.00 \\
0.00 \\
0.00 \\
0.00 \\
0.00\end{array}$ \\
\hline $\begin{array}{l}0935 \\
0940 \\
0945 \\
0950 \\
0955\end{array}$ & $\begin{array}{l}606.0 \\
610.0 \\
623.0 \\
602.0 \\
577.0\end{array}$ & $\begin{array}{l}0.01 \\
0.00 \\
0.00 \\
0.00 \\
0.01\end{array}$ & $\begin{array}{l}1500 \\
1505 \\
1510 \\
1515 \\
1520\end{array}$ & $\begin{array}{l}10.7 \\
10.7 \\
10.3 \\
10.3 \\
10.3\end{array}$ & $\begin{array}{l}0.00 \\
0.00 \\
0.00 \\
0.00 \\
0.00\end{array}$ & $\begin{array}{l}2025 \\
2030 \\
2035 \\
2040 \\
2045\end{array}$ & $\begin{array}{l}4.7 \\
4.7 \\
4.7 \\
4.7 \\
4.7\end{array}$ & $\begin{array}{l}0.00 \\
0.00 \\
0.00 \\
0.00 \\
0.00\end{array}$ \\
\hline $\begin{array}{l}1000 \\
1005 \\
1010 \\
1015 \\
1020\end{array}$ & $\begin{array}{l}550.0 \\
523.0 \\
482.0 \\
441.0 \\
400.0\end{array}$ & $\begin{array}{l}0.00 \\
0.00 \\
0.00 \\
0.00 \\
0.00\end{array}$ & $\begin{array}{l}1525 \\
1530 \\
1535 \\
1540 \\
1545\end{array}$ & $\begin{array}{r}10.3 \\
10.0 \\
10.0 \\
9.7 \\
9.3\end{array}$ & $\begin{array}{l}0.00 \\
0.00 \\
0.00 \\
0.00 \\
0.00\end{array}$ & $\begin{array}{l}2050 \\
2055 \\
2100\end{array}$ & $\begin{array}{l}4.7 \\
4.7 \\
4.7\end{array}$ & $\begin{array}{l}0.00 \\
0.00 \\
0.00\end{array}$ \\
\hline
\end{tabular}




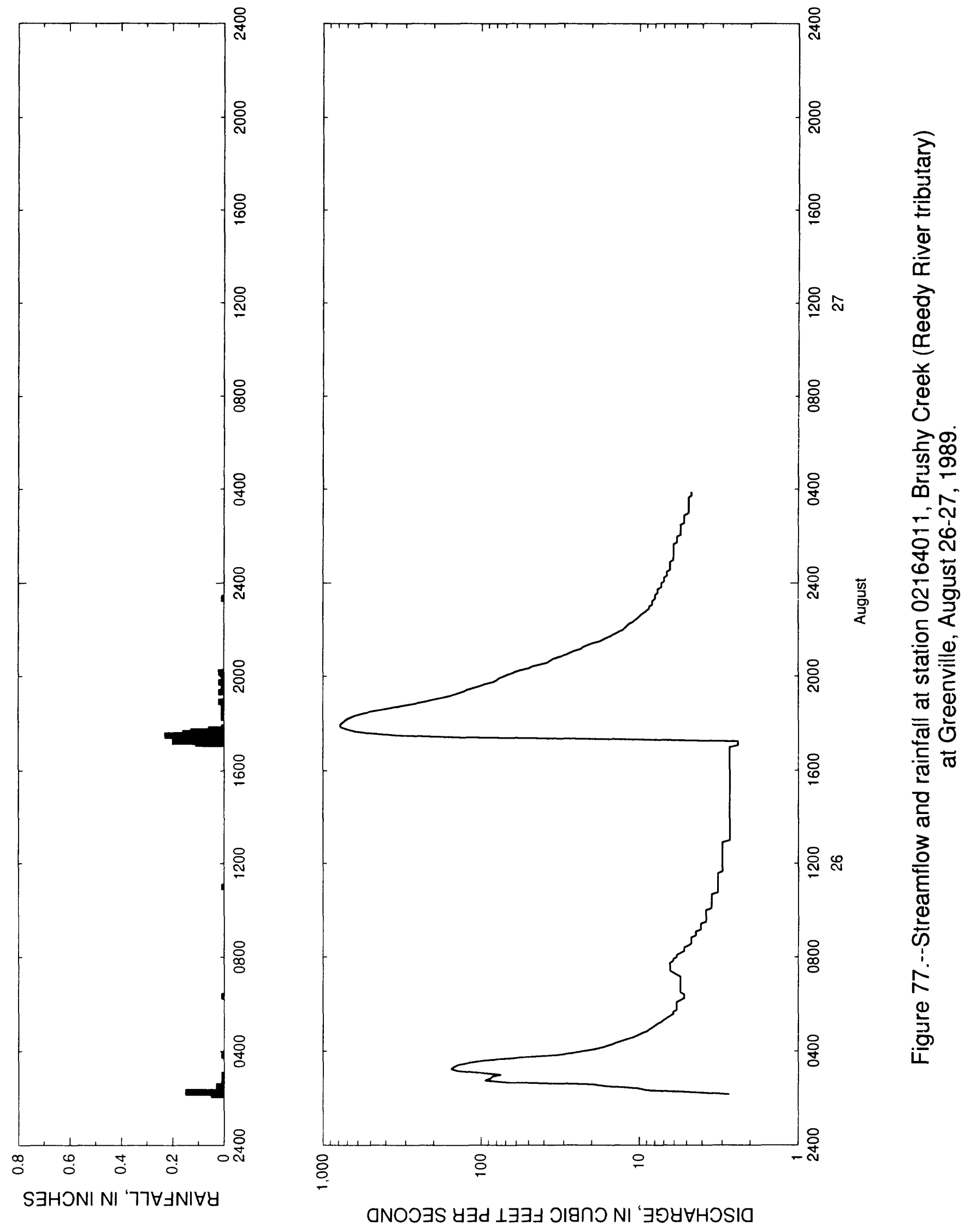


Table 76. - -Streamflow and rainfall at station 02164011, Brushy Creek (Reedy River tributary) at Greenville, August $\frac{\text { ate }}{26-27,1989}$

\begin{tabular}{|c|c|c|c|c|c|c|c|c|}
\hline $\begin{array}{l}\text { Time } \\
\text { (hours) }\end{array}$ & $\begin{array}{l}\text { Streamflow } \\
\text { (cubic feet } \\
\text { per second) }\end{array}$ & $\begin{array}{l}\text { Rain- } \\
\text { fall } \\
\text { (inches) }\end{array}$ & $\begin{array}{l}\text { Time } \\
\text { (hours) }\end{array}$ & $\begin{array}{l}\text { Streamflow } \\
\text { (cubic feet } \\
\text { per second) }\end{array}$ & $\begin{array}{l}\text { Rain- } \\
\text { fall } \\
\text { (inches) }\end{array}$ & $\begin{array}{l}\text { Time } \\
\text { (hours) }\end{array}$ & $\begin{array}{l}\text { Streamflow } \\
\text { (cubic feet } \\
\text { per second) }\end{array}$ & $\begin{array}{l}\text { Rain- } \\
\text { fall } \\
\text { (inches) }\end{array}$ \\
\hline $\begin{array}{c}\text { August } \\
0210 \\
0215 \\
0220 \\
0225\end{array}$ & $\begin{array}{r}1989 \\
2.7 \\
4.4 \\
9.0 \\
10.3\end{array}$ & $\begin{array}{l}0.05 \\
0.15 \\
0.02 \\
0.02\end{array}$ & $\begin{array}{l}0730 \\
0735 \\
0740 \\
0745 \\
0750\end{array}$ & $\begin{array}{l}6.4 \\
6.4 \\
6.4 \\
6.4 \\
6.1\end{array}$ & $\begin{array}{l}0.00 \\
0.00 \\
0.00 \\
0.00 \\
0.00\end{array}$ & $\begin{array}{l}1255 \\
1300 \\
1305 \\
1310 \\
1315\end{array}$ & $\begin{array}{l}3.0 \\
2.7 \\
2.7 \\
2.7 \\
2.7\end{array}$ & $\begin{array}{l}0.00 \\
0.00 \\
0.00 \\
0.00 \\
0.00\end{array}$ \\
\hline $\begin{array}{l}0230 \\
0235 \\
0240 \\
0245 \\
0250\end{array}$ & $\begin{array}{l}16.0 \\
19.8 \\
67.5 \\
95.0 \\
87.5\end{array}$ & $\begin{array}{l}0.03 \\
0.01 \\
0.01 \\
0.01 \\
0.00\end{array}$ & $\begin{array}{l}0755 \\
0800 \\
0805 \\
0810 \\
0815\end{array}$ & $\begin{array}{l}6.1 \\
5.8 \\
5.8 \\
5.5 \\
5.2\end{array}$ & $\begin{array}{l}0.00 \\
0.00 \\
0.00 \\
0.00 \\
0.00\end{array}$ & $\begin{array}{l}1320 \\
1325 \\
1330 \\
1335 \\
1340\end{array}$ & $\begin{array}{l}2.7 \\
2.7 \\
2.7 \\
2.7 \\
2.7\end{array}$ & $\begin{array}{l}0.00 \\
0.00 \\
0.00 \\
0.00 \\
0.00\end{array}$ \\
\hline $\begin{array}{l}0255 \\
0300 \\
0305 \\
0310 \\
0315\end{array}$ & $\begin{array}{r}85.0 \\
75.0 \\
102.0 \\
142.0 \\
156.0\end{array}$ & $\begin{array}{l}0.00 \\
0.01 \\
0.00 \\
0.00 \\
0.00\end{array}$ & $\begin{array}{l}0820 \\
0825 \\
0830 \\
0835 \\
0840\end{array}$ & $\begin{array}{l}5.2 \\
5.2 \\
4.9 \\
4.7 \\
4.7\end{array}$ & $\begin{array}{l}0.00 \\
0.00 \\
0.00 \\
0.00 \\
0.00\end{array}$ & $\begin{array}{l}1345 \\
1350 \\
1355 \\
1400 \\
1405\end{array}$ & $\begin{array}{l}2.7 \\
2.7 \\
2.7 \\
2.7 \\
2.7\end{array}$ & $\begin{array}{l}0.00 \\
0.00 \\
0.00 \\
0.00 \\
0.00\end{array}$ \\
\hline $\begin{array}{l}0320 \\
0325 \\
0330 \\
0335 \\
0340\end{array}$ & $\begin{array}{r}149.0 \\
140.0 \\
121.0 \\
100.0 \\
75.0\end{array}$ & $\begin{array}{l}0.00 \\
0.00 \\
0.00 \\
0.00 \\
0.00\end{array}$ & $\begin{array}{l}0845 \\
0850 \\
0855 \\
0900 \\
0905\end{array}$ & $\begin{array}{l}4.7 \\
4.7 \\
4.4 \\
4.4 \\
4.4\end{array}$ & $\begin{array}{l}0.00 \\
0.00 \\
0.00 \\
0.00 \\
0.00\end{array}$ & $\begin{array}{l}1410 \\
1415 \\
1420 \\
1425 \\
1430\end{array}$ & $\begin{array}{l}2.7 \\
2.7 \\
2.7 \\
2.7 \\
2.7\end{array}$ & $\begin{array}{l}0.00 \\
0.00 \\
0.00 \\
0.00 \\
0.00\end{array}$ \\
\hline $\begin{array}{l}0345 \\
0350 \\
0355 \\
0400 \\
0405\end{array}$ & $\begin{array}{l}50.0 \\
33.3 \\
26.6 \\
22.7 \\
19.1\end{array}$ & $\begin{array}{l}0.00 \\
0.01 \\
0.00 \\
0.00 \\
0.00\end{array}$ & $\begin{array}{l}0910 \\
0915 \\
0920 \\
0925 \\
0930\end{array}$ & $\begin{array}{l}4.1 \\
4.1 \\
4.1 \\
4.1 \\
3 \cdot 8\end{array}$ & $\begin{array}{l}0.00 \\
0.00 \\
0.00 \\
0.00 \\
0.00\end{array}$ & $\begin{array}{l}1435 \\
1440 \\
1445 \\
1450 \\
1455\end{array}$ & $\begin{array}{l}2.7 \\
2.7 \\
2.7 \\
2.7 \\
2.7\end{array}$ & $\begin{array}{l}0.00 \\
0.00 \\
0.00 \\
0.00 \\
0.00\end{array}$ \\
\hline $\begin{array}{l}0410 \\
0415 \\
0420 \\
0425 \\
0430\end{array}$ & $\begin{array}{l}16.9 \\
15.5 \\
14.2 \\
13.1 \\
12.0\end{array}$ & $\begin{array}{l}0.00 \\
0.00 \\
0.00 \\
0.00 \\
0.00\end{array}$ & $\begin{array}{l}0935 \\
0940 \\
0945 \\
0950 \\
0955\end{array}$ & $\begin{array}{l}3.8 \\
3.8 \\
3.8 \\
3.8 \\
3.8\end{array}$ & $\begin{array}{l}0.00 \\
0.00 \\
0.00 \\
0.00 \\
0.00\end{array}$ & $\begin{array}{l}1500 \\
1505 \\
1510 \\
1515 \\
1520\end{array}$ & $\begin{array}{l}2.7 \\
2.7 \\
2.7 \\
2.7 \\
2.7\end{array}$ & $\begin{array}{l}0.00 \\
0.00 \\
0.00 \\
0.00 \\
0.00\end{array}$ \\
\hline $\begin{array}{l}0435 \\
0440 \\
0445 \\
0450 \\
0455\end{array}$ & $\begin{array}{r}11.0 \\
10.3 \\
9.7 \\
9.0 \\
8.7\end{array}$ & $\begin{array}{l}0.00 \\
0.00 \\
0.00 \\
0.00 \\
0.00\end{array}$ & $\begin{array}{l}1000 \\
1005 \\
1010 \\
1015 \\
1020\end{array}$ & $\begin{array}{l}3.8 \\
3.5 \\
3.5 \\
3.5 \\
3.5\end{array}$ & $\begin{array}{l}0.00 \\
0.00 \\
0.00 \\
0.00 \\
0.00\end{array}$ & $\begin{array}{l}1525 \\
1530 \\
1535 \\
1540 \\
1545\end{array}$ & $\begin{array}{l}2.7 \\
2.7 \\
2.7 \\
2.7 \\
2.7\end{array}$ & $\begin{array}{l}0.00 \\
0.00 \\
0.00 \\
0.00 \\
0.00\end{array}$ \\
\hline $\begin{array}{l}0500 \\
0505 \\
0510 \\
0515 \\
0520\end{array}$ & $\begin{array}{l}8.3 \\
8.0 \\
7.7 \\
7.3 \\
7.0\end{array}$ & $\begin{array}{l}0.00 \\
0.00 \\
0.00 \\
0.00 \\
0.00\end{array}$ & $\begin{array}{l}1025 \\
1030 \\
1035 \\
1040 \\
1045\end{array}$ & $\begin{array}{l}3.5 \\
3.5 \\
3.5 \\
3.5 \\
3.2\end{array}$ & $\begin{array}{l}0.00 \\
0.00 \\
0.00 \\
0.00 \\
0.00\end{array}$ & $\begin{array}{l}1550 \\
1555 \\
1600 \\
1605 \\
1610\end{array}$ & $\begin{array}{l}2.7 \\
2.7 \\
2.7 \\
2.7 \\
2.7\end{array}$ & $\begin{array}{l}0.00 \\
0.00 \\
0.00 \\
0.00 \\
0.00\end{array}$ \\
\hline $\begin{array}{l}0525 \\
0530 \\
0535 \\
0540 \\
0545\end{array}$ & $\begin{array}{l}6.7 \\
6.4 \\
6.1 \\
6.1 \\
5.8\end{array}$ & $\begin{array}{l}0.00 \\
0.00 \\
0.00 \\
0.00 \\
0.00\end{array}$ & $\begin{array}{l}1050 \\
1055 \\
1100 \\
1105 \\
1110\end{array}$ & $\begin{array}{l}3.2 \\
3.2 \\
3.2 \\
3.2 \\
3.2\end{array}$ & $\begin{array}{l}0.00 \\
0.00 \\
0.01 \\
0.00 \\
0.00\end{array}$ & $\begin{array}{l}1615 \\
1620 \\
1625 \\
1630 \\
1635\end{array}$ & $\begin{array}{l}2.7 \\
2.7 \\
2.7 \\
2.7 \\
2.7\end{array}$ & $\begin{array}{l}0.00 \\
0.00 \\
0.00 \\
0.00 \\
0.00\end{array}$ \\
\hline $\begin{array}{l}0550 \\
0555 \\
0600 \\
0605 \\
0610\end{array}$ & $\begin{array}{l}5.8 \\
5.8 \\
5.8 \\
5.8 \\
5.5\end{array}$ & $\begin{array}{l}0.00 \\
0.00 \\
0.00 \\
0.00 \\
0.00\end{array}$ & $\begin{array}{l}1115 \\
1120 \\
1125 \\
1130 \\
1135\end{array}$ & $\begin{array}{l}3.2 \\
3.2 \\
3.2 \\
3.2 \\
3.2\end{array}$ & $\begin{array}{l}0.00 \\
0.00 \\
0.00 \\
0.00 \\
0.00\end{array}$ & $\begin{array}{l}1640 \\
1645 \\
1650 \\
1655 \\
1700\end{array}$ & $\begin{array}{l}2.7 \\
2.7 \\
2.7 \\
2.7 \\
2.7\end{array}$ & $\begin{array}{l}0.00 \\
0.00 \\
0.00 \\
0.00 \\
0.00\end{array}$ \\
\hline $\begin{array}{l}0615 \\
0620 \\
0625 \\
0630 \\
0635\end{array}$ & $\begin{array}{l}5.2 \\
5.2 \\
5.2 \\
5.5 \\
5.5\end{array}$ & $\begin{array}{l}0.00 \\
0.01 \\
0.00 \\
0.00 \\
0.00\end{array}$ & $\begin{array}{l}1140 \\
1145 \\
1150 \\
1155 \\
1200\end{array}$ & $\begin{array}{l}3.0 \\
3.0 \\
3.0 \\
3.0 \\
3.0\end{array}$ & $\begin{array}{l}0.00 \\
0.00 \\
0.00 \\
0.00 \\
0.00\end{array}$ & $\begin{array}{l}1705 \\
1710 \\
1715 \\
1720 \\
1725\end{array}$ & $\begin{array}{r}2.4 \\
2.4 \\
2.4 \\
12.4 \\
137.0\end{array}$ & $\begin{array}{l}0.00 \\
0.11 \\
0.20 \\
0.16 \\
0.19\end{array}$ \\
\hline $\begin{array}{l}0640 \\
0645 \\
0650 \\
0655 \\
0700\end{array}$ & $\begin{array}{l}5.5 \\
5.5 \\
5.5 \\
5.5 \\
5.5\end{array}$ & $\begin{array}{l}0.00 \\
0.00 \\
0.00 \\
0.00 \\
0.00\end{array}$ & $\begin{array}{l}1205 \\
1210 \\
1215 \\
1220 \\
1225\end{array}$ & $\begin{array}{l}3.0 \\
3.0 \\
3.0 \\
3.0 \\
3.0\end{array}$ & $\begin{array}{l}0.00 \\
0.00 \\
0.00 \\
0.00 \\
0.00\end{array}$ & $\begin{array}{l}1730 \\
1735 \\
1740 \\
1745 \\
1750\end{array}$ & $\begin{array}{l}347.0 \\
508.0 \\
629.0 \\
702.0 \\
767.0\end{array}$ & $\begin{array}{l}0.23 \\
0.16 \\
0.13 \\
0.06 \\
0.01\end{array}$ \\
\hline $\begin{array}{l}0705 \\
0710 \\
0715 \\
0720 \\
0725\end{array}$ & $\begin{array}{l}5.5 \\
5.5 \\
5.8 \\
6.1 \\
6.4\end{array}$ & $\begin{array}{l}0.00 \\
0.00 \\
0.00 \\
0.00 \\
0.00\end{array}$ & $\begin{array}{l}1230 \\
1235 \\
1240 \\
1245 \\
1250\end{array}$ & $\begin{array}{l}3.0 \\
3.0 \\
3.0 \\
3.0 \\
3.0\end{array}$ & $\begin{array}{l}0.00 \\
0.00 \\
0.00 \\
0.00 \\
0.00\end{array}$ & $\begin{array}{l}1755 \\
1800 \\
1805 \\
1810 \\
1815\end{array}$ & $\begin{array}{l}787.0 \\
771.0 \\
740.0 \\
709.0 \\
667.0\end{array}$ & $\begin{array}{l}0.00 \\
0.00 \\
0.00 \\
0.00 \\
0.01\end{array}$ \\
\hline
\end{tabular}


Table $76 .--$ Streamflow and rainfall at station 02164011 , Brushy Creek (Reedy River tributary) at Greenville, August $26-27,1989--$ Continued

\begin{tabular}{|c|c|c|c|c|c|c|c|c|}
\hline $\begin{array}{l}\text { Time } \\
\text { (hours) }\end{array}$ & $\begin{array}{l}\text { Streamflow } \\
\text { (cubic feet } \\
\text { per second) }\end{array}$ & $\begin{array}{l}\text { Rain- } \\
\text { fall } \\
\text { (inches) }\end{array}$ & $\begin{array}{l}\text { Time } \\
\text { (hours) }\end{array}$ & $\begin{array}{l}\text { Streamflow } \\
\text { (cubic feet } \\
\text { per second) }\end{array}$ & $\begin{array}{l}\text { Rain- } \\
\text { fall } \\
\text { (inches) }\end{array}$ & $\begin{array}{l}\text { Time } \\
\text { (hours) }\end{array}$ & $\begin{array}{l}\text { Streamflow } \\
\text { (cubic feet } \\
\text { per second) }\end{array}$ & $\begin{array}{l}\text { Rain- } \\
\text { fall } \\
\text { (inches) }\end{array}$ \\
\hline $\begin{array}{l}1820 \\
1825 \\
1830 \\
1835 \\
1840\end{array}$ & $\begin{array}{l}621.0 \\
562.0 \\
496.0 \\
425.0 \\
365.0\end{array}$ & $\begin{array}{l}0.00 \\
0.01 \\
0.01 \\
0.00 \\
0.00\end{array}$ & $\begin{array}{l}2140 \\
2145 \\
2150 \\
2155 \\
2200\end{array}$ & $\begin{array}{l}16.0 \\
15.0 \\
14.2 \\
13.5 \\
12.8\end{array}$ & $\begin{array}{l}0.00 \\
0.00 \\
0.00 \\
0.00 \\
0.00\end{array}$ & $\begin{array}{l}0055 \\
0100 \\
0105 \\
0110 \\
0115\end{array}$ & $\begin{array}{l}6.4 \\
6.1 \\
6.1 \\
6.1 \\
6.1\end{array}$ & $\begin{array}{l}0.00 \\
0.00 \\
0.00 \\
0.00 \\
0.00\end{array}$ \\
\hline $\begin{array}{l}1845 \\
1850 \\
1855 \\
1900 \\
1905\end{array}$ & $\begin{array}{l}310.0 \\
265.0 \\
228.0 \\
202.0 \\
177.0\end{array}$ & $\begin{array}{l}0.01 \\
0.00 \\
0.02 \\
0.00 \\
0.00\end{array}$ & $\begin{array}{l}2205 \\
2210 \\
2215 \\
2220 \\
2225\end{array}$ & $\begin{array}{l}12.4 \\
12.0 \\
11.7 \\
11.0 \\
10.7\end{array}$ & $\begin{array}{l}0.00 \\
0.00 \\
0.00 \\
0.00 \\
0.00\end{array}$ & $\begin{array}{l}0120 \\
0125 \\
0130 \\
0135 \\
0140\end{array}$ & $\begin{array}{l}6.1 \\
6.1 \\
6.1 \\
6.1 \\
6.1\end{array}$ & $\begin{array}{l}0.0 C \\
0.0 C \\
0.0 C \\
0.0 C \\
0.00\end{array}$ \\
\hline $\begin{array}{l}1910 \\
1915 \\
1920 \\
1925 \\
1930\end{array}$ & $\begin{array}{l}158.0 \\
144.0 \\
133.0 \\
123.0 \\
112.0\end{array}$ & $\begin{array}{l}0.00 \\
0.00 \\
0.02 \\
0.01 \\
0.01\end{array}$ & $\begin{array}{l}2230 \\
2235 \\
2240 \\
2245 \\
2250\end{array}$ & $\begin{array}{r}10.3 \\
10.0 \\
9.7 \\
9.3 \\
9.0\end{array}$ & $\begin{array}{l}0.00 \\
0.00 \\
0.00 \\
0.00 \\
0.00\end{array}$ & $\begin{array}{l}0145 \\
0150 \\
0155 \\
0200 \\
0205\end{array}$ & $\begin{array}{l}5.8 \\
5.8 \\
5.8 \\
5.8 \\
5.5\end{array}$ & $\begin{array}{l}0.00 \\
0.00 \\
0.00 \\
0.00 \\
0.00\end{array}$ \\
\hline $\begin{array}{l}1935 \\
1940 \\
1945 \\
1950 \\
1955\end{array}$ & $\begin{array}{r}102.0 \\
95.0 \\
85.0 \\
80.0 \\
77.5\end{array}$ & $\begin{array}{l}0.00 \\
0.01 \\
0.02 \\
0.00 \\
0.01\end{array}$ & $\begin{array}{l}2255 \\
2300 \\
2305 \\
2310 \\
2315\end{array}$ & $\begin{array}{l}8.7 \\
8.7 \\
8.3 \\
8.3 \\
8.3\end{array}$ & $\begin{array}{l}0.00 \\
0.00 \\
0.00 \\
0.00 \\
0.00\end{array}$ & $\begin{array}{l}0210 \\
0215 \\
0220 \\
0225 \\
0230\end{array}$ & $\begin{array}{l}5.5 \\
5.5 \\
5.5 \\
5.5 \\
5.5\end{array}$ & $\begin{array}{l}0.00 \\
0.00 \\
0.07 \\
0.07 \\
0.00\end{array}$ \\
\hline $\begin{array}{l}2000 \\
2005 \\
2010 \\
2015 \\
2020\end{array}$ & $\begin{array}{l}72.5 \\
67.5 \\
62.5 \\
56.7 \\
50.0\end{array}$ & $\begin{array}{l}0.00 \\
0.00 \\
0.02 \\
0.00 \\
0.00\end{array}$ & $\begin{array}{l}2320 \\
2325 \\
2330 \\
2335 \\
2340\end{array}$ & $\begin{array}{l}8.0 \\
8.0 \\
8.0 \\
7.7 \\
7.7\end{array}$ & $\begin{array}{l}0.01 \\
0.00 \\
0.00 \\
0.00 \\
0.00\end{array}$ & $\begin{array}{l}0235 \\
0240 \\
0245 \\
0250 \\
0255\end{array}$ & $\begin{array}{l}5.2 \\
5.2 \\
5.2 \\
5.2 \\
5.2\end{array}$ & $\begin{array}{l}0.07 \\
0.00 \\
0.07 \\
0.00 \\
0.00\end{array}$ \\
\hline $\begin{array}{l}2025 \\
2030 \\
2035 \\
2040 \\
2045\end{array}$ & $\begin{array}{l}47.5 \\
42.5 \\
38.3 \\
36.7 \\
35.0\end{array}$ & $\begin{array}{l}0.00 \\
0.00 \\
0.00 \\
0.00 \\
0.00\end{array}$ & $\begin{array}{c}2345 \\
2350 \\
2355 \\
\text { August } \\
0000\end{array}$ & $\begin{array}{r}7.7 \\
7.3 \\
7.3 \\
27,1989.3 \\
7.3\end{array}$ & $\begin{array}{l}0.00 \\
0.00 \\
0.00 \\
0.00\end{array}$ & $\begin{array}{l}0300 \\
0305 \\
0310 \\
0315 \\
0320\end{array}$ & $\begin{array}{l}4.9 \\
4.9 \\
4.9 \\
4.9 \\
4.9\end{array}$ & $\begin{array}{l}0.00 \\
0.00 \\
0.00 \\
0 . C 0 \\
0 . C 0\end{array}$ \\
\hline $\begin{array}{l}2050 \\
2055 \\
2100 \\
2105 \\
2110\end{array}$ & $\begin{array}{l}31.7 \\
29.1 \\
27.4 \\
25.8 \\
23.5\end{array}$ & $\begin{array}{l}0.00 \\
0.00 \\
0.00 \\
0.00 \\
0.00\end{array}$ & $\begin{array}{l}0005 \\
0010 \\
0015 \\
0020 \\
0025\end{array}$ & $\begin{array}{l}7.0 \\
7.0 \\
7.0 \\
6.7 \\
6.7\end{array}$ & $\begin{array}{l}0.00 \\
0.00 \\
0.00 \\
0.00 \\
0.00\end{array}$ & $\begin{array}{l}0325 \\
0330 \\
0335 \\
0340 \\
0345\end{array}$ & $\begin{array}{l}4.9 \\
4.9 \\
4.9 \\
4.9 \\
4.7\end{array}$ & $\begin{array}{l}0.00 \\
0.00 \\
0.00 \\
0.00 \\
0.00\end{array}$ \\
\hline $\begin{array}{l}2115 \\
2120 \\
2125 \\
2130 \\
2135\end{array}$ & $\begin{array}{l}22.7 \\
21.2 \\
19.8 \\
17.9 \\
16.9\end{array}$ & $\begin{array}{l}0.00 \\
0.00 \\
0.00 \\
0.00 \\
0.00\end{array}$ & $\begin{array}{l}0030 \\
0035 \\
0040 \\
0045 \\
0050\end{array}$ & $\begin{array}{l}6.7 \\
6.4 \\
6.4 \\
6.4 \\
6.4\end{array}$ & $\begin{array}{l}0.00 \\
0.00 \\
0.00 \\
0.00 \\
0.00\end{array}$ & $\begin{array}{l}0350 \\
0355 \\
0400\end{array}$ & $\begin{array}{l}4.7 \\
4.7 \\
4.7\end{array}$ & $\begin{array}{l}0.00 \\
0.00 \\
0.00\end{array}$ \\
\hline
\end{tabular}



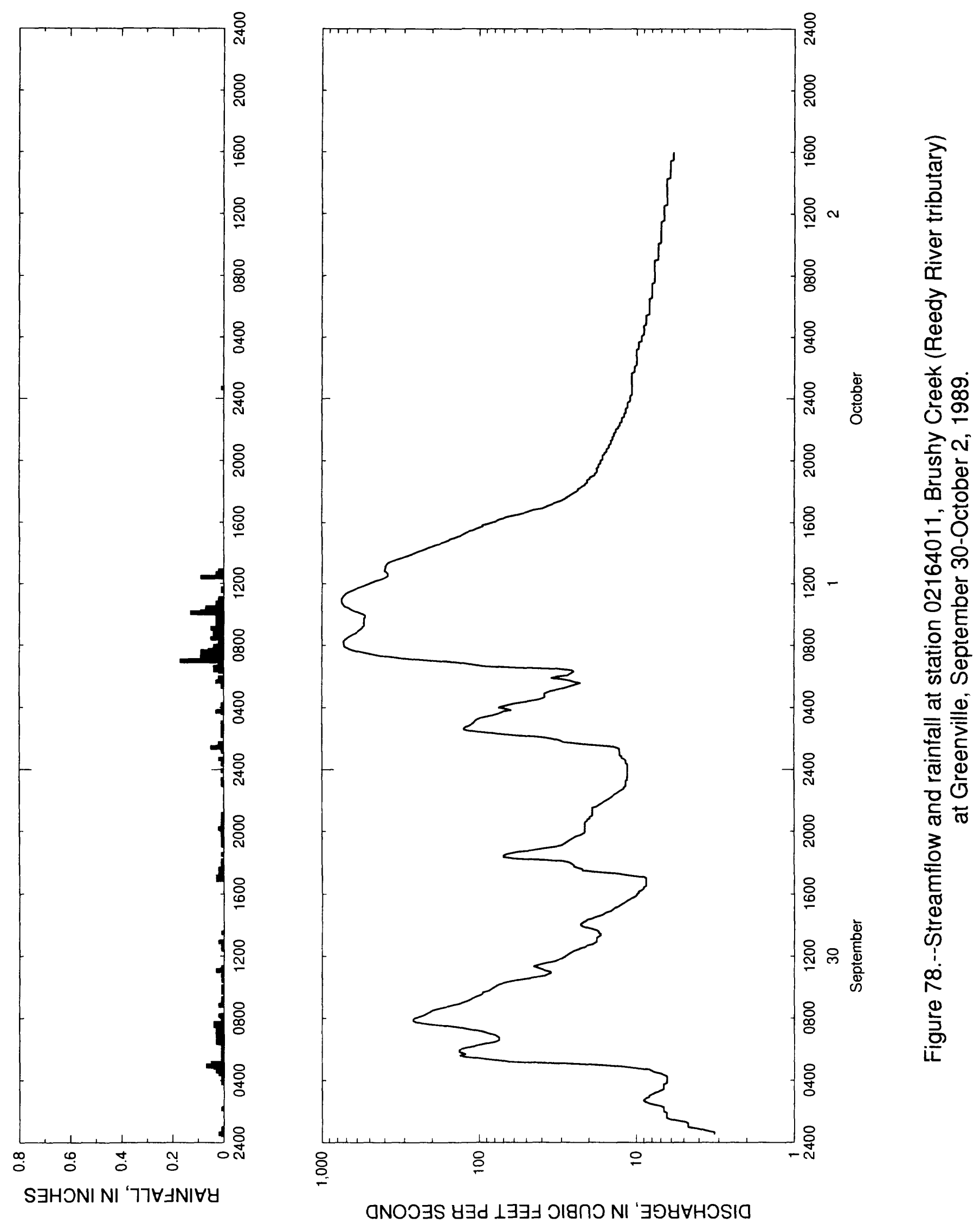
Table 77. - Streamflow and rainfall at station 02164011, Brushy Creek (Reedy River tributary) at Greenville, September 30 - October 2, 1989

\begin{tabular}{|c|c|c|c|c|c|c|c|c|}
\hline $\begin{array}{l}\text { Time } \\
\text { (hours) }\end{array}$ & $\begin{array}{l}\text { Streamflow } \\
\text { (cubic feet } \\
\text { per second) }\end{array}$ & $\begin{array}{l}\text { Rain- } \\
\text { fall } \\
\text { (inches) }\end{array}$ & $\begin{array}{l}\text { Time } \\
\text { (hours) }\end{array}$ & $\begin{array}{l}\text { Streamflow } \\
\text { (cubic feet } \\
\text { per second) }\end{array}$ & $\begin{array}{l}\text { Rain- } \\
\text { fall } \\
\text { (inches) }\end{array}$ & $\begin{array}{l}\text { Time } \\
\text { (hours) }\end{array}$ & $\begin{array}{l}\text { Streamflow } \\
\text { (cubic feet } \\
\text { per second) }\end{array}$ & $\begin{array}{l}\text { Rain- } \\
\text { fall } \\
\text { (inches) }\end{array}$ \\
\hline $\begin{array}{l}\text { September } \\
0030 \\
0035 \\
0040 \\
0045\end{array}$ & $\begin{array}{l}30,1989 \\
3.2 \\
3.2 \\
3.2 \\
3.5\end{array}$ & $\begin{array}{l}0.01 \\
0.02 \\
0.01 \\
0.01\end{array}$ & $\begin{array}{l}0550 \\
0555 \\
0600 \\
0605 \\
0610\end{array}$ & $\begin{array}{l}135.0 \\
135.0 \\
130.0 \\
121.0 \\
109.0\end{array}$ & $\begin{array}{l}0.01 \\
0.00 \\
0.01 \\
0.01 \\
0.00\end{array}$ & $\begin{array}{l}1115 \\
1120 \\
1125 \\
1130 \\
1135\end{array}$ & $\begin{array}{l}42.5 \\
45.0 \\
42.5 \\
40.0 \\
36.7\end{array}$ & $\begin{array}{l}0.01 \\
0.00 \\
0.07 \\
0.07 \\
0.00\end{array}$ \\
\hline $\begin{array}{l}0050 \\
0055 \\
0100 \\
0105 \\
0110\end{array}$ & $\begin{array}{l}3.8 \\
4.1 \\
4.7 \\
4.7 \\
4.7\end{array}$ & $\begin{array}{l}0.00 \\
0.01 \\
0.00 \\
0.00 \\
0.00\end{array}$ & $\begin{array}{l}0615 \\
0620 \\
0625 \\
0630 \\
0635\end{array}$ & $\begin{array}{r}100.0 \\
92.5 \\
82.5 \\
77.5 \\
75.0\end{array}$ & $\begin{array}{l}0.01 \\
0.00 \\
0.03 \\
0.02 \\
0.01\end{array}$ & $\begin{array}{l}1140 \\
1145 \\
1150 \\
1155 \\
1200\end{array}$ & $\begin{array}{l}33.3 \\
31.7 \\
30.0 \\
29.1 \\
28.2\end{array}$ & $\begin{array}{l}0.07 \\
0.07 \\
0.07 \\
0.09 \\
0.07\end{array}$ \\
\hline $\begin{array}{l}0115 \\
0120 \\
0125 \\
0130 \\
0135\end{array}$ & $\begin{array}{l}4.7 \\
4.9 \\
5.5 \\
6.1 \\
6.4\end{array}$ & $\begin{array}{l}0.00 \\
0.00 \\
0.00 \\
0.00 \\
0.00\end{array}$ & $\begin{array}{l}0640 \\
0645 \\
0650 \\
0655 \\
0700\end{array}$ & $\begin{array}{l}75.0 \\
75.0 \\
77.5 \\
80.0 \\
87.5\end{array}$ & $\begin{array}{l}0.03 \\
0.01 \\
0.03 \\
0.01 \\
0.03\end{array}$ & $\begin{array}{l}1205 \\
1210 \\
1215 \\
1220 \\
1225\end{array}$ & $\begin{array}{l}27.4 \\
26.6 \\
25.8 \\
25.0 \\
23.5\end{array}$ & $\begin{array}{l}0.0 ? \\
0.0 ? \\
0.00 \\
0.0 ? \\
0.01\end{array}$ \\
\hline $\begin{array}{l}0140 \\
0145 \\
0150 \\
0155 \\
0200\end{array}$ & $\begin{array}{l}6.4 \\
6.4 \\
6.4 \\
6.4 \\
6.7\end{array}$ & $\begin{array}{l}0.00 \\
0.00 \\
0.00 \\
0.00 \\
0.00\end{array}$ & $\begin{array}{l}0705 \\
0710 \\
0715 \\
0720 \\
0725\end{array}$ & $\begin{array}{r}92.5 \\
102.0 \\
114.0 \\
126.0 \\
140.0\end{array}$ & $\begin{array}{l}0.02 \\
0.01 \\
0.00 \\
0.03 \\
0.02\end{array}$ & $\begin{array}{l}1230 \\
1235 \\
1240 \\
1245 \\
1250\end{array}$ & $\begin{array}{l}22.7 \\
21.2 \\
20.5 \\
19.1 \\
18.4\end{array}$ & $\begin{array}{l}0.00 \\
0.00 \\
0.0 ? \\
0.01 \\
0.00\end{array}$ \\
\hline $\begin{array}{l}0205 \\
0210 \\
0215 \\
0220 \\
0225\end{array}$ & $\begin{array}{l}6.7 \\
6.7 \\
6.7 \\
7.0 \\
7.7\end{array}$ & $\begin{array}{l}0.00 \\
0.01 \\
0.00 \\
0.00 \\
0.00\end{array}$ & $\begin{array}{l}0730 \\
0735 \\
0740 \\
0745 \\
0750\end{array}$ & $\begin{array}{l}165.0 \\
204.0 \\
235.0 \\
256.0 \\
265.0\end{array}$ & $\begin{array}{l}0.04 \\
0.04 \\
0.04 \\
0.00 \\
0.01\end{array}$ & $\begin{array}{l}1255 \\
1300 \\
1305 \\
1310 \\
1315\end{array}$ & $\begin{array}{l}17.9 \\
17.9 \\
17.9 \\
17.9 \\
17.4\end{array}$ & $\begin{array}{l}0.02 \\
0.07 \\
0.07 \\
0.07 \\
0.00\end{array}$ \\
\hline $\begin{array}{l}0230 \\
0235 \\
0240 \\
0245 \\
0250\end{array}$ & $\begin{array}{l}8.3 \\
8.7 \\
9.0 \\
9.0 \\
8.7\end{array}$ & $\begin{array}{l}0.00 \\
0.00 \\
0.00 \\
0.00 \\
0.00\end{array}$ & $\begin{array}{l}0755 \\
0800 \\
0805 \\
0810 \\
0815\end{array}$ & $\begin{array}{l}265.0 \\
259.0 \\
241.0 \\
228.0 \\
220.0\end{array}$ & $\begin{array}{l}0.00 \\
0.00 \\
0.00 \\
0.02 \\
0.00\end{array}$ & $\begin{array}{l}1320 \\
1325 \\
1330 \\
1335 \\
1340\end{array}$ & $\begin{array}{l}16.9 \\
16.9 \\
17.4 \\
17.4 \\
17.9\end{array}$ & $\begin{array}{l}0.02 \\
0.00 \\
0.01 \\
0.07 \\
0.02\end{array}$ \\
\hline $\begin{array}{l}0255 \\
0300 \\
0305 \\
0310 \\
0315\end{array}$ & $\begin{array}{l}8.3 \\
8.3 \\
8.0 \\
7.7 \\
7.3\end{array}$ & $\begin{array}{l}0.00 \\
0.00 \\
0.00 \\
0.00 \\
0.00\end{array}$ & $\begin{array}{l}0820 \\
0825 \\
0830 \\
0835 \\
0840\end{array}$ & $\begin{array}{l}213.0 \\
206.0 \\
200.0 \\
188.0 \\
174.0\end{array}$ & $\begin{array}{l}0.00 \\
0.00 \\
0.00 \\
0.00 \\
0.00\end{array}$ & $\begin{array}{l}1345 \\
1350 \\
1355 \\
1400 \\
1405\end{array}$ & $\begin{array}{l}19.1 \\
20.5 \\
22.0 \\
22.7 \\
22.7\end{array}$ & $\begin{array}{l}0.00 \\
0.02 \\
0.00 \\
0.07 \\
0.00\end{array}$ \\
\hline $\begin{array}{l}0320 \\
0325 \\
0330 \\
0335 \\
0340\end{array}$ & $\begin{array}{l}7.0 \\
6.7 \\
6.7 \\
6.7 \\
6.7\end{array}$ & $\begin{array}{l}0.00 \\
0.00 \\
0.00 \\
0.00 \\
0.00\end{array}$ & $\begin{array}{l}0845 \\
0850 \\
0855 \\
0900 \\
0905\end{array}$ & $\begin{array}{l}160.0 \\
149.0 \\
137.0 \\
128.0 \\
121.0\end{array}$ & $\begin{array}{l}0.00 \\
0.02 \\
0.01 \\
0.01 \\
0.00\end{array}$ & $\begin{array}{l}1410 \\
1415 \\
1420 \\
1425 \\
1430\end{array}$ & $\begin{array}{l}22.0 \\
21.2 \\
20.5 \\
19.1 \\
18.4\end{array}$ & $\begin{array}{l}0.00 \\
0.00 \\
0.00 \\
0.00 \\
0.00\end{array}$ \\
\hline $\begin{array}{l}0345 \\
0350 \\
0355 \\
0400 \\
0405\end{array}$ & $\begin{array}{l}6.7 \\
6.4 \\
6.4 \\
6.4 \\
6.4\end{array}$ & $\begin{array}{l}0.00 \\
0.01 \\
0.00 \\
0.01 \\
0.00\end{array}$ & $\begin{array}{l}0910 \\
0915 \\
0920 \\
0925 \\
0930\end{array}$ & $\begin{array}{r}116.0 \\
112.0 \\
107.0 \\
102.0 \\
97.5\end{array}$ & $\begin{array}{l}0.00 \\
0.01 \\
0.00 \\
0.00 \\
0.00\end{array}$ & $\begin{array}{l}1435 \\
1440 \\
1445 \\
1450 \\
1455\end{array}$ & $\begin{array}{l}17.4 \\
16.4 \\
16.0 \\
15.5 \\
14.6\end{array}$ & $\begin{array}{l}0.02 \\
0.00 \\
0.00 \\
0.00 \\
0.00\end{array}$ \\
\hline $\begin{array}{l}0410 \\
0415 \\
0420 \\
0425 \\
0430\end{array}$ & $\begin{array}{l}6.4 \\
6.4 \\
6.7 \\
7.0 \\
7.7\end{array}$ & $\begin{array}{l}0.00 \\
0.01 \\
0.01 \\
0.02 \\
0.00\end{array}$ & $\begin{array}{l}0935 \\
0940 \\
0945 \\
0950 \\
0955\end{array}$ & $\begin{array}{l}95.0 \\
95.0 \\
87.5 \\
85.0 \\
82.5\end{array}$ & $\begin{array}{l}0.00 \\
0.01 \\
0.00 \\
0.00 \\
0.01\end{array}$ & $\begin{array}{l}1500 \\
1505 \\
1510 \\
1515 \\
1520\end{array}$ & $\begin{array}{l}14.2 \\
13.9 \\
13.1 \\
12.8 \\
12.4\end{array}$ & $\begin{array}{l}0.00 \\
0.00 \\
0.02 \\
0.09 \\
0.00\end{array}$ \\
\hline $\begin{array}{l}0435 \\
0440 \\
0445 \\
0450 \\
0455\end{array}$ & $\begin{array}{r}8.0 \\
8.3 \\
9.7 \\
11.4 \\
13.9\end{array}$ & $\begin{array}{l}0.03 \\
0.00 \\
0.01 \\
0.04 \\
0.07\end{array}$ & $\begin{array}{l}1000 \\
1005 \\
1010 \\
1015 \\
1020\end{array}$ & $\begin{array}{l}80.0 \\
77.5 \\
75.0 \\
70.0 \\
65.0\end{array}$ & $\begin{array}{l}0.01 \\
0.00 \\
0.00 \\
0.00 \\
0.00\end{array}$ & $\begin{array}{l}1525 \\
1530 \\
1535 \\
1540 \\
1545\end{array}$ & $\begin{array}{l}12.0 \\
11.7 \\
11.4 \\
11.0 \\
10.7\end{array}$ & $\begin{array}{l}0.00 \\
0.00 \\
0.00 \\
0.00 \\
0.00\end{array}$ \\
\hline $\begin{array}{l}0500 \\
0505 \\
0510 \\
0515 \\
0520\end{array}$ & $\begin{array}{l}19.4 \\
31.7 \\
65.0 \\
72.5 \\
90.6\end{array}$ & $\begin{array}{l}0.03 \\
0.05 \\
0.01 \\
0.01 \\
0.00\end{array}$ & $\begin{array}{l}1025 \\
1030 \\
1035 \\
1040 \\
1045\end{array}$ & $\begin{array}{l}60.0 \\
53.3 \\
47.5 \\
42.5 \\
38.3\end{array}$ & $\begin{array}{l}0.01 \\
0.00 \\
0.00 \\
0.00 \\
0.01\end{array}$ & $\begin{array}{l}1550 \\
1555 \\
1600 \\
1605 \\
1610\end{array}$ & $\begin{array}{r}10.3 \\
10.0 \\
10.0 \\
9.7 \\
9.7\end{array}$ & $\begin{array}{l}0.00 \\
0.00 \\
0.02 \\
0.00 \\
0.00\end{array}$ \\
\hline $\begin{array}{l}0525 \\
0530 \\
3535 \\
0540 \\
0545\end{array}$ & $\begin{array}{l}105.0 \\
126.0 \\
133.0 \\
223.0 \\
130.0\end{array}$ & $\begin{array}{l}0.00 \\
0.00 \\
0.01 \\
0.00 \\
0.00\end{array}$ & $\begin{array}{l}1050 \\
1055 \\
1100 \\
1105 \\
1110\end{array}$ & $\begin{array}{l}36.7 \\
35.0 \\
35.0 \\
38.3 \\
40.0\end{array}$ & $\begin{array}{l}0.00 \\
0.00 \\
0.00 \\
0.03 \\
0.00\end{array}$ & $\begin{array}{l}1615 \\
1620 \\
1625 \\
1630 \\
1635\end{array}$ & $\begin{array}{l}9.3 \\
9.0 \\
9.0 \\
8.7 \\
8.7\end{array}$ & $\begin{array}{l}0.00 \\
0.07 \\
0.00 \\
0.00 \\
0.00\end{array}$ \\
\hline
\end{tabular}


Table 77.--Streamflow and rainfall at station 02164011, Brushy Creek (Reedy River tributary) at Greenville, September 30 - October 2 , 1989--Continued

\begin{tabular}{|c|c|c|c|c|c|c|c|c|}
\hline $\begin{array}{l}\text { Time } \\
\text { (hours) }\end{array}$ & $\begin{array}{l}\text { Streamflow } \\
\text { (cubic feet } \\
\text { per second) }\end{array}$ & $\begin{array}{l}\text { Rain- } \\
\text { fall } \\
\text { (inches) }\end{array}$ & $\begin{array}{l}\text { Time } \\
\text { (hours) }\end{array}$ & $\begin{array}{l}\text { Streamflow } \\
\text { (cubic feet } \\
\text { per second) }\end{array}$ & $\begin{array}{l}\text { Rain- } \\
\text { fall } \\
\text { (inches) }\end{array}$ & $\begin{array}{l}\text { Time } \\
\text { (hours) }\end{array}$ & $\begin{array}{l}\text { Streamflow } \\
\text { (cubic feet } \\
\text { per second) }\end{array}$ & $\begin{array}{l}\text { Rain- } \\
\text { fall } \\
\text { (inchos) }\end{array}$ \\
\hline $\begin{array}{l}1640 \\
1645 \\
1650 \\
1655 \\
1700\end{array}$ & $\begin{array}{l}8.7 \\
8.7 \\
8.7 \\
8.7 \\
8.7\end{array}$ & $\begin{array}{l}0.00 \\
0.00 \\
0.00 \\
0.03 \\
0.00\end{array}$ & $\begin{array}{l}2205 \\
2210 \\
2215 \\
2220 \\
2225\end{array}$ & $\begin{array}{l}15.0 \\
14.6 \\
14.2 \\
13.9 \\
13.5\end{array}$ & $\begin{array}{l}0.00 \\
0.00 \\
0.00 \\
0.00 \\
0.00\end{array}$ & $\begin{array}{l}0325 \\
0330 \\
0335 \\
0340 \\
0345\end{array}$ & $\begin{array}{l}90.0 \\
82.5 \\
77.5 \\
72.5 \\
70.0\end{array}$ & $\begin{array}{l}0.00 \\
0.00 \\
0.00 \\
0.01 \\
0.03\end{array}$ \\
\hline $\begin{array}{l}1705 \\
1710 \\
1715 \\
1720 \\
1725\end{array}$ & $\begin{array}{r}9.0 \\
10.7 \\
12.4 \\
14.2 \\
19.1\end{array}$ & $\begin{array}{l}0.03 \\
0.02 \\
0.02 \\
0.01 \\
0.00\end{array}$ & $\begin{array}{l}2230 \\
2235 \\
2240 \\
2245 \\
2250\end{array}$ & $\begin{array}{l}13.1 \\
12.8 \\
12.4 \\
12.0 \\
12.0\end{array}$ & $\begin{array}{l}0.00 \\
0.00 \\
0.00 \\
0.00 \\
0.00\end{array}$ & $\begin{array}{l}0350 \\
0355 \\
0400 \\
0405 \\
0410\end{array}$ & $\begin{array}{l}62.5 \\
67.5 \\
75.0 \\
70.0 \\
65.0\end{array}$ & $\begin{array}{l}0.01 \\
0.00 \\
0.00 \\
0.00 \\
0.01\end{array}$ \\
\hline $\begin{array}{l}1730 \\
1735 \\
1740 \\
1745 \\
1750\end{array}$ & $\begin{array}{l}22.0 \\
22.0 \\
23.5 \\
25.0 \\
25.0\end{array}$ & $\begin{array}{l}0.01 \\
0.02 \\
0.00 \\
0.00 \\
0.01\end{array}$ & $\begin{array}{l}2255 \\
2300 \\
2305 \\
2310 \\
2315\end{array}$ & $\begin{array}{l}11.7 \\
11.7 \\
11.7 \\
11.7 \\
11.7\end{array}$ & $\begin{array}{l}0.00 \\
0.01 \\
0.00 \\
0.01 \\
0.00\end{array}$ & $\begin{array}{l}0415 \\
0420 \\
0425 \\
0430 \\
0435\end{array}$ & $\begin{array}{l}60.0 \\
53.3 \\
47.5 \\
42.5 \\
40.0\end{array}$ & $\begin{array}{l}0.00 \\
0.00 \\
0.00 \\
0.00 \\
0.00\end{array}$ \\
\hline $\begin{array}{l}1755 \\
1800 \\
1805 \\
1810 \\
1815\end{array}$ & $\begin{array}{l}25.8 \\
26.6 \\
29.1 \\
38.3 \\
60.0\end{array}$ & $\begin{array}{l}0.00 \\
0.00 \\
0.01 \\
0.00 \\
0.00\end{array}$ & $\begin{array}{l}2320 \\
2325 \\
2330 \\
2335 \\
2340\end{array}$ & $\begin{array}{l}11.4 \\
11.4 \\
11.4 \\
11.4 \\
11.4\end{array}$ & $\begin{array}{l}0.01 \\
0.00 \\
0.00 \\
0.00 \\
0.00\end{array}$ & $\begin{array}{l}0440 \\
0445 \\
0450 \\
0455 \\
0500\end{array}$ & $\begin{array}{l}38.3 \\
38.3 \\
38.3 \\
38.3 \\
36.7\end{array}$ & $\begin{array}{l}0.00 \\
0.00 \\
0.00 \\
0.00 \\
0.00\end{array}$ \\
\hline $\begin{array}{l}1820 \\
1825 \\
1830 \\
1835 \\
1840\end{array}$ & $\begin{array}{l}70.0 \\
70.0 \\
67.5 \\
62.5 \\
56.7\end{array}$ & $\begin{array}{l}0.00 \\
0.00 \\
0.01 \\
0.00 \\
0.00\end{array}$ & $\begin{array}{c}2345 \\
2350 \\
2355 \\
\text { October } \\
0000\end{array}$ & $\begin{array}{r}11.4 \\
11.4 \\
11.4 \\
01, \quad 1989 \\
11.4\end{array}$ & $\begin{array}{l}0.00 \\
0.00 \\
0.01 \\
0.00\end{array}$ & $\begin{array}{l}0505 \\
0510 \\
0515 \\
0520 \\
0525\end{array}$ & $\begin{array}{l}35.0 \\
31.7 \\
29.1 \\
27.4 \\
25.8\end{array}$ & $\begin{array}{l}0.00 \\
0.00 \\
0.00 \\
0.01 \\
0.00\end{array}$ \\
\hline $\begin{array}{l}1845 \\
1850 \\
1855 \\
1900 \\
1905\end{array}$ & $\begin{array}{l}47.5 \\
42.5 \\
38.3 \\
33.3 \\
30.0\end{array}$ & $\begin{array}{l}0.00 \\
0.00 \\
0.00 \\
0.00 \\
0.01\end{array}$ & $\begin{array}{l}0005 \\
0010 \\
0015 \\
0020 \\
0025\end{array}$ & $\begin{array}{l}11.4 \\
11.4 \\
11.4 \\
11.4 \\
11.7\end{array}$ & $\begin{array}{l}0.00 \\
0.00 \\
0.00 \\
0.01 \\
0.00\end{array}$ & $\begin{array}{l}0530 \\
0535 \\
0540 \\
0545 \\
0550\end{array}$ & $\begin{array}{l}24.2 \\
22.7 \\
25.0 \\
26.6 \\
30.0\end{array}$ & $\begin{array}{l}0.00 \\
0.00 \\
0.03 \\
0.00 \\
0.00\end{array}$ \\
\hline $\begin{array}{l}1910 \\
1915 \\
1920 \\
1925 \\
1930\end{array}$ & $\begin{array}{l}29.1 \\
28.2 \\
27.4 \\
26.6 \\
25.8\end{array}$ & $\begin{array}{l}0.00 \\
0.00 \\
0.01 \\
0.00 \\
0.00\end{array}$ & $\begin{array}{l}0030 \\
0035 \\
0040 \\
0045 \\
0050\end{array}$ & $\begin{array}{l}11.7 \\
11.7 \\
12.0 \\
12.4 \\
12.4\end{array}$ & $\begin{array}{l}0.00 \\
0.00 \\
0.02 \\
0.00 \\
0.00\end{array}$ & $\begin{array}{l}0555 \\
0600 \\
0605 \\
0610 \\
0615\end{array}$ & $\begin{array}{l}35.0 \\
31.7 \\
27.4 \\
26.6 \\
25.8\end{array}$ & $\begin{array}{l}0.02 \\
0.00 \\
0.00 \\
0.00 \\
0.00\end{array}$ \\
\hline $\begin{array}{l}1935 \\
1940 \\
1945 \\
1950 \\
1955\end{array}$ & $\begin{array}{l}25.0 \\
24.2 \\
22.7 \\
22.0 \\
21.2\end{array}$ & $\begin{array}{l}0.01 \\
0.00 \\
0.00 \\
0.00 \\
0.01\end{array}$ & $\begin{array}{l}0055 \\
0100 \\
0105 \\
0110 \\
0115\end{array}$ & $\begin{array}{l}12.8 \\
12.8 \\
12.8 \\
12.8 \\
12.8\end{array}$ & $\begin{array}{l}0.00 \\
0.00 \\
0.00 \\
0.01 \\
0.00\end{array}$ & $\begin{array}{l}0620 \\
0625 \\
0630 \\
0635 \\
0640\end{array}$ & $\begin{array}{l}25.0 \\
25.8 \\
31.7 \\
62.5 \\
95.0\end{array}$ & $\begin{array}{l}0.02 \\
0.04 \\
0.04 \\
0.04 \\
0.02\end{array}$ \\
\hline $\begin{array}{l}2000 \\
2005 \\
2010 \\
2015 \\
2020\end{array}$ & $\begin{array}{l}21.2 \\
21.2 \\
21.2 \\
21.2 \\
21.2\end{array}$ & $\begin{array}{l}0.00 \\
0.00 \\
0.02 \\
0.00 \\
0.00\end{array}$ & $\begin{array}{l}0120 \\
0125 \\
0130 \\
0135 \\
0140\end{array}$ & $\begin{array}{l}12.8 \\
13.5 \\
14.6 \\
19.8 \\
23.5\end{array}$ & $\begin{array}{l}0.00 \\
0.05 \\
0.02 \\
0.01 \\
0.02\end{array}$ & $\begin{array}{l}0645 \\
0650 \\
0655 \\
0700 \\
0705\end{array}$ & $\begin{array}{l}109.0 \\
119.0 \\
142.0 \\
186.0 \\
250.0\end{array}$ & $\begin{array}{l}0.02 \\
0.00 \\
0.00 \\
0.17 \\
0.07\end{array}$ \\
\hline $\begin{array}{l}2025 \\
2030 \\
2035 \\
2040 \\
2045\end{array}$ & $\begin{array}{l}21.2 \\
21.2 \\
21.2 \\
20.5 \\
20.5\end{array}$ & $\begin{array}{l}0.00 \\
0.01 \\
0.00 \\
0.00 \\
0.00\end{array}$ & $\begin{array}{l}0145 \\
0150 \\
0155 \\
0200 \\
0205\end{array}$ & $\begin{array}{l}29.1 \\
30.0 \\
31.7 \\
35.0 \\
40.0\end{array}$ & $\begin{array}{l}0.00 \\
0.00 \\
0.00 \\
0.00 \\
0.00\end{array}$ & $\begin{array}{l}0710 \\
0715 \\
0720 \\
0725 \\
0730\end{array}$ & $\begin{array}{l}312.0 \\
369.0 \\
433.0 \\
476.0 \\
525.0\end{array}$ & $\begin{array}{l}0.09 \\
0.09 \\
0.05 \\
0.03 \\
0.09\end{array}$ \\
\hline $\begin{array}{l}2050 \\
2055 \\
2100 \\
2105 \\
2110\end{array}$ & $\begin{array}{l}19.8 \\
19.8 \\
19.1 \\
19.1 \\
19.1\end{array}$ & $\begin{array}{l}0.01 \\
0.00 \\
0.00 \\
0.01 \\
0.00\end{array}$ & $\begin{array}{l}0210 \\
0215 \\
0220 \\
0225 \\
0230\end{array}$ & $\begin{array}{r}53.3 \\
70.0 \\
80.0 \\
100.0 \\
116.0\end{array}$ & $\begin{array}{l}0.01 \\
0.01 \\
0.00 \\
0.01 \\
0.00\end{array}$ & $\begin{array}{l}0735 \\
0740 \\
0745 \\
0750 \\
0755\end{array}$ & $\begin{array}{l}577.0 \\
629.0 \\
669.0 \\
698.0 \\
724.0\end{array}$ & $\begin{array}{l}0.09 \\
0.06 \\
0.03 \\
0.03 \\
0.04\end{array}$ \\
\hline $\begin{array}{l}2115 \\
2120 \\
2125 \\
2130 \\
2135\end{array}$ & $\begin{array}{l}19.1 \\
19.1 \\
19.1 \\
19.1 \\
17.9\end{array}$ & $\begin{array}{l}0.00 \\
0.00 \\
0.00 \\
0.00 \\
0.00\end{array}$ & $\begin{array}{l}0235 \\
0240 \\
0245 \\
0250 \\
0255\end{array}$ & $\begin{array}{l}126.0 \\
126.0 \\
123.0 \\
116.0 \\
112.0\end{array}$ & $\begin{array}{l}0.01 \\
0.00 \\
0.01 \\
0.00 \\
0.00\end{array}$ & $\begin{array}{l}0800 \\
0805 \\
0810 \\
0815 \\
0820\end{array}$ & $\begin{array}{l}727.0 \\
731.0 \\
733.0 \\
733.0 \\
718.0\end{array}$ & $\begin{array}{l}0.02 \\
0.02 \\
0.01 \\
0.00 \\
0.00\end{array}$ \\
\hline $\begin{array}{l}2140 \\
2145 \\
2150 \\
2155 \\
2200\end{array}$ & $\begin{array}{l}17.4 \\
16.9 \\
16.4 \\
16.0 \\
15.5\end{array}$ & $\begin{array}{l}0.00 \\
0.00 \\
0.00 \\
0.00 \\
0.00\end{array}$ & $\begin{array}{l}0300 \\
0305 \\
0310 \\
0315 \\
0320\end{array}$ & $\begin{array}{r}109.0 \\
107.0 \\
105.0 \\
102.0 \\
97.5\end{array}$ & $\begin{array}{l}0.01 \\
0.00 \\
0.00 \\
0.00 \\
0.00\end{array}$ & $\begin{array}{l}0825 \\
0830 \\
0835 \\
0840 \\
0845\end{array}$ & $\begin{array}{l}700.0 \\
683.0 \\
662.0 \\
640.0 \\
619.0\end{array}$ & $\begin{array}{l}0.05 \\
0.02 \\
0.03 \\
0.01 \\
0.04\end{array}$ \\
\hline
\end{tabular}


Table 77.--Streamflow and rainfall at station 02164011 . Brushy Creek (Reedy River tributary) at Greenrille, September 30 - October 2, 1989--Continued

\begin{tabular}{|c|c|c|c|c|c|c|c|c|}
\hline $\begin{array}{l}\text { Time } \\
\text { (hours) }\end{array}$ & $\begin{array}{l}\text { Streamflow } \\
\text { (cubic feet } \\
\text { per second) }\end{array}$ & $\begin{array}{l}\text { Rain- } \\
\text { fall } \\
\text { (inches) }\end{array}$ & $\begin{array}{l}\text { Time } \\
\text { (hours) }\end{array}$ & $\begin{array}{l}\text { Streamflow } \\
\text { (cubic feet } \\
\text { per second) }\end{array}$ & $\begin{array}{l}\text { Rain- } \\
\text { fall } \\
\text { (inches) }\end{array}$ & $\begin{array}{l}\text { Time } \\
\text { (hours) }\end{array}$ & $\begin{array}{l}\text { Streamflow } \\
\text { (cubic feet } \\
\text { per second) }\end{array}$ & $\begin{array}{l}\text { Rain- } \\
\text { fall } \\
\text { (inches) }\end{array}$ \\
\hline $\begin{array}{l}0850 \\
0855 \\
0900 \\
0905 \\
0910\end{array}$ & $\begin{array}{l}600.0 \\
588.0 \\
573.0 \\
558.0 \\
552.0\end{array}$ & $\begin{array}{l}0.02 \\
0.02 \\
0.02 \\
0.05 \\
0.02\end{array}$ & $\begin{array}{l}1415 \\
1420 \\
1425 \\
1430 \\
1435\end{array}$ & $\begin{array}{l}222.0 \\
213.0 \\
202.0 \\
193.0 \\
181.0\end{array}$ & $\begin{array}{l}0.00 \\
0.00 \\
0.00 \\
0.00 \\
0.00\end{array}$ & $\begin{array}{l}1940 \\
1945 \\
1950 \\
1955 \\
2000\end{array}$ & $\begin{array}{l}17.4 \\
17.4 \\
16.9 \\
16.9 \\
16.9\end{array}$ & $\begin{array}{l}0.00 \\
0.00 \\
0.00 \\
0.00 \\
0.00\end{array}$ \\
\hline $\begin{array}{l}0915 \\
0920 \\
0925 \\
0930 \\
0935\end{array}$ & $\begin{array}{l}540.0 \\
542.0 \\
544.0 \\
540.0 \\
542.0\end{array}$ & $\begin{array}{l}0.02 \\
0.03 \\
0.03 \\
0.03 \\
0.02\end{array}$ & $\begin{array}{l}1440 \\
1445 \\
1450 \\
1455 \\
1500\end{array}$ & $\begin{array}{l}174.0 \\
165.0 \\
158.0 \\
154.0 \\
144.0\end{array}$ & $\begin{array}{l}0.00 \\
0.00 \\
0.00 \\
0.00 \\
0.00\end{array}$ & $\begin{array}{l}2005 \\
2010 \\
2015 \\
2020 \\
2025\end{array}$ & $\begin{array}{l}16.4 \\
16.4 \\
16.4 \\
16.4 \\
16.0\end{array}$ & $\begin{array}{l}0.00 \\
0.00 \\
0.00 \\
0.00 \\
0.00\end{array}$ \\
\hline $\begin{array}{l}0940 \\
0945 \\
0950 \\
0955 \\
1000\end{array}$ & $\begin{array}{l}540.0 \\
540.0 \\
533.0 \\
533.0 \\
550.0\end{array}$ & $\begin{array}{l}0.03 \\
0.02 \\
0.03 \\
0.02 \\
0.00\end{array}$ & $\begin{array}{l}1505 \\
1510 \\
1515 \\
1520 \\
1525\end{array}$ & $\begin{array}{l}137.0 \\
130.0 \\
126.0 \\
121.0 \\
116.0\end{array}$ & $\begin{array}{l}0.00 \\
0.00 \\
0.00 \\
0.00 \\
0.00\end{array}$ & $\begin{array}{l}2030 \\
2035 \\
2040 \\
2045 \\
2050\end{array}$ & $\begin{array}{l}16.0 \\
15.5 \\
15.5 \\
15.5 \\
15.0\end{array}$ & $\begin{array}{l}0.00 \\
0.00 \\
0.00 \\
0.00 \\
0.00\end{array}$ \\
\hline $\begin{array}{l}1005 \\
1010 \\
1015 \\
1020 \\
1025\end{array}$ & $\begin{array}{l}579.0 \\
606.0 \\
638.0 \\
660.0 \\
679.0\end{array}$ & $\begin{array}{l}0.13 \\
0.09 \\
0.05 \\
0.03 \\
0.07\end{array}$ & $\begin{array}{l}1530 \\
1535 \\
1540 \\
1545 \\
1550\end{array}$ & $\begin{array}{r}109.0 \\
105.0 \\
100.0 \\
95.0 \\
95.0\end{array}$ & $\begin{array}{l}0.00 \\
0.00 \\
0.00 \\
0.00 \\
0.00\end{array}$ & $\begin{array}{l}2055 \\
2100 \\
2105 \\
2110 \\
2115\end{array}$ & $\begin{array}{l}15.0 \\
15.0 \\
14.6 \\
14.6 \\
14.6\end{array}$ & $\begin{array}{l}0.00 \\
0.00 \\
0.00 \\
0.00 \\
0.00\end{array}$ \\
\hline $\begin{array}{l}1030 \\
1035 \\
1040 \\
1045 \\
1050\end{array}$ & $\begin{array}{l}716.0 \\
731.0 \\
740.0 \\
749.0 \\
753.0\end{array}$ & $\begin{array}{l}0.02 \\
0.02 \\
0.02 \\
0.03 \\
0.02\end{array}$ & $\begin{array}{l}1555 \\
1600 \\
1605 \\
1610 \\
1615\end{array}$ & $\begin{array}{l}87.5 \\
82.5 \\
77.5 \\
75.0 \\
70.0\end{array}$ & $\begin{array}{l}0.00 \\
0.00 \\
0.00 \\
0.00 \\
0.00\end{array}$ & $\begin{array}{l}2120 \\
2125 \\
2130 \\
2135 \\
2140\end{array}$ & $\begin{array}{l}14.2 \\
14.2 \\
14.2 \\
13.9 \\
13.9\end{array}$ & $\begin{array}{l}0.00 \\
0.00 \\
0.00 \\
0.00 \\
0.00\end{array}$ \\
\hline $\begin{array}{l}1055 \\
1100 \\
1105 \\
1110 \\
1115\end{array}$ & $\begin{array}{l}751.0 \\
753.0 \\
742.0 \\
736.0 \\
720.0\end{array}$ & $\begin{array}{l}0.00 \\
0.02 \\
0.00 \\
0.00 \\
0.00\end{array}$ & $\begin{array}{l}1620 \\
1625 \\
1630 \\
1635 \\
1640\end{array}$ & $\begin{array}{l}67.5 \\
62.5 \\
56.7 \\
53.3 \\
50.0\end{array}$ & $\begin{array}{l}0.00 \\
0.00 \\
0.00 \\
0.00 \\
0.00\end{array}$ & $\begin{array}{l}2145 \\
2150 \\
2155 \\
2200 \\
2205\end{array}$ & $\begin{array}{l}13.9 \\
13.5 \\
13.5 \\
13.5 \\
13.1\end{array}$ & $\begin{array}{l}0.00 \\
0.00 \\
0.00 \\
0.00 \\
0.00\end{array}$ \\
\hline $\begin{array}{l}1120 \\
1125 \\
1130 \\
1135 \\
1140\end{array}$ & $\begin{array}{l}711.0 \\
685.0 \\
660.0 \\
631.0 \\
608.0\end{array}$ & $\begin{array}{l}0.00 \\
0.00 \\
0.01 \\
0.00 \\
0.01\end{array}$ & $\begin{array}{l}1645 \\
1650 \\
1655 \\
1700 \\
1705\end{array}$ & $\begin{array}{l}47.5 \\
45.0 \\
40.0 \\
38.3 \\
36.7\end{array}$ & $\begin{array}{l}0.00 \\
0.00 \\
0.00 \\
0.00 \\
0.00\end{array}$ & $\begin{array}{l}2210 \\
2215 \\
2220 \\
2225 \\
2230\end{array}$ & $\begin{array}{l}13.1 \\
12.8 \\
12.8 \\
12.8 \\
12.4\end{array}$ & $\begin{array}{l}0.00 \\
0.00 \\
0.00 \\
0.00 \\
0.00\end{array}$ \\
\hline $\begin{array}{l}1145 \\
1150 \\
1155 \\
1200 \\
1205\end{array}$ & $\begin{array}{l}579.0 \\
550.0 \\
527.0 \\
502.0 \\
480.0\end{array}$ & $\begin{array}{l}0.00 \\
0.00 \\
0.00 \\
0.00 \\
0.00\end{array}$ & $\begin{array}{l}1710 \\
1715 \\
1720 \\
1725 \\
1730\end{array}$ & $\begin{array}{l}35.0 \\
33.3 \\
31.7 \\
30.0 \\
29.1\end{array}$ & $\begin{array}{l}0.00 \\
0.00 \\
0.00 \\
0.00 \\
0.00\end{array}$ & $\begin{array}{l}2235 \\
2240 \\
2245 \\
2250 \\
2255\end{array}$ & $\begin{array}{l}12.4 \\
12.4 \\
12.4 \\
12.0 \\
12.0\end{array}$ & $\begin{array}{l}0.00 \\
0.00 \\
0.00 \\
0.00 \\
0.00\end{array}$ \\
\hline $\begin{array}{l}1210 \\
1215 \\
1220 \\
1225 \\
1230\end{array}$ & $\begin{array}{l}457.0 \\
429.0 \\
410.0 \\
392.0 \\
382.0\end{array}$ & $\begin{array}{l}0.00 \\
0.00 \\
0.00 \\
0.09 \\
0.00\end{array}$ & $\begin{array}{l}1735 \\
1740 \\
1745 \\
1750 \\
1755\end{array}$ & $\begin{array}{l}28.2 \\
27.4 \\
26.6 \\
25.8 \\
25.0\end{array}$ & $\begin{array}{l}0.00 \\
0.00 \\
0.00 \\
0.00 \\
0.00\end{array}$ & $\begin{array}{l}2300 \\
2305 \\
2310 \\
2315 \\
2320\end{array}$ & $\begin{array}{l}12.0 \\
11.7 \\
11.7 \\
11.7 \\
11.7\end{array}$ & $\begin{array}{l}0.00 \\
0.00 \\
0.00 \\
0.00 \\
0.00\end{array}$ \\
\hline $\begin{array}{l}1235 \\
1240 \\
1245 \\
1250 \\
1255\end{array}$ & $\begin{array}{l}382.0 \\
384.0 \\
392.0 \\
402.0 \\
400.0\end{array}$ & $\begin{array}{l}0.00 \\
0.03 \\
0.00 \\
0.02 \\
0.00\end{array}$ & $\begin{array}{l}1800 \\
1805 \\
1810 \\
1815 \\
1820\end{array}$ & $\begin{array}{l}24.2 \\
23.5 \\
23.5 \\
22.7 \\
22.0\end{array}$ & $\begin{array}{l}0.00 \\
0.00 \\
0.00 \\
0.00 \\
0.00\end{array}$ & $\begin{array}{l}2325 \\
2330 \\
2335 \\
2340 \\
2345\end{array}$ & $\begin{array}{l}11.4 \\
11.4 \\
11.4 \\
11.4 \\
11.4\end{array}$ & $\begin{array}{l}0.00 \\
0.00 \\
0.00 \\
0.00 \\
0.00\end{array}$ \\
\hline $\begin{array}{l}1300 \\
1305 \\
1310 \\
1315 \\
1320\end{array}$ & $\begin{array}{l}396.0 \\
398.0 \\
394.0 \\
390.0 \\
384.0\end{array}$ & $\begin{array}{l}0.00 \\
0.00 \\
0.00 \\
0.00 \\
0.00\end{array}$ & $\begin{array}{l}1825 \\
1830 \\
1835 \\
1840 \\
1845\end{array}$ & $\begin{array}{l}21.2 \\
21.2 \\
20.5 \\
20.5 \\
20.5\end{array}$ & $\begin{array}{l}0.00 \\
0.00 \\
0.00 \\
0.00 \\
0.00\end{array}$ & $\begin{array}{r}2350 \\
2355 \\
\text { October } 02 \text {, } \\
0000 \\
0005\end{array}$ & $\begin{array}{r}11.0 \\
11.0 \\
1989 \\
11.0 \\
11.0\end{array}$ & $\begin{array}{l}0.00 \\
0.00 \\
0.00 \\
0.00\end{array}$ \\
\hline $\begin{array}{l}1325 \\
1330 \\
1335 \\
1340 \\
1345\end{array}$ & $\begin{array}{l}367.0 \\
353.0 \\
337.0 \\
318.0 \\
302.0\end{array}$ & $\begin{array}{l}0.00 \\
0.00 \\
0.00 \\
0.00 \\
0.00\end{array}$ & $\begin{array}{l}1850 \\
1855 \\
1900 \\
1905 \\
1910\end{array}$ & $\begin{array}{l}19.8 \\
19.8 \\
19.1 \\
18.4 \\
18.4\end{array}$ & $\begin{array}{l}0.00 \\
0.00 \\
0.00 \\
0.00 \\
0.00\end{array}$ & $\begin{array}{l}0010 \\
0015 \\
0020 \\
0025 \\
0030\end{array}$ & $\begin{array}{l}11.0 \\
10.7 \\
10.7 \\
10.7 \\
10.7\end{array}$ & $\begin{array}{l}0.00 \\
0.00 \\
0.00 \\
0.00 \\
0.00\end{array}$ \\
\hline $\begin{array}{l}1350 \\
1355 \\
1400 \\
1405 \\
1410\end{array}$ & $\begin{array}{l}285.0 \\
270.0 \\
256.0 \\
246.0 \\
233.0\end{array}$ & $\begin{array}{ll}0.00 \\
0.00 \\
0.00 \\
0.00 \\
0.00\end{array}$ & $\begin{array}{l}1915 \\
1920 \\
1925 \\
1930 \\
1935\end{array}$ & $\begin{array}{l}17.9 \\
17.9 \\
17.9 \\
17.9 \\
17.4\end{array}$ & $\begin{array}{l}0.00 \\
0.00 \\
0.00 \\
0.00 \\
0.00\end{array}$ & $\begin{array}{l}0035 \\
0040 \\
0045 \\
0050 \\
0055\end{array}$ & $\begin{array}{l}10.7 \\
10.7 \\
10.7 \\
10.7 \\
10.7\end{array}$ & $\begin{array}{l}0.00 \\
0.01 \\
0.00 \\
0.00 \\
0.00\end{array}$ \\
\hline
\end{tabular}


Table 77.--Streamflow and rainfall at station 02164011, Brushy Creek (Koedy River tributary) at Greenville, September 30 - October 2 1989 -Continued

\begin{tabular}{|c|c|c|c|c|c|c|c|c|}
\hline $\begin{array}{l}\text { Time } \\
\text { (hours) }\end{array}$ & $\begin{array}{l}\text { Streamflow } \\
\text { (cubic feet } \\
\text { per second) }\end{array}$ & $\begin{array}{l}\text { Rain- } \\
\text { fall } \\
\text { (inches) }\end{array}$ & $\begin{array}{l}\text { Time } \\
\text { (hours) }\end{array}$ & $\begin{array}{l}\text { Streamflow } \\
\text { (cubic feet } \\
\text { per second) }\end{array}$ & $\begin{array}{l}\text { Rain- } \\
\text { fall } \\
\text { (inches) }\end{array}$ & $\begin{array}{l}\text { Time } \\
\text { (hours) }\end{array}$ & $\begin{array}{l}\text { Streamflow } \\
\text { (cubic feet } \\
\text { per second) }\end{array}$ & $\begin{array}{l}\text { Rain- } \\
\text { fall } \\
\text { (inches) }\end{array}$ \\
\hline $\begin{array}{l}0100 \\
0105 \\
0110 \\
0115 \\
0120\end{array}$ & $\begin{array}{l}10.7 \\
10.7 \\
10.7 \\
10.7 \\
10.7\end{array}$ & $\begin{array}{l}0.00 \\
0.00 \\
0.00 \\
0.00 \\
0.00\end{array}$ & $\begin{array}{l}0605 \\
0610 \\
0615 \\
0620 \\
0625\end{array}$ & $\begin{array}{l}8.3 \\
8.3 \\
8.3 \\
8.3 \\
8.3\end{array}$ & $\begin{array}{l}0.00 \\
0.00 \\
0.00 \\
0.00 \\
0.00\end{array}$ & $\begin{array}{l}1110 \\
1115 \\
1120 \\
1125 \\
1130\end{array}$ & $\begin{array}{l}7.0 \\
7.0 \\
7.0 \\
7.0 \\
7.0\end{array}$ & $\begin{array}{l}0.00 \\
0.00 \\
0.00 \\
0.00 \\
0.00\end{array}$ \\
\hline $\begin{array}{l}0125 \\
0130 \\
0135 \\
0140 \\
0145\end{array}$ & $\begin{array}{l}10.7 \\
10.7 \\
10.7 \\
10.7 \\
10.3\end{array}$ & $\begin{array}{l}0.00 \\
0.00 \\
0.00 \\
0.00 \\
0.00\end{array}$ & $\begin{array}{l}0630 \\
0635 \\
0640 \\
0645 \\
0650\end{array}$ & $\begin{array}{l}8.3 \\
8.0 \\
8.0 \\
8.0 \\
8.0\end{array}$ & $\begin{array}{l}0.00 \\
0.00 \\
0.00 \\
0.00 \\
0.00\end{array}$ & $\begin{array}{l}1135 \\
1140 \\
1145 \\
1150 \\
1155\end{array}$ & $\begin{array}{l}6.7 \\
6.7 \\
6.7 \\
6.7 \\
6.7\end{array}$ & $\begin{array}{l}0.00 \\
0.00 \\
0.00 \\
0.00 \\
0.00\end{array}$ \\
\hline $\begin{array}{l}0150 \\
0155 \\
0200 \\
0205 \\
0210\end{array}$ & $\begin{array}{l}10 \cdot 3 \\
10.3 \\
10.3 \\
10.3 \\
10.0\end{array}$ & $\begin{array}{l}0.00 \\
0.00 \\
0.00 \\
0.00 \\
0.00\end{array}$ & $\begin{array}{l}0655 \\
0700 \\
0705 \\
0710 \\
0715\end{array}$ & $\begin{array}{l}8.0 \\
8.0 \\
8.0 \\
8.0 \\
8.0\end{array}$ & $\begin{array}{l}0.00 \\
0.00 \\
0.00 \\
0.00 \\
0.00\end{array}$ & $\begin{array}{l}1200 \\
1205 \\
1210 \\
1215 \\
1220\end{array}$ & $\begin{array}{l}6.7 \\
6.7 \\
6.7 \\
6.7 \\
6.7\end{array}$ & $\begin{array}{l}0.00 \\
0.00 \\
0.00 \\
0.00 \\
0.00\end{array}$ \\
\hline $\begin{array}{l}0215 \\
0220 \\
0225 \\
0230 \\
0235\end{array}$ & $\begin{array}{l}10.0 \\
10.0 \\
10.0 \\
10.0 \\
10.0\end{array}$ & $\begin{array}{l}0.00 \\
0.00 \\
0.00 \\
0.00 \\
0.00\end{array}$ & $\begin{array}{l}0720 \\
0725 \\
0730 \\
0735 \\
0740\end{array}$ & $\begin{array}{l}8.0 \\
8.0 \\
8.0 \\
7.7 \\
7.7\end{array}$ & $\begin{array}{l}0.00 \\
0.00 \\
0.00 \\
0.00 \\
0.00\end{array}$ & $\begin{array}{l}1225 \\
1230 \\
1235 \\
1240 \\
1245\end{array}$ & $\begin{array}{l}6.7 \\
6.7 \\
6.4 \\
6.4 \\
6.4\end{array}$ & $\begin{array}{l}0.00 \\
0.00 \\
0.00 \\
0.00 \\
0.00\end{array}$ \\
\hline $\begin{array}{l}0240 \\
0245 \\
0250 \\
0255 \\
0300\end{array}$ & $\begin{array}{l}10.0 \\
10.0 \\
10.0 \\
10.0 \\
10.0\end{array}$ & $\begin{array}{l}0.00 \\
0.00 \\
0.00 \\
0.00 \\
0.00\end{array}$ & $\begin{array}{l}0745 \\
0750 \\
0755 \\
0800 \\
0805\end{array}$ & $\begin{array}{l}7.7 \\
7.7 \\
7.7 \\
7.7 \\
7.7\end{array}$ & $\begin{array}{l}0.00 \\
0.00 \\
0.00 \\
0.00 \\
0.00\end{array}$ & $\begin{array}{l}1250 \\
1255 \\
1300 \\
1305 \\
1310\end{array}$ & $\begin{array}{l}6.4 \\
6.4 \\
6.4 \\
6.4 \\
6.4\end{array}$ & $\begin{array}{l}0.00 \\
0.00 \\
0.00 \\
0.00 \\
0.00\end{array}$ \\
\hline $\begin{array}{l}0305 \\
0310 \\
0315 \\
0320 \\
0325\end{array}$ & $\begin{array}{r}10.0 \\
10.0 \\
9.7 \\
9.7 \\
9.7\end{array}$ & $\begin{array}{l}0.00 \\
0.00 \\
0.00 \\
0.00 \\
0.00\end{array}$ & $\begin{array}{l}0810 \\
0815 \\
0820 \\
0825 \\
0830\end{array}$ & $\begin{array}{l}7.7 \\
7.7 \\
7.7 \\
7.7 \\
7.7\end{array}$ & $\begin{array}{l}0.00 \\
0.00 \\
0.00 \\
0.00 \\
0.00\end{array}$ & $\begin{array}{l}1315 \\
1320 \\
1325 \\
1330 \\
1335\end{array}$ & $\begin{array}{l}6.4 \\
6.4 \\
6.4 \\
6.4 \\
6.4\end{array}$ & $\begin{array}{l}0.00 \\
0.00 \\
0.00 \\
0.00 \\
0.00\end{array}$ \\
\hline $\begin{array}{l}0330 \\
0335 \\
0340 \\
0345 \\
0350\end{array}$ & $\begin{array}{l}9.7 \\
9.7 \\
9.7 \\
9.3 \\
9.3\end{array}$ & $\begin{array}{l}0.00 \\
0.00 \\
0.00 \\
0.00 \\
0.00\end{array}$ & $\begin{array}{l}0835 \\
0840 \\
0845 \\
0850 \\
0855\end{array}$ & $\begin{array}{l}7.7 \\
7.7 \\
7.7 \\
7.7 \\
7.7\end{array}$ & $\begin{array}{l}0.00 \\
0.00 \\
0.00 \\
0.00 \\
0.00\end{array}$ & $\begin{array}{l}1340 \\
1345 \\
1350 \\
1355 \\
1400\end{array}$ & $\begin{array}{l}6.4 \\
6.4 \\
6.4 \\
6.4 \\
6.4\end{array}$ & $\begin{array}{l}0.00 \\
0.00 \\
0.00 \\
0.00 \\
0.00\end{array}$ \\
\hline $\begin{array}{l}0355 \\
0400 \\
0405 \\
0410 \\
0415\end{array}$ & $\begin{array}{l}9.3 \\
9.3 \\
9.3 \\
9.0 \\
9.0\end{array}$ & $\begin{array}{l}0.00 \\
0.00 \\
0.00 \\
0.00 \\
0.00\end{array}$ & $\begin{array}{l}0900 \\
0905 \\
0910 \\
0915 \\
0920\end{array}$ & $\begin{array}{l}7.7 \\
7.3 \\
7.3 \\
7.3 \\
7.3\end{array}$ & $\begin{array}{l}0.00 \\
0.00 \\
0.00 \\
0.00 \\
0.00\end{array}$ & $\begin{array}{l}1405 \\
1410 \\
1415 \\
1420 \\
1425\end{array}$ & $\begin{array}{l}6.4 \\
6.4 \\
6.4 \\
6.1 \\
6.1\end{array}$ & $\begin{array}{l}0.00 \\
0.00 \\
0.00 \\
0.00 \\
0.00\end{array}$ \\
\hline $\begin{array}{l}0420 \\
0425 \\
0430 \\
0435 \\
0440\end{array}$ & $\begin{array}{l}9.0 \\
9.0 \\
9.0 \\
9.0 \\
9.0\end{array}$ & $\begin{array}{l}0.00 \\
0.00 \\
0.00 \\
0.00 \\
0.00\end{array}$ & $\begin{array}{l}0925 \\
0930 \\
0935 \\
0940 \\
0945\end{array}$ & $\begin{array}{l}7.3 \\
7.3 \\
7.3 \\
7.3 \\
7.3\end{array}$ & $\begin{array}{l}0.00 \\
0.00 \\
0.00 \\
0.00 \\
0.00\end{array}$ & $\begin{array}{l}1430 \\
1435 \\
1440 \\
1445 \\
1450\end{array}$ & $\begin{array}{l}6.1 \\
6.1 \\
6.1 \\
6.1 \\
6.1\end{array}$ & $\begin{array}{l}0.00 \\
0.00 \\
0.00 \\
0.00 \\
0.00\end{array}$ \\
\hline $\begin{array}{l}0445 \\
0450 \\
0455 \\
0500 \\
0505\end{array}$ & $\begin{array}{l}9.0 \\
8.7 \\
8.7 \\
8.7 \\
8.7\end{array}$ & $\begin{array}{l}0.00 \\
0.00 \\
0.00 \\
0.00 \\
0.00\end{array}$ & $\begin{array}{l}0950 \\
0955 \\
1000 \\
1005 \\
1010\end{array}$ & $\begin{array}{l}7.3 \\
7.3 \\
7.3 \\
7.3 \\
7.0\end{array}$ & $\begin{array}{l}0.00 \\
0.00 \\
0.00 \\
0.00 \\
0.00\end{array}$ & $\begin{array}{l}1455 \\
1500 \\
1505 \\
1510 \\
1515\end{array}$ & $\begin{array}{l}6.1 \\
6.1 \\
6.1 \\
6.1 \\
6.1\end{array}$ & $\begin{array}{l}0.00 \\
0.00 \\
0.00 \\
0.00 \\
0.00\end{array}$ \\
\hline $\begin{array}{l}0510 \\
0515 \\
0520 \\
0525 \\
0530\end{array}$ & $\begin{array}{l}8.7 \\
8.7 \\
8.7 \\
8.7 \\
8.3\end{array}$ & $\begin{array}{l}0.00 \\
0.00 \\
0.00 \\
0.00 \\
0.00\end{array}$ & $\begin{array}{l}1015 \\
1020 \\
1025 \\
1030 \\
1035\end{array}$ & $\begin{array}{l}7.0 \\
7.0 \\
7.0 \\
7.0 \\
7.0\end{array}$ & $\begin{array}{l}0.00 \\
0.00 \\
0.00 \\
0.00 \\
0.00\end{array}$ & $\begin{array}{l}1520 \\
1525 \\
1530 \\
1535 \\
1540\end{array}$ & $\begin{array}{l}6.1 \\
6.1 \\
5.8 \\
5.8 \\
5.8\end{array}$ & $\begin{array}{l}0.00 \\
0.00 \\
0.00 \\
0.00 \\
0.00\end{array}$ \\
\hline $\begin{array}{l}0535 \\
0540 \\
0545 \\
0550 \\
0555\end{array}$ & $\begin{array}{l}8.3 \\
8.3 \\
8.3 \\
8.3 \\
8.3\end{array}$ & $\begin{array}{l}0.00 \\
0.00 \\
0.00 \\
0.00 \\
0.00\end{array}$ & $\begin{array}{l}1040 \\
1045 \\
1050 \\
1055 \\
1100\end{array}$ & $\begin{array}{l}7.0 \\
7.0 \\
7.0 \\
7.0 \\
7.0\end{array}$ & $\begin{array}{l}0.00 \\
0.00 \\
0.00 \\
0.00 \\
0.00\end{array}$ & $\begin{array}{l}1545 \\
1550 \\
1555 \\
1600\end{array}$ & $\begin{array}{l}5.8 \\
5.8 \\
5.8 \\
5.8\end{array}$ & $\begin{array}{l}0.00 \\
0.00 \\
0.00 \\
0.00\end{array}$ \\
\hline 0600 & 8.3 & 0.00 & 1105 & 7.0 & 0.00 & & & \\
\hline
\end{tabular}




\section{Station 02166975, Sample Branch at Greenwood, S.C.}

Location.--Lat $34^{\circ} 12^{\prime} 56^{\prime \prime}$, long 82 $09^{\prime} 20^{\prime \prime}$, Greenwood County, Hydrologic Unit 03050109, at culvert on U.S. Highway 25/178 bypass, 1.9 mi north of the Greenwood County Courthouse, and $1.3 \mathrm{mi}$ upstream from the mouth at Rocky Creek.

Period of record.-- November 19, 1985 to October 12, 1990.

Gage.--Digital stage recorder with 5-minute punch interval. The recorder is housed in a metal shelter atop a stilling well attached to a free-standing platform on the right bank, approximately $15 \mathrm{ft}$ upstream from a $10 \mathrm{ft}$ by $8 \mathrm{ft}$ concrete box culvert. An enameled staff gage is attached to the platform. A single crest-stage indicator is located on the right downstream wingwall.

Rating.--The stage-streamflow relation is defined by current meter measurements up to $114 \mathrm{ft}^{3} / \mathrm{s}$. The stage-streamflow relation was extended to $280 \mathrm{ft}^{3} / \mathrm{s}$ using indirect computational methods.

Rain gage and location.--Station 341256082092000 , lat $34^{\circ} 12^{\prime} 56^{\prime \prime}$, long $82^{\circ} 09^{\prime} 20^{\prime \prime}$. A shelter containing a digital cumulative rainfall recorder with a 5-minute punch interval attached to the downstream right wingwall, at U.S. Highway 25/178 bypass, $1.9 \mathrm{mi}$ north of the Greenwood County Courthouse, and 1.3 mi upstream from the mouth at Rocky Creek.

Selected basin characteristics.--

Drainage area -- $1.16 \mathrm{mi}^{2}$

Physiographic province - Piedmont

Channel slope -- $47.2 \mathrm{ft} / \mathrm{mi}$

Channel length -- $1.63 \mathrm{mi}$

Total impervious area -- 24.0 percent

Basin development factor -- 6

2-year, 2-hour rainfall amount -- 2.04 in.

Flood frequency data: $\mathrm{UQ}_{2} \quad 288 \mathrm{ft}^{3} / \mathrm{s}$

$\mathrm{UQ}_{5} \quad 446 \mathrm{ft}^{3} / \mathrm{s}$

$\mathrm{UQ}_{10} \quad 561 \mathrm{ft}^{3} / \mathrm{s}$

$\mathrm{UQ}_{25} \quad 718 \mathrm{ft}^{3} / \mathrm{s}$

$\mathrm{UQ}_{50} \quad 846 \mathrm{ft}^{3} / \mathrm{s}$

$\mathrm{UQ}_{100} \quad 980 \mathrm{ft}^{3} / \mathrm{s}$

$\mathrm{UQ}_{500} \quad 1,320 \mathrm{ft}^{3} / \mathrm{s}$ 


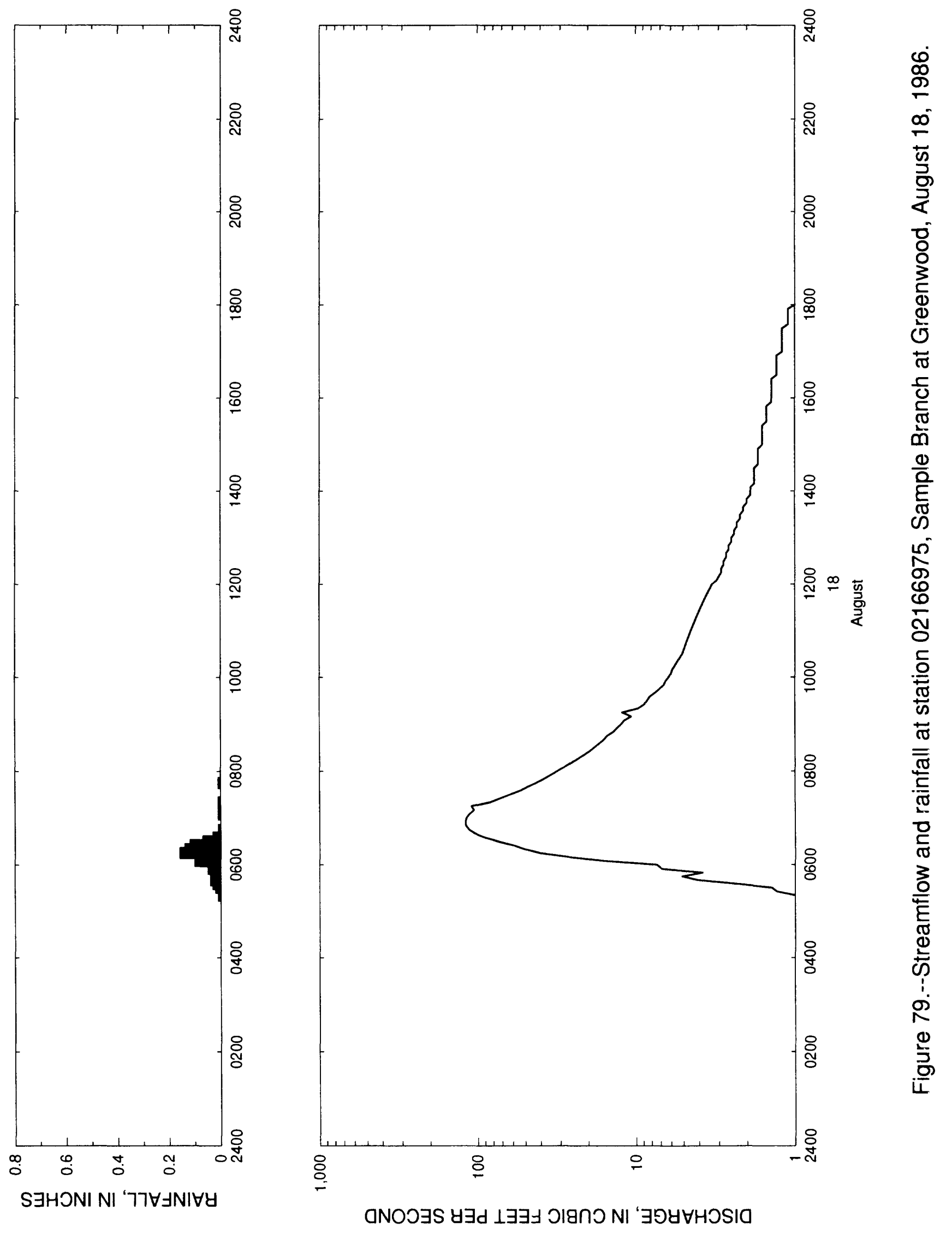


Table 78. - Streamflow and rainfall at station 02166975, Sample Branch at Greenwood, August 18,1986

\begin{tabular}{|c|c|c|c|c|c|c|c|c|}
\hline $\begin{array}{l}\text { Time } \\
\text { (hours) }\end{array}$ & $\begin{array}{l}\text { Streamflow } \\
\text { (cubic feet } \\
\text { per second) }\end{array}$ & $\begin{array}{l}\text { Rain- } \\
\text { fall } \\
\text { (inches) }\end{array}$ & $\begin{array}{l}\text { Time } \\
\text { (hours) }\end{array}$ & $\begin{array}{l}\text { Streamflow } \\
\text { (cubic feet } \\
\text { per second) }\end{array}$ & $\begin{array}{l}\text { Rain- } \\
\text { fall } \\
\text { (inches) }\end{array}$ & $\begin{array}{l}\text { Time } \\
\text { (hours) }\end{array}$ & $\begin{array}{l}\text { Streamflow } \\
\text { (cubic feet } \\
\text { per second) }\end{array}$ & $\begin{array}{l}\text { Rain- } \\
\text { fall } \\
\text { (inches) }\end{array}$ \\
\hline $\begin{array}{c}\text { August } 1 \\
0520 \\
0525 \\
0530 \\
0535\end{array}$ & $\begin{array}{r}18,1986 \\
1.0 \\
1.3 \\
1.4 \\
2.3\end{array}$ & $\begin{array}{l}0.01 \\
0.00 \\
0.02 \\
0.03\end{array}$ & $\begin{array}{l}0935 \\
0940 \\
0945 \\
0950 \\
0955\end{array}$ & $\begin{array}{l}8.2 \\
7.6 \\
7.1 \\
6.7 \\
6.5\end{array}$ & $\begin{array}{l}0.00 \\
0.00 \\
0.00 \\
0.00 \\
0.00\end{array}$ & $\begin{array}{l}1355 \\
1400 \\
1405 \\
1410 \\
1415\end{array}$ & $\begin{array}{l}1.9 \\
1.9 \\
1.9 \\
1.8 \\
1.8\end{array}$ & $\begin{array}{l}0.00 \\
0.00 \\
0.00 \\
0.00 \\
0.00\end{array}$ \\
\hline $\begin{array}{l}0540 \\
0545 \\
0550 \\
0555 \\
0600\end{array}$ & $\begin{array}{l}4.1 \\
5.1 \\
3.8 \\
6.9 \\
7.4\end{array}$ & $\begin{array}{l}0.04 \\
0.01 \\
0.01 \\
0.05 \\
0.04\end{array}$ & $\begin{array}{l}1000 \\
1005 \\
1010 \\
1015 \\
1020\end{array}$ & $\begin{array}{l}6.2 \\
6.0 \\
5.9 \\
5.7 \\
5.5\end{array}$ & $\begin{array}{l}0.00 \\
0.00 \\
0.00 \\
0.00 \\
0.00\end{array}$ & $\begin{array}{l}1420 \\
1425 \\
1430 \\
1435 \\
1440\end{array}$ & $\begin{array}{l}1.8 \\
1.8 \\
1.8 \\
1.7 \\
1.7\end{array}$ & $\begin{array}{l}0.00 \\
0.00 \\
0.00 \\
0.00 \\
0.00\end{array}$ \\
\hline $\begin{array}{l}0605 \\
0610 \\
0615 \\
0620 \\
0625\end{array}$ & $\begin{array}{l}15.7 \\
26.6 \\
40.6 \\
51.1 \\
59.6\end{array}$ & $\begin{array}{l}0.10 \\
0.10 \\
0.16 \\
0.14 \\
0.12\end{array}$ & $\begin{array}{l}1025 \\
1030 \\
1035 \\
1040 \\
1045\end{array}$ & $\begin{array}{l}5.3 \\
5.1 \\
5.0 \\
4.9 \\
4.8\end{array}$ & $\begin{array}{l}0.00 \\
0.00 \\
0.00 \\
0.00 \\
0.00\end{array}$ & $\begin{array}{l}1445 \\
1450 \\
1455 \\
1500 \\
1505\end{array}$ & $\begin{array}{l}1.7 \\
1.7 \\
1.7 \\
1.6 \\
1.6\end{array}$ & $\begin{array}{l}0.00 \\
0.00 \\
0.00 \\
0.00 \\
0.00\end{array}$ \\
\hline $\begin{array}{l}0630 \\
0635 \\
0640 \\
0645 \\
0650\end{array}$ & $\begin{array}{r}75.0 \\
91.2 \\
105.0 \\
114.0 \\
119.0\end{array}$ & $\begin{array}{l}0.07 \\
0.03 \\
0.01 \\
0.01 \\
0.00\end{array}$ & $\begin{array}{l}1050 \\
1055 \\
1100 \\
1105 \\
1110\end{array}$ & $\begin{array}{l}4.7 \\
4.6 \\
4.5 \\
4.4 \\
4.3\end{array}$ & $\begin{array}{l}0.00 \\
0.00 \\
0.00 \\
0.00 \\
0.00\end{array}$ & $\begin{array}{l}1510 \\
1515 \\
1520 \\
1525 \\
1530\end{array}$ & $\begin{array}{l}1.6 \\
1.6 \\
1.6 \\
1.6 \\
1.5\end{array}$ & $\begin{array}{l}0.00 \\
0.00 \\
0.00 \\
0.00 \\
0.00\end{array}$ \\
\hline $\begin{array}{l}0655 \\
0700 \\
0705 \\
0710 \\
0715\end{array}$ & $\begin{array}{l}120.0 \\
118.0 \\
113.0 \\
106.0 \\
110.0\end{array}$ & $\begin{array}{l}0.00 \\
0.00 \\
0.01 \\
0.00 \\
0.01\end{array}$ & $\begin{array}{l}1115 \\
1120 \\
1125 \\
1130 \\
1135\end{array}$ & $\begin{array}{l}4.2 \\
4.1 \\
4.0 \\
3.9 \\
3.8\end{array}$ & $\begin{array}{l}0.00 \\
0.00 \\
0.00 \\
0.00 \\
0.00\end{array}$ & $\begin{array}{l}1535 \\
1540 \\
1545 \\
1550 \\
1555\end{array}$ & $\begin{array}{l}1.5 \\
1.5 \\
1.5 \\
1.5 \\
1.4\end{array}$ & $\begin{array}{l}0.00 \\
0.00 \\
0.00 \\
0.00 \\
0.00\end{array}$ \\
\hline $\begin{array}{l}0720 \\
0725 \\
0730 \\
0735 \\
0740\end{array}$ & $\begin{array}{l}83.4 \\
72.1 \\
62.5 \\
53.7 \\
48.3\end{array}$ & $\begin{array}{l}0.01 \\
0.00 \\
0.00 \\
0.00 \\
0.00\end{array}$ & $\begin{array}{l}1140 \\
1145 \\
1150 \\
1155 \\
1200\end{array}$ & $\begin{array}{l}3.7 \\
3.6 \\
3.5 \\
3.4 \\
3.3\end{array}$ & $\begin{array}{l}0.00 \\
0.00 \\
0.00 \\
0.00 \\
0.00\end{array}$ & $\begin{array}{l}1600 \\
1605 \\
1610 \\
1615 \\
1620\end{array}$ & $\begin{array}{l}1.4 \\
1.4 \\
1.4 \\
1.4 \\
1.4\end{array}$ & $\begin{array}{l}0.00 \\
0.00 \\
0.00 \\
0.00 \\
0.00\end{array}$ \\
\hline $\begin{array}{l}0745 \\
0750 \\
0755 \\
0800 \\
0805\end{array}$ & $\begin{array}{l}42.6 \\
38.2 \\
34.5 \\
31.4 \\
28.5\end{array}$ & $\begin{array}{l}0.01 \\
0.00 \\
0.00 \\
0.00 \\
0.00\end{array}$ & $\begin{array}{l}1205 \\
1210 \\
1215 \\
1220 \\
1225\end{array}$ & $\begin{array}{l}3.1 \\
3.0 \\
2.9 \\
2.9 \\
2.8\end{array}$ & $\begin{array}{l}0.00 \\
0.00 \\
0.00 \\
0.00 \\
0.00\end{array}$ & $\begin{array}{l}1625 \\
1630 \\
1635 \\
1640 \\
1645\end{array}$ & $\begin{array}{l}1.4 \\
1.3 \\
1.3 \\
1.3 \\
1.3\end{array}$ & $\begin{array}{l}0.00 \\
0.00 \\
0.00 \\
0.00 \\
0.00\end{array}$ \\
\hline $\begin{array}{l}0810 \\
0815 \\
0820 \\
0825 \\
0830\end{array}$ & $\begin{array}{l}26.1 \\
23.6 \\
21.6 \\
19.8 \\
18.5\end{array}$ & $\begin{array}{l}0.00 \\
0.00 \\
0.00 \\
0.00 \\
0.00\end{array}$ & $\begin{array}{l}1230 \\
1235 \\
1240 \\
1245 \\
1250\end{array}$ & $\begin{array}{l}2.8 \\
2.7 \\
2.7 \\
2.6 \\
2.6\end{array}$ & $\begin{array}{l}0.00 \\
0.00 \\
0.00 \\
0.00 \\
0.00\end{array}$ & $\begin{array}{l}1650 \\
1655 \\
1700 \\
1705 \\
1710\end{array}$ & $\begin{array}{l}1.3 \\
1.3 \\
1.2 \\
1.2 \\
1.2\end{array}$ & $\begin{array}{l}0.00 \\
0.00 \\
0.00 \\
0.00 \\
0.00\end{array}$ \\
\hline $\begin{array}{l}0835 \\
0840 \\
0845 \\
0850 \\
0855\end{array}$ & $\begin{array}{l}17.2 \\
16.0 \\
15.2 \\
13.9 \\
13.2\end{array}$ & $\begin{array}{l}0.00 \\
0.00 \\
0.00 \\
0.00 \\
0.00\end{array}$ & $\begin{array}{l}1255 \\
1300 \\
1305 \\
1310 \\
1315\end{array}$ & $\begin{array}{l}2.5 \\
2.5 \\
2.4 \\
2.4 \\
2.3\end{array}$ & $\begin{array}{l}0.00 \\
0.00 \\
0.00 \\
0.00 \\
0.00\end{array}$ & $\begin{array}{l}1715 \\
1720 \\
1725 \\
1730 \\
1735\end{array}$ & $\begin{array}{l}1.2 \\
1.2 \\
1.2 \\
1.2 \\
1.1\end{array}$ & $\begin{array}{l}0.00 \\
0.00 \\
0.00 \\
0.00 \\
0.00\end{array}$ \\
\hline $\begin{array}{l}0900 \\
0905 \\
0910 \\
0915 \\
0920\end{array}$ & $\begin{array}{r}12.4 \\
11.8 \\
10.7 \\
12.2 \\
9.7\end{array}$ & $\begin{array}{l}0.00 \\
0.00 \\
0.00 \\
0.00 \\
0.00\end{array}$ & $\begin{array}{l}1320 \\
1325 \\
1330 \\
1335 \\
1340\end{array}$ & $\begin{array}{l}2.3 \\
2.2 \\
2.2 \\
2.1 \\
2.1\end{array}$ & $\begin{array}{l}0.00 \\
0.00 \\
0.00 \\
0.00 \\
0.00\end{array}$ & $\begin{array}{l}1740 \\
1745 \\
1750 \\
1755 \\
1800\end{array}$ & $\begin{array}{l}1.1 \\
1.1 \\
1.1 \\
1.1 \\
1.0\end{array}$ & $\begin{array}{l}0.00 \\
0.00 \\
0.00 \\
0.00 \\
0.00\end{array}$ \\
\hline $\begin{array}{l}0925 \\
0930\end{array}$ & $\begin{array}{l}8.9 \\
8.5\end{array}$ & $\begin{array}{l}0.00 \\
0.00\end{array}$ & $\begin{array}{l}1345 \\
1350\end{array}$ & $\begin{array}{l}2.0 \\
2.0\end{array}$ & $\begin{array}{l}0.00 \\
0.00\end{array}$ & & & \\
\hline
\end{tabular}




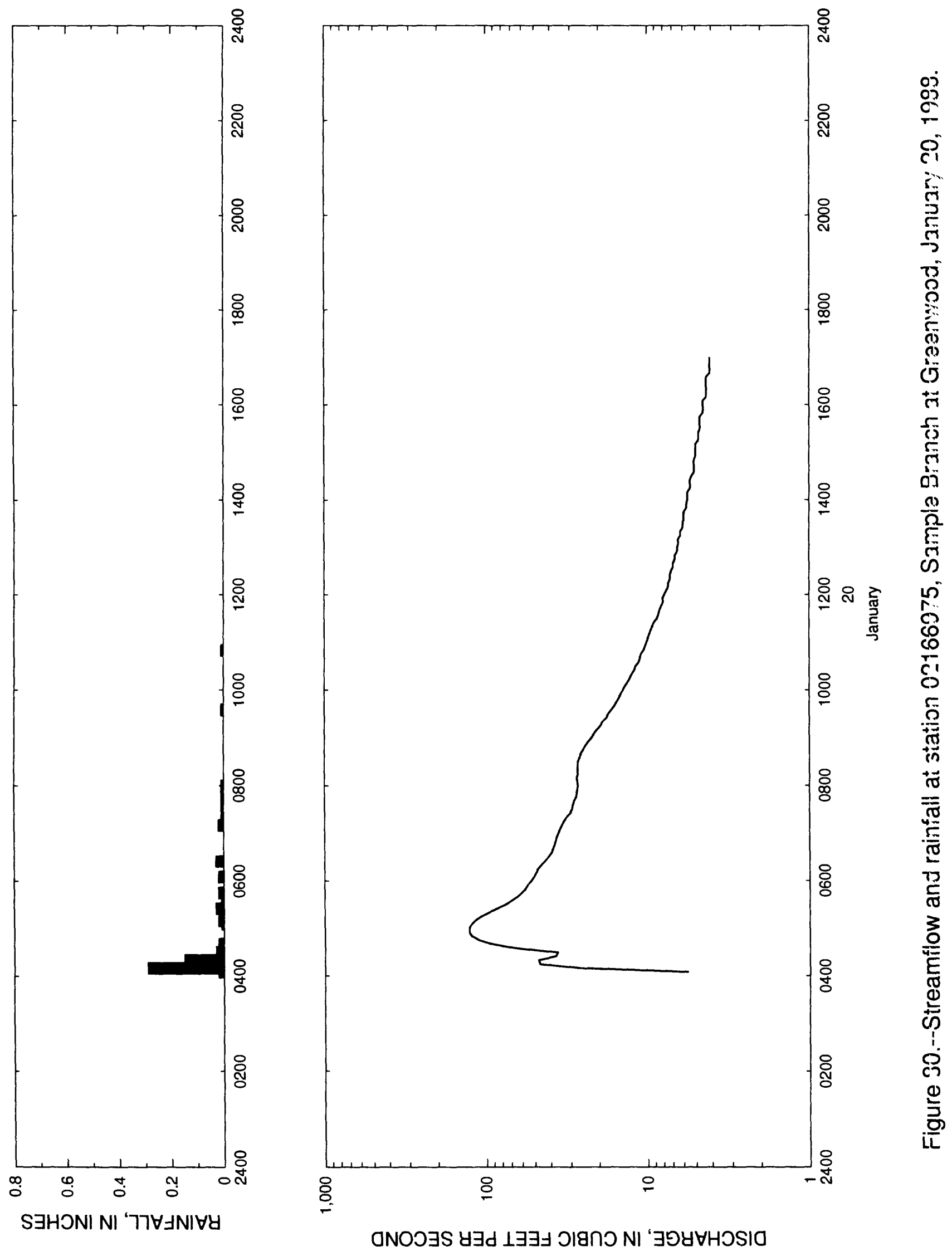


Table 79. - - Streamflow and rainfal1 at station 02166975, Sample Branch at Greenwood, January 20,1988

\begin{tabular}{|c|c|c|c|c|c|c|c|c|}
\hline $\begin{array}{l}\text { Time } \\
\text { (hours) }\end{array}$ & $\begin{array}{l}\text { Streamflow } \\
\text { (cubic feet } \\
\text { per second) }\end{array}$ & $\begin{array}{l}\text { Rain- } \\
\text { fall } \\
\text { (inches) }\end{array}$ & $\begin{array}{l}\text { Time } \\
\text { (hours) }\end{array}$ & $\begin{array}{l}\text { Streamflow } \\
\text { (cubic feet } \\
\text { per second) }\end{array}$ & $\begin{array}{l}\text { Rain- } \\
\text { fall } \\
\text { (inches) }\end{array}$ & $\begin{array}{l}\text { Time } \\
\text { (hours) }\end{array}$ & $\begin{array}{l}\text { Streamflow } \\
\text { (cubic feet } \\
\text { per second) }\end{array}$ & $\begin{array}{l}\text { Rain- } \\
\text { fall } \\
\text { (inches) }\end{array}$ \\
\hline $\begin{array}{l}\text { January } \\
0405 \\
0410 \\
0415 \\
0420\end{array}$ & $\begin{array}{r}20,1988 \\
5.6 \\
26.3 \\
46.6 \\
47.5\end{array}$ & $\begin{array}{l}0.02 \\
0.29 \\
0.07 \\
0.15\end{array}$ & $\begin{array}{l}0825 \\
0830 \\
0835 \\
0840 \\
0845\end{array}$ & $\begin{array}{l}26.9 \\
26.9 \\
26.3 \\
25.8 \\
25.0\end{array}$ & $\begin{array}{l}0.00 \\
0.00 \\
0.00 \\
0.00 \\
0.00\end{array}$ & $\begin{array}{l}1250 \\
1255 \\
1300 \\
1305 \\
1310\end{array}$ & $\begin{array}{l}6.7 \\
6.5 \\
6.5 \\
6.4 \\
6.4\end{array}$ & $\begin{array}{l}0.00 \\
0.00 \\
0.00 \\
0.00 \\
0.00\end{array}$ \\
\hline $\begin{array}{l}0425 \\
0430 \\
0435 \\
0440 \\
0445\end{array}$ & $\begin{array}{r}37.1 \\
36.3 \\
65.7 \\
91.9 \\
111.0\end{array}$ & $\begin{array}{l}0.00 \\
0.03 \\
0.00 \\
0.02 \\
0.00\end{array}$ & $\begin{array}{l}0850 \\
0855 \\
0900 \\
0905 \\
0910\end{array}$ & $\begin{array}{l}24.2 \\
23.3 \\
22.2 \\
21.4 \\
20.6\end{array}$ & $\begin{array}{l}0.00 \\
0.00 \\
0.00 \\
0.00 \\
0.00\end{array}$ & $\begin{array}{l}1315 \\
1320 \\
1325 \\
1330 \\
1335\end{array}$ & $\begin{array}{l}6.2 \\
6.2 \\
6.0 \\
6.0 \\
5.9\end{array}$ & $\begin{array}{l}0.00 \\
0.00 \\
0.00 \\
0.00 \\
0.00\end{array}$ \\
\hline $\begin{array}{l}0450 \\
0455 \\
0500 \\
0505 \\
0510\end{array}$ & $\begin{array}{l}123.0 \\
128.0 \\
128.0 \\
123.0 \\
117.0\end{array}$ & $\begin{array}{l}0.00 \\
0.00 \\
0.00 \\
0.01 \\
0.02\end{array}$ & $\begin{array}{l}0915 \\
0920 \\
0925 \\
0930 \\
0935\end{array}$ & $\begin{array}{l}19.5 \\
19.0 \\
17.9 \\
17.4 \\
16.7\end{array}$ & $\begin{array}{l}0.00 \\
0.00 \\
0.00 \\
0.00 \\
0.01\end{array}$ & $\begin{array}{l}1340 \\
1345 \\
1350 \\
1355 \\
1400\end{array}$ & $\begin{array}{l}5.9 \\
5.9 \\
5.7 \\
5.7 \\
5.6\end{array}$ & $\begin{array}{l}0.00 \\
0.00 \\
0.00 \\
0.00 \\
0.00\end{array}$ \\
\hline $\begin{array}{l}0515 \\
0520 \\
0525 \\
0530 \\
0535\end{array}$ & $\begin{array}{r}108.0 \\
96.3 \\
85.4 \\
76.2 \\
69.4\end{array}$ & $\begin{array}{l}0.00 \\
0.00 \\
0.03 \\
0.00 \\
0.01\end{array}$ & $\begin{array}{l}0940 \\
0945 \\
0950 \\
0955 \\
1000\end{array}$ & $\begin{array}{l}16.0 \\
15.5 \\
15.0 \\
14.6 \\
14.1\end{array}$ & $\begin{array}{l}0.00 \\
0.00 \\
0.00 \\
0.00 \\
0.00\end{array}$ & $\begin{array}{l}1405 \\
1410 \\
1415 \\
1420 \\
1425\end{array}$ & $\begin{array}{l}5.6 \\
5.6 \\
5.4 \\
5.4 \\
5.4\end{array}$ & $\begin{array}{l}0.00 \\
0.00 \\
0.00 \\
0.00 \\
0.00\end{array}$ \\
\hline $\begin{array}{l}0540 \\
0545 \\
0550 \\
0555 \\
0600\end{array}$ & $\begin{array}{l}63.9 \\
60.2 \\
57.2 \\
55.1 \\
52.5\end{array}$ & $\begin{array}{l}0.00 \\
0.02 \\
0.00 \\
0.00 \\
0.00\end{array}$ & $\begin{array}{l}1005 \\
1010 \\
1015 \\
1020 \\
1025\end{array}$ & $\begin{array}{l}13.7 \\
13.2 \\
12.8 \\
12.4 \\
12.0\end{array}$ & $\begin{array}{l}0.00 \\
0.00 \\
0.00 \\
0.00 \\
0.00\end{array}$ & $\begin{array}{l}1430 \\
1435 \\
1440 \\
1445 \\
1450\end{array}$ & $\begin{array}{l}5.3 \\
5.1 \\
5.1 \\
5.1 \\
5.1\end{array}$ & $\begin{array}{l}0.00 \\
0.00 \\
0.00 \\
0.00 \\
0.00\end{array}$ \\
\hline $\begin{array}{l}0605 \\
0610 \\
0615 \\
0620 \\
0625\end{array}$ & $\begin{array}{l}50.6 \\
49.2 \\
47.8 \\
45.4 \\
43.2\end{array}$ & $\begin{array}{l}0.02 \\
0.00 \\
0.00 \\
0.00 \\
0.03\end{array}$ & $\begin{array}{l}1030 \\
1035 \\
1040 \\
1045 \\
1050\end{array}$ & $\begin{array}{l}11.8 \\
11.3 \\
11.1 \\
10.9 \\
10.5\end{array}$ & $\begin{array}{l}0.00 \\
0.00 \\
0.00 \\
0.00 \\
0.01\end{array}$ & $\begin{array}{l}1455 \\
1500 \\
1505 \\
1510 \\
1515\end{array}$ & $\begin{array}{l}5.0 \\
5.0 \\
5.0 \\
5.0 \\
4.8\end{array}$ & $\begin{array}{l}0.00 \\
0.00 \\
0.00 \\
0.00 \\
0.00\end{array}$ \\
\hline $\begin{array}{l}0630 \\
0635 \\
0640 \\
0645 \\
0650\end{array}$ & $\begin{array}{l}41.2 \\
39.5 \\
38.5 \\
37.7 \\
37.1\end{array}$ & $\begin{array}{l}0.00 \\
0.00 \\
0.00 \\
0.00 \\
0.00\end{array}$ & $\begin{array}{l}1055 \\
1100 \\
1105 \\
1110 \\
1115\end{array}$ & $\begin{array}{r}10.3 \\
10.1 \\
9.9 \\
9.7 \\
9.5\end{array}$ & $\begin{array}{l}0.00 \\
0.00 \\
0.00 \\
0.00 \\
0.00\end{array}$ & $\begin{array}{l}1520 \\
1525 \\
1530 \\
1535 \\
1540\end{array}$ & $\begin{array}{l}4.8 \\
4.8 \\
4.7 \\
4.7 \\
4.7\end{array}$ & $\begin{array}{l}0.00 \\
0.00 \\
0.00 \\
0.00 \\
0.00\end{array}$ \\
\hline $\begin{array}{l}0655 \\
0700 \\
0705 \\
0710 \\
0715\end{array}$ & $\begin{array}{l}36.6 \\
35.8 \\
34.8 \\
34.0 \\
33.0\end{array}$ & $\begin{array}{l}0.00 \\
0.00 \\
0.00 \\
0.02 \\
0.00\end{array}$ & $\begin{array}{l}1120 \\
1125 \\
1130 \\
1135 \\
1140\end{array}$ & $\begin{array}{l}9.3 \\
9.1 \\
8.7 \\
8.5 \\
8.4\end{array}$ & $\begin{array}{l}0.00 \\
0.00 \\
0.00 \\
0.00 \\
0.00\end{array}$ & $\begin{array}{l}1545 \\
1550 \\
1555 \\
1600 \\
1605\end{array}$ & $\begin{array}{l}4.7 \\
4.5 \\
4.5 \\
4.5 \\
4.5\end{array}$ & $\begin{array}{l}0.00 \\
0.00 \\
0.00 \\
0.00 \\
0.00\end{array}$ \\
\hline $\begin{array}{l}0720 \\
0725 \\
0730 \\
0735 \\
0740\end{array}$ & $\begin{array}{l}31.7 \\
30.1 \\
29.3 \\
29.0 \\
28.5\end{array}$ & $\begin{array}{l}0.00 \\
0.01 \\
0.01 \\
0.00 \\
0.00\end{array}$ & $\begin{array}{l}1145 \\
1150 \\
1155 \\
1200 \\
1205\end{array}$ & $\begin{array}{l}8.2 \\
8.0 \\
8.0 \\
7.8 \\
7.6\end{array}$ & $\begin{array}{l}0.00 \\
0.00 \\
0.00 \\
0.00 \\
0.00\end{array}$ & $\begin{array}{l}1610 \\
1615 \\
1620 \\
1625 \\
1630\end{array}$ & $\begin{array}{l}4.3 \\
4.3 \\
4.3 \\
4.3 \\
4.3\end{array}$ & $\begin{array}{l}0.00 \\
0.00 \\
0.00 \\
0.00 \\
0.00\end{array}$ \\
\hline $\begin{array}{l}0745 \\
0750 \\
0755 \\
0800 \\
0805\end{array}$ & $\begin{array}{l}27.7 \\
27.4 \\
27.1 \\
26.9 \\
27.1\end{array}$ & $\begin{array}{l}0.01 \\
0.01 \\
0.00 \\
0.01 \\
0.00\end{array}$ & $\begin{array}{l}1210 \\
1215 \\
1220 \\
1225 \\
1230\end{array}$ & $\begin{array}{l}7.4 \\
7.4 \\
7.2 \\
7.2 \\
7.1\end{array}$ & $\begin{array}{l}0.00 \\
0.00 \\
0.00 \\
0.00 \\
0.00\end{array}$ & $\begin{array}{l}1635 \\
1640 \\
1645 \\
1650 \\
1655\end{array}$ & $\begin{array}{l}4.3 \\
4.1 \\
4.1 \\
4.1 \\
4.1\end{array}$ & $\begin{array}{l}0.00 \\
0.00 \\
0.00 \\
0.00 \\
0.00\end{array}$ \\
\hline $\begin{array}{l}0810 \\
0815 \\
0820\end{array}$ & $\begin{array}{l}27.4 \\
26.9 \\
26.9\end{array}$ & $\begin{array}{l}0.00 \\
0.00 \\
0.00\end{array}$ & $\begin{array}{l}1235 \\
1240 \\
1245\end{array}$ & $\begin{array}{l}6.9 \\
6.9 \\
6.7\end{array}$ & $\begin{array}{l}0.00 \\
0.00 \\
0.00\end{array}$ & 1700 & 4.1 & 0.00 \\
\hline
\end{tabular}




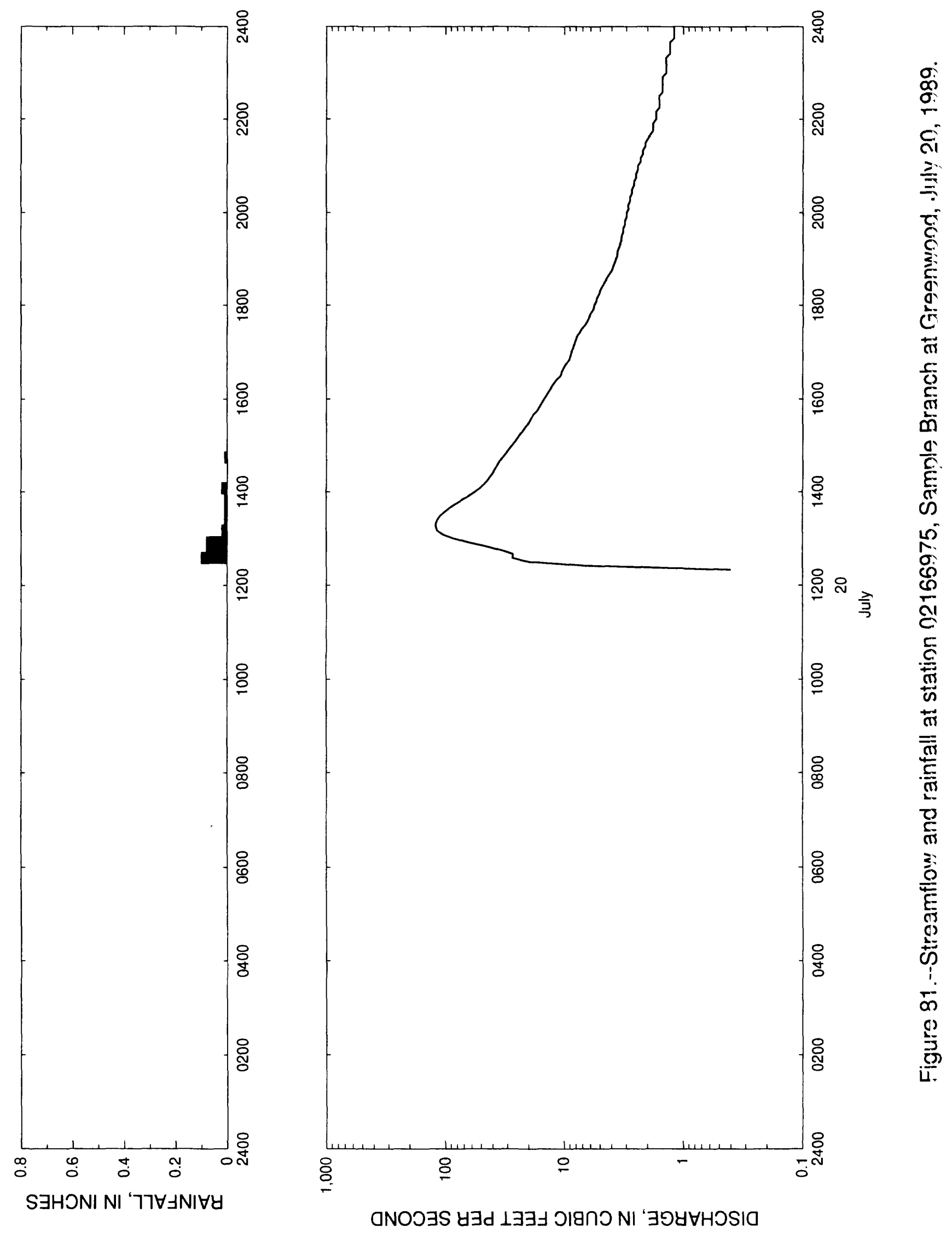


Table 80.- Streamflow and rainfall at station 02166975, Sample Branch at Greenwood, July 20,1989

\begin{tabular}{|c|c|c|c|c|c|c|c|c|}
\hline $\begin{array}{l}\text { Time } \\
\text { (hours) }\end{array}$ & $\begin{array}{l}\text { Streamflow } \\
\text { (cubic feet } \\
\text { per second) }\end{array}$ & $\begin{array}{l}\text { Rain- } \\
\text { fall } \\
\text { (inches) }\end{array}$ & $\begin{array}{l}\text { Time } \\
\text { (hours) }\end{array}$ & $\begin{array}{l}\text { Streamflow } \\
\text { (cubic feet } \\
\text { per second) }\end{array}$ & $\begin{array}{l}\text { Rain- } \\
\text { fall } \\
\text { (inches) }\end{array}$ & $\begin{array}{l}\text { Time } \\
\text { (hours) }\end{array}$ & $\begin{array}{l}\text { Streamflow } \\
\text { (cubic feet } \\
\text { per second) }\end{array}$ & $\begin{array}{l}\text { Pain- } \\
\text { fa11 } \\
\text { (inches) }\end{array}$ \\
\hline $\begin{array}{l}\text { July 20, } \\
1220 \\
1225 \\
1230 \\
1235\end{array}$ & $\begin{array}{r}1989 \\
0.4 \\
6.7 \\
19.3 \\
27.1\end{array}$ & $\begin{array}{l}0.00 \\
0.00 \\
0.00 \\
0.10\end{array}$ & $\begin{array}{l}1615 \\
1620 \\
1625 \\
1630 \\
1635\end{array}$ & $\begin{array}{l}12.8 \\
12.2 \\
11.5 \\
10.7 \\
10.5\end{array}$ & $\begin{array}{l}0.00 \\
0.00 \\
0.00 \\
0.00 \\
0.00\end{array}$ & $\begin{array}{l}2015 \\
2020 \\
2025 \\
2030 \\
2035\end{array}$ & $\begin{array}{l}2.8 \\
2.8 \\
2.7 \\
2.7 \\
2.6\end{array}$ & $\begin{array}{l}0.00 \\
0.00 \\
0.00 \\
0.00 \\
0.00\end{array}$ \\
\hline $\begin{array}{l}1240 \\
1245 \\
1250 \\
1255 \\
1300\end{array}$ & $\begin{array}{l}26.9 \\
34.0 \\
45.7 \\
65.1 \\
85.8\end{array}$ & $\begin{array}{l}0.08 \\
0.05 \\
0.05 \\
0.08 \\
0.02\end{array}$ & $\begin{array}{l}1640 \\
1645 \\
1650 \\
1655 \\
1700\end{array}$ & $\begin{array}{r}10.1 \\
9.7 \\
9.1 \\
8.9 \\
8.7\end{array}$ & $\begin{array}{l}0.00 \\
0.00 \\
0.00 \\
0.00 \\
0.00\end{array}$ & $\begin{array}{l}2040 \\
2045 \\
2050 \\
2055 \\
2100\end{array}$ & $\begin{array}{l}2.6 \\
2.5 \\
2.5 \\
2.4 \\
2.4\end{array}$ & $\begin{array}{l}0.00 \\
0.00 \\
0.00 \\
0.00 \\
0.00\end{array}$ \\
\hline $\begin{array}{l}1305 \\
1310 \\
1315 \\
1320 \\
1325\end{array}$ & $\begin{array}{l}105.0 \\
117.0 \\
120.0 \\
120.0 \\
116.0\end{array}$ & $\begin{array}{l}0.01 \\
0.02 \\
0.01 \\
0.00 \\
0.00\end{array}$ & $\begin{array}{l}1705 \\
1710 \\
1715 \\
1720 \\
1725\end{array}$ & $\begin{array}{l}8.4 \\
8.2 \\
8.0 \\
7.8 \\
7.4\end{array}$ & $\begin{array}{l}0.00 \\
0.00 \\
0.00 \\
0.00 \\
0.00\end{array}$ & $\begin{array}{l}2105 \\
2110 \\
2115 \\
2120 \\
2125\end{array}$ & $\begin{array}{l}2.3 \\
2.3 \\
2.2 \\
2.2 \\
2.1\end{array}$ & $\begin{array}{l}0.00 \\
0.00 \\
0.00 \\
0.00 \\
0.00\end{array}$ \\
\hline $\begin{array}{l}1330 \\
1335 \\
1340 \\
1345 \\
1350\end{array}$ & $\begin{array}{r}110.0 \\
101.0 \\
91.9 \\
81.8 \\
72.8\end{array}$ & $\begin{array}{l}0.01 \\
0.00 \\
0.00 \\
0.01 \\
0.01\end{array}$ & $\begin{array}{l}1730 \\
1735 \\
1740 \\
1745 \\
1750\end{array}$ & $\begin{array}{l}7.1 \\
6.7 \\
6.4 \\
6.2 \\
6.0\end{array}$ & $\begin{array}{l}0.00 \\
0.00 \\
0.00 \\
0.00 \\
0.00\end{array}$ & $\begin{array}{l}2130 \\
2135 \\
2140 \\
2145 \\
2150\end{array}$ & $\begin{array}{l}2.1 \\
2.0 \\
1.9 \\
1.8 \\
1.8\end{array}$ & $\begin{array}{l}0.00 \\
0.00 \\
0.00 \\
0.00 \\
0.00\end{array}$ \\
\hline $\begin{array}{l}1355 \\
1400 \\
1405 \\
1410 \\
1415\end{array}$ & $\begin{array}{l}63.9 \\
56.6 \\
51.4 \\
47.8 \\
44.6\end{array}$ & $\begin{array}{l}0.01 \\
0.00 \\
0.02 \\
0.00 \\
0.00\end{array}$ & $\begin{array}{l}1755 \\
1800 \\
1805 \\
1810 \\
1815\end{array}$ & $\begin{array}{l}5.7 \\
5.6 \\
5.4 \\
5.3 \\
5.1\end{array}$ & $\begin{array}{l}0.00 \\
0.00 \\
0.00 \\
0.00 \\
0.00\end{array}$ & $\begin{array}{l}2155 \\
2200 \\
2205 \\
2210 \\
2215\end{array}$ & $\begin{array}{l}1.8 \\
1.7 \\
1.7 \\
1.7 \\
1.6\end{array}$ & $\begin{array}{l}0.00 \\
0.00 \\
0.00 \\
0.00 \\
0.00\end{array}$ \\
\hline $\begin{array}{l}1420 \\
1425 \\
1430 \\
1435 \\
1440\end{array}$ & $\begin{array}{l}42.3 \\
40.1 \\
38.7 \\
36.9 \\
35.3\end{array}$ & $\begin{array}{l}0.00 \\
0.00 \\
0.00 \\
0.00 \\
0.00\end{array}$ & $\begin{array}{l}1820 \\
1825 \\
1830 \\
1835 \\
1840\end{array}$ & $\begin{array}{l}5.0 \\
4.8 \\
4.6 \\
4.4 \\
4.2\end{array}$ & $\begin{array}{l}0.00 \\
0.00 \\
0.00 \\
0.00 \\
0.00\end{array}$ & $\begin{array}{l}2220 \\
2225 \\
2230 \\
2235 \\
2240\end{array}$ & $\begin{array}{l}1.6 \\
1.6 \\
1.6 \\
1.5 \\
1.5\end{array}$ & $\begin{array}{l}0.00 \\
0.00 \\
0.00 \\
0.00 \\
0.00\end{array}$ \\
\hline $\begin{array}{l}1445 \\
1450 \\
1455 \\
1500 \\
1505\end{array}$ & $\begin{array}{l}33.0 \\
31.1 \\
29.5 \\
27.7 \\
26.1\end{array}$ & $\begin{array}{l}0.01 \\
0.00 \\
0.00 \\
0.00 \\
0.00\end{array}$ & $\begin{array}{l}1845 \\
1850 \\
1855 \\
1900 \\
1905\end{array}$ & $\begin{array}{l}4.0 \\
3.9 \\
3.8 \\
3.7 \\
3.6\end{array}$ & $\begin{array}{l}0.00 \\
0.00 \\
0.00 \\
0.00 \\
0.00\end{array}$ & $\begin{array}{l}2245 \\
2250 \\
2255 \\
2300 \\
2305\end{array}$ & $\begin{array}{l}1.5 \\
1.5 \\
1.5 \\
1.4 \\
1.4\end{array}$ & $\begin{array}{l}0.00 \\
0.00 \\
0.00 \\
0.00 \\
0.00\end{array}$ \\
\hline $\begin{array}{l}1510 \\
1515 \\
1520 \\
1525 \\
1530\end{array}$ & $\begin{array}{l}24.8 \\
23.6 \\
22.2 \\
21.1 \\
19.8\end{array}$ & $\begin{array}{l}0.00 \\
0.00 \\
0.00 \\
0.00 \\
0.00\end{array}$ & $\begin{array}{l}1910 \\
1915 \\
1920 \\
1925 \\
1930\end{array}$ & $\begin{array}{l}3.6 \\
3.5 \\
3.4 \\
3.3 \\
3.3\end{array}$ & $\begin{array}{l}0.00 \\
0.00 \\
0.00 \\
0.00 \\
0.00\end{array}$ & $\begin{array}{l}2310 \\
2315 \\
2320 \\
2325 \\
2330\end{array}$ & $\begin{array}{l}1.4 \\
1.4 \\
1.4 \\
1.3 \\
1.3\end{array}$ & $\begin{array}{l}0.00 \\
0.00 \\
0.00 \\
0.00 \\
0.00\end{array}$ \\
\hline $\begin{array}{l}1535 \\
1540 \\
1545 \\
1550 \\
1555\end{array}$ & $\begin{array}{l}19.0 \\
18.2 \\
16.9 \\
16.2 \\
15.5\end{array}$ & $\begin{array}{l}0.00 \\
0.00 \\
0.00 \\
0.00 \\
0.00\end{array}$ & $\begin{array}{l}1935 \\
1940 \\
1945 \\
1950 \\
1955\end{array}$ & $\begin{array}{l}3.2 \\
3.2 \\
3.1 \\
3.1 \\
3.0\end{array}$ & $\begin{array}{l}0.00 \\
0.00 \\
0.00 \\
0.00 \\
0.00\end{array}$ & $\begin{array}{l}2335 \\
2340 \\
2345 \\
2350 \\
2355\end{array}$ & $\begin{array}{l}1.3 \\
1.3 \\
1.2 \\
1.2 \\
1.2\end{array}$ & $\begin{array}{l}0.00 \\
0.00 \\
0.00 \\
0.00 \\
0.00\end{array}$ \\
\hline $\begin{array}{l}1600 \\
1605 \\
1610\end{array}$ & $\begin{array}{l}14.8 \\
14.1 \\
13.5\end{array}$ & $\begin{array}{l}0.00 \\
0.00 \\
0.00\end{array}$ & $\begin{array}{l}2000 \\
2005 \\
2010\end{array}$ & $\begin{array}{l}3.0 \\
2.9 \\
2.9\end{array}$ & $\begin{array}{l}0.00 \\
0.00 \\
0.00\end{array}$ & $\underset{0000}{\text { July }} 21$ & 19891.2 & 0.00 \\
\hline
\end{tabular}



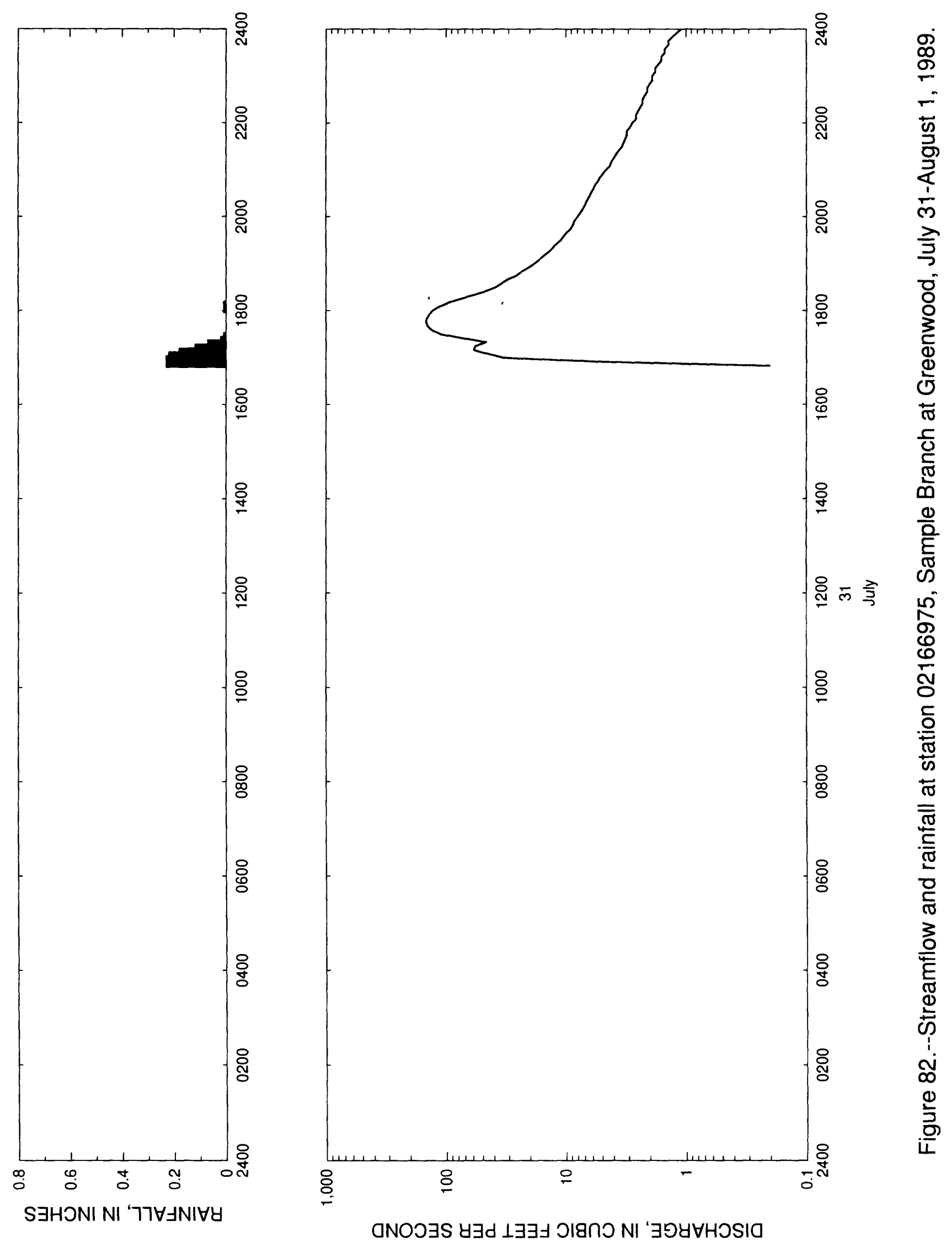
Table 81.--Streamflow and rainfall at station 02166975. Sample Branch at Greenwood, July 31 - August 1,1989

\begin{tabular}{|c|c|c|c|c|c|c|c|c|}
\hline $\begin{array}{l}\text { Time } \\
\text { (hours) }\end{array}$ & $\begin{array}{l}\text { Streamflow } \\
\text { (cubic feet } \\
\text { per second) }\end{array}$ & $\begin{array}{l}\text { Rain- } \\
\text { fal1 } \\
\text { (inches) }\end{array}$ & $\begin{array}{l}\text { Time } \\
\text { (hours) }\end{array}$ & $\begin{array}{l}\text { Streamflow } \\
\text { (cubic feet } \\
\text { per second) }\end{array}$ & $\begin{array}{l}\text { Rain- } \\
\text { fall } \\
\text { (inches) }\end{array}$ & $\begin{array}{l}\text { Time } \\
\text { (hours) }\end{array}$ & $\begin{array}{l}\text { Streamflow } \\
\text { (cubic feet } \\
\text { per second) }\end{array}$ & $\begin{array}{l}\text { Rain- } \\
\text { fall } \\
\text { (incres) }\end{array}$ \\
\hline $\begin{array}{l}\text { July } 31, \\
1650 \\
1655 \\
1700 \\
1705\end{array}$ & $\begin{array}{r}1989 \\
0.2 \\
5.0 \\
32.5 \\
44.3\end{array}$ & $\begin{array}{l}0.00 \\
0.23 \\
0.22 \\
0.18\end{array}$ & $\begin{array}{l}1915 \\
1920 \\
1925 \\
1930 \\
1935\end{array}$ & $\begin{array}{l}14.1 \\
13.0 \\
12.2 \\
11.1 \\
10.5\end{array}$ & $\begin{array}{l}0.00 \\
0.00 \\
0.00 \\
0.00 \\
0.00\end{array}$ & $\begin{array}{l}2145 \\
2150 \\
2155 \\
2200 \\
2205\end{array}$ & $\begin{array}{l}3.1 \\
3.0 \\
2.9 \\
2.8 \\
2.6\end{array}$ & $\begin{array}{l}0.00 \\
0.00 \\
0.00 \\
0.00 \\
0.00\end{array}$ \\
\hline $\begin{array}{l}1710 \\
1715 \\
1720 \\
1725 \\
1730\end{array}$ & $\begin{array}{r}59.0 \\
57.5 \\
46.3 \\
72.4 \\
110.0\end{array}$ & $\begin{array}{l}0.12 \\
0.07 \\
0.02 \\
0.01 \\
0.00\end{array}$ & $\begin{array}{l}1940 \\
1945 \\
1950 \\
1955 \\
2000\end{array}$ & $\begin{array}{l}9.9 \\
9.1 \\
8.7 \\
8.5 \\
8.0\end{array}$ & $\begin{array}{l}0.00 \\
0.00 \\
0.00 \\
0.00 \\
0.00\end{array}$ & $\begin{array}{l}2210 \\
2215 \\
2220 \\
2225 \\
2230\end{array}$ & $\begin{array}{l}2.6 \\
2.5 \\
2.4 \\
2.3 \\
2.3\end{array}$ & $\begin{array}{l}0.00 \\
0.00 \\
0.00 \\
0.00 \\
0.00\end{array}$ \\
\hline $\begin{array}{l}1735 \\
1740 \\
1745 \\
1750 \\
1755\end{array}$ & $\begin{array}{l}131.0 \\
142.0 \\
147.0 \\
145.0 \\
139.0\end{array}$ & $\begin{array}{l}0.00 \\
0.00 \\
0.00 \\
0.00 \\
0.00\end{array}$ & $\begin{array}{l}2005 \\
2010 \\
2015 \\
2020 \\
2025\end{array}$ & $\begin{array}{l}7.6 \\
7.2 \\
6.9 \\
6.7 \\
6.4\end{array}$ & $\begin{array}{l}0.00 \\
0.00 \\
0.00 \\
0.00 \\
0.00\end{array}$ & $\begin{array}{l}2235 \\
2240 \\
2245 \\
2250 \\
2255\end{array}$ & $\begin{array}{l}2.2 \\
2.1 \\
2.1 \\
2.0 \\
1.9\end{array}$ & $\begin{array}{l}0.00 \\
0.07 \\
0.07 \\
0.00 \\
0.00\end{array}$ \\
\hline $\begin{array}{l}1800 \\
1805 \\
1810 \\
1815 \\
1820\end{array}$ & $\begin{array}{r}130.0 \\
116.0 \\
98.0 \\
77.2 \\
60.2\end{array}$ & $\begin{array}{l}0.00 \\
0.01 \\
0.00 \\
0.00 \\
0.00\end{array}$ & $\begin{array}{l}2030 \\
2035 \\
2040 \\
2045 \\
2050\end{array}$ & $\begin{array}{l}6.2 \\
5.9 \\
5.7 \\
5.4 \\
5.2\end{array}$ & $\begin{array}{l}0.00 \\
0.00 \\
0.00 \\
0.00 \\
0.00\end{array}$ & $\begin{array}{l}2300 \\
2305 \\
2310 \\
2315 \\
2320\end{array}$ & $\begin{array}{l}1.9 \\
1.8 \\
1.8 \\
1.7 \\
1.6\end{array}$ & $\begin{array}{l}0.0 ? \\
0.00 \\
0.07 \\
0.07 \\
0.07\end{array}$ \\
\hline $\begin{array}{l}1825 \\
1830 \\
1835 \\
1840 \\
1845\end{array}$ & $\begin{array}{l}47.2 \\
39.2 \\
34.8 \\
30.6 \\
26.1\end{array}$ & $\begin{array}{l}0.00 \\
0.00 \\
0.00 \\
0.00 \\
0.00\end{array}$ & $\begin{array}{l}2055 \\
2100 \\
2105 \\
2110 \\
2115\end{array}$ & $\begin{array}{l}4.9 \\
4.6 \\
4.3 \\
4.2 \\
4.0\end{array}$ & $\begin{array}{l}0.00 \\
0.00 \\
0.00 \\
0.00 \\
0.00\end{array}$ & $\begin{array}{l}2325 \\
2330 \\
2335 \\
2340 \\
2345\end{array}$ & $\begin{array}{l}1.6 \\
1.5 \\
1.5 \\
1.4 \\
1.4\end{array}$ & $\begin{array}{l}0.00 \\
0.00 \\
0.00 \\
0.00 \\
0.00\end{array}$ \\
\hline $\begin{array}{l}1850 \\
1855 \\
1900 \\
1905 \\
1910\end{array}$ & $\begin{array}{l}23.6 \\
20.8 \\
18.5 \\
16.9 \\
15.5\end{array}$ & $\begin{array}{l}.00 \\
0.00 \\
0.00 \\
0.00 \\
0.00\end{array}$ & $\begin{array}{l}2120 \\
2125 \\
2130 \\
2135 \\
2140\end{array}$ & $\begin{array}{l}3.8 \\
3.6 \\
3.4 \\
3.3 \\
3.2\end{array}$ & $\begin{array}{l}0.00 \\
0.00 \\
0.00 \\
0.00 \\
0.00\end{array}$ & $\begin{array}{c}2350 \\
2355 \\
\text { August } \\
0000\end{array}$ & 1. $1989^{1.3} \begin{array}{r}1.2 \\
1.1\end{array}$ & $\begin{array}{l}0.00 \\
0.00 \\
0.00\end{array}$ \\
\hline
\end{tabular}




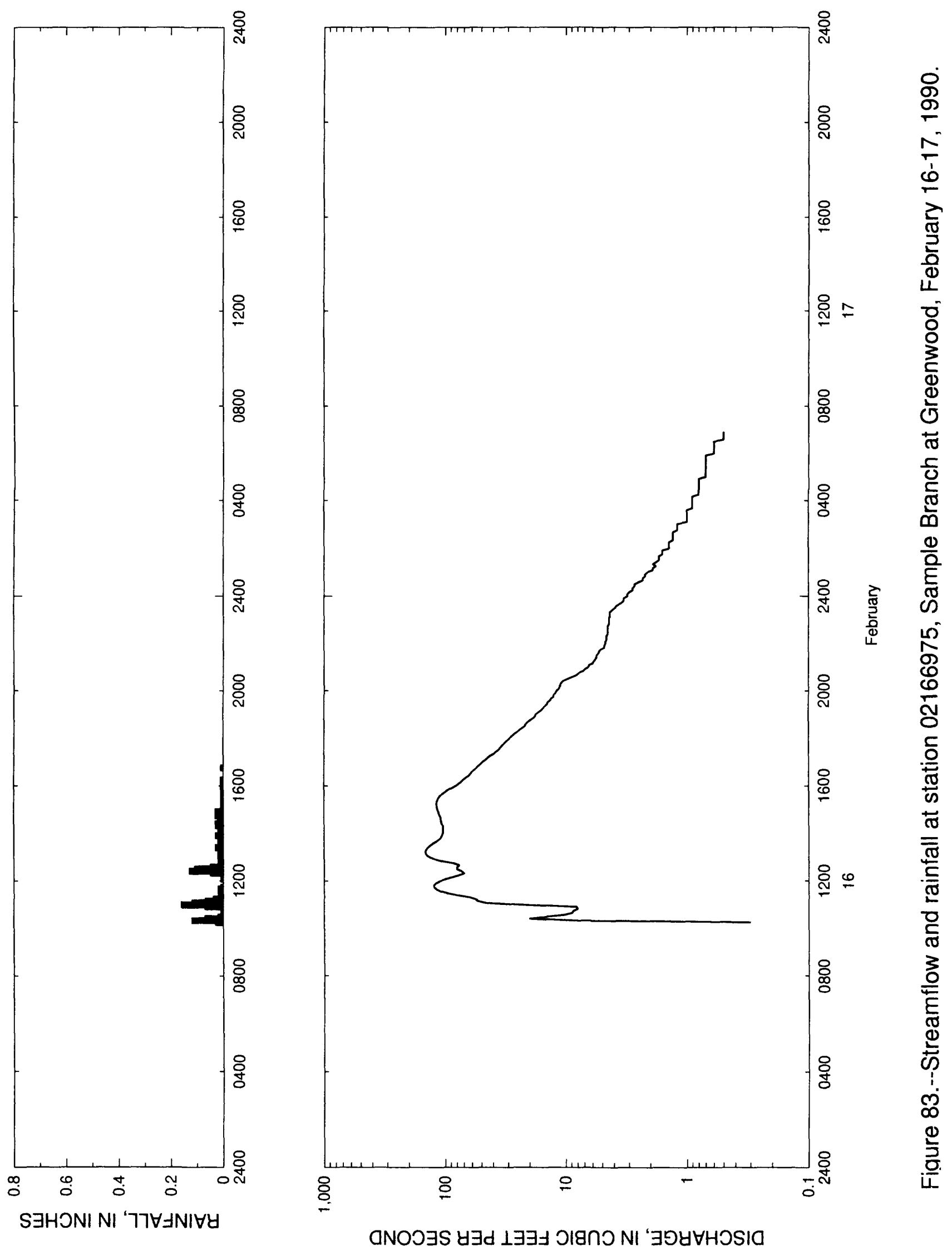


Table 82.--Streamflow and rainfall at station 02166975, Sample Branch at Greenwood, February $16-17,1990$

\begin{tabular}{|c|c|c|c|c|c|c|c|c|}
\hline $\begin{array}{l}\text { Time } \\
\text { (hours) }\end{array}$ & $\begin{array}{l}\text { Streamflow } \\
\text { (cubic feet } \\
\text { per second) }\end{array}$ & $\begin{array}{l}\text { Rain- } \\
\text { fall } \\
\text { (inches) }\end{array}$ & $\begin{array}{l}\text { Time } \\
\text { (hours) }\end{array}$ & $\begin{array}{l}\text { Streamflow } \\
\text { (cubic feet } \\
\text { per second) }\end{array}$ & $\begin{array}{l}\text { Rain- } \\
\text { fal1 } \\
\text { (inches) }\end{array}$ & $\begin{array}{l}\text { Time } \\
\text { (hours) }\end{array}$ & $\begin{array}{l}\text { Streamflow } \\
\text { (cubic feet } \\
\text { per second) }\end{array}$ & $\begin{array}{l}\text { Rain- } \\
\text { fal1 } \\
\text { (inches) }\end{array}$ \\
\hline $\begin{array}{l}\text { February } \\
1015 \\
1020 \\
1025 \\
1030\end{array}$ & 16, $\begin{array}{r}1990 \\
0.3 \\
7.6 \\
20.3 \\
14.8\end{array}$ & $\begin{array}{l}0.03 \\
0.12 \\
0.07 \\
0.02\end{array}$ & $\begin{array}{l}1535 \\
1540 \\
1545 \\
1550 \\
1555\end{array}$ & $\begin{array}{r}111.0 \\
105.0 \\
99.7 \\
95.0 \\
87.5\end{array}$ & $\begin{array}{l}0.01 \\
0.00 \\
0.01 \\
0.00 \\
0.01\end{array}$ & $\begin{array}{l}2100 \\
2105 \\
2110 \\
2115 \\
2120\end{array}$ & $\begin{array}{l}6.5 \\
6.4 \\
6.0 \\
5.9 \\
5.7\end{array}$ & $\begin{array}{l}0.00 \\
0.00 \\
0.00 \\
0.00 \\
0.00\end{array}$ \\
\hline $\begin{array}{l}1035 \\
1040 \\
1045 \\
1050 \\
1055\end{array}$ & $\begin{array}{r}10.3 \\
8.9 \\
8.7 \\
8.0 \\
8.2\end{array}$ & $\begin{array}{l}0.00 \\
0.01 \\
0.01 \\
0.00 \\
0.07\end{array}$ & $\begin{array}{l}1600 \\
1605 \\
1610 \\
1615 \\
1620\end{array}$ & $\begin{array}{l}81.8 \\
77.8 \\
73.7 \\
70.9 \\
67.8\end{array}$ & $\begin{array}{l}0.00 \\
0.01 \\
0.00 \\
0.01 \\
0.00\end{array}$ & $\begin{array}{l}2125 \\
2130 \\
2135 \\
2140 \\
2145\end{array}$ & $\begin{array}{l}5.6 \\
5.6 \\
5.4 \\
5.3 \\
5.1\end{array}$ & $\begin{array}{l}0.00 \\
0.00 \\
0.00 \\
0.00 \\
0.00\end{array}$ \\
\hline $\begin{array}{l}1100 \\
1105 \\
1110 \\
1115 \\
1120\end{array}$ & $\begin{array}{l}21.6 \\
46.0 \\
54.0 \\
55.7 \\
63.1\end{array}$ & $\begin{array}{l}0.16 \\
0.12 \\
0.07 \\
0.04 \\
0.02\end{array}$ & $\begin{array}{l}1625 \\
1630 \\
1635 \\
1640 \\
1645\end{array}$ & $\begin{array}{l}64.2 \\
62.2 \\
60.4 \\
57.8 \\
54.9\end{array}$ & $\begin{array}{l}0.00 \\
0.00 \\
0.00 \\
0.00 \\
0.01\end{array}$ & $\begin{array}{l}2150 \\
2155 \\
2200 \\
2205 \\
2210\end{array}$ & $\begin{array}{l}4.8 \\
4.8 \\
4.7 \\
4.7 \\
4.6\end{array}$ & $\begin{array}{l}0.00 \\
0.00 \\
0.00 \\
0.00 \\
0.00\end{array}$ \\
\hline $\begin{array}{l}1125 \\
1130 \\
1135 \\
1140 \\
1145\end{array}$ & $\begin{array}{r}79.8 \\
96.0 \\
110.0 \\
118.0 \\
124.0\end{array}$ & $\begin{array}{l}0.01 \\
0.02 \\
0.01 \\
0.02 \\
0.01\end{array}$ & $\begin{array}{l}1650 \\
1655 \\
1700 \\
1705 \\
1710\end{array}$ & $\begin{array}{l}52.8 \\
50.8 \\
48.9 \\
46.3 \\
44.6\end{array}$ & $\begin{array}{l}0.00 \\
0.00 \\
0.00 \\
0.00 \\
0.00\end{array}$ & $\begin{array}{l}2215 \\
2220 \\
2225 \\
2230 \\
2235\end{array}$ & $\begin{array}{l}4.6 \\
4.6 \\
4.5 \\
4.5 \\
4.5\end{array}$ & $\begin{array}{l}0.00 \\
0.00 \\
0.00 \\
0.00 \\
0.00\end{array}$ \\
\hline $\begin{array}{l}1150 \\
1155 \\
1200 \\
1205 \\
1210\end{array}$ & $\begin{array}{r}124.0 \\
119.0 \\
111.0 \\
100.0 \\
88.1\end{array}$ & $\begin{array}{l}0.00 \\
0.00 \\
0.00 \\
0.01 \\
0.00\end{array}$ & $\begin{array}{l}1715 \\
1720 \\
1725 \\
1730 \\
1735\end{array}$ & $\begin{array}{l}42.3 \\
39.5 \\
37.9 \\
36.1 \\
35.0\end{array}$ & $\begin{array}{l}0.00 \\
0.00 \\
0.00 \\
0.00 \\
0.00\end{array}$ & $\begin{array}{l}2240 \\
2245 \\
2250 \\
2255 \\
2300\end{array}$ & $\begin{array}{l}4.5 \\
4.5 \\
4.4 \\
4.4 \\
4.4\end{array}$ & $\begin{array}{l}0.00 \\
0.00 \\
0.00 \\
0.00 \\
0.00\end{array}$ \\
\hline $\begin{array}{l}1215 \\
1220 \\
1225 \\
1230 \\
1235\end{array}$ & $\begin{array}{l}76.9 \\
70.0 \\
73.4 \\
80.1 \\
80.1\end{array}$ & $\begin{array}{l}0.00 \\
0.05 \\
0.13 \\
0.11 \\
0.05\end{array}$ & $\begin{array}{l}1740 \\
1745 \\
1750 \\
1755 \\
1800\end{array}$ & $\begin{array}{l}33.8 \\
32.5 \\
31.4 \\
30.1 \\
29.0\end{array}$ & $\begin{array}{l}0.00 \\
0.00 \\
0.00 \\
0.00 \\
0.00\end{array}$ & $\begin{array}{l}2305 \\
2310 \\
2315 \\
2320 \\
2325\end{array}$ & $\begin{array}{l}4.4 \\
4.3 \\
4.3 \\
4.3 \\
4.1\end{array}$ & $\begin{array}{l}0.00 \\
0.00 \\
0.00 \\
0.00 \\
0.00\end{array}$ \\
\hline $\begin{array}{l}1240 \\
1245 \\
1250 \\
1255 \\
1300\end{array}$ & $\begin{array}{r}76.6 \\
86.1 \\
106.0 \\
121.0 \\
133.0\end{array}$ & $\begin{array}{l}0.02 \\
0.02 \\
0.02 \\
0.02 \\
0.01\end{array}$ & $\begin{array}{l}1805 \\
1810 \\
1815 \\
1820 \\
1825\end{array}$ & $\begin{array}{l}27.7 \\
26.6 \\
25.3 \\
24.3 \\
23.0\end{array}$ & $\begin{array}{l}0.00 \\
0.00 \\
0.00 \\
0.00 \\
0.00\end{array}$ & $\begin{array}{l}2330 \\
2335 \\
2340 \\
2345 \\
2350\end{array}$ & $\begin{array}{l}3.9 \\
3.8 \\
3.6 \\
3.4 \\
3.3\end{array}$ & $\begin{array}{l}0.00 \\
0.00 \\
0.00 \\
0.10 \\
0.10\end{array}$ \\
\hline $\begin{array}{l}1305 \\
1310 \\
1315 \\
1320 \\
1325\end{array}$ & $\begin{array}{l}141.0 \\
145.0 \\
146.0 \\
144.0 \\
140.0\end{array}$ & $\begin{array}{l}0.01 \\
0.02 \\
0.01 \\
0.01 \\
0.03\end{array}$ & $\begin{array}{l}1830 \\
1835 \\
1840 \\
1845 \\
1850\end{array}$ & $\begin{array}{l}21.9 \\
21.6 \\
20.8 \\
19.8 \\
18.7\end{array}$ & $\begin{array}{l}0.00 \\
0.00 \\
0.00 \\
0.00 \\
0.00\end{array}$ & $\begin{array}{l}2355 \\
\text { February } \\
0000 \\
0005 \\
0010\end{array}$ & $\begin{array}{r}3.3 \\
17,1990 \\
3.1 \\
3.1 \\
3.0\end{array}$ & $\begin{array}{l}0 .<0 \\
0 .<0 \\
0.00 \\
0 . c 0\end{array}$ \\
\hline $\begin{array}{l}1330 \\
1335 \\
1340 \\
1345 \\
1350\end{array}$ & $\begin{array}{l}134.0 \\
127.0 \\
119.0 \\
113.0 \\
109.0\end{array}$ & $\begin{array}{l}0.02 \\
0.02 \\
0.02 \\
0.01 \\
0.02\end{array}$ & $\begin{array}{l}1855 \\
1900 \\
1905 \\
1910 \\
1915\end{array}$ & $\begin{array}{l}17.9 \\
17.7 \\
16.9 \\
16.0 \\
15.5\end{array}$ & $\begin{array}{l}0.00 \\
0.00 \\
0.00 \\
0.00 \\
0.00\end{array}$ & $\begin{array}{l}0015 \\
0020 \\
0025 \\
0030 \\
0035\end{array}$ & $\begin{array}{l}2.8 \\
2.8 \\
2.7 \\
2.7 \\
2.5\end{array}$ & $\begin{array}{l}0 . C 0 \\
0 . C 0 \\
0 . C 0 \\
0 . C 0 \\
0 . C 0\end{array}$ \\
\hline $\begin{array}{l}1355 \\
1400 \\
1405 \\
1410 \\
1415\end{array}$ & $\begin{array}{l}107.0 \\
105.0 \\
105.0 \\
105.0 \\
105.0\end{array}$ & $\begin{array}{l}0.03 \\
0.02 \\
0.01 \\
0.02 \\
0.02\end{array}$ & $\begin{array}{l}1920 \\
1925 \\
1930 \\
1935 \\
1940\end{array}$ & $\begin{array}{l}15.0 \\
14.3 \\
14.1 \\
13.5 \\
13.2\end{array}$ & $\begin{array}{l}0.00 \\
0.00 \\
0.00 \\
0.00 \\
0.00\end{array}$ & $\begin{array}{l}0040 \\
0045 \\
0050 \\
0055 \\
0100\end{array}$ & $\begin{array}{l}2.3 \\
2.3 \\
2.2 \\
2.2 \\
2.1\end{array}$ & $\begin{array}{l}0.60 \\
0.00 \\
0.00 \\
0.00 \\
0.00\end{array}$ \\
\hline $\begin{array}{l}1420 \\
1425 \\
1430 \\
1435 \\
1440\end{array}$ & $\begin{array}{l}105.0 \\
107.0 \\
108.0 \\
109.0 \\
109.0\end{array}$ & $\begin{array}{l}0.03 \\
0.03 \\
0.02 \\
0.02 \\
0.02\end{array}$ & $\begin{array}{l}1945 \\
1950 \\
1955 \\
2000 \\
2005\end{array}$ & $\begin{array}{l}12.6 \\
12.6 \\
12.2 \\
12.0 \\
11.5\end{array}$ & $\begin{array}{l}0.00 \\
0.00 \\
0.00 \\
0.00 \\
0.00\end{array}$ & $\begin{array}{l}0105 \\
0110 \\
0115 \\
0120 \\
0125\end{array}$ & $\begin{array}{l}1.9 \\
1.9 \\
1.8 \\
1.9 \\
1.8\end{array}$ & $\begin{array}{l}0 . c 0 \\
0 . c 0 \\
0.00 \\
0 . c 0 \\
0 . c 0\end{array}$ \\
\hline $\begin{array}{l}1445 \\
1450 \\
1455 \\
1500 \\
1505\end{array}$ & $\begin{array}{l}111.0 \\
113.0 \\
114.0 \\
116.0 \\
117.0\end{array}$ & $\begin{array}{l}0.03 \\
0.02 \\
0.03 \\
0.01 \\
0.00\end{array}$ & $\begin{array}{l}2010 \\
2015 \\
2020 \\
2025 \\
2030\end{array}$ & $\begin{array}{r}11.3 \\
11.1 \\
10.9 \\
10.5 \\
9.7\end{array}$ & $\begin{array}{l}0.00 \\
0.00 \\
0.00 \\
0.00 \\
0.00\end{array}$ & $\begin{array}{l}0130 \\
0135 \\
0140 \\
0145 \\
0150\end{array}$ & $\begin{array}{l}1.7 \\
1.7 \\
1.7 \\
1.6 \\
1.6\end{array}$ & $\begin{array}{l}0.00 \\
0 . C 0 \\
0 . C 0 \\
0 . C 0 \\
0 . C 0\end{array}$ \\
\hline $\begin{array}{l}1510 \\
1515 \\
1520 \\
1525 \\
1530\end{array}$ & $\begin{array}{l}118.0 \\
119.0 \\
118.0 \\
116.0 \\
114.0\end{array}$ & $\begin{array}{l}0.01 \\
0.00 \\
0.00 \\
0.01 \\
0.00\end{array}$ & $\begin{array}{l}2035 \\
2040 \\
2045 \\
2050 \\
2055\end{array}$ & $\begin{array}{l}8.9 \\
8.2 \\
7.8 \\
7.2 \\
6.9\end{array}$ & $\begin{array}{l}0.00 \\
0.00 \\
0.00 \\
0.00 \\
0.00\end{array}$ & $\begin{array}{l}0155 \\
0200 \\
0205 \\
0210 \\
0215\end{array}$ & $\begin{array}{l}1.6 \\
1.4 \\
1.4 \\
1.4 \\
1.4\end{array}$ & $\begin{array}{l}0 . c 0 \\
0 . c 0 \\
0.00 \\
0 . c 0 \\
0 . c 0\end{array}$ \\
\hline
\end{tabular}


Table 82.--Streamflow and rainfall at station 02166975, Sample Branch at Greenwood, February 16-17, 1990--Continued

\begin{tabular}{|c|c|c|c|c|c|c|c|c|}
\hline $\begin{array}{l}\text { Time } \\
\text { (hours) }\end{array}$ & $\begin{array}{l}\text { Streamflow } \\
\text { (cubic feet } \\
\text { per second) }\end{array}$ & $\begin{array}{l}\text { Rain- } \\
\text { fall } \\
\text { (inches) }\end{array}$ & $\begin{array}{l}\text { Time } \\
\text { (hours) }\end{array}$ & $\begin{array}{l}\text { Streamflow } \\
\text { (cubic feet } \\
\text { per second) }\end{array}$ & $\begin{array}{l}\text { Rain- } \\
\text { fall } \\
\text { (inches) }\end{array}$ & $\begin{array}{l}\text { Time } \\
\text { (hours) }\end{array}$ & $\begin{array}{l}\text { Streamflow } \\
\text { (cubic feet } \\
\text { per second) }\end{array}$ & $\begin{array}{l}\text { Rain- } \\
\text { fall } \\
\text { (inches) }\end{array}$ \\
\hline $\begin{array}{l}0220 \\
0225 \\
0230 \\
0235 \\
0240\end{array}$ & $\begin{array}{l}1.3 \\
1.3 \\
1.3 \\
1.3 \\
1.3\end{array}$ & $\begin{array}{l}0.00 \\
0.00 \\
0.00 \\
0.00 \\
0.00\end{array}$ & $\begin{array}{l}0400 \\
0405 \\
0410 \\
0415 \\
0420\end{array}$ & $\begin{array}{l}0.9 \\
0.9 \\
0.9 \\
0.8 \\
0.8\end{array}$ & $\begin{array}{l}0.00 \\
0.00 \\
0.00 \\
0.00 \\
0.00\end{array}$ & $\begin{array}{l}0540 \\
0545 \\
0550 \\
0555 \\
0600\end{array}$ & $\begin{array}{l}0.7 \\
0.7 \\
0.7 \\
0.7 \\
0.6\end{array}$ & $\begin{array}{l}0.00 \\
0.00 \\
0.00 \\
0.00 \\
0.00\end{array}$ \\
\hline $\begin{array}{l}0245 \\
0250 \\
0255 \\
0300 \\
0305\end{array}$ & $\begin{array}{l}1.2 \\
1.2 \\
1.2 \\
1.2 \\
1.0\end{array}$ & $\begin{array}{l}0.00 \\
0.00 \\
0.00 \\
0.00 \\
0.00\end{array}$ & $\begin{array}{l}0425 \\
0430 \\
0435 \\
0440 \\
0445\end{array}$ & $\begin{array}{l}0.8 \\
0.8 \\
0.8 \\
0.8 \\
0.8\end{array}$ & $\begin{array}{l}0.00 \\
0.00 \\
0.00 \\
0.00 \\
0.00\end{array}$ & $\begin{array}{l}0605 \\
0610 \\
0615 \\
0620 \\
0625\end{array}$ & $\begin{array}{l}0.6 \\
0.6 \\
0.6 \\
0.6 \\
0.6\end{array}$ & $\begin{array}{l}0.00 \\
0.00 \\
0.00 \\
0.00 \\
0.00\end{array}$ \\
\hline $\begin{array}{l}0310 \\
0315 \\
0320 \\
0325 \\
0330\end{array}$ & $\begin{array}{l}1.0 \\
1.0 \\
1.0 \\
1.0 \\
1.0\end{array}$ & $\begin{array}{l}0.00 \\
0.00 \\
0.00 \\
0.00 \\
0.00\end{array}$ & $\begin{array}{l}0450 \\
0455 \\
0500 \\
0505 \\
0510\end{array}$ & $\begin{array}{l}0.8 \\
0.8 \\
0.7 \\
0.7 \\
0.7\end{array}$ & $\begin{array}{l}0.00 \\
0.00 \\
0.00 \\
0.00 \\
0.00\end{array}$ & $\begin{array}{l}0630 \\
0635 \\
0640 \\
0645 \\
0650\end{array}$ & $\begin{array}{l}0.6 \\
0.5 \\
0.5 \\
0.5 \\
0.5\end{array}$ & $\begin{array}{l}0.00 \\
0.00 \\
0.00 \\
0.00 \\
0.00\end{array}$ \\
\hline $\begin{array}{l}0335 \\
0340 \\
0345 \\
0350 \\
0355\end{array}$ & $\begin{array}{l}1.0 \\
0.9 \\
0.9 \\
0.9 \\
0.9\end{array}$ & $\begin{array}{l}0.00 \\
0.00 \\
0.00 \\
0.00 \\
0.00\end{array}$ & $\begin{array}{l}0515 \\
0520 \\
0525 \\
0530 \\
0535\end{array}$ & $\begin{array}{l}0.7 \\
0.7 \\
0.7 \\
0.7 \\
0.7\end{array}$ & $\begin{array}{l}0.00 \\
0.00 \\
0.00 \\
0.00 \\
0.00\end{array}$ & $\begin{array}{l}0655 \\
0700\end{array}$ & $\begin{array}{l}0.5 \\
0.5\end{array}$ & $\begin{array}{l}0.00 \\
0.00\end{array}$ \\
\hline
\end{tabular}




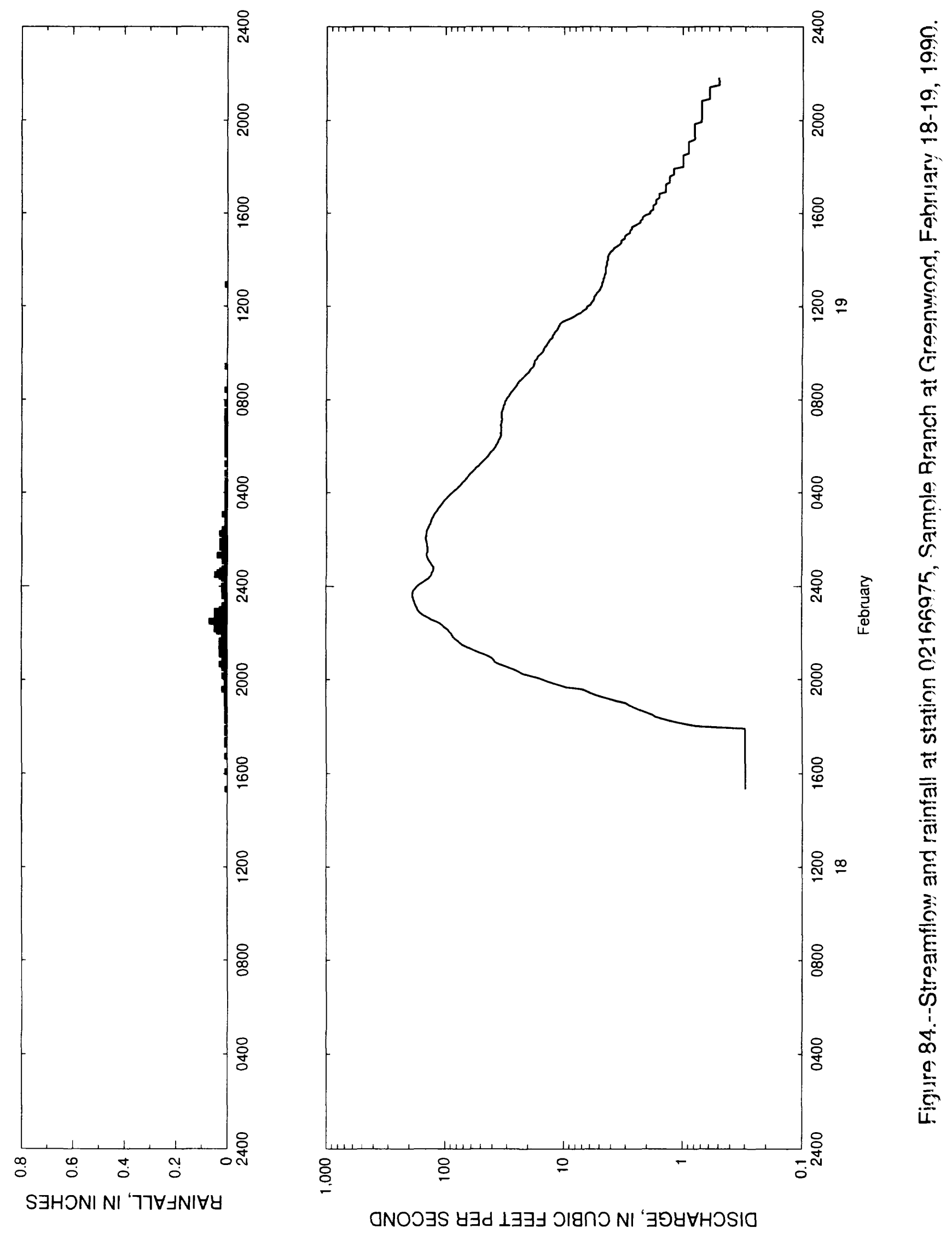


Table 83. - Streamflow and rainfall at station 02166975, Sample Branch at Greenwood,

February $18-19,1990$

\begin{tabular}{|c|c|c|c|c|c|c|c|c|}
\hline $\begin{array}{l}\text { Time } \\
\text { (hours) }\end{array}$ & $\begin{array}{l}\text { Streamflow } \\
\text { (cubic feet } \\
\text { per second) }\end{array}$ & $\begin{array}{l}\text { Rain- } \\
\text { fall } \\
\text { (inches) }\end{array}$ & $\begin{array}{l}\text { Time } \\
\text { (hours) }\end{array}$ & $\begin{array}{l}\text { Streamflow } \\
\text { (cubic feet } \\
\text { per second) }\end{array}$ & $\begin{array}{l}\text { Rain- } \\
\text { fall } \\
\text { (inches) }\end{array}$ & $\begin{array}{l}\text { Time } \\
\text { (hours) }\end{array}$ & $\begin{array}{l}\text { Streamflow } \\
\text { (cubic feet } \\
\text { per second) }\end{array}$ & $\begin{array}{l}\text { Rain- } \\
\text { fall } \\
\text { (inchos) }\end{array}$ \\
\hline $\begin{array}{c}\text { February } \\
1520 \\
1525 \\
1530 \\
1535\end{array}$ & $\begin{array}{r}18,190 \\
0.3 \\
0.3 \\
0.3 \\
0.3\end{array}$ & $\begin{array}{l}0.01 \\
0.00 \\
0.00 \\
0.00\end{array}$ & $\begin{array}{l}2040 \\
2045 \\
2050 \\
2055 \\
2100\end{array}$ & $\begin{array}{l}35.0 \\
37.9 \\
38.7 \\
40.1 \\
42.9\end{array}$ & $\begin{array}{l}0.03 \\
0.02 \\
0.02 \\
0.02 \\
0.02\end{array}$ & $\begin{array}{l}0200 \\
0205 \\
0210 \\
0215 \\
0220\end{array}$ & $\begin{array}{l}146.0 \\
147.0 \\
145.0 \\
144.0 \\
143.0\end{array}$ & $\begin{array}{l}0.02 \\
0.01 \\
0.00 \\
0.03 \\
0.02\end{array}$ \\
\hline $\begin{array}{l}1540 \\
1545 \\
1550 \\
1555 \\
1600\end{array}$ & $\begin{array}{l}0.3 \\
0.3 \\
0.3 \\
0.3 \\
0.3\end{array}$ & $\begin{array}{l}0.00 \\
0.00 \\
0.00 \\
0.00 \\
0.00\end{array}$ & $\begin{array}{l}2105 \\
2110 \\
2115 \\
2120 \\
2125\end{array}$ & $\begin{array}{l}46.6 \\
51.7 \\
56.6 \\
61.0 \\
65.4\end{array}$ & $\begin{array}{l}0.03 \\
0.02 \\
0.03 \\
0.02 \\
0.03\end{array}$ & $\begin{array}{l}0225 \\
0230 \\
0235 \\
0240 \\
0245\end{array}$ & $\begin{array}{l}142.0 \\
139.0 \\
137.0 \\
134.0 \\
132.0\end{array}$ & $\begin{array}{l}0.02 \\
0.01 \\
0.01 \\
0.01 \\
0.01\end{array}$ \\
\hline $\begin{array}{l}1605 \\
1610 \\
1615 \\
1620 \\
1625\end{array}$ & $\begin{array}{l}0.3 \\
0.3 \\
0.3 \\
0.3 \\
0.3\end{array}$ & $\begin{array}{l}0.01 \\
0.00 \\
0.00 \\
0.00 \\
0.00\end{array}$ & $\begin{array}{l}2130 \\
2135 \\
2140 \\
2145 \\
2150\end{array}$ & $\begin{array}{l}71.2 \\
74.6 \\
77.8 \\
82.1 \\
85.4\end{array}$ & $\begin{array}{l}0.02 \\
0.01 \\
0.03 \\
0.02 \\
0.02\end{array}$ & $\begin{array}{l}0250 \\
0255 \\
0300 \\
0305 \\
0310\end{array}$ & $\begin{array}{l}131.0 \\
129.0 \\
126.0 \\
124.0 \\
121.0\end{array}$ & $\begin{array}{l}0.01 \\
0.01 \\
0.01 \\
0.02 \\
0.00\end{array}$ \\
\hline $\begin{array}{l}1630 \\
1635 \\
1640 \\
1645 \\
1650\end{array}$ & $\begin{array}{l}0.3 \\
0.3 \\
0.3 \\
0.3 \\
0.3\end{array}$ & $\begin{array}{l}0.00 \\
0.00 \\
0.00 \\
0.01 \\
0.00\end{array}$ & $\begin{array}{l}2155 \\
2200 \\
2205 \\
2210 \\
2215\end{array}$ & $\begin{array}{r}87.1 \\
88.8 \\
92.6 \\
95.0 \\
101.0\end{array}$ & $\begin{array}{l}0.02 \\
0.02 \\
0.04 \\
0.05 \\
0.05\end{array}$ & $\begin{array}{l}0315 \\
0320 \\
0325 \\
0330 \\
0335\end{array}$ & $\begin{array}{l}117.0 \\
115.0 \\
111.0 \\
108.0 \\
105.0\end{array}$ & $\begin{array}{l}0.01 \\
0.01 \\
0.00 \\
0.01 \\
0.01\end{array}$ \\
\hline $\begin{array}{l}1655 \\
1700 \\
1705 \\
1710 \\
1715\end{array}$ & $\begin{array}{l}0.3 \\
0.3 \\
0.3 \\
0.3 \\
0.3\end{array}$ & $\begin{array}{l}0.00 \\
0.00 \\
0.00 \\
0.00 \\
0.01\end{array}$ & $\begin{array}{l}2220 \\
2225 \\
2230 \\
2235 \\
2240\end{array}$ & $\begin{array}{l}105.0 \\
110.0 \\
119.0 \\
131.0 \\
139.0\end{array}$ & $\begin{array}{l}0.05 \\
0.04 \\
0.07 \\
0.04 \\
0.04\end{array}$ & $\begin{array}{l}0340 \\
0345 \\
0350 \\
0355 \\
0400\end{array}$ & $\begin{array}{r}102.0 \\
98.3 \\
95.3 \\
91.9 \\
87.8\end{array}$ & $\begin{array}{l}0.00 \\
0.01 \\
0.01 \\
0.00 \\
0.00\end{array}$ \\
\hline $\begin{array}{l}1720 \\
1725 \\
1730 \\
1735 \\
1740\end{array}$ & $\begin{array}{l}0.3 \\
0.3 \\
0.3 \\
0.3 \\
0.3\end{array}$ & $\begin{array}{l}0.00 \\
0.01 \\
0.00 \\
0.00 \\
0.00\end{array}$ & $\begin{array}{l}2245 \\
2250 \\
2255 \\
2300 \\
2305\end{array}$ & $\begin{array}{l}150.0 \\
159.0 \\
166.0 \\
171.0 \\
173.0\end{array}$ & $\begin{array}{l}0.05 \\
0.05 \\
0.05 \\
0.03 \\
0.02\end{array}$ & $\begin{array}{l}0405 \\
0410 \\
0415 \\
0420 \\
0425\end{array}$ & $\begin{array}{l}84.4 \\
80.5 \\
77.8 \\
74.6 \\
72.4\end{array}$ & $\begin{array}{l}0.01 \\
0.00 \\
0.00 \\
0.01 \\
0.00\end{array}$ \\
\hline $\begin{array}{l}1745 \\
1750 \\
1755 \\
1800 \\
1805\end{array}$ & $\begin{array}{l}0.3 \\
0.3 \\
0.3 \\
0.7 \\
0.9\end{array}$ & $\begin{array}{l}0.01 \\
0.00 \\
0.01 \\
0.00 \\
0.00\end{array}$ & $\begin{array}{l}2310 \\
2315 \\
2320 \\
2325 \\
2330\end{array}$ & $\begin{array}{l}177.0 \\
180.0 \\
182.0 \\
185.0 \\
187.0\end{array}$ & $\begin{array}{l}0.02 \\
0.01 \\
0.01 \\
0.01 \\
0.01\end{array}$ & $\begin{array}{l}0430 \\
0435 \\
0440 \\
0445 \\
0450\end{array}$ & $\begin{array}{l}69.7 \\
67.2 \\
64.8 \\
63.1 \\
61.0\end{array}$ & $\begin{array}{l}0.01 \\
0.00 \\
0.00 \\
0.00 \\
0.01\end{array}$ \\
\hline $\begin{array}{l}1810 \\
1815 \\
1820 \\
1825 \\
1830\end{array}$ & $\begin{array}{l}1.1 \\
1.3 \\
1.5 \\
1.7 \\
1.8\end{array}$ & $\begin{array}{l}0.00 \\
0.01 \\
0.00 \\
0.00 \\
0.01\end{array}$ & $\begin{array}{l}2335 \\
2340 \\
2345 \\
2350 \\
2355\end{array}$ & $\begin{array}{l}189.0 \\
189.0 \\
187.0 \\
183.0 \\
177.0\end{array}$ & $\begin{array}{l}0.02 \\
0.02 \\
0.02 \\
0.02 \\
0.02\end{array}$ & $\begin{array}{l}0455 \\
0500 \\
0505 \\
0510 \\
0515\end{array}$ & $\begin{array}{l}58.4 \\
56.3 \\
54.9 \\
52.0 \\
50.6\end{array}$ & $\begin{array}{l}0.00 \\
0.00 \\
0.00 \\
0.00 \\
0.01\end{array}$ \\
\hline $\begin{array}{l}1835 \\
1840 \\
1845 \\
1850 \\
1855\end{array}$ & $\begin{array}{l}2.0 \\
2.2 \\
2.4 \\
2.6 \\
2.8\end{array}$ & $\begin{array}{l}0.00 \\
0.01 \\
0.01 \\
0.00 \\
0.01\end{array}$ & $\begin{array}{c}\text { February } \\
0000 \\
0005 \\
0010 \\
0015\end{array}$ & 19, $\begin{array}{r}1990 \\
172.0 \\
164.0 \\
155.0 \\
147.0\end{array}$ & $\begin{array}{l}0.02 \\
0.01 \\
0.00 \\
0.00\end{array}$ & $\begin{array}{l}0520 \\
0525 \\
0530 \\
0535 \\
0540\end{array}$ & $\begin{array}{l}48.6 \\
46.9 \\
45.2 \\
43.7 \\
42.6\end{array}$ & $\begin{array}{l}0.00 \\
0.00 \\
0.00 \\
0.00 \\
0.01\end{array}$ \\
\hline $\begin{array}{l}1900 \\
1905 \\
1910 \\
1915 \\
1920\end{array}$ & $\begin{array}{l}3.0 \\
3.6 \\
4.1 \\
4.7 \\
5.3\end{array}$ & $\begin{array}{l}0.01 \\
0.01 \\
0.01 \\
0.00 \\
0.01\end{array}$ & $\begin{array}{l}0020 \\
0025 \\
0030 \\
0035 \\
0040\end{array}$ & $\begin{array}{l}138.0 \\
134.0 \\
131.0 \\
130.0 \\
127.0\end{array}$ & $\begin{array}{l}0.02 \\
0.03 \\
0.05 \\
0.04 \\
0.03\end{array}$ & $\begin{array}{l}0545 \\
0550 \\
0555 \\
0600 \\
0605\end{array}$ & $\begin{array}{l}41.5 \\
39.8 \\
38.7 \\
37.7 \\
37.1\end{array}$ & $\begin{array}{l}0.00 \\
0.00 \\
0.01 \\
0.00 \\
0.00\end{array}$ \\
\hline $\begin{array}{l}1925 \\
1930 \\
1935 \\
1940 \\
1945\end{array}$ & $\begin{array}{r}5.9 \\
6.4 \\
7.0 \\
9.5 \\
10.7\end{array}$ & $\begin{array}{l}0.01 \\
0.01 \\
0.02 \\
0.01 \\
0.01\end{array}$ & $\begin{array}{l}0045 \\
0050 \\
0055 \\
0100 \\
0105\end{array}$ & $\begin{array}{l}126.0 \\
126.0 \\
130.0 \\
133.0 \\
137.0\end{array}$ & $\begin{array}{l}0.02 \\
0.01 \\
0.01 \\
0.01 \\
0.02\end{array}$ & $\begin{array}{l}0610 \\
0615 \\
0620 \\
0625 \\
0630\end{array}$ & $\begin{array}{l}36.1 \\
35.8 \\
35.0 \\
34.3 \\
34.0\end{array}$ & $\begin{array}{l}0.01 \\
0.00 \\
0.01 \\
0.00 \\
0.01\end{array}$ \\
\hline $\begin{array}{l}1950 \\
1955 \\
2000 \\
2005 \\
2010\end{array}$ & $\begin{array}{l}12.2 \\
13.7 \\
15.0 \\
16.7 \\
19.5\end{array}$ & $\begin{array}{l}0.01 \\
0.01 \\
0.01 \\
0.01 \\
0.02\end{array}$ & $\begin{array}{l}0110 \\
0115 \\
0120 \\
0125 \\
0130\end{array}$ & $\begin{array}{l}140.0 \\
142.0 \\
144.0 \\
144.0 \\
141.0\end{array}$ & $\begin{array}{l}0.02 \\
0.02 \\
0.04 \\
0.02 \\
0.01\end{array}$ & $\begin{array}{l}0635 \\
0640 \\
0645 \\
0650 \\
0655\end{array}$ & $\begin{array}{l}34.3 \\
33.8 \\
34.0 \\
33.8 \\
34.3\end{array}$ & $\begin{array}{l}0.00 \\
0.01 \\
0.00 \\
0.01 \\
0.00\end{array}$ \\
\hline $\begin{array}{l}2015 \\
2020 \\
2025 \\
2030 \\
2035\end{array}$ & $\begin{array}{l}21.9 \\
23.9 \\
25.8 \\
28.5 \\
31.4\end{array}$ & $\begin{array}{l}0.01 \\
0.01 \\
0.01 \\
0.02 \\
0.02\end{array}$ & $\begin{array}{l}0135 \\
0140 \\
0145 \\
0150 \\
0155\end{array}$ & $\begin{array}{l}141.0 \\
141.0 \\
143.0 \\
143.0 \\
145.0\end{array}$ & $\begin{array}{l}0.02 \\
0.03 \\
0.02 \\
0.01 \\
0.03\end{array}$ & $\begin{array}{l}0700 \\
0705 \\
0710 \\
0715 \\
0720\end{array}$ & $\begin{array}{l}33.8 \\
33.5 \\
33.0 \\
33.5 \\
33.5\end{array}$ & $\begin{array}{l}0.01 \\
0.0 C \\
0.0 C \\
0.01 \\
0.0 C\end{array}$ \\
\hline
\end{tabular}


Table 83. - Streamflow and rainfal1 at station 02166975, Sample Branch at Greenwood, February $18-19,1990^{--C o n t i n u e d}$

\begin{tabular}{|c|c|c|c|c|c|c|c|c|}
\hline $\begin{array}{l}\text { Time } \\
\text { (hours) }\end{array}$ & $\begin{array}{l}\text { Streamflow } \\
\text { (cubic feet } \\
\text { per second) }\end{array}$ & $\begin{array}{l}\text { Rain- } \\
\text { fall } \\
\text { (inches) }\end{array}$ & $\begin{array}{l}\text { Time } \\
\text { (hours) }\end{array}$ & $\begin{array}{l}\text { Streamflow } \\
\text { (cubic feet } \\
\text { per second) }\end{array}$ & $\begin{array}{l}\text { Rain- } \\
\text { fall } \\
\text { (inches) }\end{array}$ & $\begin{array}{l}\text { Time } \\
\text { (hours) }\end{array}$ & $\begin{array}{l}\text { Streamflow } \\
\text { (cubic feet } \\
\text { per second) }\end{array}$ & $\begin{array}{l}\text { Rain- } \\
\text { fall } \\
\text { (inches) }\end{array}$ \\
\hline $\begin{array}{l}0725 \\
0730 \\
0735 \\
0740 \\
0745\end{array}$ & $\begin{array}{l}33.3 \\
33.3 \\
32.7 \\
32.5 \\
32.2\end{array}$ & $\begin{array}{l}0.00 \\
0.01 \\
0.00 \\
0.00 \\
0.00\end{array}$ & $\begin{array}{l}1220 \\
1225 \\
1230 \\
1235 \\
1240\end{array}$ & $\begin{array}{l}5.6 \\
5.6 \\
5.4 \\
5.3 \\
5.1\end{array}$ & $\begin{array}{l}0.00 \\
0.00 \\
0.00 \\
0.00 \\
0.00\end{array}$ & $\begin{array}{l}1715 \\
1720 \\
1725 \\
1730 \\
1735\end{array}$ & $\begin{array}{l}1.4 \\
1.3 \\
1.3 \\
1.3 \\
1.3\end{array}$ & $\begin{array}{l}0.00 \\
0.00 \\
0.00 \\
0.00 \\
0.00\end{array}$ \\
\hline $\begin{array}{l}0750 \\
0755 \\
0800 \\
0805 \\
0810\end{array}$ & $\begin{array}{l}31.4 \\
31.4 \\
30.6 \\
30.1 \\
29.0\end{array}$ & $\begin{array}{l}0.01 \\
0.00 \\
0.00 \\
0.00 \\
0.00\end{array}$ & $\begin{array}{l}1245 \\
1250 \\
1255 \\
1300 \\
1305\end{array}$ & $\begin{array}{l}5.0 \\
4.9 \\
4.8 \\
4.8 \\
4.7\end{array}$ & $\begin{array}{l}0.00 \\
0.00 \\
0.01 \\
0.00 \\
0.00\end{array}$ & $\begin{array}{l}1740 \\
1745 \\
1750 \\
1755 \\
1800\end{array}$ & $\begin{array}{l}1.2 \\
1.2 \\
1.2 \\
1.2 \\
1.0\end{array}$ & $\begin{array}{l}0.00 \\
0.00 \\
0.00 \\
0.00 \\
0.00\end{array}$ \\
\hline $\begin{array}{l}0815 \\
0820 \\
0825 \\
0830 \\
0835\end{array}$ & $\begin{array}{l}28.5 \\
27.7 \\
26.9 \\
26.1 \\
25.3\end{array}$ & $\begin{array}{l}0.00 \\
0.00 \\
0.01 \\
0.00 \\
0.00\end{array}$ & $\begin{array}{l}1310 \\
1315 \\
1320 \\
1325 \\
1330\end{array}$ & $\begin{array}{l}4.7 \\
4.6 \\
4.6 \\
4.5 \\
4.5\end{array}$ & $\begin{array}{l}0.00 \\
0.00 \\
0.00 \\
0.00 \\
0.00\end{array}$ & $\begin{array}{l}1805 \\
1810 \\
1815 \\
1820 \\
1825\end{array}$ & $\begin{array}{l}1.0 \\
1.0 \\
1.0 \\
1.0 \\
1.0\end{array}$ & $\begin{array}{l}0.00 \\
0.00 \\
0.00 \\
0.00 \\
0.00\end{array}$ \\
\hline $\begin{array}{l}0840 \\
0845 \\
0850 \\
0855 \\
0900\end{array}$ & $\begin{array}{l}24.8 \\
24.2 \\
23.3 \\
22.5 \\
21.6\end{array}$ & $\begin{array}{l}0.00 \\
0.00 \\
0.00 \\
0.00 \\
0.00\end{array}$ & $\begin{array}{l}1335 \\
1340 \\
1345 \\
1350 \\
1355\end{array}$ & $\begin{array}{l}4.5 \\
4.5 \\
4.4 \\
4.4 \\
4.4\end{array}$ & $\begin{array}{l}0.00 \\
0.00 \\
0.00 \\
0.00 \\
0.00\end{array}$ & $\begin{array}{l}1830 \\
1835 \\
1840 \\
1845 \\
1850\end{array}$ & $\begin{array}{l}1.0 \\
0.9 \\
0.9 \\
0.9 \\
0.9\end{array}$ & $\begin{array}{l}0.00 \\
0.00 \\
0.00 \\
0.00 \\
0.00\end{array}$ \\
\hline $\begin{array}{l}0905 \\
0910 \\
0915 \\
0920 \\
0925\end{array}$ & $\begin{array}{l}20.8 \\
20.0 \\
19.5 \\
19.0 \\
18.2\end{array}$ & $\begin{array}{l}0.00 \\
0.00 \\
0.00 \\
0.00 \\
0.01\end{array}$ & $\begin{array}{l}1400 \\
1405 \\
1410 \\
1415 \\
1420\end{array}$ & $\begin{array}{l}4.3 \\
4.3 \\
4.3 \\
4.2 \\
4.1\end{array}$ & $\begin{array}{l}0.00 \\
0.00 \\
0.00 \\
0.00 \\
0.00\end{array}$ & $\begin{array}{l}1855 \\
1900 \\
1905 \\
1910 \\
1915\end{array}$ & $\begin{array}{l}0.9 \\
0.9 \\
0.9 \\
0.8 \\
0.8\end{array}$ & $\begin{array}{l}0.00 \\
0.00 \\
0.00 \\
0.00 \\
0.00\end{array}$ \\
\hline $\begin{array}{l}0930 \\
0935 \\
0940 \\
0945 \\
0950\end{array}$ & $\begin{array}{l}17.9 \\
17.7 \\
17.7 \\
16.9 \\
16.7\end{array}$ & $\begin{array}{l}0.00 \\
0.00 \\
0.00 \\
0.00 \\
0.00\end{array}$ & $\begin{array}{l}1425 \\
1430 \\
1435 \\
1440 \\
1445\end{array}$ & $\begin{array}{l}3.9 \\
3.8 \\
3.6 \\
3.4 \\
3.3\end{array}$ & $\begin{array}{l}0.00 \\
0.00 \\
0.00 \\
0.00 \\
0.00\end{array}$ & $\begin{array}{l}1920 \\
1925 \\
1930 \\
1935 \\
1940\end{array}$ & $\begin{array}{l}0.8 \\
0.8 \\
0.8 \\
0.8 \\
0.8\end{array}$ & $\begin{array}{l}0.00 \\
0.00 \\
0.00 \\
0.00 \\
0.00\end{array}$ \\
\hline $\begin{array}{l}0955 \\
1000 \\
1005 \\
1010 \\
1015\end{array}$ & $\begin{array}{l}16.2 \\
15.5 \\
15.0 \\
14.8 \\
14.6\end{array}$ & $\begin{array}{l}0.00 \\
0.00 \\
0.00 \\
0.00 \\
0.00\end{array}$ & $\begin{array}{l}1450 \\
1455 \\
1500 \\
1505 \\
1510\end{array}$ & $\begin{array}{l}3.3 \\
3.1 \\
3.1 \\
3.0 \\
2.8\end{array}$ & $\begin{array}{l}0.00 \\
0.00 \\
0.00 \\
0.00 \\
0.00\end{array}$ & $\begin{array}{l}1945 \\
1950 \\
1955 \\
2000 \\
2005\end{array}$ & $\begin{array}{l}0.8 \\
0.8 \\
0.7 \\
0.7 \\
0.7\end{array}$ & $\begin{array}{l}0.00 \\
0.00 \\
0.00 \\
0.00 \\
0.00\end{array}$ \\
\hline $\begin{array}{l}1020 \\
1025 \\
1030 \\
1035 \\
1040\end{array}$ & $\begin{array}{l}14.1 \\
13.9 \\
13.5 \\
13.2 \\
12.6\end{array}$ & $\begin{array}{l}0.00 \\
0.00 \\
0.00 \\
0.00 \\
0.00\end{array}$ & $\begin{array}{l}1515 \\
1520 \\
1525 \\
1530 \\
1535\end{array}$ & $\begin{array}{l}2.8 \\
2.7 \\
2.7 \\
2.5 \\
2.3\end{array}$ & $\begin{array}{l}0.00 \\
0.00 \\
0.00 \\
0.00 \\
0.00\end{array}$ & $\begin{array}{l}2010 \\
2015 \\
2020 \\
2025 \\
2030\end{array}$ & $\begin{array}{l}0.7 \\
0.7 \\
0.7 \\
0.7 \\
0.7\end{array}$ & $\begin{array}{l}0.00 \\
0.00 \\
0.00 \\
0.00 \\
0.00\end{array}$ \\
\hline $\begin{array}{l}1045 \\
1050 \\
1055 \\
1100 \\
1105\end{array}$ & $\begin{array}{l}12.6 \\
12.2 \\
12.0 \\
11.5 \\
11.3\end{array}$ & $\begin{array}{l}0.00 \\
0.00 \\
0.00 \\
0.00 \\
0.00\end{array}$ & $\begin{array}{l}1540 \\
1545 \\
1550 \\
1555 \\
1600\end{array}$ & $\begin{array}{l}2.3 \\
2.2 \\
2.2 \\
2.1 \\
1.9\end{array}$ & $\begin{array}{l}0.00 \\
0.00 \\
0.00 \\
0.00 \\
0.00\end{array}$ & $\begin{array}{l}2035 \\
2040 \\
2045 \\
2050 \\
2055\end{array}$ & $\begin{array}{l}0.7 \\
0.7 \\
0.7 \\
0.7 \\
0.6\end{array}$ & $\begin{array}{l}0.00 \\
0.00 \\
0.00 \\
0.00 \\
0.00\end{array}$ \\
\hline $\begin{array}{l}1110 \\
1115 \\
1120 \\
1125 \\
1130\end{array}$ & $\begin{array}{r}11.1 \\
10.9 \\
10.5 \\
9.7 \\
8.9\end{array}$ & $\begin{array}{l}0.00 \\
0.00 \\
0.00 \\
0.00 \\
0.00\end{array}$ & $\begin{array}{l}1605 \\
1610 \\
1615 \\
1620 \\
1625\end{array}$ & $\begin{array}{l}1.9 \\
1.8 \\
1.8 \\
1.8 \\
1.7\end{array}$ & $\begin{array}{l}0.00 \\
0.00 \\
0.00 \\
0.00 \\
0.00\end{array}$ & $\begin{array}{l}2100 \\
2105 \\
2110 \\
2115 \\
2120\end{array}$ & $\begin{array}{l}0.6 \\
0.6 \\
0.6 \\
0.6 \\
0.6\end{array}$ & $\begin{array}{l}0.00 \\
0.00 \\
0.00 \\
0.00 \\
0.00\end{array}$ \\
\hline $\begin{array}{l}1135 \\
1140 \\
1145 \\
1150 \\
1155\end{array}$ & $\begin{array}{l}8.2 \\
7.8 \\
7.2 \\
6.9 \\
6.5\end{array}$ & $\begin{array}{l}0.00 \\
0.00 \\
0.00 \\
0.00 \\
0.00\end{array}$ & $\begin{array}{l}1630 \\
1635 \\
1640 \\
1645 \\
1650\end{array}$ & $\begin{array}{l}1.7 \\
1.7 \\
1.6 \\
1.6 \\
1.6\end{array}$ & $\begin{array}{l}0.00 \\
0.00 \\
0.00 \\
0.00 \\
0.00\end{array}$ & $\begin{array}{l}2125 \\
2130 \\
2135 \\
2140 \\
2145\end{array}$ & $\begin{array}{l}0.6 \\
0.5 \\
0.5 \\
0.5 \\
0.5\end{array}$ & $\begin{array}{l}0.00 \\
0.00 \\
0.00 \\
0.00 \\
0.00\end{array}$ \\
\hline $\begin{array}{l}1200 \\
1205 \\
1210 \\
1215\end{array}$ & $\begin{array}{l}6.4 \\
6.0 \\
5.9 \\
5.7\end{array}$ & $\begin{array}{l}0.00 \\
0.00 \\
0.00 \\
0.00\end{array}$ & $\begin{array}{l}1655 \\
1700 \\
1705 \\
1710\end{array}$ & $\begin{array}{l}1.4 \\
1.4 \\
1.4 \\
1.4\end{array}$ & $\begin{array}{l}0.00 \\
0.00 \\
0.00 \\
0.00\end{array}$ & $\begin{array}{l}2150 \\
2155 \\
2200\end{array}$ & $\begin{array}{l}0.5 \\
0.5 \\
0.5\end{array}$ & $\begin{array}{l}0.00 \\
0.00 \\
0.00\end{array}$ \\
\hline
\end{tabular}



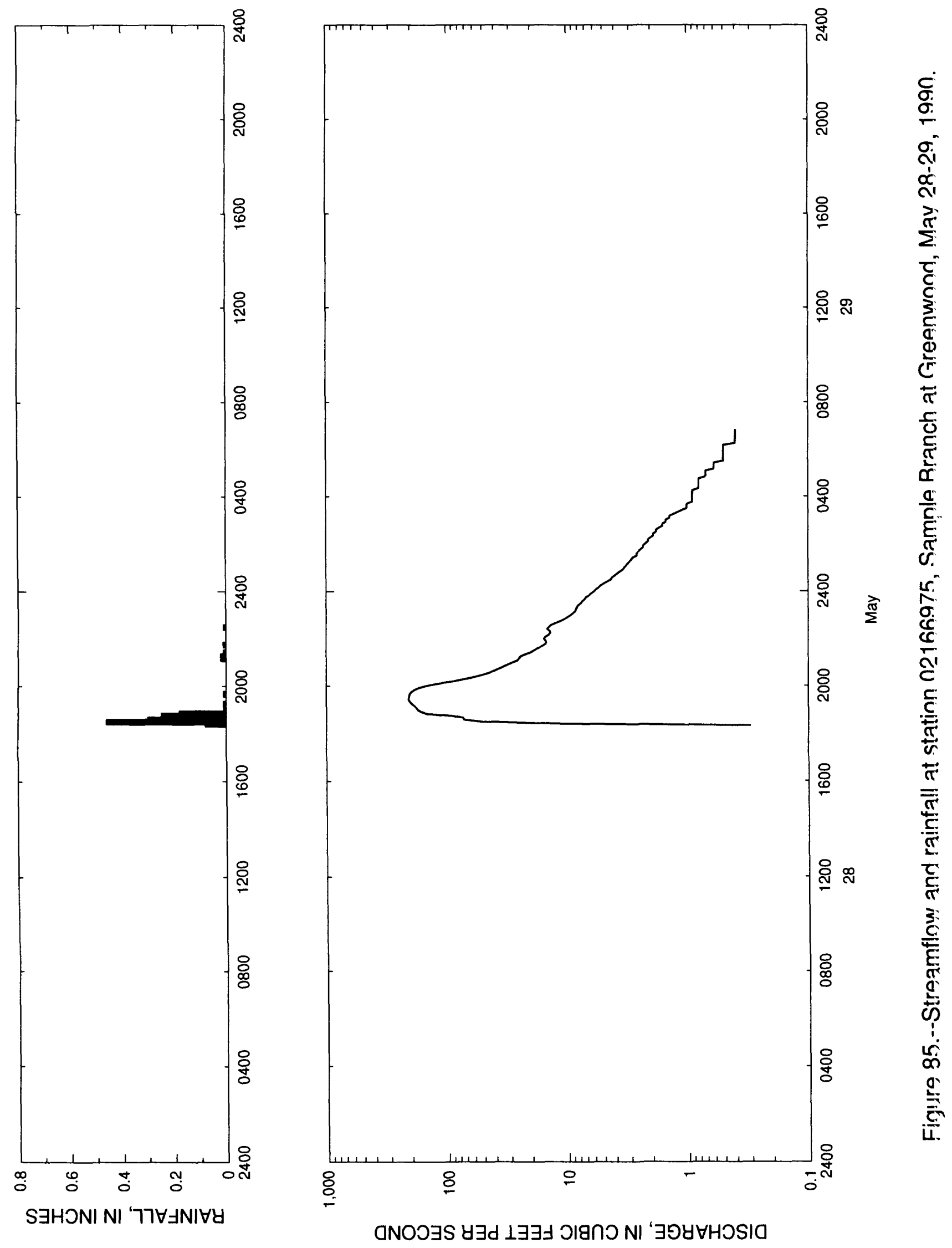
Table $84 .-$ - Streamflow and rainfall at station 02166975. Sample Branch at Greenwood, May $28-29,1990$

\begin{tabular}{|c|c|c|c|c|c|c|c|c|}
\hline $\begin{array}{l}\text { Time } \\
\text { (hours) }\end{array}$ & $\begin{array}{l}\text { Streamflow } \\
\text { (cubic feet } \\
\text { per second) }\end{array}$ & $\begin{array}{l}\text { Rain- } \\
\text { fall } \\
\text { (inches) }\end{array}$ & $\begin{array}{l}\text { Time } \\
\text { (hours) }\end{array}$ & $\begin{array}{l}\text { Streamflow } \\
\text { (cubic feet } \\
\text { per second) }\end{array}$ & $\begin{array}{l}\text { Rain- } \\
\text { fall } \\
\text { (inches) }\end{array}$ & $\begin{array}{l}\text { Time } \\
\text { (hours) }\end{array}$ & $\begin{array}{l}\text { Streamflow } \\
\text { (cubic feet } \\
\text { per second) }\end{array}$ & $\begin{array}{l}\text { Rair- } \\
\text { fall } \\
\text { (inches) }\end{array}$ \\
\hline $\begin{array}{c}\text { May 28, } \\
1820 \\
1825 \\
1830 \\
1835\end{array}$ & $\begin{array}{r}1990 \\
0.3 \\
11.5 \\
51.4 \\
72.4\end{array}$ & $\begin{array}{l}0.00 \\
0.08 \\
0.46 \\
0.30\end{array}$ & $\begin{array}{l}2235 \\
2240 \\
2245 \\
2250 \\
2255\end{array}$ & $\begin{array}{r}13.5 \\
12.4 \\
11.3 \\
10.5 \\
9.9\end{array}$ & $\begin{array}{l}0.00 \\
0.00 \\
0.00 \\
0.00 \\
0.00\end{array}$ & $\begin{array}{l}0250 \\
0255 \\
0300 \\
0305 \\
0310\end{array}$ & $\begin{array}{l}1.6 \\
1.5 \\
1.5 \\
1.4 \\
1.4\end{array}$ & $\begin{array}{l}0.00 \\
0.00 \\
0.0 C \\
0.0 C \\
0.0 C\end{array}$ \\
\hline $\begin{array}{l}1840 \\
1845 \\
1850 \\
1855 \\
1900\end{array}$ & $\begin{array}{r}73.4 \\
90.9 \\
147.0 \\
165.0 \\
176.0\end{array}$ & $\begin{array}{l}0.07 \\
0.25 \\
0.18 \\
0.01 \\
0.00\end{array}$ & $\begin{array}{l}2300 \\
2305 \\
2310 \\
2315 \\
2320\end{array}$ & $\begin{array}{l}9.3 \\
8.9 \\
8.5 \\
8.4 \\
8.2\end{array}$ & $\begin{array}{l}0.00 \\
0.00 \\
0.00 \\
0.00 \\
0.00\end{array}$ & $\begin{array}{l}0315 \\
0320 \\
0325 \\
0330 \\
0335\end{array}$ & $\begin{array}{l}1.3 \\
1.2 \\
1.1 \\
1.0 \\
1.0\end{array}$ & $\begin{array}{l}0.0 \mathrm{C} \\
0.0 \mathrm{C} \\
0.0 \mathrm{C} \\
0.0 \mathrm{C} \\
0.0 \mathrm{C}\end{array}$ \\
\hline $\begin{array}{l}1905 \\
1910 \\
1915 \\
1920 \\
1925\end{array}$ & $\begin{array}{l}181.0 \\
187.0 \\
196.0 \\
203.0 \\
208.0\end{array}$ & $\begin{array}{l}0.01 \\
0.00 \\
0.01 \\
0.00 \\
0.00\end{array}$ & $\begin{array}{l}2325 \\
2330 \\
2335 \\
2340 \\
2345\end{array}$ & $\begin{array}{l}8.0 \\
7.6 \\
7.4 \\
7.1 \\
6.9\end{array}$ & $\begin{array}{l}0.00 \\
0.00 \\
0.00 \\
0.00 \\
0.00\end{array}$ & $\begin{array}{l}0340 \\
0345 \\
0350 \\
0355 \\
0400\end{array}$ & $\begin{array}{l}1.0 \\
0.9 \\
0.9 \\
0.9 \\
0.9\end{array}$ & $\begin{array}{l}0.0 C \\
0.0 C \\
0.0 C \\
0.0 C \\
0.0 C\end{array}$ \\
\hline $\begin{array}{l}1930 \\
1935 \\
1940 \\
1945 \\
1950\end{array}$ & $\begin{array}{l}207.0 \\
206.0 \\
203.0 \\
197.0 \\
186.0\end{array}$ & $\begin{array}{l}0.00 \\
0.00 \\
0.01 \\
0.00 \\
0.00\end{array}$ & $\begin{array}{c}2350 \\
2355 \\
\text { May 29, } \\
0000 \\
0005\end{array}$ & $\begin{array}{l}6.5 \\
6.2 \\
5.9 \\
5.7\end{array}$ & $\begin{array}{l}0.00 \\
0.00 \\
0.00 \\
0.00\end{array}$ & $\begin{array}{l}0405 \\
0410 \\
0415 \\
0420 \\
0425\end{array}$ & $\begin{array}{l}0.9 \\
0.9 \\
0.9 \\
0.8 \\
0.8\end{array}$ & $\begin{array}{l}0.0 \mathrm{C} \\
0.0 \mathrm{C} \\
0.0 \mathrm{C} \\
0.0 \mathrm{C} \\
0.0 \mathrm{C}\end{array}$ \\
\hline $\begin{array}{l}1955 \\
2000 \\
2005 \\
2010 \\
2015\end{array}$ & $\begin{array}{r}171.0 \\
151.0 \\
126.0 \\
99.7 \\
77.8\end{array}$ & $\begin{array}{l}0.00 \\
0.00 \\
0.00 \\
0.00 \\
0.00\end{array}$ & $\begin{array}{l}0010 \\
0015 \\
0020 \\
0025 \\
0030\end{array}$ & $\begin{array}{l}5.4 \\
5.2 \\
4.9 \\
4.6 \\
4.3\end{array}$ & $\begin{array}{l}0.00 \\
0.00 \\
0.00 \\
0.00 \\
0.00\end{array}$ & $\begin{array}{l}0430 \\
0435 \\
0440 \\
0445 \\
0450\end{array}$ & $\begin{array}{l}0.8 \\
0.8 \\
0.8 \\
0.8 \\
0.7\end{array}$ & $\begin{array}{l}0.0 C \\
0.0 C \\
0.0 C \\
0.0 C \\
0.0 C\end{array}$ \\
\hline $\begin{array}{l}2020 \\
2025 \\
2030 \\
2035 \\
2040\end{array}$ & $\begin{array}{l}64.2 \\
55.1 \\
48.6 \\
43.4 \\
39.3\end{array}$ & $\begin{array}{l}0.00 \\
0.00 \\
0.00 \\
0.00 \\
0.00\end{array}$ & $\begin{array}{l}0035 \\
0040 \\
0045 \\
0050 \\
0055\end{array}$ & $\begin{array}{l}4.2 \\
4.0 \\
3.8 \\
3.6 \\
3.4\end{array}$ & $\begin{array}{l}0.00 \\
0.00 \\
0.00 \\
0.00 \\
0.00\end{array}$ & $\begin{array}{l}0455 \\
0500 \\
0505 \\
0510 \\
0515\end{array}$ & $\begin{array}{l}0.7 \\
0.7 \\
0.7 \\
0.6 \\
0.6\end{array}$ & $\begin{array}{l}0.0 C \\
0.0 C \\
0.0 C \\
0.0 C \\
0.0 C\end{array}$ \\
\hline $\begin{array}{l}2045 \\
2050 \\
2055 \\
2100 \\
2105\end{array}$ & $\begin{array}{l}36.1 \\
33.3 \\
30.6 \\
28.2 \\
25.8\end{array}$ & $\begin{array}{l}0.00 \\
0.00 \\
0.00 \\
0.00 \\
0.00\end{array}$ & $\begin{array}{l}0100 \\
0105 \\
0110 \\
0115 \\
0120\end{array}$ & $\begin{array}{l}3.3 \\
3.2 \\
3.1 \\
3.0 \\
2.9\end{array}$ & $\begin{array}{l}0.00 \\
0.00 \\
0.00 \\
0.00 \\
0.00\end{array}$ & $\begin{array}{l}0520 \\
0525 \\
0530 \\
0535 \\
0540\end{array}$ & $\begin{array}{l}0.6 \\
0.6 \\
0.5 \\
0.5 \\
0.5\end{array}$ & $\begin{array}{l}0.0 C \\
0.0 C \\
0.0 C \\
0.0 C \\
0.0 C\end{array}$ \\
\hline $\begin{array}{l}2110 \\
2115 \\
2120 \\
2125 \\
2130\end{array}$ & $\begin{array}{l}25.0 \\
24.2 \\
22.2 \\
20.0 \\
18.7\end{array}$ & $\begin{array}{l}0.02 \\
0.02 \\
0.00 \\
0.01 \\
0.00\end{array}$ & $\begin{array}{l}0125 \\
0130 \\
0135 \\
0140 \\
0145\end{array}$ & $\begin{array}{l}2.8 \\
2.6 \\
2.6 \\
2.5 \\
2.4\end{array}$ & $\begin{array}{l}0.00 \\
0.00 \\
0.00 \\
0.00 \\
0.00\end{array}$ & $\begin{array}{l}0545 \\
0550 \\
0555 \\
0500 \\
0605\end{array}$ & $\begin{array}{l}0.5 \\
0.5 \\
0.5 \\
0.5 \\
0.5\end{array}$ & $\begin{array}{l}0.0 C \\
0.0 C \\
0.0 C \\
0.0 C \\
0.0 C\end{array}$ \\
\hline $\begin{array}{l}2135 \\
2140 \\
2145 \\
2150 \\
2155\end{array}$ & $\begin{array}{l}17.7 \\
16.2 \\
15.2 \\
14.8 \\
15.0\end{array}$ & $\begin{array}{l}0.00 \\
0.00 \\
0.01 \\
0.00 \\
0.00\end{array}$ & $\begin{array}{l}0150 \\
0155 \\
0200 \\
0205 \\
0210\end{array}$ & $\begin{array}{l}2.3 \\
2.3 \\
2.2 \\
2.1 \\
2.1\end{array}$ & $\begin{array}{l}0.00 \\
0.00 \\
0.00 \\
0.00 \\
0.00\end{array}$ & $\begin{array}{l}0610 \\
0615 \\
0620 \\
0625 \\
0630\end{array}$ & $\begin{array}{l}0.5 \\
0.4 \\
0.4 \\
0.4 \\
0.4\end{array}$ & $\begin{array}{l}0.0 C \\
0.0 C \\
0.0 C \\
0.0 C \\
0.0 C\end{array}$ \\
\hline $\begin{array}{l}2200 \\
2205 \\
2210 \\
2215 \\
2220\end{array}$ & $\begin{array}{l}15.5 \\
15.0 \\
14.1 \\
13.7 \\
13.9\end{array}$ & $\begin{array}{l}0.00 \\
0.00 \\
0.00 \\
0.00 \\
0.00\end{array}$ & $\begin{array}{l}0215 \\
0220 \\
0225 \\
0230 \\
0235\end{array}$ & $\begin{array}{l}2.0 \\
1.9 \\
1.9 \\
1.8 \\
1.8\end{array}$ & $\begin{array}{l}0.00 \\
0.00 \\
0.00 \\
0.00 \\
0.00\end{array}$ & $\begin{array}{l}0635 \\
0640 \\
0645 \\
0650 \\
0655\end{array}$ & $\begin{array}{l}0.4 \\
0.4 \\
0.4 \\
0.4 \\
0.4\end{array}$ & $\begin{array}{l}0.0 C \\
0.0 C \\
0.0 C \\
0.0 C \\
0.00\end{array}$ \\
\hline $\begin{array}{l}2225 \\
2230\end{array}$ & $\begin{array}{l}14.6 \\
14.1\end{array}$ & $\begin{array}{l}0.00 \\
0.01\end{array}$ & $\begin{array}{l}0240 \\
0245\end{array}$ & $\begin{array}{l}1.7 \\
1.6\end{array}$ & $\begin{array}{l}0.00 \\
0.00\end{array}$ & 0700 & 0.4 & $0.0 \mathrm{C}$ \\
\hline
\end{tabular}




\section{Station 02167020, Crane Creek Tributary at Columbia, S.C.}

Location.--Lat $34^{\circ} 03^{\prime} 02^{\prime \prime}$, long $81^{\circ} 02^{\prime} 05^{\prime \prime}$, Richland County, Hydrologic Unit 03050106, at culvert on Carola Street (State secondary road 876), $0.3 \mathrm{mi}$ north of Columbia College, and $1.3 \mathrm{mi}$ upstream from the mouth at Crane Creek.

Period of record.-- October 9, 1985 to October 11, 1989.

Gage.--Digital stage recorder with 5-minute punch interval. The recorder is housed in a metal shelter atop a stilling well attached to a free-standing platform located on the right bank approximately $8 \mathrm{ft}$ upstream from the single $4.0 \mathrm{ft}$ reinforced concrete fipe culvert. An enameled staff gage is attached to the platform. A crest-stage indicatcr is located on the downstream left bank near the culvert exit.

Rating.--The stage-streamflow relation is defined by current meter measurements up to $15.1 \mathrm{ft}^{3} / \mathrm{s}$. The stage-streamflow relation was extended to $200 \mathrm{ft}^{3} / \mathrm{s}$ using indirect computational methods.

Rain gage and location.--Station 340253081021800 , lat $34^{\circ} 02^{\prime} 53^{\prime \prime}$, long $81^{\circ} 02^{\prime} 18^{\prime \prime}$. A shelter containing a digital cumulative rainfall recorder with a 5-minute punch interval near the Eau Clare High School recreation field on Columbia College Roc $t$ (State secondary road 124), and $3.2 \mathrm{mi}$ north of the State Capitol Building.

Selected basin characteristics.--

Drainage area $-0.28 \mathrm{mi}^{2}$

Physiographic province -- Inner Coastal Plain

Channel slope -- $196.0 \mathrm{ft} / \mathrm{mi}$

Channel length -- $0.69 \mathrm{mi}$

Total impervious area -- 40.0 percent

Basin development factor -- 8

2-year, 2-hour rainfall amount -- $2.10 \mathrm{in}$.

Flood frequency data: $\mathrm{UQ}_{2}$

$161 \mathrm{ft}^{3} / \mathrm{s}$

$\mathrm{UQ}_{5} \quad 260 \mathrm{ft}^{3} / \mathrm{s}$

$\mathrm{UQ}_{10} \quad 323 \mathrm{ft}^{3} / \mathrm{s}$

$\mathrm{UQ}_{25} \quad 396 \mathrm{ft}^{3} / \mathrm{s}$

$\mathrm{UQ}_{50} \quad 445 \mathrm{ft}^{3} / \mathrm{s}$

$\mathrm{UQ}_{100} \quad 491 \mathrm{ft}^{3} / \mathrm{s}$

$\mathrm{UQ}_{500} \quad 584 \mathrm{ft}^{3} / \mathrm{s}$ 

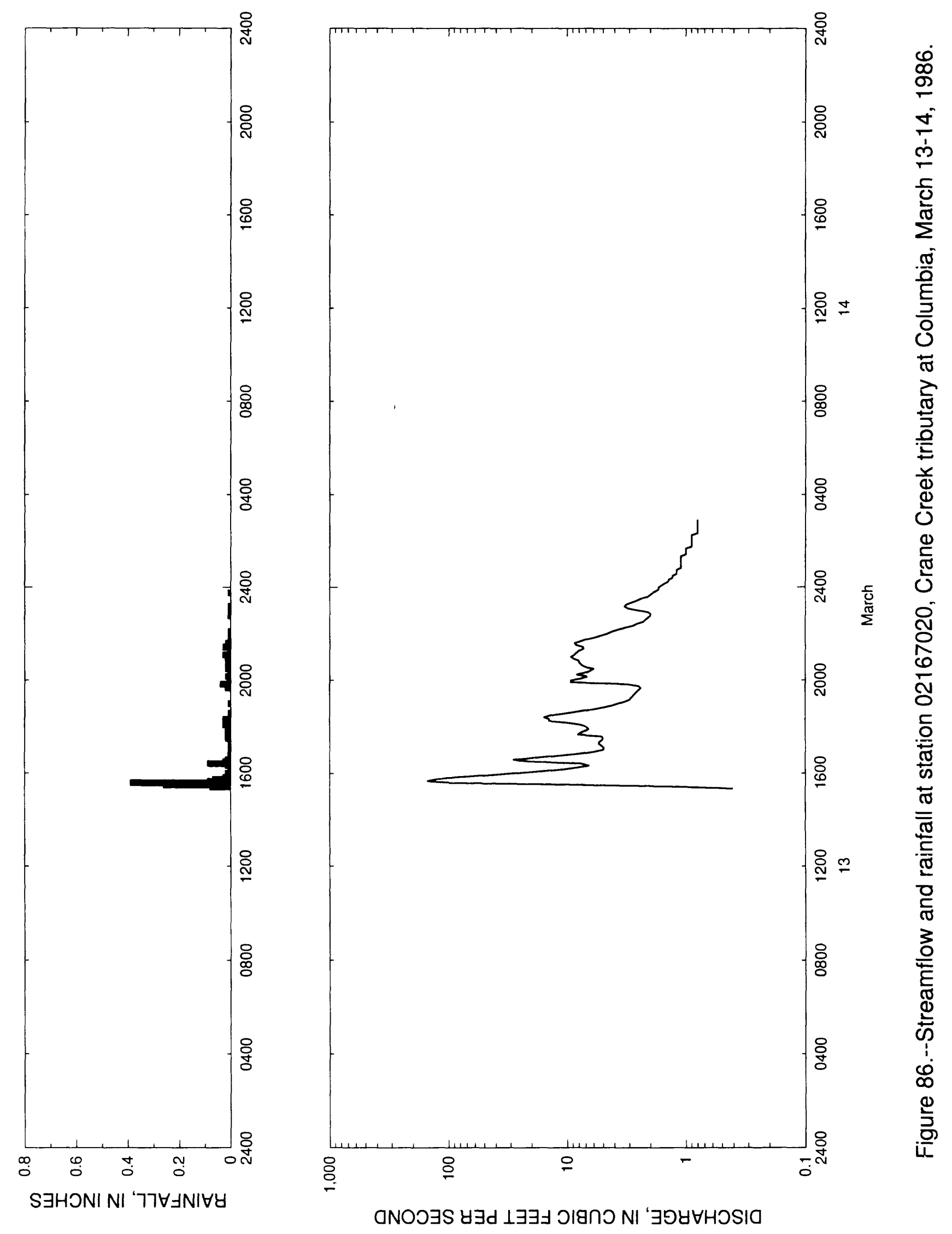
Table 85. - Streamflow and rainfall at station 02167020, Crane Creek trihutary at Columbia, March $13-14,1986$

\begin{tabular}{|c|c|c|c|c|c|c|c|c|}
\hline $\begin{array}{l}\text { Time } \\
\text { (hours) }\end{array}$ & $\begin{array}{l}\text { Streamflow } \\
\text { (cubic feet } \\
\text { per second) }\end{array}$ & $\begin{array}{l}\text { Rain- } \\
\text { fal1 } \\
\text { (inches) }\end{array}$ & $\begin{array}{l}\text { Time } \\
\text { (hours) }\end{array}$ & $\begin{array}{l}\text { Streamflow } \\
\text { (cubic feet } \\
\text { per second) }\end{array}$ & $\begin{array}{l}\text { Rain- } \\
\text { fall } \\
\text { (inches) }\end{array}$ & $\begin{array}{l}\text { Time } \\
\text { (hours) }\end{array}$ & $\begin{array}{l}\text { Streamflow } \\
\text { (cubic feet } \\
\text { per second) }\end{array}$ & $\begin{array}{l}\text { Rain- } \\
\text { fal1 } \\
\text { (inches) }\end{array}$ \\
\hline $\begin{array}{c}\text { March } 13, \\
1520 \\
1525 \\
1530 \\
1535\end{array}$ & $\begin{array}{r}1986 \\
0.4 \\
1.3 \\
8.3 \\
93.9\end{array}$ & $\begin{array}{l}0.00 \\
0.08 \\
0.26 \\
0.39\end{array}$ & $\begin{array}{l}1915 \\
1920 \\
1925 \\
1930 \\
1935\end{array}$ & $\begin{array}{l}2.9 \\
2.8 \\
2.7 \\
2.6 \\
2.5\end{array}$ & $\begin{array}{l}0.00 \\
0.00 \\
0.00 \\
0.00 \\
0.00\end{array}$ & $\begin{array}{l}2315 \\
2320 \\
2325 \\
2330 \\
2335\end{array}$ & $\begin{array}{l}3.2 \\
2.9 \\
2.6 \\
2.4 \\
2.1\end{array}$ & $\begin{array}{l}0.00 \\
0.00 \\
0.00 \\
0.00 \\
0.00\end{array}$ \\
\hline $\begin{array}{l}1540 \\
1545 \\
1550 \\
1555 \\
1600\end{array}$ & $\begin{array}{r}152.0 \\
127.0 \\
88.6 \\
47.6 \\
27.8\end{array}$ & $\begin{array}{l}0.09 \\
0.07 \\
0.03 \\
0.01 \\
0.02\end{array}$ & $\begin{array}{l}1940 \\
1945 \\
1950 \\
1955 \\
2000\end{array}$ & $\begin{array}{l}2.4 \\
2.5 \\
3.1 \\
9.3 \\
9.3\end{array}$ & $\begin{array}{l}0.02 \\
0.01 \\
0.04 \\
0.00 \\
0.00\end{array}$ & $\begin{array}{r}2340 \\
2345 \\
2350 \\
2355 \\
\text { March 14, }\end{array}$ & $\begin{array}{r}2.0 \\
1.9 \\
1.8 \\
1.7\end{array}$ & $\begin{array}{l}0.00 \\
0.01 \\
0.00 \\
0.00\end{array}$ \\
\hline $\begin{array}{l}1605 \\
1610 \\
1615 \\
1620 \\
1625\end{array}$ & $\begin{array}{r}16.7 \\
10.6 \\
7.9 \\
6.5 \\
7.7\end{array}$ & $\begin{array}{l}0.00 \\
0.00 \\
0.01 \\
0.02 \\
0.09\end{array}$ & $\begin{array}{l}2005 \\
2010 \\
2015 \\
2020 \\
2025\end{array}$ & $\begin{array}{l}7.6 \\
6.8 \\
8.3 \\
7.0 \\
6.4\end{array}$ & $\begin{array}{l}0.01 \\
0.02 \\
0.00 \\
0.01 \\
0.01\end{array}$ & $\begin{array}{l}0000 \\
0005 \\
0010 \\
0015 \\
0020\end{array}$ & $\begin{array}{l}1.7 \\
1.6 \\
1.5 \\
1.4 \\
1.4\end{array}$ & $\begin{array}{l}0.00 \\
0.00 \\
0.00 \\
0.00 \\
0.00\end{array}$ \\
\hline $\begin{array}{l}1630 \\
1635 \\
1640 \\
1645 \\
1650\end{array}$ & $\begin{array}{r}19.8 \\
28.3 \\
19.1 \\
11.8 \\
7.9\end{array}$ & $\begin{array}{l}0.03 \\
0.02 \\
0.00 \\
0.00 \\
0.01\end{array}$ & $\begin{array}{l}2030 \\
2035 \\
2040 \\
2045 \\
2050\end{array}$ & $\begin{array}{l}6.0 \\
7.2 \\
7.6 \\
7.9 \\
8.0\end{array}$ & $\begin{array}{l}0.02 \\
0.01 \\
0.02 \\
0.01 \\
0.02\end{array}$ & $\begin{array}{l}0025 \\
0030 \\
0035 \\
0040 \\
0045\end{array}$ & $\begin{array}{l}1.3 \\
1.3 \\
1.2 \\
1.2 \\
1.2\end{array}$ & $\begin{array}{l}0.00 \\
0.00 \\
0.00 \\
0.00 \\
0.00\end{array}$ \\
\hline $\begin{array}{l}1655 \\
1700 \\
1705 \\
1710 \\
1715\end{array}$ & $\begin{array}{l}6.0 \\
5.0 \\
4.9 \\
5.1 \\
5.4\end{array}$ & $\begin{array}{l}0.00 \\
0.01 \\
0.01 \\
0.01 \\
0.01\end{array}$ & $\begin{array}{l}2055 \\
2100 \\
2105 \\
2110 \\
2115\end{array}$ & $\begin{array}{l}8.8 \\
9.3 \\
8.7 \\
8.4 \\
8.0\end{array}$ & $\begin{array}{l}0.02 \\
0.00 \\
0.03 \\
0.00 \\
0.01\end{array}$ & $\begin{array}{l}0050 \\
0055 \\
0100 \\
0105 \\
0110\end{array}$ & $\begin{array}{l}1.1 \\
1.1 \\
1.1 \\
1.1 \\
1.1\end{array}$ & $\begin{array}{l}0.00 \\
0.00 \\
0.00 \\
0.00 \\
0.00\end{array}$ \\
\hline $\begin{array}{l}1720 \\
1725 \\
1730 \\
1735 \\
1740\end{array}$ & $\begin{array}{l}5.4 \\
5.1 \\
5.0 \\
5.1 \\
8.1\end{array}$ & $\begin{array}{l}0.01 \\
0.00 \\
0.02 \\
0.02 \\
0.01\end{array}$ & $\begin{array}{l}2120 \\
2125 \\
2130 \\
2135 \\
2140\end{array}$ & $\begin{array}{l}7.3 \\
7.4 \\
8.4 \\
8.7 \\
7.7\end{array}$ & $\begin{array}{l}0.01 \\
0.03 \\
0.00 \\
0.02 \\
0.00\end{array}$ & $\begin{array}{l}0115 \\
0120 \\
0125 \\
0130 \\
0135\end{array}$ & $\begin{array}{l}1.1 \\
1.1 \\
1.0 \\
1.0 \\
1.0\end{array}$ & $\begin{array}{l}0.00 \\
0.00 \\
0.00 \\
0.00 \\
0.00\end{array}$ \\
\hline $\begin{array}{l}1745 \\
1750 \\
1755 \\
1800 \\
1805\end{array}$ & $\begin{array}{l}7.7 \\
7.0 \\
6.6 \\
6.9 \\
7.7\end{array}$ & $\begin{array}{l}0.00 \\
0.02 \\
0.01 \\
0.01 \\
0.03\end{array}$ & $\begin{array}{l}2145 \\
2150 \\
2155 \\
2200 \\
2205\end{array}$ & $\begin{array}{l}6.9 \\
5.9 \\
5.2 \\
4.6 \\
4.2\end{array}$ & $\begin{array}{l}0.00 \\
0.01 \\
0.00 \\
0.00 \\
0.01\end{array}$ & $\begin{array}{l}0140 \\
0145 \\
0150 \\
0155 \\
0200\end{array}$ & $\begin{array}{l}1.0 \\
0.9 \\
0.9 \\
0.9 \\
0.9\end{array}$ & $\begin{array}{l}0.00 \\
0.00 \\
0.00 \\
0.00 \\
0.00\end{array}$ \\
\hline $\begin{array}{l}1810 \\
1815 \\
1820 \\
1825 \\
1830\end{array}$ & $\begin{array}{r}9.8 \\
14.2 \\
14.2 \\
15.7 \\
13.7\end{array}$ & $\begin{array}{l}0.03 \\
0.02 \\
0.03 \\
0.01 \\
0.01\end{array}$ & $\begin{array}{l}2210 \\
2215 \\
2220 \\
2225 \\
2230\end{array}$ & $\begin{array}{l}3.7 \\
3.3 \\
2.8 \\
2.6 \\
2.3\end{array}$ & $\begin{array}{l}0.00 \\
0.00 \\
0.00 \\
0.00 \\
0.00\end{array}$ & $\begin{array}{l}0205 \\
0210 \\
0215 \\
0220 \\
0225\end{array}$ & $\begin{array}{l}0.9 \\
0.9 \\
0.9 \\
0.8 \\
0.8\end{array}$ & $\begin{array}{l}0.00 \\
0.00 \\
0.00 \\
0.00 \\
0.00\end{array}$ \\
\hline $\begin{array}{l}1835 \\
1840 \\
1845 \\
1850 \\
1855\end{array}$ & $\begin{array}{r}10.3 \\
7.9 \\
6.1 \\
5.0 \\
4.2\end{array}$ & $\begin{array}{l}0.01 \\
0.00 \\
0.00 \\
0.00 \\
0.00\end{array}$ & $\begin{array}{l}2235 \\
2240 \\
2245 \\
2250 \\
2255\end{array}$ & $\begin{array}{l}2.2 \\
2.1 \\
2.0 \\
2.0 \\
2.1\end{array}$ & $\begin{array}{l}0.00 \\
0.00 \\
0.01 \\
0.00 \\
0.01\end{array}$ & $\begin{array}{l}0230 \\
0235 \\
0240 \\
0245 \\
0250\end{array}$ & $\begin{array}{l}0.8 \\
0.8 \\
0.8 \\
0.8 \\
0.8\end{array}$ & $\begin{array}{l}0.00 \\
0.00 \\
0.00 \\
0.00 \\
0.00\end{array}$ \\
\hline $\begin{array}{l}1900 \\
1905 \\
1910\end{array}$ & $\begin{array}{l}3.7 \\
3.3 \\
3.0\end{array}$ & $\begin{array}{l}0.01 \\
0.00 \\
0.00\end{array}$ & $\begin{array}{l}2300 \\
2305 \\
2310\end{array}$ & $\begin{array}{l}2.6 \\
3.1 \\
3.3\end{array}$ & $\begin{array}{l}0.00 \\
0.00 \\
0.01\end{array}$ & $\begin{array}{l}0255 \\
0300\end{array}$ & $\begin{array}{l}0.8 \\
0.8\end{array}$ & $\begin{array}{l}0.00 \\
0.00\end{array}$ \\
\hline
\end{tabular}




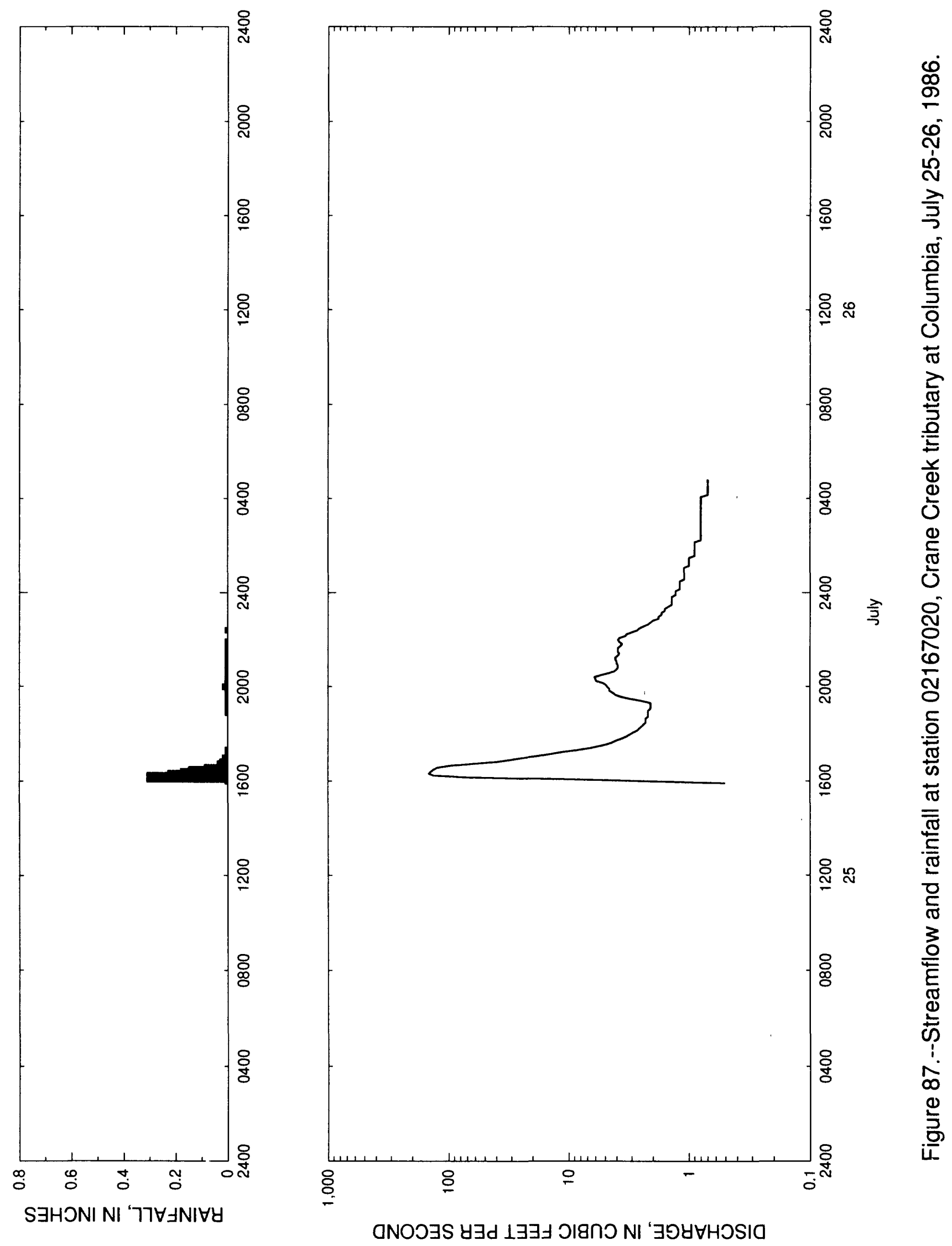


Table 86. - Streamflow and rainfall at station 02167020 , Crane Creek tributary at Columbia, July 25-26, 1986

\begin{tabular}{|c|c|c|c|c|c|c|c|c|}
\hline $\begin{array}{l}\text { Time } \\
\text { (hours) }\end{array}$ & $\begin{array}{l}\text { Streamflow } \\
\text { (cubic feet } \\
\text { per second) }\end{array}$ & $\begin{array}{l}\text { Rain- } \\
\text { fall } \\
\text { (inches) }\end{array}$ & $\begin{array}{l}\text { Time } \\
\text { (hours) }\end{array}$ & $\begin{array}{l}\text { Streamflow } \\
\text { (cubic feet } \\
\text { per second) }\end{array}$ & $\begin{array}{l}\text { Rain- } \\
\text { fall } \\
\text { (inches) }\end{array}$ & $\begin{array}{l}\text { Time } \\
\text { (hours) }\end{array}$ & $\begin{array}{l}\text { Streamflow } \\
\text { (cubic feet } \\
\text { per second) }\end{array}$ & $\begin{array}{l}\text { Rain- } \\
\text { fall } \\
\text { (inchos) }\end{array}$ \\
\hline $\begin{array}{l}\text { July } 25 \\
1555 \\
1600 \\
1605 \\
1610\end{array}$ & $\begin{array}{r}1986 \\
0.5 \\
2.2 \\
9.7 \\
66.7\end{array}$ & $\begin{array}{l}0.00 \\
0.01 \\
0.31 \\
0.27\end{array}$ & $\begin{array}{l}2020 \\
2025 \\
2030 \\
2035 \\
2040\end{array}$ & $\begin{array}{l}6.0 \\
6.1 \\
5.4 \\
4.7 \\
4.2\end{array}$ & $\begin{array}{l}0.00 \\
0.01 \\
0.00 \\
0.01 \\
0.01\end{array}$ & $\begin{array}{l}0045 \\
0050 \\
0055 \\
0100 \\
0105\end{array}$ & $\begin{array}{l}1.1 \\
1.1 \\
1.1 \\
1.1 \\
1.1\end{array}$ & $\begin{array}{l}0.00 \\
0.00 \\
0.00 \\
0.00 \\
0.00\end{array}$ \\
\hline $\begin{array}{l}1615 \\
1620 \\
1625 \\
1630 \\
1635\end{array}$ & $\begin{array}{l}134.0 \\
146.0 \\
140.0 \\
133.0 \\
124.0\end{array}$ & $\begin{array}{l}0.31 \\
0.23 \\
0.18 \\
0.15 \\
0.09\end{array}$ & $\begin{array}{l}2045 \\
2050 \\
2055 \\
2100 \\
2105\end{array}$ & $\begin{array}{l}4.0 \\
3.9 \\
3.9 \\
4.0 \\
4.0\end{array}$ & $\begin{array}{l}0.00 \\
0.01 \\
0.00 \\
0.01 \\
0.01\end{array}$ & $\begin{array}{l}0110 \\
0115 \\
0120 \\
0125 \\
0130\end{array}$ & $\begin{array}{l}1.0 \\
1.0 \\
1.0 \\
1.0 \\
1.0\end{array}$ & $\begin{array}{l}0.00 \\
0.00 \\
0.00 \\
0.00 \\
0.00\end{array}$ \\
\hline $\begin{array}{l}1640 \\
1645 \\
1650 \\
1655 \\
1700\end{array}$ & $\begin{array}{l}98.3 \\
60.9 \\
39.4 \\
30.7 \\
24.3\end{array}$ & $\begin{array}{l}0.04 \\
0.04 \\
0.03 \\
0.02 \\
0.02\end{array}$ & $\begin{array}{l}2110 \\
2115 \\
2120 \\
2125 \\
2130\end{array}$ & $\begin{array}{l}4.1 \\
4.1 \\
3.9 \\
3.8 \\
3.9\end{array}$ & $\begin{array}{l}0.00 \\
0.01 \\
0.01 \\
0.01 \\
0.00\end{array}$ & $\begin{array}{l}0135 \\
0140 \\
0145 \\
0150 \\
0155\end{array}$ & $\begin{array}{l}0.9 \\
0.9 \\
0.9 \\
0.9 \\
0.9\end{array}$ & $\begin{array}{l}0.00 \\
0.00 \\
0.00 \\
0.00 \\
0.00\end{array}$ \\
\hline $\begin{array}{l}1705 \\
1710 \\
1715 \\
1720 \\
1725\end{array}$ & $\begin{array}{r}18.1 \\
13.9 \\
11.3 \\
8.5 \\
6.6\end{array}$ & $\begin{array}{l}0.01 \\
0.00 \\
0.00 \\
0.01 \\
0.00\end{array}$ & $\begin{array}{l}2135 \\
2140 \\
2145 \\
2150 \\
2155\end{array}$ & $\begin{array}{l}3.9 \\
3.9 \\
3.7 \\
3.6 \\
3.8\end{array}$ & $\begin{array}{l}0.01 \\
0.00 \\
0.01 \\
0.00 \\
0.01\end{array}$ & $\begin{array}{l}0200 \\
0205 \\
0210 \\
0215 \\
0220\end{array}$ & $\begin{array}{l}0.9 \\
0.9 \\
0.9 \\
0.8 \\
0.8\end{array}$ & $\begin{array}{l}0.00 \\
0.00 \\
0.00 \\
0.00 \\
0.00\end{array}$ \\
\hline $\begin{array}{l}1730 \\
1735 \\
1740 \\
1745 \\
1750\end{array}$ & $\begin{array}{l}5.6 \\
4.8 \\
4.3 \\
4.0 \\
3.6\end{array}$ & $\begin{array}{l}0.00 \\
0.00 \\
0.00 \\
0.00 \\
0.00\end{array}$ & $\begin{array}{l}2200 \\
2205 \\
2210 \\
2215 \\
2220\end{array}$ & $\begin{array}{l}3.9 \\
3.8 \\
3.4 \\
3.3 \\
3.0\end{array}$ & $\begin{array}{l}0.00 \\
0.00 \\
0.00 \\
0.00 \\
0.00\end{array}$ & $\begin{array}{l}0225 \\
0230 \\
0235 \\
0240 \\
0245\end{array}$ & $\begin{array}{l}0.8 \\
0.8 \\
0.8 \\
0.8 \\
0.8\end{array}$ & $\begin{array}{l}0.00 \\
0.00 \\
0.00 \\
0.00 \\
0.00\end{array}$ \\
\hline $\begin{array}{l}1755 \\
1800 \\
1805 \\
1810 \\
1815\end{array}$ & $\begin{array}{l}3.3 \\
3.1 \\
2.9 \\
2.7 \\
2.6\end{array}$ & $\begin{array}{l}0.00 \\
0.00 \\
0.00 \\
0.00 \\
0.00\end{array}$ & $\begin{array}{l}2225 \\
2230 \\
2235 \\
2240 \\
2245\end{array}$ & $\begin{array}{l}2.7 \\
2.6 \\
2.4 \\
2.2 \\
2.1\end{array}$ & $\begin{array}{l}0.01 \\
0.00 \\
0.00 \\
0.00 \\
0.00\end{array}$ & $\begin{array}{l}0250 \\
0255 \\
0300 \\
0305 \\
0310\end{array}$ & $\begin{array}{l}0.8 \\
0.8 \\
0.8 \\
0.8 \\
0.8\end{array}$ & $\begin{array}{l}0.00 \\
0.00 \\
0.00 \\
0.00 \\
0.00\end{array}$ \\
\hline $\begin{array}{l}1820 \\
1825 \\
1830 \\
1835 \\
1840\end{array}$ & $\begin{array}{l}2.5 \\
2.4 \\
2.3 \\
2.3 \\
2.3\end{array}$ & $\begin{array}{l}0.00 \\
0.00 \\
0.00 \\
0.00 \\
0.00\end{array}$ & $\begin{array}{l}2250 \\
2255 \\
2300 \\
2305 \\
2310\end{array}$ & $\begin{array}{l}2.0 \\
1.8 \\
1.8 \\
1.7 \\
1.7\end{array}$ & $\begin{array}{l}0.00 \\
0.00 \\
0.00 \\
0.00 \\
0.00\end{array}$ & $\begin{array}{l}0315 \\
0320 \\
0325 \\
0330 \\
0335\end{array}$ & $\begin{array}{l}0.8 \\
0.8 \\
0.8 \\
0.8 \\
0.8\end{array}$ & $\begin{array}{l}0.00 \\
0.00 \\
0.00 \\
0.00 \\
0.00\end{array}$ \\
\hline $\begin{array}{l}1845 \\
1850 \\
1855 \\
1900 \\
1905\end{array}$ & $\begin{array}{l}2.2 \\
2.2 \\
2.2 \\
2.2 \\
2.1\end{array}$ & $\begin{array}{l}0.00 \\
0.00 \\
0.01 \\
0.00 \\
0.01\end{array}$ & $\begin{array}{l}2315 \\
2320 \\
2325 \\
2330 \\
2335\end{array}$ & $\begin{array}{l}1.6 \\
1.6 \\
1.5 \\
1.4 \\
1.4\end{array}$ & $\begin{array}{l}0.00 \\
0.00 \\
0.00 \\
0.00 \\
0.00\end{array}$ & $\begin{array}{l}0340 \\
0345 \\
0350 \\
0355 \\
0400\end{array}$ & $\begin{array}{l}0.8 \\
0.8 \\
0.8 \\
0.8 \\
0.8\end{array}$ & $\begin{array}{l}0.00 \\
0.00 \\
0.00 \\
0.00 \\
0.00\end{array}$ \\
\hline $\begin{array}{l}1910 \\
1915 \\
1920 \\
1925 \\
1930\end{array}$ & $\begin{array}{l}2.1 \\
2.1 \\
2.1 \\
2.5 \\
3.1\end{array}$ & $\begin{array}{l}0.01 \\
0.01 \\
0.01 \\
0.01 \\
0.01\end{array}$ & $\begin{array}{l}2340 \\
2345 \\
2350 \\
2355 \\
\text { July 26. }\end{array}$ & $\begin{array}{r}1.4 \\
1.4 \\
1.4 \\
1986\end{array}$ & $\begin{array}{l}0.00 \\
0.00 \\
0.00 \\
0.00\end{array}$ & $\begin{array}{l}0405 \\
0410 \\
0415 \\
0420 \\
0425\end{array}$ & $\begin{array}{l}0.8 \\
0.7 \\
0.7 \\
0.7 \\
0.7\end{array}$ & $\begin{array}{l}0.00 \\
0.00 \\
0.00 \\
0.00 \\
0.00\end{array}$ \\
\hline $\begin{array}{l}1935 \\
1940 \\
1945 \\
1950 \\
1955\end{array}$ & $\begin{array}{l}3.7 \\
4.1 \\
4.3 \\
4.6 \\
4.6\end{array}$ & $\begin{array}{l}0.00 \\
0.01 \\
0.01 \\
0.01 \\
0.01\end{array}$ & $\begin{array}{l}0000 \\
0005 \\
0010 \\
0015 \\
0020\end{array}$ & $\begin{array}{l}1.3 \\
1.3 \\
1.2 \\
1.2 \\
1.2\end{array}$ & $\begin{array}{l}0.00 \\
0.00 \\
0.00 \\
0.00 \\
0.00\end{array}$ & $\begin{array}{l}0430 \\
0435 \\
0440 \\
0445 \\
0450\end{array}$ & $\begin{array}{l}0.7 \\
0.7 \\
0.7 \\
0.7 \\
0.7\end{array}$ & $\begin{array}{l}0.00 \\
0.00 \\
0.00 \\
0.00 \\
0.00\end{array}$ \\
\hline $\begin{array}{l}2000 \\
2005 \\
2010 \\
2015\end{array}$ & $\begin{array}{l}4.8 \\
4.9 \\
5.2 \\
5.9\end{array}$ & $\begin{array}{l}0.02 \\
0.01 \\
0.01 \\
0.01\end{array}$ & $\begin{array}{l}0025 \\
0030 \\
0035 \\
0040\end{array}$ & $\begin{array}{l}1.2 \\
1.2 \\
1.1 \\
1.1\end{array}$ & $\begin{array}{l}0.00 \\
0.00 \\
0.00 \\
0.00\end{array}$ & $\begin{array}{l}0455 \\
0500\end{array}$ & $\begin{array}{l}0.7 \\
0.7\end{array}$ & $\begin{array}{l}0.00 \\
0.00\end{array}$ \\
\hline
\end{tabular}




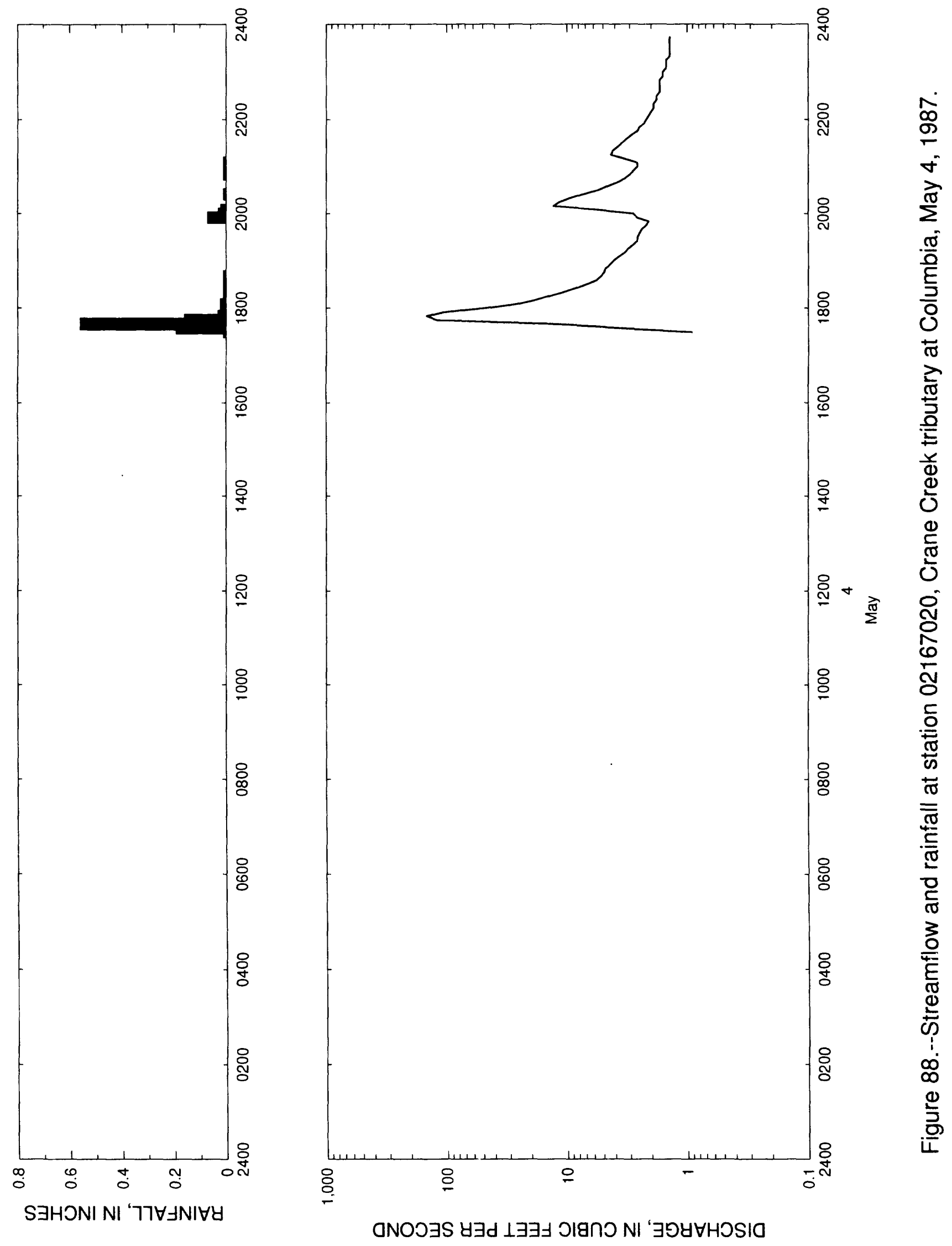


Table 87.--Streamflow and rainfall at station 02167020, Crane Creek tributary at Columbia,

May 4,1987

\begin{tabular}{|c|c|c|c|c|c|c|c|c|}
\hline $\begin{array}{l}\text { Time } \\
\text { (hours) }\end{array}$ & $\begin{array}{l}\text { Streamflow } \\
\text { (cubic feet } \\
\text { per second) }\end{array}$ & $\begin{array}{l}\text { Rain- } \\
\text { fall } \\
\text { (inches) }\end{array}$ & $\begin{array}{l}\text { Time } \\
\text { (hours) }\end{array}$ & $\begin{array}{l}\text { Streamflow } \\
\text { (cubic feet } \\
\text { per second) }\end{array}$ & $\begin{array}{l}\text { Rain- } \\
\text { fall } \\
\text { (inches) }\end{array}$ & $\begin{array}{l}\text { Time } \\
\text { (hours) }\end{array}$ & $\begin{array}{l}\text { Streamflow } \\
\text { (cubic feet } \\
\text { per second) }\end{array}$ & $\begin{array}{l}\text { Rain- } \\
\text { fall } \\
\text { (inches) }\end{array}$ \\
\hline $\begin{array}{c}\text { May 4, } \\
1730 \\
1735 \\
1740 \\
1745\end{array}$ & $\begin{array}{r}1987 \quad 0.9 \\
3.6 \\
12.3 \\
121.0\end{array}$ & $\begin{array}{l}0.01 \\
0.19 \\
0.56 \\
0.16\end{array}$ & $\begin{array}{l}1940 \\
1945 \\
1950 \\
1955 \\
2000\end{array}$ & $\begin{array}{l}2.4 \\
2.2 \\
2.1 \\
2.6 \\
2.8\end{array}$ & $\begin{array}{l}0.00 \\
0.00 \\
0.00 \\
0.07 \\
0.03\end{array}$ & $\begin{array}{l}2155 \\
2200 \\
2205 \\
2210 \\
2215\end{array}$ & $\begin{array}{l}2.3 \\
2.2 \\
2.1 \\
2.0 \\
1.9\end{array}$ & $\begin{array}{l}0.00 \\
0.00 \\
0.00 \\
0.00 \\
0.00\end{array}$ \\
\hline $\begin{array}{l}1750 \\
1755 \\
1800 \\
1805 \\
1810\end{array}$ & $\begin{array}{r}147.0 \\
106.0 \\
47.9 \\
26.4 \\
18.9\end{array}$ & $\begin{array}{l}0.03 \\
0.01 \\
0.02 \\
0.02 \\
0.01\end{array}$ & $\begin{array}{l}2005 \\
2010 \\
2015 \\
2020 \\
2025\end{array}$ & $\begin{array}{r}5.7 \\
13.0 \\
11.6 \\
9.4 \\
7.3\end{array}$ & $\begin{array}{l}0.02 \\
0.00 \\
0.00 \\
0.00 \\
0.01\end{array}$ & $\begin{array}{l}2220 \\
2225 \\
2230 \\
2235 \\
2240\end{array}$ & $\begin{array}{l}1.9 \\
1.8 \\
1.8 \\
1.7 \\
1.7\end{array}$ & $\begin{array}{l}0.00 \\
0.00 \\
0.00 \\
0.00 \\
0.00\end{array}$ \\
\hline $\begin{array}{l}1815 \\
1820 \\
1825 \\
1830 \\
1835\end{array}$ & $\begin{array}{r}14.4 \\
10.9 \\
8.5 \\
6.9 \\
5.7\end{array}$ & $\begin{array}{l}0.00 \\
0.01 \\
0.00 \\
0.01 \\
0.00\end{array}$ & $\begin{array}{l}2030 \\
2035 \\
2040 \\
2045 \\
2050\end{array}$ & $\begin{array}{l}5.5 \\
4.6 \\
3.8 \\
3.3 \\
3.0\end{array}$ & $\begin{array}{l}0.00 \\
0.00 \\
0.00 \\
0.00 \\
0.01\end{array}$ & $\begin{array}{l}2245 \\
2250 \\
2255 \\
2300 \\
2305\end{array}$ & $\begin{array}{l}1.7 \\
1.7 \\
1.6 \\
1.6 \\
1.5\end{array}$ & $\begin{array}{l}0.00 \\
0.00 \\
0.00 \\
0.00 \\
0.00\end{array}$ \\
\hline $\begin{array}{l}1840 \\
1845 \\
1850 \\
1855 \\
1900\end{array}$ & $\begin{array}{l}5.2 \\
4.9 \\
4.8 \\
4.4 \\
4.1\end{array}$ & $\begin{array}{l}0.01 \\
0.00 \\
0.00 \\
0.00 \\
0.00\end{array}$ & $\begin{array}{l}2055 \\
2100 \\
2105 \\
2110 \\
2115\end{array}$ & $\begin{array}{l}2.8 \\
2.6 \\
2.6 \\
3.3 \\
4.3\end{array}$ & $\begin{array}{l}0.01 \\
0.01 \\
0.01 \\
0.00 \\
0.00\end{array}$ & $\begin{array}{l}2310 \\
2315 \\
2320 \\
2325 \\
2330\end{array}$ & $\begin{array}{l}1.5 \\
1.5 \\
1.4 \\
1.4 \\
1.4\end{array}$ & $\begin{array}{l}0.00 \\
0.00 \\
0.00 \\
0.00 \\
0.00\end{array}$ \\
\hline $\begin{array}{l}1905 \\
1910 \\
1915 \\
1920 \\
1925\end{array}$ & $\begin{array}{l}3.7 \\
3.3 \\
3.1 \\
2.8 \\
2.6\end{array}$ & $\begin{array}{l}0.00 \\
0.00 \\
0.00 \\
0.00 \\
0.00\end{array}$ & $\begin{array}{l}2120 \\
2125 \\
2130 \\
2135 \\
2140\end{array}$ & $\begin{array}{l}4.2 \\
3.8 \\
3.5 \\
3.2 \\
2.9\end{array}$ & $\begin{array}{l}0.00 \\
0.00 \\
0.00 \\
0.00 \\
0.00\end{array}$ & $\begin{array}{l}2335 \\
2340 \\
2345 \\
2350 \\
2355\end{array}$ & $\begin{array}{l}1.4 \\
1.4 \\
1.4 \\
1.4 \\
1.4\end{array}$ & $\begin{array}{l}0.00 \\
0.00 \\
0.00 \\
0.00 \\
0.00\end{array}$ \\
\hline $\begin{array}{l}1930 \\
1935\end{array}$ & $\begin{array}{l}2.6 \\
2.5\end{array}$ & $\begin{array}{l}0.00 \\
0.00\end{array}$ & $\begin{array}{l}2145 \\
2150\end{array}$ & $\begin{array}{l}2.6 \\
2.5\end{array}$ & $\begin{array}{l}0.00 \\
0.00\end{array}$ & & & \\
\hline
\end{tabular}




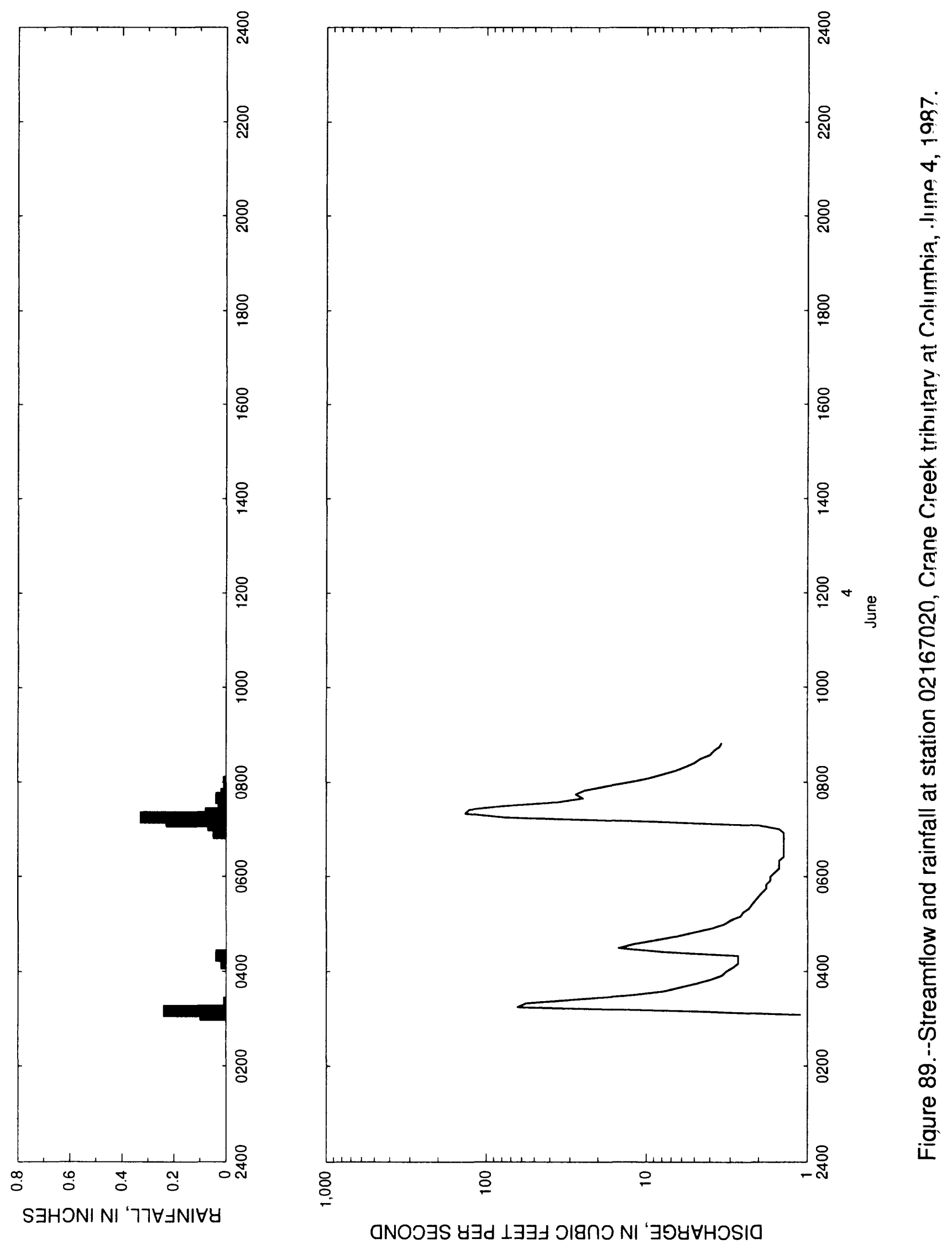


Table 88. - Streamflow and rainfall at station 02167020, Crane Creek tributary at Columbia,

\section{June 4, 1987}

\begin{tabular}{|c|c|c|c|c|c|c|c|c|}
\hline $\begin{array}{l}\text { Time } \\
\text { (hours) }\end{array}$ & $\begin{array}{l}\text { Streamflow } \\
\text { (cubic feet } \\
\text { per second) }\end{array}$ & $\begin{array}{l}\text { Rain- } \\
\text { fall } \\
\text { (inches) }\end{array}$ & $\begin{array}{l}\text { Time } \\
\text { (hours) }\end{array}$ & $\begin{array}{l}\text { Streamflow } \\
\text { (cubic feet } \\
\text { per second) }\end{array}$ & $\begin{array}{l}\text { Rain- } \\
\text { fall } \\
\text { (inches) }\end{array}$ & $\begin{array}{l}\text { Time } \\
\text { (hours) }\end{array}$ & $\begin{array}{l}\text { Streamflow } \\
\text { (cubic feet } \\
\text { per second) }\end{array}$ & $\begin{array}{l}\text { Rain- } \\
\text { fall } \\
\text { (inches) }\end{array}$ \\
\hline $\begin{array}{l}\text { June } 4 \text {, } \\
0305 \\
0310 \\
0315 \\
0320\end{array}$ & $1987 \quad \begin{array}{r}1.1 \\
5.2 \\
54.2 \\
56.6\end{array}$ & $\begin{array}{l}0.10 \\
0.24 \\
0.01 \\
0.01\end{array}$ & $\begin{array}{l}0505 \\
0510 \\
0515 \\
0520 \\
0525\end{array}$ & $\begin{array}{l}3.0 \\
2.6 \\
2.5 \\
2.3 \\
2.2\end{array}$ & $\begin{array}{l}0.00 \\
0.00 \\
0.00 \\
0.00 \\
0.00\end{array}$ & $\begin{array}{l}0710 \\
0715 \\
0720 \\
0725 \\
0730\end{array}$ & $\begin{array}{r}8.5 \\
76.0 \\
136.0 \\
128.0 \\
77.0\end{array}$ & $\begin{array}{l}0.23 \\
0.33 \\
0.08 \\
0.03 \\
0.01\end{array}$ \\
\hline $\begin{array}{l}0325 \\
0330 \\
0335 \\
0340 \\
0345\end{array}$ & $\begin{array}{r}25.9 \\
12.8 \\
8.0 \\
6.2 \\
4.9\end{array}$ & $\begin{array}{l}0.00 \\
0.00 \\
0.00 \\
0.00 \\
0.00\end{array}$ & $\begin{array}{l}0530 \\
0535 \\
0540 \\
0545 \\
0550\end{array}$ & $\begin{array}{l}2.1 \\
2.0 \\
1.9 \\
1.8 \\
1.8\end{array}$ & $\begin{array}{l}0.00 \\
0.00 \\
0.00 \\
0.00 \\
0.00\end{array}$ & $\begin{array}{l}0735 \\
0740 \\
0745 \\
0750 \\
0755\end{array}$ & $\begin{array}{l}35.9 \\
25.0 \\
27.8 \\
24.5 \\
18.3\end{array}$ & $\begin{array}{l}0.03 \\
0.04 \\
0.02 \\
0.01 \\
0.00\end{array}$ \\
\hline $\begin{array}{l}0350 \\
0355 \\
0400 \\
0405 \\
0410\end{array}$ & $\begin{array}{l}4.0 \\
3.4 \\
3.2 \\
2.9 \\
2.7\end{array}$ & $\begin{array}{l}0.00 \\
0.00 \\
0.00 \\
0.00 \\
0.02\end{array}$ & $\begin{array}{l}0555 \\
0600 \\
0605 \\
0610 \\
0615\end{array}$ & $\begin{array}{l}1.7 \\
1.7 \\
1.6 \\
1.5 \\
1.5\end{array}$ & $\begin{array}{l}0.00 \\
0.00 \\
0.00 \\
0.00 \\
0.00\end{array}$ & $\begin{array}{l}0800 \\
0805 \\
0810 \\
0815 \\
0820\end{array}$ & $\begin{array}{r}13.0 \\
9.8 \\
8.0 \\
6.6 \\
5.7\end{array}$ & $\begin{array}{l}0.01 \\
0.00 \\
0.00 \\
0.00 \\
0.00\end{array}$ \\
\hline $\begin{array}{l}0415 \\
0420 \\
0425 \\
0430 \\
0435\end{array}$ & $\begin{array}{r}2.7 \\
2.7 \\
7.9 \\
15.0 \\
12.1\end{array}$ & $\begin{array}{l}0.02 \\
0.04 \\
0.00 \\
0.00 \\
0.00\end{array}$ & $\begin{array}{l}0620 \\
0625 \\
0630 \\
0635 \\
0640\end{array}$ & $\begin{array}{l}1.5 \\
1.4 \\
1.4 \\
1.4 \\
1.4\end{array}$ & $\begin{array}{l}0.00 \\
0.00 \\
0.00 \\
0.00 \\
0.00\end{array}$ & $\begin{array}{l}0825 \\
0830 \\
0835 \\
0840 \\
0845\end{array}$ & $\begin{array}{l}5.0 \\
4.6 \\
4.0 \\
3.8 \\
3.5\end{array}$ & $\begin{array}{l}0.00 \\
0.00 \\
0.00 \\
0.00 \\
0.00\end{array}$ \\
\hline $\begin{array}{l}0440 \\
0445 \\
0450 \\
0455 \\
0500\end{array}$ & $\begin{array}{l}8.7 \\
6.4 \\
5.0 \\
3.9 \\
3.3\end{array}$ & $\begin{array}{l}0.00 \\
0.00 \\
0.00 \\
0.00 \\
0.00\end{array}$ & $\begin{array}{l}0645 \\
0650 \\
0655 \\
0700 \\
0705\end{array}$ & $\begin{array}{l}1.4 \\
1.4 \\
1.4 \\
1.5 \\
2.0\end{array}$ & $\begin{array}{l}0.00 \\
0.00 \\
0.05 \\
0.00 \\
0.07\end{array}$ & $\begin{array}{l}0850 \\
0855 \\
0900\end{array}$ & $\begin{array}{l}3.4 \\
3.3 \\
3.2\end{array}$ & $\begin{array}{l}0.00 \\
0.00 \\
0.00\end{array}$ \\
\hline
\end{tabular}




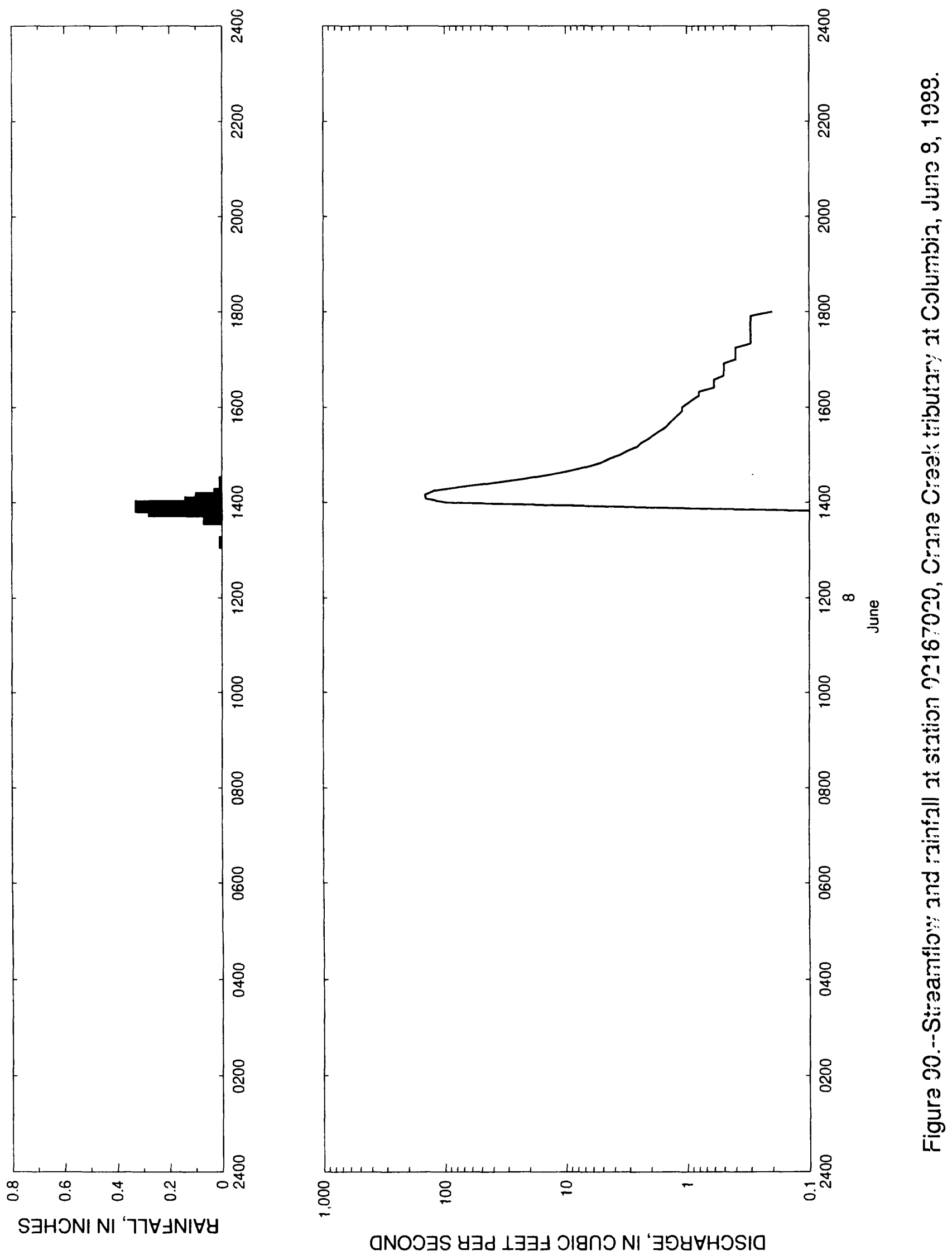


Table 89.--Streamflow and rainfall at station 02167020, Crane Creek tributary at Columbia,

June 8,1988

\begin{tabular}{|c|c|c|c|c|c|c|c|c|}
\hline $\begin{array}{l}\text { Time } \\
\text { (hours) }\end{array}$ & $\begin{array}{l}\text { Streamflow } \\
\text { (cubic feet } \\
\text { per second) }\end{array}$ & $\begin{array}{l}\text { Rain- } \\
\text { fall } \\
\text { (inches) }\end{array}$ & $\begin{array}{l}\text { Time } \\
\text { (hours) }\end{array}$ & $\begin{array}{l}\text { Streamflow } \\
\text { (cubic feet } \\
\text { per second) }\end{array}$ & $\begin{array}{l}\text { Rain- } \\
\text { fall } \\
\text { (inches) }\end{array}$ & $\begin{array}{l}\text { Time } \\
\text { (hours) }\end{array}$ & $\begin{array}{l}\text { Streamflow } \\
\text { (cubic feet } \\
\text { per second) }\end{array}$ & $\begin{array}{l}\text { Rain- } \\
\text { fall } \\
\text { (inchos) }\end{array}$ \\
\hline $\begin{array}{l}\text { June } 8 \text {, } \\
1310 \\
1315 \\
1320 \\
1325\end{array}$ & $\begin{array}{l}0.1 \\
0.1 \\
0.1 \\
0.1\end{array}$ & $\begin{array}{l}0.01 \\
0.00 \\
0.00 \\
0.00\end{array}$ & $\begin{array}{l}1445 \\
1450 \\
1455 \\
1500 \\
1505\end{array}$ & $\begin{array}{l}6.8 \\
5.2 \\
4.4 \\
3.6 \\
3.1\end{array}$ & $\begin{array}{l}0.00 \\
0.00 \\
0.00 \\
0.00 \\
0.00\end{array}$ & $\begin{array}{l}1625 \\
1630 \\
1635 \\
1640 \\
1645\end{array}$ & $\begin{array}{l}0.6 \\
0.6 \\
0.6 \\
0.5 \\
0.5\end{array}$ & $\begin{array}{l}0.00 \\
0.00 \\
0.00 \\
0.00 \\
0.00\end{array}$ \\
\hline $\begin{array}{l}1330 \\
1335 \\
1340 \\
1345 \\
1350\end{array}$ & $\begin{array}{l}0.1 \\
0.1 \\
0.1 \\
0.1 \\
0.1\end{array}$ & $\begin{array}{l}0.00 \\
0.00 \\
0.07 \\
0.05 \\
0.28\end{array}$ & $\begin{array}{l}1510 \\
1515 \\
1520 \\
1525 \\
1530\end{array}$ & $\begin{array}{l}2.6 \\
2.4 \\
2.1 \\
1.9 \\
1.7\end{array}$ & $\begin{array}{l}0.00 \\
0.00 \\
0.00 \\
0.00 \\
0.00\end{array}$ & $\begin{array}{l}1650 \\
1655 \\
1700 \\
1705 \\
1710\end{array}$ & $\begin{array}{l}0.5 \\
0.5 \\
0.4 \\
0.4 \\
0.4\end{array}$ & $\begin{array}{l}0.00 \\
0.00 \\
0.00 \\
0.00 \\
0.00\end{array}$ \\
\hline $\begin{array}{l}1355 \\
1400 \\
1405 \\
1410 \\
1415\end{array}$ & $\begin{array}{r}3.3 \\
95.3 \\
143.0 \\
146.0 \\
120.0\end{array}$ & $\begin{array}{l}0.33 \\
0.14 \\
0.10 \\
0.03 \\
0.01\end{array}$ & $\begin{array}{l}1535 \\
1540 \\
1545 \\
1550 \\
1555\end{array}$ & $\begin{array}{l}1.5 \\
1.4 \\
1.3 \\
1.2 \\
1.1\end{array}$ & $\begin{array}{l}0.00 \\
0.00 \\
0.00 \\
0.00 \\
0.00\end{array}$ & $\begin{array}{l}1715 \\
1720 \\
1725 \\
1730 \\
1735\end{array}$ & $\begin{array}{l}0.4 \\
0.3 \\
0.3 \\
0.3 \\
0.3\end{array}$ & $\begin{array}{l}0.00 \\
0.00 \\
0.00 \\
0.00 \\
0.00\end{array}$ \\
\hline $\begin{array}{l}1420 \\
1425 \\
1430 \\
1435 \\
1440\end{array}$ & $\begin{array}{r}69.8 \\
37.5 \\
21.7 \\
13.9 \\
9.3\end{array}$ & $\begin{array}{l}0.01 \\
0.01 \\
0.00 \\
0.00 \\
0.00\end{array}$ & $\begin{array}{l}1600 \\
1605 \\
1610 \\
1615 \\
1620\end{array}$ & $\begin{array}{l}1.1 \\
1.0 \\
0.9 \\
0.8 \\
0.8\end{array}$ & $\begin{array}{l}0.00 \\
0.00 \\
0.00 \\
0.00 \\
0.00\end{array}$ & $\begin{array}{l}1740 \\
1745 \\
1750 \\
1755 \\
1800\end{array}$ & $\begin{array}{l}0.3 \\
0.3 \\
0.3 \\
0.3 \\
0.2\end{array}$ & $\begin{array}{l}0.00 \\
0.00 \\
0.00 \\
0.00 \\
0.00\end{array}$ \\
\hline
\end{tabular}



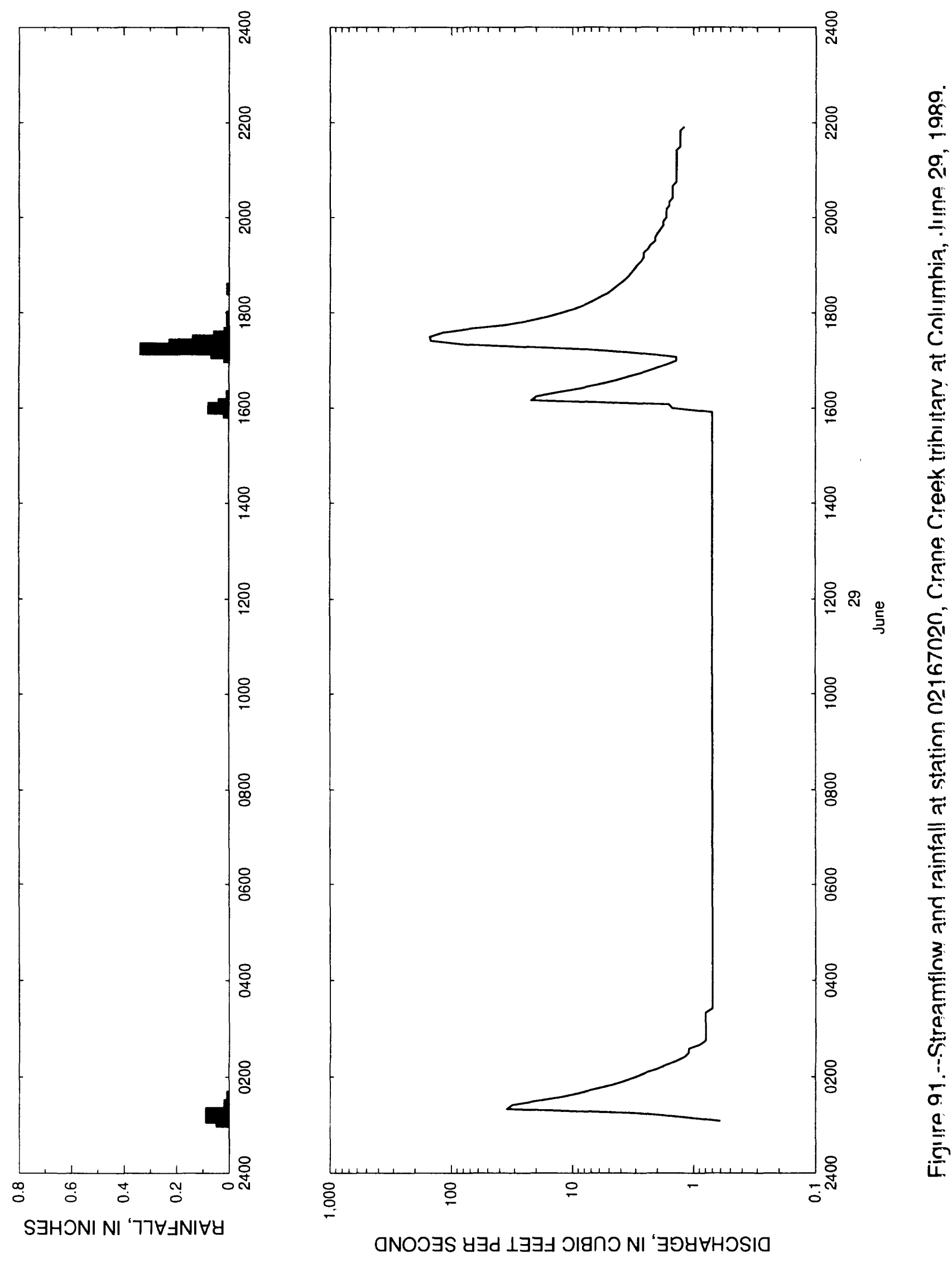
Table 90.--Streamflow and rainfall at station 02167020 , Crane Creek tributary at Columbia, June 29, 1989

\begin{tabular}{|c|c|c|c|c|c|c|c|c|}
\hline $\begin{array}{l}\text { Time } \\
\text { (hours) }\end{array}$ & $\begin{array}{l}\text { Streamflow } \\
\text { (cubic feet } \\
\text { per second) }\end{array}$ & $\begin{array}{l}\text { Rain- } \\
\text { fall } \\
\text { (inches) }\end{array}$ & $\begin{array}{l}\text { Time } \\
\text { (hours) }\end{array}$ & $\begin{array}{l}\text { Streamflow } \\
\text { (cubic feet } \\
\text { per second) }\end{array}$ & $\begin{array}{l}\text { Rain- } \\
\text { fall } \\
\text { (inches) }\end{array}$ & $\begin{array}{l}\text { Time } \\
\text { (hours) }\end{array}$ & $\begin{array}{l}\text { Streamflow } \\
\text { (cubic feet } \\
\text { per second) }\end{array}$ & $\begin{array}{l}\text { Rain- } \\
\text { fall } \\
\text { (inches) }\end{array}$ \\
\hline $\begin{array}{l}\text { June } 29 \text {, } \\
0105 \\
0110 \\
0115 \\
0120\end{array}$ & $\begin{array}{r}1989 \\
0.6 \\
1.2 \\
2.9 \\
34.8\end{array}$ & $\begin{array}{l}0.05 \\
0.09 \\
0.09 \\
0.02\end{array}$ & $\begin{array}{l}0625 \\
0630 \\
0635 \\
0640 \\
0645\end{array}$ & $\begin{array}{l}0.7 \\
0.7 \\
0.7 \\
0.7 \\
0.7\end{array}$ & $\begin{array}{l}0.00 \\
0.00 \\
0.00 \\
0.00 \\
0.00\end{array}$ & $\begin{array}{l}1150 \\
1155 \\
1200 \\
1205 \\
1210\end{array}$ & $\begin{array}{l}0.7 \\
0.7 \\
0.7 \\
0.7 \\
0.7\end{array}$ & $\begin{array}{l}0.00 \\
0.00 \\
0.00 \\
0.00 \\
0.00\end{array}$ \\
\hline $\begin{array}{l}0125 \\
0130 \\
0135 \\
0140 \\
0145\end{array}$ & $\begin{array}{r}31.5 \\
20.2 \\
12.6 \\
8.7 \\
6.4\end{array}$ & $\begin{array}{l}0.02 \\
0.00 \\
0.01 \\
0.00 \\
0.00\end{array}$ & $\begin{array}{l}0650 \\
0655 \\
0700 \\
0705 \\
0710\end{array}$ & $\begin{array}{l}0.7 \\
0.7 \\
0.7 \\
0.7 \\
0.7\end{array}$ & $\begin{array}{l}0.00 \\
0.00 \\
0.00 \\
0.00 \\
0.00\end{array}$ & $\begin{array}{l}1215 \\
1220 \\
1225 \\
1230 \\
1235\end{array}$ & $\begin{array}{l}0.7 \\
0.7 \\
0.7 \\
0.7 \\
0.7\end{array}$ & $\begin{array}{l}0.00 \\
0.00 \\
0.00 \\
0.00 \\
0.00\end{array}$ \\
\hline $\begin{array}{l}0150 \\
0155 \\
0200 \\
0205 \\
0210\end{array}$ & $\begin{array}{l}4.7 \\
3.7 \\
3.0 \\
2.5 \\
2.0\end{array}$ & $\begin{array}{l}0.00 \\
0.00 \\
0.00 \\
0.00 \\
0.00\end{array}$ & $\begin{array}{l}0715 \\
0720 \\
0725 \\
0730 \\
0735\end{array}$ & $\begin{array}{l}0.7 \\
0.7 \\
0.7 \\
0.7 \\
0.7\end{array}$ & $\begin{array}{l}0.00 \\
0.00 \\
0.00 \\
0.00 \\
0.00\end{array}$ & $\begin{array}{l}1240 \\
1245 \\
1250 \\
1255 \\
1300\end{array}$ & $\begin{array}{l}0.7 \\
0.7 \\
0.7 \\
0.7 \\
0.7\end{array}$ & $\begin{array}{l}0.00 \\
0.00 \\
0.00 \\
0.00 \\
0.00\end{array}$ \\
\hline $\begin{array}{l}0215 \\
0220 \\
0225 \\
0230 \\
0235\end{array}$ & $\begin{array}{l}1.7 \\
1.4 \\
1.2 \\
1.1 \\
1.1\end{array}$ & $\begin{array}{l}0.00 \\
0.00 \\
0.00 \\
0.00 \\
0.00\end{array}$ & $\begin{array}{l}0740 \\
0745 \\
0750 \\
0755 \\
0800\end{array}$ & $\begin{array}{l}0.7 \\
0.7 \\
0.7 \\
0.7 \\
0.7\end{array}$ & $\begin{array}{l}0.00 \\
0.00 \\
0.00 \\
0.00 \\
0.00\end{array}$ & $\begin{array}{l}1305 \\
1310 \\
1315 \\
1320 \\
1325\end{array}$ & $\begin{array}{l}0.7 \\
0.7 \\
0.7 \\
0.7 \\
0.7\end{array}$ & $\begin{array}{l}0.00 \\
0.00 \\
0.00 \\
0.00 \\
0.00\end{array}$ \\
\hline $\begin{array}{l}0240 \\
0245 \\
0250 \\
0255 \\
0300\end{array}$ & $\begin{array}{l}0.9 \\
0.8 \\
0.8 \\
0.8 \\
0.8\end{array}$ & $\begin{array}{l}0.00 \\
0.00 \\
0.00 \\
0.00 \\
0.00\end{array}$ & $\begin{array}{l}0805 \\
0810 \\
0815 \\
0820 \\
0825\end{array}$ & $\begin{array}{l}0.7 \\
0.7 \\
0.7 \\
0.7 \\
0.7\end{array}$ & $\begin{array}{l}0.00 \\
0.00 \\
0.00 \\
0.00 \\
0.00\end{array}$ & $\begin{array}{l}1330 \\
1335 \\
1340 \\
1345 \\
1350\end{array}$ & $\begin{array}{l}0.7 \\
0.7 \\
0.7 \\
0.7 \\
0.7\end{array}$ & $\begin{array}{l}0.00 \\
0.00 \\
0.00 \\
0.00 \\
0.00\end{array}$ \\
\hline $\begin{array}{l}0305 \\
0310 \\
0315 \\
0320 \\
0325\end{array}$ & $\begin{array}{l}0.8 \\
0.8 \\
0.8 \\
0.8 \\
0.7\end{array}$ & $\begin{array}{l}0.00 \\
0.00 \\
0.00 \\
0.00 \\
0.00\end{array}$ & $\begin{array}{l}0830 \\
0835 \\
0840 \\
0845 \\
0850\end{array}$ & $\begin{array}{l}0.7 \\
0.7 \\
0.7 \\
0.7 \\
0.7\end{array}$ & $\begin{array}{l}0.00 \\
0.00 \\
0.00 \\
0.00 \\
0.00\end{array}$ & $\begin{array}{l}1355 \\
1400 \\
1405 \\
1410 \\
1415\end{array}$ & $\begin{array}{l}0.7 \\
0.7 \\
0.7 \\
0.7 \\
0.7\end{array}$ & $\begin{array}{l}0.00 \\
0.00 \\
0.00 \\
0.00 \\
0.00\end{array}$ \\
\hline $\begin{array}{l}0330 \\
0335 \\
0340 \\
0345 \\
0350\end{array}$ & $\begin{array}{l}0.7 \\
0.7 \\
0.7 \\
0.7 \\
0.7\end{array}$ & $\begin{array}{l}0.00 \\
0.00 \\
0.00 \\
0.00 \\
0.00\end{array}$ & $\begin{array}{l}0855 \\
0900 \\
0905 \\
0910 \\
0915\end{array}$ & $\begin{array}{l}0.7 \\
0.7 \\
0.7 \\
0.7 \\
0.7\end{array}$ & $\begin{array}{l}0.00 \\
0.00 \\
0.00 \\
0.00 \\
0.00\end{array}$ & $\begin{array}{l}1420 \\
1425 \\
1430 \\
1435 \\
1440\end{array}$ & $\begin{array}{l}0.7 \\
0.7 \\
0.7 \\
0.7 \\
0.7\end{array}$ & $\begin{array}{l}0.00 \\
0.00 \\
0.00 \\
0.00 \\
0.00\end{array}$ \\
\hline $\begin{array}{l}0355 \\
0400 \\
0405 \\
0410 \\
0415\end{array}$ & $\begin{array}{l}0.7 \\
0.7 \\
0.7 \\
0.7 \\
0.7\end{array}$ & $\begin{array}{l}0.00 \\
0.00 \\
0.00 \\
0.00 \\
0.00\end{array}$ & $\begin{array}{l}0920 \\
0925 \\
0930 \\
0935 \\
0940\end{array}$ & $\begin{array}{l}0.7 \\
0.7 \\
0.7 \\
0.7 \\
0.7\end{array}$ & $\begin{array}{l}0.00 \\
0.00 \\
0.00 \\
0.00 \\
0.00\end{array}$ & $\begin{array}{l}1445 \\
1450 \\
1455 \\
1500 \\
1505\end{array}$ & $\begin{array}{l}0.7 \\
0.7 \\
0.7 \\
0.7 \\
0.7\end{array}$ & $\begin{array}{l}0.00 \\
0.00 \\
0.00 \\
0.00 \\
0.00\end{array}$ \\
\hline $\begin{array}{l}0420 \\
0425 \\
0430 \\
0435 \\
0440\end{array}$ & $\begin{array}{l}0.7 \\
0.7 \\
0.7 \\
0.7 \\
0.7\end{array}$ & $\begin{array}{l}0.00 \\
0.00 \\
0.00 \\
0.00 \\
0.00\end{array}$ & $\begin{array}{l}0945 \\
0950 \\
0955 \\
1000 \\
1005\end{array}$ & $\begin{array}{l}0.7 \\
0.7 \\
0.7 \\
0.7 \\
0.7\end{array}$ & $\begin{array}{l}0.00 \\
0.00 \\
0.00 \\
0.00 \\
0.00\end{array}$ & $\begin{array}{l}1510 \\
1515 \\
1520 \\
1525 \\
1530\end{array}$ & $\begin{array}{l}0.7 \\
0.7 \\
0.7 \\
0.7 \\
0.7\end{array}$ & $\begin{array}{l}0.00 \\
0.00 \\
0.00 \\
0.00 \\
0.00\end{array}$ \\
\hline $\begin{array}{l}0445 \\
0450 \\
0455 \\
0500 \\
0505\end{array}$ & $\begin{array}{l}0.7 \\
0.7 \\
0.7 \\
0.7 \\
0.7\end{array}$ & $\begin{array}{l}0.00 \\
0.00 \\
0.00 \\
0.00 \\
0.00\end{array}$ & $\begin{array}{l}1010 \\
1015 \\
1020 \\
1025 \\
1030\end{array}$ & $\begin{array}{l}0.7 \\
0.7 \\
0.7 \\
0.7 \\
0.7\end{array}$ & $\begin{array}{l}0.00 \\
0.00 \\
0.00 \\
0.00 \\
0.00\end{array}$ & $\begin{array}{l}1535 \\
1540 \\
1545 \\
1550 \\
1555\end{array}$ & $\begin{array}{l}0.7 \\
0.7 \\
0.7 \\
0.7 \\
0.7\end{array}$ & $\begin{array}{l}0.00 \\
0.00 \\
0.00 \\
0.00 \\
0.02\end{array}$ \\
\hline $\begin{array}{l}0510 \\
0515 \\
0520 \\
0525 \\
0530\end{array}$ & $\begin{array}{l}0.7 \\
0.7 \\
0.7 \\
0.7 \\
0.7\end{array}$ & $\begin{array}{l}0.00 \\
0.00 \\
0.00 \\
0.00 \\
0.00\end{array}$ & $\begin{array}{l}1035 \\
1040 \\
1045 \\
1050 \\
1055\end{array}$ & $\begin{array}{l}0.7 \\
0.7 \\
0.7 \\
0.7 \\
0.7\end{array}$ & $\begin{array}{l}0.00 \\
0.00 \\
0.00 \\
0.00 \\
0.00\end{array}$ & $\begin{array}{l}1600 \\
1605 \\
1610 \\
1615 \\
1620\end{array}$ & $\begin{array}{r}1.5 \\
1.6 \\
21.9 \\
19.8 \\
13.3\end{array}$ & $\begin{array}{l}0.08 \\
0.04 \\
0.00 \\
0.01 \\
0.00\end{array}$ \\
\hline $\begin{array}{l}0535 \\
0540 \\
0545 \\
0550 \\
0555\end{array}$ & $\begin{array}{l}0.7 \\
0.7 \\
0.7 \\
0.7 \\
0.7\end{array}$ & $\begin{array}{l}0.00 \\
0.00 \\
0.00 \\
0.00 \\
0.00\end{array}$ & $\begin{array}{l}1100 \\
1105 \\
1110 \\
1115 \\
1120\end{array}$ & $\begin{array}{l}0.7 \\
0.7 \\
0.7 \\
0.7 \\
0.7\end{array}$ & $\begin{array}{l}0.00 \\
0.00 \\
0.00 \\
0.00 \\
0.00\end{array}$ & $\begin{array}{l}1625 \\
1630 \\
1635 \\
1640 \\
1645\end{array}$ & $\begin{array}{l}8.5 \\
6.1 \\
4.4 \\
3.4 \\
2.6\end{array}$ & $\begin{array}{l}0.00 \\
0.00 \\
0.00 \\
0.00 \\
0.00\end{array}$ \\
\hline $\begin{array}{l}0600 \\
0605 \\
0610 \\
0615 \\
0620\end{array}$ & $\begin{array}{l}0.7 \\
0.7 \\
0.7 \\
0.7 \\
0.7\end{array}$ & $\begin{array}{l}0.00 \\
0.00 \\
0.00 \\
0.00 \\
0.00\end{array}$ & $\begin{array}{l}1125 \\
1130 \\
1135 \\
1140 \\
1145\end{array}$ & $\begin{array}{l}0.7 \\
0.7 \\
0.7 \\
0.7 \\
0.7\end{array}$ & $\begin{array}{l}0.00 \\
0.00 \\
0.00 \\
0.00 \\
0.00\end{array}$ & $\begin{array}{l}1650 \\
1655 \\
1700 \\
1705 \\
1710\end{array}$ & $\begin{array}{l}2.1 \\
1.7 \\
1.4 \\
1.4 \\
3.0\end{array}$ & $\begin{array}{l}0.00 \\
0.00 \\
0.00 \\
0.02 \\
0.07\end{array}$ \\
\hline
\end{tabular}


Table 90.--Streamf1ow and rainfal1 at station 02167020, Crane Creek tributary at Columbia, June $29,1989--$ Continued

\begin{tabular}{|c|c|c|c|c|c|c|c|c|}
\hline $\begin{array}{l}\text { Time } \\
\text { (hours) }\end{array}$ & $\begin{array}{l}\text { Streamflow } \\
\text { (cubic feet } \\
\text { per second) }\end{array}$ & $\begin{array}{l}\text { Rain- } \\
\text { fall } \\
\text { (inches) }\end{array}$ & $\begin{array}{l}\text { Time } \\
\text { (hours) }\end{array}$ & $\begin{array}{l}\text { Streamflow } \\
\text { (cubic feet } \\
\text { per second) }\end{array}$ & $\begin{array}{l}\text { Rain- } \\
\text { fall } \\
\text { (inches) }\end{array}$ & $\begin{array}{l}\text { Time } \\
\text { (hours) }\end{array}$ & $\begin{array}{l}\text { Streamflow } \\
\text { (cubic feet } \\
\text { per second) }\end{array}$ & $\begin{array}{l}\text { Rain- } \\
\text { fal1 } \\
\text { (inches) }\end{array}$ \\
\hline $\begin{array}{l}1715 \\
1720 \\
1725 \\
1730 \\
1735\end{array}$ & $\begin{array}{r}9.5 \\
74.7 \\
149.0 \\
152.0 \\
120.0\end{array}$ & $\begin{array}{l}0.34 \\
0.23 \\
0.14 \\
0.06 \\
0.02\end{array}$ & $\begin{array}{l}1855 \\
1900 \\
1905 \\
1910 \\
1915\end{array}$ & $\begin{array}{l}3.1 \\
2.9 \\
2.7 \\
2.6 \\
2.6\end{array}$ & $\begin{array}{l}0.00 \\
0.00 \\
0.00 \\
0.00 \\
0.00\end{array}$ & $\begin{array}{l}2035 \\
2040 \\
2045 \\
2050 \\
2055\end{array}$ & $\begin{array}{l}1.5 \\
1.5 \\
1.4 \\
1.4 \\
1.4\end{array}$ & $\begin{array}{l}0.00 \\
0.00 \\
0.09 \\
0.09 \\
0.00\end{array}$ \\
\hline $\begin{array}{l}1740 \\
1745 \\
1750 \\
1755 \\
1800\end{array}$ & $\begin{array}{l}70.8 \\
35.3 \\
22.8 \\
16.3 \\
12.4\end{array}$ & $\begin{array}{l}0.01 \\
0.00 \\
0.01 \\
0.01 \\
0.00\end{array}$ & $\begin{array}{l}1920 \\
1925 \\
1930 \\
1935 \\
1940\end{array}$ & $\begin{array}{l}2.4 \\
2.3 \\
2.1 \\
2.1 \\
2.0\end{array}$ & $\begin{array}{l}0.00 \\
0.00 \\
0.00 \\
0.00 \\
0.00\end{array}$ & $\begin{array}{l}2100 \\
2105 \\
2110 \\
2115 \\
2120\end{array}$ & $\begin{array}{l}1.4 \\
1.4 \\
1.4 \\
1.4 \\
1.4\end{array}$ & $\begin{array}{l}0.0 ? \\
0.0 ? \\
0.00 \\
0.00 \\
0.07\end{array}$ \\
\hline $\begin{array}{l}1805 \\
1810 \\
1815 \\
1820 \\
1825\end{array}$ & $\begin{array}{l}9.7 \\
8.0 \\
6.8 \\
5.9 \\
5.1\end{array}$ & $\begin{array}{l}0.00 \\
0.00 \\
0.00 \\
0.00 \\
0.00\end{array}$ & $\begin{array}{l}1945 \\
1950 \\
1955 \\
2000 \\
2005\end{array}$ & $\begin{array}{l}1.9 \\
1.8 \\
1.8 \\
1.7 \\
1.7\end{array}$ & $\begin{array}{l}0.00 \\
0.00 \\
0.00 \\
0.00 \\
0.00\end{array}$ & $\begin{array}{l}2125 \\
2130 \\
2135 \\
2140 \\
2145\end{array}$ & $\begin{array}{l}1.4 \\
1.3 \\
1.3 \\
1.3 \\
1.3\end{array}$ & $\begin{array}{l}0.07 \\
0.00 \\
0.00 \\
0.00 \\
0.00\end{array}$ \\
\hline $\begin{array}{l}1830 \\
1835 \\
1840 \\
1845 \\
1850\end{array}$ & $\begin{array}{l}4.6 \\
4.2 \\
3.8 \\
3.5 \\
3.3\end{array}$ & $\begin{array}{l}0.01 \\
0.00 \\
0.00 \\
0.00 \\
0.00\end{array}$ & $\begin{array}{l}2010 \\
2015 \\
2020 \\
2025 \\
2030\end{array}$ & $\begin{array}{l}1.7 \\
1.6 \\
1.6 \\
1.5 \\
1.5\end{array}$ & $\begin{array}{l}0.00 \\
0.00 \\
0.00 \\
0.00 \\
0.00\end{array}$ & $\begin{array}{l}2150 \\
2155 \\
2200\end{array}$ & $\begin{array}{l}1.3 \\
1.2 \\
1.2\end{array}$ & $\begin{array}{l}0.10 \\
0.10 \\
0.10\end{array}$ \\
\hline
\end{tabular}




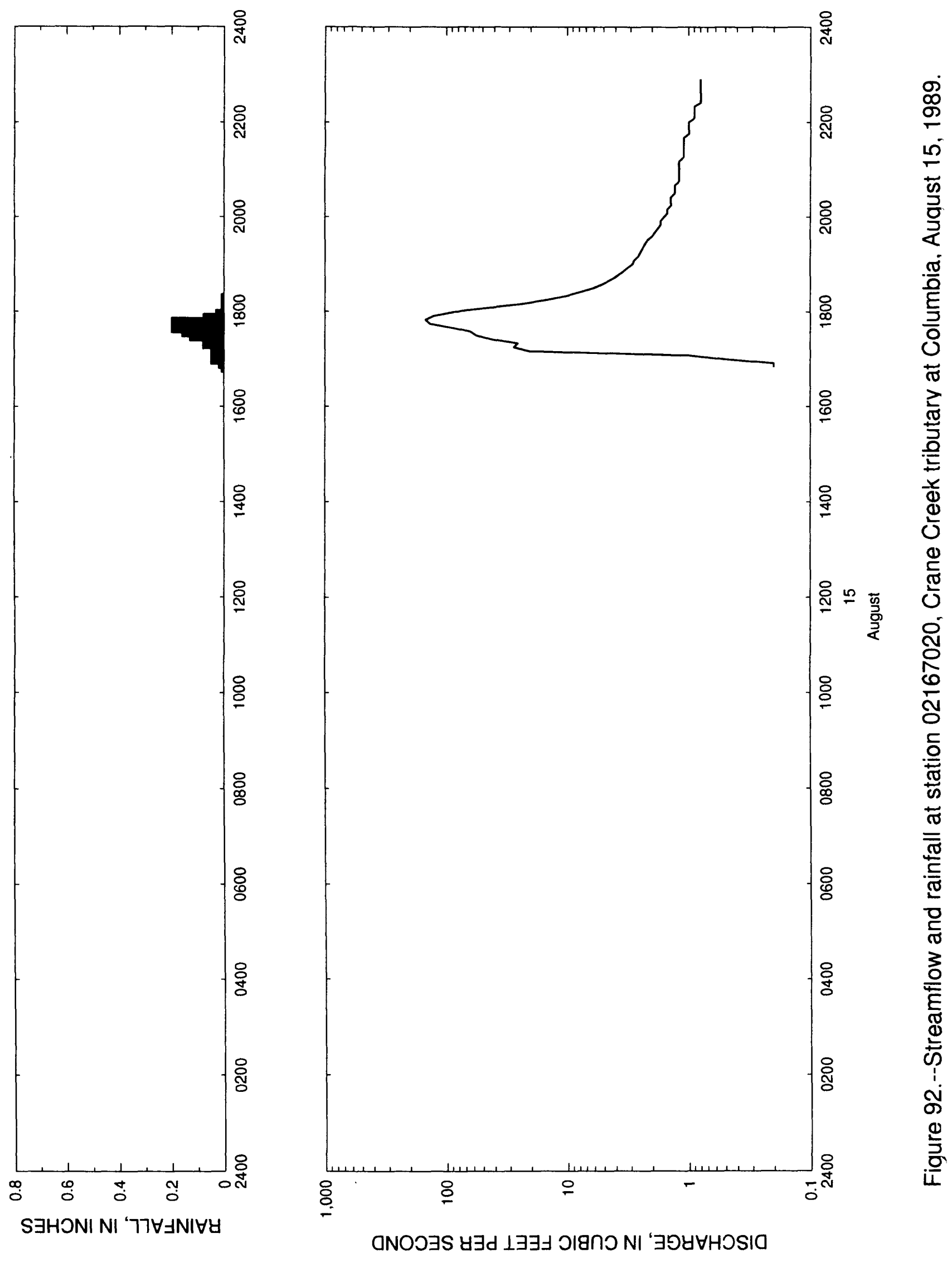


Table 91. - - Streamflow and rainfall at station 02167020, Crane Creek tributary at Columbia, August 15,1989

\begin{tabular}{|c|c|c|c|c|c|c|c|c|}
\hline $\begin{array}{l}\text { Time } \\
\text { (hours) }\end{array}$ & $\begin{array}{l}\text { Streamflow } \\
\text { (cubic feet } \\
\text { per second) }\end{array}$ & $\begin{array}{l}\text { Rain- } \\
\text { fall } \\
\text { (inches) }\end{array}$ & $\begin{array}{l}\text { Time } \\
\text { (hours) }\end{array}$ & $\begin{array}{l}\text { Streamflow } \\
\text { (cubic feet } \\
\text { per second) }\end{array}$ & $\begin{array}{l}\text { Rain- } \\
\text { fall } \\
\text { (inches) }\end{array}$ & $\begin{array}{l}\text { Time } \\
\text { (hours) }\end{array}$ & $\begin{array}{l}\text { Streamflow } \\
\text { (cubic feet } \\
\text { per second) }\end{array}$ & $\begin{array}{l}\text { Rain- } \\
\text { fall } \\
\text { (inchos) }\end{array}$ \\
\hline $\begin{array}{l}\text { August } \\
1650 \\
1655 \\
1700 \\
1705\end{array}$ & 15, $\begin{array}{r}1989 \\
0.2 \\
0.2 \\
0.5 \\
1.0\end{array}$ & $\begin{array}{l}0.01 \\
0.02 \\
0.05 \\
0.05\end{array}$ & $\begin{array}{l}1855 \\
1900 \\
1905 \\
1910 \\
1915\end{array}$ & $\begin{array}{l}3.2 \\
2.9 \\
2.8 \\
2.6 \\
2.5\end{array}$ & $\begin{array}{l}0.00 \\
0.00 \\
0.00 \\
0.00 \\
0.00\end{array}$ & $\begin{array}{l}2105 \\
2110 \\
2115 \\
2120 \\
2125\end{array}$ & $\begin{array}{l}1.2 \\
1.2 \\
1.1 \\
1.1 \\
1.1\end{array}$ & $\begin{array}{l}0.00 \\
0.00 \\
0.00 \\
0.00 \\
0.00\end{array}$ \\
\hline $\begin{array}{l}1710 \\
1715 \\
1720 \\
1725 \\
1730\end{array}$ & $\begin{array}{l}20.4 \\
27.6 \\
25.5 \\
41.1 \\
56.0\end{array}$ & $\begin{array}{l}0.03 \\
0.04 \\
0.08 \\
0.07 \\
0.13\end{array}$ & $\begin{array}{l}1920 \\
1925 \\
1930 \\
1935 \\
1940\end{array}$ & $\begin{array}{l}2.4 \\
2.3 \\
2.2 \\
2.0 \\
1.9\end{array}$ & $\begin{array}{l}0.00 \\
0.00 \\
0.00 \\
0.00 \\
0.00\end{array}$ & $\begin{array}{l}2130 \\
2135 \\
2140 \\
2145 \\
2150\end{array}$ & $\begin{array}{l}1.1 \\
1.1 \\
1.1 \\
1.0 \\
1.0\end{array}$ & $\begin{array}{l}0.00 \\
0.00 \\
0.00 \\
0.00 \\
0.00\end{array}$ \\
\hline $\begin{array}{l}1735 \\
1740 \\
1745 \\
1750 \\
1755\end{array}$ & $\begin{array}{r}63.3 \\
90.3 \\
137.0 \\
149.0 \\
128.0\end{array}$ & $\begin{array}{l}0.16 \\
0.20 \\
0.20 \\
0.08 \\
0.03\end{array}$ & $\begin{array}{l}1945 \\
1950 \\
1955 \\
2000 \\
2005\end{array}$ & $\begin{array}{l}1.8 \\
1.7 \\
1.7 \\
1.6 \\
1.5\end{array}$ & $\begin{array}{l}0.00 \\
0.00 \\
0.00 \\
0.00 \\
0.00\end{array}$ & $\begin{array}{l}2155 \\
2200 \\
2205 \\
2210 \\
2215\end{array}$ & $\begin{array}{l}1.0 \\
1.0 \\
0.9 \\
0.9 \\
0.9\end{array}$ & $\begin{array}{l}0.00 \\
0.00 \\
0.00 \\
0.00 \\
0.00\end{array}$ \\
\hline $\begin{array}{l}1800 \\
1805 \\
1810 \\
1815 \\
1820\end{array}$ & $\begin{array}{l}86.4 \\
46.2 \\
23.9 \\
14.8 \\
10.3\end{array}$ & $\begin{array}{l}0.01 \\
0.00 \\
0.00 \\
0.01 \\
0.00\end{array}$ & $\begin{array}{l}2010 \\
2015 \\
2020 \\
2025 \\
2030\end{array}$ & $\begin{array}{l}1.5 \\
1.4 \\
1.4 \\
1.4 \\
1.3\end{array}$ & $\begin{array}{l}0.00 \\
0.00 \\
0.00 \\
0.00 \\
0.00\end{array}$ & $\begin{array}{l}2220 \\
2225 \\
2230 \\
2235 \\
2240\end{array}$ & $\begin{array}{l}0.9 \\
0.8 \\
0.8 \\
0.8 \\
0.8\end{array}$ & $\begin{array}{l}0.00 \\
0.00 \\
0.00 \\
0.00 \\
0.0 C\end{array}$ \\
\hline $\begin{array}{l}1825 \\
1830 \\
1835 \\
1840 \\
1845\end{array}$ & $\begin{array}{l}7.9 \\
6.1 \\
5.1 \\
4.4 \\
3.9\end{array}$ & $\begin{array}{l}0.00 \\
0.00 \\
0.00 \\
0.00 \\
0.00\end{array}$ & $\begin{array}{l}2035 \\
2040 \\
2045 \\
2050 \\
2055\end{array}$ & $\begin{array}{l}1.3 \\
1.3 \\
1.2 \\
1.2 \\
1.2\end{array}$ & $\begin{array}{l}0.00 \\
0.00 \\
0.00 \\
0.00 \\
0.00\end{array}$ & $\begin{array}{l}2245 \\
2250 \\
2255 \\
2300\end{array}$ & $\begin{array}{l}0.8 \\
0.8 \\
0.8 \\
0.8\end{array}$ & $\begin{array}{l}0.0 C \\
0.0 C \\
0.0 C \\
0.0 C\end{array}$ \\
\hline 1850 & 3.5 & 0.00 & 2100 & 1.2 & 0.00 & & & \\
\hline
\end{tabular}




\section{Station 02168845, Saluda River Tributary at Columbia, S.C.}

Location.--Lat $34^{\circ} 02^{\prime} 26^{\prime \prime}$, long $81^{\circ} 08^{\prime 2} 29^{\prime \prime}$, Richland County, Hydrologic Unit 03050109, at culvert on Bush River Road (State secondary road 273), 1.3 mi northwest of Inters'ate Highway 20,6.7 mi west of the State Capitol Building, and $0.7 \mathrm{mi}$ upstream from the mouth at the Saluda River.

Period of record.-- October 18, 1985 to October 11, 1989.

Gage.--Digital stage recorder with 5-minute punch interval. The recorder is housed in a metal shelter atop a stilling well attached to a free-standing platform on the right bank $8 \mathrm{ft}$ upstream from the $6.5 \mathrm{ft}$ by $7.8 \mathrm{ft}$ corrugated metal pipe arch culvert. An enameled staff gage is attached to the platform. One crest-stage indicator is located on the downstream left bank near the culvert exit.

Rating.--The stage-streamflow relation is defined by current meter measurements up to $100 \mathrm{ft}^{3} / \mathrm{s}$. The stage-streamflow relation was extended to $278 \mathrm{ft}^{3} / \mathrm{s}$ using indirect computational methods.

Rain gage and location.--Station 340240081081400 , lat $34^{\circ} 02^{\prime} 40^{\prime \prime}$, long $81^{\circ} 08^{\prime} 14^{\prime \prime}$. A shelter containing a digital cumulative rainfall recorder with a 5-minute punch interval, in a vacant lot on the north side of St. Andrews Road (State secondary rc ad 42), west of the Lutheran Church cemetery, and $0.9 \mathrm{mi}$ east from the Allied Signal Plant.

Selected basin characteristics.--

Drainage area -- $0.45 \mathrm{mi}^{2}$

Physiographic province -- Piedmont

Channel slope $-120.0 \mathrm{ft} / \mathrm{mi}$

Channel length -- $1.07 \mathrm{mi}$

Total impervious area -- 23.0 percent

Basin development factor -- 9

2-year, 2-hour rainfall amount -- $2.10 \mathrm{in}$.

Flood frequency data: $\mathrm{UQ}_{2} \quad 109 \mathrm{ft}^{3} / \mathrm{s}$

$\mathrm{UQ}_{5} \quad 184 \mathrm{ft}^{3} / \mathrm{s}$

$\mathrm{UQ}_{10} \quad 237 \mathrm{ft}^{3} / \mathrm{s}$

$\mathrm{UQ}_{25} \quad 307 \mathrm{ft}^{3} / \mathrm{s}$

$\mathrm{UQ}_{50} \quad 359 \mathrm{ft}^{3} / \mathrm{s}$

$\mathrm{UQ}_{100} \quad 412 \mathrm{ft}^{3} / \mathrm{s}$

$\mathrm{UQ}_{500} \quad 536 \mathrm{ft}^{3} / \mathrm{s}$ 


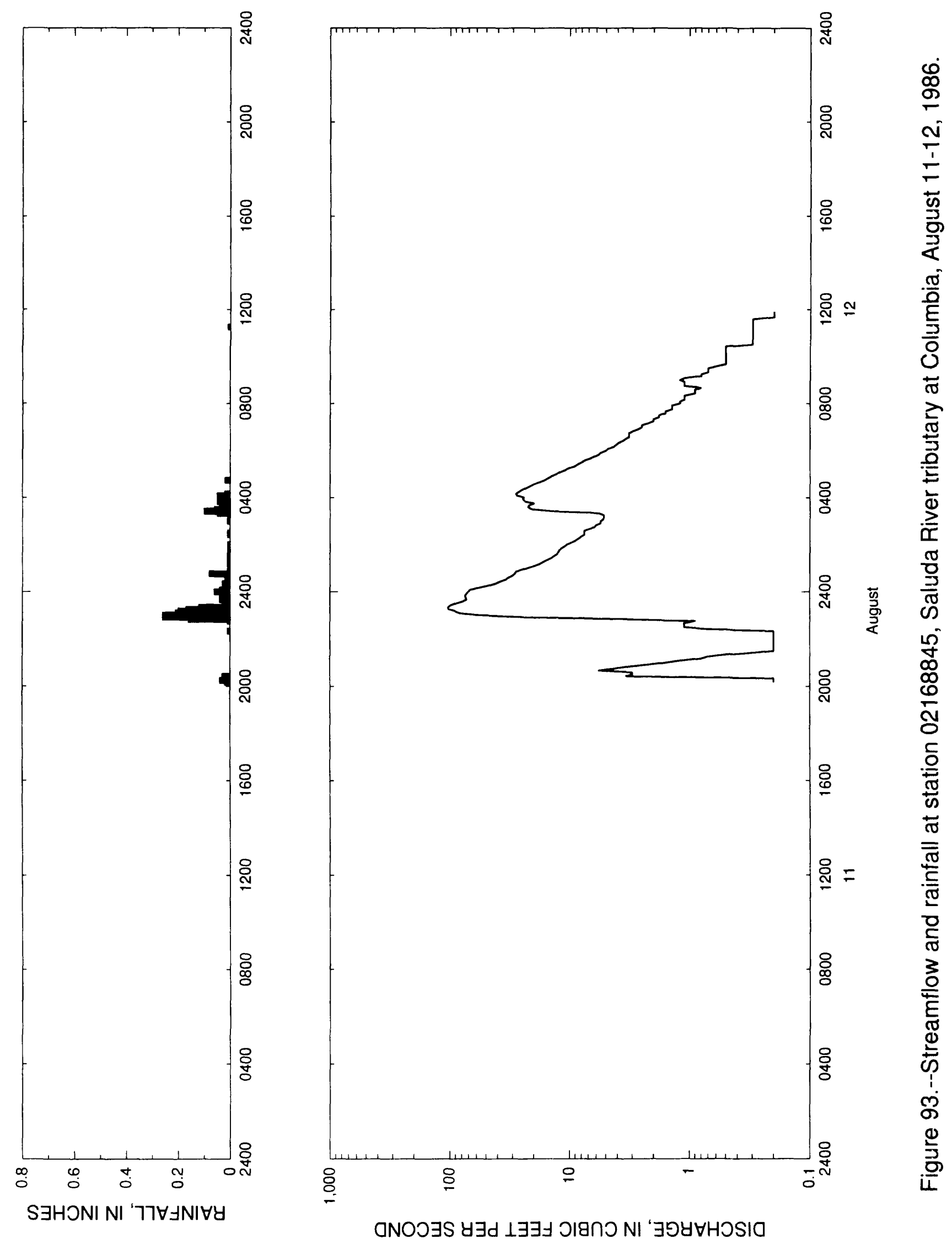


Table 92,--Streamflow and rainfall at station 02168845, Saluda River tributary at Columbia, August $11-12,1986$

\begin{tabular}{|c|c|c|c|c|c|c|c|c|}
\hline $\begin{array}{l}\text { Time } \\
\text { (hours) }\end{array}$ & $\begin{array}{l}\text { Streamflow } \\
\text { (cubic feet } \\
\text { per second) }\end{array}$ & $\begin{array}{l}\text { Rain- } \\
\text { fall } \\
\text { (inches) }\end{array}$ & $\begin{array}{l}\text { Time } \\
\text { (hours) }\end{array}$ & $\begin{array}{l}\text { Streamflow } \\
\text { (cubic feet } \\
\text { per second) }\end{array}$ & $\begin{array}{l}\text { Rain- } \\
\text { fall } \\
\text { (inches) }\end{array}$ & $\begin{array}{l}\text { Time } \\
\text { (hours) }\end{array}$ & $\begin{array}{l}\text { Streamflow } \\
\text { (cubic feet } \\
\text { per second) }\end{array}$ & $\begin{array}{l}\text { Rain- } \\
\text { fall } \\
\text { (inchee) }\end{array}$ \\
\hline $\begin{array}{l}\text { August } 1 \\
2010 \\
2015 \\
2020 \\
2025\end{array}$ & $\begin{array}{r}1986 \\
0.2 \\
0.2 \\
0.2 \\
3.4\end{array}$ & $\begin{array}{l}0.02 \\
0.04 \\
0.01 \\
0.03\end{array}$ & $\begin{array}{l}0125 \\
0130 \\
0135 \\
0140 \\
0145\end{array}$ & $\begin{array}{l}14.2 \\
13.5 \\
12.7 \\
12.5 \\
12.2\end{array}$ & $\begin{array}{l}0.00 \\
0.01 \\
0.01 \\
0.01 \\
0.01\end{array}$ & $\begin{array}{l}0650 \\
0655 \\
0700 \\
0705 \\
0710\end{array}$ & $\begin{array}{l}3.0 \\
2.7 \\
2.5 \\
2.5 \\
2.2\end{array}$ & $\begin{array}{l}0.00 \\
0.00 \\
0.00 \\
0.00 \\
0.00\end{array}$ \\
\hline $\begin{array}{l}2030 \\
2035 \\
2040 \\
2045 \\
2050\end{array}$ & $\begin{array}{l}3.0 \\
3.0 \\
5.7 \\
4.1 \\
3.2\end{array}$ & $\begin{array}{l}0.00 \\
0.00 \\
0.00 \\
0.00 \\
0.00\end{array}$ & $\begin{array}{l}0150 \\
0155 \\
0200 \\
0205 \\
0210\end{array}$ & $\begin{array}{r}11.7 \\
11.0 \\
10.5 \\
9.6 \\
8.9\end{array}$ & $\begin{array}{l}0.01 \\
0.00 \\
0.01 \\
0.00 \\
0.00\end{array}$ & $\begin{array}{l}0715 \\
0720 \\
0725 \\
0730 \\
0735\end{array}$ & $\begin{array}{l}2.0 \\
2.0 \\
1.8 \\
1.8 \\
1.6\end{array}$ & $\begin{array}{l}0.00 \\
0.00 \\
0.00 \\
0.00 \\
0.00\end{array}$ \\
\hline $\begin{array}{l}2055 \\
2100 \\
2105 \\
2110 \\
2115\end{array}$ & $\begin{array}{l}2.2 \\
1.6 \\
1.2 \\
0.8 \\
0.7\end{array}$ & $\begin{array}{l}0.00 \\
0.00 \\
0.00 \\
0.00 \\
0.00\end{array}$ & $\begin{array}{l}0215 \\
0220 \\
0225 \\
0230 \\
0235\end{array}$ & $\begin{array}{l}8.4 \\
8.0 \\
7.5 \\
7.5 \\
7.5\end{array}$ & $\begin{array}{l}0.00 \\
0.00 \\
0.01 \\
0.01 \\
0.00\end{array}$ & $\begin{array}{l}0740 \\
0745 \\
0750 \\
0755 \\
0800\end{array}$ & $\begin{array}{l}1.6 \\
1.4 \\
1.4 \\
1.4 \\
1.2\end{array}$ & $\begin{array}{l}0.00 \\
0.00 \\
0.00 \\
0.00 \\
0.00\end{array}$ \\
\hline $\begin{array}{l}2120 \\
2125 \\
2130 \\
2135 \\
2140\end{array}$ & $\begin{array}{l}0.5 \\
0.3 \\
0.2 \\
0.2 \\
0.2\end{array}$ & $\begin{array}{l}0.00 \\
0.00 \\
0.00 \\
0.00 \\
0.00\end{array}$ & $\begin{array}{l}0240 \\
0245 \\
0250 \\
0255 \\
0300\end{array}$ & $\begin{array}{l}6.7 \\
6.2 \\
6.0 \\
5.5 \\
5.5\end{array}$ & $\begin{array}{l}0.00 \\
0.00 \\
0.00 \\
0.00 \\
0.01\end{array}$ & $\begin{array}{l}0805 \\
0810 \\
0815 \\
0820 \\
0825\end{array}$ & $\begin{array}{l}1.2 \\
1.1 \\
1.1 \\
1.1 \\
0.9\end{array}$ & $\begin{array}{l}0.00 \\
0.00 \\
0.00 \\
0.00 \\
0.00\end{array}$ \\
\hline $\begin{array}{l}2145 \\
2150 \\
2155 \\
2200 \\
2205\end{array}$ & $\begin{array}{l}0.2 \\
0.2 \\
0.2 \\
0.2 \\
0.2\end{array}$ & $\begin{array}{l}0.00 \\
0.00 \\
0.00 \\
0.00 \\
0.00\end{array}$ & $\begin{array}{l}0305 \\
0310 \\
0315 \\
0320 \\
0325\end{array}$ & $\begin{array}{r}5.2 \\
5.2 \\
5.2 \\
5.7 \\
14.0\end{array}$ & $\begin{array}{l}0.00 \\
0.00 \\
0.01 \\
0.05 \\
0.10\end{array}$ & $\begin{array}{l}0830 \\
0835 \\
0840 \\
0845 \\
0850\end{array}$ & $\begin{array}{l}0.9 \\
0.9 \\
0.8 \\
1.1 \\
1.1\end{array}$ & $\begin{array}{l}0.00 \\
0.00 \\
0.00 \\
0.00 \\
0.00\end{array}$ \\
\hline $\begin{array}{l}2210 \\
2215 \\
2220 \\
2225 \\
2230\end{array}$ & $\begin{array}{l}0.2 \\
0.2 \\
0.2 \\
0.7 \\
1.1\end{array}$ & $\begin{array}{l}0.00 \\
0.00 \\
0.01 \\
0.00 \\
0.00\end{array}$ & $\begin{array}{l}0330 \\
0335 \\
0340 \\
0345 \\
0350\end{array}$ & $\begin{array}{l}20.7 \\
22.2 \\
21.9 \\
19.8 \\
23.6\end{array}$ & $\begin{array}{l}0.06 \\
0.04 \\
0.02 \\
0.03 \\
0.05\end{array}$ & $\begin{array}{l}0855 \\
0900 \\
0905 \\
0910 \\
0915\end{array}$ & $\begin{array}{l}1.1 \\
1.2 \\
1.1 \\
0.8 \\
0.8\end{array}$ & $\begin{array}{l}0.00 \\
0.00 \\
0.00 \\
0.00 \\
0.00\end{array}$ \\
\hline $\begin{array}{l}2235 \\
2240 \\
2245 \\
2250 \\
2255\end{array}$ & $\begin{array}{r}1.1 \\
1.1 \\
0.9 \\
3.2 \\
25.4\end{array}$ & $\begin{array}{l}0.00 \\
0.00 \\
0.01 \\
0.16 \\
0.26\end{array}$ & $\begin{array}{l}0355 \\
0400 \\
0405 \\
0410 \\
0415\end{array}$ & $\begin{array}{l}24.6 \\
24.1 \\
27.5 \\
28.0 \\
26.4\end{array}$ & $\begin{array}{l}0.02 \\
0.03 \\
0.05 \\
0.02 \\
0.00\end{array}$ & $\begin{array}{l}0920 \\
0925 \\
0930 \\
0935 \\
0940\end{array}$ & $\begin{array}{l}0.7 \\
0.7 \\
0.7 \\
0.6 \\
0.5\end{array}$ & $\begin{array}{l}0.00 \\
0.00 \\
0.00 \\
0.00 \\
0.00\end{array}$ \\
\hline $\begin{array}{l}2300 \\
2305 \\
2310 \\
2315 \\
2320\end{array}$ & $\begin{array}{r}58.1 \\
82.9 \\
90.8 \\
103.0 \\
104.0\end{array}$ & $\begin{array}{l}0.26 \\
0.21 \\
0.20 \\
0.17 \\
0.12\end{array}$ & $\begin{array}{l}0420 \\
0425 \\
0430 \\
0435 \\
0440\end{array}$ & $\begin{array}{l}24.9 \\
22.9 \\
21.2 \\
19.8 \\
17.9\end{array}$ & $\begin{array}{l}0.00 \\
0.00 \\
0.00 \\
0.00 \\
0.00\end{array}$ & $\begin{array}{l}0945 \\
0950 \\
0955 \\
1000 \\
1005\end{array}$ & $\begin{array}{l}0.5 \\
0.5 \\
0.5 \\
0.5 \\
0.5\end{array}$ & $\begin{array}{l}0.00 \\
0.00 \\
0.00 \\
0.00 \\
0.00\end{array}$ \\
\hline $\begin{array}{l}2325 \\
2330 \\
2335 \\
2340 \\
2345\end{array}$ & $\begin{array}{l}98.6 \\
89.2 \\
78.7 \\
72.4 \\
73.8\end{array}$ & $\begin{array}{l}0.03 \\
0.00 \\
0.02 \\
0.04 \\
0.02\end{array}$ & $\begin{array}{l}0445 \\
0450 \\
0455 \\
0500 \\
0505\end{array}$ & $\begin{array}{l}16.3 \\
15.2 \\
14.2 \\
13.0 \\
12.2\end{array}$ & $\begin{array}{l}0.02 \\
0.00 \\
0.00 \\
0.00 \\
0.00\end{array}$ & $\begin{array}{l}1010 \\
1015 \\
1020 \\
1025 \\
1030\end{array}$ & $\begin{array}{l}0.5 \\
0.5 \\
0.5 \\
0.5 \\
0.3\end{array}$ & $\begin{array}{l}0.00 \\
0.00 \\
0.00 \\
0.00 \\
0.00\end{array}$ \\
\hline $\begin{array}{c}2350 \\
2355 \\
\text { August } \\
0000 \\
0005\end{array}$ & $\begin{array}{r}74.6 \\
72.4 \\
12,1986 \\
69.8 \\
67.6\end{array}$ & $\begin{array}{l}0.04 \\
0.04 \\
0.06 \\
0.04\end{array}$ & $\begin{array}{l}0510 \\
0515 \\
0520 \\
0525 \\
0530\end{array}$ & $\begin{array}{r}11.0 \\
10.3 \\
9.1 \\
8.6 \\
8.0\end{array}$ & $\begin{array}{l}0.00 \\
0.00 \\
0.00 \\
0.00 \\
0.00\end{array}$ & $\begin{array}{l}1035 \\
1040 \\
1045 \\
1050 \\
1055\end{array}$ & $\begin{array}{l}0.3 \\
0.3 \\
0.3 \\
0.3 \\
0.3\end{array}$ & $\begin{array}{l}0.00 \\
0.00 \\
0.00 \\
0.00 \\
0.00\end{array}$ \\
\hline $\begin{array}{l}0010 \\
0015 \\
0020 \\
0025 \\
0030\end{array}$ & $\begin{array}{l}57.5 \\
48.2 \\
42.0 \\
38.4 \\
34.3\end{array}$ & $\begin{array}{l}0.01 \\
0.03 \\
0.03 \\
0.00 \\
0.02\end{array}$ & $\begin{array}{l}0535 \\
0540 \\
0545 \\
0550 \\
0555\end{array}$ & $\begin{array}{l}7.5 \\
6.7 \\
6.2 \\
5.7 \\
5.5\end{array}$ & $\begin{array}{l}0.00 \\
0.00 \\
0.00 \\
0.00 \\
0.00\end{array}$ & $\begin{array}{l}1100 \\
1105 \\
1110 \\
1115 \\
1120\end{array}$ & $\begin{array}{l}0.3 \\
0.3 \\
0.3 \\
0.3 \\
0.3\end{array}$ & $\begin{array}{l}0.00 \\
0.00 \\
0.00 \\
0.01 \\
0.00\end{array}$ \\
\hline $\begin{array}{l}0035 \\
0040 \\
0045 \\
0050 \\
0055\end{array}$ & $\begin{array}{l}32.6 \\
30.2 \\
28.8 \\
28.0 \\
25.2\end{array}$ & $\begin{array}{l}0.01 \\
0.02 \\
0.08 \\
0.01 \\
0.00\end{array}$ & $\begin{array}{l}0600 \\
0605 \\
0610 \\
0615 \\
0620\end{array}$ & $\begin{array}{l}5.0 \\
4.8 \\
4.3 \\
4.1 \\
3.9\end{array}$ & $\begin{array}{l}0.00 \\
0.00 \\
0.00 \\
0.00 \\
0.00\end{array}$ & $\begin{array}{l}1125 \\
1130 \\
1135 \\
1140 \\
1145\end{array}$ & $\begin{array}{l}0.3 \\
0.3 \\
0.3 \\
0.2 \\
0.2\end{array}$ & $\begin{array}{l}0.00 \\
0.00 \\
0.00 \\
0.00 \\
0.00\end{array}$ \\
\hline $\begin{array}{l}0100 \\
0105 \\
0110 \\
0115 \\
0120\end{array}$ & $\begin{array}{l}22.4 \\
19.8 \\
17.9 \\
16.6 \\
15.4\end{array}$ & $\begin{array}{l}0.01 \\
0.00 \\
0.00 \\
0.01 \\
0.01\end{array}$ & $\begin{array}{l}0625 \\
0630 \\
0635 \\
0640 \\
0645\end{array}$ & $\begin{array}{l}3.6 \\
3.4 \\
3.2 \\
3.2 \\
3.2\end{array}$ & $\begin{array}{l}0.00 \\
0.00 \\
0.00 \\
0.00 \\
0.00\end{array}$ & $\begin{array}{l}1150 \\
1155 \\
1200\end{array}$ & $\begin{array}{l}0.2 \\
0.2 \\
0.2\end{array}$ & $\begin{array}{l}0.00 \\
0.00 \\
0.00\end{array}$ \\
\hline
\end{tabular}



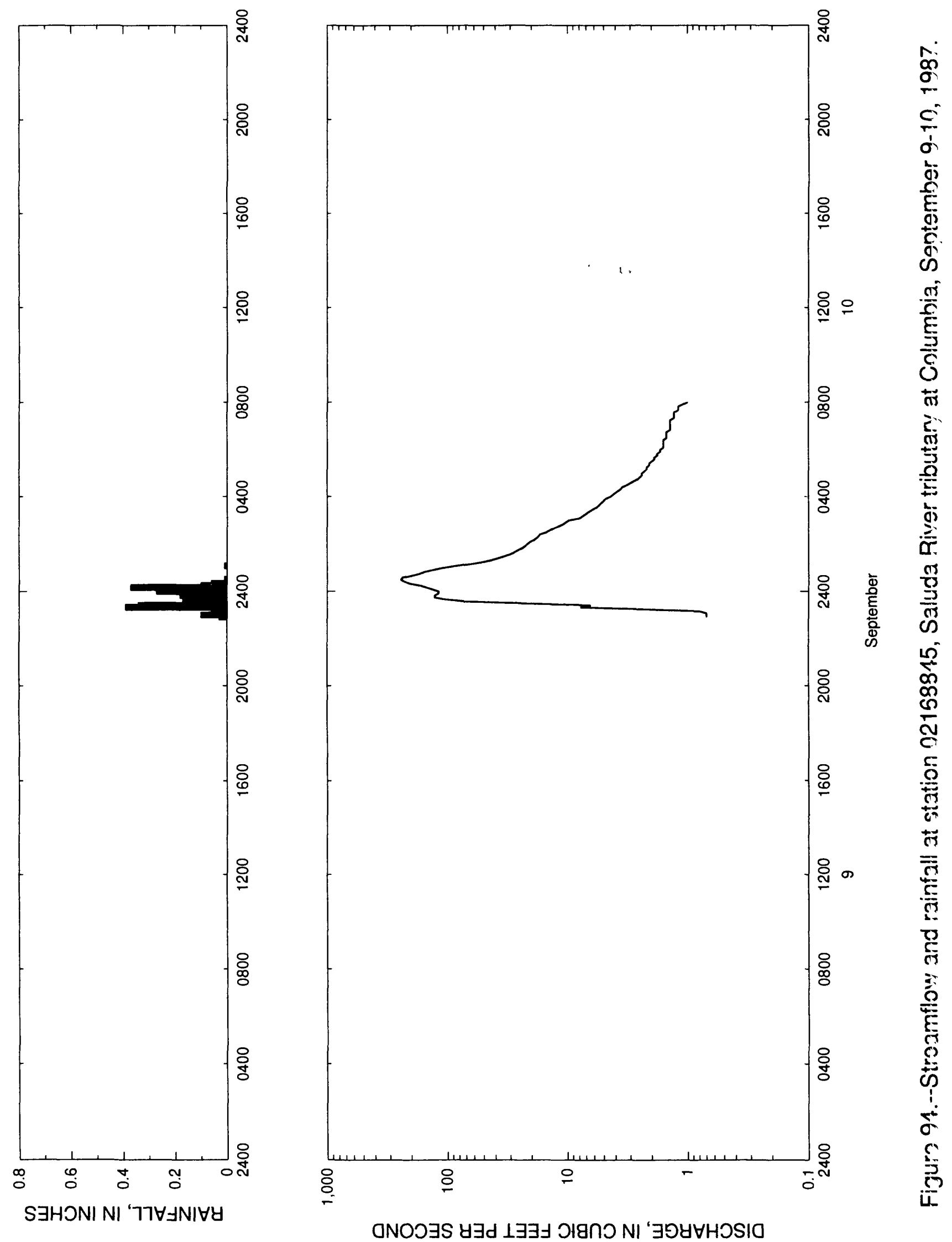
Table 93. - - Streamflow and rainfall at station 02168845, Saluda River tributary at Columbia, September $9-10,1987$

\begin{tabular}{|c|c|c|c|c|c|c|c|c|}
\hline $\begin{array}{l}\text { Time } \\
\text { (hours) }\end{array}$ & $\begin{array}{l}\text { Streamflow } \\
\text { (cubic feet } \\
\text { per second) }\end{array}$ & $\begin{array}{l}\text { Rain- } \\
\text { fall } \\
\text { (inches) }\end{array}$ & $\begin{array}{l}\text { Time } \\
\text { (hours) }\end{array}$ & $\begin{array}{l}\text { Streamflow } \\
\text { (cubic feet } \\
\text { per second) }\end{array}$ & $\begin{array}{l}\text { Rain- } \\
\text { fall } \\
\text { (inches) }\end{array}$ & $\begin{array}{l}\text { Time } \\
\text { (hours) }\end{array}$ & $\begin{array}{l}\text { Streamflow } \\
\text { (cubic feet } \\
\text { per second) }\end{array}$ & $\begin{array}{l}\text { Rain- } \\
\text { fall } \\
\text { (inches) }\end{array}$ \\
\hline $\begin{array}{l}\text { September } \\
2255 \\
2300 \\
2305 \\
2310\end{array}$ & $\begin{array}{r}1987 \\
0.7 \\
0.7 \\
0.7 \\
0.8\end{array}$ & $\begin{array}{l}0.03 \\
0.10 \\
0.01 \\
0.01\end{array}$ & $\begin{array}{l}0155 \\
0200 \\
0205 \\
0210 \\
0215\end{array}$ & $\begin{array}{l}22.6 \\
21.7 \\
20.7 \\
19.1 \\
18.1\end{array}$ & $\begin{array}{l}0.00 \\
0.00 \\
0.00 \\
0.00 \\
0.00\end{array}$ & $\begin{array}{l}0505 \\
0510 \\
0515 \\
0520 \\
0525\end{array}$ & $\begin{array}{l}2.3 \\
2.2 \\
2.2 \\
2.1 \\
2.1\end{array}$ & $\begin{array}{l}0.00 \\
0.00 \\
0.00 \\
0.00 \\
0.00\end{array}$ \\
\hline $\begin{array}{l}2315 \\
2320 \\
2325 \\
2330 \\
2335\end{array}$ & $\begin{array}{r}2.2 \\
7.7 \\
6.5 \\
24.1 \\
73.1\end{array}$ & $\begin{array}{l}0.06 \\
0.39 \\
0.34 \\
0.12 \\
0.16\end{array}$ & $\begin{array}{l}0220 \\
0225 \\
0230 \\
0235 \\
0240\end{array}$ & $\begin{array}{l}17.4 \\
16.9 \\
15.0 \\
14.0 \\
13.0\end{array}$ & $\begin{array}{l}0.00 \\
0.00 \\
0.00 \\
0.00 \\
0.00\end{array}$ & $\begin{array}{l}0530 \\
0535 \\
0540 \\
0545 \\
0550\end{array}$ & $\begin{array}{l}2.0 \\
1.9 \\
1.9 \\
1.8 \\
1.8\end{array}$ & $\begin{array}{l}0.00 \\
0.00 \\
0.00 \\
0.00 \\
0.00\end{array}$ \\
\hline $\begin{array}{c}2340 \\
2345 \\
2350 \\
2355 \\
\text { September }\end{array}$ & $\begin{array}{c}104.0 \\
128.0 \\
128.0 \\
119.0 \\
\times \quad 10,1987\end{array}$ & $\begin{array}{l}0.17 \\
0.03 \\
0.18 \\
0.06\end{array}$ & $\begin{array}{l}0245 \\
0250 \\
0255 \\
0300 \\
0305\end{array}$ & $\begin{array}{r}12.0 \\
11.0 \\
10.4 \\
9.8 \\
8.0\end{array}$ & $\begin{array}{l}0.00 \\
0.00 \\
0.00 \\
0.00 \\
0.00\end{array}$ & $\begin{array}{l}0555 \\
0600 \\
0605 \\
0610 \\
0615\end{array}$ & $\begin{array}{l}1.7 \\
1.7 \\
1.6 \\
1.6 \\
1.6\end{array}$ & $\begin{array}{l}0.00 \\
0.00 \\
0.00 \\
0.00 \\
0.00\end{array}$ \\
\hline $\begin{array}{l}0000 \\
0005 \\
0010 \\
0015 \\
0020\end{array}$ & $\begin{array}{l}118.0 \\
133.0 \\
148.0 \\
166.0 \\
204.0\end{array}$ & $\begin{array}{l}0.27 \\
0.25 \\
0.37 \\
0.10 \\
0.06\end{array}$ & $\begin{array}{l}0310 \\
0315 \\
0320 \\
0325 \\
0330\end{array}$ & $\begin{array}{l}7.6 \\
7.2 \\
6.8 \\
6.4 \\
6.0\end{array}$ & $\begin{array}{l}0.00 \\
0.00 \\
0.00 \\
0.00 \\
0.00\end{array}$ & $\begin{array}{l}0620 \\
0625 \\
0630 \\
0635 \\
0640\end{array}$ & $\begin{array}{l}1.6 \\
1.6 \\
1.5 \\
1.5 \\
1.5\end{array}$ & $\begin{array}{l}0.00 \\
0.00 \\
0.00 \\
0.00 \\
0.00\end{array}$ \\
\hline $\begin{array}{l}0025 \\
0030 \\
0035 \\
0040 \\
0045\end{array}$ & $\begin{array}{l}231.0 \\
245.0 \\
237.0 \\
199.0 \\
172.0\end{array}$ & $\begin{array}{l}0.01 \\
0.01 \\
0.00 \\
0.00 \\
0.00\end{array}$ & $\begin{array}{l}0335 \\
0340 \\
0345 \\
0350 \\
0355\end{array}$ & $\begin{array}{l}5.6 \\
5.4 \\
5.2 \\
5.0 \\
4.8\end{array}$ & $\begin{array}{l}0.00 \\
0.00 \\
0.00 \\
0.00 \\
0.00\end{array}$ & $\begin{array}{l}0645 \\
0650 \\
0655 \\
0700 \\
0705\end{array}$ & $\begin{array}{l}1.5 \\
1.4 \\
1.4 \\
1.4 \\
1.4\end{array}$ & $\begin{array}{l}0.00 \\
0.00 \\
0.00 \\
0.00 \\
0.00\end{array}$ \\
\hline $\begin{array}{l}0050 \\
0055 \\
0100 \\
0105 \\
0110\end{array}$ & $\begin{array}{r}155.0 \\
131.0 \\
110.0 \\
87.2 \\
64.8\end{array}$ & $\begin{array}{l}0.00 \\
0.00 \\
0.00 \\
0.01 \\
0.00\end{array}$ & $\begin{array}{l}0400 \\
0405 \\
0410 \\
0415 \\
0420\end{array}$ & $\begin{array}{l}4.4 \\
4.2 \\
4.0 \\
3.8 \\
3.6\end{array}$ & $\begin{array}{l}0.00 \\
0.00 \\
0.00 \\
0.00 \\
0.00\end{array}$ & $\begin{array}{l}0710 \\
0715 \\
0720 \\
0725 \\
0730\end{array}$ & $\begin{array}{l}1.4 \\
1.4 \\
1.3 \\
1.3 \\
1.3\end{array}$ & $\begin{array}{l}0.00 \\
0.00 \\
0.00 \\
0.00 \\
0.00\end{array}$ \\
\hline $\begin{array}{l}0115 \\
0120 \\
0125 \\
0130 \\
0135\end{array}$ & $\begin{array}{l}51.1 \\
42.9 \\
37.5 \\
33.2 \\
29.6\end{array}$ & $\begin{array}{l}0.00 \\
0.00 \\
0.00 \\
0.00 \\
0.00\end{array}$ & $\begin{array}{l}0425 \\
0430 \\
0435 \\
0440 \\
0445\end{array}$ & $\begin{array}{l}3.5 \\
3.2 \\
3.0 \\
2.8 \\
2.6\end{array}$ & $\begin{array}{l}0.00 \\
0.00 \\
0.00 \\
0.00 \\
0.00\end{array}$ & $\begin{array}{l}0735 \\
0740 \\
0745 \\
0750 \\
0755\end{array}$ & $\begin{array}{l}1.3 \\
1.2 \\
1.2 \\
1.2 \\
1.1\end{array}$ & $\begin{array}{l}0.00 \\
0.00 \\
0.00 \\
0.00 \\
0.00\end{array}$ \\
\hline $\begin{array}{l}0140 \\
0145 \\
0150\end{array}$ & $\begin{array}{l}27.5 \\
25.7 \\
23.9\end{array}$ & $\begin{array}{l}0.00 \\
0.00 \\
0.00\end{array}$ & $\begin{array}{l}0450 \\
0455 \\
0500\end{array}$ & $\begin{array}{l}2.5 \\
2.4 \\
2.4\end{array}$ & $\begin{array}{l}0.00 \\
0.00 \\
0.00\end{array}$ & 0800 & 1.0 & 0.00 \\
\hline
\end{tabular}



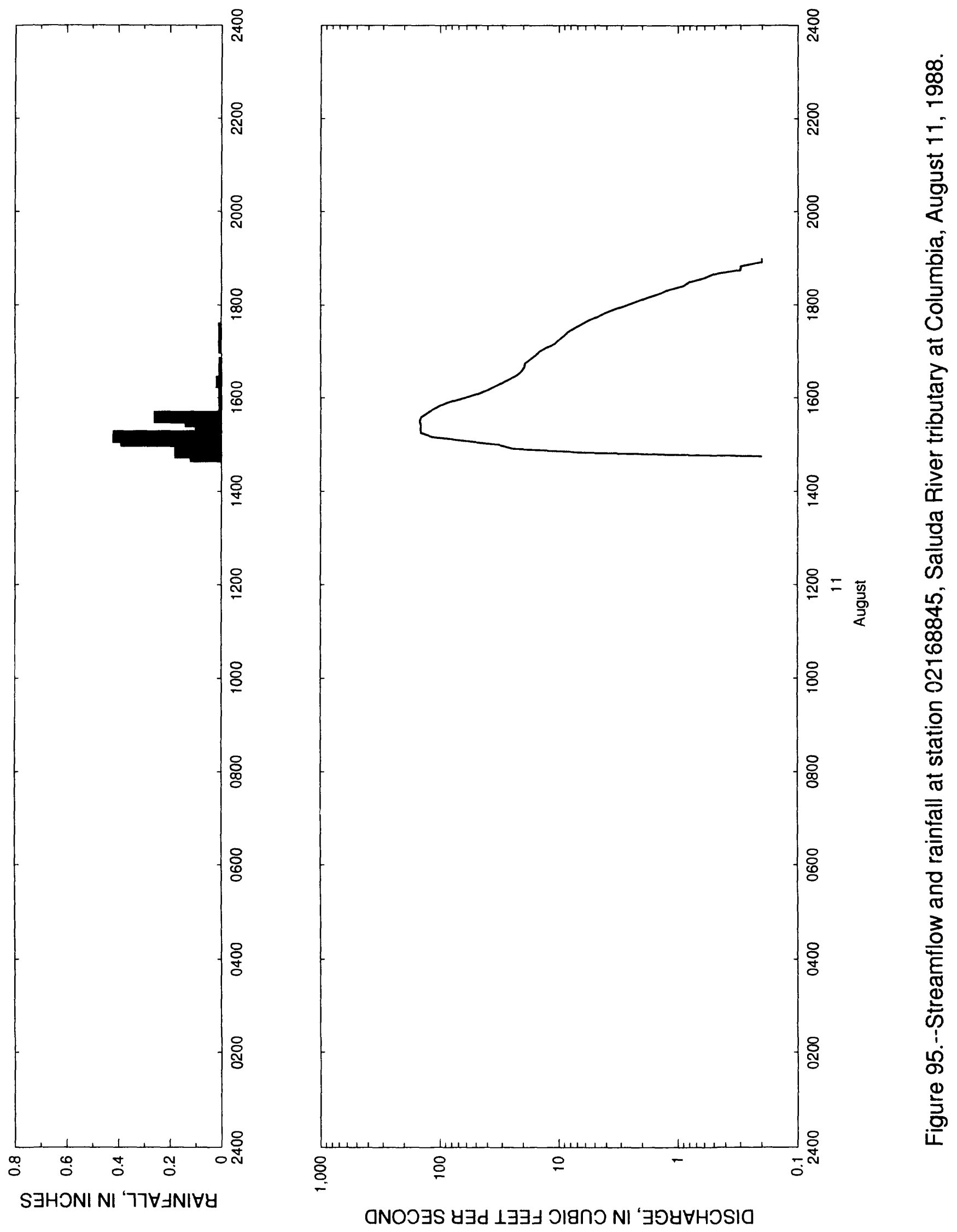
Table 94.--Streamflow and rainfall at station 02168845, Saluda River tributary at Columbia, August 11, 1988

\begin{tabular}{|c|c|c|c|c|c|c|c|c|}
\hline $\begin{array}{l}\text { Time } \\
\text { (hours) }\end{array}$ & $\begin{array}{l}\text { Streamflow } \\
\text { (cubic feet } \\
\text { per second) }\end{array}$ & $\begin{array}{l}\text { Rain- } \\
\text { fall } \\
\text { (inches) }\end{array}$ & $\begin{array}{l}\text { Time } \\
\text { (hours) }\end{array}$ & $\begin{array}{l}\text { Streamflow } \\
\text { (cubic feet } \\
\text { per second) }\end{array}$ & $\begin{array}{l}\text { Rain- } \\
\text { fall } \\
\text { (inches) }\end{array}$ & $\begin{array}{l}\text { Time } \\
\text { (hours) }\end{array}$ & $\begin{array}{l}\text { Streamflow } \\
\text { (cubic feet } \\
\text { per second) }\end{array}$ & $\begin{array}{l}\text { Rain- } \\
\text { fall } \\
\text { (inches) }\end{array}$ \\
\hline $\begin{array}{l}\text { August } \\
1445 \\
1450 \\
1455 \\
1500\end{array}$ & $\begin{array}{r}11, \quad 1988 \\
0.2 \\
6.0 \\
24.4 \\
31.8\end{array}$ & $\begin{array}{l}0.12 \\
0.18 \\
0.10 \\
0.18\end{array}$ & $\begin{array}{l}1610 \\
1615 \\
1620 \\
1625 \\
1630\end{array}$ & $\begin{array}{l}39.9 \\
34.1 \\
29.6 \\
25.4 \\
22.2\end{array}$ & $\begin{array}{l}0.00 \\
0.01 \\
0.02 \\
0.01 \\
0.01\end{array}$ & $\begin{array}{l}1740 \\
1745 \\
1750 \\
1755 \\
1800\end{array}$ & $\begin{array}{l}5.7 \\
4.8 \\
4.1 \\
3.4 \\
2.7\end{array}$ & $\begin{array}{l}0.00 \\
0.00 \\
0.00 \\
0.00 \\
0.00\end{array}$ \\
\hline $\begin{array}{l}1505 \\
1510 \\
1515 \\
1520 \\
1525\end{array}$ & $\begin{array}{r}60.8 \\
116.0 \\
145.0 \\
146.0 \\
145.0\end{array}$ & $\begin{array}{l}0.39 \\
0.42 \\
0.10 \\
0.02 \\
0.02\end{array}$ & $\begin{array}{l}1635 \\
1640 \\
1645 \\
1650 \\
1655\end{array}$ & $\begin{array}{l}20.5 \\
19.5 \\
19.3 \\
17.5 \\
15.7\end{array}$ & $\begin{array}{l}0.01 \\
0.01 \\
0.01 \\
0.00 \\
0.00\end{array}$ & $\begin{array}{l}1805 \\
1810 \\
1815 \\
1 \varepsilon 20 \\
1825\end{array}$ & $\begin{array}{l}2.2 \\
1.8 \\
1.4 \\
1.2 \\
0.9\end{array}$ & $\begin{array}{l}0.00 \\
0.00 \\
0.00 \\
0.00 \\
0.00\end{array}$ \\
\hline $\begin{array}{l}1530 \\
1535 \\
1540 \\
1545 \\
1550\end{array}$ & $\begin{array}{l}148.0 \\
144.0 \\
128.0 \\
116.0 \\
101.0\end{array}$ & $\begin{array}{l}0.14 \\
0.26 \\
0.01 \\
0.01 \\
0.01\end{array}$ & $\begin{array}{l}1700 \\
1705 \\
1710 \\
1715 \\
1720\end{array}$ & $\begin{array}{r}14.5 \\
12.7 \\
10.8 \\
10.0 \\
9.1\end{array}$ & $\begin{array}{l}0.00 \\
0.01 \\
0.00 \\
0.01 \\
0.00\end{array}$ & $\begin{array}{l}1830 \\
1835 \\
1840 \\
1845 \\
1850\end{array}$ & $\begin{array}{l}0.8 \\
0.6 \\
0.5 \\
0.3 \\
0.3\end{array}$ & $\begin{array}{l}0.00 \\
0.00 \\
0.00 \\
0.00 \\
0.00\end{array}$ \\
\hline $\begin{array}{l}1555 \\
1600 \\
1605\end{array}$ & $\begin{array}{l}81.8 \\
61.6 \\
48.5\end{array}$ & $\begin{array}{l}0.01 \\
0.01 \\
0.00\end{array}$ & $\begin{array}{l}1725 \\
1730 \\
1735\end{array}$ & $\begin{array}{l}8.4 \\
7.5 \\
6.5\end{array}$ & $\begin{array}{l}0.01 \\
0.01 \\
0.00\end{array}$ & $\begin{array}{l}1855 \\
1900\end{array}$ & $\begin{array}{l}0.2 \\
0.2\end{array}$ & $\begin{array}{l}0.00 \\
0.00\end{array}$ \\
\hline
\end{tabular}



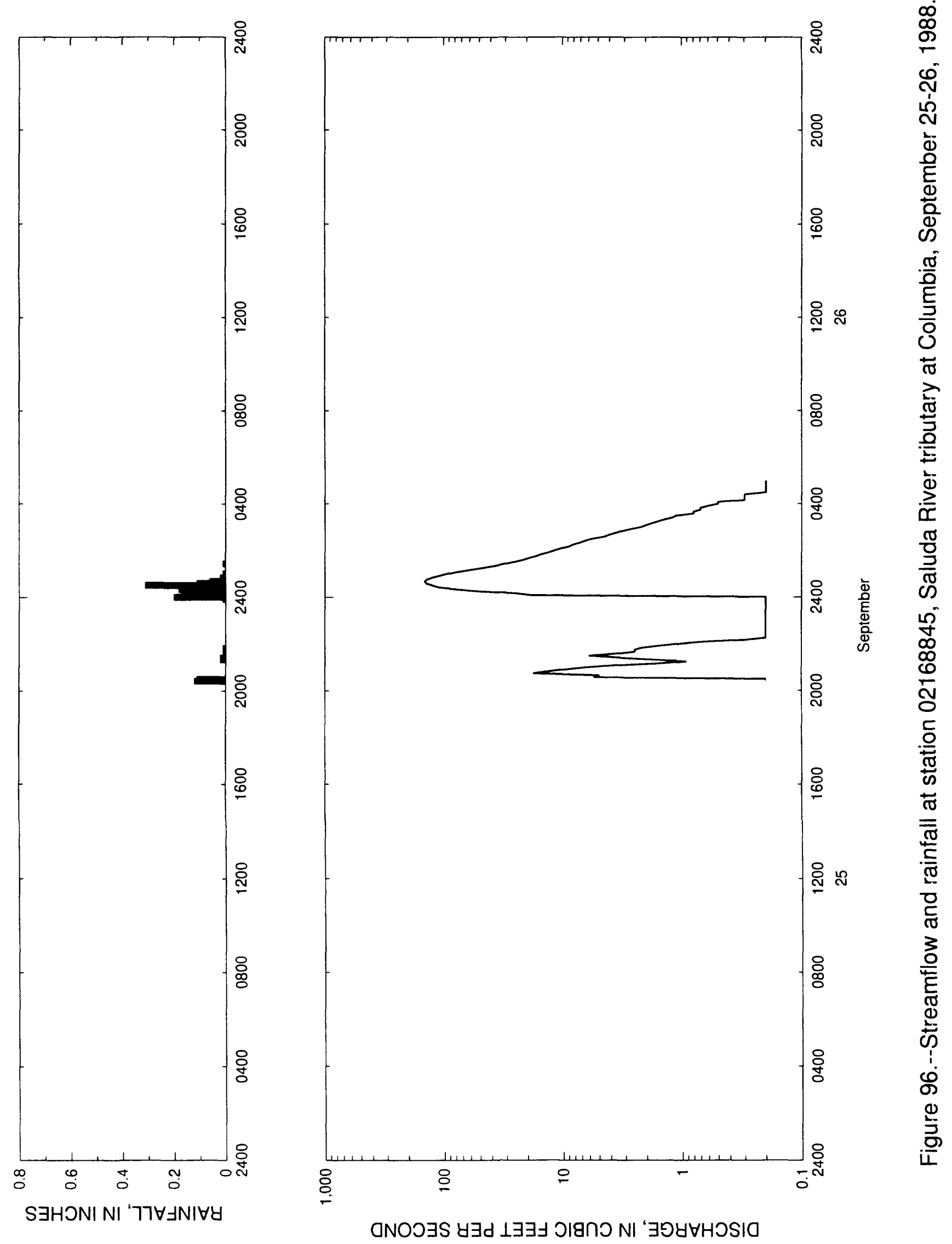
Table 95. - Streamflow and rainfall at station 02168845, Saluda River tributary at Columbia, September $25-26,1988$

\begin{tabular}{|c|c|c|c|c|c|c|c|c|}
\hline $\begin{array}{l}\text { Time } \\
\text { (hours) }\end{array}$ & $\begin{array}{l}\text { Streamflow } \\
\text { (cubic feet } \\
\text { per second) }\end{array}$ & $\begin{array}{l}\text { Rain- } \\
\text { fall } \\
\text { (inches) }\end{array}$ & $\begin{array}{l}\text { Time } \\
\text { (hours) }\end{array}$ & $\begin{array}{l}\text { Streamflow } \\
\text { (cubic feet } \\
\text { per second) }\end{array}$ & $\begin{array}{l}\text { Rain- } \\
\text { fall } \\
\text { (inches) }\end{array}$ & $\begin{array}{l}\text { Time } \\
\text { (hours) }\end{array}$ & $\begin{array}{l}\text { Streamflow } \\
\text { (cubic feet } \\
\text { per second) }\end{array}$ & $\begin{array}{l}\text { Rain- } \\
\text { fall } \\
\text { (inches) }\end{array}$ \\
\hline $\begin{array}{l}\text { Sept ember } \\
2025 \\
2030 \\
2035 \\
2040\end{array}$ & $\begin{aligned} &=25, 1988 \\
& 0.2 \\
& 0.2 \\
& 5.5 \\
& 5.0\end{aligned}$ & $\begin{array}{l}0.12 \\
0.11 \\
0.00 \\
0.00\end{array}$ & $\begin{array}{l}2320 \\
2325 \\
2330 \\
2335 \\
2340\end{array}$ & $\begin{array}{l}0.2 \\
0.2 \\
0.2 \\
0.2 \\
0.2\end{array}$ & $\begin{array}{l}0.00 \\
0.00 \\
0.00 \\
0.00 \\
0.00\end{array}$ & $\begin{array}{l}0215 \\
0220 \\
0225 \\
0230 \\
0235\end{array}$ & $\begin{array}{l}8.2 \\
7.2 \\
6.5 \\
5.7 \\
4.5\end{array}$ & $\begin{array}{l}0.00 \\
0.00 \\
0.00 \\
0.00 \\
0.00\end{array}$ \\
\hline $\begin{array}{l}2045 \\
2050 \\
2055 \\
2100 \\
2105\end{array}$ & $\begin{array}{r}17.7 \\
13.2 \\
9.3 \\
6.2 \\
3.6\end{array}$ & $\begin{array}{l}0.00 \\
0.00 \\
0.00 \\
0.00 \\
0.00\end{array}$ & $\begin{array}{l}2345 \\
2350 \\
2355 \\
\text { September } \\
0000\end{array}$ & $\begin{array}{ll} & 0.2 \\
& 0.2 \\
0.2 \\
\times 26, \\
1988 \\
0.2\end{array}$ & $\begin{array}{l}0.00 \\
0.00 \\
0.01 \\
0.20\end{array}$ & $\begin{array}{l}0240 \\
0245 \\
0250 \\
0255 \\
0300\end{array}$ & $\begin{array}{l}4.1 \\
3.6 \\
3.2 \\
2.7 \\
2.2\end{array}$ & $\begin{array}{l}0.00 \\
0.00 \\
0.00 \\
0.00 \\
0.00\end{array}$ \\
\hline $\begin{array}{l}2110 \\
2115 \\
2120 \\
2125 \\
2130\end{array}$ & $\begin{array}{l}1.6 \\
0.9 \\
1.8 \\
3.4 \\
6.0\end{array}$ & $\begin{array}{l}0.00 \\
0.00 \\
0.02 \\
0.02 \\
0.01\end{array}$ & $\begin{array}{l}0005 \\
0010 \\
0015 \\
0020 \\
0025\end{array}$ & $\begin{array}{r}18.4 \\
24.9 \\
51.1 \\
78.0 \\
112.0\end{array}$ & $\begin{array}{l}0.17 \\
0.16 \\
0.07 \\
0.18 \\
0.06\end{array}$ & $\begin{array}{l}0305 \\
0310 \\
0315 \\
0320 \\
0325\end{array}$ & $\begin{array}{l}2.0 \\
1.8 \\
1.6 \\
1.4 \\
1.2\end{array}$ & $\begin{array}{l}0.00 \\
0.00 \\
0.00 \\
0.00 \\
0.00\end{array}$ \\
\hline $\begin{array}{l}2135 \\
2140 \\
2145 \\
2150 \\
2155\end{array}$ & $\begin{array}{l}3.6 \\
2.5 \\
2.5 \\
2.2 \\
1.6\end{array}$ & $\begin{array}{l}0.00 \\
0.01 \\
0.00 \\
0.01 \\
0.00\end{array}$ & $\begin{array}{l}0030 \\
0035 \\
0040 \\
0045 \\
0050\end{array}$ & $\begin{array}{l}125.0 \\
141.0 \\
146.0 \\
140.0 \\
125.0\end{array}$ & $\begin{array}{l}0.31 \\
0.11 \\
0.06 \\
0.01 \\
0.02\end{array}$ & $\begin{array}{l}0330 \\
0335 \\
0340 \\
0345 \\
0350\end{array}$ & $\begin{array}{l}1.1 \\
0.8 \\
0.8 \\
0.7 \\
0.7\end{array}$ & $\begin{array}{l}0.00 \\
0.00 \\
0.00 \\
0.00 \\
0.00\end{array}$ \\
\hline $\begin{array}{l}2200 \\
2205 \\
2210 \\
2215 \\
2220\end{array}$ & $\begin{array}{l}1.1 \\
0.7 \\
0.3 \\
0.2 \\
0.2\end{array}$ & $\begin{array}{l}0.00 \\
0.00 \\
0.00 \\
0.00 \\
0.00\end{array}$ & $\begin{array}{l}0055 \\
0100 \\
0105 \\
0110 \\
0115\end{array}$ & $\begin{array}{r}108.0 \\
92.4 \\
76.1 \\
59.2 \\
46.0\end{array}$ & $\begin{array}{l}0.01 \\
0.01 \\
0.00 \\
0.00 \\
0.00\end{array}$ & $\begin{array}{l}0355 \\
0400 \\
0405 \\
0410 \\
0415\end{array}$ & $\begin{array}{l}0.6 \\
0.5 \\
0.5 \\
0.3 \\
0.3\end{array}$ & $\begin{array}{l}0.00 \\
0.00 \\
0.00 \\
0.00 \\
0.00\end{array}$ \\
\hline $\begin{array}{l}2225 \\
2230 \\
2235 \\
2240 \\
2245\end{array}$ & $\begin{array}{l}0.2 \\
0.2 \\
0.2 \\
0.2 \\
0.2\end{array}$ & $\begin{array}{l}0.00 \\
0.00 \\
0.00 \\
0.00 \\
0.00\end{array}$ & $\begin{array}{l}0120 \\
0125 \\
0130 \\
0135 \\
0140\end{array}$ & $\begin{array}{l}36.6 \\
30.4 \\
25.4 \\
21.7 \\
19.1\end{array}$ & $\begin{array}{l}0.00 \\
0.01 \\
0.00 \\
0.00 \\
0.00\end{array}$ & $\begin{array}{l}0420 \\
0425 \\
0430 \\
0435 \\
0440\end{array}$ & $\begin{array}{l}0.3 \\
0.3 \\
0.2 \\
0.2 \\
0.2\end{array}$ & $\begin{array}{l}0.00 \\
0.00 \\
0.00 \\
0.00 \\
0.00\end{array}$ \\
\hline $\begin{array}{l}2250 \\
2255 \\
2300 \\
2305 \\
2310\end{array}$ & $\begin{array}{l}0.2 \\
0.2 \\
0.2 \\
0.2 \\
0.2\end{array}$ & $\begin{array}{l}0.00 \\
0.00 \\
0.00 \\
0.00 \\
0.00\end{array}$ & $\begin{array}{l}0145 \\
0150 \\
0155 \\
0200 \\
0205\end{array}$ & $\begin{array}{l}16.8 \\
15.2 \\
13.2 \\
11.7 \\
10.3\end{array}$ & $\begin{array}{l}0.00 \\
0.00 \\
0.00 \\
0.00 \\
0.00\end{array}$ & $\begin{array}{l}0445 \\
0450 \\
0455 \\
0500\end{array}$ & $\begin{array}{l}0.2 \\
0.2 \\
0.2 \\
0.2\end{array}$ & $\begin{array}{l}0.00 \\
0.00 \\
0.00 \\
0.00\end{array}$ \\
\hline 2315 & 0.2 & 0.00 & 0210 & 8.9 & 0.00 & & & \\
\hline
\end{tabular}




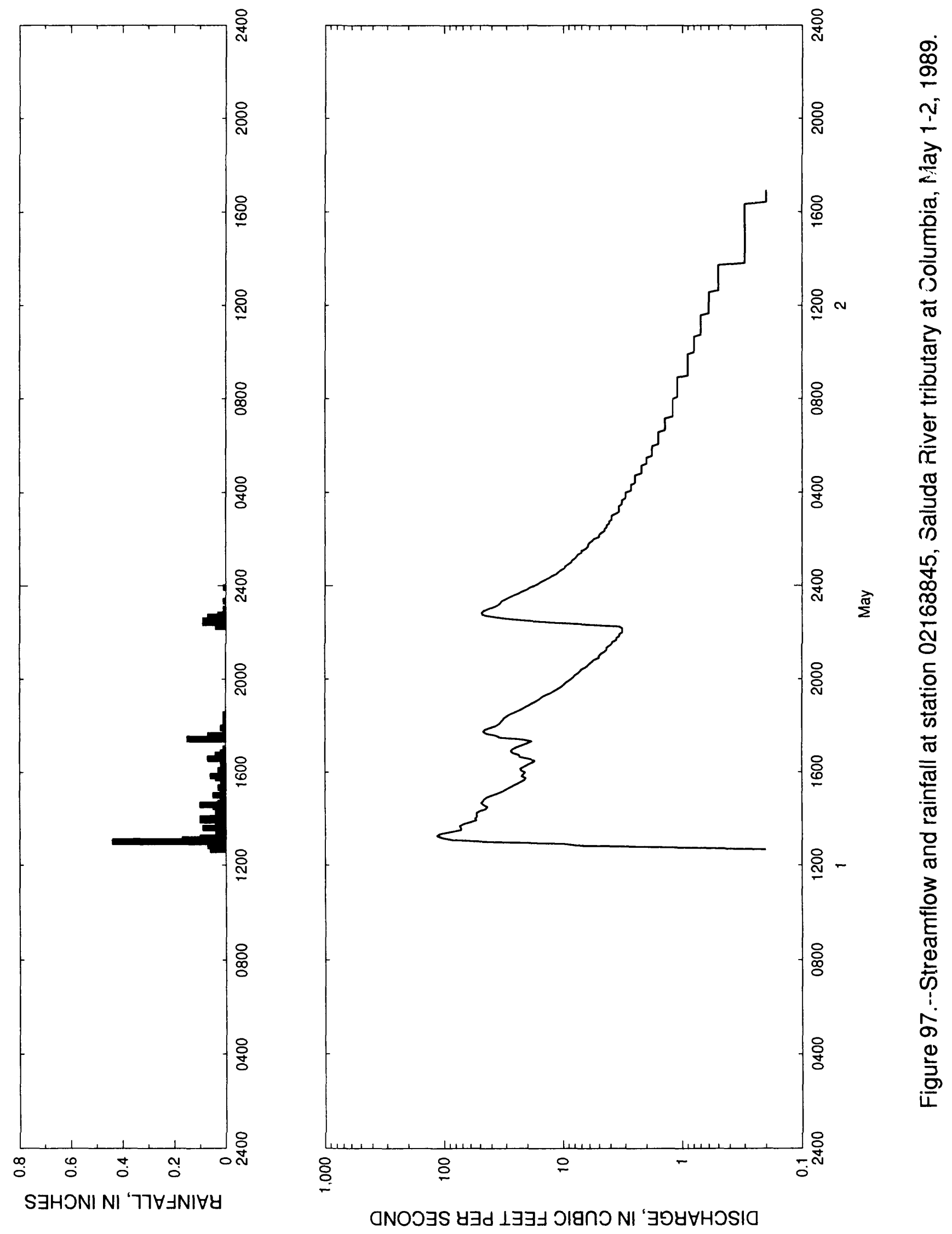


Table 96. - Streamflow and rainfall at station 02168845, Saluda River tributary at Columbia, May $1-2,1989$

\begin{tabular}{|c|c|c|c|c|c|c|c|c|}
\hline $\begin{array}{l}\text { Time } \\
\text { (hours) }\end{array}$ & $\begin{array}{l}\text { Streamflow } \\
\text { (cubic feet } \\
\text { per second) }\end{array}$ & $\begin{array}{l}\text { Rain- } \\
\text { fall } \\
\text { (inches) }\end{array}$ & $\begin{array}{l}\text { Time } \\
\text { (hours) }\end{array}$ & $\begin{array}{l}\text { Streamflow } \\
\text { (cubic feet } \\
\text { per second) }\end{array}$ & $\begin{array}{l}\text { Rain- } \\
\text { fall } \\
\text { (inches) }\end{array}$ & $\begin{array}{l}\text { Time } \\
\text { (hours) }\end{array}$ & $\begin{array}{l}\text { Streamflow } \\
\text { (cubic feet } \\
\text { per second) }\end{array}$ & $\begin{array}{l}\text { Rain- } \\
\text { fall } \\
\text { (inches) }\end{array}$ \\
\hline $\begin{array}{c}\text { May 1, } 1 \\
1240 \\
1245 \\
1250 \\
1255\end{array}$ & $\begin{array}{r}0.2 \\
0.9 \\
7.7 \\
10.0\end{array}$ & $\begin{array}{l}0.06 \\
0.05 \\
0.07 \\
0.07\end{array}$ & $\begin{array}{l}1800 \\
1805 \\
1810 \\
1815 \\
1820\end{array}$ & $\begin{array}{l}36.9 \\
34.6 \\
33.5 \\
32.4 \\
31.5\end{array}$ & $\begin{array}{l}0.01 \\
0.01 \\
0.01 \\
0.01 \\
0.01\end{array}$ & $\begin{array}{l}2325 \\
2330 \\
2335 \\
2340 \\
2345\end{array}$ & $\begin{array}{l}30.4 \\
28.3 \\
26.2 \\
23.9 \\
22.2\end{array}$ & $\begin{array}{l}0.00 \\
0.00 \\
0.00 \\
0.00 \\
0.00\end{array}$ \\
\hline $\begin{array}{l}1300 \\
1305 \\
1310 \\
1315 \\
1320\end{array}$ & $\begin{array}{r}42.0 \\
85.6 \\
105.0 \\
116.0 \\
109.0\end{array}$ & $\begin{array}{l}0.44 \\
0.17 \\
0.10 \\
0.03 \\
0.04\end{array}$ & $\begin{array}{l}1825 \\
1830 \\
1835 \\
1840 \\
1845\end{array}$ & $\begin{array}{l}29.9 \\
28.0 \\
25.7 \\
23.6 \\
21.9\end{array}$ & $\begin{array}{l}0.00 \\
0.01 \\
0.00 \\
0.00 \\
0.00\end{array}$ & $\begin{array}{c}2350 \\
2355 \\
\text { May 2, } \\
0000 \\
0005\end{array}$ & $\begin{array}{l}20.2 \\
19.1 \\
17.5 \\
16.3\end{array}$ & $\begin{array}{l}0.00 \\
0.01 \\
0.00 \\
0.00\end{array}$ \\
\hline $\begin{array}{l}1325 \\
1330 \\
1335 \\
1340 \\
1345\end{array}$ & $\begin{array}{l}90.0 \\
72.4 \\
72.4 \\
74.6 \\
69.4\end{array}$ & $\begin{array}{l}0.04 \\
0.04 \\
0.09 \\
0.04 \\
0.03\end{array}$ & $\begin{array}{l}1850 \\
1855 \\
1900 \\
1905 \\
1910\end{array}$ & $\begin{array}{l}20.5 \\
19.1 \\
17.9 \\
16.6 \\
15.7\end{array}$ & $\begin{array}{l}0.00 \\
0.00 \\
0.00 \\
0.00 \\
0.00\end{array}$ & $\begin{array}{l}0010 \\
0015 \\
0020 \\
0025 \\
0030\end{array}$ & $\begin{array}{l}15.4 \\
14.2 \\
13.2 \\
12.5 \\
11.5\end{array}$ & $\begin{array}{l}0.00 \\
0.00 \\
0.00 \\
0.00 \\
0.00\end{array}$ \\
\hline $\begin{array}{l}1350 \\
1355 \\
1400 \\
1405 \\
1410\end{array}$ & $\begin{array}{l}60.9 \\
54.1 \\
55.1 \\
53.1 \\
53.4\end{array}$ & $\begin{array}{l}0.02 \\
0.10 \\
0.10 \\
0.03 \\
0.04\end{array}$ & $\begin{array}{l}1915 \\
1920 \\
1925 \\
1930 \\
1935\end{array}$ & $\begin{array}{l}15.0 \\
14.0 \\
12.7 \\
12.0 \\
11.2\end{array}$ & $\begin{array}{l}0.00 \\
0.00 \\
0.00 \\
0.00 \\
0.00\end{array}$ & $\begin{array}{l}0035 \\
0040 \\
0045 \\
0050 \\
0055\end{array}$ & $\begin{array}{r}11.0 \\
10.5 \\
9.8 \\
9.6 \\
9.1\end{array}$ & $\begin{array}{l}0.00 \\
0.00 \\
0.00 \\
0.00 \\
0.00\end{array}$ \\
\hline $\begin{array}{l}1415 \\
1420 \\
1425 \\
1430 \\
1435\end{array}$ & $\begin{array}{l}53.4 \\
49.5 \\
44.8 \\
43.2 \\
46.3\end{array}$ & $\begin{array}{l}0.04 \\
0.03 \\
0.03 \\
0.05 \\
0.10\end{array}$ & $\begin{array}{l}1940 \\
1945 \\
1950 \\
1955 \\
2000\end{array}$ & $\begin{array}{r}10.5 \\
10.0 \\
9.6 \\
9.1 \\
8.6\end{array}$ & $\begin{array}{l}0.00 \\
0.00 \\
0.00 \\
0.00 \\
0.00\end{array}$ & $\begin{array}{l}0100 \\
0105 \\
0110 \\
0115 \\
0120\end{array}$ & $\begin{array}{l}8.6 \\
8.4 \\
8.0 \\
7.7 \\
7.5\end{array}$ & $\begin{array}{l}0.00 \\
0.00 \\
0.00 \\
0.00 \\
0.00\end{array}$ \\
\hline $\begin{array}{l}1440 \\
1445 \\
1450 \\
1455 \\
1500\end{array}$ & $\begin{array}{l}48.9 \\
47.3 \\
46.3 \\
43.8 \\
39.6\end{array}$ & $\begin{array}{l}0.03 \\
0.02 \\
0.02 \\
0.02 \\
0.05\end{array}$ & $\begin{array}{l}2005 \\
2010 \\
2015 \\
2020 \\
2025\end{array}$ & $\begin{array}{l}8.2 \\
8.0 \\
7.5 \\
7.2 \\
7.0\end{array}$ & $\begin{array}{l}0.00 \\
0.00 \\
0.00 \\
0.00 \\
0.00\end{array}$ & $\begin{array}{l}0125 \\
0130 \\
0135 \\
0140 \\
0145\end{array}$ & $\begin{array}{l}7.0 \\
7.0 \\
6.5 \\
6.2 \\
6.2\end{array}$ & $\begin{array}{l}0.00 \\
0.00 \\
0.00 \\
0.00 \\
0.00\end{array}$ \\
\hline $\begin{array}{l}1505 \\
1510 \\
1515 \\
1520 \\
1525\end{array}$ & $\begin{array}{l}35.5 \\
32.4 \\
30.4 \\
28.5 \\
26.4\end{array}$ & $\begin{array}{l}0.02 \\
0.01 \\
0.02 \\
0.03 \\
0.02\end{array}$ & $\begin{array}{l}2030 \\
2035 \\
2040 \\
2045 \\
2050\end{array}$ & $\begin{array}{l}6.5 \\
6.2 \\
6.0 \\
5.7 \\
5.5\end{array}$ & $\begin{array}{l}0.00 \\
0.00 \\
0.00 \\
0.00 \\
0.00\end{array}$ & $\begin{array}{l}0150 \\
0155 \\
0200 \\
0205 \\
0210\end{array}$ & $\begin{array}{l}6.0 \\
5.7 \\
5.5 \\
5.0 \\
5.0\end{array}$ & $\begin{array}{l}0.00 \\
0.00 \\
0.00 \\
0.00 \\
0.00\end{array}$ \\
\hline $\begin{array}{l}1530 \\
1535 \\
1540 \\
1545 \\
1550\end{array}$ & $\begin{array}{l}24.6 \\
22.9 \\
21.2 \\
20.7 \\
22.4\end{array}$ & $\begin{array}{l}0.02 \\
0.01 \\
0.02 \\
0.04 \\
0.06\end{array}$ & $\begin{array}{l}2055 \\
2100 \\
2105 \\
2110 \\
2115\end{array}$ & $\begin{array}{l}5.0 \\
5.0 \\
4.8 \\
4.5 \\
4.3\end{array}$ & $\begin{array}{l}0.00 \\
0.00 \\
0.00 \\
0.00 \\
0.00\end{array}$ & $\begin{array}{l}0215 \\
0220 \\
0225 \\
0230 \\
0235\end{array}$ & $\begin{array}{l}4.8 \\
4.5 \\
4.5 \\
4.3 \\
4.3\end{array}$ & $\begin{array}{l}0.00 \\
0.00 \\
0.00 \\
0.00 \\
0.00\end{array}$ \\
\hline $\begin{array}{l}1555 \\
1600 \\
1605 \\
1610 \\
1615\end{array}$ & $\begin{array}{l}21.7 \\
20.9 \\
22.6 \\
22.9 \\
21.2\end{array}$ & $\begin{array}{l}0.02 \\
0.02 \\
0.03 \\
0.02 \\
0.02\end{array}$ & $\begin{array}{l}2120 \\
2125 \\
2130 \\
2135 \\
2140\end{array}$ & $\begin{array}{l}4.3 \\
4.1 \\
3.9 \\
3.9 \\
3.6\end{array}$ & $\begin{array}{l}0.00 \\
0.00 \\
0.00 \\
0.00 \\
0.00\end{array}$ & $\begin{array}{l}0240 \\
0245 \\
0250 \\
0255 \\
0300\end{array}$ & $\begin{array}{l}4.1 \\
4.1 \\
3.9 \\
3.9 \\
3.9\end{array}$ & $\begin{array}{l}0.00 \\
0.00 \\
0.00 \\
0.00 \\
0.00\end{array}$ \\
\hline $\begin{array}{l}1620 \\
1625 \\
1630 \\
1635 \\
1640\end{array}$ & $\begin{array}{l}19.8 \\
18.4 \\
17.3 \\
19.3 \\
23.1\end{array}$ & $\begin{array}{l}0.01 \\
0.01 \\
0.02 \\
0.07 \\
0.04\end{array}$ & $\begin{array}{l}2145 \\
2150 \\
2155 \\
2200 \\
2205\end{array}$ & $\begin{array}{l}3.6 \\
3.4 \\
3.4 \\
3.2 \\
3.2\end{array}$ & $\begin{array}{l}0.00 \\
0.00 \\
0.00 \\
0.00 \\
0.00\end{array}$ & $\begin{array}{l}0305 \\
0310 \\
0315 \\
0320 \\
0325\end{array}$ & $\begin{array}{l}3.6 \\
3.4 \\
3.4 \\
3.4 \\
3.4\end{array}$ & $\begin{array}{l}0.00 \\
0.00 \\
0.00 \\
0.00 \\
0.00\end{array}$ \\
\hline $\begin{array}{l}1645 \\
1650 \\
1655 \\
1700 \\
1705\end{array}$ & $\begin{array}{l}23.4 \\
26.4 \\
27.5 \\
26.4 \\
24.4\end{array}$ & $\begin{array}{l}0.04 \\
0.02 \\
0.01 \\
0.01 \\
0.00\end{array}$ & $\begin{array}{l}2210 \\
2215 \\
2220 \\
2225 \\
2230\end{array}$ & $\begin{array}{r}3.2 \\
3.4 \\
6.5 \\
12.2 \\
20.0\end{array}$ & $\begin{array}{l}0.00 \\
0.04 \\
0.03 \\
0.09 \\
0.09\end{array}$ & $\begin{array}{l}0330 \\
0335 \\
0340 \\
0345 \\
0350\end{array}$ & $\begin{array}{l}3.2 \\
3.2 \\
3.2 \\
3.0 \\
3.0\end{array}$ & $\begin{array}{l}0.00 \\
0.00 \\
0.00 \\
0.00 \\
0.00\end{array}$ \\
\hline $\begin{array}{l}1710 \\
1715 \\
1720 \\
1725 \\
1730\end{array}$ & $\begin{array}{l}21.9 \\
19.8 \\
18.4 \\
22.2 \\
34.1\end{array}$ & $\begin{array}{l}0.00 \\
0.00 \\
0.00 \\
0.15 \\
0.04\end{array}$ & $\begin{array}{l}2235 \\
2240 \\
2245 \\
2250 \\
2255\end{array}$ & $\begin{array}{l}29.9 \\
39.0 \\
47.9 \\
48.5 \\
46.6\end{array}$ & $\begin{array}{l}0.07 \\
0.07 \\
0.03 \\
0.01 \\
0.01\end{array}$ & $\begin{array}{l}0355 \\
0400 \\
0405 \\
0410 \\
0415\end{array}$ & $\begin{array}{l}3.0 \\
3.0 \\
2.7 \\
2.7 \\
2.7\end{array}$ & $\begin{array}{l}0.00 \\
0.00 \\
0.00 \\
0.00 \\
0.00\end{array}$ \\
\hline $\begin{array}{l}1735 \\
1740 \\
1745 \\
1750 \\
1755\end{array}$ & $\begin{array}{l}36.9 \\
44.1 \\
47.0 \\
45.7 \\
41.4\end{array}$ & $\begin{array}{l}0.07 \\
0.01 \\
0.01 \\
0.01 \\
0.02\end{array}$ & $\begin{array}{l}2300 \\
2305 \\
2310 \\
2315 \\
2320\end{array}$ & $\begin{array}{l}42.9 \\
38.1 \\
35.2 \\
33.8 \\
32.9\end{array}$ & $\begin{array}{l}0.01 \\
0.00 \\
0.00 \\
0.00 \\
0.01\end{array}$ & $\begin{array}{l}0420 \\
0425 \\
0430 \\
0435 \\
0440\end{array}$ & $\begin{array}{l}2.7 \\
2.5 \\
2.5 \\
2.5 \\
2.5\end{array}$ & $\begin{array}{l}0.00 \\
0.00 \\
0.00 \\
0.00 \\
0.00\end{array}$ \\
\hline
\end{tabular}


Table 96. --Streamflow and rainfall at station 02168845, Saluda River tributary at Columbia, May $1-2,1989--$ Continued

\begin{tabular}{|c|c|c|c|c|c|c|c|c|}
\hline $\begin{array}{l}\text { Time } \\
\text { (hours) }\end{array}$ & $\begin{array}{l}\text { Streamflow } \\
\text { (cubic feet } \\
\text { per second) }\end{array}$ & $\begin{array}{l}\text { Rain- } \\
\text { fall } \\
\text { (inches) }\end{array}$ & $\begin{array}{l}\text { Time } \\
\text { (hours) }\end{array}$ & $\begin{array}{l}\text { Streamflow } \\
\text { (cubic feet } \\
\text { per second) }\end{array}$ & $\begin{array}{l}\text { Rain- } \\
\text { fall } \\
\text { (inches) }\end{array}$ & $\begin{array}{l}\text { Time } \\
\text { (hours) }\end{array}$ & $\begin{array}{l}\text { Streamflow } \\
\text { (cubic feet } \\
\text { per second) }\end{array}$ & $\begin{array}{l}\text { Rain- } \\
\text { fall } \\
\text { (inches) }\end{array}$ \\
\hline $\begin{array}{l}0445 \\
0450 \\
0455 \\
0500 \\
0505\end{array}$ & $\begin{array}{l}2.5 \\
2.2 \\
2.2 \\
2.2 \\
2.2\end{array}$ & $\begin{array}{l}0.00 \\
0.00 \\
0.00 \\
0.00 \\
0.00\end{array}$ & $\begin{array}{l}0855 \\
0900 \\
0905 \\
0910 \\
0915\end{array}$ & $\begin{array}{l}1.1 \\
0.9 \\
0.9 \\
0.9 \\
0.9\end{array}$ & $\begin{array}{l}0.00 \\
0.00 \\
0.00 \\
0.00 \\
0.00\end{array}$ & $\begin{array}{l}1305 \\
1310 \\
1315 \\
1320 \\
1325\end{array}$ & $\begin{array}{l}0.5 \\
0.5 \\
0.5 \\
0.5 \\
0.5\end{array}$ & $\begin{array}{l}0.00 \\
0.00 \\
0.00 \\
0.00 \\
0.00\end{array}$ \\
\hline $\begin{array}{l}0510 \\
0515 \\
0520 \\
0525 \\
0530\end{array}$ & $\begin{array}{l}2.2 \\
2.0 \\
2.0 \\
2.0 \\
2.0\end{array}$ & $\begin{array}{l}0.00 \\
0.00 \\
0.00 \\
0.00 \\
0.00\end{array}$ & $\begin{array}{l}0920 \\
0925 \\
0930 \\
0935 \\
0940\end{array}$ & $\begin{array}{l}0.9 \\
0.9 \\
0.9 \\
0.9 \\
0.9\end{array}$ & $\begin{array}{l}0.00 \\
0.00 \\
0.00 \\
0.00 \\
0.00\end{array}$ & $\begin{array}{l}1330 \\
1335 \\
1340 \\
1345 \\
1350\end{array}$ & $\begin{array}{l}0.5 \\
0.5 \\
0.5 \\
0.5 \\
0.3\end{array}$ & $\begin{array}{l}0.00 \\
0.00 \\
0.00 \\
0.00 \\
0.00\end{array}$ \\
\hline $\begin{array}{l}0535 \\
0540 \\
0545 \\
0550 \\
0555\end{array}$ & $\begin{array}{l}1.8 \\
1.8 \\
1.8 \\
1.8 \\
1.8\end{array}$ & $\begin{array}{l}0.00 \\
0.00 \\
0.00 \\
0.00 \\
0.00\end{array}$ & $\begin{array}{l}0945 \\
0950 \\
0955 \\
1000 \\
1005\end{array}$ & $\begin{array}{l}0.9 \\
0.9 \\
0.9 \\
0.8 \\
0.8\end{array}$ & $\begin{array}{l}0.00 \\
0.00 \\
0.00 \\
0.00 \\
0.00\end{array}$ & $\begin{array}{l}1355 \\
1400 \\
1405 \\
1410 \\
1415\end{array}$ & $\begin{array}{l}0.3 \\
0.3 \\
0.3 \\
0.3 \\
0.3\end{array}$ & $\begin{array}{l}0.00 \\
0.00 \\
0.00 \\
0.00 \\
0.00\end{array}$ \\
\hline $\begin{array}{l}0600 \\
0605 \\
0610 \\
0615 \\
0620\end{array}$ & $\begin{array}{l}1.8 \\
1.6 \\
1.6 \\
1.6 \\
1.6\end{array}$ & $\begin{array}{l}0.00 \\
0.00 \\
0.00 \\
0.00 \\
0.00\end{array}$ & $\begin{array}{l}1010 \\
1015 \\
1020 \\
1025 \\
1030\end{array}$ & $\begin{array}{l}0.8 \\
0.8 \\
0.8 \\
0.8 \\
0.8\end{array}$ & $\begin{array}{l}0.00 \\
0.00 \\
0.00 \\
0.00 \\
0.00\end{array}$ & $\begin{array}{l}1420 \\
1425 \\
1430 \\
1435 \\
1440\end{array}$ & $\begin{array}{l}0.3 \\
0.3 \\
0.3 \\
0.3 \\
0.3\end{array}$ & $\begin{array}{l}0.00 \\
0.00 \\
0.00 \\
0.00 \\
0.00\end{array}$ \\
\hline $\begin{array}{l}0625 \\
0630 \\
0635 \\
0640 \\
0645\end{array}$ & $\begin{array}{l}1.6 \\
1.6 \\
1.6 \\
1.4 \\
1.4\end{array}$ & $\begin{array}{l}0.00 \\
0.00 \\
0.00 \\
0.00 \\
0.00\end{array}$ & $\begin{array}{l}1035 \\
1040 \\
1045 \\
1050 \\
1055\end{array}$ & $\begin{array}{l}0.8 \\
0.8 \\
0.7 \\
0.7 \\
0.7\end{array}$ & $\begin{array}{l}0.00 \\
0.00 \\
0.00 \\
0.00 \\
0.00\end{array}$ & $\begin{array}{l}1445 \\
1450 \\
1455 \\
1500 \\
1505\end{array}$ & $\begin{array}{l}0.3 \\
0.3 \\
0.3 \\
0.3 \\
0.3\end{array}$ & $\begin{array}{l}0.00 \\
0.00 \\
0.00 \\
0.00 \\
0.00\end{array}$ \\
\hline $\begin{array}{l}0650 \\
0655 \\
0700 \\
0705 \\
0710\end{array}$ & $\begin{array}{l}1.4 \\
1.4 \\
1.4 \\
1.4 \\
1.4\end{array}$ & $\begin{array}{l}0.00 \\
0.00 \\
0.00 \\
0.00 \\
0.00\end{array}$ & $\begin{array}{l}1100 \\
1105 \\
1110 \\
1115 \\
1120\end{array}$ & $\begin{array}{l}0.7 \\
0.7 \\
0.7 \\
0.7 \\
0.7\end{array}$ & $\begin{array}{l}0.00 \\
0.00 \\
0.00 \\
0.00 \\
0.00\end{array}$ & $\begin{array}{l}1510 \\
1515 \\
1520 \\
1525 \\
1530\end{array}$ & $\begin{array}{l}0.3 \\
0.3 \\
0.3 \\
0.3 \\
0.3\end{array}$ & $\begin{array}{l}0.00 \\
0.00 \\
0.00 \\
0.00 \\
0.00\end{array}$ \\
\hline $\begin{array}{l}0715 \\
0720 \\
0725 \\
0730 \\
0735\end{array}$ & $\begin{array}{l}1.2 \\
1.2 \\
1.2 \\
1.2 \\
1.2\end{array}$ & $\begin{array}{l}0.00 \\
0.00 \\
0.00 \\
0.00 \\
0.00\end{array}$ & $\begin{array}{l}1125 \\
1130 \\
1135 \\
1140 \\
1145\end{array}$ & $\begin{array}{l}0.7 \\
0.7 \\
0.7 \\
0.6 \\
0.6\end{array}$ & $\begin{array}{l}0.00 \\
0.00 \\
0.00 \\
0.00 \\
0.00\end{array}$ & $\begin{array}{l}1535 \\
1540 \\
1545 \\
1550 \\
1555\end{array}$ & $\begin{array}{l}0.3 \\
0.3 \\
0.3 \\
0.3 \\
0.3\end{array}$ & $\begin{array}{l}0.00 \\
0.00 \\
0.00 \\
0.00 \\
0.00\end{array}$ \\
\hline $\begin{array}{l}0740 \\
0745 \\
0750 \\
0755 \\
0800\end{array}$ & $\begin{array}{l}1.2 \\
1.2 \\
1.2 \\
1.2 \\
1.2\end{array}$ & $\begin{array}{l}0.00 \\
0.00 \\
0.00 \\
0.00 \\
0.00\end{array}$ & $\begin{array}{l}1150 \\
1155 \\
1200 \\
1205 \\
1210\end{array}$ & $\begin{array}{l}0.6 \\
0.6 \\
0.6 \\
0.6 \\
0.6\end{array}$ & $\begin{array}{l}0.00 \\
0.00 \\
0.00 \\
0.00 \\
0.00\end{array}$ & $\begin{array}{l}1600 \\
1605 \\
1610 \\
1615 \\
1620\end{array}$ & $\begin{array}{l}0.3 \\
0.3 \\
0.3 \\
0.3 \\
0.3\end{array}$ & $\begin{array}{l}0.00 \\
0.00 \\
0.00 \\
0.00 \\
0.00\end{array}$ \\
\hline $\begin{array}{l}0805 \\
0810 \\
0815 \\
0820 \\
0825\end{array}$ & $\begin{array}{l}1.1 \\
1.1 \\
1.1 \\
1.1 \\
1.1\end{array}$ & $\begin{array}{l}0.00 \\
0.00 \\
0.00 \\
0.00 \\
0.00\end{array}$ & $\begin{array}{l}1215 \\
1220 \\
1225 \\
1230 \\
1235\end{array}$ & $\begin{array}{l}0.6 \\
0.6 \\
0.6 \\
0.6 \\
0.6\end{array}$ & $\begin{array}{l}0.00 \\
0.00 \\
0.00 \\
0.00 \\
0.00\end{array}$ & $\begin{array}{l}1625 \\
1630 \\
1635 \\
1640 \\
1645\end{array}$ & $\begin{array}{l}0.2 \\
0.2 \\
0.2 \\
0.2 \\
0.2\end{array}$ & $\begin{array}{l}0.00 \\
0.00 \\
0.00 \\
0.00 \\
0.00\end{array}$ \\
\hline $\begin{array}{l}0830 \\
0835 \\
0840 \\
0845 \\
0850\end{array}$ & $\begin{array}{l}1.1 \\
1.1 \\
1.1 \\
1.1 \\
1.1\end{array}$ & $\begin{array}{l}0.00 \\
0.00 \\
0.00 \\
0.00 \\
0.00\end{array}$ & $\begin{array}{l}1240 \\
1245 \\
1250 \\
1255 \\
1300\end{array}$ & $\begin{array}{l}0.5 \\
0.5 \\
0.5 \\
0.5 \\
0.5\end{array}$ & $\begin{array}{l}0.00 \\
0.00 \\
0.00 \\
0.00 \\
0.00\end{array}$ & $\begin{array}{l}1650 \\
1655 \\
1700\end{array}$ & $\begin{array}{l}0.2 \\
0.2 \\
0.2\end{array}$ & $\begin{array}{l}0.00 \\
0.00 \\
0.00\end{array}$ \\
\hline
\end{tabular}




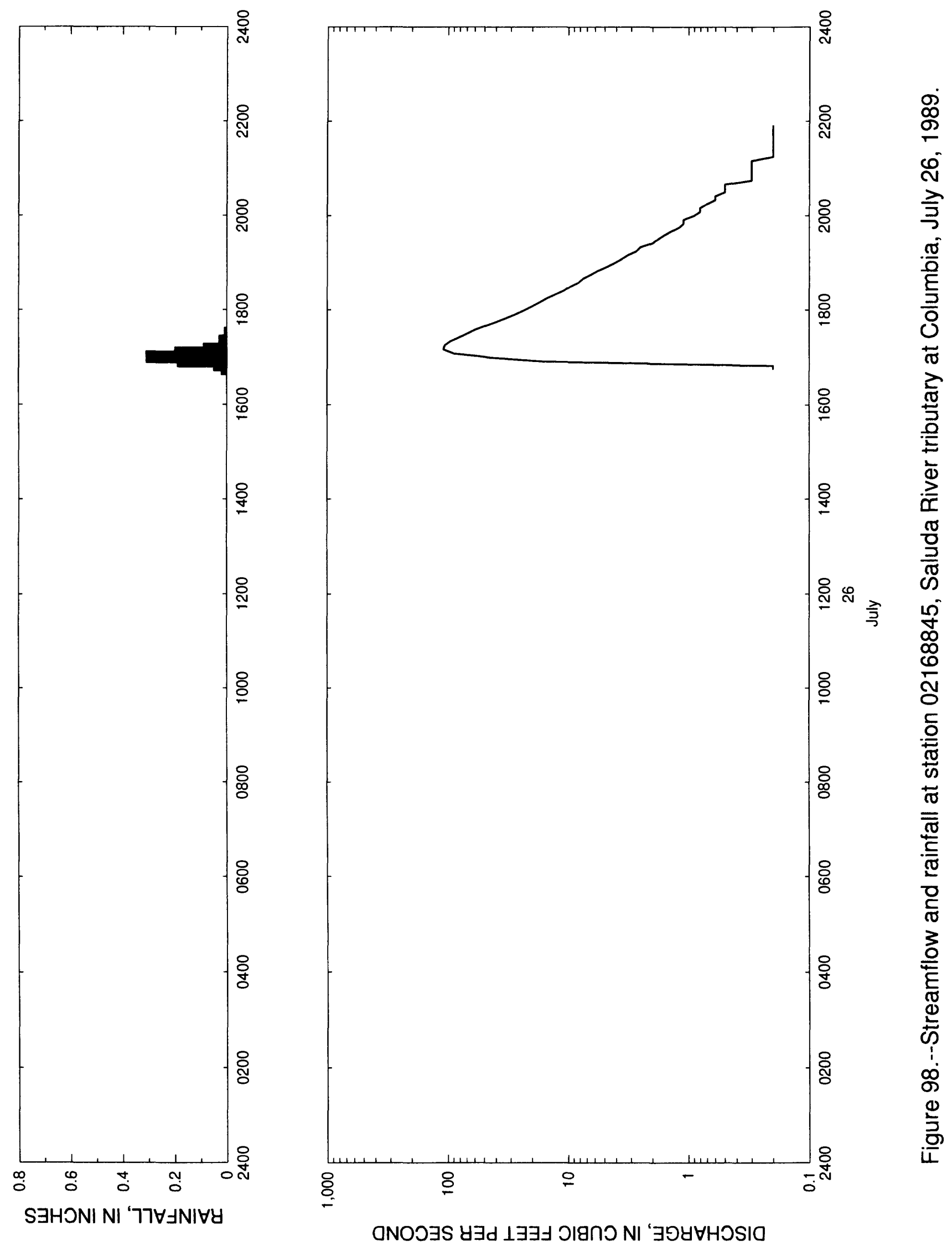


Table 97. - Streamflow and rainfall at station 02168845, Saluda River tributary at Columbia, July 26,1989

\begin{tabular}{|c|c|c|c|c|c|c|c|c|}
\hline $\begin{array}{l}\text { Time } \\
\text { (hours) }\end{array}$ & $\begin{array}{l}\text { Streamflow } \\
\text { (cubic feet } \\
\text { per second) }\end{array}$ & $\begin{array}{l}\text { Rain- } \\
\text { fall } \\
\text { (inches) }\end{array}$ & $\begin{array}{l}\text { Time } \\
\text { (hours) }\end{array}$ & $\begin{array}{l}\text { Streamflow } \\
\text { (cubic feet } \\
\text { per second) }\end{array}$ & $\begin{array}{l}\text { Rain- } \\
\text { fall } \\
\text { (inches) }\end{array}$ & $\begin{array}{l}\text { Time } \\
\text { (hours) }\end{array}$ & $\begin{array}{l}\text { Streamflow } \\
\text { (cubic feet } \\
\text { per second) }\end{array}$ & $\begin{array}{l}\text { Rair- } \\
\text { fall } \\
\text { (incres) }\end{array}$ \\
\hline $\begin{array}{l}\text { July } 26, \\
1645 \\
1650 \\
1655 \\
1700\end{array}$ & $\begin{array}{r}1989 \\
0.2 \\
0.2 \\
16.3 \\
45.1\end{array}$ & $\begin{array}{l}0.02 \\
0.05 \\
0.19 \\
0.31\end{array}$ & $\begin{array}{l}1830 \\
1835 \\
1840 \\
1845 \\
1850\end{array}$ & $\begin{array}{l}9.6 \\
8.2 \\
7.5 \\
6.5 \\
5.7\end{array}$ & $\begin{array}{l}0.00 \\
0.00 \\
0.00 \\
0.00 \\
0.00\end{array}$ & $\begin{array}{l}2020 \\
2025 \\
2030 \\
2035 \\
2040\end{array}$ & $\begin{array}{l}0.6 \\
0.6 \\
0.5 \\
0.5 \\
0.5\end{array}$ & $\begin{array}{l}0.00 \\
0.00 \\
0.00 \\
0.00 \\
0.00\end{array}$ \\
\hline $\begin{array}{l}1705 \\
1710 \\
1715 \\
1720 \\
1725\end{array}$ & $\begin{array}{r}89.2 \\
109.0 \\
106.0 \\
95.2 \\
80.6\end{array}$ & $\begin{array}{l}0.20 \\
0.09 \\
0.03 \\
0.03 \\
0.00\end{array}$ & $\begin{array}{l}1855 \\
1900 \\
1905 \\
1910 \\
1915\end{array}$ & $\begin{array}{l}4.8 \\
4.1 \\
3.6 \\
3.2 \\
2.7\end{array}$ & $\begin{array}{l}0.00 \\
0.00 \\
0.00 \\
0.00 \\
0.00\end{array}$ & $\begin{array}{l}2045 \\
2050 \\
2055 \\
2100 \\
2105\end{array}$ & $\begin{array}{l}0.3 \\
0.3 \\
0.3 \\
0.3 \\
0.3\end{array}$ & $\begin{array}{l}0.00 \\
0.00 \\
0.00 \\
0.00 \\
0.00\end{array}$ \\
\hline $\begin{array}{l}1730 \\
1735 \\
1740 \\
1745 \\
1750\end{array}$ & $\begin{array}{l}69.1 \\
58.5 \\
47.9 \\
39.3 \\
32.4\end{array}$ & $\begin{array}{l}0.01 \\
0.00 \\
0.00 \\
0.00 \\
0.00\end{array}$ & $\begin{array}{l}1920 \\
1925 \\
1930 \\
1935 \\
1940\end{array}$ & $\begin{array}{l}2.5 \\
2.0 \\
1.8 \\
1.6 \\
1.4\end{array}$ & $\begin{array}{l}0.00 \\
0.00 \\
0.00 \\
0.00 \\
0.00\end{array}$ & $\begin{array}{l}2110 \\
2115 \\
2120 \\
2125 \\
2130\end{array}$ & $\begin{array}{l}0.3 \\
0.2 \\
0.2 \\
0.2 \\
0.2\end{array}$ & $\begin{array}{l}0.00 \\
0.00 \\
0.07 \\
0.07 \\
0.07\end{array}$ \\
\hline $\begin{array}{l}1755 \\
1800 \\
1805 \\
1810 \\
1815\end{array}$ & $\begin{array}{l}27.0 \\
22.9 \\
19.8 \\
17.3 \\
15.0\end{array}$ & $\begin{array}{l}0.00 \\
0.00 \\
0.00 \\
0.00 \\
0.00\end{array}$ & $\begin{array}{l}1945 \\
1950 \\
1955 \\
2000 \\
2005\end{array}$ & $\begin{array}{l}1.2 \\
1.1 \\
1.1 \\
0.9 \\
0.8\end{array}$ & $\begin{array}{l}0.00 \\
0.00 \\
0.00 \\
0.00 \\
0.00\end{array}$ & $\begin{array}{l}2135 \\
2140 \\
2145 \\
2150 \\
2155\end{array}$ & $\begin{array}{l}0.2 \\
0.2 \\
0.2 \\
0.2 \\
0.2\end{array}$ & $\begin{array}{l}0.0 ? \\
0.0 ? \\
0.0 ? \\
0.0 ? \\
0.0 ?\end{array}$ \\
\hline $\begin{array}{l}1820 \\
1825\end{array}$ & $\begin{array}{l}12.7 \\
10.8\end{array}$ & $\begin{array}{l}0.00 \\
0.00\end{array}$ & $\begin{array}{l}2010 \\
2015\end{array}$ & $\begin{array}{l}0.8 \\
0.7\end{array}$ & $\begin{array}{l}0.00 \\
0.00\end{array}$ & 2200 & 0.2 & 0.07 \\
\hline
\end{tabular}




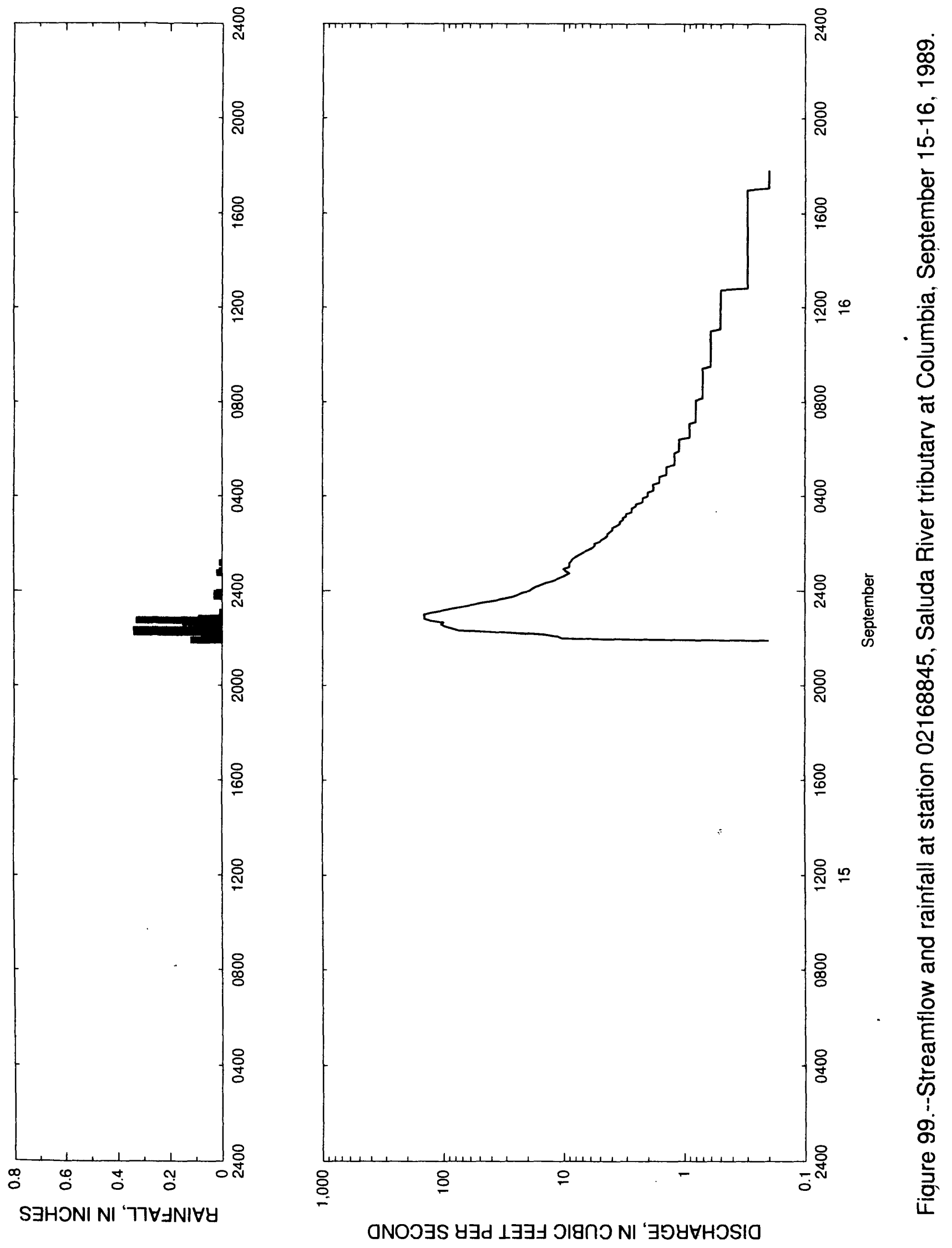


Table 98. - - Streamflow and rainfall at station 02168845, Saluda River tributary at Columbia, September $15-16,1989$

\begin{tabular}{|c|c|c|c|c|c|c|c|c|}
\hline $\begin{array}{l}\text { Time } \\
\text { (hours) }\end{array}$ & $\begin{array}{l}\text { Streamflow } \\
\text { (cubic feet } \\
\text { per second) }\end{array}$ & $\begin{array}{l}\text { Rain- } \\
\text { fall } \\
\text { (inches) }\end{array}$ & $\begin{array}{l}\text { Time } \\
\text { (hours) }\end{array}$ & $\begin{array}{l}\text { Streamflow } \\
\text { (cubic feet } \\
\text { per second) }\end{array}$ & $\begin{array}{l}\text { Rain- } \\
\text { fal1 } \\
\text { (inches) }\end{array}$ & $\begin{array}{l}\text { Time } \\
\text { (hours) }\end{array}$ & $\begin{array}{l}\text { Streamflow } \\
\text { (cubic feet } \\
\text { per second) }\end{array}$ & $\begin{array}{l}\text { Rain- } \\
\text { fall } \\
\text { (inches) }\end{array}$ \\
\hline $\begin{array}{l}\text { September } \\
2155 \\
2200 \\
2205 \\
2210\end{array}$ & [15, $\begin{array}{c}1989 \\
0.2 \\
10.3 \\
11.2 \\
14.5\end{array}$ & $\begin{array}{l}0.12 \\
0.06 \\
0.07 \\
0.06\end{array}$ & $\begin{array}{l}0310 \\
0315 \\
0320 \\
0325 \\
0330\end{array}$ & $\begin{array}{l}3.0 \\
3.0 \\
2.7 \\
2.7 \\
2.7\end{array}$ & $\begin{array}{l}0.00 \\
0.00 \\
0.00 \\
0.00 \\
0.00\end{array}$ & $\begin{array}{l}0835 \\
0840 \\
0845 \\
0850 \\
0855\end{array}$ & $\begin{array}{l}0.7 \\
0.7 \\
0.7 \\
0.7 \\
0.7\end{array}$ & $\begin{array}{l}0.00 \\
0.00 \\
0.00 \\
0.00 \\
0.00\end{array}$ \\
\hline $\begin{array}{l}2215 \\
2220 \\
2225 \\
2230 \\
2235\end{array}$ & $\begin{array}{r}31.3 \\
74.2 \\
84.9 \\
97.6 \\
104.0\end{array}$ & $\begin{array}{l}0.34 \\
0.34 \\
0.01 \\
0.07 \\
0.09\end{array}$ & $\begin{array}{l}0335 \\
0340 \\
0345 \\
0350 \\
0355\end{array}$ & $\begin{array}{l}2.5 \\
2.5 \\
2.2 \\
2.2 \\
2.2\end{array}$ & $\begin{array}{l}0.00 \\
0.00 \\
0.00 \\
0.00 \\
0.00\end{array}$ & $\begin{array}{l}0900 \\
0905 \\
0910 \\
0915 \\
0920\end{array}$ & $\begin{array}{l}0.7 \\
0.7 \\
0.7 \\
0.7 \\
0.7\end{array}$ & $\begin{array}{l}0.00 \\
0.00 \\
0.00 \\
0.00 \\
0.00\end{array}$ \\
\hline $\begin{array}{l}2240 \\
2245 \\
2250 \\
2255 \\
2300\end{array}$ & $\begin{array}{r}98.9 \\
127.0 \\
144.0 \\
143.0 \\
145.0\end{array}$ & $\begin{array}{l}0.15 \\
0.33 \\
0.09 \\
0.01 \\
0.00\end{array}$ & $\begin{array}{l}0400 \\
0405 \\
0410 \\
0415 \\
0420\end{array}$ & $\begin{array}{l}2.0 \\
2.0 \\
2.0 \\
1.8 \\
1.8\end{array}$ & $\begin{array}{l}0.00 \\
0.00 \\
0.00 \\
0.00 \\
0.00\end{array}$ & $\begin{array}{l}0925 \\
0930 \\
0935 \\
0940 \\
0945\end{array}$ & $\begin{array}{l}0.7 \\
0.6 \\
0.6 \\
0.6 \\
0.6\end{array}$ & $\begin{array}{l}0.00 \\
0.00 \\
0.00 \\
0.00 \\
0.00\end{array}$ \\
\hline $\begin{array}{l}2305 \\
2310 \\
2315 \\
2320 \\
2325\end{array}$ & $\begin{array}{r}125.0 \\
101.0 \\
84.9 \\
69.4 \\
55.8\end{array}$ & $\begin{array}{l}0.01 \\
0.00 \\
0.00 \\
0.00 \\
0.00\end{array}$ & $\begin{array}{l}0425 \\
0430 \\
0435 \\
0440 \\
0445\end{array}$ & $\begin{array}{l}1.8 \\
1.8 \\
1.6 \\
1.6 \\
1.6\end{array}$ & $\begin{array}{l}0.00 \\
0.00 \\
0.00 \\
0.00 \\
0.00\end{array}$ & $\begin{array}{l}0950 \\
0955 \\
1000 \\
1005 \\
1010\end{array}$ & $\begin{array}{l}0.6 \\
0.6 \\
0.6 \\
0.6 \\
0.6\end{array}$ & $\begin{array}{l}0.00 \\
0.00 \\
0.00 \\
0.00 \\
0.00\end{array}$ \\
\hline $\begin{array}{l}2330 \\
2335 \\
2340 \\
2345 \\
2350\end{array}$ & $\begin{array}{l}47.9 \\
37.8 \\
31.3 \\
26.4 \\
23.9\end{array}$ & $\begin{array}{l}0.00 \\
0.00 \\
0.00 \\
0.03 \\
0.03\end{array}$ & $\begin{array}{l}0450 \\
0455 \\
0500 \\
0505 \\
0510\end{array}$ & $\begin{array}{l}1.6 \\
1.4 \\
1.4 \\
1.4 \\
1.4\end{array}$ & $\begin{array}{l}0.00 \\
0.00 \\
0.00 \\
0.00 \\
0.00\end{array}$ & $\begin{array}{l}1015 \\
1020 \\
1025 \\
1030 \\
1035\end{array}$ & $\begin{array}{l}0.6 \\
0.6 \\
0.6 \\
0.6 \\
0.6\end{array}$ & $\begin{array}{l}0.00 \\
0.00 \\
0.00 \\
0.00 \\
0.00\end{array}$ \\
\hline $\begin{array}{l}2355 \\
\text { Sept ember } \\
0000 \\
0005 \\
0010\end{array}$ & $\begin{array}{c}22.2 \\
16,1989 \\
19.1 \\
18.2 \\
17.0\end{array}$ & $\begin{array}{l}0.02 \\
0.00 \\
0.00 \\
0.00\end{array}$ & $\begin{array}{l}0515 \\
0520 \\
0525 \\
0530 \\
0535\end{array}$ & $\begin{array}{l}1.4 \\
1.2 \\
1.2 \\
1.2 \\
1.2\end{array}$ & $\begin{array}{l}0.00 \\
0.00 \\
0.00 \\
0.00 \\
0.00\end{array}$ & $\begin{array}{l}1040 \\
1045 \\
1050 \\
1055 \\
1100\end{array}$ & $\begin{array}{l}0.6 \\
0.6 \\
0.6 \\
0.6 \\
0.6\end{array}$ & $\begin{array}{l}0.00 \\
0.00 \\
0.00 \\
0.00 \\
0.00\end{array}$ \\
\hline $\begin{array}{l}0015 \\
0020 \\
0025 \\
0030 \\
0035\end{array}$ & $\begin{array}{l}15.4 \\
14.0 \\
12.2 \\
11.2 \\
10.3\end{array}$ & $\begin{array}{l}0.00 \\
0.00 \\
0.00 \\
0.00 \\
0.00\end{array}$ & $\begin{array}{l}0540 \\
0545 \\
0550 \\
0555 \\
0600\end{array}$ & $\begin{array}{l}1.2 \\
1.2 \\
1.2 \\
1.1 \\
1.1\end{array}$ & $\begin{array}{l}0.00 \\
0.00 \\
0.00 \\
0.00 \\
0.00\end{array}$ & $\begin{array}{l}1105 \\
1110 \\
1115 \\
1120 \\
1125\end{array}$ & $\begin{array}{l}0.5 \\
0.5 \\
0.5 \\
0.5 \\
0.5\end{array}$ & $\begin{array}{l}0.00 \\
0.00 \\
0.00 \\
0.00 \\
0.00\end{array}$ \\
\hline $\begin{array}{l}0040 \\
0045 \\
0050 \\
0055 \\
0100\end{array}$ & $\begin{array}{r}9.6 \\
8.9 \\
9.6 \\
10.0 \\
8.9\end{array}$ & $\begin{array}{l}0.00 \\
0.02 \\
0.01 \\
0.00 \\
0.00\end{array}$ & $\begin{array}{l}0605 \\
0610 \\
0615 \\
0620 \\
0625\end{array}$ & $\begin{array}{l}1.1 \\
1.1 \\
1.1 \\
1.1 \\
1.1\end{array}$ & $\begin{array}{l}0.00 \\
0.00 \\
0.00 \\
0.00 \\
0.00\end{array}$ & $\begin{array}{l}1130 \\
1135 \\
1140 \\
1145 \\
1150\end{array}$ & $\begin{array}{l}0.5 \\
0.5 \\
0.5 \\
0.5 \\
0.5\end{array}$ & $\begin{array}{l}0.00 \\
0.00 \\
0.00 \\
0.00 \\
0.00\end{array}$ \\
\hline $\begin{array}{l}0105 \\
0110 \\
0115 \\
0120 \\
0125\end{array}$ & $\begin{array}{l}8.9 \\
8.9 \\
8.6 \\
8.4 \\
8.0\end{array}$ & $\begin{array}{l}0.00 \\
0.01 \\
0.00 \\
0.00 \\
0.00\end{array}$ & $\begin{array}{l}0630 \\
0635 \\
0640 \\
0645 \\
0650\end{array}$ & $\begin{array}{l}0.9 \\
0.9 \\
0.9 \\
0.9 \\
0.9\end{array}$ & $\begin{array}{l}0.00 \\
0.00 \\
0.00 \\
0.00 \\
0.00\end{array}$ & $\begin{array}{l}1155 \\
1200 \\
1205 \\
1210 \\
1215\end{array}$ & $\begin{array}{l}0.5 \\
0.5 \\
0.5 \\
0.5 \\
0.5\end{array}$ & $\begin{array}{l}0.00 \\
0.00 \\
0.00 \\
0.00 \\
0.00\end{array}$ \\
\hline $\begin{array}{l}0130 \\
0135 \\
0140 \\
0145 \\
0150\end{array}$ & $\begin{array}{l}7.5 \\
7.0 \\
6.5 \\
6.0 \\
5.7\end{array}$ & $\begin{array}{l}0.00 \\
0.00 \\
0.00 \\
0.00 \\
0.00\end{array}$ & $\begin{array}{l}0655 \\
0700 \\
0705 \\
0710 \\
0715\end{array}$ & $\begin{array}{l}0.9 \\
0.9 \\
0.9 \\
0.8 \\
0.8\end{array}$ & $\begin{array}{l}0.00 \\
0.00 \\
0.00 \\
0.00 \\
0.00\end{array}$ & $\begin{array}{l}1220 \\
1225 \\
1230 \\
1235 \\
1240\end{array}$ & $\begin{array}{l}0.5 \\
0.5 \\
0.5 \\
0.5 \\
0.5\end{array}$ & $\begin{array}{l}0.00 \\
0.00 \\
0.00 \\
0.00 \\
0.00\end{array}$ \\
\hline $\begin{array}{l}0155 \\
0200 \\
0205 \\
0210 \\
0215\end{array}$ & $\begin{array}{l}5.5 \\
5.5 \\
5.0 \\
4.8 \\
4.5\end{array}$ & $\begin{array}{l}0.00 \\
0.00 \\
0.00 \\
0.00 \\
0.00\end{array}$ & $\begin{array}{l}0720 \\
0725 \\
0730 \\
0735 \\
0740\end{array}$ & $\begin{array}{l}0.8 \\
0.8 \\
0.8 \\
0.8 \\
0.8\end{array}$ & $\begin{array}{l}0.00 \\
0.00 \\
0.00 \\
0.00 \\
0.00\end{array}$ & $\begin{array}{l}1245 \\
1250 \\
1255 \\
1300 \\
1305\end{array}$ & $\begin{array}{l}0.5 \\
0.3 \\
0.3 \\
0.3 \\
0.3\end{array}$ & $\begin{array}{l}0.00 \\
0.00 \\
0.00 \\
0.00 \\
0.00\end{array}$ \\
\hline $\begin{array}{l}0220 \\
0225 \\
0230 \\
0235 \\
0240\end{array}$ & $\begin{array}{l}4.3 \\
4.3 \\
4.1 \\
3.9 \\
3.9\end{array}$ & $\begin{array}{l}0.00 \\
0.00 \\
0.00 \\
0.00 \\
0.00\end{array}$ & $\begin{array}{l}0745 \\
0750 \\
0755 \\
0800 \\
0805\end{array}$ & $\begin{array}{l}0.8 \\
0.8 \\
0.8 \\
0.8 \\
0.8\end{array}$ & $\begin{array}{l}0.00 \\
0.00 \\
0.00 \\
0.00 \\
0.00\end{array}$ & $\begin{array}{l}1310 \\
1315 \\
1320 \\
1325 \\
1330\end{array}$ & $\begin{array}{l}0.3 \\
0.3 \\
0.3 \\
0.3 \\
0.3\end{array}$ & $\begin{array}{l}0.00 \\
0.00 \\
0.00 \\
0.00 \\
0.00\end{array}$ \\
\hline $\begin{array}{l}0245 \\
0250 \\
0255 \\
0300 \\
0305\end{array}$ & $\begin{array}{l}3.6 \\
3.4 \\
3.4 \\
3.2 \\
3.2\end{array}$ & $\begin{array}{l}0.00 \\
0.00 \\
0.00 \\
0.00 \\
0.00\end{array}$ & $\begin{array}{l}0810 \\
0815 \\
0820 \\
0825 \\
0830\end{array}$ & $\begin{array}{l}0.7 \\
0.7 \\
0.7 \\
0.7 \\
0.7\end{array}$ & $\begin{array}{l}0.00 \\
0.00 \\
0.00 \\
0.00 \\
0.00\end{array}$ & $\begin{array}{l}1335 \\
1340 \\
1345 \\
1350 \\
1355\end{array}$ & $\begin{array}{l}0.3 \\
0.3 \\
0.3 \\
0.3 \\
0.3\end{array}$ & $\begin{array}{l}0.00 \\
0.00 \\
0.00 \\
0.00 \\
0.00\end{array}$ \\
\hline
\end{tabular}


Table 98.--Streamflow and rainfall at station 02168845, Saluda River tributary at Columbia, September 15-16, 1989--Continued

\begin{tabular}{|c|c|c|c|c|c|c|c|c|}
\hline $\begin{array}{l}\text { Time } \\
\text { (hours) }\end{array}$ & $\begin{array}{l}\text { Streamflow } \\
\text { (cubic feet } \\
\text { per second) }\end{array}$ & $\begin{array}{l}\text { Rain- } \\
\text { fall } \\
\text { (inches) }\end{array}$ & $\begin{array}{l}\text { Time } \\
\text { (hours) }\end{array}$ & $\begin{array}{l}\text { Streamflow } \\
\text { (cubic feet } \\
\text { per second) }\end{array}$ & $\begin{array}{l}\text { Rain- } \\
\text { fall } \\
\text { (inches) }\end{array}$ & $\begin{array}{l}\text { Time } \\
\text { (hours) }\end{array}$ & $\begin{array}{l}\text { Streamflow } \\
\text { (cubic feet } \\
\text { per second) }\end{array}$ & $\begin{array}{l}\text { Rain- } \\
\text { fall } \\
\text { (inches) }\end{array}$ \\
\hline $\begin{array}{l}1400 \\
1405 \\
1410 \\
1415 \\
1420\end{array}$ & $\begin{array}{l}0.3 \\
0.3 \\
0.3 \\
0.3 \\
0.3\end{array}$ & $\begin{array}{l}0.00 \\
0.00 \\
0.00 \\
0.00 \\
0.00\end{array}$ & $\begin{array}{l}1525 \\
1530 \\
1535 \\
1540 \\
1545\end{array}$ & $\begin{array}{l}0.3 \\
0.3 \\
0.3 \\
0.3 \\
0.3\end{array}$ & $\begin{array}{l}0.00 \\
0.00 \\
0.00 \\
0.00 \\
0.00\end{array}$ & $\begin{array}{l}1650 \\
1655 \\
1700 \\
1705 \\
1710\end{array}$ & $\begin{array}{l}0.3 \\
0.3 \\
0.3 \\
0.2 \\
0.2\end{array}$ & $\begin{array}{l}0.00 \\
0.00 \\
0.00 \\
0.00 \\
0.00\end{array}$ \\
\hline $\begin{array}{l}1425 \\
1430 \\
1435 \\
1440 \\
1445\end{array}$ & $\begin{array}{l}0.3 \\
0.3 \\
0.3 \\
0.3 \\
0.3\end{array}$ & $\begin{array}{l}0.00 \\
0.00 \\
0.00 \\
0.00 \\
0.00\end{array}$ & $\begin{array}{l}1550 \\
1555 \\
1600 \\
1605 \\
1610\end{array}$ & $\begin{array}{l}0.3 \\
0.3 \\
0.3 \\
0.3 \\
0.3\end{array}$ & $\begin{array}{l}0.00 \\
0.00 \\
0.00 \\
0.00 \\
0.00\end{array}$ & $\begin{array}{l}1715 \\
1720 \\
1725 \\
1730 \\
1735\end{array}$ & $\begin{array}{l}0.2 \\
0.2 \\
0.2 \\
0.2 \\
0.2\end{array}$ & $\begin{array}{l}0.00 \\
0.00 \\
0.00 \\
0.00 \\
0.00\end{array}$ \\
\hline $\begin{array}{l}1450 \\
1455 \\
1500 \\
1505 \\
1510\end{array}$ & $\begin{array}{l}0.3 \\
0.3 \\
0.3 \\
0.3 \\
0.3\end{array}$ & $\begin{array}{l}0.00 \\
0.00 \\
0.00 \\
0.00 \\
0.00\end{array}$ & $\begin{array}{l}1615 \\
1620 \\
1625 \\
1630 \\
1635\end{array}$ & $\begin{array}{l}0.3 \\
0.3 \\
0.3 \\
0.3 \\
0.3\end{array}$ & $\begin{array}{l}0.00 \\
0.00 \\
0.00 \\
0.00 \\
0.00\end{array}$ & $\begin{array}{l}1740 \\
1745 \\
1750 \\
1755 \\
1800\end{array}$ & $\begin{array}{l}0.2 \\
0.2 \\
0.2 \\
0.2 \\
0.2\end{array}$ & $\begin{array}{l}0.00 \\
0.00 \\
0.00 \\
0.00 \\
0.00\end{array}$ \\
\hline $\begin{array}{l}1515 \\
1520\end{array}$ & $\begin{array}{l}0.3 \\
0.3\end{array}$ & $\begin{array}{l}0.00 \\
0.00\end{array}$ & $\begin{array}{l}1640 \\
1645\end{array}$ & $\begin{array}{l}0.3 \\
0.3\end{array}$ & $\begin{array}{l}0.00 \\
0.00\end{array}$ & & & \\
\hline
\end{tabular}




\section{Station 02169505, Rocky Branch at Columbia, S.C.}

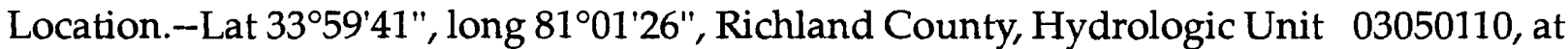
culvert on Pickens Street (State secondary road 2077), $0.7 \mathrm{mi}$ southeast of the State Capitol Building, and $2.0 \mathrm{mi}$ upstream from the mouth at the Congaree River.

Period of record.-- August 14, 1984 to December 6, 1990.

Gage.--Digital stage recorder with 5-minute punch interval. The recorder is housed in a metal shelter atop a stilling well attached to the right upstream wingwall of a triple $7.1 \mathrm{ft}$ by $7 \mathrm{ft}$ concrete box culvert. A sealed intake pipe extends $20 \mathrm{ft}$ upstream to a separate stilling basin (sand trap) with a removable lid. An enameled staff gage is attached on the right upstream bank opposite the recording gage intake. One c"eststage indicator is located on the right downstream wingwall. The second crest-stage indicator is located on the left upstream bank opposite the stage recorder intake.

Rating.--The stage-streamflow relation is defined by current meter measurements $\varepsilon$ nd the dye-dilution method to approximately $250 \mathrm{ft}^{3} / \mathrm{s}$. The stage-streamflow relation was extended to $1,175 \mathrm{ft}^{3} / \mathrm{s}$ using indirect computational methods.

Rain gage and location.-Station number 335940081013100 , lat $33^{\circ} 59^{\prime} 40^{\prime \prime}$, long $81^{\circ} 01^{\prime} 31^{\prime \prime}$. A shelter containing a digital cumulative rainfall recorder with a 5-minute punch interval in a parking lot at the corner of Blossom (U.S. Highway 21) and Pickens Streets (State secondary road 2077) at the University of South Carolina, and $0.6 \mathrm{mi}$ southeast from the State Capitol Building.

Selected basin characteristics.--

Drainage area $-2.41 \mathrm{mi}^{2}$

Physiographic province - Inner Coastal Plain

Channel slope -- $75.5 \mathrm{ft} / \mathrm{mi}$

Channel length - $1.90 \mathrm{mi}$

Total impervious area -- 51.0 percent

Basin development factor -- 12

2-year, 2-hour rainfall amount -- 2.15 in.

Flood frequency data: $\mathrm{UQ}_{2} \quad 1,120 \mathrm{ft}^{3} / \mathrm{s}$

$\mathrm{UQ}_{5} \quad 1,660 \mathrm{ft}^{3} / \mathrm{s}$

$\mathrm{UQ}_{10} \quad 1,980 \mathrm{ft}^{3} / \mathrm{s}$

$\mathrm{UQ}_{25} \quad 2,310 \mathrm{ft}^{3} / \mathrm{s}$

$\mathrm{UQ}_{50} \quad 2,530 \mathrm{ft}^{3} / \mathrm{s}$

$\mathrm{UQ}_{100} \quad 2,720 \mathrm{ft}^{3} / \mathrm{s}$

$\mathrm{UQ}_{500} \quad 3,090 \mathrm{ft}^{3} / \mathrm{s}$ 


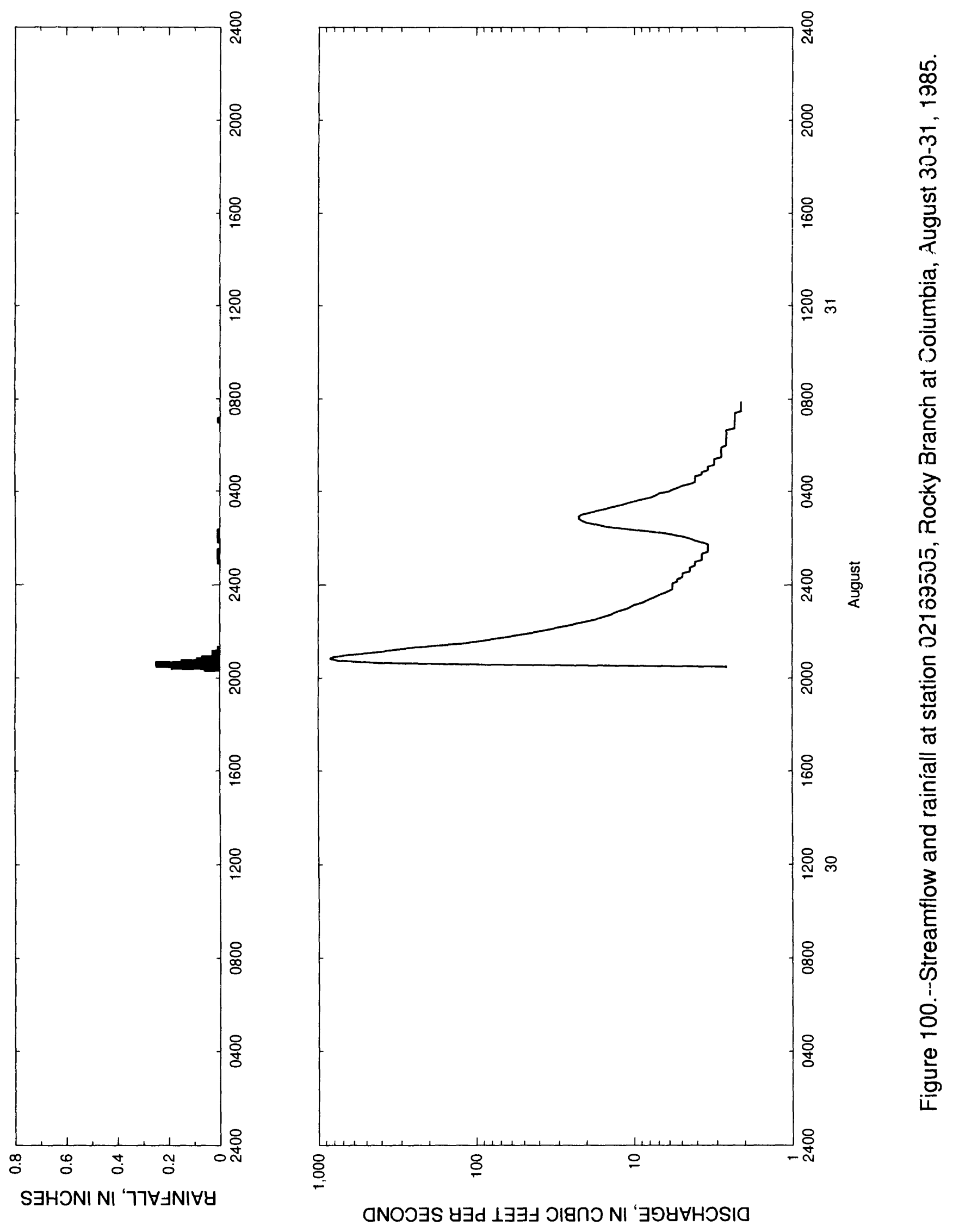


Table 99. - Streamflow and rainfa11 at station 02169505, Rocky Branch at Columbia, August $30-31,1985$

\begin{tabular}{|c|c|c|c|c|c|c|c|c|}
\hline $\begin{array}{l}\text { Time } \\
\text { (hours) }\end{array}$ & $\begin{array}{l}\text { Streamflow } \\
\text { (cubic feet } \\
\text { per second) }\end{array}$ & $\begin{array}{l}\text { Rain- } \\
\text { fall } \\
\text { (inches) }\end{array}$ & $\begin{array}{l}\text { Time } \\
\text { (hours) }\end{array}$ & $\begin{array}{l}\text { Streamflow } \\
\text { (cubic feet } \\
\text { per second) }\end{array}$ & $\begin{array}{l}\text { Rain- } \\
\text { fall } \\
\text { (inches) }\end{array}$ & $\begin{array}{l}\text { Time } \\
\text { (hours) }\end{array}$ & $\begin{array}{l}\text { Streamflow } \\
\text { (cubic feet } \\
\text { per second) }\end{array}$ & $\begin{array}{l}\text { Rain- } \\
\text { fall } \\
\text { (inches) }\end{array}$ \\
\hline $\begin{array}{c}\text { August } \\
2025 \\
2030 \\
2035 \\
2040\end{array}$ & $\begin{array}{r}30,1985 \\
2.6 \\
2.6 \\
80.0 \\
414.0\end{array}$ & $\begin{array}{l}0.06 \\
0.19 \\
0.25 \\
0.15\end{array}$ & $\begin{array}{l}0015 \\
0020 \\
0025 \\
0030 \\
0035\end{array}$ & $\begin{array}{l}5.3 \\
4.9 \\
4.9 \\
4.9 \\
4.4\end{array}$ & $\begin{array}{l}0.00 \\
0.00 \\
0.00 \\
0.00 \\
0.00\end{array}$ & $\begin{array}{l}0415 \\
0420 \\
0425 \\
0430 \\
0435\end{array}$ & $\begin{array}{l}4 \cdot 9 \\
4.4 \\
4.1 \\
4.1 \\
4 \cdot 1\end{array}$ & $\begin{array}{l}0.00 \\
0.00 \\
0.00 \\
0.00 \\
0.00\end{array}$ \\
\hline $\begin{array}{l}2045 \\
2050 \\
2055 \\
2100 \\
2105\end{array}$ & $\begin{array}{l}747.0 \\
847.0 \\
796.0 \\
644.0 \\
490.0\end{array}$ & $\begin{array}{l}0.09 \\
0.07 \\
0.02 \\
0.03 \\
0.03\end{array}$ & $\begin{array}{l}0040 \\
0045 \\
0050 \\
0055 \\
0100\end{array}$ & $\begin{array}{l}4.4 \\
4.4 \\
4.1 \\
4.1 \\
4.1\end{array}$ & $\begin{array}{l}0.00 \\
0.00 \\
0.00 \\
0.00 \\
0.01\end{array}$ & $\begin{array}{l}0440 \\
0445 \\
0450 \\
0455 \\
0500\end{array}$ & $\begin{array}{l}4.1 \\
3.7 \\
3.7 \\
3.4 \\
3.4\end{array}$ & $\begin{array}{l}0.00 \\
0.00 \\
0.00 \\
0.00 \\
0.00\end{array}$ \\
\hline $\begin{array}{l}2110 \\
2115 \\
2120 \\
2125 \\
2130\end{array}$ & $\begin{array}{l}388.0 \\
310.0 \\
246.0 \\
174.0 \\
124.0\end{array}$ & $\begin{array}{l}0.00 \\
0.01 \\
0.00 \\
0.00 \\
0.00\end{array}$ & $\begin{array}{l}0105 \\
0110 \\
0115 \\
0120 \\
0125\end{array}$ & $\begin{array}{l}3.7 \\
3.7 \\
3.7 \\
3.7 \\
3.4\end{array}$ & $\begin{array}{l}0.00 \\
0.01 \\
0.00 \\
0.00 \\
0.01\end{array}$ & $\begin{array}{l}0505 \\
0510 \\
0515 \\
0520 \\
0525\end{array}$ & $\begin{array}{l}3.4 \\
3.1 \\
3.1 \\
3.1 \\
3.1\end{array}$ & $\begin{array}{l}0.00 \\
0.00 \\
0.00 \\
0.00 \\
0.00\end{array}$ \\
\hline $\begin{array}{l}2135 \\
2140 \\
2145 \\
2150 \\
2155\end{array}$ & $\begin{array}{l}97.4 \\
81.1 \\
67.7 \\
56.9 \\
48.3\end{array}$ & $\begin{array}{l}0.00 \\
0.00 \\
0.00 \\
0.00 \\
0.00\end{array}$ & $\begin{array}{l}0130 \\
0135 \\
0140 \\
0145 \\
0150\end{array}$ & $\begin{array}{l}3.4 \\
3.4 \\
3.4 \\
3.4 \\
3.7\end{array}$ & $\begin{array}{l}0.00 \\
0.00 \\
0.00 \\
0.00 \\
0.00\end{array}$ & $\begin{array}{l}0530 \\
0535 \\
0540 \\
0545 \\
0550\end{array}$ & $\begin{array}{l}2.8 \\
2.8 \\
2.8 \\
2.8 \\
2.8\end{array}$ & $\begin{array}{l}0.00 \\
0.00 \\
0.00 \\
0.00 \\
0.00\end{array}$ \\
\hline $\begin{array}{l}2200 \\
2205 \\
2210 \\
2215 \\
2220\end{array}$ & $\begin{array}{l}40.9 \\
35.3 \\
31.0 \\
26.8 \\
23.7\end{array}$ & $\begin{array}{l}0.00 \\
0.00 \\
0.00 \\
0.00 \\
0.00\end{array}$ & $\begin{array}{l}0155 \\
0200 \\
0205 \\
0210 \\
0215\end{array}$ & $\begin{array}{l}4.1 \\
4.4 \\
4.9 \\
5.7 \\
6.9\end{array}$ & $\begin{array}{l}0.01 \\
0.01 \\
0.01 \\
0.01 \\
0.01\end{array}$ & $\begin{array}{l}0555 \\
0600 \\
0605 \\
0610 \\
0615\end{array}$ & $\begin{array}{l}2.8 \\
2.6 \\
2.6 \\
2.6 \\
2.6\end{array}$ & $\begin{array}{l}0.00 \\
0.00 \\
0.00 \\
0.00 \\
0.00\end{array}$ \\
\hline $\begin{array}{l}2225 \\
2230 \\
2235 \\
2240 \\
2245\end{array}$ & $\begin{array}{l}20.6 \\
18.4 \\
16.4 \\
15.1 \\
13.8\end{array}$ & $\begin{array}{l}0.00 \\
0.00 \\
0.00 \\
0.00 \\
0.00\end{array}$ & $\begin{array}{l}0220 \\
0225 \\
0230 \\
0235 \\
0240\end{array}$ & $\begin{array}{r}9.3 \\
12.0 \\
15.1 \\
17.1 \\
19.9\end{array}$ & $\begin{array}{l}0.00 \\
0.00 \\
0.00 \\
0.00 \\
0.00\end{array}$ & $\begin{array}{l}0620 \\
0625 \\
0630 \\
0635 \\
0640\end{array}$ & $\begin{array}{l}2.6 \\
2.6 \\
2.6 \\
2.6 \\
2.6\end{array}$ & $\begin{array}{l}0.00 \\
0.00 \\
0.00 \\
0.00 \\
0.00\end{array}$ \\
\hline $\begin{array}{l}2250 \\
2255 \\
2300 \\
2305 \\
2310\end{array}$ & $\begin{array}{r}13.2 \\
12.0 \\
10.9 \\
10.4 \\
9.9\end{array}$ & $\begin{array}{l}0.00 \\
0.00 \\
0.00 \\
0.00 \\
0.00\end{array}$ & $\begin{array}{l}0245 \\
0250 \\
0255 \\
0300 \\
0305\end{array}$ & $\begin{array}{l}21.4 \\
22.2 \\
22.2 \\
21.4 \\
19.1\end{array}$ & $\begin{array}{l}0.00 \\
0.00 \\
0.00 \\
0.00 \\
0.00\end{array}$ & $\begin{array}{l}0645 \\
0650 \\
0655 \\
0700 \\
0705\end{array}$ & $\begin{array}{l}2.3 \\
2.3 \\
2.3 \\
2.3 \\
2.3\end{array}$ & $\begin{array}{l}0.00 \\
0.00 \\
0.00 \\
0.00 \\
0.01\end{array}$ \\
\hline $\begin{array}{l}2315 \\
2320 \\
2325 \\
2330 \\
2335\end{array}$ & $\begin{array}{l}8.8 \\
8.3 \\
7.8 \\
7.3 \\
6.9\end{array}$ & $\begin{array}{l}0.00 \\
0.00 \\
0.00 \\
0.00 \\
0.00\end{array}$ & $\begin{array}{l}0310 \\
0315 \\
0320 \\
0325 \\
0330\end{array}$ & $\begin{array}{l}17.1 \\
15.1 \\
13.8 \\
12.0 \\
10.9\end{array}$ & $\begin{array}{l}0.00 \\
0.00 \\
0.00 \\
0.00 \\
0.00\end{array}$ & $\begin{array}{l}0710 \\
0715 \\
0720 \\
0725 \\
0730\end{array}$ & $\begin{array}{l}2.3 \\
2.3 \\
2.3 \\
2.3 \\
2.1\end{array}$ & $\begin{array}{l}0.00 \\
0.00 \\
0.00 \\
0.00 \\
0.00\end{array}$ \\
\hline $\begin{array}{c}2340 \\
2345 \\
2350 \\
2355 \\
\text { August }\end{array}$ & $\begin{array}{r}6.4 \\
6.0 \\
5.7 \\
5.7 \\
31,1985\end{array}$ & $\begin{array}{l}0.00 \\
0.00 \\
0.00 \\
0.00\end{array}$ & $\begin{array}{l}0335 \\
0340 \\
0345 \\
0350 \\
0355\end{array}$ & $\begin{array}{l}9.9 \\
8.8 \\
7.8 \\
7.3 \\
6.9\end{array}$ & $\begin{array}{l}0.00 \\
0.00 \\
0.00 \\
0.00 \\
0.00\end{array}$ & $\begin{array}{l}0735 \\
0740 \\
0745 \\
0750 \\
0755\end{array}$ & $\begin{array}{l}2.1 \\
2.1 \\
2.1 \\
2.1 \\
2.1\end{array}$ & $\begin{array}{l}0.00 \\
0.00 \\
0.00 \\
0.00 \\
0.00\end{array}$ \\
\hline $\begin{array}{l}0000 \\
0005 \\
0010\end{array}$ & $\begin{array}{l}5.7 \\
5.7 \\
5.3\end{array}$ & $\begin{array}{l}0.00 \\
0.00 \\
0.00\end{array}$ & $\begin{array}{l}0400 \\
0405 \\
0410\end{array}$ & $\begin{array}{l}6.0 \\
5.7 \\
5.3\end{array}$ & $\begin{array}{l}0.00 \\
0.00 \\
0.00\end{array}$ & 0800 & 2.1 & 0.00 \\
\hline
\end{tabular}




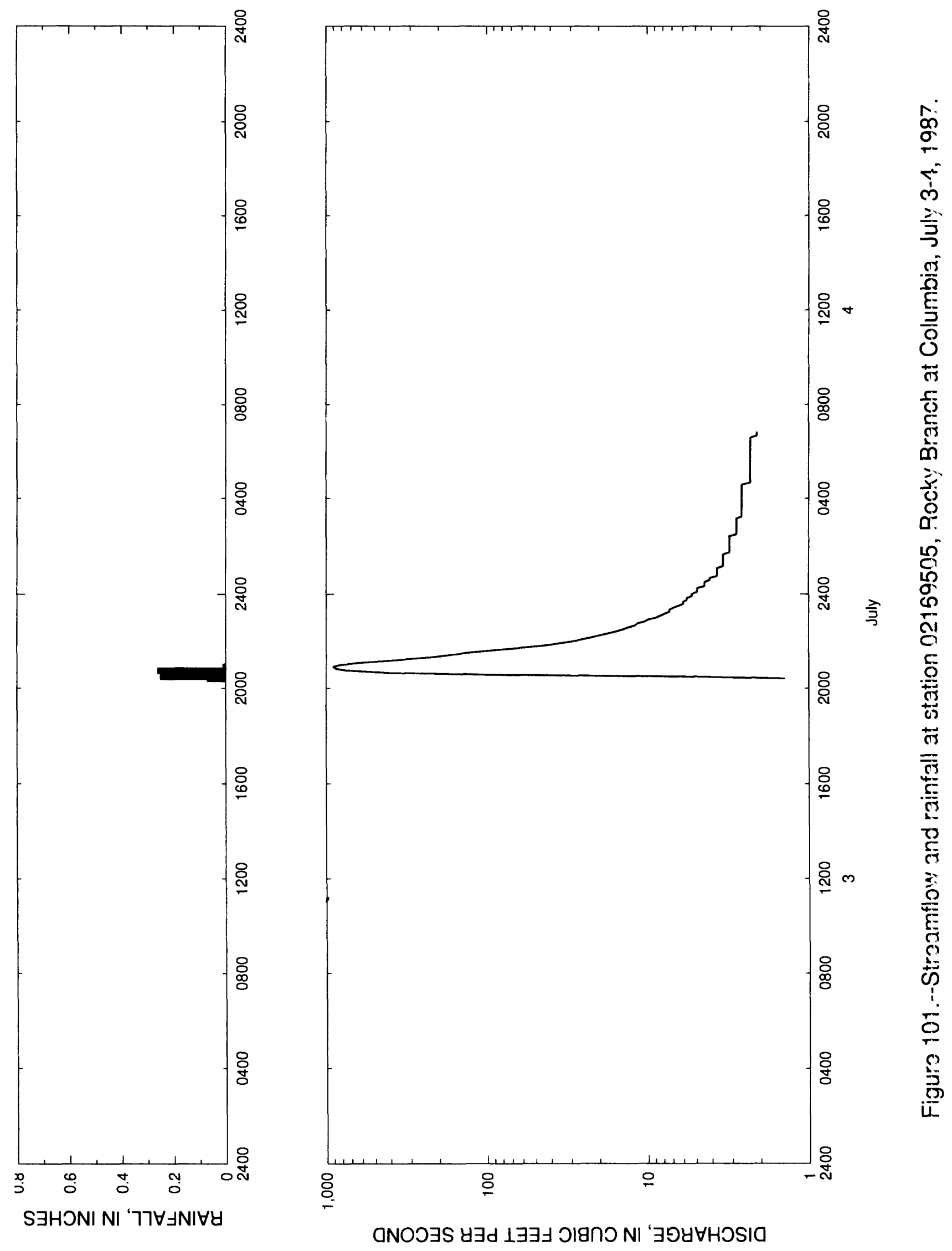


Table 100.--Streamflow and rainfall at station 02169505, Rocky Branch at Columbia, July $3-4,1987$

\begin{tabular}{|c|c|c|c|c|c|c|c|c|c|}
\hline $\begin{array}{l}\text { Time } \\
\text { (hours) }\end{array}$ & $\begin{array}{l}\text { Streamflow } \\
\text { (cubic feet } \\
\text { per second) }\end{array}$ & $\begin{array}{l}\text { Rain- } \\
\text { fall } \\
\text { (inches) }\end{array}$ & $\begin{array}{l}\text { Time } \\
\text { (hours) }\end{array}$ & $\begin{array}{l}\text { Str } \\
\text { (cub } \\
\text { per }\end{array}$ & $\begin{array}{l}\text { eamflow } \\
\text { ic feet } \\
\text { second) }\end{array}$ & $\begin{array}{l}\text { Rain- } \\
\text { fall } \\
\text { (inches) }\end{array}$ & $\begin{array}{l}\text { Time } \\
\text { (hours) }\end{array}$ & $\begin{array}{l}\text { Streamflow } \\
\text { (cubic feet } \\
\text { per second) }\end{array}$ & $\begin{array}{l}\text { Rain- } \\
\text { fall } \\
\text { (inches) }\end{array}$ \\
\hline $\begin{array}{l}\text { July } 3, \\
2025 \\
2030 \\
2035 \\
2040\end{array}$ & $\begin{array}{r}1987 \quad 1.4 \\
5.7 \\
94.7 \\
412.0\end{array}$ & $\begin{array}{l}0.07 \\
0.25 \\
0.15 \\
0.08\end{array}$ & $\begin{array}{l}\text { July } 4 \\
0000 \\
0005 \\
0010 \\
0015\end{array}$ & 1987 & $\begin{array}{l}5.3 \\
4.9 \\
4.9 \\
4.9\end{array}$ & $\begin{array}{l}0.00 \\
0.00 \\
0.00 \\
0.00\end{array}$ & $\begin{array}{l}0335 \\
0340 \\
0345 \\
0350 \\
0355\end{array}$ & $\begin{array}{l}2.6 \\
2.6 \\
2.6 \\
2.6 \\
2.6\end{array}$ & $\begin{array}{l}0.00 \\
0.00 \\
0.00 \\
0.00 \\
0.00\end{array}$ \\
\hline $\begin{array}{l}2045 \\
2050 \\
2055 \\
2100 \\
2105\end{array}$ & $\begin{array}{l}722.0 \\
871.0 \\
907.0 \\
825.0 \\
623.0\end{array}$ & $\begin{array}{l}0.26 \\
0.00 \\
0.01 \\
0.00 \\
0.00\end{array}$ & $\begin{array}{l}0020 \\
0025 \\
0030 \\
0035 \\
0040\end{array}$ & & $\begin{array}{l}4.4 \\
4.4 \\
4.4 \\
4.1 \\
4.1\end{array}$ & $\begin{array}{l}0.00 \\
0.00 \\
0.00 \\
0.00 \\
0.00\end{array}$ & $\begin{array}{l}0400 \\
0405 \\
0410 \\
0415 \\
0420\end{array}$ & $\begin{array}{l}2.6 \\
2.6 \\
2.6 \\
2.6 \\
2.6\end{array}$ & $\begin{array}{l}0.00 \\
0.00 \\
0.00 \\
0.00 \\
0.00\end{array}$ \\
\hline $\begin{array}{l}2110 \\
2115 \\
2120 \\
2125 \\
2130\end{array}$ & $\begin{array}{l}433.0 \\
301.0 \\
217.0 \\
173.0 \\
141.0\end{array}$ & $\begin{array}{l}0.00 \\
0.00 \\
0.00 \\
0.00 \\
0.00\end{array}$ & $\begin{array}{l}0045 \\
0050 \\
0055 \\
0100 \\
0105\end{array}$ & & $\begin{array}{l}3.7 \\
3.7 \\
3.7 \\
3.7 \\
3.7\end{array}$ & $\begin{array}{l}0.00 \\
0.00 \\
0.00 \\
0.00 \\
0.00\end{array}$ & $\begin{array}{l}0425 \\
0430 \\
0435 \\
0440 \\
0445\end{array}$ & $\begin{array}{l}2.6 \\
2.6 \\
2.6 \\
2.3 \\
2.3\end{array}$ & $\begin{array}{l}0.00 \\
0.00 \\
0.00 \\
0.00 \\
0.00\end{array}$ \\
\hline $\begin{array}{l}2135 \\
2140 \\
2145 \\
2150 \\
2155\end{array}$ & $\begin{array}{r}107.0 \\
77.6 \\
55.8 \\
41.9 \\
35.3\end{array}$ & $\begin{array}{l}0.00 \\
0.00 \\
0.00 \\
0.00 \\
0.00\end{array}$ & $\begin{array}{l}0110 \\
0115 \\
0120 \\
0125 \\
0130\end{array}$ & & $\begin{array}{l}3.4 \\
3.4 \\
3.4 \\
3.4 \\
3.4\end{array}$ & $\begin{array}{l}0.00 \\
0.00 \\
0.00 \\
0.00 \\
0.00\end{array}$ & $\begin{array}{l}0450 \\
0455 \\
0500 \\
0505 \\
0510\end{array}$ & $\begin{array}{l}2.3 \\
2.3 \\
2.3 \\
2.3 \\
2.3\end{array}$ & $\begin{array}{l}0.00 \\
0.00 \\
0.00 \\
0.00 \\
0.00\end{array}$ \\
\hline $\begin{array}{l}2200 \\
2205 \\
2210 \\
2215 \\
2220\end{array}$ & $\begin{array}{l}29.3 \\
25.2 \\
22.2 \\
19.9 \\
17.8\end{array}$ & $\begin{array}{l}0.00 \\
0.00 \\
0.00 \\
0.00 \\
0.00\end{array}$ & $\begin{array}{l}0135 \\
0140 \\
0145 \\
0150 \\
0155\end{array}$ & & $\begin{array}{l}3.4 \\
3.4 \\
3.1 \\
3.1 \\
3.1\end{array}$ & $\begin{array}{l}0.00 \\
0.00 \\
0.00 \\
0.00 \\
0.00\end{array}$ & $\begin{array}{l}0515 \\
0520 \\
0525 \\
0530 \\
0535\end{array}$ & $\begin{array}{l}2.3 \\
2.3 \\
2.3 \\
2.3 \\
2.3\end{array}$ & $\begin{array}{l}0.00 \\
0.00 \\
0.00 \\
0.00 \\
0.00\end{array}$ \\
\hline $\begin{array}{l}2225 \\
2230 \\
2235 \\
2240 \\
2245\end{array}$ & $\begin{array}{l}15.8 \\
14.4 \\
13.2 \\
12.0 \\
11.5\end{array}$ & $\begin{array}{l}0.00 \\
0.00 \\
0.00 \\
0.00 \\
0.00\end{array}$ & $\begin{array}{l}0200 \\
0205 \\
0210 \\
0215 \\
0220\end{array}$ & & $\begin{array}{l}3.1 \\
3.1 \\
3.1 \\
3.1 \\
3.1\end{array}$ & $\begin{array}{l}0.00 \\
0.00 \\
0.00 \\
0.00 \\
0.00\end{array}$ & $\begin{array}{l}0540 \\
0545 \\
0550 \\
0555 \\
0600\end{array}$ & $\begin{array}{l}2.3 \\
2.3 \\
2.3 \\
2.3 \\
2.3\end{array}$ & $\begin{array}{l}0.00 \\
0.00 \\
0.00 \\
0.00 \\
0.00\end{array}$ \\
\hline $\begin{array}{l}2250 \\
2255 \\
2300 \\
2305 \\
2310\end{array}$ & $\begin{array}{r}10.4 \\
9.9 \\
8.8 \\
8.3 \\
7.8\end{array}$ & $\begin{array}{l}0.00 \\
0.00 \\
0.00 \\
0.00 \\
0.00\end{array}$ & $\begin{array}{l}0225 \\
0230 \\
0235 \\
0240 \\
0245\end{array}$ & & $\begin{array}{l}3.1 \\
2.8 \\
2.8 \\
2.8 \\
2.8\end{array}$ & $\begin{array}{l}0.00 \\
0.00 \\
0.00 \\
0.00 \\
0.00\end{array}$ & $\begin{array}{l}0605 \\
0610 \\
0615 \\
0620 \\
0625\end{array}$ & $\begin{array}{l}2.3 \\
2.3 \\
2.3 \\
2.3 \\
2.3\end{array}$ & $\begin{array}{l}0.00 \\
0.00 \\
0.00 \\
0.00 \\
0.00\end{array}$ \\
\hline $\begin{array}{l}2315 \\
2320 \\
2325 \\
2330 \\
2335\end{array}$ & $\begin{array}{l}7.3 \\
7.3 \\
6.9 \\
6.4 \\
6.0\end{array}$ & $\begin{array}{l}0.00 \\
0.00 \\
0.00 \\
0.00 \\
0.00\end{array}$ & $\begin{array}{l}0250 \\
0255 \\
0300 \\
0305 \\
0310\end{array}$ & & $\begin{array}{l}2.8 \\
2.8 \\
2.8 \\
2.8 \\
2.8\end{array}$ & $\begin{array}{l}0.00 \\
0.00 \\
0.00 \\
0.00 \\
0.00\end{array}$ & $\begin{array}{l}0630 \\
0635 \\
0640 \\
0645 \\
0650\end{array}$ & $\begin{array}{l}2.3 \\
2.3 \\
2.1 \\
2.1 \\
2.1\end{array}$ & $\begin{array}{l}0.00 \\
0.00 \\
0.00 \\
0.00 \\
0.00\end{array}$ \\
\hline $\begin{array}{l}2340 \\
2345 \\
2350 \\
2355\end{array}$ & $\begin{array}{l}6.0 \\
5.7 \\
5.7 \\
5.3\end{array}$ & $\begin{array}{l}0.00 \\
0.00 \\
0.00 \\
0.00\end{array}$ & $\begin{array}{l}0315 \\
0320 \\
0325 \\
0330\end{array}$ & & $\begin{array}{l}2.6 \\
2.6 \\
2.6 \\
2.6\end{array}$ & $\begin{array}{l}0.00 \\
0.00 \\
0.00 \\
0.00\end{array}$ & $\begin{array}{l}0655 \\
0700\end{array}$ & $\begin{array}{l}2.1 \\
2.1\end{array}$ & $\begin{array}{l}0.00 \\
0.00\end{array}$ \\
\hline
\end{tabular}



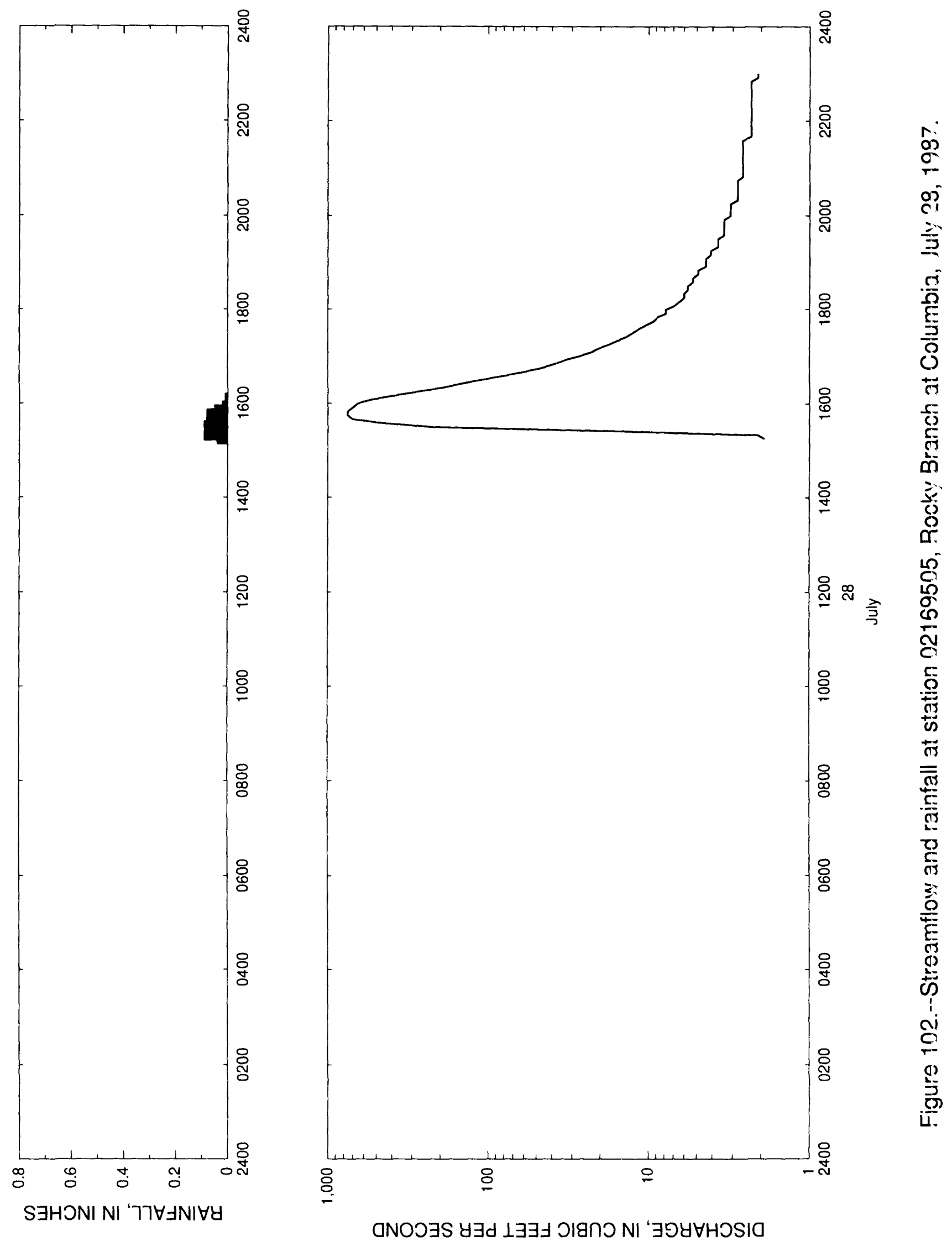
Table 101.--Streamflow and rainfall at station 02169505, Rocky Branch at Columbia, July 28, 1987

\begin{tabular}{|c|c|c|c|c|c|c|c|c|}
\hline $\begin{array}{l}\text { Time } \\
\text { (hours) }\end{array}$ & $\begin{array}{l}\text { Streamflow } \\
\text { (cubic feet } \\
\text { per second) }\end{array}$ & $\begin{array}{l}\text { Rain- } \\
\text { fall } \\
\text { (inches) }\end{array}$ & $\begin{array}{l}\text { Time } \\
\text { (hours) }\end{array}$ & $\begin{array}{l}\text { Streamflow } \\
\text { (cubic feet } \\
\text { per second) }\end{array}$ & $\begin{array}{l}\text { Rain- } \\
\text { fall } \\
\text { (inches) }\end{array}$ & $\begin{array}{l}\text { Time } \\
\text { (hours) }\end{array}$ & $\begin{array}{l}\text { Streamflow } \\
\text { (cubic feet } \\
\text { per second) }\end{array}$ & $\begin{array}{l}\text { Rain- } \\
\text { fall } \\
\text { (inches) }\end{array}$ \\
\hline $\begin{array}{l}\text { July 28, } \\
1515 \\
1520 \\
1525 \\
1530\end{array}$ & $\begin{array}{r}1987 \\
1.9 \\
2.1 \\
15.1 \\
218.0\end{array}$ & $\begin{array}{l}0.04 \\
0.09 \\
0.03 \\
0.09\end{array}$ & $\begin{array}{l}1750 \\
1755 \\
1800 \\
1805 \\
1810\end{array}$ & $\begin{array}{l}8.8 \\
7.8 \\
7.8 \\
6.9 \\
6.4\end{array}$ & $\begin{array}{l}0.00 \\
0.00 \\
0.00 \\
0.00 \\
0.00\end{array}$ & $\begin{array}{l}2030 \\
2035 \\
2040 \\
2045 \\
2050\end{array}$ & $\begin{array}{l}2.8 \\
2.8 \\
2.8 \\
2.8 \\
2.6\end{array}$ & $\begin{array}{l}0.00 \\
0.00 \\
0.00 \\
0.0 C \\
0.0 C\end{array}$ \\
\hline $\begin{array}{l}1535 \\
1540 \\
1545 \\
1550 \\
1555\end{array}$ & $\begin{array}{l}458.0 \\
699.0 \\
760.0 \\
751.0 \\
697.0\end{array}$ & $\begin{array}{l}0.05 \\
0.02 \\
0.08 \\
0.05 \\
0.02\end{array}$ & $\begin{array}{l}1815 \\
1820 \\
1825 \\
1830 \\
1835\end{array}$ & $\begin{array}{l}6.0 \\
6.0 \\
5.7 \\
5.7 \\
5.3\end{array}$ & $\begin{array}{l}0.00 \\
0.00 \\
0.00 \\
0.00 \\
0.00\end{array}$ & $\begin{array}{l}2055 \\
2100 \\
2105 \\
2110 \\
2115\end{array}$ & $\begin{array}{l}2.6 \\
2.6 \\
2.6 \\
2.6 \\
2.6\end{array}$ & $\begin{array}{l}0.05 \\
0.05 \\
0.00 \\
0.00 \\
0.00\end{array}$ \\
\hline $\begin{array}{l}1600 \\
1605 \\
1610 \\
1615 \\
1620\end{array}$ & $\begin{array}{l}650.0 \\
533.0 \\
388.0 \\
274.0 \\
194.0\end{array}$ & $\begin{array}{l}0.01 \\
0.01 \\
0.00 \\
0.00 \\
0.00\end{array}$ & $\begin{array}{l}1840 \\
1845 \\
1850 \\
1855 \\
1900\end{array}$ & $\begin{array}{l}5.3 \\
4.9 \\
4.9 \\
4.4 \\
4.4\end{array}$ & $\begin{array}{l}0.00 \\
0.00 \\
0.00 \\
0.00 \\
0.00\end{array}$ & $\begin{array}{l}2120 \\
2125 \\
2130 \\
2135 \\
2140\end{array}$ & $\begin{array}{l}2.6 \\
2.6 \\
2.6 \\
2.6 \\
2.3\end{array}$ & $\begin{array}{l}0.00 \\
0.00 \\
0.00 \\
0.00 \\
0.00\end{array}$ \\
\hline $\begin{array}{l}1625 \\
1630 \\
1635 \\
1640 \\
1645\end{array}$ & $\begin{array}{r}149.0 \\
110.0 \\
81.1 \\
61.5 \\
47.2\end{array}$ & $\begin{array}{l}0.00 \\
0.00 \\
0.00 \\
0.00 \\
0.00\end{array}$ & $\begin{array}{l}1905 \\
1910 \\
1915 \\
1920 \\
1925\end{array}$ & $\begin{array}{l}4.4 \\
4.1 \\
4.1 \\
3.7 \\
3.7\end{array}$ & $\begin{array}{l}0.00 \\
0.00 \\
0.00 \\
0.00 \\
0.00\end{array}$ & $\begin{array}{l}2145 \\
2150 \\
2155 \\
2200 \\
2205\end{array}$ & $\begin{array}{l}2.3 \\
2.3 \\
2.3 \\
2.3 \\
2.3\end{array}$ & $\begin{array}{l}0.00 \\
0.00 \\
0.00 \\
0.00 \\
0.00\end{array}$ \\
\hline $\begin{array}{l}1650 \\
1655 \\
1700 \\
1705 \\
1710\end{array}$ & $\begin{array}{l}39.0 \\
33.5 \\
27.6 \\
23.0 \\
20.6\end{array}$ & $\begin{array}{l}0.00 \\
0.00 \\
0.00 \\
0.00 \\
0.00\end{array}$ & $\begin{array}{l}1930 \\
1935 \\
1940 \\
1945 \\
1950\end{array}$ & $\begin{array}{l}3.7 \\
3.4 \\
3.4 \\
3.4 \\
3.4\end{array}$ & $\begin{array}{l}0.00 \\
0.00 \\
0.00 \\
0.00 \\
0.00\end{array}$ & $\begin{array}{l}2210 \\
2215 \\
2220 \\
2225 \\
2230\end{array}$ & $\begin{array}{l}2.3 \\
2.3 \\
2.3 \\
2.3 \\
2.3\end{array}$ & $\begin{array}{l}0.00 \\
0.00 \\
0.00 \\
0.00 \\
0.00\end{array}$ \\
\hline $\begin{array}{l}1715 \\
1720 \\
1725 \\
1730 \\
1735\end{array}$ & $\begin{array}{l}17.8 \\
15.8 \\
13.8 \\
12.6 \\
11.5\end{array}$ & $\begin{array}{l}0.00 \\
0.00 \\
0.00 \\
0.00 \\
0.00\end{array}$ & $\begin{array}{l}1955 \\
2000 \\
2005 \\
2010 \\
2015\end{array}$ & $\begin{array}{l}3.4 \\
3.1 \\
3.1 \\
3.1 \\
3.1\end{array}$ & $\begin{array}{l}0.00 \\
0.00 \\
0.00 \\
0.00 \\
0.00\end{array}$ & $\begin{array}{l}2235 \\
2240 \\
2245 \\
2250 \\
2255\end{array}$ & $\begin{array}{l}2.3 \\
2.3 \\
2.3 \\
2.3 \\
2.1\end{array}$ & $\begin{array}{l}0.00 \\
0.00 \\
0.00 \\
0.00 \\
0.00\end{array}$ \\
\hline $\begin{array}{l}1740 \\
1745\end{array}$ & $\begin{array}{r}10.4 \\
9.3\end{array}$ & $\begin{array}{l}0.00 \\
0.00\end{array}$ & $\begin{array}{l}2020 \\
2025\end{array}$ & $\begin{array}{l}2.8 \\
2.8\end{array}$ & $\begin{array}{l}0.00 \\
0.00\end{array}$ & 2300 & 2.1 & 0.00 \\
\hline
\end{tabular}




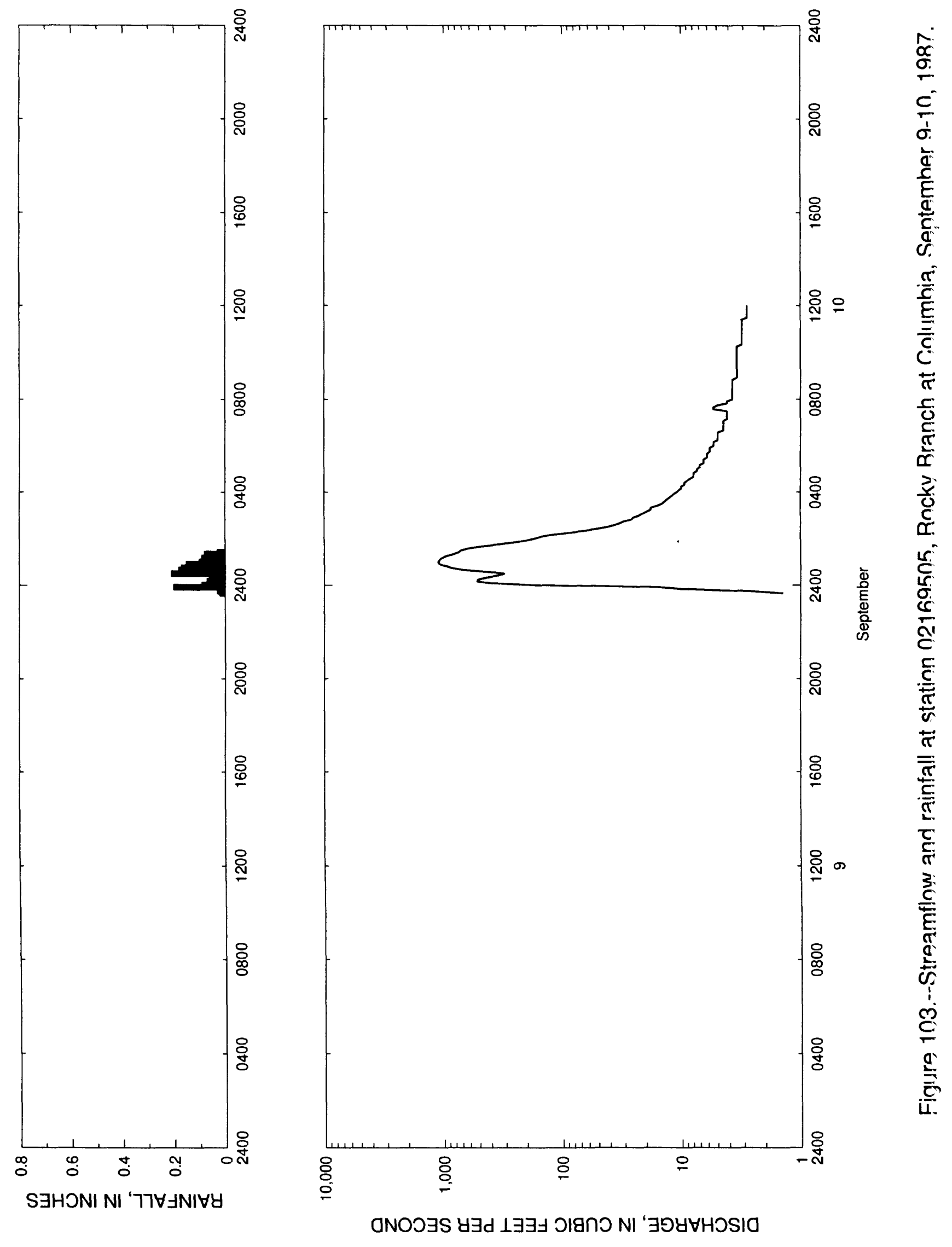


Table 102. - Streamflow and rainfal1 at station 02169505, Rocky Branch at Columbia, September $9-10,1987$

\begin{tabular}{|c|c|c|c|c|c|c|c|c|}
\hline $\begin{array}{l}\text { Time } \\
\text { (hours) }\end{array}$ & $\begin{array}{l}\text { Streamflow } \\
\text { (cubic feet } \\
\text { per second) }\end{array}$ & $\begin{array}{l}\text { Rain- } \\
\text { fall } \\
\text { (inches) }\end{array}$ & $\begin{array}{l}\text { Time } \\
\text { (hours) }\end{array}$ & $\begin{array}{l}\text { Streamflow } \\
\text { (cubic feet } \\
\text { per second) }\end{array}$ & $\begin{array}{l}\text { Rain- } \\
\text { fall } \\
\text { (inches) }\end{array}$ & $\begin{array}{l}\text { Time } \\
\text { (hours) }\end{array}$ & $\begin{array}{l}\text { Streamflow } \\
\text { (cubic feet } \\
\text { per second) }\end{array}$ & $\begin{array}{l}\text { Rain- } \\
\text { fall } \\
\text { (inches) }\end{array}$ \\
\hline $\begin{array}{l}\text { September } \\
2335 \\
2340 \\
2345 \\
2350\end{array}$ & $\begin{array}{r}9,1987 \\
1.4 \\
1.4 \\
2.6 \\
9.3\end{array}$ & $\begin{array}{l}0.02 \\
0.02 \\
0.03 \\
0.03\end{array}$ & $\begin{array}{l}0340 \\
0345 \\
0350 \\
0355 \\
0400\end{array}$ & $\begin{array}{l}13.2 \\
12.6 \\
12.0 \\
11.5 \\
10.9\end{array}$ & $\begin{array}{l}0.00 \\
0.00 \\
0.00 \\
0.00 \\
0.00\end{array}$ & $\begin{array}{l}0755 \\
0800 \\
0805 \\
0810 \\
0815\end{array}$ & $\begin{array}{l}4.1 \\
3.7 \\
3.7 \\
3.7 \\
3.7\end{array}$ & $\begin{array}{l}0.00 \\
0.00 \\
0.00 \\
0.00 \\
0.00\end{array}$ \\
\hline $\begin{array}{l}2355 \\
\text { September } \\
0000 \\
0005 \\
0010\end{array}$ & $\begin{array}{c}15.8 \\
10,1987 \\
152.0 \\
367.0 \\
516.0\end{array}$ & $\begin{array}{l}0.20 \\
0.09 \\
0.05 \\
0.07\end{array}$ & $\begin{array}{l}0405 \\
0410 \\
0415 \\
0420 \\
0425\end{array}$ & $\begin{array}{r}10.4 \\
9.9 \\
9.9 \\
9.3 \\
9.3\end{array}$ & $\begin{array}{l}0.00 \\
0.00 \\
0.00 \\
0.00 \\
0.00\end{array}$ & $\begin{array}{l}0820 \\
0825 \\
0830 \\
0835 \\
0840\end{array}$ & $\begin{array}{l}3.7 \\
3.7 \\
3.7 \\
3.7 \\
3.7\end{array}$ & $\begin{array}{l}0.00 \\
0.00 \\
0.00 \\
0.00 \\
0.00\end{array}$ \\
\hline $\begin{array}{l}0015 \\
0020 \\
0025 \\
0030 \\
0035\end{array}$ & $\begin{array}{l}514.0 \\
433.0 \\
349.0 \\
305.0 \\
416.0\end{array}$ & $\begin{array}{l}0.06 \\
0.01 \\
0.05 \\
0.21 \\
0.15\end{array}$ & $\begin{array}{l}0430 \\
0435 \\
0440 \\
0445 \\
0450\end{array}$ & $\begin{array}{l}8.8 \\
8.3 \\
7.8 \\
7.8 \\
7.8\end{array}$ & $\begin{array}{l}0.00 \\
0.00 \\
0.00 \\
0.00 \\
0.00\end{array}$ & $\begin{array}{l}0845 \\
0850 \\
0855 \\
0900 \\
0905\end{array}$ & $\begin{array}{l}3.7 \\
3.7 \\
3.4 \\
3.4 \\
3.4\end{array}$ & $\begin{array}{l}0.00 \\
0.00 \\
0.00 \\
0.00 \\
0.00\end{array}$ \\
\hline $\begin{array}{l}0040 \\
0045 \\
0050 \\
0055 \\
0100\end{array}$ & $\begin{array}{r}689.0 \\
855.0 \\
973.0 \\
1080.0 \\
1100.0\end{array}$ & $\begin{array}{l}0.18 \\
0.17 \\
0.15 \\
0.15 \\
0.10\end{array}$ & $\begin{array}{l}0455 \\
0500 \\
0505 \\
0510 \\
0515\end{array}$ & $\begin{array}{l}7.3 \\
7.3 \\
6.9 \\
6.9 \\
6.4\end{array}$ & $\begin{array}{l}0.00 \\
0.00 \\
0.00 \\
0.00 \\
0.00\end{array}$ & $\begin{array}{l}0910 \\
0915 \\
0920 \\
0925 \\
0930\end{array}$ & $\begin{array}{l}3.4 \\
3.4 \\
3.4 \\
3.4 \\
3.4\end{array}$ & $\begin{array}{l}0.00 \\
0.00 \\
0.00 \\
0.00 \\
0.00\end{array}$ \\
\hline $\begin{array}{l}0105 \\
0110 \\
0115 \\
0120 \\
0125\end{array}$ & $\begin{array}{r}1080.0 \\
1040.0 \\
941.0 \\
823.0 \\
745.0\end{array}$ & $\begin{array}{l}0.04 \\
0.09 \\
0.05 \\
0.08 \\
0.03\end{array}$ & $\begin{array}{l}0520 \\
0525 \\
0530 \\
0535 \\
0540\end{array}$ & $\begin{array}{l}6.4 \\
6.4 \\
6.0 \\
6.0 \\
6.0\end{array}$ & $\begin{array}{l}0.00 \\
0.00 \\
0.00 \\
0.00 \\
0.00\end{array}$ & $\begin{array}{l}0935 \\
0940 \\
0945 \\
0950 \\
0955\end{array}$ & $\begin{array}{l}3.4 \\
3.4 \\
3.4 \\
3.4 \\
3.4\end{array}$ & $\begin{array}{l}0.00 \\
0.00 \\
0.00 \\
0.00 \\
0.00\end{array}$ \\
\hline $\begin{array}{l}0130 \\
0135 \\
0140 \\
0145 \\
0150\end{array}$ & $\begin{array}{l}711.0 \\
617.0 \\
472.0 \\
343.0 \\
258.0\end{array}$ & $\begin{array}{l}0.00 \\
0.00 \\
0.00 \\
0.00 \\
0.00\end{array}$ & $\begin{array}{l}0545 \\
0550 \\
0555 \\
0600 \\
0605\end{array}$ & $\begin{array}{l}5.7 \\
5.7 \\
5.7 \\
5.3 \\
5.3\end{array}$ & $\begin{array}{l}0.00 \\
0.00 \\
0.00 \\
0.00 \\
0.00\end{array}$ & $\begin{array}{l}1000 \\
1005 \\
1010 \\
1015 \\
1020\end{array}$ & $\begin{array}{l}3.4 \\
3.4 \\
3.4 \\
3.4 \\
3.1\end{array}$ & $\begin{array}{l}0.00 \\
0.00 \\
0.00 \\
0.00 \\
0.00\end{array}$ \\
\hline $\begin{array}{l}0155 \\
0200 \\
0205 \\
0210 \\
0215\end{array}$ & $\begin{array}{r}204.0 \\
173.0 \\
152.0 \\
123.0 \\
89.6\end{array}$ & $\begin{array}{l}0.00 \\
0.00 \\
0.00 \\
0.00 \\
0.00\end{array}$ & $\begin{array}{l}0610 \\
0615 \\
0620 \\
0625 \\
0630\end{array}$ & $\begin{array}{l}5.3 \\
4.9 \\
4.9 \\
4.9 \\
4.9\end{array}$ & $\begin{array}{l}0.00 \\
0.00 \\
0.00 \\
0.00 \\
0.00\end{array}$ & $\begin{array}{l}1025 \\
1030 \\
1035 \\
1040 \\
1045\end{array}$ & $\begin{array}{l}3.1 \\
3.1 \\
3 \cdot 1 \\
3.1 \\
3.1\end{array}$ & $\begin{array}{l}0.00 \\
0.00 \\
0.00 \\
0.00 \\
0.00\end{array}$ \\
\hline $\begin{array}{l}0220 \\
0225 \\
0230 \\
0235 \\
0240\end{array}$ & $\begin{array}{l}66.6 \\
51.5 \\
41.9 \\
36.2 \\
32.7\end{array}$ & $\begin{array}{l}0.00 \\
0.00 \\
0.00 \\
0.00 \\
0.00\end{array}$ & $\begin{array}{l}0635 \\
0640 \\
0645 \\
0650 \\
0655\end{array}$ & $\begin{array}{l}4.9 \\
4.4 \\
4.4 \\
4.4 \\
4.4\end{array}$ & $\begin{array}{l}0.00 \\
0.00 \\
0.00 \\
0.00 \\
0.00\end{array}$ & $\begin{array}{l}1050 \\
1055 \\
1100 \\
1105 \\
1110\end{array}$ & $\begin{array}{l}3.1 \\
3 \cdot 1 \\
3 \cdot 1 \\
3 \cdot 1 \\
3 \cdot 1\end{array}$ & $\begin{array}{l}0.00 \\
0.00 \\
0.00 \\
0.00 \\
0.00\end{array}$ \\
\hline $\begin{array}{l}0245 \\
0250 \\
0255 \\
0300 \\
0305\end{array}$ & $\begin{array}{l}30.1 \\
26.0 \\
25.2 \\
22.2 \\
20.6\end{array}$ & $\begin{array}{l}0.00 \\
0.00 \\
0.00 \\
0.00 \\
0.00\end{array}$ & $\begin{array}{l}0700 \\
0705 \\
0710 \\
0715 \\
0720\end{array}$ & $\begin{array}{l}4.4 \\
4.4 \\
4.1 \\
4.1 \\
4.1\end{array}$ & $\begin{array}{l}0.00 \\
0.00 \\
0.00 \\
0.00 \\
0.00\end{array}$ & $\begin{array}{l}1115 \\
1120 \\
1125 \\
1130 \\
1135\end{array}$ & $\begin{array}{l}3.1 \\
3.1 \\
3.1 \\
2.8 \\
2.8\end{array}$ & $\begin{array}{l}0.00 \\
0.00 \\
0.00 \\
0.00 \\
0.00\end{array}$ \\
\hline $\begin{array}{l}0310 \\
0315 \\
0320 \\
0325 \\
0330\end{array}$ & $\begin{array}{l}19.1 \\
17.8 \\
17.8 \\
15.8 \\
14.4\end{array}$ & $\begin{array}{l}0.00 \\
0.00 \\
0.00 \\
0.00 \\
0.00\end{array}$ & $\begin{array}{l}0725 \\
0730 \\
0735 \\
0740 \\
0745\end{array}$ & $\begin{array}{l}4.1 \\
4.1 \\
5.3 \\
5.3 \\
4.9\end{array}$ & $\begin{array}{l}0.00 \\
0.00 \\
0.00 \\
0.00 \\
0.00\end{array}$ & $\begin{array}{l}1140 \\
1145 \\
1150 \\
1155 \\
1200\end{array}$ & $\begin{array}{l}2.8 \\
2.8 \\
2.8 \\
2.8 \\
2.8\end{array}$ & $\begin{array}{l}0.00 \\
0.00 \\
0.00 \\
0.00 \\
0.00\end{array}$ \\
\hline 0335 & 13.8 & 0.00 & 0750 & 4.1 & 0.00 & & & \\
\hline
\end{tabular}




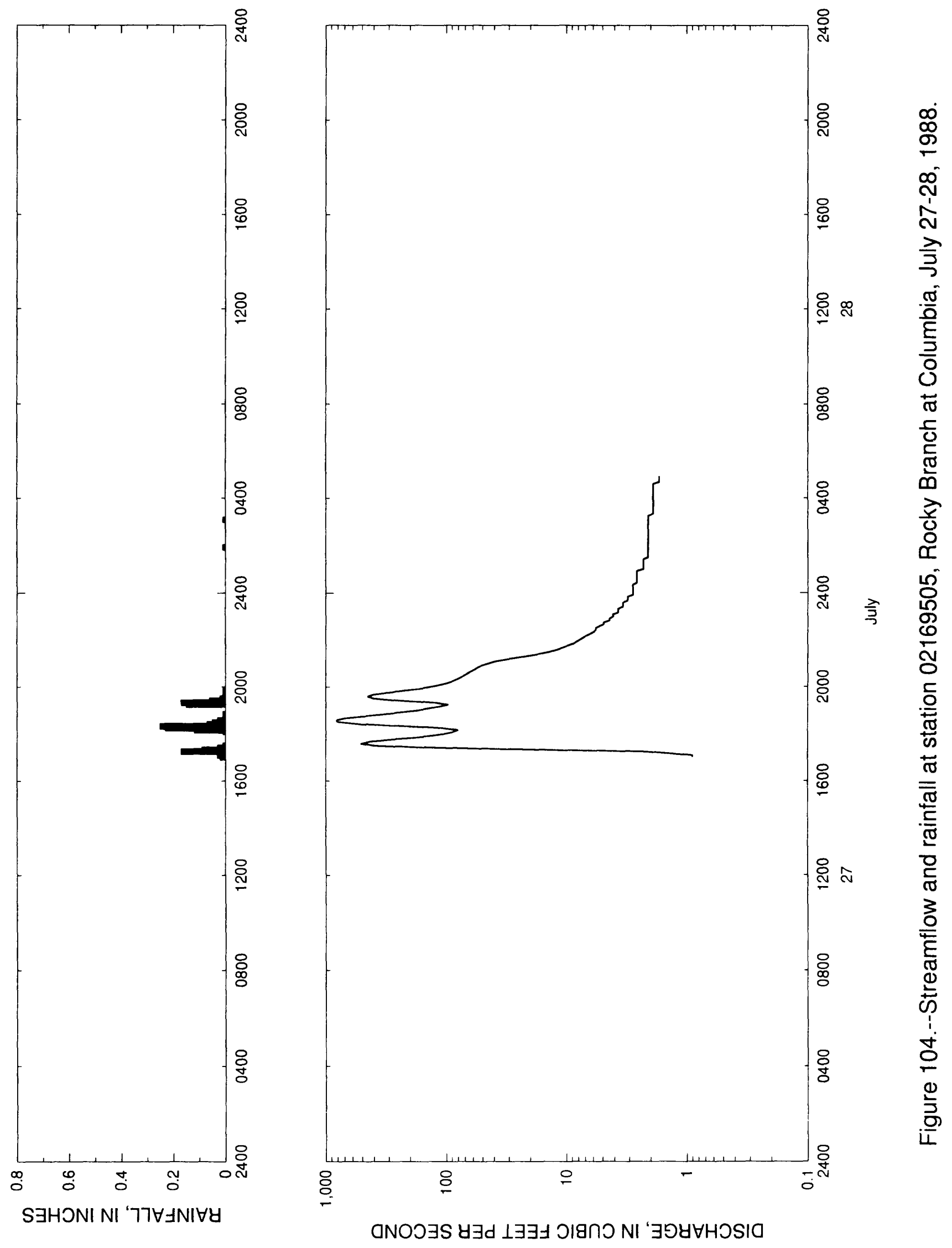


Table 103.- - Streamflow and rainfall at station 02169505, Rocky Branch at Columbia, July $27-28,1988$

\begin{tabular}{|c|c|c|c|c|c|c|c|c|}
\hline $\begin{array}{l}\text { Time } \\
\text { (hours) }\end{array}$ & $\begin{array}{l}\text { Streamflow } \\
\text { (cubic feet } \\
\text { per second) }\end{array}$ & $\begin{array}{l}\text { Rain- } \\
\text { fall } \\
\text { (inches) }\end{array}$ & $\begin{array}{l}\text { Time } \\
\text { (hours) }\end{array}$ & $\begin{array}{l}\text { Streamflow } \\
\text { (cubic feet } \\
\text { per second) }\end{array}$ & $\begin{array}{l}\text { Rain- } \\
\text { fall } \\
\text { (inches) }\end{array}$ & $\begin{array}{l}\text { Time } \\
\text { (hours) }\end{array}$ & $\begin{array}{l}\text { Streamflow } \\
\text { (cubic feet } \\
\text { per second) }\end{array}$ & $\begin{array}{l}\text { Rain- } \\
\text { fall } \\
\text { (inches) }\end{array}$ \\
\hline $\begin{array}{l}\text { July } 27, \\
1700 \\
1705 \\
1710 \\
1715\end{array}$ & $\begin{array}{r}1988 \\
0.9 \\
0.9 \\
1.4 \\
2.3\end{array}$ & $\begin{array}{l}0.02 \\
0.03 \\
0.03 \\
0.17\end{array}$ & $\begin{array}{l}2105 \\
2110 \\
2115 \\
2120 \\
2125\end{array}$ & $\begin{array}{l}39.0 \\
31.8 \\
25.2 \\
19.9 \\
16.4\end{array}$ & $\begin{array}{l}0.00 \\
0.00 \\
0.00 \\
0.00 \\
0.00\end{array}$ & $\begin{array}{l}0110 \\
0115 \\
0120 \\
0125 \\
0130\end{array}$ & $\begin{array}{l}2.3 \\
2.3 \\
2.3 \\
2.3 \\
2.1\end{array}$ & $\begin{array}{l}0.00 \\
0.00 \\
0.00 \\
0.00 \\
0.00\end{array}$ \\
\hline $\begin{array}{l}1720 \\
1725 \\
1730 \\
1735 \\
1740\end{array}$ & $\begin{array}{r}20.6 \\
124.0 \\
394.0 \\
516.0 \\
433.0\end{array}$ & $\begin{array}{l}0.09 \\
0.03 \\
0.01 \\
0.00 \\
0.00\end{array}$ & $\begin{array}{l}2130 \\
2135 \\
2140 \\
2145 \\
2150\end{array}$ & $\begin{array}{r}13.8 \\
12.0 \\
10.9 \\
9.9 \\
8.8\end{array}$ & $\begin{array}{l}0.00 \\
0.00 \\
0.00 \\
0.00 \\
0.00\end{array}$ & $\begin{array}{l}0135 \\
0140 \\
0145 \\
0150 \\
0155\end{array}$ & $\begin{array}{l}2.1 \\
2.1 \\
2.1 \\
2.1 \\
2.1\end{array}$ & $\begin{array}{l}0.00 \\
0.00 \\
0.00 \\
0.00 \\
0.01\end{array}$ \\
\hline $\begin{array}{l}1745 \\
1750 \\
1755 \\
1800 \\
1805\end{array}$ & $\begin{array}{r}299.0 \\
189.0 \\
135.0 \\
105.0 \\
88.4\end{array}$ & $\begin{array}{l}0.00 \\
0.00 \\
0.00 \\
0.00 \\
0.01\end{array}$ & $\begin{array}{l}2155 \\
2200 \\
2205 \\
2210 \\
2215\end{array}$ & $\begin{array}{l}8.3 \\
7.8 \\
7.3 \\
6.9 \\
6.4\end{array}$ & $\begin{array}{l}0.00 \\
0.00 \\
0.00 \\
0.00 \\
0.00\end{array}$ & $\begin{array}{l}0200 \\
0205 \\
0210 \\
0215 \\
0220\end{array}$ & $\begin{array}{l}2.1 \\
2.1 \\
2.1 \\
2.1 \\
2.1\end{array}$ & $\begin{array}{l}0.00 \\
0.00 \\
0.00 \\
0.00 \\
0.00\end{array}$ \\
\hline $\begin{array}{l}1810 \\
1815 \\
1820 \\
1825 \\
1830\end{array}$ & $\begin{array}{r}80.0 \\
108.0 \\
235.0 \\
520.0 \\
796.0\end{array}$ & $\begin{array}{l}0.12 \\
0.23 \\
0.25 \\
0.07 \\
0.05\end{array}$ & $\begin{array}{l}2220 \\
2225 \\
2230 \\
2235 \\
2240\end{array}$ & $\begin{array}{l}6.0 \\
5.7 \\
5.7 \\
5.3 \\
4.9\end{array}$ & $\begin{array}{l}0.00 \\
0.00 \\
0.00 \\
0.00 \\
0.00\end{array}$ & $\begin{array}{l}0225 \\
0230 \\
0235 \\
0240 \\
0245\end{array}$ & $\begin{array}{l}2.1 \\
2.1 \\
2.1 \\
2.1 \\
2.1\end{array}$ & $\begin{array}{l}0.00 \\
0.00 \\
0.00 \\
0.00 \\
0.00\end{array}$ \\
\hline $\begin{array}{l}1835 \\
1840 \\
1845 \\
1850 \\
1855\end{array}$ & $\begin{array}{l}816.0 \\
688.0 \\
488.0 \\
341.0 \\
246.0\end{array}$ & $\begin{array}{l}0.03 \\
0.00 \\
0.00 \\
0.01 \\
0.00\end{array}$ & $\begin{array}{l}2245 \\
2250 \\
2255 \\
2300 \\
2305\end{array}$ & $\begin{array}{l}4.9 \\
4.4 \\
4.4 \\
4.1 \\
4.1\end{array}$ & $\begin{array}{l}0.00 \\
0.00 \\
0.00 \\
0.00 \\
0.00\end{array}$ & $\begin{array}{l}0250 \\
0255 \\
0300 \\
0305 \\
0310\end{array}$ & $\begin{array}{l}2.1 \\
2.1 \\
2.1 \\
2.1 \\
2.1\end{array}$ & $\begin{array}{l}0.00 \\
0.00 \\
0.00 \\
0.01 \\
0.00\end{array}$ \\
\hline $\begin{array}{l}1900 \\
1905 \\
1910 \\
1915 \\
1920\end{array}$ & $\begin{array}{r}176.0 \\
141.0 \\
114.0 \\
97.4 \\
124.0\end{array}$ & $\begin{array}{l}0.00 \\
0.00 \\
0.00 \\
0.15 \\
0.17\end{array}$ & $\begin{array}{l}2310 \\
2315 \\
2320 \\
2325 \\
2330\end{array}$ & $\begin{array}{l}3.7 \\
3.7 \\
3.7 \\
3.4 \\
3.4\end{array}$ & $\begin{array}{l}0.00 \\
0.00 \\
0.00 \\
0.00 \\
0.00\end{array}$ & $\begin{array}{l}0315 \\
0320 \\
0325 \\
0330 \\
0335\end{array}$ & $\begin{array}{l}2.1 \\
1.9 \\
1.9 \\
1.9 \\
1.9\end{array}$ & $\begin{array}{l}0.00 \\
0.00 \\
0.00 \\
0.00 \\
0.00\end{array}$ \\
\hline $\begin{array}{l}1925 \\
1930 \\
1935 \\
1940 \\
1945\end{array}$ & $\begin{array}{l}248.0 \\
399.0 \\
452.0 \\
403.0 \\
310.0\end{array}$ & $\begin{array}{l}0.06 \\
0.02 \\
0.01 \\
0.01 \\
0.00\end{array}$ & $\begin{array}{l}2335 \\
2340 \\
2345 \\
2350 \\
2355\end{array}$ & $\begin{array}{l}3.4 \\
3.1 \\
3.1 \\
3.1 \\
2.8\end{array}$ & $\begin{array}{l}0.00 \\
0.00 \\
0.00 \\
0.00 \\
0.00\end{array}$ & $\begin{array}{l}0340 \\
0345 \\
0350 \\
0355 \\
0400\end{array}$ & $\begin{array}{l}1.9 \\
1.9 \\
1.9 \\
1.9 \\
1.9\end{array}$ & $\begin{array}{l}0.00 \\
0.00 \\
0.00 \\
0.00 \\
0.00\end{array}$ \\
\hline $\begin{array}{l}1950 \\
1955 \\
2000 \\
2005 \\
2010\end{array}$ & $\begin{array}{r}226.0 \\
168.0 \\
137.0 \\
115.0 \\
98.7\end{array}$ & $\begin{array}{l}0.01 \\
0.00 \\
0.00 \\
0.00 \\
0.00\end{array}$ & $\begin{array}{l}\text { July } 28 \\
0000 \\
0005 \\
0010 \\
0015\end{array}$ & $\begin{array}{r}1988 \\
2.8 \\
2.8 \\
2.8 \\
2.8\end{array}$ & $\begin{array}{l}0.00 \\
0.00 \\
0.00 \\
0.00\end{array}$ & $\begin{array}{l}0405 \\
0410 \\
0415 \\
0420 \\
0425\end{array}$ & $\begin{array}{l}1.9 \\
1.9 \\
1.9 \\
1.9 \\
1.9\end{array}$ & $\begin{array}{l}0.00 \\
0.00 \\
0.00 \\
0.00 \\
0.00\end{array}$ \\
\hline $\begin{array}{l}2015 \\
2020 \\
2025 \\
2030 \\
2035\end{array}$ & $\begin{array}{l}88.4 \\
81.1 \\
75.4 \\
70.9 \\
66.6\end{array}$ & $\begin{array}{l}0.00 \\
0.00 \\
0.00 \\
0.00 \\
0.00\end{array}$ & $\begin{array}{l}0020 \\
0025 \\
0030 \\
0035 \\
0040\end{array}$ & $\begin{array}{l}2.8 \\
2.6 \\
2.6 \\
2.6 \\
2.6\end{array}$ & $\begin{array}{l}0.00 \\
0.00 \\
0.00 \\
0.00 \\
0.00\end{array}$ & $\begin{array}{l}0430 \\
0435 \\
0440 \\
0445 \\
0450\end{array}$ & $\begin{array}{l}1.9 \\
1.9 \\
1.7 \\
1.7 \\
1.7\end{array}$ & $\begin{array}{l}0.00 \\
0.00 \\
0.00 \\
0.00 \\
0.00\end{array}$ \\
\hline $\begin{array}{l}2040 \\
2045 \\
2050 \\
2055 \\
2100\end{array}$ & $\begin{array}{l}62.5 \\
58.1 \\
54.7 \\
49.4 \\
44.0\end{array}$ & $\begin{array}{l}0.00 \\
0.00 \\
0.00 \\
0.00 \\
0.00\end{array}$ & $\begin{array}{l}0045 \\
0050 \\
0055 \\
0100 \\
0105\end{array}$ & $\begin{array}{l}2.6 \\
2.6 \\
2.6 \\
2.3 \\
2.3\end{array}$ & $\begin{array}{l}0.00 \\
0.00 \\
0.00 \\
0.00 \\
0.00\end{array}$ & $\begin{array}{l}0455 \\
0500\end{array}$ & $\begin{array}{l}1.7 \\
1.7\end{array}$ & $\begin{array}{l}0.00 \\
0.00\end{array}$ \\
\hline
\end{tabular}




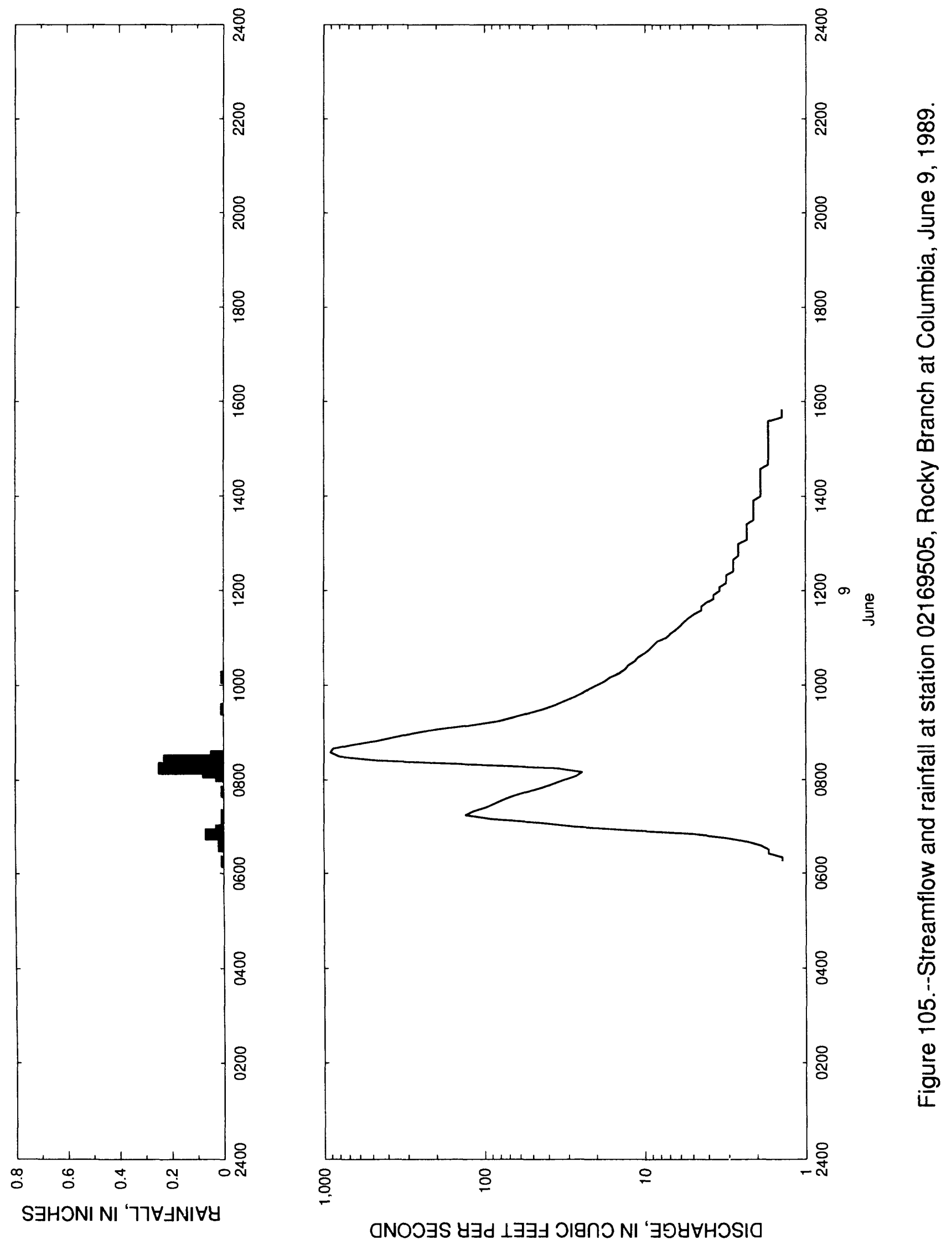


Table 104.--Streamflow and rainfal1 at station 02169505, Rocky Branch at Columbia, June 9,1989

\begin{tabular}{|c|c|c|c|c|c|c|c|c|}
\hline $\begin{array}{l}\text { Time } \\
\text { (hours) }\end{array}$ & $\begin{array}{l}\text { Streamflow } \\
\text { (cubic feet } \\
\text { per second) }\end{array}$ & $\begin{array}{l}\text { Rain- } \\
\text { fall } \\
\text { (inches) }\end{array}$ & $\begin{array}{l}\text { Time } \\
\text { (hours) }\end{array}$ & $\begin{array}{l}\text { Streamflow } \\
\text { (cubic feet } \\
\text { per second) }\end{array}$ & $\begin{array}{l}\text { Rain- } \\
\text { fall } \\
\text { (inches) }\end{array}$ & $\begin{array}{l}\text { Time } \\
\text { (hours) }\end{array}$ & $\begin{array}{l}\text { Streamflow } \\
\text { (cubic feet } \\
\text { per second) }\end{array}$ & $\begin{array}{l}\text { Rain- } \\
\text { fall } \\
\text { (inches) }\end{array}$ \\
\hline $\begin{array}{c}\text { June } 9 \text {, } \\
0615 \\
0620 \\
0625 \\
0630\end{array}$ & $\begin{array}{l}1.4 \\
1.4 \\
1.7 \\
1.7\end{array}$ & $\begin{array}{l}0.01 \\
0.00 \\
0.00 \\
0.00\end{array}$ & $\begin{array}{l}0930 \\
0935 \\
0940 \\
0945 \\
0950\end{array}$ & $\begin{array}{l}42.9 \\
36.2 \\
31.8 \\
27.6 \\
24.5\end{array}$ & $\begin{array}{l}0.01 \\
0.00 \\
0.00 \\
0.00 \\
0.00\end{array}$ & $\begin{array}{l}1250 \\
1255 \\
1300 \\
1305 \\
1310\end{array}$ & $\begin{array}{l}2.6 \\
2.6 \\
2.6 \\
2.3 \\
2.3\end{array}$ & $\begin{array}{l}0.00 \\
0.00 \\
0.0 ? \\
0.09 \\
0.0 ?\end{array}$ \\
\hline $\begin{array}{l}0635 \\
0640 \\
0645 \\
0650 \\
0655\end{array}$ & $\begin{array}{r}1.9 \\
2.3 \\
3.1 \\
4.9 \\
12.6\end{array}$ & $\begin{array}{l}0.02 \\
0.01 \\
0.02 \\
0.07 \\
0.03\end{array}$ & $\begin{array}{l}0955 \\
1000 \\
1005 \\
1010 \\
1015\end{array}$ & $\begin{array}{l}22.2 \\
19.9 \\
17.8 \\
16.4 \\
14.4\end{array}$ & $\begin{array}{l}0.00 \\
0.00 \\
0.00 \\
0.01 \\
0.00\end{array}$ & $\begin{array}{l}1315 \\
1320 \\
1325 \\
1330 \\
1335\end{array}$ & $\begin{array}{l}2.3 \\
2.3 \\
2.3 \\
2.1 \\
2.1\end{array}$ & $\begin{array}{l}0.00 \\
0.00 \\
0.0 ? \\
0.07 \\
0.07\end{array}$ \\
\hline $\begin{array}{l}0700 \\
0705 \\
0710 \\
0715 \\
0720\end{array}$ & $\begin{array}{r}27.6 \\
44.0 \\
90.9 \\
132.0 \\
117.0\end{array}$ & $\begin{array}{l}0.00 \\
0.01 \\
0.01 \\
0.01 \\
0.00\end{array}$ & $\begin{array}{l}1020 \\
1025 \\
1030 \\
1035 \\
1040\end{array}$ & $\begin{array}{r}13.2 \\
12.6 \\
11.5 \\
10.9 \\
9.9\end{array}$ & $\begin{array}{l}0.00 \\
0.00 \\
0.00 \\
0.00 \\
0.00\end{array}$ & $\begin{array}{l}1340 \\
1345 \\
1350 \\
1355 \\
1400\end{array}$ & $\begin{array}{l}2.1 \\
2.1 \\
2.1 \\
2.1 \\
1.9\end{array}$ & $\begin{array}{l}0.00 \\
0.00 \\
0.00 \\
0.00 \\
0.00\end{array}$ \\
\hline $\begin{array}{l}0725 \\
0730 \\
0735 \\
0740 \\
0745\end{array}$ & $\begin{array}{l}97.4 \\
85.9 \\
75.4 \\
64.6 \\
53.7\end{array}$ & $\begin{array}{l}0.00 \\
0.00 \\
0.00 \\
0.00 \\
0.01\end{array}$ & $\begin{array}{l}1045 \\
1050 \\
1055 \\
1100 \\
1105\end{array}$ & $\begin{array}{l}9.3 \\
8.8 \\
8.3 \\
7.3 \\
6.9\end{array}$ & $\begin{array}{l}0.00 \\
0.00 \\
0.00 \\
0.00 \\
0.00\end{array}$ & $\begin{array}{l}1405 \\
1410 \\
1415 \\
1420 \\
1425\end{array}$ & $\begin{array}{l}1.9 \\
1.9 \\
1.9 \\
1.9 \\
1.9\end{array}$ & $\begin{array}{l}0 . C 0 \\
0 . C 0 \\
0 . C 0 \\
0 . C 0 \\
0 . C 0\end{array}$ \\
\hline $\begin{array}{l}0750 \\
0755 \\
0800 \\
0805 \\
0810\end{array}$ & $\begin{array}{l}44.0 \\
37.1 \\
31.8 \\
26.8 \\
24.5\end{array}$ & $\begin{array}{l}0.00 \\
0.00 \\
0.00 \\
0.03 \\
0.08\end{array}$ & $\begin{array}{l}1110 \\
1115 \\
1120 \\
1125 \\
1130\end{array}$ & $\begin{array}{l}6.4 \\
6.0 \\
5.7 \\
5.3 \\
4.9\end{array}$ & $\begin{array}{l}0.00 \\
0.00 \\
0.00 \\
0.00 \\
0.00\end{array}$ & $\begin{array}{l}1430 \\
1435 \\
1440 \\
1445 \\
1450\end{array}$ & $\begin{array}{l}1.9 \\
1.9 \\
1.7 \\
1.7 \\
1.7\end{array}$ & $\begin{array}{l}0.00 \\
0.00 \\
0.00 \\
0.00 \\
0.00\end{array}$ \\
\hline $\begin{array}{l}0815 \\
0820 \\
0825 \\
0830 \\
0835\end{array}$ & $\begin{array}{r}35.3 \\
124.0 \\
468.0 \\
802.0 \\
913.0\end{array}$ & $\begin{array}{l}0.25 \\
0.20 \\
0.23 \\
0.05 \\
0.00\end{array}$ & $\begin{array}{l}1135 \\
1140 \\
1145 \\
1150 \\
1155\end{array}$ & $\begin{array}{l}4.4 \\
4.4 \\
4.1 \\
3.7 \\
3.7\end{array}$ & $\begin{array}{l}0.00 \\
0.00 \\
0.00 \\
0.00 \\
0.00\end{array}$ & $\begin{array}{l}1455 \\
1500 \\
1505 \\
1510 \\
1515\end{array}$ & $\begin{array}{l}1.7 \\
1.7 \\
1.7 \\
1.7 \\
1.7\end{array}$ & $\begin{array}{l}0.00 \\
0.00 \\
0.00 \\
0.00 \\
0.00\end{array}$ \\
\hline $\begin{array}{l}0840 \\
0845 \\
0850 \\
0855 \\
0900\end{array}$ & $\begin{array}{l}879.0 \\
665.0 \\
460.0 \\
353.0 \\
272.0\end{array}$ & $\begin{array}{l}0.00 \\
0.00 \\
0.00 \\
0.00 \\
0.00\end{array}$ & $\begin{array}{l}1200 \\
1205 \\
1210 \\
1215 \\
1220\end{array}$ & $\begin{array}{l}3.4 \\
3.4 \\
3.1 \\
3.1 \\
3.1\end{array}$ & $\begin{array}{l}0.00 \\
0.00 \\
0.00 \\
0.00 \\
0.00\end{array}$ & $\begin{array}{l}1520 \\
1525 \\
1530 \\
1535 \\
1540\end{array}$ & $\begin{array}{l}1.7 \\
1.7 \\
1.7 \\
1.7 \\
1.4\end{array}$ & $\begin{array}{l}0.00 \\
0.00 \\
0.00 \\
0.00 \\
0.00\end{array}$ \\
\hline $\begin{array}{l}0905 \\
0910 \\
0915 \\
0920 \\
0925\end{array}$ & $\begin{array}{r}192.0 \\
120.0 \\
81.1 \\
64.6 \\
52.6\end{array}$ & $\begin{array}{l}0.00 \\
0.00 \\
0.00 \\
0.00 \\
0.00\end{array}$ & $\begin{array}{l}1225 \\
1230 \\
1235 \\
1240 \\
1245\end{array}$ & $\begin{array}{l}2.8 \\
2.8 \\
2.8 \\
2.8 \\
2.6\end{array}$ & $\begin{array}{l}0.00 \\
0.00 \\
0.00 \\
0.00 \\
0.00\end{array}$ & $\begin{array}{l}1545 \\
1550 \\
1555 \\
1600\end{array}$ & $\begin{array}{l}1.4 \\
1.4 \\
1.4 \\
1.4\end{array}$ & $\begin{array}{l}0.00 \\
0.00 \\
0.00 \\
0.00\end{array}$ \\
\hline
\end{tabular}



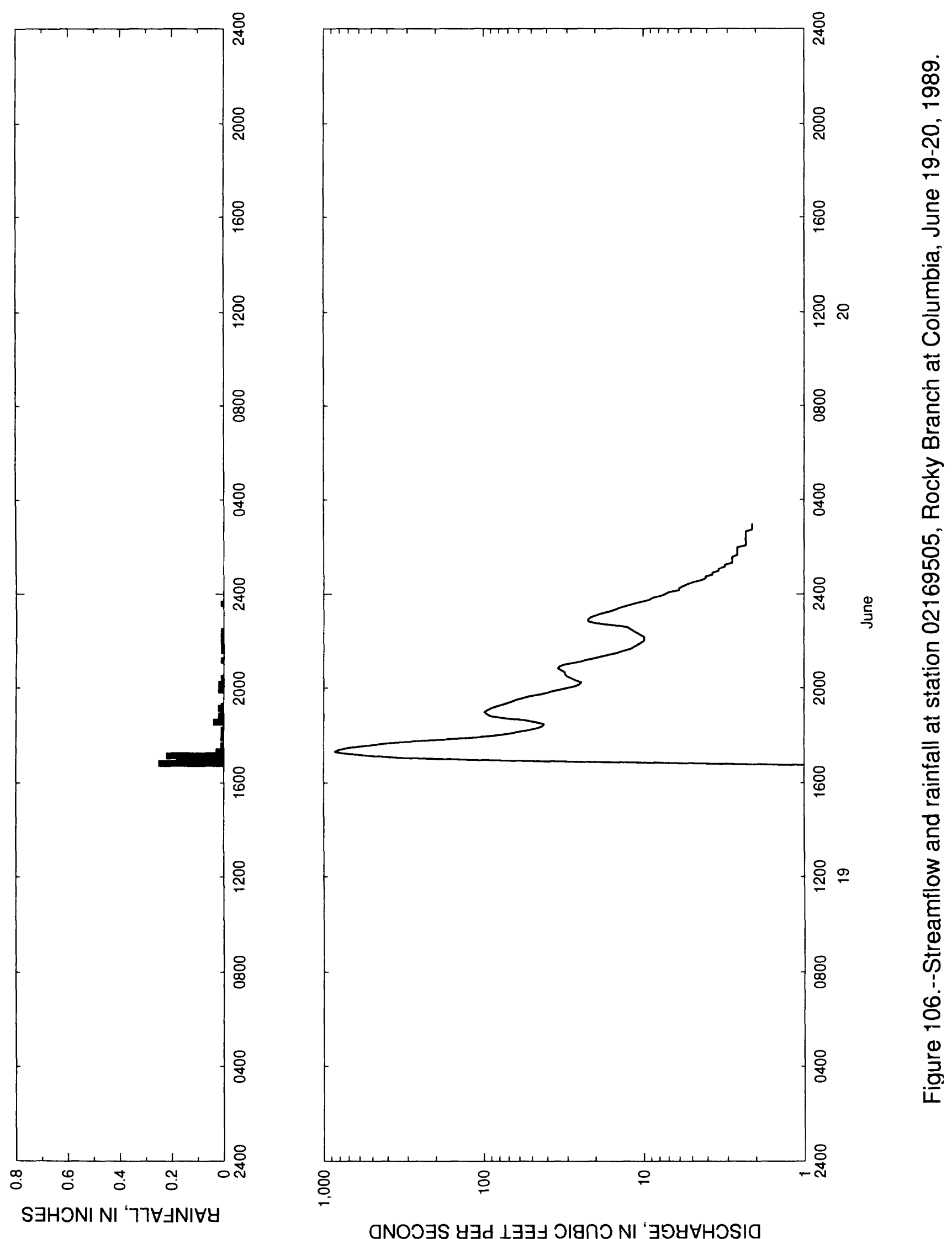
Table 105.--Streamflow and rainfall at station 02169505, Rocky Branch at Columbia June $19-20,1989$

\begin{tabular}{|c|c|c|c|c|c|c|c|c|}
\hline $\begin{array}{l}\text { Time } \\
\text { hours ) }\end{array}$ & $\begin{array}{l}\text { Streamflow } \\
\text { (cubic feet } \\
\text { per second) }\end{array}$ & $\begin{array}{l}\text { Rain - } \\
\text { fal1 } \\
\text { (inches) }\end{array}$ & $\begin{array}{l}\text { Time } \\
\text { (hours) }\end{array}$ & $\begin{array}{l}\text { Streamflow } \\
\text { (cub1c feet } \\
\text { per second) }\end{array}$ & $\begin{array}{l}\text { Rain- } \\
\text { fall } \\
\text { (inches) }\end{array}$ & $\begin{array}{l}\text { Time } \\
\text { (hours) }\end{array}$ & $\begin{array}{l}\text { Streamflow } \\
\text { (cubic feet } \\
\text { per second) }\end{array}$ & $\begin{array}{l}\text { Rain- } \\
\text { fall } \\
\text { (inches) }\end{array}$ \\
\hline $\begin{array}{c}\text { June } \\
1645 \\
1650 \\
1655 \\
1700\end{array}$ & $\begin{array}{r}9,1989 \\
1.0 \\
4.9 \\
33.5 \\
127.0\end{array}$ & $\begin{array}{l}0.00 \\
0.25 \\
0.18 \\
0.18\end{array}$ & $\begin{array}{l}2010 \\
2015 \\
2020 \\
2025 \\
2030\end{array}$ & $\begin{array}{l}25.2 \\
24.5 \\
26.8 \\
28.4 \\
30.1\end{array}$ & $\begin{array}{l}0.02 \\
0.00 \\
0.00 \\
0.01 \\
0.00\end{array}$ & $\begin{array}{l}2340 \\
2345 \\
2350 \\
2355 \\
\text { June } 20\end{array}$ & $\begin{array}{r}10.4 \\
9.3 \\
8.8 \\
7.8\end{array}$ & $\begin{array}{l}0.00 \\
0.00 \\
0.00 \\
0.00\end{array}$ \\
\hline $\begin{array}{l}1705 \\
1710 \\
1715 \\
1720 \\
1725\end{array}$ & $\begin{array}{l}345.0 \\
535.0 \\
734.0 \\
857.0 \\
810.0\end{array}$ & $\begin{array}{l}0.18 \\
0.22 \\
0.01 \\
0.03 \\
0.00\end{array}$ & $\begin{array}{l}2035 \\
2040 \\
2045 \\
2050 \\
2055\end{array}$ & $\begin{array}{l}31.0 \\
31.0 \\
32.7 \\
34.4 \\
33.5\end{array}$ & $\begin{array}{l}0.00 \\
0.00 \\
0.00 \\
0.00 \\
0.00\end{array}$ & $\begin{array}{l}0000 \\
0005 \\
0010 \\
0015 \\
0020\end{array}$ & $\begin{array}{l}7.3 \\
6.9 \\
6.0 \\
6.0 \\
5.7\end{array}$ & $\begin{array}{l}0.00 \\
0.00 \\
0.00 \\
0.00 \\
0.00\end{array}$ \\
\hline $\begin{array}{l}1730 \\
1735 \\
1740 \\
1745 \\
1750\end{array}$ & $\begin{array}{l}688.0 \\
539.0 \\
416.0 \\
309.0 \\
199.0\end{array}$ & $\begin{array}{l}0.00 \\
0.01 \\
0.00 \\
0.00 \\
0.00\end{array}$ & $\begin{array}{l}2100 \\
2105 \\
2110 \\
2115 \\
2120\end{array}$ & $\begin{array}{l}31.0 \\
26.8 \\
23.7 \\
20.6 \\
18.4\end{array}$ & $\begin{array}{l}0.00 \\
0.00 \\
0.01 \\
0.00 \\
0.00\end{array}$ & $\begin{array}{l}0025 \\
0030 \\
0035 \\
0040 \\
0045\end{array}$ & $\begin{array}{l}5.3 \\
4.9 \\
4.4 \\
4.1 \\
4.1\end{array}$ & $\begin{array}{l}0.00 \\
0.00 \\
0.00 \\
0.0 C \\
0.0 C\end{array}$ \\
\hline $\begin{array}{l}1755 \\
1800 \\
1805 \\
1810 \\
1815\end{array}$ & $\begin{array}{r}126.0 \\
88.4 \\
70.9 \\
60.3 \\
51.5\end{array}$ & $\begin{array}{l}0.01 \\
0.01 \\
0.01 \\
0.01 \\
0.01\end{array}$ & $\begin{array}{l}2125 \\
2130 \\
2135 \\
2140 \\
2145\end{array}$ & $\begin{array}{l}16.4 \\
14.4 \\
13.2 \\
12.0 \\
11.5\end{array}$ & $\begin{array}{l}0.00 \\
0.00 \\
0.01 \\
0.00 \\
0.01\end{array}$ & $\begin{array}{l}0050 \\
0055 \\
0100 \\
0105 \\
0110\end{array}$ & $\begin{array}{l}3.7 \\
3.7 \\
3.4 \\
3.4 \\
3.1\end{array}$ & $\begin{array}{l}0.0 C \\
0.0 C \\
0.0 C \\
0.0 C \\
0.0 C\end{array}$ \\
\hline $\begin{array}{l}1820 \\
1825 \\
1830 \\
1835 \\
1840\end{array}$ & $\begin{array}{l}46.1 \\
42.9 \\
41.9 \\
47.2 \\
55.8\end{array}$ & $\begin{array}{l}0.00 \\
0.00 \\
0.00 \\
0.04 \\
0.02\end{array}$ & $\begin{array}{l}2150 \\
2155 \\
2200 \\
2205 \\
2210\end{array}$ & $\begin{array}{r}10.9 \\
10.4 \\
9.9 \\
9.9 \\
9.9\end{array}$ & $\begin{array}{l}0.00 \\
0.01 \\
0.00 \\
0.01 \\
0.00\end{array}$ & $\begin{array}{l}0115 \\
0120 \\
0125 \\
0130 \\
0135\end{array}$ & $\begin{array}{l}3.1 \\
2.8 \\
2.8 \\
2.8 \\
2.8\end{array}$ & $\begin{array}{l}0.00 \\
0.00 \\
0.00 \\
0.00 \\
0.00\end{array}$ \\
\hline $\begin{array}{l}1845 \\
1850 \\
1855 \\
1900 \\
1905\end{array}$ & $\begin{array}{l}74.2 \\
90.9 \\
96.0 \\
98.7 \\
94.1\end{array}$ & $\begin{array}{l}0.00 \\
0.02 \\
0.01 \\
0.01 \\
0.00\end{array}$ & $\begin{array}{l}2215 \\
2220 \\
2225 \\
2230 \\
2235\end{array}$ & $\begin{array}{l}10.4 \\
10.9 \\
11.5 \\
12.0 \\
12.6\end{array}$ & $\begin{array}{l}0.01 \\
0.00 \\
0.01 \\
0.00 \\
0.00\end{array}$ & $\begin{array}{l}0140 \\
0145 \\
0150 \\
0155 \\
0200\end{array}$ & $\begin{array}{l}2.6 \\
2.6 \\
2.6 \\
2.6 \\
2.6\end{array}$ & $\begin{array}{l}0.00 \\
0.00 \\
0.00 \\
0.00 \\
0.00\end{array}$ \\
\hline $\begin{array}{l}1910 \\
1915 \\
1920 \\
1925 \\
1930\end{array}$ & $\begin{array}{l}89.6 \\
82.3 \\
75.4 \\
68.8 \\
63.5\end{array}$ & $\begin{array}{l}0.02 \\
0.01 \\
0.00 \\
0.00 \\
0.00\end{array}$ & $\begin{array}{l}2240 \\
2245 \\
2250 \\
2255 \\
2300\end{array}$ & $\begin{array}{l}15.1 \\
19.9 \\
22.2 \\
22.2 \\
21.4\end{array}$ & $\begin{array}{l}0.00 \\
0.00 \\
0.00 \\
0.00 \\
0.00\end{array}$ & $\begin{array}{l}0205 \\
0210 \\
0215 \\
0220 \\
0225\end{array}$ & $\begin{array}{l}2.3 \\
2.3 \\
2.3 \\
2.3 \\
2.3\end{array}$ & $\begin{array}{l}0.00 \\
0.00 \\
0.00 \\
0.00 \\
0.00\end{array}$ \\
\hline $\begin{array}{l}1935 \\
1940 \\
1945 \\
1950 \\
1955\end{array}$ & $\begin{array}{l}56.9 \\
51.5 \\
44.0 \\
39.0 \\
34.4\end{array}$ & $\begin{array}{l}0.00 \\
0.00 \\
0.00 \\
0.00 \\
0.02\end{array}$ & $\begin{array}{l}2305 \\
2310 \\
2315 \\
2320 \\
2325\end{array}$ & $\begin{array}{l}19.9 \\
18.4 \\
16.4 \\
15.1 \\
13.8\end{array}$ & $\begin{array}{l}0.00 \\
0.00 \\
0.00 \\
0.00 \\
0.00\end{array}$ & $\begin{array}{l}0230 \\
0235 \\
0240 \\
0245 \\
0250\end{array}$ & $\begin{array}{l}2.3 \\
2.3 \\
2.3 \\
2.1 \\
2.1\end{array}$ & $\begin{array}{l}0.00 \\
0.00 \\
0.00 \\
0.00 \\
0.00\end{array}$ \\
\hline $\begin{array}{l}2000 \\
2005\end{array}$ & $\begin{array}{l}30.1 \\
26.8\end{array}$ & $\begin{array}{l}0.01 \\
0.01\end{array}$ & $\begin{array}{l}2330 \\
2335\end{array}$ & $\begin{array}{l}12.6 \\
11.5\end{array}$ & $\begin{array}{l}0.00 \\
0.01\end{array}$ & $\begin{array}{l}0255 \\
0300\end{array}$ & $\begin{array}{l}2.1 \\
2.1\end{array}$ & $\begin{array}{l}0.00 \\
0.00\end{array}$ \\
\hline
\end{tabular}




\section{Station 02169568, Pen Branch at Columbia, S.C.}

Location.-Lat $34^{\circ} 00^{\prime} 46^{\prime \prime}$, long $80^{\circ} 58^{\prime} 56^{\prime \prime}$, Richland County, Hydrologic Unit 03050110, at culvert on Brentwood Street (road F-1507), $0.6 \mathrm{mi}$ southeast of the intersection of Forest Drive (S.C. Highway 12) and Beltline Boulevard (S.C. Highway 16), and $1.3 \mathrm{mi}$ upstream from the mouth at Lake Katherine (Gills Creek).

Period of record.-- October 15, 1985 to October 11, 1990.

Gage.--Digital stage recorder with 5-minute punch interval. The recorder is housed in a metal shelter atop a stilling well attached to a free-standing platform on the right bank approximately $15 \mathrm{ft}$ upstream from the double $7 \mathrm{ft}$ reinforced concrete pipe culverts. An enameled staff gage is attached to the platform. A crest-stage indicator is located on the right downstream wingwall.

Rating.--The stage-streamflow relation is defined by current meter measurements up to $78 \mathrm{ft}^{3} / \mathrm{s}$. The stage-streamflow relation was extended to $1,045 \mathrm{ft}^{3} / \mathrm{s}$ using indirect computational methods.

Rain gage and location.-Station 340053080590200 , lat $34^{\circ} 00^{\prime} 53^{\prime \prime}$, long $80^{\circ} 59^{\prime} 02^{\prime \prime}$. A shelter containing a digital cumulative rainfall recorder with a 5-minute punch interval near the A.C. Flora High School recreation field on Falcon Drive (road F1507), 3.0 mi east of the State Capitol Building.

Selected basin characteristics.--

Drainage area $-2.26 \mathrm{mi}^{2}$

Physiographic province - Inner Coastal Plain

Channel slope -- $55.5 \mathrm{ft} / \mathrm{mi}$

Channel length -- $2.30 \mathrm{mi}$

Total impervious area -- 29.0 percent

Basin development factor -- 10

2-year, 2-hour rainfall amount -- $2.10 \mathrm{in}$.

Flood frequency data: $\mathrm{UQ}_{2} \quad 378 \mathrm{ft}^{3} / \mathrm{s}$

$\mathrm{UQ}_{5} \quad 596 \mathrm{ft}^{3} / \mathrm{s}$

$\mathrm{UQ}_{10} \quad 749 \mathrm{ft}^{3} / \mathrm{s}$

$\mathrm{UQ}_{25} \quad 949 \mathrm{ft}^{3} / \mathrm{s}$

$\mathrm{UQ}_{50} \quad 1,100 \mathrm{ft}^{3} / \mathrm{s}$

$\mathrm{UQ}_{100} \quad 1,260 \mathrm{ft}^{3} / \mathrm{s}$

$\mathrm{UQ}_{500} \quad 1,630 \mathrm{ft}^{3} / \mathrm{s}$ 


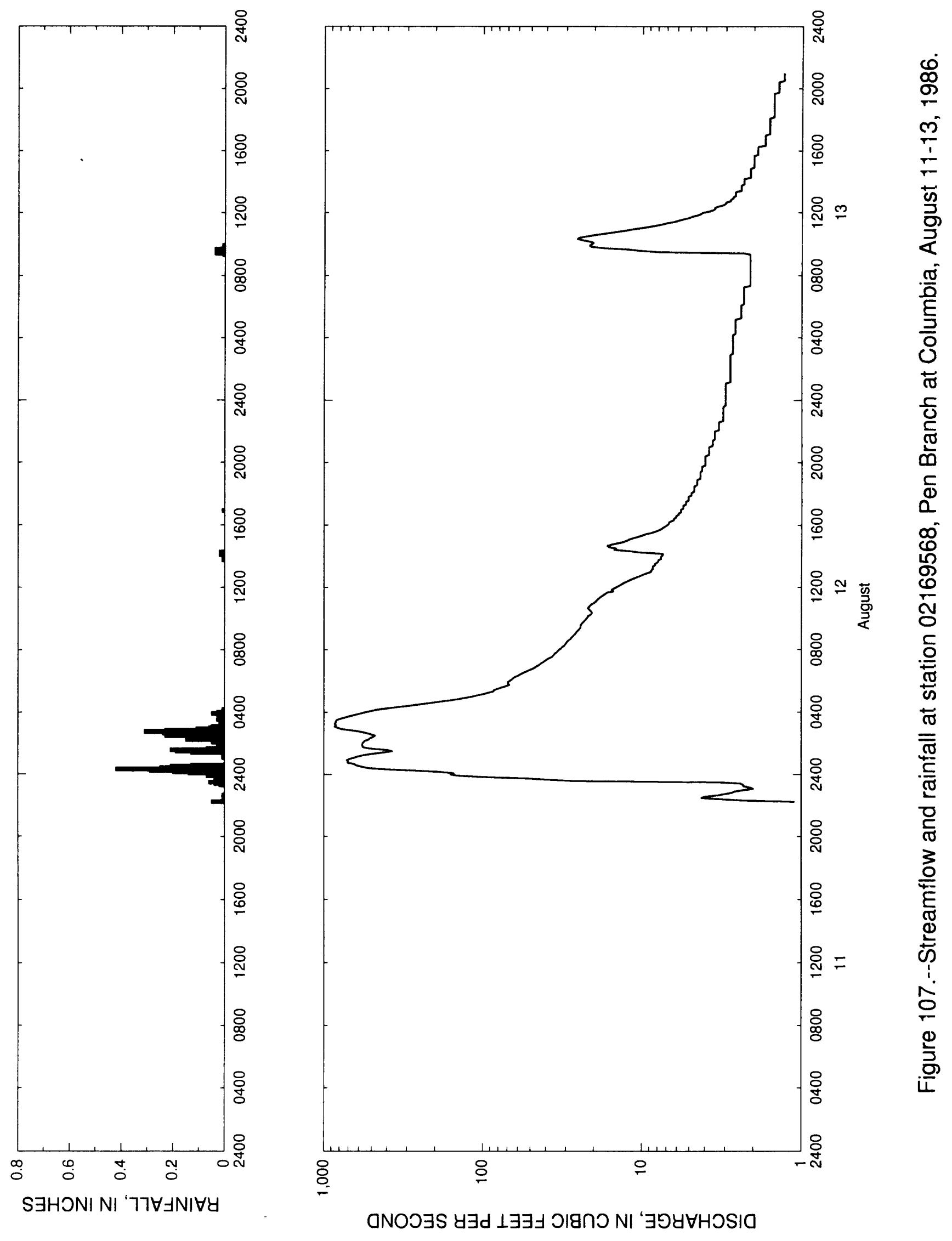




\begin{tabular}{|c|c|c|c|c|c|c|c|c|}
\hline $\begin{array}{l}\text { Time } \\
\text { (hours) }\end{array}$ & $\begin{array}{l}\text { Streamflow } \\
\text { (cubic feet } \\
\text { per second) }\end{array}$ & $\begin{array}{l}\text { Rain- } \\
\text { fall } \\
\text { (inches) }\end{array}$ & $\begin{array}{l}\text { Time } \\
\text { (hours) }\end{array}$ & $\begin{array}{l}\text { Streamflow } \\
\text { (cubic feet } \\
\text { per second) }\end{array}$ & $\begin{array}{l}\text { Rain- } \\
\text { fall } \\
\text { (inches) }\end{array}$ & $\begin{array}{l}\text { Time } \\
\text { (hours) }\end{array}$ & $\begin{array}{l}\text { Streamflow } \\
\text { (cubic feet } \\
\text { per second) }\end{array}$ & $\begin{array}{l}\text { Rain- } \\
\text { fall } \\
\text { (inches) }\end{array}$ \\
\hline $\begin{array}{l}\text { August } \\
2215 \\
2220 \\
2225 \\
2230\end{array}$ & $\begin{array}{r}11,1986 \\
1.1 \\
2.3 \\
3.1 \\
4.2\end{array}$ & $\begin{array}{l}0.05 \\
0.00 \\
0.00 \\
0.01\end{array}$ & $\begin{array}{l}0330 \\
0335 \\
0340 \\
0345 \\
0350\end{array}$ & $\begin{array}{l}832.0 \\
780.0 \\
733.0 \\
679.0 \\
635.0\end{array}$ & $\begin{array}{l}0.03 \\
0.02 \\
0.01 \\
0.01 \\
0.03\end{array}$ & $\begin{array}{l}0855 \\
0900 \\
0905 \\
0910 \\
0915\end{array}$ & $\begin{array}{l}26.8 \\
26.4 \\
26.0 \\
25.6 \\
25.1\end{array}$ & $\begin{array}{l}0.00 \\
0.00 \\
0.00 \\
0.00 \\
0.00\end{array}$ \\
\hline $\begin{array}{l}2235 \\
2240 \\
2245 \\
2250 \\
2255\end{array}$ & $\begin{array}{l}4.0 \\
3.3 \\
3.0 \\
2.7 \\
2.6\end{array}$ & $\begin{array}{l}0.00 \\
0.01 \\
0.00 \\
0.00 \\
0.00\end{array}$ & $\begin{array}{l}0355 \\
0400 \\
0405 \\
0410 \\
0415\end{array}$ & $\begin{array}{l}590.0 \\
549.0 \\
507.0 \\
465.0 \\
401.0\end{array}$ & $\begin{array}{l}0.05 \\
0.03 \\
0.00 \\
0.01 \\
0.00\end{array}$ & $\begin{array}{l}0920 \\
0925 \\
0930 \\
0935 \\
0940\end{array}$ & $\begin{array}{l}24.7 \\
24.3 \\
24.3 \\
24.3 \\
23.9\end{array}$ & $\begin{array}{l}0.00 \\
0.00 \\
0.00 \\
0.00 \\
0.00\end{array}$ \\
\hline $\begin{array}{l}2300 \\
2305 \\
2310 \\
2315 \\
2320\end{array}$ & $\begin{array}{l}2.3 \\
2.0 \\
2.1 \\
2.3 \\
2.3\end{array}$ & $\begin{array}{l}0.00 \\
0.00 \\
0.00 \\
0.00 \\
0.02\end{array}$ & $\begin{array}{l}0420 \\
0425 \\
0430 \\
0435 \\
0440\end{array}$ & $\begin{array}{l}341.0 \\
291.0 \\
249.0 \\
216.0 \\
188.0\end{array}$ & $\begin{array}{l}0.00 \\
0.00 \\
0.00 \\
0.00 \\
0.00\end{array}$ & $\begin{array}{l}0945 \\
0950 \\
0955 \\
1000 \\
1005\end{array}$ & $\begin{array}{l}23.5 \\
23.1 \\
22.6 \\
22.3 \\
21.9\end{array}$ & $\begin{array}{l}0.00 \\
0.00 \\
0.00 \\
0.00 \\
0.00\end{array}$ \\
\hline $\begin{array}{l}2325 \\
2330 \\
2335 \\
2340 \\
2345\end{array}$ & $\begin{array}{r}2.4 \\
3.3 \\
26.8 \\
38.9 \\
54.3\end{array}$ & $\begin{array}{l}0.04 \\
0.06 \\
0.04 \\
0.04 \\
0.02\end{array}$ & $\begin{array}{l}0445 \\
0450 \\
0455 \\
0500 \\
0505\end{array}$ & $\begin{array}{l}165.0 \\
144.0 \\
129.0 \\
117.0 \\
108.0\end{array}$ & $\begin{array}{l}0.00 \\
0.00 \\
0.00 \\
0.00 \\
0.00\end{array}$ & $\begin{array}{l}1010 \\
1015 \\
1020 \\
1025 \\
1030\end{array}$ & $\begin{array}{l}21.9 \\
21.1 \\
20.7 \\
20.7 \\
21.1\end{array}$ & $\begin{array}{l}0.00 \\
0.00 \\
0.00 \\
0.00 \\
0.00\end{array}$ \\
\hline $\begin{array}{l}2350 \\
2355 \\
\\
0000 \\
0005\end{array}$ & $\begin{array}{r}99.5 \\
145.0 \\
\text { August } 12, \\
160.0 \\
152.0\end{array}$ & $\begin{array}{c}0.01 \\
0.07 \\
1986 \\
0.03 \\
0.14\end{array}$ & $\begin{array}{l}0510 \\
0515 \\
0520 \\
0525 \\
0530\end{array}$ & $\begin{array}{l}99.5 \\
93.0 \\
86.0 \\
85.3 \\
81.1\end{array}$ & $\begin{array}{l}0.00 \\
0.00 \\
0.00 \\
0.00 \\
0.00\end{array}$ & $\begin{array}{l}1035 \\
1040 \\
1045 \\
1050 \\
1055\end{array}$ & $\begin{array}{l}21.5 \\
21.9 \\
21.5 \\
21.1 \\
20.7\end{array}$ & $\begin{array}{l}0.00 \\
0.00 \\
0.00 \\
0.00 \\
0.00\end{array}$ \\
\hline $\begin{array}{l}0010 \\
0015 \\
0020 \\
0025 \\
0030\end{array}$ & $\begin{array}{l}187.0 \\
264.0 \\
412.0 \\
531.0 \\
584.0\end{array}$ & $\begin{array}{l}0.20 \\
0.29 \\
0.42 \\
0.25 \\
0.21\end{array}$ & $\begin{array}{l}0535 \\
0540 \\
0545 \\
0550 \\
0555\end{array}$ & $\begin{array}{l}76.3 \\
71.7 \\
67.9 \\
69.8 \\
69.8\end{array}$ & $\begin{array}{l}0.00 \\
0.00 \\
0.00 \\
0.00 \\
0.00\end{array}$ & $\begin{array}{l}1100 \\
1105 \\
1110 \\
1115 \\
1120\end{array}$ & $\begin{array}{l}20.0 \\
19.6 \\
19.2 \\
18.9 \\
18.5\end{array}$ & $\begin{array}{l}0.00 \\
0.00 \\
0.00 \\
0.00 \\
0.00\end{array}$ \\
\hline $\begin{array}{l}0035 \\
0040 \\
0045 \\
0050 \\
0055\end{array}$ & $\begin{array}{l}625.0 \\
648.0 \\
712.0 \\
705.0 \\
719.0\end{array}$ & $\begin{array}{l}0.13 \\
0.00 \\
0.00 \\
0.00 \\
0.00\end{array}$ & $\begin{array}{l}0600 \\
0605 \\
0610 \\
0615 \\
0620\end{array}$ & $\begin{array}{l}67.9 \\
66.1 \\
64.8 \\
63.0 \\
60.0\end{array}$ & $\begin{array}{l}0.00 \\
0.00 \\
0.00 \\
0.00 \\
0.00\end{array}$ & $\begin{array}{l}1125 \\
1130 \\
1135 \\
1140 \\
1145\end{array}$ & $\begin{array}{l}18.0 \\
17.5 \\
17.0 \\
16.6 \\
15.1\end{array}$ & $\begin{array}{l}0.00 \\
0.00 \\
0.00 \\
0.00 \\
0.00\end{array}$ \\
\hline $\begin{array}{l}0100 \\
0105 \\
0110 \\
0115 \\
0120\end{array}$ & $\begin{array}{l}689.0 \\
644.0 \\
608.0 \\
557.0 \\
493.0\end{array}$ & $\begin{array}{l}0.00 \\
0.01 \\
0.01 \\
0.00 \\
0.01\end{array}$ & $\begin{array}{l}0625 \\
0630 \\
0635 \\
0640 \\
0645\end{array}$ & $\begin{array}{l}58.3 \\
56.0 \\
53.8 \\
51.6 \\
49.4\end{array}$ & $\begin{array}{l}0.00 \\
0.00 \\
0.00 \\
0.00 \\
0.00\end{array}$ & $\begin{array}{l}1150 \\
1155 \\
1200 \\
1205 \\
1210\end{array}$ & $\begin{array}{l}15.6 \\
15.1 \\
14.6 \\
14.1 \\
13.6\end{array}$ & $\begin{array}{l}0.00 \\
0.00 \\
0.00 \\
0.00 \\
0.00\end{array}$ \\
\hline $\begin{array}{l}0125 \\
0130 \\
0135 \\
0140 \\
0145\end{array}$ & $\begin{array}{l}421.0 \\
372.0 \\
404.0 \\
508.0 \\
568.0\end{array}$ & $\begin{array}{l}0.13 \\
0.19 \\
0.21 \\
0.07 \\
0.03\end{array}$ & $\begin{array}{l}0650 \\
0655 \\
0700 \\
0705 \\
0710\end{array}$ & $\begin{array}{l}47.5 \\
46.3 \\
44.5 \\
43.4 \\
42.2\end{array}$ & $\begin{array}{l}0.00 \\
0.00 \\
0.00 \\
0.00 \\
0.00\end{array}$ & $\begin{array}{l}1215 \\
1220 \\
1225 \\
1230 \\
1235\end{array}$ & $\begin{array}{l}13.2 \\
12.7 \\
12.2 \\
11.7 \\
11.2\end{array}$ & $\begin{array}{l}0.00 \\
0.00 \\
0.00 \\
0.00 \\
0.00\end{array}$ \\
\hline $\begin{array}{l}0150 \\
0155 \\
0200 \\
0205 \\
0210\end{array}$ & $\begin{array}{l}571.0 \\
575.0 \\
572.0 \\
563.0 \\
552.0\end{array}$ & $\begin{array}{l}0.02 \\
0.02 \\
0.02 \\
0.05 \\
0.03\end{array}$ & $\begin{array}{l}0715 \\
0720 \\
0725 \\
0730 \\
0735\end{array}$ & $\begin{array}{l}41.1 \\
40.0 \\
38.9 \\
37.3 \\
36.3\end{array}$ & $\begin{array}{l}0.00 \\
0.00 \\
0.00 \\
0.00 \\
0.00\end{array}$ & $\begin{array}{l}1240 \\
1245 \\
1250 \\
1255 \\
1300\end{array}$ & $\begin{array}{r}10.7 \\
10.2 \\
9.8 \\
9.3 \\
8.8\end{array}$ & $\begin{array}{l}0.00 \\
0.00 \\
0.00 \\
0.00 \\
0.00\end{array}$ \\
\hline $\begin{array}{l}0215 \\
0220 \\
0225 \\
0230 \\
0235\end{array}$ & $\begin{array}{l}524.0 \\
514.0 \\
493.0 \\
476.0 \\
504.0\end{array}$ & $\begin{array}{l}0.15 \\
0.11 \\
0.06 \\
0.23 \\
0.14\end{array}$ & $\begin{array}{l}0740 \\
0745 \\
0750 \\
0755 \\
0800\end{array}$ & $\begin{array}{l}35.8 \\
35.3 \\
34.3 \\
33.8 \\
33.3\end{array}$ & $\begin{array}{l}0.00 \\
0.00 \\
0.00 \\
0.00 \\
0.00\end{array}$ & $\begin{array}{l}1305 \\
1310 \\
1315 \\
1320 \\
1325\end{array}$ & $\begin{array}{l}8.8 \\
8.6 \\
8.6 \\
8.6 \\
8.3\end{array}$ & $\begin{array}{l}0.00 \\
0.00 \\
0.00 \\
0.00 \\
0.00\end{array}$ \\
\hline $\begin{array}{l}0240 \\
0245 \\
0250 \\
0255 \\
0300\end{array}$ & $\begin{array}{l}544.0 \\
590.0 \\
670.0 \\
775.0 \\
821.0\end{array}$ & $\begin{array}{l}0.24 \\
0.31 \\
0.23 \\
0.11 \\
0.06\end{array}$ & $\begin{array}{l}0805 \\
0810 \\
0815 \\
0820 \\
0825\end{array}$ & $\begin{array}{l}32.3 \\
31.8 \\
30.9 \\
30.4 \\
30.0\end{array}$ & $\begin{array}{l}0.00 \\
0.00 \\
0.00 \\
0.00 \\
0.00\end{array}$ & $\begin{array}{l}1330 \\
1335 \\
1340 \\
1345 \\
1350\end{array}$ & $\begin{array}{l}8.3 \\
8.1 \\
7.9 \\
7.9 \\
7.6\end{array}$ & $\begin{array}{l}0.00 \\
0.00 \\
0.00 \\
0.01 \\
0.00\end{array}$ \\
\hline $\begin{array}{l}0305 \\
0310 \\
0315 \\
0320 \\
0325\end{array}$ & $\begin{array}{l}859.0 \\
843.0 \\
859.0 \\
843.0 \\
843.0\end{array}$ & $\begin{array}{l}0.05 \\
0.02 \\
0.01 \\
0.01 \\
0.02\end{array}$ & $\begin{array}{l}0830 \\
0835 \\
0840 \\
0845 \\
0850\end{array}$ & $\begin{array}{l}29.5 \\
29.0 \\
28.2 \\
27.7 \\
27.3\end{array}$ & $\begin{array}{l}0.00 \\
0.00 \\
0.00 \\
0.00 \\
0.00\end{array}$ & $\begin{array}{l}1355 \\
1400 \\
1405 \\
1410 \\
1415\end{array}$ & $\begin{array}{r}7.6 \\
7.6 \\
7.4 \\
7.4 \\
10.3\end{array}$ & $\begin{array}{l}0.00 \\
0.00 \\
0.02 \\
0.01 \\
0.02\end{array}$ \\
\hline
\end{tabular}




\begin{tabular}{|c|c|c|c|c|c|c|c|c|}
\hline $\begin{array}{l}\text { Time } \\
\text { (hours) }\end{array}$ & $\begin{array}{l}\text { Streamflow } \\
\text { (cubic feet } \\
\text { per second) }\end{array}$ & $\begin{array}{l}\text { Rain- } \\
\text { fall } \\
\text { (inches) }\end{array}$ & $\begin{array}{l}\text { Time } \\
\text { (hours) }\end{array}$ & $\begin{array}{l}\text { Streamflow } \\
\text { (cubic feet } \\
\text { per second) }\end{array}$ & $\begin{array}{l}\text { Rain- } \\
\text { fall } \\
\text { (inches) }\end{array}$ & $\begin{array}{l}\text { Time } \\
\text { (hours) }\end{array}$ & $\begin{array}{l}\text { Streamflow } \\
\text { (cubic feet } \\
\text { per second) }\end{array}$ & $\begin{array}{l}\text { Rain- } \\
\text { fall } \\
\text { (inches) }\end{array}$ \\
\hline $\begin{array}{l}1420 \\
1425 \\
1430 \\
1435 \\
1440\end{array}$ & $\begin{array}{l}12.0 \\
14.9 \\
14.6 \\
16.1 \\
16.5\end{array}$ & $\begin{array}{l}0.00 \\
0.00 \\
0.00 \\
0.00 \\
0.00\end{array}$ & $\begin{array}{l}1945 \\
1950 \\
1955 \\
2000 \\
2005\end{array}$ & $\begin{array}{l}4.2 \\
4.0 \\
4.0 \\
4.0 \\
4.0\end{array}$ & $\begin{array}{l}0.00 \\
0.00 \\
0.00 \\
0.00 \\
0.00\end{array}$ & $\begin{array}{l}0105 \\
0110 \\
0115 \\
0120 \\
0125\end{array}$ & $\begin{array}{l}3.0 \\
2.8 \\
2.8 \\
2.8 \\
2.8\end{array}$ & $\begin{array}{l}0.00 \\
0.00 \\
0.00 \\
0.00 \\
0.00\end{array}$ \\
\hline $\begin{array}{l}1445 \\
1450 \\
1455 \\
1500 \\
1505\end{array}$ & $\begin{array}{l}15.5 \\
14.3 \\
13.1 \\
12.5 \\
12.0\end{array}$ & $\begin{array}{l}0.00 \\
0.00 \\
0.00 \\
0.00 \\
0.00\end{array}$ & $\begin{array}{l}2010 \\
2015 \\
2020 \\
2025 \\
2030\end{array}$ & $\begin{array}{l}4.0 \\
4.0 \\
4.0 \\
4.0 \\
3.8\end{array}$ & $\begin{array}{l}0.00 \\
0.00 \\
0.00 \\
0.00 \\
0.00\end{array}$ & $\begin{array}{l}0130 \\
0135 \\
0140 \\
0145 \\
0150\end{array}$ & $\begin{array}{l}2.8 \\
2.8 \\
2.8 \\
2.8 \\
2.8\end{array}$ & $\begin{array}{l}0.00 \\
0.00 \\
0.00 \\
0.00 \\
0.00\end{array}$ \\
\hline $\begin{array}{l}1510 \\
1515 \\
1520 \\
1525 \\
1530\end{array}$ & $\begin{array}{r}11.4 \\
10.6 \\
10.0 \\
9.5 \\
8.8\end{array}$ & $\begin{array}{l}0.00 \\
0.00 \\
0.00 \\
0.00 \\
0.00\end{array}$ & $\begin{array}{l}2035 \\
2040 \\
2045 \\
2050 \\
2055\end{array}$ & $\begin{array}{l}3.8 \\
3.8 \\
3.8 \\
3.8 \\
3.8\end{array}$ & $\begin{array}{l}0.00 \\
0.00 \\
0.00 \\
0.00 \\
0.00\end{array}$ & $\begin{array}{l}0155 \\
0200 \\
0205 \\
0210 \\
0215\end{array}$ & $\begin{array}{l}2.8 \\
2.8 \\
2.8 \\
2.8 \\
2.8\end{array}$ & $\begin{array}{l}0.00 \\
0.00 \\
0.00 \\
0.00 \\
0.00\end{array}$ \\
\hline $\begin{array}{l}1535 \\
1540 \\
1545 \\
1550 \\
1555\end{array}$ & $\begin{array}{l}8.3 \\
7.9 \\
7.6 \\
7.4 \\
7.2\end{array}$ & $\begin{array}{l}0.00 \\
0.00 \\
0.00 \\
0.00 \\
0.00\end{array}$ & $\begin{array}{l}2100 \\
2105 \\
2110 \\
2115 \\
2120\end{array}$ & $\begin{array}{l}3.8 \\
3.6 \\
3.6 \\
3.6 \\
3.6\end{array}$ & $\begin{array}{l}0.00 \\
0.00 \\
0.00 \\
0.00 \\
0.00\end{array}$ & $\begin{array}{l}0220 \\
0225 \\
0230 \\
0235 \\
0240\end{array}$ & $\begin{array}{l}2.8 \\
2.8 \\
2.8 \\
2.8 \\
2.8\end{array}$ & $\begin{array}{l}0.00 \\
0.00 \\
0.00 \\
0.00 \\
0.00\end{array}$ \\
\hline $\begin{array}{l}1600 \\
1605 \\
1610 \\
1615 \\
1620\end{array}$ & $\begin{array}{l}7.0 \\
6.8 \\
6.8 \\
6.6 \\
6.3\end{array}$ & $\begin{array}{l}0.00 \\
0.00 \\
0.00 \\
0.00 \\
0.00\end{array}$ & $\begin{array}{l}2125 \\
2130 \\
2135 \\
2140 \\
2145\end{array}$ & $\begin{array}{l}3.6 \\
3.5 \\
3.5 \\
3.5 \\
3.5\end{array}$ & $\begin{array}{l}0.00 \\
0.00 \\
0.00 \\
0.00 \\
0.00\end{array}$ & $\begin{array}{l}0245 \\
0250 \\
0255 \\
0300 \\
0305\end{array}$ & $\begin{array}{l}2.8 \\
2.8 \\
2.8 \\
2.7 \\
2.7\end{array}$ & $\begin{array}{l}0.00 \\
0.00 \\
0.00 \\
0.00 \\
0.00\end{array}$ \\
\hline $\begin{array}{l}1625 \\
1630 \\
1635 \\
1640 \\
1645\end{array}$ & $\begin{array}{l}6.3 \\
6.1 \\
6.1 \\
5.9 \\
5.9\end{array}$ & $\begin{array}{l}0.00 \\
0.00 \\
0.00 \\
0.00 \\
0.00\end{array}$ & $\begin{array}{l}2150 \\
2155 \\
2200 \\
2205 \\
2210\end{array}$ & $\begin{array}{l}3.5 \\
3.5 \\
3.5 \\
3.3 \\
3.3\end{array}$ & $\begin{array}{l}0.00 \\
0.00 \\
0.00 \\
0.00 \\
0.00\end{array}$ & $\begin{array}{l}0310 \\
0315 \\
0320 \\
0325 \\
0330\end{array}$ & $\begin{array}{l}2.7 \\
2.7 \\
2.7 \\
2.7 \\
2.7\end{array}$ & $\begin{array}{l}0.00 \\
0.00 \\
0.00 \\
0.00 \\
0.00\end{array}$ \\
\hline $\begin{array}{l}1650 \\
1655 \\
1700 \\
1705 \\
1710\end{array}$ & $\begin{array}{l}5.7 \\
5.7 \\
5.7 \\
5.5 \\
5.5\end{array}$ & $\begin{array}{l}0.00 \\
0.01 \\
0.00 \\
0.00 \\
0.00\end{array}$ & $\begin{array}{l}2215 \\
2220 \\
2225 \\
2230 \\
2235\end{array}$ & $\begin{array}{l}3.3 \\
3.3 \\
3.3 \\
3.3 \\
3.3\end{array}$ & $\begin{array}{l}0.00 \\
0.00 \\
0.00 \\
0.00 \\
0.00\end{array}$ & $\begin{array}{l}0335 \\
0340 \\
0345 \\
0350 \\
0355\end{array}$ & $\begin{array}{l}2.7 \\
2.7 \\
2.7 \\
2.7 \\
2.7\end{array}$ & $\begin{array}{l}0.00 \\
0.00 \\
0.00 \\
0.00 \\
0.00\end{array}$ \\
\hline $\begin{array}{l}1715 \\
1720 \\
1725 \\
1730 \\
1735\end{array}$ & $\begin{array}{l}5.5 \\
5.3 \\
5.3 \\
5.3 \\
5.1\end{array}$ & $\begin{array}{l}0.00 \\
0.00 \\
0.00 \\
0.00 \\
0.00\end{array}$ & $\begin{array}{l}2240 \\
2245 \\
2250 \\
2255 \\
2300\end{array}$ & $\begin{array}{l}3 \cdot 1 \\
3 \cdot 1 \\
3 \cdot 1 \\
3 \cdot 1 \\
3 \cdot 1\end{array}$ & $\begin{array}{l}0.00 \\
0.00 \\
0.00 \\
0.00 \\
0.00\end{array}$ & $\begin{array}{l}0400 \\
0405 \\
0410 \\
0415 \\
0420\end{array}$ & $\begin{array}{l}2.7 \\
2.7 \\
2.7 \\
2.6 \\
2.6\end{array}$ & $\begin{array}{l}0.00 \\
0.00 \\
0.00 \\
0.00 \\
0.00\end{array}$ \\
\hline $\begin{array}{l}1740 \\
1745 \\
1750 \\
1755 \\
1800\end{array}$ & $\begin{array}{l}5.1 \\
5.1 \\
5.1 \\
4.9 \\
4.9\end{array}$ & $\begin{array}{l}0.00 \\
0.00 \\
0.00 \\
0.00 \\
0.00\end{array}$ & $\begin{array}{l}2305 \\
2310 \\
2315 \\
2320 \\
2325\end{array}$ & $\begin{array}{l}3.1 \\
3.1 \\
3 \cdot 1 \\
3.1 \\
3.1\end{array}$ & $\begin{array}{l}0.00 \\
0.00 \\
0.00 \\
0.00 \\
0.00\end{array}$ & $\begin{array}{l}0425 \\
0430 \\
0435 \\
0440 \\
0445\end{array}$ & $\begin{array}{l}2.6 \\
2.6 \\
2.6 \\
2.6 \\
2.6\end{array}$ & $\begin{array}{l}0.00 \\
0.00 \\
0.00 \\
0.00 \\
0.00\end{array}$ \\
\hline $\begin{array}{l}1805 \\
1810 \\
1815 \\
1820 \\
1825\end{array}$ & $\begin{array}{l}4.9 \\
4.7 \\
4.7 \\
4.7 \\
4.7\end{array}$ & $\begin{array}{l}0.00 \\
0.00 \\
0.00 \\
0.00 \\
0.00\end{array}$ & $\begin{array}{l}2330 \\
2335 \\
2340 \\
2345 \\
2350\end{array}$ & $\begin{array}{l}3.1 \\
3.1 \\
3.0 \\
3.0 \\
3.0\end{array}$ & $\begin{array}{l}0.00 \\
0.00 \\
0.00 \\
0.00 \\
0.00\end{array}$ & $\begin{array}{l}0450 \\
0455 \\
0500 \\
0505 \\
0510\end{array}$ & $\begin{array}{l}2.6 \\
2.6 \\
2.6 \\
2.6 \\
2.6\end{array}$ & $\begin{array}{l}0.00 \\
0.00 \\
0.00 \\
0.00 \\
0.00\end{array}$ \\
\hline $\begin{array}{l}1830 \\
1835 \\
1840 \\
1845 \\
1850\end{array}$ & $\begin{array}{l}4.7 \\
4.5 \\
4.5 \\
4.5 \\
4.5\end{array}$ & $\begin{array}{l}0.00 \\
0.00 \\
0.00 \\
0.00 \\
0.00\end{array}$ & $\begin{array}{c}2355 \\
\text { August } \\
0000 \\
0005 \\
0010\end{array}$ & $\begin{array}{r}3.0 \\
1986 \\
3.0 \\
3.0 \\
3.0\end{array}$ & $\begin{array}{l}0.00 \\
0.00 \\
0.00 \\
0.00\end{array}$ & $\begin{array}{l}0515 \\
0520 \\
0525 \\
0530 \\
0535\end{array}$ & $\begin{array}{l}2.4 \\
2.4 \\
2.4 \\
2.4 \\
2.4\end{array}$ & $\begin{array}{l}0.00 \\
0.00 \\
0.00 \\
0.00 \\
0.00\end{array}$ \\
\hline $\begin{array}{l}1855 \\
1900 \\
1905 \\
1910 \\
1915\end{array}$ & $\begin{array}{l}4.5 \\
4.3 \\
4.3 \\
4.3 \\
4.3\end{array}$ & $\begin{array}{l}0.00 \\
0.00 \\
0.00 \\
0.00 \\
0.00\end{array}$ & $\begin{array}{l}0015 \\
0020 \\
0025 \\
0030 \\
0035\end{array}$ & $\begin{array}{l}3.0 \\
3.0 \\
3.0 \\
3.0 \\
3.0\end{array}$ & $\begin{array}{l}0.00 \\
0.00 \\
0.00 \\
0.00 \\
0.00\end{array}$ & $\begin{array}{l}0540 \\
0545 \\
0550 \\
0555 \\
0600\end{array}$ & $\begin{array}{l}2.4 \\
2.4 \\
2.4 \\
2.4 \\
2.4\end{array}$ & $\begin{array}{l}0.00 \\
0.00 \\
0.00 \\
0.00 \\
0.00\end{array}$ \\
\hline $\begin{array}{l}1920 \\
1925 \\
1930 \\
1935 \\
1940\end{array}$ & $\begin{array}{l}4.3 \\
4.3 \\
4.2 \\
4.2 \\
4.2\end{array}$ & $\begin{array}{l}0.00 \\
0.00 \\
0.00 \\
0.00 \\
0.00\end{array}$ & $\begin{array}{l}0040 \\
0045 \\
0050 \\
0055 \\
0100\end{array}$ & $\begin{array}{l}3.0 \\
3.0 \\
3.0 \\
3.0 \\
3.0\end{array}$ & $\begin{array}{l}0.00 \\
0.00 \\
0.00 \\
0.00 \\
0.00\end{array}$ & $\begin{array}{l}0605 \\
0610 \\
0615 \\
0620 \\
0625\end{array}$ & $\begin{array}{l}2.4 \\
2.3 \\
2.3 \\
2.3 \\
2.3\end{array}$ & $\begin{array}{l}0.00 \\
0.00 \\
0.00 \\
0.00 \\
0.00\end{array}$ \\
\hline
\end{tabular}


Table 106. --Streamflow and rainfall at station 02169568, Pen Branch at Columbia, August $11-13,1986-$-Continued

\begin{tabular}{|c|c|c|c|c|c|c|c|c|}
\hline $\begin{array}{l}\text { Time } \\
\text { (hours) }\end{array}$ & $\begin{array}{l}\text { Streamflow } \\
\text { (cubic feet } \\
\text { per second) }\end{array}$ & $\begin{array}{l}\text { Rain- } \\
\text { fall } \\
\text { (inches) }\end{array}$ & $\begin{array}{l}\text { Time } \\
\text { (hours) }\end{array}$ & $\begin{array}{l}\text { Streamflow } \\
\text { (cubic feet } \\
\text { per second) }\end{array}$ & $\begin{array}{l}\text { Rain- } \\
\text { fall } \\
\text { (inches) }\end{array}$ & $\begin{array}{l}\text { Time } \\
\text { (hours) }\end{array}$ & $\begin{array}{l}\text { Streamflow } \\
\text { (cubic feet } \\
\text { per second) }\end{array}$ & $\begin{array}{l}\text { Rein- } \\
\text { feli } \\
\text { (irches) }\end{array}$ \\
\hline $\begin{array}{l}0630 \\
0635 \\
0640 \\
0645 \\
0650\end{array}$ & $\begin{array}{l}2.3 \\
2.3 \\
2.3 \\
2.3 \\
2.3\end{array}$ & $\begin{array}{l}0.00 \\
0.00 \\
0.00 \\
0.00 \\
0.00\end{array}$ & $\begin{array}{l}1125 \\
1130 \\
1135 \\
1140 \\
1145\end{array}$ & $\begin{array}{l}6.3 \\
5.9 \\
5.5 \\
5.1 \\
4.9\end{array}$ & $\begin{array}{l}0.00 \\
0.00 \\
0.00 \\
0.00 \\
0.00\end{array}$ & $\begin{array}{l}1620 \\
1625 \\
1630 \\
1635 \\
1640\end{array}$ & $\begin{array}{l}1.7 \\
1.7 \\
1.7 \\
1.7 \\
1.7\end{array}$ & $\begin{array}{l}0.00 \\
0.00 \\
0.00 \\
0.00 \\
0.00\end{array}$ \\
\hline $\begin{array}{l}0655 \\
0700 \\
0705 \\
0710 \\
0715\end{array}$ & $\begin{array}{l}2.3 \\
2.3 \\
2.3 \\
2.3 \\
2.3\end{array}$ & $\begin{array}{l}0.00 \\
0.00 \\
0.00 \\
0.00 \\
0.00\end{array}$ & $\begin{array}{l}1150 \\
1155 \\
1200 \\
1205 \\
1210\end{array}$ & $\begin{array}{l}4.5 \\
4.3 \\
4.2 \\
3.8 \\
3.6\end{array}$ & $\begin{array}{l}0.00 \\
0.00 \\
0.00 \\
0.00 \\
0.00\end{array}$ & $\begin{array}{l}1645 \\
1650 \\
1655 \\
1700 \\
1705\end{array}$ & $\begin{array}{l}1.7 \\
1.7 \\
1.7 \\
1.7 \\
1.6\end{array}$ & $\begin{array}{l}0.00 \\
0.00 \\
0.00 \\
0.00 \\
0.00\end{array}$ \\
\hline $\begin{array}{l}0720 \\
0725 \\
0730 \\
0735 \\
0740\end{array}$ & $\begin{array}{l}2.1 \\
2.1 \\
2.1 \\
2.1 \\
2.1\end{array}$ & $\begin{array}{l}0.00 \\
0.00 \\
0.00 \\
0.00 \\
0.00\end{array}$ & $\begin{array}{l}1215 \\
1220 \\
1225 \\
1230 \\
1235\end{array}$ & $\begin{array}{l}3.5 \\
3.5 \\
3.3 \\
3.1 \\
3.0\end{array}$ & $\begin{array}{l}0.00 \\
0.00 \\
0.00 \\
0.00 \\
0.00\end{array}$ & $\begin{array}{l}1710 \\
1715 \\
1720 \\
1725 \\
1730\end{array}$ & $\begin{array}{l}1.6 \\
1.6 \\
1.6 \\
1.6 \\
1.6\end{array}$ & $\begin{array}{l}0.00 \\
0.00 \\
0.00 \\
0.00 \\
0.00\end{array}$ \\
\hline $\begin{array}{l}0745 \\
0750 \\
0755 \\
0800 \\
0805\end{array}$ & $\begin{array}{l}2 \cdot 1 \\
2 \cdot 1 \\
2 \cdot 1 \\
2 \cdot 1 \\
2 \cdot 1\end{array}$ & $\begin{array}{l}0.00 \\
0.00 \\
0.00 \\
0.00 \\
0.00\end{array}$ & $\begin{array}{l}1240 \\
1245 \\
1250 \\
1255 \\
1300\end{array}$ & $\begin{array}{l}3.0 \\
2.8 \\
2.8 \\
2.7 \\
2.7\end{array}$ & $\begin{array}{l}0.00 \\
0.00 \\
0.00 \\
0.00 \\
0.00\end{array}$ & $\begin{array}{l}1735 \\
1740 \\
1745 \\
1750 \\
1755\end{array}$ & $\begin{array}{l}1.6 \\
1.6 \\
1.6 \\
1.6 \\
1.6\end{array}$ & $\begin{array}{l}0.00 \\
0.00 \\
0.00 \\
0.00 \\
0.00\end{array}$ \\
\hline $\begin{array}{l}0810 \\
0815 \\
0820 \\
0825 \\
0830\end{array}$ & $\begin{array}{l}2.1 \\
2.1 \\
2.1 \\
2.1 \\
2.1\end{array}$ & $\begin{array}{l}0.00 \\
0.00 \\
0.00 \\
0.00 \\
0.00\end{array}$ & $\begin{array}{l}1305 \\
1310 \\
1315 \\
1320 \\
1325\end{array}$ & $\begin{array}{l}2.6 \\
2.6 \\
2.6 \\
2.6 \\
2.4\end{array}$ & $\begin{array}{l}0.00 \\
0.00 \\
0.00 \\
0.00 \\
0.00\end{array}$ & $\begin{array}{l}1800 \\
1805 \\
1810 \\
1815 \\
1820\end{array}$ & $\begin{array}{l}1.6 \\
1.6 \\
1.5 \\
1.5 \\
1.5\end{array}$ & $\begin{array}{l}0.00 \\
0.00 \\
0.00 \\
0.00 \\
0.00\end{array}$ \\
\hline $\begin{array}{l}0835 \\
0840 \\
0845 \\
0850 \\
0855\end{array}$ & $\begin{array}{l}2.1 \\
2.1 \\
2.1 \\
2.1 \\
2.1\end{array}$ & $\begin{array}{l}0.00 \\
0.00 \\
0.00 \\
0.00 \\
0.00\end{array}$ & $\begin{array}{l}1330 \\
1335 \\
1340 \\
1345 \\
1350\end{array}$ & $\begin{array}{l}2.4 \\
2.4 \\
2.4 \\
2.4 \\
2.3\end{array}$ & $\begin{array}{l}0.00 \\
0.00 \\
0.00 \\
0.00 \\
0.00\end{array}$ & $\begin{array}{l}1825 \\
1830 \\
1835 \\
1840 \\
1845\end{array}$ & $\begin{array}{l}1.5 \\
1.5 \\
1.5 \\
1.5 \\
1.5\end{array}$ & $\begin{array}{l}0.00 \\
0.00 \\
0.00 \\
0.00 \\
0.00\end{array}$ \\
\hline $\begin{array}{l}0900 \\
0905 \\
0910 \\
0915 \\
0920\end{array}$ & $\begin{array}{l}2.1 \\
2.1 \\
2.1 \\
2.1 \\
2.1\end{array}$ & $\begin{array}{l}0.00 \\
0.00 \\
0.00 \\
0.00 \\
0.01\end{array}$ & $\begin{array}{l}1355 \\
1400 \\
1405 \\
1410 \\
1415\end{array}$ & $\begin{array}{l}2.3 \\
2.3 \\
2.3 \\
2.3 \\
2.1\end{array}$ & $\begin{array}{l}0.00 \\
0.00 \\
0.00 \\
0.00 \\
0.00\end{array}$ & $\begin{array}{l}1850 \\
1855 \\
1900 \\
1905 \\
1910\end{array}$ & $\begin{array}{l}1.5 \\
1.5 \\
1.5 \\
1.5 \\
1.5\end{array}$ & $\begin{array}{l}0.00 \\
0.00 \\
0.00 \\
0.00 \\
0.00\end{array}$ \\
\hline $\begin{array}{l}0925 \\
0930 \\
0935 \\
0940 \\
0945\end{array}$ & $\begin{array}{r}2.3 \\
7.9 \\
10.3 \\
12.3 \\
17.5\end{array}$ & $\begin{array}{l}0.04 \\
0.02 \\
0.03 \\
0.04 \\
0.00\end{array}$ & $\begin{array}{l}1420 \\
1425 \\
1430 \\
1435 \\
1440\end{array}$ & $\begin{array}{l}2.1 \\
2.1 \\
2.1 \\
2.1 \\
2.1\end{array}$ & $\begin{array}{l}0.00 \\
0.00 \\
0.00 \\
0.00 \\
0.00\end{array}$ & $\begin{array}{l}1915 \\
1920 \\
1925 \\
1930 \\
1935\end{array}$ & $\begin{array}{l}1.5 \\
1.5 \\
1.5 \\
1.5 \\
1.5\end{array}$ & $\begin{array}{l}0.00 \\
0.00 \\
0.00 \\
0.00 \\
0.00\end{array}$ \\
\hline $\begin{array}{l}0950 \\
0955 \\
1000 \\
1005 \\
1010\end{array}$ & $\begin{array}{l}21.1 \\
21.5 \\
20.7 \\
20.3 \\
21.5\end{array}$ & $\begin{array}{l}0.00 \\
0.01 \\
0.00 \\
0.00 \\
0.00\end{array}$ & $\begin{array}{l}1445 \\
1450 \\
1455 \\
1500 \\
1505\end{array}$ & $\begin{array}{l}2.1 \\
2.1 \\
2.0 \\
2.0 \\
2.0\end{array}$ & $\begin{array}{l}0.00 \\
0.00 \\
0.00 \\
0.00 \\
0.00\end{array}$ & $\begin{array}{l}1940 \\
1945 \\
1950 \\
1955 \\
2000\end{array}$ & $\begin{array}{l}1.5 \\
1.4 \\
1.4 \\
1.4 \\
1.4\end{array}$ & $\begin{array}{l}0.00 \\
0.00 \\
0.00 \\
0.00 \\
0.00\end{array}$ \\
\hline $\begin{array}{l}1015 \\
1020 \\
1025 \\
1030 \\
1035\end{array}$ & $\begin{array}{l}23.9 \\
25.6 \\
24.7 \\
22.3 \\
20.0\end{array}$ & $\begin{array}{l}0.00 \\
0.00 \\
0.00 \\
0.00 \\
0.00\end{array}$ & $\begin{array}{l}1510 \\
1515 \\
1520 \\
1525 \\
1530\end{array}$ & $\begin{array}{l}2.0 \\
2.0 \\
2.0 \\
2.0 \\
2.0\end{array}$ & $\begin{array}{l}0.00 \\
0.00 \\
0.00 \\
0.00 \\
0.00\end{array}$ & $\begin{array}{l}2005 \\
2010 \\
2015 \\
2020 \\
2025\end{array}$ & $\begin{array}{l}1.4 \\
1.4 \\
1.4 \\
1.4 \\
1.4\end{array}$ & $\begin{array}{l}0.00 \\
0.00 \\
0.00 \\
0.00 \\
0.00\end{array}$ \\
\hline $\begin{array}{l}1040 \\
1045 \\
1050 \\
1055 \\
1100\end{array}$ & $\begin{array}{l}17.5 \\
15.2 \\
13.4 \\
12.0 \\
10.6\end{array}$ & $\begin{array}{l}0.00 \\
0.00 \\
0.00 \\
0.00 \\
0.00\end{array}$ & $\begin{array}{l}1535 \\
1540 \\
1545 \\
1550 \\
1555\end{array}$ & $\begin{array}{l}2.0 \\
2.0 \\
1.9 \\
1.9 \\
1.9\end{array}$ & $\begin{array}{l}0.00 \\
0.00 \\
0.00 \\
0.00 \\
0.00\end{array}$ & $\begin{array}{l}2030 \\
2035 \\
2040 \\
2045 \\
2050\end{array}$ & $\begin{array}{l}1.3 \\
1.3 \\
1.3 \\
1.3 \\
1.3\end{array}$ & $\begin{array}{l}0.00 \\
0.00 \\
0.00 \\
0.00 \\
0.00\end{array}$ \\
\hline $\begin{array}{l}1105 \\
1110 \\
1115 \\
1120\end{array}$ & $\begin{array}{l}9.3 \\
8.3 \\
7.6 \\
7.0\end{array}$ & $\begin{array}{l}0.00 \\
0.00 \\
0.00 \\
0.00\end{array}$ & $\begin{array}{l}1600 \\
1605 \\
1610 \\
1615\end{array}$ & $\begin{array}{l}1.9 \\
1.9 \\
1.9 \\
1.9\end{array}$ & $\begin{array}{l}0.00 \\
0.00 \\
0.00 \\
0.00\end{array}$ & $\begin{array}{l}2055 \\
2100\end{array}$ & $\begin{array}{l}1.3 \\
1.3\end{array}$ & $\begin{array}{l}0.00 \\
0.00\end{array}$ \\
\hline
\end{tabular}




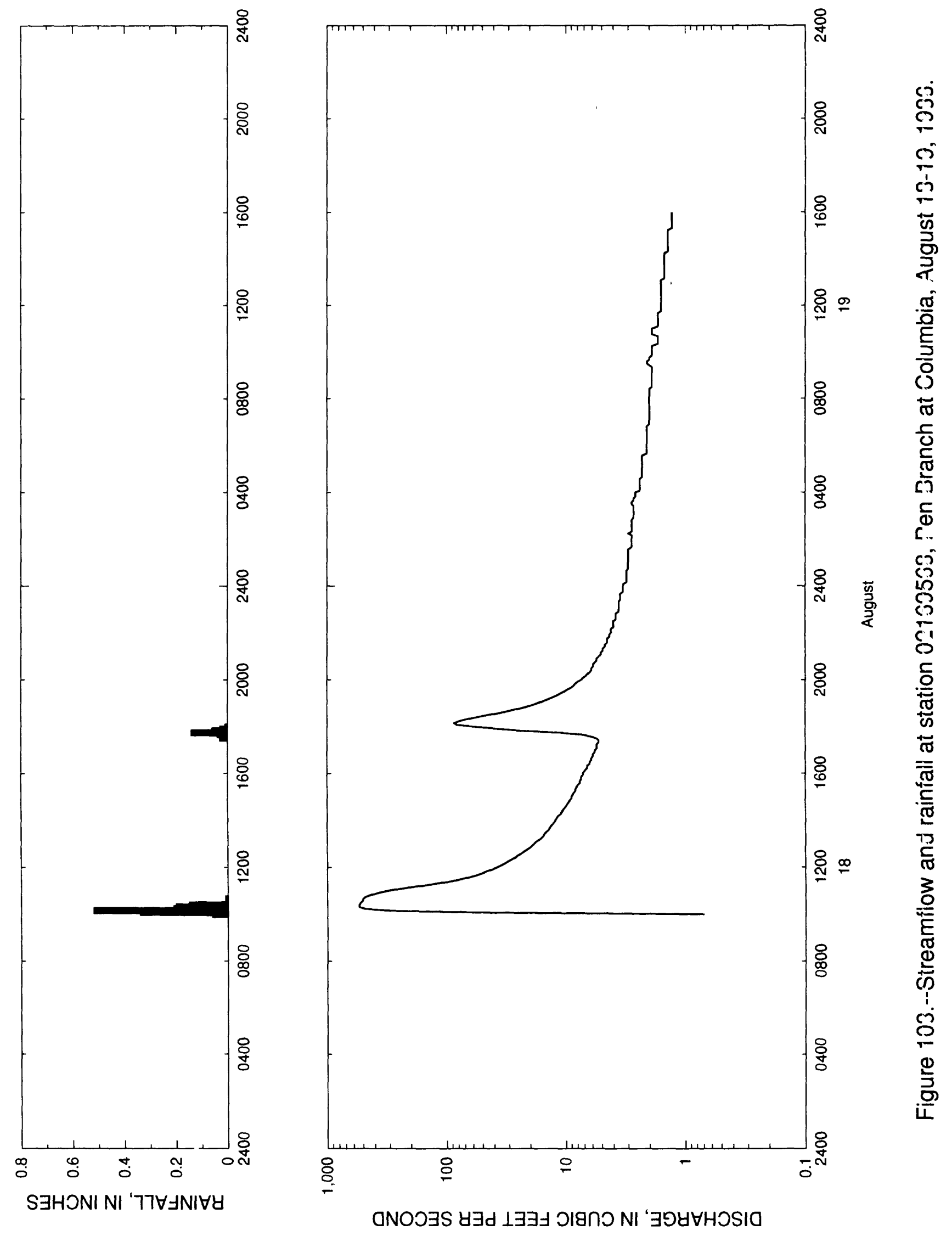


Table 107.--Streamflow and rainfall at station 02169568. Pen Branch at Columbia, August 18-19, 1986

\begin{tabular}{|c|c|c|c|c|c|c|c|c|}
\hline $\begin{array}{l}\text { Time } \\
\text { (hours) }\end{array}$ & $\begin{array}{l}\text { Streamflow } \\
\text { (cubic feet } \\
\text { per second) }\end{array}$ & $\begin{array}{l}\text { Rain- } \\
\text { fall } \\
\text { (inches) }\end{array}$ & $\begin{array}{l}\text { Time } \\
\text { (hours) }\end{array}$ & $\begin{array}{l}\text { Streamflow } \\
\text { (cubic feet } \\
\text { per second) }\end{array}$ & $\begin{array}{l}\text { Rain- } \\
\text { fall } \\
\text { (inches) }\end{array}$ & $\begin{array}{l}\text { Time } \\
\text { (hours) }\end{array}$ & $\begin{array}{l}\text { Streamflow } \\
\text { (cubic feet } \\
\text { per second) }\end{array}$ & $\begin{array}{l}\text { Rain- } \\
\text { fall } \\
\text { (inches) }\end{array}$ \\
\hline $\begin{array}{l}\text { August } 1 \\
1000 \\
1005 \\
1010 \\
1015\end{array}$ & $\begin{array}{r}18,196 \\
0.7 \\
50.0 \\
294.0 \\
486.0\end{array}$ & $\begin{array}{l}0.06 \\
0.34 \\
0.52 \\
0.21\end{array}$ & $\begin{array}{l}1520 \\
1525 \\
1530 \\
1535 \\
1540\end{array}$ & $\begin{array}{l}8.3 \\
8.1 \\
7.9 \\
7.6 \\
7.6\end{array}$ & $\begin{array}{l}0.00 \\
0.00 \\
0.00 \\
0.00 \\
0.00\end{array}$ & $\begin{array}{l}2045 \\
2050 \\
2055 \\
2100 \\
2105\end{array}$ & $\begin{array}{l}5.7 \\
5.5 \\
5.5 \\
5.3 \\
5.1\end{array}$ & $\begin{array}{l}0.00 \\
0.00 \\
0.00 \\
0.00 \\
0.00\end{array}$ \\
\hline $\begin{array}{l}1020 \\
1025 \\
1030 \\
1035 \\
1040\end{array}$ & $\begin{array}{l}544.0 \\
541.0 \\
527.0 \\
508.0 \\
502.0\end{array}$ & $\begin{array}{l}0.20 \\
0.15 \\
0.01 \\
0.00 \\
0.01\end{array}$ & $\begin{array}{l}1545 \\
1550 \\
1555 \\
1600 \\
1605\end{array}$ & $\begin{array}{l}7.4 \\
7.4 \\
7.2 \\
7.2 \\
7.0\end{array}$ & $\begin{array}{l}0.00 \\
0.00 \\
0.00 \\
0.00 \\
0.00\end{array}$ & $\begin{array}{l}2110 \\
2115 \\
2120 \\
2125 \\
2130\end{array}$ & $\begin{array}{l}5.1 \\
4.9 \\
4.9 \\
4.7 \\
4.7\end{array}$ & $\begin{array}{l}0.00 \\
0.00 \\
0.00 \\
0.00 \\
0.00\end{array}$ \\
\hline $\begin{array}{l}1045 \\
1050 \\
1055 \\
1100 \\
1105\end{array}$ & $\begin{array}{l}480.0 \\
436.0 \\
384.0 \\
322.0 \\
256.0\end{array}$ & $\begin{array}{l}0.00 \\
0.00 \\
0.00 \\
0.00 \\
0.00\end{array}$ & $\begin{array}{l}1610 \\
1615 \\
1620 \\
1625 \\
1630\end{array}$ & $\begin{array}{l}6.8 \\
6.6 \\
6.6 \\
6.3 \\
6.3\end{array}$ & $\begin{array}{l}0.00 \\
0.00 \\
0.00 \\
0.00 \\
0.00\end{array}$ & $\begin{array}{l}2135 \\
2140 \\
2145 \\
2150 \\
2155\end{array}$ & $\begin{array}{l}4.5 \\
4.5 \\
4.5 \\
4.3 \\
4.3\end{array}$ & $\begin{array}{l}0.00 \\
0.00 \\
0.00 \\
0.00 \\
0.00\end{array}$ \\
\hline $\begin{array}{l}1110 \\
1115 \\
1120 \\
1125 \\
1130\end{array}$ & $\begin{array}{r}197.0 \\
149.0 \\
115.0 \\
91.4 \\
75.0\end{array}$ & $\begin{array}{l}0.00 \\
0.00 \\
0.00 \\
0.00 \\
0.00\end{array}$ & $\begin{array}{l}1635 \\
1640 \\
1645 \\
1650 \\
1655\end{array}$ & $\begin{array}{l}6.1 \\
6.1 \\
5.9 \\
5.9 \\
5.7\end{array}$ & $\begin{array}{l}0.00 \\
0.00 \\
0.00 \\
0.00 \\
0.00\end{array}$ & $\begin{array}{l}2200 \\
2205 \\
2210 \\
2215 \\
2220\end{array}$ & $\begin{array}{l}4.2 \\
4.2 \\
4.2 \\
4.0 \\
4.0\end{array}$ & $\begin{array}{l}0.00 \\
0.00 \\
0.00 \\
0.00 \\
0.00\end{array}$ \\
\hline $\begin{array}{l}1135 \\
1140 \\
1145 \\
1150 \\
1155\end{array}$ & $\begin{array}{l}64.8 \\
56.6 \\
50.5 \\
46.3 \\
41.7\end{array}$ & $\begin{array}{l}0.00 \\
0.00 \\
0.00 \\
0.00 \\
0.00\end{array}$ & $\begin{array}{l}1700 \\
1705 \\
1710 \\
1715 \\
1720\end{array}$ & $\begin{array}{l}5.7 \\
5.5 \\
5.5 \\
5.5 \\
5.3\end{array}$ & $\begin{array}{l}0.00 \\
0.00 \\
0.00 \\
0.00 \\
0.00\end{array}$ & $\begin{array}{l}2225 \\
2230 \\
2235 \\
2240 \\
2245\end{array}$ & $\begin{array}{l}4.0 \\
4.0 \\
3.8 \\
3.8 \\
3.8\end{array}$ & $\begin{array}{l}0.00 \\
0.00 \\
0.00 \\
0.00 \\
0.00\end{array}$ \\
\hline $\begin{array}{l}1200 \\
1205 \\
1210 \\
1215 \\
1220\end{array}$ & $\begin{array}{l}38.4 \\
35.3 \\
32.8 \\
30.9 \\
28.6\end{array}$ & $\begin{array}{l}0.00 \\
0.00 \\
0.00 \\
0.00 \\
0.00\end{array}$ & $\begin{array}{l}1725 \\
1730 \\
1735 \\
1740 \\
1745\end{array}$ & $\begin{array}{r}5.3 \\
5.5 \\
6.1 \\
7.4 \\
11.4\end{array}$ & $\begin{array}{l}0.00 \\
0.03 \\
0.00 \\
0.04 \\
0.14\end{array}$ & $\begin{array}{l}2250 \\
2255 \\
2300 \\
2305 \\
2310\end{array}$ & $\begin{array}{l}3.8 \\
3.6 \\
3.6 \\
3.6 \\
3.6\end{array}$ & $\begin{array}{l}0.00 \\
0.00 \\
0.00 \\
0.00 \\
0.00\end{array}$ \\
\hline $\begin{array}{l}1225 \\
1230 \\
1235 \\
1240 \\
1245\end{array}$ & $\begin{array}{l}26.8 \\
25.6 \\
23.9 \\
22.6 \\
21.1\end{array}$ & $\begin{array}{l}0.00 \\
0.00 \\
0.00 \\
0.00 \\
0.00\end{array}$ & $\begin{array}{l}1750 \\
1755 \\
1800 \\
1805 \\
1810\end{array}$ & $\begin{array}{l}24.3 \\
37.3 \\
56.0 \\
81.8 \\
86.8\end{array}$ & $\begin{array}{l}0.06 \\
0.03 \\
0.01 \\
0.00 \\
0.00\end{array}$ & $\begin{array}{l}2315 \\
2320 \\
2325 \\
2330 \\
2335\end{array}$ & $\begin{array}{l}3.6 \\
3.6 \\
3.5 \\
3.5 \\
3.5\end{array}$ & $\begin{array}{l}0.00 \\
0.00 \\
0.00 \\
0.00 \\
0.00\end{array}$ \\
\hline $\begin{array}{l}1250 \\
1255 \\
1300 \\
1305 \\
1310\end{array}$ & $\begin{array}{l}20.0 \\
19.2 \\
18.5 \\
17.8 \\
16.8\end{array}$ & $\begin{array}{l}0.00 \\
0.00 \\
0.00 \\
0.00 \\
0.00\end{array}$ & $\begin{array}{l}1815 \\
1820 \\
1825 \\
1830 \\
1835\end{array}$ & $\begin{array}{l}78.4 \\
66.7 \\
56.0 \\
45.7 \\
36.8\end{array}$ & $\begin{array}{l}0.00 \\
0.00 \\
0.00 \\
0.00 \\
0.00\end{array}$ & $\begin{array}{r}2340 \\
2345 \\
2350 \\
2355 \\
\text { August }\end{array}$ & $\begin{array}{r}3.5 \\
3.3 \\
3.3 \\
3.3 \\
19,1986\end{array}$ & $\begin{array}{l}0.00 \\
0.00 \\
0.00 \\
0.00\end{array}$ \\
\hline $\begin{array}{l}1315 \\
1320 \\
1325 \\
1330 \\
1335\end{array}$ & $\begin{array}{l}16.1 \\
15.5 \\
15.2 \\
14.6 \\
14.0\end{array}$ & $\begin{array}{l}0.00 \\
0.00 \\
0.00 \\
0.00 \\
0.00\end{array}$ & $\begin{array}{l}1840 \\
1845 \\
1850 \\
1855 \\
1900\end{array}$ & $\begin{array}{l}30.9 \\
26.4 \\
22.6 \\
19.6 \\
17.5\end{array}$ & $\begin{array}{l}0.00 \\
0.00 \\
0.00 \\
0.00 \\
0.00\end{array}$ & $\begin{array}{l}0000 \\
0005 \\
0010 \\
0015 \\
0020\end{array}$ & $\begin{array}{l}3.3 \\
3.3 \\
3.1 \\
3.1 \\
3.1\end{array}$ & $\begin{array}{l}0.00 \\
0.00 \\
0.00 \\
0.00 \\
0.00\end{array}$ \\
\hline $\begin{array}{l}1340 \\
1345 \\
1350 \\
1355 \\
1400\end{array}$ & $\begin{array}{l}13.7 \\
13.4 \\
12.8 \\
12.5 \\
12.3\end{array}$ & $\begin{array}{l}0.00 \\
0.00 \\
0.00 \\
0.00 \\
0.00\end{array}$ & $\begin{array}{l}1905 \\
1910 \\
1915 \\
1920 \\
1925\end{array}$ & $\begin{array}{l}15.8 \\
14.3 \\
13.1 \\
12.0 \\
11.1\end{array}$ & $\begin{array}{l}0.00 \\
0.00 \\
0.00 \\
0.00 \\
0.00\end{array}$ & $\begin{array}{l}0025 \\
0030 \\
0035 \\
0040 \\
0045\end{array}$ & $\begin{array}{l}3.1 \\
3.1 \\
3.1 \\
3.1 \\
3 \cdot 0\end{array}$ & $\begin{array}{l}0.00 \\
0.00 \\
0.00 \\
0.00 \\
0.00\end{array}$ \\
\hline $\begin{array}{l}1405 \\
1410 \\
1415 \\
1420 \\
1425\end{array}$ & $\begin{array}{l}12.0 \\
11.7 \\
11.1 \\
10.9 \\
10.6\end{array}$ & $\begin{array}{l}0.00 \\
0.00 \\
0.00 \\
0.00 \\
0.00\end{array}$ & $\begin{array}{l}1930 \\
1935 \\
1940 \\
1945 \\
1950\end{array}$ & $\begin{array}{r}10.3 \\
9.8 \\
9.0 \\
8.6 \\
8.3\end{array}$ & $\begin{array}{l}0.00 \\
0.00 \\
0.00 \\
0.00 \\
0.00\end{array}$ & $\begin{array}{l}0050 \\
0055 \\
0100 \\
0105 \\
0110\end{array}$ & $\begin{array}{l}3.0 \\
3.0 \\
3.0 \\
3.0 \\
3.0\end{array}$ & $\begin{array}{l}0.00 \\
0.00 \\
0.00 \\
0.00 \\
0.00\end{array}$ \\
\hline $\begin{array}{l}1430 \\
1435 \\
1440 \\
1445 \\
1450\end{array}$ & $\begin{array}{r}10.3 \\
10.0 \\
9.8 \\
9.5 \\
9.3\end{array}$ & $\begin{array}{l}0.00 \\
0.00 \\
0.00 \\
0.00 \\
0.00\end{array}$ & $\begin{array}{l}1955 \\
2000 \\
2005 \\
2010 \\
2015\end{array}$ & $\begin{array}{l}7.9 \\
7.4 \\
7.2 \\
6.8 \\
6.6\end{array}$ & $\begin{array}{l}0.00 \\
0.00 \\
0.00 \\
0.00 \\
0.00\end{array}$ & $\begin{array}{l}0115 \\
0120 \\
0125 \\
0130 \\
0135\end{array}$ & $\begin{array}{l}3.0 \\
3.0 \\
3.0 \\
3.0 \\
3.0\end{array}$ & $\begin{array}{l}0.00 \\
0.00 \\
0.00 \\
0.00 \\
0.00\end{array}$ \\
\hline $\begin{array}{l}1455 \\
1500 \\
1505 \\
1510 \\
1515\end{array}$ & $\begin{array}{l}9.0 \\
9.0 \\
8.8 \\
8.6 \\
8.3\end{array}$ & $\begin{array}{l}0.00 \\
0.00 \\
0.00 \\
0.00 \\
0.00\end{array}$ & $\begin{array}{l}2020 \\
2025 \\
2030 \\
2035 \\
2040\end{array}$ & $\begin{array}{l}6.3 \\
6.1 \\
6.1 \\
5.9 \\
5.9\end{array}$ & $\begin{array}{l}0.00 \\
0.00 \\
0.00 \\
0.00 \\
0.00\end{array}$ & $\begin{array}{l}0140 \\
0145 \\
0150 \\
0155 \\
0200\end{array}$ & $\begin{array}{l}2.8 \\
2.8 \\
2.8 \\
2.8 \\
2.8\end{array}$ & $\begin{array}{l}0.00 \\
0.00 \\
0.00 \\
0.00 \\
0.00\end{array}$ \\
\hline
\end{tabular}


Table 107.--Streamflow and rainfall at station 02169568, Pen Branch at Columbia, August $18-19,1986^{--C o n t i n u e d}$

\begin{tabular}{|c|c|c|c|c|c|c|c|c|}
\hline $\begin{array}{l}\text { Time } \\
\text { (hours) }\end{array}$ & $\begin{array}{l}\text { Streamflow } \\
\text { (cubic feet } \\
\text { per second) }\end{array}$ & $\begin{array}{l}\text { Rain- } \\
\text { fall } \\
\text { (inches) }\end{array}$ & $\begin{array}{l}\text { Time } \\
\text { (hours) }\end{array}$ & $\begin{array}{l}\text { Streamflow } \\
\text { (cubic feet } \\
\text { per second) }\end{array}$ & $\begin{array}{l}\text { Rain- } \\
\text { fall } \\
\text { (inches) }\end{array}$ & $\begin{array}{l}\text { Time } \\
\text { (hours) }\end{array}$ & $\begin{array}{l}\text { Streamflow } \\
\text { (cubic feet } \\
\text { per second) }\end{array}$ & $\begin{array}{l}\text { Rain- } \\
\text { fall } \\
\text { (inches) }\end{array}$ \\
\hline $\begin{array}{l}0205 \\
0210 \\
0215 \\
0220 \\
0225\end{array}$ & $\begin{array}{l}2.8 \\
2.8 \\
3.0 \\
2.8 \\
2.8\end{array}$ & $\begin{array}{l}0.00 \\
0.00 \\
0.00 \\
0.00 \\
0.00\end{array}$ & $\begin{array}{l}0645 \\
0650 \\
0655 \\
0700 \\
0705\end{array}$ & $\begin{array}{l}2.1 \\
2.1 \\
2.0 \\
2.0 \\
2.0\end{array}$ & $\begin{array}{l}0.00 \\
0.00 \\
0.00 \\
0.00 \\
0.00\end{array}$ & $\begin{array}{l}1125 \\
1130 \\
1135 \\
1140 \\
1145\end{array}$ & $\begin{array}{l}1.7 \\
1.7 \\
1.7 \\
1.7 \\
1.6\end{array}$ & $\begin{array}{l}0.00 \\
0.00 \\
0.00 \\
0.00 \\
0.00\end{array}$ \\
\hline $\begin{array}{l}0230 \\
0235 \\
0240 \\
0245 \\
0250\end{array}$ & $\begin{array}{l}2.8 \\
2.8 \\
2.8 \\
2.8 \\
2.8\end{array}$ & $\begin{array}{l}0.00 \\
0.00 \\
0.00 \\
0.00 \\
0.00\end{array}$ & $\begin{array}{l}0710 \\
0715 \\
0720 \\
0725 \\
0730\end{array}$ & $\begin{array}{l}2.0 \\
2.0 \\
2.0 \\
2.0 \\
2.0\end{array}$ & $\begin{array}{l}0.00 \\
0.00 \\
0.00 \\
0.00 \\
0.00\end{array}$ & $\begin{array}{l}1150 \\
1155 \\
1200 \\
1205 \\
1210\end{array}$ & $\begin{array}{l}1.6 \\
1.6 \\
1.6 \\
1.6 \\
1.6\end{array}$ & $\begin{array}{l}0.00 \\
0.00 \\
0.00 \\
0.00 \\
0.00\end{array}$ \\
\hline $\begin{array}{l}0255 \\
0300 \\
0305 \\
0310 \\
0315\end{array}$ & $\begin{array}{l}2.7 \\
2.7 \\
2.7 \\
2.7 \\
2.7\end{array}$ & $\begin{array}{l}0.00 \\
0.00 \\
0.00 \\
0.00 \\
0.00\end{array}$ & $\begin{array}{l}0735 \\
0740 \\
0745 \\
0750 \\
0755\end{array}$ & $\begin{array}{l}2.0 \\
2.0 \\
2.0 \\
2.0 \\
2.0\end{array}$ & $\begin{array}{l}0.00 \\
0.00 \\
0.00 \\
0.00 \\
0.00\end{array}$ & $\begin{array}{l}1215 \\
1220 \\
1225 \\
1230 \\
1235\end{array}$ & $\begin{array}{l}1.6 \\
1.6 \\
1.6 \\
1.6 \\
1.6\end{array}$ & $\begin{array}{l}0.00 \\
0.00 \\
0.00 \\
0.00 \\
0.00\end{array}$ \\
\hline $\begin{array}{l}0320 \\
0325 \\
0330 \\
0335 \\
0340\end{array}$ & $\begin{array}{l}2.7 \\
2.7 \\
2.8 \\
2.8 \\
2.7\end{array}$ & $\begin{array}{l}0.00 \\
0.00 \\
0.00 \\
0.00 \\
0.00\end{array}$ & $\begin{array}{l}0800 \\
0805 \\
0810 \\
0815 \\
0820\end{array}$ & $\begin{array}{l}2.0 \\
2.0 \\
2.0 \\
2.0 \\
2.0\end{array}$ & $\begin{array}{l}0.00 \\
0.00 \\
0.00 \\
0.00 \\
0.00\end{array}$ & $\begin{array}{l}1240 \\
1245 \\
1250 \\
1255 \\
1300\end{array}$ & $\begin{array}{l}1.6 \\
1.6 \\
1.6 \\
1.6 \\
1.6\end{array}$ & $\begin{array}{l}0.00 \\
0.00 \\
0.00 \\
0.00 \\
0.00\end{array}$ \\
\hline $\begin{array}{l}0345 \\
0350 \\
0355 \\
0400 \\
0405\end{array}$ & $\begin{array}{l}2.7 \\
2.6 \\
2.6 \\
2.6 \\
2.4\end{array}$ & $\begin{array}{l}0.00 \\
0.00 \\
0.00 \\
0.00 \\
0.00\end{array}$ & $\begin{array}{l}0825 \\
0830 \\
0835 \\
0840 \\
0845\end{array}$ & $\begin{array}{l}2.0 \\
1.9 \\
1.9 \\
1.9 \\
1.9\end{array}$ & $\begin{array}{l}0.00 \\
0.00 \\
0.00 \\
0.00 \\
0.00\end{array}$ & $\begin{array}{l}1305 \\
1310 \\
1315 \\
1320 \\
1325\end{array}$ & $\begin{array}{l}1.6 \\
1.5 \\
1.5 \\
1.5 \\
1.5\end{array}$ & $\begin{array}{l}0.00 \\
0.00 \\
0.00 \\
0.00 \\
0.00\end{array}$ \\
\hline $\begin{array}{l}0410 \\
0415 \\
0420 \\
0425 \\
0430\end{array}$ & $\begin{array}{l}2.4 \\
2.4 \\
2.4 \\
2.4 \\
2.4\end{array}$ & $\begin{array}{l}6.00 \\
0.00 \\
0.00 \\
0.00 \\
0.00\end{array}$ & $\begin{array}{l}0850 \\
0855 \\
0900 \\
0905 \\
0910\end{array}$ & $\begin{array}{l}1.9 \\
1.9 \\
1.9 \\
1.9 \\
1.9\end{array}$ & $\begin{array}{l}0.00 \\
0.00 \\
0.00 \\
0.00 \\
0.00\end{array}$ & $\begin{array}{l}1330 \\
1335 \\
1340 \\
1345 \\
1350\end{array}$ & $\begin{array}{l}1.5 \\
1.5 \\
1.5 \\
1.5 \\
1.5\end{array}$ & $\begin{array}{l}0.00 \\
0.00 \\
0.00 \\
0.00 \\
0.00\end{array}$ \\
\hline $\begin{array}{l}0435 \\
0440 \\
0445 \\
0450 \\
0455\end{array}$ & $\begin{array}{l}2.4 \\
2.3 \\
2.3 \\
2.3 \\
2.3\end{array}$ & $\begin{array}{l}0.00 \\
0.00 \\
0.00 \\
0.00 \\
0.00\end{array}$ & $\begin{array}{l}0915 \\
0920 \\
0925 \\
0930 \\
0935\end{array}$ & $\begin{array}{l}1.9 \\
1.9 \\
2.0 \\
2.1 \\
2.1\end{array}$ & $\begin{array}{l}0.00 \\
0.00 \\
0.00 \\
0.00 \\
0.00\end{array}$ & $\begin{array}{l}1355 \\
1400 \\
1405 \\
1410 \\
1415\end{array}$ & $\begin{array}{l}1.5 \\
1.5 \\
1.5 \\
1.5 \\
1.5\end{array}$ & $\begin{array}{l}0.00 \\
0.00 \\
0.00 \\
0.00 \\
0.00\end{array}$ \\
\hline $\begin{array}{l}0500 \\
0505 \\
0510 \\
0515 \\
0520\end{array}$ & $\begin{array}{l}2.3 \\
2.3 \\
2.3 \\
2.3 \\
2.3\end{array}$ & $\begin{array}{l}0.00 \\
0.00 \\
0.00 \\
0.00 \\
0.00\end{array}$ & $\begin{array}{l}0940 \\
0945 \\
0950 \\
0955 \\
1000\end{array}$ & $\begin{array}{l}2.0 \\
2.0 \\
1.9 \\
1.9 \\
1.9\end{array}$ & $\begin{array}{l}0.00 \\
0.00 \\
0.00 \\
0.00 \\
0.00\end{array}$ & $\begin{array}{l}1420 \\
1425 \\
1430 \\
1435 \\
1440\end{array}$ & $\begin{array}{l}1.4 \\
1.4 \\
1.4 \\
1.4 \\
1.4\end{array}$ & $\begin{array}{l}0.00 \\
0.00 \\
0.00 \\
0.00 \\
0.00\end{array}$ \\
\hline $\begin{array}{l}0525 \\
0530 \\
0535 \\
0540 \\
0545\end{array}$ & $\begin{array}{l}2.3 \\
2.3 \\
2.3 \\
2.1 \\
2.1\end{array}$ & $\begin{array}{l}0.00 \\
0.00 \\
0.00 \\
0.00 \\
0.00\end{array}$ & $\begin{array}{l}1005 \\
1010 \\
1015 \\
1020 \\
1025\end{array}$ & $\begin{array}{l}1.9 \\
1.9 \\
1.9 \\
1.7 \\
1.7\end{array}$ & $\begin{array}{l}0.00 \\
0.00 \\
0.00 \\
0.00 \\
0.00\end{array}$ & $\begin{array}{l}1445 \\
1450 \\
1455 \\
1500 \\
1505\end{array}$ & $\begin{array}{l}1.4 \\
1.4 \\
1.4 \\
1.4 \\
1.4\end{array}$ & $\begin{array}{l}0.00 \\
0.00 \\
0.00 \\
0.00 \\
0.00\end{array}$ \\
\hline $\begin{array}{l}0550 \\
0555 \\
0600 \\
0605 \\
0610\end{array}$ & $\begin{array}{l}2.1 \\
2.1 \\
2.1 \\
2.1 \\
2.1\end{array}$ & $\begin{array}{l}0.00 \\
0.00 \\
0.00 \\
0.00 \\
0.00\end{array}$ & $\begin{array}{l}1030 \\
1035 \\
1040 \\
1045 \\
1050\end{array}$ & $\begin{array}{l}1.7 \\
1.7 \\
1.7 \\
1.9 \\
1.9\end{array}$ & $\begin{array}{l}0.00 \\
0.00 \\
0.00 \\
0.00 \\
0.00\end{array}$ & $\begin{array}{l}1510 \\
1515 \\
1520 \\
1525 \\
1530\end{array}$ & $\begin{array}{l}1.4 \\
1.4 \\
1.3 \\
1.3 \\
1.3\end{array}$ & $\begin{array}{l}0.00 \\
0.00 \\
0.00 \\
0.00 \\
0.00\end{array}$ \\
\hline $\begin{array}{l}0615 \\
0620 \\
0625 \\
0630 \\
0635\end{array}$ & $\begin{array}{l}2.1 \\
2.1 \\
2.1 \\
2.1 \\
2.1\end{array}$ & $\begin{array}{l}0.00 \\
0.00 \\
0.00 \\
0.00 \\
0.00\end{array}$ & $\begin{array}{l}1055 \\
1100 \\
1105 \\
1110 \\
1115\end{array}$ & $\begin{array}{l}1.9 \\
1.9 \\
1.7 \\
1.7 \\
1.7\end{array}$ & $\begin{array}{l}0.00 \\
0.00 \\
0.00 \\
0.00 \\
0.00\end{array}$ & $\begin{array}{l}1535 \\
1540 \\
1545 \\
1550 \\
1555\end{array}$ & $\begin{array}{l}1.3 \\
1.3 \\
1.3 \\
1.3 \\
1.3\end{array}$ & $\begin{array}{l}0.00 \\
0.00 \\
0.00 \\
0.00 \\
0.00\end{array}$ \\
\hline 0640 & 2.1 & 0.00 & 1120 & 1.7 & 0.00 & 1600 & 1.3 & 0.00 \\
\hline
\end{tabular}



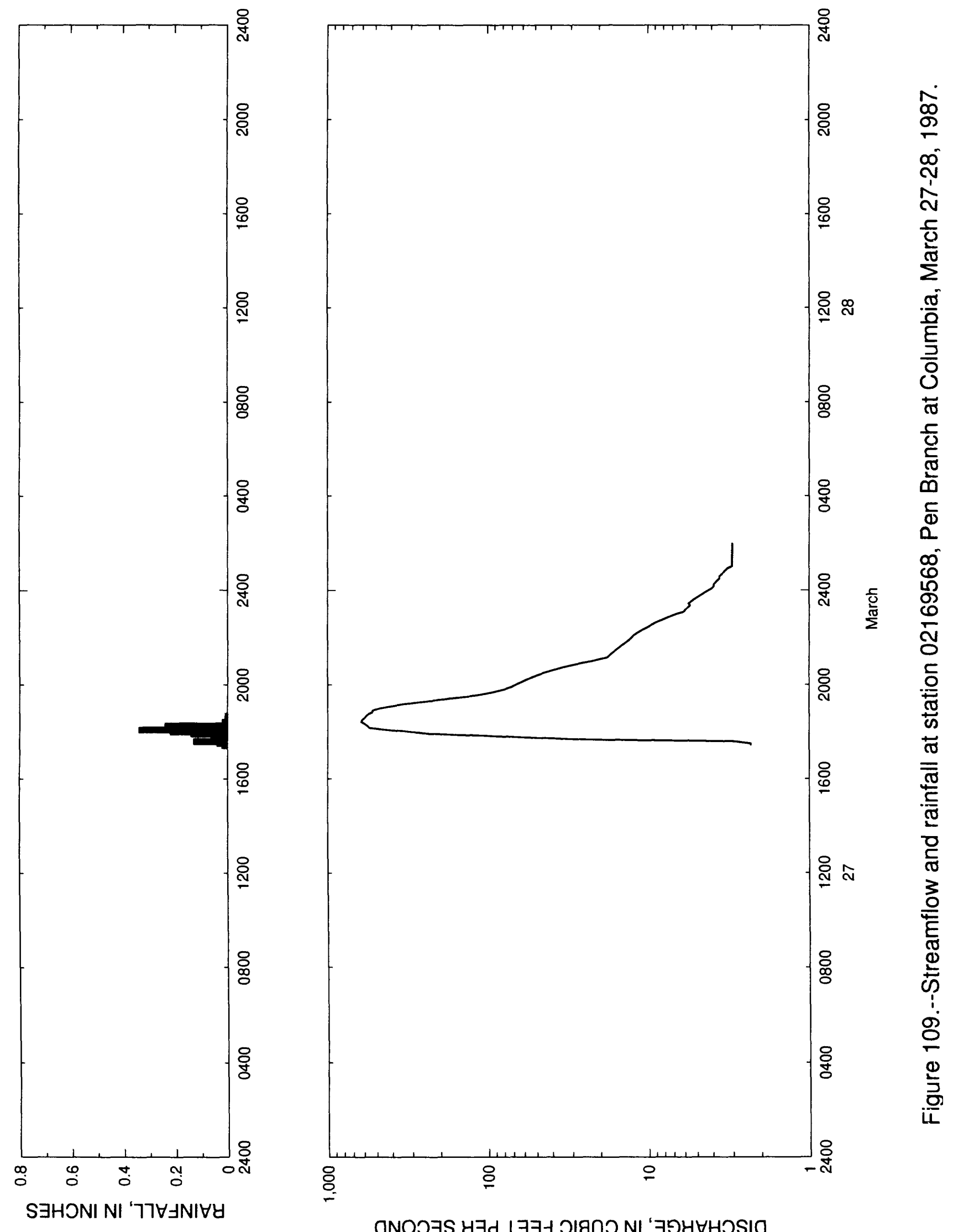
Table 108. - Streamflow and rainfall at station 02169568, Pen Branch at Columbia, March 27-28, 1987

\begin{tabular}{|c|c|c|c|c|c|c|c|c|}
\hline $\begin{array}{l}\text { Time } \\
\text { (hours) }\end{array}$ & $\begin{array}{l}\text { Streamflow } \\
\text { (cubic feet } \\
\text { per second) }\end{array}$ & $\begin{array}{l}\text { Rain- } \\
\text { fall } \\
\text { (inches) }\end{array}$ & $\begin{array}{l}\text { Time } \\
\text { (hours) }\end{array}$ & $\begin{array}{l}\text { Streamflow } \\
\text { (cubic feet } \\
\text { per second) }\end{array}$ & $\begin{array}{l}\text { Rain- } \\
\text { fall } \\
\text { (inches) }\end{array}$ & $\begin{array}{l}\text { Time } \\
\text { (hours) }\end{array}$ & $\begin{array}{l}\text { Streamflow } \\
\text { (cubic feet } \\
\text { per second) }\end{array}$ & $\begin{array}{l}\text { Rain- } \\
\text { fall } \\
\text { (inches) }\end{array}$ \\
\hline $\begin{array}{l}\text { March } 27, \\
1720 \\
1725 \\
1730 \\
1735\end{array}$ & $\begin{array}{r}1987 \\
2.3 \\
2.3 \\
2.3 \\
3.0\end{array}$ & $\begin{array}{l}0.03 \\
0.02 \\
0.04 \\
0.13\end{array}$ & $\begin{array}{l}2015 \\
2020 \\
2025 \\
2030 \\
2035\end{array}$ & $\begin{array}{l}56.1 \\
52.4 \\
48.6 \\
44.9 \\
41.1\end{array}$ & $\begin{array}{l}0.00 \\
0.00 \\
0.00 \\
0.00 \\
0.00\end{array}$ & $\begin{array}{l}2315 \\
2320 \\
2325 \\
2330 \\
2335\end{array}$ & $\begin{array}{l}5.7 \\
5.5 \\
5.6 \\
5.4 \\
5.2\end{array}$ & $\begin{array}{l}0.00 \\
0.0 C \\
0.0 C \\
0.0 C \\
0.0 C\end{array}$ \\
\hline $\begin{array}{l}1740 \\
1745 \\
1750 \\
1755 \\
1800\end{array}$ & $\begin{array}{r}24.7 \\
52.1 \\
104.0 \\
231.0 \\
306.0\end{array}$ & $\begin{array}{l}0.06 \\
0.06 \\
0.03 \\
0.14 \\
0.22\end{array}$ & $\begin{array}{l}2040 \\
2045 \\
2050 \\
2055 \\
2100\end{array}$ & $\begin{array}{l}37.4 \\
33.6 \\
29.9 \\
26.1 \\
22.4\end{array}$ & $\begin{array}{l}0.00 \\
0.00 \\
0.00 \\
0.00 \\
0.00\end{array}$ & $\begin{array}{r}2340 \\
2345 \\
2350 \\
2355 \\
\text { March 28, }\end{array}$ & $\begin{array}{r}5.0 \\
4.8 \\
4.6 \\
4.4\end{array}$ & $\begin{array}{l}0.00 \\
0.00 \\
0.00 \\
0.00\end{array}$ \\
\hline $\begin{array}{l}1805 \\
1810 \\
1815 \\
1820 \\
1825\end{array}$ & $\begin{array}{l}430.0 \\
552.0 \\
568.0 \\
590.0 \\
620.0\end{array}$ & $\begin{array}{l}0.34 \\
0.06 \\
0.24 \\
0.02 \\
0.02\end{array}$ & $\begin{array}{l}2105 \\
2110 \\
2115 \\
2120 \\
2125\end{array}$ & $\begin{array}{l}20.2 \\
18.0 \\
17.4 \\
16.9 \\
16.3\end{array}$ & $\begin{array}{l}0.00 \\
0.00 \\
0.00 \\
0.00 \\
0.00\end{array}$ & $\begin{array}{l}0000 \\
0005 \\
0010 \\
0015 \\
0020\end{array}$ & $\begin{array}{l}4.2 \\
4.0 \\
3.9 \\
3.9 \\
3.8\end{array}$ & $\begin{array}{l}0.00 \\
0.00 \\
0.00 \\
0.00 \\
0.00\end{array}$ \\
\hline $\begin{array}{l}1830 \\
1835 \\
1840 \\
1845 \\
1850\end{array}$ & $\begin{array}{l}614.0 \\
594.0 \\
579.0 \\
564.0 \\
528.0\end{array}$ & $\begin{array}{l}0.00 \\
0.00 \\
0.01 \\
0.00 \\
0.00\end{array}$ & $\begin{array}{l}2130 \\
2135 \\
2140 \\
2145 \\
2150\end{array}$ & $\begin{array}{l}15.7 \\
15.1 \\
14.6 \\
14.0 \\
13.5\end{array}$ & $\begin{array}{l}0.00 \\
0.00 \\
0.00 \\
0.00 \\
0.00\end{array}$ & $\begin{array}{l}0025 \\
0030 \\
0035 \\
0040 \\
0045\end{array}$ & $\begin{array}{l}3.7 \\
3.6 \\
3.6 \\
3.5 \\
3.4\end{array}$ & $\begin{array}{l}0.00 \\
0.00 \\
0.00 \\
0.00 \\
0.09\end{array}$ \\
\hline $\begin{array}{l}1855 \\
1900 \\
1905 \\
1910 \\
1915\end{array}$ & $\begin{array}{l}523 . d \\
475.0 \\
409.0 \\
345.0 \\
277.0\end{array}$ & $\begin{array}{l}0.00 \\
0.00 \\
0.00 \\
0.00 \\
0.00\end{array}$ & $\begin{array}{l}2155 \\
2200 \\
2205 \\
2210 \\
2215\end{array}$ & $\begin{array}{l}13.0 \\
12.6 \\
12.3 \\
11.8 \\
11.3\end{array}$ & $\begin{array}{l}0.00 \\
0.00 \\
0.00 \\
0.00 \\
0.00\end{array}$ & $\begin{array}{l}0050 \\
0055 \\
0100 \\
0105 \\
0110\end{array}$ & $\begin{array}{l}3.3 \\
3.2 \\
3.0 \\
3.0 \\
3.0\end{array}$ & $\begin{array}{l}0.00 \\
0.0 ? \\
0.0 ? \\
0.0 ? \\
0.0 ?\end{array}$ \\
\hline $\begin{array}{l}1920 \\
1925 \\
1930 \\
1935 \\
1940\end{array}$ & $\begin{array}{r}220.0 \\
173.0 \\
135.0 \\
111.0 \\
96.2\end{array}$ & $\begin{array}{l}0.00 \\
0.00 \\
0.00 \\
0.00 \\
0.00\end{array}$ & $\begin{array}{l}2220 \\
2225 \\
2230 \\
2235 \\
2240\end{array}$ & $\begin{array}{r}10.8 \\
10.2 \\
9.7 \\
9.2 \\
8.7\end{array}$ & $\begin{array}{l}0.00 \\
0.00 \\
0.00 \\
0.00 \\
0.00\end{array}$ & $\begin{array}{l}0115 \\
0120 \\
0125 \\
0130 \\
0135\end{array}$ & $\begin{array}{l}3.0 \\
3.0 \\
3.0 \\
3.0 \\
3.0\end{array}$ & $\begin{array}{l}0.07 \\
0.07 \\
0.07 \\
0.07 \\
0.00\end{array}$ \\
\hline $\begin{array}{l}1945 \\
1950 \\
1955 \\
2000 \\
2005\end{array}$ & $\begin{array}{l}86.0 \\
77.0 \\
71.1 \\
67.3 \\
63.6\end{array}$ & $\begin{array}{l}0.00 \\
0.00 \\
0.00 \\
0.00 \\
0.00\end{array}$ & $\begin{array}{l}2245 \\
2250 \\
2255 \\
2300 \\
2305\end{array}$ & $\begin{array}{l}8.1 \\
7.6 \\
7.1 \\
6.6 \\
6.0\end{array}$ & $\begin{array}{l}0.00 \\
0.00 \\
0.00 \\
0.00 \\
0.00\end{array}$ & $\begin{array}{l}0140 \\
0145 \\
0150 \\
0155 \\
0200\end{array}$ & $\begin{array}{l}3.0 \\
3.0 \\
3.0 \\
3.0 \\
3.0\end{array}$ & $\begin{array}{l}0.00 \\
0.00 \\
0 . C 0 \\
0 . C 0 \\
0 . C 0\end{array}$ \\
\hline 2010 & 59.9 & 0.00 & 2310 & 5.9 & 0.00 & & & \\
\hline
\end{tabular}




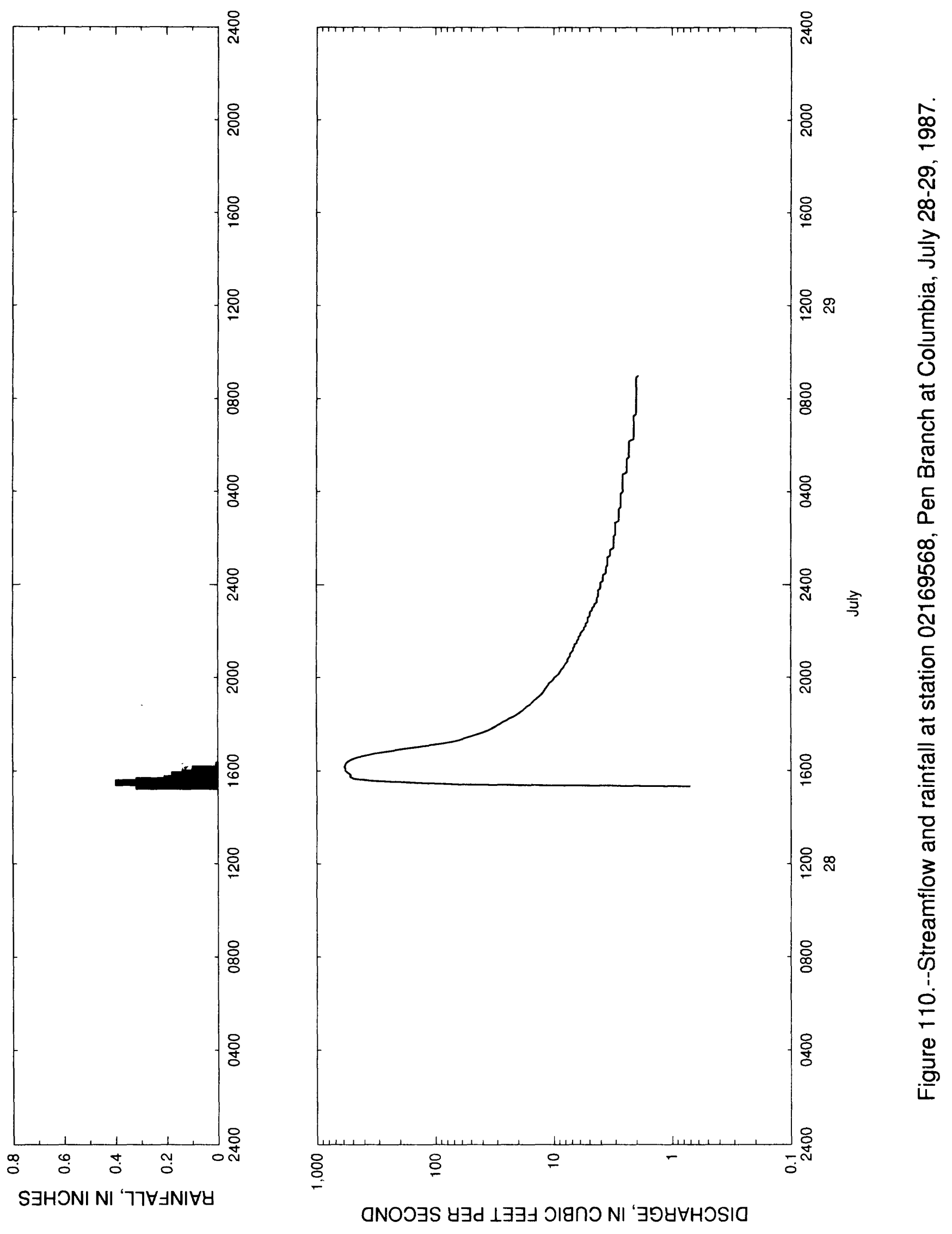


Table 109.--Streamflow and rainfall at station 02169568, Pen Branch at Columbia, July $28-29,1987$

\begin{tabular}{|c|c|c|c|c|c|c|c|c|}
\hline $\begin{array}{l}\text { Time } \\
\text { (hours) }\end{array}$ & $\begin{array}{l}\text { Streamflow } \\
\text { (cubic feet } \\
\text { per second) }\end{array}$ & $\begin{array}{l}\text { Rain- } \\
\text { fall } \\
\text { (inches) }\end{array}$ & $\begin{array}{l}\text { Time } \\
\text { (hours) }\end{array}$ & $\begin{array}{l}\text { Streamflow } \\
\text { (cubic feet } \\
\text { per second) }\end{array}$ & $\begin{array}{l}\text { Rain- } \\
\text { fall } \\
\text { (inches) }\end{array}$ & $\begin{array}{l}\text { Time } \\
\text { (hours) }\end{array}$ & $\begin{array}{l}\text { Streamflow } \\
\text { (cubic feet } \\
\text { per second) }\end{array}$ & $\begin{array}{l}\text { Rain- } \\
\text { fall } \\
\text { (inches) }\end{array}$ \\
\hline $\begin{array}{l}\text { July 28, } \\
1515 \\
1520 \\
1525 \\
1530\end{array}$ & $\begin{array}{r}1987 \\
0.4 \\
0.7 \\
57.7 \\
155.0\end{array}$ & $\begin{array}{l}0.08 \\
0.32 \\
0.24 \\
0.40\end{array}$ & $\begin{array}{l}2035 \\
2040 \\
2045 \\
2050 \\
2055\end{array}$ & $\begin{array}{l}7.9 \\
7.6 \\
7.6 \\
7.4 \\
7.2\end{array}$ & $\begin{array}{l}0.00 \\
0.00 \\
0.00 \\
0.00 \\
0.00\end{array}$ & $\begin{array}{l}0155 \\
0200 \\
0205 \\
0210 \\
0215\end{array}$ & $\begin{array}{l}3.1 \\
3.1 \\
3.1 \\
3.0 \\
3.0\end{array}$ & $\begin{array}{l}0.00 \\
0.00 \\
0.00 \\
0.00 \\
0.00\end{array}$ \\
\hline $\begin{array}{l}1535 \\
1540 \\
1545 \\
1550 \\
1555\end{array}$ & $\begin{array}{l}353.0 \\
489.0 \\
524.0 \\
519.0 \\
551.0\end{array}$ & $\begin{array}{l}0.32 \\
0.21 \\
0.12 \\
0.18 \\
0.14\end{array}$ & $\begin{array}{l}2100 \\
2105 \\
2110 \\
2115 \\
2120\end{array}$ & $\begin{array}{l}7.2 \\
7.0 \\
6.8 \\
6.8 \\
6.6\end{array}$ & $\begin{array}{l}0.00 \\
0.00 \\
0.00 \\
0.00 \\
0.00\end{array}$ & $\begin{array}{l}0220 \\
0225 \\
0230 \\
0235 \\
0240\end{array}$ & $\begin{array}{l}3.0 \\
3.0 \\
3.0 \\
3.0 \\
3.0\end{array}$ & $\begin{array}{l}0.00 \\
0.00 \\
0.00 \\
0.00 \\
0.00\end{array}$ \\
\hline $\begin{array}{l}1600 \\
1605 \\
1610 \\
1615 \\
1620\end{array}$ & $\begin{array}{l}576.0 \\
576.0 \\
584.0 \\
578.0 \\
567.0\end{array}$ & $\begin{array}{l}0.03 \\
0.10 \\
0.01 \\
0.01 \\
0.00\end{array}$ & $\begin{array}{l}2125 \\
2130 \\
2135 \\
2140 \\
2145\end{array}$ & $\begin{array}{l}6.6 \\
6.3 \\
6.3 \\
6.1 \\
6.1\end{array}$ & $\begin{array}{l}0.00 \\
0.00 \\
0.00 \\
0.00 \\
0.00\end{array}$ & $\begin{array}{l}0245 \\
0250 \\
0255 \\
0300 \\
0305\end{array}$ & $\begin{array}{l}2.8 \\
2.8 \\
2.8 \\
2.8 \\
2.8\end{array}$ & $\begin{array}{l}0.00 \\
0.00 \\
0.00 \\
0.00 \\
0.00\end{array}$ \\
\hline $\begin{array}{l}1625 \\
1630 \\
1635 \\
1640 \\
1645\end{array}$ & $\begin{array}{l}535.0 \\
497.0 \\
446.0 \\
374.0 \\
319.0\end{array}$ & $\begin{array}{l}0.00 \\
0.00 \\
0.00 \\
0.00 \\
0.00\end{array}$ & $\begin{array}{l}2150 \\
2155 \\
2200 \\
2205 \\
2210\end{array}$ & $\begin{array}{l}5.9 \\
5.9 \\
5.7 \\
5.5 \\
5.5\end{array}$ & $\begin{array}{l}0.00 \\
0.00 \\
0.00 \\
0.00 \\
0.00\end{array}$ & $\begin{array}{l}0310 \\
0315 \\
0320 \\
0325 \\
0330\end{array}$ & $\begin{array}{l}2.8 \\
2.8 \\
2.7 \\
2.7 \\
2.7\end{array}$ & $\begin{array}{l}0 . C 0 \\
0 . c 0 \\
0 . c 0 \\
0 . C 0 \\
0 . C 0\end{array}$ \\
\hline $\begin{array}{l}1650 \\
1655 \\
1700 \\
1705 \\
1710\end{array}$ & $\begin{array}{r}252.0 \\
197.0 \\
151.0 \\
115.0 \\
86.8\end{array}$ & $\begin{array}{l}0.00 \\
0.00 \\
0.00 \\
0.00 \\
0.00\end{array}$ & $\begin{array}{l}2215 \\
2220 \\
2225 \\
2230 \\
2235\end{array}$ & $\begin{array}{l}5.3 \\
5.3 \\
5.1 \\
5.1 \\
5.1\end{array}$ & $\begin{array}{l}0.00 \\
0.00 \\
0.00 \\
0.00 \\
0.00\end{array}$ & $\begin{array}{l}0335 \\
0340 \\
0345 \\
0350 \\
0355\end{array}$ & $\begin{array}{l}2.7 \\
2.7 \\
2.7 \\
2.7 \\
2.7\end{array}$ & $\begin{array}{l}0 . C 0 \\
0 . C 0 \\
0 . C 0 \\
0 . C 0 \\
0 . C 0\end{array}$ \\
\hline $\begin{array}{l}1715 \\
1720 \\
1725 \\
1730 \\
1735\end{array}$ & $\begin{array}{l}71.1 \\
61.2 \\
54.9 \\
48.8 \\
43.4\end{array}$ & $\begin{array}{l}0.00 \\
0.00 \\
0.00 \\
0.00 \\
0.00\end{array}$ & $\begin{array}{l}2240 \\
2245 \\
2250 \\
2255 \\
2300\end{array}$ & $\begin{array}{l}4.9 \\
4.9 \\
4.9 \\
4.7 \\
4.7\end{array}$ & $\begin{array}{l}0.00 \\
0.00 \\
0.00 \\
0.00 \\
0.00\end{array}$ & $\begin{array}{l}0400 \\
0405 \\
0410 \\
0415 \\
0420\end{array}$ & $\begin{array}{l}2.6 \\
2.6 \\
2.6 \\
2.6 \\
2.6\end{array}$ & $\begin{array}{l}0 . C 0 \\
0 . C 0 \\
0 . C 0 \\
0 . C 0 \\
0 . C 0\end{array}$ \\
\hline $\begin{array}{l}1740 \\
1745 \\
1750 \\
1755 \\
1800\end{array}$ & $\begin{array}{l}38.9 \\
35.3 \\
32.8 \\
30.4 \\
28.2\end{array}$ & $\begin{array}{l}0.00 \\
0.00 \\
0.00 \\
0.00 \\
0.00\end{array}$ & $\begin{array}{l}2305 \\
2310 \\
2315 \\
2320 \\
2325\end{array}$ & $\begin{array}{l}4.5 \\
4.5 \\
4.3 \\
4.3 \\
4.3\end{array}$ & $\begin{array}{l}0.00 \\
0.00 \\
0.00 \\
0.00 \\
0.00\end{array}$ & $\begin{array}{l}0425 \\
0430 \\
0435 \\
0440 \\
0445\end{array}$ & $\begin{array}{l}2.6 \\
2.6 \\
2.6 \\
2.6 \\
2.6\end{array}$ & $\begin{array}{l}0.00 \\
0.00 \\
0.00 \\
0.00 \\
0.00\end{array}$ \\
\hline $\begin{array}{l}1805 \\
1810 \\
1815 \\
1820 \\
1825\end{array}$ & $\begin{array}{l}26.8 \\
24.7 \\
23.5 \\
21.5 \\
20.3\end{array}$ & $\begin{array}{l}0.00 \\
0.00 \\
0.00 \\
0.00 \\
0.00\end{array}$ & $\begin{array}{l}2330 \\
2335 \\
2340 \\
2345 \\
2350\end{array}$ & $\begin{array}{l}4.2 \\
4.2 \\
4.2 \\
4.2 \\
4.0\end{array}$ & $\begin{array}{l}0.00 \\
0.00 \\
0.00 \\
0.00 \\
0.00\end{array}$ & $\begin{array}{l}0450 \\
0455 \\
0500 \\
0505 \\
0510\end{array}$ & $\begin{array}{l}2.4 \\
2.4 \\
2.4 \\
2.4 \\
2.4\end{array}$ & $\begin{array}{l}0.00 \\
0.00 \\
0.00 \\
0.00 \\
0.00\end{array}$ \\
\hline $\begin{array}{l}1830 \\
1835 \\
1840 \\
1845 \\
1850\end{array}$ & $\begin{array}{l}19.2 \\
18.2 \\
17.5 \\
16.8 \\
15.8\end{array}$ & $\begin{array}{l}0.00 \\
0.00 \\
0.00 \\
0.00 \\
0.00\end{array}$ & $\begin{array}{l}2355 \\
\text { July } 29, \\
0000 \\
0005 \\
0010\end{array}$ & $\begin{array}{r}4.0 \\
1987 \\
4.0 \\
4.0 \\
3.8\end{array}$ & $\begin{array}{l}0.00 \\
0.00 \\
0.00 \\
0.00\end{array}$ & $\begin{array}{l}0515 \\
0520 \\
0525 \\
0530 \\
0535\end{array}$ & $\begin{array}{l}2.4 \\
2.4 \\
2.4 \\
2.3 \\
2.3\end{array}$ & $\begin{array}{l}0.00 \\
0.00 \\
0.00 \\
0.00 \\
0.00\end{array}$ \\
\hline $\begin{array}{l}1855 \\
1900 \\
1905 \\
1910 \\
1915\end{array}$ & $\begin{array}{l}15.2 \\
14.6 \\
14.0 \\
13.4 \\
12.8\end{array}$ & $\begin{array}{l}0.00 \\
0.00 \\
0.00 \\
0.00 \\
0.00\end{array}$ & $\begin{array}{l}0015 \\
0020 \\
0025 \\
0030 \\
0035\end{array}$ & $\begin{array}{l}3.8 \\
3.8 \\
3.8 \\
3.6 \\
3.6\end{array}$ & $\begin{array}{l}0.00 \\
0.00 \\
0.00 \\
0.00 \\
0.00\end{array}$ & $\begin{array}{l}0540 \\
0545 \\
0550 \\
0555 \\
0600\end{array}$ & $\begin{array}{l}2.3 \\
2.3 \\
2.3 \\
2.3 \\
2.3\end{array}$ & $\begin{array}{l}0.00 \\
0.00 \\
0.00 \\
0.00 \\
0.07\end{array}$ \\
\hline $\begin{array}{l}1920 \\
1925 \\
1930 \\
1935 \\
1940\end{array}$ & $\begin{array}{l}12.3 \\
12.0 \\
11.7 \\
11.4 \\
11.1\end{array}$ & $\begin{array}{l}0.00 \\
0.00 \\
0.00 \\
0.00 \\
0.00\end{array}$ & $\begin{array}{l}0040 \\
0045 \\
0050 \\
0055 \\
0100\end{array}$ & $\begin{array}{l}3.6 \\
3.6 \\
3.5 \\
3.5 \\
3.5\end{array}$ & $\begin{array}{l}0.00 \\
0.00 \\
0.00 \\
0.00 \\
0.00\end{array}$ & $\begin{array}{l}0605 \\
0610 \\
0615 \\
0620 \\
0625\end{array}$ & $\begin{array}{l}2.3 \\
2.3 \\
2.1 \\
2.1 \\
2.1\end{array}$ & $\begin{array}{l}0.00 \\
0.00 \\
0.00 \\
0.00 \\
0.00\end{array}$ \\
\hline $\begin{array}{l}1945 \\
1950 \\
1955 \\
2000 \\
2005\end{array}$ & $\begin{array}{r}10.9 \\
10.3 \\
10.0 \\
9.8 \\
9.3\end{array}$ & $\begin{array}{l}0.00 \\
0.00 \\
0.00 \\
0.00 \\
0.00\end{array}$ & $\begin{array}{l}0105 \\
0110 \\
0115 \\
0120 \\
0125\end{array}$ & $\begin{array}{l}3.5 \\
3.5 \\
3.3 \\
3.3 \\
3.3\end{array}$ & $\begin{array}{l}0.00 \\
0.00 \\
0.00 \\
0.00 \\
0.00\end{array}$ & $\begin{array}{l}0630 \\
0635 \\
0640 \\
0645 \\
0650\end{array}$ & $\begin{array}{l}2.1 \\
2.1 \\
2.1 \\
2.1 \\
2.1\end{array}$ & $\begin{array}{l}0.00 \\
0.00 \\
0.0 n \\
0.07 \\
0.00\end{array}$ \\
\hline $\begin{array}{l}2010 \\
2015 \\
2020 \\
2025 \\
2030\end{array}$ & $\begin{array}{l}9.0 \\
8.8 \\
8.6 \\
8.3 \\
8.1\end{array}$ & $\begin{array}{l}0.00 \\
0.00 \\
0.00 \\
0.00 \\
0.00\end{array}$ & $\begin{array}{l}0130 \\
0135 \\
0140 \\
0145 \\
0150\end{array}$ & $\begin{array}{l}3.3 \\
3.1 \\
3.1 \\
3.1 \\
3.1\end{array}$ & $\begin{array}{l}0.00 \\
0.00 \\
0.00 \\
0.00 \\
0.00\end{array}$ & $\begin{array}{l}0655 \\
0700 \\
0705 \\
0710 \\
0715\end{array}$ & $\begin{array}{l}2.1 \\
2.1 \\
2.1 \\
2.1 \\
2.1\end{array}$ & $\begin{array}{l}0.00 \\
0.02 \\
0.00 \\
0.00 \\
0.0 ?\end{array}$ \\
\hline
\end{tabular}


Table 109. - - Streamflow and rainfall at station 02169568, Pen Branch at Columbia, July 28-29, 1987--Continued

\begin{tabular}{|c|c|c|c|c|c|c|c|c|}
\hline $\begin{array}{l}\text { Time } \\
\text { (hours) }\end{array}$ & $\begin{array}{l}\text { Streamflow } \\
\text { (cubic feet } \\
\text { per second) }\end{array}$ & $\begin{array}{l}\text { Rain- } \\
\text { fall } \\
\text { (inches) }\end{array}$ & $\begin{array}{l}\text { Time } \\
\text { (hours) }\end{array}$ & $\begin{array}{l}\text { Streamflow } \\
\text { (cubic feet } \\
\text { per second) }\end{array}$ & $\begin{array}{l}\text { Rain- } \\
\text { fall } \\
\text { (inches) }\end{array}$ & $\begin{array}{l}\text { Time } \\
\text { (hours) }\end{array}$ & $\begin{array}{l}\text { Streamflow } \\
\text { (cubic feet } \\
\text { per second) }\end{array}$ & $\begin{array}{l}\text { Rain- } \\
\text { fall } \\
\text { (inches) }\end{array}$ \\
\hline $\begin{array}{l}0720 \\
0725 \\
0730 \\
0735 \\
0740\end{array}$ & $\begin{array}{l}2.0 \\
2.0 \\
2.0 \\
2.0 \\
2.0\end{array}$ & $\begin{array}{l}0.00 \\
0.00 \\
0.00 \\
0.00 \\
0.00\end{array}$ & $\begin{array}{l}0755 \\
0800 \\
0805 \\
0810 \\
0815\end{array}$ & $\begin{array}{l}2.0 \\
2.0 \\
2.0 \\
2.0 \\
2.0\end{array}$ & $\begin{array}{l}0.00 \\
0.00 \\
0.00 \\
0.00 \\
0.00\end{array}$ & $\begin{array}{l}0830 \\
0835 \\
0840 \\
0845 \\
0850\end{array}$ & $\begin{array}{l}2.0 \\
2.0 \\
2.0 \\
2.0 \\
2.0\end{array}$ & $\begin{array}{l}0.00 \\
0.00 \\
0.00 \\
0.00 \\
0.00\end{array}$ \\
\hline $\begin{array}{l}0745 \\
0750\end{array}$ & $\begin{array}{l}2.0 \\
2.0\end{array}$ & $\begin{array}{l}0.00 \\
0.00\end{array}$ & $\begin{array}{l}0820 \\
0825\end{array}$ & $\begin{array}{l}2.0 \\
2.0\end{array}$ & $\begin{array}{l}0.00 \\
0.00\end{array}$ & $\begin{array}{l}0855 \\
0900\end{array}$ & $\begin{array}{l}2.0 \\
1.9\end{array}$ & $\begin{array}{l}0.00 \\
0.00\end{array}$ \\
\hline
\end{tabular}




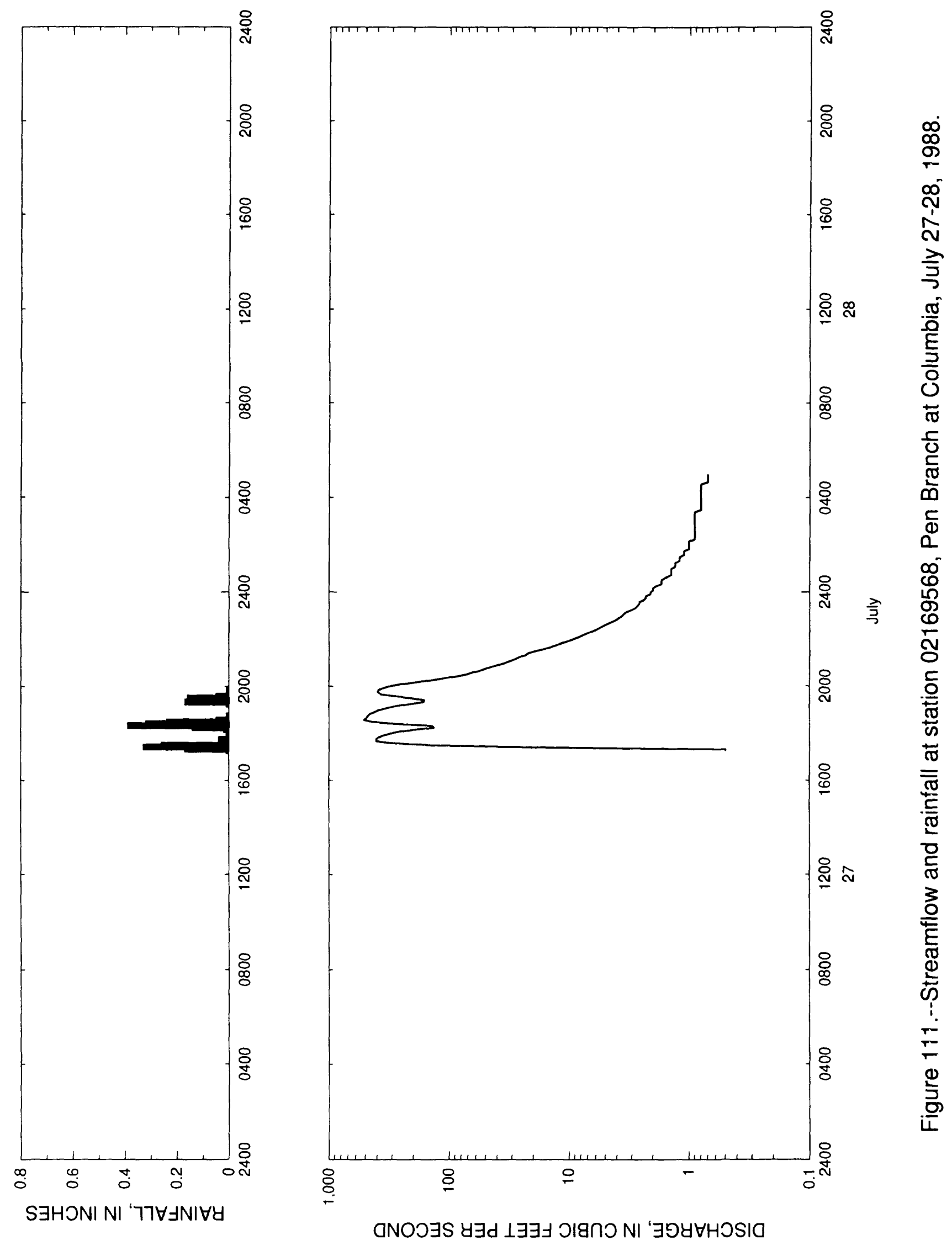


Table 110.--Streamflow and rainfall at station 02169568, Pen Branch at Columbia, July $27-28,1988$

\begin{tabular}{|c|c|c|c|c|c|c|c|c|}
\hline $\begin{array}{l}\text { Time } \\
\text { (hours) }\end{array}$ & $\begin{array}{l}\text { Streamflow } \\
\text { (cubic feet } \\
\text { per second) }\end{array}$ & $\begin{array}{l}\text { Rain- } \\
\text { fal1 } \\
\text { (inches) }\end{array}$ & $\begin{array}{l}\text { Time } \\
\text { (hours) }\end{array}$ & $\begin{array}{l}\text { Streamflow } \\
\text { (cubic feet } \\
\text { per second) }\end{array}$ & $\begin{array}{l}\text { Rain- } \\
\text { fall } \\
\text { (inches) }\end{array}$ & $\begin{array}{l}\text { Time } \\
\text { (hours) }\end{array}$ & $\begin{array}{l}\text { Streamflow } \\
\text { (cubic feet } \\
\text { per second) }\end{array}$ & $\begin{array}{l}\text { Rain- } \\
\text { fall } \\
\text { (inches) }\end{array}$ \\
\hline $\begin{array}{l}\text { July } 27 \\
1710 \\
1715 \\
1720 \\
1725\end{array}$ & $\begin{array}{r}1988 \\
0.5 \\
0.5 \\
0.5 \\
20.7\end{array}$ & $\begin{array}{l}0.05 \\
0.01 \\
0.17 \\
0.33\end{array}$ & $\begin{array}{l}2110 \\
2115 \\
2120 \\
2125 \\
2130\end{array}$ & $\begin{array}{l}27.7 \\
25.6 \\
23.1 \\
21.9 \\
19.2\end{array}$ & $\begin{array}{l}0.00 \\
0.00 \\
0.00 \\
0.00 \\
0.00\end{array}$ & $\begin{array}{l}0110 \\
0115 \\
0120 \\
0125 \\
0130\end{array}$ & $\begin{array}{l}1.3 \\
1 \cdot 3 \\
1 \cdot 2 \\
1.2 \\
1.2\end{array}$ & $\begin{array}{l}0.00 \\
0.00 \\
0.00 \\
0.00 \\
0.00\end{array}$ \\
\hline $\begin{array}{l}1730 \\
1735 \\
1740 \\
1745 \\
1750\end{array}$ & $\begin{array}{l}136.0 \\
294.0 \\
405.0 \\
406.0 \\
386.0\end{array}$ & $\begin{array}{l}0.26 \\
0.04 \\
0.02 \\
0.04 \\
0.00\end{array}$ & $\begin{array}{l}2135 \\
2140 \\
2145 \\
2150 \\
2155\end{array}$ & $\begin{array}{l}16.1 \\
14.3 \\
12.8 \\
11.4 \\
10.0\end{array}$ & $\begin{array}{l}0.00 \\
0.00 \\
0.00 \\
0.00 \\
0.00\end{array}$ & $\begin{array}{l}0135 \\
0140 \\
0145 \\
0150 \\
0155\end{array}$ & $\begin{array}{l}1.1 \\
1.1 \\
1.1 \\
1.0 \\
1.0\end{array}$ & $\begin{array}{l}0.00 \\
0.00 \\
0.00 \\
0.00 \\
0.00\end{array}$ \\
\hline $\begin{array}{l}1755 \\
1800 \\
1805 \\
1810 \\
1815\end{array}$ & $\begin{array}{l}358.0 \\
310.0 \\
257.0 \\
192.0 \\
134.0\end{array}$ & $\begin{array}{l}0.01 \\
0.00 \\
0.00 \\
0.02 \\
0.14\end{array}$ & $\begin{array}{l}2200 \\
2205 \\
2210 \\
2215 \\
2220\end{array}$ & $\begin{array}{l}9.3 \\
8.3 \\
7.6 \\
7.0 \\
6.3\end{array}$ & $\begin{array}{l}0.00 \\
0.00 \\
0.00 \\
0.00 \\
0.00\end{array}$ & $\begin{array}{l}0200 \\
0205 \\
0210 \\
0215 \\
0220\end{array}$ & $\begin{array}{l}1.0 \\
1.0 \\
1.0 \\
0.9 \\
0.9\end{array}$ & $\begin{array}{l}0.00 \\
0.00 \\
0.00 \\
0.00 \\
0.00\end{array}$ \\
\hline $\begin{array}{l}1820 \\
1825 \\
1830 \\
1835 \\
1840\end{array}$ & $\begin{array}{l}140.0 \\
282.0 \\
441.0 \\
512.0 \\
488.0\end{array}$ & $\begin{array}{l}0.39 \\
0.32 \\
0.24 \\
0.05 \\
0.01\end{array}$ & $\begin{array}{l}2225 \\
2230 \\
2235 \\
2240 \\
2245\end{array}$ & $\begin{array}{l}5.9 \\
5.5 \\
5.1 \\
4.7 \\
4.3\end{array}$ & $\begin{array}{l}0.00 \\
0.00 \\
0.00 \\
0.00 \\
0.00\end{array}$ & $\begin{array}{l}0225 \\
0230 \\
0235 \\
0240 \\
0245\end{array}$ & $\begin{array}{l}0.9 \\
0.9 \\
0.9 \\
0.9 \\
0.9\end{array}$ & $\begin{array}{l}0.00 \\
0.00 \\
0.00 \\
0.00 \\
0.00\end{array}$ \\
\hline $\begin{array}{l}1845 \\
1850 \\
1855 \\
1900 \\
1905\end{array}$ & $\begin{array}{l}476.0 \\
458.0 \\
416.0 \\
381.0 \\
330.0\end{array}$ & $\begin{array}{l}0.01 \\
0.00 \\
0.00 \\
0.00 \\
0.00\end{array}$ & $\begin{array}{l}2250 \\
2255 \\
2300 \\
2305 \\
2310\end{array}$ & $\begin{array}{l}4.0 \\
3.8 \\
3.6 \\
3.5 \\
3.3\end{array}$ & $\begin{array}{l}0.00 \\
0.00 \\
0.00 \\
0.00 \\
0.00\end{array}$ & $\begin{array}{l}0250 \\
0255 \\
0300 \\
0305 \\
0310\end{array}$ & $\begin{array}{l}0.9 \\
0.9 \\
0.9 \\
0.9 \\
0.9\end{array}$ & $\begin{array}{l}0.00 \\
0.00 \\
0.00 \\
0.00 \\
0.00\end{array}$ \\
\hline $\begin{array}{l}1910 \\
1915 \\
1920 \\
1925 \\
1930\end{array}$ & $\begin{array}{l}276.0 \\
216.0 \\
164.0 \\
162.0 \\
210.0\end{array}$ & $\begin{array}{l}0.00 \\
0.01 \\
0.17 \\
0.14 \\
0.16\end{array}$ & $\begin{array}{l}2315 \\
2320 \\
2325 \\
2330 \\
2335\end{array}$ & $\begin{array}{l}3.0 \\
2.8 \\
2.7 \\
2.6 \\
2.6\end{array}$ & $\begin{array}{l}0.00 \\
0.00 \\
0.00 \\
0.00 \\
0.00\end{array}$ & $\begin{array}{l}0315 \\
0320 \\
0325 \\
0330 \\
0335\end{array}$ & $\begin{array}{l}0.9 \\
0.9 \\
0.9 \\
0.8 \\
0.8\end{array}$ & $\begin{array}{l}0.00 \\
0.00 \\
0.00 \\
0.00 \\
0.00\end{array}$ \\
\hline $\begin{array}{l}1935 \\
1940 \\
1945 \\
1950 \\
1955\end{array}$ & $\begin{array}{l}283.0 \\
368.0 \\
393.0 \\
389.0 \\
362.0\end{array}$ & $\begin{array}{l}0.05 \\
0.01 \\
0.00 \\
0.01 \\
0.00\end{array}$ & $\begin{array}{c}2340 \\
2345 \\
2350 \\
2355 \\
\text { July 28, }\end{array}$ & $\begin{array}{r}2.4 \\
2.3 \\
2.3 \\
1988 \\
2.1\end{array}$ & $\begin{array}{l}0.00 \\
0.00 \\
0.00 \\
0.00\end{array}$ & $\begin{array}{l}0340 \\
0345 \\
0350 \\
0355 \\
0400\end{array}$ & $\begin{array}{l}0.8 \\
0.8 \\
0.8 \\
0.8 \\
0.8\end{array}$ & $\begin{array}{l}0.00 \\
0.00 \\
0.00 \\
0.00 \\
0.00\end{array}$ \\
\hline $\begin{array}{l}2000 \\
2005 \\
2010 \\
2015 \\
2020\end{array}$ & $\begin{array}{l}319.0 \\
254.0 \\
191.0 \\
144.0 \\
110.0\end{array}$ & $\begin{array}{l}0.00 \\
0.00 \\
0.00 \\
0.00 \\
0.00\end{array}$ & $\begin{array}{l}0000 \\
0005 \\
0010 \\
0015 \\
0020\end{array}$ & $\begin{array}{l}2.1 \\
2.0 \\
2.0 \\
1.9 \\
1.7\end{array}$ & $\begin{array}{l}0.00 \\
0.00 \\
0.00 \\
0.00 \\
0.00\end{array}$ & $\begin{array}{l}0405 \\
0410 \\
0415 \\
0420 \\
0425\end{array}$ & $\begin{array}{l}0.8 \\
0.8 \\
0.8 \\
0.8 \\
0.8\end{array}$ & $\begin{array}{l}0.00 \\
0.00 \\
0.00 \\
0.00 \\
0.00\end{array}$ \\
\hline $\begin{array}{l}2025 \\
2030 \\
2035 \\
2040 \\
2045\end{array}$ & $\begin{array}{l}86.8 \\
71.1 \\
63.6 \\
54.9 \\
49.4\end{array}$ & $\begin{array}{l}0.00 \\
0.00 \\
0.00 \\
0.00 \\
0.00\end{array}$ & $\begin{array}{l}0025 \\
0030 \\
0035 \\
0040 \\
0045\end{array}$ & $\begin{array}{l}1.7 \\
1.7 \\
1.6 \\
1.5 \\
1.4\end{array}$ & $\begin{array}{l}0.00 \\
0.00 \\
0.00 \\
0.00 \\
0.00\end{array}$ & $\begin{array}{l}0430 \\
0435 \\
0440 \\
0445 \\
0450\end{array}$ & $\begin{array}{l}0.8 \\
0.8 \\
0.7 \\
0.7 \\
0.7\end{array}$ & $\begin{array}{l}0.00 \\
0.00 \\
0.00 \\
0.00 \\
0.00\end{array}$ \\
\hline $\begin{array}{l}2050 \\
2055 \\
2100 \\
2105\end{array}$ & $\begin{array}{l}43.4 \\
37.9 \\
33.8 \\
30.4\end{array}$ & $\begin{array}{l}0.00 \\
0.00 \\
0.00 \\
0.00\end{array}$ & $\begin{array}{l}0050 \\
0055 \\
0100 \\
0105\end{array}$ & $\begin{array}{l}1.4 \\
1.4 \\
1.4 \\
1.3\end{array}$ & $\begin{array}{l}0.00 \\
0.00 \\
0.00 \\
0.00\end{array}$ & $\begin{array}{l}0455 \\
0500\end{array}$ & $\begin{array}{l}0.7 \\
0.7\end{array}$ & $\begin{array}{l}0.00 \\
0.00\end{array}$ \\
\hline
\end{tabular}




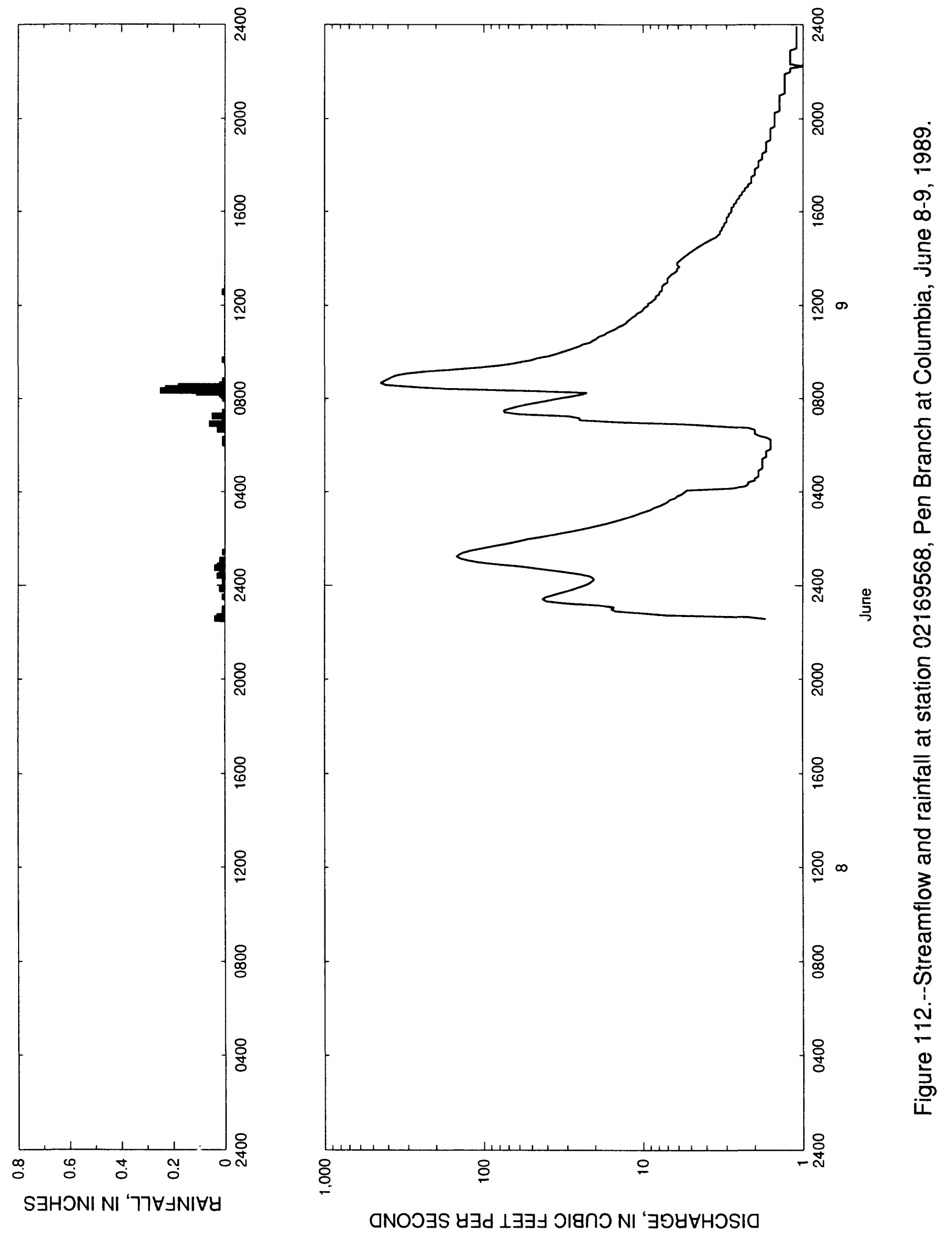




\begin{tabular}{|c|c|c|c|c|c|c|c|c|}
\hline $\begin{array}{l}\text { Time } \\
\text { (hours) }\end{array}$ & $\begin{array}{l}\text { Streamflow } \\
\text { (cubic feet } \\
\text { per second) }\end{array}$ & $\begin{array}{l}\text { Rain- } \\
\text { fal1 } \\
\text { (inches) }\end{array}$ & $\begin{array}{l}\text { Time } \\
\text { (hours) }\end{array}$ & $\begin{array}{l}\text { Streamflow } \\
\text { (cubic feet } \\
\text { per second) }\end{array}$ & $\begin{array}{l}\text { Rain- } \\
\text { fall } \\
\text { (inches) }\end{array}$ & $\begin{array}{l}\text { Time } \\
\text { (hours) }\end{array}$ & $\begin{array}{l}\text { Streamflow } \\
\text { (cubic feet } \\
\text { per second) }\end{array}$ & $\begin{array}{l}\text { Rain- } \\
\text { fal1 } \\
\text { (inches) }\end{array}$ \\
\hline $\begin{array}{l}\text { June } 8 \\
2235 \\
2240 \\
2245 \\
2250\end{array}$ & $\begin{array}{r}1989 \quad 1.7 \\
2.2 \\
7.2 \\
10.3\end{array}$ & $\begin{array}{l}0.04 \\
0.03 \\
0.01 \\
0.00\end{array}$ & $\begin{array}{l}0350 \\
0355 \\
0400 \\
0405 \\
0410\end{array}$ & $\begin{array}{l}6.1 \\
5.7 \\
5.5 \\
5.3 \\
2.8\end{array}$ & $\begin{array}{l}0.00 \\
0.00 \\
0.00 \\
0.00 \\
0.00\end{array}$ & $\begin{array}{l}0915 \\
0920 \\
0925 \\
0930 \\
0935\end{array}$ & $\begin{array}{r}161.0 \\
111.0 \\
83.2 \\
67.3 \\
58.3\end{array}$ & $\begin{array}{l}0.00 \\
0.00 \\
0.00 \\
0.00 \\
0.00\end{array}$ \\
\hline $\begin{array}{l}2255 \\
2300 \\
2305 \\
2310 \\
2315\end{array}$ & $\begin{array}{l}14.9 \\
15.8 \\
15.2 \\
19.2 \\
31.3\end{array}$ & $\begin{array}{l}0.00 \\
0.01 \\
0.00 \\
0.00 \\
0.00\end{array}$ & $\begin{array}{l}0415 \\
0420 \\
0425 \\
0430 \\
0435\end{array}$ & $\begin{array}{l}2.3 \\
2.2 \\
2.2 \\
2.0 \\
2.0\end{array}$ & $\begin{array}{l}0.00 \\
0.00 \\
0.00 \\
0.00 \\
0.00\end{array}$ & $\begin{array}{l}0940 \\
0945 \\
0950 \\
0955 \\
1000\end{array}$ & $\begin{array}{l}50.0 \\
45.7 \\
38.9 \\
35.3 \\
32.3\end{array}$ & $\begin{array}{l}0.01 \\
0.00 \\
0.00 \\
0.00 \\
0.00\end{array}$ \\
\hline $\begin{array}{l}2320 \\
2325 \\
2330 \\
2335 \\
2340\end{array}$ & $\begin{array}{l}40.6 \\
42.8 \\
41.1 \\
37.3 \\
33.8\end{array}$ & $\begin{array}{l}0.00 \\
0.00 \\
0.01 \\
0.00 \\
0.00\end{array}$ & $\begin{array}{l}0440 \\
0445 \\
0450 \\
0455 \\
0500\end{array}$ & $\begin{array}{l}1.9 \\
1.9 \\
1.9 \\
1.9 \\
1.8\end{array}$ & $\begin{array}{l}0.00 \\
0.00 \\
0.00 \\
0.00 \\
0.00\end{array}$ & $\begin{array}{l}1005 \\
1010 \\
1015 \\
1020 \\
1025\end{array}$ & $\begin{array}{l}29.5 \\
27.3 \\
25.1 \\
23.9 \\
21.5\end{array}$ & $\begin{array}{l}0.00 \\
0.00 \\
0.00 \\
0.00 \\
0.00\end{array}$ \\
\hline $\begin{array}{c}2345 \\
2350 \\
2355 \\
\text { June } 9 \\
0000\end{array}$ & $\begin{array}{r}30.4 \\
27.7 \\
25.6 \\
1989 \\
\\
23.5\end{array}$ & $\begin{array}{l}0.00 \\
0.02 \\
0.00 \\
0.00\end{array}$ & $\begin{array}{l}0505 \\
0510 \\
0515 \\
0520 \\
0525\end{array}$ & $\begin{array}{l}1.8 \\
1.8 \\
1.8 \\
1.8 \\
1.8\end{array}$ & $\begin{array}{l}0.00 \\
0.00 \\
0.00 \\
0.00 \\
0.00\end{array}$ & $\begin{array}{l}1030 \\
1035 \\
1040 \\
1045 \\
1050\end{array}$ & $\begin{array}{l}20.7 \\
19.6 \\
18.9 \\
17.5 \\
16.8\end{array}$ & $\begin{array}{l}0.00 \\
0.00 \\
0.00 \\
0.00 \\
0.00\end{array}$ \\
\hline $\begin{array}{l}0005 \\
0010 \\
0015 \\
0020 \\
0025\end{array}$ & $\begin{array}{l}21.9 \\
21.1 \\
20.3 \\
20.7 \\
21.9\end{array}$ & $\begin{array}{l}0.00 \\
0.01 \\
0.01 \\
0.01 \\
0.03\end{array}$ & $\begin{array}{l}0530 \\
0535 \\
0540 \\
0545 \\
0550\end{array}$ & $\begin{array}{l}1.7 \\
1.7 \\
1.7 \\
1.7 \\
1.6\end{array}$ & $\begin{array}{l}0.00 \\
0.00 \\
0.00 \\
0.00 \\
0.00\end{array}$ & $\begin{array}{l}1055 \\
1100 \\
1105 \\
1110 \\
1115\end{array}$ & $\begin{array}{l}15.8 \\
14.9 \\
14.3 \\
13.4 \\
12.8\end{array}$ & $\begin{array}{l}0.00 \\
0.00 \\
0.00 \\
0.00 \\
0.00\end{array}$ \\
\hline $\begin{array}{l}0030 \\
0035 \\
0040 \\
0045 \\
0050\end{array}$ & $\begin{array}{l}25.1 \\
30.9 \\
38.4 \\
47.5 \\
60.6\end{array}$ & $\begin{array}{l}0.02 \\
0.02 \\
0.02 \\
0.04 \\
0.03\end{array}$ & $\begin{array}{l}0555 \\
0600 \\
0605 \\
0610 \\
0615\end{array}$ & $\begin{array}{l}1.6 \\
1.6 \\
1.6 \\
1.6 \\
1.6\end{array}$ & $\begin{array}{l}0.00 \\
0.00 \\
0.01 \\
0.00 \\
0.01\end{array}$ & $\begin{array}{l}1120 \\
1125 \\
1130 \\
1135 \\
1140\end{array}$ & $\begin{array}{l}12.5 \\
12.0 \\
11.7 \\
11.1 \\
10.9\end{array}$ & $\begin{array}{l}0.00 \\
0.00 \\
0.00 \\
0.00 \\
0.00\end{array}$ \\
\hline $\begin{array}{l}0055 \\
0100 \\
0105 \\
0110 \\
0115\end{array}$ & $\begin{array}{r}82.5 \\
107.0 \\
125.0 \\
140.0 \\
148.0\end{array}$ & $\begin{array}{l}0.02 \\
0.02 \\
0.02 \\
0.00 \\
0.00\end{array}$ & $\begin{array}{l}0620 \\
0625 \\
0630 \\
0635 \\
0640\end{array}$ & $\begin{array}{l}1.7 \\
1.9 \\
2.0 \\
2.0 \\
2.0\end{array}$ & $\begin{array}{l}0.00 \\
0.00 \\
0.00 \\
0.00 \\
0.03\end{array}$ & $\begin{array}{l}1145 \\
1150 \\
1155 \\
1200 \\
1205\end{array}$ & $\begin{array}{r}10.3 \\
10.0 \\
9.8 \\
9.3 \\
9.3\end{array}$ & $\begin{array}{l}0.00 \\
0.00 \\
0.00 \\
0.00 \\
0.00\end{array}$ \\
\hline $\begin{array}{l}0120 \\
0125 \\
0130 \\
0135 \\
0140\end{array}$ & $\begin{array}{r}143.0 \\
135.0 \\
122.0 \\
106.0 \\
91.4\end{array}$ & $\begin{array}{l}0.00 \\
0.01 \\
0.00 \\
0.00 \\
0.00\end{array}$ & $\begin{array}{l}0645 \\
0650 \\
0655 \\
0700 \\
0705\end{array}$ & $\begin{array}{r}2.2 \\
3.5 \\
5.5 \\
14.0 \\
25.1\end{array}$ & $\begin{array}{l}0.00 \\
0.03 \\
0.06 \\
0.00 \\
0.01\end{array}$ & $\begin{array}{l}1210 \\
1215 \\
1220 \\
1225 \\
1230\end{array}$ & $\begin{array}{l}8.8 \\
8.6 \\
8.3 \\
8.3 \\
7.9\end{array}$ & $\begin{array}{l}0.00 \\
0.00 \\
0.00 \\
0.00 \\
0.00\end{array}$ \\
\hline $\begin{array}{l}0145 \\
0150 \\
0155 \\
0200 \\
0205\end{array}$ & $\begin{array}{l}79.0 \\
67.9 \\
59.5 \\
52.7 \\
43.4\end{array}$ & $\begin{array}{l}0.00 \\
0.00 \\
0.00 \\
0.00 \\
0.00\end{array}$ & $\begin{array}{l}0710 \\
0715 \\
0720 \\
0725 \\
0730\end{array}$ & $\begin{array}{l}25.1 \\
29.5 \\
59.5 \\
74.4 \\
75.0\end{array}$ & $\begin{array}{l}0.00 \\
0.05 \\
0.00 \\
0.01 \\
0.00\end{array}$ & $\begin{array}{l}1235 \\
1240 \\
1245 \\
1250 \\
1255\end{array}$ & $\begin{array}{l}7.9 \\
7.6 \\
7.6 \\
7.6 \\
7.4\end{array}$ & $\begin{array}{l}0.01 \\
0.00 \\
0.00 \\
0.00 \\
0.00\end{array}$ \\
\hline $\begin{array}{l}0210 \\
0215 \\
0220 \\
0225 \\
0230\end{array}$ & $\begin{array}{l}37.3 \\
32.3 \\
27.7 \\
24.3 \\
21.5\end{array}$ & $\begin{array}{l}0.00 \\
0.00 \\
0.00 \\
0.00 \\
0.00\end{array}$ & $\begin{array}{l}0735 \\
0740 \\
0745 \\
0750 \\
0755\end{array}$ & $\begin{array}{l}68.6 \\
61.2 \\
54.9 \\
46.9 \\
40.0\end{array}$ & $\begin{array}{l}0.00 \\
0.00 \\
0.00 \\
0.00 \\
0.00\end{array}$ & $\begin{array}{l}1300 \\
1305 \\
1310 \\
1315 \\
1320\end{array}$ & $\begin{array}{l}7.0 \\
7.0 \\
7.0 \\
6.8 \\
6.6\end{array}$ & $\begin{array}{l}0.00 \\
0.00 \\
0.00 \\
0.00 \\
0.00\end{array}$ \\
\hline $\begin{array}{l}0235 \\
0240 \\
0245 \\
0250 \\
0255\end{array}$ & $\begin{array}{l}18.9 \\
16.8 \\
15.2 \\
13.7 \\
12.5\end{array}$ & $\begin{array}{l}0.00 \\
0.00 \\
0.00 \\
0.00 \\
0.00\end{array}$ & $\begin{array}{l}0800 \\
0805 \\
0810 \\
0815 \\
0820\end{array}$ & $\begin{array}{l}34.3 \\
28.6 \\
24.7 \\
22.6 \\
48.8\end{array}$ & $\begin{array}{l}0.01 \\
0.00 \\
0.02 \\
0.11 \\
0.25\end{array}$ & $\begin{array}{l}1325 \\
1330 \\
1335 \\
1340 \\
1345\end{array}$ & $\begin{array}{l}6.3 \\
6.1 \\
6.1 \\
5.9 \\
6.1\end{array}$ & $\begin{array}{l}0.00 \\
0.00 \\
0.00 \\
0.00 \\
0.00\end{array}$ \\
\hline $\begin{array}{l}0300 \\
0305 \\
0310 \\
0315 \\
0320\end{array}$ & $\begin{array}{r}11.4 \\
10.6 \\
9.8 \\
9.0 \\
8.6\end{array}$ & $\begin{array}{l}0.00 \\
0.00 \\
0.00 \\
0.00 \\
0.00\end{array}$ & $\begin{array}{l}0825 \\
0830 \\
0835 \\
0840 \\
0845\end{array}$ & $\begin{array}{l}167.0 \\
274.0 \\
412.0 \\
446.0 \\
425.0\end{array}$ & $\begin{array}{l}0.23 \\
0.18 \\
0.02 \\
0.00 \\
0.01\end{array}$ & $\begin{array}{l}1350 \\
1355 \\
1400 \\
1405 \\
1410\end{array}$ & $\begin{array}{l}6.1 \\
5.9 \\
5.7 \\
5.5 \\
5.3\end{array}$ & $\begin{array}{l}0.00 \\
0.00 \\
0.00 \\
0.00 \\
0.00\end{array}$ \\
\hline $\begin{array}{l}0325 \\
0330 \\
0335 \\
0340 \\
0345\end{array}$ & $\begin{array}{l}7.9 \\
7.4 \\
7.0 \\
6.8 \\
6.3\end{array}$ & $\begin{array}{l}0.00 \\
0.00 \\
0.00 \\
0.00 \\
0.00\end{array}$ & $\begin{array}{l}0850 \\
0855 \\
0900 \\
0905 \\
0910\end{array}$ & $\begin{array}{l}400.0 \\
381.0 \\
356.0 \\
306.0 \\
235.0\end{array}$ & $\begin{array}{l}0.00 \\
0.00 \\
0.00 \\
0.00 \\
0.00\end{array}$ & $\begin{array}{l}1415 \\
1420 \\
1425 \\
1430 \\
1435\end{array}$ & $\begin{array}{l}5.1 \\
4.9 \\
4.7 \\
4.5 \\
4.3\end{array}$ & $\begin{array}{l}0.00 \\
0.00 \\
0.00 \\
0.00 \\
0.00\end{array}$ \\
\hline
\end{tabular}


Table 111. - Streamflow and rainfall at station 02169568, Pen Branch at Columbia, June $8-9,1989--$ Continued

\begin{tabular}{|c|c|c|c|c|c|c|c|c|}
\hline $\begin{array}{l}\text { Time } \\
\text { (hours) }\end{array}$ & $\begin{array}{l}\text { Streamflow } \\
\text { (cubic feet } \\
\text { per second) }\end{array}$ & $\begin{array}{l}\text { Rain- } \\
\text { fall } \\
\text { (inches) }\end{array}$ & $\begin{array}{l}\text { Time } \\
\text { (hours) }\end{array}$ & $\begin{array}{l}\text { Streamflow } \\
\text { (cubic feet } \\
\text { per second) }\end{array}$ & $\begin{array}{l}\text { Rain- } \\
\text { fall } \\
\text { (inches) }\end{array}$ & $\begin{array}{l}\text { Time } \\
\text { (hours) }\end{array}$ & $\begin{array}{l}\text { Streamflow } \\
\text { (cubic feet } \\
\text { per second) }\end{array}$ & $\begin{array}{l}\text { Rain- } \\
\text { fall } \\
\text { (inches) }\end{array}$ \\
\hline $\begin{array}{l}1440 \\
1445 \\
1450 \\
1455 \\
1500\end{array}$ & $\begin{array}{l}4.1 \\
3.9 \\
3.7 \\
3.5 \\
3.4\end{array}$ & $\begin{array}{l}0.00 \\
0.00 \\
0.00 \\
0.00 \\
0.00\end{array}$ & $\begin{array}{l}1750 \\
1755 \\
1800 \\
1805 \\
1810\end{array}$ & $\begin{array}{l}2.0 \\
1.9 \\
1.9 \\
1.9 \\
1.9\end{array}$ & $\begin{array}{l}0.00 \\
0.00 \\
0.00 \\
0.00 \\
0.00\end{array}$ & $\begin{array}{l}2100 \\
2105 \\
2110 \\
2115 \\
2120\end{array}$ & $\begin{array}{l}1.4 \\
1.3 \\
1.3 \\
1.3 \\
1.3\end{array}$ & $\begin{array}{l}0.00 \\
0.00 \\
0.00 \\
0.00 \\
0.00\end{array}$ \\
\hline $\begin{array}{l}1505 \\
1510 \\
1515 \\
1520 \\
1525\end{array}$ & $\begin{array}{l}3.3 \\
3.3 \\
3.2 \\
3.2 \\
3.1\end{array}$ & $\begin{array}{l}0.00 \\
0.00 \\
0.00 \\
0.00 \\
0.00\end{array}$ & $\begin{array}{l}1815 \\
1820 \\
1825 \\
1830 \\
1835\end{array}$ & $\begin{array}{l}1.8 \\
1.8 \\
1.8 \\
1.8 \\
1.7\end{array}$ & $\begin{array}{l}0.00 \\
0.00 \\
0.00 \\
0.00 \\
0.00\end{array}$ & $\begin{array}{l}2125 \\
2130 \\
2135 \\
2140 \\
2145\end{array}$ & $\begin{array}{l}1.3 \\
1.3 \\
1.3 \\
1.3 \\
1.3\end{array}$ & $\begin{array}{l}0.00 \\
0.00 \\
0.00 \\
0.00 \\
0.00\end{array}$ \\
\hline $\begin{array}{l}1530 \\
1535 \\
1540 \\
1545 \\
1550\end{array}$ & $\begin{array}{l}3.1 \\
3.0 \\
3.0 \\
3.0 \\
2.9\end{array}$ & $\begin{array}{l}0.00 \\
0.00 \\
0.00 \\
0.00 \\
0.00\end{array}$ & $\begin{array}{l}1840 \\
1845 \\
1850 \\
1855 \\
1900\end{array}$ & $\begin{array}{l}1.7 \\
1.7 \\
1.7 \\
1.7 \\
1.7\end{array}$ & $\begin{array}{l}0.00 \\
0.00 \\
0.00 \\
0.00 \\
0.00\end{array}$ & $\begin{array}{l}2150 \\
2155 \\
2200 \\
2205 \\
2210\end{array}$ & $\begin{array}{l}1.3 \\
1.3 \\
1.2 \\
1.2 \\
1.2\end{array}$ & $\begin{array}{l}0.00 \\
0.00 \\
0.00 \\
0.00 \\
0.00\end{array}$ \\
\hline $\begin{array}{l}1555 \\
1600 \\
1605 \\
1610 \\
1615\end{array}$ & $\begin{array}{l}2.9 \\
2.8 \\
2.8 \\
2.8 \\
2.7\end{array}$ & $\begin{array}{l}0.00 \\
0.00 \\
0.00 \\
0.00 \\
0.00\end{array}$ & $\begin{array}{l}1905 \\
1910 \\
1915 \\
1920 \\
1925\end{array}$ & $\begin{array}{l}1.6 \\
1.6 \\
1.6 \\
1.6 \\
1.6\end{array}$ & $\begin{array}{l}0.00 \\
0.00 \\
0.00 \\
0.00 \\
0.00\end{array}$ & $\begin{array}{l}2215 \\
2220 \\
2225 \\
2230 \\
2235\end{array}$ & $\begin{array}{l}1.0 \\
1.2 \\
1.2 \\
1.2 \\
1.2\end{array}$ & $\begin{array}{l}0.00 \\
0.00 \\
0.00 \\
0.00 \\
0.00\end{array}$ \\
\hline $\begin{array}{l}1620 \\
1625 \\
1630 \\
1635 \\
1640\end{array}$ & $\begin{array}{l}2.7 \\
2.6 \\
2.6 \\
2.5 \\
2.5\end{array}$ & $\begin{array}{l}0.00 \\
0.00 \\
0.00 \\
0.00 \\
0.00\end{array}$ & $\begin{array}{l}1930 \\
1935 \\
1940 \\
1945 \\
1950\end{array}$ & $\begin{array}{l}1.6 \\
1.6 \\
1.5 \\
1.5 \\
1.5\end{array}$ & $\begin{array}{l}0.00 \\
0.00 \\
0.00 \\
0.00 \\
0.00\end{array}$ & $\begin{array}{l}2240 \\
2245 \\
2250 \\
2255 \\
2300\end{array}$ & $\begin{array}{l}1.2 \\
1.2 \\
1.2 \\
1.2 \\
1.1\end{array}$ & $\begin{array}{l}0.00 \\
0.00 \\
0.00 \\
0.00 \\
0.00\end{array}$ \\
\hline $\begin{array}{l}1645 \\
1650 \\
1655 \\
1700 \\
1705\end{array}$ & $\begin{array}{l}2.4 \\
2.4 \\
2.3 \\
2.3 \\
2.2\end{array}$ & $\begin{array}{l}0.00 \\
0.00 \\
0.00 \\
0.00 \\
0.00\end{array}$ & $\begin{array}{l}1955 \\
2000 \\
2005 \\
2010 \\
2015\end{array}$ & $\begin{array}{l}1.5 \\
1.5 \\
1.5 \\
1.5 \\
1.5\end{array}$ & $\begin{array}{l}0.00 \\
0.00 \\
0.00 \\
0.00 \\
0.00\end{array}$ & $\begin{array}{l}2305 \\
2310 \\
2315 \\
2320 \\
2325\end{array}$ & $\begin{array}{l}1.1 \\
1.1 \\
1.1 \\
1.1 \\
1.1\end{array}$ & $\begin{array}{l}0.00 \\
0.00 \\
0.00 \\
0.00 \\
0.00\end{array}$ \\
\hline $\begin{array}{l}1710 \\
1715 \\
1720 \\
1725 \\
1730\end{array}$ & $\begin{array}{l}2.2 \\
2.1 \\
2.1 \\
2.1 \\
2.1\end{array}$ & $\begin{array}{l}0.00 \\
0.00 \\
0.00 \\
0.00 \\
0.00\end{array}$ & $\begin{array}{l}2020 \\
2025 \\
2030 \\
2035 \\
2040\end{array}$ & $\begin{array}{l}1.4 \\
1.4 \\
1.4 \\
1.4 \\
1.4\end{array}$ & $\begin{array}{l}0.00 \\
0.00 \\
0.00 \\
0.00 \\
0.00\end{array}$ & $\begin{array}{l}2330 \\
2335 \\
2340 \\
2345 \\
2350\end{array}$ & $\begin{array}{l}1.1 \\
1.1 \\
1.1 \\
1.1 \\
1.1\end{array}$ & $\begin{array}{l}0.00 \\
0.00 \\
0.00 \\
0.00 \\
0.00\end{array}$ \\
\hline $\begin{array}{l}1735 \\
1740 \\
1745\end{array}$ & $\begin{array}{l}2.0 \\
2.0 \\
2.0\end{array}$ & $\begin{array}{l}0.00 \\
0.00 \\
0.00\end{array}$ & $\begin{array}{l}2045 \\
2050 \\
2055\end{array}$ & $\begin{array}{l}1.4 \\
1.4 \\
1.4\end{array}$ & $\begin{array}{l}0.00 \\
0.00 \\
0.00\end{array}$ & 2355 & 1.1 & 0.00 \\
\hline
\end{tabular}



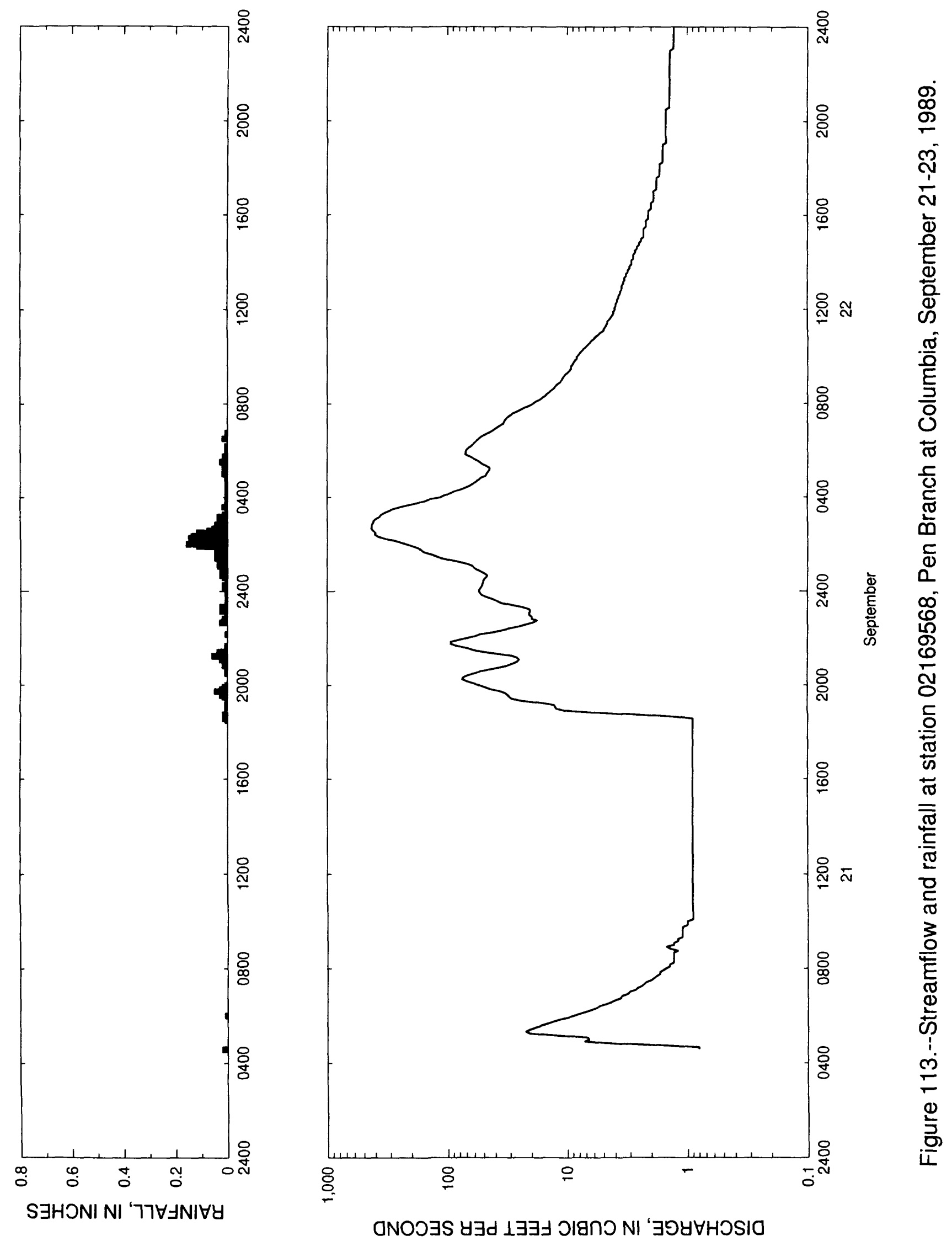
Table 112 - Streamflow and rainfall at station 02169568, Pen Branch at Columbia, September 21-23, 1989

\begin{tabular}{|c|c|c|c|c|c|c|c|c|}
\hline $\begin{array}{l}\text { Time } \\
\text { (hours) }\end{array}$ & $\begin{array}{l}\text { Streamflow } \\
\text { (cubic feet } \\
\text { per second) }\end{array}$ & $\begin{array}{l}\text { Rain- } \\
\text { fall } \\
\text { (inches) }\end{array}$ & $\begin{array}{l}\text { Time } \\
\text { (hours) }\end{array}$ & $\begin{array}{l}\text { Streamflow } \\
\text { (cubic feet } \\
\text { per second) }\end{array}$ & $\begin{array}{l}\text { Rain- } \\
\text { fall } \\
\text { (inches) }\end{array}$ & $\begin{array}{l}\text { Time } \\
\text { (hours) }\end{array}$ & $\begin{array}{l}\text { Streamflow } \\
\text { (cubic feet } \\
\text { per second) }\end{array}$ & $\begin{array}{l}\text { Rain- } \\
\text { fall } \\
\text { (inches) }\end{array}$ \\
\hline $\begin{array}{l}\text { September } \\
0435 \\
0440 \\
0445 \\
0450\end{array}$ & $\begin{aligned} & 21, 1989 \\
& 0.8 \\
& 0.8 \\
& 1.7 \\
& 4.2\end{aligned}$ & $\begin{array}{l}0.02 \\
0.00 \\
0.00 \\
0.00\end{array}$ & $\begin{array}{l}0955 \\
1000 \\
1005 \\
1010 \\
1015\end{array}$ & $\begin{array}{l}1.0 \\
1.0 \\
0.9 \\
0.9 \\
0.9\end{array}$ & $\begin{array}{l}0.00 \\
0.00 \\
0.00 \\
0.00 \\
0.00\end{array}$ & $\begin{array}{l}1520 \\
1525 \\
1530 \\
1535 \\
1540\end{array}$ & $\begin{array}{l}0.9 \\
0.9 \\
0.9 \\
0.9 \\
0.9\end{array}$ & $\begin{array}{l}0.00 \\
0.00 \\
0.00 \\
0.00 \\
0.00\end{array}$ \\
\hline $\begin{array}{l}0455 \\
0500 \\
0505 \\
0510 \\
0515\end{array}$ & $\begin{array}{r}7.2 \\
6.6 \\
6.8 \\
12.3 \\
20.7\end{array}$ & $\begin{array}{l}0.00 \\
0.00 \\
0.00 \\
0.00 \\
0.00\end{array}$ & $\begin{array}{l}1020 \\
1025 \\
1030 \\
1035 \\
1040\end{array}$ & $\begin{array}{l}0.9 \\
0.9 \\
0.9 \\
0.9 \\
0.9\end{array}$ & $\begin{array}{l}0.00 \\
0.00 \\
0.00 \\
0.00 \\
0.00\end{array}$ & $\begin{array}{l}1545 \\
1550 \\
1555 \\
1600 \\
1605\end{array}$ & $\begin{array}{l}0.9 \\
0.9 \\
0.9 \\
0.9 \\
0.9\end{array}$ & $\begin{array}{l}0.00 \\
0.00 \\
0.00 \\
0.00 \\
0.00\end{array}$ \\
\hline $\begin{array}{l}0520 \\
0525 \\
0530 \\
0535 \\
0540\end{array}$ & $\begin{array}{l}22.3 \\
20.7 \\
18.5 \\
16.5 \\
14.6\end{array}$ & $\begin{array}{l}0.00 \\
0.00 \\
0.00 \\
0.00 \\
0.00\end{array}$ & $\begin{array}{l}1045 \\
1050 \\
1055 \\
1100 \\
1105\end{array}$ & $\begin{array}{l}0.9 \\
0.9 \\
0.9 \\
0.9 \\
0.9\end{array}$ & $\begin{array}{l}0.00 \\
0.00 \\
0.00 \\
0.00 \\
0.00\end{array}$ & $\begin{array}{l}1610 \\
1615 \\
1620 \\
1625 \\
1630\end{array}$ & $\begin{array}{l}0.9 \\
0.9 \\
0.9 \\
0.9 \\
0.9\end{array}$ & $\begin{array}{l}0.00 \\
0.00 \\
0.00 \\
0.00 \\
0.00\end{array}$ \\
\hline $\begin{array}{l}0545 \\
0550 \\
0555 \\
0600 \\
0605\end{array}$ & $\begin{array}{r}13.1 \\
11.7 \\
10.0 \\
8.8 \\
7.9\end{array}$ & $\begin{array}{l}0.00 \\
0.00 \\
0.00 \\
0.01 \\
0.00\end{array}$ & $\begin{array}{l}1110 \\
1115 \\
1120 \\
1125 \\
1130\end{array}$ & $\begin{array}{l}0.9 \\
0.9 \\
0.9 \\
0.9 \\
0.9\end{array}$ & $\begin{array}{l}0.00 \\
0.00 \\
0.00 \\
0.00 \\
0.00\end{array}$ & $\begin{array}{l}1635 \\
1640 \\
1645 \\
1650 \\
1655\end{array}$ & $\begin{array}{l}0.9 \\
0.9 \\
0.9 \\
0.9 \\
0.9\end{array}$ & $\begin{array}{l}0.00 \\
0.00 \\
0.00 \\
0.00 \\
0.00\end{array}$ \\
\hline $\begin{array}{l}0610 \\
0615 \\
0620 \\
0625 \\
0630\end{array}$ & $\begin{array}{l}7.0 \\
6.3 \\
5.7 \\
5.3 \\
4.7\end{array}$ & $\begin{array}{l}0.00 \\
0.00 \\
0.00 \\
0.00 \\
0.00\end{array}$ & $\begin{array}{l}1135 \\
1140 \\
1145 \\
1150 \\
1155\end{array}$ & $\begin{array}{l}0.9 \\
0.9 \\
0.9 \\
0.9 \\
0.9\end{array}$ & $\begin{array}{l}0.00 \\
0.00 \\
0.00 \\
0.00 \\
0.00\end{array}$ & $\begin{array}{l}1700 \\
1705 \\
1710 \\
1715 \\
1720\end{array}$ & $\begin{array}{l}0.9 \\
0.9 \\
0.9 \\
0.9 \\
0.9\end{array}$ & $\begin{array}{l}0.00 \\
0.00 \\
0.00 \\
0.00 \\
0.00\end{array}$ \\
\hline $\begin{array}{l}0635 \\
0640 \\
0645 \\
0650 \\
0655\end{array}$ & $\begin{array}{l}4.3 \\
4.0 \\
3.6 \\
3.5 \\
3.1\end{array}$ & $\begin{array}{l}0.00 \\
0.00 \\
0.00 \\
0.00 \\
0.00\end{array}$ & $\begin{array}{l}1200 \\
1205 \\
1210 \\
1215 \\
1220\end{array}$ & $\begin{array}{l}0.9 \\
0.9 \\
0.9 \\
0.9 \\
0.9\end{array}$ & $\begin{array}{l}0.00 \\
0.00 \\
0.00 \\
0.00 \\
0.00\end{array}$ & $\begin{array}{l}1725 \\
1730 \\
1735 \\
1740 \\
1745\end{array}$ & $\begin{array}{l}0.9 \\
0.9 \\
0.9 \\
0.9 \\
0.9\end{array}$ & $\begin{array}{l}0.00 \\
0.00 \\
0.00 \\
0.00 \\
0.00\end{array}$ \\
\hline $\begin{array}{l}0700 \\
0705 \\
0710 \\
0715 \\
0720\end{array}$ & $\begin{array}{l}3.0 \\
2.7 \\
2.6 \\
2.4 \\
2.3\end{array}$ & $\begin{array}{l}0.00 \\
0.00 \\
0.00 \\
0.00 \\
0.00\end{array}$ & $\begin{array}{l}1225 \\
1230 \\
1235 \\
1240 \\
1245\end{array}$ & $\begin{array}{l}0.9 \\
0.9 \\
0.9 \\
0.9 \\
0.9\end{array}$ & $\begin{array}{l}0.00 \\
0.00 \\
0.00 \\
0.00 \\
0.00\end{array}$ & $\begin{array}{l}1750 \\
1755 \\
1800 \\
1805 \\
1810\end{array}$ & $\begin{array}{l}0.9 \\
0.9 \\
0.9 \\
0.9 \\
0.9\end{array}$ & $\begin{array}{l}0.00 \\
0.00 \\
0.00 \\
0.00 \\
0.00\end{array}$ \\
\hline $\begin{array}{l}0725 \\
0730 \\
0735 \\
0740 \\
0745\end{array}$ & $\begin{array}{l}2.2 \\
2.0 \\
1.9 \\
1.8 \\
1.7\end{array}$ & $\begin{array}{l}0.00 \\
0.00 \\
0.00 \\
0.00 \\
0.00\end{array}$ & $\begin{array}{l}1250 \\
1255 \\
1300 \\
1305 \\
1310\end{array}$ & $\begin{array}{l}0.9 \\
0.9 \\
0.9 \\
0.9 \\
0.9\end{array}$ & $\begin{array}{l}0.00 \\
0.00 \\
0.00 \\
0.00 \\
0.00\end{array}$ & $\begin{array}{l}1815 \\
1820 \\
1825 \\
1830 \\
1835\end{array}$ & $\begin{array}{l}0.9 \\
0.9 \\
0.9 \\
0.9 \\
0.9\end{array}$ & $\begin{array}{l}0.00 \\
0.00 \\
0.00 \\
0.01 \\
0.02\end{array}$ \\
\hline $\begin{array}{l}0750 \\
0755 \\
0800 \\
0805 \\
0810\end{array}$ & $\begin{array}{l}1.7 \\
1.6 \\
1.5 \\
1.4 \\
1.4\end{array}$ & $\begin{array}{l}0.00 \\
0.00 \\
0.00 \\
0.00 \\
0.00\end{array}$ & $\begin{array}{l}1315 \\
1320 \\
1325 \\
1330 \\
1335\end{array}$ & $\begin{array}{l}0.9 \\
0.9 \\
0.9 \\
0.9 \\
0.9\end{array}$ & $\begin{array}{l}0.00 \\
0.00 \\
0.00 \\
0.00 \\
0.00\end{array}$ & $\begin{array}{l}1840 \\
1845 \\
1850 \\
1855 \\
1900\end{array}$ & $\begin{array}{r}1.3 \\
2.6 \\
5.5 \\
10.3 \\
12.3\end{array}$ & $\begin{array}{l}0.02 \\
0.02 \\
0.01 \\
0.01 \\
0.01\end{array}$ \\
\hline $\begin{array}{l}0815 \\
0820 \\
0825 \\
0830 \\
0835\end{array}$ & $\begin{array}{l}1.3 \\
1.3 \\
1.3 \\
1.3 \\
1.3\end{array}$ & $\begin{array}{l}0.00 \\
0.00 \\
0.00 \\
0.00 \\
0.00\end{array}$ & $\begin{array}{l}1340 \\
1345 \\
1350 \\
1355 \\
1400\end{array}$ & $\begin{array}{l}0.9 \\
0.9 \\
0.9 \\
0.9 \\
0.9\end{array}$ & $\begin{array}{l}0.00 \\
0.00 \\
0.00 \\
0.00 \\
0.00\end{array}$ & $\begin{array}{l}1905 \\
1910 \\
1915 \\
1920 \\
1925\end{array}$ & $\begin{array}{l}12.5 \\
12.8 \\
16.5 \\
23.5 \\
29.0\end{array}$ & $\begin{array}{l}0.00 \\
0.01 \\
0.01 \\
0.01 \\
0.00\end{array}$ \\
\hline $\begin{array}{l}0840 \\
0845 \\
0850 \\
0855 \\
0900\end{array}$ & $\begin{array}{l}1.3 \\
1.2 \\
1.4 \\
1.5 \\
1.3\end{array}$ & $\begin{array}{l}0.00 \\
0.00 \\
0.00 \\
0.00 \\
0.00\end{array}$ & $\begin{array}{l}1405 \\
1410 \\
1415 \\
1420 \\
1425\end{array}$ & $\begin{array}{l}0.9 \\
0.9 \\
0.9 \\
0.9 \\
0.9\end{array}$ & $\begin{array}{l}0.00 \\
0.00 \\
0.00 \\
0.00 \\
0.00\end{array}$ & $\begin{array}{l}1930 \\
1935 \\
1940 \\
1945 \\
1950\end{array}$ & $\begin{array}{l}30.4 \\
31.3 \\
32.8 \\
36.3 \\
44.0\end{array}$ & $\begin{array}{l}0.02 \\
0.03 \\
0.01 \\
0.05 \\
0.03\end{array}$ \\
\hline $\begin{array}{l}0905 \\
0910 \\
0915 \\
0920 \\
0925\end{array}$ & $\begin{array}{l}1.3 \\
1.2 \\
1.2 \\
1.1 \\
1.1\end{array}$ & $\begin{array}{l}0.00 \\
0.00 \\
0.00 \\
0.00 \\
0.00\end{array}$ & $\begin{array}{l}1430 \\
1435 \\
1440 \\
1445 \\
1450\end{array}$ & $\begin{array}{l}0.9 \\
0.9 \\
0.9 \\
0.9 \\
0.9\end{array}$ & $\begin{array}{l}0.00 \\
0.00 \\
0.00 \\
0.00 \\
0.00\end{array}$ & $\begin{array}{l}1955 \\
2000 \\
2005 \\
2010 \\
2015\end{array}$ & $\begin{array}{l}48.8 \\
54.3 \\
60.1 \\
68.6 \\
75.0\end{array}$ & $\begin{array}{l}0.02 \\
0.01 \\
0.00 \\
0.00 \\
0.00\end{array}$ \\
\hline $\begin{array}{l}0930 \\
0935 \\
0940 \\
0945 \\
0950\end{array}$ & $\begin{array}{l}1.1 \\
1.1 \\
1.1 \\
1.1 \\
1.0\end{array}$ & $\begin{array}{l}0.00 \\
0.00 \\
0.00 \\
0.00 \\
0.00\end{array}$ & $\begin{array}{l}1455 \\
1500 \\
1505 \\
1510 \\
1515\end{array}$ & $\begin{array}{l}0.9 \\
0.9 \\
0.9 \\
0.9 \\
0.9\end{array}$ & $\begin{array}{l}0.00 \\
0.00 \\
0.00 \\
0.00 \\
0.00\end{array}$ & $\begin{array}{l}2020 \\
2025 \\
2030 \\
2035 \\
2040\end{array}$ & $\begin{array}{l}73.7 \\
67.9 \\
60.6 \\
53.2 \\
44.5\end{array}$ & $\begin{array}{l}0.00 \\
0.00 \\
0.01 \\
0.00 \\
0.00\end{array}$ \\
\hline
\end{tabular}


Table 112. --Streamflow and rainfall at station 02169568, Pen Branch at Columbia, September $21-23,1989--$ Continued

\begin{tabular}{|c|c|c|c|c|c|c|c|c|}
\hline $\begin{array}{l}\text { Time } \\
\text { (hours) }\end{array}$ & $\begin{array}{l}\text { Streamflow } \\
\text { (cubic feet } \\
\text { per second) }\end{array}$ & $\begin{array}{l}\text { Rain- } \\
\text { fall } \\
\text { (inches) }\end{array}$ & $\begin{array}{l}\text { Time } \\
\text { (hours) }\end{array}$ & $\begin{array}{l}\text { Streamflow } \\
\text { (cubic feet } \\
\text { per second) }\end{array}$ & $\begin{array}{l}\text { Rain- } \\
\text { fall } \\
\text { (inches) }\end{array}$ & $\begin{array}{l}\text { Time } \\
\text { (hours) }\end{array}$ & $\begin{array}{l}\text { Streamflow } \\
\text { (cubic feet } \\
\text { per second) }\end{array}$ & $\begin{array}{l}\text { Rein- } \\
\text { fall } \\
\text { (inches) }\end{array}$ \\
\hline $\begin{array}{l}2045 \\
2050 \\
2055 \\
2100 \\
2105\end{array}$ & $\begin{array}{l}36.8 \\
31.3 \\
28.2 \\
26.0 \\
25.1\end{array}$ & $\begin{array}{l}0.01 \\
0.02 \\
0.02 \\
0.01 \\
0.03\end{array}$ & $\begin{array}{l}0205 \\
0210 \\
0215 \\
0220 \\
0225\end{array}$ & $\begin{array}{l}251.0 \\
291.0 \\
340.0 \\
380.0 \\
401.0\end{array}$ & $\begin{array}{l}0.14 \\
0.14 \\
0.15 \\
0.14 \\
0.11\end{array}$ & $\begin{array}{l}0730 \\
0735 \\
0740 \\
0745 \\
0750\end{array}$ & $\begin{array}{l}29.5 \\
28.2 \\
26.0 \\
24.3 \\
22.6\end{array}$ & $\begin{array}{l}0.00 \\
0.00 \\
0.00 \\
0.00 \\
0.00\end{array}$ \\
\hline $\begin{array}{l}2110 \\
2115 \\
2120 \\
2125 \\
2130\end{array}$ & $\begin{array}{l}26.0 \\
29.0 \\
37.3 \\
51.6 \\
61.2\end{array}$ & $\begin{array}{l}0.02 \\
0.06 \\
0.04 \\
0.04 \\
0.00\end{array}$ & $\begin{array}{l}0230 \\
0235 \\
0240 \\
0245 \\
0250\end{array}$ & $\begin{array}{l}398.0 \\
417.0 \\
431.0 \\
428.0 \\
427.0\end{array}$ & $\begin{array}{l}0.12 \\
0.08 \\
0.06 \\
0.05 \\
0.05\end{array}$ & $\begin{array}{l}0755 \\
0800 \\
0805 \\
0810 \\
0815\end{array}$ & $\begin{array}{l}20.7 \\
19.2 \\
18.2 \\
16.8 \\
16.1\end{array}$ & $\begin{array}{l}0.00 \\
0.00 \\
0.00 \\
0.00 \\
0.00\end{array}$ \\
\hline $\begin{array}{l}2135 \\
2140 \\
2145 \\
2150 \\
2155\end{array}$ & $\begin{array}{l}69.2 \\
84.6 \\
93.8 \\
93.8 \\
81.8\end{array}$ & $\begin{array}{l}0.00 \\
0.01 \\
0.00 \\
0.00 \\
0.00\end{array}$ & $\begin{array}{l}0255 \\
0300 \\
0305 \\
0310 \\
0315\end{array}$ & $\begin{array}{l}418.0 \\
410.0 \\
394.0 \\
368.0 \\
360.0\end{array}$ & $\begin{array}{l}0.04 \\
0.03 \\
0.03 \\
0.04 \\
0.02\end{array}$ & $\begin{array}{l}0820 \\
0825 \\
0830 \\
0835 \\
0840\end{array}$ & $\begin{array}{l}15.2 \\
14.6 \\
14.0 \\
13.4 \\
12.8\end{array}$ & $\begin{array}{l}0.00 \\
0.00 \\
0.00 \\
0.00 \\
0.00\end{array}$ \\
\hline $\begin{array}{l}2200 \\
2205 \\
2210 \\
2215 \\
2220\end{array}$ & $\begin{array}{l}69.8 \\
60.1 \\
52.7 \\
41.7 \\
35.3\end{array}$ & $\begin{array}{l}0.00 \\
0.00 \\
0.01 \\
0.00 \\
0.00\end{array}$ & $\begin{array}{l}0320 \\
0325 \\
0330 \\
0335 \\
0340\end{array}$ & $\begin{array}{l}339.0 \\
311.0 \\
280.0 \\
248.0 \\
212.0\end{array}$ & $\begin{array}{l}0.01 \\
0.00 \\
0.01 \\
0.02 \\
0.00\end{array}$ & $\begin{array}{l}0845 \\
0850 \\
0855 \\
0900 \\
0905\end{array}$ & $\begin{array}{l}12.5 \\
12.0 \\
11.4 \\
11.1 \\
10.9\end{array}$ & $\begin{array}{l}0.00 \\
0.00 \\
0.00 \\
0.00 \\
0.00\end{array}$ \\
\hline $\begin{array}{l}2225 \\
2230 \\
2235 \\
2240 \\
2245\end{array}$ & $\begin{array}{l}30.4 \\
25.6 \\
22.3 \\
19.6 \\
17.8\end{array}$ & $\begin{array}{l}0.00 \\
0.00 \\
0.00 \\
0.03 \\
0.02\end{array}$ & $\begin{array}{l}0345 \\
0350 \\
0355 \\
0400 \\
0405\end{array}$ & $\begin{array}{l}182.0 \\
154.0 \\
141.0 \\
115.0 \\
107.0\end{array}$ & $\begin{array}{l}0.01 \\
0.00 \\
0.01 \\
0.01 \\
0.01\end{array}$ & $\begin{array}{l}0910 \\
0915 \\
0920 \\
0925 \\
0930\end{array}$ & $\begin{array}{r}10.6 \\
10.3 \\
9.8 \\
9.5 \\
9.3\end{array}$ & $\begin{array}{l}0.00 \\
0.00 \\
0.00 \\
0.00 \\
0.00\end{array}$ \\
\hline $\begin{array}{l}2250 \\
2255 \\
2300 \\
2305 \\
2310\end{array}$ & $\begin{array}{l}19.6 \\
19.6 \\
20.7 \\
20.7 \\
20.3\end{array}$ & $\begin{array}{l}0.02 \\
0.01 \\
0.00 \\
0.01 \\
0.03\end{array}$ & $\begin{array}{l}0410 \\
0415 \\
0420 \\
0425 \\
0430\end{array}$ & $\begin{array}{l}94.6 \\
87.5 \\
78.4 \\
71.1 \\
65.4\end{array}$ & $\begin{array}{l}0.00 \\
0.00 \\
0.01 \\
0.01 \\
0.01\end{array}$ & $\begin{array}{l}0935 \\
0940 \\
0945 \\
0950 \\
0955\end{array}$ & $\begin{array}{l}9.3 \\
9.0 \\
8.8 \\
8.6 \\
8.3\end{array}$ & $\begin{array}{l}0.00 \\
0.00 \\
0.00 \\
0.00 \\
0.00\end{array}$ \\
\hline $\begin{array}{l}2315 \\
2320 \\
2325 \\
2330 \\
2335\end{array}$ & $\begin{array}{l}20.7 \\
23.5 \\
29.0 \\
35.3 \\
38.4\end{array}$ & $\begin{array}{l}0.02 \\
0.03 \\
0.01 \\
0.01 \\
0.01\end{array}$ & $\begin{array}{l}0435 \\
0440 \\
0445 \\
0450 \\
0455\end{array}$ & $\begin{array}{l}61.8 \\
57.7 \\
54.3 \\
52.1 \\
47.5\end{array}$ & $\begin{array}{l}0.00 \\
0.00 \\
0.01 \\
0.01 \\
0.00\end{array}$ & $\begin{array}{l}1000 \\
1005 \\
1010 \\
1015 \\
1020\end{array}$ & $\begin{array}{l}8.3 \\
8.0 \\
7.8 \\
7.5 \\
7.3\end{array}$ & $\begin{array}{l}0.00 \\
0.00 \\
0.00 \\
0.00 \\
0.00\end{array}$ \\
\hline $\begin{array}{l}2340 \\
2345 \\
2350 \\
2355\end{array}$ & $\begin{array}{c}41.7 \\
46.9 \\
51.1 \\
53.2 \\
\text { September }\end{array}$ & $\begin{array}{c}0.01 \\
0.01 \\
0.01 \\
0.01 \\
22, .1989\end{array}$ & $\begin{array}{l}0500 \\
0505 \\
0510 \\
0515 \\
0520\end{array}$ & $\begin{array}{l}46.9 \\
45.7 \\
44.5 \\
44.0 \\
46.9\end{array}$ & $\begin{array}{l}0.02 \\
0.01 \\
0.02 \\
0.02 \\
0.01\end{array}$ & $\begin{array}{l}1025 \\
1030 \\
1035 \\
1040 \\
1045\end{array}$ & $\begin{array}{l}7.0 \\
6.8 \\
6.5 \\
6.3 \\
6.0\end{array}$ & $\begin{array}{l}0.00 \\
0.00 \\
0.00 \\
0.00 \\
0.00\end{array}$ \\
\hline $\begin{array}{l}0000 \\
0005 \\
0010 \\
0015 \\
0020\end{array}$ & $\begin{array}{l}54.3 \\
53.8 \\
52.1 \\
51.1 \\
50.5\end{array}$ & $\begin{array}{l}0.01 \\
0.01 \\
0.02 \\
0.02 \\
0.01\end{array}$ & $\begin{array}{l}0525 \\
0530 \\
0535 \\
0540 \\
0545\end{array}$ & $\begin{array}{l}51.1 \\
53.8 \\
57.2 \\
60.6 \\
65.4\end{array}$ & $\begin{array}{l}0.02 \\
0.03 \\
0.01 \\
0.02 \\
0.02\end{array}$ & $\begin{array}{l}1050 \\
1055 \\
1100 \\
1105 \\
1110\end{array}$ & $\begin{array}{l}5.8 \\
5.5 \\
5.3 \\
5.0 \\
4.9\end{array}$ & $\begin{array}{l}0.00 \\
0.00 \\
0.00 \\
0.00 \\
0.00\end{array}$ \\
\hline $\begin{array}{l}0025 \\
0030 \\
0035 \\
0040 \\
0045\end{array}$ & $\begin{array}{l}50.1 \\
49.4 \\
47.5 \\
46.3 \\
48.8\end{array}$ & $\begin{array}{l}0.00 \\
0.01 \\
0.02 \\
0.03 \\
0.03\end{array}$ & $\begin{array}{l}0550 \\
0555 \\
0600 \\
0605 \\
0610\end{array}$ & $\begin{array}{l}71.1 \\
70.5 \\
69.8 \\
67.9 \\
64.2\end{array}$ & $\begin{array}{l}0.00 \\
0.01 \\
0.00 \\
0.00 \\
0.01\end{array}$ & $\begin{array}{l}1115 \\
1120 \\
1125 \\
1130 \\
1135\end{array}$ & $\begin{array}{l}4.8 \\
4.7 \\
4.6 \\
4.6 \\
4.4\end{array}$ & $\begin{array}{l}0.00 \\
0.00 \\
0.00 \\
0.00 \\
0.00\end{array}$ \\
\hline $\begin{array}{l}0050 \\
0055 \\
0100 \\
0105 \\
0110\end{array}$ & $\begin{array}{l}52.7 \\
56.6 \\
60.1 \\
61.8 \\
67.9\end{array}$ & $\begin{array}{l}0.02 \\
0.03 \\
0.02 \\
0.04 \\
0.04\end{array}$ & $\begin{array}{l}0615 \\
0620 \\
0625 \\
0630 \\
0635\end{array}$ & $\begin{array}{l}61.2 \\
58.9 \\
56.6 \\
54.3 \\
52.1\end{array}$ & $\begin{array}{l}0.00 \\
0.00 \\
0.00 \\
0.02 \\
0.00\end{array}$ & $\begin{array}{l}1140 \\
1145 \\
1150 \\
1155 \\
1200\end{array}$ & $\begin{array}{l}4.3 \\
4.2 \\
4.1 \\
4.1 \\
4.0\end{array}$ & $\begin{array}{l}0.00 \\
0.00 \\
0.00 \\
0.00 \\
0.00\end{array}$ \\
\hline $\begin{array}{l}0115 \\
0120 \\
0125 \\
0130 \\
0135\end{array}$ & $\begin{array}{r}81.1 \\
97.0 \\
114.0 \\
126.0 \\
140.0\end{array}$ & $\begin{array}{l}0.04 \\
0.03 \\
0.05 \\
0.04 \\
0.04\end{array}$ & $\begin{array}{l}0640 \\
0645 \\
0650 \\
0655 \\
0700\end{array}$ & $\begin{array}{l}48.8 \\
45.1 \\
42.2 \\
40.1 \\
37.9\end{array}$ & $\begin{array}{l}0.01 \\
0.01 \\
0.00 \\
0.00 \\
0.00\end{array}$ & $\begin{array}{l}1205 \\
1210 \\
1215 \\
1220 \\
1225\end{array}$ & $\begin{array}{l}4.0 \\
3.9 \\
3.9 \\
3.8 \\
3.8\end{array}$ & $\begin{array}{l}0.00 \\
0.00 \\
0.00 \\
0.00 \\
0.00\end{array}$ \\
\hline $\begin{array}{l}0140 \\
0145 \\
0150 \\
0155 \\
0200\end{array}$ & $\begin{array}{l}159.0 \\
166.0 \\
175.0 \\
194.0 \\
220.0\end{array}$ & $\begin{array}{l}0.05 \\
0.05 \\
0.05 \\
0.12 \\
0.16\end{array}$ & $\begin{array}{l}0705 \\
0710 \\
0715 \\
0720 \\
0725\end{array}$ & $\begin{array}{l}35.8 \\
33.8 \\
33.3 \\
32.3 \\
31.3\end{array}$ & $\begin{array}{l}0.00 \\
0.00 \\
0.00 \\
0.00 \\
0.00\end{array}$ & $\begin{array}{l}1230 \\
1235 \\
1240 \\
1245 \\
1250\end{array}$ & $\begin{array}{l}3.7 \\
3.7 \\
3.6 \\
3.6 \\
3.5\end{array}$ & $\begin{array}{l}0.00 \\
0.00 \\
0.00 \\
0.00 \\
0.00\end{array}$ \\
\hline
\end{tabular}


Table 112,--Streamflow and rainfall at station 02169568. Pen Branch at Columbia, September 21-23, 1989--Continued

\begin{tabular}{|c|c|c|c|c|c|c|c|c|}
\hline $\begin{array}{l}\text { Time } \\
\text { (hours) }\end{array}$ & $\begin{array}{l}\text { Streamflow } \\
\text { (cubic feet } \\
\text { per second) }\end{array}$ & $\begin{array}{l}\text { Rain- } \\
\text { fall } \\
\text { (inches) }\end{array}$ & $\begin{array}{l}\text { Time } \\
\text { (hours) }\end{array}$ & $\begin{array}{l}\text { Streamflow } \\
\text { (cubic feet } \\
\text { per second) }\end{array}$ & $\begin{array}{l}\text { Rain- } \\
\text { fall } \\
\text { (inches) }\end{array}$ & $\begin{array}{l}\text { Time } \\
\text { (hours) }\end{array}$ & $\begin{array}{l}\text { Streamflow } \\
\text { (cubic feet } \\
\text { per second) }\end{array}$ & $\begin{array}{l}\text { Rain- } \\
\text { fall } \\
\text { (inches) }\end{array}$ \\
\hline $\begin{array}{l}1255 \\
1300 \\
1305 \\
1310 \\
1315\end{array}$ & $\begin{array}{l}3.5 \\
3.5 \\
3.4 \\
3.4 \\
3.3\end{array}$ & $\begin{array}{l}0.00 \\
0.00 \\
0.00 \\
0.00 \\
0.00\end{array}$ & $\begin{array}{l}1640 \\
1645 \\
1650 \\
1655 \\
1700\end{array}$ & $\begin{array}{l}1.9 \\
1.9 \\
1.9 \\
1.9 \\
1.9\end{array}$ & $\begin{array}{l}0.00 \\
0.00 \\
0.00 \\
0.00 \\
0.00\end{array}$ & $\begin{array}{l}2025 \\
2030 \\
2035 \\
2040 \\
2045\end{array}$ & $\begin{array}{l}1.5 \\
1.5 \\
1.4 \\
1.4 \\
1.4\end{array}$ & $\begin{array}{l}0.00 \\
0.00 \\
0.00 \\
0.00 \\
0.00\end{array}$ \\
\hline $\begin{array}{l}1320 \\
1325 \\
1330 \\
1335 \\
1340\end{array}$ & $\begin{array}{l}3.3 \\
3.2 \\
3.2 \\
3.1 \\
3.1\end{array}$ & $\begin{array}{l}0.00 \\
0.00 \\
0.00 \\
0.00 \\
0.00\end{array}$ & $\begin{array}{l}1705 \\
1710 \\
1715 \\
1720 \\
1725\end{array}$ & $\begin{array}{l}1.8 \\
1.8 \\
1.8 \\
1.8 \\
1.8\end{array}$ & $\begin{array}{l}0.00 \\
0.00 \\
0.00 \\
0.00 \\
0.00\end{array}$ & $\begin{array}{l}2050 \\
2055 \\
2100 \\
2105 \\
2110\end{array}$ & $\begin{array}{l}1.4 \\
1.4 \\
1.4 \\
1.4 \\
1.4\end{array}$ & $\begin{array}{l}0.00 \\
0.00 \\
0.00 \\
0.00 \\
0.00\end{array}$ \\
\hline $\begin{array}{l}1345 \\
1350 \\
1355 \\
1400 \\
1405\end{array}$ & $\begin{array}{l}3.0 \\
3.0 \\
2.9 \\
2.9 \\
2.9\end{array}$ & $\begin{array}{l}0.00 \\
0.00 \\
0.00 \\
0.00 \\
0.00\end{array}$ & $\begin{array}{l}1730 \\
1735 \\
1740 \\
1745 \\
1750\end{array}$ & $\begin{array}{l}1.8 \\
1.8 \\
1.7 \\
1.7 \\
1.7\end{array}$ & $\begin{array}{l}0.00 \\
0.00 \\
0.00 \\
0.00 \\
0.00\end{array}$ & $\begin{array}{l}2115 \\
2120 \\
2125 \\
2130 \\
2135\end{array}$ & $\begin{array}{l}1.4 \\
1.4 \\
1.4 \\
1.4 \\
1.4\end{array}$ & $\begin{array}{l}0.00 \\
0.00 \\
0.00 \\
0.00 \\
0.00\end{array}$ \\
\hline $\begin{array}{l}1410 \\
1415 \\
1420 \\
1425 \\
1430\end{array}$ & $\begin{array}{l}2.8 \\
2.8 \\
2.8 \\
2.7 \\
2.7\end{array}$ & $\begin{array}{l}0.00 \\
0.00 \\
0.00 \\
0.00 \\
0.00\end{array}$ & $\begin{array}{l}1755 \\
1800 \\
1805 \\
1810 \\
1815\end{array}$ & $\begin{array}{l}1.7 \\
1.7 \\
1.7 \\
1.7 \\
1.6\end{array}$ & $\begin{array}{l}0.00 \\
0.00 \\
0.00 \\
0.00 \\
0.00\end{array}$ & $\begin{array}{l}2140 \\
2145 \\
2150 \\
2155 \\
2200\end{array}$ & $\begin{array}{l}1.4 \\
1.4 \\
1.4 \\
1.4 \\
1.4\end{array}$ & $\begin{array}{l}0.00 \\
0.00 \\
0.00 \\
0.00 \\
0.00\end{array}$ \\
\hline $\begin{array}{l}1435 \\
1440 \\
1445 \\
1450 \\
1455\end{array}$ & $\begin{array}{l}2.6 \\
2.6 \\
2.5 \\
2.5 \\
2.4\end{array}$ & $\begin{array}{l}0.00 \\
0.00 \\
0.00 \\
0.00 \\
0.00\end{array}$ & $\begin{array}{l}1820 \\
1825 \\
1830 \\
1835 \\
1840\end{array}$ & $\begin{array}{l}1.6 \\
1.6 \\
1.6 \\
1.6 \\
1.6\end{array}$ & $\begin{array}{l}0.00 \\
0.00 \\
0.00 \\
0.00 \\
0.00\end{array}$ & $\begin{array}{l}2205 \\
2210 \\
2215 \\
2220 \\
2225\end{array}$ & $\begin{array}{l}1.4 \\
1.4 \\
1.4 \\
1.4 \\
1.4\end{array}$ & $\begin{array}{l}0.00 \\
0.00 \\
0.00 \\
0.00 \\
0.00\end{array}$ \\
\hline $\begin{array}{l}1500 \\
1505 \\
1510 \\
1515 \\
1520\end{array}$ & $\begin{array}{l}2.4 \\
2.3 \\
2.3 \\
2.3 \\
2.3\end{array}$ & $\begin{array}{l}0.00 \\
0.00 \\
0.00 \\
0.00 \\
0.00\end{array}$ & $\begin{array}{l}1845 \\
1850 \\
1855 \\
1900 \\
1905\end{array}$ & $\begin{array}{l}1.6 \\
1.6 \\
1.6 \\
1.6 \\
1.5\end{array}$ & $\begin{array}{l}0.00 \\
0.00 \\
0.00 \\
0.00 \\
0.00\end{array}$ & $\begin{array}{l}2230 \\
2235 \\
2240 \\
2245 \\
2250\end{array}$ & $\begin{array}{l}1.4 \\
1.4 \\
1.4 \\
1.4 \\
1.4\end{array}$ & $\begin{array}{l}0.00 \\
0.00 \\
0.00 \\
0.00 \\
0.00\end{array}$ \\
\hline $\begin{array}{l}1525 \\
1530 \\
1535 \\
1540 \\
1545\end{array}$ & $\begin{array}{l}2.3 \\
2.2 \\
2.2 \\
2.2 \\
2.2\end{array}$ & $\begin{array}{l}0.00 \\
0.00 \\
0.00 \\
0.00 \\
0.00\end{array}$ & $\begin{array}{l}1910 \\
1915 \\
1920 \\
1925 \\
1930\end{array}$ & $\begin{array}{l}1.5 \\
1.5 \\
1.5 \\
1.5 \\
1.5\end{array}$ & $\begin{array}{l}0.00 \\
0.00 \\
0.00 \\
0.00 \\
0.00\end{array}$ & $\begin{array}{l}2255 \\
2300 \\
2305 \\
2310 \\
2315\end{array}$ & $\begin{array}{l}1.4 \\
1.4 \\
1.3 \\
1.3 \\
1.3\end{array}$ & $\begin{array}{l}0.00 \\
0.00 \\
0.00 \\
0.00 \\
0.00\end{array}$ \\
\hline $\begin{array}{l}1550 \\
1555 \\
1600 \\
1605 \\
1610\end{array}$ & $\begin{array}{l}2 \cdot 1 \\
2 \cdot 1 \\
2 \cdot 1 \\
2 \cdot 1 \\
2 \cdot 1\end{array}$ & $\begin{array}{l}0.00 \\
0.00 \\
0.00 \\
0.00 \\
0.00\end{array}$ & $\begin{array}{l}1935 \\
1940 \\
1945 \\
1950 \\
1955\end{array}$ & $\begin{array}{l}1.5 \\
1.5 \\
1.5 \\
1.5 \\
1.5\end{array}$ & $\begin{array}{l}0.00 \\
0.00 \\
0.00 \\
0.00 \\
0.00\end{array}$ & $\begin{array}{l}2320 \\
2325 \\
2330 \\
2335 \\
2340\end{array}$ & $\begin{array}{l}1.3 \\
1.3 \\
1.3 \\
1.3 \\
1.3\end{array}$ & $\begin{array}{l}0.00 \\
0.00 \\
0.00 \\
0.00 \\
0.00\end{array}$ \\
\hline $\begin{array}{l}1615 \\
1620 \\
1625 \\
1630 \\
1635\end{array}$ & $\begin{array}{l}2.0 \\
2.0 \\
2.0 \\
2.0 \\
1.9\end{array}$ & $\begin{array}{l}0.00 \\
0.00 \\
0.00 \\
0.00 \\
0.00\end{array}$ & $\begin{array}{l}2000 \\
2005 \\
2010 \\
2015 \\
2020\end{array}$ & $\begin{array}{l}1.5 \\
1.5 \\
1.5 \\
1.5 \\
1.5\end{array}$ & $\begin{array}{l}0.00 \\
0.00 \\
0.00 \\
0.00 \\
0.00\end{array}$ & $\begin{array}{l}2345 \\
2350 \\
2355 \\
\text { Sept ember } \\
0000\end{array}$ & $\begin{array}{ll} & 1.3 \\
1.3 \\
1.3 \\
123, \\
1989 \\
1.3\end{array}$ & $\begin{array}{l}0.00 \\
0.00 \\
0.00 \\
0.00\end{array}$ \\
\hline
\end{tabular}


Location.-Lat 32 $52^{\prime 2} 0^{\prime \prime}$, long 7959'28", Charleston County, Hydrologic Unit 03050201, at culvert on a Southern Railroad line (State secondary road 39), 0.3 mi east of the intersection of Rivers Avenue (U.S. Highway 52) and Meeting Street (State secondary road 39), and $1.6 \mathrm{mi}$ upstream from the mouth at the Cooper River.

Period of record.-- December 4, 1985 to October 23, 1989.

Gage.--Digital stage recorder with 5-minute punch interval. The recorder is housed in a metal shelter atop a stilling well attached to a free-standing platform on the right bank, approximately $33 \mathrm{ft}$ upstream from the 4 - $\mathrm{ft}$ reinforced concrete pipe culvert under the rail line. An enameled staff gage is attached to the platform. A crest-stage indicator is located near the culvert exit on the right bank.

Rating.--The stage-streamflow relation is defined by current meter measurements up to $1.5 \mathrm{ft}^{3} / \mathrm{s}$. The stage-streamflow relation was extended to $100 \mathrm{ft}^{3} / \mathrm{s}$ using indirect computational methods.

Rain gage and location.-Station 325223079593000 , lat $32^{\circ} 52^{\prime} 23^{\prime \prime}$, long $79^{\circ} 59^{\prime} 30^{\prime \prime}$. A shelter containing a digital cumulative rainfall recorder with a 5-minute punch interval just west of the tennis courts in the park on the north side of Bexley Street (State secondary road 672), $0.3 \mathrm{mi}$ east of the intersection of Rivers Avenue (U.S. Highway 52) and Meeting Street (State secondary road 39), and 1.6 mi upstream from the mouth at the Cooper River.

Selected basin characteristics.--

Drainage area $--0.21 \mathrm{mi}^{2}$

Physiographic province - Lower Coastal Plain

Channel slope -- $54.3 \mathrm{ft} / \mathrm{mi}$

Channel length -- $0.62 \mathrm{mi}$

Total impervious area -- 36.0 percent

Basin development factor -9

2-year, 2-hour rainfall amount -- 2.50 in.

\begin{tabular}{|c|c|c|}
\hline Flood frequency data: & $\mathrm{UQ}_{2}$ & $85 \mathrm{ft}^{3} / \mathrm{s}$ \\
\hline & $\mathrm{UQ}_{5}$ & $136 \mathrm{ft}^{3} / \mathrm{s}$ \\
\hline & $\mathrm{UQ}_{10}$ & $178 \mathrm{ft}^{3} / \mathrm{s}$ \\
\hline & $\mathrm{UQ}_{25}$ & $243 \mathrm{ft}^{3} / \mathrm{s}$ \\
\hline & $\mathrm{UQ}_{50}$ & $300 \mathrm{ft}^{3} / \mathrm{s}$ \\
\hline & $\mathrm{UQ}_{100}$ & $365 \mathrm{ft}^{3} / \mathrm{s}$ \\
\hline & $\mathrm{UQ}_{500}$ & $555 \mathrm{ft}^{3} / \mathrm{s}$ \\
\hline
\end{tabular}



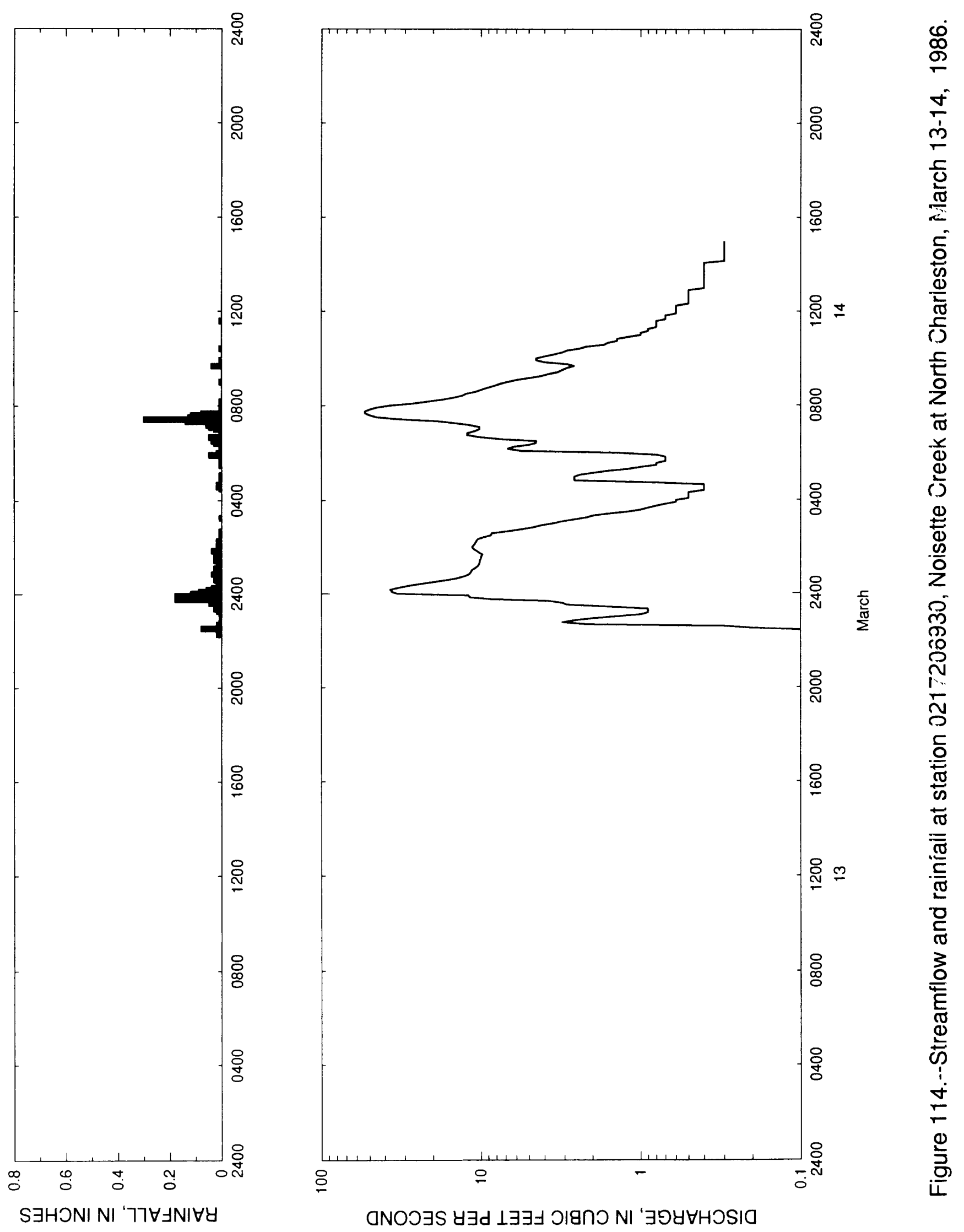
Table 113.--Streamflow and rainfall at station 0217206930, Noisette Creek at North Charleston,

March 13-14,1986

\begin{tabular}{|c|c|c|c|c|c|c|c|c|}
\hline $\begin{array}{l}\text { Time } \\
\text { (hours) }\end{array}$ & $\begin{array}{l}\text { Streamflow } \\
\text { (cubic feet } \\
\text { per second) }\end{array}$ & $\begin{array}{l}\text { Rain- } \\
\text { fall } \\
\text { (inches) }\end{array}$ & $\begin{array}{l}\text { Time } \\
\text { (hours) }\end{array}$ & $\begin{array}{l}\text { Streamflow } \\
\text { (cubic feet } \\
\text { per second) }\end{array}$ & $\begin{array}{l}\text { Rain- } \\
\text { fall } \\
\text { (inches) }\end{array}$ & $\begin{array}{l}\text { Time } \\
\text { (hours) }\end{array}$ & $\begin{array}{l}\text { Streamflow } \\
\text { (cubic feet } \\
\text { per second) }\end{array}$ & $\begin{array}{l}\text { Rain- } \\
\text { fall } \\
\text { (inches) }\end{array}$ \\
\hline $\begin{array}{r}\text { March } 13, \\
2215 \\
2220 \\
2225 \\
2230\end{array}$ & $\begin{array}{r}1986 \\
0.1 \\
0.1 \\
0.1 \\
0.2\end{array}$ & $\begin{array}{l}0.02 \\
0.00 \\
0.01 \\
0.08\end{array}$ & $\begin{array}{l}0330 \\
0335 \\
0340 \\
0345 \\
0350\end{array}$ & $\begin{array}{l}1.2 \\
1.0 \\
0.9 \\
0.8 \\
0.7\end{array}$ & $\begin{array}{l}0.00 \\
0.00 \\
0.00 \\
0.00 \\
0.00\end{array}$ & $\begin{array}{l}0855 \\
0900 \\
0905 \\
0910 \\
0915\end{array}$ & $\begin{array}{l}7.6 \\
6.8 \\
6.0 \\
5.0 \\
4.2\end{array}$ & $\begin{array}{l}0.00 \\
0.01 \\
0.00 \\
0.00 \\
0.00\end{array}$ \\
\hline $\begin{array}{l}2235 \\
2240 \\
2245 \\
2250 \\
2255\end{array}$ & $\begin{array}{l}0.3 \\
2.2 \\
3.1 \\
2.6 \\
2.0\end{array}$ & $\begin{array}{l}0.01 \\
0.02 \\
0.00 \\
0.00 \\
0.01\end{array}$ & $\begin{array}{l}0355 \\
0400 \\
0405 \\
0410 \\
0415\end{array}$ & $\begin{array}{l}0.6 \\
0.6 \\
0.5 \\
0.5 \\
0.5\end{array}$ & $\begin{array}{l}0.00 \\
0.00 \\
0.00 \\
0.00 \\
0.00\end{array}$ & $\begin{array}{l}0920 \\
0925 \\
0930 \\
0935 \\
0940\end{array}$ & $\begin{array}{l}3.8 \\
3.3 \\
3.1 \\
2.9 \\
2.6\end{array}$ & $\begin{array}{l}0.00 \\
0.00 \\
0.00 \\
0.00 \\
0.04\end{array}$ \\
\hline $\begin{array}{l}2300 \\
2305 \\
2310 \\
2315 \\
2320\end{array}$ & $\begin{array}{l}1.4 \\
1.0 \\
0.9 \\
0.9 \\
0.9\end{array}$ & $\begin{array}{l}0.01 \\
0.01 \\
0.01 \\
0.02 \\
0.03\end{array}$ & $\begin{array}{l}0420 \\
0425 \\
0430 \\
0435 \\
0440\end{array}$ & $\begin{array}{l}0.5 \\
0.4 \\
0.4 \\
0.4 \\
0.4\end{array}$ & $\begin{array}{l}0.00 \\
0.00 \\
0.01 \\
0.02 \\
0.02\end{array}$ & $\begin{array}{l}0945 \\
0950 \\
0955 \\
1000 \\
1005\end{array}$ & $\begin{array}{l}2.9 \\
4.0 \\
4.5 \\
4.5 \\
4.0\end{array}$ & $\begin{array}{l}0.00 \\
0.00 \\
0.01 \\
0.00 \\
0.00\end{array}$ \\
\hline $\begin{array}{l}2325 \\
2330 \\
2335 \\
2340 \\
2345\end{array}$ & $\begin{array}{l}1.6 \\
2.9 \\
3.1 \\
3.8 \\
8.7\end{array}$ & $\begin{array}{l}0.02 \\
0.00 \\
0.05 \\
0.04 \\
0.18\end{array}$ & $\begin{array}{l}0445 \\
0450 \\
0455 \\
0500 \\
0505\end{array}$ & $\begin{array}{l}0.8 \\
2.6 \\
2.6 \\
2.6 \\
2.4\end{array}$ & $\begin{array}{l}0.01 \\
0.01 \\
0.00 \\
0.00 \\
0.01\end{array}$ & $\begin{array}{l}1010 \\
1015 \\
1020 \\
1025 \\
1030\end{array}$ & $\begin{array}{l}3.5 \\
3.1 \\
2.9 \\
2.4 \\
2.2\end{array}$ & $\begin{array}{l}0.00 \\
0.00 \\
0.00 \\
0.01 \\
0.00\end{array}$ \\
\hline $\begin{array}{r}2350 \\
2355 \\
\text { March } 14 \\
0000 \\
0005\end{array}$ & $\begin{array}{r}11.8 \\
12.0 \\
1986 \\
33.6 \\
36.4\end{array}$ & $\begin{array}{l}0.14 \\
0.18 \\
0.12 \\
0.09\end{array}$ & $\begin{array}{l}0510 \\
0515 \\
0520 \\
0525 \\
0530\end{array}$ & $\begin{array}{l}2.0 \\
1.6 \\
1.2 \\
1.0 \\
0.8\end{array}$ & $\begin{array}{l}0.00 \\
0.00 \\
0.00 \\
0.00 \\
0.01\end{array}$ & $\begin{array}{l}1035 \\
1040 \\
1045 \\
1050 \\
1055\end{array}$ & $\begin{array}{l}1.7 \\
1.6 \\
1.4 \\
1.4 \\
1.2\end{array}$ & $\begin{array}{l}0.00 \\
0.00 \\
0.00 \\
0.00 \\
0.00\end{array}$ \\
\hline $\begin{array}{l}0010 \\
0015 \\
0020 \\
0025 \\
0030\end{array}$ & $\begin{array}{l}37.1 \\
32.9 \\
28.4 \\
23.6 \\
19.5\end{array}$ & $\begin{array}{l}0.06 \\
0.04 \\
0.02 \\
0.02 \\
0.01\end{array}$ & $\begin{array}{l}0535 \\
0540 \\
0545 \\
0550 \\
0555\end{array}$ & $\begin{array}{l}0.8 \\
0.7 \\
0.7 \\
0.7 \\
0.8\end{array}$ & $\begin{array}{l}0.01 \\
0.00 \\
0.00 \\
0.01 \\
0.05\end{array}$ & $\begin{array}{l}1100 \\
1105 \\
1110 \\
1115 \\
1120\end{array}$ & $\begin{array}{l}1.0 \\
1.0 \\
0.9 \\
0.9 \\
0.8\end{array}$ & $\begin{array}{l}0.00 \\
0.00 \\
0.00 \\
0.00 \\
0.00\end{array}$ \\
\hline $\begin{array}{l}0035 \\
0040 \\
0045 \\
0050 \\
0055\end{array}$ & $\begin{array}{l}16.1 \\
13.9 \\
12.6 \\
11.8 \\
11.6\end{array}$ & $\begin{array}{l}0.03 \\
0.01 \\
0.03 \\
0.04 \\
0.01\end{array}$ & $\begin{array}{l}0600 \\
0605 \\
0610 \\
0615 \\
0620\end{array}$ & $\begin{array}{l}1.4 \\
5.6 \\
6.8 \\
6.3 \\
5.0\end{array}$ & $\begin{array}{l}0.02 \\
0.01 \\
0.01 \\
0.00 \\
0.01\end{array}$ & $\begin{array}{l}1125 \\
1130 \\
1135 \\
1140 \\
1145\end{array}$ & $\begin{array}{l}0.8 \\
0.8 \\
0.8 \\
0.7 \\
0.7\end{array}$ & $\begin{array}{l}0.00 \\
0.00 \\
0.01 \\
0.00 \\
0.00\end{array}$ \\
\hline $\begin{array}{l}0100 \\
0105 \\
0110 \\
0115 \\
0120\end{array}$ & $\begin{array}{l}11.4 \\
10.9 \\
10.5 \\
10.3 \\
10.2\end{array}$ & $\begin{array}{l}0.02 \\
0.03 \\
0.02 \\
0.02 \\
0.01\end{array}$ & $\begin{array}{l}0625 \\
0630 \\
0635 \\
0640 \\
0645\end{array}$ & $\begin{array}{r}4.5 \\
4.5 \\
7.6 \\
10.3 \\
12.2\end{array}$ & $\begin{array}{l}0.03 \\
0.04 \\
0.04 \\
0.05 \\
0.01\end{array}$ & $\begin{array}{l}1150 \\
1155 \\
1200 \\
1205 \\
1210\end{array}$ & $\begin{array}{l}0.7 \\
0.6 \\
0.6 \\
0.6 \\
0.6\end{array}$ & $\begin{array}{l}0.00 \\
0.00 \\
0.00 \\
0.00 \\
0.00\end{array}$ \\
\hline $\begin{array}{l}0125 \\
0130 \\
0135 \\
0140 \\
0145\end{array}$ & $\begin{array}{r}10.2 \\
10.0 \\
10.0 \\
9.8 \\
10.3\end{array}$ & $\begin{array}{l}0.03 \\
0.02 \\
0.02 \\
0.03 \\
0.02\end{array}$ & $\begin{array}{l}0650 \\
0655 \\
0700 \\
0705 \\
0710\end{array}$ & $\begin{array}{l}12.2 \\
10.9 \\
10.2 \\
10.2 \\
11.8\end{array}$ & $\begin{array}{l}0.01 \\
0.01 \\
0.03 \\
0.05 \\
0.06\end{array}$ & $\begin{array}{l}1215 \\
1220 \\
1225 \\
1230 \\
1235\end{array}$ & $\begin{array}{l}0.6 \\
0.5 \\
0.5 \\
0.5 \\
0.5\end{array}$ & $\begin{array}{l}0.00 \\
0.00 \\
0.00 \\
0.00 \\
0.00\end{array}$ \\
\hline $\begin{array}{l}0150 \\
0155 \\
0200 \\
0205 \\
0210\end{array}$ & $\begin{array}{l}10.7 \\
11.2 \\
11.4 \\
11.1 \\
10.9\end{array}$ & $\begin{array}{l}0.04 \\
0.02 \\
0.02 \\
0.02 \\
0.02\end{array}$ & $\begin{array}{l}0715 \\
0720 \\
0725 \\
0730 \\
0735\end{array}$ & $\begin{array}{l}14.6 \\
18.6 \\
32.2 \\
45.2 \\
49.7\end{array}$ & $\begin{array}{l}0.05 \\
0.14 \\
0.30 \\
0.13 \\
0.12\end{array}$ & $\begin{array}{l}1240 \\
1245 \\
1250 \\
1255 \\
1300\end{array}$ & $\begin{array}{l}0.5 \\
0.5 \\
0.5 \\
0.5 \\
0.4\end{array}$ & $\begin{array}{l}0.00 \\
0.00 \\
0.00 \\
0.00 \\
0.00\end{array}$ \\
\hline $\begin{array}{l}0215 \\
0220 \\
0225 \\
0230 \\
0235\end{array}$ & $\begin{array}{r}10.7 \\
10.5 \\
9.6 \\
8.7 \\
8.6\end{array}$ & $\begin{array}{l}0.02 \\
0.01 \\
0.00 \\
0.01 \\
0.00\end{array}$ & $\begin{array}{l}0740 \\
0745 \\
0750 \\
0755 \\
0800\end{array}$ & $\begin{array}{l}53.4 \\
53.4 \\
49.7 \\
45.2 \\
37.4\end{array}$ & $\begin{array}{l}0.08 \\
0.01 \\
0.00 \\
0.01 \\
0.00\end{array}$ & $\begin{array}{l}1305 \\
1310 \\
1315 \\
1320 \\
1325\end{array}$ & $\begin{array}{l}0.4 \\
0.4 \\
0.4 \\
0.4 \\
0.4\end{array}$ & $\begin{array}{l}0.00 \\
0.00 \\
0.00 \\
0.00 \\
0.00\end{array}$ \\
\hline $\begin{array}{l}0240 \\
0245 \\
0250 \\
0255 \\
0300\end{array}$ & $\begin{array}{l}6.8 \\
5.6 \\
4.7 \\
4.2 \\
3.5\end{array}$ & $\begin{array}{l}0.01 \\
0.00 \\
0.00 \\
0.00 \\
0.00\end{array}$ & $\begin{array}{l}0805 \\
0810 \\
0815 \\
0820 \\
0825\end{array}$ & $\begin{array}{l}26.9 \\
21.6 \\
17.4 \\
15.0 \\
13.1\end{array}$ & $\begin{array}{l}0.00 \\
0.01 \\
0.00 \\
0.00 \\
0.00\end{array}$ & $\begin{array}{l}1330 \\
1335 \\
1340 \\
1345 \\
1350\end{array}$ & $\begin{array}{l}0.4 \\
0.4 \\
0.4 \\
0.4 \\
0.4\end{array}$ & $\begin{array}{l}0.00 \\
0.00 \\
0.00 \\
0.00 \\
0.00\end{array}$ \\
\hline $\begin{array}{l}0305 \\
0310 \\
0315 \\
0320 \\
0325\end{array}$ & $\begin{array}{l}3.1 \\
2.6 \\
2.2 \\
2.0 \\
1.6\end{array}$ & $\begin{array}{l}0.00 \\
0.00 \\
0.01 \\
0.00 \\
0.00\end{array}$ & $\begin{array}{l}0830 \\
0835 \\
0840 \\
0845 \\
0850\end{array}$ & $\begin{array}{r}12.4 \\
10.9 \\
10.0 \\
9.2 \\
8.3\end{array}$ & $\begin{array}{l}0.00 \\
0.00 \\
0.00 \\
0.00 \\
0.00\end{array}$ & $\begin{array}{l}1355 \\
1400 \\
1405 \\
1410 \\
1415\end{array}$ & $\begin{array}{l}0.4 \\
0.4 \\
0.4 \\
0.3 \\
0.3\end{array}$ & $\begin{array}{l}0.00 \\
0.00 \\
0.00 \\
0.00 \\
0.00\end{array}$ \\
\hline
\end{tabular}


Table 113,--Streamflow and rainfall at station 0217206930, Noisette Creek at North Charleston, March $13-14,1986-$ Continued

\begin{tabular}{|c|c|c|c|c|c|c|c|c|}
\hline $\begin{array}{l}\text { Time } \\
\text { (hours) }\end{array}$ & $\begin{array}{l}\text { Streamflow } \\
\text { (cubic feet } \\
\text { per second) }\end{array}$ & $\begin{array}{l}\text { Rain- } \\
\text { fall } \\
\text { (inches) }\end{array}$ & $\begin{array}{l}\text { Time } \\
\text { (hours) }\end{array}$ & $\begin{array}{l}\text { Streamflow } \\
\text { (cubic feet } \\
\text { per second) }\end{array}$ & $\begin{array}{l}\text { Rain- } \\
\text { fall } \\
\text { (inches) }\end{array}$ & $\begin{array}{l}\text { Time } \\
\text { (hours) }\end{array}$ & $\begin{array}{l}\text { Streamflow } \\
\text { (cubic feet } \\
\text { per second) }\end{array}$ & $\begin{array}{l}\text { Rain- } \\
\text { fall } \\
\text { (inches) }\end{array}$ \\
\hline $\begin{array}{l}1420 \\
1425 \\
1430 \\
1435\end{array}$ & $\begin{array}{l}0.3 \\
0.3 \\
0.3 \\
0.3\end{array}$ & $\begin{array}{l}0.00 \\
0.00 \\
0.00 \\
0.00\end{array}$ & $\begin{array}{l}1440 \\
1445 \\
1450 \\
1455\end{array}$ & $\begin{array}{l}0.3 \\
0.3 \\
0.3 \\
0.3\end{array}$ & $\begin{array}{l}0.00 \\
0.00 \\
0.00 \\
0.00\end{array}$ & 1500 & 0.3 & 0.00 \\
\hline
\end{tabular}




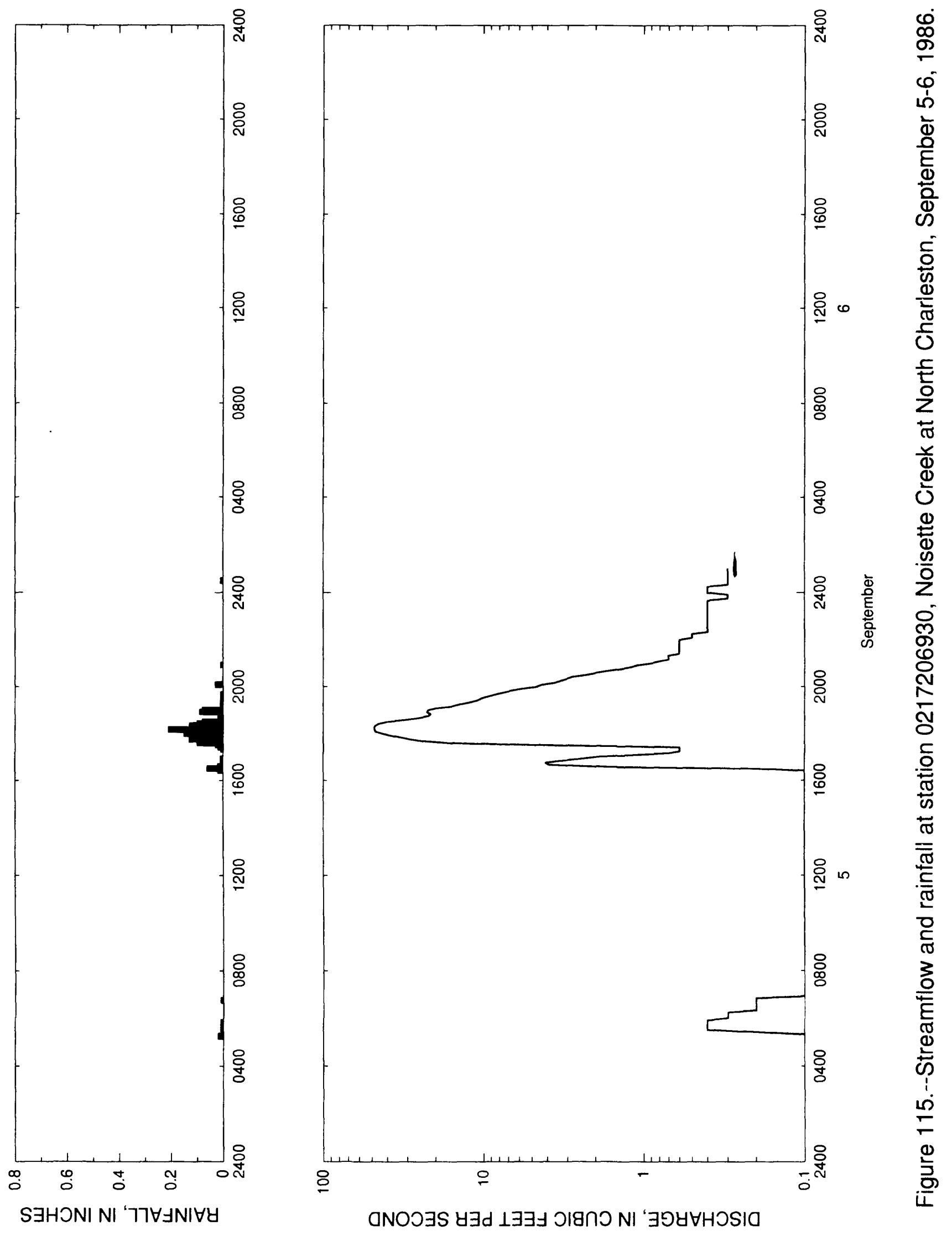


Table 114.--Streamflow and rainfall at station 0217206930, Noisette Creek at North Charleston, September $5-6,1986$

\begin{tabular}{|c|c|c|c|c|c|c|c|c|}
\hline $\begin{array}{l}\text { Time } \\
\text { (hours) }\end{array}$ & $\begin{array}{l}\text { Streamflow } \\
\text { (cubic feet } \\
\text { per second) }\end{array}$ & $\begin{array}{l}\text { Rain- } \\
\text { fall } \\
\text { (inches) }\end{array}$ & $\begin{array}{l}\text { Time } \\
\text { (hours) }\end{array}$ & $\begin{array}{l}\text { Streamflow } \\
\text { (cubic feet } \\
\text { per second) }\end{array}$ & $\begin{array}{l}\text { Rain- } \\
\text { fall } \\
\text { (inches) }\end{array}$ & $\begin{array}{l}\text { Time } \\
\text { (hours) }\end{array}$ & $\begin{array}{l}\text { Streamflow } \\
\text { (cubic feet } \\
\text { per second) }\end{array}$ & $\begin{array}{l}\text { Rain- } \\
\text { fall } \\
\text { (inches) }\end{array}$ \\
\hline $\begin{array}{l}\text { September } \\
0515 \\
0520 \\
0525 \\
0530\end{array}$ & $\begin{array}{r}5,1986 \\
0.1 \\
0.1 \\
0.2 \\
0.4\end{array}$ & $\begin{array}{l}0.02 \\
0.01 \\
0.00 \\
0.01\end{array}$ & $\begin{array}{l}1035 \\
1040 \\
1045 \\
1050 \\
1055\end{array}$ & $\begin{array}{l}0.1 \\
0.1 \\
0.1 \\
0.1 \\
0.1\end{array}$ & $\begin{array}{l}0.00 \\
0.00 \\
0.00 \\
0.00 \\
0.00\end{array}$ & $\begin{array}{l}1600 \\
1605 \\
1610 \\
1615 \\
1620\end{array}$ & $\begin{array}{l}0.1 \\
0.1 \\
0.1 \\
0.1 \\
0.1\end{array}$ & $\begin{array}{l}0.00 \\
0.00 \\
0.00 \\
0.00 \\
0.00\end{array}$ \\
\hline $\begin{array}{l}0535 \\
0540 \\
0545 \\
0550 \\
0555\end{array}$ & $\begin{array}{l}0.4 \\
0.4 \\
0.4 \\
0.4 \\
0.4\end{array}$ & $\begin{array}{l}0.00 \\
0.01 \\
0.00 \\
0.01 \\
0.00\end{array}$ & $\begin{array}{l}1100 \\
1105 \\
1110 \\
1115 \\
1120\end{array}$ & $\begin{array}{l}0.1 \\
0.1 \\
0.1 \\
0.1 \\
0.1\end{array}$ & $\begin{array}{l}0.00 \\
0.00 \\
0.00 \\
0.00 \\
0.00\end{array}$ & $\begin{array}{l}1625 \\
1630 \\
1635 \\
1640 \\
1645\end{array}$ & $\begin{array}{l}0.1 \\
0.2 \\
1.7 \\
3.9 \\
4.1\end{array}$ & $\begin{array}{l}0.02 \\
0.06 \\
0.02 \\
0.01 \\
0.01\end{array}$ \\
\hline $\begin{array}{l}0600 \\
0605 \\
0610 \\
0615 \\
0620\end{array}$ & $\begin{array}{l}0.3 \\
0.3 \\
0.3 \\
0.3 \\
0.2\end{array}$ & $\begin{array}{l}0.00 \\
0.00 \\
0.00 \\
0.00 \\
0.00\end{array}$ & $\begin{array}{l}1125 \\
1130 \\
1135 \\
1140 \\
1145\end{array}$ & $\begin{array}{l}0.1 \\
0.1 \\
0.1 \\
0.1 \\
0.1\end{array}$ & $\begin{array}{l}0.00 \\
0.00 \\
0.00 \\
0.00 \\
0.00\end{array}$ & $\begin{array}{l}1650 \\
1655 \\
1700 \\
1705 \\
1710\end{array}$ & $\begin{array}{l}3.3 \\
2.5 \\
2.0 \\
1.2 \\
0.7\end{array}$ & $\begin{array}{l}0.00 \\
0.01 \\
0.00 \\
0.00 \\
0.00\end{array}$ \\
\hline $\begin{array}{l}0625 \\
0630 \\
0635 \\
0640 \\
0645\end{array}$ & $\begin{array}{l}0.2 \\
0.2 \\
0.2 \\
0.2 \\
0.2\end{array}$ & $\begin{array}{l}0.00 \\
0.00 \\
0.00 \\
0.00 \\
0.01\end{array}$ & $\begin{array}{l}1150 \\
1155 \\
1200 \\
1205 \\
1210\end{array}$ & $\begin{array}{l}0.1 \\
0.1 \\
0.1 \\
0.1 \\
0.1\end{array}$ & $\begin{array}{l}0.00 \\
0.00 \\
0.00 \\
0.00 \\
0.00\end{array}$ & $\begin{array}{l}1715 \\
1720 \\
1725 \\
1730 \\
1735\end{array}$ & $\begin{array}{r}0.6 \\
0.6 \\
0.6 \\
4.1 \\
15.8\end{array}$ & $\begin{array}{l}0.00 \\
0.01 \\
0.02 \\
0.03 \\
0.10\end{array}$ \\
\hline $\begin{array}{l}0650 \\
0655 \\
0700 \\
0705 \\
0710\end{array}$ & $\begin{array}{l}0.2 \\
0.1 \\
0.1 \\
0.1 \\
0.1\end{array}$ & $\begin{array}{l}0.00 \\
0.00 \\
0.00 \\
0.00 \\
0.00\end{array}$ & $\begin{array}{l}1215 \\
1220 \\
1225 \\
1230 \\
1235\end{array}$ & $\begin{array}{l}0.1 \\
0.1 \\
0.1 \\
0.1 \\
0.1\end{array}$ & $\begin{array}{l}0.00 \\
0.00 \\
0.00 \\
0.00 \\
0.00\end{array}$ & $\begin{array}{l}1740 \\
1745 \\
1750 \\
1755 \\
1800\end{array}$ & $\begin{array}{l}23.6 \\
28.6 \\
32.6 \\
37.9 \\
42.7\end{array}$ & $\begin{array}{l}0.09 \\
0.13 \\
0.13 \\
0.12 \\
0.15\end{array}$ \\
\hline $\begin{array}{l}0715 \\
0720 \\
0725 \\
0730 \\
0735\end{array}$ & $\begin{array}{l}0.1 \\
0.1 \\
0.1 \\
0.1 \\
0.1\end{array}$ & $\begin{array}{l}0.00 \\
0.00 \\
0.00 \\
0.00 \\
0.00\end{array}$ & $\begin{array}{l}1240 \\
1245 \\
1250 \\
1255 \\
1300\end{array}$ & $\begin{array}{l}0.1 \\
0.1 \\
0.1 \\
0.1 \\
0.1\end{array}$ & $\begin{array}{l}0.00 \\
0.00 \\
0.00 \\
0.00 \\
0.00\end{array}$ & $\begin{array}{l}1805 \\
1810 \\
1815 \\
1820 \\
1825\end{array}$ & $\begin{array}{l}47.4 \\
48.0 \\
48.3 \\
47.7 \\
45.5\end{array}$ & $\begin{array}{l}0.14 \\
0.21 \\
0.11 \\
0.13 \\
0.10\end{array}$ \\
\hline $\begin{array}{l}0740 \\
0745 \\
0750 \\
0755 \\
0800\end{array}$ & $\begin{array}{l}0.1 \\
0.1 \\
0.1 \\
0.1 \\
0.1\end{array}$ & $\begin{array}{l}0.00 \\
0.00 \\
0.00 \\
0.00 \\
0.00\end{array}$ & $\begin{array}{l}1305 \\
1310 \\
1315 \\
1320 \\
1325\end{array}$ & $\begin{array}{l}0.1 \\
0.1 \\
0.1 \\
0.1 \\
0.1\end{array}$ & $\begin{array}{l}0.00 \\
0.00 \\
0.00 \\
0.00 \\
0.00\end{array}$ & $\begin{array}{l}1830 \\
1835 \\
1840 \\
1845 \\
1850\end{array}$ & $\begin{array}{l}40.5 \\
31.2 \\
25.8 \\
22.2 \\
21.4\end{array}$ & $\begin{array}{l}0.08 \\
0.02 \\
0.02 \\
0.01 \\
0.01\end{array}$ \\
\hline $\begin{array}{l}0805 \\
0810 \\
0815 \\
0820 \\
0825\end{array}$ & $\begin{array}{l}0.1 \\
0.1 \\
0.1 \\
0.1 \\
0.1\end{array}$ & $\begin{array}{l}0.00 \\
0.00 \\
0.00 \\
0.00 \\
0.00\end{array}$ & $\begin{array}{l}1330 \\
1335 \\
1340 \\
1345 \\
1350\end{array}$ & $\begin{array}{l}0.1 \\
0.1 \\
0.1 \\
0.1 \\
0.1\end{array}$ & $\begin{array}{l}0.00 \\
0.00 \\
0.00 \\
0.00 \\
0.00\end{array}$ & $\begin{array}{l}1855 \\
1900 \\
1905 \\
1910 \\
1915\end{array}$ & $\begin{array}{l}22.6 \\
22.2 \\
19.8 \\
15.7 \\
14.2\end{array}$ & $\begin{array}{l}0.09 \\
0.08 \\
0.01 \\
0.00 \\
0.01\end{array}$ \\
\hline $\begin{array}{l}0830 \\
0835 \\
0840 \\
0845 \\
0850\end{array}$ & $\begin{array}{l}0.1 \\
0.1 \\
0.1 \\
0.1 \\
0.1\end{array}$ & $\begin{array}{l}0.00 \\
0.00 \\
0.00 \\
0.00 \\
0.00\end{array}$ & $\begin{array}{l}1355 \\
1400 \\
1405 \\
1410 \\
1415\end{array}$ & $\begin{array}{l}0.1 \\
0.1 \\
0.1 \\
0.1 \\
0.1\end{array}$ & $\begin{array}{l}0.00 \\
0.00 \\
0.00 \\
0.00 \\
0.00\end{array}$ & $\begin{array}{l}1920 \\
1925 \\
1930 \\
1935 \\
1940\end{array}$ & $\begin{array}{r}12.4 \\
11.1 \\
10.3 \\
9.4 \\
8.5\end{array}$ & $\begin{array}{l}0.00 \\
0.01 \\
0.01 \\
0.01 \\
0.01\end{array}$ \\
\hline $\begin{array}{l}0855 \\
0900 \\
0905 \\
0910 \\
0915\end{array}$ & $\begin{array}{l}0.1 \\
0.1 \\
0.1 \\
0.1 \\
0.1\end{array}$ & $\begin{array}{l}0.00 \\
0.00 \\
0.00 \\
0.00 \\
0.00\end{array}$ & $\begin{array}{l}1420 \\
1425 \\
1430 \\
1435 \\
1440\end{array}$ & $\begin{array}{l}0.1 \\
0.1 \\
0.1 \\
0.1 \\
0.1\end{array}$ & $\begin{array}{l}0.00 \\
0.00 \\
0.00 \\
0.00 \\
0.00\end{array}$ & $\begin{array}{l}1945 \\
1950 \\
1955 \\
2000 \\
2005\end{array}$ & $\begin{array}{l}7.6 \\
6.7 \\
5.8 \\
4.7 \\
4.3\end{array}$ & $\begin{array}{l}0.00 \\
0.00 \\
0.00 \\
0.00 \\
0.03\end{array}$ \\
\hline $\begin{array}{l}0920 \\
0925 \\
0930 \\
0935 \\
0940\end{array}$ & $\begin{array}{l}0.1 \\
0.1 \\
0.1 \\
0.1 \\
0.1\end{array}$ & $\begin{array}{l}0.00 \\
0.00 \\
0.00 \\
0.00 \\
0.00\end{array}$ & $\begin{array}{l}1445 \\
1450 \\
1455 \\
1500 \\
1505\end{array}$ & $\begin{array}{l}0.1 \\
0.1 \\
0.1 \\
0.1 \\
0.1\end{array}$ & $\begin{array}{l}0.00 \\
0.00 \\
0.00 \\
0.00 \\
0.00\end{array}$ & $\begin{array}{l}2010 \\
2015 \\
2020 \\
2025 \\
2030\end{array}$ & $\begin{array}{l}3.6 \\
3.3 \\
3.0 \\
2.8 \\
2.3\end{array}$ & $\begin{array}{l}0.00 \\
0.00 \\
0.00 \\
0.00 \\
0.00\end{array}$ \\
\hline $\begin{array}{l}0945 \\
0950 \\
0955 \\
1000 \\
1005\end{array}$ & $\begin{array}{l}0.1 \\
0.1 \\
0.1 \\
0.1 \\
5.1\end{array}$ & $\begin{array}{l}0.00 \\
0.00 \\
0.00 \\
0.00 \\
0.00\end{array}$ & $\begin{array}{l}1510 \\
1515 \\
1520 \\
1525 \\
1530\end{array}$ & $\begin{array}{l}0.1 \\
0.1 \\
0.1 \\
0.1 \\
0.1\end{array}$ & $\begin{array}{l}0.00 \\
0.00 \\
0.00 \\
0.00 \\
0.00\end{array}$ & $\begin{array}{l}2035 \\
2040 \\
2045 \\
2050 \\
2055\end{array}$ & $\begin{array}{l}2.0 \\
1.7 \\
1.4 \\
1.2 \\
1.1\end{array}$ & $\begin{array}{l}0.00 \\
0.00 \\
0.00 \\
0.00 \\
0.01\end{array}$ \\
\hline $\begin{array}{l}1010 \\
1015 \\
1020 \\
1025 \\
1030\end{array}$ & $\begin{array}{l}0.1 \\
0.1 \\
0.1 \\
0.1 \\
0.1\end{array}$ & $\begin{array}{l}0.00 \\
0.00 \\
0.00 \\
0.00 \\
0.00\end{array}$ & $\begin{array}{l}1535 \\
1540 \\
1545 \\
1550 \\
1555\end{array}$ & $\begin{array}{l}0.1 \\
0.1 \\
0.1 \\
0.1 \\
0.1\end{array}$ & $\begin{array}{l}0.00 \\
0.00 \\
0.00 \\
0.00 \\
0.00\end{array}$ & $\begin{array}{l}2100 \\
2105 \\
2110 \\
2115 \\
2120\end{array}$ & $\begin{array}{l}0.9 \\
0.8 \\
0.7 \\
0.7 \\
0.7\end{array}$ & $\begin{array}{l}0.00 \\
0.00 \\
0.00 \\
0.00 \\
0.00\end{array}$ \\
\hline
\end{tabular}


Table 114. - -Streamflow and rainfall at station 0217206930, Noisette Craek at North Charleston, Sept ember 5-6,1986--Continued

\begin{tabular}{|c|c|c|c|c|c|c|c|c|c|}
\hline $\begin{array}{l}\text { Time } \\
\text { (hours) }\end{array}$ & $\begin{array}{l}\text { Streamflow } \\
\text { (cubic feet } \\
\text { per second) }\end{array}$ & $\begin{array}{l}\text { Rain- } \\
\text { fall } \\
\text { (inches) }\end{array}$ & $\begin{array}{l}\text { Time } \\
\text { (hours) }\end{array}$ & $\begin{array}{l}\text { Str } \\
\text { (cub } \\
\text { per }\end{array}$ & $\begin{array}{l}\text { reamflow } \\
\text { oic feet } \\
\text { second) }\end{array}$ & $\begin{array}{l}\text { Rain- } \\
\text { fall } \\
\text { (inches) }\end{array}$ & $\begin{array}{l}\text { Time } \\
\text { (hours) }\end{array}$ & $\begin{array}{l}\text { Streamflow } \\
\text { (cubic feet } \\
\text { per second) }\end{array}$ & $\begin{array}{l}\text { Rain- } \\
\text { fall } \\
\text { (inches) }\end{array}$ \\
\hline $\begin{array}{l}2125 \\
2130 \\
2135 \\
2140 \\
2145\end{array}$ & $\begin{array}{l}0.6 \\
0.6 \\
0.6 \\
0.6 \\
0.6\end{array}$ & $\begin{array}{l}0.00 \\
0.00 \\
0.00 \\
0.00 \\
0.00\end{array}$ & $\begin{array}{l}2245 \\
2250 \\
2255 \\
2300 \\
2305\end{array}$ & & $\begin{array}{l}0.4 \\
0.4 \\
0.4 \\
0.4 \\
0.4\end{array}$ & $\begin{array}{l}0.00 \\
0.00 \\
0.00 \\
0.00 \\
0.00\end{array}$ & $\begin{array}{l}0000 \\
0005 \\
0010 \\
0015 \\
0020\end{array}$ & $\begin{array}{l}0.4 \\
0.4 \\
0.4 \\
0.4 \\
0.3\end{array}$ & $\begin{array}{l}0.00 \\
0.00 \\
0.00 \\
0.00 \\
0.00\end{array}$ \\
\hline $\begin{array}{l}2150 \\
2155 \\
2200 \\
2205 \\
2210\end{array}$ & $\begin{array}{l}0.6 \\
0.6 \\
0.6 \\
0.5 \\
0.5\end{array}$ & $\begin{array}{l}0.00 \\
0.00 \\
0.00 \\
0.00 \\
0.00\end{array}$ & $\begin{array}{l}2310 \\
2315 \\
2320 \\
2325 \\
2330\end{array}$ & & $\begin{array}{l}0.4 \\
0.4 \\
0.4 \\
0.4 \\
0.4\end{array}$ & $\begin{array}{l}0.00 \\
0.00 \\
0.00 \\
0.00 \\
0.00\end{array}$ & $\begin{array}{l}0025 \\
0030 \\
0035 \\
0040 \\
0045\end{array}$ & $\begin{array}{l}0.3 \\
0.3 \\
0.3 \\
0.3 \\
0.3\end{array}$ & $\begin{array}{l}0.00 \\
0.01 \\
0.00 \\
0.00 \\
0.00\end{array}$ \\
\hline $\begin{array}{l}2215 \\
2220 \\
2225 \\
2230 \\
2235\end{array}$ & $\begin{array}{l}0.5 \\
0.4 \\
0.4 \\
0.4 \\
0.4\end{array}$ & $\begin{array}{l}0.00 \\
0.00 \\
0.00 \\
0.00 \\
0.00\end{array}$ & $\begin{array}{l}2335 \\
2340 \\
2345 \\
2350 \\
2355\end{array}$ & & $\begin{array}{l}0.4 \\
0.4 \\
0.3 \\
0.3 \\
0.3\end{array}$ & $\begin{array}{l}0.00 \\
0.00 \\
0.00 \\
0.00 \\
0.00\end{array}$ & $\begin{array}{l}0050 \\
0055 \\
0100\end{array}$ & $\begin{array}{l}0.3 \\
0.3 \\
0.3\end{array}$ & $\begin{array}{l}0.00 \\
0.00 \\
0.00\end{array}$ \\
\hline 2240 & 0.4 & 0.00 & Septembe & r 6 , & 1986 & & & & \\
\hline
\end{tabular}




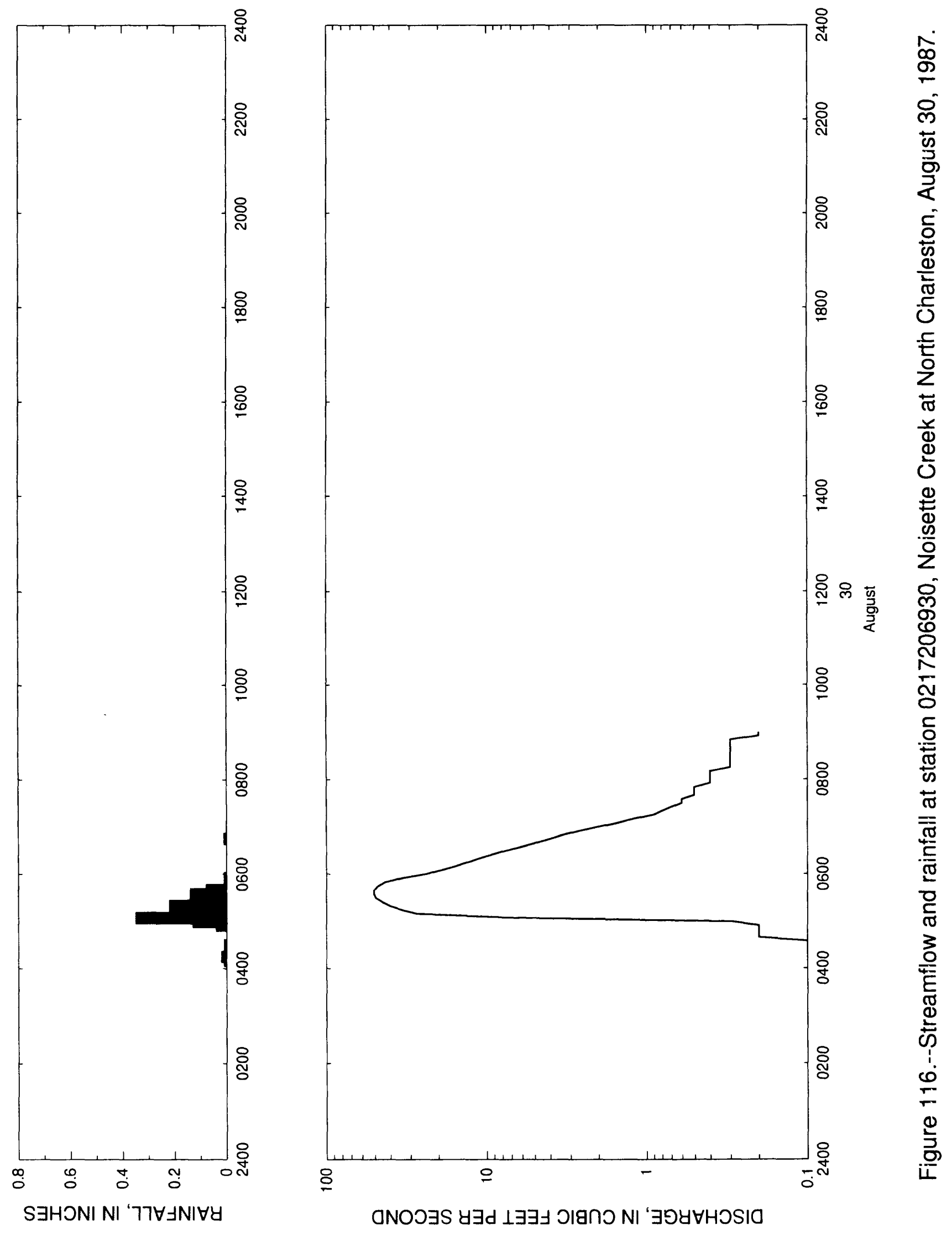


Table 115. --Streamflow and rainfall at station 0217206930, Noisette Craek at North Charleston, August 30,1987

\begin{tabular}{|c|c|c|c|c|c|c|c|c|}
\hline $\begin{array}{l}\text { Time } \\
\text { (hours) }\end{array}$ & $\begin{array}{l}\text { Streamflow } \\
\text { (cubic feet } \\
\text { per second) }\end{array}$ & $\begin{array}{l}\text { Rain- } \\
\text { fall } \\
\text { (inches) }\end{array}$ & $\begin{array}{l}\text { Time } \\
\text { (hours) }\end{array}$ & $\begin{array}{l}\text { Streamflow } \\
\text { (cubic feet } \\
\text { per second) }\end{array}$ & $\begin{array}{l}\text { Rain- } \\
\text { fall } \\
\text { (inches) }\end{array}$ & $\begin{array}{l}\text { Time } \\
\text { (hours) }\end{array}$ & $\begin{array}{l}\text { Streamflow } \\
\text { (cubic feet } \\
\text { per second) }\end{array}$ & $\begin{array}{l}\text { Rain- } \\
\text { fall } \\
\text { (inches) }\end{array}$ \\
\hline $\begin{array}{l}\text { August } \\
0410 \\
0415 \\
0420 \\
0425\end{array}$ & $\begin{array}{r}30,1987 \\
0.1 \\
0.1 \\
0.1 \\
0.1\end{array}$ & $\begin{array}{l}0.01 \\
0.02 \\
0.01 \\
0.00\end{array}$ & $\begin{array}{l}0545 \\
0550 \\
0555 \\
0600 \\
0605\end{array}$ & $\begin{array}{l}48.0 \\
43.2 \\
33.9 \\
23.9 \\
19.3\end{array}$ & $\begin{array}{l}0.01 \\
0.00 \\
0.01 \\
0.00 \\
0.00\end{array}$ & $\begin{array}{l}0725 \\
0730 \\
0735 \\
0740 \\
0745\end{array}$ & $\begin{array}{l}0.7 \\
0.6 \\
0.6 \\
0.5 \\
0.5\end{array}$ & $\begin{array}{l}0.00 \\
0.00 \\
0.00 \\
0.00 \\
0.00\end{array}$ \\
\hline $\begin{array}{l}0430 \\
0435 \\
0440 \\
0445 \\
0450\end{array}$ & $\begin{array}{l}0.1 \\
0.1 \\
0.2 \\
0.2 \\
0.2\end{array}$ & $\begin{array}{l}0.01 \\
0.00 \\
0.00 \\
0.00 \\
0.00\end{array}$ & $\begin{array}{l}0610 \\
0615 \\
0620 \\
0625 \\
0630\end{array}$ & $\begin{array}{r}15.6 \\
13.1 \\
11.1 \\
9.2 \\
7.6\end{array}$ & $\begin{array}{l}0.00 \\
0.00 \\
0.00 \\
0.00 \\
0.00\end{array}$ & $\begin{array}{l}0750 \\
0755 \\
0800 \\
0805 \\
0810\end{array}$ & $\begin{array}{l}0.5 \\
0.4 \\
0.4 \\
0.4 \\
0.4\end{array}$ & $\begin{array}{l}0.00 \\
0.00 \\
0.00 \\
0.00 \\
0.00\end{array}$ \\
\hline $\begin{array}{l}0455 \\
0500 \\
0505 \\
0510 \\
0515\end{array}$ & $\begin{array}{r}0.2 \\
0.3 \\
7.6 \\
27.5 \\
34.1\end{array}$ & $\begin{array}{l}0.04 \\
0.13 \\
0.35 \\
0.17 \\
0.17\end{array}$ & $\begin{array}{l}0635 \\
0640 \\
0645 \\
0650 \\
0655\end{array}$ & $\begin{array}{l}6.0 \\
4.9 \\
4.0 \\
3.3 \\
2.6\end{array}$ & $\begin{array}{l}0.00 \\
0.00 \\
0.01 \\
0.00 \\
0.00\end{array}$ & $\begin{array}{l}0815 \\
0820 \\
0825 \\
0830 \\
0835\end{array}$ & $\begin{array}{l}0.3 \\
0.3 \\
0.3 \\
0.3 \\
0.3\end{array}$ & $\begin{array}{l}0.00 \\
0.00 \\
0.00 \\
0.00 \\
0.00\end{array}$ \\
\hline $\begin{array}{l}0520 \\
0525 \\
0530 \\
0535 \\
0540\end{array}$ & $\begin{array}{l}40.3 \\
44.9 \\
49.4 \\
50.6 \\
50.6\end{array}$ & $\begin{array}{l}0.22 \\
0.13 \\
0.12 \\
0.14 \\
0.08\end{array}$ & $\begin{array}{l}0700 \\
0705 \\
0710 \\
0715 \\
0720\end{array}$ & $\begin{array}{l}2.0 \\
1.5 \\
1.2 \\
0.9 \\
0.8\end{array}$ & $\begin{array}{l}0.00 \\
0.00 \\
0.00 \\
0.00 \\
0.00\end{array}$ & $\begin{array}{l}0840 \\
0845 \\
0850 \\
0855 \\
0900\end{array}$ & $\begin{array}{l}0.3 \\
0.3 \\
0.3 \\
0.2 \\
0.2\end{array}$ & $\begin{array}{l}0.00 \\
0.00 \\
0.00 \\
0.00 \\
0.00\end{array}$ \\
\hline
\end{tabular}




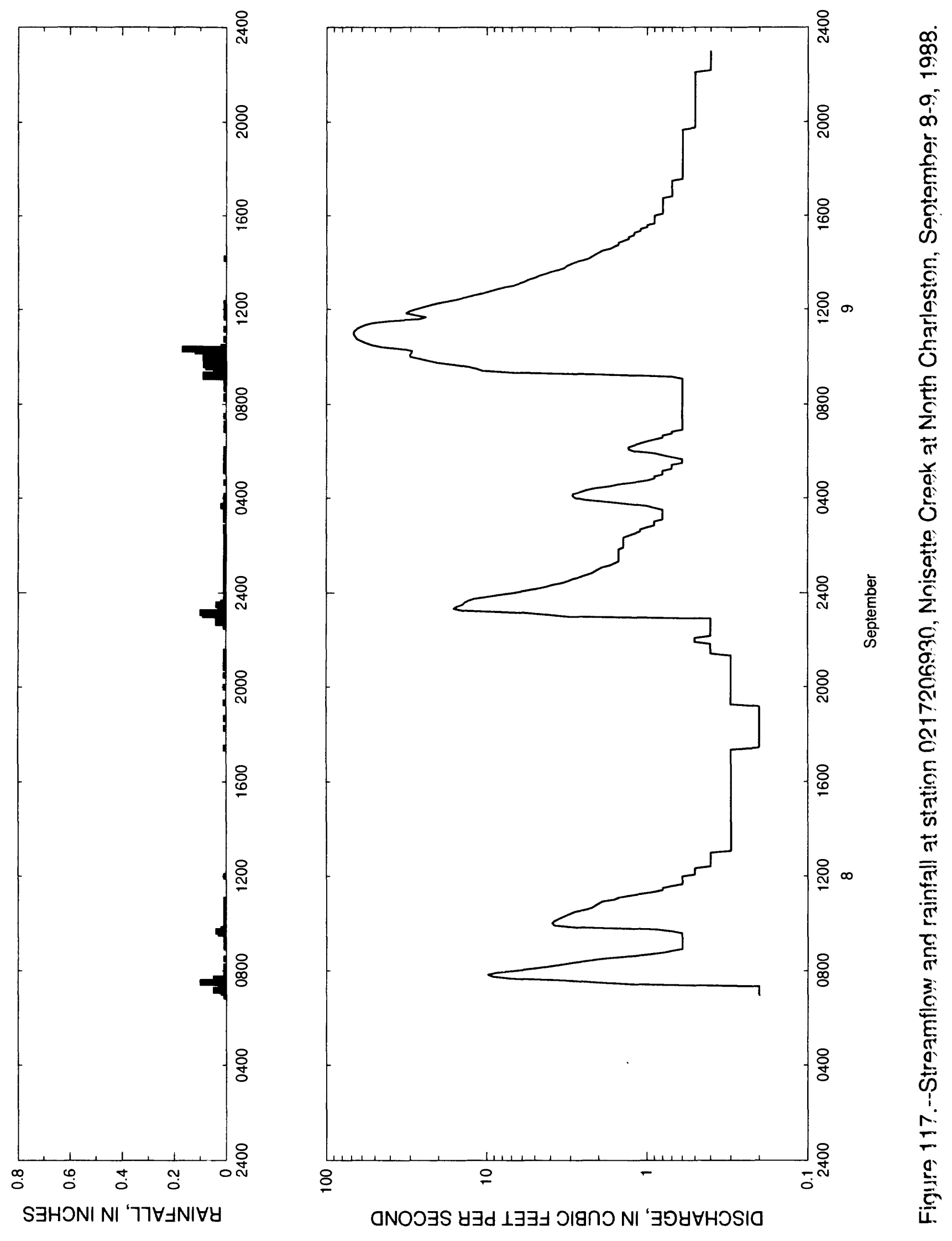


Table 116. - Streamflow and rainfall at station 0217206930, Noisette Creek at North Charleston, September $8-9,1988$

\begin{tabular}{|c|c|c|c|c|c|c|c|c|}
\hline $\begin{array}{l}\text { Time } \\
\text { (hours) }\end{array}$ & $\begin{array}{l}\text { Streamflow } \\
\text { (cubic feet } \\
\text { per second) }\end{array}$ & $\begin{array}{l}\text { Rain- } \\
\text { fall } \\
\text { (inches) }\end{array}$ & $\begin{array}{l}\text { Time } \\
\text { (hours) }\end{array}$ & $\begin{array}{l}\text { Streamflow } \\
\text { (cubic feet } \\
\text { per second) }\end{array}$ & $\begin{array}{l}\text { Rain- } \\
\text { fall } \\
\text { (inches) }\end{array}$ & $\begin{array}{l}\text { Time } \\
\text { (hours) }\end{array}$ & $\begin{array}{l}\text { Streamflow } \\
\text { (cubic feet } \\
\text { per second) }\end{array}$ & $\begin{array}{l}\text { Rain- } \\
\text { fall } \\
\text { (inches) }\end{array}$ \\
\hline $\begin{array}{l}\text { September } \\
0655 \\
0700 \\
0705 \\
0710\end{array}$ & $\begin{aligned} & 08, 1988 \\
& 0.2 \\
& 0.2 \\
& 0.2 \\
& 0.2\end{aligned}$ & $\begin{array}{l}0.01 \\
0.01 \\
0.02 \\
0.05\end{array}$ & $\begin{array}{l}1215 \\
1220 \\
1225 \\
1230 \\
1235\end{array}$ & $\begin{array}{l}0.5 \\
0.5 \\
0.4 \\
0.4 \\
0.4\end{array}$ & $\begin{array}{l}0.00 \\
0.00 \\
0.00 \\
0.00 \\
0.00\end{array}$ & $\begin{array}{l}1740 \\
1745 \\
1750 \\
1755 \\
1800\end{array}$ & $\begin{array}{l}0.2 \\
0.2 \\
0.2 \\
0.2 \\
0.2\end{array}$ & $\begin{array}{l}0.00 \\
0.00 \\
0.00 \\
0.00 \\
0.00\end{array}$ \\
\hline $\begin{array}{l}0715 \\
0720 \\
0725 \\
0730 \\
0735\end{array}$ & $\begin{array}{l}0.2 \\
0.2 \\
1.2 \\
2.1 \\
3.2\end{array}$ & $\begin{array}{l}0.03 \\
0.01 \\
0.03 \\
0.10 \\
0.03\end{array}$ & $\begin{array}{l}1240 \\
1245 \\
1250 \\
1255 \\
1300\end{array}$ & $\begin{array}{l}0.4 \\
0.4 \\
0.4 \\
0.4 \\
0.4\end{array}$ & $\begin{array}{l}0.00 \\
0.00 \\
0.00 \\
0.00 \\
0.00\end{array}$ & $\begin{array}{l}1805 \\
1810 \\
1815 \\
1820 \\
1825\end{array}$ & $\begin{array}{l}0.2 \\
0.2 \\
0.2 \\
0.2 \\
0.2\end{array}$ & $\begin{array}{l}0.00 \\
0.00 \\
0.01 \\
0.00 \\
0.00\end{array}$ \\
\hline $\begin{array}{l}0740 \\
0745 \\
0750 \\
0755 \\
0800\end{array}$ & $\begin{array}{l}7.0 \\
9.2 \\
9.8 \\
8.7 \\
6.7\end{array}$ & $\begin{array}{l}0.05 \\
0.01 \\
0.01 \\
0.01 \\
0.01\end{array}$ & $\begin{array}{l}1305 \\
1310 \\
1315 \\
1320 \\
1325\end{array}$ & $\begin{array}{l}0.3 \\
0.3 \\
0.3 \\
0.3 \\
0.3\end{array}$ & $\begin{array}{l}0.00 \\
0.00 \\
0.00 \\
0.00 \\
0.00\end{array}$ & $\begin{array}{l}1830 \\
1835 \\
1840 \\
1845 \\
1850\end{array}$ & $\begin{array}{l}0.2 \\
0.2 \\
0.2 \\
0.2 \\
0.2\end{array}$ & $\begin{array}{l}0.00 \\
0.00 \\
0.01 \\
0.00 \\
0.00\end{array}$ \\
\hline $\begin{array}{l}0805 \\
0810 \\
0815 \\
0820 \\
0825\end{array}$ & $\begin{array}{l}5.2 \\
4.1 \\
3.4 \\
2.9 \\
2.3\end{array}$ & $\begin{array}{l}0.01 \\
0.01 \\
0.00 \\
0.00 \\
0.00\end{array}$ & $\begin{array}{l}1330 \\
1335 \\
1340 \\
1345 \\
1350\end{array}$ & $\begin{array}{l}0.3 \\
0.3 \\
0.3 \\
0.3 \\
0.3\end{array}$ & $\begin{array}{l}0.00 \\
0.00 \\
0.00 \\
0.00 \\
0.00\end{array}$ & $\begin{array}{l}1855 \\
1900 \\
1905 \\
1910 \\
1915\end{array}$ & $\begin{array}{l}0.2 \\
0.2 \\
0.2 \\
0.2 \\
0.3\end{array}$ & $\begin{array}{l}0.00 \\
0.00 \\
0.00 \\
0.00 \\
0.00\end{array}$ \\
\hline $\begin{array}{l}0830 \\
0835 \\
0840 \\
0845 \\
0850\end{array}$ & $\begin{array}{l}1.9 \\
1.4 \\
1.0 \\
0.8 \\
0.7\end{array}$ & $\begin{array}{l}0.01 \\
0.00 \\
0.00 \\
0.00 \\
0.00\end{array}$ & $\begin{array}{l}1355 \\
1400 \\
1405 \\
1410 \\
1415\end{array}$ & $\begin{array}{l}0.3 \\
0.3 \\
0.3 \\
0.3 \\
0.3\end{array}$ & $\begin{array}{l}0.00 \\
0.00 \\
0.00 \\
0.00 \\
0.00\end{array}$ & $\begin{array}{l}1920 \\
1925 \\
1930 \\
1935 \\
1940\end{array}$ & $\begin{array}{l}0.3 \\
0.3 \\
0.3 \\
0.3 \\
0.3\end{array}$ & $\begin{array}{l}0.01 \\
0.00 \\
0.00 \\
0.00 \\
0.00\end{array}$ \\
\hline $\begin{array}{l}0855 \\
0900 \\
0905 \\
0910 \\
0915\end{array}$ & $\begin{array}{l}0.6 \\
0.6 \\
0.6 \\
0.6 \\
0.6\end{array}$ & $\begin{array}{l}0.00 \\
0.01 \\
0.00 \\
0.01 \\
0.01\end{array}$ & $\begin{array}{l}1420 \\
1425 \\
1430 \\
1435 \\
1440\end{array}$ & $\begin{array}{l}0.3 \\
0.3 \\
0.3 \\
0.3 \\
0.3\end{array}$ & $\begin{array}{l}0.00 \\
0.00 \\
0.00 \\
0.00 \\
0.00\end{array}$ & $\begin{array}{l}1945 \\
1950 \\
1955 \\
2000 \\
2005\end{array}$ & $\begin{array}{l}0.3 \\
0.3 \\
0.3 \\
0.3 \\
0.3\end{array}$ & $\begin{array}{l}0.00 \\
0.00 \\
0.00 \\
0.01 \\
0.00\end{array}$ \\
\hline $\begin{array}{l}0920 \\
0925 \\
0930 \\
0935 \\
0940\end{array}$ & $\begin{array}{l}0.6 \\
0.6 \\
0.6 \\
0.6 \\
0.7\end{array}$ & $\begin{array}{l}0.01 \\
0.00 \\
0.00 \\
0.03 \\
0.04\end{array}$ & $\begin{array}{l}1445 \\
1450 \\
1455 \\
1500 \\
1505\end{array}$ & $\begin{array}{l}0.3 \\
0.3 \\
0.3 \\
0.3 \\
0.3\end{array}$ & $\begin{array}{l}0.00 \\
0.00 \\
0.00 \\
0.00 \\
0.00\end{array}$ & $\begin{array}{l}2010 \\
2015 \\
2020 \\
2025 \\
2030\end{array}$ & $\begin{array}{l}0.3 \\
0.3 \\
0.3 \\
0.3 \\
0.3\end{array}$ & $\begin{array}{l}0.00 \\
0.00 \\
0.00 \\
0.00 \\
0.01\end{array}$ \\
\hline $\begin{array}{l}0945 \\
0950 \\
0955 \\
1000 \\
1005\end{array}$ & $\begin{array}{l}0.9 \\
2.8 \\
3.8 \\
3.9 \\
3.8\end{array}$ & $\begin{array}{l}0.02 \\
0.01 \\
0.01 \\
0.01 \\
0.01\end{array}$ & $\begin{array}{l}1510 \\
1515 \\
1520 \\
1525 \\
1530\end{array}$ & $\begin{array}{l}0.3 \\
0.3 \\
0.3 \\
0.3 \\
0.3\end{array}$ & $\begin{array}{l}0.00 \\
0.00 \\
0.00 \\
0.00 \\
0.00\end{array}$ & $\begin{array}{l}2035 \\
2040 \\
2045 \\
2050 \\
2055\end{array}$ & $\begin{array}{l}0.3 \\
0.3 \\
0.3 \\
0.3 \\
0.3\end{array}$ & $\begin{array}{l}0.00 \\
0.00 \\
0.00 \\
0.01 \\
0.01\end{array}$ \\
\hline $\begin{array}{l}1010 \\
1015 \\
1020 \\
1025 \\
1030\end{array}$ & $\begin{array}{l}3.6 \\
3.4 \\
3.2 \\
3.0 \\
2.8\end{array}$ & $\begin{array}{l}0.01 \\
0.01 \\
0.01 \\
0.00 \\
0.01\end{array}$ & $\begin{array}{l}1535 \\
1540 \\
1545 \\
1550 \\
1555\end{array}$ & $\begin{array}{l}0.3 \\
0.3 \\
0.3 \\
0.3 \\
0.3\end{array}$ & $\begin{array}{l}0.00 \\
0.00 \\
0.00 \\
0.00 \\
0.00\end{array}$ & $\begin{array}{l}2100 \\
2105 \\
2110 \\
2115 \\
2120\end{array}$ & $\begin{array}{l}0.3 \\
0.3 \\
0.3 \\
0.3 \\
0.3\end{array}$ & $\begin{array}{l}0.00 \\
0.01 \\
0.00 \\
0.01 \\
0.00\end{array}$ \\
\hline $\begin{array}{l}1035 \\
1040 \\
1045 \\
1050 \\
1055\end{array}$ & $\begin{array}{l}2.4 \\
2.2 \\
2.1 \\
2.0 \\
1.9\end{array}$ & $\begin{array}{l}0.00 \\
0.01 \\
0.01 \\
0.01 \\
0.00\end{array}$ & $\begin{array}{l}1600 \\
1605 \\
1610 \\
1615 \\
1620\end{array}$ & $\begin{array}{l}0.3 \\
0.3 \\
0.3 \\
0.3 \\
0.3\end{array}$ & $\begin{array}{l}0.00 \\
0.00 \\
0.00 \\
0.00 \\
0.00\end{array}$ & $\begin{array}{l}2125 \\
2130 \\
2135 \\
2140 \\
2145\end{array}$ & $\begin{array}{l}0.4 \\
0.4 \\
0.4 \\
0.4 \\
0.4\end{array}$ & $\begin{array}{l}0.00 \\
0.01 \\
0.00 \\
0.00 \\
0.00\end{array}$ \\
\hline $\begin{array}{l}1100 \\
1105 \\
1110 \\
1115 \\
1120\end{array}$ & $\begin{array}{l}1.6 \\
1.5 \\
1.3 \\
1.1 \\
0.9\end{array}$ & $\begin{array}{l}0.01 \\
0.00 \\
0.00 \\
0.00 \\
0.00\end{array}$ & $\begin{array}{l}1625 \\
1630 \\
1635 \\
1640 \\
1645\end{array}$ & $\begin{array}{l}0.3 \\
0.3 \\
0.3 \\
0.3 \\
0.3\end{array}$ & $\begin{array}{l}0.00 \\
0.00 \\
0.00 \\
0.00 \\
0.00\end{array}$ & $\begin{array}{l}2150 \\
2155 \\
2200 \\
2205 \\
2210\end{array}$ & $\begin{array}{l}0.4 \\
0.5 \\
0.5 \\
0.5 \\
0.4\end{array}$ & $\begin{array}{l}0.00 \\
0.00 \\
0.00 \\
0.00 \\
0.00\end{array}$ \\
\hline $\begin{array}{l}1125 \\
1130 \\
1135 \\
1140 \\
1145\end{array}$ & $\begin{array}{l}0.8 \\
0.8 \\
0.7 \\
0.6 \\
0.6\end{array}$ & $\begin{array}{l}0.00 \\
0.00 \\
0.00 \\
0.00 \\
0.00\end{array}$ & $\begin{array}{l}1650 \\
1655 \\
1700 \\
1705 \\
1710\end{array}$ & $\begin{array}{l}0.3 \\
0.3 \\
0.3 \\
0.3 \\
0.3\end{array}$ & $\begin{array}{l}0.00 \\
0.00 \\
0.00 \\
0.00 \\
0.00\end{array}$ & $\begin{array}{l}2215 \\
2220 \\
2225 \\
2230 \\
2235\end{array}$ & $\begin{array}{l}0.4 \\
0.4 \\
0.4 \\
0.4 \\
0.4\end{array}$ & $\begin{array}{l}0.00 \\
0.00 \\
0.00 \\
0.00 \\
0.01\end{array}$ \\
\hline $\begin{array}{l}1150 \\
1155 \\
1200 \\
1205 \\
1210\end{array}$ & $\begin{array}{l}0.6 \\
0.6 \\
0.6 \\
0.5 \\
0.5\end{array}$ & $\begin{array}{l}0.00 \\
0.00 \\
0.01 \\
0.00 \\
0.00\end{array}$ & $\begin{array}{l}1715 \\
1720 \\
1725 \\
1730 \\
1735\end{array}$ & $\begin{array}{l}0.3 \\
0.3 \\
0.2 \\
0.2 \\
0.2\end{array}$ & $\begin{array}{l}0.00 \\
0.00 \\
0.01 \\
0.00 \\
0.00\end{array}$ & $\begin{array}{l}2240 \\
2245 \\
2250 \\
2255 \\
2300\end{array}$ & $\begin{array}{l}0.4 \\
0.4 \\
0.4 \\
0.4 \\
3.1\end{array}$ & $\begin{array}{l}0.01 \\
0.04 \\
0.04 \\
0.02 \\
0.02\end{array}$ \\
\hline
\end{tabular}


Table 116. - Streamflow and rainfall at station 0217206930, Noisette Creek at North Charleston, September $8-9,1988^{--C o n t i n u e d}$

\begin{tabular}{|c|c|c|c|c|c|c|c|c|}
\hline $\begin{array}{l}\text { Time } \\
\text { (hours) }\end{array}$ & $\begin{array}{l}\text { Streamflow } \\
\text { (cubic feet } \\
\text { per second) }\end{array}$ & $\begin{array}{l}\text { Rain- } \\
\text { fall } \\
\text { (inches) }\end{array}$ & $\begin{array}{l}\text { Time } \\
\text { (hours) }\end{array}$ & $\begin{array}{l}\text { Streamflow } \\
\text { (cubic feet } \\
\text { per second) }\end{array}$ & $\begin{array}{l}\text { Rain- } \\
\text { fall } \\
\text { (inches) }\end{array}$ & $\begin{array}{l}\text { Time } \\
\text { (hours) }\end{array}$ & $\begin{array}{l}\text { Streamflow } \\
\text { (cubic feet } \\
\text { per second) }\end{array}$ & $\begin{array}{l}\text { Rain- } \\
\text { fall } \\
\text { (inches) }\end{array}$ \\
\hline $\begin{array}{l}2305 \\
2310 \\
2315 \\
2320 \\
2325\end{array}$ & $\begin{array}{r}4.2 \\
6.0 \\
13.9 \\
16.1 \\
15.4\end{array}$ & $\begin{array}{l}0.09 \\
0.10 \\
0.02 \\
0.02 \\
0.03\end{array}$ & $\begin{array}{l}0425 \\
0430 \\
0435 \\
0440 \\
0445\end{array}$ & $\begin{array}{l}2.1 \\
1.7 \\
1.5 \\
1.2 \\
1.0\end{array}$ & $\begin{array}{l}0.00 \\
0.00 \\
0.00 \\
0.01 \\
0.00\end{array}$ & $\begin{array}{l}0950 \\
0955 \\
1000 \\
1005 \\
1010\end{array}$ & $\begin{array}{l}23.2 \\
26.2 \\
30.0 \\
30.2 \\
29.5\end{array}$ & $\begin{array}{l}0.19 \\
0.19 \\
0.15 \\
0.15 \\
0.19\end{array}$ \\
\hline $\begin{array}{l}2330 \\
2335 \\
2340 \\
2345 \\
2350\end{array}$ & $\begin{array}{l}14.2 \\
13.7 \\
13.0 \\
12.0 \\
10.0\end{array}$ & $\begin{array}{l}0.04 \\
0.02 \\
0.01 \\
0.01 \\
0.00\end{array}$ & $\begin{array}{l}0450 \\
0455 \\
0500 \\
0505 \\
0510\end{array}$ & $\begin{array}{l}0.9 \\
0.9 \\
0.8 \\
0.8 \\
0.8\end{array}$ & $\begin{array}{l}0.00 \\
0.00 \\
0.00 \\
0.00 \\
0.01\end{array}$ & $\begin{array}{l}1015 \\
1020 \\
1025 \\
1030 \\
1035\end{array}$ & $\begin{array}{l}29.3 \\
33.6 \\
45.2 \\
52.2 \\
56.8\end{array}$ & $\begin{array}{l}0.12 \\
0.17 \\
0.02 \\
0.00 \\
0.10\end{array}$ \\
\hline $\begin{array}{l}2355 \\
0000 \\
0005 \\
0010\end{array}$ & $\begin{array}{l}8.3 \\
\text { September } \\
6.8 \\
5.8 \\
4.9\end{array}$ & $\begin{array}{l}0.01 \\
09,1988 \\
0.00 \\
0.01 \\
0.00\end{array}$ & $\begin{array}{l}0515 \\
0520 \\
0525 \\
0530 \\
0535\end{array}$ & $\begin{array}{l}0.7 \\
0.7 \\
0.7 \\
0.6 \\
0.6\end{array}$ & $\begin{array}{l}0.00 \\
0.00 \\
0.01 \\
0.00 \\
0.01\end{array}$ & $\begin{array}{l}1040 \\
1045 \\
1050 \\
1055 \\
1100\end{array}$ & $\begin{array}{l}61.0 \\
64.9 \\
66.1 \\
67.4 \\
68.0\end{array}$ & $\begin{array}{l}0 . C 0 \\
0 . C 1 \\
0 . C 0 \\
0 . C 0 \\
0 . C 0\end{array}$ \\
\hline $\begin{array}{l}0015 \\
0020 \\
0025 \\
0030 \\
0035\end{array}$ & $\begin{array}{l}4.3 \\
3.9 \\
3.4 \\
3.1 \\
2.9\end{array}$ & $\begin{array}{l}0.01 \\
0.00 \\
0.01 \\
0.00 \\
0.00\end{array}$ & $\begin{array}{l}0540 \\
0545 \\
0550 \\
0555 \\
0600\end{array}$ & $\begin{array}{l}0.6 \\
0.7 \\
0.8 \\
0.9 \\
1.2\end{array}$ & $\begin{array}{l}0.01 \\
0.01 \\
0.01 \\
0.00 \\
0.00\end{array}$ & $\begin{array}{l}1105 \\
1110 \\
1115 \\
1120 \\
1125\end{array}$ & $\begin{array}{l}66.8 \\
64.9 \\
61.6 \\
57.4 \\
51.7\end{array}$ & $\begin{array}{l}0 . C 0 \\
0 . C 1 \\
0 . C 0 \\
0 . C 0 \\
0 . C 0\end{array}$ \\
\hline $\begin{array}{l}0040 \\
0045 \\
0050 \\
0055 \\
0100\end{array}$ & $\begin{array}{l}2.6 \\
2.4 \\
2.2 \\
2.1 \\
2.0\end{array}$ & $\begin{array}{l}0.01 \\
0.00 \\
0.01 \\
0.00 \\
0.00\end{array}$ & $\begin{array}{l}0605 \\
0610 \\
0615 \\
0620 \\
0625\end{array}$ & $\begin{array}{l}1.3 \\
1.3 \\
1.2 \\
1.1 \\
1.0\end{array}$ & $\begin{array}{l}0.01 \\
0.00 \\
0.00 \\
0.00 \\
0.00\end{array}$ & $\begin{array}{l}1130 \\
1135 \\
1140 \\
1145 \\
1150\end{array}$ & $\begin{array}{l}40.9 \\
26.4 \\
24.1 \\
28.0 \\
31.9\end{array}$ & $\begin{array}{l}0 . C 0 \\
0 . C 0 \\
0 . C 1 \\
0 . C 0 \\
0 . C 1\end{array}$ \\
\hline $\begin{array}{l}0105 \\
0110 \\
0115 \\
0120 \\
0125\end{array}$ & $\begin{array}{l}1.9 \\
1.7 \\
1.6 \\
1.5 \\
1.5\end{array}$ & $\begin{array}{l}0.01 \\
0.00 \\
0.01 \\
0.00 \\
0.01\end{array}$ & $\begin{array}{l}0630 \\
0635 \\
0640 \\
0645 \\
0650\end{array}$ & $\begin{array}{l}0.9 \\
0.8 \\
0.8 \\
0.7 \\
0.7\end{array}$ & $\begin{array}{l}0.00 \\
0.00 \\
0.00 \\
0.00 \\
0.00\end{array}$ & $\begin{array}{l}1155 \\
1200 \\
1205 \\
1210 \\
1215\end{array}$ & $\begin{array}{l}30.5 \\
27.7 \\
25.1 \\
22.6 \\
20.2\end{array}$ & $\begin{array}{l}0.00 \\
0 . C 1 \\
0.00 \\
0.00 \\
0.01\end{array}$ \\
\hline $\begin{array}{l}0130 \\
0135 \\
0140 \\
0145 \\
0150\end{array}$ & $\begin{array}{l}1.5 \\
1.5 \\
1.5 \\
1.5 \\
1.5\end{array}$ & $\begin{array}{l}0.00 \\
0.01 \\
0.01 \\
0.00 \\
0.01\end{array}$ & $\begin{array}{l}0655 \\
0700 \\
0705 \\
0710 \\
0715\end{array}$ & $\begin{array}{l}0.6 \\
0.6 \\
0.6 \\
0.6 \\
0.6\end{array}$ & $\begin{array}{l}0.01 \\
0.00 \\
0.00 \\
0.01 \\
0.00\end{array}$ & $\begin{array}{l}1220 \\
1225 \\
1230 \\
1235 \\
1240\end{array}$ & $\begin{array}{l}17.4 \\
15.2 \\
13.3 \\
12.0 \\
10.5\end{array}$ & $\begin{array}{l}0.00 \\
0.00 \\
0.00 \\
0.00 \\
0.00\end{array}$ \\
\hline $\begin{array}{l}0155 \\
0200 \\
0205 \\
0210 \\
0215\end{array}$ & $\begin{array}{l}1.4 \\
1.4 \\
1.4 \\
1.4 \\
1.4\end{array}$ & $\begin{array}{l}0.00 \\
0.01 \\
0.00 \\
0.00 \\
0.01\end{array}$ & $\begin{array}{l}0720 \\
0725 \\
0730 \\
0735 \\
0740\end{array}$ & $\begin{array}{l}0.6 \\
0.6 \\
0.6 \\
0.6 \\
0.6\end{array}$ & $\begin{array}{l}0.00 \\
0.00 \\
0.01 \\
0.00 \\
0.00\end{array}$ & $\begin{array}{l}1245 \\
1250 \\
1255 \\
1300 \\
1305\end{array}$ & $\begin{array}{l}9.6 \\
8.7 \\
7.8 \\
6.8 \\
6.3\end{array}$ & $\begin{array}{l}0.00 \\
0.00 \\
0.00 \\
0.00 \\
0.00\end{array}$ \\
\hline $\begin{array}{l}0220 \\
0225 \\
0230 \\
0235 \\
0240\end{array}$ & $\begin{array}{l}1.4 \\
1.3 \\
1.2 \\
1.1 \\
1.1\end{array}$ & $\begin{array}{l}0.00 \\
0.00 \\
0.01 \\
0.00 \\
0.00\end{array}$ & $\begin{array}{l}0745 \\
0750 \\
0755 \\
0800 \\
0805\end{array}$ & $\begin{array}{l}0.6 \\
0.6 \\
0.6 \\
0.6 \\
0.6\end{array}$ & $\begin{array}{l}0.00 \\
0.00 \\
0.00 \\
0.00 \\
0.00\end{array}$ & $\begin{array}{l}1310 \\
1315 \\
1320 \\
1325 \\
1330\end{array}$ & $\begin{array}{l}5.8 \\
5.5 \\
5.0 \\
4.7 \\
4.3\end{array}$ & $\begin{array}{l}0.00 \\
0.00 \\
0.00 \\
0.00 \\
0.00\end{array}$ \\
\hline $\begin{array}{l}0245 \\
0250 \\
0255 \\
0300 \\
0305\end{array}$ & $\begin{array}{l}1.0 \\
0.9 \\
0.9 \\
0.9 \\
0.8\end{array}$ & $\begin{array}{l}0.01 \\
0.00 \\
0.00 \\
0.00 \\
0.01\end{array}$ & $\begin{array}{l}0810 \\
0815 \\
0820 \\
0825 \\
0830\end{array}$ & $\begin{array}{l}0.6 \\
0.6 \\
0.6 \\
0.6 \\
0.6\end{array}$ & $\begin{array}{l}0.00 \\
0.01 \\
0.01 \\
0.00 \\
0.00\end{array}$ & $\begin{array}{l}1335 \\
1340 \\
1345 \\
1350 \\
1355\end{array}$ & $\begin{array}{l}4.0 \\
3.6 \\
3.3 \\
3.2 \\
3.0\end{array}$ & $\begin{array}{l}0.00 \\
0.00 \\
0.00 \\
0.00 \\
0.00\end{array}$ \\
\hline $\begin{array}{l}0310 \\
0315 \\
0320 \\
0325 \\
0330\end{array}$ & $\begin{array}{l}0.8 \\
0.8 \\
0.8 \\
0.8 \\
0.8\end{array}$ & $\begin{array}{l}0.00 \\
0.01 \\
0.00 \\
0.01 \\
0.01\end{array}$ & $\begin{array}{l}0835 \\
0840 \\
0845 \\
0850 \\
0855\end{array}$ & $\begin{array}{l}0.6 \\
0.6 \\
0.6 \\
0.6 \\
0.6\end{array}$ & $\begin{array}{l}0.00 \\
0.01 \\
0.00 \\
0.00 \\
0.01\end{array}$ & $\begin{array}{l}1400 \\
1405 \\
1410 \\
1415 \\
1420\end{array}$ & $\begin{array}{l}2.8 \\
2.5 \\
2.3 \\
2.2 \\
2.1\end{array}$ & $\begin{array}{l}0.00 \\
0.00 \\
0.01 \\
0.00 \\
0.00\end{array}$ \\
\hline $\begin{array}{l}0335 \\
0340 \\
0345 \\
0350 \\
0355\end{array}$ & $\begin{array}{l}0.9 \\
1.0 \\
1.3 \\
1.7 \\
2.4\end{array}$ & $\begin{array}{l}0.00 \\
0.02 \\
0.01 \\
0.01 \\
0.01\end{array}$ & $\begin{array}{l}0900 \\
0905 \\
0910 \\
0915 \\
0920\end{array}$ & $\begin{array}{l}0.6 \\
0.6 \\
0.7 \\
1.7 \\
6.7\end{array}$ & $\begin{array}{l}0.01 \\
0.01 \\
0.09 \\
0.09 \\
0.02\end{array}$ & $\begin{array}{l}1425 \\
1430 \\
1435 \\
1440 \\
1445\end{array}$ & $\begin{array}{l}2.0 \\
1.9 \\
1.7 \\
1.6 \\
1.5\end{array}$ & $\begin{array}{l}0.00 \\
0.00 \\
0.00 \\
0.00 \\
0.00\end{array}$ \\
\hline $\begin{array}{l}3400 \\
0405 \\
0410 \\
3415 \\
0420\end{array}$ & $\begin{array}{l}2.8 \\
2.9 \\
2.9 \\
2.6 \\
2.4\end{array}$ & $\begin{array}{l}0.01 \\
0.01 \\
0.00 \\
0.00 \\
0.00\end{array}$ & $\begin{array}{l}0925 \\
0930 \\
0935 \\
0940 \\
0945\end{array}$ & $\begin{array}{l}10.7 \\
11.6 \\
13.1 \\
15.8 \\
20.4\end{array}$ & $\begin{array}{l}0.03 \\
0.05 \\
0.08 \\
0.09 \\
0.06\end{array}$ & $\begin{array}{l}1450 \\
1455 \\
1500 \\
1505 \\
1510\end{array}$ & $\begin{array}{l}1.5 \\
1.4 \\
1.3 \\
1.3 \\
1.2\end{array}$ & $\begin{array}{l}0.00 \\
0.00 \\
0.00 \\
0.00 \\
0.00\end{array}$ \\
\hline
\end{tabular}


Table 116.--Streamflow and rainfall at station 0217206930, Noisette Creak at North Charleston, September 8-9,1988--Cont inued

\begin{tabular}{|c|c|c|c|c|c|c|c|c|}
\hline $\begin{array}{l}\text { Time } \\
\text { (hours) }\end{array}$ & $\begin{array}{l}\text { Streamflow } \\
\text { (cubic feet } \\
\text { per second) }\end{array}$ & $\begin{array}{l}\text { Rain- } \\
\text { fall } \\
\text { (inches) }\end{array}$ & $\begin{array}{l}\text { Time } \\
\text { (hours) }\end{array}$ & $\begin{array}{l}\text { Streamflow } \\
\text { (cubic feet } \\
\text { per second) }\end{array}$ & $\begin{array}{l}\text { Rain- } \\
\text { fall } \\
\text { (inches) }\end{array}$ & $\begin{array}{l}\text { Time } \\
\text { (hours) }\end{array}$ & $\begin{array}{l}\text { Streamflow } \\
\text { (cubic feet } \\
\text { per second) }\end{array}$ & $\begin{array}{l}\text { Rain- } \\
\text { fal1 } \\
\text { (inches) }\end{array}$ \\
\hline $\begin{array}{l}1515 \\
1520 \\
1525 \\
1530 \\
1535\end{array}$ & $\begin{array}{l}1.2 \\
1.1 \\
1.1 \\
1.0 \\
1.0\end{array}$ & $\begin{array}{l}0.00 \\
0.00 \\
0.00 \\
0.00 \\
0.00\end{array}$ & $\begin{array}{l}1755 \\
1800 \\
1805 \\
1810 \\
1815\end{array}$ & $\begin{array}{l}0.6 \\
0.6 \\
0.6 \\
0.6 \\
0.6\end{array}$ & $\begin{array}{l}0.00 \\
0.00 \\
0.00 \\
0.00 \\
0.00\end{array}$ & $\begin{array}{l}2035 \\
2040 \\
2045 \\
2050 \\
2055\end{array}$ & $\begin{array}{l}0.5 \\
0.5 \\
0.5 \\
0.5 \\
0.5\end{array}$ & $\begin{array}{l}0.00 \\
0.00 \\
0.00 \\
0.00 \\
0.00\end{array}$ \\
\hline $\begin{array}{l}1540 \\
1545 \\
1550 \\
1555 \\
1600\end{array}$ & $\begin{array}{l}0.9 \\
0.9 \\
0.9 \\
0.9 \\
0.9\end{array}$ & $\begin{array}{l}0.00 \\
0.00 \\
0.00 \\
0.00 \\
0.00\end{array}$ & $\begin{array}{l}1820 \\
1825 \\
1830 \\
1835 \\
1840\end{array}$ & $\begin{array}{l}0.6 \\
0.6 \\
0.6 \\
0.6 \\
0.6\end{array}$ & $\begin{array}{l}0.00 \\
0.00 \\
0.00 \\
0.00 \\
0.00\end{array}$ & $\begin{array}{l}2100 \\
2105 \\
2110 \\
2115 \\
2120\end{array}$ & $\begin{array}{l}0.5 \\
0.5 \\
0.5 \\
0.5 \\
0.5\end{array}$ & $\begin{array}{l}0.00 \\
0.00 \\
0.00 \\
0.00 \\
0.00\end{array}$ \\
\hline $\begin{array}{l}1605 \\
1610 \\
1615 \\
1620 \\
1625\end{array}$ & $\begin{array}{l}0.8 \\
0.8 \\
0.8 \\
0.8 \\
0.8\end{array}$ & $\begin{array}{l}0.00 \\
0.00 \\
0.00 \\
0.00 \\
0.00\end{array}$ & $\begin{array}{l}1845 \\
1850 \\
1855 \\
1900 \\
1905\end{array}$ & $\begin{array}{l}0.6 \\
0.6 \\
0.6 \\
0.6 \\
0.6\end{array}$ & $\begin{array}{l}0.00 \\
0.00 \\
0.00 \\
0.00 \\
0.00\end{array}$ & $\begin{array}{l}2125 \\
2130 \\
2135 \\
2140 \\
2145\end{array}$ & $\begin{array}{l}0.5 \\
0.5 \\
0.5 \\
0.5 \\
0.5\end{array}$ & $\begin{array}{l}0.00 \\
0.00 \\
0.00 \\
0.00 \\
0.00\end{array}$ \\
\hline $\begin{array}{l}1630 \\
1635 \\
1640 \\
1645 \\
1650\end{array}$ & $\begin{array}{l}0.8 \\
0.8 \\
0.8 \\
0.8 \\
0.7\end{array}$ & $\begin{array}{l}0.00 \\
0.00 \\
0.00 \\
0.00 \\
0.00\end{array}$ & $\begin{array}{l}1910 \\
1915 \\
1920 \\
1925 \\
1930\end{array}$ & $\begin{array}{l}0.6 \\
0.6 \\
0.6 \\
0.6 \\
0.6\end{array}$ & $\begin{array}{l}0.00 \\
0.00 \\
0.00 \\
0.00 \\
0.00\end{array}$ & $\begin{array}{l}2150 \\
2155 \\
2200 \\
2205 \\
2210\end{array}$ & $\begin{array}{l}0.5 \\
0.5 \\
0.5 \\
0.5 \\
0.4\end{array}$ & $\begin{array}{l}0.00 \\
0.00 \\
0.00 \\
0.00 \\
0.00\end{array}$ \\
\hline $\begin{array}{l}1655 \\
1700 \\
1705 \\
1710 \\
1715\end{array}$ & $\begin{array}{l}0.7 \\
0.7 \\
0.7 \\
0.7 \\
0.7\end{array}$ & $\begin{array}{l}0.00 \\
0.00 \\
0.00 \\
0.00 \\
0.00\end{array}$ & $\begin{array}{l}1935 \\
1940 \\
1945 \\
1950 \\
1955\end{array}$ & $\begin{array}{l}0.6 \\
0.6 \\
0.5 \\
0.5 \\
0.5\end{array}$ & $\begin{array}{l}0.00 \\
0.00 \\
0.00 \\
0.00 \\
0.00\end{array}$ & $\begin{array}{l}2215 \\
2220 \\
2225 \\
2230 \\
2235\end{array}$ & $\begin{array}{l}0.4 \\
0.4 \\
0.4 \\
0.4 \\
0.4\end{array}$ & $\begin{array}{l}0.00 \\
0.00 \\
0.00 \\
0.00 \\
0.00\end{array}$ \\
\hline $\begin{array}{l}1720 \\
1725 \\
1730 \\
1735 \\
1740\end{array}$ & $\begin{array}{l}0.7 \\
0.7 \\
0.7 \\
0.6 \\
0.6\end{array}$ & $\begin{array}{l}0.00 \\
0.00 \\
0.00 \\
0.00 \\
0.00\end{array}$ & $\begin{array}{l}2000 \\
2005 \\
2010 \\
2015 \\
2020\end{array}$ & $\begin{array}{l}0.5 \\
0.5 \\
0.5 \\
0.5 \\
0.5\end{array}$ & $\begin{array}{l}0.00 \\
0.00 \\
0.00 \\
0.00 \\
0.00\end{array}$ & $\begin{array}{l}2240 \\
2245 \\
2250 \\
2255 \\
2300\end{array}$ & $\begin{array}{l}0.4 \\
0.4 \\
0.4 \\
0.4 \\
0.4\end{array}$ & $\begin{array}{l}0.00 \\
0.00 \\
0.00 \\
0.00 \\
0.00\end{array}$ \\
\hline $\begin{array}{l}1745 \\
1750\end{array}$ & $\begin{array}{l}0.6 \\
0.6\end{array}$ & $\begin{array}{l}0.00 \\
0.00\end{array}$ & $\begin{array}{l}2025 \\
2030\end{array}$ & $\begin{array}{l}0.5 \\
0.5\end{array}$ & $\begin{array}{l}0.00 \\
0.00\end{array}$ & & & \\
\hline
\end{tabular}




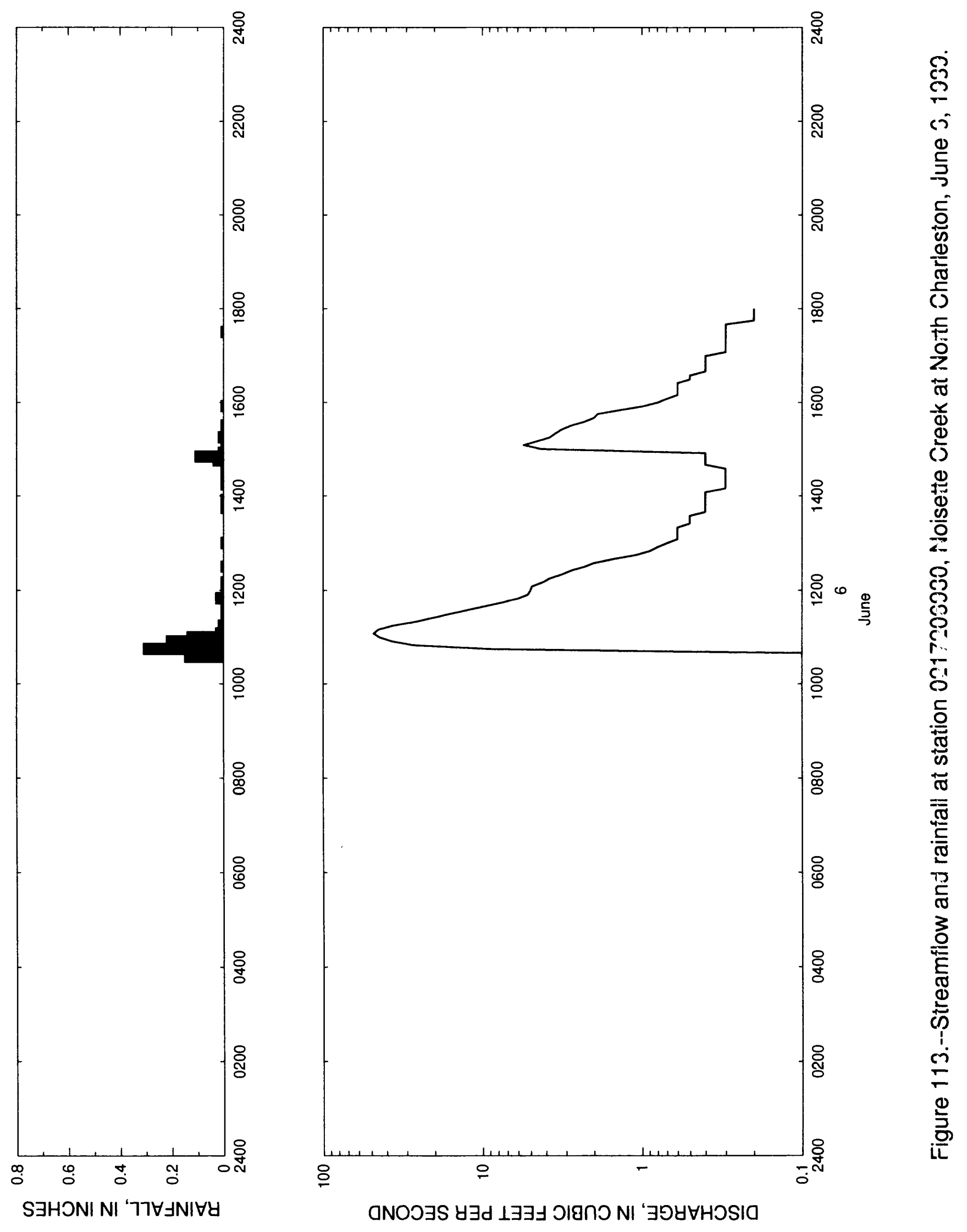


Table 117.--Streamflow and rainfall at station 0217206930, Noisette Creek at North Charleston, June 6,1989

\begin{tabular}{|c|c|c|c|c|c|c|c|c|}
\hline $\begin{array}{l}\text { Time } \\
\text { (hours) }\end{array}$ & $\begin{array}{l}\text { Streamflow } \\
\text { (cubic feet } \\
\text { per second) }\end{array}$ & $\begin{array}{l}\text { Rain- } \\
\text { fall } \\
\text { (inches) }\end{array}$ & $\begin{array}{l}\text { Time } \\
\text { (hours) }\end{array}$ & $\begin{array}{l}\text { Streamflow } \\
\text { (cubic feet } \\
\text { per second) }\end{array}$ & $\begin{array}{l}\text { Rain- } \\
\text { fall } \\
\text { (inches) }\end{array}$ & $\begin{array}{l}\text { Time } \\
\text { (hours) }\end{array}$ & $\begin{array}{l}\text { Streamflow } \\
\text { (cubic feet } \\
\text { per second) }\end{array}$ & $\begin{array}{l}\text { Rain- } \\
\text { fall } \\
\text { (inches) }\end{array}$ \\
\hline $\begin{array}{c}\text { June } 6, \\
1035 \\
1040 \\
1045 \\
1050\end{array}$ & $1989 \quad \begin{array}{r}0.1 \\
0.1 \\
8.9 \\
27.3\end{array}$ & $\begin{array}{l}0.15 \\
0.11 \\
0.31 \\
0.16\end{array}$ & $\begin{array}{l}1305 \\
1310 \\
1315 \\
1320 \\
1325\end{array}$ & $\begin{array}{l}0.6 \\
0.6 \\
0.6 \\
0.6 \\
0.5\end{array}$ & $\begin{array}{l}0.00 \\
0.00 \\
0.00 \\
0.00 \\
0.00\end{array}$ & $\begin{array}{l}1540 \\
1545 \\
1550 \\
1555 \\
1600\end{array}$ & $\begin{array}{l}2.0 \\
1.9 \\
1.4 \\
1.0 \\
0.8\end{array}$ & $\begin{array}{l}0.00 \\
0.00 \\
0.00 \\
0.01 \\
0.00\end{array}$ \\
\hline $\begin{array}{l}1055 \\
1100 \\
1105 \\
1110 \\
1115\end{array}$ & $\begin{array}{l}36.9 \\
44.1 \\
48.3 \\
44.9 \\
36.6\end{array}$ & $\begin{array}{l}0.22 \\
0.14 \\
0.03 \\
0.01 \\
0.02\end{array}$ & $\begin{array}{l}1330 \\
1335 \\
1340 \\
1345 \\
1350\end{array}$ & $\begin{array}{l}0.5 \\
0.5 \\
0.4 \\
0.4 \\
0.4\end{array}$ & $\begin{array}{l}0.00 \\
0.00 \\
0.00 \\
0.01 \\
0.00\end{array}$ & $\begin{array}{l}1605 \\
1610 \\
1615 \\
1620 \\
1625\end{array}$ & $\begin{array}{l}0.7 \\
0.6 \\
0.6 \\
0.6 \\
0.6\end{array}$ & $\begin{array}{l}0.00 \\
0.00 \\
0.00 \\
0.00 \\
0.00\end{array}$ \\
\hline $\begin{array}{l}1120 \\
1125 \\
1130 \\
1135 \\
1140\end{array}$ & $\begin{array}{r}26.2 \\
20.6 \\
16.1 \\
12.4 \\
9.6\end{array}$ & $\begin{array}{l}0.01 \\
0.01 \\
0.00 \\
0.01 \\
0.00\end{array}$ & $\begin{array}{l}1355 \\
1400 \\
1405 \\
1410 \\
1415\end{array}$ & $\begin{array}{l}0.4 \\
0.4 \\
0.4 \\
0.3 \\
0.3\end{array}$ & $\begin{array}{l}0.01 \\
0.00 \\
0.00 \\
0.00 \\
0.01\end{array}$ & $\begin{array}{l}1630 \\
1635 \\
1640 \\
1645 \\
1650\end{array}$ & $\begin{array}{l}0.5 \\
0.5 \\
0.4 \\
0.4 \\
0.4\end{array}$ & $\begin{array}{l}0.00 \\
0.00 \\
0.00 \\
0.00 \\
0.00\end{array}$ \\
\hline $\begin{array}{l}1145 \\
1150 \\
1155 \\
1200 \\
1205\end{array}$ & $\begin{array}{l}7.4 \\
6.0 \\
5.2 \\
5.0 \\
4.9\end{array}$ & $\begin{array}{l}0.01 \\
0.03 \\
0.01 \\
0.01 \\
0.00\end{array}$ & $\begin{array}{l}1420 \\
1425 \\
1430 \\
1435 \\
1440\end{array}$ & $\begin{array}{l}0.3 \\
0.3 \\
0.3 \\
0.3 \\
0.4\end{array}$ & $\begin{array}{l}0.01 \\
0.00 \\
0.00 \\
0.01 \\
0.00\end{array}$ & $\begin{array}{l}1655 \\
1700 \\
1705 \\
1710 \\
1715\end{array}$ & $\begin{array}{l}0.4 \\
0.4 \\
0.3 \\
0.3 \\
0.3\end{array}$ & $\begin{array}{l}0.00 \\
0.00 \\
0.00 \\
0.00 \\
0.00\end{array}$ \\
\hline $\begin{array}{l}1210 \\
1215 \\
1220 \\
1225 \\
1230\end{array}$ & $\begin{array}{l}4.2 \\
3.8 \\
3.2 \\
2.8 \\
2.3\end{array}$ & $\begin{array}{l}0.01 \\
0.00 \\
0.00 \\
0.00 \\
0.01\end{array}$ & $\begin{array}{l}1445 \\
1450 \\
1455 \\
1500 \\
1505\end{array}$ & $\begin{array}{l}0.4 \\
0.4 \\
0.4 \\
4.3 \\
5.5\end{array}$ & $\begin{array}{l}0.04 \\
0.11 \\
0.02 \\
0.01 \\
0.00\end{array}$ & $\begin{array}{l}1720 \\
1725 \\
1730 \\
1735 \\
1740\end{array}$ & $\begin{array}{l}0.3 \\
0.3 \\
0.3 \\
0.3 \\
0.3\end{array}$ & $\begin{array}{l}0.00 \\
0.00 \\
0.01 \\
0.00 \\
0.00\end{array}$ \\
\hline $\begin{array}{l}1235 \\
1240 \\
1245 \\
1250 \\
1255\end{array}$ & $\begin{array}{l}2.0 \\
1.5 \\
1.1 \\
0.9 \\
0.8\end{array}$ & $\begin{array}{l}0.00 \\
0.00 \\
0.00 \\
0.00 \\
0.00\end{array}$ & $\begin{array}{l}1510 \\
1515 \\
1520 \\
1525 \\
1530\end{array}$ & $\begin{array}{l}4.6 \\
3.8 \\
3.5 \\
3.2 \\
2.8\end{array}$ & $\begin{array}{l}0.01 \\
0.02 \\
0.01 \\
0.00 \\
0.01\end{array}$ & $\begin{array}{l}1745 \\
1750 \\
1755 \\
1800\end{array}$ & $\begin{array}{l}0.2 \\
0.2 \\
0.2 \\
0.2\end{array}$ & $\begin{array}{l}0.00 \\
0.00 \\
0.00 \\
0.00\end{array}$ \\
\hline 1300 & 0.7 & 0.01 & 1535 & 2.3 & 0.00 & & & \\
\hline
\end{tabular}




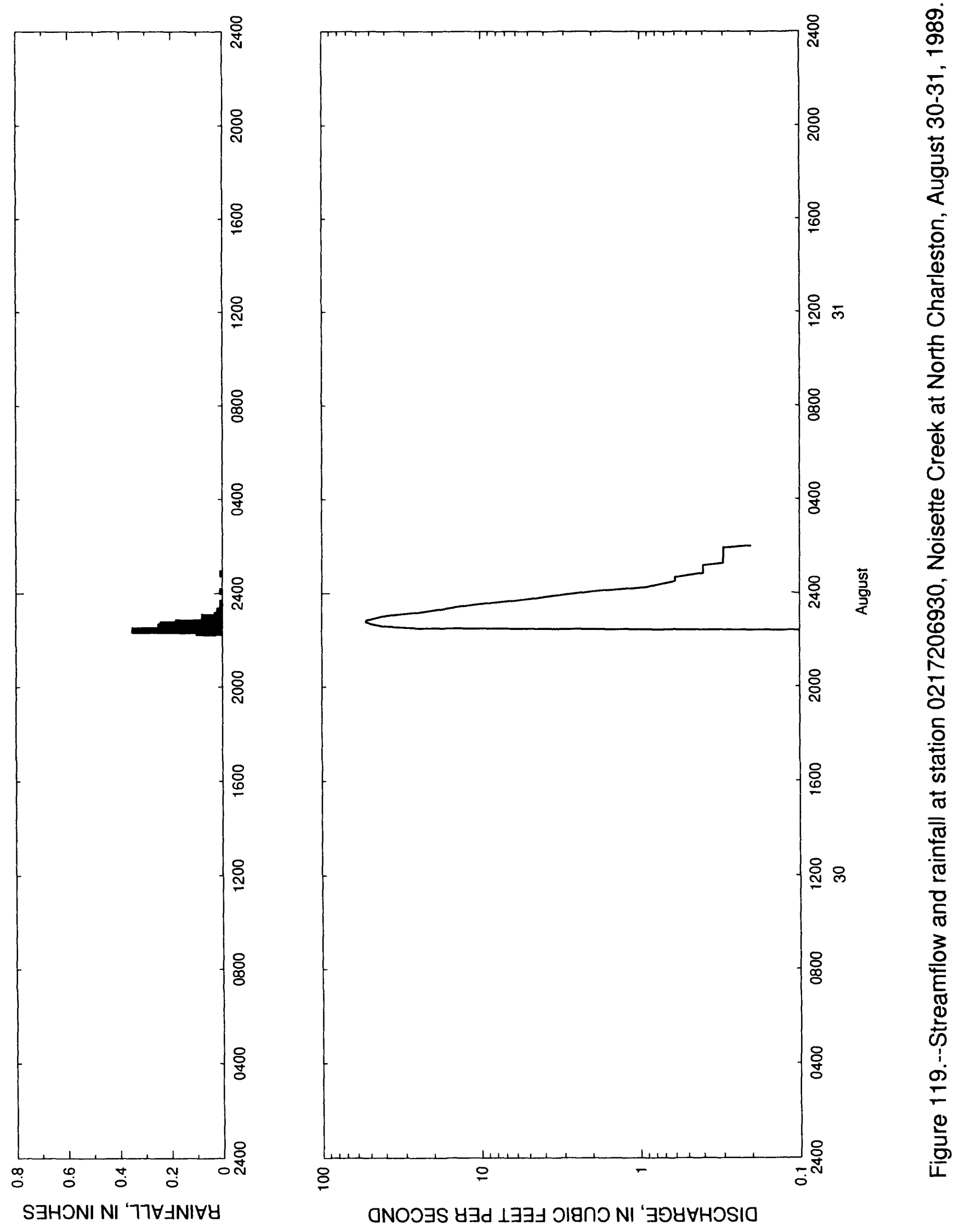


Table 118. - Streamflow and rainfall at station 0217206930, Noisette Creek at North Charleston, August $30-31,1989$

\begin{tabular}{|c|c|c|c|c|c|c|c|c|}
\hline $\begin{array}{l}\text { Time } \\
\text { (hours) }\end{array}$ & $\begin{array}{l}\text { Streamflow } \\
\text { (cubic feet } \\
\text { per second) }\end{array}$ & $\begin{array}{l}\text { Rain- } \\
\text { fall } \\
\text { (inches) }\end{array}$ & $\begin{array}{l}\text { Time } \\
\text { (hours) }\end{array}$ & $\begin{array}{l}\text { Streamflow } \\
\text { (cubic feet } \\
\text { per second) }\end{array}$ & $\begin{array}{l}\text { Rain- } \\
\text { fall } \\
\text { (inches) }\end{array}$ & $\begin{array}{l}\text { Time } \\
\text { (hours) }\end{array}$ & $\begin{array}{l}\text { Streamflow } \\
\text { (cubic feet } \\
\text { per second) }\end{array}$ & $\begin{array}{l}\text { Rain- } \\
\text { fall } \\
\text { (inches) }\end{array}$ \\
\hline $\begin{array}{c}\text { August } \\
2220 \\
2225 \\
2230 \\
2235\end{array}$ & $\begin{array}{r}30,1989 \\
0.1 \\
0.1 \\
25.8 \\
41.9\end{array}$ & $\begin{array}{l}0.10 \\
0.35 \\
0.25 \\
0.25\end{array}$ & $\begin{array}{l}2335 \\
2340 \\
2345 \\
2350 \\
2355\end{array}$ & $\begin{array}{l}8.5 \\
6.3 \\
4.9 \\
4.0 \\
3.1\end{array}$ & $\begin{array}{l}0.01 \\
0.00 \\
0.00 \\
0.00 \\
0.00\end{array}$ & $\begin{array}{l}0050 \\
0055 \\
0100 \\
0105 \\
0110\end{array}$ & $\begin{array}{l}0.4 \\
0.4 \\
0.4 \\
0.4 \\
0.4\end{array}$ & $\begin{array}{l}0.01 \\
0.00 \\
0.00 \\
0.00 \\
0.00\end{array}$ \\
\hline $\begin{array}{l}2240 \\
2245 \\
2250 \\
2255 \\
2300\end{array}$ & $\begin{array}{l}47.7 \\
52.8 \\
52.5 \\
47.4 \\
42.2\end{array}$ & $\begin{array}{l}0.24 \\
0.18 \\
0.03 \\
0.02 \\
0.08\end{array}$ & $\begin{array}{l}\text { August } \\
0000 \\
0005 \\
0010 \\
0015\end{array}$ & $\begin{array}{r}31,1989 \\
2.4 \\
1.9 \\
1.3 \\
0.9\end{array}$ & $\begin{array}{l}0.00 \\
0.01 \\
0.00 \\
0.00\end{array}$ & $\begin{array}{l}0115 \\
0120 \\
0125 \\
0130 \\
0135\end{array}$ & $\begin{array}{l}0.3 \\
0.3 \\
0.3 \\
0.3 \\
0.3\end{array}$ & $\begin{array}{l}0.00 \\
0.00 \\
0.00 \\
0.00 \\
0.00\end{array}$ \\
\hline $\begin{array}{l}2305 \\
2310 \\
2315 \\
2320 \\
2325\end{array}$ & $\begin{array}{l}33.9 \\
24.9 \\
20.4 \\
16.5 \\
13.5\end{array}$ & $\begin{array}{l}0.03 \\
0.01 \\
0.02 \\
0.01 \\
0.01\end{array}$ & $\begin{array}{l}0020 \\
0025 \\
0030 \\
0035 \\
0040\end{array}$ & $\begin{array}{l}0.8 \\
0.7 \\
0.6 \\
0.6 \\
0.6\end{array}$ & $\begin{array}{l}0.00 \\
0.00 \\
0.00 \\
0.00 \\
0.00\end{array}$ & $\begin{array}{l}0140 \\
0145 \\
0150 \\
0155 \\
0200\end{array}$ & $\begin{array}{l}0.3 \\
0.3 \\
0.3 \\
0.3 \\
0.2\end{array}$ & $\begin{array}{l}0.00 \\
0.00 \\
0.00 \\
0.00 \\
0.00\end{array}$ \\
\hline 2330 & 10.9 & 0.00 & 0045 & 0.5 & 0.00 & & & \\
\hline
\end{tabular}




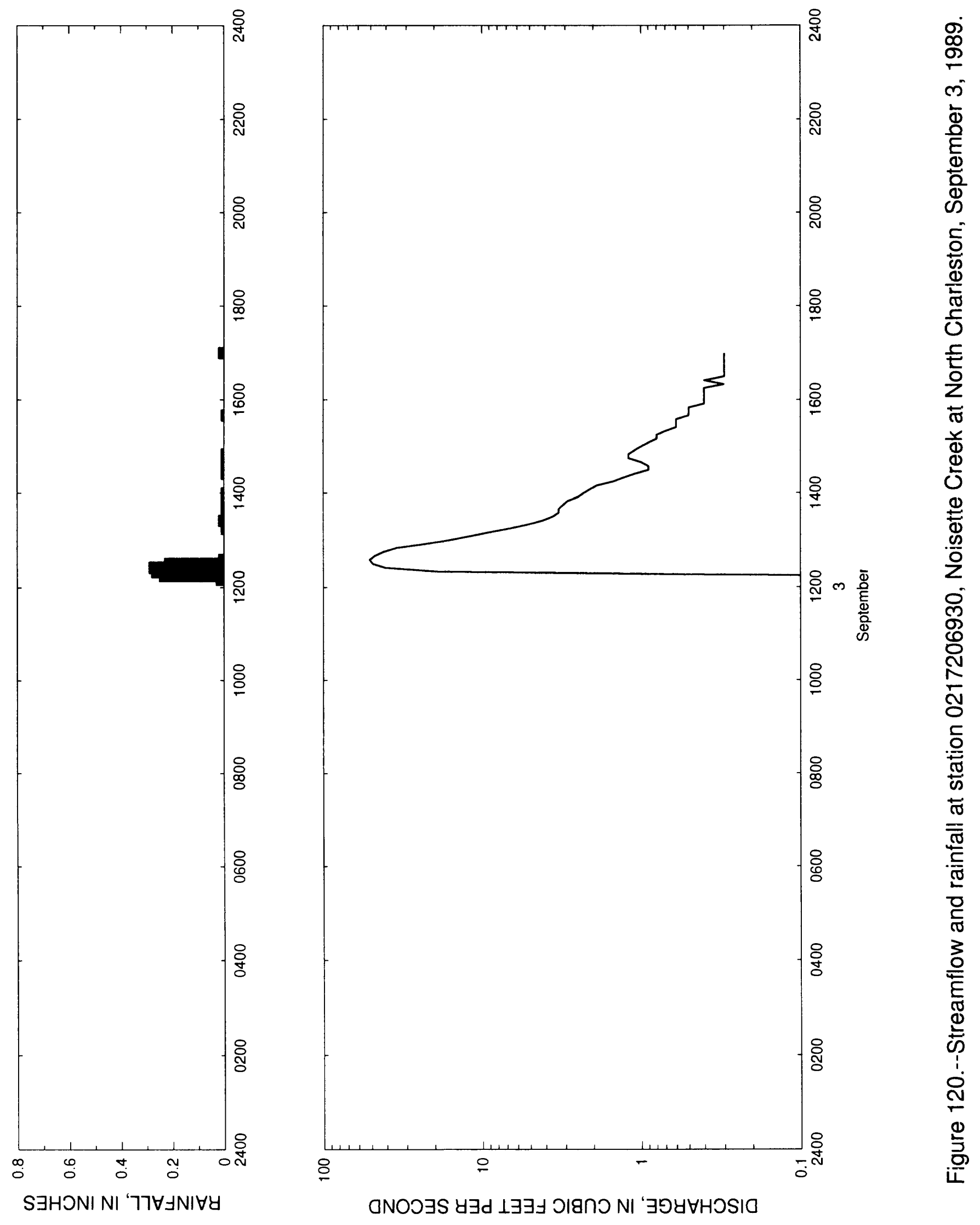


Table 119.--Streamflow and rainfall at station 0217206930, Noisette Creek at North Charleston, September 3,1989

\begin{tabular}{|c|c|c|c|c|c|c|c|c|}
\hline $\begin{array}{l}\text { Time } \\
\text { (hours) }\end{array}$ & $\begin{array}{l}\text { Streamflow } \\
\text { (cubic feet } \\
\text { per second) }\end{array}$ & $\begin{array}{l}\text { Rain- } \\
\text { fall } \\
\text { (inches) }\end{array}$ & $\begin{array}{l}\text { Time } \\
\text { (hours) }\end{array}$ & $\begin{array}{l}\text { Streamflow } \\
\text { (cubic feet } \\
\text { per second) }\end{array}$ & $\begin{array}{l}\text { Rain- } \\
\text { fall } \\
\text { (inches) }\end{array}$ & $\begin{array}{l}\text { Time } \\
\text { (hours) }\end{array}$ & $\begin{array}{l}\text { Streamflow } \\
\text { (cubic feet } \\
\text { per second) }\end{array}$ & $\begin{array}{l}\text { Rain- } \\
\text { fall } \\
\text { (inches) }\end{array}$ \\
\hline $\begin{array}{l}\text { September } \\
1210 \\
1215 \\
1220 \\
1225\end{array}$ & $\begin{array}{r}3,1989 \\
0.1 \\
0.1 \\
18.8 \\
40.8\end{array}$ & $\begin{array}{l}0.03 \\
0.25 \\
0.28 \\
0.29\end{array}$ & $\begin{array}{l}1345 \\
1350 \\
1355 \\
1400 \\
1405\end{array}$ & $\begin{array}{l}3.1 \\
2.9 \\
2.5 \\
2.3 \\
2.1\end{array}$ & $\begin{array}{l}0.00 \\
0.01 \\
0.00 \\
0.01 \\
0.00\end{array}$ & $\begin{array}{l}1525 \\
1530 \\
1535 \\
1540 \\
1545\end{array}$ & $\begin{array}{l}0.6 \\
0.6 \\
0.6 \\
0.5 \\
0.5\end{array}$ & $\begin{array}{l}0.00 \\
0.00 \\
0.00 \\
0.01 \\
0.00\end{array}$ \\
\hline $\begin{array}{l}1230 \\
1235 \\
1240 \\
1245 \\
1250\end{array}$ & $\begin{array}{l}48.8 \\
51.1 \\
47.4 \\
41.9 \\
34.6\end{array}$ & $\begin{array}{l}0.23 \\
0.02 \\
0.00 \\
0.00 \\
0.00\end{array}$ & $\begin{array}{l}1410 \\
1415 \\
1420 \\
1425 \\
1430\end{array}$ & $\begin{array}{l}1.9 \\
1.5 \\
1.3 \\
1.1 \\
0.9\end{array}$ & $\begin{array}{l}0.00 \\
0.00 \\
0.00 \\
0.01 \\
0.01\end{array}$ & $\begin{array}{l}1550 \\
1555 \\
1600 \\
1605 \\
1610\end{array}$ & $\begin{array}{l}0.5 \\
0.4 \\
0.4 \\
0.4 \\
0.4\end{array}$ & $\begin{array}{l}0.00 \\
0.00 \\
0.00 \\
0.00 \\
0.00\end{array}$ \\
\hline $\begin{array}{l}1255 \\
1300 \\
1305 \\
1310 \\
1315\end{array}$ & $\begin{array}{r}23.0 \\
16.1 \\
12.0 \\
9.1 \\
6.7\end{array}$ & $\begin{array}{l}0.00 \\
0.00 \\
0.00 \\
0.00 \\
0.01\end{array}$ & $\begin{array}{l}1435 \\
1440 \\
1445 \\
1450 \\
1455\end{array}$ & $\begin{array}{l}0.9 \\
1.0 \\
1.2 \\
1.2 \\
1.1\end{array}$ & $\begin{array}{l}0.00 \\
0.01 \\
0.00 \\
0.01 \\
0.00\end{array}$ & $\begin{array}{l}1615 \\
1620 \\
1625 \\
1630 \\
1635\end{array}$ & $\begin{array}{l}0.4 \\
0.3 \\
0.4 \\
0.3 \\
0.3\end{array}$ & $\begin{array}{l}0.00 \\
0.00 \\
0.00 \\
0.00 \\
0.00\end{array}$ \\
\hline $\begin{array}{l}1320 \\
1325 \\
1330 \\
1335 \\
1340\end{array}$ & $\begin{array}{l}5.2 \\
4.2 \\
3.6 \\
3.3 \\
3.3\end{array}$ & $\begin{array}{l}0.00 \\
0.02 \\
0.01 \\
0.01 \\
0.01\end{array}$ & $\begin{array}{l}1500 \\
1505 \\
1510 \\
1515 \\
1520\end{array}$ & $\begin{array}{l}1.0 \\
0.9 \\
0.8 \\
0.8 \\
0.7\end{array}$ & $\begin{array}{l}0.00 \\
0.00 \\
0.00 \\
0.00 \\
0.00\end{array}$ & $\begin{array}{l}1640 \\
1645 \\
1650 \\
1655 \\
1700\end{array}$ & $\begin{array}{l}0.3 \\
0.3 \\
0.3 \\
0.3 \\
0.3\end{array}$ & $\begin{array}{l}0.00 \\
0.00 \\
0.00 \\
0.00 \\
0.02\end{array}$ \\
\hline
\end{tabular}




\section{Station 02173491, Hess Branch at Orangeburg, S.C.}

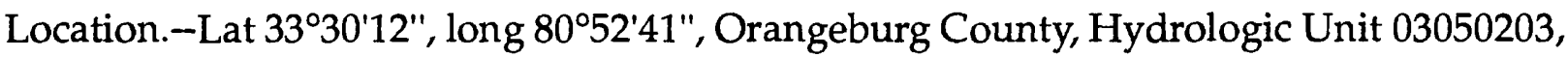
at culvert on Middleton Road (State secondary road 211), 1.4 mi northwest of Orangeburg City Hall, and $0.5 \mathrm{mi}$ upstream from the mouth at the North Fork Edisto River.

Period of record.-- May 8, 1986 to October 5, 1990.

Gage.--Digital stage recorder with 5-minute punch interval. The recorder is housed in a metal shelter atop a stilling well attached to a free-standing platform $10 \mathrm{ft}$ upstream from an $8.1 \mathrm{ft}$ by $6 \mathrm{ft}$ concrete box culvert. One crest-stage indicator is located on the right downstream wingwall.

Rating.--The stage-streamflow relation is defined by current meter measurements up to $26.9 \mathrm{ft}^{3} / \mathrm{s}$. The stage-streamflow relation was extended to $317 \mathrm{ft}^{3} / \mathrm{s}$ using indire $-\mathrm{t}$ computational methods.

Rain gage and location.--Station 333027080520800 , lat $33^{\circ} 30^{\prime} 27^{\prime \prime}$, long $80^{\circ} 52^{\prime} 08^{\prime \prime}$. A shelter containing a digital cumulative rainfall recorder with a 5-minute punch interval on Columbia Road (U.S. Business Route 21/178), and $1.4 \mathrm{mi}$ north of Orangeburg City Hall.

Selected basin characteristics.--

Drainage area -- $0.45 \mathrm{mi}^{2}$

Physiographic province - Inner Coastal Plain

Channel slope $-82.0 \mathrm{ft} / \mathrm{mi}$

Channel length -- $1.17 \mathrm{mi}$

Total impervious area -- 29.0 percent

Basin development factor -- 7

2-year, 2-hour rainfall amount -- 2.20 in.

Flood frequency data: $\mathrm{UQ}_{2} \quad 148 \mathrm{ft}^{3} / \mathrm{s}$

$\mathrm{UQ}_{5} \quad 232 \mathrm{ft}^{3} / \mathrm{s}$

$\mathrm{UQ}_{10} \quad 290 \mathrm{ft}^{3} / \mathrm{s}$

$\mathrm{UQ}_{25} \quad 362 \mathrm{ft}^{3} / \mathrm{s}$

$\mathrm{UQ}_{50} \quad 416 \mathrm{ft}^{3} / \mathrm{s}$

$\mathrm{UQ}_{100} \quad 470 \mathrm{ft}^{3} / \mathrm{s}$

$\mathrm{UQ}_{500} \quad 600 \mathrm{ft}^{3} / \mathrm{s}$ 


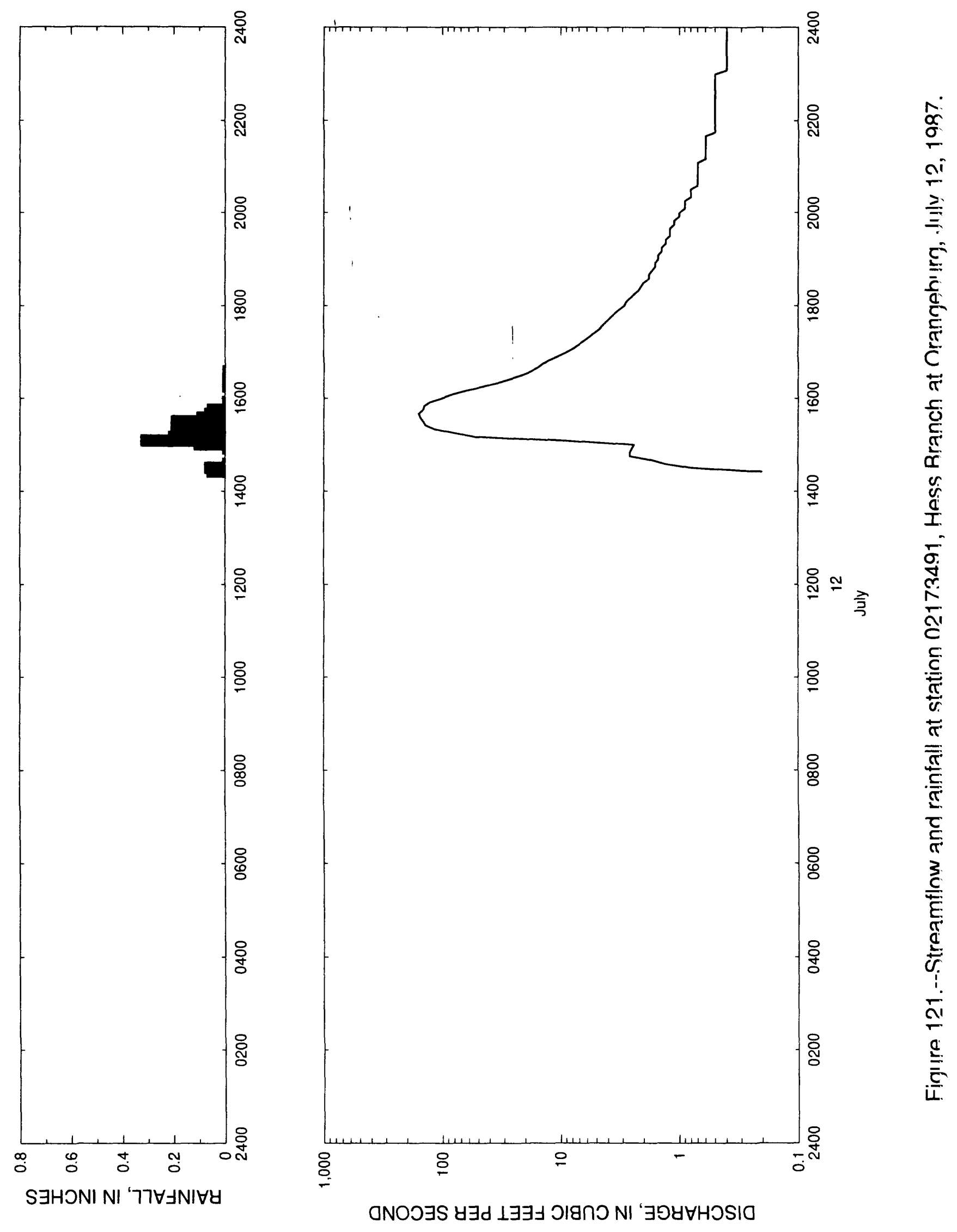


Table 120.--Streamflow and rainfa11 at station 02173491 , Hess Branch at Orangeburg. July 12,1987

\begin{tabular}{|c|c|c|c|c|c|c|c|c|}
\hline $\begin{array}{l}\text { Time } \\
\text { (hours) }\end{array}$ & $\begin{array}{l}\text { Streamflow } \\
\text { (cubic feet } \\
\text { per second) }\end{array}$ & $\begin{array}{l}\text { Rain- } \\
\text { fall } \\
\text { (inches) }\end{array}$ & $\begin{array}{l}\text { Time } \\
\text { (hours) }\end{array}$ & $\begin{array}{l}\text { Streamflow } \\
\text { (cubic feet } \\
\text { per second) }\end{array}$ & $\begin{array}{l}\text { Rain- } \\
\text { fall } \\
\text { (inches) }\end{array}$ & $\begin{array}{l}\text { Time } \\
\text { (hours) }\end{array}$ & $\begin{array}{l}\text { Streamflow } \\
\text { (cubic feet } \\
\text { per second) }\end{array}$ & $\begin{array}{l}\text { Rain- } \\
\text { fall } \\
\text { (inches) }\end{array}$ \\
\hline $\begin{array}{l}\text { July } 12, \\
1425 \\
1430 \\
1435 \\
1440\end{array}$ & $\begin{array}{r}1987 \\
0.2 \\
0.8 \\
1.3 \\
1.7\end{array}$ & $\begin{array}{l}0.07 \\
0.08 \\
0.01 \\
0.00\end{array}$ & $\begin{array}{l}1740 \\
1745 \\
1750 \\
1755 \\
1800\end{array}$ & $\begin{array}{l}4.1 \\
3.8 \\
3.5 \\
3.2 \\
2.9\end{array}$ & $\begin{array}{l}0.00 \\
0.00 \\
0.00 \\
0.00 \\
0.00\end{array}$ & $\begin{array}{l}2100 \\
2105 \\
2110 \\
2115 \\
2120\end{array}$ & $\begin{array}{l}0.7 \\
0.7 \\
0.6 \\
0.6 \\
0.6\end{array}$ & $\begin{array}{l}0.00 \\
0.00 \\
0.00 \\
0.00 \\
0.00\end{array}$ \\
\hline $\begin{array}{l}1445 \\
1450 \\
1455 \\
1500 \\
1505\end{array}$ & $\begin{array}{l}2.6 \\
2.6 \\
2.5 \\
2.4 \\
8.9\end{array}$ & $\begin{array}{l}0.00 \\
0.00 \\
0.01 \\
0.12 \\
0.33\end{array}$ & $\begin{array}{l}1805 \\
1810 \\
1815 \\
1820 \\
1825\end{array}$ & $\begin{array}{l}2.8 \\
2.6 \\
2.4 \\
2.2 \\
2.1\end{array}$ & $\begin{array}{l}0.00 \\
0.00 \\
0.00 \\
0.00 \\
0.00\end{array}$ & $\begin{array}{l}2125 \\
2130 \\
2135 \\
2140 \\
2145\end{array}$ & $\begin{array}{l}0.6 \\
0.6 \\
0.6 \\
0.6 \\
0.5\end{array}$ & $\begin{array}{l}0.00 \\
0.00 \\
0.00 \\
0.00 \\
0.00\end{array}$ \\
\hline $\begin{array}{l}1510 \\
1515 \\
1520 \\
1525 \\
1530\end{array}$ & $\begin{array}{r}52.6 \\
78.8 \\
116.0 \\
139.0 \\
146.0\end{array}$ & $\begin{array}{l}0.22 \\
0.11 \\
0.16 \\
0.21 \\
0.21\end{array}$ & $\begin{array}{l}1830 \\
1835 \\
1840 \\
1845 \\
1850\end{array}$ & $\begin{array}{l}2.0 \\
1.8 \\
1.8 \\
1.7 \\
1.6\end{array}$ & $\begin{array}{l}0.00 \\
0.00 \\
0.00 \\
0.00 \\
0.00\end{array}$ & $\begin{array}{l}2150 \\
2155 \\
2200 \\
2205 \\
2210\end{array}$ & $\begin{array}{l}0.5 \\
0.5 \\
0.5 \\
0.5 \\
0.5\end{array}$ & $\begin{array}{l}0.00 \\
0.00 \\
0.00 \\
0.00 \\
0.00\end{array}$ \\
\hline $\begin{array}{l}1535 \\
1540 \\
1545 \\
1550 \\
1555\end{array}$ & $\begin{array}{l}154.0 \\
159.0 \\
146.0 \\
143.0 \\
128.0\end{array}$ & $\begin{array}{l}0.11 \\
0.08 \\
0.07 \\
0.01 \\
0.01\end{array}$ & $\begin{array}{l}1855 \\
1900 \\
1905 \\
1910 \\
1915\end{array}$ & $\begin{array}{l}1.6 \\
1.5 \\
1.5 \\
1.4 \\
1.4\end{array}$ & $\begin{array}{l}0.00 \\
0.00 \\
0.00 \\
0.00 \\
0.00\end{array}$ & $\begin{array}{l}2215 \\
2220 \\
2225 \\
2230 \\
2235\end{array}$ & $\begin{array}{l}0.5 \\
0.5 \\
0.5 \\
0.5 \\
0.5\end{array}$ & $\begin{array}{l}0.00 \\
0.00 \\
0.00 \\
0.00 \\
0.00\end{array}$ \\
\hline $\begin{array}{l}1600 \\
1605 \\
1610 \\
1615 \\
1620\end{array}$ & $\begin{array}{r}102.0 \\
82.4 \\
63.6 \\
45.6 \\
34.2\end{array}$ & $\begin{array}{l}0.00 \\
0.00 \\
0.00 \\
0.01 \\
0.01\end{array}$ & $\begin{array}{l}1920 \\
1925 \\
1930 \\
1935 \\
1940\end{array}$ & $\begin{array}{l}1.3 \\
1.3 \\
1.2 \\
1.2 \\
1.2\end{array}$ & $\begin{array}{l}0.00 \\
0.00 \\
0.00 \\
0.00 \\
0.00\end{array}$ & $\begin{array}{l}2240 \\
2245 \\
2250 \\
2255 \\
2300\end{array}$ & $\begin{array}{l}0.5 \\
0.5 \\
0.5 \\
0.5 \\
0.5\end{array}$ & $\begin{array}{l}0.00 \\
0.00 \\
0.00 \\
0.00 \\
0.00\end{array}$ \\
\hline $\begin{array}{l}1625 \\
1630 \\
1635 \\
1640 \\
1645\end{array}$ & $\begin{array}{l}26.9 \\
21.3 \\
17.8 \\
15.7 \\
14.2\end{array}$ & $\begin{array}{l}0.00 \\
0.00 \\
0.01 \\
0.00 \\
0.00\end{array}$ & $\begin{array}{l}1945 \\
1950 \\
1955 \\
2000 \\
2005\end{array}$ & $\begin{array}{l}1.1 \\
1.1 \\
1.0 \\
1.0 \\
0.9\end{array}$ & $\begin{array}{l}0.00 \\
0.00 \\
0.00 \\
0.00 \\
0.00\end{array}$ & $\begin{array}{l}2305 \\
2310 \\
2315 \\
2320 \\
2325\end{array}$ & $\begin{array}{l}0.4 \\
0.4 \\
0.4 \\
0.4 \\
0.4\end{array}$ & $\begin{array}{l}0.00 \\
0.00 \\
0.00 \\
0.00 \\
0.00\end{array}$ \\
\hline $\begin{array}{l}1650 \\
1655 \\
1700 \\
1705 \\
1710\end{array}$ & $\begin{array}{r}12.1 \\
10.3 \\
8.9 \\
7.8 \\
7.0\end{array}$ & $\begin{array}{l}0.00 \\
0.00 \\
0.00 \\
0.00 \\
0.00\end{array}$ & $\begin{array}{l}2010 \\
2015 \\
2020 \\
2025 \\
2030\end{array}$ & $\begin{array}{l}0.9 \\
0.9 \\
0.8 \\
0.8 \\
0.8\end{array}$ & $\begin{array}{l}0.00 \\
0.00 \\
0.00 \\
0.00 \\
0.00\end{array}$ & $\begin{array}{l}2330 \\
2335 \\
2340 \\
2345 \\
2350\end{array}$ & $\begin{array}{l}0.4 \\
0.4 \\
0.4 \\
0.4 \\
0.4\end{array}$ & $\begin{array}{l}0.00 \\
0.00 \\
0.00 \\
0.00 \\
0.00\end{array}$ \\
\hline $\begin{array}{l}1715 \\
1720 \\
1725 \\
1730 \\
1735\end{array}$ & $\begin{array}{l}6.3 \\
5.7 \\
5.2 \\
4.7 \\
4.4\end{array}$ & $\begin{array}{l}0.00 \\
0.00 \\
0.00 \\
0.00 \\
0.00\end{array}$ & $\begin{array}{l}2035 \\
2040 \\
2045 \\
2050 \\
2055\end{array}$ & $\begin{array}{l}0.7 \\
0.7 \\
0.7 \\
0.7 \\
0.7\end{array}$ & $\begin{array}{l}0.00 \\
0.00 \\
0.00 \\
0.00 \\
0.00\end{array}$ & 2355 & 0.4 & 0.00 \\
\hline
\end{tabular}




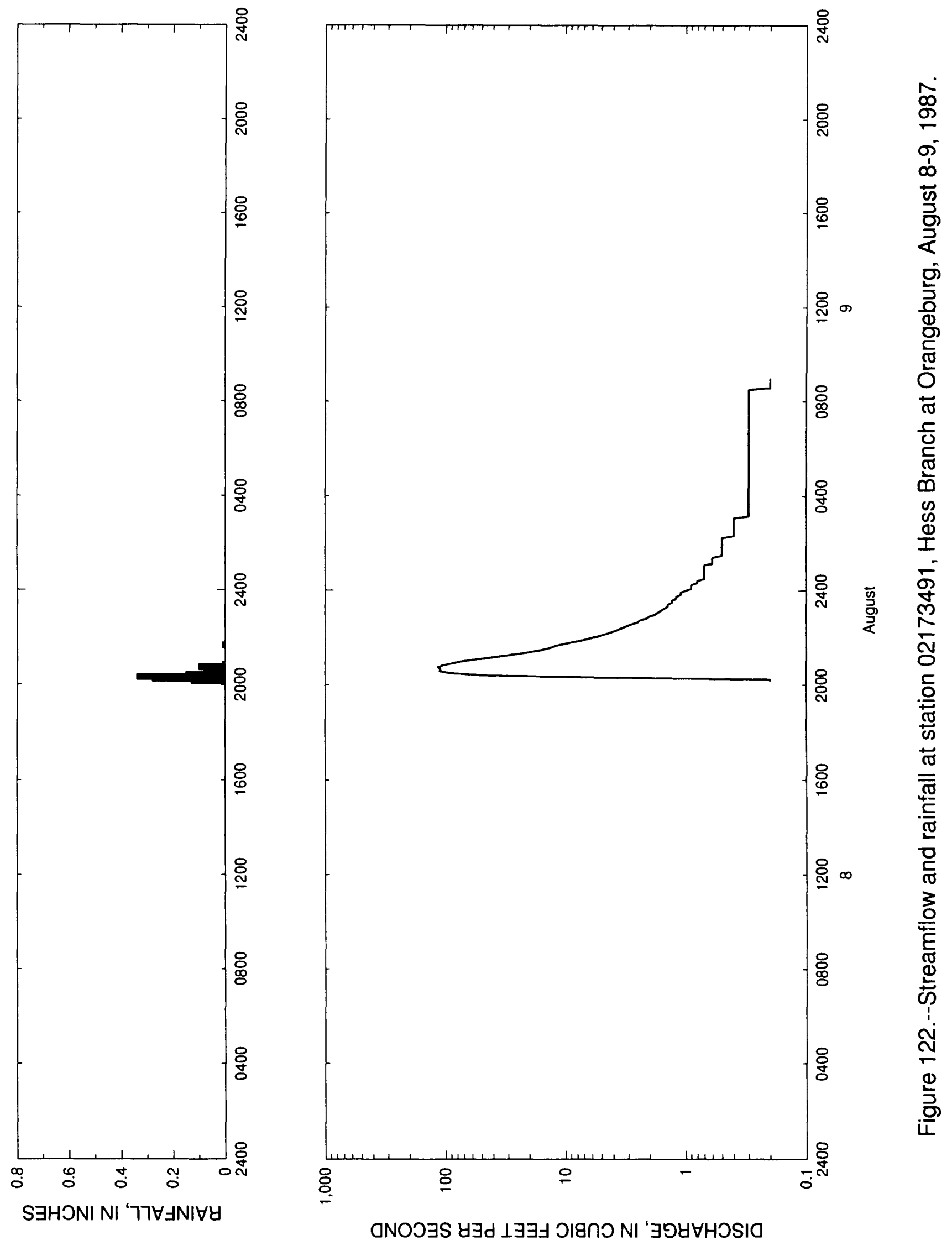


Table 121. - Streamflow and rainfall at station 02173491, Hess Branch at Orangeburg, August $8-9,1987$

\begin{tabular}{|c|c|c|c|c|c|c|c|c|}
\hline $\begin{array}{l}\text { Time } \\
\text { (hours) }\end{array}$ & $\begin{array}{l}\text { Streamflow } \\
\text { (cubic feet } \\
\text { per second) }\end{array}$ & $\begin{array}{l}\text { Rain- } \\
\text { fall } \\
\text { (inches) }\end{array}$ & $\begin{array}{l}\text { Time } \\
\text { (hours) }\end{array}$ & $\begin{array}{l}\text { Streamflow } \\
\text { (cubic feet } \\
\text { per second) }\end{array}$ & $\begin{array}{l}\text { Rain- } \\
\text { fall } \\
\text { (inches) }\end{array}$ & $\begin{array}{l}\text { Time } \\
\text { (hours) }\end{array}$ & $\begin{array}{l}\text { Streamflow } \\
\text { (cubic feet } \\
\text { per second) }\end{array}$ & $\begin{array}{l}\text { Rain- } \\
\text { fall } \\
\text { (inches) }\end{array}$ \\
\hline $\begin{array}{l}\text { August } 8 \\
2010 \\
2015 \\
2020 \\
2025\end{array}$ & $\begin{array}{r}1987 \\
0.2 \\
0.2 \\
5.8 \\
50.7\end{array}$ & $\begin{array}{l}0.13 \\
0.28 \\
0.34 \\
0.15\end{array}$ & $\begin{array}{l}0025 \\
0030 \\
0035 \\
0040 \\
0045\end{array}$ & $\begin{array}{l}0.8 \\
0.7 \\
0.7 \\
0.7 \\
0.7\end{array}$ & $\begin{array}{l}0.00 \\
0.00 \\
0.00 \\
0.00 \\
0.00\end{array}$ & $\begin{array}{l}0450 \\
0455 \\
0500 \\
0505 \\
0510\end{array}$ & $\begin{array}{l}0.3 \\
0.3 \\
0.3 \\
0.3 \\
0.3\end{array}$ & $\begin{array}{l}0.00 \\
0.00 \\
0.00 \\
0.00 \\
0.00\end{array}$ \\
\hline $\begin{array}{l}2030 \\
2035 \\
2040 \\
2045 \\
2050\end{array}$ & $\begin{array}{r}90.6 \\
112.0 \\
110.0 \\
116.0 \\
105.0\end{array}$ & $\begin{array}{l}0.05 \\
0.08 \\
0.05 \\
0.10 \\
0.01\end{array}$ & $\begin{array}{l}0050 \\
0055 \\
0100 \\
0105 \\
0110\end{array}$ & $\begin{array}{l}0.7 \\
0.7 \\
0.7 \\
0.7 \\
0.6\end{array}$ & $\begin{array}{l}0.00 \\
0.00 \\
0.00 \\
0.00 \\
0.00\end{array}$ & $\begin{array}{l}0515 \\
0520 \\
0525 \\
0530 \\
0535\end{array}$ & $\begin{array}{l}0.3 \\
0.3 \\
0.3 \\
0.3 \\
0.3\end{array}$ & $\begin{array}{l}0.00 \\
0.00 \\
0.00 \\
0.00 \\
0.00\end{array}$ \\
\hline $\begin{array}{l}2055 \\
2100 \\
2105 \\
2110 \\
2115\end{array}$ & $\begin{array}{l}87.8 \\
73.6 \\
56.0 \\
41.8 \\
30.7\end{array}$ & $\begin{array}{l}0.00 \\
0.00 \\
0.00 \\
0.00 \\
0.00\end{array}$ & $\begin{array}{l}0115 \\
0120 \\
0125 \\
0130 \\
0135\end{array}$ & $\begin{array}{l}0.6 \\
0.6 \\
0.6 \\
0.5 \\
0.5\end{array}$ & $\begin{array}{l}0.00 \\
0.00 \\
0.00 \\
0.00 \\
0.00\end{array}$ & $\begin{array}{l}0540 \\
0545 \\
0550 \\
0555 \\
0600\end{array}$ & $\begin{array}{l}0.3 \\
0.3 \\
0.3 \\
0.3 \\
0.3\end{array}$ & $\begin{array}{l}0.00 \\
0.00 \\
0.00 \\
0.00 \\
0.00\end{array}$ \\
\hline $\begin{array}{l}2120 \\
2125 \\
2130 \\
2135 \\
2140\end{array}$ & $\begin{array}{l}23.3 \\
18.5 \\
15.5 \\
13.3 \\
12.1\end{array}$ & $\begin{array}{l}0.00 \\
0.00 \\
0.00 \\
0.00 \\
0.01\end{array}$ & $\begin{array}{l}0140 \\
0145 \\
0150 \\
0155 \\
0200\end{array}$ & $\begin{array}{l}0.5 \\
0.5 \\
0.5 \\
0.5 \\
0.5\end{array}$ & $\begin{array}{l}0.00 \\
0.00 \\
0.00 \\
0.00 \\
0.00\end{array}$ & $\begin{array}{l}0605 \\
0610 \\
0615 \\
0620 \\
0625\end{array}$ & $\begin{array}{l}0.3 \\
0.3 \\
0.3 \\
0.3 \\
0.3\end{array}$ & $\begin{array}{l}0.00 \\
0.00 \\
0.00 \\
0.00 \\
0.00\end{array}$ \\
\hline $\begin{array}{l}2145 \\
2150 \\
2155 \\
2200 \\
2205\end{array}$ & $\begin{array}{r}10.1 \\
8.4 \\
7.0 \\
6.0 \\
5.2\end{array}$ & $\begin{array}{l}0.00 \\
0.00 \\
0.00 \\
0.00 \\
0.00\end{array}$ & $\begin{array}{l}0205 \\
0210 \\
0215 \\
0220 \\
0225\end{array}$ & $\begin{array}{l}0.5 \\
0.5 \\
0.5 \\
0.4 \\
0.4\end{array}$ & $\begin{array}{l}0.00 \\
0.00 \\
0.00 \\
0.00 \\
0.00\end{array}$ & $\begin{array}{l}0630 \\
0635 \\
0640 \\
0645 \\
0650\end{array}$ & $\begin{array}{l}0.3 \\
0.3 \\
0.3 \\
0.3 \\
0.3\end{array}$ & $\begin{array}{l}0.00 \\
0.00 \\
0.00 \\
0.00 \\
0.00\end{array}$ \\
\hline $\begin{array}{l}2210 \\
2215 \\
2220 \\
2225 \\
2230\end{array}$ & $\begin{array}{l}4.6 \\
4.1 \\
3.7 \\
3.4 \\
3.1\end{array}$ & $\begin{array}{l}0.00 \\
0.00 \\
0.00 \\
0.00 \\
0.00\end{array}$ & $\begin{array}{l}0230 \\
0235 \\
0240 \\
0245 \\
0250\end{array}$ & $\begin{array}{l}0.4 \\
0.4 \\
0.4 \\
0.4 \\
0.4\end{array}$ & $\begin{array}{l}0.00 \\
0.00 \\
0.00 \\
0.00 \\
0.00\end{array}$ & $\begin{array}{l}0655 \\
0700 \\
0705 \\
0710 \\
0715\end{array}$ & $\begin{array}{l}0.3 \\
0.3 \\
0.3 \\
0.3 \\
0.3\end{array}$ & $\begin{array}{l}0.00 \\
0.00 \\
0.00 \\
0.00 \\
0.00\end{array}$ \\
\hline $\begin{array}{l}2235 \\
2240 \\
2245 \\
2250 \\
2255\end{array}$ & $\begin{array}{l}2.8 \\
2.5 \\
2.4 \\
2.1 \\
2.0\end{array}$ & $\begin{array}{l}0.00 \\
0.00 \\
0.00 \\
0.00 \\
0.00\end{array}$ & $\begin{array}{l}0255 \\
0300 \\
0305 \\
0310 \\
0315\end{array}$ & $\begin{array}{l}0.4 \\
0.4 \\
0.4 \\
0.3 \\
0.3\end{array}$ & $\begin{array}{l}0.00 \\
0.00 \\
0.00 \\
0.00 \\
0.00\end{array}$ & $\begin{array}{l}0720 \\
0725 \\
0730 \\
0735 \\
0740\end{array}$ & $\begin{array}{l}0.3 \\
0.3 \\
0.3 \\
0.3 \\
0.3\end{array}$ & $\begin{array}{l}0.00 \\
0.00 \\
0.00 \\
0.00 \\
0.00\end{array}$ \\
\hline $\begin{array}{l}2300 \\
2305 \\
2310 \\
2315 \\
2320\end{array}$ & $\begin{array}{l}1.8 \\
1.7 \\
1.6 \\
1.5 \\
1.4\end{array}$ & $\begin{array}{l}0.00 \\
0.00 \\
0.00 \\
0.00 \\
0.00\end{array}$ & $\begin{array}{l}0320 \\
0325 \\
0330 \\
0335 \\
0340\end{array}$ & $\begin{array}{l}0.3 \\
0.3 \\
0.3 \\
0.3 \\
0.3\end{array}$ & $\begin{array}{l}0.00 \\
0.00 \\
0.00 \\
0.00 \\
0.00\end{array}$ & $\begin{array}{l}0745 \\
0750 \\
0755 \\
0800 \\
0805\end{array}$ & $\begin{array}{l}0.3 \\
0.3 \\
0.3 \\
0.3 \\
0.3\end{array}$ & $\begin{array}{l}0.00 \\
0.00 \\
0.00 \\
0.00 \\
0.00\end{array}$ \\
\hline $\begin{array}{l}2325 \\
2330 \\
2335 \\
2340 \\
2345\end{array}$ & $\begin{array}{l}1.4 \\
1.3 \\
1.3 \\
1.2 \\
1.2\end{array}$ & $\begin{array}{l}0.00 \\
0.00 \\
0.00 \\
0.00 \\
0.00\end{array}$ & $\begin{array}{l}0345 \\
0350 \\
0355 \\
0400 \\
0405\end{array}$ & $\begin{array}{l}0.3 \\
0.3 \\
0.3 \\
0.3 \\
0.3\end{array}$ & $\begin{array}{l}0.00 \\
0.00 \\
0.00 \\
0.00 \\
0.00\end{array}$ & $\begin{array}{l}0810 \\
0815 \\
0820 \\
0825 \\
0830\end{array}$ & $\begin{array}{l}0.3 \\
0.3 \\
0.3 \\
0.3 \\
0.3\end{array}$ & $\begin{array}{l}0.00 \\
0.00 \\
0.00 \\
0.00 \\
0.00\end{array}$ \\
\hline $\begin{array}{l}2350 \\
2355 \\
\text { August } 9 \\
0000 \\
0005\end{array}$ & $\begin{array}{r}1.1 \\
1.1 \\
1987 \\
1.0 \\
0.9\end{array}$ & $\begin{array}{l}0.00 \\
0.00 \\
0.00 \\
0.00\end{array}$ & $\begin{array}{l}0410 \\
0415 \\
0420 \\
0425 \\
0430\end{array}$ & $\begin{array}{l}0.3 \\
0.3 \\
0.3 \\
0.3 \\
0.3\end{array}$ & $\begin{array}{l}0.00 \\
0.00 \\
0.00 \\
0.00 \\
0.00\end{array}$ & $\begin{array}{l}0835 \\
0840 \\
0845 \\
0850 \\
0855\end{array}$ & $\begin{array}{l}0.2 \\
0.2 \\
0.2 \\
0.2 \\
0.2\end{array}$ & $\begin{array}{l}0.00 \\
0.00 \\
0.00 \\
0.00 \\
0.00\end{array}$ \\
\hline $\begin{array}{l}0010 \\
0015 \\
0020\end{array}$ & $\begin{array}{l}0.9 \\
0.9 \\
0.8\end{array}$ & $\begin{array}{l}0.00 \\
0.00 \\
0.00\end{array}$ & $\begin{array}{l}0435 \\
0440 \\
0445\end{array}$ & $\begin{array}{l}0.3 \\
0.3 \\
0.3\end{array}$ & $\begin{array}{l}0.00 \\
0.00 \\
0.00\end{array}$ & 0900 & 0.2 & 0.00 \\
\hline
\end{tabular}




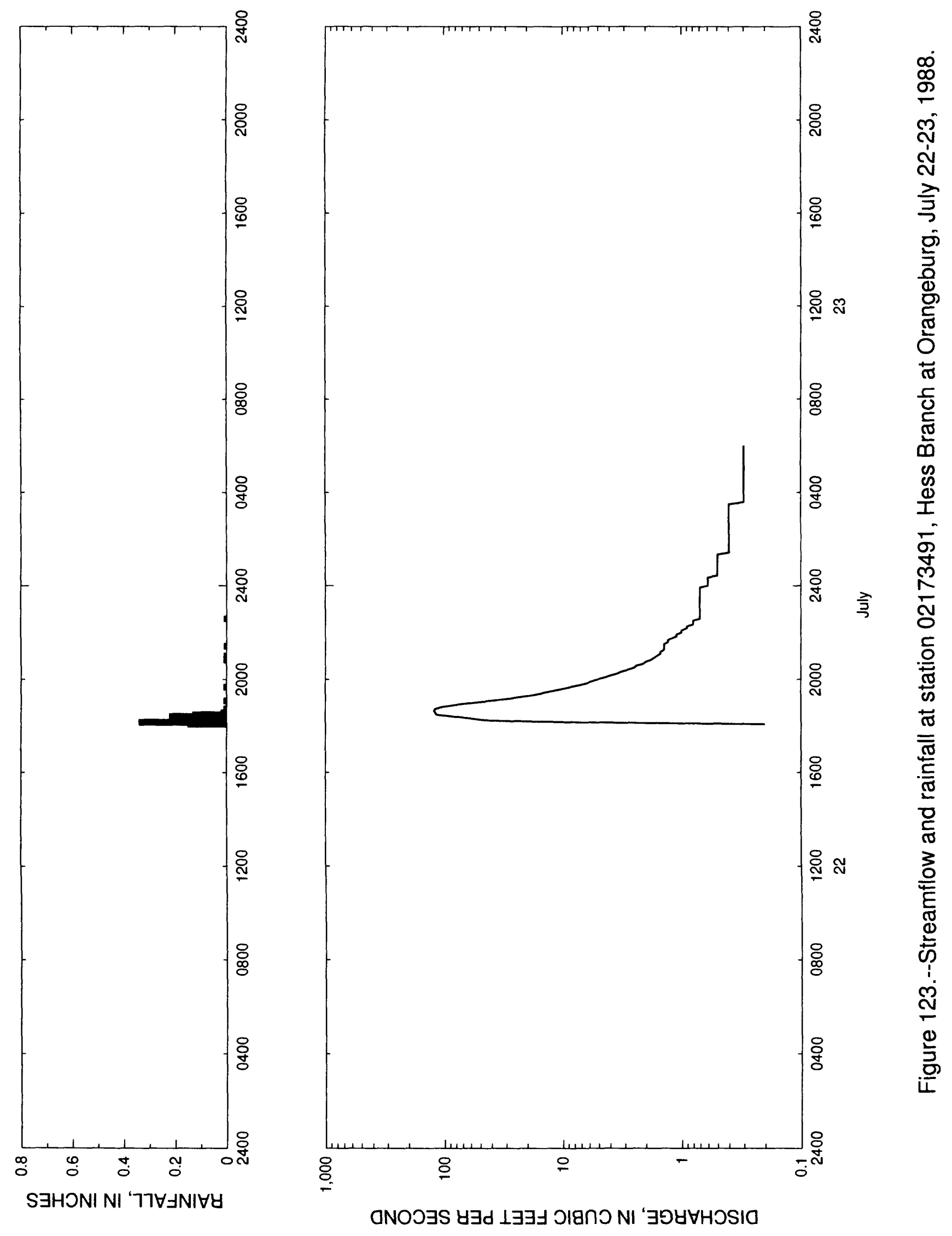


Table 122.--Streamflow and rainfall at station 02173491, Hess Branch at Orangeburg, July $22-23,1988$

\begin{tabular}{|c|c|c|c|c|c|c|c|c|}
\hline $\begin{array}{l}\text { Time } \\
\text { (hours) }\end{array}$ & $\begin{array}{l}\text { Streamflow } \\
\text { (cubic feet } \\
\text { per second) }\end{array}$ & $\begin{array}{l}\text { Rain- } \\
\text { fall } \\
\text { (inches) }\end{array}$ & $\begin{array}{l}\text { Time } \\
\text { (hours) }\end{array}$ & $\begin{array}{l}\text { Streamflow } \\
\text { (cubic feet } \\
\text { per second) }\end{array}$ & $\begin{array}{l}\text { Rain- } \\
\text { fall } \\
\text { (inches) }\end{array}$ & $\begin{array}{l}\text { Time } \\
\text { (hours) }\end{array}$ & $\begin{array}{l}\text { Streamflow } \\
\text { (cubic feet } \\
\text { per second) }\end{array}$ & $\begin{array}{l}\text { Rair- } \\
\text { fall } \\
\text { (incles) }\end{array}$ \\
\hline $\begin{array}{l}\text { July } 22, \\
1805 \\
1810 \\
1815 \\
1820\end{array}$ & $\begin{array}{r}1988 \\
0.2 \\
7.0 \\
42.8 \\
58.4\end{array}$ & $\begin{array}{l}0.15 \\
0.34 \\
0.19 \\
0.14\end{array}$ & $\begin{array}{l}2205 \\
2210 \\
2215 \\
2220 \\
2225\end{array}$ & $\begin{array}{l}1.0 \\
0.9 \\
0.9 \\
0.8 \\
0.8\end{array}$ & $\begin{array}{l}0.00 \\
0.00 \\
0.00 \\
0.00 \\
0.00\end{array}$ & $\begin{array}{l}0205 \\
0210 \\
0215 \\
0220 \\
0225\end{array}$ & $\begin{array}{l}0.4 \\
0.4 \\
0.4 \\
0.4 \\
0.4\end{array}$ & $\begin{array}{l}0.00 \\
0.00 \\
0.00 \\
0.00 \\
0.00\end{array}$ \\
\hline $\begin{array}{l}1825 \\
1830 \\
1835 \\
1840 \\
1845\end{array}$ & $\begin{array}{r}80.6 \\
116.0 \\
119.0 \\
122.0 \\
119.0\end{array}$ & $\begin{array}{l}0.22 \\
0.13 \\
0.02 \\
0.00 \\
0.01\end{array}$ & $\begin{array}{l}2230 \\
2235 \\
2240 \\
2245 \\
2250\end{array}$ & $\begin{array}{l}0.8 \\
0.7 \\
0.7 \\
0.7 \\
0.7\end{array}$ & $\begin{array}{l}0.00 \\
0.01 \\
0.00 \\
0.00 \\
0.00\end{array}$ & $\begin{array}{l}0230 \\
0235 \\
0240 \\
0245 \\
0250\end{array}$ & $\begin{array}{l}0.4 \\
0.4 \\
0.4 \\
0.4 \\
0.4\end{array}$ & $\begin{array}{l}0.00 \\
0.00 \\
0.00 \\
0.00 \\
0.00\end{array}$ \\
\hline $\begin{array}{l}1850 \\
1855 \\
1900 \\
1905 \\
1910\end{array}$ & $\begin{array}{r}105.0 \\
81.9 \\
58.4 \\
41.8 \\
30.4\end{array}$ & $\begin{array}{l}0.00 \\
0.00 \\
0.00 \\
0.01 \\
0.00\end{array}$ & $\begin{array}{l}2255 \\
2300 \\
2305 \\
2310 \\
2315\end{array}$ & $\begin{array}{l}0.7 \\
0.7 \\
0.7 \\
0.7 \\
0.7\end{array}$ & $\begin{array}{l}0.00 \\
0.00 \\
0.00 \\
0.00 \\
0.00\end{array}$ & $\begin{array}{l}0255 \\
0300 \\
0305 \\
0310 \\
0315\end{array}$ & $\begin{array}{l}0.4 \\
0.4 \\
0.4 \\
0.4 \\
0.4\end{array}$ & $\begin{array}{l}0.00 \\
0.00 \\
0.00 \\
0.00 \\
0.00\end{array}$ \\
\hline $\begin{array}{l}1915 \\
1920 \\
1925 \\
1930 \\
1935\end{array}$ & $\begin{array}{l}23.2 \\
18.1 \\
14.8 \\
12.3 \\
10.3\end{array}$ & $\begin{array}{l}0.00 \\
0.00 \\
0.00 \\
0.00 \\
0.00\end{array}$ & $\begin{array}{l}2320 \\
2325 \\
2330 \\
2335 \\
2340\end{array}$ & $\begin{array}{l}0.7 \\
0.7 \\
0.7 \\
0.7 \\
0.7\end{array}$ & $\begin{array}{l}0.00 \\
0.00 \\
0.00 \\
0.00 \\
0.00\end{array}$ & $\begin{array}{l}0320 \\
0325 \\
0330 \\
0335 \\
0340\end{array}$ & $\begin{array}{l}0.4 \\
0.4 \\
0.4 \\
0.3 \\
0.3\end{array}$ & $\begin{array}{l}0.00 \\
0.0 C \\
0.0 C \\
0.0 C \\
0.0 C\end{array}$ \\
\hline $\begin{array}{l}1940 \\
1945 \\
1950 \\
1955 \\
2000\end{array}$ & $\begin{array}{l}8.7 \\
7.3 \\
6.3 \\
5.7 \\
5.1\end{array}$ & $\begin{array}{l}0.01 \\
0.00 \\
0.00 \\
0.00 \\
0.00\end{array}$ & $\begin{array}{l}2345 \\
2350 \\
2355 \\
\text { July } 23 \\
0000\end{array}$ & $\begin{array}{ll} & 0.7 \\
& 0.7 \\
& 0.7 \\
1988 & \\
& 0.6\end{array}$ & $\begin{array}{l}0.00 \\
0.00 \\
0.00 \\
0.00\end{array}$ & $\begin{array}{l}0345 \\
0350 \\
0355 \\
0400 \\
0405\end{array}$ & $\begin{array}{l}0.3 \\
0.3 \\
0.3 \\
0.3 \\
0.3\end{array}$ & $\begin{array}{l}0.0 C \\
0.0 C \\
0.0 C \\
0.0 C \\
0.0 C\end{array}$ \\
\hline $\begin{array}{l}2005 \\
2010 \\
2015 \\
2020 \\
2025\end{array}$ & $\begin{array}{l}4.4 \\
4.0 \\
3.5 \\
3.2 \\
2.8\end{array}$ & $\begin{array}{l}0.00 \\
0.00 \\
0.00 \\
0.00 \\
0.00\end{array}$ & $\begin{array}{l}0005 \\
0010 \\
0015 \\
0020 \\
0025\end{array}$ & $\begin{array}{l}0.6 \\
0.6 \\
0.6 \\
0.6 \\
0.5\end{array}$ & $\begin{array}{l}0.00 \\
0.00 \\
0.00 \\
0.00 \\
0.00\end{array}$ & $\begin{array}{l}0410 \\
0415 \\
0420 \\
0425 \\
0430\end{array}$ & $\begin{array}{l}0.3 \\
0.3 \\
0.3 \\
0.3 \\
0.3\end{array}$ & $\begin{array}{l}0.0 C \\
0.0 C \\
0.0 C \\
0.0 C \\
0.0 C\end{array}$ \\
\hline $\begin{array}{l}2030 \\
2035 \\
2040 \\
2045 \\
2050\end{array}$ & $\begin{array}{l}2.5 \\
2.4 \\
2.1 \\
2.0 \\
1.8\end{array}$ & $\begin{array}{l}0.00 \\
0.00 \\
0.00 \\
0.00 \\
0.01\end{array}$ & $\begin{array}{l}0030 \\
0035 \\
0040 \\
0045 \\
0050\end{array}$ & $\begin{array}{l}0.5 \\
0.5 \\
0.5 \\
0.5 \\
0.5\end{array}$ & $\begin{array}{l}0.00 \\
0.00 \\
0.00 \\
0.00 \\
0.00\end{array}$ & $\begin{array}{l}0435 \\
0440 \\
0445 \\
0450 \\
0455\end{array}$ & $\begin{array}{l}0.3 \\
0.3 \\
0.3 \\
0.3 \\
0.3\end{array}$ & $\begin{array}{l}0.0 C \\
0.0 C \\
0.0 C \\
0.0 C \\
0.0 C\end{array}$ \\
\hline $\begin{array}{l}2055 \\
2100 \\
2105 \\
2110 \\
2115\end{array}$ & $\begin{array}{l}1.7 \\
1.6 \\
1.5 \\
1.5 \\
1.4\end{array}$ & $\begin{array}{l}0.00 \\
0.01 \\
0.00 \\
0.00 \\
0.00\end{array}$ & $\begin{array}{l}0055 \\
0100 \\
0105 \\
0110 \\
0115\end{array}$ & $\begin{array}{l}0.5 \\
0.5 \\
0.5 \\
0.5 \\
0.5\end{array}$ & $\begin{array}{l}0.00 \\
0.00 \\
0.00 \\
0.00 \\
0.00\end{array}$ & $\begin{array}{l}0500 \\
0505 \\
0510 \\
0515 \\
0520\end{array}$ & $\begin{array}{l}0.3 \\
0.3 \\
0.3 \\
0.3 \\
0.3\end{array}$ & $\begin{array}{l}0.0 C \\
0.0 C \\
0.0 C \\
0.0 C \\
0.0 C\end{array}$ \\
\hline $\begin{array}{l}2120 \\
2125 \\
2130 \\
2135 \\
2140\end{array}$ & $\begin{array}{l}1.4 \\
1.4 \\
1.4 \\
1.3 \\
1.3\end{array}$ & $\begin{array}{l}0.00 \\
0.01 \\
0.00 \\
0.00 \\
0.00\end{array}$ & $\begin{array}{l}0120 \\
0125 \\
0130 \\
0135 \\
0140\end{array}$ & $\begin{array}{l}0.5 \\
0.4 \\
0.4 \\
0.4 \\
0.4\end{array}$ & $\begin{array}{l}0.00 \\
0.00 \\
0.00 \\
0.00 \\
0.00\end{array}$ & $\begin{array}{l}0525 \\
0530 \\
0535 \\
0540 \\
0545\end{array}$ & $\begin{array}{l}0.3 \\
0.3 \\
0.3 \\
0.3 \\
0.3\end{array}$ & $\begin{array}{l}0.0 \mathrm{C} \\
0.0 \mathrm{C} \\
0.0 \mathrm{C} \\
0.0 \mathrm{C} \\
0.0 \mathrm{C}\end{array}$ \\
\hline $\begin{array}{l}2145 \\
2150 \\
2155 \\
2200\end{array}$ & $\begin{array}{l}1.2 \\
1.1 \\
1.1 \\
1.0\end{array}$ & $\begin{array}{l}0.00 \\
0.00 \\
0.00 \\
0.00\end{array}$ & $\begin{array}{l}0145 \\
0150 \\
0155 \\
0200\end{array}$ & $\begin{array}{l}0.4 \\
0.4 \\
0.4 \\
0.4\end{array}$ & $\begin{array}{l}0.00 \\
0.00 \\
0.00 \\
0.00\end{array}$ & $\begin{array}{l}0550 \\
0555 \\
0600\end{array}$ & $\begin{array}{l}0.3 \\
0.3 \\
0.3\end{array}$ & $\begin{array}{l}0.0 \mathrm{C} \\
0.0 \mathrm{C} \\
0.0 \mathrm{C}\end{array}$ \\
\hline
\end{tabular}



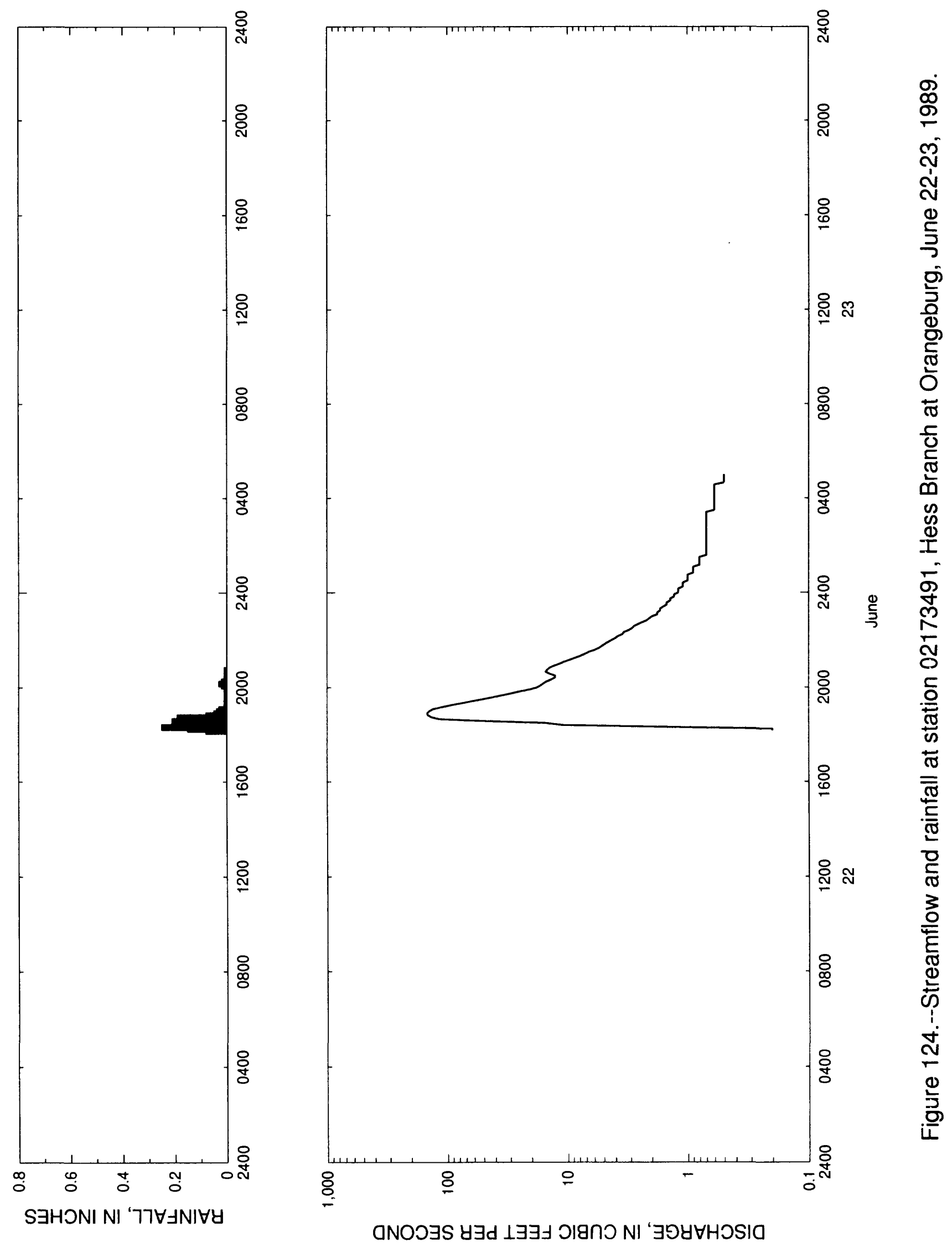
Table 123. - - Streamflow and rainfall at station 02173491, Hess Branch at Orangeburg, June $22-23,1989$

\begin{tabular}{|c|c|c|c|c|c|c|c|c|}
\hline $\begin{array}{l}\text { Time } \\
\text { (hours) }\end{array}$ & $\begin{array}{l}\text { Streamflow } \\
\text { (cubic feet } \\
\text { per second) }\end{array}$ & $\begin{array}{l}\text { Rain- } \\
\text { fall } \\
\text { (inches) }\end{array}$ & $\begin{array}{l}\text { Time } \\
\text { (hours) }\end{array}$ & $\begin{array}{l}\text { Streamflow } \\
\text { (cubic feet } \\
\text { per second) }\end{array}$ & $\begin{array}{l}\text { Rain- } \\
\text { fal1 } \\
\text { (inches) }\end{array}$ & $\begin{array}{l}\text { Time } \\
\text { (hours) }\end{array}$ & $\begin{array}{l}\text { Streamflow } \\
\text { (cubic feet } \\
\text { per second) }\end{array}$ & $\begin{array}{l}\text { Rain- } \\
\text { fall } \\
\text { (inches) }\end{array}$ \\
\hline $\begin{array}{c}\text { June } 22 \text {. } \\
1810 \\
1815 \\
1820 \\
1825\end{array}$ & $\begin{array}{r}1989 \\
0.2 \\
0.2 \\
1.7 \\
11.0\end{array}$ & $\begin{array}{l}0.08 \\
0.15 \\
0.25 \\
0.12\end{array}$ & $\begin{array}{l}2150 \\
2155 \\
2200 \\
2205 \\
2210\end{array}$ & $\begin{array}{l}4.9 \\
4.6 \\
4.3 \\
4.0 \\
3.8\end{array}$ & $\begin{array}{l}0.00 \\
0.00 \\
0.00 \\
0.00 \\
0.00\end{array}$ & $\begin{array}{l}0130 \\
0135 \\
0140 \\
0145 \\
0150\end{array}$ & $\begin{array}{l}0.8 \\
0.7 \\
0.7 \\
0.7 \\
0.7\end{array}$ & $\begin{array}{l}0.00 \\
0.00 \\
0.00 \\
0.00 \\
0.00\end{array}$ \\
\hline $\begin{array}{l}1830 \\
1835 \\
1840 \\
1845 \\
1850\end{array}$ & $\begin{array}{r}15.5 \\
51.8 \\
117.0 \\
136.0 \\
145.0\end{array}$ & $\begin{array}{l}0.10 \\
0.21 \\
0.12 \\
0.19 \\
0.08\end{array}$ & $\begin{array}{l}2215 \\
2220 \\
2225 \\
2230 \\
2235\end{array}$ & $\begin{array}{l}3.5 \\
3.4 \\
3.1 \\
2.9 \\
2.8\end{array}$ & $\begin{array}{l}0.00 \\
0.00 \\
0.00 \\
0.00 \\
0.00\end{array}$ & $\begin{array}{l}0155 \\
0200 \\
0205 \\
0210 \\
0215\end{array}$ & $\begin{array}{l}0.7 \\
0.7 \\
0.7 \\
0.7 \\
0.7\end{array}$ & $\begin{array}{l}0.00 \\
0.00 \\
0.00 \\
0.00 \\
0.00\end{array}$ \\
\hline $\begin{array}{l}1855 \\
1900 \\
1905 \\
1910 \\
1915\end{array}$ & $\begin{array}{r}148.0 \\
142.0 \\
133.0 \\
114.0 \\
95.3\end{array}$ & $\begin{array}{l}0.05 \\
0.04 \\
0.03 \\
0.01 \\
0.01\end{array}$ & $\begin{array}{l}2240 \\
2245 \\
2250 \\
2255 \\
2300\end{array}$ & $\begin{array}{l}2.6 \\
2.4 \\
2.2 \\
2.1 \\
2.0\end{array}$ & $\begin{array}{l}0.00 \\
0.00 \\
0.00 \\
0.00 \\
0.00\end{array}$ & $\begin{array}{l}0220 \\
0225 \\
0230 \\
0235 \\
0240\end{array}$ & $\begin{array}{l}0.7 \\
0.7 \\
0.7 \\
0.7 \\
0.7\end{array}$ & $\begin{array}{l}0.00 \\
0.00 \\
0.00 \\
0.00 \\
0.00\end{array}$ \\
\hline $\begin{array}{l}1920 \\
1925 \\
1930 \\
1935 \\
1940\end{array}$ & $\begin{array}{l}78.4 \\
64.0 \\
51.8 \\
42.8 \\
35.8\end{array}$ & $\begin{array}{l}0.01 \\
0.00 \\
0.01 \\
0.00 \\
0.00\end{array}$ & $\begin{array}{l}2305 \\
2310 \\
2315 \\
2320 \\
2325\end{array}$ & $\begin{array}{l}1.8 \\
1.8 \\
1.7 \\
1.7 \\
1.6\end{array}$ & $\begin{array}{l}0.00 \\
0.00 \\
0.00 \\
0.00 \\
0.00\end{array}$ & $\begin{array}{l}0245 \\
0250 \\
0255 \\
0300 \\
0305\end{array}$ & $\begin{array}{l}0.7 \\
0.7 \\
0.7 \\
0.7 \\
0.7\end{array}$ & $\begin{array}{l}0.00 \\
0.00 \\
0.00 \\
0.00 \\
0.00\end{array}$ \\
\hline $\begin{array}{l}1945 \\
1950 \\
1955 \\
2000 \\
2005\end{array}$ & $\begin{array}{l}29.8 \\
25.1 \\
20.8 \\
18.1 \\
16.9\end{array}$ & $\begin{array}{l}0.01 \\
0.00 \\
0.01 \\
0.01 \\
0.02\end{array}$ & $\begin{array}{l}2330 \\
2335 \\
2340 \\
2345 \\
2350\end{array}$ & $\begin{array}{l}1.5 \\
1.5 \\
1.4 \\
1.4 \\
1.3\end{array}$ & $\begin{array}{l}0.00 \\
0.00 \\
0.00 \\
0.00 \\
0.00\end{array}$ & $\begin{array}{l}0310 \\
0315 \\
0320 \\
0325 \\
0330\end{array}$ & $\begin{array}{l}0.7 \\
0.7 \\
0.7 \\
0.7 \\
0.6\end{array}$ & $\begin{array}{l}0.00 \\
0.00 \\
0.00 \\
0.00 \\
0.00\end{array}$ \\
\hline $\begin{array}{l}2010 \\
2015 \\
2020 \\
2025 \\
2030\end{array}$ & $\begin{array}{l}16.0 \\
15.1 \\
13.7 \\
12.7 \\
12.7\end{array}$ & $\begin{array}{l}0.03 \\
0.02 \\
0.00 \\
0.01 \\
0.01\end{array}$ & $\begin{array}{l}2355 \\
\text { June } 23 \\
0000 \\
0005 \\
0010\end{array}$ & $1989 \begin{array}{l}1.3 \\
1.2 \\
1.2 \\
1.2\end{array}$ & $\begin{array}{l}0.00 \\
0.00 \\
0.00 \\
0.00\end{array}$ & $\begin{array}{l}0335 \\
0340 \\
0345 \\
0350 \\
0355\end{array}$ & $\begin{array}{l}0.6 \\
0.6 \\
0.6 \\
0.6 \\
0.6\end{array}$ & $\begin{array}{l}0.00 \\
0.00 \\
0.00 \\
0.00 \\
0.00\end{array}$ \\
\hline $\begin{array}{l}2035 \\
2040 \\
2045 \\
2050 \\
2055\end{array}$ & $\begin{array}{l}14.2 \\
15.3 \\
14.8 \\
14.2 \\
13.1\end{array}$ & $\begin{array}{l}0.00 \\
0.00 \\
0.01 \\
0.00 \\
0.00\end{array}$ & $\begin{array}{l}0015 \\
0020 \\
0025 \\
0030 \\
0035\end{array}$ & $\begin{array}{l}1.1 \\
1.1 \\
1.1 \\
1.0 \\
1.0\end{array}$ & $\begin{array}{l}0.00 \\
0.00 \\
0.00 \\
0.00 \\
0.00\end{array}$ & $\begin{array}{l}0400 \\
0405 \\
0410 \\
0415 \\
0420\end{array}$ & $\begin{array}{l}0.6 \\
0.6 \\
0.6 \\
0.6 \\
0.6\end{array}$ & $\begin{array}{l}0.00 \\
0.00 \\
0.00 \\
0.00 \\
0.00\end{array}$ \\
\hline $\begin{array}{l}2100 \\
2105 \\
2110 \\
2115 \\
2120\end{array}$ & $\begin{array}{r}11.8 \\
10.8 \\
9.7 \\
8.7 \\
7.8\end{array}$ & $\begin{array}{l}0.00 \\
0.00 \\
0.00 \\
0.00 \\
0.00\end{array}$ & $\begin{array}{l}0040 \\
0045 \\
0050 \\
0055 \\
0100\end{array}$ & $\begin{array}{l}1.0 \\
1.0 \\
0.9 \\
0.9 \\
0.9\end{array}$ & $\begin{array}{l}0.00 \\
0.00 \\
0.00 \\
0.00 \\
0.00\end{array}$ & $\begin{array}{l}0425 \\
0430 \\
0435 \\
0440 \\
0445\end{array}$ & $\begin{array}{l}0.6 \\
0.6 \\
0.6 \\
0.5 \\
0.5\end{array}$ & $\begin{array}{l}0.00 \\
0.00 \\
0.00 \\
0.00 \\
0.00\end{array}$ \\
\hline $\begin{array}{l}2125 \\
2130 \\
2135 \\
2140 \\
2145\end{array}$ & $\begin{array}{l}7.2 \\
6.7 \\
6.0 \\
5.5 \\
5.2\end{array}$ & $\begin{array}{l}0.00 \\
0.00 \\
0.00 \\
0.00 \\
0.00\end{array}$ & $\begin{array}{l}0105 \\
0110 \\
0115 \\
0120 \\
0125\end{array}$ & $\begin{array}{l}0.9 \\
0.8 \\
0.8 \\
0.8 \\
0.8\end{array}$ & $\begin{array}{l}0.00 \\
0.00 \\
0.00 \\
0.00 \\
0.00\end{array}$ & $\begin{array}{l}0450 \\
0455 \\
0500\end{array}$ & $\begin{array}{l}0.5 \\
0.5 \\
0.5\end{array}$ & $\begin{array}{l}0.00 \\
0.00 \\
0.00\end{array}$ \\
\hline
\end{tabular}




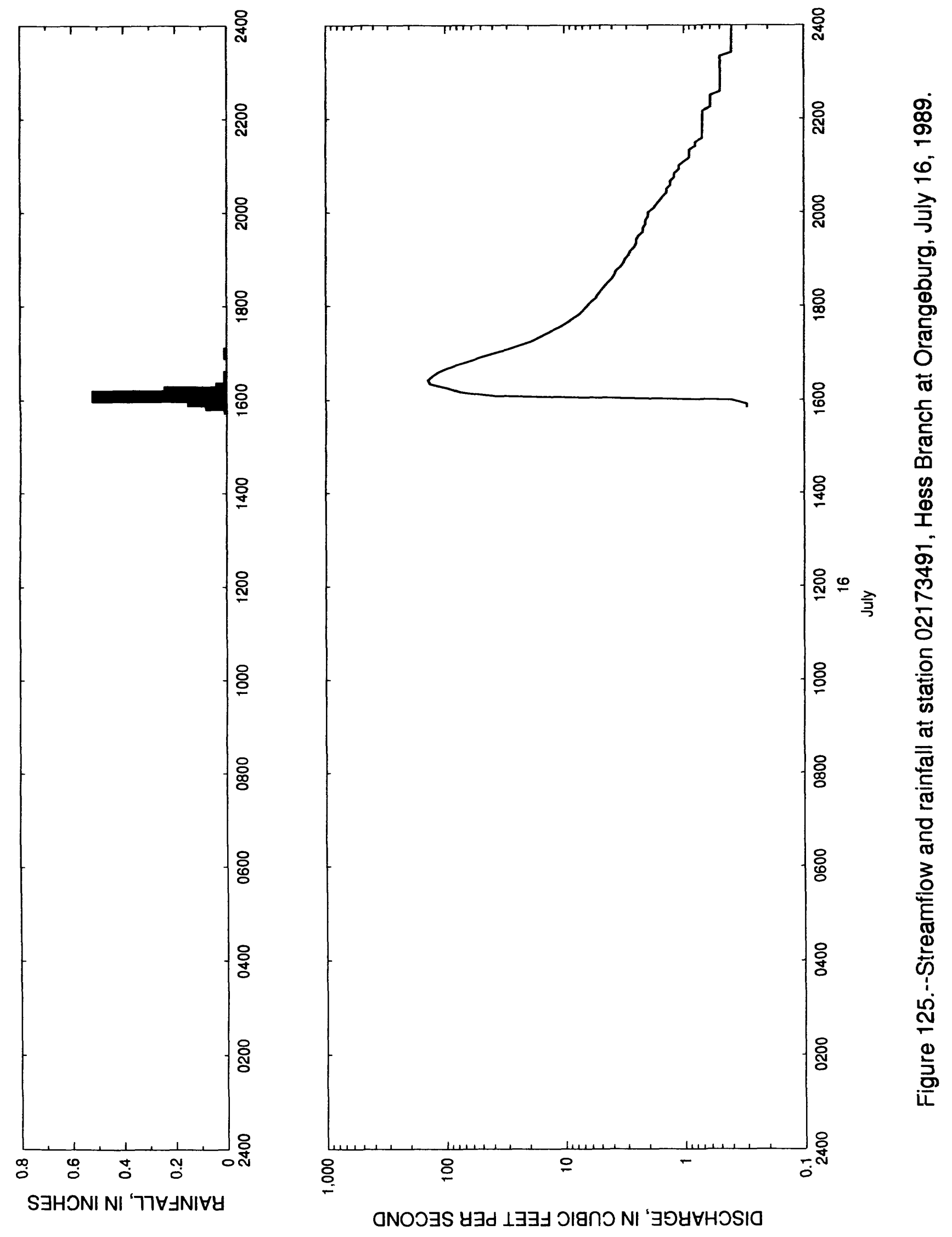


Table 124. - Streamflow and rainfall at station 02173491, Bess Branch at Orangeburg. July 16,1989

\begin{tabular}{|c|c|c|c|c|c|c|c|c|}
\hline $\begin{array}{l}\text { Time } \\
\text { (hours) }\end{array}$ & $\begin{array}{l}\text { Streamflow } \\
\text { (cubic feet } \\
\text { per second) }\end{array}$ & $\begin{array}{l}\text { Rain- } \\
\text { fall } \\
\text { (inches) }\end{array}$ & $\begin{array}{l}\text { Time } \\
\text { (hours) }\end{array}$ & $\begin{array}{l}\text { Streamflow } \\
\text { (cubic feet } \\
\text { per second) }\end{array}$ & $\begin{array}{l}\text { Rain- } \\
\text { fal1 } \\
\text { (inches) }\end{array}$ & $\begin{array}{l}\text { Time } \\
\text { (hours) }\end{array}$ & $\begin{array}{l}\text { Streamflow } \\
\text { (cubic feet } \\
\text { per second) }\end{array}$ & $\begin{array}{l}\text { Rain- } \\
\text { fall } \\
\text { (inchea) }\end{array}$ \\
\hline $\begin{array}{l}\text { July } 16 \\
1550 \\
1555 \\
1600 \\
1605\end{array}$ & $1989 \begin{array}{r}0.3 \\
0.3 \\
0.4 \\
37.7\end{array}$ & $\begin{array}{l}0.01 \\
0.08 \\
0.15 \\
0.52\end{array}$ & $\begin{array}{l}1835 \\
1840 \\
1845 \\
1850 \\
1855\end{array}$ & $\begin{array}{l}4.0 \\
3.8 \\
3.7 \\
3.4 \\
3.2\end{array}$ & $\begin{array}{l}0.00 \\
0.00 \\
0.00 \\
0.00 \\
0.00\end{array}$ & $\begin{array}{l}2125 \\
2130 \\
2135 \\
2140 \\
2145\end{array}$ & $\begin{array}{l}0.8 \\
0.8 \\
0.7 \\
0.7 \\
0.7\end{array}$ & $\begin{array}{l}0.00 \\
0.00 \\
0.00 \\
0.00 \\
0.00\end{array}$ \\
\hline $\begin{array}{l}1610 \\
1615 \\
1620 \\
1625 \\
1630\end{array}$ & $\begin{array}{r}74.4 \\
96.7 \\
135.0 \\
140.0 \\
129.0\end{array}$ & $\begin{array}{l}0.24 \\
0.04 \\
0.01 \\
0.00 \\
0.01\end{array}$ & $\begin{array}{l}1900 \\
1905 \\
1910 \\
1915 \\
1920\end{array}$ & $\begin{array}{l}3.1 \\
2.9 \\
2.8 \\
2.6 \\
2.5\end{array}$ & $\begin{array}{l}0.00 \\
0.00 \\
0.00 \\
0.00 \\
0.00\end{array}$ & $\begin{array}{l}2150 \\
2155 \\
2200 \\
2205 \\
2210\end{array}$ & $\begin{array}{l}0.7 \\
0.7 \\
0.7 \\
0.7 \\
0.7\end{array}$ & $\begin{array}{l}0.00 \\
0.00 \\
0.00 \\
0.00 \\
0.00\end{array}$ \\
\hline $\begin{array}{l}1635 \\
1640 \\
1645 \\
1650 \\
1655\end{array}$ & $\begin{array}{r}116.0 \\
97.7 \\
78.4 \\
62.3 \\
49.6\end{array}$ & $\begin{array}{l}0.00 \\
0.00 \\
0.00 \\
0.00 \\
0.00\end{array}$ & $\begin{array}{l}1925 \\
1930 \\
1935 \\
1940 \\
1945\end{array}$ & $\begin{array}{l}2.5 \\
2.4 \\
2.2 \\
2.2 \\
2.1\end{array}$ & $\begin{array}{l}0.00 \\
0.00 \\
0.00 \\
0.00 \\
0.00\end{array}$ & $\begin{array}{l}2215 \\
2220 \\
2225 \\
2230 \\
2235\end{array}$ & $\begin{array}{l}0.6 \\
0.6 \\
0.6 \\
0.6 \\
0.5\end{array}$ & $\begin{array}{l}0.00 \\
0.00 \\
0.00 \\
0.00 \\
0.00\end{array}$ \\
\hline $\begin{array}{l}1700 \\
1705 \\
1710 \\
1715 \\
1720\end{array}$ & $\begin{array}{l}38.4 \\
29.2 \\
23.7 \\
19.0 \\
16.4\end{array}$ & $\begin{array}{l}0.01 \\
0.00 \\
0.00 \\
0.00 \\
0.00\end{array}$ & $\begin{array}{l}1950 \\
1955 \\
2000 \\
2005 \\
2010\end{array}$ & $\begin{array}{l}2.1 \\
2.0 \\
2.0 \\
1.8 \\
1.7\end{array}$ & $\begin{array}{l}0.00 \\
0.00 \\
0.00 \\
0.00 \\
0.00\end{array}$ & $\begin{array}{l}2240 \\
2245 \\
2250 \\
2255 \\
2300\end{array}$ & $\begin{array}{l}0.5 \\
0.5 \\
0.5 \\
0.5 \\
0.5\end{array}$ & $\begin{array}{l}0.00 \\
0.00 \\
0.00 \\
0.00 \\
0.00\end{array}$ \\
\hline $\begin{array}{l}1725 \\
1730 \\
1735 \\
1740 \\
1745\end{array}$ & $\begin{array}{r}14.2 \\
12.3 \\
10.5 \\
9.3 \\
8.4\end{array}$ & $\begin{array}{l}0.00 \\
0.00 \\
0.00 \\
0.00 \\
0.00\end{array}$ & $\begin{array}{l}2015 \\
2020 \\
2025 \\
2030 \\
2035\end{array}$ & $\begin{array}{l}1.6 \\
1.5 \\
1.4 \\
1.4 \\
1.3\end{array}$ & $\begin{array}{l}0.00 \\
0.00 \\
0.00 \\
0.00 \\
0.00\end{array}$ & $\begin{array}{l}2305 \\
2310 \\
2315 \\
2320 \\
2325\end{array}$ & $\begin{array}{l}0.5 \\
0.5 \\
0.5 \\
0.5 \\
0.4\end{array}$ & $\begin{array}{l}0.00 \\
0.00 \\
0.00 \\
0.00 \\
0.00\end{array}$ \\
\hline $\begin{array}{l}1750 \\
1755 \\
1800 \\
1805 \\
1810\end{array}$ & $\begin{array}{l}7.5 \\
7.0 \\
6.5 \\
6.0 \\
5.5\end{array}$ & $\begin{array}{l}0.00 \\
0.00 \\
0.00 \\
0.00 \\
0.00\end{array}$ & $\begin{array}{l}2040 \\
2045 \\
2050 \\
2055 \\
2100\end{array}$ & $\begin{array}{l}1.3 \\
1.2 \\
1.2 \\
1.1 \\
1.1\end{array}$ & $\begin{array}{l}0.00 \\
0.00 \\
0.00 \\
0.00 \\
0.00\end{array}$ & $\begin{array}{l}2330 \\
2335 \\
2340 \\
2345 \\
2350\end{array}$ & $\begin{array}{l}0.4 \\
0.4 \\
0.4 \\
0.4 \\
0.4\end{array}$ & $\begin{array}{l}0.00 \\
0.00 \\
0.00 \\
0.00 \\
0.00\end{array}$ \\
\hline $\begin{array}{l}1815 \\
1820 \\
1825 \\
1830\end{array}$ & $\begin{array}{l}5.2 \\
4.9 \\
4.6 \\
4.3\end{array}$ & $\begin{array}{l}0.00 \\
0.00 \\
0.00 \\
0.00\end{array}$ & $\begin{array}{l}2105 \\
2110 \\
2115 \\
2120\end{array}$ & $\begin{array}{l}1.0 \\
0.9 \\
0.9 \\
0.9\end{array}$ & $\begin{array}{l}0.00 \\
0.00 \\
0.00 \\
0.00\end{array}$ & 2355 & 0.4 & 0.00 \\
\hline
\end{tabular}




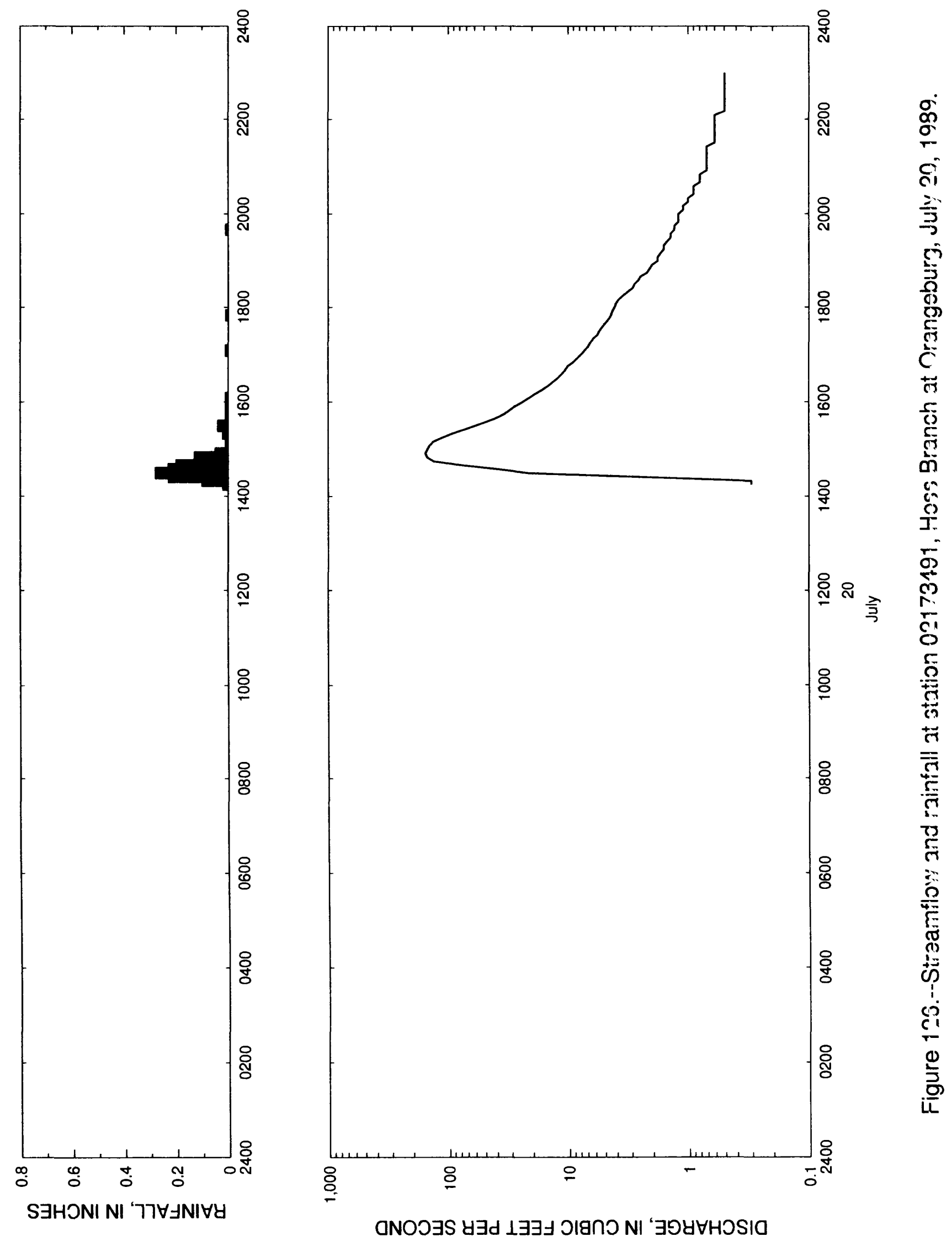


Table 125.--Streamflow and rainfall at station 02173491 , Hess Branch at Orangeburg. July 20,1989

\begin{tabular}{|c|c|c|c|c|c|c|c|c|}
\hline $\begin{array}{l}\text { Time } \\
\text { (hours) }\end{array}$ & $\begin{array}{l}\text { Streamflow } \\
\text { (cubic feet } \\
\text { per second) }\end{array}$ & $\begin{array}{l}\text { Rain- } \\
\text { fall } \\
\text { (inches) }\end{array}$ & $\begin{array}{l}\text { Time } \\
\text { (hours) }\end{array}$ & $\begin{array}{l}\text { Streamflow } \\
\text { (cubic feet } \\
\text { per second) }\end{array}$ & $\begin{array}{l}\text { Rain- } \\
\text { fall } \\
\text { (inches) }\end{array}$ & $\begin{array}{l}\text { Time } \\
\text { (hours) }\end{array}$ & $\begin{array}{l}\text { Streamflow } \\
\text { (cubic feet } \\
\text { per second) }\end{array}$ & $\begin{array}{l}\text { Rain- } \\
\text { fall } \\
\text { (inches) }\end{array}$ \\
\hline $\begin{array}{l}\text { July } 20 \\
1415 \\
1420 \\
1425 \\
1430\end{array}$ & $\begin{array}{r}1989 \\
0.3 \\
0.3 \\
2.4 \\
21.3\end{array}$ & $\begin{array}{l}0.02 \\
0.10 \\
0.23 \\
0.28\end{array}$ & $\begin{array}{l}1710 \\
1715 \\
1720 \\
1725 \\
1730\end{array}$ & $\begin{array}{l}6.8 \\
6.5 \\
6.2 \\
5.7 \\
5.5\end{array}$ & $\begin{array}{l}0.00 \\
0.00 \\
0.00 \\
0.00 \\
0.00\end{array}$ & $\begin{array}{l}2010 \\
2015 \\
2020 \\
2025 \\
2030\end{array}$ & $\begin{array}{l}1.1 \\
1.0 \\
1.0 \\
0.9 \\
0.9\end{array}$ & $\begin{array}{l}0.00 \\
0.00 \\
0.00 \\
0.00 \\
0.00\end{array}$ \\
\hline $\begin{array}{l}1435 \\
1440 \\
14.45 \\
1450 \\
1455\end{array}$ & $\begin{array}{r}39.4 \\
78.4 \\
133.0 \\
150.0 \\
156.0\end{array}$ & $\begin{array}{l}0.23 \\
0.20 \\
0.06 \\
0.13 \\
0.05\end{array}$ & $\begin{array}{l}1735 \\
1740 \\
1745 \\
1750 \\
1755\end{array}$ & $\begin{array}{l}5.2 \\
4.9 \\
4.6 \\
4.4 \\
4.3\end{array}$ & $\begin{array}{l}0.00 \\
0.00 \\
0.00 \\
0.01 \\
0.00\end{array}$ & $\begin{array}{l}2035 \\
2040 \\
2045 \\
2050 \\
2055\end{array}$ & $\begin{array}{l}0.9 \\
0.8 \\
0.8 \\
0.8 \\
0.7\end{array}$ & $\begin{array}{l}0.00 \\
0.00 \\
0.00 \\
0.00 \\
0.00\end{array}$ \\
\hline $\begin{array}{l}1500 \\
1505 \\
1510 \\
1515 \\
1520\end{array}$ & $\begin{array}{r}150.0 \\
144.0 \\
134.0 \\
113.0 \\
93.9\end{array}$ & $\begin{array}{l}0.00 \\
0.00 \\
0.01 \\
0.00 \\
0.02\end{array}$ & $\begin{array}{l}1800 \\
1805 \\
1810 \\
1815 \\
1820\end{array}$ & $\begin{array}{l}4.1 \\
4.0 \\
3.8 \\
3.5 \\
3.2\end{array}$ & $\begin{array}{l}0.00 \\
0.00 \\
0.00 \\
0.00 \\
0.00\end{array}$ & $\begin{array}{l}2100 \\
2105 \\
2110 \\
2115 \\
2120\end{array}$ & $\begin{array}{l}0.7 \\
0.7 \\
0.7 \\
0.7 \\
0.7\end{array}$ & $\begin{array}{l}0.00 \\
0.00 \\
0.00 \\
0.00 \\
0.00\end{array}$ \\
\hline $\begin{array}{l}1525 \\
1530 \\
1535 \\
1540 \\
1545\end{array}$ & $\begin{array}{l}74.0 \\
59.5 \\
47.8 \\
39.4 \\
33.8\end{array}$ & $\begin{array}{l}0.02 \\
0.04 \\
0.01 \\
0.00 \\
0.01\end{array}$ & $\begin{array}{l}1825 \\
1830 \\
1835 \\
1840 \\
1845\end{array}$ & $\begin{array}{l}2.9 \\
2.8 \\
2.6 \\
2.5 \\
2.2\end{array}$ & $\begin{array}{l}0.00 \\
0.00 \\
0.00 \\
0.00 \\
0.00\end{array}$ & $\begin{array}{l}2125 \\
2130 \\
2135 \\
2140 \\
2145\end{array}$ & $\begin{array}{l}0.7 \\
0.6 \\
0.6 \\
0.6 \\
0.6\end{array}$ & $\begin{array}{l}0.00 \\
0.00 \\
0.00 \\
0.00 \\
0.00\end{array}$ \\
\hline $\begin{array}{l}1550 \\
1555 \\
1600 \\
1605 \\
1610\end{array}$ & $\begin{array}{l}30.4 \\
27.4 \\
24.0 \\
21.3 \\
19.0\end{array}$ & $\begin{array}{l}0.00 \\
0.01 \\
0.00 \\
0.01 \\
0.00\end{array}$ & $\begin{array}{l}1850 \\
1855 \\
1900 \\
1905 \\
1910\end{array}$ & $\begin{array}{l}2.1 \\
2.0 \\
1.8 \\
1.8 \\
1.7\end{array}$ & $\begin{array}{l}0.00 \\
0.00 \\
0.00 \\
0.00 \\
0.00\end{array}$ & $\begin{array}{l}2150 \\
2155 \\
2200 \\
2205 \\
2210\end{array}$ & $\begin{array}{l}0.6 \\
0.6 \\
0.6 \\
0.6 \\
0.5\end{array}$ & $\begin{array}{l}0.00 \\
0.00 \\
0.00 \\
0.00 \\
0.00\end{array}$ \\
\hline $\begin{array}{l}1615 \\
1620 \\
1625 \\
1630 \\
1635\end{array}$ & $\begin{array}{l}16.6 \\
14.8 \\
13.5 \\
12.3 \\
11.4\end{array}$ & $\begin{array}{l}0.00 \\
0.00 \\
0.00 \\
0.00 \\
0.00\end{array}$ & $\begin{array}{l}1915 \\
1920 \\
1925 \\
1930 \\
1935\end{array}$ & $\begin{array}{l}1.6 \\
1.6 \\
1.5 \\
1.4 \\
1.4\end{array}$ & $\begin{array}{l}0.00 \\
0.00 \\
0.00 \\
0.00 \\
0.00\end{array}$ & $\begin{array}{l}2215 \\
2220 \\
2225 \\
2230 \\
2235\end{array}$ & $\begin{array}{l}0.5 \\
0.5 \\
0.5 \\
0.5 \\
0.5\end{array}$ & $\begin{array}{l}0.00 \\
0.00 \\
0.00 \\
0.00 \\
0.00\end{array}$ \\
\hline $\begin{array}{l}1640 \\
1645 \\
1650 \\
1655 \\
1700\end{array}$ & $\begin{array}{r}10.6 \\
10.1 \\
9.1 \\
8.4 \\
7.8\end{array}$ & $\begin{array}{l}0.00 \\
0.00 \\
0.00 \\
0.00 \\
0.00\end{array}$ & $\begin{array}{l}1940 \\
1945 \\
1950 \\
1955 \\
2000\end{array}$ & $\begin{array}{l}1.3 \\
1.3 \\
1.2 \\
1.2 \\
1.2\end{array}$ & $\begin{array}{l}0.01 \\
0.00 \\
0.00 \\
0.00 \\
0.00\end{array}$ & $\begin{array}{l}2240 \\
2245 \\
2250 \\
2255 \\
2300\end{array}$ & $\begin{array}{l}0.5 \\
0.5 \\
0.5 \\
0.5 \\
0.5\end{array}$ & $\begin{array}{l}0.00 \\
0.00 \\
0.00 \\
0.00 \\
0.00\end{array}$ \\
\hline 1705 & 7.3 & 0.01 & 2005 & 1.1 & 0.00 & & & \\
\hline
\end{tabular}




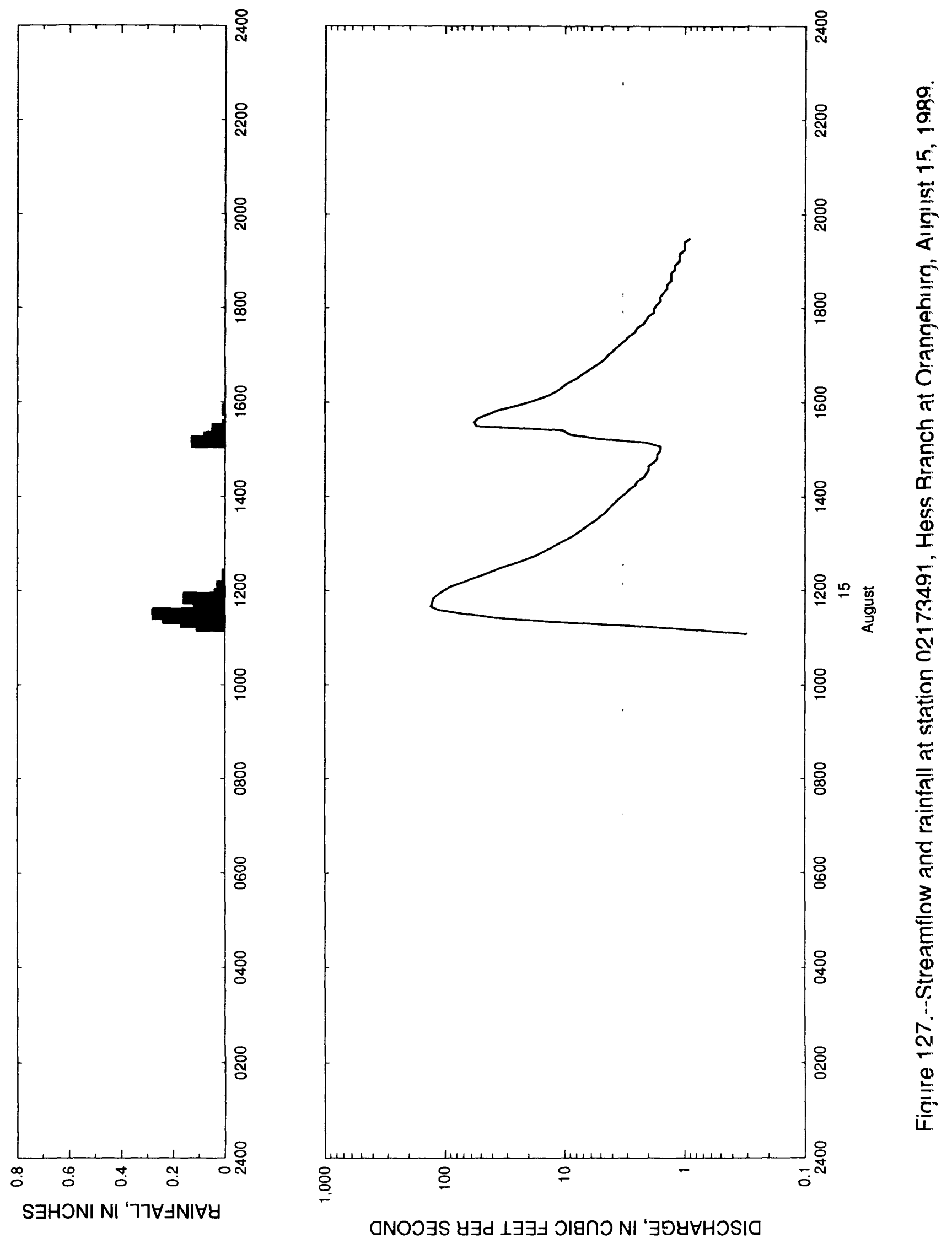


Table 126. --Streamflow and rainfall at station 02173491, Hess Branch at Orangeburg. August 15,1989

\begin{tabular}{|c|c|c|c|c|c|c|c|c|}
\hline $\begin{array}{l}\text { Time } \\
\text { (hours) }\end{array}$ & $\begin{array}{l}\text { Streamflow } \\
\text { (cubic feet } \\
\text { per second) }\end{array}$ & $\begin{array}{l}\text { Rain- } \\
\text { fall } \\
\text { (inches) }\end{array}$ & $\begin{array}{l}\text { Time } \\
\text { (hours) }\end{array}$ & $\begin{array}{l}\text { Streamflow } \\
\text { (cubic feet } \\
\text { per second) }\end{array}$ & $\begin{array}{l}\text { Rain- } \\
\text { fall } \\
\text { (inches) }\end{array}$ & $\begin{array}{l}\text { Time } \\
\text { (hours) }\end{array}$ & $\begin{array}{l}\text { Streamflow } \\
\text { (cubic feet } \\
\text { per second) }\end{array}$ & $\begin{array}{l}\text { Rain- } \\
\text { fall } \\
\text { (in?hes) }\end{array}$ \\
\hline $\begin{array}{l}\text { August } \\
1105 \\
1110 \\
1115 \\
1120\end{array}$ & 15. $\begin{array}{r}1989 \\
0.3 \\
0.8 \\
2.4 \\
11.6\end{array}$ & $\begin{array}{l}0.00 \\
0.00 \\
0.11 \\
0.17\end{array}$ & $\begin{array}{l}1355 \\
1400 \\
1405 \\
1410 \\
1415\end{array}$ & $\begin{array}{l}3.7 \\
3.4 \\
3.1 \\
2.9 \\
2.6\end{array}$ & $\begin{array}{l}0.00 \\
0.00 \\
0.00 \\
0.00 \\
0.00\end{array}$ & $\begin{array}{l}1650 \\
1655 \\
1700 \\
1705 \\
1710\end{array}$ & $\begin{array}{l}5.2 \\
4.7 \\
4.4 \\
4.0 \\
3.7\end{array}$ & $\begin{array}{l}0.00 \\
0.00 \\
0.00 \\
0.00 \\
0.00\end{array}$ \\
\hline $\begin{array}{l}1125 \\
1130 \\
1135 \\
1140 \\
1145\end{array}$ & $\begin{array}{r}34.2 \\
63.1 \\
110.0 \\
131.0 \\
128.0\end{array}$ & $\begin{array}{l}0.24 \\
0.28 \\
0.08 \\
0.12 \\
0.02\end{array}$ & $\begin{array}{l}1420 \\
1425 \\
1430 \\
1435 \\
1440\end{array}$ & $\begin{array}{l}2.5 \\
2.2 \\
2.1 \\
2.0 \\
2.0\end{array}$ & $\begin{array}{l}0.00 \\
0.00 \\
0.00 \\
0.00 \\
0.00\end{array}$ & $\begin{array}{l}1715 \\
1720 \\
1725 \\
1730 \\
1735\end{array}$ & $\begin{array}{l}3.4 \\
3.1 \\
2.9 \\
2.6 \\
2.5\end{array}$ & $\begin{array}{l}0.00 \\
0.00 \\
0.00 \\
0.00 \\
0.00\end{array}$ \\
\hline $\begin{array}{l}1150 \\
1155 \\
1200 \\
1205 \\
1210\end{array}$ & $\begin{array}{r}126.0 \\
116.0 \\
103.0 \\
91.1 \\
74.0\end{array}$ & $\begin{array}{l}0.16 \\
0.04 \\
0.00 \\
0.03 \\
0.01\end{array}$ & $\begin{array}{l}1445 \\
1450 \\
1455 \\
1500 \\
1505\end{array}$ & $\begin{array}{l}1.8 \\
1.7 \\
1.7 \\
1.6 \\
1.6\end{array}$ & $\begin{array}{l}0.00 \\
0.00 \\
0.00 \\
0.00 \\
0.00\end{array}$ & $\begin{array}{l}1740 \\
1745 \\
1750 \\
1755 \\
1800\end{array}$ & $\begin{array}{l}2.2 \\
2.1 \\
2.0 \\
1.8 \\
1.8\end{array}$ & $\begin{array}{l}0.00 \\
0.00 \\
0.00 \\
0.00 \\
0.00\end{array}$ \\
\hline $\begin{array}{l}1215 \\
1220 \\
1225 \\
1230 \\
1235\end{array}$ & $\begin{array}{l}60.3 \\
48.9 \\
40.4 \\
33.2 \\
26.6\end{array}$ & $\begin{array}{l}0.00 \\
0.01 \\
0.00 \\
0.00 \\
0.00\end{array}$ & $\begin{array}{l}1510 \\
1515 \\
1520 \\
1525 \\
1530\end{array}$ & $\begin{array}{r}2.1 \\
5.2 \\
9.1 \\
10.5 \\
54.5\end{array}$ & $\begin{array}{l}0.13 \\
0.08 \\
0.05 \\
0.05 \\
0.01\end{array}$ & $\begin{array}{l}1805 \\
1810 \\
1815 \\
1820 \\
1825\end{array}$ & $\begin{array}{l}1.7 \\
1.6 \\
1.6 \\
1.5 \\
1.4\end{array}$ & $\begin{array}{l}0.00 \\
0.00 \\
0.00 \\
0.00 \\
0.00\end{array}$ \\
\hline $\begin{array}{l}1240 \\
1245 \\
1250 \\
1255 \\
1300\end{array}$ & $\begin{array}{l}21.3 \\
17.3 \\
15.1 \\
13.1 \\
11.4\end{array}$ & $\begin{array}{l}0.00 \\
0.00 \\
0.00 \\
0.00 \\
0.00\end{array}$ & $\begin{array}{l}1535 \\
1540 \\
1545 \\
1550 \\
1555\end{array}$ & $\begin{array}{l}57.6 \\
53.0 \\
44.2 \\
36.1 \\
27.1\end{array}$ & $\begin{array}{l}0.00 \\
0.00 \\
0.00 \\
0.01 \\
0.00\end{array}$ & $\begin{array}{l}1830 \\
1835 \\
1840 \\
1845 \\
1850\end{array}$ & $\begin{array}{l}1.4 \\
1.3 \\
1.3 \\
1.3 \\
1.2\end{array}$ & $\begin{array}{l}0.00 \\
0.00 \\
0.00 \\
0.00 \\
0.00\end{array}$ \\
\hline $\begin{array}{l}1305 \\
1310 \\
1315 \\
1320 \\
1325\end{array}$ & $\begin{array}{l}9.9 \\
8.6 \\
7.7 \\
6.8 \\
6.2\end{array}$ & $\begin{array}{l}0.00 \\
0.00 \\
0.00 \\
0.00 \\
0.00\end{array}$ & $\begin{array}{l}1600 \\
1605 \\
1610 \\
1615 \\
1620\end{array}$ & $\begin{array}{l}20.3 \\
16.4 \\
13.5 \\
11.6 \\
10.5\end{array}$ & $\begin{array}{l}0.00 \\
0.00 \\
0.00 \\
0.00 \\
0.00\end{array}$ & $\begin{array}{l}1855 \\
1900 \\
1905 \\
1910 \\
1915\end{array}$ & $\begin{array}{l}1.2 \\
1.1 \\
1.1 \\
1.1 \\
1.0\end{array}$ & $\begin{array}{l}0.00 \\
0.00 \\
0.00 \\
0.00 \\
0.00\end{array}$ \\
\hline $\begin{array}{l}1330 \\
1335 \\
1340 \\
1345 \\
1350\end{array}$ & $\begin{array}{l}5.5 \\
5.1 \\
4.6 \\
4.3 \\
4.0\end{array}$ & $\begin{array}{l}0.00 \\
0.00 \\
0.00 \\
0.00 \\
0.00\end{array}$ & $\begin{array}{l}1625 \\
1630 \\
1635 \\
1640 \\
1645\end{array}$ & $\begin{array}{l}9.5 \\
8.2 \\
7.3 \\
6.5 \\
5.8\end{array}$ & $\begin{array}{l}0.00 \\
0.00 \\
0.00 \\
0.00 \\
0.00\end{array}$ & $\begin{array}{l}1920 \\
1925 \\
1930\end{array}$ & $\begin{array}{l}1.0 \\
1.0 \\
0.9\end{array}$ & $\begin{array}{l}0.00 \\
0.00 \\
0.00\end{array}$ \\
\hline
\end{tabular}




\section{Station 02173495, Sunnyside Canal at Orangeburg, S.C.}

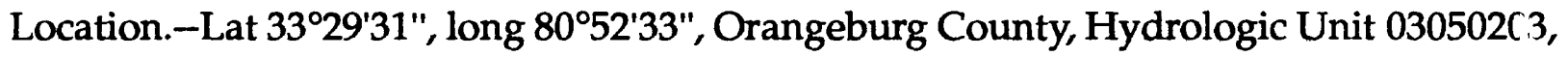
at bridge on Riverside Street (State secondary road 125), $0.7 \mathrm{mi}$ west of Orangeburg City Hall, and $0.2 \mathrm{mi}$ upstream from the mouth at the North Fork Edisto River.

Period of record.- November 14, 1985 to October 19, 1990.

Gage.-Digital stage recorder with 5-minute punch interval. The recorder is housed in a metal shelter atop a stilling well attached to the upstream side of the bridge over the concrete-lined channel.

Rating.-The stage-streamflow relation is defined by current meter measurements up to approximately $600 \mathrm{ft}^{3} / \mathrm{s}$. The stage-streamflow relation was extended to $1,175 \mathrm{ft}^{3} / \mathrm{s}$ graphically on logarithmic paper.

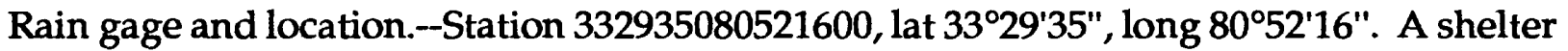
containing a digital cumulative rainfall recorder with a 5-minute punch interval attached to the left downstream wingwall at a culvert on Waring Street (State secondary road 248), $0.5 \mathrm{mi}$ northwest of Orangeburg City Hall, and about $0.4 \mathrm{mi}$ upstream from the mouth at the North Fork Edisto River.

Selected basin characteristics.-

Drainage area $-1.07 \mathrm{mi}^{2}$

Physiographic province - Inner Coastal Plain

Channel slope $-67.4 \mathrm{ft} / \mathrm{mi}$

Channel length $-1.44 \mathrm{mi}$

Total impervious area -37.0 percent

Basin development factor -8

2-year, 2-hour rainfall amount -- 2.20 in.

\begin{tabular}{|c|c|c|}
\hline \multirow[t]{7}{*}{ Flood frequency data: } & $\mathrm{UQ}_{2}$ & $554 \mathrm{ft}^{3} / \mathrm{s}$ \\
\hline & $\mathrm{UQ}_{5}$ & $852 \mathrm{ft}^{3} / \mathrm{s}$ \\
\hline & $\mathrm{UQ}_{10}$ & $1,040 \mathrm{ft}^{3} / \mathrm{s}$ \\
\hline & $\mathrm{UQ}_{25}$ & $1,260 \mathrm{ft}^{3} / \mathrm{s}$ \\
\hline & $\mathrm{UQ}_{50}$ & $1,410 \mathrm{ft}^{3} / \mathrm{s}$ \\
\hline & $\mathrm{UQ}_{100}$ & $1,550 \mathrm{ft}^{3} / \mathrm{s}$ \\
\hline & $\mathrm{UQ}_{500}$ & $1,870 \mathrm{ft}^{3} / \mathrm{s}$ \\
\hline
\end{tabular}



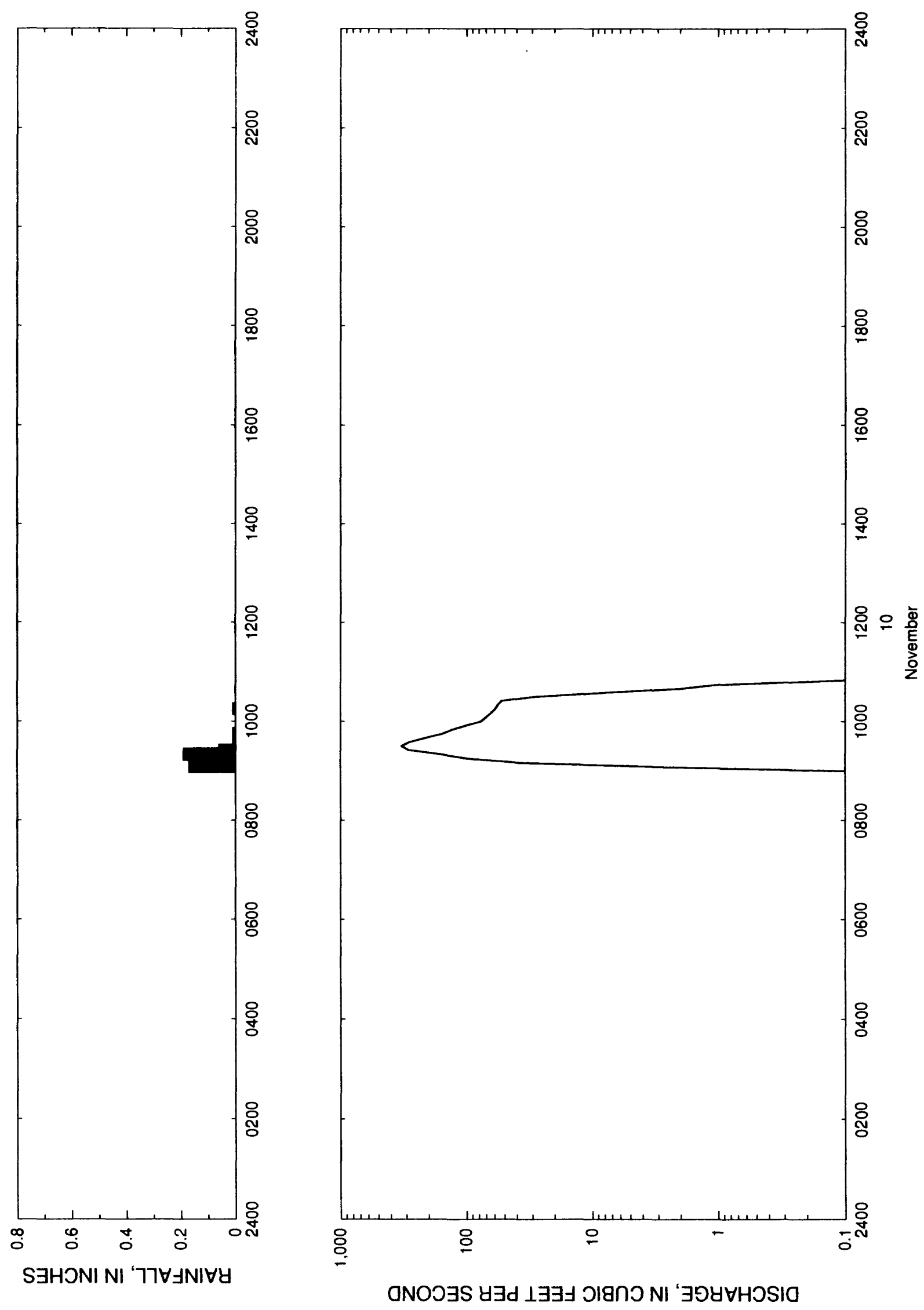

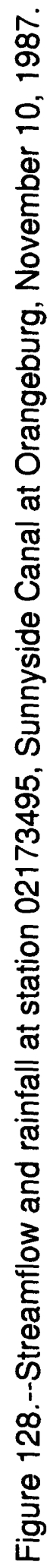
aNOOتS $y \exists d 1 \exists \exists \exists$ כ 
Table 127.- - Streamflow and rainfa11 at station 02173495, Sunnyside Canal at Orangeburg. November 10,1987

\begin{tabular}{|c|c|c|c|c|c|c|c|c|}
\hline $\begin{array}{l}\text { Time } \\
\text { (hours) }\end{array}$ & $\begin{array}{l}\text { Streamflow } \\
\text { (cubic feet } \\
\text { per second) }\end{array}$ & $\begin{array}{l}\text { Rain- } \\
\text { fall } \\
\text { (inches) }\end{array}$ & $\begin{array}{l}\text { Time } \\
\text { (hours) }\end{array}$ & $\begin{array}{l}\text { Streamflow } \\
\text { (cubic feet } \\
\text { per second) }\end{array}$ & $\begin{array}{l}\text { Rain- } \\
\text { fall } \\
\text { (inches) }\end{array}$ & $\begin{array}{l}\text { Time } \\
\text { (hours) }\end{array}$ & $\begin{array}{l}\text { Streamflow } \\
\text { (cubic feet } \\
\text { per second) }\end{array}$ & $\begin{array}{l}\text { Rain- } \\
\text { fall } \\
\text { (inche) }\end{array}$ \\
\hline $\begin{array}{l}\text { November } \\
0900 \\
0905 \\
0910 \\
0915\end{array}$ & $\begin{array}{r}1987 \\
0.1 \\
3.0 \\
38.8 \\
99.3\end{array}$ & $\begin{array}{l}0.00 \\
0.17 \\
0.13 \\
0.16\end{array}$ & $\begin{array}{l}0940 \\
0945 \\
0950 \\
0955 \\
1000\end{array}$ & $\begin{array}{r}212.0 \\
155.0 \\
132.0 \\
102.0 \\
76.8\end{array}$ & $\begin{array}{l}0.00 \\
0.01 \\
0.00 \\
0.00 \\
0.00\end{array}$ & $\begin{array}{l}1025 \\
1030 \\
1035 \\
1040 \\
1045\end{array}$ & $\begin{array}{r}52.6 \\
28.8 \\
8.2 \\
2.0 \\
1.0\end{array}$ & $\begin{array}{l}0.00 \\
0.00 \\
0.00 \\
0.00 \\
0.00\end{array}$ \\
\hline $\begin{array}{l}0920 \\
0925 \\
0930 \\
0935\end{array}$ & $\begin{array}{l}163.0 \\
290.0 \\
331.0 \\
285.0\end{array}$ & $\begin{array}{l}0.19 \\
0.06 \\
0.01 \\
0.00\end{array}$ & $\begin{array}{l}1005 \\
1010 \\
1015 \\
1020\end{array}$ & $\begin{array}{l}69.8 \\
63.8 \\
59.4 \\
56.3\end{array}$ & $\begin{array}{l}0.00 \\
0.00 \\
0.01 \\
0.00\end{array}$ & $\begin{array}{l}1050 \\
1055 \\
1100\end{array}$ & $\begin{array}{l}0.1 \\
0.1 \\
0.1\end{array}$ & $\begin{array}{l}0.00 \\
0.00 \\
0.00\end{array}$ \\
\hline
\end{tabular}




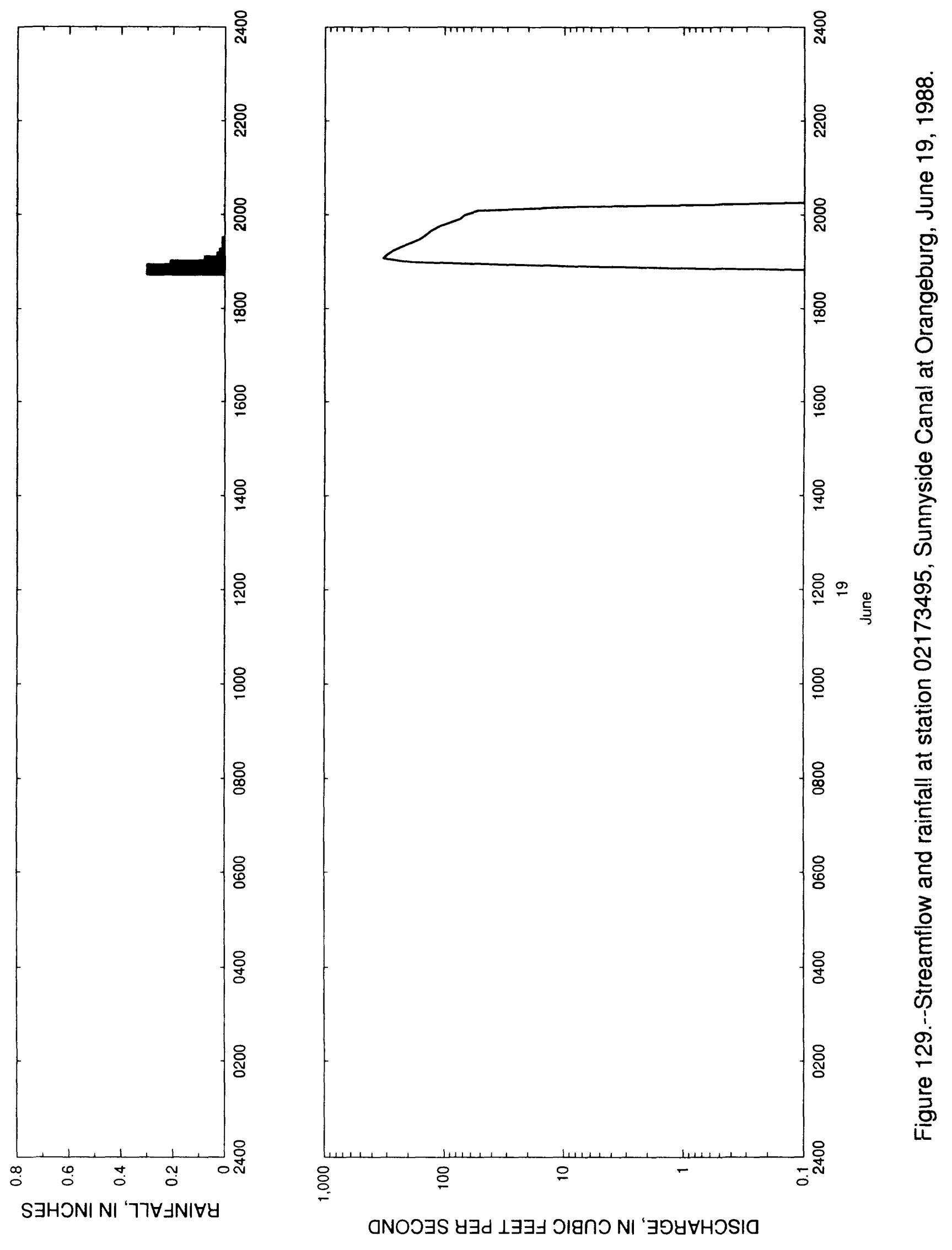


Table 128.--Streamflow and rainfal1 at station 02173495, Sunnyside Canal at Orangeburg, June 19,1988

\begin{tabular}{|c|c|c|c|c|c|c|c|c|}
\hline $\begin{array}{l}\text { Time } \\
\text { (hours) }\end{array}$ & $\begin{array}{l}\text { Streamflow } \\
\text { (cubic feet } \\
\text { per second) }\end{array}$ & $\begin{array}{l}\text { Rain- } \\
\text { fall } \\
\text { (inches) }\end{array}$ & $\begin{array}{l}\text { Time } \\
\text { (hours) }\end{array}$ & $\begin{array}{l}\text { Streamflow } \\
\text { (cubic feet } \\
\text { per second) }\end{array}$ & $\begin{array}{l}\text { Rain- } \\
\text { fall } \\
\text { (inches) }\end{array}$ & $\begin{array}{l}\text { Time } \\
\text { (hours) }\end{array}$ & $\begin{array}{l}\text { Streamflow } \\
\text { (cubic feet } \\
\text { per second) }\end{array}$ & $\begin{array}{l}\text { Rain- } \\
\text { fall } \\
\text { (inches) }\end{array}$ \\
\hline $\begin{array}{l}\text { June } 19, \\
1850 \\
1855 \\
1900 \\
1905\end{array}$ & $\begin{array}{r}1988 \quad 0.1 \\
10.0 \\
191.0 \\
328.0\end{array}$ & $\begin{array}{l}0.30 \\
0.21 \\
0.08 \\
0.03\end{array}$ & $\begin{array}{l}1935 \\
1940 \\
1945 \\
1950 \\
1955\end{array}$ & $\begin{array}{r}143.0 \\
131.0 \\
114.0 \\
91.4 \\
74.3\end{array}$ & $\begin{array}{l}0.00 \\
0.00 \\
0.00 \\
0.00 \\
0.00\end{array}$ & $\begin{array}{l}2025 \\
2030 \\
2035 \\
2040 \\
2045\end{array}$ & $\begin{array}{l}0.1 \\
0.1 \\
0.1 \\
0.1 \\
0.1\end{array}$ & $\begin{array}{l}0.00 \\
0.00 \\
0.00 \\
0.00 \\
0.00\end{array}$ \\
\hline $\begin{array}{l}1910 \\
1915 \\
1920 \\
1925 \\
1930\end{array}$ & $\begin{array}{l}299.0 \\
267.0 \\
226.0 \\
187.0 \\
159.0\end{array}$ & $\begin{array}{l}0.02 \\
0.01 \\
0.00 \\
0.01 \\
0.00\end{array}$ & $\begin{array}{l}2000 \\
2005 \\
2010 \\
2015 \\
2020\end{array}$ & $\begin{array}{r}68.1 \\
52.6 \\
8.2 \\
0.1 \\
0.1\end{array}$ & $\begin{array}{l}0.00 \\
0.00 \\
0.00 \\
0.00 \\
0.00\end{array}$ & $\begin{array}{l}2050 \\
2055 \\
2100\end{array}$ & $\begin{array}{l}0.1 \\
0.1 \\
0.1\end{array}$ & $\begin{array}{l}0.00 \\
0.00 \\
0.00\end{array}$ \\
\hline
\end{tabular}




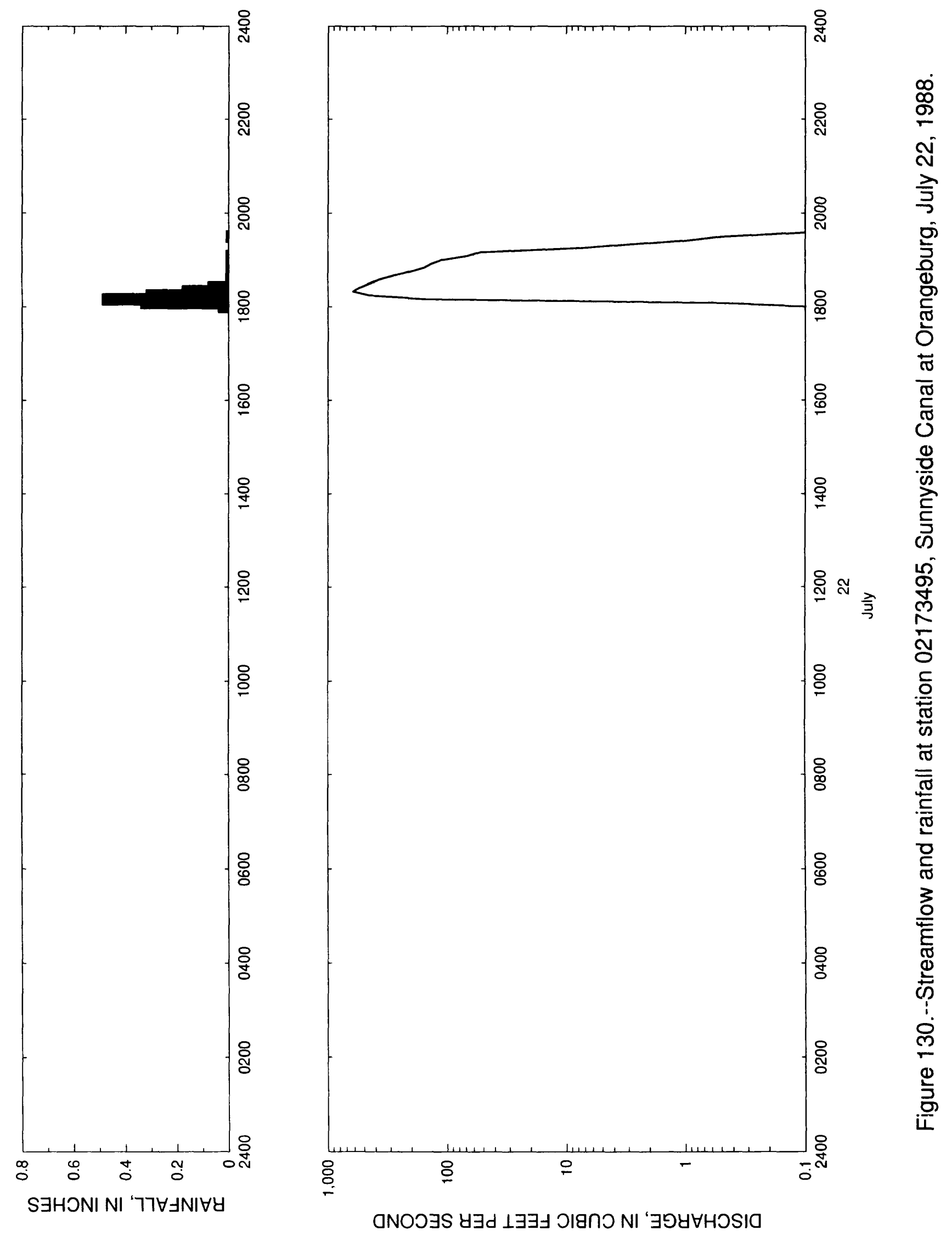


Table 129. - Streamflow and rainfa11 at station 02173495, Sunnyside Canai at Orangeburg, July 22,1988

\begin{tabular}{|c|c|c|c|c|c|c|c|c|}
\hline $\begin{array}{l}\text { Time } \\
\text { (hours) }\end{array}$ & $\begin{array}{l}\text { Streamflow } \\
\text { (cubic feet } \\
\text { per second) }\end{array}$ & $\begin{array}{l}\text { Rain- } \\
\text { fall } \\
\text { (inches) }\end{array}$ & $\begin{array}{l}\text { Time } \\
\text { (hours) }\end{array}$ & $\begin{array}{l}\text { Streamflow } \\
\text { (cubic feet } \\
\text { per second) }\end{array}$ & $\begin{array}{l}\text { Rain- } \\
\text { fall } \\
\text { (inches) }\end{array}$ & $\begin{array}{l}\text { Time } \\
\text { (hours) }\end{array}$ & $\begin{array}{l}\text { Streamflow } \\
\text { (cubic feet } \\
\text { per second) }\end{array}$ & $\begin{array}{l}\text { Rain- } \\
\text { fall } \\
\text { (inches) }\end{array}$ \\
\hline $\begin{array}{l}\text { July } 22, \\
1800 \\
1805 \\
1810 \\
1815\end{array}$ & $\begin{array}{r}1988 \\
0.1 \\
0.5 \\
148.0 \\
458.0\end{array}$ & $\begin{array}{l}0.04 \\
0.34 \\
0.49 \\
0.32\end{array}$ & $\begin{array}{l}1840 \\
1845 \\
1850 \\
1855 \\
1900\end{array}$ & $\begin{array}{l}280.0 \\
206.0 \\
157.0 \\
136.0 \\
110.0\end{array}$ & $\begin{array}{l}0.00 \\
0.00 \\
0.01 \\
0.00 \\
0.00\end{array}$ & $\begin{array}{l}1925 \\
1930 \\
1935 \\
1940 \\
1945\end{array}$ & $\begin{array}{l}1.0 \\
0.5 \\
0.1 \\
0.1 \\
0.1\end{array}$ & $\begin{array}{l}0.00 \\
0.01 \\
0.00 \\
0.00 \\
0.00\end{array}$ \\
\hline $\begin{array}{l}1820 \\
1825 \\
1830 \\
1835\end{array}$ & $\begin{array}{l}618.0 \\
545.0 \\
446.0 \\
372.0\end{array}$ & $\begin{array}{l}0.18 \\
0.08 \\
0.01 \\
0.01\end{array}$ & $\begin{array}{l}1905 \\
1910 \\
1915 \\
1920\end{array}$ & $\begin{array}{r}68.1 \\
52.6 \\
8.2 \\
3.0\end{array}$ & $\begin{array}{l}0.01 \\
0.00 \\
0.00 \\
0.00\end{array}$ & $\begin{array}{l}1950 \\
1955 \\
2000\end{array}$ & $\begin{array}{l}0.1 \\
0.1 \\
0.1\end{array}$ & $\begin{array}{l}0.00 \\
0.00 \\
0.00\end{array}$ \\
\hline
\end{tabular}



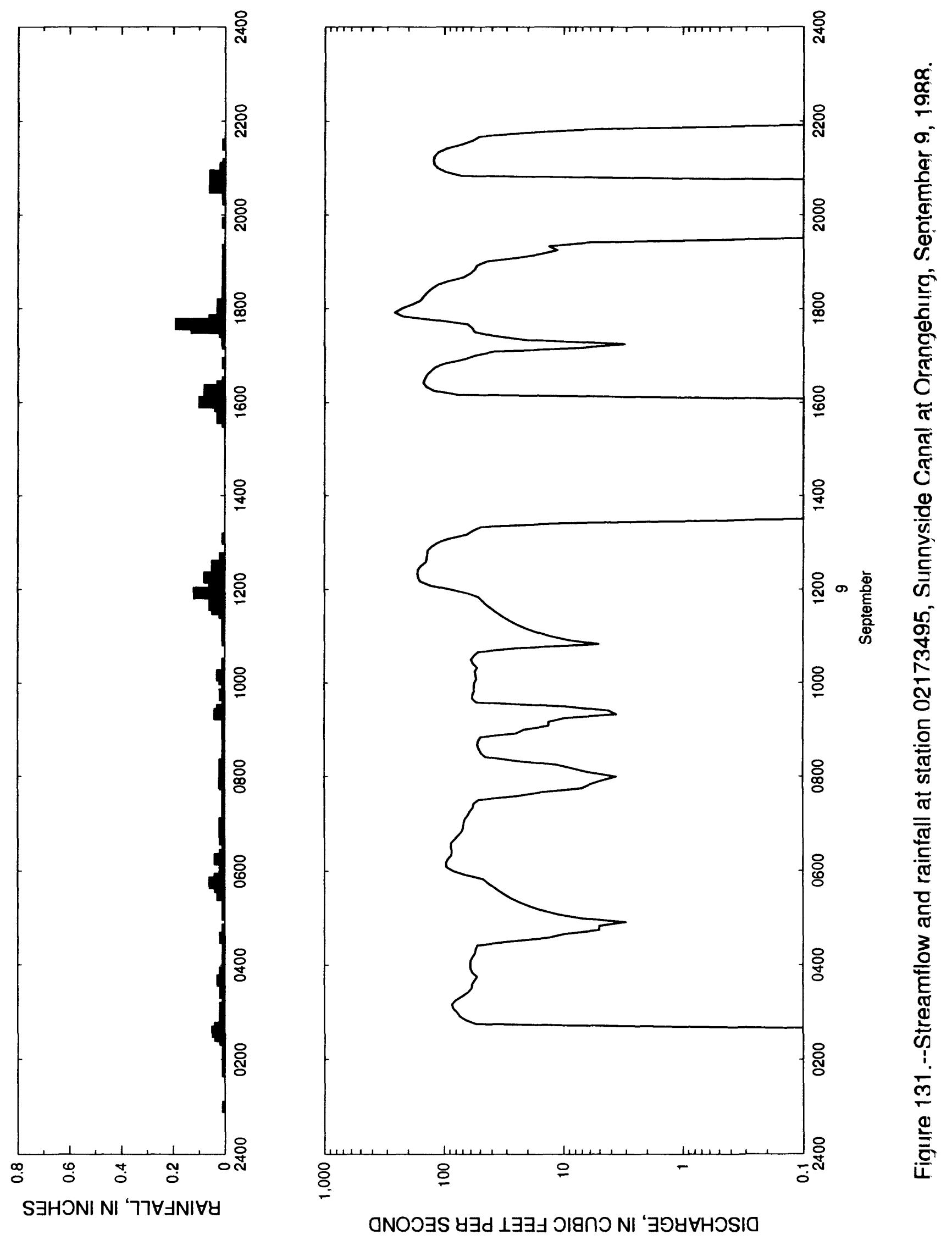
Table 130.--Streamflow and rainfall at station 02173495. Sunnyside Canal at Orangeburg. September 9, 1988

\begin{tabular}{|c|c|c|c|c|c|c|c|c|}
\hline $\begin{array}{l}\text { Time } \\
\text { (hours) }\end{array}$ & $\begin{array}{l}\text { Streamflow } \\
\text { (cubic feet } \\
\text { per second) }\end{array}$ & $\begin{array}{l}\text { Rain- } \\
\text { fall } \\
\text { (inches) }\end{array}$ & $\begin{array}{l}\text { Time } \\
\text { (hours) }\end{array}$ & $\begin{array}{l}\text { Streamflow } \\
\text { (cubic feet } \\
\text { per second) }\end{array}$ & $\begin{array}{l}\text { Rain- } \\
\text { fall } \\
\text { (inches) }\end{array}$ & $\begin{array}{l}\text { Time } \\
\text { (hours) }\end{array}$ & $\begin{array}{l}\text { Streamflow } \\
\text { (cubic feet } \\
\text { per second) }\end{array}$ & $\begin{array}{l}\text { Rain- } \\
\text { fall } \\
\text { (inches) }\end{array}$ \\
\hline $\begin{array}{l}\text { September } \\
0100 \\
0105 \\
0110 \\
0115\end{array}$ & $\begin{array}{r}1988 \\
0.1 \\
0.1 \\
0.1 \\
0.1\end{array}$ & $\begin{array}{l}0.01 \\
0.00 \\
0.00 \\
0.00\end{array}$ & $\begin{array}{l}0620 \\
0625 \\
0630 \\
0635 \\
0640\end{array}$ & $\begin{array}{l}86.5 \\
86.1 \\
87.7 \\
87.3 \\
81.3\end{array}$ & $\begin{array}{l}0.02 \\
0.01 \\
0.01 \\
0.01 \\
0.02\end{array}$ & $\begin{array}{l}1145 \\
1150 \\
1155 \\
1200 \\
1205\end{array}$ & $\begin{array}{r}47.9 \\
51.8 \\
63.8 \\
87.7 \\
130.0\end{array}$ & $\begin{array}{l}0.05 \\
0.03 \\
0.12 \\
0.06 \\
0.03\end{array}$ \\
\hline $\begin{array}{l}0120 \\
0125 \\
0130 \\
0135 \\
0140\end{array}$ & $\begin{array}{l}0.1 \\
0.1 \\
0.1 \\
0.1 \\
0.1\end{array}$ & $\begin{array}{l}0.00 \\
0.00 \\
0.00 \\
0.00 \\
0.00\end{array}$ & $\begin{array}{l}0645 \\
0650 \\
0655 \\
0700 \\
0705\end{array}$ & $\begin{array}{l}75.5 \\
70.6 \\
68.9 \\
68.1 \\
66.8\end{array}$ & $\begin{array}{l}0.02 \\
0.02 \\
0.00 \\
0.02 \\
0.01\end{array}$ & $\begin{array}{l}1210 \\
1215 \\
1220 \\
1225 \\
1230\end{array}$ & $\begin{array}{l}158.0 \\
165.0 \\
167.0 \\
166.0 \\
157.0\end{array}$ & $\begin{array}{l}0.06 \\
0.08 \\
0.02 \\
0.01 \\
0.05\end{array}$ \\
\hline $\begin{array}{l}0145 \\
0150 \\
0155 \\
0200 \\
0205\end{array}$ & $\begin{array}{l}0.1 \\
0.1 \\
0.1 \\
0.1 \\
0.1\end{array}$ & $\begin{array}{l}0.01 \\
0.00 \\
0.01 \\
0.00 \\
0.00\end{array}$ & $\begin{array}{l}0710 \\
0715 \\
0720 \\
0725 \\
0730\end{array}$ & $\begin{array}{l}62.9 \\
60.7 \\
57.2 \\
56.3 \\
51.0\end{array}$ & $\begin{array}{l}0.01 \\
0.00 \\
0.01 \\
0.00 \\
0.01\end{array}$ & $\begin{array}{l}1235 \\
1240 \\
1245 \\
1250 \\
1255\end{array}$ & $\begin{array}{l}143.0 \\
140.0 \\
139.0 \\
138.0 \\
128.0\end{array}$ & $\begin{array}{l}0.02 \\
0.02 \\
0.00 \\
0.00 \\
0.00\end{array}$ \\
\hline $\begin{array}{l}0210 \\
0215 \\
0220 \\
0225 \\
0230\end{array}$ & $\begin{array}{l}0.1 \\
0.1 \\
0.1 \\
0.1 \\
0.1\end{array}$ & $\begin{array}{l}0.01 \\
0.01 \\
0.01 \\
0.02 \\
0.04\end{array}$ & $\begin{array}{l}0735 \\
0740 \\
0745 \\
0750 \\
0755\end{array}$ & $\begin{array}{r}24.8 \\
15.6 \\
7.0 \\
5.9 \\
4.7\end{array}$ & $\begin{array}{l}0.00 \\
0.01 \\
0.01 \\
0.02 \\
0.01\end{array}$ & $\begin{array}{l}1300 \\
1305 \\
1310 \\
1315 \\
1320\end{array}$ & $\begin{array}{r}114.0 \\
90.6 \\
64.7 \\
57.7 \\
48.9\end{array}$ & $\begin{array}{l}0.00 \\
0.01 \\
0.00 \\
0.00 \\
0.00\end{array}$ \\
\hline $\begin{array}{l}0235 \\
0240 \\
0245 \\
0250 \\
0255\end{array}$ & $\begin{array}{r}0.1 \\
0.1 \\
53.4 \\
65.6 \\
73.9\end{array}$ & $\begin{array}{l}0.05 \\
0.04 \\
0.02 \\
0.02 \\
0.02\end{array}$ & $\begin{array}{l}0800 \\
0805 \\
0810 \\
0815 \\
0820\end{array}$ & $\begin{array}{r}3.6 \\
5.9 \\
8.2 \\
11.4 \\
24.8\end{array}$ & $\begin{array}{l}0.02 \\
0.01 \\
0.01 \\
0.02 \\
0.01\end{array}$ & $\begin{array}{l}1325 \\
1330 \\
1335 \\
1340 \\
1345\end{array}$ & $\begin{array}{r}10.0 \\
0.1 \\
0.1 \\
0.1 \\
0.1\end{array}$ & $\begin{array}{l}0.00 \\
0.00 \\
0.00 \\
0.00 \\
0.00\end{array}$ \\
\hline $\begin{array}{l}0300 \\
0305 \\
0310 \\
0315 \\
0320\end{array}$ & $\begin{array}{l}78.0 \\
84.1 \\
85.7 \\
80.4 \\
71.4\end{array}$ & $\begin{array}{l}0.01 \\
0.02 \\
0.01 \\
0.01 \\
0.01\end{array}$ & $\begin{array}{l}0825 \\
0830 \\
0835 \\
0840 \\
0845\end{array}$ & $\begin{array}{l}45.0 \\
48.9 \\
51.0 \\
52.6 \\
51.8\end{array}$ & $\begin{array}{l}0.01 \\
0.01 \\
0.00 \\
0.01 \\
0.01\end{array}$ & $\begin{array}{l}1350 \\
1355 \\
1400 \\
1405 \\
1410\end{array}$ & $\begin{array}{l}0.1 \\
0.1 \\
0.1 \\
0.1 \\
0.1\end{array}$ & $\begin{array}{l}0.00 \\
0.00 \\
0.00 \\
0.00 \\
0.00\end{array}$ \\
\hline $\begin{array}{l}0325 \\
0330 \\
0335 \\
0340 \\
0345\end{array}$ & $\begin{array}{l}62.9 \\
59.0 \\
58.1 \\
55.4 \\
52.6\end{array}$ & $\begin{array}{l}0.02 \\
0.01 \\
0.02 \\
0.03 \\
0.01\end{array}$ & $\begin{array}{l}0850 \\
0855 \\
0900 \\
0905 \\
0910\end{array}$ & $\begin{array}{l}48.9 \\
24.8 \\
21.3 \\
13.3 \\
13.3\end{array}$ & $\begin{array}{l}0.01 \\
0.01 \\
0.01 \\
0.01 \\
0.00\end{array}$ & $\begin{array}{l}1415 \\
1420 \\
1425 \\
1430 \\
1435\end{array}$ & $\begin{array}{l}0.1 \\
0.1 \\
0.1 \\
0.1 \\
0.1\end{array}$ & $\begin{array}{l}0.00 \\
0.00 \\
0.00 \\
0.00 \\
0.00\end{array}$ \\
\hline $\begin{array}{l}0350 \\
0355 \\
0400 \\
0405 \\
0410\end{array}$ & $\begin{array}{l}57.7 \\
59.9 \\
60.3 \\
59.9 \\
57.7\end{array}$ & $\begin{array}{l}0.02 \\
0.01 \\
0.01 \\
0.01 \\
0.01\end{array}$ & $\begin{array}{l}0915 \\
0920 \\
0925 \\
0930 \\
0935\end{array}$ & $\begin{array}{r}9.7 \\
3.6 \\
4.2 \\
9.7 \\
53.4\end{array}$ & $\begin{array}{l}0.01 \\
0.04 \\
0.03 \\
0.01 \\
0.00\end{array}$ & $\begin{array}{l}1440 \\
1445 \\
1450 \\
1455 \\
1500\end{array}$ & $\begin{array}{l}0.1 \\
0.1 \\
0.1 \\
0.1 \\
0.1\end{array}$ & $\begin{array}{l}0.00 \\
0.00 \\
0.00 \\
0.00 \\
0.00\end{array}$ \\
\hline $\begin{array}{l}0415 \\
0420 \\
0425 \\
0430 \\
0435\end{array}$ & $\begin{array}{l}55.0 \\
54.2 \\
52.6 \\
28.8 \\
13.3\end{array}$ & $\begin{array}{l}0.00 \\
0.01 \\
0.01 \\
0.00 \\
0.02\end{array}$ & $\begin{array}{l}0940 \\
0945 \\
0950 \\
0955 \\
1000\end{array}$ & $\begin{array}{l}58.1 \\
57.7 \\
55.9 \\
55.9 \\
55.4\end{array}$ & $\begin{array}{l}0.01 \\
0.02 \\
0.01 \\
0.01 \\
0.00\end{array}$ & $\begin{array}{l}1505 \\
1510 \\
1515 \\
1520 \\
1525\end{array}$ & $\begin{array}{l}0.1 \\
0.1 \\
0.1 \\
0.1 \\
0.1\end{array}$ & $\begin{array}{l}0.00 \\
0.00 \\
0.00 \\
0.00 \\
0.00\end{array}$ \\
\hline $\begin{array}{l}0440 \\
0445 \\
0450 \\
0455 \\
0500\end{array}$ & $\begin{array}{l}9.7 \\
5.0 \\
5.0 \\
3.0 \\
7.0\end{array}$ & $\begin{array}{l}0.00 \\
0.01 \\
0.00 \\
0.00 \\
0.00\end{array}$ & $\begin{array}{l}1005 \\
1010 \\
1015 \\
1020 \\
1025\end{array}$ & $\begin{array}{l}53.4 \\
54.2 \\
55.0 \\
52.6 \\
57.2\end{array}$ & $\begin{array}{l}0.02 \\
0.03 \\
0.00 \\
0.00 \\
0.01\end{array}$ & $\begin{array}{l}1530 \\
1535 \\
1540 \\
1545 \\
1550\end{array}$ & $\begin{array}{l}0.1 \\
0.1 \\
0.1 \\
0.1 \\
0.1\end{array}$ & $\begin{array}{l}0.00 \\
0.01 \\
0.03 \\
0.01 \\
0.01\end{array}$ \\
\hline $\begin{array}{l}0505 \\
0510 \\
0515 \\
0520 \\
0525\end{array}$ & $\begin{array}{l}11.0 \\
15.0 \\
19.0 \\
23.0 \\
27.0\end{array}$ & $\begin{array}{l}0.01 \\
0.00 \\
0.01 \\
0.01 \\
0.01\end{array}$ & $\begin{array}{l}1030 \\
1035 \\
1040 \\
1045 \\
1050\end{array}$ & $\begin{array}{r}59.4 \\
56.3 \\
51.8 \\
24.8 \\
5.0\end{array}$ & $\begin{array}{l}0.00 \\
0.00 \\
0.00 \\
0.00 \\
0.00\end{array}$ & $\begin{array}{l}1555 \\
1600 \\
1605 \\
1610 \\
1615\end{array}$ & $\begin{array}{r}0.1 \\
0.1 \\
0.1 \\
77.2 \\
121.0\end{array}$ & $\begin{array}{l}0.04 \\
0.10 \\
0.06 \\
0.05 \\
0.08\end{array}$ \\
\hline $\begin{array}{l}0530 \\
0535 \\
0540 \\
0545 \\
0550\end{array}$ & $\begin{array}{l}31.0 \\
35.0 \\
38.9 \\
42.9 \\
46.9\end{array}$ & $\begin{array}{l}0.03 \\
0.03 \\
0.04 \\
0.06 \\
0.04\end{array}$ & $\begin{array}{l}1055 \\
1100 \\
1105 \\
1110 \\
1115\end{array}$ & $\begin{array}{r}8.9 \\
12.8 \\
16.7 \\
20.6 \\
24.5\end{array}$ & $\begin{array}{l}0.01 \\
0.01 \\
0.00 \\
0.00 \\
0.01\end{array}$ & $\begin{array}{l}1620 \\
1625 \\
1630 \\
1635 \\
1640\end{array}$ & $\begin{array}{l}141.0 \\
150.0 \\
146.0 \\
140.0 \\
130.0\end{array}$ & $\begin{array}{l}0.03 \\
0.01 \\
0.00 \\
0.00 \\
0.00\end{array}$ \\
\hline $\begin{array}{l}0555 \\
0600 \\
0605 \\
0610 \\
0615\end{array}$ & $\begin{array}{l}66.4 \\
83.3 \\
95.4 \\
96.2 \\
92.6\end{array}$ & $\begin{array}{l}0.02 \\
0.01 \\
0.01 \\
0.02 \\
0.04\end{array}$ & $\begin{array}{l}1120 \\
1125 \\
1130 \\
1135 \\
1140\end{array}$ & $\begin{array}{l}28.4 \\
32.3 \\
36.2 \\
40.1 \\
44.0\end{array}$ & $\begin{array}{l}0.00 \\
0.00 \\
0.02 \\
0.05 \\
0.06\end{array}$ & $\begin{array}{l}1645 \\
1650 \\
1655 \\
1700 \\
1705\end{array}$ & $\begin{array}{r}120.0 \\
97.4 \\
68.1 \\
55.4 \\
38.8\end{array}$ & $\begin{array}{l}0.00 \\
0.01 \\
0.00 \\
0.00 \\
0.00\end{array}$ \\
\hline
\end{tabular}


Table 130.--Streamflow and rainfall at station 02173495, Sunnyside Canal at Orangeburg. September 9,1988--Continued

\begin{tabular}{|c|c|c|c|c|c|c|c|c|}
\hline $\begin{array}{l}\text { Time } \\
\text { (hours) }\end{array}$ & $\begin{array}{l}\text { Streamflow } \\
\text { (cubic feet } \\
\text { per second) }\end{array}$ & $\begin{array}{l}\text { Rain- } \\
\text { fall } \\
\text { (inches) }\end{array}$ & $\begin{array}{l}\text { Time } \\
\text { (hours) }\end{array}$ & $\begin{array}{l}\text { Streamflow } \\
\text { (cubic feet } \\
\text { per second) }\end{array}$ & $\begin{array}{l}\text { Rain- } \\
\text { fall } \\
\text { (inches) }\end{array}$ & $\begin{array}{l}\text { Time } \\
\text { (hours) }\end{array}$ & $\begin{array}{l}\text { Streamflow } \\
\text { (cubic feet } \\
\text { per second) }\end{array}$ & $\begin{array}{l}\text { Rain- } \\
\text { fall } \\
\text { (inches) }\end{array}$ \\
\hline $\begin{array}{l}1710 \\
1715 \\
1720 \\
1725 \\
1730\end{array}$ & $\begin{array}{r}7.0 \\
3.0 \\
20.5 \\
38.0 \\
55.4\end{array}$ & $\begin{array}{l}0.00 \\
0.01 \\
0.01 \\
0.01 \\
0.02\end{array}$ & $\begin{array}{l}1850 \\
1855 \\
1900 \\
1905 \\
1910\end{array}$ & $\begin{array}{l}55.4 \\
53.4 \\
45.0 \\
24.8 \\
15.6\end{array}$ & $\begin{array}{l}0.01 \\
0.01 \\
0.01 \\
0.00 \\
0.00\end{array}$ & $\begin{array}{l}2030 \\
2035 \\
2040 \\
2045 \\
2050\end{array}$ & $\begin{array}{r}0.1 \\
0.1 \\
0.1 \\
0.1 \\
71.8\end{array}$ & $\begin{array}{l}0.00 \\
0.06 \\
c .06 \\
c .05 \\
c .06\end{array}$ \\
\hline $\begin{array}{l}1735 \\
1740 \\
1745 \\
1750 \\
1755\end{array}$ & $\begin{array}{r}58.1 \\
63.4 \\
110.0 \\
221.0 \\
259.0\end{array}$ & $\begin{array}{l}0.13 \\
0.19 \\
0.06 \\
0.03 \\
0.01\end{array}$ & $\begin{array}{l}1915 \\
1920 \\
1925 \\
1930 \\
1935\end{array}$ & $\begin{array}{r}11.4 \\
13.3 \\
5.9 \\
0.1 \\
0.1\end{array}$ & $\begin{array}{l}0.01 \\
0.00 \\
0.00 \\
0.00 \\
0.00\end{array}$ & $\begin{array}{l}2055 \\
2100 \\
2105 \\
2110 \\
2115\end{array}$ & $\begin{array}{r}97.8 \\
114.0 \\
122.0 \\
124.0 \\
122.0\end{array}$ & $\begin{array}{l}c .02 \\
c .02 \\
c .01 \\
0.00 \\
0.00\end{array}$ \\
\hline $\begin{array}{l}1800 \\
1805 \\
1810 \\
1815 \\
1820\end{array}$ & $\begin{array}{l}228.0 \\
187.0 \\
160.0 \\
149.0 \\
140.0\end{array}$ & $\begin{array}{l}0.03 \\
0.03 \\
0.00 \\
0.01 \\
0.00\end{array}$ & $\begin{array}{l}1940 \\
1945 \\
1950 \\
1955 \\
2000\end{array}$ & $\begin{array}{l}0.1 \\
0.1 \\
0.1 \\
0.1 \\
0.1\end{array}$ & $\begin{array}{l}0.00 \\
0.00 \\
0.01 \\
0.00 \\
0.00\end{array}$ & $\begin{array}{l}2120 \\
2125 \\
2130 \\
2135 \\
2140\end{array}$ & $\begin{array}{r}114.0 \\
95.4 \\
71.4 \\
57.7 \\
51.0\end{array}$ & $\begin{array}{l}0.00 \\
0.00 \\
0.01 \\
0.00 \\
0.00\end{array}$ \\
\hline $\begin{array}{l}1825 \\
1830 \\
1835 \\
1840 \\
1845\end{array}$ & $\begin{array}{r}129.0 \\
115.0 \\
92.6 \\
68.9 \\
60.3\end{array}$ & $\begin{array}{l}0.00 \\
0.01 \\
0.00 \\
0.00 \\
0.01\end{array}$ & $\begin{array}{l}2005 \\
2010 \\
2015 \\
2020 \\
2025\end{array}$ & $\begin{array}{l}0.1 \\
0.1 \\
0.1 \\
0.1 \\
0.1\end{array}$ & $\begin{array}{l}0.00 \\
0.00 \\
0.00 \\
0.01 \\
0.01\end{array}$ & $\begin{array}{l}2145 \\
2150 \\
2155 \\
2200\end{array}$ & $\begin{array}{r}21.3 \\
5.0 \\
0.1 \\
0.1\end{array}$ & $\begin{array}{l}0.00 \\
0.00 \\
0.00 \\
0.00\end{array}$ \\
\hline
\end{tabular}




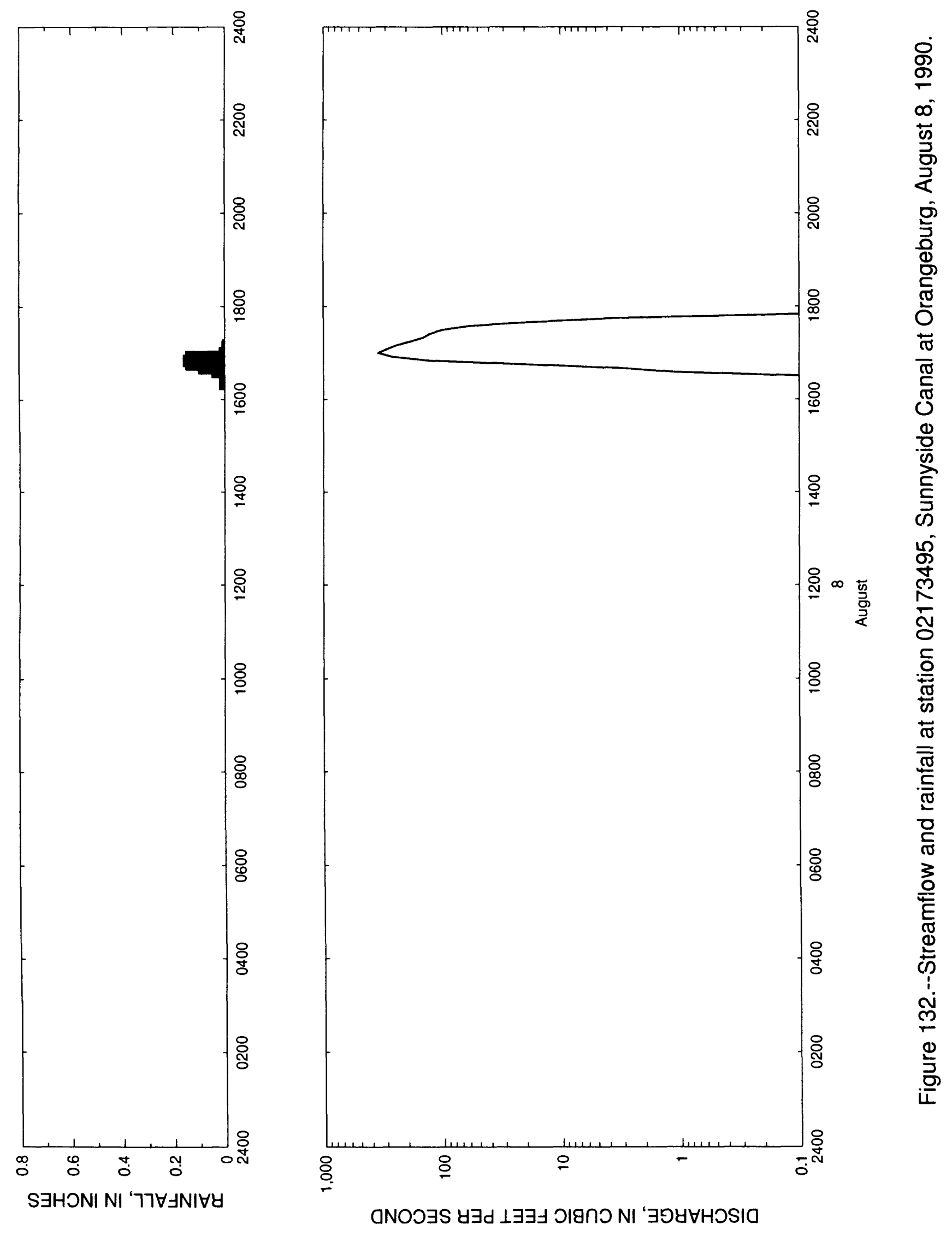


Table 131. --Streamflow and rainfall at station 02173495, Sunnyside Canal at Orangeburg. August 8, 1990

\begin{tabular}{|c|c|c|c|c|c|c|c|c|}
\hline $\begin{array}{l}\text { Time } \\
\text { (hours) }\end{array}$ & $\begin{array}{l}\text { Streamflow } \\
\text { (cubic feet } \\
\text { per second) }\end{array}$ & $\begin{array}{l}\text { Rain- } \\
\text { fall } \\
\text { (inches) }\end{array}$ & $\begin{array}{l}\text { Time } \\
\text { (hours) }\end{array}$ & $\begin{array}{l}\text { Streamflow } \\
\text { (cubic feet } \\
\text { per second) }\end{array}$ & $\begin{array}{l}\text { Rain- } \\
\text { fall } \\
\text { (inches) }\end{array}$ & $\begin{array}{l}\text { Time } \\
\text { (hours) }\end{array}$ & $\begin{array}{l}\text { Streamflow } \\
\text { (cubic feet } \\
\text { per second) }\end{array}$ & $\begin{array}{l}\text { Rain- } \\
\text { fall } \\
\text { (inchos) }\end{array}$ \\
\hline $\begin{array}{l}\text { August } 8 \\
1620 \\
1625 \\
1630 \\
1635\end{array}$ & $\begin{array}{r}1990 \\
0.1 \\
0.1 \\
0.1 \\
1.1\end{array}$ & $\begin{array}{l}0.02 \\
0.02 \\
0.01 \\
0.05\end{array}$ & $\begin{array}{l}1655 \\
1700 \\
1705 \\
1710 \\
1715\end{array}$ & $\begin{array}{l}262.0 \\
346.0 \\
293.0 \\
242.0 \\
185.0\end{array}$ & $\begin{array}{l}0.15 \\
0.02 \\
0.01 \\
0.01 \\
0.00\end{array}$ & $\begin{array}{l}1735 \\
1740 \\
1745 \\
1750 \\
1755\end{array}$ & $\begin{array}{r}59.4 \\
18.2 \\
3.6 \\
0.1 \\
0.1\end{array}$ & $\begin{array}{l}0.00 \\
0.00 \\
0.00 \\
0.00 \\
0.00\end{array}$ \\
\hline $\begin{array}{l}1640 \\
1645 \\
1650\end{array}$ & $\begin{array}{r}3.1 \\
18 \cdot 2 \\
127.0\end{array}$ & $\begin{array}{l}0.10 \\
0.15 \\
0.16\end{array}$ & $\begin{array}{l}1720 \\
1725 \\
1730\end{array}$ & $\begin{array}{r}145.0 \\
128.0 \\
99.3\end{array}$ & $\begin{array}{l}0.00 \\
0.00 \\
0.00\end{array}$ & 1800 & 0.1 & 0.00 \\
\hline
\end{tabular}




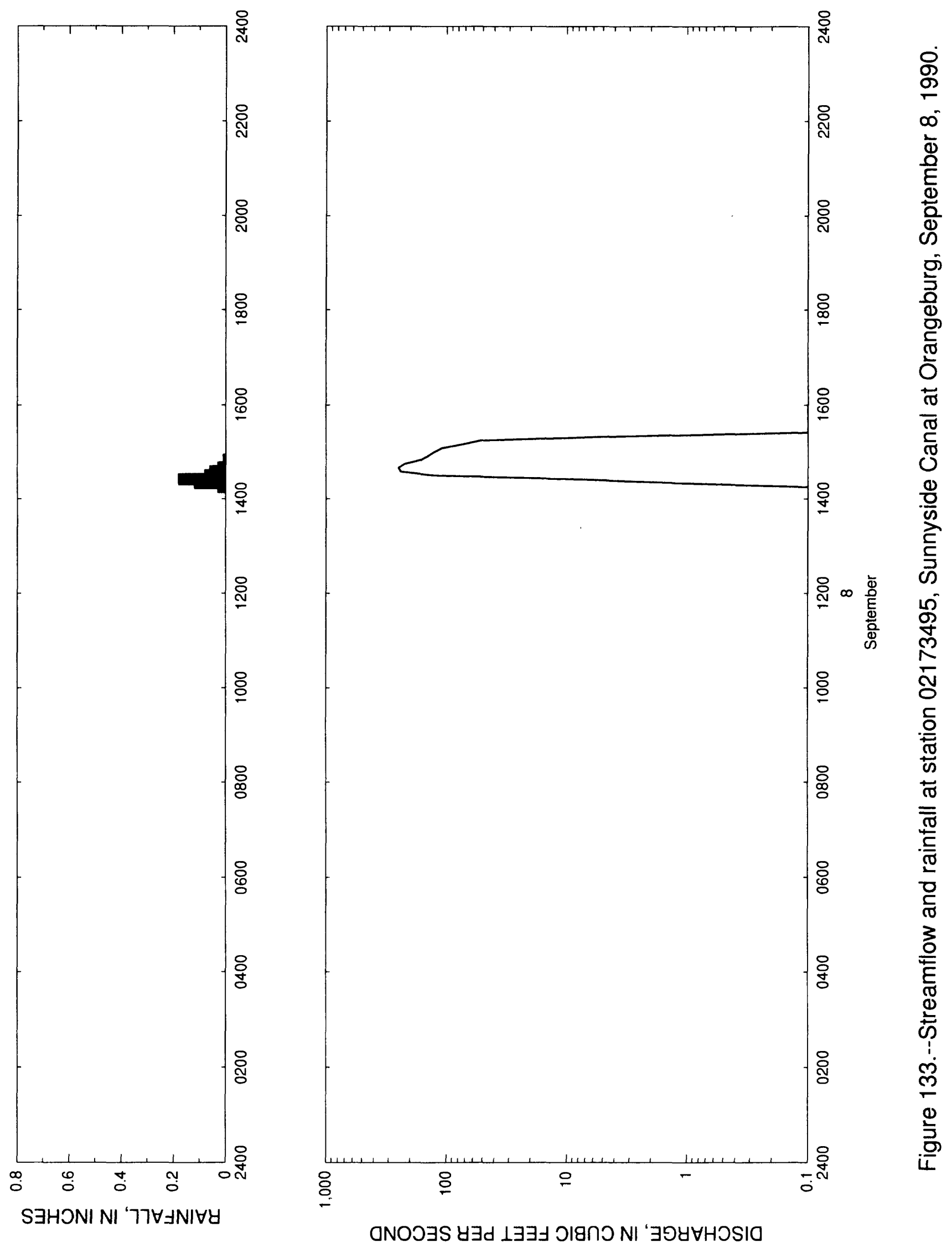


Table 132.--Streamflow and rainfall at station 02173495. Sunnyside Canal at Orangeburg, September 8,1990

\begin{tabular}{|c|c|c|c|c|c|c|c|c|}
\hline $\begin{array}{l}\text { Time } \\
\text { (hours) }\end{array}$ & $\begin{array}{l}\text { Streamflow } \\
\text { (cubic feet } \\
\text { per second) }\end{array}$ & $\begin{array}{l}\text { Rain- } \\
\text { fall } \\
\text { (inches) }\end{array}$ & $\begin{array}{l}\text { Time } \\
\text { (hours) }\end{array}$ & $\begin{array}{l}\text { Streamflow } \\
\text { (cubic feet } \\
\text { per second) }\end{array}$ & $\begin{array}{l}\text { Rain- } \\
\text { fall } \\
\text { (inches) }\end{array}$ & $\begin{array}{l}\text { Time } \\
\text { (hours) }\end{array}$ & $\begin{array}{l}\text { Streamflow } \\
\text { (cubic feet } \\
\text { per second) }\end{array}$ & $\begin{array}{l}\text { Rain- } \\
\text { fall } \\
\text { (inches) }\end{array}$ \\
\hline $\begin{array}{l}\text { September } \\
1415 \\
1420 \\
1425 \\
1430\end{array}$ & $\begin{array}{r}8,1990 \\
0.1 \\
1.0 \\
8.0 \\
127.0\end{array}$ & $\begin{array}{l}0.03 \\
0.12 \\
0.18 \\
0.08\end{array}$ & $\begin{array}{l}1450 \\
1455 \\
1500 \\
1505 \\
1510\end{array}$ & $\begin{array}{r}165.0 \\
143.0 \\
128.0 \\
110.0 \\
73.5\end{array}$ & $\begin{array}{l}0.01 \\
0.00 \\
0.00 \\
0.00 \\
0.00\end{array}$ & $\begin{array}{l}1530 \\
1535 \\
1540 \\
1545 \\
1550\end{array}$ & $\begin{array}{l}0.1 \\
0.1 \\
0.1 \\
0.1 \\
0.1\end{array}$ & $\begin{array}{l}0.01 \\
0.0 \text { ? } \\
0.07 \\
0.07 \\
0.07\end{array}$ \\
\hline $\begin{array}{l}1435 \\
1440 \\
1445\end{array}$ & $\begin{array}{l}239.0 \\
249.0 \\
223.0\end{array}$ & $\begin{array}{l}0.06 \\
0.03 \\
0.01\end{array}$ & $\begin{array}{l}1515 \\
1520 \\
1525\end{array}$ & $\begin{array}{r}51.0 \\
3.6 \\
0.1\end{array}$ & $\begin{array}{l}0.00 \\
0.00 \\
0.00\end{array}$ & $\begin{array}{l}1555 \\
1600\end{array}$ & $\begin{array}{l}0.1 \\
0.1\end{array}$ & $\begin{array}{l}0.00 \\
0.00\end{array}$ \\
\hline
\end{tabular}



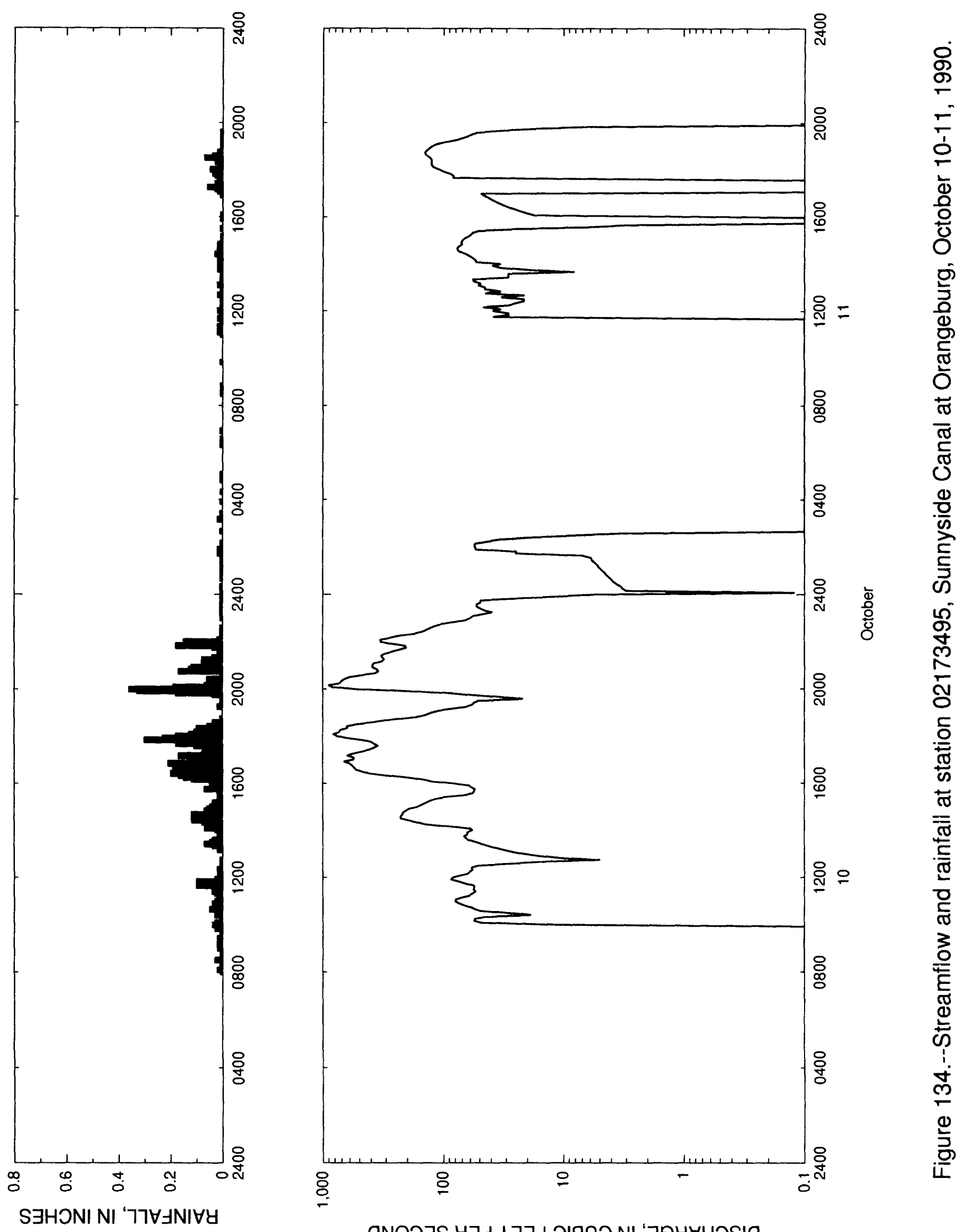

ONOJ $\exists S$ y 
Table 133.--Streamflow and rainfall at station 02173495, Sunnyside Canal at Orangeburg, October $10-11,1990$

\begin{tabular}{|c|c|c|c|c|c|c|c|c|}
\hline $\begin{array}{l}\text { Time } \\
\text { (hours) }\end{array}$ & $\begin{array}{l}\text { Streamflow } \\
\text { (cubic feet } \\
\text { per second) }\end{array}$ & $\begin{array}{l}\text { Rain- } \\
\text { fall } \\
\text { (inches) }\end{array}$ & $\begin{array}{l}\text { Time } \\
\text { (hours) }\end{array}$ & $\begin{array}{l}\text { Streamflow } \\
\text { (cubic feet } \\
\text { per second) }\end{array}$ & $\begin{array}{l}\text { Rain- } \\
\text { fall } \\
\text { (inches) }\end{array}$ & $\begin{array}{l}\text { Time } \\
\text { (hours) }\end{array}$ & $\begin{array}{l}\text { Streamflow } \\
\text { (cubic feet } \\
\text { per second) }\end{array}$ & $\begin{array}{l}\text { Rain- } \\
\text { fall } \\
\text { (inches) }\end{array}$ \\
\hline $\begin{array}{l}\text { October } \\
0800 \\
0805 \\
0810 \\
0815\end{array}$ & $\begin{array}{r}10,1990 \\
0.1 \\
0.1 \\
0.1 \\
0.1\end{array}$ & $\begin{array}{l}0.01 \\
0.02 \\
0.01 \\
0.01\end{array}$ & $\begin{array}{l}1320 \\
1325 \\
1330 \\
1335 \\
1340\end{array}$ & $\begin{array}{l}42.0 \\
47.3 \\
52.6 \\
61.6 \\
64.7\end{array}$ & $\begin{array}{l}0.04 \\
0.07 \\
0.05 \\
0.04 \\
0.02\end{array}$ & $\begin{array}{l}1845 \\
1850 \\
1855 \\
1900 \\
1905\end{array}$ & $\begin{array}{l}214.0 \\
158.0 \\
139.0 \\
126.0 \\
110.0\end{array}$ & $\begin{array}{l}0.01 \\
0.00 \\
0.00 \\
0.00 \\
0.00\end{array}$ \\
\hline $\begin{array}{l}0820 \\
0825 \\
0830 \\
0835 \\
0840\end{array}$ & $\begin{array}{l}0.1 \\
0.1 \\
0.1 \\
0.1 \\
0.1\end{array}$ & $\begin{array}{l}0.01 \\
0.01 \\
0.03 \\
0.01 \\
0.01\end{array}$ & $\begin{array}{l}1345 \\
1350 \\
1355 \\
1400 \\
1405\end{array}$ & $\begin{array}{l}67.7 \\
62.9 \\
63.4 \\
57.2 \\
60.7\end{array}$ & $\begin{array}{l}0.02 \\
0.01 \\
0.00 \\
0.03 \\
0.07\end{array}$ & $\begin{array}{l}1910 \\
1915 \\
1920 \\
1925 \\
1930\end{array}$ & $\begin{array}{l}84.9 \\
64.7 \\
57.2 \\
55.4 \\
51.0\end{array}$ & $\begin{array}{l}0.00 \\
0.02 \\
0.00 \\
0.00 \\
0.01\end{array}$ \\
\hline $\begin{array}{l}0845 \\
0850 \\
0855 \\
0900 \\
0905\end{array}$ & $\begin{array}{l}0.1 \\
0.1 \\
0.1 \\
0.1 \\
0.1\end{array}$ & $\begin{array}{l}0.01 \\
0.01 \\
0.01 \\
0.02 \\
0.01\end{array}$ & $\begin{array}{l}1410 \\
1415 \\
1420 \\
1425 \\
1430\end{array}$ & $\begin{array}{r}92.2 \\
141.0 \\
164.0 \\
189.0 \\
226.0\end{array}$ & $\begin{array}{l}0.07 \\
0.04 \\
0.08 \\
0.12 \\
0.12\end{array}$ & $\begin{array}{l}1935 \\
1940 \\
1945 \\
1950 \\
1955\end{array}$ & $\begin{array}{r}21.3 \\
33.5 \\
58.1 \\
93.4 \\
202.0\end{array}$ & $\begin{array}{l}0.00 \\
0.01 \\
0.04 \\
0.18 \\
0.33\end{array}$ \\
\hline $\begin{array}{l}0910 \\
0915 \\
0920 \\
0925 \\
0930\end{array}$ & $\begin{array}{l}0.1 \\
0.1 \\
0.1 \\
0.1 \\
0.1\end{array}$ & $\begin{array}{l}0.02 \\
0.01 \\
0.01 \\
0.02 \\
0.01\end{array}$ & $\begin{array}{l}1435 \\
1440 \\
1445 \\
1450 \\
1455\end{array}$ & $\begin{array}{l}226.0 \\
219.0 \\
216.0 \\
206.0 \\
193.0\end{array}$ & $\begin{array}{l}0.10 \\
0.12 \\
0.05 \\
0.07 \\
0.06\end{array}$ & $\begin{array}{l}2000 \\
2005 \\
2010 \\
2015 \\
2020\end{array}$ & $\begin{array}{l}540.0 \\
830.0 \\
898.0 \\
726.0 \\
700.0\end{array}$ & $\begin{array}{l}0.36 \\
0.19 \\
0.07 \\
0.06 \\
0.04\end{array}$ \\
\hline $\begin{array}{l}0935 \\
0940 \\
0945 \\
0950 \\
0955\end{array}$ & $\begin{array}{l}0.1 \\
0.1 \\
0.1 \\
0.1 \\
0.1\end{array}$ & $\begin{array}{l}0.01 \\
0.01 \\
0.01 \\
0.03 \\
0.03\end{array}$ & $\begin{array}{l}1500 \\
1505 \\
1510 \\
1515 \\
1520\end{array}$ & $\begin{array}{l}165.0 \\
151.0 \\
140.0 \\
130.0 \\
118.0\end{array}$ & $\begin{array}{l}0.05 \\
0.02 \\
0.04 \\
0.02 \\
0.01\end{array}$ & $\begin{array}{l}2025 \\
2030 \\
2035 \\
2040 \\
2045\end{array}$ & $\begin{array}{l}663.0 \\
599.0 \\
478.0 \\
369.0 \\
346.0\end{array}$ & $\begin{array}{l}0.06 \\
0.01 \\
0.00 \\
0.01 \\
0.17\end{array}$ \\
\hline $\begin{array}{l}1000 \\
1005 \\
1010 \\
1015 \\
1020\end{array}$ & $\begin{array}{l}11.4 \\
48.9 \\
55.4 \\
54.2 \\
45.0\end{array}$ & $\begin{array}{l}0.04 \\
0.03 \\
0.00 \\
0.01 \\
0.01\end{array}$ & $\begin{array}{l}1525 \\
1530 \\
1535 \\
1540 \\
1545\end{array}$ & $\begin{array}{l}97.0 \\
67.3 \\
56.3 \\
55.0 \\
54.2\end{array}$ & $\begin{array}{l}0.00 \\
0.02 \\
0.01 \\
0.01 \\
0.07\end{array}$ & $\begin{array}{l}2050 \\
2055 \\
2100 \\
2105 \\
2110\end{array}$ & $\begin{array}{l}356.0 \\
389.0 \\
386.0 \\
379.0 \\
325.0\end{array}$ & $\begin{array}{l}0.13 \\
0.12 \\
0.08 \\
0.02 \\
0.05\end{array}$ \\
\hline $\begin{array}{l}1025 \\
1030 \\
1035 \\
1040 \\
1045\end{array}$ & $\begin{array}{l}18.2 \\
28.8 \\
48.9 \\
55.0 \\
59.0\end{array}$ & $\begin{array}{l}0.03 \\
0.02 \\
0.02 \\
0.05 \\
0.04\end{array}$ & $\begin{array}{l}1550 \\
1555 \\
1600 \\
1605 \\
1610\end{array}$ & $\begin{array}{r}59.0 \\
61.6 \\
82.9 \\
124.0 \\
144.0\end{array}$ & $\begin{array}{l}0.05 \\
0.05 \\
0.05 \\
0.04 \\
0.12\end{array}$ & $\begin{array}{l}2115 \\
2120 \\
2125 \\
2130 \\
2135\end{array}$ & $\begin{array}{l}310.0 \\
319.0 \\
328.0 \\
307.0 \\
267.0\end{array}$ & $\begin{array}{l}0.08 \\
0.04 \\
0.01 \\
0.02 \\
0.02\end{array}$ \\
\hline $\begin{array}{l}1050 \\
1055 \\
1100 \\
1105 \\
1110\end{array}$ & $\begin{array}{l}66.8 \\
74.3 \\
80.0 \\
78.8 \\
69.8\end{array}$ & $\begin{array}{l}0.03 \\
0.04 \\
0.03 \\
0.02 \\
0.01\end{array}$ & $\begin{array}{l}1615 \\
1620 \\
1625 \\
1630 \\
1635\end{array}$ & $\begin{array}{l}195.0 \\
296.0 \\
410.0 \\
470.0 \\
536.0\end{array}$ & $\begin{array}{l}0.15 \\
0.17 \\
0.20 \\
0.16 \\
0.19\end{array}$ & $\begin{array}{l}2140 \\
2145 \\
2150 \\
2155 \\
2200\end{array}$ & $\begin{array}{l}232.0 \\
204.0 \\
208.0 \\
277.0 \\
334.0\end{array}$ & $\begin{array}{l}0.00 \\
0.04 \\
0.18 \\
0.13 \\
0.15\end{array}$ \\
\hline $\begin{array}{l}1115 \\
1120 \\
1125 \\
1130 \\
1135\end{array}$ & $\begin{array}{l}60.3 \\
56.8 \\
53.4 \\
55.9 \\
55.0\end{array}$ & $\begin{array}{l}0.01 \\
0.03 \\
0.04 \\
0.02 \\
0.01\end{array}$ & $\begin{array}{l}1640 \\
1645 \\
1650 \\
1655 \\
1700\end{array}$ & $\begin{array}{l}549.0 \\
572.0 \\
599.0 \\
668.0 \\
558.0\end{array}$ & $\begin{array}{l}0.16 \\
0.12 \\
0.21 \\
0.10 \\
0.13\end{array}$ & $\begin{array}{l}2205 \\
2210 \\
2215 \\
2220 \\
2225\end{array}$ & $\begin{array}{l}331.0 \\
274.0 \\
230.0 \\
176.0 \\
150.0\end{array}$ & $\begin{array}{l}0.02 \\
0.00 \\
0.00 \\
0.01 \\
0.00\end{array}$ \\
\hline $\begin{array}{l}1140 \\
1145 \\
1150 \\
1155 \\
1200\end{array}$ & $\begin{array}{l}55.4 \\
65.1 \\
74.7 \\
86.5 \\
84.1\end{array}$ & $\begin{array}{l}0.10 \\
0.04 \\
0.10 \\
0.03 \\
0.02\end{array}$ & $\begin{array}{l}1705 \\
1710 \\
1715 \\
1720 \\
1725\end{array}$ & $\begin{array}{l}554.0 \\
628.0 \\
567.0 \\
486.0 \\
417.0\end{array}$ & $\begin{array}{l}0.13 \\
0.17 \\
0.08 \\
0.01 \\
0.00\end{array}$ & $\begin{array}{l}2230 \\
2235 \\
2240 \\
2245 \\
2250\end{array}$ & $\begin{array}{r}138.0 \\
128.0 \\
117.0 \\
102.0 \\
82.9\end{array}$ & $\begin{array}{l}0.00 \\
0.01 \\
0.00 \\
0.00 \\
0.00\end{array}$ \\
\hline $\begin{array}{l}1205 \\
1210 \\
1215 \\
1220 \\
1225\end{array}$ & $\begin{array}{l}73.9 \\
63.4 \\
60.3 \\
56.8 \\
58.1\end{array}$ & $\begin{array}{l}0.02 \\
0.02 \\
0.02 \\
0.02 \\
0.01\end{array}$ & $\begin{array}{l}1730 \\
1735 \\
1740 \\
1745 \\
1750\end{array}$ & $\begin{array}{l}379.0 \\
350.0 \\
375.0 \\
399.0 \\
470.0\end{array}$ & $\begin{array}{l}0.07 \\
0.11 \\
0.18 \\
0.10 \\
0.30\end{array}$ & $\begin{array}{l}2255 \\
2300 \\
2305 \\
2310 \\
2315\end{array}$ & $\begin{array}{l}66.0 \\
59.4 \\
56.3 \\
46.9 \\
38.8\end{array}$ & $\begin{array}{l}0.00 \\
0.01 \\
0.00 \\
0.01 \\
0.01\end{array}$ \\
\hline $\begin{array}{l}1230 \\
1235 \\
1240 \\
1245 \\
1250\end{array}$ & $\begin{array}{r}51.0 \\
28.8 \\
15.6 \\
5.0 \\
20.3\end{array}$ & $\begin{array}{l}0.01 \\
0.00 \\
0.00 \\
0.01 \\
0.00\end{array}$ & $\begin{array}{l}1755 \\
1800 \\
1805 \\
1810 \\
1815\end{array}$ & $\begin{array}{l}648.0 \\
760.0 \\
818.0 \\
732.0 \\
721.0\end{array}$ & $\begin{array}{l}0.23 \\
0.18 \\
0.13 \\
0.11 \\
0.01\end{array}$ & $\begin{array}{l}2320 \\
2325 \\
2330 \\
2335 \\
2340\end{array}$ & $\begin{array}{l}45.0 \\
48.9 \\
52.6 \\
52.6 \\
48.9\end{array}$ & $\begin{array}{l}0.01 \\
0.01 \\
0.01 \\
0.00 \\
0.01\end{array}$ \\
\hline $\begin{array}{l}1255 \\
1300 \\
1305 \\
1310 \\
1315\end{array}$ & $\begin{array}{l}15.6 \\
20.9 \\
26.2 \\
31.4 \\
36.7\end{array}$ & $\begin{array}{l}0.00 \\
0.00 \\
0.00 \\
0.02 \\
0.01\end{array}$ & $\begin{array}{l}1820 \\
1825 \\
1830 \\
1835 \\
1840\end{array}$ & $\begin{array}{l}628.0 \\
633.0 \\
523.0 \\
382.0 \\
310.0\end{array}$ & $\begin{array}{l}0.10 \\
0.06 \\
0.01 \\
0.04 \\
0.00\end{array}$ & $\begin{array}{l}2345 \\
2350 \\
2355 \\
\text { October } \\
0000\end{array}$ & $\begin{array}{r}48.9 \\
24.8 \\
11.4 \\
11,1990 \\
5.9\end{array}$ & $\begin{array}{l}0.00 \\
0.00 \\
0.01 \\
0.00\end{array}$ \\
\hline
\end{tabular}


Table 133 - Streamflow and rainfall at station 02173495, Sunnyside Canal at Orangeburg, October $10-11,1990--$ Continued

\begin{tabular}{|c|c|c|c|c|c|c|c|c|}
\hline $\begin{array}{l}\text { Time } \\
\text { (hours) }\end{array}$ & $\begin{array}{l}\text { Streamflow } \\
\text { (cubic feet } \\
\text { per second) }\end{array}$ & $\begin{array}{l}\text { Rain- } \\
\text { fall } \\
\text { (inches) }\end{array}$ & $\begin{array}{l}\text { Time } \\
\text { (hours) }\end{array}$ & $\begin{array}{l}\text { Streamflow } \\
\text { (cubic feet } \\
\text { per second) }\end{array}$ & $\begin{array}{l}\text { Rain- } \\
\text { fall } \\
\text { (inches) }\end{array}$ & $\begin{array}{l}\text { Time } \\
\text { (hours) }\end{array}$ & $\begin{array}{l}\text { Streamflow } \\
\text { (cubic feet } \\
\text { per second) }\end{array}$ & $\begin{array}{l}\text { Rain- } \\
\text { fall } \\
\text { (inches) }\end{array}$ \\
\hline $\begin{array}{l}0005 \\
0010 \\
0015 \\
0020 \\
0025\end{array}$ & $\begin{array}{l}0.1 \\
3.0 \\
3.2 \\
3.3 \\
3.5\end{array}$ & $\begin{array}{l}0.01 \\
0.00 \\
0.00 \\
0.01 \\
0.00\end{array}$ & $\begin{array}{l}0530 \\
0535 \\
0540 \\
0545 \\
0550\end{array}$ & $\begin{array}{l}0.1 \\
0.1 \\
0.1 \\
0.1 \\
0.1\end{array}$ & $\begin{array}{l}0.00 \\
0.00 \\
0.00 \\
0.00 \\
0.00\end{array}$ & $\begin{array}{l}1055 \\
1100 \\
1105 \\
1110 \\
1115\end{array}$ & $\begin{array}{l}0.1 \\
0.1 \\
0.1 \\
0.1 \\
0.1\end{array}$ & $\begin{array}{l}0.00 \\
0.01 \\
0.02 \\
0.01 \\
0.01\end{array}$ \\
\hline $\begin{array}{l}0030 \\
0035 \\
0040 \\
0045 \\
0050\end{array}$ & $\begin{array}{l}3.7 \\
3.9 \\
4.0 \\
4.2 \\
4.4\end{array}$ & $\begin{array}{l}0.00 \\
0.00 \\
0.01 \\
0.00 \\
0.01\end{array}$ & $\begin{array}{l}0555 \\
0600 \\
0605 \\
0610 \\
0615\end{array}$ & $\begin{array}{l}0.1 \\
0.1 \\
0.1 \\
0.1 \\
0.1\end{array}$ & $\begin{array}{l}0.00 \\
0.00 \\
0.00 \\
0.00 \\
0.00\end{array}$ & $\begin{array}{l}1120 \\
1125 \\
1130 \\
1135 \\
1140\end{array}$ & $\begin{array}{l}0.1 \\
0.1 \\
0.1 \\
0.1 \\
0.1\end{array}$ & $\begin{array}{l}0.02 \\
0.01 \\
0.01 \\
0.01 \\
0.02\end{array}$ \\
\hline $\begin{array}{l}0055 \\
0100 \\
0105 \\
0110 \\
0115\end{array}$ & $\begin{array}{l}4.5 \\
4.7 \\
4.9 \\
5.1 \\
5.2\end{array}$ & $\begin{array}{l}0.01 \\
0.00 \\
0.01 \\
0.01 \\
0.01\end{array}$ & $\begin{array}{l}0620 \\
0625 \\
0630 \\
0635 \\
0640\end{array}$ & $\begin{array}{l}0.1 \\
0.1 \\
0.1 \\
0.1 \\
0.1\end{array}$ & $\begin{array}{l}0.01 \\
0.00 \\
0.00 \\
0.01 \\
0.00\end{array}$ & $\begin{array}{l}1145 \\
1150 \\
1155 \\
1200 \\
1205\end{array}$ & $\begin{array}{l}38.8 \\
28.8 \\
28.8 \\
38.8 \\
33.5\end{array}$ & $\begin{array}{l}0.01 \\
0.01 \\
0.01 \\
0.02 \\
0.01\end{array}$ \\
\hline $\begin{array}{l}0120 \\
0125 \\
0130 \\
0135 \\
0140\end{array}$ & $\begin{array}{l}5.4 \\
5.6 \\
5.8 \\
5.9 \\
7.0\end{array}$ & $\begin{array}{l}0.01 \\
0.01 \\
0.01 \\
0.01 \\
0.01\end{array}$ & $\begin{array}{l}0645 \\
0650 \\
0655 \\
0700 \\
0705\end{array}$ & $\begin{array}{l}0.1 \\
0.1 \\
0.1 \\
0.1 \\
0.1\end{array}$ & $\begin{array}{l}0.00 \\
0.00 \\
0.01 \\
0.00 \\
0.00\end{array}$ & $\begin{array}{l}1210 \\
1215 \\
1220 \\
1225 \\
1230\end{array}$ & $\begin{array}{l}46.9 \\
28.8 \\
24.8 \\
21.3 \\
21.3\end{array}$ & $\begin{array}{l}0.01 \\
0.01 \\
0.01 \\
0.01 \\
0.01\end{array}$ \\
\hline $\begin{array}{l}0145 \\
0150 \\
0155 \\
0200 \\
0205\end{array}$ & $\begin{array}{l}24.8 \\
24.8 \\
53.4 \\
54.2 \\
55.0\end{array}$ & $\begin{array}{l}0.02 \\
0.01 \\
0.02 \\
0.01 \\
0.01\end{array}$ & $\begin{array}{l}0710 \\
0715 \\
0720 \\
0725 \\
0730\end{array}$ & $\begin{array}{l}0.1 \\
0.1 \\
0.1 \\
0.1 \\
0.1\end{array}$ & $\begin{array}{l}0.00 \\
0.00 \\
0.00 \\
0.00 \\
0.00\end{array}$ & $\begin{array}{l}1235 \\
1240 \\
1245 \\
1250 \\
1255\end{array}$ & $\begin{array}{l}33.5 \\
21.3 \\
45.0 \\
33.5 \\
45.0\end{array}$ & $\begin{array}{l}0.01 \\
0.02 \\
0.01 \\
0.01 \\
0.01\end{array}$ \\
\hline $\begin{array}{l}0210 \\
0210 \\
0220 \\
0225 \\
0230\end{array}$ & $\begin{array}{r}54.2 \\
54.2 \\
33.5 \\
18.2 \\
8.2\end{array}$ & $\begin{array}{l}0.01 \\
0.01 \\
0.00 \\
0.00 \\
0.00\end{array}$ & $\begin{array}{l}0735 \\
0740 \\
0745 \\
0750 \\
0755\end{array}$ & $\begin{array}{l}0.1 \\
0.1 \\
0.1 \\
0.1 \\
0.1\end{array}$ & $\begin{array}{l}0.00 \\
0.00 \\
0.00 \\
0.00 \\
0.00\end{array}$ & $\begin{array}{l}1300 \\
1305 \\
1310 \\
1315 \\
1320\end{array}$ & $\begin{array}{l}45.0 \\
51.0 \\
48.9 \\
55.4 \\
56.3\end{array}$ & $\begin{array}{l}0.01 \\
0.02 \\
0.01 \\
0.00 \\
0.01\end{array}$ \\
\hline $\begin{array}{l}0235 \\
0240 \\
0245 \\
0250 \\
0255\end{array}$ & $\begin{array}{l}3.6 \\
0.1 \\
0.1 \\
0.1 \\
0.1\end{array}$ & $\begin{array}{l}0.00 \\
0.01 \\
0.00 \\
0.00 \\
0.00\end{array}$ & $\begin{array}{l}0800 \\
0805 \\
0810 \\
0815 \\
0820\end{array}$ & $\begin{array}{l}0.1 \\
0.1 \\
0.1 \\
0.1 \\
0.1\end{array}$ & $\begin{array}{l}0.00 \\
0.00 \\
0.00 \\
0.00 \\
0.00\end{array}$ & $\begin{array}{l}1325 \\
1330 \\
1335 \\
1340 \\
1345\end{array}$ & $\begin{array}{r}28.8 \\
28.8 \\
28.8 \\
8.2 \\
18.2\end{array}$ & $\begin{array}{l}0.01 \\
0.01 \\
0.01 \\
0.01 \\
0.02\end{array}$ \\
\hline $\begin{array}{l}0300 \\
0305 \\
0310 \\
0315 \\
0320\end{array}$ & $\begin{array}{l}0.1 \\
0.1 \\
0.1 \\
0.1 \\
0.1\end{array}$ & $\begin{array}{l}0.00 \\
0.00 \\
0.02 \\
0.00 \\
0.00\end{array}$ & $\begin{array}{l}0825 \\
0830 \\
0835 \\
0840 \\
0845\end{array}$ & $\begin{array}{l}0.1 \\
0.1 \\
0.1 \\
0.1 \\
0.1\end{array}$ & $\begin{array}{l}0.00 \\
0.01 \\
0.00 \\
0.01 \\
0.00\end{array}$ & $\begin{array}{l}1350 \\
1355 \\
1400 \\
1405 \\
1410\end{array}$ & $\begin{array}{l}33.5 \\
38.8 \\
33.5 \\
53.4 \\
54.2\end{array}$ & $\begin{array}{l}0.01 \\
0.01 \\
0.02 \\
0.01 \\
0.02\end{array}$ \\
\hline $\begin{array}{l}0325 \\
0330 \\
0335 \\
0340 \\
0345\end{array}$ & $\begin{array}{l}0.1 \\
0.1 \\
0.1 \\
0.1 \\
0.1\end{array}$ & $\begin{array}{l}0.01 \\
0.00 \\
0.00 \\
0.00 \\
0.00\end{array}$ & $\begin{array}{l}0850 \\
0855 \\
0900 \\
0905 \\
0910\end{array}$ & $\begin{array}{l}0.1 \\
0.1 \\
0.1 \\
0.1 \\
0.1\end{array}$ & $\begin{array}{l}0.01 \\
0.00 \\
0.00 \\
0.00 \\
0.00\end{array}$ & $\begin{array}{l}1415 \\
1420 \\
1425 \\
1430 \\
1435\end{array}$ & $\begin{array}{l}56.8 \\
60.3 \\
64.7 \\
71.0 \\
75.9\end{array}$ & $\begin{array}{l}0.02 \\
0.02 \\
0.03 \\
0.02 \\
0.01\end{array}$ \\
\hline $\begin{array}{l}0350 \\
0355 \\
0400 \\
0405 \\
0410\end{array}$ & $\begin{array}{l}0.1 \\
0.1 \\
0.1 \\
0.1 \\
0.1\end{array}$ & $\begin{array}{l}0.00 \\
0.01 \\
0.00 \\
0.00 \\
0.00\end{array}$ & $\begin{array}{l}0915 \\
0920 \\
0925 \\
0930 \\
0935\end{array}$ & $\begin{array}{l}0.1 \\
0.1 \\
0.1 \\
0.1 \\
0.1\end{array}$ & $\begin{array}{l}0.00 \\
0.00 \\
0.00 \\
0.00 \\
0.00\end{array}$ & $\begin{array}{l}1440 \\
1445 \\
1450 \\
1455 \\
1500\end{array}$ & $\begin{array}{l}77.2 \\
75.1 \\
70.2 \\
71.4 \\
69.8\end{array}$ & $\begin{array}{l}0.02 \\
0.01 \\
0.02 \\
0.01 \\
0.01\end{array}$ \\
\hline $\begin{array}{l}0415 \\
0420 \\
0425 \\
0430 \\
0435\end{array}$ & $\begin{array}{l}0.1 \\
0.1 \\
0.1 \\
0.1 \\
0.1\end{array}$ & $\begin{array}{l}0.00 \\
0.01 \\
0.00 \\
0.00 \\
0.00\end{array}$ & $\begin{array}{l}0940 \\
0945 \\
0950 \\
0955 \\
1000\end{array}$ & $\begin{array}{l}0.1 \\
0.1 \\
0.1 \\
0.1 \\
0.1\end{array}$ & $\begin{array}{l}0.00 \\
0.00 \\
0.01 \\
0.00 \\
0.00\end{array}$ & $\begin{array}{l}1505 \\
1510 \\
1515 \\
1520 \\
1525\end{array}$ & $\begin{array}{l}66.8 \\
62.1 \\
59.0 \\
57.2 \\
51.0\end{array}$ & $\begin{array}{l}0.01 \\
0.01 \\
0.00 \\
0.00 \\
0.00\end{array}$ \\
\hline $\begin{array}{l}0440 \\
0445 \\
0450 \\
0455 \\
0500\end{array}$ & $\begin{array}{l}0.1 \\
0.1 \\
0.1 \\
0.1 \\
0.1\end{array}$ & $\begin{array}{l}0.00 \\
0.00 \\
0.01 \\
0.00 \\
0.00\end{array}$ & $\begin{array}{l}1005 \\
1010 \\
1015 \\
1020 \\
1025\end{array}$ & $\begin{array}{l}0.1 \\
0.1 \\
0.1 \\
0.1 \\
0.1\end{array}$ & $\begin{array}{l}0.00 \\
0.00 \\
0.00 \\
0.00 \\
0.00\end{array}$ & $\begin{array}{l}1530 \\
1535 \\
1540 \\
1545 \\
1550\end{array}$ & $\begin{array}{r}24.8 \\
5.9 \\
3.0 \\
0.1 \\
0.1\end{array}$ & $\begin{array}{l}0.01 \\
0.00 \\
0.00 \\
0.00 \\
0.00\end{array}$ \\
\hline $\begin{array}{l}0505 \\
0510 \\
0515 \\
0520 \\
0525\end{array}$ & $\begin{array}{l}0.1 \\
0.1 \\
0.1 \\
0.1 \\
0.1\end{array}$ & $\begin{array}{l}0.01 \\
0.00 \\
0.00 \\
0.00 \\
0.00\end{array}$ & $\begin{array}{l}1030 \\
1035 \\
1040 \\
1045 \\
1050\end{array}$ & $\begin{array}{l}0.1 \\
0.1 \\
0.1 \\
0.1 \\
0.1\end{array}$ & $\begin{array}{l}0.00 \\
0.00 \\
0.00 \\
0.00 \\
0.00\end{array}$ & $\begin{array}{l}1555 \\
1600 \\
1605 \\
1610 \\
1615\end{array}$ & $\begin{array}{r}0.1 \\
0.1 \\
17.2 \\
20.1 \\
22.9\end{array}$ & $\begin{array}{l}0.01 \\
0.00 \\
0.01 \\
0.00 \\
0.00\end{array}$ \\
\hline
\end{tabular}


Table 133. - Streamflow and rainfal1 at station 02173495, Sunnyside Cana1 at Orangeburg. October 10-11, 1990--Cont inued

\begin{tabular}{|c|c|c|c|c|c|c|c|c|}
\hline $\begin{array}{l}\text { Time } \\
\text { (hours) }\end{array}$ & $\begin{array}{l}\text { Streamflow } \\
\text { (cubic feet } \\
\text { per second) }\end{array}$ & $\begin{array}{l}\text { Rain- } \\
\text { fall } \\
\text { (inches) }\end{array}$ & $\begin{array}{l}\text { Time } \\
\text { (hours) }\end{array}$ & $\begin{array}{l}\text { Streamflow } \\
\text { (cubic feet } \\
\text { per second) }\end{array}$ & $\begin{array}{l}\text { Rain- } \\
\text { fall } \\
\text { (inches) }\end{array}$ & $\begin{array}{l}\text { Time } \\
\text { (hours) }\end{array}$ & $\begin{array}{l}\text { Streamflow } \\
\text { (cubic feet } \\
\text { per second) }\end{array}$ & $\begin{array}{l}\text { Rain- } \\
\text { fall } \\
\text { (inches) }\end{array}$ \\
\hline $\begin{array}{l}1620 \\
1625 \\
1630 \\
1635 \\
1640\end{array}$ & $\begin{array}{l}25.7 \\
28.6 \\
31.4 \\
34.3 \\
37.1\end{array}$ & $\begin{array}{l}0.00 \\
0.00 \\
0.00 \\
0.00 \\
0.00\end{array}$ & $\begin{array}{l}1735 \\
1740 \\
1745 \\
1750 \\
1755\end{array}$ & $\begin{array}{r}0.1 \\
83.3 \\
82.5 \\
87.7 \\
98.6\end{array}$ & $\begin{array}{l}0.02 \\
0.02 \\
0.03 \\
0.04 \\
0.02\end{array}$ & $\begin{array}{l}1850 \\
1855 \\
1900 \\
1905 \\
1910\end{array}$ & $\begin{array}{r}138.0 \\
132.0 \\
126.0 \\
115.0 \\
98.9\end{array}$ & $\begin{array}{l}0.00 \\
0.01 \\
0.01 \\
0.01 \\
0.00\end{array}$ \\
\hline $\begin{array}{l}1645 \\
1650 \\
1655 \\
1700 \\
1705\end{array}$ & $\begin{array}{r}40.0 \\
42.8 \\
45.6 \\
48.5 \\
0.1\end{array}$ & $\begin{array}{l}0.00 \\
0.00 \\
0.01 \\
0.01 \\
0.02\end{array}$ & $\begin{array}{l}1800 \\
1805 \\
1810 \\
1815 \\
1820\end{array}$ & $\begin{array}{l}107.0 \\
118.0 \\
124.0 \\
127.0 \\
126.0\end{array}$ & $\begin{array}{l}0.05 \\
0.02 \\
0.02 \\
0.02 \\
0.03\end{array}$ & $\begin{array}{l}1915 \\
1920 \\
1925 \\
1930 \\
1935\end{array}$ & $\begin{array}{l}82.9 \\
70.6 \\
62.9 \\
58.5 \\
52.6\end{array}$ & $\begin{array}{l}0.00 \\
0.01 \\
0.00 \\
0.00 \\
0.01\end{array}$ \\
\hline $\begin{array}{l}1710 \\
1715 \\
1720 \\
1725 \\
1730\end{array}$ & $\begin{array}{l}0.1 \\
0.1 \\
0.1 \\
0.1 \\
0.1\end{array}$ & $\begin{array}{l}0.03 \\
0.06 \\
0.03 \\
0.03 \\
0.01\end{array}$ & $\begin{array}{l}1825 \\
1830 \\
1835 \\
1840 \\
1845\end{array}$ & $\begin{array}{l}126.0 \\
129.0 \\
135.0 \\
141.0 \\
143.0\end{array}$ & $\begin{array}{l}0.01 \\
0.07 \\
0.04 \\
0.02 \\
0.02\end{array}$ & $\begin{array}{l}1940 \\
1945 \\
1950 \\
1955 \\
2000\end{array}$ & $\begin{array}{r}33.5 \\
18.2 \\
7.0 \\
0.1 \\
0.1\end{array}$ & $\begin{array}{l}0.00 \\
0.00 \\
0.00 \\
0.00 \\
0.00\end{array}$ \\
\hline
\end{tabular}




\section{Station 02174240, Middlepen Branch at Orangeburg, S.C.}

Location.-Lat $33^{\circ} 29^{\prime} 14^{\prime \prime}$, long $80^{\circ} 49^{\prime} 50^{\prime \prime}$, Orangeburg County, Hydrologic Unit 03050203, at culvert on U.S. Highway 21/178 bypass, 1.9 mi east of Orangeburg City Hall, and $4.0 \mathrm{mi}$ upstream from the mouth at Cow Castle Creek.

Period of record.-- November 25, 1985 to October 19, 1990.

Gage.--Digital stage recorder with 5-minute punch interval. The recorder is housed in a metal shelter atop a stilling well attached to the right upstream wingwall of a triple 6 $\mathrm{ft}$ by $10 \mathrm{ft}$ concrete box culvert. A sealed intake pipe extends $30 \mathrm{ft}$ upstream to a separate stilling basin. An enameled staff gage is located opposite the recording gage intake on the right bank. One crest-stage indicator is located next to the staff gag $€$. on the right upstream bank. A second crest-stage indicator is attached to the right downstream wingwall.

Rating.--The stage-streamflow relation is defined by current meter measurements up to $250 \mathrm{ft}^{3} / \mathrm{s}$.

Rain gage and location.--Station 332914080495000 , lat $33^{\circ} 29^{\prime} 14^{\prime \prime}$, long $80^{\circ} 49^{\prime} 50^{\prime \prime}$. A shelter containing a digital cumulative rainfall recorder with a 5-minute punch attached to the right downstream wingwall of the culvert at U.S. Highway $21 / 178$ bypass, $1.9 \mathrm{mi}$ east of Orangeburg City Hall, and $4.0 \mathrm{mi}$ upstream from the mouth at Cow Castle. Creek.

Selected basin characteristics.--

Drainage area $-2.40 \mathrm{mi}^{2}$

Physiographic province -- Inner Coastal Plain

Channel slope -- $31.5 \mathrm{ft} / \mathrm{mi}$

Channel length -- $3.30 \mathrm{mi}$

Total impervious area -- 26.0 percent

Basin development factor -- 4

2-year, 2-hour rainfall amount -- $2.20 \mathrm{in}$.

Flood frequency data: $\mathrm{UQ}_{2}$ $428 \mathrm{ft}^{3} / \mathrm{s}$

$\begin{array}{lr}\mathrm{UQ}_{5} & 730 \mathrm{ft}^{3} / \mathrm{s} \\ \mathrm{UQ}_{10} & 952 \mathrm{ft}^{3} / \mathrm{s} \\ \mathrm{UQ}_{25} & 1,250 \mathrm{ft}^{3} / \mathrm{s} \\ \mathrm{UQ}_{50} & 1,480 \mathrm{ft}^{3} / \mathrm{s} \\ \mathrm{UQ}_{100} & 1,730 \mathrm{ft}^{3} / \mathrm{s} \\ \mathrm{UQ}_{500} & 2,320 \mathrm{ft}^{3} / \mathrm{s}\end{array}$



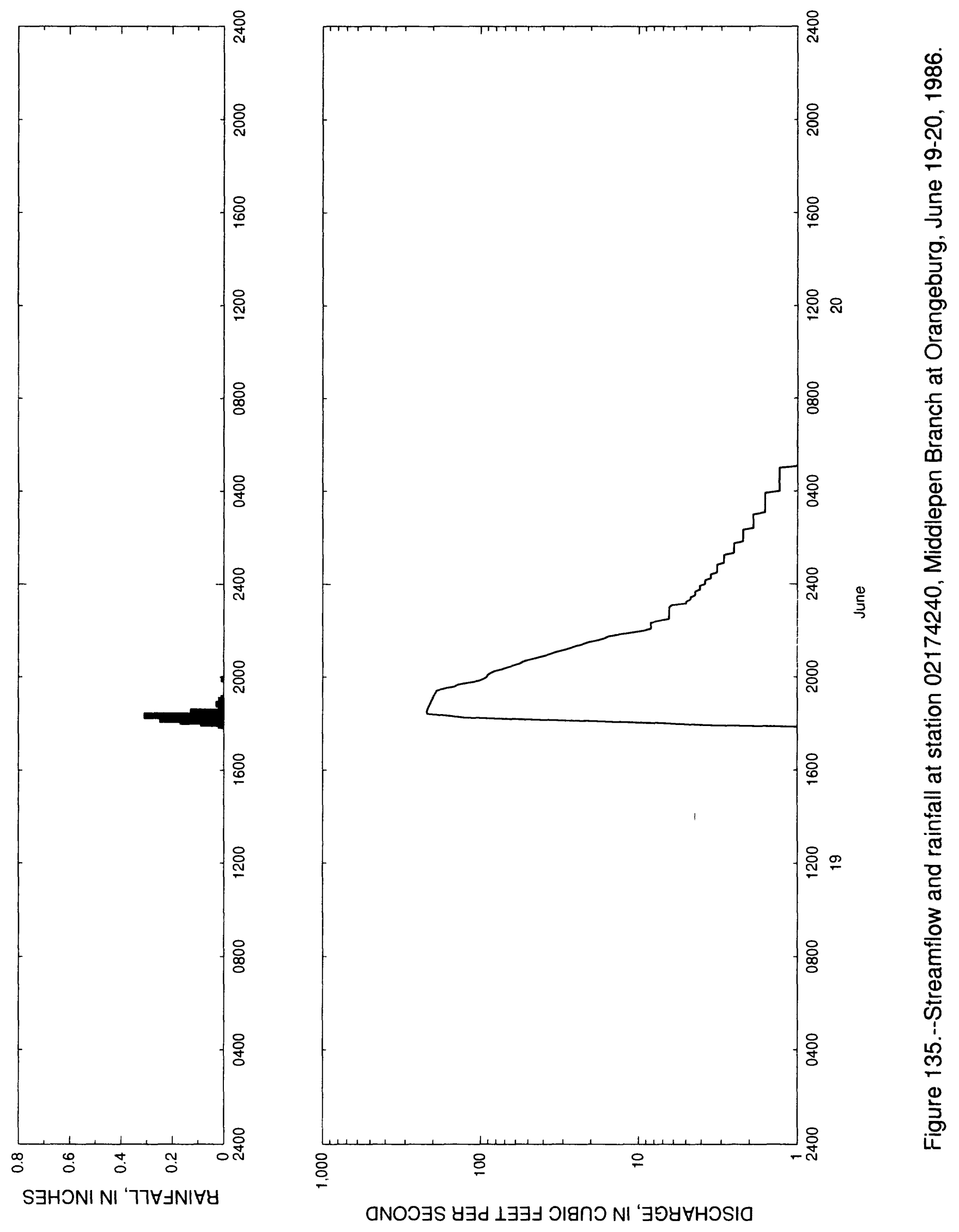
Table 134.--Streamflow and rainfall at station 02174240, Middlepen Branch at Orangeburg, June $19-20,1986$

\begin{tabular}{|c|c|c|c|c|c|c|c|c|}
\hline $\begin{array}{l}\text { Time } \\
\text { (hours) }\end{array}$ & $\begin{array}{l}\text { Streamflow } \\
\text { (cubic feet } \\
\text { per second) }\end{array}$ & $\begin{array}{l}\text { Rain- } \\
\text { fall } \\
\text { (inches) }\end{array}$ & $\begin{array}{l}\text { Time } \\
\text { (hours) }\end{array}$ & $\begin{array}{l}\text { Streamflow } \\
\text { (cubic feet } \\
\text { per second) }\end{array}$ & $\begin{array}{l}\text { Rain- } \\
\text { fall } \\
\text { (inches) }\end{array}$ & $\begin{array}{l}\text { Time } \\
\text { (hours) }\end{array}$ & $\begin{array}{l}\text { Streamflow } \\
\text { (cubic feet } \\
\text { per second) }\end{array}$ & $\begin{array}{l}\text { Rain } \\
\text { fall } \\
\text { (inchos) }\end{array}$ \\
\hline $\begin{array}{l}\text { June } 19 \text {, } \\
1745 \\
1750 \\
1755 \\
1800\end{array}$ & $\begin{array}{r}1986 \\
0.1 \\
0.7 \\
3.8 \\
6.7\end{array}$ & $\begin{array}{l}0.00 \\
0.00 \\
0.02 \\
0.09\end{array}$ & $\begin{array}{l}2230 \\
2235 \\
2240 \\
2245 \\
2250\end{array}$ & $\begin{array}{l}6.4 \\
6.4 \\
6.4 \\
6.4 \\
6.4\end{array}$ & $\begin{array}{l}0.00 \\
0.00 \\
0.00 \\
0.00 \\
0.00\end{array}$ & $\begin{array}{l}0315 \\
0320 \\
0325 \\
0330 \\
0335\end{array}$ & $\begin{array}{l}1.6 \\
1.6 \\
1.6 \\
1.6 \\
1.6\end{array}$ & $\begin{array}{l}0.00 \\
0.00 \\
0.00 \\
0.00 \\
0.00\end{array}$ \\
\hline $\begin{array}{l}1805 \\
1810 \\
1815 \\
1820 \\
1825\end{array}$ & $\begin{array}{r}18.2 \\
50.1 \\
127.0 \\
163.0 \\
218.0\end{array}$ & $\begin{array}{l}0.17 \\
0.25 \\
0.11 \\
0.31 \\
0.13\end{array}$ & $\begin{array}{l}2255 \\
2300 \\
2305 \\
2310 \\
2315\end{array}$ & $\begin{array}{l}6.4 \\
6.4 \\
6.2 \\
5.0 \\
5.0\end{array}$ & $\begin{array}{l}0.00 \\
0.00 \\
0.00 \\
0.00 \\
0.00\end{array}$ & $\begin{array}{l}0340 \\
0345 \\
0350 \\
0355 \\
0400\end{array}$ & $\begin{array}{l}1.6 \\
1.6 \\
1.6 \\
1.6 \\
1.3\end{array}$ & $\begin{array}{l}0.00 \\
0.00 \\
0.00 \\
0.00 \\
0.00\end{array}$ \\
\hline $\begin{array}{l}1830 \\
1835 \\
1840 \\
1845 \\
1850\end{array}$ & $\begin{array}{l}220.0 \\
218.0 \\
216.0 \\
213.0 \\
210.0\end{array}$ & $\begin{array}{l}0.13 \\
0.01 \\
0.01 \\
0.02 \\
0.03\end{array}$ & $\begin{array}{l}2320 \\
2325 \\
2330 \\
2335 \\
2340\end{array}$ & $\begin{array}{l}4.7 \\
4.7 \\
4.4 \\
4.4 \\
4.4\end{array}$ & $\begin{array}{l}0.00 \\
0.00 \\
0.00 \\
0.00 \\
0.00\end{array}$ & $\begin{array}{l}0405 \\
0410 \\
0415 \\
0420 \\
0425\end{array}$ & $\begin{array}{l}1.3 \\
1.3 \\
1.3 \\
1.3 \\
1.3\end{array}$ & $\begin{array}{l}0.00 \\
0.00 \\
0.00 \\
0.00 \\
0.00\end{array}$ \\
\hline $\begin{array}{l}1855 \\
1900 \\
1905 \\
1910 \\
1915\end{array}$ & $\begin{array}{l}208.0 \\
205.0 \\
202.0 \\
199.0 \\
196.0\end{array}$ & $\begin{array}{l}0.00 \\
0.02 \\
0.01 \\
0.00 \\
0.00\end{array}$ & $\begin{array}{l}2345 \\
2350 \\
2355 \\
\text { June } 20 \\
0000\end{array}$ & $\begin{array}{lr} & 4.1 \\
& 4.1 \\
& 4.1 \\
1986 & \\
& 3.8\end{array}$ & $\begin{array}{l}0.00 \\
0.00 \\
0.00 \\
0.00\end{array}$ & $\begin{array}{l}0430 \\
0435 \\
0440 \\
0445 \\
0450\end{array}$ & $\begin{array}{l}1.3 \\
1.3 \\
1.3 \\
1.3 \\
1.3\end{array}$ & $\begin{array}{l}0.00 \\
0.00 \\
0.00 \\
0.00 \\
0.00\end{array}$ \\
\hline $\begin{array}{l}1920 \\
1925 \\
1930 \\
1935 \\
1940\end{array}$ & $\begin{array}{l}193.0 \\
190.0 \\
170.0 \\
146.0 \\
139.0\end{array}$ & $\begin{array}{l}0.00 \\
0.00 \\
0.00 \\
0.00 \\
0.00\end{array}$ & $\begin{array}{l}0005 \\
0010 \\
0015 \\
0020 \\
0025\end{array}$ & $\begin{array}{l}3.8 \\
3.8 \\
3.5 \\
3.5 \\
3.5\end{array}$ & $\begin{array}{l}0.00 \\
0.00 \\
0.00 \\
0.00 \\
0.00\end{array}$ & $\begin{array}{l}0455 \\
0500 \\
0505 \\
0510 \\
0515\end{array}$ & $\begin{array}{l}1.3 \\
1.3 \\
1.0 \\
1.0 \\
1.0\end{array}$ & $\begin{array}{l}0.00 \\
0.00 \\
0.00 \\
0.00 \\
0.00\end{array}$ \\
\hline $\begin{array}{l}1945 \\
1950 \\
1955 \\
2000 \\
2005\end{array}$ & $\begin{array}{r}120.0 \\
102.0 \\
95.6 \\
91.6 \\
90.5\end{array}$ & $\begin{array}{l}0.00 \\
0.00 \\
0.01 \\
0.00 \\
0.00\end{array}$ & $\begin{array}{l}0030 \\
0035 \\
0040 \\
0045 \\
0050\end{array}$ & $\begin{array}{l}3.2 \\
3.2 \\
3.2 \\
3.2 \\
3.2\end{array}$ & $\begin{array}{l}0.00 \\
0.00 \\
0.00 \\
0.00 \\
0.00\end{array}$ & $\begin{array}{l}0520 \\
0525 \\
0530 \\
0535 \\
0540\end{array}$ & $\begin{array}{l}1.0 \\
1.0 \\
1.0 \\
1.0 \\
1.0\end{array}$ & $\begin{array}{l}0.00 \\
0.00 \\
0.00 \\
0.00 \\
0.00\end{array}$ \\
\hline $\begin{array}{l}2010 \\
2015 \\
2020 \\
2025 \\
2030\end{array}$ & $\begin{array}{l}86.7 \\
81.7 \\
73.1 \\
67.6 \\
61.7\end{array}$ & $\begin{array}{l}0.00 \\
0.00 \\
0.00 \\
0.00 \\
0.00\end{array}$ & $\begin{array}{l}0055 \\
0100 \\
0105 \\
0110 \\
0115\end{array}$ & $\begin{array}{l}2.9 \\
2.9 \\
2.9 \\
2.9 \\
2.9\end{array}$ & $\begin{array}{l}0.00 \\
0.00 \\
0.00 \\
0.00 \\
0.00\end{array}$ & $\begin{array}{l}0545 \\
0550 \\
0555 \\
0600 \\
0605\end{array}$ & $\begin{array}{l}1.0 \\
1.0 \\
1.0 \\
1.0 \\
1.0\end{array}$ & $\begin{array}{l}0.00 \\
0.00 \\
0.00 \\
0.00 \\
0.00\end{array}$ \\
\hline $\begin{array}{l}2035 \\
2040 \\
2045 \\
2050 \\
2055\end{array}$ & $\begin{array}{l}56.6 \\
54.1 \\
48.7 \\
44.0 \\
39.4\end{array}$ & $\begin{array}{l}0.00 \\
0.00 \\
0.00 \\
0.00 \\
0.00\end{array}$ & $\begin{array}{l}0120 \\
0125 \\
0130 \\
0135 \\
0140\end{array}$ & $\begin{array}{l}2.5 \\
2.5 \\
2.5 \\
2.5 \\
2.5\end{array}$ & $\begin{array}{l}0.00 \\
0.00 \\
0.00 \\
0.00 \\
0.00\end{array}$ & $\begin{array}{l}0610 \\
0615 \\
0620 \\
0625 \\
0630\end{array}$ & $\begin{array}{l}1.0 \\
1.0 \\
1.0 \\
1.0 \\
1.0\end{array}$ & $\begin{array}{l}0.00 \\
0.00 \\
0.00 \\
0.00 \\
0.00\end{array}$ \\
\hline $\begin{array}{l}2100 \\
2105 \\
2110 \\
2115 \\
2120\end{array}$ & $\begin{array}{l}35.7 \\
33.0 \\
29.5 \\
26.9 \\
25.1\end{array}$ & $\begin{array}{l}0.00 \\
0.00 \\
0.00 \\
0.00 \\
0.00\end{array}$ & $\begin{array}{l}0145 \\
0150 \\
0155 \\
0200 \\
0205\end{array}$ & $\begin{array}{l}2.5 \\
2.2 \\
2.2 \\
2.2 \\
2.2\end{array}$ & $\begin{array}{l}0.00 \\
0.00 \\
0.00 \\
0.00 \\
0.00\end{array}$ & $\begin{array}{l}0635 \\
0640 \\
0645 \\
0650 \\
0655\end{array}$ & $\begin{array}{l}1.0 \\
1.0 \\
1.0 \\
1.0 \\
1.0\end{array}$ & $\begin{array}{l}0.00 \\
0.00 \\
0.00 \\
0.00 \\
0.00\end{array}$ \\
\hline $\begin{array}{l}2125 \\
2130 \\
2135 \\
2140 \\
2145\end{array}$ & $\begin{array}{l}22.5 \\
20.7 \\
18.1 \\
16.4 \\
15.5\end{array}$ & $\begin{array}{l}0.00 \\
0.00 \\
0.00 \\
0.00 \\
0.00\end{array}$ & $\begin{array}{l}0210 \\
0215 \\
0220 \\
0225 \\
0230\end{array}$ & $\begin{array}{l}2.2 \\
2.2 \\
2.2 \\
1.9 \\
1.9\end{array}$ & $\begin{array}{l}0.00 \\
0.00 \\
0.00 \\
0.00 \\
0.00\end{array}$ & $\begin{array}{l}0700 \\
0705 \\
0710 \\
0715 \\
0720\end{array}$ & $\begin{array}{l}0.7 \\
0.7 \\
0.7 \\
0.7 \\
0.7\end{array}$ & $\begin{array}{l}0.00 \\
0.00 \\
0.00 \\
0.00 \\
0.00\end{array}$ \\
\hline $\begin{array}{l}2150 \\
2155 \\
2200 \\
2205 \\
2210\end{array}$ & $\begin{array}{r}13.2 \\
11.0 \\
9.3 \\
8.4 \\
8.4\end{array}$ & $\begin{array}{l}0.00 \\
0.00 \\
0.00 \\
0.00 \\
0.00\end{array}$ & $\begin{array}{l}0235 \\
0240 \\
0245 \\
0250 \\
0255\end{array}$ & $\begin{array}{l}1.9 \\
1.9 \\
1.9 \\
1.9 \\
1.9\end{array}$ & $\begin{array}{l}0.00 \\
0.00 \\
0.00 \\
0.00 \\
0.00\end{array}$ & $\begin{array}{l}0725 \\
0730 \\
0735 \\
0740 \\
0745\end{array}$ & $\begin{array}{l}0.7 \\
0.7 \\
0.7 \\
0.7 \\
0.7\end{array}$ & $\begin{array}{l}0.00 \\
0.00 \\
0.00 \\
0.00 \\
0.00\end{array}$ \\
\hline $\begin{array}{l}2215 \\
2220 \\
2225\end{array}$ & $\begin{array}{l}8.4 \\
8.4 \\
7.4\end{array}$ & $\begin{array}{l}0.00 \\
0.00 \\
0.00\end{array}$ & $\begin{array}{l}0300 \\
0305 \\
0310\end{array}$ & $\begin{array}{l}1.9 \\
1.6 \\
1.6\end{array}$ & $\begin{array}{l}0.00 \\
0.00 \\
0.00\end{array}$ & $\begin{array}{l}0750 \\
0755 \\
0800\end{array}$ & $\begin{array}{l}0.7 \\
0.7 \\
0.7\end{array}$ & $\begin{array}{l}0.00 \\
0.00 \\
0.00\end{array}$ \\
\hline
\end{tabular}




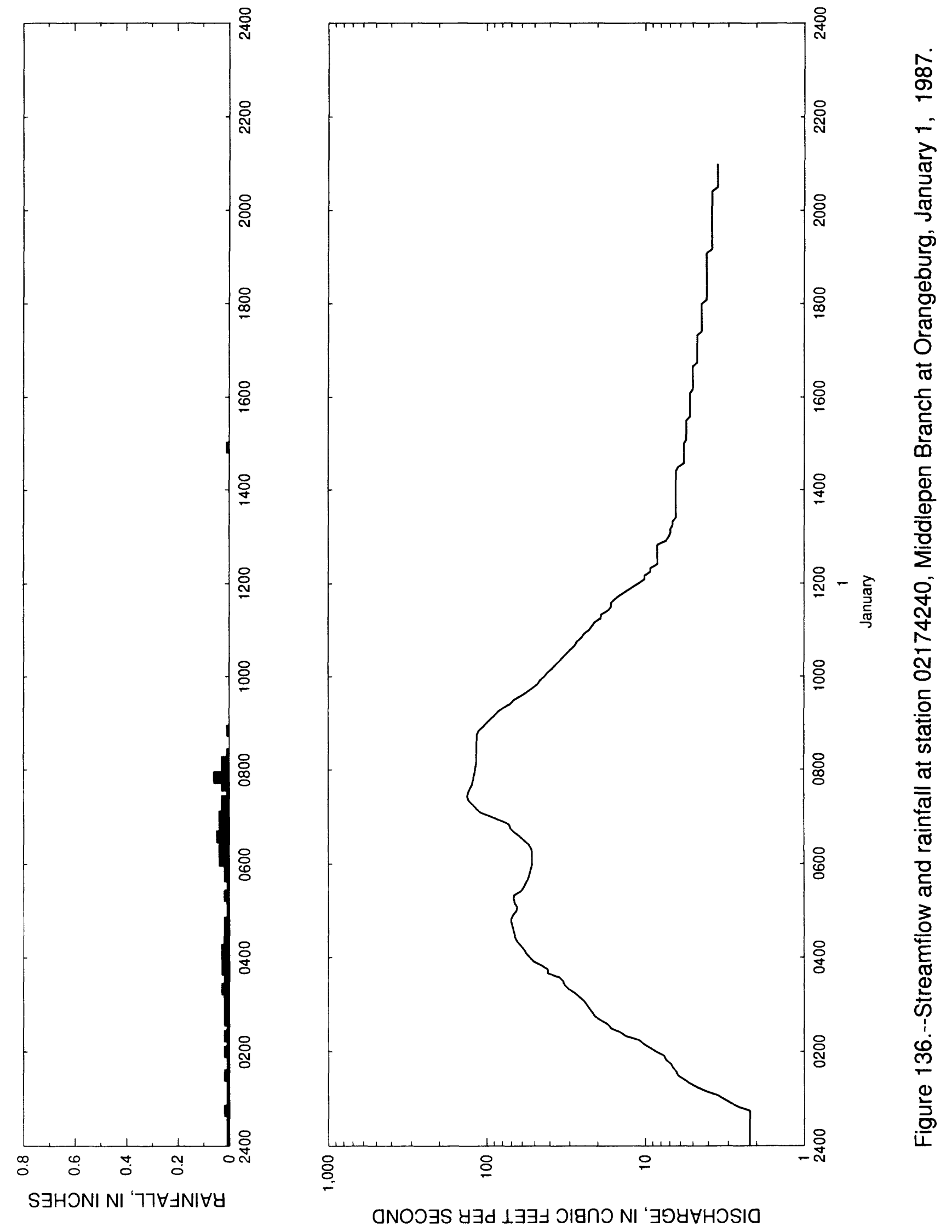




\begin{tabular}{|c|c|c|c|c|c|c|c|c|}
\hline $\begin{array}{l}\text { Time } \\
\text { (hours) }\end{array}$ & $\begin{array}{l}\text { Streamflow } \\
\text { (cubic feet } \\
\text { per second) }\end{array}$ & $\begin{array}{l}\text { Rain- } \\
\text { fall } \\
\text { (inches) }\end{array}$ & $\begin{array}{l}\text { Time } \\
\text { (hours) }\end{array}$ & $\begin{array}{l}\text { Streamflow } \\
\text { (cubic feet } \\
\text { per second) }\end{array}$ & $\begin{array}{l}\text { Rain- } \\
\text { fall } \\
\text { (inches) }\end{array}$ & $\begin{array}{l}\text { Time } \\
\text { (hours) }\end{array}$ & $\begin{array}{l}\text { Streamflow } \\
\text { (cubic feet } \\
\text { per second) }\end{array}$ & $\begin{array}{l}\text { Rain- } \\
\text { fall } \\
\text { (inches) }\end{array}$ \\
\hline $\begin{array}{l}\text { January } \\
0000 \\
0005 \\
0010 \\
0015\end{array}$ & $\begin{array}{r}1,1987 \\
2.2 \\
2.2 \\
2.2 \\
2.2\end{array}$ & $\begin{array}{l}0.00 \\
0.01 \\
0.00 \\
0.01\end{array}$ & $\begin{array}{l}0520 \\
0525 \\
0530 \\
0535 \\
0540\end{array}$ & $\begin{array}{l}67.2 \\
61.0 \\
58.6 \\
57.0 \\
55.0\end{array}$ & $\begin{array}{l}0.02 \\
0.00 \\
0.01 \\
0.00 \\
0.00\end{array}$ & $\begin{array}{l}1045 \\
1050 \\
1055 \\
1100 \\
1105\end{array}$ & $\begin{array}{l}26.9 \\
25.1 \\
24.2 \\
22.5 \\
21.6\end{array}$ & $\begin{array}{l}0.00 \\
0.00 \\
0.00 \\
0.00 \\
0.00\end{array}$ \\
\hline $\begin{array}{l}0020 \\
0025 \\
0030 \\
0035 \\
0040\end{array}$ & $\begin{array}{l}2.2 \\
2.2 \\
2.2 \\
2.2 \\
2.2\end{array}$ & $\begin{array}{l}0.00 \\
0.01 \\
0.01 \\
0.01 \\
0.00\end{array}$ & $\begin{array}{l}0545 \\
0550 \\
0555 \\
0600 \\
0605\end{array}$ & $\begin{array}{l}54.1 \\
53.3 \\
52.4 \\
51.5 \\
51.5\end{array}$ & $\begin{array}{l}0.02 \\
0.02 \\
0.02 \\
0.02 \\
0.04\end{array}$ & $\begin{array}{l}1110 \\
1115 \\
1120 \\
1125 \\
1130\end{array}$ & $\begin{array}{l}20.7 \\
19.0 \\
19.0 \\
17.2 \\
16.4\end{array}$ & $\begin{array}{l}0.00 \\
0.00 \\
0.00 \\
0.00 \\
0.00\end{array}$ \\
\hline $\begin{array}{l}0045 \\
0050 \\
0055 \\
0100 \\
0105\end{array}$ & $\begin{array}{l}2.2 \\
2.6 \\
2.9 \\
3.2 \\
3.5\end{array}$ & $\begin{array}{l}0.02 \\
0.01 \\
0.00 \\
0.01 \\
0.00\end{array}$ & $\begin{array}{l}0610 \\
0615 \\
0620 \\
0625 \\
0630\end{array}$ & $\begin{array}{l}51.5 \\
51.5 \\
52.5 \\
54.4 \\
58.3\end{array}$ & $\begin{array}{l}0.03 \\
0.02 \\
0.04 \\
0.03 \\
0.02\end{array}$ & $\begin{array}{l}1135 \\
1140 \\
1145 \\
1150 \\
1155\end{array}$ & $\begin{array}{l}16.4 \\
15.5 \\
14.4 \\
13.2 \\
12.1\end{array}$ & $\begin{array}{l}0.00 \\
0.00 \\
0.00 \\
0.00 \\
0.00\end{array}$ \\
\hline $\begin{array}{l}0110 \\
0115 \\
0120 \\
0125 \\
0130\end{array}$ & $\begin{array}{l}4.1 \\
4.7 \\
5.2 \\
5.7 \\
6.2\end{array}$ & $\begin{array}{l}0.01 \\
0.00 \\
0.01 \\
0.01 \\
0.02\end{array}$ & $\begin{array}{l}0635 \\
0640 \\
0645 \\
0650 \\
0655\end{array}$ & $\begin{array}{l}62.1 \\
67.1 \\
70.8 \\
72.2 \\
82.5\end{array}$ & $\begin{array}{l}0.05 \\
0.03 \\
0.04 \\
0.02 \\
0.01\end{array}$ & $\begin{array}{l}1200 \\
1205 \\
1210 \\
1215 \\
1220\end{array}$ & $\begin{array}{r}11.0 \\
10.1 \\
10.1 \\
9.3 \\
9.3\end{array}$ & $\begin{array}{l}0.00 \\
0.00 \\
0.00 \\
0.00 \\
0.00\end{array}$ \\
\hline $\begin{array}{l}0135 \\
0140 \\
0145 \\
0150 \\
0155\end{array}$ & $\begin{array}{l}6.4 \\
6.7 \\
6.9 \\
7.4 \\
7.6\end{array}$ & $\begin{array}{l}0.01 \\
0.01 \\
0.01 \\
0.01 \\
0.00\end{array}$ & $\begin{array}{l}0700 \\
0705 \\
0710 \\
0715 \\
0720\end{array}$ & $\begin{array}{r}94.5 \\
109.0 \\
116.0 \\
122.0 \\
129.0\end{array}$ & $\begin{array}{l}0.04 \\
0.03 \\
0.01 \\
0.02 \\
0.03\end{array}$ & $\begin{array}{l}1225 \\
1230 \\
1235 \\
1240 \\
1245\end{array}$ & $\begin{array}{l}8.4 \\
8.4 \\
8.4 \\
8.4 \\
8.4\end{array}$ & $\begin{array}{l}0.00 \\
0.00 \\
0.00 \\
0.00 \\
0.00\end{array}$ \\
\hline $\begin{array}{l}0200 \\
0205 \\
0210 \\
0215 \\
0220\end{array}$ & $\begin{array}{r}8.5 \\
9.3 \\
10.2 \\
11.0 \\
13.3\end{array}$ & $\begin{array}{l}0.02 \\
0.01 \\
0.01 \\
0.01 \\
0.02\end{array}$ & $\begin{array}{l}0725 \\
0730 \\
0735 \\
0740 \\
0745\end{array}$ & $\begin{array}{l}133.0 \\
131.0 \\
128.0 \\
124.0 \\
122.0\end{array}$ & $\begin{array}{l}0.01 \\
0.01 \\
0.01 \\
0.03 \\
0.01\end{array}$ & $\begin{array}{l}1250 \\
1255 \\
1300 \\
1305 \\
1310\end{array}$ & $\begin{array}{l}8.4 \\
7.4 \\
7.1 \\
6.9 \\
6.9\end{array}$ & $\begin{array}{l}0.00 \\
0.00 \\
0.00 \\
0.00 \\
0.00\end{array}$ \\
\hline $\begin{array}{l}0225 \\
0230 \\
0235 \\
0240 \\
0245\end{array}$ & $\begin{array}{l}14.4 \\
16.4 \\
17.3 \\
19.0 \\
20.8\end{array}$ & $\begin{array}{l}0.01 \\
0.01 \\
0.01 \\
0.02 \\
0.01\end{array}$ & $\begin{array}{l}0750 \\
0755 \\
0800 \\
0805 \\
0810\end{array}$ & $\begin{array}{l}121.0 \\
119.0 \\
118.0 \\
117.0 \\
116.0\end{array}$ & $\begin{array}{l}0.06 \\
0.03 \\
0.02 \\
0.02 \\
0.03\end{array}$ & $\begin{array}{l}1315 \\
1320 \\
1325 \\
1330 \\
1335\end{array}$ & $\begin{array}{l}6.7 \\
6.7 \\
6.4 \\
6.4 \\
6.4\end{array}$ & $\begin{array}{l}0.00 \\
0.00 \\
0.00 \\
0.00 \\
0.00\end{array}$ \\
\hline $\begin{array}{l}0250 \\
0255 \\
0300 \\
0305 \\
0310\end{array}$ & $\begin{array}{l}21.6 \\
22.5 \\
23.4 \\
24.3 \\
26.0\end{array}$ & $\begin{array}{l}0.02 \\
0.02 \\
0.02 \\
0.02 \\
0.02\end{array}$ & $\begin{array}{l}0815 \\
0820 \\
0825 \\
0830 \\
0835\end{array}$ & $\begin{array}{l}116.0 \\
116.0 \\
116.0 \\
116.0 \\
116.0\end{array}$ & $\begin{array}{l}0.01 \\
0.01 \\
0.00 \\
0.00 \\
0.00\end{array}$ & $\begin{array}{l}1340 \\
1345 \\
1350 \\
1355 \\
1400\end{array}$ & $\begin{array}{l}6.4 \\
6.4 \\
6.4 \\
6.4 \\
6.4\end{array}$ & $\begin{array}{l}0.00 \\
0.00 \\
0.00 \\
0.00 \\
0.00\end{array}$ \\
\hline $\begin{array}{l}0315 \\
0320 \\
0325 \\
0330 \\
0335\end{array}$ & $\begin{array}{l}27.8 \\
30.4 \\
32.1 \\
33.0 \\
34.9\end{array}$ & $\begin{array}{l}0.02 \\
0.03 \\
0.02 \\
0.02 \\
0.02\end{array}$ & $\begin{array}{l}0840 \\
0845 \\
0850 \\
0855 \\
0900\end{array}$ & $\begin{array}{l}115.0 \\
115.0 \\
112.0 \\
105.0 \\
100.0\end{array}$ & $\begin{array}{l}0.00 \\
0.00 \\
0.01 \\
0.00 \\
0.00\end{array}$ & $\begin{array}{l}1405 \\
1410 \\
1415 \\
1420 \\
1425\end{array}$ & $\begin{array}{l}6.4 \\
6.4 \\
6.4 \\
6.4 \\
6.4\end{array}$ & $\begin{array}{l}0.00 \\
0.00 \\
0.00 \\
0.00 \\
0.00\end{array}$ \\
\hline $\begin{array}{l}0340 \\
0345 \\
0350 \\
0355 \\
0400\end{array}$ & $\begin{array}{l}41.4 \\
41.3 \\
45.1 \\
50.7 \\
53.5\end{array}$ & $\begin{array}{l}0.02 \\
0.03 \\
0.03 \\
0.03 \\
0.03\end{array}$ & $\begin{array}{l}0905 \\
0910 \\
0915 \\
0920 \\
0925\end{array}$ & $\begin{array}{l}94.6 \\
88.5 \\
84.2 \\
77.2 \\
70.9\end{array}$ & $\begin{array}{l}0.00 \\
0.00 \\
0.00 \\
0.00 \\
0.00\end{array}$ & $\begin{array}{l}1430 \\
1435 \\
1440 \\
1445 \\
1450\end{array}$ & $\begin{array}{l}6.2 \\
5.7 \\
5.7 \\
5.7 \\
5.7\end{array}$ & $\begin{array}{l}0.00 \\
0.00 \\
0.00 \\
0.00 \\
0.00\end{array}$ \\
\hline $\begin{array}{l}0405 \\
0410 \\
0415 \\
0420 \\
0425\end{array}$ & $\begin{array}{l}56.3 \\
58.1 \\
61.0 \\
64.0 \\
66.0\end{array}$ & $\begin{array}{l}0.03 \\
0.03 \\
0.02 \\
0.02 \\
0.01\end{array}$ & $\begin{array}{l}0930 \\
0935 \\
0940 \\
0945 \\
0950\end{array}$ & $\begin{array}{l}67.3 \\
60.8 \\
55.7 \\
51.4 \\
47.8\end{array}$ & $\begin{array}{l}0.00 \\
0.00 \\
0.00 \\
0.00 \\
0.00\end{array}$ & $\begin{array}{l}1455 \\
1500 \\
1505 \\
1510 \\
1515\end{array}$ & $\begin{array}{l}5.7 \\
5.7 \\
5.5 \\
5.5 \\
5.5\end{array}$ & $\begin{array}{l}0.01 \\
0.00 \\
0.00 \\
0.00 \\
0.00\end{array}$ \\
\hline $\begin{array}{l}0430 \\
0435 \\
0440 \\
0445 \\
0450\end{array}$ & $\begin{array}{l}67.0 \\
68.0 \\
69.0 \\
70.0 \\
70.0\end{array}$ & $\begin{array}{l}0.01 \\
0.02 \\
0.01 \\
0.02 \\
0.01\end{array}$ & $\begin{array}{l}0955 \\
1000 \\
1005 \\
1010 \\
1015\end{array}$ & $\begin{array}{l}45.9 \\
43.1 \\
41.3 \\
38.5 \\
36.7\end{array}$ & $\begin{array}{l}0.00 \\
0.00 \\
0.00 \\
0.00 \\
0.00\end{array}$ & $\begin{array}{l}1520 \\
1525 \\
1530 \\
1535 \\
1540\end{array}$ & $\begin{array}{l}5.5 \\
5.5 \\
5.5 \\
5.2 \\
5.2\end{array}$ & $\begin{array}{l}0.00 \\
0.00 \\
0.00 \\
0.00 \\
0.00\end{array}$ \\
\hline $\begin{array}{l}0455 \\
0500 \\
0505 \\
0510 \\
0515\end{array}$ & $\begin{array}{l}68.0 \\
64.9 \\
64.3 \\
66.6 \\
67.4\end{array}$ & $\begin{array}{l}0.01 \\
0.01 \\
0.01 \\
0.01 \\
0.01\end{array}$ & $\begin{array}{l}1020 \\
1025 \\
1030 \\
1035 \\
1040\end{array}$ & $\begin{array}{l}34.8 \\
33.0 \\
31.2 \\
29.5 \\
27.7\end{array}$ & $\begin{array}{l}0.00 \\
0.00 \\
0.00 \\
0.00 \\
0.00\end{array}$ & $\begin{array}{l}1545 \\
1550 \\
1555 \\
1600 \\
1605\end{array}$ & $\begin{array}{l}5.2 \\
5.2 \\
5.2 \\
5.2 \\
5.2\end{array}$ & $\begin{array}{l}0.00 \\
0.00 \\
0.00 \\
0.00 \\
0.00\end{array}$ \\
\hline
\end{tabular}


Table 135. - - Streamflow and rainfall at station 02174240, Middlepen Branch at Orangeburg, January $1,1987^{--C o n t i n u e d}$

\begin{tabular}{|c|c|c|c|c|c|c|c|c|}
\hline $\begin{array}{l}\text { Time } \\
\text { (hours) }\end{array}$ & $\begin{array}{l}\text { Streamflow } \\
\text { (cubic feet } \\
\text { per second) }\end{array}$ & $\begin{array}{l}\text { Rain- } \\
\text { fall } \\
\text { (inches) }\end{array}$ & $\begin{array}{l}\text { Time } \\
\text { (hours) }\end{array}$ & $\begin{array}{l}\text { Streamflow } \\
\text { (cubic feet } \\
\text { per second) }\end{array}$ & $\begin{array}{l}\text { Rain- } \\
\text { fall } \\
\text { (inches) }\end{array}$ & $\begin{array}{l}\text { Time } \\
\text { (hours) }\end{array}$ & $\begin{array}{l}\text { Streamflow } \\
\text { (cubic feet } \\
\text { per second) }\end{array}$ & $\begin{array}{l}\text { Rain- } \\
\text { fall } \\
\text { (inches) }\end{array}$ \\
\hline $\begin{array}{l}1610 \\
1615 \\
1620 \\
1625 \\
1630\end{array}$ & $\begin{array}{l}5.0 \\
5.0 \\
5.0 \\
5.0 \\
5.0\end{array}$ & $\begin{array}{l}0.00 \\
0.00 \\
0.00 \\
0.00 \\
0.00\end{array}$ & $\begin{array}{l}1750 \\
1755 \\
1800 \\
1805 \\
1810\end{array}$ & $\begin{array}{l}4.4 \\
4.4 \\
4.4 \\
4.1 \\
4.1\end{array}$ & $\begin{array}{l}0.00 \\
0.00 \\
0.00 \\
0.00 \\
0.00\end{array}$ & $\begin{array}{l}1930 \\
1935 \\
1940 \\
1945 \\
1950\end{array}$ & $\begin{array}{l}3.8 \\
3.8 \\
3.8 \\
3.8 \\
3.8\end{array}$ & $\begin{array}{l}0.00 \\
0.00 \\
0.00 \\
0.00 \\
0.00\end{array}$ \\
\hline $\begin{array}{l}1635 \\
1640 \\
1645 \\
1650 \\
1655\end{array}$ & $\begin{array}{l}5.0 \\
5.0 \\
4.7 \\
4.7 \\
4.7\end{array}$ & $\begin{array}{l}0.00 \\
0.00 \\
0.00 \\
0.00 \\
0.00\end{array}$ & $\begin{array}{l}1815 \\
1820 \\
1825 \\
1830 \\
1835\end{array}$ & $\begin{array}{l}4 \cdot 1 \\
4 \cdot 1 \\
4 \cdot 1 \\
4 \cdot 1 \\
4 \cdot 1\end{array}$ & $\begin{array}{l}0.00 \\
0.00 \\
0.00 \\
0.00 \\
0.00\end{array}$ & $\begin{array}{l}1955 \\
2000 \\
2005 \\
2010 \\
2015\end{array}$ & $\begin{array}{l}3.8 \\
3.8 \\
3.8 \\
3.8 \\
3.8\end{array}$ & $\begin{array}{l}0.00 \\
0.00 \\
0.00 \\
0.00 \\
0.00\end{array}$ \\
\hline $\begin{array}{l}1700 \\
1705 \\
1710 \\
1715 \\
1720\end{array}$ & $\begin{array}{l}4.7 \\
4.7 \\
4.7 \\
4.7 \\
4.7\end{array}$ & $\begin{array}{l}0.00 \\
0.00 \\
0.00 \\
0.00 \\
0.00\end{array}$ & $\begin{array}{l}1840 \\
1845 \\
1850 \\
1855 \\
1900\end{array}$ & $\begin{array}{l}4 \cdot 1 \\
4 \cdot 1 \\
4 \cdot 1 \\
4 \cdot 1 \\
4.1\end{array}$ & $\begin{array}{l}0.00 \\
0.00 \\
0.00 \\
0.00 \\
0.00\end{array}$ & $\begin{array}{l}2020 \\
2025 \\
2030 \\
2035 \\
2040\end{array}$ & $\begin{array}{l}3.8 \\
3.8 \\
3.5 \\
3.5 \\
3.5\end{array}$ & $\begin{array}{l}0.00 \\
0.00 \\
0.00 \\
0.00 \\
0.00\end{array}$ \\
\hline $\begin{array}{l}1725 \\
1730 \\
1735 \\
1740 \\
1745\end{array}$ & $\begin{array}{l}4.4 \\
4.4 \\
4.4 \\
4.4 \\
4.4\end{array}$ & $\begin{array}{l}0.00 \\
0.00 \\
0.00 \\
0.00 \\
0.00\end{array}$ & $\begin{array}{l}1905 \\
1910 \\
1915 \\
1920 \\
1925\end{array}$ & $\begin{array}{l}4.1 \\
3.8 \\
3.8 \\
3.8 \\
3.8\end{array}$ & $\begin{array}{l}0.00 \\
0.00 \\
0.00 \\
0.00 \\
0.00\end{array}$ & $\begin{array}{l}2045 \\
2050 \\
2055 \\
2100\end{array}$ & $\begin{array}{l}3.5 \\
3.5 \\
3.5 \\
3.5\end{array}$ & $\begin{array}{l}0.00 \\
0.00 \\
0.00 \\
0.00\end{array}$ \\
\hline
\end{tabular}




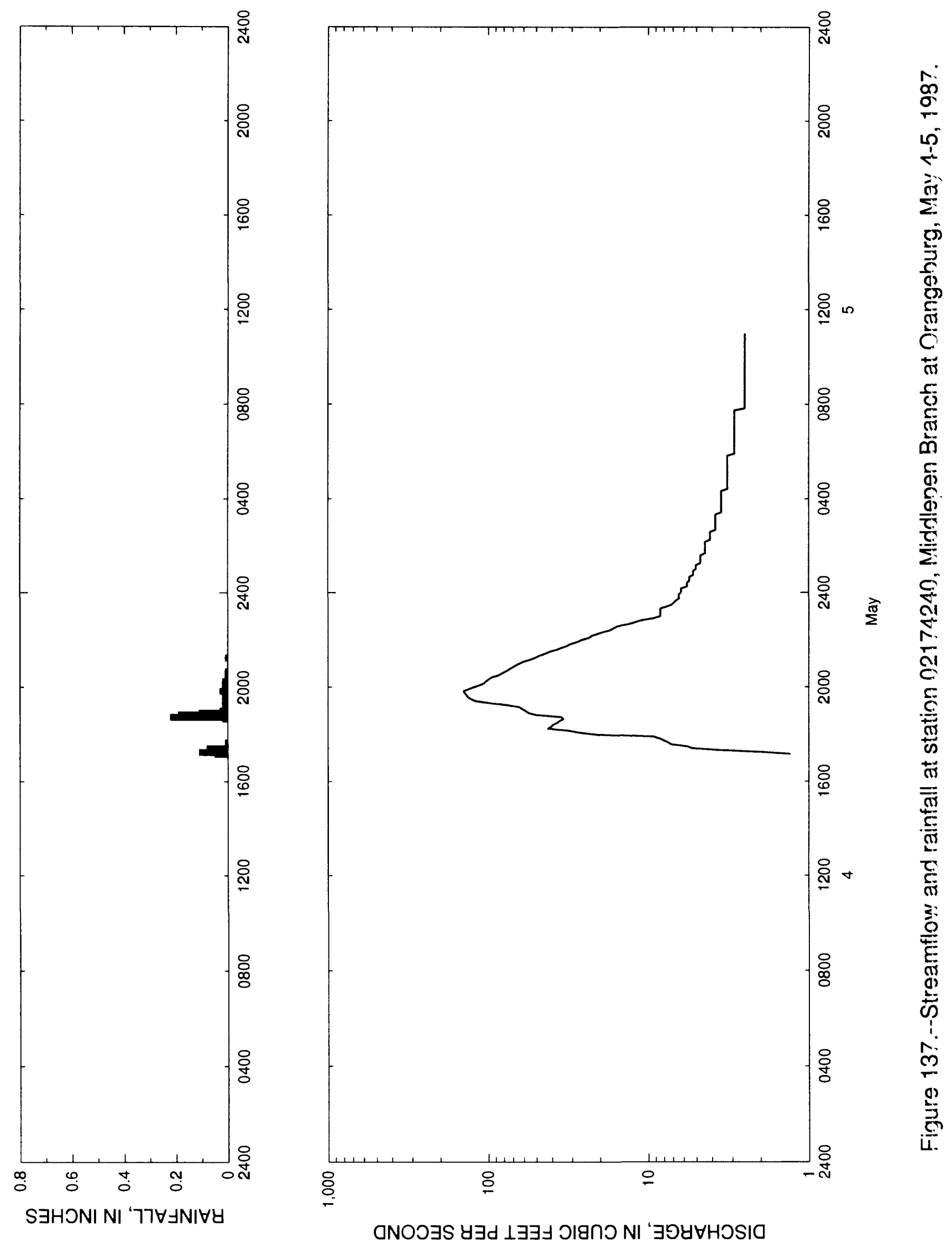


Table 136. - - Streamflow and rainfall at station 02174240, Middlepen Branch at Orangeburg, May $4-5,1987$

\begin{tabular}{|c|c|c|c|c|c|c|c|c|}
\hline $\begin{array}{l}\text { Time } \\
\text { (hours) }\end{array}$ & $\begin{array}{l}\text { Streamflow } \\
\text { (cubic feet } \\
\text { per second) }\end{array}$ & $\begin{array}{l}\text { Rain- } \\
\text { fall } \\
\text { (inches) }\end{array}$ & $\begin{array}{l}\text { Time } \\
\text { (hours) }\end{array}$ & $\begin{array}{l}\text { Streamflow } \\
\text { (cubic feet } \\
\text { per second) }\end{array}$ & $\begin{array}{l}\text { Rain- } \\
\text { fall } \\
\text { (inches) }\end{array}$ & $\begin{array}{l}\text { Time } \\
\text { (hours) }\end{array}$ & $\begin{array}{l}\text { Streamflow } \\
\text { (cubic feet } \\
\text { per second) }\end{array}$ & $\begin{array}{l}\text { Rain- } \\
\text { fall } \\
\text { (inches) }\end{array}$ \\
\hline $\begin{array}{r}\text { May } 4 \\
1710 \\
1715 \\
1720 \\
1725\end{array}$ & $\begin{array}{l}1.3 \\
1.9 \\
3.5 \\
5.3\end{array}$ & $\begin{array}{l}0.05 \\
0.11 \\
0.07 \\
0.08\end{array}$ & $\begin{array}{l}2230 \\
2235 \\
2240 \\
2245 \\
2250\end{array}$ & $\begin{array}{l}16.4 \\
15.5 \\
13.2 \\
12.1 \\
11.0\end{array}$ & $\begin{array}{l}0.00 \\
0.00 \\
0.00 \\
0.00 \\
0.00\end{array}$ & $\begin{array}{l}0350 \\
0355 \\
0400 \\
0405 \\
0410\end{array}$ & $\begin{array}{l}3.5 \\
3.5 \\
3.5 \\
3.5 \\
3.5\end{array}$ & $\begin{array}{l}0.00 \\
0.00 \\
0.00 \\
0.00 \\
0.00\end{array}$ \\
\hline $\begin{array}{l}1730 \\
1735 \\
1740 \\
1745 \\
1750\end{array}$ & $\begin{array}{l}5.7 \\
7.2 \\
7.5 \\
8.0 \\
8.5\end{array}$ & $\begin{array}{l}0.01 \\
0.01 \\
0.01 \\
0.00 \\
0.00\end{array}$ & $\begin{array}{l}2255 \\
2300 \\
2305 \\
2310 \\
2315\end{array}$ & $\begin{array}{l}9.3 \\
8.4 \\
8.4 \\
8.4 \\
8.4\end{array}$ & $\begin{array}{l}0.00 \\
0.00 \\
0.00 \\
0.00 \\
0.00\end{array}$ & $\begin{array}{l}0415 \\
0420 \\
0425 \\
0430 \\
0435\end{array}$ & $\begin{array}{l}3.5 \\
3.5 \\
3.2 \\
3.2 \\
3.2\end{array}$ & $\begin{array}{l}0.00 \\
0.00 \\
0.00 \\
0.00 \\
0.00\end{array}$ \\
\hline $\begin{array}{l}1755 \\
1800 \\
1805 \\
1810 \\
1815\end{array}$ & $\begin{array}{r}9.3 \\
20.8 \\
26.9 \\
31.3 \\
42.4\end{array}$ & $\begin{array}{l}0.00 \\
0.00 \\
0.00 \\
0.00 \\
0.00\end{array}$ & $\begin{array}{l}2320 \\
2325 \\
2330 \\
2335 \\
2340\end{array}$ & $\begin{array}{l}8.4 \\
7.6 \\
7.1 \\
6.9 \\
6.7\end{array}$ & $\begin{array}{l}0.00 \\
0.00 \\
0.00 \\
0.00 \\
0.00\end{array}$ & $\begin{array}{l}0440 \\
0445 \\
0450 \\
0455 \\
0500\end{array}$ & $\begin{array}{l}3.2 \\
3.2 \\
3.2 \\
3.2 \\
3.2\end{array}$ & $\begin{array}{l}0.00 \\
0.00 \\
0.00 \\
0.00 \\
0.00\end{array}$ \\
\hline $\begin{array}{l}1820 \\
1825 \\
1830 \\
1835 \\
1840\end{array}$ & $\begin{array}{l}40.4 \\
39.5 \\
37.0 \\
35.7 \\
33.9\end{array}$ & $\begin{array}{l}0.00 \\
0.00 \\
0.00 \\
0.00 \\
0.02\end{array}$ & $\begin{array}{r}2345 \\
2350 \\
2355 \\
\text { May 5, } \\
0000\end{array}$ & 1987 & $\begin{array}{l}0.00 \\
0.00 \\
0.00 \\
0.00\end{array}$ & $\begin{array}{l}0505 \\
0510 \\
0515 \\
0520 \\
0525\end{array}$ & $\begin{array}{l}3.2 \\
3.2 \\
3.2 \\
3.2 \\
3.2\end{array}$ & $\begin{array}{l}0.00 \\
0.00 \\
0.00 \\
0.00 \\
0.00\end{array}$ \\
\hline $\begin{array}{l}1845 \\
1850 \\
1855 \\
1900 \\
1905\end{array}$ & $\begin{array}{l}34.9 \\
49.8 \\
55.6 \\
58.2 \\
61.1\end{array}$ & $\begin{array}{l}0.22 \\
0.19 \\
0.11 \\
0.03 \\
0.02\end{array}$ & $\begin{array}{l}0005 \\
0010 \\
0015 \\
0020 \\
0025\end{array}$ & $\begin{array}{l}6.2 \\
6.2 \\
5.7 \\
5.7 \\
5.7\end{array}$ & $\begin{array}{l}0.00 \\
0.00 \\
0.00 \\
0.00 \\
0.00\end{array}$ & $\begin{array}{l}0530 \\
0535 \\
0540 \\
0545 \\
0550\end{array}$ & $\begin{array}{l}3.2 \\
3.2 \\
3.2 \\
3.2 \\
3.2\end{array}$ & $\begin{array}{l}0.00 \\
0.00 \\
0.00 \\
0.00 \\
0.00\end{array}$ \\
\hline $\begin{array}{l}1910 \\
1915 \\
1920 \\
1925 \\
1930\end{array}$ & $\begin{array}{r}63.9 \\
76.0 \\
96.0 \\
120.0 \\
128.0\end{array}$ & $\begin{array}{l}0.01 \\
0.00 \\
0.02 \\
0.01 \\
0.02\end{array}$ & $\begin{array}{l}0030 \\
0035 \\
0040 \\
0045 \\
0050\end{array}$ & $\begin{array}{l}5.5 \\
5.5 \\
5.5 \\
5.2 \\
5.2\end{array}$ & $\begin{array}{l}0.00 \\
0.00 \\
0.00 \\
0.00 \\
0.00\end{array}$ & $\begin{array}{l}0555 \\
0600 \\
0605 \\
0610 \\
0615\end{array}$ & $\begin{array}{l}2.9 \\
2.9 \\
2.9 \\
2.9 \\
2.9\end{array}$ & $\begin{array}{l}0.00 \\
0.00 \\
0.00 \\
0.00 \\
0.00\end{array}$ \\
\hline $\begin{array}{l}1935 \\
1940 \\
1945 \\
1950 \\
1955\end{array}$ & $\begin{array}{l}134.0 \\
137.0 \\
140.0 \\
142.0 \\
132.0\end{array}$ & $\begin{array}{l}0.02 \\
0.01 \\
0.02 \\
0.03 \\
0.01\end{array}$ & $\begin{array}{l}0055 \\
0100 \\
0105 \\
0110 \\
0115\end{array}$ & $\begin{array}{l}5.2 \\
5.0 \\
5.0 \\
5.0 \\
4.7\end{array}$ & $\begin{array}{l}0.00 \\
0.00 \\
0.00 \\
0.00 \\
0.00\end{array}$ & $\begin{array}{l}0620 \\
0625 \\
0630 \\
0635 \\
0640\end{array}$ & $\begin{array}{l}2.9 \\
2.9 \\
2.9 \\
2.9 \\
2.9\end{array}$ & $\begin{array}{l}0.00 \\
0.00 \\
0.00 \\
0.00 \\
0.00\end{array}$ \\
\hline $\begin{array}{l}2000 \\
2005 \\
2010 \\
2015 \\
2020\end{array}$ & $\begin{array}{r}123.0 \\
113.0 \\
106.0 \\
103.0 \\
98.9\end{array}$ & $\begin{array}{l}0.01 \\
0.02 \\
0.01 \\
0.02 \\
0.01\end{array}$ & $\begin{array}{l}0120 \\
0125 \\
0130 \\
0135 \\
0140\end{array}$ & $\begin{array}{l}4.7 \\
4.7 \\
4.7 \\
4.7 \\
4.4\end{array}$ & $\begin{array}{l}0.00 \\
0.00 \\
0.00 \\
0.00 \\
0.00\end{array}$ & $\begin{array}{l}0645 \\
0650 \\
0655 \\
0700 \\
0705\end{array}$ & $\begin{array}{l}2.9 \\
2.9 \\
2.9 \\
2.9 \\
2.9\end{array}$ & $\begin{array}{l}0.00 \\
0.00 \\
0.00 \\
0.00 \\
0.00\end{array}$ \\
\hline $\begin{array}{l}2025 \\
2030 \\
2035 \\
2040 \\
2045\end{array}$ & $\begin{array}{l}94.9 \\
86.2 \\
82.2 \\
77.8 \\
74.1\end{array}$ & $\begin{array}{l}0.01 \\
0.00 \\
0.01 \\
0.01 \\
0.00\end{array}$ & $\begin{array}{l}0145 \\
0150 \\
0155 \\
0200 \\
0205\end{array}$ & $\begin{array}{l}4.4 \\
4.4 \\
4.4 \\
4.4 \\
4.4\end{array}$ & $\begin{array}{l}0.00 \\
0.00 \\
0.00 \\
0.00 \\
0.00\end{array}$ & $\begin{array}{l}0710 \\
0715 \\
0720 \\
0725 \\
0730\end{array}$ & $\begin{array}{l}2.9 \\
2.9 \\
2.9 \\
2.9 \\
2.9\end{array}$ & $\begin{array}{l}0.00 \\
0.00 \\
0.00 \\
0.00 \\
0.00\end{array}$ \\
\hline $\begin{array}{l}2050 \\
2055 \\
2100 \\
2105 \\
2110\end{array}$ & $\begin{array}{l}70.9 \\
67.5 \\
63.9 \\
60.3 \\
54.8\end{array}$ & $\begin{array}{l}0.00 \\
0.00 \\
0.00 \\
0.00 \\
0.00\end{array}$ & $\begin{array}{l}0210 \\
0215 \\
0220 \\
0225 \\
0230\end{array}$ & $\begin{array}{l}4 \cdot 4 \\
4.1 \\
4.1 \\
4.1 \\
4.1\end{array}$ & $\begin{array}{l}0.00 \\
0.00 \\
0.00 \\
0.00 \\
0.00\end{array}$ & $\begin{array}{l}0735 \\
0740 \\
0745 \\
0750 \\
0755\end{array}$ & $\begin{array}{l}2.9 \\
2.9 \\
2.9 \\
2.5 \\
2.5\end{array}$ & $\begin{array}{l}0.00 \\
0.00 \\
0.00 \\
0.00 \\
0.00\end{array}$ \\
\hline $\begin{array}{l}2115 \\
2120 \\
2125 \\
2130 \\
2135\end{array}$ & $\begin{array}{l}50.5 \\
47.8 \\
44.1 \\
41.3 \\
37.6\end{array}$ & $\begin{array}{l}0.01 \\
0.00 \\
0.00 \\
0.00 \\
0.00\end{array}$ & $\begin{array}{l}0235 \\
0240 \\
0245 \\
0250 \\
0255\end{array}$ & $\begin{array}{l}4.1 \\
3.8 \\
3.8 \\
3.8 \\
3.8\end{array}$ & $\begin{array}{l}0.00 \\
0.00 \\
0.00 \\
0.00 \\
0.00\end{array}$ & $\begin{array}{l}0800 \\
0805 \\
0810 \\
0815 \\
0820\end{array}$ & $\begin{array}{l}2.5 \\
2.5 \\
2.5 \\
2.5 \\
2.5\end{array}$ & $\begin{array}{l}0.00 \\
0.00 \\
0.00 \\
0.00 \\
0.00\end{array}$ \\
\hline $\begin{array}{l}2140 \\
2145 \\
2150 \\
2155 \\
2200\end{array}$ & 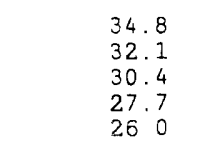 & $\begin{array}{l}0.00 \\
0.00 \\
0.00 \\
0.00 \\
0.00\end{array}$ & $\begin{array}{l}0300 \\
0305 \\
0310 \\
0315 \\
0320\end{array}$ & $\begin{array}{l}3.8 \\
3.8 \\
3.8 \\
3.8 \\
3.8\end{array}$ & $\begin{array}{l}0.00 \\
0.00 \\
0.00 \\
0.00 \\
0.00\end{array}$ & $\begin{array}{l}0825 \\
0830 \\
0835 \\
0840 \\
0845\end{array}$ & $\begin{array}{l}2.5 \\
2.5 \\
2.5 \\
2.5 \\
2.5\end{array}$ & $\begin{array}{l}0.00 \\
0.00 \\
0.00 \\
0.00 \\
0.00\end{array}$ \\
\hline $\begin{array}{l}2205 \\
2210 \\
2215 \\
2220 \\
2225\end{array}$ & $\begin{array}{l}23.4 \\
22.5 \\
20.7 \\
19.0 \\
17.2\end{array}$ & $\begin{array}{l}0.00 \\
0.00 \\
0.00 \\
0.00 \\
0.00\end{array}$ & $\begin{array}{l}0325 \\
0330 \\
0335 \\
0340 \\
0345\end{array}$ & $\begin{array}{l}3.5 \\
3.5 \\
3.5 \\
3.5 \\
3.5\end{array}$ & $\begin{array}{l}0.00 \\
0.00 \\
0.00 \\
0.00 \\
0.00\end{array}$ & $\begin{array}{l}0850 \\
0855 \\
0900 \\
0905 \\
0910\end{array}$ & $\begin{array}{l}2.5 \\
2.5 \\
2.5 \\
2.5 \\
2.5\end{array}$ & $\begin{array}{l}0.00 \\
0.00 \\
0.00 \\
0.00 \\
0.00\end{array}$ \\
\hline
\end{tabular}


Table 136.--Streamflow and rainfall at station 02174240, Middlepen Brar.sh at Orangeburg.

May $4-5,1987--$ Continued

\begin{tabular}{|c|c|c|c|c|c|c|c|c|}
\hline $\begin{array}{l}\text { Time } \\
\text { (hours) }\end{array}$ & $\begin{array}{l}\text { Streamflow } \\
\text { (cubic feet } \\
\text { per second) }\end{array}$ & $\begin{array}{l}\text { Rain- } \\
\text { fall } \\
\text { (inches) }\end{array}$ & $\begin{array}{l}\text { Time } \\
\text { (hours) }\end{array}$ & $\begin{array}{l}\text { Streamflow } \\
\text { (cubic feet } \\
\text { per second) }\end{array}$ & $\begin{array}{l}\text { Rain- } \\
\text { fall } \\
\text { (inches) }\end{array}$ & $\begin{array}{l}\text { Time } \\
\text { (hours) }\end{array}$ & $\begin{array}{l}\text { Streamflow } \\
\text { (cubic feet } \\
\text { per second) }\end{array}$ & $\begin{array}{l}\text { Rain- } \\
\text { fall } \\
\text { (inches) }\end{array}$ \\
\hline $\begin{array}{l}0915 \\
0920 \\
0925 \\
0930 \\
0935\end{array}$ & $\begin{array}{l}2.5 \\
2.5 \\
2.5 \\
2.5 \\
2.5\end{array}$ & $\begin{array}{l}0.00 \\
0.00 \\
0.00 \\
0.00 \\
0.00\end{array}$ & $\begin{array}{l}0955 \\
1000 \\
1005 \\
1010 \\
1015\end{array}$ & $\begin{array}{l}2.5 \\
2.5 \\
2.5 \\
2.5 \\
2.5\end{array}$ & $\begin{array}{l}0.00 \\
0.00 \\
0.00 \\
0.00 \\
0.00\end{array}$ & $\begin{array}{l}1035 \\
1040 \\
1045 \\
1050 \\
1055\end{array}$ & $\begin{array}{l}2.5 \\
2.5 \\
2.5 \\
2.5 \\
2.5\end{array}$ & $\begin{array}{l}0.00 \\
0.00 \\
0.00 \\
0.00 \\
0.00\end{array}$ \\
\hline $\begin{array}{l}0940 \\
0945 \\
0950\end{array}$ & $\begin{array}{l}2.5 \\
2.5 \\
2.5\end{array}$ & $\begin{array}{l}0.00 \\
0.00 \\
0.00\end{array}$ & $\begin{array}{l}1020 \\
1025 \\
1030\end{array}$ & $\begin{array}{l}2.5 \\
2.5 \\
2.5\end{array}$ & $\begin{array}{l}0.00 \\
0.00 \\
0.00\end{array}$ & 1100 & 2.5 & 0.00 \\
\hline
\end{tabular}




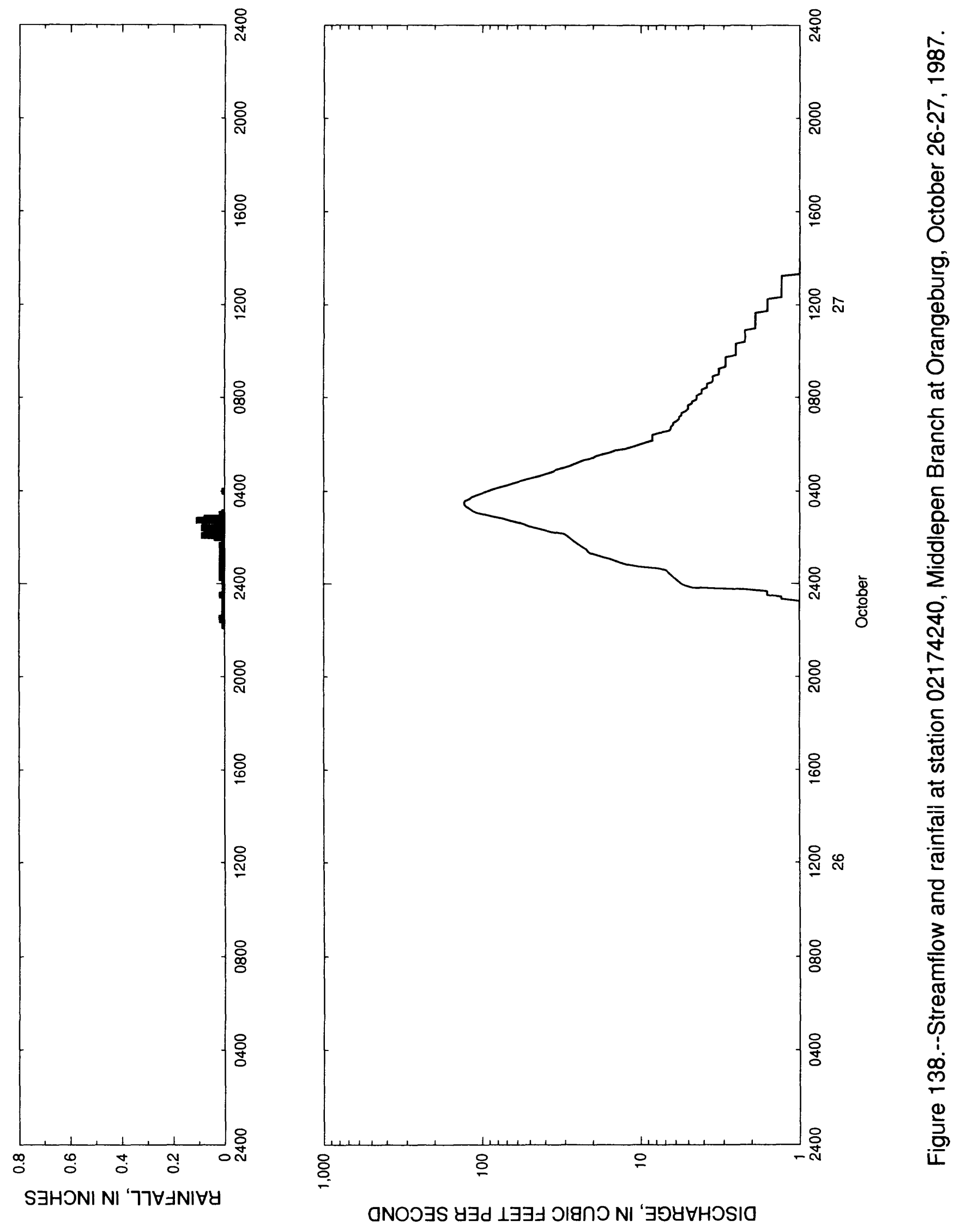


Table 137. - Streamflow and rainfa1l at station 02174240, Middlepen Branch at Orangeburg.

\section{October 26-27, 1987}

\begin{tabular}{|c|c|c|c|c|c|c|c|c|}
\hline $\begin{array}{l}\text { Time } \\
\text { (hours) }\end{array}$ & $\begin{array}{l}\text { Streamflow } \\
\text { (cubic feet } \\
\text { per second) }\end{array}$ & $\begin{array}{l}\text { Rain- } \\
\text { fall } \\
\text { (inches) }\end{array}$ & $\begin{array}{l}\text { Time } \\
\text { (hours) }\end{array}$ & $\begin{array}{l}\text { Streamflow } \\
\text { (cubic feet } \\
\text { per second) }\end{array}$ & $\begin{array}{l}\text { Rain- } \\
\text { fall } \\
\text { (inches) }\end{array}$ & $\begin{array}{l}\text { Time } \\
\text { (hours) }\end{array}$ & $\begin{array}{l}\text { Streamflow } \\
\text { (cubic feet } \\
\text { per second) }\end{array}$ & $\begin{array}{l}\text { Rain- } \\
\text { fall } \\
\text { (inchos) }\end{array}$ \\
\hline $\begin{array}{l}\text { October } \\
2210 \\
2215 \\
2220 \\
2225\end{array}$ & $\begin{array}{r}1987 \\
1.0 \\
1.0 \\
1.0 \\
1.0\end{array}$ & $\begin{array}{l}0.01 \\
0.00 \\
0.01 \\
0.02\end{array}$ & $\begin{array}{l}0325 \\
0330 \\
0335 \\
0340 \\
0345\end{array}$ & $\begin{array}{l}129.0 \\
130.0 \\
128.0 \\
120.0 \\
116.0\end{array}$ & $\begin{array}{l}0.00 \\
0.00 \\
0.00 \\
0.00 \\
0.00\end{array}$ & $\begin{array}{l}0850 \\
0855 \\
0900 \\
0905 \\
0910\end{array}$ & $\begin{array}{l}3.5 \\
3.5 \\
3.2 \\
3.2 \\
3.2\end{array}$ & $\begin{array}{l}0.00 \\
0.00 \\
0.00 \\
0.00 \\
0.00\end{array}$ \\
\hline $\begin{array}{l}2230 \\
2235 \\
2240 \\
2245 \\
2250\end{array}$ & $\begin{array}{l}1.0 \\
1.0 \\
1.0 \\
1.0 \\
1.0\end{array}$ & $\begin{array}{l}0.02 \\
0.01 \\
0.01 \\
0.01 \\
0.01\end{array}$ & $\begin{array}{l}0350 \\
0355 \\
0400 \\
0405 \\
0410\end{array}$ & $\begin{array}{r}108.0 \\
100.0 \\
92.1 \\
85.2 \\
77.7\end{array}$ & $\begin{array}{l}0.00 \\
0.00 \\
0.01 \\
0.00 \\
0.00\end{array}$ & $\begin{array}{l}0915 \\
0920 \\
0925 \\
0930 \\
0935\end{array}$ & $\begin{array}{l}3.2 \\
2.9 \\
2.9 \\
2.9 \\
2.9\end{array}$ & $\begin{array}{l}0.00 \\
0.00 \\
0.00 \\
0.00 \\
0.00\end{array}$ \\
\hline $\begin{array}{l}22.55 \\
2300 \\
2305 \\
2310 \\
2315\end{array}$ & $\begin{array}{l}1.0 \\
1.0 \\
1.0 \\
1.0 \\
1.0\end{array}$ & $\begin{array}{l}0.00 \\
0.01 \\
0.00 \\
0.01 \\
0.00\end{array}$ & $\begin{array}{l}0415 \\
0420 \\
0425 \\
0430 \\
0435\end{array}$ & $\begin{array}{l}69.5 \\
64.3 \\
58.2 \\
53.1 \\
47.7\end{array}$ & $\begin{array}{l}0.00 \\
0.00 \\
0.00 \\
0.00 \\
0.00\end{array}$ & $\begin{array}{l}0940 \\
0945 \\
0950 \\
0955 \\
1000\end{array}$ & $\begin{array}{l}2.9 \\
2.9 \\
2.5 \\
2.5 \\
2.5\end{array}$ & $\begin{array}{l}0.00 \\
0.00 \\
0.00 \\
0.00 \\
0.00\end{array}$ \\
\hline $\begin{array}{l}2320 \\
2325 \\
2330 \\
2335 \\
2340\end{array}$ & $\begin{array}{l}1.3 \\
1.3 \\
1.6 \\
1.6 \\
1.6\end{array}$ & $\begin{array}{l}0.01 \\
0.00 \\
0.02 \\
0.01 \\
0.01\end{array}$ & $\begin{array}{l}0440 \\
0445 \\
0450 \\
0455 \\
0500\end{array}$ & $\begin{array}{l}43.1 \\
39.4 \\
35.7 \\
33.9 \\
30.3\end{array}$ & $\begin{array}{l}0.00 \\
0.00 \\
0.00 \\
0.00 \\
0.00\end{array}$ & $\begin{array}{l}1005 \\
1010 \\
1015 \\
1020 \\
1025\end{array}$ & $\begin{array}{l}2.5 \\
2.5 \\
2.5 \\
2.5 \\
2.2\end{array}$ & $\begin{array}{l}0.00 \\
0.00 \\
0.00 \\
0.00 \\
0.00\end{array}$ \\
\hline $\begin{array}{l}2345 \\
2350 \\
2355 \\
\text { October } \\
0000\end{array}$ & $\begin{array}{r}2.2 \\
4.7 \\
5.2 \\
27,1987 \\
5.5\end{array}$ & $\begin{array}{l}0.01 \\
0.01 \\
0.00 \\
0.01\end{array}$ & $\begin{array}{l}0505 \\
0510 \\
0515 \\
0520 \\
0525\end{array}$ & $\begin{array}{l}27.7 \\
26.0 \\
24.2 \\
22.5 \\
19.9\end{array}$ & $\begin{array}{l}0.00 \\
0.00 \\
0.00 \\
0.00 \\
0.00\end{array}$ & $\begin{array}{l}1030 \\
1035 \\
1040 \\
1045 \\
1050\end{array}$ & $\begin{array}{l}2.2 \\
2.2 \\
2.2 \\
2.2 \\
2.2\end{array}$ & $\begin{array}{l}0.00 \\
0.00 \\
0.00 \\
0.00 \\
0.00\end{array}$ \\
\hline $\begin{array}{l}0005 \\
0010 \\
0015 \\
0020 \\
0025\end{array}$ & $\begin{array}{l}5.7 \\
5.9 \\
6.1 \\
6.3 \\
6.5\end{array}$ & $\begin{array}{l}0.00 \\
0.01 \\
0.02 \\
0.02 \\
0.02\end{array}$ & $\begin{array}{l}0530 \\
0535 \\
0540 \\
0545 \\
0550\end{array}$ & $\begin{array}{l}19.0 \\
17.2 \\
15.5 \\
14.4 \\
12.1\end{array}$ & $\begin{array}{l}0.00 \\
0.00 \\
0.00 \\
0.00 \\
0.00\end{array}$ & $\begin{array}{l}1055 \\
1100 \\
1105 \\
1110 \\
1115\end{array}$ & $\begin{array}{l}2.2 \\
1.9 \\
1.9 \\
1.9 \\
1.9\end{array}$ & $\begin{array}{l}0.00 \\
0.00 \\
0.00 \\
0.00 \\
0.00\end{array}$ \\
\hline $\begin{array}{l}0030 \\
0035 \\
0040 \\
0045 \\
0050\end{array}$ & $\begin{array}{r}6.7 \\
6.9 \\
7.6 \\
10.2 \\
12.1\end{array}$ & $\begin{array}{l}0.01 \\
0.02 \\
0.00 \\
0.02 \\
0.00\end{array}$ & $\begin{array}{l}0555 \\
0600 \\
0605 \\
0610 \\
0615\end{array}$ & $\begin{array}{r}11.0 \\
10.1 \\
9.3 \\
8.4 \\
8.4\end{array}$ & $\begin{array}{l}0.00 \\
0.00 \\
0.00 \\
0.00 \\
0.00\end{array}$ & $\begin{array}{l}1120 \\
1125 \\
1130 \\
1135 \\
1140\end{array}$ & $\begin{array}{l}1.9 \\
1.9 \\
1.9 \\
1.9 \\
1.9\end{array}$ & $\begin{array}{l}0.00 \\
0.00 \\
0.00 \\
0.00 \\
0.00\end{array}$ \\
\hline $\begin{array}{l}0055 \\
0100 \\
0105 \\
0110 \\
0115\end{array}$ & $\begin{array}{l}13.3 \\
14.4 \\
15.5 \\
17.3 \\
19.0\end{array}$ & $\begin{array}{l}0.01 \\
0.02 \\
0.01 \\
0.01 \\
0.02\end{array}$ & $\begin{array}{l}0620 \\
0625 \\
0630 \\
0635 \\
0640\end{array}$ & $\begin{array}{l}8.4 \\
8.4 \\
7.6 \\
6.6 \\
6.4\end{array}$ & $\begin{array}{l}0.00 \\
0.00 \\
0.00 \\
0.00 \\
0.00\end{array}$ & $\begin{array}{l}1145 \\
1150 \\
1155 \\
1200 \\
1205\end{array}$ & $\begin{array}{l}1.6 \\
1.6 \\
1.6 \\
1.6 \\
1.6\end{array}$ & $\begin{array}{l}0.00 \\
0.00 \\
0.00 \\
0.00 \\
0.00\end{array}$ \\
\hline $\begin{array}{l}0120 \\
0125 \\
0130 \\
0135 \\
0140\end{array}$ & $\begin{array}{l}20.8 \\
21.6 \\
22.0 \\
23.0 \\
24.0\end{array}$ & $\begin{array}{l}0.02 \\
0.02 \\
0.01 \\
0.01 \\
0.02\end{array}$ & $\begin{array}{l}0645 \\
0650 \\
0655 \\
0700 \\
0705\end{array}$ & $\begin{array}{l}6.4 \\
6.2 \\
6.2 \\
5.9 \\
5.7\end{array}$ & $\begin{array}{l}0.00 \\
0.00 \\
0.00 \\
0.00 \\
0.00\end{array}$ & $\begin{array}{l}1210 \\
1215 \\
1220 \\
1225 \\
1230\end{array}$ & $\begin{array}{l}1.6 \\
1.6 \\
1.3 \\
1.3 \\
1.3\end{array}$ & $\begin{array}{l}0.00 \\
0.00 \\
0.00 \\
0.00 \\
0.00\end{array}$ \\
\hline $\begin{array}{l}0145 \\
0150 \\
0155 \\
0200 \\
0205\end{array}$ & $\begin{array}{l}25.0 \\
26.0 \\
27.0 \\
28.0 \\
29.0\end{array}$ & $\begin{array}{l}0.01 \\
0.01 \\
0.01 \\
0.04 \\
0.09\end{array}$ & $\begin{array}{l}0710 \\
0715 \\
0720 \\
0725 \\
0730\end{array}$ & $\begin{array}{l}5.7 \\
5.5 \\
5.5 \\
5.2 \\
5.0\end{array}$ & $\begin{array}{l}0.00 \\
0.00 \\
0.00 \\
0.00 \\
0.00\end{array}$ & $\begin{array}{l}1235 \\
1240 \\
1245 \\
1250 \\
1255\end{array}$ & $\begin{array}{l}1.3 \\
1.3 \\
1.3 \\
1.3 \\
1.3\end{array}$ & $\begin{array}{l}0.00 \\
0.00 \\
0.00 \\
0.00 \\
0.00\end{array}$ \\
\hline $\begin{array}{l}0210 \\
0215 \\
0220 \\
0225 \\
0230\end{array}$ & $\begin{array}{l}30.4 \\
36.8 \\
40.4 \\
45.1 \\
50.7\end{array}$ & $\begin{array}{l}0.08 \\
0.08 \\
0.06 \\
0.09 \\
0.04\end{array}$ & $\begin{array}{l}0735 \\
0740 \\
0745 \\
0750 \\
0755\end{array}$ & $\begin{array}{l}5.0 \\
5.0 \\
4.7 \\
4.7 \\
4.4\end{array}$ & $\begin{array}{l}0.00 \\
0.00 \\
0.00 \\
0.00 \\
0.00\end{array}$ & $\begin{array}{l}1300 \\
1305 \\
1310 \\
1315 \\
1320\end{array}$ & $\begin{array}{l}1.3 \\
1.3 \\
1.3 \\
1.3 \\
1.0\end{array}$ & $\begin{array}{l}0.00 \\
0.00 \\
0.00 \\
0.00 \\
0.00\end{array}$ \\
\hline $\begin{array}{l}0235 \\
0240 \\
0245 \\
0250 \\
0255\end{array}$ & $\begin{array}{l}54.5 \\
59.4 \\
67.6 \\
74.2 \\
86.2\end{array}$ & $\begin{array}{l}0.01 \\
0.03 \\
0.11 \\
0.08 \\
0.02\end{array}$ & $\begin{array}{l}0800 \\
0805 \\
0810 \\
0815 \\
0820\end{array}$ & $\begin{array}{l}4.4 \\
4.4 \\
4.1 \\
4.1 \\
4.1\end{array}$ & $\begin{array}{l}0.00 \\
0.00 \\
0.00 \\
0.00 \\
0.00\end{array}$ & $\begin{array}{l}1325 \\
1330 \\
1335 \\
1340 \\
1345\end{array}$ & $\begin{array}{l}1.0 \\
1.0 \\
1.0 \\
1.0 \\
1.0\end{array}$ & $\begin{array}{l}0.00 \\
0.00 \\
0.00 \\
0.00 \\
0.00\end{array}$ \\
\hline $\begin{array}{l}0300 \\
0305 \\
0310 \\
0315 \\
0320\end{array}$ & $\begin{array}{r}97.6 \\
109.0 \\
115.0 \\
119.0 \\
125.0\end{array}$ & $\begin{array}{l}0.02 \\
0.01 \\
0.00 \\
0.00 \\
0.00\end{array}$ & $\begin{array}{l}0825 \\
0830 \\
0835 \\
0840 \\
0845\end{array}$ & $\begin{array}{l}3.8 \\
3.8 \\
3.8 \\
3.5 \\
3.5\end{array}$ & $\begin{array}{l}0.00 \\
0.00 \\
0.00 \\
0.00 \\
0.00\end{array}$ & $\begin{array}{l}1350 \\
1355 \\
1400\end{array}$ & $\begin{array}{l}1.0 \\
1.0 \\
1.0\end{array}$ & $\begin{array}{l}0.00 \\
0.00 \\
0.00\end{array}$ \\
\hline
\end{tabular}




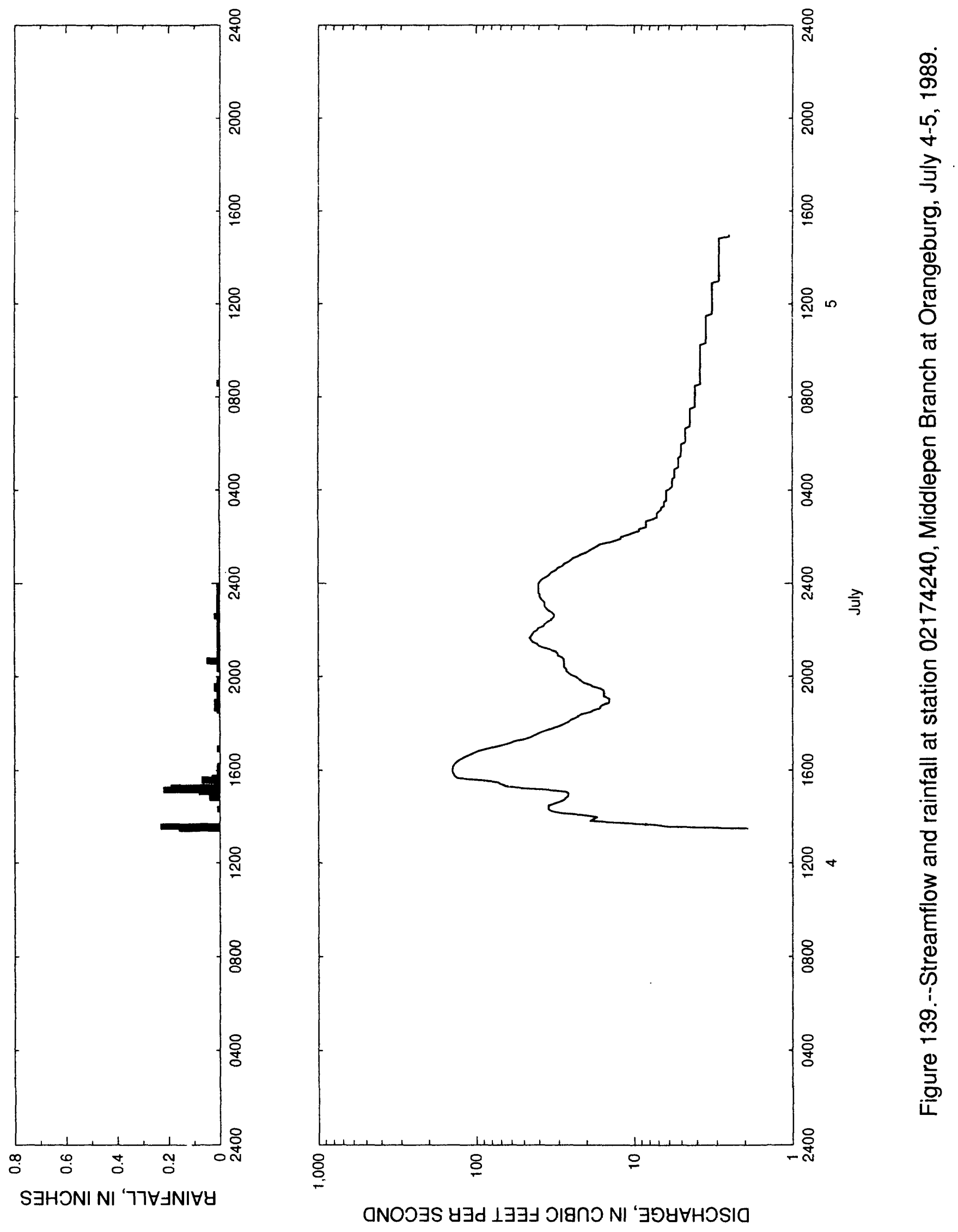


Table 138. - Streamflow and rainfall at station 02174240. Middlepen Branch at Orangeburg, July $4-5,1989$

\begin{tabular}{|c|c|c|c|c|c|c|c|c|}
\hline $\begin{array}{l}\text { Time } \\
\text { (hours) }\end{array}$ & $\begin{array}{l}\text { Streamflow } \\
\text { (cubic feet } \\
\text { per second) }\end{array}$ & $\begin{array}{l}\text { Rain- } \\
\text { fall } \\
\text { (inches) }\end{array}$ & $\begin{array}{l}\text { Time } \\
\text { (hours) }\end{array}$ & $\begin{array}{l}\text { Streamflow } \\
\text { (cubic feet } \\
\text { per second) }\end{array}$ & $\begin{array}{l}\text { Rain- } \\
\text { fall } \\
\text { (inches) }\end{array}$ & $\begin{array}{l}\text { Time } \\
\text { (hours) }\end{array}$ & $\begin{array}{l}\text { Streamflow } \\
\text { (cubic feet } \\
\text { per second) }\end{array}$ & $\begin{array}{l}\text { Rain- } \\
\text { fall } \\
\text { (inches) }\end{array}$ \\
\hline $\begin{array}{l}\text { July } 4, \\
1330 \\
1335 \\
1340 \\
1345\end{array}$ & $\begin{array}{r}1989 \quad 1.9 \\
6.0 \\
7.6 \\
12.2\end{array}$ & $\begin{array}{l}0.16 \\
0.23 \\
0.00 \\
0.00\end{array}$ & $\begin{array}{l}1850 \\
1855 \\
1900 \\
1905 \\
1910\end{array}$ & $\begin{array}{l}15.5 \\
14.4 \\
14.4 \\
14.4 \\
15.5\end{array}$ & $\begin{array}{l}0.01 \\
0.02 \\
0.01 \\
0.01 \\
0.00\end{array}$ & $\begin{array}{l}0010 \\
0015 \\
0020 \\
0025 \\
0030\end{array}$ & $\begin{array}{l}38.5 \\
36.7 \\
34.8 \\
33.9 \\
33.0\end{array}$ & $\begin{array}{l}0.00 \\
0.00 \\
0.00 \\
0.00 \\
0.00\end{array}$ \\
\hline $\begin{array}{l}1350 \\
1355 \\
1400 \\
1405 \\
1410\end{array}$ & $\begin{array}{l}19.0 \\
18.1 \\
17.2 \\
20.8 \\
28.7\end{array}$ & $\begin{array}{l}0.00 \\
0.00 \\
0.00 \\
0.00 \\
0.00\end{array}$ & $\begin{array}{l}1915 \\
1920 \\
1925 \\
1930 \\
1935\end{array}$ & $\begin{array}{l}15.5 \\
15.5 \\
15.5 \\
16.4 \\
18.1\end{array}$ & $\begin{array}{l}0.01 \\
0.01 \\
0.01 \\
0.02 \\
0.02\end{array}$ & $\begin{array}{l}0035 \\
0040 \\
0045 \\
0050 \\
0055\end{array}$ & $\begin{array}{l}31.2 \\
30.4 \\
28.6 \\
27.7 \\
26.0\end{array}$ & $\begin{array}{l}0.00 \\
0.00 \\
0.00 \\
0.00 \\
0.00\end{array}$ \\
\hline $\begin{array}{l}1415 \\
1420 \\
1425 \\
1430 \\
1435\end{array}$ & $\begin{array}{l}33.0 \\
34.9 \\
34.8 \\
34.8 \\
32.1\end{array}$ & $\begin{array}{l}0.00 \\
0.01 \\
0.00 \\
0.00 \\
0.00\end{array}$ & $\begin{array}{l}1940 \\
1945 \\
1950 \\
1955 \\
2000\end{array}$ & $\begin{array}{l}19.0 \\
20.8 \\
21.6 \\
22.5 \\
23.4\end{array}$ & $\begin{array}{l}0.01 \\
0.00 \\
0.01 \\
0.00 \\
0.00\end{array}$ & $\begin{array}{l}0100 \\
0105 \\
0110 \\
0115 \\
0120\end{array}$ & $\begin{array}{l}25.1 \\
24.2 \\
22.5 \\
21.6 \\
19.9\end{array}$ & $\begin{array}{l}0.00 \\
0.00 \\
0.00 \\
0.00 \\
0.00\end{array}$ \\
\hline $\begin{array}{l}1440 \\
1445 \\
1450 \\
1455 \\
1500\end{array}$ & $\begin{array}{l}29.5 \\
27.7 \\
26.9 \\
26.0 \\
26.0\end{array}$ & $\begin{array}{l}0.00 \\
0.00 \\
0.04 \\
0.01 \\
0.00\end{array}$ & $\begin{array}{l}2005 \\
2010 \\
2015 \\
2020 \\
2025\end{array}$ & $\begin{array}{l}25.1 \\
26.0 \\
26.9 \\
26.9 \\
27.8\end{array}$ & $\begin{array}{l}0.00 \\
0.00 \\
0.00 \\
0.01 \\
0.00\end{array}$ & $\begin{array}{l}0125 \\
0130 \\
0135 \\
0140 \\
0145\end{array}$ & $\begin{array}{l}19.0 \\
18.1 \\
17.2 \\
16.4 \\
14.4\end{array}$ & $\begin{array}{l}0.00 \\
0.00 \\
0.00 \\
0.00 \\
0.00\end{array}$ \\
\hline $\begin{array}{l}1505 \\
1510 \\
1515 \\
1520 \\
1525\end{array}$ & $\begin{array}{l}26.9 \\
34.9 \\
52.0 \\
65.3 \\
70.2\end{array}$ & $\begin{array}{l}0.08 \\
0.22 \\
0.19 \\
0.01 \\
0.00\end{array}$ & $\begin{array}{l}2030 \\
2035 \\
2040 \\
2045 \\
2050\end{array}$ & $\begin{array}{l}27.8 \\
27.8 \\
27.8 \\
27.8 \\
28.6\end{array}$ & $\begin{array}{l}0.00 \\
0.01 \\
0.05 \\
0.01 \\
0.01\end{array}$ & $\begin{array}{l}0150 \\
0155 \\
0200 \\
0205 \\
0210\end{array}$ & $\begin{array}{l}13.2 \\
12.1 \\
12.1 \\
11.0 \\
10.1\end{array}$ & $\begin{array}{l}0.00 \\
0.00 \\
0.00 \\
0.00 \\
0.00\end{array}$ \\
\hline $\begin{array}{l}1530 \\
1535 \\
1540 \\
1545 \\
1550\end{array}$ & $\begin{array}{r}73.5 \\
95.1 \\
132.0 \\
137.0 \\
139.0\end{array}$ & $\begin{array}{l}0.02 \\
0.07 \\
0.03 \\
0.01 \\
0.01\end{array}$ & $\begin{array}{l}2055 \\
2100 \\
2105 \\
2110 \\
2115\end{array}$ & $\begin{array}{l}30.4 \\
30.4 \\
31.3 \\
34.0 \\
37.7\end{array}$ & $\begin{array}{l}0.01 \\
0.01 \\
0.01 \\
0.01 \\
0.00\end{array}$ & $\begin{array}{l}0215 \\
0220 \\
0225 \\
0230 \\
0235\end{array}$ & $\begin{array}{l}9.3 \\
9.3 \\
8.4 \\
8.4 \\
8.4\end{array}$ & $\begin{array}{l}0.00 \\
0.00 \\
0.00 \\
0.00 \\
0.00\end{array}$ \\
\hline $\begin{array}{l}1555 \\
1600 \\
1605 \\
1610 \\
1615\end{array}$ & $\begin{array}{l}141.0 \\
142.0 \\
141.0 \\
140.0 \\
138.0\end{array}$ & $\begin{array}{l}0.00 \\
0.01 \\
0.00 \\
0.01 \\
0.00\end{array}$ & $\begin{array}{l}2120 \\
2125 \\
2130 \\
2135 \\
2140\end{array}$ & $\begin{array}{l}40.4 \\
41.3 \\
44.1 \\
45.0 \\
46.0\end{array}$ & $\begin{array}{l}0.00 \\
0.01 \\
0.00 \\
0.00 \\
0.01\end{array}$ & $\begin{array}{l}0240 \\
0245 \\
0250 \\
0255 \\
0300\end{array}$ & $\begin{array}{l}8.4 \\
7.6 \\
7.1 \\
7.1 \\
7.1\end{array}$ & $\begin{array}{l}0.00 \\
0.00 \\
0.00 \\
0.00 \\
0.00\end{array}$ \\
\hline $\begin{array}{l}1620 \\
1625 \\
1630 \\
1635 \\
1640\end{array}$ & $\begin{array}{l}135.0 \\
130.0 \\
123.0 \\
118.0 \\
111.0\end{array}$ & $\begin{array}{l}0.00 \\
0.00 \\
0.00 \\
0.00 \\
0.00\end{array}$ & $\begin{array}{l}2145 \\
2150 \\
2155 \\
2200 \\
2205\end{array}$ & $\begin{array}{l}45.0 \\
44.1 \\
43.2 \\
41.3 \\
40.4\end{array}$ & $\begin{array}{l}0.00 \\
0.01 \\
0.01 \\
0.01 \\
0.01\end{array}$ & $\begin{array}{l}0305 \\
0310 \\
0315 \\
0320 \\
0325\end{array}$ & $\begin{array}{l}6.9 \\
6.7 \\
6.7 \\
6.4 \\
6.4\end{array}$ & $\begin{array}{l}0.00 \\
0.00 \\
0.00 \\
0.00 \\
0.00\end{array}$ \\
\hline $\begin{array}{l}1645 \\
1650 \\
1655 \\
1700 \\
1705\end{array}$ & $\begin{array}{r}104.0 \\
96.9 \\
86.3 \\
77.8 \\
68.3\end{array}$ & $\begin{array}{l}0.00 \\
0.00 \\
0.01 \\
0.00 \\
0.00\end{array}$ & $\begin{array}{l}2210 \\
2215 \\
2220 \\
2225 \\
2230\end{array}$ & $\begin{array}{l}37.6 \\
36.7 \\
35.8 \\
33.9 \\
33.0\end{array}$ & $\begin{array}{l}0.01 \\
0.01 \\
0.01 \\
0.01 \\
0.00\end{array}$ & $\begin{array}{l}0330 \\
0335 \\
0340 \\
0345 \\
0350\end{array}$ & $\begin{array}{l}6.4 \\
6.2 \\
6.2 \\
6.2 \\
6.2\end{array}$ & $\begin{array}{l}0.00 \\
0.00 \\
0.00 \\
0.00 \\
0.00\end{array}$ \\
\hline $\begin{array}{l}1710 \\
1715 \\
1720 \\
1725 \\
1730\end{array}$ & $\begin{array}{l}61.5 \\
57.5 \\
50.4 \\
45.9 \\
43.1\end{array}$ & $\begin{array}{l}0.00 \\
0.00 \\
0.00 \\
0.00 \\
0.00\end{array}$ & $\begin{array}{l}2235 \\
2240 \\
2245 \\
2250 \\
2255\end{array}$ & $\begin{array}{l}32.1 \\
32.1 \\
33.0 \\
34.9 \\
35.8\end{array}$ & $\begin{array}{l}0.02 \\
0.01 \\
0.01 \\
0.01 \\
0.01\end{array}$ & $\begin{array}{l}0355 \\
0400 \\
0405 \\
0410 \\
0415\end{array}$ & $\begin{array}{l}6.2 \\
6.2 \\
5.9 \\
5.7 \\
5.7\end{array}$ & $\begin{array}{l}0.00 \\
0.00 \\
0.00 \\
0.00 \\
0.00\end{array}$ \\
\hline $\begin{array}{l}1735 \\
1740 \\
1745 \\
1750 \\
1755\end{array}$ & $\begin{array}{l}40.4 \\
37.6 \\
34.8 \\
32.1 \\
29.5\end{array}$ & $\begin{array}{l}0.00 \\
0.00 \\
0.00 \\
0.00 \\
0.00\end{array}$ & $\begin{array}{l}2300 \\
2305 \\
2310 \\
2315 \\
2320\end{array}$ & $\begin{array}{l}36.7 \\
36.7 \\
36.7 \\
37.6 \\
38.6\end{array}$ & $\begin{array}{l}0.01 \\
0.01 \\
0.01 \\
0.01 \\
0.01\end{array}$ & $\begin{array}{l}0420 \\
0425 \\
0430 \\
0435 \\
0440\end{array}$ & $\begin{array}{l}5.7 \\
5.7 \\
5.7 \\
5.5 \\
5.5\end{array}$ & $\begin{array}{l}0.00 \\
0.00 \\
0.00 \\
0.00 \\
0.00\end{array}$ \\
\hline $\begin{array}{l}1800 \\
1805 \\
1810 \\
1815 \\
1820\end{array}$ & $\begin{array}{l}27.7 \\
26.0 \\
25.1 \\
23.4 \\
22.5\end{array}$ & $\begin{array}{l}0.00 \\
0.00 \\
0.00 \\
0.00 \\
0.00\end{array}$ & $\begin{array}{l}2325 \\
2330 \\
2335 \\
2340 \\
2345\end{array}$ & $\begin{array}{l}39.5 \\
39.5 \\
40.4 \\
40.4 \\
40.4\end{array}$ & $\begin{array}{l}0.00 \\
0.01 \\
0.00 \\
0.01 \\
0.00\end{array}$ & $\begin{array}{l}0445 \\
0450 \\
0455 \\
0500 \\
0505\end{array}$ & $\begin{array}{l}5.5 \\
5.5 \\
5.5 \\
5.2 \\
5.2\end{array}$ & $\begin{array}{l}0.00 \\
0.00 \\
0.00 \\
0.00 \\
0.00\end{array}$ \\
\hline $\begin{array}{l}1825 \\
1830 \\
1835 \\
1840 \\
1845\end{array}$ & $\begin{array}{l}21.6 \\
19.0 \\
18.1 \\
16.4 \\
16.4\end{array}$ & $\begin{array}{l}0.00 \\
0.00 \\
0.01 \\
0.02 \\
0.02\end{array}$ & $\begin{array}{l}2350 \\
2355 \\
\text { July } 5, \\
0000 \\
0005\end{array}$ & $\begin{array}{r}40.4 \\
40.4 \\
1989 \begin{array}{r}40.4 \\
39.5\end{array}\end{array}$ & $\begin{array}{l}0.01 \\
0.00 \\
0.00 \\
0.00\end{array}$ & $\begin{array}{l}0510 \\
0515 \\
0520 \\
0525 \\
0530\end{array}$ & $\begin{array}{l}5.2 \\
5.2 \\
5.2 \\
5.2 \\
5.0\end{array}$ & $\begin{array}{l}0.00 \\
0.00 \\
0.00 \\
0.00 \\
0.00\end{array}$ \\
\hline
\end{tabular}


Table 138.--Streamflow and rainfall at station 02174240, Middlepen Branch at Orangeburg. July $4-5,1989--$ Continued

\begin{tabular}{|c|c|c|c|c|c|c|c|c|}
\hline $\begin{array}{l}\text { Time } \\
\text { (hours) }\end{array}$ & $\begin{array}{l}\text { Streamflow } \\
\text { (cubic feet } \\
\text { per second) }\end{array}$ & $\begin{array}{l}\text { Rain- } \\
\text { fall } \\
\text { (inches) }\end{array}$ & $\begin{array}{l}\text { Time } \\
\text { (hours) }\end{array}$ & $\begin{array}{l}\text { Streamflow } \\
\text { (cubic feet } \\
\text { per second) }\end{array}$ & $\begin{array}{l}\text { Rain- } \\
\text { fall } \\
\text { (inches) }\end{array}$ & $\begin{array}{l}\text { Time } \\
\text { (hours) }\end{array}$ & $\begin{array}{l}\text { Streamflow } \\
\text { (cubic feet } \\
\text { per second) }\end{array}$ & $\begin{array}{l}\text { Rein- } \\
\text { fall } \\
\text { (irches) }\end{array}$ \\
\hline $\begin{array}{l}0535 \\
0540 \\
0545 \\
0550 \\
0555\end{array}$ & $\begin{array}{l}5.0 \\
5.0 \\
5.0 \\
5.0 \\
5.0\end{array}$ & $\begin{array}{l}0.00 \\
0.00 \\
0.00 \\
0.00 \\
0.00\end{array}$ & $\begin{array}{l}0845 \\
0850 \\
0855 \\
0900 \\
0905\end{array}$ & $\begin{array}{l}3.8 \\
3.8 \\
3.8 \\
3.8 \\
3.8\end{array}$ & $\begin{array}{l}0.00 \\
0.00 \\
0.00 \\
0.00 \\
0.00\end{array}$ & $\begin{array}{l}1155 \\
1200 \\
1205 \\
1210 \\
1215\end{array}$ & $\begin{array}{l}3.2 \\
3.2 \\
3.2 \\
3.2 \\
3.2\end{array}$ & $\begin{array}{l}0.00 \\
0.00 \\
0.00 \\
0.00 \\
0.00\end{array}$ \\
\hline $\begin{array}{l}0600 \\
0605 \\
0610 \\
0615 \\
0620\end{array}$ & $\begin{array}{l}5.0 \\
4.7 \\
4.7 \\
4.7 \\
4.7\end{array}$ & $\begin{array}{l}0.00 \\
0.00 \\
0.00 \\
0.00 \\
0.00\end{array}$ & $\begin{array}{l}0910 \\
0915 \\
0920 \\
0925 \\
0930\end{array}$ & $\begin{array}{l}3.8 \\
3.8 \\
3.8 \\
3.8 \\
3.8\end{array}$ & $\begin{array}{l}0.00 \\
0.00 \\
0.00 \\
0.00 \\
0.00\end{array}$ & $\begin{array}{l}1220 \\
1225 \\
1230 \\
1235 \\
1240\end{array}$ & $\begin{array}{l}3.2 \\
3.2 \\
3.2 \\
3.2 \\
3.2\end{array}$ & $\begin{array}{l}0.00 \\
0.00 \\
0.00 \\
0.00 \\
0.00\end{array}$ \\
\hline $\begin{array}{l}0625 \\
0630 \\
0635 \\
0640 \\
0645\end{array}$ & $\begin{array}{l}4.7 \\
4.7 \\
4.7 \\
4.7 \\
4.4\end{array}$ & $\begin{array}{l}0.00 \\
0.00 \\
0.00 \\
0.00 \\
0.00\end{array}$ & $\begin{array}{l}0935 \\
0940 \\
0945 \\
0950 \\
0955\end{array}$ & $\begin{array}{l}3.8 \\
3.8 \\
3.8 \\
3.8 \\
3.8\end{array}$ & $\begin{array}{l}0.00 \\
0.00 \\
0.00 \\
0.00 \\
0.00\end{array}$ & $\begin{array}{l}1245 \\
1250 \\
1255 \\
1300 \\
1305\end{array}$ & $\begin{array}{l}3.2 \\
3.2 \\
3.2 \\
2.9 \\
2.9\end{array}$ & $\begin{array}{l}0.00 \\
0.00 \\
0.00 \\
0.00 \\
0.00\end{array}$ \\
\hline $\begin{array}{l}0650 \\
0655 \\
0700 \\
0705 \\
0710\end{array}$ & $\begin{array}{l}4.4 \\
4.4 \\
4.4 \\
4.4 \\
4.4\end{array}$ & $\begin{array}{l}0.00 \\
0.00 \\
0.00 \\
0.00 \\
0.00\end{array}$ & $\begin{array}{l}1000 \\
1005 \\
1010 \\
1015 \\
1020\end{array}$ & $\begin{array}{l}3.8 \\
3.8 \\
3.8 \\
3.8 \\
3.5\end{array}$ & $\begin{array}{l}0.00 \\
0.00 \\
0.00 \\
0.00 \\
0.00\end{array}$ & $\begin{array}{l}1310 \\
1315 \\
1320 \\
1325 \\
1330\end{array}$ & $\begin{array}{l}2.9 \\
2.9 \\
2.9 \\
2.9 \\
2.9\end{array}$ & $\begin{array}{l}0.00 \\
0.00 \\
0.00 \\
0.00 \\
0.00\end{array}$ \\
\hline $\begin{array}{l}0715 \\
0720 \\
0725 \\
0730 \\
0735\end{array}$ & $\begin{array}{l}4.4 \\
4.4 \\
4.4 \\
4.4 \\
4.1\end{array}$ & $\begin{array}{l}0.00 \\
0.00 \\
0.00 \\
0.00 \\
0.00\end{array}$ & $\begin{array}{l}1025 \\
1030 \\
1035 \\
1040 \\
1045\end{array}$ & $\begin{array}{l}3.5 \\
3.5 \\
3.5 \\
3.5 \\
3.5\end{array}$ & $\begin{array}{l}0.00 \\
0.00 \\
0.00 \\
0.00 \\
0.00\end{array}$ & $\begin{array}{l}1335 \\
1340 \\
1345 \\
1350 \\
1355\end{array}$ & $\begin{array}{l}2.9 \\
2.9 \\
2.9 \\
2.9 \\
2.9\end{array}$ & $\begin{array}{l}0.00 \\
0.00 \\
0.00 \\
0.00 \\
0.00\end{array}$ \\
\hline $\begin{array}{l}0740 \\
0745 \\
0750 \\
0755 \\
0800\end{array}$ & $\begin{array}{l}4.1 \\
4 \cdot 1 \\
4.1 \\
4.1 \\
4.1\end{array}$ & $\begin{array}{l}0.00 \\
0.00 \\
0.00 \\
0.00 \\
0.00\end{array}$ & $\begin{array}{l}1050 \\
1055 \\
1100 \\
1105 \\
1110\end{array}$ & $\begin{array}{l}3.5 \\
3.5 \\
3.5 \\
3.5 \\
3.5\end{array}$ & $\begin{array}{l}0.00 \\
0.00 \\
0.00 \\
0.00 \\
0.00\end{array}$ & $\begin{array}{l}1400 \\
1405 \\
1410 \\
1415 \\
1420\end{array}$ & $\begin{array}{l}2.9 \\
2.9 \\
2.9 \\
2.9 \\
2.9\end{array}$ & $\begin{array}{l}0.00 \\
0.00 \\
0.00 \\
0.00 \\
0.00\end{array}$ \\
\hline $\begin{array}{l}0805 \\
0810 \\
0815 \\
0820 \\
0825\end{array}$ & $\begin{array}{l}4 \cdot 1 \\
4 \cdot 1 \\
4 \cdot 1 \\
4 \cdot 1 \\
4 \cdot 1\end{array}$ & $\begin{array}{l}0.00 \\
0.00 \\
0.00 \\
0.00 \\
0.00\end{array}$ & $\begin{array}{l}1115 \\
1120 \\
1125 \\
1130 \\
1135\end{array}$ & $\begin{array}{l}3.5 \\
3.5 \\
3.5 \\
3.5 \\
3.2\end{array}$ & $\begin{array}{l}0.00 \\
0.00 \\
0.00 \\
0.00 \\
0.00\end{array}$ & $\begin{array}{l}1425 \\
1430 \\
1435 \\
1440 \\
1445\end{array}$ & $\begin{array}{l}2.9 \\
2.9 \\
2.9 \\
2.9 \\
2.9\end{array}$ & $\begin{array}{l}0.00 \\
0.00 \\
0.00 \\
0.00 \\
0.00\end{array}$ \\
\hline $\begin{array}{l}0830 \\
0835 \\
0840\end{array}$ & $\begin{array}{l}4.1 \\
3.8 \\
3.8\end{array}$ & $\begin{array}{l}0.00 \\
0.01 \\
0.00\end{array}$ & $\begin{array}{l}1140 \\
1145 \\
1150\end{array}$ & $\begin{array}{l}3.2 \\
3.2 \\
3.2\end{array}$ & $\begin{array}{l}0.00 \\
0.00 \\
0.00\end{array}$ & $\begin{array}{l}1450 \\
1455 \\
1500\end{array}$ & $\begin{array}{l}2.9 \\
2.5 \\
2.5\end{array}$ & $\begin{array}{l}0.00 \\
0.00 \\
0.00\end{array}$ \\
\hline
\end{tabular}



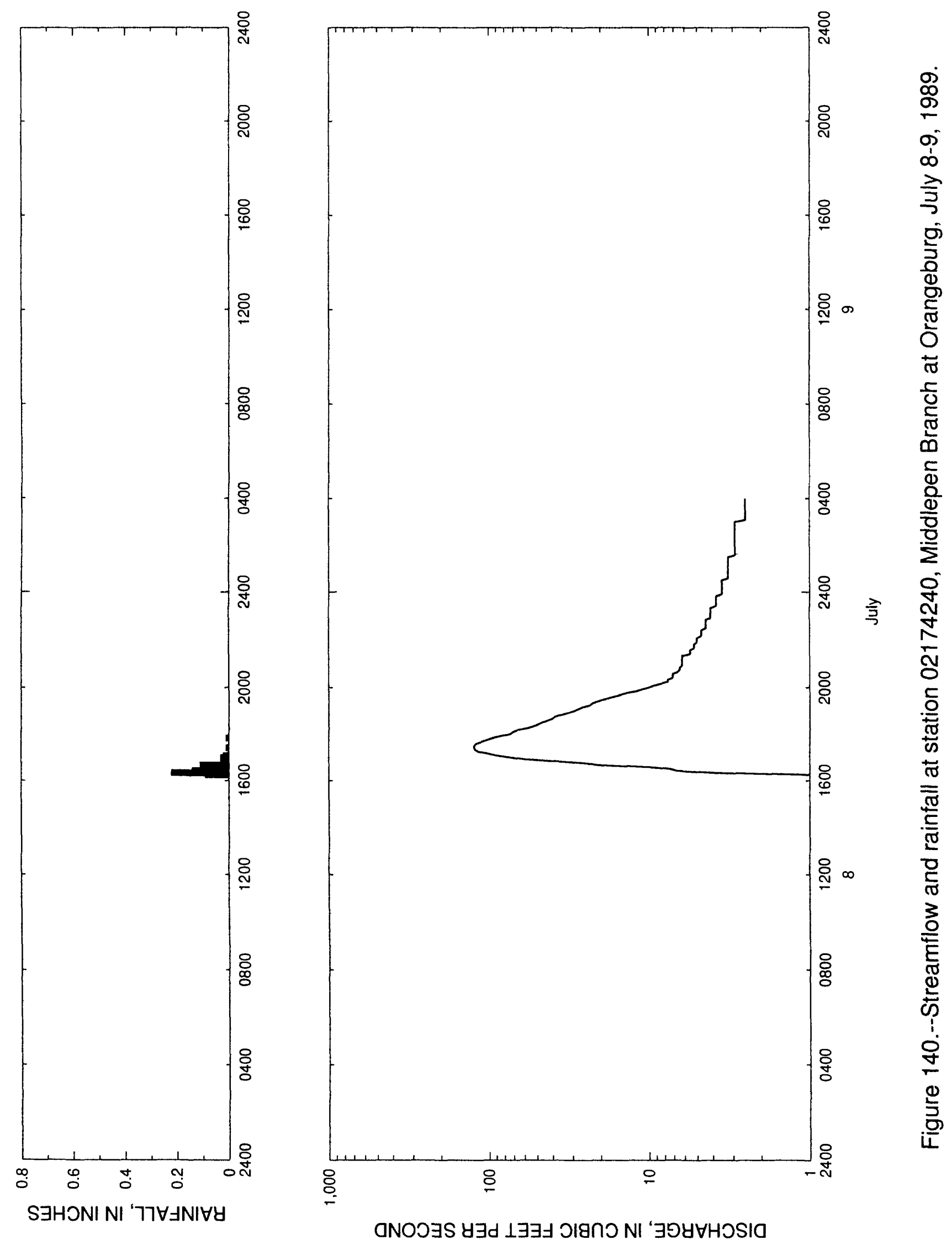
Table 139. - - Streamflow and rainfall at station 02174240, Middlepen Branch at Orangeburg. July $8-9,1989$

\begin{tabular}{|c|c|c|c|c|c|c|c|c|}
\hline $\begin{array}{l}\text { Time } \\
\text { (hours) }\end{array}$ & $\begin{array}{l}\text { Streamflow } \\
\text { (cubic feet } \\
\text { per second) }\end{array}$ & $\begin{array}{l}\text { Rain- } \\
\text { fall } \\
\text { (inches) }\end{array}$ & $\begin{array}{l}\text { Time } \\
\text { (hours) }\end{array}$ & $\begin{array}{l}\text { Streamflow } \\
\text { (cubic feet } \\
\text { per second) }\end{array}$ & $\begin{array}{l}\text { Rain- } \\
\text { fali } \\
\text { (inches) }\end{array}$ & $\begin{array}{l}\text { Time } \\
\text { (hours) }\end{array}$ & $\begin{array}{l}\text { Streamflow } \\
\text { (cubic feet } \\
\text { per second) }\end{array}$ & $\begin{array}{l}\text { Rain- } \\
\text { fall } \\
\text { (in?hes) }\end{array}$ \\
\hline $\begin{array}{c}\text { July } 8 \text {, } \\
1615 \\
1620 \\
1625 \\
1630\end{array}$ & $\begin{array}{l}1.0 \\
3.8 \\
6.7 \\
7.4\end{array}$ & $\begin{array}{l}0.09 \\
0.22 \\
0.14 \\
0.05\end{array}$ & $\begin{array}{l}2010 \\
2015 \\
2020 \\
2025 \\
2030\end{array}$ & $\begin{array}{l}8.4 \\
7.6 \\
7.6 \\
7.1 \\
7.1\end{array}$ & $\begin{array}{l}0.00 \\
0.00 \\
0.00 \\
0.00 \\
0.00\end{array}$ & $\begin{array}{l}0005 \\
0010 \\
0015 \\
0020 \\
0025\end{array}$ & $\begin{array}{l}3.5 \\
3.5 \\
3.5 \\
3.5 \\
3.5\end{array}$ & $\begin{array}{l}0.00 \\
0.00 \\
0.00 \\
0.00 \\
0.00\end{array}$ \\
\hline $\begin{array}{l}1635 \\
1640 \\
1645 \\
1650 \\
1655\end{array}$ & $\begin{array}{l}10.2 \\
20.8 \\
25.2 \\
38.7 \\
59.8\end{array}$ & $\begin{array}{l}0.05 \\
0.11 \\
0.03 \\
0.02 \\
0.02\end{array}$ & $\begin{array}{l}2035 \\
2040 \\
2045 \\
2050 \\
2055\end{array}$ & $\begin{array}{l}7.1 \\
6.6 \\
6.4 \\
6.4 \\
6.2\end{array}$ & $\begin{array}{l}0.00 \\
0.00 \\
0.00 \\
0.00 \\
0.00\end{array}$ & $\begin{array}{l}0030 \\
0035 \\
0040 \\
0045 \\
0050\end{array}$ & $\begin{array}{l}3.5 \\
3.2 \\
3.2 \\
3.2 \\
3.2\end{array}$ & $\begin{array}{l}0.00 \\
0.00 \\
0.00 \\
0.00 \\
0.00\end{array}$ \\
\hline $\begin{array}{l}1700 \\
1705 \\
1710 \\
1715 \\
1720\end{array}$ & $\begin{array}{r}74.0 \\
89.0 \\
102.0 \\
117.0 \\
123.0\end{array}$ & $\begin{array}{l}0.03 \\
0.02 \\
0.00 \\
0.00 \\
0.00\end{array}$ & $\begin{array}{l}2100 \\
2105 \\
2110 \\
2115 \\
2120\end{array}$ & $\begin{array}{l}6.2 \\
6.2 \\
6.2 \\
6.2 \\
6.2\end{array}$ & $\begin{array}{l}0.00 \\
0.00 \\
0.00 \\
0.00 \\
0.00\end{array}$ & $\begin{array}{l}0055 \\
0100 \\
0105 \\
0110 \\
0115\end{array}$ & $\begin{array}{l}3.2 \\
3.2 \\
3.2 \\
3.2 \\
3.2\end{array}$ & $\begin{array}{l}0.00 \\
0.00 \\
0.00 \\
0.00 \\
0.00\end{array}$ \\
\hline $\begin{array}{l}1725 \\
1730 \\
1735 \\
1740 \\
1745\end{array}$ & $\begin{array}{l}124.0 \\
124.0 \\
121.0 \\
112.0 \\
103.0\end{array}$ & $\begin{array}{l}0.01 \\
0.00 \\
0.00 \\
0.00 \\
0.00\end{array}$ & $\begin{array}{l}2125 \\
2130 \\
2135 \\
2140 \\
2145\end{array}$ & $\begin{array}{l}5.5 \\
5.5 \\
5.5 \\
5.2 \\
5.2\end{array}$ & $\begin{array}{l}0.00 \\
0.00 \\
0.00 \\
0.00 \\
0.00\end{array}$ & $\begin{array}{l}0120 \\
0125 \\
0130 \\
0135 \\
0140\end{array}$ & $\begin{array}{l}3.2 \\
3.2 \\
3.2 \\
2.9 \\
2.9\end{array}$ & $\begin{array}{l}0.00 \\
0.00 \\
0.00 \\
0.00 \\
0.00\end{array}$ \\
\hline $\begin{array}{l}1750 \\
1755 \\
1800 \\
1805 \\
1810\end{array}$ & $\begin{array}{l}95.0 \\
86.0 \\
74.0 \\
70.9 \\
67.3\end{array}$ & $\begin{array}{l}0.01 \\
0.00 \\
0.00 \\
0.00 \\
0.00\end{array}$ & $\begin{array}{l}2150 \\
2155 \\
2200 \\
2205 \\
2210\end{array}$ & $\begin{array}{l}5.2 \\
5.0 \\
5.0 \\
5.0 \\
4.7\end{array}$ & $\begin{array}{l}0.00 \\
0.00 \\
0.00 \\
0.00 \\
0.00\end{array}$ & $\begin{array}{l}0145 \\
0150 \\
0155 \\
0200 \\
0205\end{array}$ & $\begin{array}{l}2.9 \\
2.9 \\
2.9 \\
2.9 \\
2.9\end{array}$ & $\begin{array}{l}0.00 \\
0.00 \\
0.00 \\
0.00 \\
0.00\end{array}$ \\
\hline $\begin{array}{l}1815 \\
1820 \\
1825 \\
1830 \\
1835\end{array}$ & $\begin{array}{l}58.0 \\
53.1 \\
49.6 \\
46.8 \\
43.1\end{array}$ & $\begin{array}{l}0.00 \\
0.00 \\
0.00 \\
0.00 \\
0.00\end{array}$ & $\begin{array}{l}2215 \\
2220 \\
2225 \\
2230 \\
2235\end{array}$ & $\begin{array}{l}4.7 \\
4.7 \\
4.7 \\
4.4 \\
4.4\end{array}$ & $\begin{array}{l}0.00 \\
0.00 \\
0.00 \\
0.00 \\
0.00\end{array}$ & $\begin{array}{l}0210 \\
0215 \\
0220 \\
0225 \\
0230\end{array}$ & $\begin{array}{l}2.9 \\
2.9 \\
2.9 \\
2.9 \\
2.9\end{array}$ & $\begin{array}{l}0.00 \\
0.00 \\
0.00 \\
0.00 \\
0.00\end{array}$ \\
\hline $\begin{array}{l}1840 \\
1845 \\
1850 \\
1855 \\
1900\end{array}$ & $\begin{array}{l}40.4 \\
38.5 \\
35.7 \\
32.1 \\
29.5\end{array}$ & $\begin{array}{l}0.00 \\
0.00 \\
0.00 \\
0.00 \\
0.00\end{array}$ & $\begin{array}{l}2240 \\
2245 \\
2250 \\
2255 \\
2300\end{array}$ & $\begin{array}{l}4.4 \\
4.4 \\
4.4 \\
4.1 \\
4.1\end{array}$ & $\begin{array}{l}0.00 \\
0.00 \\
0.00 \\
0.00 \\
0.00\end{array}$ & $\begin{array}{l}0235 \\
0240 \\
0245 \\
0250 \\
0255\end{array}$ & $\begin{array}{l}2.9 \\
2.9 \\
2.9 \\
2.9 \\
2.9\end{array}$ & $\begin{array}{l}0.00 \\
0.00 \\
0.00 \\
0.00 \\
0.00\end{array}$ \\
\hline $\begin{array}{l}1905 \\
1910 \\
1915 \\
1920 \\
1925\end{array}$ & $\begin{array}{l}27.7 \\
26.0 \\
23.4 \\
22.5 \\
20.7\end{array}$ & $\begin{array}{l}0.00 \\
0.00 \\
0.00 \\
0.00 \\
0.00\end{array}$ & $\begin{array}{l}2305 \\
2310 \\
2315 \\
2320 \\
2325\end{array}$ & $\begin{array}{l}4.1 \\
4.1 \\
4.1 \\
4.1 \\
3.8\end{array}$ & $\begin{array}{l}0.00 \\
0.00 \\
0.00 \\
0.00 \\
0.00\end{array}$ & $\begin{array}{l}0300 \\
0305 \\
0310 \\
0315 \\
0320\end{array}$ & $\begin{array}{l}2.9 \\
2.5 \\
2.5 \\
2.5 \\
2.5\end{array}$ & $\begin{array}{l}0.00 \\
0.00 \\
0.00 \\
0.00 \\
0.00\end{array}$ \\
\hline $\begin{array}{l}1930 \\
1935 \\
1940 \\
1945 \\
1950\end{array}$ & $\begin{array}{l}19.0 \\
17.2 \\
15.5 \\
14.4 \\
12.1\end{array}$ & $\begin{array}{l}0.00 \\
0.00 \\
0.00 \\
0.00 \\
0.00\end{array}$ & $\begin{array}{l}2330 \\
2335 \\
2340 \\
2345 \\
2350\end{array}$ & $\begin{array}{l}3.8 \\
3.8 \\
3.8 \\
3.8 \\
3.8\end{array}$ & $\begin{array}{l}0.00 \\
0.00 \\
0.00 \\
0.00 \\
0.00\end{array}$ & $\begin{array}{r}0325 \\
0330 \\
1 \quad 0335 \\
0340 \\
0345\end{array}$ & $\begin{array}{l}2.5 \\
2.5 \\
2.5 \\
2.5 \\
2.5\end{array}$ & $\begin{array}{l}0.00 \\
0.00 \\
0.00 \\
0.00 \\
0.00\end{array}$ \\
\hline $\begin{array}{l}1955 \\
2000 \\
2005\end{array}$ & $\begin{array}{r}11.0 \\
10.0 \\
9.3\end{array}$ & $\begin{array}{l}0.00 \\
0.00 \\
0.00\end{array}$ & $\begin{array}{l}2355 \\
\text { July } 9 \text {, } \\
0000\end{array}$ & $\begin{array}{l}3.5 \\
3.5\end{array}$ & $\begin{array}{l}0.00 \\
0.00\end{array}$ & $\begin{array}{l}0350 \\
0355 \\
0400\end{array}$ & $\begin{array}{l}2.5 \\
2.5 \\
2.5\end{array}$ & $\begin{array}{l}0.00 \\
0.00 \\
0.00\end{array}$ \\
\hline
\end{tabular}




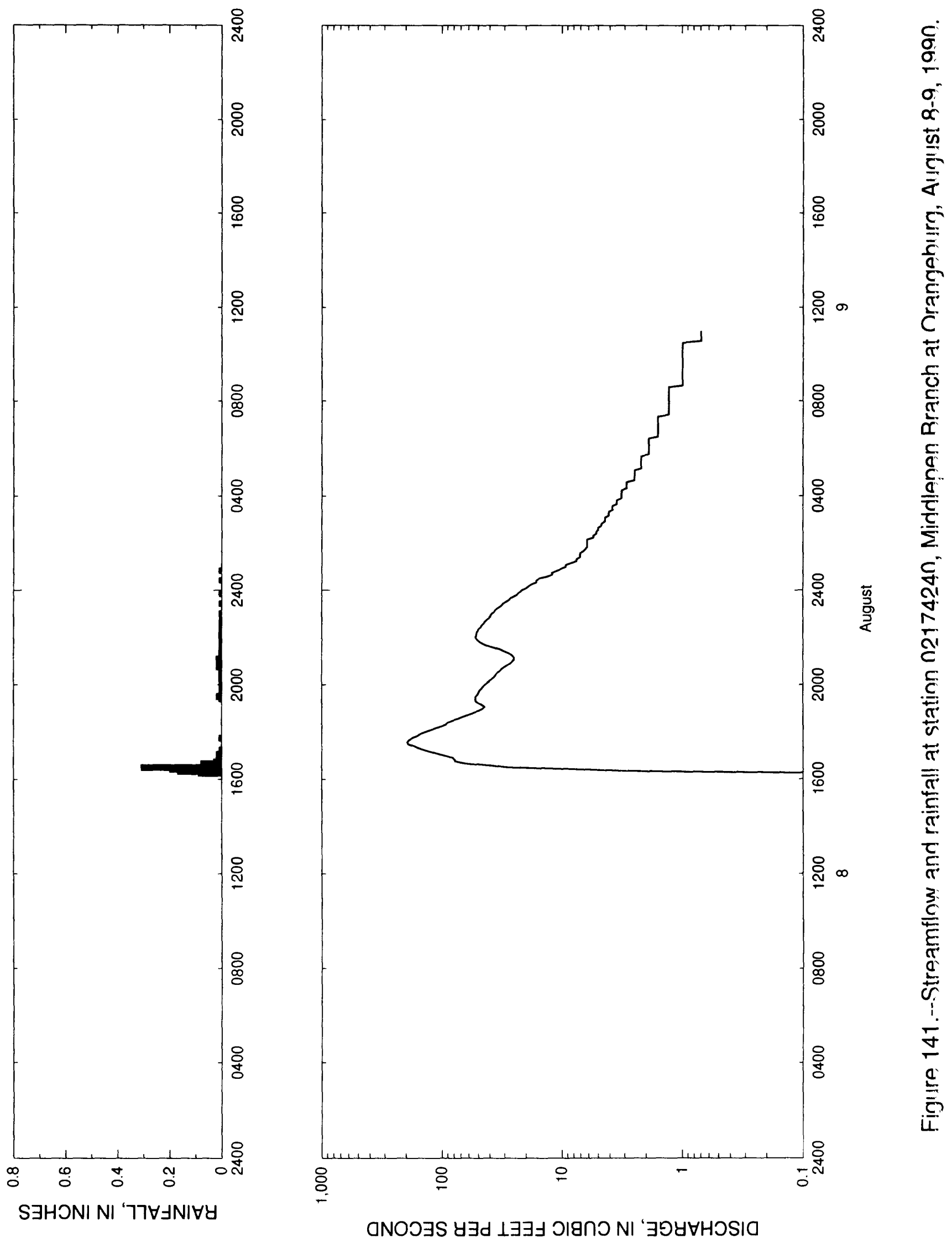


Table 140.--Streamflow and rainfall at station 02174240, Middlepen Branch at Orangeburg, August $8-9,1990$

\begin{tabular}{|c|c|c|c|c|c|c|c|c|}
\hline $\begin{array}{l}\text { Time } \\
\text { (hours) }\end{array}$ & $\begin{array}{l}\text { Streamflow } \\
\text { (cubic feet } \\
\text { per second) }\end{array}$ & $\begin{array}{l}\text { Rain- } \\
\text { fall } \\
\text { (inches) }\end{array}$ & $\begin{array}{l}\text { Time } \\
\text { (hours) }\end{array}$ & $\begin{array}{l}\text { Streamflow } \\
\text { (cubic feet } \\
\text { per second) }\end{array}$ & $\begin{array}{l}\text { Rain- } \\
\text { fall } \\
\text { (inches) }\end{array}$ & $\begin{array}{l}\text { Time } \\
\text { (hours) }\end{array}$ & $\begin{array}{l}\text { Streamflow } \\
\text { (cubic feet } \\
\text { per second) }\end{array}$ & $\begin{array}{l}\text { Rain- } \\
\text { fall } \\
\text { (inches) }\end{array}$ \\
\hline $\begin{array}{c}\text { August } 8 \text {, } \\
1615 \\
1620 \\
1625 \\
1630\end{array}$ & $\begin{array}{r}1990 \\
0.1 \\
2.6 \\
7.5 \\
27.9\end{array}$ & $\begin{array}{l}0.09 \\
0.17 \\
0.20 \\
0.31\end{array}$ & $\begin{array}{l}2135 \\
2140 \\
2145 \\
2150 \\
2155\end{array}$ & $\begin{array}{l}37.7 \\
43.2 \\
46.9 \\
49.7 \\
51.6\end{array}$ & $\begin{array}{l}0.01 \\
0.01 \\
0.01 \\
0.01 \\
0.00\end{array}$ & $\begin{array}{l}0255 \\
0300 \\
0305 \\
0310 \\
0315\end{array}$ & $\begin{array}{l}4.4 \\
4.4 \\
4.4 \\
4.1 \\
4.1\end{array}$ & $\begin{array}{l}0 . C O \\
0 . C 0 \\
0 . C 0 \\
0 . C 0 \\
0 . C 0\end{array}$ \\
\hline $\begin{array}{l}1635 \\
1640 \\
1645 \\
1650 \\
1655\end{array}$ & $\begin{array}{l}38.7 \\
63.4 \\
77.9 \\
79.1 \\
81.6\end{array}$ & $\begin{array}{l}0.07 \\
0.08 \\
0.03 \\
0.02 \\
0.01\end{array}$ & $\begin{array}{l}2200 \\
2205 \\
2210 \\
2215 \\
2220\end{array}$ & $\begin{array}{l}52.5 \\
51.5 \\
51.5 \\
50.6 \\
49.6\end{array}$ & $\begin{array}{l}0.01 \\
0.01 \\
0.01 \\
0.01 \\
0.01\end{array}$ & $\begin{array}{l}0320 \\
0325 \\
0330 \\
0335 \\
0340\end{array}$ & $\begin{array}{l}4.1 \\
3.8 \\
3.8 \\
3.8 \\
3.5\end{array}$ & $\begin{array}{l}0 . C 0 \\
0 . C 0 \\
0 . C 0 \\
0 . C 0 \\
0 . C 0\end{array}$ \\
\hline $\begin{array}{l}1700 \\
1705 \\
1710 \\
1715 \\
1720\end{array}$ & $\begin{array}{r}94.1 \\
109.0 \\
124.0 \\
141.0 \\
158.0\end{array}$ & $\begin{array}{l}0.01 \\
0.02 \\
0.00 \\
0.01 \\
0.00\end{array}$ & $\begin{array}{l}2225 \\
2230 \\
2235 \\
2240 \\
2245\end{array}$ & $\begin{array}{l}47.8 \\
46.9 \\
45.0 \\
44.1 \\
42.2\end{array}$ & $\begin{array}{l}0.00 \\
0.00 \\
0.01 \\
0.00 \\
0.00\end{array}$ & $\begin{array}{l}0345 \\
0350 \\
0355 \\
0400 \\
0405\end{array}$ & $\begin{array}{l}3.5 \\
3.5 \\
3.2 \\
3.2 \\
3.2\end{array}$ & $\begin{array}{l}0.00 \\
0.00 \\
0.00 \\
0.00 \\
0.00\end{array}$ \\
\hline $\begin{array}{l}1725 \\
1730 \\
1735 \\
1740 \\
1745\end{array}$ & $\begin{array}{l}171.0 \\
191.0 \\
195.0 \\
189.0 \\
178.0\end{array}$ & $\begin{array}{l}0.00 \\
0.00 \\
0.00 \\
0.00 \\
0.01\end{array}$ & $\begin{array}{l}2250 \\
2255 \\
2300 \\
2305 \\
2310\end{array}$ & $\begin{array}{l}40.4 \\
39.5 \\
38.5 \\
36.7 \\
35.8\end{array}$ & $\begin{array}{l}0.01 \\
0.00 \\
0.01 \\
0.00 \\
0.00\end{array}$ & $\begin{array}{l}0410 \\
0415 \\
0420 \\
0425 \\
0430\end{array}$ & $\begin{array}{l}3.2 \\
3.2 \\
2.9 \\
2.9 \\
2.9\end{array}$ & $\begin{array}{l}0.00 \\
0.00 \\
0.00 \\
0.00 \\
0.00\end{array}$ \\
\hline $\begin{array}{l}1750 \\
1755 \\
1800 \\
1805 \\
1810\end{array}$ & $\begin{array}{l}162.0 \\
154.0 \\
142.0 \\
128.0 \\
114.0\end{array}$ & $\begin{array}{l}0.00 \\
0.00 \\
0.00 \\
0.00 \\
0.00\end{array}$ & $\begin{array}{l}2315 \\
2320 \\
2325 \\
2330 \\
2335\end{array}$ & $\begin{array}{l}33.9 \\
32.1 \\
31.2 \\
29.5 \\
27.7\end{array}$ & $\begin{array}{l}0.00 \\
0.00 \\
0.01 \\
0.00 \\
0.00\end{array}$ & $\begin{array}{l}0435 \\
0440 \\
0445 \\
0450 \\
0455\end{array}$ & $\begin{array}{l}2.9 \\
2.5 \\
2.5 \\
2.5 \\
2.5\end{array}$ & $\begin{array}{l}0.00 \\
0.00 \\
0.00 \\
0.00 \\
0.00\end{array}$ \\
\hline $\begin{array}{l}1815 \\
1820 \\
1825 \\
1830 \\
1835\end{array}$ & $\begin{array}{r}102.0 \\
93.5 \\
90.1 \\
81.9 \\
73.4\end{array}$ & $\begin{array}{l}0.00 \\
0.00 \\
0.00 \\
0.00 \\
0.00\end{array}$ & $\begin{array}{c}2340 \\
2345 \\
2350 \\
2355 \\
\text { August g }\end{array}$ & $\begin{array}{r}26.9 \\
25.1 \\
23.4 \\
22.5 \\
, 1990\end{array}$ & $\begin{array}{l}0.00 \\
0.00 \\
0.01 \\
0.00\end{array}$ & $\begin{array}{l}0500 \\
0505 \\
0510 \\
0515 \\
0520\end{array}$ & $\begin{array}{l}2.5 \\
2.5 \\
2.2 \\
2.2 \\
2.2\end{array}$ & $\begin{array}{l}0.01 \\
0.00 \\
0.07 \\
0.00 \\
0.07\end{array}$ \\
\hline $\begin{array}{l}1840 \\
1845 \\
1850 \\
1855 \\
1900\end{array}$ & $\begin{array}{l}67.2 \\
60.7 \\
54.8 \\
49.6 \\
45.9\end{array}$ & $\begin{array}{l}0.00 \\
0.00 \\
0.00 \\
0.00 \\
0.00\end{array}$ & $\begin{array}{l}0000 \\
0005 \\
0010 \\
0015 \\
0020\end{array}$ & $\begin{array}{l}21.6 \\
19.9 \\
19.0 \\
18.1 \\
16.4\end{array}$ & $\begin{array}{l}0.00 \\
0.00 \\
0.00 \\
0.00 \\
0.00\end{array}$ & $\begin{array}{l}0525 \\
0530 \\
0535 \\
0540 \\
0545\end{array}$ & $\begin{array}{l}2.2 \\
2.2 \\
2.2 \\
2.2 \\
1.9\end{array}$ & $\begin{array}{l}0.00 \\
0.07 \\
0.07 \\
0.00 \\
0.00\end{array}$ \\
\hline $\begin{array}{l}1905 \\
1910 \\
1915 \\
1920 \\
1925\end{array}$ & $\begin{array}{l}44.1 \\
46.9 \\
50.7 \\
52.5 \\
52.4\end{array}$ & $\begin{array}{l}0.00 \\
0.00 \\
0.00 \\
0.00 \\
0.01\end{array}$ & $\begin{array}{l}0025 \\
0030 \\
0035 \\
0040 \\
0045\end{array}$ & $\begin{array}{l}16.4 \\
15.5 \\
13.2 \\
12.1 \\
12.1\end{array}$ & $\begin{array}{l}0.01 \\
0.00 \\
0.00 \\
0.00 \\
0.00\end{array}$ & $\begin{array}{l}0550 \\
0555 \\
0600 \\
0605 \\
0610\end{array}$ & $\begin{array}{l}1.9 \\
1.9 \\
1.9 \\
1.9 \\
1.9\end{array}$ & $\begin{array}{l}0.00 \\
0.00 \\
0.00 \\
0.07 \\
0.00\end{array}$ \\
\hline $\begin{array}{l}1930 \\
1935 \\
1940 \\
1945 \\
1950\end{array}$ & $\begin{array}{l}52.4 \\
50.5 \\
49.6 \\
48.7 \\
46.9\end{array}$ & $\begin{array}{l}0.02 \\
0.01 \\
0.01 \\
0.01 \\
0.01\end{array}$ & $\begin{array}{l}0050 \\
0055 \\
0100 \\
0105 \\
0110\end{array}$ & $\begin{array}{r}11.0 \\
10.1 \\
9.3 \\
9.3 \\
8.4\end{array}$ & $\begin{array}{l}0.01 \\
0.00 \\
0.00 \\
0.00 \\
0.00\end{array}$ & $\begin{array}{l}0615 \\
0620 \\
0625 \\
0630 \\
0635\end{array}$ & $\begin{array}{l}1.9 \\
1.9 \\
1.9 \\
1.6 \\
1.6\end{array}$ & $\begin{array}{l}0.07 \\
0.07 \\
0.07 \\
0.07 \\
0.00\end{array}$ \\
\hline $\begin{array}{l}1955 \\
2000 \\
2005 \\
2010 \\
2015\end{array}$ & $\begin{array}{l}45.9 \\
44.1 \\
42.2 \\
40.4 \\
38.5\end{array}$ & $\begin{array}{l}0.00 \\
0.01 \\
0.00 \\
0.00 \\
0.01\end{array}$ & $\begin{array}{l}0115 \\
0120 \\
0125 \\
0130 \\
0135\end{array}$ & $\begin{array}{l}7.6 \\
7.6 \\
7.1 \\
7.1 \\
7.1\end{array}$ & $\begin{array}{l}0.00 \\
0.00 \\
0.00 \\
0.00 \\
0.00\end{array}$ & $\begin{array}{l}0640 \\
0645 \\
0650 \\
0655 \\
0700\end{array}$ & $\begin{array}{l}1.6 \\
1.6 \\
1.6 \\
1.6 \\
1.6\end{array}$ & $\begin{array}{l}0.00 \\
0.00 \\
0.00 \\
0.00 \\
0.00\end{array}$ \\
\hline $\begin{array}{l}2020 \\
2025 \\
2030 \\
2035 \\
2040\end{array}$ & $\begin{array}{l}36.7 \\
35.8 \\
34.8 \\
33.0 \\
32.1\end{array}$ & $\begin{array}{l}0.00 \\
0.01 \\
0.01 \\
0.01 \\
0.00\end{array}$ & $\begin{array}{l}0140 \\
0145 \\
0150 \\
0155 \\
0200\end{array}$ & $\begin{array}{l}6.6 \\
6.4 \\
6.2 \\
6.2 \\
6.2\end{array}$ & $\begin{array}{l}0.00 \\
0.00 \\
0.00 \\
0.00 \\
0.00\end{array}$ & $\begin{array}{l}0705 \\
0710 \\
0715 \\
0720 \\
0725\end{array}$ & $\begin{array}{l}1.6 \\
1.6 \\
1.6 \\
1.6 \\
1.3\end{array}$ & $\begin{array}{l}0.02 \\
0.02 \\
0.00 \\
0.00 \\
0.00\end{array}$ \\
\hline $\begin{array}{l}2045 \\
2050 \\
2055 \\
2100 \\
2105\end{array}$ & 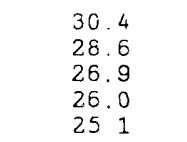 & $\begin{array}{l}0.02 \\
0.00 \\
0.02 \\
0.01 \\
0.02\end{array}$ & $\begin{array}{l}0205 \\
0210 \\
0215 \\
0220 \\
0225\end{array}$ & $\begin{array}{l}6.2 \\
6.2 \\
5.5 \\
5.5 \\
5.2\end{array}$ & $\begin{array}{l}0.00 \\
0.00 \\
0.00 \\
0.00 \\
0.00\end{array}$ & $\begin{array}{l}0730 \\
0735 \\
0740 \\
0745 \\
0750\end{array}$ & $\begin{array}{l}1.3 \\
1.3 \\
1.3 \\
1.3 \\
1.3\end{array}$ & $\begin{array}{l}0.07 \\
0.00 \\
0.00 \\
0.07 \\
0.07\end{array}$ \\
\hline $\begin{array}{l}2110 \\
2115 \\
2120 \\
2125 \\
2130\end{array}$ & $\begin{array}{l}25.1 \\
26.0 \\
27.8 \\
30.4 \\
33.0\end{array}$ & $\begin{array}{l}0.01 \\
0.01 \\
0.01 \\
0.01 \\
0.01\end{array}$ & $\begin{array}{l}0230 \\
0235 \\
0240 \\
0245 \\
0250\end{array}$ & $\begin{array}{l}5.2 \\
5.0 \\
5.0 \\
4.7 \\
4.7\end{array}$ & $\begin{array}{l}0.00 \\
0.00 \\
0.00 \\
0.00 \\
0.00\end{array}$ & $\begin{array}{l}0755 \\
0800 \\
0805 \\
0810 \\
0815\end{array}$ & $\begin{array}{l}1.3 \\
1.3 \\
1.3 \\
1.3 \\
1.3\end{array}$ & $\begin{array}{l}0.00 \\
0.00 \\
0.00 \\
0.00 \\
0.00\end{array}$ \\
\hline
\end{tabular}


Table 140.--Streamflow and rainfall at station 02174240, Middlepen Brarsh at Orangeburg. August 8-9,1990--Continued

\begin{tabular}{|c|c|c|c|c|c|c|c|c|}
\hline $\begin{array}{l}\text { Time } \\
\text { (hours) }\end{array}$ & $\begin{array}{l}\text { Streamflow } \\
\text { (cubic feet } \\
\text { per second) }\end{array}$ & $\begin{array}{l}\text { Rain- } \\
\text { fall } \\
\text { (inches) }\end{array}$ & $\begin{array}{l}\text { Time } \\
\text { (hours) }\end{array}$ & $\begin{array}{l}\text { Streamflow } \\
\text { (cubic feet } \\
\text { per second) }\end{array}$ & $\begin{array}{l}\text { Rain- } \\
\text { fall } \\
\text { (inches) }\end{array}$ & $\begin{array}{l}\text { Time } \\
\text { (hours) }\end{array}$ & $\begin{array}{l}\text { Streamflow } \\
\text { (cubic feet } \\
\text { per second) }\end{array}$ & $\begin{array}{l}\text { Rain- } \\
\text { fall } \\
\text { (inches) }\end{array}$ \\
\hline $\begin{array}{l}0820 \\
0825 \\
0830 \\
0835 \\
0840\end{array}$ & $\begin{array}{l}1.3 \\
1.3 \\
1.3 \\
1.3 \\
1.0\end{array}$ & $\begin{array}{l}0.00 \\
0.00 \\
0.00 \\
0.00 \\
0.00\end{array}$ & $\begin{array}{l}0915 \\
0920 \\
0925 \\
0930 \\
0935\end{array}$ & $\begin{array}{l}1.0 \\
1.0 \\
1.0 \\
1.0 \\
1.0\end{array}$ & $\begin{array}{l}0.00 \\
0.00 \\
0.00 \\
0.00 \\
0.00\end{array}$ & $\begin{array}{l}1010 \\
1015 \\
1020 \\
1025 \\
1030\end{array}$ & $\begin{array}{l}1.0 \\
1.0 \\
1.0 \\
1.0 \\
1.0\end{array}$ & $\begin{array}{l}0.00 \\
0.00 \\
0.00 \\
0.00 \\
0.00\end{array}$ \\
\hline $\begin{array}{l}0845 \\
0850 \\
0855 \\
0900 \\
0905\end{array}$ & $\begin{array}{l}1.0 \\
1.0 \\
1.0 \\
1.0 \\
1.0\end{array}$ & $\begin{array}{l}0.00 \\
0.00 \\
0.00 \\
0.00 \\
0.00\end{array}$ & $\begin{array}{l}0940 \\
0945 \\
0950 \\
0955 \\
1000\end{array}$ & $\begin{array}{l}1.0 \\
1.0 \\
1.0 \\
1.0 \\
1.0\end{array}$ & $\begin{array}{l}0.00 \\
0.00 \\
0.00 \\
0.00 \\
0.00\end{array}$ & $\begin{array}{l}1035 \\
1040 \\
1045 \\
1050 \\
1055\end{array}$ & $\begin{array}{l}0.7 \\
0.7 \\
0.7 \\
0.7 \\
0.7\end{array}$ & $\begin{array}{l}0.00 \\
0.00 \\
0.00 \\
0.00 \\
0.00\end{array}$ \\
\hline 0910 & 1.0 & 0.00 & 1005 & 1.0 & 0.00 & 1100 & 0.7 & 0.00 \\
\hline
\end{tabular}




\section{Station 02176380, Coosawhatchie River Tributary at Allendale, S.C.}

Location.-Lat $32^{\circ} 59^{\prime} 53^{\prime \prime}$, long $81^{\circ} 19^{\prime} 01^{\prime \prime}$, Allendale County, Hydrologic Unit 03050208, at culvert on Allendale County secondary road 129, $0.9 \mathrm{mi}$ southwest of Allendale City Hall, and $0.4 \mathrm{mi}$ upstream from the mouth at Coosawhatchie River.

Period of record.-- May 8, 1986 to October 5, 1990.

Gage.--Digital stage recorder with 5-minute punch interval. The recorder is housed in a metal shelter atop a stilling well attached to a free-standing platform $2 \mathrm{ft}$ upstream from a single 6-ft reinforced concrete pipe culvert on the right bank. An enameled staff gage is attached to the platform. One crest-stage indicator is located on the left downstream bank near the culvert exit. A second crest-stage indicator is located $20 \mathrm{ft}$ upstream on the left bank.

Rating.-The stage-streamflow relation is defined by current meter measurements up to $85 \mathrm{ft}^{3} / \mathrm{s}$. The stage-streamflow relation was extended to $160 \mathrm{ft}^{3} / \mathrm{s}$ using indirect computational methods.

Rain gage and location.--Station 330040081183800 , lat $33^{\circ} 00^{\prime} 40^{\prime \prime}$, long $81^{\circ} 18^{\prime} 38^{\prime \prime}$. A shelter containing a digital cumulative rainfall recorder with a 5-minute pund. interval located by a grain elevator on Bay Street (Allendale County road 98), $0.3 \mathrm{mi}$ northwest of Allendale City Hall.

Selected basin characteristics.--

Drainage area $-2.06 \mathrm{mi}^{2}$

Physiographic province -- Lower Coastal Plain

Channel slope -- $24.3 \mathrm{ft} / \mathrm{mi}$

Channel length - $2.02 \mathrm{mi}$

Total impervious area -- 13.0 percent

Basin development factor -- 2

2-year, 2-hour rainfall amount -- 2.28 in.

Flood frequency data: $\mathrm{UQ}_{2} \quad 107 \mathrm{ft}^{3} / \mathrm{s}$

$\begin{array}{cr}\mathrm{UQ}_{5} & 206 \mathrm{ft}^{3} / \mathrm{s} \\ \mathrm{UQ}_{10} & 308 \mathrm{ft}^{3} / \mathrm{s} \\ \mathrm{UQ}_{25} & 497 \mathrm{ft}^{3} / \mathrm{s} \\ \mathrm{UQ}_{50} & 695 \mathrm{ft}^{3} / \mathrm{s} \\ \mathrm{UQ}_{100} & 958 \mathrm{ft}^{3} / \mathrm{s} \\ \mathrm{UQ}_{500} & 1,930 \mathrm{ft}^{3} / \mathrm{s}\end{array}$




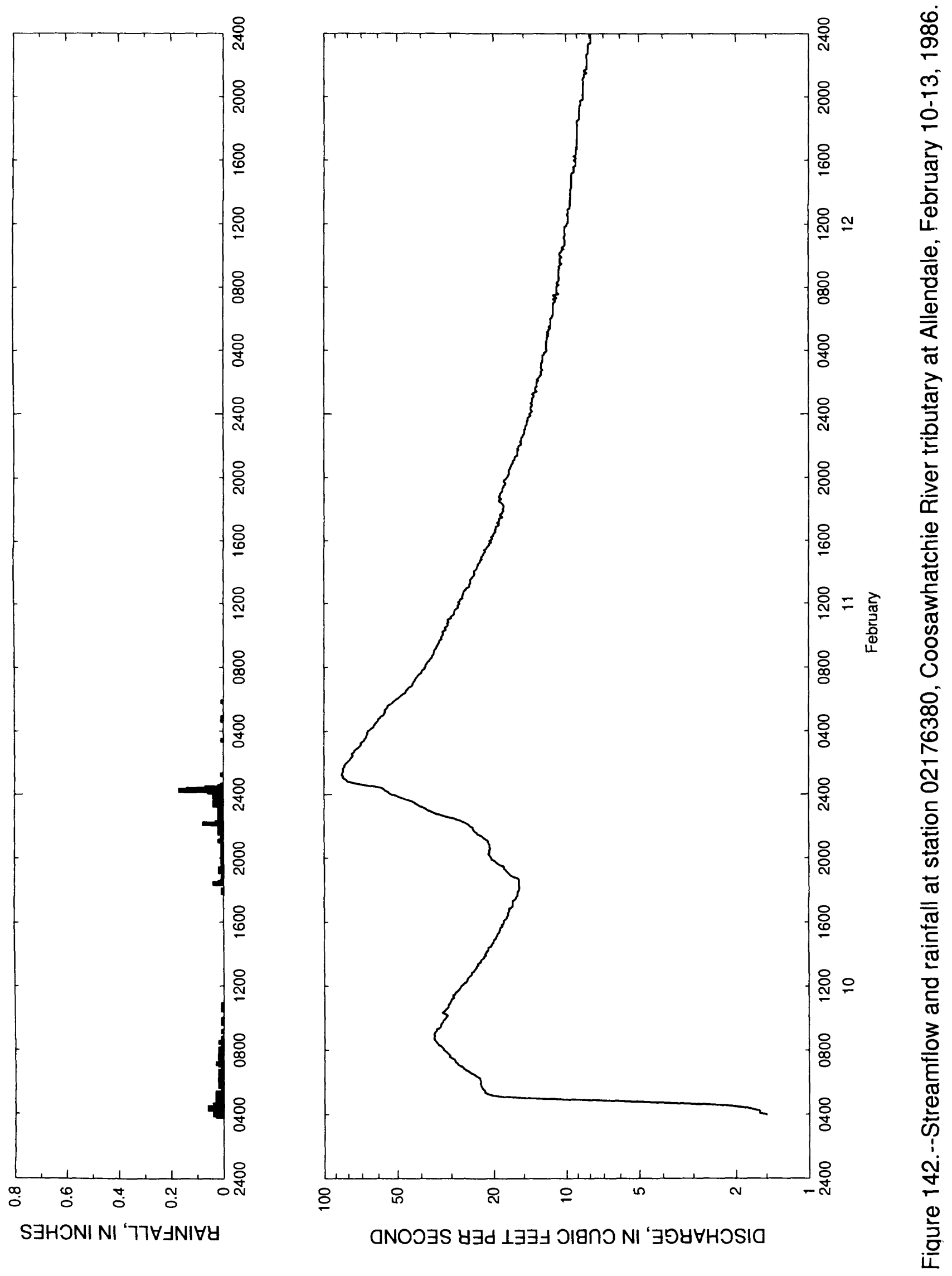


Table 141.- Streamflow and rainfall at station 02176380 , Coosawhatchie River tributary at Allendale, February $10-13,1986$

\begin{tabular}{|c|c|c|c|c|c|c|c|c|}
\hline $\begin{array}{l}\text { Time } \\
\text { (hours) }\end{array}$ & $\begin{array}{l}\text { Streamflow } \\
\text { (cubic feet } \\
\text { per second) }\end{array}$ & $\begin{array}{l}\text { Rain- } \\
\text { fall } \\
\text { (inches) }\end{array}$ & $\begin{array}{l}\text { Time } \\
\text { (hours) }\end{array}$ & $\begin{array}{l}\text { Streamflow } \\
\text { (cubic feet } \\
\text { per second) }\end{array}$ & $\begin{array}{l}\text { Rain- } \\
\text { fall } \\
\text { (inches) }\end{array}$ & $\begin{array}{l}\text { Time } \\
\text { (hours) }\end{array}$ & $\begin{array}{l}\text { Streamflow } \\
\text { (cubic feet } \\
\text { per second) }\end{array}$ & $\begin{array}{l}\text { Rain- } \\
\text { fall } \\
\text { (inches) }\end{array}$ \\
\hline $\begin{array}{c}\text { February } \\
0355 \\
0400 \\
0405 \\
0410\end{array}$ & $\begin{array}{r}10,1986 \\
1.5 \\
1.5 \\
1.6 \\
1.6\end{array}$ & $\begin{array}{l}0.03 \\
0.04 \\
0.03 \\
0.02\end{array}$ & $\begin{array}{l}0915 \\
0920 \\
0925 \\
0930 \\
0935\end{array}$ & $\begin{array}{l}34.4 \\
34.4 \\
33.4 \\
33.1 \\
33.1\end{array}$ & $\begin{array}{l}0.00 \\
0.00 \\
0.00 \\
0.00 \\
0.00\end{array}$ & $\begin{array}{l}1440 \\
1445 \\
1450 \\
1455 \\
1500\end{array}$ & $\begin{array}{l}20.2 \\
20.0 \\
20.0 \\
19.8 \\
19.5\end{array}$ & $\begin{array}{l}0.00 \\
0.00 \\
0.00 \\
0.00 \\
0.00\end{array}$ \\
\hline $\begin{array}{l}0415 \\
0420 \\
0425 \\
0430 \\
0435\end{array}$ & $\begin{array}{l}1.6 \\
1.7 \\
1.8 \\
2.0 \\
2.3\end{array}$ & $\begin{array}{l}0.03 \\
0.06 \\
0.06 \\
0.04 \\
0.04\end{array}$ & $\begin{array}{l}0940 \\
0945 \\
0950 \\
0955 \\
1000\end{array}$ & $\begin{array}{l}32.9 \\
32.4 \\
32.4 \\
31.9 \\
31.7\end{array}$ & $\begin{array}{l}0.01 \\
0.00 \\
0.00 \\
0.01 \\
0.00\end{array}$ & $\begin{array}{l}1505 \\
1510 \\
1515 \\
1520 \\
1525\end{array}$ & $\begin{array}{l}19.5 \\
19.3 \\
19.3 \\
19.1 \\
18.9\end{array}$ & $\begin{array}{l}0.00 \\
0.00 \\
0.00 \\
0.00 \\
0.00\end{array}$ \\
\hline $\begin{array}{l}0440 \\
0445 \\
0450 \\
0455 \\
0500\end{array}$ & $\begin{array}{r}3.1 \\
4.4 \\
6.3 \\
9.8 \\
14.2\end{array}$ & $\begin{array}{l}0.02 \\
0.02 \\
0.02 \\
0.03 \\
0.03\end{array}$ & $\begin{array}{l}1005 \\
1010 \\
1015 \\
1020 \\
1025\end{array}$ & $\begin{array}{l}31.2 \\
31.0 \\
31.7 \\
32.7 \\
31.9\end{array}$ & $\begin{array}{l}0.00 \\
0.00 \\
0.00 \\
0.00 \\
0.00\end{array}$ & $\begin{array}{l}1530 \\
1535 \\
1540 \\
1545 \\
1550\end{array}$ & $\begin{array}{l}18.9 \\
18.7 \\
18.7 \\
18.3 \\
18.5\end{array}$ & $\begin{array}{l}0.00 \\
0.00 \\
0.00 \\
0.00 \\
0.00\end{array}$ \\
\hline $\begin{array}{l}0505 \\
0510 \\
0515 \\
0520 \\
0525\end{array}$ & $\begin{array}{l}18.1 \\
20.2 \\
21.0 \\
21.7 \\
21.7\end{array}$ & $\begin{array}{l}0.01 \\
0.03 \\
0.01 \\
0.03 \\
0.01\end{array}$ & $\begin{array}{l}1030 \\
1035 \\
1040 \\
1045 \\
1050\end{array}$ & $\begin{array}{l}31.7 \\
31.2 \\
30.8 \\
30.8 \\
30.8\end{array}$ & $\begin{array}{l}0.01 \\
0.01 \\
0.00 \\
0.00 \\
0.01\end{array}$ & $\begin{array}{l}1555 \\
1600 \\
1605 \\
1610 \\
1615\end{array}$ & $\begin{array}{l}18.1 \\
18.1 \\
18.1 \\
17.8 \\
17.6\end{array}$ & $\begin{array}{l}0.00 \\
0.00 \\
0.00 \\
0.00 \\
0.00\end{array}$ \\
\hline $\begin{array}{l}0530 \\
0535 \\
0540 \\
0545 \\
0550\end{array}$ & $\begin{array}{l}21.9 \\
22.2 \\
22.4 \\
22.6 \\
22.6\end{array}$ & $\begin{array}{l}0.01 \\
0.01 \\
0.01 \\
0.02 \\
0.01\end{array}$ & $\begin{array}{l}1055 \\
1100 \\
1105 \\
1110 \\
1115\end{array}$ & $\begin{array}{l}30.3 \\
30.3 \\
30.0 \\
30.0 \\
29.3\end{array}$ & $\begin{array}{l}0.00 \\
0.00 \\
0.00 \\
0.00 \\
0.00\end{array}$ & $\begin{array}{l}1620 \\
1625 \\
1630 \\
1635 \\
1640\end{array}$ & $\begin{array}{l}17.6 \\
17.4 \\
17.4 \\
17.4 \\
17.2\end{array}$ & $\begin{array}{l}0.00 \\
0.00 \\
0.00 \\
0.00 \\
0.00\end{array}$ \\
\hline $\begin{array}{l}0555 \\
0600 \\
0605 \\
0610 \\
0615\end{array}$ & $\begin{array}{l}22.8 \\
22.6 \\
22.6 \\
22.8 \\
22.8\end{array}$ & $\begin{array}{l}0.02 \\
0.02 \\
0.02 \\
0.02 \\
0.02\end{array}$ & $\begin{array}{l}1120 \\
1125 \\
1130 \\
1135 \\
1140\end{array}$ & $\begin{array}{l}29.5 \\
29.5 \\
28.8 \\
28.8 \\
28.3\end{array}$ & $\begin{array}{l}0.00 \\
0.00 \\
0.00 \\
0.00 \\
0.00\end{array}$ & $\begin{array}{l}1645 \\
1650 \\
1655 \\
1700 \\
1705\end{array}$ & $\begin{array}{l}17.2 \\
17.2 \\
16.8 \\
16.6 \\
16.6\end{array}$ & $\begin{array}{l}0.00 \\
0.00 \\
0.00 \\
0.00 \\
0.00\end{array}$ \\
\hline $\begin{array}{l}0620 \\
0625 \\
0630 \\
0635 \\
0640\end{array}$ & $\begin{array}{l}23.3 \\
23.8 \\
24.2 \\
24.9 \\
25.3\end{array}$ & $\begin{array}{l}0.02 \\
0.01 \\
0.02 \\
0.01 \\
0.02\end{array}$ & $\begin{array}{l}1145 \\
1150 \\
1155 \\
1200 \\
1205\end{array}$ & $\begin{array}{l}27.9 \\
27.6 \\
27.4 \\
27.2 \\
26.7\end{array}$ & $\begin{array}{l}0.00 \\
0.00 \\
0.00 \\
0.00 \\
0.00\end{array}$ & $\begin{array}{l}1710 \\
1715 \\
1720 \\
1725 \\
1730\end{array}$ & $\begin{array}{l}16.6 \\
16.6 \\
16.6 \\
16.3 \\
16.1\end{array}$ & $\begin{array}{l}0.00 \\
0.00 \\
0.00 \\
0.00 \\
0.00\end{array}$ \\
\hline $\begin{array}{l}0645 \\
0650 \\
0655 \\
0700 \\
0705\end{array}$ & $\begin{array}{l}26.0 \\
26.7 \\
26.9 \\
27.4 \\
28.1\end{array}$ & $\begin{array}{l}0.01 \\
0.01 \\
0.00 \\
0.01 \\
0.02\end{array}$ & $\begin{array}{l}1210 \\
1215 \\
1220 \\
1225 \\
1230\end{array}$ & $\begin{array}{l}26.5 \\
26.0 \\
25.8 \\
25.8 \\
25.6\end{array}$ & $\begin{array}{l}0.00 \\
0.00 \\
0.00 \\
0.00 \\
0.00\end{array}$ & $\begin{array}{l}1735 \\
1740 \\
1745 \\
1750 \\
1755\end{array}$ & $\begin{array}{l}16.1 \\
15.9 \\
15.9 \\
15.9 \\
15.9\end{array}$ & $\begin{array}{l}0.00 \\
0.00 \\
0.00 \\
0.01 \\
0.01\end{array}$ \\
\hline $\begin{array}{l}0710 \\
0715 \\
0720 \\
0725 \\
0730\end{array}$ & $\begin{array}{l}28.3 \\
28.8 \\
29.0 \\
29.0 \\
29.8\end{array}$ & $\begin{array}{l}0.03 \\
0.01 \\
0.01 \\
0.02 \\
0.02\end{array}$ & $\begin{array}{l}1235 \\
1240 \\
1245 \\
1250 \\
1255\end{array}$ & $\begin{array}{l}25.3 \\
24.9 \\
24.7 \\
24.7 \\
24.2\end{array}$ & $\begin{array}{l}0.00 \\
0.00 \\
0.00 \\
0.00 \\
0.00\end{array}$ & $\begin{array}{l}1800 \\
1805 \\
1810 \\
1815 \\
1820\end{array}$ & $\begin{array}{l}15.7 \\
15.7 \\
15.7 \\
15.7 \\
15.7\end{array}$ & $\begin{array}{l}0.01 \\
0.00 \\
0.00 \\
0.00 \\
0.00\end{array}$ \\
\hline $\begin{array}{l}0735 \\
0740 \\
0745 \\
0750 \\
0755\end{array}$ & $\begin{array}{l}30.5 \\
30.3 \\
30.8 \\
31.2 \\
31.7\end{array}$ & $\begin{array}{l}0.01 \\
0.02 \\
0.01 \\
0.02 \\
0.02\end{array}$ & $\begin{array}{l}1300 \\
1305 \\
1310 \\
1315 \\
1320\end{array}$ & $\begin{array}{l}24.0 \\
23.8 \\
23.5 \\
23.5 \\
23.1\end{array}$ & $\begin{array}{l}0.00 \\
0.00 \\
0.00 \\
0.00 \\
0.00\end{array}$ & $\begin{array}{l}1825 \\
1830 \\
1835 \\
1840 \\
1845\end{array}$ & $\begin{array}{l}15.7 \\
15.7 \\
15.7 \\
15.7 \\
15.9\end{array}$ & $\begin{array}{l}0.04 \\
0.02 \\
0.01 \\
0.00 \\
0.01\end{array}$ \\
\hline $\begin{array}{l}0800 \\
0805 \\
0810 \\
0815 \\
0820\end{array}$ & $\begin{array}{l}32.2 \\
32.4 \\
32.7 \\
33.1 \\
33.9\end{array}$ & $\begin{array}{l}0.02 \\
0.02 \\
0.01 \\
0.01 \\
0.01\end{array}$ & $\begin{array}{l}1325 \\
1330 \\
1335 \\
1340 \\
1345\end{array}$ & $\begin{array}{l}23.3 \\
22.6 \\
22.6 \\
22.4 \\
21.9\end{array}$ & $\begin{array}{l}0.00 \\
0.00 \\
0.00 \\
0.00 \\
0.00\end{array}$ & $\begin{array}{l}1850 \\
1855 \\
1900 \\
1905 \\
1910\end{array}$ & $\begin{array}{l}16.6 \\
17.0 \\
17.2 \\
17.4 \\
17.6\end{array}$ & $\begin{array}{l}0.00 \\
0.00 \\
0.00 \\
0.01 \\
0.02\end{array}$ \\
\hline $\begin{array}{l}0825 \\
0830 \\
0835 \\
0840 \\
0845\end{array}$ & $\begin{array}{l}34.1 \\
34.6 \\
34.8 \\
35.3 \\
35.3\end{array}$ & $\begin{array}{l}0.01 \\
0.02 \\
0.01 \\
0.00 \\
0.01\end{array}$ & $\begin{array}{l}1350 \\
1355 \\
1400 \\
1405 \\
1410\end{array}$ & $\begin{array}{l}21.9 \\
21.5 \\
21.7 \\
21.5 \\
21.3\end{array}$ & $\begin{array}{l}0.00 \\
0.00 \\
0.00 \\
0.00 \\
0.00\end{array}$ & $\begin{array}{l}1915 \\
1920 \\
1925 \\
1930 \\
1935\end{array}$ & $\begin{array}{l}17.8 \\
18.1 \\
18.1 \\
18.3 \\
18.9\end{array}$ & $\begin{array}{l}0.02 \\
0.02 \\
0.00 \\
0.01 \\
0.00\end{array}$ \\
\hline $\begin{array}{l}0850 \\
0855 \\
0900 \\
0905 \\
0910\end{array}$ & $\begin{array}{l}35.1 \\
35.1 \\
35.3 \\
35.1 \\
34.8\end{array}$ & $\begin{array}{l}0.00 \\
0.00 \\
0.00 \\
0.00 \\
0.01\end{array}$ & $\begin{array}{l}1415 \\
1420 \\
1425 \\
1430 \\
1435\end{array}$ & $\begin{array}{l}21.0 \\
21.0 \\
21.0 \\
20.4 \\
20.4\end{array}$ & $\begin{array}{l}0.00 \\
0.00 \\
0.00 \\
0.00 \\
0.00\end{array}$ & $\begin{array}{l}1940 \\
1945 \\
1950 \\
1955 \\
2000\end{array}$ & $\begin{array}{l}19.3 \\
19.5 \\
19.8 \\
20.4 \\
20.4\end{array}$ & $\begin{array}{l}0.01 \\
0.00 \\
0.01 \\
0.00 \\
0.00\end{array}$ \\
\hline
\end{tabular}


Table 141. - - Streamflow and rainfall at station 02176380. Coosawhatchie River tributary at Allendale, February 10-13,1986--Cont inued

\begin{tabular}{|c|c|c|c|c|c|c|c|c|}
\hline $\begin{array}{l}\text { Time } \\
\text { (hours) }\end{array}$ & $\begin{array}{l}\text { Streamflow } \\
\text { (cubic feet } \\
\text { per second) }\end{array}$ & $\begin{array}{l}\text { Rain- } \\
\text { fall } \\
\text { (inches) }\end{array}$ & $\begin{array}{l}\text { Time } \\
\text { (hours) }\end{array}$ & $\begin{array}{l}\text { Streamflow } \\
\text { (cubic feet } \\
\text { per second) }\end{array}$ & $\begin{array}{l}\text { Rain- } \\
\text { fall } \\
\text { (inches) }\end{array}$ & $\begin{array}{l}\text { Time } \\
\text { (hours) }\end{array}$ & $\begin{array}{l}\text { Streamflow } \\
\text { (cubic feet } \\
\text { per second) }\end{array}$ & $\begin{array}{l}\text { Rain- } \\
\text { fall } \\
\text { (inchos) }\end{array}$ \\
\hline $\begin{array}{l}2005 \\
2010 \\
2015 \\
2020 \\
2025\end{array}$ & $\begin{array}{l}20.6 \\
20.8 \\
21.0 \\
20.8 \\
20.8\end{array}$ & $\begin{array}{l}0.00 \\
0.01 \\
0.01 \\
0.00 \\
0.00\end{array}$ & $\begin{array}{l}0125 \\
0130 \\
0135 \\
0140 \\
0145\end{array}$ & $\begin{array}{l}83.7 \\
83.4 \\
83.7 \\
83.4 \\
82.5\end{array}$ & $\begin{array}{l}0.00 \\
0.00 \\
0.00 \\
0.00 \\
0.00\end{array}$ & $\begin{array}{l}0650 \\
0655 \\
0700 \\
0705 \\
0710\end{array}$ & $\begin{array}{l}43.4 \\
43.1 \\
43.1 \\
42.6 \\
42.3\end{array}$ & $\begin{array}{l}0.00 \\
0.00 \\
0.00 \\
0.00 \\
0.00\end{array}$ \\
\hline $\begin{array}{l}2030 \\
2035 \\
2040 \\
2045 \\
2050\end{array}$ & $\begin{array}{l}20.8 \\
20.6 \\
20.8 \\
20.8 \\
20.8\end{array}$ & $\begin{array}{l}0.00 \\
0.01 \\
0.00 \\
0.01 \\
0.01\end{array}$ & $\begin{array}{l}0150 \\
0155 \\
0200 \\
0205 \\
0210\end{array}$ & $\begin{array}{l}82.5 \\
81.9 \\
80.9 \\
80.0 \\
78.7\end{array}$ & $\begin{array}{l}0.00 \\
0.00 \\
0.00 \\
0.00 \\
0.00\end{array}$ & $\begin{array}{l}0715 \\
0720 \\
0725 \\
0730 \\
0735\end{array}$ & $\begin{array}{l}42.1 \\
41.8 \\
41.3 \\
41.0 \\
40.5\end{array}$ & $\begin{array}{l}0.00 \\
0.00 \\
0.00 \\
0.00 \\
0.00\end{array}$ \\
\hline $\begin{array}{l}2055 \\
2100 \\
2105 \\
2110 \\
2115\end{array}$ & $\begin{array}{l}21.0 \\
21.0 \\
21.0 \\
21.5 \\
21.9\end{array}$ & $\begin{array}{l}0.01 \\
0.01 \\
0.02 \\
0.00 \\
0.00\end{array}$ & $\begin{array}{l}0215 \\
0220 \\
0225 \\
0230 \\
0235\end{array}$ & $\begin{array}{l}78.0 \\
77.3 \\
76.3 \\
76.3 \\
76.7\end{array}$ & $\begin{array}{l}0.00 \\
0.00 \\
0.00 \\
0.00 \\
0.00\end{array}$ & $\begin{array}{l}0740 \\
0745 \\
0750 \\
0755 \\
0800\end{array}$ & $\begin{array}{l}39.7 \\
39.7 \\
39.4 \\
38.6 \\
38.4\end{array}$ & $\begin{array}{l}0.00 \\
0.00 \\
0.00 \\
0.00 \\
0.00\end{array}$ \\
\hline $\begin{array}{l}2120 \\
2125 \\
2130 \\
2135 \\
2140\end{array}$ & $\begin{array}{l}22.2 \\
22.6 \\
23.3 \\
23.5 \\
24.0\end{array}$ & $\begin{array}{l}0.01 \\
0.00 \\
0.01 \\
0.02 \\
0.01\end{array}$ & $\begin{array}{l}0240 \\
0245 \\
0250 \\
0255 \\
0300\end{array}$ & $\begin{array}{l}75.3 \\
75.0 \\
74.0 \\
72.7 \\
71.8\end{array}$ & $\begin{array}{l}0.00 \\
0.00 \\
0.00 \\
0.00 \\
0.00\end{array}$ & $\begin{array}{l}0805 \\
0810 \\
0815 \\
0820 \\
0825\end{array}$ & $\begin{array}{l}37.9 \\
38.1 \\
37.6 \\
37.4 \\
36.8\end{array}$ & $\begin{array}{l}0.00 \\
0.00 \\
0.00 \\
0.00 \\
0.00\end{array}$ \\
\hline $\begin{array}{l}2145 \\
2150 \\
2155 \\
2200 \\
2205\end{array}$ & $\begin{array}{l}24.2 \\
24.4 \\
24.4 \\
25.1 \\
25.3\end{array}$ & $\begin{array}{l}0.01 \\
0.02 \\
0.02 \\
0.01 \\
0.00\end{array}$ & $\begin{array}{l}0305 \\
0310 \\
0315 \\
0320 \\
0325\end{array}$ & $\begin{array}{l}70.8 \\
70.5 \\
70.8 \\
69.5 \\
68.2\end{array}$ & $\begin{array}{l}0.00 \\
0.00 \\
0.00 \\
0.00 \\
0.01\end{array}$ & $\begin{array}{l}0830 \\
0835 \\
0840 \\
0845 \\
0850\end{array}$ & $\begin{array}{l}36.6 \\
36.1 \\
35.8 \\
35.8 \\
35.3\end{array}$ & $\begin{array}{l}0.00 \\
0.00 \\
0.00 \\
0.00 \\
0.00\end{array}$ \\
\hline $\begin{array}{l}2210 \\
2215 \\
2220 \\
2225 \\
2230\end{array}$ & $\begin{array}{l}25.8 \\
26.7 \\
27.4 \\
28.3 \\
29.3\end{array}$ & $\begin{array}{l}0.08 \\
0.03 \\
0.02 \\
0.02 \\
0.02\end{array}$ & $\begin{array}{l}0330 \\
0335 \\
0340 \\
0345 \\
0350\end{array}$ & $\begin{array}{l}68.2 \\
67.3 \\
67.0 \\
66.7 \\
66.4\end{array}$ & $\begin{array}{l}0.00 \\
0.00 \\
0.00 \\
0.00 \\
0.00\end{array}$ & $\begin{array}{l}0855 \\
0900 \\
0905 \\
0910 \\
0915\end{array}$ & $\begin{array}{l}35.3 \\
35.1 \\
35.1 \\
34.6 \\
34.4\end{array}$ & $\begin{array}{l}0.00 \\
0.00 \\
0.00 \\
0.00 \\
0.00\end{array}$ \\
\hline $\begin{array}{l}2235 \\
2240 \\
2245 \\
2250 \\
2255\end{array}$ & $\begin{array}{l}31.2 \\
32.7 \\
34.1 \\
35.3 \\
36.1\end{array}$ & $\begin{array}{l}0.02 \\
0.02 \\
0.02 \\
0.01 \\
0.02\end{array}$ & $\begin{array}{l}0355 \\
0400 \\
0405 \\
0410 \\
0415\end{array}$ & $\begin{array}{l}66.1 \\
66.1 \\
64.8 \\
63.6 \\
62.4\end{array}$ & $\begin{array}{l}0.00 \\
0.00 \\
0.00 \\
0.00 \\
0.00\end{array}$ & $\begin{array}{l}0920 \\
0925 \\
0930 \\
0935 \\
0940\end{array}$ & $\begin{array}{l}34.1 \\
33.9 \\
33.6 \\
33.4 \\
33.4\end{array}$ & $\begin{array}{l}0.00 \\
0.00 \\
0.00 \\
0.00 \\
0.00\end{array}$ \\
\hline $\begin{array}{l}2300 \\
2305 \\
2310 \\
2315 \\
2320\end{array}$ & $\begin{array}{l}37.4 \\
38.1 \\
38.9 \\
40.5 \\
41.0\end{array}$ & $\begin{array}{l}0.01 \\
0.02 \\
0.02 \\
0.01 \\
0.04\end{array}$ & $\begin{array}{l}0420 \\
0425 \\
0430 \\
0435 \\
0440\end{array}$ & $\begin{array}{l}62.4 \\
61.8 \\
61.2 \\
60.6 \\
59.7\end{array}$ & $\begin{array}{l}0.00 \\
0.00 \\
0.00 \\
0.00 \\
0.01\end{array}$ & $\begin{array}{l}0945 \\
0950 \\
0955 \\
1000 \\
1005\end{array}$ & $\begin{array}{l}32.7 \\
32.9 \\
32.7 \\
32.4 \\
32.2\end{array}$ & $\begin{array}{l}0.00 \\
0.00 \\
0.00 \\
0.00 \\
0.00\end{array}$ \\
\hline $\begin{array}{l}2325 \\
2330 \\
2335 \\
2340 \\
2345\end{array}$ & $\begin{array}{l}42.1 \\
42.6 \\
43.9 \\
45.8 \\
47.5\end{array}$ & $\begin{array}{l}0.04 \\
0.04 \\
0.02 \\
0.00 \\
0.02\end{array}$ & $\begin{array}{l}0445 \\
0450 \\
0455 \\
0500 \\
0505\end{array}$ & $\begin{array}{l}60.0 \\
58.8 \\
58.5 \\
57.0 \\
56.7\end{array}$ & $\begin{array}{l}0.01 \\
0.01 \\
0.00 \\
0.00 \\
0.00\end{array}$ & $\begin{array}{l}1010 \\
1015 \\
1020 \\
1025 \\
1030\end{array}$ & $\begin{array}{l}32.4 \\
32.4 \\
31.4 \\
31.7 \\
31.7\end{array}$ & $\begin{array}{l}0.00 \\
0.00 \\
0.00 \\
0.00 \\
0.00\end{array}$ \\
\hline $\begin{array}{l}2350 \\
2355 \\
0000 \\
0005\end{array}$ & $\begin{array}{c}49.2 \\
50.6 \\
\text { February } \\
52.6 \\
53.8\end{array}$ & $\begin{array}{c}0.04 \\
0.01 \\
11,1986 \\
0.01 \\
0.02\end{array}$ & $\begin{array}{l}0510 \\
0515 \\
0520 \\
0525 \\
0530\end{array}$ & $\begin{array}{l}56.4 \\
55.9 \\
56.2 \\
55.3 \\
54.7\end{array}$ & $\begin{array}{l}0.00 \\
0.00 \\
0.00 \\
0.00 \\
0.00\end{array}$ & $\begin{array}{l}1035 \\
1040 \\
1045 \\
1050 \\
1055\end{array}$ & $\begin{array}{l}31.0 \\
30.8 \\
31.0 \\
30.5 \\
30.8\end{array}$ & $\begin{array}{l}0.00 \\
0.00 \\
0.00 \\
0.00 \\
0.00\end{array}$ \\
\hline $\begin{array}{l}0010 \\
0015 \\
0020 \\
0025 \\
0030\end{array}$ & $\begin{array}{l}54.4 \\
55.9 \\
56.7 \\
57.9 \\
61.8\end{array}$ & $\begin{array}{l}0.06 \\
0.17 \\
0.14 \\
0.07 \\
0.02\end{array}$ & $\begin{array}{l}0535 \\
0540 \\
0545 \\
0550 \\
0555\end{array}$ & $\begin{array}{l}54.7 \\
53.8 \\
52.3 \\
51.8 \\
50.9\end{array}$ & $\begin{array}{l}0.00 \\
0.00 \\
0.00 \\
0.01 \\
0.00\end{array}$ & $\begin{array}{l}1100 \\
1105 \\
1110 \\
1115 \\
1120\end{array}$ & $\begin{array}{l}30.8 \\
29.8 \\
30.0 \\
29.5 \\
29.0\end{array}$ & $\begin{array}{l}0.00 \\
0.00 \\
0.00 \\
0.00 \\
0.00\end{array}$ \\
\hline $\begin{array}{l}0035 \\
0040 \\
0045 \\
0050 \\
0055\end{array}$ & $\begin{array}{l}67.6 \\
73.0 \\
77.7 \\
80.6 \\
80.9\end{array}$ & $\begin{array}{l}0.01 \\
0.00 \\
0.00 \\
0.00 \\
0.00\end{array}$ & $\begin{array}{l}0600 \\
0605 \\
0610 \\
0615 \\
0620\end{array}$ & $\begin{array}{l}50.3 \\
49.2 \\
48.6 \\
48.0 \\
47.2\end{array}$ & $\begin{array}{l}0.00 \\
0.00 \\
0.00 \\
0.00 \\
0.00\end{array}$ & $\begin{array}{l}1125 \\
1130 \\
1135 \\
1140 \\
1145\end{array}$ & $\begin{array}{l}29.0 \\
29.0 \\
28.8 \\
28.3 \\
27.9\end{array}$ & $\begin{array}{l}0.00 \\
0.00 \\
0.00 \\
0.00 \\
0.00\end{array}$ \\
\hline $\begin{array}{l}0100 \\
0105 \\
0110 \\
0115 \\
0120\end{array}$ & $\begin{array}{l}82.8 \\
84.1 \\
83.4 \\
84.7 \\
84.1\end{array}$ & $\begin{array}{l}0.00 \\
0.00 \\
0.00 \\
0.01 \\
0.00\end{array}$ & $\begin{array}{l}0625 \\
0630 \\
0635 \\
0640 \\
0645\end{array}$ & $\begin{array}{l}46.1 \\
46.1 \\
45.5 \\
45.0 \\
44.5\end{array}$ & $\begin{array}{l}0.00 \\
0.00 \\
0.00 \\
0.00 \\
0.00\end{array}$ & $\begin{array}{l}1150 \\
1155 \\
1200 \\
1205 \\
1210\end{array}$ & $\begin{array}{l}28 \cdot 1 \\
27 \cdot 9 \\
27 \cdot 6 \\
27 \cdot 9 \\
27 \cdot 4\end{array}$ & $\begin{array}{l}0.00 \\
0.00 \\
0.00 \\
0.00 \\
0.00\end{array}$ \\
\hline
\end{tabular}


Table 141. - Streamflow and rainfal1 at station 02176380 , Coosawhatchie River tributary at Allendale, February $10-13,1986--$ Continued

\begin{tabular}{|c|c|c|c|c|c|c|c|c|}
\hline $\begin{array}{l}\text { Time } \\
\text { (hours) }\end{array}$ & $\begin{array}{l}\text { Streamflow } \\
\text { (cubic feet } \\
\text { per second) }\end{array}$ & $\begin{array}{l}\text { Rain- } \\
\text { fall } \\
\text { (inches) }\end{array}$ & $\begin{array}{l}\text { Time } \\
\text { (hours) }\end{array}$ & $\begin{array}{l}\text { Streamflow } \\
\text { (cubic feet } \\
\text { per second) }\end{array}$ & $\begin{array}{l}\text { Rain- } \\
\text { fall } \\
\text { (inches) }\end{array}$ & $\begin{array}{l}\text { Time } \\
\text { (hours) }\end{array}$ & $\begin{array}{l}\text { Streamflow } \\
\text { (cubic feet } \\
\text { per second) }\end{array}$ & $\begin{array}{l}\text { Fain- } \\
\text { fall } \\
\text { (inches) }\end{array}$ \\
\hline $\begin{array}{l}1215 \\
1220 \\
1225 \\
1230 \\
1235\end{array}$ & $\begin{array}{l}27.4 \\
26.7 \\
26.9 \\
26.7 \\
26.7\end{array}$ & $\begin{array}{l}0.00 \\
0.00 \\
0.00 \\
0.00 \\
0.00\end{array}$ & $\begin{array}{l}1740 \\
1745 \\
1750 \\
1755 \\
1800\end{array}$ & $\begin{array}{l}18.7 \\
18.3 \\
18.3 \\
18.1 \\
18.3\end{array}$ & $\begin{array}{l}0.00 \\
0.00 \\
0.00 \\
0.00 \\
0.00\end{array}$ & $\begin{array}{l}2305 \\
2310 \\
2315 \\
2320 \\
2325\end{array}$ & $\begin{array}{l}14.7 \\
14.7 \\
14.7 \\
14.5 \\
14.5\end{array}$ & $\begin{array}{l}0.00 \\
0.00 \\
0.00 \\
0.00 \\
0.00\end{array}$ \\
\hline $\begin{array}{l}1240 \\
1245 \\
1250 \\
1255 \\
1300\end{array}$ & $\begin{array}{l}26.5 \\
26.5 \\
26.2 \\
26.0 \\
25.8\end{array}$ & $\begin{array}{l}0.00 \\
0.00 \\
0.00 \\
0.00 \\
0.00\end{array}$ & $\begin{array}{l}1805 \\
1810 \\
1815 \\
1820 \\
1825\end{array}$ & $\begin{array}{l}18.1 \\
18.1 \\
18.1 \\
18.3 \\
18.5\end{array}$ & $\begin{array}{l}0.00 \\
0.00 \\
0.00 \\
0.00 \\
0.00\end{array}$ & $\begin{array}{l}2330 \\
2335 \\
2340 \\
2345 \\
2350\end{array}$ & $\begin{array}{l}14.5 \\
14.4 \\
14.4 \\
14.4 \\
14.2\end{array}$ & $\begin{array}{l}0.00 \\
0.00 \\
0.00 \\
0.00 \\
0.00\end{array}$ \\
\hline $\begin{array}{l}1305 \\
1310 \\
1315 \\
1320 \\
1325\end{array}$ & $\begin{array}{l}25.1 \\
25.1 \\
25.1 \\
24.9 \\
24.9\end{array}$ & $\begin{array}{l}0.00 \\
0.00 \\
0.00 \\
0.00 \\
0.00\end{array}$ & $\begin{array}{l}1830 \\
1835 \\
1840 \\
1845 \\
1850\end{array}$ & $\begin{array}{l}18.9 \\
18.9 \\
18.5 \\
18.9 \\
18.9\end{array}$ & $\begin{array}{l}0.00 \\
0.00 \\
0.00 \\
0.00 \\
0.00\end{array}$ & $\begin{array}{l}2355 \\
\text { February } \\
0000 \\
0005 \\
0010\end{array}$ & $12, \begin{array}{l}14.0 \\
1986 \\
14.2 \\
14.0 \\
13.8\end{array}$ & $\begin{array}{l}0.00 \\
c .00 \\
c .00 \\
0.00\end{array}$ \\
\hline $\begin{array}{l}1330 \\
1335 \\
1340 \\
1345 \\
1350\end{array}$ & $\begin{array}{l}24.9 \\
24.7 \\
24.4 \\
24.2 \\
23.8\end{array}$ & $\begin{array}{l}0.00 \\
0.00 \\
0.00 \\
0.00 \\
0.00\end{array}$ & $\begin{array}{l}1855 \\
1900 \\
1905 \\
1910 \\
1915\end{array}$ & $\begin{array}{l}18.7 \\
18.7 \\
18.5 \\
18.3 \\
18.3\end{array}$ & $\begin{array}{l}0.00 \\
0.00 \\
0.00 \\
0.00 \\
0.00\end{array}$ & $\begin{array}{l}0015 \\
0020 \\
0025 \\
0030 \\
0035\end{array}$ & $\begin{array}{l}14.0 \\
14.0 \\
14.0 \\
13.8 \\
13.8\end{array}$ & $\begin{array}{l}C .00 \\
C .00 \\
C .00 \\
C .00 \\
C .00\end{array}$ \\
\hline $\begin{array}{l}1355 \\
1400 \\
1405 \\
1410 \\
1415\end{array}$ & $\begin{array}{l}23.8 \\
24.0 \\
24.0 \\
23.5 \\
23.3\end{array}$ & $\begin{array}{l}0.00 \\
0.00 \\
0.00 \\
0.00 \\
0.00\end{array}$ & $\begin{array}{l}1920 \\
1925 \\
1930 \\
1935 \\
1940\end{array}$ & $\begin{array}{l}18.3 \\
18.1 \\
18.1 \\
17.8 \\
17.8\end{array}$ & $\begin{array}{l}0.00 \\
0.00 \\
0.00 \\
0.00 \\
0.00\end{array}$ & $\begin{array}{l}0040 \\
0045 \\
0050 \\
0055 \\
0100\end{array}$ & $\begin{array}{l}14.0 \\
13.8 \\
13.8 \\
13.8 \\
13.8\end{array}$ & $\begin{array}{l}C .00 \\
C .00 \\
c .00 \\
C .00 \\
c .00\end{array}$ \\
\hline $\begin{array}{l}1420 \\
1425 \\
1430 \\
1435 \\
1440\end{array}$ & $\begin{array}{l}23.3 \\
23.1 \\
23.1 \\
22.8 \\
22.6\end{array}$ & $\begin{array}{l}0.00 \\
0.00 \\
0.00 \\
0.00 \\
0.00\end{array}$ & $\begin{array}{l}1945 \\
1950 \\
1955 \\
2000 \\
2005\end{array}$ & $\begin{array}{l}18.1 \\
18.1 \\
17.8 \\
17.6 \\
17.4\end{array}$ & $\begin{array}{l}0.00 \\
0.00 \\
0.00 \\
0.00 \\
0.00\end{array}$ & $\begin{array}{l}0105 \\
0110 \\
0115 \\
0120 \\
0125\end{array}$ & $\begin{array}{l}13.6 \\
13.6 \\
13.8 \\
13.6 \\
13.2\end{array}$ & $\begin{array}{l}C .00 \\
C .00 \\
C .00 \\
C .00 \\
C .00\end{array}$ \\
\hline $\begin{array}{l}1445 \\
1450 \\
1455 \\
1500 \\
1505\end{array}$ & $\begin{array}{l}22.6 \\
22.2 \\
22.4 \\
22.2 \\
21.9\end{array}$ & $\begin{array}{l}0.00 \\
0.00 \\
0.00 \\
0.00 \\
0.00\end{array}$ & $\begin{array}{l}2010 \\
2015 \\
2020 \\
2025 \\
2030\end{array}$ & $\begin{array}{l}17.4 \\
17.2 \\
17.2 \\
17.2 \\
17.2\end{array}$ & $\begin{array}{l}0.00 \\
0.00 \\
0.00 \\
0.00 \\
0.00\end{array}$ & $\begin{array}{l}0130 \\
0135 \\
0140 \\
0145 \\
0150\end{array}$ & $\begin{array}{l}13.4 \\
13.4 \\
13.4 \\
13.2 \\
13.2\end{array}$ & $\begin{array}{l}C .00 \\
C .00 \\
0.00 \\
0.00 \\
0.00\end{array}$ \\
\hline $\begin{array}{l}1510 \\
1515 \\
1520 \\
1525 \\
1530\end{array}$ & $\begin{array}{l}21.9 \\
21.7 \\
21.5 \\
21.7 \\
21.3\end{array}$ & $\begin{array}{l}0.00 \\
0.00 \\
0.00 \\
0.00 \\
0.00\end{array}$ & $\begin{array}{l}2035 \\
2040 \\
2045 \\
2050 \\
2055\end{array}$ & $\begin{array}{l}17.0 \\
17.0 \\
16.8 \\
16.8 \\
16.6\end{array}$ & $\begin{array}{l}0.00 \\
0.00 \\
0.00 \\
0.00 \\
0.00\end{array}$ & $\begin{array}{l}0155 \\
0200 \\
0205 \\
0210 \\
0215\end{array}$ & $\begin{array}{l}13.2 \\
13.2 \\
13.0 \\
13.2 \\
13.0\end{array}$ & $\begin{array}{l}0.00 \\
0.00 \\
0.00 \\
0.00 \\
0.00\end{array}$ \\
\hline $\begin{array}{l}1535 \\
1540 \\
1545 \\
1550 \\
1555\end{array}$ & $\begin{array}{l}21.3 \\
21.0 \\
20.8 \\
20.8 \\
20.4\end{array}$ & $\begin{array}{l}0.00 \\
0.00 \\
0.00 \\
0.00 \\
0.00\end{array}$ & $\begin{array}{l}2100 \\
2105 \\
2110 \\
2115 \\
2120\end{array}$ & $\begin{array}{l}16.6 \\
16.6 \\
16.3 \\
16.3 \\
16.3\end{array}$ & $\begin{array}{l}0.00 \\
0.00 \\
0.00 \\
0.00 \\
0.00\end{array}$ & $\begin{array}{l}0220 \\
0225 \\
0230 \\
0235 \\
0240\end{array}$ & $\begin{array}{l}12.9 \\
12.7 \\
12.7 \\
12.7 \\
12.7\end{array}$ & $\begin{array}{l}0.00 \\
0.00 \\
0.00 \\
0.00 \\
0.00\end{array}$ \\
\hline $\begin{array}{l}1600 \\
1605 \\
1610 \\
1615 \\
1620\end{array}$ & $\begin{array}{l}20.8 \\
20.4 \\
20.2 \\
20.4 \\
20.0\end{array}$ & $\begin{array}{l}0.00 \\
0.00 \\
0.00 \\
0.00 \\
0.00\end{array}$ & $\begin{array}{l}2125 \\
2130 \\
2135 \\
2140 \\
2145\end{array}$ & $\begin{array}{l}15.9 \\
15.9 \\
15.9 \\
15.9 \\
15.7\end{array}$ & $\begin{array}{l}0.00 \\
0.00 \\
0.00 \\
0.00 \\
0.00\end{array}$ & $\begin{array}{l}0245 \\
0250 \\
0255 \\
0300 \\
0305\end{array}$ & $\begin{array}{l}12.5 \\
12.7 \\
12.7 \\
12.7 \\
12.7\end{array}$ & $\begin{array}{l}0.00 \\
0.00 \\
0.00 \\
0.00 \\
0.00\end{array}$ \\
\hline $\begin{array}{l}1625 \\
1630 \\
1635 \\
1640 \\
1645\end{array}$ & $\begin{array}{l}20.0 \\
19.8 \\
19.5 \\
19.8 \\
19.5\end{array}$ & $\begin{array}{l}0.00 \\
0.00 \\
0.00 \\
0.00 \\
0.00\end{array}$ & $\begin{array}{l}2150 \\
2155 \\
2200 \\
2205 \\
2210\end{array}$ & $\begin{array}{l}15.9 \\
15.7 \\
15.7 \\
15.3 \\
15.3\end{array}$ & $\begin{array}{l}0.00 \\
0.00 \\
0.00 \\
0.00 \\
0.00\end{array}$ & $\begin{array}{l}0310 \\
0315 \\
0320 \\
0325 \\
0330\end{array}$ & $\begin{array}{l}12.7 \\
12.5 \\
12.5 \\
12.5 \\
12.5\end{array}$ & $\begin{array}{l}0.00 \\
0.00 \\
0.00 \\
0.00 \\
0.00\end{array}$ \\
\hline $\begin{array}{l}1650 \\
1655 \\
1700 \\
1705 \\
170\end{array}$ & $\begin{array}{l}19.5 \\
19.5 \\
18.9 \\
18.9 \\
193\end{array}$ & $\begin{array}{l}0.00 \\
0.00 \\
0.00 \\
0.00 \\
0.00\end{array}$ & $\begin{array}{l}2215 \\
2220 \\
2225 \\
2230 \\
2235\end{array}$ & $\begin{array}{l}15.5 \\
15.3 \\
15.3 \\
15.3 \\
15.1\end{array}$ & $\begin{array}{l}0.00 \\
0.00 \\
0.00 \\
0.00 \\
0.00\end{array}$ & $\begin{array}{l}0335 \\
0340 \\
0345 \\
0350 \\
0355\end{array}$ & $\begin{array}{l}12.5 \\
12.5 \\
12.3 \\
12.3 \\
12.1\end{array}$ & $\begin{array}{l}0.00 \\
0.00 \\
0.00 \\
0.00 \\
0.00\end{array}$ \\
\hline $\begin{array}{l}1715 \\
1720 \\
1725 \\
1730 \\
1735\end{array}$ & $\begin{array}{l}18.9 \\
18.9 \\
18.9 \\
18.3 \\
18.7\end{array}$ & $\begin{array}{l}0.00 \\
0.00 \\
0.00 \\
0.00 \\
0.00\end{array}$ & $\begin{array}{l}2240 \\
2245 \\
2250 \\
2255 \\
2300\end{array}$ & $\begin{array}{l}15.1 \\
14.9 \\
14.9 \\
14.9 \\
14.9\end{array}$ & $\begin{array}{l}0.00 \\
0.00 \\
0.00 \\
0.00 \\
0.00\end{array}$ & $\begin{array}{l}0400 \\
0405 \\
0410 \\
0415 \\
0420\end{array}$ & $\begin{array}{l}12.0 \\
12.1 \\
12.1 \\
12.1 \\
12.1\end{array}$ & $\begin{array}{l}0.00 \\
0.00 \\
0.00 \\
0.00 \\
0.00\end{array}$ \\
\hline
\end{tabular}


Table 141. - Streamflow and rainfall at station 02176380 , Coosawhatchie River tributary at Allendale, February $10-13,1986--$ Continued

\begin{tabular}{|c|c|c|c|c|c|c|c|c|}
\hline $\begin{array}{l}\text { Time } \\
\text { (hours) }\end{array}$ & $\begin{array}{l}\text { Streamflow } \\
\text { (cubic feet } \\
\text { per second) }\end{array}$ & $\begin{array}{l}\text { Rain- } \\
\text { fall } \\
\text { (inches) }\end{array}$ & $\begin{array}{l}\text { Time } \\
\text { (hours) }\end{array}$ & $\begin{array}{l}\text { Streamflow } \\
\text { (cubic feet } \\
\text { per second) }\end{array}$ & $\begin{array}{l}\text { Rain- } \\
\text { fall } \\
\text { (inches) }\end{array}$ & $\begin{array}{l}\text { Time } \\
\text { (hours) }\end{array}$ & $\begin{array}{l}\text { Streamflow } \\
\text { (cubic feet } \\
\text { per second) }\end{array}$ & $\begin{array}{l}\text { Rain- } \\
\text { fall } \\
\text { (inches) }\end{array}$ \\
\hline $\begin{array}{l}0425 \\
0430 \\
0435 \\
0440 \\
0445\end{array}$ & $\begin{array}{l}12.1 \\
12.1 \\
12.0 \\
12.0 \\
12.0\end{array}$ & $\begin{array}{l}0.00 \\
0.00 \\
0.00 \\
0.00 \\
0.00\end{array}$ & $\begin{array}{l}0950 \\
0955 \\
1000 \\
1005 \\
1010\end{array}$ & $\begin{array}{l}10.6 \\
10.4 \\
10.6 \\
10.6 \\
10.6\end{array}$ & $\begin{array}{l}0.00 \\
0.00 \\
0.00 \\
0.00 \\
0.00\end{array}$ & $\begin{array}{l}1515 \\
1520 \\
1525 \\
1530 \\
1535\end{array}$ & $\begin{array}{l}9.3 \\
9.3 \\
9.3 \\
9.3 \\
9.3\end{array}$ & $\begin{array}{l}0.00 \\
0.00 \\
0.00 \\
0.00 \\
0.00\end{array}$ \\
\hline $\begin{array}{l}0450 \\
0455 \\
0500 \\
0505 \\
0510\end{array}$ & $\begin{array}{l}12.0 \\
11.8 \\
12.0 \\
11.8 \\
12.0\end{array}$ & $\begin{array}{l}0.00 \\
0.00 \\
0.00 \\
0.00 \\
0.00\end{array}$ & $\begin{array}{l}1015 \\
1020 \\
1025 \\
1030 \\
1035\end{array}$ & $\begin{array}{l}10.4 \\
10.4 \\
10.2 \\
10.4 \\
10.2\end{array}$ & $\begin{array}{l}0.00 \\
0.00 \\
0.00 \\
0.00 \\
0.00\end{array}$ & $\begin{array}{l}1540 \\
1545 \\
1550 \\
1555 \\
1600\end{array}$ & $\begin{array}{l}9.1 \\
9.1 \\
9.1 \\
9.1 \\
9.3\end{array}$ & $\begin{array}{l}0.00 \\
0.00 \\
0.00 \\
0.00 \\
0.00\end{array}$ \\
\hline $\begin{array}{l}0515 \\
0520 \\
0525 \\
0530 \\
0535\end{array}$ & $\begin{array}{l}11.8 \\
11.8 \\
11.6 \\
11.8 \\
11.6\end{array}$ & $\begin{array}{l}0.00 \\
0.00 \\
0.00 \\
0.00 \\
0.00\end{array}$ & $\begin{array}{l}1040 \\
1045 \\
1050 \\
1055 \\
1100\end{array}$ & $\begin{array}{l}10.1 \\
10.1 \\
10.1 \\
10.1 \\
10.1\end{array}$ & $\begin{array}{l}0.00 \\
0.00 \\
0.00 \\
0.00 \\
0.00\end{array}$ & $\begin{array}{l}1605 \\
1610 \\
1615 \\
1620 \\
1625\end{array}$ & $\begin{array}{l}9.1 \\
9.1 \\
9.3 \\
9.1 \\
9.1\end{array}$ & $\begin{array}{l}0.00 \\
0.00 \\
0.00 \\
0.00 \\
0.00\end{array}$ \\
\hline $\begin{array}{l}0540 \\
0545 \\
0550 \\
0555 \\
0600\end{array}$ & $\begin{array}{l}11.6 \\
11.6 \\
11.6 \\
11.6 \\
11.6\end{array}$ & $\begin{array}{l}0.00 \\
0.00 \\
0.00 \\
0.00 \\
0.00\end{array}$ & $\begin{array}{l}1105 \\
1110 \\
1115 \\
1120 \\
1125\end{array}$ & $\begin{array}{l}10.2 \\
10.2 \\
10.1 \\
10.1 \\
10.1\end{array}$ & $\begin{array}{l}0.00 \\
0.00 \\
0.00 \\
0.00 \\
0.00\end{array}$ & $\begin{array}{l}1630 \\
1635 \\
1640 \\
1645 \\
1650\end{array}$ & $\begin{array}{l}9.1 \\
9.1 \\
9.1 \\
9.0 \\
9.1\end{array}$ & $\begin{array}{l}0.00 \\
0.00 \\
0.00 \\
0.00 \\
0.00\end{array}$ \\
\hline $\begin{array}{l}0605 \\
0610 \\
0615 \\
0620 \\
0625\end{array}$ & $\begin{array}{l}11.4 \\
11.4 \\
11.3 \\
11.3 \\
11.3\end{array}$ & $\begin{array}{l}0.00 \\
0.00 \\
0.00 \\
0.00 \\
0.00\end{array}$ & $\begin{array}{l}1130 \\
1135 \\
1140 \\
1145 \\
1150\end{array}$ & $\begin{array}{l}10.1 \\
10.1 \\
10.1 \\
10.1 \\
10.1\end{array}$ & $\begin{array}{l}0.00 \\
0.00 \\
0.00 \\
0.00 \\
0.00\end{array}$ & $\begin{array}{l}1655 \\
1700 \\
1705 \\
1710 \\
1715\end{array}$ & $\begin{array}{l}9.0 \\
9.0 \\
9.0 \\
9.0 \\
9.0\end{array}$ & $\begin{array}{l}0.00 \\
0.00 \\
0.00 \\
0.00 \\
0.00\end{array}$ \\
\hline $\begin{array}{l}0630 \\
0635 \\
0640 \\
0645 \\
0650\end{array}$ & $\begin{array}{l}11.3 \\
11.3 \\
11.3 \\
11.3 \\
11.3\end{array}$ & $\begin{array}{l}0.00 \\
0.00 \\
0.00 \\
0.00 \\
0.00\end{array}$ & $\begin{array}{l}1155 \\
1200 \\
1205 \\
1210 \\
1215\end{array}$ & $\begin{array}{l}9.9 \\
9.9 \\
9.8 \\
9.8 \\
9.8\end{array}$ & $\begin{array}{l}0.00 \\
0.00 \\
0.00 \\
0.00 \\
0.00\end{array}$ & $\begin{array}{l}1720 \\
1725 \\
1730 \\
1735 \\
1740\end{array}$ & $\begin{array}{l}9.0 \\
9.0 \\
9.0 \\
9.0 \\
9.0\end{array}$ & $\begin{array}{l}0.00 \\
0.00 \\
0.00 \\
0.00 \\
0.00\end{array}$ \\
\hline $\begin{array}{l}0655 \\
0700 \\
0705 \\
0710 \\
0715\end{array}$ & $\begin{array}{l}11.3 \\
11.3 \\
11.1 \\
11.1 \\
11.3\end{array}$ & $\begin{array}{l}0.00 \\
0.00 \\
0.00 \\
0.00 \\
0.00\end{array}$ & $\begin{array}{l}1220 \\
1225 \\
1230 \\
1235 \\
1240\end{array}$ & $\begin{array}{l}9.8 \\
9.8 \\
9.8 \\
9.9 \\
9.8\end{array}$ & $\begin{array}{l}0.00 \\
0.00 \\
0.00 \\
0.00 \\
0.00\end{array}$ & $\begin{array}{l}1745 \\
1750 \\
1755 \\
1800 \\
1805\end{array}$ & $\begin{array}{l}9.0 \\
9.0 \\
9.0 \\
9.0 \\
9.0\end{array}$ & $\begin{array}{l}0.00 \\
0.00 \\
0.00 \\
0.00 \\
0.00\end{array}$ \\
\hline $\begin{array}{l}0720 \\
0725 \\
0730 \\
0735 \\
0740\end{array}$ & $\begin{array}{l}10.9 \\
11.1 \\
11.3 \\
10.7 \\
10.9\end{array}$ & $\begin{array}{l}0.00 \\
0.00 \\
0.00 \\
0.00 \\
0.00\end{array}$ & $\begin{array}{l}1245 \\
1250 \\
1255 \\
1300 \\
1305\end{array}$ & $\begin{array}{l}9.8 \\
9.8 \\
9.8 \\
9.6 \\
9.6\end{array}$ & $\begin{array}{l}0.00 \\
0.00 \\
0.00 \\
0.00 \\
0.00\end{array}$ & $\begin{array}{l}1810 \\
1815 \\
1820 \\
1825 \\
1830\end{array}$ & $\begin{array}{l}9.0 \\
9.0 \\
9.0 \\
9.0 \\
9.0\end{array}$ & $\begin{array}{l}0.00 \\
0.00 \\
0.00 \\
0.00 \\
0.00\end{array}$ \\
\hline $\begin{array}{l}0745 \\
0750 \\
0755 \\
0800 \\
0805\end{array}$ & $\begin{array}{l}10.9 \\
10.9 \\
10.9 \\
10.9 \\
10.9\end{array}$ & $\begin{array}{l}0.00 \\
0.00 \\
0.00 \\
0.00 \\
0.00\end{array}$ & $\begin{array}{l}1310 \\
1315 \\
1320 \\
1325 \\
1330\end{array}$ & $\begin{array}{l}9.6 \\
9.6 \\
9.6 \\
9.6 \\
9.6\end{array}$ & $\begin{array}{l}0.00 \\
0.00 \\
0.00 \\
0.00 \\
0.00\end{array}$ & $\begin{array}{l}1835 \\
1840 \\
1845 \\
1850 \\
1855\end{array}$ & $\begin{array}{l}8.8 \\
8.8 \\
8.8 \\
8.8 \\
8.8\end{array}$ & $\begin{array}{l}0.00 \\
0.00 \\
0.00 \\
0.00 \\
0.00\end{array}$ \\
\hline $\begin{array}{l}0810 \\
0815 \\
0820 \\
0825 \\
0830\end{array}$ & $\begin{array}{l}10.7 \\
10.9 \\
10.9 \\
10.7 \\
10.7\end{array}$ & $\begin{array}{l}0.00 \\
0.00 \\
0.00 \\
0.00 \\
0.00\end{array}$ & $\begin{array}{l}1335 \\
1340 \\
1345 \\
1350 \\
1355\end{array}$ & $\begin{array}{l}9.6 \\
9.6 \\
9.6 \\
9.6 \\
9.6\end{array}$ & $\begin{array}{l}0.00 \\
0.00 \\
0.00 \\
0.00 \\
0.00\end{array}$ & $\begin{array}{l}1900 \\
1905 \\
1910 \\
1915 \\
1920\end{array}$ & $\begin{array}{l}8.8 \\
8.8 \\
8.8 \\
8.8 \\
8.8\end{array}$ & $\begin{array}{l}0.00 \\
0.00 \\
0.00 \\
0.00 \\
0.00\end{array}$ \\
\hline $\begin{array}{l}0835 \\
0840 \\
0845 \\
0850 \\
0855\end{array}$ & $\begin{array}{l}10.7 \\
10.7 \\
10.7 \\
10.7 \\
10.7\end{array}$ & $\begin{array}{l}0.00 \\
0.00 \\
0.00 \\
0.00 \\
0.00\end{array}$ & $\begin{array}{l}1400 \\
1405 \\
1410 \\
1415 \\
1420\end{array}$ & $\begin{array}{l}9.6 \\
9.6 \\
9.6 \\
9.5 \\
9.5\end{array}$ & $\begin{array}{l}0.00 \\
0.00 \\
0.00 \\
0.00 \\
0.00\end{array}$ & $\begin{array}{l}1925 \\
1930 \\
1935 \\
1940 \\
1945\end{array}$ & $\begin{array}{l}8.8 \\
8.7 \\
8.7 \\
8.7 \\
8.7\end{array}$ & $\begin{array}{l}0.00 \\
0.00 \\
0.00 \\
0.00 \\
0.00\end{array}$ \\
\hline $\begin{array}{l}0900 \\
0905 \\
0910 \\
0915 \\
0920\end{array}$ & $\begin{array}{l}10.7 \\
10.7 \\
10.7 \\
10.6 \\
10.7\end{array}$ & $\begin{array}{l}0.00 \\
0.00 \\
0.00 \\
0.00 \\
0.00\end{array}$ & $\begin{array}{l}1425 \\
1430 \\
1435 \\
1440 \\
1445\end{array}$ & $\begin{array}{l}9.5 \\
9.5 \\
9.5 \\
9.5 \\
9.5\end{array}$ & $\begin{array}{l}0.00 \\
0.00 \\
0.00 \\
0.00 \\
0.00\end{array}$ & $\begin{array}{l}1950 \\
1955 \\
2000 \\
2005 \\
2010\end{array}$ & $\begin{array}{l}8.5 \\
8.5 \\
8.5 \\
8.5 \\
8.5\end{array}$ & $\begin{array}{l}0.00 \\
0.00 \\
0.00 \\
0.00 \\
0.00\end{array}$ \\
\hline $\begin{array}{l}0925 \\
0930 \\
0935 \\
0940 \\
0945\end{array}$ & $\begin{array}{l}10.6 \\
10.4 \\
10.6 \\
10.6 \\
10.6\end{array}$ & $\begin{array}{l}0.00 \\
0.00 \\
0.00 \\
0.00 \\
0.00\end{array}$ & $\begin{array}{l}1450 \\
1455 \\
1500 \\
1505 \\
1510\end{array}$ & $\begin{array}{l}9.5 \\
9.5 \\
9.5 \\
9.5 \\
9.5\end{array}$ & $\begin{array}{l}0.00 \\
0.00 \\
0.00 \\
0.00 \\
0.00\end{array}$ & $\begin{array}{l}2015 \\
2020 \\
2025 \\
2030 \\
2035\end{array}$ & $\begin{array}{l}8.5 \\
8.5 \\
8.5 \\
8.5 \\
8.5\end{array}$ & $\begin{array}{l}0.00 \\
0.00 \\
0.00 \\
0.00 \\
0.00\end{array}$ \\
\hline
\end{tabular}


Table 141. - Streamflow and rainfall at station 02176380 , Coosawhatchie River tributary at Allendale, February 10-13,1986--Cont inued

\begin{tabular}{|c|c|c|c|c|c|c|c|c|c|}
\hline $\begin{array}{l}\text { Time } \\
\text { (hours) }\end{array}$ & $\begin{array}{l}\text { Streamflow } \\
\text { (cubic feet } \\
\text { per second) }\end{array}$ & $\begin{array}{l}\text { Rain- } \\
\text { fall } \\
\text { (inches) }\end{array}$ & $\begin{array}{l}\text { Time } \\
\text { (hours) }\end{array}$ & $\begin{array}{l}\text { Streamflow } \\
\text { (cubic feet } \\
\text { per second) }\end{array}$ & $\begin{array}{l}\text { Rain- } \\
\text { fall } \\
\text { (inches) }\end{array}$ & $\begin{array}{l}\text { Time } \\
\text { (hours) }\end{array}$ & $\begin{array}{l}\text { Str } \\
\text { scuk } \\
\text { per }\end{array}$ & $\begin{array}{l}\text { reamflow } \\
\text { bic feet } \\
\text { second) }\end{array}$ & $\begin{array}{l}\text { Rain- } \\
\text { fall } \\
\text { (incres) }\end{array}$ \\
\hline $\begin{array}{l}2040 \\
2045 \\
2050 \\
2055 \\
2100\end{array}$ & $\begin{array}{l}8.5 \\
8.5 \\
8.5 \\
8.5 \\
8.5\end{array}$ & $\begin{array}{l}0.00 \\
0.00 \\
0.00 \\
0.00 \\
0.00\end{array}$ & $\begin{array}{l}2155 \\
2200 \\
2205 \\
2210 \\
2215\end{array}$ & $\begin{array}{l}8.2 \\
8.2 \\
8.2 \\
8.2 \\
8.2\end{array}$ & $\begin{array}{l}0.00 \\
0.00 \\
0.00 \\
0.00 \\
0.00\end{array}$ & $\begin{array}{l}2310 \\
2315 \\
2320 \\
2325 \\
2330\end{array}$ & & $\begin{array}{l}8.1 \\
8.1 \\
8.1 \\
7.9 \\
7.9\end{array}$ & $\begin{array}{l}0.0 C \\
0.0 C \\
0.0 C \\
0.00 \\
0.00\end{array}$ \\
\hline $\begin{array}{l}2105 \\
2110 \\
2115 \\
2120 \\
2125\end{array}$ & $\begin{array}{l}8.5 \\
8.5 \\
8.4 \\
8.4 \\
8.4\end{array}$ & $\begin{array}{l}0.00 \\
0.00 \\
0.00 \\
0.00 \\
0.00\end{array}$ & $\begin{array}{l}2220 \\
2225 \\
2230 \\
2235 \\
2240\end{array}$ & $\begin{array}{l}8.2 \\
8.2 \\
8.2 \\
8.2 \\
8.2\end{array}$ & $\begin{array}{l}0.00 \\
0.00 \\
0.00 \\
0.00 \\
0.00\end{array}$ & $\begin{array}{l}2335 \\
2340 \\
2345 \\
2350 \\
2355\end{array}$ & & $\begin{array}{l}7.9 \\
7.9 \\
7.9 \\
7.9 \\
7.9\end{array}$ & $\begin{array}{l}0.00 \\
0.00 \\
0.00 \\
0.00 \\
0.00\end{array}$ \\
\hline $\begin{array}{l}2130 \\
2135 \\
2140 \\
2145 \\
2150\end{array}$ & $\begin{array}{l}8.2 \\
8.4 \\
8.4 \\
8.2 \\
8.2\end{array}$ & $\begin{array}{l}0.00 \\
0.00 \\
0.00 \\
0.00 \\
0.00\end{array}$ & $\begin{array}{l}2245 \\
2250 \\
2255 \\
2300 \\
2305\end{array}$ & $\begin{array}{l}8.1 \\
8.1 \\
8.1 \\
8.1 \\
8.1\end{array}$ & $\begin{array}{l}0.00 \\
0.00 \\
0.00 \\
0.00 \\
0.00\end{array}$ & $\begin{array}{c}\text { February } \\
0000\end{array}$ & 13 & $\begin{array}{r}1986 \\
7.9\end{array}$ & 0.00 \\
\hline
\end{tabular}



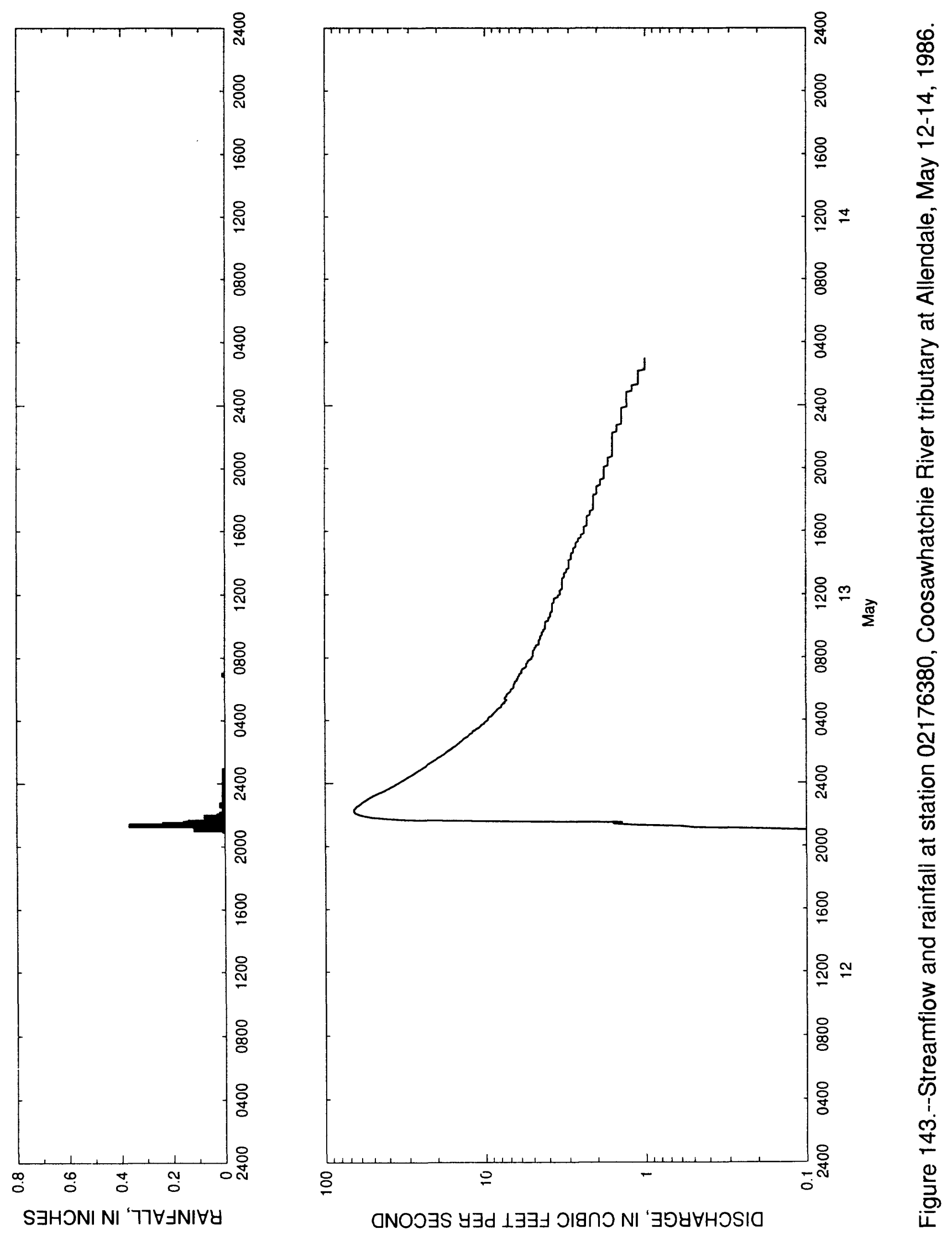

May $12-14,1986$

\begin{tabular}{|c|c|c|c|c|c|c|c|c|c|}
\hline $\begin{array}{l}\text { Time } \\
\text { (hours) }\end{array}$ & $\begin{array}{l}\text { Str } \\
\text { (cub } \\
\text { per }\end{array}$ & $\begin{array}{l}\text { reamflow } \\
\text { bic feet } \\
\text { second) }\end{array}$ & $\begin{array}{l}\text { Rain- } \\
\text { fall } \\
\text { (inches) }\end{array}$ & $\begin{array}{l}\text { Time } \\
\text { (hours) }\end{array}$ & $\begin{array}{l}\text { Streamflow } \\
\text { (cubic feet } \\
\text { per second) }\end{array}$ & $\begin{array}{l}\text { Rain- } \\
\text { fall } \\
\text { (inches) }\end{array}$ & $\begin{array}{l}\text { Time } \\
\text { (hours) }\end{array}$ & $\begin{array}{l}\text { Streamflow } \\
\text { (cubic feet } \\
\text { per second) }\end{array}$ & $\begin{array}{l}\text { Rain- } \\
\text { fall } \\
\text { (inches) }\end{array}$ \\
\hline $\begin{array}{c}\text { May } 12, \\
2100 \\
2105 \\
2110 \\
2115\end{array}$ & 1986 & $\begin{array}{l}0.1 \\
0.2 \\
0.5 \\
0.6\end{array}$ & $\begin{array}{l}0.01 \\
0.12 \\
0.06 \\
0.11\end{array}$ & $\begin{array}{l}0215 \\
0220 \\
0225 \\
0230 \\
0235\end{array}$ & $\begin{array}{l}15.9 \\
15.3 \\
15.1 \\
14.7 \\
14.4\end{array}$ & $\begin{array}{l}0.00 \\
0.00 \\
0.00 \\
0.00 \\
0.00\end{array}$ & $\begin{array}{l}0740 \\
0745 \\
0750 \\
0755 \\
0800\end{array}$ & $\begin{array}{l}5.4 \\
5.4 \\
5.3 \\
5.1 \\
5.1\end{array}$ & $\begin{array}{l}0.00 \\
0.00 \\
0.00 \\
0.00 \\
0.00\end{array}$ \\
\hline $\begin{array}{l}2120 \\
2125 \\
2130 \\
2135 \\
2140\end{array}$ & & $\begin{array}{r}1.2 \\
1.6 \\
1.4 \\
9.9 \\
31.2\end{array}$ & $\begin{array}{l}0.37 \\
0.24 \\
0.16 \\
0.14 \\
0.07\end{array}$ & $\begin{array}{l}0240 \\
0245 \\
0250 \\
0255 \\
0300\end{array}$ & $\begin{array}{l}14.0 \\
13.8 \\
13.4 \\
13.0 \\
12.7\end{array}$ & $\begin{array}{l}0.00 \\
0.00 \\
0.00 \\
0.00 \\
0.00\end{array}$ & $\begin{array}{l}0805 \\
0810 \\
0815 \\
0820 \\
0825\end{array}$ & $\begin{array}{l}5.0 \\
5.0 \\
5.0 \\
5.0 \\
5.0\end{array}$ & $\begin{array}{l}0.00 \\
0.00 \\
0.00 \\
0.00 \\
0.00\end{array}$ \\
\hline $\begin{array}{l}2145 \\
2150 \\
2155 \\
2200 \\
2205\end{array}$ & & $\begin{array}{l}42.3 \\
51.2 \\
57.0 \\
61.2 \\
64.2\end{array}$ & $\begin{array}{l}0.04 \\
0.04 \\
0.08 \\
0.03 \\
0.02\end{array}$ & $\begin{array}{l}0305 \\
0310 \\
0315 \\
0320 \\
0325\end{array}$ & $\begin{array}{l}12.5 \\
12.0 \\
12.0 \\
11.6 \\
11.3\end{array}$ & $\begin{array}{l}0.00 \\
0.00 \\
0.00 \\
0.00 \\
0.00\end{array}$ & $\begin{array}{l}0830 \\
0835 \\
0840 \\
0845 \\
0850\end{array}$ & $\begin{array}{l}4.9 \\
4.9 \\
4.8 \\
4.8 \\
4.6\end{array}$ & $\begin{array}{l}0.00 \\
0.00 \\
0.00 \\
0.00 \\
0.00\end{array}$ \\
\hline $\begin{array}{l}2210 \\
2215 \\
2220 \\
2225 \\
2230\end{array}$ & & $\begin{array}{l}66.1 \\
66.4 \\
66.1 \\
64.8 \\
63.6\end{array}$ & $\begin{array}{l}0.01 \\
0.01 \\
0.01 \\
0.01 \\
0.01\end{array}$ & $\begin{array}{l}0330 \\
0335 \\
0340 \\
0345 \\
0350\end{array}$ & $\begin{array}{l}10.9 \\
10.7 \\
10.6 \\
10.2 \\
10.1\end{array}$ & $\begin{array}{l}0.00 \\
0.00 \\
0.00 \\
0.00 \\
0.00\end{array}$ & $\begin{array}{l}0855 \\
0900 \\
0905 \\
0910 \\
0915\end{array}$ & $\begin{array}{l}4.6 \\
4.6 \\
4.6 \\
4.5 \\
4.5\end{array}$ & $\begin{array}{l}0.00 \\
0.00 \\
0.00 \\
0.00 \\
0.00\end{array}$ \\
\hline $\begin{array}{l}2235 \\
2240 \\
2245 \\
2250 \\
2255\end{array}$ & & $\begin{array}{l}61.8 \\
60.0 \\
58.8 \\
57.3 \\
55.6\end{array}$ & $\begin{array}{l}0.02 \\
0.02 \\
0.01 \\
0.01 \\
0.01\end{array}$ & $\begin{array}{l}0355 \\
0400 \\
0405 \\
0410 \\
0415\end{array}$ & $\begin{array}{l}9.9 \\
9.6 \\
9.6 \\
9.5 \\
9.1\end{array}$ & $\begin{array}{l}0.00 \\
0.00 \\
0.00 \\
0.00 \\
0.00\end{array}$ & $\begin{array}{l}0920 \\
0925 \\
0930 \\
0935 \\
0940\end{array}$ & $\begin{array}{l}4.5 \\
4.4 \\
4.4 \\
4.4 \\
4.3\end{array}$ & $\begin{array}{l}0.00 \\
0.00 \\
0.00 \\
0.00 \\
0.00\end{array}$ \\
\hline $\begin{array}{l}2300 \\
2305 \\
2310 \\
2315 \\
2320\end{array}$ & & $\begin{array}{l}54.1 \\
52.3 \\
50.6 \\
48.6 \\
46.7\end{array}$ & $\begin{array}{l}0.01 \\
0.00 \\
0.01 \\
0.00 \\
0.01\end{array}$ & $\begin{array}{l}0420 \\
0425 \\
0430 \\
0435 \\
0440\end{array}$ & $\begin{array}{l}9.0 \\
8.8 \\
8.7 \\
8.5 \\
8.4\end{array}$ & $\begin{array}{l}0.00 \\
0.00 \\
0.00 \\
0.00 \\
0.00\end{array}$ & $\begin{array}{l}0945 \\
0950 \\
0955 \\
1000 \\
1005\end{array}$ & $\begin{array}{l}4.3 \\
4.2 \\
4.2 \\
4.2 \\
4.2\end{array}$ & $\begin{array}{l}0.00 \\
0.00 \\
0.00 \\
0.00 \\
0.00\end{array}$ \\
\hline $\begin{array}{l}2325 \\
2330 \\
2335 \\
2340 \\
2345\end{array}$ & & $\begin{array}{l}44.5 \\
42.8 \\
41.3 \\
39.9 \\
38.6\end{array}$ & $\begin{array}{l}0.01 \\
0.00 \\
0.01 \\
0.00 \\
0.01\end{array}$ & $\begin{array}{l}0445 \\
0450 \\
0455 \\
0500 \\
0505\end{array}$ & $\begin{array}{l}8.2 \\
7.9 \\
7.9 \\
7.8 \\
7.5\end{array}$ & $\begin{array}{l}0.00 \\
0.00 \\
0.00 \\
0.00 \\
0.00\end{array}$ & $\begin{array}{l}1010 \\
1015 \\
1020 \\
1025 \\
1030\end{array}$ & $\begin{array}{l}4.2 \\
4.2 \\
4.0 \\
4.0 \\
4.0\end{array}$ & $\begin{array}{l}0.00 \\
0.00 \\
0.00 \\
0.00 \\
0.00\end{array}$ \\
\hline $\begin{array}{c}2350 \\
2355 \\
\text { May } 13 \\
0000 \\
0005\end{array}$ & 1986 & $\begin{array}{l}37.1 \\
36.1 \\
34.8 \\
33.9\end{array}$ & $\begin{array}{l}0.00 \\
0.00 \\
0.01 \\
0.00\end{array}$ & $\begin{array}{l}0510 \\
0515 \\
0520 \\
0525 \\
0530\end{array}$ & $\begin{array}{l}7.5 \\
7.3 \\
7.5 \\
7.5 \\
7.3\end{array}$ & $\begin{array}{l}0.00 \\
0.00 \\
0.00 \\
0.00 \\
0.00\end{array}$ & $\begin{array}{l}1035 \\
1040 \\
1045 \\
1050 \\
1055\end{array}$ & $\begin{array}{l}3.9 \\
3.9 \\
3.9 \\
3.9 \\
3.8\end{array}$ & $\begin{array}{l}0.00 \\
0.00 \\
0.00 \\
0.00 \\
0.00\end{array}$ \\
\hline $\begin{array}{l}0010 \\
0015 \\
0020 \\
0025 \\
0030\end{array}$ & & $\begin{array}{l}32.7 \\
31.7 \\
30.8 \\
29.8 \\
28.8\end{array}$ & $\begin{array}{l}0.00 \\
0.00 \\
0.01 \\
0.00 \\
0.00\end{array}$ & $\begin{array}{l}0535 \\
0540 \\
0545 \\
0550 \\
0555\end{array}$ & $\begin{array}{l}7.3 \\
7.2 \\
7.0 \\
6.9 \\
6.9\end{array}$ & $\begin{array}{l}0.00 \\
0.00 \\
0.00 \\
0.00 \\
0.00\end{array}$ & $\begin{array}{l}1100 \\
1105 \\
1110 \\
1115 \\
1120\end{array}$ & $\begin{array}{l}3.8 \\
3.8 \\
3.8 \\
3.8 \\
3.8\end{array}$ & $\begin{array}{l}0.00 \\
0.00 \\
0.00 \\
0.00 \\
0.00\end{array}$ \\
\hline $\begin{array}{l}0035 \\
0040 \\
0045 \\
0050 \\
0055\end{array}$ & & $\begin{array}{l}27.9 \\
27.2 \\
26.5 \\
25.6 \\
24.9\end{array}$ & $\begin{array}{l}0.01 \\
0.00 \\
0.00 \\
0.01 \\
0.00\end{array}$ & $\begin{array}{l}0600 \\
0605 \\
0610 \\
0615 \\
0620\end{array}$ & $\begin{array}{l}6.7 \\
6.6 \\
6.6 \\
6.6 \\
6.5\end{array}$ & $\begin{array}{l}0.00 \\
0.00 \\
0.00 \\
0.00 \\
0.00\end{array}$ & $\begin{array}{l}1125 \\
1130 \\
1135 \\
1140 \\
1145\end{array}$ & $\begin{array}{l}3.8 \\
3.7 \\
3.7 \\
3.7 \\
3.7\end{array}$ & $\begin{array}{l}0.00 \\
0.00 \\
0.00 \\
0.00 \\
0.00\end{array}$ \\
\hline $\begin{array}{l}0100 \\
0105 \\
0110 \\
0115 \\
0120\end{array}$ & & $\begin{array}{l}24.2 \\
23.5 \\
23.1 \\
22.4 \\
21.7\end{array}$ & $\begin{array}{l}0.00 \\
0.00 \\
0.00 \\
0.00 \\
0.00\end{array}$ & $\begin{array}{l}0625 \\
0630 \\
0635 \\
0640 \\
0645\end{array}$ & $\begin{array}{l}6.5 \\
6.3 \\
6.3 \\
6.2 \\
6.2\end{array}$ & $\begin{array}{l}0.00 \\
0.00 \\
0.00 \\
0.00 \\
0.00\end{array}$ & $\begin{array}{l}1150 \\
1155 \\
1200 \\
1205 \\
1210\end{array}$ & $\begin{array}{l}3.5 \\
3.5 \\
3.4 \\
3.4 \\
3.4\end{array}$ & $\begin{array}{l}0.00 \\
0.00 \\
0.00 \\
0.00 \\
0.00\end{array}$ \\
\hline $\begin{array}{l}0125 \\
0130 \\
0135 \\
0140 \\
0145\end{array}$ & & $\begin{array}{l}21.0 \\
20.4 \\
20.0 \\
19.3 \\
18.7\end{array}$ & $\begin{array}{l}0.00 \\
0.00 \\
0.00 \\
0.00 \\
0.00\end{array}$ & $\begin{array}{l}0650 \\
0655 \\
0700 \\
0705 \\
0710\end{array}$ & $\begin{array}{l}6.1 \\
6.1 \\
5.9 \\
5.9 \\
5.9\end{array}$ & $\begin{array}{l}0.00 \\
0.01 \\
0.00 \\
0.00 \\
0.00\end{array}$ & $\begin{array}{l}1215 \\
1220 \\
1225 \\
1230 \\
1235\end{array}$ & $\begin{array}{l}3.4 \\
3.3 \\
3.3 \\
3.3 \\
3.3\end{array}$ & $\begin{array}{l}0.00 \\
0.00 \\
0.00 \\
0.00 \\
0.00\end{array}$ \\
\hline $\begin{array}{l}0150 \\
0155 \\
0200 \\
0205 \\
0210\end{array}$ & & $\begin{array}{l}18.1 \\
17.8 \\
17.4 \\
16.8 \\
16.3\end{array}$ & $\begin{array}{l}0.00 \\
0.00 \\
0.00 \\
0.00 \\
0.00\end{array}$ & $\begin{array}{l}0715 \\
0720 \\
0725 \\
0730 \\
0735\end{array}$ & $\begin{array}{l}5.8 \\
5.6 \\
5.5 \\
5.5 \\
5.5\end{array}$ & $\begin{array}{l}0.00 \\
0.00 \\
0.00 \\
0.00 \\
0.00\end{array}$ & $\begin{array}{l}1240 \\
1245 \\
1250 \\
1255 \\
1300\end{array}$ & $\begin{array}{l}3.3 \\
3.3 \\
3.3 \\
3.3 \\
3.3\end{array}$ & $\begin{array}{l}0.00 \\
0.00 \\
0.00 \\
0.00 \\
0.00\end{array}$ \\
\hline
\end{tabular}


Table 142 --Streamflow and rainfa11 at station 02176380 , Coosawhatchie River tributary at Allendale, May $12-14,1986^{--C o n t i n u e d}$

\begin{tabular}{|c|c|c|c|c|c|c|c|c|c|}
\hline $\begin{array}{l}\text { Time } \\
\text { (hours) }\end{array}$ & $\begin{array}{l}\text { Streamflow } \\
\text { (cubic feet } \\
\text { per second) }\end{array}$ & $\begin{array}{l}\text { Rain- } \\
\text { fal1 } \\
\text { (inches) }\end{array}$ & $\begin{array}{l}\text { Time } \\
\text { (hours) }\end{array}$ & $\begin{array}{l}\text { Streamflow } \\
\text { (cubic feet } \\
\text { per second) }\end{array}$ & $\begin{array}{l}\text { Rain- } \\
\text { fall } \\
\text { (inches) }\end{array}$ & $\begin{array}{l}\text { Time } \\
\text { (hours) }\end{array}$ & $\begin{array}{l}\text { Str } \\
\text { (cub } \\
\text { per }\end{array}$ & $\begin{array}{l}\text { reamflow } \\
\text { oic feet } \\
\text { second) }\end{array}$ & $\begin{array}{l}\text { Rain- } \\
\text { fall } \\
\text { (inches) }\end{array}$ \\
\hline $\begin{array}{l}1305 \\
1310 \\
1315 \\
1320 \\
1325\end{array}$ & $\begin{array}{l}3.2 \\
3.2 \\
3.2 \\
3.2 \\
3.1\end{array}$ & $\begin{array}{l}0.00 \\
0.00 \\
0.00 \\
0.00 \\
0.00\end{array}$ & $\begin{array}{l}1750 \\
1755 \\
1800 \\
1805 \\
1810\end{array}$ & $\begin{array}{l}2.1 \\
2.1 \\
2.1 \\
2.1 \\
2.1\end{array}$ & $\begin{array}{l}0.00 \\
0.00 \\
0.00 \\
0.00 \\
0.00\end{array}$ & $\begin{array}{l}2235 \\
2240 \\
2245 \\
2250 \\
2255\end{array}$ & & $\begin{array}{l}1.5 \\
1.5 \\
1.5 \\
1.4 \\
1.4\end{array}$ & $\begin{array}{l}0.00 \\
0.00 \\
0.00 \\
0.00 \\
0.00\end{array}$ \\
\hline $\begin{array}{l}1330 \\
1335 \\
1340 \\
1345 \\
1350\end{array}$ & $\begin{array}{l}3.1 \\
3.1 \\
3.0 \\
3.0 \\
3.0\end{array}$ & $\begin{array}{l}0.00 \\
0.00 \\
0.00 \\
0.00 \\
0.00\end{array}$ & $\begin{array}{l}1815 \\
1820 \\
1825 \\
1830 \\
1835\end{array}$ & $\begin{array}{l}2.1 \\
2.0 \\
2.0 \\
2.0 \\
2.0\end{array}$ & $\begin{array}{l}0.00 \\
0.00 \\
0.00 \\
0.00 \\
0.00\end{array}$ & $\begin{array}{l}2300 \\
2305 \\
2310 \\
2315 \\
2320\end{array}$ & & $\begin{array}{l}1.4 \\
1.4 \\
1.4 \\
1.4 \\
1.4\end{array}$ & $\begin{array}{l}0.00 \\
0.00 \\
0.00 \\
0.00 \\
0.00\end{array}$ \\
\hline $\begin{array}{l}1355 \\
1400 \\
1405 \\
1410 \\
1415\end{array}$ & $\begin{array}{l}3.0 \\
3.0 \\
3.0 \\
3.0 \\
2.9\end{array}$ & $\begin{array}{l}0.00 \\
0.00 \\
0.00 \\
0.00 \\
0.00\end{array}$ & $\begin{array}{l}1840 \\
1845 \\
1850 \\
1855 \\
1900\end{array}$ & $\begin{array}{l}2.0 \\
2.0 \\
2.0 \\
1.9 \\
1.9\end{array}$ & $\begin{array}{l}0.00 \\
0.00 \\
0.00 \\
0.00 \\
0.00\end{array}$ & $\begin{array}{l}2325 \\
2330 \\
2335 \\
2340 \\
2345\end{array}$ & & $\begin{array}{l}1.4 \\
1.4 \\
1.4 \\
1.4 \\
1.4\end{array}$ & $\begin{array}{l}0.00 \\
0.00 \\
0.00 \\
0.00 \\
0.00\end{array}$ \\
\hline $\begin{array}{l}1420 \\
1425 \\
1430 \\
1435 \\
1440\end{array}$ & $\begin{array}{l}2.9 \\
2.9 \\
2.9 \\
2.9 \\
2.8\end{array}$ & $\begin{array}{l}0.00 \\
0.00 \\
0.00 \\
0.00 \\
0.00\end{array}$ & $\begin{array}{l}1905 \\
1910 \\
1915 \\
1920 \\
1925\end{array}$ & $\begin{array}{l}1.9 \\
1.9 \\
1.9 \\
1.8 \\
1.8\end{array}$ & $\begin{array}{l}0.00 \\
0.00 \\
0.00 \\
0.00 \\
0.00\end{array}$ & $\begin{array}{c}2350 \\
2355 \\
\text { May 14, } \\
0000 \\
0005\end{array}$ & 1986 & $\begin{array}{l}1.4 \\
1.3 \\
1.3 \\
1.3\end{array}$ & $\begin{array}{l}0.00 \\
0.00 \\
0.00 \\
0.00\end{array}$ \\
\hline $\begin{array}{l}1445 \\
1450 \\
1455 \\
1500 \\
1505\end{array}$ & $\begin{array}{l}2.8 \\
2.8 \\
2.8 \\
2.7 \\
2.7\end{array}$ & $\begin{array}{l}0.00 \\
0.00 \\
0.00 \\
0.00 \\
0.00\end{array}$ & $\begin{array}{l}1930 \\
1935 \\
1940 \\
1945 \\
1950\end{array}$ & $\begin{array}{l}1.8 \\
1.8 \\
1.8 \\
1.8 \\
1.8\end{array}$ & $\begin{array}{l}0.00 \\
0.00 \\
0.00 \\
0.00 \\
0.00\end{array}$ & $\begin{array}{l}0010 \\
0015 \\
0020 \\
0025 \\
0030\end{array}$ & & $\begin{array}{l}1.3 \\
1.3 \\
1.3 \\
1.3 \\
1.3\end{array}$ & $\begin{array}{l}0.00 \\
0.00 \\
0.00 \\
0.00 \\
0.00\end{array}$ \\
\hline $\begin{array}{l}1510 \\
1515 \\
1520 \\
1525 \\
1530\end{array}$ & $\begin{array}{l}2.7 \\
2.7 \\
2.6 \\
2.6 \\
2.6\end{array}$ & $\begin{array}{l}0.00 \\
0.00 \\
0.00 \\
0.00 \\
0.00\end{array}$ & $\begin{array}{l}1955 \\
2000 \\
2005 \\
2010 \\
2015\end{array}$ & $\begin{array}{l}1.8 \\
1.8 \\
1.8 \\
1.7 \\
1.7\end{array}$ & $\begin{array}{l}0.00 \\
0.00 \\
0.00 \\
0.00 \\
0.00\end{array}$ & $\begin{array}{l}0035 \\
0040 \\
0045 \\
0050 \\
0055\end{array}$ & & $\begin{array}{l}1.3 \\
1.3 \\
1.3 \\
1.3 \\
1.2\end{array}$ & $\begin{array}{l}0.00 \\
0.00 \\
0.00 \\
0.00 \\
0.00\end{array}$ \\
\hline $\begin{array}{l}1535 \\
1540 \\
1545 \\
1550 \\
1555\end{array}$ & $\begin{array}{l}2.5 \\
2.5 \\
2.5 \\
2.4 \\
2.4\end{array}$ & $\begin{array}{l}0.00 \\
0.00 \\
0.00 \\
0.00 \\
0.00\end{array}$ & $\begin{array}{l}2020 \\
2025 \\
2030 \\
2035 \\
2040\end{array}$ & $\begin{array}{l}1.7 \\
1.7 \\
1.7 \\
1.7 \\
1.7\end{array}$ & $\begin{array}{l}0.00 \\
0.00 \\
0.00 \\
0.00 \\
0.00\end{array}$ & $\begin{array}{l}0100 \\
0105 \\
0110 \\
0115 \\
0120\end{array}$ & & $\begin{array}{l}1.2 \\
1.2 \\
1.2 \\
1.2 \\
1.1\end{array}$ & $\begin{array}{l}0.00 \\
0.00 \\
0.00 \\
0.00 \\
0.00\end{array}$ \\
\hline $\begin{array}{l}1600 \\
1605 \\
1610 \\
1615 \\
1620\end{array}$ & $\begin{array}{l}2.4 \\
2.4 \\
2.4 \\
2.4 \\
2.3\end{array}$ & $\begin{array}{l}0.00 \\
0.00 \\
0.00 \\
0.00 \\
0.00\end{array}$ & $\begin{array}{l}2045 \\
2050 \\
2055 \\
2100 \\
2105\end{array}$ & $\begin{array}{l}1.6 \\
1.6 \\
1.6 \\
1.6 \\
1.6\end{array}$ & $\begin{array}{l}0.00 \\
0.00 \\
0.00 \\
0.00 \\
0.00\end{array}$ & $\begin{array}{l}0125 \\
0130 \\
0135 \\
0140 \\
0145\end{array}$ & & $\begin{array}{l}1.1 \\
1.1 \\
1.1 \\
1.1 \\
1.1\end{array}$ & $\begin{array}{l}0.00 \\
0.00 \\
0.00 \\
0.00 \\
0.00\end{array}$ \\
\hline $\begin{array}{l}1625 \\
1630 \\
1635 \\
1640 \\
1645\end{array}$ & $\begin{array}{l}2.3 \\
2.3 \\
2.3 \\
2.3 \\
2.3\end{array}$ & $\begin{array}{l}0.00 \\
0.00 \\
0.00 \\
0.00 \\
0.00\end{array}$ & $\begin{array}{l}2110 \\
2115 \\
2120 \\
2125 \\
2130\end{array}$ & $\begin{array}{l}1.6 \\
1.6 \\
1.6 \\
1.6 \\
1.6\end{array}$ & $\begin{array}{l}0.00 \\
0.00 \\
0.00 \\
0.00 \\
0.00\end{array}$ & $\begin{array}{l}0150 \\
0155 \\
0200 \\
0205 \\
0210\end{array}$ & & $\begin{array}{l}1.1 \\
1.1 \\
1.1 \\
1.1 \\
1.1\end{array}$ & $\begin{array}{l}0.00 \\
0.00 \\
0.00 \\
0.00 \\
0.00\end{array}$ \\
\hline $\begin{array}{l}1650 \\
1655 \\
1700 \\
1705 \\
1710\end{array}$ & $\begin{array}{l}2.3 \\
2.3 \\
2.2 \\
2.2 \\
2.2\end{array}$ & $\begin{array}{l}0.00 \\
0.00 \\
0.00 \\
0.00 \\
0.00\end{array}$ & $\begin{array}{l}2135 \\
2140 \\
2145 \\
2150 \\
2155\end{array}$ & $\begin{array}{l}1.6 \\
1.6 \\
1.6 \\
1.6 \\
1.6\end{array}$ & $\begin{array}{l}0.00 \\
0.00 \\
0.00 \\
0.00 \\
0.00\end{array}$ & $\begin{array}{l}0215 \\
0220 \\
0225 \\
0230 \\
0235\end{array}$ & & $\begin{array}{l}1.0 \\
1.0 \\
1.0 \\
1.0 \\
1.0\end{array}$ & $\begin{array}{l}0.00 \\
0.00 \\
0.00 \\
0.00 \\
0.00\end{array}$ \\
\hline $\begin{array}{l}1715 \\
1720 \\
1725 \\
1730 \\
1735\end{array}$ & $\begin{array}{l}2.2 \\
2.1 \\
2.1 \\
2.1 \\
2.1\end{array}$ & $\begin{array}{l}0.00 \\
0.00 \\
0.00 \\
0.00 \\
0.00\end{array}$ & $\begin{array}{l}2200 \\
2205 \\
2210 \\
2215 \\
2220\end{array}$ & $\begin{array}{l}1.6 \\
1.6 \\
1.6 \\
1.6 \\
1.5\end{array}$ & $\begin{array}{l}0.00 \\
0.00 \\
0.00 \\
0.00 \\
0.00\end{array}$ & $\begin{array}{l}0240 \\
0245 \\
0250 \\
0255 \\
0300\end{array}$ & & $\begin{array}{l}1.0 \\
1.0 \\
1.0 \\
1.0 \\
1.0\end{array}$ & $\begin{array}{l}0.00 \\
0.00 \\
0.00 \\
0.00 \\
0.00\end{array}$ \\
\hline $\begin{array}{l}1740 \\
1745\end{array}$ & $\begin{array}{l}2.1 \\
2.1\end{array}$ & $\begin{array}{l}0.00 \\
0.00\end{array}$ & $\begin{array}{l}2225 \\
2230\end{array}$ & $\begin{array}{l}1.5 \\
1.5\end{array}$ & $\begin{array}{l}0.00 \\
0.00\end{array}$ & & & & \\
\hline
\end{tabular}



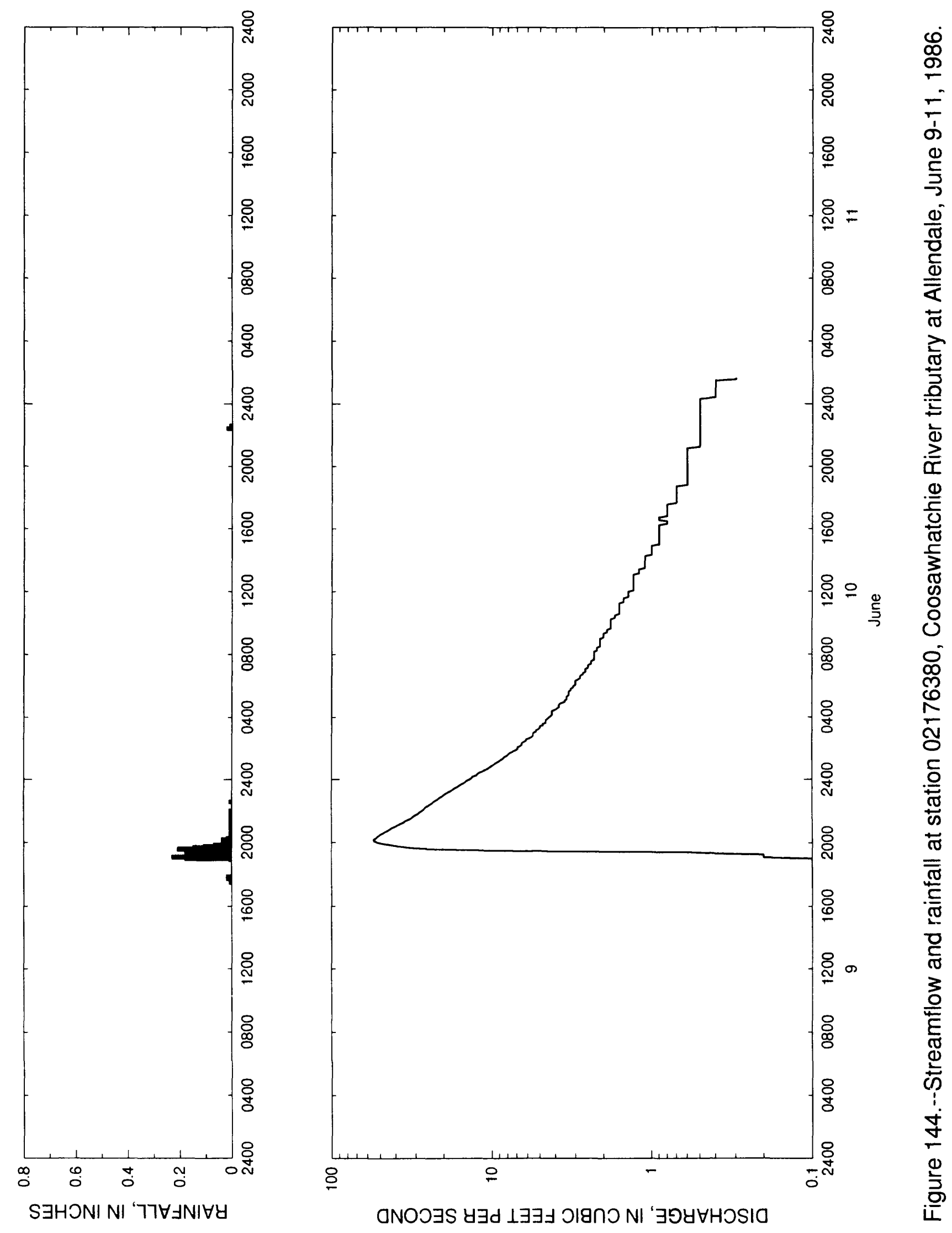

June 9-11, 1986

\begin{tabular}{|c|c|c|c|c|c|c|c|c|}
\hline $\begin{array}{l}\text { Time } \\
\text { (hours) }\end{array}$ & $\begin{array}{l}\text { Streamflow } \\
\text { (cubic feet } \\
\text { per second) }\end{array}$ & $\begin{array}{l}\text { Rain- } \\
\text { fall } \\
\text { (inches) }\end{array}$ & $\begin{array}{l}\text { Time } \\
\text { (hours) }\end{array}$ & $\begin{array}{l}\text { Streamflow } \\
\text { (cubic feet } \\
\text { per second) }\end{array}$ & $\begin{array}{l}\text { Rain- } \\
\text { fall } \\
\text { (inches) }\end{array}$ & $\begin{array}{l}\text { Time } \\
\text { (hours) }\end{array}$ & $\begin{array}{l}\text { Streamflow } \\
\text { (cubic feet } \\
\text { per second) }\end{array}$ & $\begin{array}{l}\text { Rain- } \\
\text { fall } \\
\text { (inches) }\end{array}$ \\
\hline $\begin{array}{l}\text { June } 9 \\
1730 \\
1735 \\
1740 \\
1745\end{array}$ & $\begin{array}{l}0.1 \\
0.1 \\
0.1 \\
0.1\end{array}$ & $\begin{array}{l}0.01 \\
0.00 \\
0.00 \\
0.02\end{array}$ & $\begin{array}{l}2250 \\
2255 \\
2300 \\
2305 \\
2310\end{array}$ & $\begin{array}{l}21.3 \\
20.6 \\
20.1 \\
19.5 \\
18.9\end{array}$ & $\begin{array}{l}0.00 \\
0.00 \\
0.00 \\
0.00 \\
0.00\end{array}$ & $\begin{array}{l}0410 \\
0415 \\
0420 \\
0425 \\
0430\end{array}$ & $\begin{array}{l}4.2 \\
4.2 \\
4.2 \\
4.2 \\
4.0\end{array}$ & $\begin{array}{l}0.00 \\
0.00 \\
0.00 \\
0.00 \\
0.00\end{array}$ \\
\hline $\begin{array}{l}1750 \\
1755 \\
1800 \\
1805 \\
1810\end{array}$ & $\begin{array}{l}0.1 \\
0.1 \\
0.1 \\
0.1 \\
0.1\end{array}$ & $\begin{array}{l}0.02 \\
0.00 \\
0.00 \\
0.00 \\
0.00\end{array}$ & $\begin{array}{l}2315 \\
2320 \\
2325 \\
2330 \\
2335\end{array}$ & $\begin{array}{l}18.1 \\
17.6 \\
17.2 \\
16.6 \\
16.1\end{array}$ & $\begin{array}{l}0.00 \\
0.00 \\
0.00 \\
0.00 \\
0.00\end{array}$ & $\begin{array}{l}0435 \\
0440 \\
0445 \\
0450 \\
0455\end{array}$ & $\begin{array}{l}3.9 \\
3.8 \\
3.8 \\
3.8 \\
3.7\end{array}$ & $\begin{array}{l}0.00 \\
0.00 \\
0.00 \\
0.00 \\
0.00\end{array}$ \\
\hline $\begin{array}{l}1815 \\
1820 \\
1825 \\
1830 \\
1835\end{array}$ & $\begin{array}{l}0.1 \\
0.1 \\
0.1 \\
0.1 \\
0.1\end{array}$ & $\begin{array}{l}0.00 \\
0.00 \\
0.00 \\
0.00 \\
0.00\end{array}$ & $\begin{array}{l}2340 \\
2345 \\
2350 \\
2355 \\
\text { June } 10\end{array}$ & $\begin{array}{r}15.7 \\
15.1 \\
14.7 \\
14.4\end{array}$ & $\begin{array}{l}0.00 \\
0.00 \\
0.00 \\
0.00\end{array}$ & $\begin{array}{l}0500 \\
0505 \\
0510 \\
0515 \\
0520\end{array}$ & $\begin{array}{l}3.5 \\
3.5 \\
3.4 \\
3.4 \\
3.4\end{array}$ & $\begin{array}{l}0.00 \\
0.00 \\
0.00 \\
0.00 \\
0.00\end{array}$ \\
\hline $\begin{array}{l}1840 \\
1845 \\
1850 \\
1855 \\
1900\end{array}$ & $\begin{array}{l}0.1 \\
0.1 \\
0.1 \\
0.1 \\
0.1\end{array}$ & $\begin{array}{l}0.00 \\
0.00 \\
0.00 \\
0.01 \\
0.18\end{array}$ & $\begin{array}{l}0000 \\
0005 \\
0010 \\
0015 \\
0020\end{array}$ & $\begin{array}{l}13.8 \\
13.4 \\
13.2 \\
12.5 \\
12.3\end{array}$ & $\begin{array}{l}0.00 \\
0.00 \\
0.00 \\
0.00 \\
0.00\end{array}$ & $\begin{array}{l}0525 \\
0530 \\
0535 \\
0540 \\
0545\end{array}$ & $\begin{array}{l}3.3 \\
3.3 \\
3.3 \\
3.3 \\
3.2\end{array}$ & $\begin{array}{l}0.00 \\
0.00 \\
0.00 \\
0.00 \\
0.00\end{array}$ \\
\hline $\begin{array}{l}1905 \\
1910 \\
1915 \\
1920 \\
1925\end{array}$ & $\begin{array}{l}0.2 \\
0.2 \\
0.2 \\
0.4 \\
0.6\end{array}$ & $\begin{array}{l}0.23 \\
0.04 \\
0.02 \\
0.12 \\
0.18\end{array}$ & $\begin{array}{l}0025 \\
0030 \\
0035 \\
0040 \\
0045\end{array}$ & $\begin{array}{l}12.0 \\
11.4 \\
11.1 \\
10.7 \\
10.4\end{array}$ & $\begin{array}{l}0.00 \\
0.00 \\
0.00 \\
0.00 \\
0.00\end{array}$ & $\begin{array}{l}0550 \\
0555 \\
0600 \\
0605 \\
0610\end{array}$ & $\begin{array}{l}3.2 \\
3.1 \\
3.1 \\
3.0 \\
3.0\end{array}$ & $\begin{array}{l}0.00 \\
0.00 \\
0.00 \\
0.00 \\
0.00\end{array}$ \\
\hline $\begin{array}{l}1930 \\
1935 \\
1940 \\
1945 \\
1950\end{array}$ & $\begin{array}{r}9.5 \\
24.9 \\
32.7 \\
38.4 \\
42.8\end{array}$ & $\begin{array}{l}0.14 \\
0.21 \\
0.15 \\
0.11 \\
0.07\end{array}$ & $\begin{array}{l}0050 \\
0055 \\
0100 \\
0105 \\
0110\end{array}$ & $\begin{array}{r}10.1 \\
9.8 \\
9.6 \\
9.3 \\
9.0\end{array}$ & $\begin{array}{l}0.00 \\
0.00 \\
0.00 \\
0.00 \\
0.00\end{array}$ & $\begin{array}{l}0615 \\
0620 \\
0625 \\
0630 \\
0635\end{array}$ & $\begin{array}{l}3.0 \\
3.0 \\
2.9 \\
2.8 \\
2.8\end{array}$ & $\begin{array}{l}0.00 \\
0.00 \\
0.00 \\
0.00 \\
0.00\end{array}$ \\
\hline $\begin{array}{l}1955 \\
2000 \\
2005 \\
2010 \\
2015\end{array}$ & $\begin{array}{l}48.6 \\
52.1 \\
54.4 \\
55.0 \\
53.2\end{array}$ & $\begin{array}{l}0.04 \\
0.02 \\
0.01 \\
0.04 \\
0.02\end{array}$ & $\begin{array}{l}0115 \\
0120 \\
0125 \\
0130 \\
0135\end{array}$ & $\begin{array}{l}8.8 \\
8.5 \\
8.4 \\
8.1 \\
7.9\end{array}$ & $\begin{array}{l}0.00 \\
0.00 \\
0.00 \\
0.00 \\
0.00\end{array}$ & $\begin{array}{l}0640 \\
0645 \\
0650 \\
0655 \\
0700\end{array}$ & $\begin{array}{l}2.8 \\
2.7 \\
2.7 \\
2.6 \\
2.6\end{array}$ & $\begin{array}{l}0.00 \\
0.00 \\
0.00 \\
0.00 \\
0.00\end{array}$ \\
\hline $\begin{array}{l}2020 \\
2025 \\
2030 \\
2035 \\
2040\end{array}$ & $\begin{array}{l}52.1 \\
50.9 \\
49.7 \\
47.8 \\
46.4\end{array}$ & $\begin{array}{l}0.01 \\
0.01 \\
0.01 \\
0.01 \\
0.00\end{array}$ & $\begin{array}{l}0140 \\
0145 \\
0150 \\
0155 \\
0200\end{array}$ & $\begin{array}{l}7.8 \\
7.5 \\
7.3 \\
7.0 \\
6.9\end{array}$ & $\begin{array}{l}0.00 \\
0.00 \\
0.00 \\
0.00 \\
0.00\end{array}$ & $\begin{array}{l}0705 \\
0710 \\
0715 \\
0720 \\
0725\end{array}$ & $\begin{array}{l}2.6 \\
2.5 \\
2.5 \\
2.5 \\
2.4\end{array}$ & $\begin{array}{l}0.00 \\
0.00 \\
0.00 \\
0.00 \\
0.00\end{array}$ \\
\hline $\begin{array}{l}2045 \\
2050 \\
2055 \\
2100 \\
2105\end{array}$ & $\begin{array}{l}44.7 \\
43.4 \\
42.1 \\
40.2 \\
38.9\end{array}$ & $\begin{array}{l}0.00 \\
0.00 \\
0.01 \\
0.00 \\
0.00\end{array}$ & $\begin{array}{l}0205 \\
0210 \\
0215 \\
0220 \\
0225\end{array}$ & $\begin{array}{l}6.9 \\
6.6 \\
6.5 \\
6.5 \\
6.3\end{array}$ & $\begin{array}{l}0.00 \\
0.00 \\
0.00 \\
0.00 \\
0.00\end{array}$ & $\begin{array}{l}0730 \\
0735 \\
0740 \\
0745 \\
0750\end{array}$ & $\begin{array}{l}2.4 \\
2.4 \\
2.3 \\
2.3 \\
2.3\end{array}$ & $\begin{array}{l}0.00 \\
0.00 \\
0.00 \\
0.00 \\
0.00\end{array}$ \\
\hline $\begin{array}{l}2110 \\
2115 \\
2120 \\
2125 \\
2130\end{array}$ & $\begin{array}{l}37.6 \\
35.8 \\
35.1 \\
33.6 \\
32.2\end{array}$ & $\begin{array}{l}0.01 \\
0.01 \\
0.01 \\
0.00 \\
0.01\end{array}$ & $\begin{array}{l}0230 \\
0235 \\
0240 \\
0245 \\
0250\end{array}$ & $\begin{array}{l}6.1 \\
6.1 \\
5.8 \\
5.6 \\
5.5\end{array}$ & $\begin{array}{l}0.00 \\
0.00 \\
0.00 \\
0.00 \\
0.00\end{array}$ & $\begin{array}{l}0755 \\
0800 \\
0805 \\
0810 \\
0815\end{array}$ & $\begin{array}{l}2.3 \\
2.3 \\
2.3 \\
2.3 \\
2.2\end{array}$ & $\begin{array}{l}0.00 \\
0.00 \\
0.00 \\
0.00 \\
0.00\end{array}$ \\
\hline $\begin{array}{l}2135 \\
2140 \\
2145 \\
2150 \\
2155\end{array}$ & $\begin{array}{l}31.5 \\
30.8 \\
29.8 \\
28.8 \\
28.3\end{array}$ & $\begin{array}{l}0.01 \\
0.00 \\
0.01 \\
0.00 \\
0.00\end{array}$ & $\begin{array}{l}0255 \\
0300 \\
0305 \\
0310 \\
0315\end{array}$ & $\begin{array}{l}5.5 \\
5.5 \\
5.3 \\
5.3 \\
5.1\end{array}$ & $\begin{array}{l}0.00 \\
0.00 \\
0.00 \\
0.00 \\
0.00\end{array}$ & $\begin{array}{l}0820 \\
0825 \\
0830 \\
0835 \\
0840\end{array}$ & $\begin{array}{l}2.2 \\
2.2 \\
2.1 \\
2.1 \\
2.1\end{array}$ & $\begin{array}{l}0.00 \\
0.00 \\
0.00 \\
0.00 \\
0.00\end{array}$ \\
\hline $\begin{array}{l}2200 \\
2205 \\
2210 \\
2215 \\
2220\end{array}$ & $\begin{array}{l}27.4 \\
26.7 \\
26.2 \\
25.6 \\
24.9\end{array}$ & $\begin{array}{l}0.01 \\
0.00 \\
0.00 \\
0.00 \\
0.00\end{array}$ & $\begin{array}{l}0320 \\
0325 \\
0330 \\
0335 \\
0340\end{array}$ & $\begin{array}{l}5.0 \\
5.0 \\
4.8 \\
4.8 \\
4.6\end{array}$ & $\begin{array}{l}0.00 \\
0.00 \\
0.00 \\
0.00 \\
0.00\end{array}$ & $\begin{array}{l}0845 \\
0850 \\
0855 \\
0900 \\
0905\end{array}$ & $\begin{array}{l}2 \cdot 1 \\
2 \cdot 1 \\
2 \cdot 1 \\
2 \cdot 1 \\
2 \cdot 0\end{array}$ & $\begin{array}{l}0.00 \\
0.00 \\
0.00 \\
0.00 \\
0.00\end{array}$ \\
\hline $\begin{array}{l}2225 \\
2230 \\
2235 \\
2240 \\
2245\end{array}$ & $\begin{array}{l}24.2 \\
23.5 \\
23.1 \\
22.4 \\
21.7\end{array}$ & $\begin{array}{l}0.00 \\
0.00 \\
0.01 \\
0.00 \\
0.00\end{array}$ & $\begin{array}{l}0345 \\
0350 \\
0355 \\
0400 \\
0405\end{array}$ & $\begin{array}{l}4.6 \\
4.6 \\
4.5 \\
4.4 \\
4.3\end{array}$ & $\begin{array}{l}0.00 \\
0.00 \\
0.00 \\
0.00 \\
0.00\end{array}$ & $\begin{array}{l}0910 \\
0915 \\
0920 \\
0925 \\
0930\end{array}$ & $\begin{array}{l}2.0 \\
2.0 \\
2.0 \\
1.9 \\
1.9\end{array}$ & $\begin{array}{l}0.00 \\
0.00 \\
0.00 \\
0.00 \\
0.00\end{array}$ \\
\hline
\end{tabular}


Table 143. - Streamflow and rainfall at station 02176380, Coosawhatchie River tributary at Allendale, June $9-11,1986^{--C o n t i n u e d}$

\begin{tabular}{|c|c|c|c|c|c|c|c|c|}
\hline $\begin{array}{l}\text { Time } \\
\text { (hours) }\end{array}$ & $\begin{array}{l}\text { Streamflow } \\
\text { (cubic feet } \\
\text { per second) }\end{array}$ & $\begin{array}{l}\text { Rain- } \\
\text { fall } \\
\text { (inches) }\end{array}$ & $\begin{array}{l}\text { Time } \\
\text { (hours) }\end{array}$ & $\begin{array}{l}\text { Streamflow } \\
\text { (cubic feet } \\
\text { per second) }\end{array}$ & $\begin{array}{l}\text { Rain- } \\
\text { fall } \\
\text { (inches) }\end{array}$ & $\begin{array}{l}\text { Time } \\
\text { (hours) }\end{array}$ & $\begin{array}{l}\text { Streamflow } \\
\text { (cubic feet } \\
\text { per second) }\end{array}$ & $\begin{array}{l}\text { Rain- } \\
\text { fall } \\
\text { (inches) }\end{array}$ \\
\hline $\begin{array}{l}0935 \\
0940 \\
0945 \\
0950 \\
0955\end{array}$ & $\begin{array}{l}1.9 \\
1.8 \\
1.8 \\
1.8 \\
1.8\end{array}$ & $\begin{array}{l}0.00 \\
0.00 \\
0.00 \\
0.00 \\
0.00\end{array}$ & $\begin{array}{l}1500 \\
1505 \\
1510 \\
1515 \\
1520\end{array}$ & $\begin{array}{l}0.9 \\
0.9 \\
0.9 \\
0.9 \\
0.9\end{array}$ & $\begin{array}{l}0.00 \\
0.00 \\
0.00 \\
0.00 \\
0.00\end{array}$ & $\begin{array}{l}2025 \\
2030 \\
2035 \\
2040 \\
2045\end{array}$ & $\begin{array}{l}0.6 \\
0.6 \\
0.6 \\
0.6 \\
0.6\end{array}$ & $\begin{array}{l}0.00 \\
0.00 \\
0.00 \\
0.00 \\
0.00\end{array}$ \\
\hline $\begin{array}{l}1000 \\
1005 \\
1010 \\
1015 \\
1020\end{array}$ & $\begin{array}{l}1.8 \\
1.8 \\
1.8 \\
1.8 \\
1.7\end{array}$ & $\begin{array}{l}0.00 \\
0.00 \\
0.00 \\
0.00 \\
0.00\end{array}$ & $\begin{array}{l}1525 \\
1530 \\
1535 \\
1540 \\
1545\end{array}$ & $\begin{array}{l}0.9 \\
0.9 \\
0.9 \\
0.9 \\
0.9\end{array}$ & $\begin{array}{l}0.00 \\
0.00 \\
0.00 \\
0.00 \\
0.00\end{array}$ & $\begin{array}{l}2050 \\
2055 \\
2100 \\
2105 \\
2110\end{array}$ & $\begin{array}{l}0.6 \\
0.6 \\
0.6 \\
0.6 \\
0.6\end{array}$ & $\begin{array}{l}0.00 \\
0.00 \\
0.00 \\
0.00 \\
0.00\end{array}$ \\
\hline $\begin{array}{l}1025 \\
1030 \\
1035 \\
1040 \\
1045\end{array}$ & $\begin{array}{l}1.7 \\
1.7 \\
1.6 \\
1.6 \\
1.6\end{array}$ & $\begin{array}{l}0.00 \\
0.00 \\
0.00 \\
0.00 \\
0.00\end{array}$ & $\begin{array}{l}1550 \\
1555 \\
1600 \\
1605 \\
1610\end{array}$ & $\begin{array}{l}0.9 \\
0.9 \\
0.9 \\
0.9 \\
0.9\end{array}$ & $\begin{array}{l}0.00 \\
0.00 \\
0.00 \\
0.00 \\
0.00\end{array}$ & $\begin{array}{l}2115 \\
2120 \\
2125 \\
2130 \\
2135\end{array}$ & $\begin{array}{l}0.5 \\
0.5 \\
0.5 \\
0.5 \\
0.5\end{array}$ & $\begin{array}{l}0.00 \\
0.00 \\
0.00 \\
0.00 \\
0.00\end{array}$ \\
\hline $\begin{array}{l}1050 \\
1055 \\
1100 \\
1105 \\
1110\end{array}$ & $\begin{array}{l}1.6 \\
1.6 \\
1.6 \\
1.6 \\
1.6\end{array}$ & $\begin{array}{l}0.00 \\
0.00 \\
0.00 \\
0.00 \\
0.00\end{array}$ & $\begin{array}{l}1615 \\
1620 \\
1625 \\
1630 \\
1635\end{array}$ & $\begin{array}{l}0.9 \\
0.8 \\
0.8 \\
0.8 \\
0.9\end{array}$ & $\begin{array}{l}0.00 \\
0.00 \\
0.00 \\
0.00 \\
0.00\end{array}$ & $\begin{array}{l}2140 \\
2145 \\
2150 \\
2155 \\
2200\end{array}$ & $\begin{array}{l}0.5 \\
0.5 \\
0.5 \\
0.5 \\
0.5\end{array}$ & $\begin{array}{l}0.00 \\
0.00 \\
0.00 \\
0.00 \\
0.00\end{array}$ \\
\hline $\begin{array}{l}1115 \\
1120 \\
1125 \\
1130 \\
1135\end{array}$ & $\begin{array}{l}1.6 \\
1.5 \\
1.5 \\
1.5 \\
1.5\end{array}$ & $\begin{array}{l}0.00 \\
0.00 \\
0.00 \\
0.00 \\
0.00\end{array}$ & $\begin{array}{l}1640 \\
1645 \\
1650 \\
1655 \\
1700\end{array}$ & $\begin{array}{l}0.9 \\
0.9 \\
0.8 \\
0.8 \\
0.8\end{array}$ & $\begin{array}{l}0.00 \\
0.00 \\
0.00 \\
0.00 \\
0.00\end{array}$ & $\begin{array}{l}2205 \\
2210 \\
2215 \\
2220 \\
2225\end{array}$ & $\begin{array}{l}0.5 \\
0.5 \\
0.5 \\
0.5 \\
0.5\end{array}$ & $\begin{array}{l}0.00 \\
0.00 \\
0.00 \\
0.00 \\
0.02\end{array}$ \\
\hline $\begin{array}{l}1140 \\
1145 \\
1150 \\
1155 \\
1200\end{array}$ & $\begin{array}{l}1.4 \\
1.4 \\
1.4 \\
1.4 \\
1.4\end{array}$ & $\begin{array}{l}0.00 \\
0.00 \\
0.00 \\
0.00 \\
0.00\end{array}$ & $\begin{array}{l}1705 \\
1710 \\
1715 \\
1720 \\
1725\end{array}$ & $\begin{array}{l}0.8 \\
0.8 \\
0.8 \\
0.8 \\
0.8\end{array}$ & $\begin{array}{l}0.00 \\
0.00 \\
0.00 \\
0.00 \\
0.00\end{array}$ & $\begin{array}{l}2230 \\
2235 \\
2240 \\
2245 \\
2250\end{array}$ & $\begin{array}{l}0.5 \\
0.5 \\
0.5 \\
0.5 \\
0.5\end{array}$ & $\begin{array}{l}0.01 \\
0.01 \\
0.00 \\
0.00 \\
0.00\end{array}$ \\
\hline $\begin{array}{l}1205 \\
1210 \\
1215 \\
1220 \\
1225\end{array}$ & $\begin{array}{l}1.3 \\
1.3 \\
1.3 \\
1.3 \\
1.3\end{array}$ & $\begin{array}{l}0.00 \\
0.00 \\
0.00 \\
0.00 \\
0.00\end{array}$ & $\begin{array}{l}1730 \\
1735 \\
1740 \\
1745 \\
1750\end{array}$ & $\begin{array}{l}0.8 \\
0.8 \\
0.7 \\
0.7 \\
0.7\end{array}$ & $\begin{array}{l}0.00 \\
0.00 \\
0.00 \\
0.00 \\
0.00\end{array}$ & $\begin{array}{l}2255 \\
2300 \\
2305 \\
2310 \\
2315\end{array}$ & $\begin{array}{l}0.5 \\
0.5 \\
0.5 \\
0.5 \\
0.5\end{array}$ & $\begin{array}{l}0.00 \\
0.00 \\
0.00 \\
0.00 \\
0.00\end{array}$ \\
\hline $\begin{array}{l}1230 \\
1235 \\
1240 \\
1245 \\
1250\end{array}$ & $\begin{array}{l}1.3 \\
1.3 \\
1.3 \\
1.3 \\
1.3\end{array}$ & $\begin{array}{l}0.00 \\
0.00 \\
0.00 \\
0.00 \\
0.00\end{array}$ & $\begin{array}{l}1755 \\
1800 \\
1805 \\
1810 \\
1815\end{array}$ & $\begin{array}{l}0.7 \\
0.7 \\
0.7 \\
0.7 \\
0.7\end{array}$ & $\begin{array}{l}0.00 \\
0.00 \\
0.00 \\
0.00 \\
0.00\end{array}$ & $\begin{array}{l}2320 \\
2325 \\
2330 \\
2335 \\
2340\end{array}$ & $\begin{array}{l}0.5 \\
0.5 \\
0.5 \\
0.5 \\
0.5\end{array}$ & $\begin{array}{l}0.00 \\
0.00 \\
0.00 \\
0.00 \\
0.00\end{array}$ \\
\hline $\begin{array}{l}1255 \\
1300 \\
1305 \\
1310 \\
1315\end{array}$ & $\begin{array}{l}1.3 \\
1.3 \\
1.3 \\
1.2 \\
1.2\end{array}$ & $\begin{array}{l}0.00 \\
0.00 \\
0.00 \\
0.00 \\
0.00\end{array}$ & $\begin{array}{l}1820 \\
1825 \\
1830 \\
1835 \\
1840\end{array}$ & $\begin{array}{l}0.7 \\
0.7 \\
0.7 \\
0.7 \\
0.7\end{array}$ & $\begin{array}{l}0.00 \\
0.00 \\
0.00 \\
0.00 \\
0.00\end{array}$ & $\begin{array}{l}2345 \\
2350 \\
2355 \\
\text { June } 11 \\
0000\end{array}$ & $\begin{array}{ll} & 0.5 \\
& 0.5 \\
& 0.5 \\
1986 & \\
& 0.5\end{array}$ & $\begin{array}{l}0.00 \\
0.00 \\
0.00 \\
0.00\end{array}$ \\
\hline $\begin{array}{l}1320 \\
1325 \\
1330 \\
1335 \\
1340\end{array}$ & $\begin{array}{l}1.2 \\
1.2 \\
1.1 \\
1.1 \\
1.1\end{array}$ & $\begin{array}{l}0.00 \\
0.00 \\
0.00 \\
0.00 \\
0.00\end{array}$ & $\begin{array}{l}1845 \\
1850 \\
1855 \\
1900 \\
1905\end{array}$ & $\begin{array}{l}0.7 \\
0.6 \\
0.6 \\
0.6 \\
0.6\end{array}$ & $\begin{array}{l}0.00 \\
0.00 \\
0.00 \\
0.00 \\
0.00\end{array}$ & $\begin{array}{l}0005 \\
0010 \\
0015 \\
0020 \\
0025\end{array}$ & $\begin{array}{l}0.5 \\
0.5 \\
0.5 \\
0.5 \\
0.4\end{array}$ & $\begin{array}{l}0.00 \\
0.00 \\
0.00 \\
0.00 \\
0.00\end{array}$ \\
\hline $\begin{array}{l}1345 \\
1350 \\
1355 \\
1400 \\
1405\end{array}$ & $\begin{array}{l}1.1 \\
1.1 \\
1.1 \\
1.1 \\
1.1\end{array}$ & $\begin{array}{l}0.00 \\
0.00 \\
0.00 \\
0.00 \\
0.00\end{array}$ & $\begin{array}{l}1910 \\
1915 \\
1920 \\
1925 \\
1930\end{array}$ & $\begin{array}{l}0.6 \\
0.6 \\
0.6 \\
0.6 \\
0.6\end{array}$ & $\begin{array}{l}0.00 \\
0.00 \\
0.00 \\
0.00 \\
0.00\end{array}$ & $\begin{array}{l}0030 \\
0035 \\
0040 \\
0045 \\
0050\end{array}$ & $\begin{array}{l}0.4 \\
0.4 \\
0.4 \\
0.4 \\
0.4\end{array}$ & $\begin{array}{l}0.00 \\
0.00 \\
0.00 \\
0.00 \\
0.00\end{array}$ \\
\hline $\begin{array}{l}1410 \\
1415 \\
1420 \\
1425 \\
1430\end{array}$ & $\begin{array}{l}1.1 \\
1.1 \\
1.0 \\
1.0 \\
1.0\end{array}$ & $\begin{array}{l}0.00 \\
0.00 \\
0.00 \\
0.00 \\
0.00\end{array}$ & $\begin{array}{l}1935 \\
1940 \\
1945 \\
1950 \\
1955\end{array}$ & $\begin{array}{l}0.6 \\
0.6 \\
0.6 \\
0.6 \\
0.6\end{array}$ & $\begin{array}{l}0.00 \\
0.00 \\
0.00 \\
0.00 \\
0.00\end{array}$ & $\begin{array}{l}0055 \\
0100 \\
0105 \\
0110 \\
0115\end{array}$ & $\begin{array}{l}0.4 \\
0.4 \\
0.4 \\
0.4 \\
0.4\end{array}$ & $\begin{array}{l}0.00 \\
0.00 \\
0.00 \\
0.00 \\
0.00\end{array}$ \\
\hline $\begin{array}{l}1435 \\
1440 \\
1445 \\
1450 \\
1455\end{array}$ & $\begin{array}{l}1.0 \\
1.0 \\
1.0 \\
1.0 \\
1.0\end{array}$ & $\begin{array}{l}0.00 \\
0.00 \\
0.00 \\
0.00 \\
0.00\end{array}$ & $\begin{array}{l}2000 \\
2005 \\
2010 \\
2015 \\
2020\end{array}$ & $\begin{array}{l}0.6 \\
0.6 \\
0.6 \\
0.6 \\
0.6\end{array}$ & $\begin{array}{l}0.00 \\
0.00 \\
0.00 \\
0.00 \\
0.00\end{array}$ & $\begin{array}{l}0120 \\
0125 \\
0130 \\
0135 \\
0140\end{array}$ & $\begin{array}{l}0.4 \\
0.4 \\
0.4 \\
0.3 \\
0.3\end{array}$ & $\begin{array}{l}0.00 \\
0.00 \\
0.00 \\
0.00 \\
0.00\end{array}$ \\
\hline
\end{tabular}




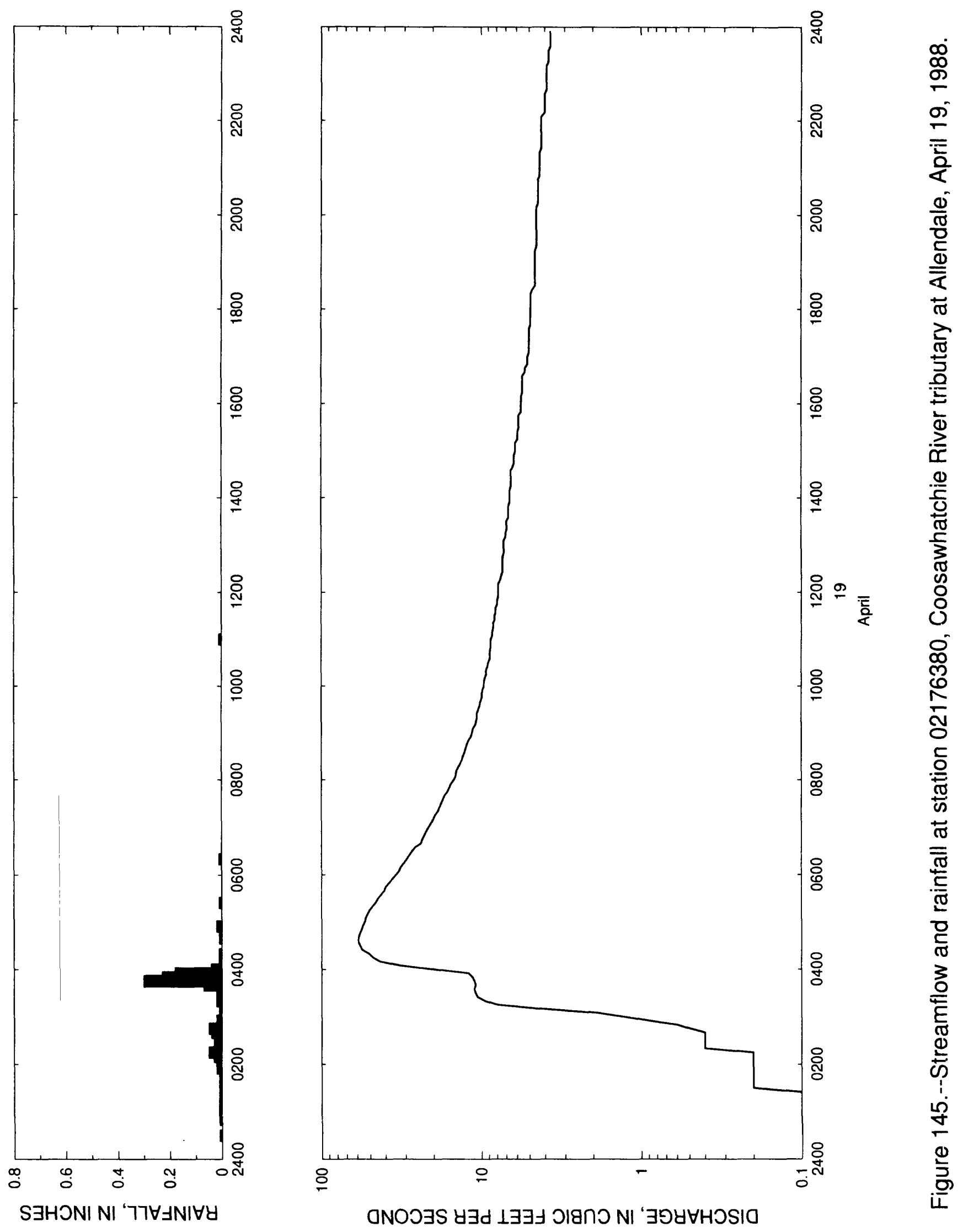


Table 144 - - Streamflow and rainfall at station 02176380 , Coosawhatchie River tributary at Allendale, April 19, 1988

\begin{tabular}{|c|c|c|c|c|c|c|c|c|}
\hline $\begin{array}{l}\text { Time } \\
\text { (hours) }\end{array}$ & $\begin{array}{l}\text { Streamflow } \\
\text { (cubic feet } \\
\text { per second) }\end{array}$ & $\begin{array}{l}\text { Rain- } \\
\text { fall } \\
\text { (inches) }\end{array}$ & $\begin{array}{l}\text { Time } \\
\text { (hours) }\end{array}$ & $\begin{array}{l}\text { Streamflow } \\
\text { (cubic feet } \\
\text { per second) }\end{array}$ & $\begin{array}{l}\text { Rain- } \\
\text { fall } \\
\text { (inches) }\end{array}$ & $\begin{array}{l}\text { Time } \\
\text { (hours) }\end{array}$ & $\begin{array}{l}\text { Streamflow } \\
\text { (cubic feet } \\
\text { per second) }\end{array}$ & $\begin{array}{l}\text { Rain- } \\
\text { fall } \\
\text { (inches) }\end{array}$ \\
\hline $\begin{array}{l}\text { Apri1 19, } \\
0030 \\
0035 \\
0040 \\
0045\end{array}$ & $\begin{array}{r}1988 \\
0.1 \\
0.1 \\
0.1 \\
0.1\end{array}$ & $\begin{array}{l}0.01 \\
0.00 \\
0.00 \\
0.00\end{array}$ & $\begin{array}{l}0550 \\
0555 \\
0600 \\
0605 \\
0610\end{array}$ & $\begin{array}{l}37.9 \\
36.1 \\
34.4 \\
32.9 \\
31.9\end{array}$ & $\begin{array}{l}0.00 \\
0.00 \\
0.00 \\
0.00 \\
0.00\end{array}$ & $\begin{array}{l}1115 \\
1120 \\
1125 \\
1130 \\
1135\end{array}$ & $\begin{array}{l}8.4 \\
8.4 \\
8.2 \\
8.2 \\
8.1\end{array}$ & $\begin{array}{l}0.07 \\
0.01 \\
0.07 \\
0.07 \\
0.00\end{array}$ \\
\hline $\begin{array}{l}0050 \\
0055 \\
0100 \\
0105 \\
0110\end{array}$ & $\begin{array}{l}0.1 \\
0.1 \\
0.1 \\
0.1 \\
0.1\end{array}$ & $\begin{array}{l}0.01 \\
0.01 \\
0.01 \\
0.01 \\
0.00\end{array}$ & $\begin{array}{l}0615 \\
0620 \\
0625 \\
0630 \\
0635\end{array}$ & $\begin{array}{l}30.5 \\
29.3 \\
28.3 \\
27.2 \\
26.0\end{array}$ & $\begin{array}{l}0.00 \\
0.01 \\
0.00 \\
0.00 \\
0.00\end{array}$ & $\begin{array}{l}1140 \\
1145 \\
1150 \\
1155 \\
1200\end{array}$ & $\begin{array}{l}8.1 \\
7.9 \\
7.9 \\
7.8 \\
7.8\end{array}$ & $\begin{array}{l}0.01 \\
0.01 \\
0.00 \\
0.00 \\
0.00\end{array}$ \\
\hline $\begin{array}{l}0115 \\
0120 \\
0125 \\
0130 \\
0135\end{array}$ & $\begin{array}{l}0.1 \\
0.1 \\
0.1 \\
0.2 \\
0.2\end{array}$ & $\begin{array}{l}0.01 \\
0.00 \\
0.01 \\
0.01 \\
0.00\end{array}$ & $\begin{array}{l}0640 \\
0645 \\
0650 \\
0655 \\
0700\end{array}$ & $\begin{array}{l}24.0 \\
23.5 \\
22.8 \\
22.2 \\
21.5\end{array}$ & $\begin{array}{l}0.00 \\
0.00 \\
0.00 \\
0.00 \\
0.00\end{array}$ & $\begin{array}{l}1205 \\
1210 \\
1215 \\
1220 \\
1225\end{array}$ & $\begin{array}{l}7.8 \\
7.8 \\
7.6 \\
7.5 \\
7.3\end{array}$ & $\begin{array}{l}0.00 \\
0.00 \\
0.00 \\
0.07 \\
0.00\end{array}$ \\
\hline $\begin{array}{l}0140 \\
0145 \\
0150 \\
0155 \\
0200\end{array}$ & $\begin{array}{l}0.2 \\
0.2 \\
0.2 \\
0.2 \\
0.2\end{array}$ & $\begin{array}{l}0.01 \\
0.00 \\
0.01 \\
0.02 \\
0.02\end{array}$ & $\begin{array}{l}0705 \\
0710 \\
0715 \\
0720 \\
0725\end{array}$ & $\begin{array}{l}20.8 \\
20.0 \\
19.5 \\
18.7 \\
18.3\end{array}$ & $\begin{array}{l}0.00 \\
0.00 \\
0.00 \\
0.00 \\
0.00\end{array}$ & $\begin{array}{l}1230 \\
1235 \\
1240 \\
1245 \\
1250\end{array}$ & $\begin{array}{l}7.3 \\
7.3 \\
7.3 \\
7.3 \\
7.2\end{array}$ & $\begin{array}{l}0.0 \text { ? } \\
0.0 \text { ? } \\
0.00 \\
0.00 \\
0.0 \text { ? }\end{array}$ \\
\hline $\begin{array}{l}0205 \\
0210 \\
0215 \\
0220 \\
0225\end{array}$ & $\begin{array}{l}0.2 \\
0.2 \\
0.2 \\
0.4 \\
0.4\end{array}$ & $\begin{array}{l}0.02 \\
0.03 \\
0.05 \\
0.03 \\
0.02\end{array}$ & $\begin{array}{l}0730 \\
0735 \\
0740 \\
0745 \\
0750\end{array}$ & $\begin{array}{l}17.8 \\
17.4 \\
17.0 \\
16.3 \\
15.9\end{array}$ & $\begin{array}{l}0.00 \\
0.00 \\
0.00 \\
0.00 \\
0.00\end{array}$ & $\begin{array}{l}1255 \\
1300 \\
1305 \\
1310 \\
1315\end{array}$ & $\begin{array}{l}7.2 \\
7.2 \\
7.2 \\
7.0 \\
7.0\end{array}$ & $\begin{array}{l}0.00 \\
0.00 \\
0.00 \\
0.07 \\
0.00\end{array}$ \\
\hline $\begin{array}{l}0230 \\
0235 \\
0240 \\
0245 \\
0250\end{array}$ & $\begin{array}{l}0.4 \\
0.4 \\
0.4 \\
0.5 \\
0.6\end{array}$ & $\begin{array}{l}0.03 \\
0.02 \\
0.04 \\
0.05 \\
0.02\end{array}$ & $\begin{array}{l}0755 \\
0800 \\
0805 \\
0810 \\
0815\end{array}$ & $\begin{array}{l}15.5 \\
14.9 \\
14.5 \\
14.4 \\
14.0\end{array}$ & $\begin{array}{l}0.00 \\
0.00 \\
0.00 \\
0.00 \\
0.00\end{array}$ & $\begin{array}{l}1320 \\
1325 \\
1330 \\
1335 \\
1340\end{array}$ & $\begin{array}{l}6.9 \\
6.9 \\
6.9 \\
6.7 \\
6.7\end{array}$ & $\begin{array}{l}0.00 \\
0.01 \\
0.07 \\
0.07 \\
0.00\end{array}$ \\
\hline $\begin{array}{l}0255 \\
0300 \\
0305 \\
0310 \\
0315\end{array}$ & $\begin{array}{l}0.9 \\
1.3 \\
1.9 \\
4.2 \\
7.9\end{array}$ & $\begin{array}{l}0.02 \\
0.00 \\
0.01 \\
0.00 \\
0.00\end{array}$ & $\begin{array}{l}0820 \\
0825 \\
0830 \\
0835 \\
0840\end{array}$ & $\begin{array}{l}13.6 \\
13.2 \\
13.0 \\
12.7 \\
12.5\end{array}$ & $\begin{array}{l}0.00 \\
0.00 \\
0.00 \\
0.00 \\
0.00\end{array}$ & $\begin{array}{l}1345 \\
1350 \\
1355 \\
1400 \\
1405\end{array}$ & $\begin{array}{l}6.7 \\
6.7 \\
6.6 \\
6.6 \\
6.6\end{array}$ & $\begin{array}{l}0.07 \\
0.00 \\
0.00 \\
0.07 \\
0.07\end{array}$ \\
\hline $\begin{array}{l}0320 \\
0325 \\
0330 \\
0335 \\
0340\end{array}$ & $\begin{array}{r}9.5 \\
10.6 \\
10.9 \\
11.1 \\
10.9\end{array}$ & $\begin{array}{l}0.02 \\
0.02 \\
0.02 \\
0.02 \\
0.07\end{array}$ & $\begin{array}{l}0845 \\
0850 \\
0855 \\
0900 \\
0905\end{array}$ & $\begin{array}{l}12.3 \\
12.0 \\
11.6 \\
11.4 \\
11.3\end{array}$ & $\begin{array}{l}0.00 \\
0.00 \\
0.00 \\
0.00 \\
0.00\end{array}$ & $\begin{array}{l}1410 \\
1415 \\
1420 \\
1425 \\
1430\end{array}$ & $\begin{array}{l}6.6 \\
6.5 \\
6.5 \\
6.5 \\
6.5\end{array}$ & $\begin{array}{l}0.07 \\
0.07 \\
0.07 \\
0.00 \\
0.00\end{array}$ \\
\hline $\begin{array}{l}0345 \\
0350 \\
0355 \\
0400 \\
0405\end{array}$ & $\begin{array}{l}11.1 \\
11.4 \\
12.1 \\
19.5 \\
32.9\end{array}$ & $\begin{array}{l}0.30 \\
0.23 \\
0.18 \\
0.04 \\
0.01\end{array}$ & $\begin{array}{l}0910 \\
0915 \\
0920 \\
0925 \\
0930\end{array}$ & $\begin{array}{l}10.9 \\
10.7 \\
10.6 \\
10.6 \\
10.4\end{array}$ & $\begin{array}{l}0.00 \\
0.00 \\
0.00 \\
0.00 \\
0.00\end{array}$ & $\begin{array}{l}1435 \\
1440 \\
1445 \\
1450 \\
1455\end{array}$ & $\begin{array}{l}6.5 \\
6.3 \\
6.2 \\
6.2 \\
6.2\end{array}$ & $\begin{array}{l}0.07 \\
0.00 \\
0.00 \\
0.00 \\
0.01\end{array}$ \\
\hline $\begin{array}{l}0410 \\
0415 \\
0420 \\
0425 \\
0430\end{array}$ & $\begin{array}{l}43.4 \\
47.8 \\
50.6 \\
55.9 \\
57.6\end{array}$ & $\begin{array}{l}0.00 \\
0.00 \\
0.01 \\
0.00 \\
0.00\end{array}$ & $\begin{array}{l}0935 \\
0940 \\
0945 \\
0950 \\
0955\end{array}$ & $\begin{array}{r}10.2 \\
10.1 \\
9.9 \\
9.9 \\
9.8\end{array}$ & $\begin{array}{l}0.00 \\
0.00 \\
0.00 \\
0.00 \\
0.00\end{array}$ & $\begin{array}{l}1500 \\
1505 \\
1510 \\
1515 \\
1520\end{array}$ & $\begin{array}{l}6.1 \\
6.1 \\
6.1 \\
5.9 \\
5.9\end{array}$ & $\begin{array}{l}0.01 \\
0.00 \\
0.00 \\
0.00 \\
0.07\end{array}$ \\
\hline $\begin{array}{l}0435 \\
0440 \\
0445 \\
0450 \\
0455\end{array}$ & $\begin{array}{l}59.1 \\
59.1 \\
58.2 \\
56.7 \\
55.6\end{array}$ & $\begin{array}{l}0.00 \\
0.01 \\
0.01 \\
0.00 \\
0.02\end{array}$ & $\begin{array}{l}1000 \\
1005 \\
1010 \\
1015 \\
1020\end{array}$ & $\begin{array}{l}9.6 \\
9.6 \\
9.5 \\
9.3 \\
9.3\end{array}$ & $\begin{array}{l}0.00 \\
0.00 \\
0.00 \\
0.00 \\
0.00\end{array}$ & $\begin{array}{l}1525 \\
1530 \\
1535 \\
1540 \\
1545\end{array}$ & $\begin{array}{l}5.9 \\
5.8 \\
5.8 \\
5.8 \\
5.8\end{array}$ & $\begin{array}{l}0.00 \\
0.00 \\
0.00 \\
0.07 \\
0.00\end{array}$ \\
\hline $\begin{array}{l}0500 \\
0505 \\
0510 \\
0515 \\
0520\end{array}$ & $\begin{array}{l}54.1 \\
53.2 \\
51.8 \\
50.3 \\
48.3\end{array}$ & $\begin{array}{l}0.00 \\
0.00 \\
0.00 \\
0.00 \\
0.00\end{array}$ & $\begin{array}{l}1025 \\
1030 \\
1035 \\
1040 \\
1045\end{array}$ & $\begin{array}{l}9.1 \\
9.0 \\
8.8 \\
8.8 \\
8.8\end{array}$ & $\begin{array}{l}0.00 \\
0.00 \\
0.00 \\
0.00 \\
0.00\end{array}$ & $\begin{array}{l}1550 \\
1555 \\
1600 \\
1605 \\
1610\end{array}$ & $\begin{array}{l}5.6 \\
5.6 \\
5.6 \\
5.6 \\
5.6\end{array}$ & $\begin{array}{l}0.01 \\
0.00 \\
0.00 \\
0.00 \\
0.01\end{array}$ \\
\hline $\begin{array}{l}0525 \\
0530 \\
0535 \\
0540 \\
0545\end{array}$ & $\begin{array}{l}46.1 \\
44.5 \\
42.6 \\
40.7 \\
39.9\end{array}$ & $\begin{array}{l}0.01 \\
0.00 \\
0.00 \\
0.00 \\
0.00\end{array}$ & $\begin{array}{l}1050 \\
1055 \\
1100 \\
1105 \\
1110\end{array}$ & $\begin{array}{l}8.7 \\
8.7 \\
8.7 \\
8.5 \\
8.5\end{array}$ & $\begin{array}{l}0.00 \\
0.00 \\
0.01 \\
0.00 \\
0.00\end{array}$ & $\begin{array}{l}1615 \\
1620 \\
1625 \\
1630 \\
1635\end{array}$ & $\begin{array}{l}5.5 \\
5.5 \\
5.5 \\
5.5 \\
5.5\end{array}$ & $\begin{array}{l}0.00 \\
0.00 \\
0.01 \\
0.01 \\
0.00\end{array}$ \\
\hline
\end{tabular}


Table 144 --Streamflow and rainfall at station 02176380 , Coosawhatchie River tributary at Allendale, April 19,1988--Continued

\begin{tabular}{|c|c|c|c|c|c|c|c|c|}
\hline $\begin{array}{l}\text { Time } \\
\text { (hours) }\end{array}$ & $\begin{array}{l}\text { Streamflow } \\
\text { (cubic feet } \\
\text { per second) }\end{array}$ & $\begin{array}{l}\text { Rain- } \\
\text { fall } \\
\text { (inches) }\end{array}$ & $\begin{array}{l}\text { Time } \\
\text { (hours) }\end{array}$ & $\begin{array}{l}\text { Streamflow } \\
\text { (cubic feet } \\
\text { per second) }\end{array}$ & $\begin{array}{l}\text { Rain- } \\
\text { fa1l } \\
\text { (inches) }\end{array}$ & $\begin{array}{l}\text { Time } \\
\text { (hours) }\end{array}$ & $\begin{array}{l}\text { Streamflow } \\
\text { (cubic feet } \\
\text { per second) }\end{array}$ & $\begin{array}{l}\text { Rain- } \\
\text { fall } \\
\text { (inches) }\end{array}$ \\
\hline $\begin{array}{l}1640 \\
1645 \\
1650 \\
1655 \\
1700\end{array}$ & $\begin{array}{l}5.3 \\
5.3 \\
5.1 \\
5.1 \\
5.1\end{array}$ & $\begin{array}{l}0.00 \\
0.00 \\
0.00 \\
0.00 \\
0.00\end{array}$ & $\begin{array}{l}1910 \\
1915 \\
1920 \\
1925 \\
1930\end{array}$ & $\begin{array}{l}4.6 \\
4.6 \\
4.5 \\
4.5 \\
4.5\end{array}$ & $\begin{array}{l}0.00 \\
0.00 \\
0.00 \\
0.00 \\
0.00\end{array}$ & $\begin{array}{l}2140 \\
2145 \\
2150 \\
2155 \\
2200\end{array}$ & $\begin{array}{l}4.2 \\
4.2 \\
4.2 \\
4.2 \\
4.2\end{array}$ & $\begin{array}{l}0.00 \\
0.00 \\
0.00 \\
0.00 \\
0.00\end{array}$ \\
\hline $\begin{array}{l}1705 \\
1710 \\
1715 \\
1720 \\
1725\end{array}$ & $\begin{array}{l}5.0 \\
5.0 \\
5.0 \\
5.0 \\
5.0\end{array}$ & $\begin{array}{l}0.00 \\
0.00 \\
0.00 \\
0.00 \\
0.00\end{array}$ & $\begin{array}{l}1935 \\
1940 \\
1945 \\
1950 \\
1955\end{array}$ & $\begin{array}{l}4.5 \\
4.5 \\
4.5 \\
4.5 \\
4.5\end{array}$ & $\begin{array}{l}0.00 \\
0.00 \\
0.00 \\
0.00 \\
0.00\end{array}$ & $\begin{array}{l}2205 \\
2210 \\
2215 \\
2220 \\
2225\end{array}$ & $\begin{array}{l}4.2 \\
4.0 \\
4.0 \\
4.0 \\
4.0\end{array}$ & $\begin{array}{l}0.00 \\
0.00 \\
0.00 \\
0.00 \\
0.00\end{array}$ \\
\hline $\begin{array}{l}1730 \\
1735 \\
1740 \\
1745 \\
1750\end{array}$ & $\begin{array}{l}5.0 \\
5.0 \\
4.9 \\
4.9 \\
4.9\end{array}$ & $\begin{array}{l}0.00 \\
0.00 \\
0.00 \\
0.00 \\
0.00\end{array}$ & $\begin{array}{l}2000 \\
2005 \\
2010 \\
2015 \\
2020\end{array}$ & $\begin{array}{l}4.5 \\
4.5 \\
4.5 \\
4.4 \\
4.4\end{array}$ & $\begin{array}{l}0.00 \\
0.00 \\
0.00 \\
0.00 \\
0.00\end{array}$ & $\begin{array}{l}2230 \\
2235 \\
2240 \\
2245 \\
2250\end{array}$ & $\begin{array}{l}4.0 \\
4.0 \\
3.9 \\
3.9 \\
3.9\end{array}$ & $\begin{array}{l}0.00 \\
0.00 \\
0.00 \\
0.00 \\
0.00\end{array}$ \\
\hline $\begin{array}{l}1755 \\
1800 \\
1805 \\
1810 \\
1815\end{array}$ & $\begin{array}{l}4.9 \\
4.9 \\
4.9 \\
4.9 \\
4.9\end{array}$ & $\begin{array}{l}0.00 \\
0.00 \\
0.00 \\
0.00 \\
0.00\end{array}$ & $\begin{array}{l}2025 \\
2030 \\
2035 \\
2040 \\
2045\end{array}$ & $\begin{array}{l}4.4 \\
4.4 \\
4.4 \\
4.4 \\
4.4\end{array}$ & $\begin{array}{l}0.00 \\
0.00 \\
0.00 \\
0.00 \\
0.00\end{array}$ & $\begin{array}{l}2255 \\
2300 \\
2305 \\
2310 \\
2315\end{array}$ & $\begin{array}{l}3.9 \\
3.9 \\
3.9 \\
3.9 \\
3.8\end{array}$ & $\begin{array}{l}0.00 \\
0.00 \\
0.00 \\
0.00 \\
0.00\end{array}$ \\
\hline $\begin{array}{l}1820 \\
1825 \\
1830 \\
1835 \\
1840\end{array}$ & $\begin{array}{l}4.9 \\
4.8 \\
4.6 \\
4.6 \\
4.6\end{array}$ & $\begin{array}{l}0.00 \\
0.00 \\
0.00 \\
0.00 \\
0.00\end{array}$ & $\begin{array}{l}2050 \\
2055 \\
2100 \\
2105 \\
2110\end{array}$ & $\begin{array}{l}4.3 \\
4.3 \\
4.3 \\
4.3 \\
4.3\end{array}$ & $\begin{array}{l}0.00 \\
0.00 \\
0.00 \\
0.00 \\
0.00\end{array}$ & $\begin{array}{l}2320 \\
2325 \\
2330 \\
2335 \\
2340\end{array}$ & $\begin{array}{l}3.8 \\
3.8 \\
3.8 \\
3.7 \\
3.7\end{array}$ & $\begin{array}{l}0.00 \\
0.00 \\
0.00 \\
0.00 \\
0.00\end{array}$ \\
\hline $\begin{array}{l}1845 \\
1850 \\
1855 \\
1900 \\
1905\end{array}$ & $\begin{array}{l}4.6 \\
4.6 \\
4.6 \\
4.6 \\
4.6\end{array}$ & $\begin{array}{l}0.00 \\
0.00 \\
0.00 \\
0.00 \\
0.00\end{array}$ & $\begin{array}{l}2115 \\
2120 \\
2125 \\
2130 \\
2135\end{array}$ & $\begin{array}{l}4.3 \\
4.3 \\
4.2 \\
4.2 \\
4.2\end{array}$ & $\begin{array}{l}0.00 \\
0.00 \\
0.00 \\
0.00 \\
0.00\end{array}$ & $\begin{array}{l}2345 \\
2350 \\
2355\end{array}$ & $\begin{array}{l}3.7 \\
3.7 \\
3.7\end{array}$ & $\begin{array}{l}0.00 \\
0.00 \\
0.00\end{array}$ \\
\hline
\end{tabular}




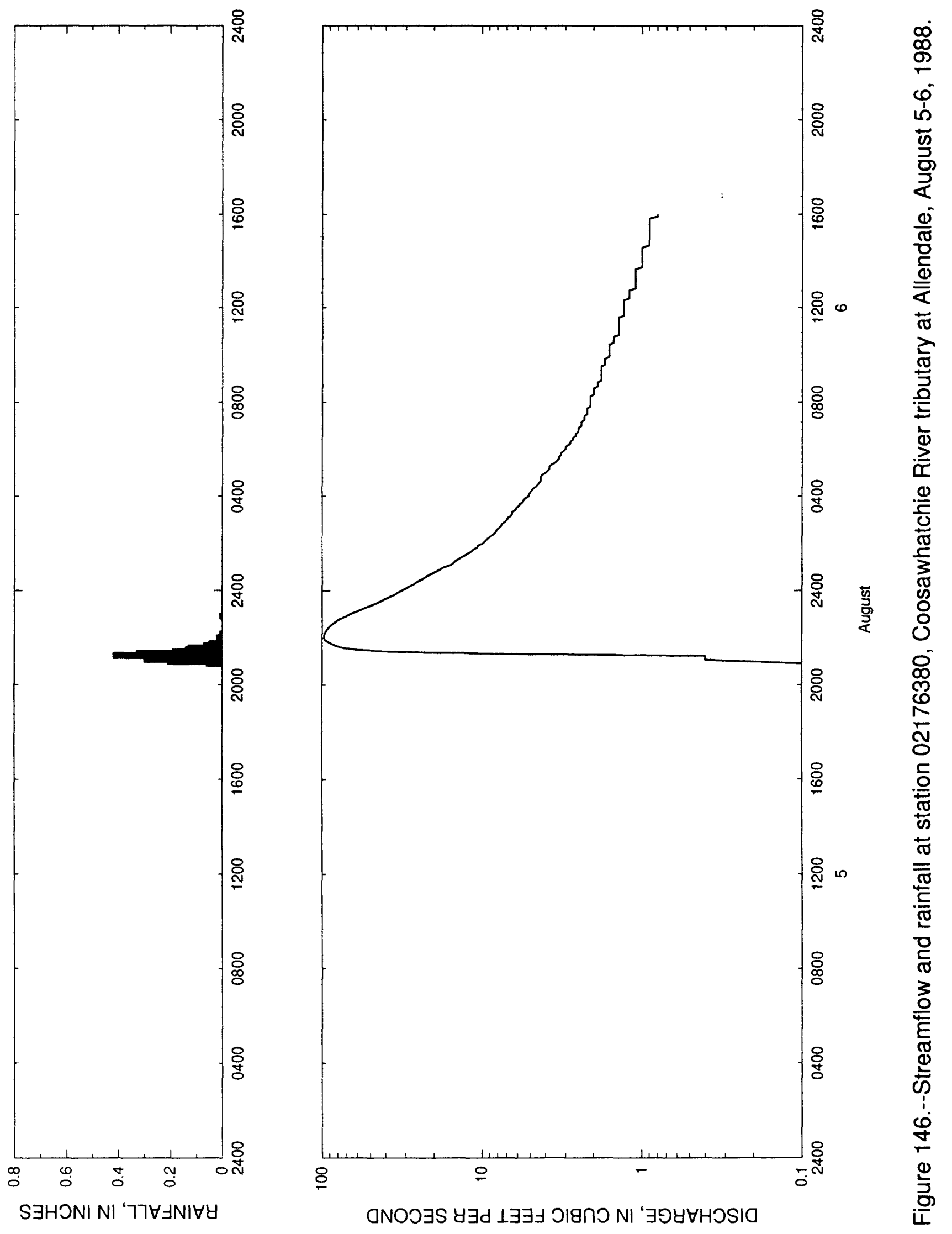



August $5-6,1988$

\begin{tabular}{|c|c|c|c|c|c|c|c|c|}
\hline $\begin{array}{l}\text { Time } \\
\text { (hours) }\end{array}$ & $\begin{array}{l}\text { Streamflow } \\
\text { (cubic feet } \\
\text { per second) }\end{array}$ & $\begin{array}{l}\text { Rain- } \\
\text { fall } \\
\text { (inches) }\end{array}$ & $\begin{array}{l}\text { Time } \\
\text { (hours) }\end{array}$ & $\begin{array}{l}\text { Streamflow } \\
\text { (cubic feet } \\
\text { per second) }\end{array}$ & $\begin{array}{l}\text { Rain- } \\
\text { fall } \\
\text { (inches) }\end{array}$ & $\begin{array}{l}\text { Time } \\
\text { (hours) }\end{array}$ & $\begin{array}{l}\text { Streamflow } \\
\text { (cubic feet } \\
\text { per second) }\end{array}$ & $\begin{array}{l}\text { Rain- } \\
\text { fall } \\
\text { (inches) }\end{array}$ \\
\hline $\begin{array}{c}\text { August } \\
2055 \\
2100 \\
2105 \\
2110\end{array}$ & 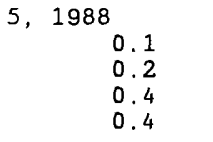 & $\begin{array}{l}0.06 \\
0.21 \\
0.30 \\
0.26\end{array}$ & $\begin{array}{l}0210 \\
0215 \\
0220 \\
0225 \\
0230\end{array}$ & $\begin{array}{l}9.3 \\
9.0 \\
8.7 \\
8.4 \\
8.2\end{array}$ & $\begin{array}{l}0.00 \\
0.00 \\
0.00 \\
0.00 \\
0.00\end{array}$ & $\begin{array}{l}0735 \\
0740 \\
0745 \\
0750 \\
0755\end{array}$ & $\begin{array}{l}2.2 \\
2.2 \\
2.2 \\
2.1 \\
2.1\end{array}$ & $\begin{array}{l}0.00 \\
0.00 \\
0.00 \\
0.00 \\
0.00\end{array}$ \\
\hline $\begin{array}{l}2115 \\
2120 \\
2125 \\
2130 \\
2135\end{array}$ & $\begin{array}{r}0.4 \\
7.3 \\
37.1 \\
58.5 \\
74.0\end{array}$ & $\begin{array}{l}0.42 \\
0.33 \\
0.19 \\
0.14 \\
0.13\end{array}$ & $\begin{array}{l}0235 \\
0240 \\
0245 \\
0250 \\
0255\end{array}$ & $\begin{array}{l}8.1 \\
7.8 \\
7.6 \\
7.5 \\
7.2\end{array}$ & $\begin{array}{l}0.00 \\
0.00 \\
0.00 \\
0.00 \\
0.00\end{array}$ & $\begin{array}{l}0800 \\
0805 \\
0810 \\
0815 \\
0820\end{array}$ & $\begin{array}{l}2.1 \\
2.1 \\
2.1 \\
2.1 \\
2.0\end{array}$ & $\begin{array}{l}0.00 \\
0.00 \\
0.00 \\
0.00 \\
0.00\end{array}$ \\
\hline $\begin{array}{l}2140 \\
2145 \\
2150 \\
2155 \\
2200\end{array}$ & $\begin{array}{l}81.5 \\
87.2 \\
91.7 \\
96.0 \\
96.9\end{array}$ & $\begin{array}{l}0.07 \\
0.05 \\
0.02 \\
0.01 \\
0.02\end{array}$ & $\begin{array}{l}0300 \\
0305 \\
0310 \\
0315 \\
0320\end{array}$ & $\begin{array}{l}7.0 \\
6.9 \\
6.6 \\
6.5 \\
6.5\end{array}$ & $\begin{array}{l}0.00 \\
0.00 \\
0.00 \\
0.00 \\
0.00\end{array}$ & $\begin{array}{l}0825 \\
0830 \\
0835 \\
0840 \\
0845\end{array}$ & $\begin{array}{l}2.0 \\
2.0 \\
2.0 \\
1.9 \\
1.9\end{array}$ & $\begin{array}{l}0.00 \\
0.00 \\
0.00 \\
0.00 \\
0.00\end{array}$ \\
\hline $\begin{array}{l}2205 \\
2210 \\
2215 \\
2220 \\
2225\end{array}$ & $\begin{array}{l}96.9 \\
96.6 \\
95.7 \\
94.0 \\
92.4\end{array}$ & $\begin{array}{l}0.01 \\
0.01 \\
0.00 \\
0.00 \\
0.00\end{array}$ & $\begin{array}{l}0325 \\
0330 \\
0335 \\
0340 \\
0345\end{array}$ & $\begin{array}{l}6.2 \\
6.1 \\
5.9 \\
5.8 \\
5.6\end{array}$ & $\begin{array}{l}0.00 \\
0.00 \\
0.00 \\
0.00 \\
0.00\end{array}$ & $\begin{array}{l}0850 \\
0855 \\
0900 \\
0905 \\
0910\end{array}$ & $\begin{array}{l}1.9 \\
1.8 \\
1.8 \\
1.8 \\
1.8\end{array}$ & $\begin{array}{l}0.00 \\
0.00 \\
0.00 \\
0.00 \\
0.00\end{array}$ \\
\hline $\begin{array}{l}2230 \\
2235 \\
2240 \\
2245 \\
2250\end{array}$ & $\begin{array}{l}89.8 \\
86.9 \\
83.1 \\
79.9 \\
75.7\end{array}$ & $\begin{array}{l}0.00 \\
0.00 \\
0.00 \\
0.00 \\
0.00\end{array}$ & $\begin{array}{l}0350 \\
0355 \\
0400 \\
0405 \\
0410\end{array}$ & $\begin{array}{l}5.5 \\
5.4 \\
5.1 \\
5.1 \\
5.0\end{array}$ & $\begin{array}{l}0.00 \\
0.00 \\
0.00 \\
0.00 \\
0.00\end{array}$ & $\begin{array}{l}0915 \\
0920 \\
0925 \\
0930 \\
0935\end{array}$ & $\begin{array}{l}1.8 \\
1.8 \\
1.8 \\
1.8 \\
1.7\end{array}$ & $\begin{array}{l}0.00 \\
0.00 \\
0.00 \\
0.00 \\
0.00\end{array}$ \\
\hline $\begin{array}{l}2255 \\
2300 \\
2305 \\
2310 \\
2315\end{array}$ & $\begin{array}{l}71.1 \\
67.3 \\
63.0 \\
58.5 \\
54.7\end{array}$ & $\begin{array}{l}0.01 \\
0.00 \\
0.00 \\
0.00 \\
0.00\end{array}$ & $\begin{array}{l}0415 \\
0420 \\
0425 \\
0430 \\
0435\end{array}$ & $\begin{array}{l}4.9 \\
4.8 \\
4.6 \\
4.5 \\
4.4\end{array}$ & $\begin{array}{l}0.00 \\
0.00 \\
0.00 \\
0.00 \\
0.00\end{array}$ & $\begin{array}{l}0940 \\
0945 \\
0950 \\
0955 \\
1000\end{array}$ & $\begin{array}{l}1.7 \\
1.7 \\
1.7 \\
1.6 \\
1.6\end{array}$ & $\begin{array}{l}0.00 \\
0.00 \\
0.00 \\
0.00 \\
0.00\end{array}$ \\
\hline $\begin{array}{l}2320 \\
2325 \\
2330 \\
2335 \\
2340\end{array}$ & $\begin{array}{l}51.2 \\
48.0 \\
45.0 \\
42.3 \\
39.9\end{array}$ & $\begin{array}{l}0.00 \\
0.00 \\
0.00 \\
0.00 \\
0.00\end{array}$ & $\begin{array}{l}0440 \\
0445 \\
0450 \\
0455 \\
0500\end{array}$ & $\begin{array}{l}4.3 \\
4.3 \\
4.3 \\
4.2 \\
4.0\end{array}$ & $\begin{array}{l}0.00 \\
0.00 \\
0.00 \\
0.00 \\
0.00\end{array}$ & $\begin{array}{l}1005 \\
1010 \\
1015 \\
1020 \\
1025\end{array}$ & $\begin{array}{l}1.6 \\
1.6 \\
1.6 \\
1.6 \\
1.6\end{array}$ & $\begin{array}{l}0.00 \\
0.00 \\
0.00 \\
0.00 \\
0.00\end{array}$ \\
\hline $\begin{array}{c}2345 \\
2350 \\
2355 \\
\text { August } \\
0000\end{array}$ & $\begin{array}{r}37.4 \\
35.1 \\
33.6 \\
6,1988 \\
31.7\end{array}$ & $\begin{array}{l}0.00 \\
0.00 \\
0.00 \\
0.00\end{array}$ & $\begin{array}{l}0505 \\
0510 \\
0515 \\
0520 \\
0525\end{array}$ & $\begin{array}{l}3.9 \\
3.8 \\
3.8 \\
3.7 \\
3.5\end{array}$ & $\begin{array}{l}0.00 \\
0.00 \\
0.00 \\
0.00 \\
0.00\end{array}$ & $\begin{array}{l}1030 \\
1035 \\
1040 \\
1045 \\
1050\end{array}$ & $\begin{array}{l}1.5 \\
1.5 \\
1.5 \\
1.5 \\
1.4\end{array}$ & $\begin{array}{l}0.00 \\
0.00 \\
0.00 \\
0.00 \\
0.00\end{array}$ \\
\hline $\begin{array}{l}0005 \\
0010 \\
0015 \\
0020 \\
0025\end{array}$ & $\begin{array}{l}30.0 \\
28.6 \\
26.9 \\
26.0 \\
24.7\end{array}$ & $\begin{array}{l}0.00 \\
0.00 \\
0.00 \\
0.00 \\
0.00\end{array}$ & $\begin{array}{l}0530 \\
0535 \\
0540 \\
0545 \\
0550\end{array}$ & $\begin{array}{l}3.4 \\
3.3 \\
3.3 \\
3.2 \\
3.2\end{array}$ & $\begin{array}{l}0.00 \\
0.00 \\
0.00 \\
0.00 \\
0.00\end{array}$ & $\begin{array}{l}1055 \\
1100 \\
1105 \\
1110 \\
1115\end{array}$ & $\begin{array}{l}1.4 \\
1.4 \\
1.4 \\
1.4 \\
1.4\end{array}$ & $\begin{array}{l}0.00 \\
0.00 \\
0.00 \\
0.00 \\
0.00\end{array}$ \\
\hline $\begin{array}{l}0030 \\
0035 \\
0040 \\
0045 \\
0050\end{array}$ & $\begin{array}{l}23.5 \\
22.6 \\
21.5 \\
20.2 \\
19.1\end{array}$ & $\begin{array}{l}0.00 \\
0.00 \\
0.00 \\
0.00 \\
0.00\end{array}$ & $\begin{array}{l}0555 \\
0600 \\
0605 \\
0610 \\
0615\end{array}$ & $\begin{array}{l}3.1 \\
3.0 \\
3.0 \\
2.9 \\
2.8\end{array}$ & $\begin{array}{l}0.00 \\
0.00 \\
0.00 \\
0.00 \\
0.00\end{array}$ & $\begin{array}{l}1120 \\
1125 \\
1130 \\
1135 \\
1140\end{array}$ & $\begin{array}{l}1.4 \\
1.4 \\
1.4 \\
1.4 \\
1.3\end{array}$ & $\begin{array}{l}0.00 \\
0.00 \\
0.00 \\
0.00 \\
0.00\end{array}$ \\
\hline $\begin{array}{l}0055 \\
0100 \\
0105 \\
0110 \\
0115\end{array}$ & $\begin{array}{l}18.1 \\
17.2 \\
15.7 \\
15.1 \\
14.7\end{array}$ & $\begin{array}{l}0.00 \\
0.00 \\
0.00 \\
0.00 \\
0.00\end{array}$ & $\begin{array}{l}0620 \\
0625 \\
0630 \\
0635 \\
0640\end{array}$ & $\begin{array}{l}2.8 \\
2.7 \\
2.7 \\
2.6 \\
2.6\end{array}$ & $\begin{array}{l}0.00 \\
0.00 \\
0.00 \\
0.00 \\
0.00\end{array}$ & $\begin{array}{l}1145 \\
1150 \\
1155 \\
1200 \\
1205\end{array}$ & $\begin{array}{l}1.3 \\
1.3 \\
1.3 \\
1.3 \\
1.3\end{array}$ & $\begin{array}{l}0.00 \\
0.00 \\
0.00 \\
0.00 \\
0.00\end{array}$ \\
\hline $\begin{array}{l}0120 \\
0125 \\
0130 \\
0135 \\
0140\end{array}$ & $\begin{array}{l}14.0 \\
13.4 \\
12.7 \\
12.1 \\
11.6\end{array}$ & $\begin{array}{l}0.00 \\
0.00 \\
0.00 \\
0.00 \\
0.00\end{array}$ & $\begin{array}{l}0645 \\
0650 \\
0655 \\
0700 \\
0705\end{array}$ & $\begin{array}{l}2.5 \\
2.5 \\
2.5 \\
2.4 \\
2.4\end{array}$ & $\begin{array}{l}0.00 \\
0.00 \\
0.00 \\
0.00 \\
0.00\end{array}$ & $\begin{array}{l}1210 \\
1215 \\
1220 \\
1225 \\
1230\end{array}$ & $\begin{array}{l}1.3 \\
1.3 \\
1.3 \\
1.2 \\
1.2\end{array}$ & $\begin{array}{l}0.00 \\
0.00 \\
0.00 \\
0.00 \\
0.00\end{array}$ \\
\hline $\begin{array}{l}0145 \\
0150 \\
0155 \\
0200 \\
0205\end{array}$ & $\begin{array}{r}11.3 \\
10.7 \\
10.6 \\
9.9 \\
9.6\end{array}$ & $\begin{array}{l}0.00 \\
0.00 \\
0.00 \\
0.00 \\
0.00\end{array}$ & $\begin{array}{l}0710 \\
0715 \\
0720 \\
0725 \\
0730\end{array}$ & $\begin{array}{l}2.4 \\
2.3 \\
2.3 \\
2.3 \\
2.2\end{array}$ & $\begin{array}{l}0.00 \\
0.00 \\
0.00 \\
0.00 \\
0.00\end{array}$ & $\begin{array}{l}1235 \\
1240 \\
1245 \\
1250 \\
1255\end{array}$ & $\begin{array}{l}1.2 \\
1.2 \\
1.2 \\
1.1 \\
1.1\end{array}$ & $\begin{array}{l}0.00 \\
0.00 \\
0.00 \\
0.00 \\
0.00\end{array}$ \\
\hline
\end{tabular}


Table 145. - Streamflow and rainfall at station 02176380 , Coosawhatchie River tributary at Allendale, August $5-6,1988^{--C o n t i n u e d}$

\begin{tabular}{|c|c|c|c|c|c|c|c|c|}
\hline $\begin{array}{l}\text { Time } \\
\text { (hours) }\end{array}$ & $\begin{array}{l}\text { Streamflow } \\
\text { (cubic feet } \\
\text { per second) }\end{array}$ & $\begin{array}{l}\text { Rain- } \\
\text { fall } \\
\text { (inches) }\end{array}$ & $\begin{array}{l}\text { Time } \\
\text { (hours) }\end{array}$ & $\begin{array}{l}\text { Streamflow } \\
\text { (cubic feet } \\
\text { per second) }\end{array}$ & $\begin{array}{l}\text { Rain- } \\
\text { fall } \\
\text { (inches) }\end{array}$ & $\begin{array}{l}\text { Time } \\
\text { (hours) }\end{array}$ & $\begin{array}{l}\text { Streamflow } \\
\text { (cubic feet } \\
\text { per second) }\end{array}$ & $\begin{array}{l}\text { Rain- } \\
\text { fall } \\
\text { (inches) }\end{array}$ \\
\hline $\begin{array}{l}1300 \\
1305 \\
1310 \\
1315 \\
1320\end{array}$ & $\begin{array}{l}1.1 \\
1.1 \\
1.1 \\
1.1 \\
1.1\end{array}$ & $\begin{array}{l}0.00 \\
0.00 \\
0.00 \\
0.00 \\
0.00\end{array}$ & $\begin{array}{l}1405 \\
1410 \\
1415 \\
1420 \\
1425\end{array}$ & $\begin{array}{l}1.0 \\
1.0 \\
1.0 \\
1.0 \\
1.0\end{array}$ & $\begin{array}{l}0.00 \\
0.00 \\
0.00 \\
0.00 \\
0.00\end{array}$ & $\begin{array}{l}1510 \\
1515 \\
1520 \\
1525 \\
1530\end{array}$ & $\begin{array}{l}0.9 \\
0.9 \\
0.9 \\
0.9 \\
0.9\end{array}$ & $\begin{array}{l}0.00 \\
0.00 \\
0.00 \\
0.00 \\
0.00\end{array}$ \\
\hline $\begin{array}{l}1325 \\
1330 \\
1335 \\
1340 \\
1345\end{array}$ & $\begin{array}{l}1.1 \\
1.1 \\
1.1 \\
1.1 \\
1.0\end{array}$ & $\begin{array}{l}0.00 \\
0.00 \\
0.00 \\
0.00 \\
0.00\end{array}$ & $\begin{array}{l}1430 \\
1435 \\
1440 \\
1445 \\
1450\end{array}$ & $\begin{array}{l}1.0 \\
1.0 \\
0.9 \\
0.9 \\
0.9\end{array}$ & $\begin{array}{l}0.00 \\
0.00 \\
0.00 \\
0.00 \\
0.00\end{array}$ & $\begin{array}{l}1535 \\
1540 \\
1545 \\
1550 \\
1555\end{array}$ & $\begin{array}{l}0.9 \\
0.9 \\
0.9 \\
0.9 \\
0.8\end{array}$ & $\begin{array}{l}0.00 \\
0.00 \\
0.00 \\
0.00 \\
0.00\end{array}$ \\
\hline $\begin{array}{l}1350 \\
1355 \\
1400\end{array}$ & $\begin{array}{l}1.0 \\
1.0 \\
1.0\end{array}$ & $\begin{array}{l}0.00 \\
0.00 \\
0.00\end{array}$ & $\begin{array}{l}1455 \\
1500 \\
1505\end{array}$ & $\begin{array}{l}0.9 \\
0.9 \\
0.9\end{array}$ & $\begin{array}{l}0.00 \\
0.00 \\
0.00\end{array}$ & 1600 & 0.8 & 0.00 \\
\hline
\end{tabular}



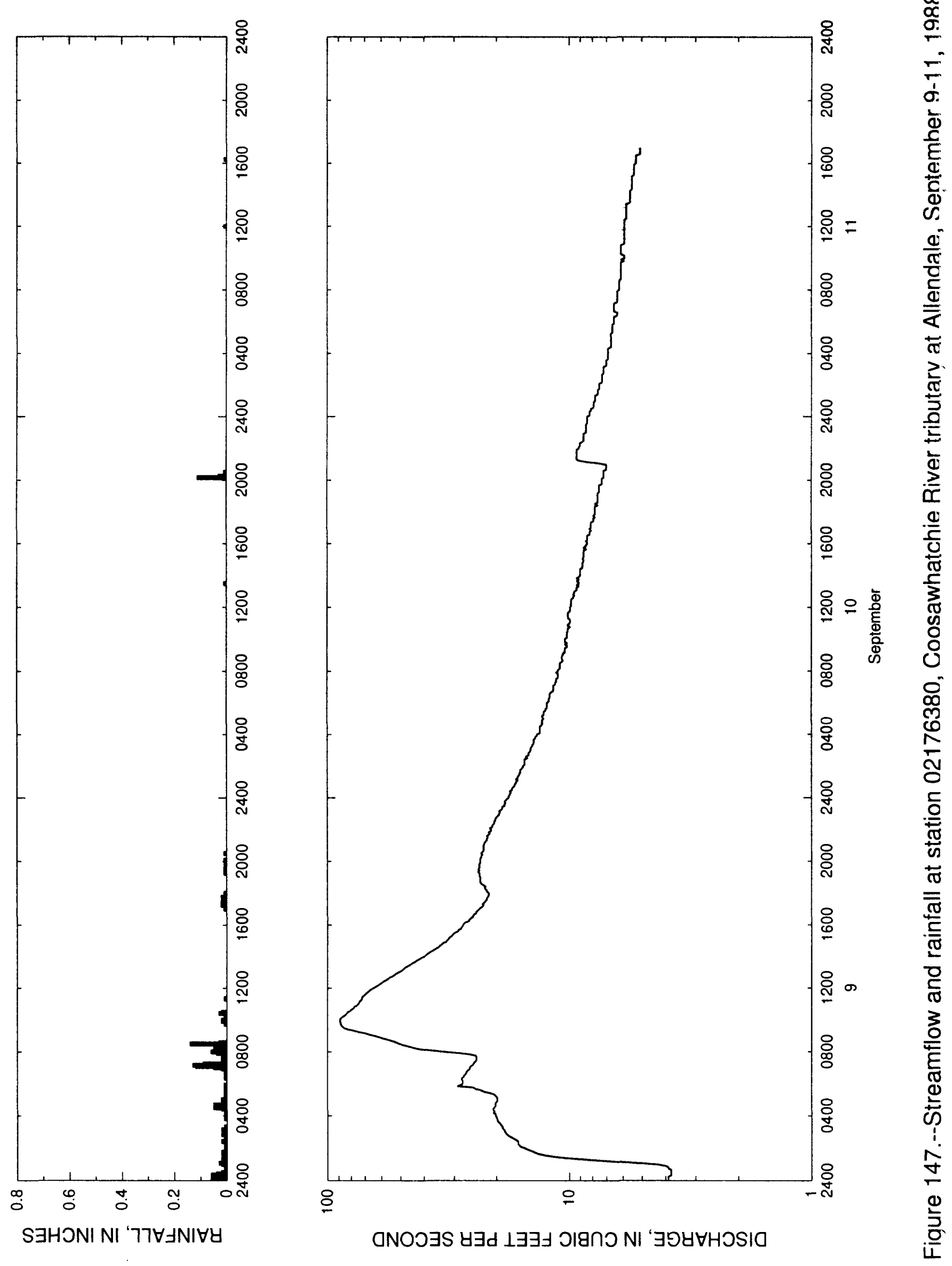
Table 146.--Streamflow and rainfall at station 02176380, Coosawhatchie River tributary at Allendale, September $9-11,1988$

\begin{tabular}{|c|c|c|c|c|c|c|c|c|}
\hline $\begin{array}{l}\text { Time } \\
\text { (hours) }\end{array}$ & $\begin{array}{l}\text { Streamflow } \\
\text { (cubic feet } \\
\text { per second) }\end{array}$ & $\begin{array}{l}\text { Rain- } \\
\text { fall } \\
\text { (inches) }\end{array}$ & $\begin{array}{l}\text { Time } \\
\text { (hours) }\end{array}$ & $\begin{array}{l}\text { Streamflow } \\
\text { (cubic feet } \\
\text { per second) }\end{array}$ & $\begin{array}{l}\text { Rain- } \\
\text { fall } \\
\text { (inches) }\end{array}$ & $\begin{array}{l}\text { Time } \\
\text { (hours) }\end{array}$ & $\begin{array}{l}\text { Streamflow } \\
\text { (cubic feet } \\
\text { per second) }\end{array}$ & $\begin{array}{l}\text { Rain- } \\
\text { fall } \\
\text { (inches) }\end{array}$ \\
\hline $\begin{array}{l}\text { September } \\
0005 \\
0010 \\
0015 \\
0020\end{array}$ & $\begin{array}{c}09,1988 \\
3.9 \\
3.9 \\
3.9 \\
3.8\end{array}$ & $\begin{array}{l}0.06 \\
0.03 \\
0.03 \\
0.06\end{array}$ & $\begin{array}{l}0525 \\
0530 \\
0535 \\
0540 \\
0545\end{array}$ & $\begin{array}{l}21.5 \\
22.6 \\
23.3 \\
24.4 \\
25.1\end{array}$ & $\begin{array}{l}0.00 \\
0.01 \\
0.00 \\
0.00 \\
0.01\end{array}$ & $\begin{array}{l}1050 \\
1055 \\
1100 \\
1105 \\
1110\end{array}$ & $\begin{array}{l}77.7 \\
75.7 \\
74.7 \\
74.3 \\
73.7\end{array}$ & $\begin{array}{l}0.00 \\
0.00 \\
0.00 \\
0.00 \\
0.00\end{array}$ \\
\hline $\begin{array}{l}0025 \\
0030 \\
0035 \\
0040 \\
0045\end{array}$ & $\begin{array}{l}3.8 \\
3.8 \\
3.8 \\
3.8 \\
3.9\end{array}$ & $\begin{array}{l}0.04 \\
0.02 \\
0.01 \\
0.00 \\
0.01\end{array}$ & $\begin{array}{l}0550 \\
0555 \\
0600 \\
0605 \\
0610\end{array}$ & $\begin{array}{l}29.0 \\
28.1 \\
27.6 \\
27.6 \\
27.6\end{array}$ & $\begin{array}{l}0.00 \\
0.01 \\
0.00 \\
0.00 \\
0.00\end{array}$ & $\begin{array}{l}1115 \\
1120 \\
1125 \\
1130 \\
1135\end{array}$ & $\begin{array}{l}72.7 \\
72.1 \\
72.1 \\
71.1 \\
70.1\end{array}$ & $\begin{array}{l}0.00 \\
0.01 \\
0.00 \\
0.00 \\
0.00\end{array}$ \\
\hline $\begin{array}{l}0050 \\
0055 \\
0100 \\
0105 \\
0110\end{array}$ & $\begin{array}{l}3.9 \\
4.0 \\
4.3 \\
5.0 \\
6.2\end{array}$ & $\begin{array}{l}0.01 \\
0.01 \\
0.02 \\
0.03 \\
0.02\end{array}$ & $\begin{array}{l}0615 \\
0620 \\
0625 \\
0630 \\
0635\end{array}$ & $\begin{array}{l}27.9 \\
27.9 \\
27.4 \\
27.2 \\
26.9\end{array}$ & $\begin{array}{l}0.00 \\
0.01 \\
0.00 \\
0.00 \\
0.00\end{array}$ & $\begin{array}{l}1140 \\
1145 \\
1150 \\
1155 \\
1200\end{array}$ & $\begin{array}{l}69.2 \\
68.2 \\
67.3 \\
66.1 \\
64.8\end{array}$ & $\begin{array}{l}0.00 \\
0.00 \\
0.00 \\
0.00 \\
0.00\end{array}$ \\
\hline $\begin{array}{l}0115 \\
0120 \\
0125 \\
0130 \\
0135\end{array}$ & $\begin{array}{r}7.5 \\
9.0 \\
10.6 \\
12.0 \\
12.9\end{array}$ & $\begin{array}{l}0.01 \\
0.02 \\
0.01 \\
0.01 \\
0.01\end{array}$ & $\begin{array}{l}0640 \\
0645 \\
0650 \\
0655 \\
0700\end{array}$ & $\begin{array}{l}26.7 \\
26.5 \\
26.2 \\
25.8 \\
25.8\end{array}$ & $\begin{array}{l}0.01 \\
0.00 \\
0.00 \\
0.02 \\
0.05\end{array}$ & $\begin{array}{l}1205 \\
1210 \\
1215 \\
1220 \\
1225\end{array}$ & $\begin{array}{l}63.3 \\
62.1 \\
60.9 \\
59.7 \\
58.8\end{array}$ & $\begin{array}{l}0.00 \\
0.00 \\
0.00 \\
0.00 \\
0.00\end{array}$ \\
\hline $\begin{array}{l}0140 \\
0145 \\
0150 \\
0155 \\
0200\end{array}$ & $\begin{array}{l}13.6 \\
14.0 \\
14.4 \\
14.9 \\
15.3\end{array}$ & $\begin{array}{l}0.02 \\
0.02 \\
0.01 \\
0.00 \\
0.01\end{array}$ & $\begin{array}{l}0705 \\
0710 \\
0715 \\
0720 \\
0725\end{array}$ & $\begin{array}{l}25.6 \\
25.1 \\
24.9 \\
24.7 \\
24.4\end{array}$ & $\begin{array}{l}0.12 \\
0.13 \\
0.09 \\
0.02 \\
0.01\end{array}$ & $\begin{array}{l}1230 \\
1235 \\
1240 \\
1245 \\
1250\end{array}$ & $\begin{array}{l}57.3 \\
56.2 \\
55.3 \\
53.8 \\
52.9\end{array}$ & $\begin{array}{l}0.00 \\
0.00 \\
0.00 \\
0.00 \\
0.00\end{array}$ \\
\hline $\begin{array}{l}0205 \\
0210 \\
0215 \\
0220 \\
0225\end{array}$ & $\begin{array}{l}15.9 \\
16.1 \\
16.3 \\
16.3 \\
16.3\end{array}$ & $\begin{array}{l}0.01 \\
0.00 \\
0.01 \\
0.00 \\
0.02\end{array}$ & $\begin{array}{l}0730 \\
0735 \\
0740 \\
0745 \\
0750\end{array}$ & $\begin{array}{l}24.2 \\
24.2 \\
24.2 \\
24.4 \\
25.6\end{array}$ & $\begin{array}{l}0.00 \\
0.02 \\
0.02 \\
0.01 \\
0.02\end{array}$ & $\begin{array}{l}1255 \\
1300 \\
1305 \\
1310 \\
1315\end{array}$ & $\begin{array}{l}52.1 \\
50.9 \\
49.7 \\
48.9 \\
48.3\end{array}$ & $\begin{array}{l}0.00 \\
0.00 \\
0.00 \\
0.00 \\
0.00\end{array}$ \\
\hline $\begin{array}{l}0230 \\
0235 \\
0240 \\
0245 \\
0250\end{array}$ & $\begin{array}{l}16.6 \\
17.0 \\
17.4 \\
17.8 \\
18.1\end{array}$ & $\begin{array}{l}0.01 \\
0.01 \\
0.01 \\
0.01 \\
0.02\end{array}$ & $\begin{array}{l}0755 \\
0800 \\
0805 \\
0810 \\
0815\end{array}$ & $\begin{array}{l}28.6 \\
33.1 \\
37.4 \\
41.5 \\
44.2\end{array}$ & $\begin{array}{l}0.04 \\
0.06 \\
0.03 \\
0.05 \\
0.02\end{array}$ & $\begin{array}{l}1320 \\
1325 \\
1330 \\
1335 \\
1340\end{array}$ & $\begin{array}{l}47.5 \\
46.4 \\
45.5 \\
44.7 \\
43.6\end{array}$ & $\begin{array}{l}0.00 \\
0.00 \\
0.00 \\
0.00 \\
0.00\end{array}$ \\
\hline $\begin{array}{l}0255 \\
0300 \\
0305 \\
0310 \\
0315\end{array}$ & $\begin{array}{l}18.3 \\
18.5 \\
18.5 \\
18.7 \\
18.9\end{array}$ & $\begin{array}{l}0.00 \\
0.00 \\
0.01 \\
0.02 \\
0.01\end{array}$ & $\begin{array}{l}0820 \\
0825 \\
0830 \\
0835 \\
0840\end{array}$ & $\begin{array}{l}46.1 \\
48.3 \\
50.3 \\
51.8 \\
53.5\end{array}$ & $\begin{array}{l}0.00 \\
0.05 \\
0.14 \\
0.03 \\
0.00\end{array}$ & $\begin{array}{l}1345 \\
1350 \\
1355 \\
1400 \\
1405\end{array}$ & $\begin{array}{l}42.8 \\
41.8 \\
41.0 \\
39.9 \\
39.2\end{array}$ & $\begin{array}{l}0.00 \\
0.00 \\
0.00 \\
0.00 \\
0.00\end{array}$ \\
\hline $\begin{array}{l}0320 \\
0325 \\
0330 \\
0335 \\
0340\end{array}$ & $\begin{array}{l}18.9 \\
19.1 \\
19.3 \\
19.5 \\
19.8\end{array}$ & $\begin{array}{l}0.01 \\
0.00 \\
0.00 \\
0.00 \\
0.00\end{array}$ & $\begin{array}{l}0845 \\
0850 \\
0855 \\
0900 \\
0905\end{array}$ & $\begin{array}{l}55.9 \\
58.8 \\
61.2 \\
63.9 \\
67.3\end{array}$ & $\begin{array}{l}0.00 \\
0.00 \\
0.00 \\
0.00 \\
0.00\end{array}$ & $\begin{array}{l}1410 \\
1415 \\
1420 \\
1425 \\
1430\end{array}$ & $\begin{array}{l}38.6 \\
37.9 \\
37.1 \\
36.3 \\
35.6\end{array}$ & $\begin{array}{l}0.00 \\
0.00 \\
0.00 \\
0.00 \\
0.00\end{array}$ \\
\hline $\begin{array}{l}0345 \\
0350 \\
0355 \\
0400 \\
0405\end{array}$ & $\begin{array}{l}19.8 \\
20.0 \\
20.0 \\
20.2 \\
20.2\end{array}$ & $\begin{array}{l}0.00 \\
0.01 \\
0.00 \\
0.01 \\
0.00\end{array}$ & $\begin{array}{l}0910 \\
0915 \\
0920 \\
0925 \\
0930\end{array}$ & $\begin{array}{l}69.8 \\
74.3 \\
77.7 \\
82.5 \\
85.6\end{array}$ & $\begin{array}{l}0.00 \\
0.00 \\
0.00 \\
0.00 \\
0.00\end{array}$ & $\begin{array}{l}1435 \\
1440 \\
1445 \\
1450 \\
1455\end{array}$ & $\begin{array}{l}34.8 \\
34.4 \\
33.9 \\
33.4 \\
32.4\end{array}$ & $\begin{array}{l}0.00 \\
0.00 \\
0.00 \\
0.00 \\
0.00\end{array}$ \\
\hline $\begin{array}{l}0410 \\
0415 \\
0420 \\
0425 \\
0430\end{array}$ & $\begin{array}{l}20.6 \\
20.4 \\
20.6 \\
20.6 \\
20.4\end{array}$ & $\begin{array}{l}0.01 \\
0.01 \\
0.01 \\
0.02 \\
0.05\end{array}$ & $\begin{array}{l}0935 \\
0940 \\
0945 \\
0950 \\
0955\end{array}$ & $\begin{array}{l}86.9 \\
87.9 \\
88.5 \\
88.5 \\
89.1\end{array}$ & $\begin{array}{l}0.00 \\
0.00 \\
0.01 \\
0.00 \\
0.02\end{array}$ & $\begin{array}{l}1500 \\
1505 \\
1510 \\
1515 \\
1520\end{array}$ & $\begin{array}{l}32.2 \\
31.7 \\
31.5 \\
31.0 \\
30.5\end{array}$ & $\begin{array}{l}0.00 \\
0.00 \\
0.00 \\
0.00 \\
0.00\end{array}$ \\
\hline $\begin{array}{l}0435 \\
0440 \\
0445 \\
0450 \\
0455\end{array}$ & $\begin{array}{l}20.2 \\
20.2 \\
20.2 \\
20.0 \\
19.8\end{array}$ & $\begin{array}{l}0.04 \\
0.05 \\
0.02 \\
0.01 \\
0.02\end{array}$ & $\begin{array}{l}1000 \\
1005 \\
1010 \\
1015 \\
1020\end{array}$ & $\begin{array}{l}88.8 \\
88.5 \\
87.5 \\
85.6 \\
84.4\end{array}$ & $\begin{array}{l}0.02 \\
0.01 \\
0.01 \\
0.01 \\
0.01\end{array}$ & $\begin{array}{l}1525 \\
1530 \\
1535 \\
1540 \\
1545\end{array}$ & $\begin{array}{l}30.3 \\
29.8 \\
29.0 \\
28.8 \\
28.1\end{array}$ & $\begin{array}{l}0.00 \\
0.00 \\
0.00 \\
0.00 \\
0.00\end{array}$ \\
\hline $\begin{array}{l}0500 \\
2505 \\
0510 \\
0515 \\
0520\end{array}$ & $\begin{array}{l}19.8 \\
19.8 \\
20.0 \\
20.2 \\
20.6\end{array}$ & $\begin{array}{l}0.02 \\
0.00 \\
0.01 \\
0.00 \\
0.01\end{array}$ & $\begin{array}{l}1025 \\
1030 \\
1035 \\
1040 \\
1045\end{array}$ & $\begin{array}{l}83.3 \\
82.5 \\
80.6 \\
79.7 \\
78.0\end{array}$ & $\begin{array}{l}0.03 \\
0.02 \\
0.00 \\
0.00 \\
0.00\end{array}$ & $\begin{array}{l}1550 \\
1555 \\
1600 \\
1605 \\
1610\end{array}$ & $\begin{array}{l}28.1 \\
27.6 \\
27.6 \\
27.2 \\
26.9\end{array}$ & $\begin{array}{l}0.00 \\
0.00 \\
0.00 \\
0.00 \\
0.00\end{array}$ \\
\hline
\end{tabular}


Table 146. - Streamflow and rainfall at station 02176380 , Coosawhatchie River tributary at Allendale, September 9-11, 1988--Continued

\begin{tabular}{|c|c|c|c|c|c|c|c|c|}
\hline $\begin{array}{l}\text { Time } \\
\text { (hours) }\end{array}$ & $\begin{array}{l}\text { Streamflow } \\
\text { (cubic feet } \\
\text { per second) }\end{array}$ & $\begin{array}{l}\text { Rain- } \\
\text { fall } \\
\text { (inches) }\end{array}$ & $\begin{array}{l}\text { Time } \\
\text { (hours) }\end{array}$ & $\begin{array}{l}\text { Streamflow } \\
\text { (cubic feet } \\
\text { per second) }\end{array}$ & $\begin{array}{l}\text { Rain- } \\
\text { fall } \\
\text { (inches) }\end{array}$ & $\begin{array}{l}\text { Time } \\
\text { (hours) }\end{array}$ & $\begin{array}{l}\text { Streamflow } \\
\text { (cubic feet } \\
\text { per second) }\end{array}$ & $\begin{array}{l}\text { Rain- } \\
\text { fall } \\
\text { (inches) }\end{array}$ \\
\hline $\begin{array}{l}1615 \\
1620 \\
1625 \\
1630 \\
1635\end{array}$ & $\begin{array}{l}26.0 \\
26.0 \\
25.6 \\
25.1 \\
24.9\end{array}$ & $\begin{array}{l}0.00 \\
0.00 \\
0.00 \\
0.00 \\
0.00\end{array}$ & $\begin{array}{l}2140 \\
2145 \\
2150 \\
2155 \\
2200\end{array}$ & $\begin{array}{l}21.5 \\
21.3 \\
21.5 \\
21.0 \\
21.0\end{array}$ & $\begin{array}{l}0.00 \\
0.00 \\
0.00 \\
0.00 \\
0.00\end{array}$ & $\begin{array}{l}0300 \\
0305 \\
0310 \\
0315 \\
0320\end{array}$ & $\begin{array}{l}14.4 \\
14.4 \\
14.4 \\
14.2 \\
14.2\end{array}$ & $\begin{array}{l}0.00 \\
0.00 \\
0.00 \\
0.00 \\
0.00\end{array}$ \\
\hline $\begin{array}{l}1640 \\
1645 \\
1650 \\
1655 \\
1700\end{array}$ & $\begin{array}{l}24.7 \\
24.2 \\
24.2 \\
23.8 \\
23.5\end{array}$ & $\begin{array}{l}0.00 \\
0.00 \\
0.00 \\
0.00 \\
0.01\end{array}$ & $\begin{array}{l}2205 \\
2210 \\
2215 \\
2220 \\
2225\end{array}$ & $\begin{array}{l}21.3 \\
20.8 \\
20.8 \\
20.6 \\
20.4\end{array}$ & $\begin{array}{l}0.00 \\
0.00 \\
0.00 \\
0.00 \\
0.00\end{array}$ & $\begin{array}{l}0325 \\
0330 \\
0335 \\
0340 \\
0345\end{array}$ & $\begin{array}{l}14.0 \\
14.0 \\
14.0 \\
14.0 \\
13.8\end{array}$ & $\begin{array}{l}0.00 \\
0.00 \\
0.00 \\
0.00 \\
0.00\end{array}$ \\
\hline $\begin{array}{l}1705 \\
1710 \\
1715 \\
1720 \\
1725\end{array}$ & $\begin{array}{l}23.3 \\
22.8 \\
22.6 \\
22.8 \\
22.4\end{array}$ & $\begin{array}{l}0.00 \\
0.01 \\
0.02 \\
0.01 \\
0.02\end{array}$ & $\begin{array}{l}2230 \\
2235 \\
2240 \\
2245 \\
2250\end{array}$ & $\begin{array}{l}20.4 \\
20.2 \\
20.2 \\
20.0 \\
19.8\end{array}$ & $\begin{array}{l}0.00 \\
0.00 \\
0.00 \\
0.00 \\
0.00\end{array}$ & $\begin{array}{l}0350 \\
0355 \\
0400 \\
0405 \\
0410\end{array}$ & $\begin{array}{l}13.8 \\
13.6 \\
13.6 \\
13.2 \\
13.2\end{array}$ & $\begin{array}{l}0.00 \\
0.00 \\
0.00 \\
0.00 \\
0.00\end{array}$ \\
\hline $\begin{array}{l}1730 \\
1735 \\
1740 \\
1745 \\
1750\end{array}$ & $\begin{array}{l}22.2 \\
21.9 \\
21.9 \\
21.7 \\
21.5\end{array}$ & $\begin{array}{l}0.01 \\
0.01 \\
0.01 \\
0.02 \\
0.01\end{array}$ & $\begin{array}{l}2255 \\
2300 \\
2305 \\
2310 \\
2315\end{array}$ & $\begin{array}{l}19.5 \\
19.5 \\
19.3 \\
19.5 \\
19.1\end{array}$ & $\begin{array}{l}0.00 \\
0.00 \\
0.00 \\
0.00 \\
0.00\end{array}$ & $\begin{array}{l}0415 \\
0420 \\
0425 \\
0430 \\
0435\end{array}$ & $\begin{array}{l}13.2 \\
13.2 \\
13.2 \\
13.2 \\
13.0\end{array}$ & $\begin{array}{l}0.00 \\
0.00 \\
0.00 \\
0.00 \\
0.00\end{array}$ \\
\hline $\begin{array}{l}1755 \\
1800 \\
1805 \\
1810 \\
1815\end{array}$ & $\begin{array}{l}21.5 \\
21.5 \\
21.9 \\
21.9 \\
22.2\end{array}$ & $\begin{array}{l}0.00 \\
0.01 \\
0.00 \\
0.00 \\
0.00\end{array}$ & $\begin{array}{l}2320 \\
2325 \\
2330 \\
2335 \\
2340\end{array}$ & $\begin{array}{l}18.9 \\
18.9 \\
18.5 \\
18.5 \\
18.3\end{array}$ & $\begin{array}{l}0.00 \\
0.00 \\
0.00 \\
0.00 \\
0.00\end{array}$ & $\begin{array}{l}0440 \\
0445 \\
0450 \\
0455 \\
0500\end{array}$ & $\begin{array}{l}12.9 \\
12.9 \\
12.9 \\
12.9 \\
12.7\end{array}$ & $\begin{array}{l}0.00 \\
0.00 \\
0.00 \\
0.00 \\
0.00\end{array}$ \\
\hline $\begin{array}{l}1820 \\
1825 \\
1830 \\
1835 \\
1840\end{array}$ & $\begin{array}{l}22.4 \\
22.2 \\
22.6 \\
23.1 \\
23.3\end{array}$ & $\begin{array}{l}0.00 \\
0.00 \\
0.00 \\
0.00 \\
0.00\end{array}$ & $\begin{array}{l}2345 \\
2350 \\
2355 \\
\text { September } \\
0000\end{array}$ & $\begin{array}{c}18.5 \\
18.3 \\
18.1 \\
1 \quad 10,1988 \\
17.8\end{array}$ & $\begin{array}{l}0.00 \\
0.00 \\
0.00 \\
0.00\end{array}$ & $\begin{array}{l}0505 \\
0510 \\
0515 \\
0520 \\
0525\end{array}$ & $\begin{array}{l}12.9 \\
12.9 \\
12.7 \\
12.7 \\
12.7\end{array}$ & $\begin{array}{l}0.00 \\
0.00 \\
0.00 \\
0.00 \\
0.00\end{array}$ \\
\hline $\begin{array}{l}1845 \\
1850 \\
1855 \\
1900 \\
1905\end{array}$ & $\begin{array}{l}23.3 \\
23.3 \\
23.3 \\
23.3 \\
23.5\end{array}$ & $\begin{array}{l}0.00 \\
0.00 \\
0.00 \\
0.00 \\
0.00\end{array}$ & $\begin{array}{l}0005 \\
0010 \\
0015 \\
0020 \\
0025\end{array}$ & $\begin{array}{l}17.8 \\
17.6 \\
17.6 \\
17.4 \\
17.6\end{array}$ & $\begin{array}{l}0.00 \\
0.00 \\
0.00 \\
0.00 \\
0.00\end{array}$ & $\begin{array}{l}0530 \\
0535 \\
0540 \\
0545 \\
0550\end{array}$ & $\begin{array}{l}12.5 \\
12.5 \\
12.3 \\
12.3 \\
12.3\end{array}$ & $\begin{array}{l}0.00 \\
0.00 \\
0.00 \\
0.00 \\
0.00\end{array}$ \\
\hline $\begin{array}{l}1910 \\
1915 \\
1920 \\
1925 \\
1930\end{array}$ & $\begin{array}{l}23.5 \\
23.5 \\
23.8 \\
23.5 \\
23.8\end{array}$ & $\begin{array}{l}0.00 \\
0.01 \\
0.00 \\
0.01 \\
0.00\end{array}$ & $\begin{array}{l}0030 \\
0035 \\
0040 \\
0045 \\
0050\end{array}$ & $\begin{array}{l}17.2 \\
17.2 \\
17.0 \\
16.8 \\
16.8\end{array}$ & $\begin{array}{l}0.00 \\
0.00 \\
0.00 \\
0.00 \\
0.00\end{array}$ & $\begin{array}{l}0555 \\
0600 \\
0605 \\
0610 \\
0615\end{array}$ & $\begin{array}{l}12.3 \\
12.3 \\
12.1 \\
12.1 \\
12.1\end{array}$ & $\begin{array}{l}0.00 \\
0.00 \\
0.00 \\
0.00 \\
0.00\end{array}$ \\
\hline $\begin{array}{l}1935 \\
1940 \\
1945 \\
1950 \\
1955\end{array}$ & $\begin{array}{l}23.5 \\
23.5 \\
23.5 \\
23.5 \\
23.3\end{array}$ & $\begin{array}{l}0.01 \\
0.00 \\
0.00 \\
0.00 \\
0.01\end{array}$ & $\begin{array}{l}0055 \\
0100 \\
0105 \\
0110 \\
0115\end{array}$ & $\begin{array}{l}16.6 \\
16.6 \\
16.3 \\
16.6 \\
16.3\end{array}$ & $\begin{array}{l}0.00 \\
0.00 \\
0.00 \\
0.00 \\
0.00\end{array}$ & $\begin{array}{l}0620 \\
0625 \\
0630 \\
0635 \\
0640\end{array}$ & $\begin{array}{l}12.0 \\
12.0 \\
12.0 \\
12.0 \\
11.8\end{array}$ & $\begin{array}{l}0.00 \\
0.00 \\
0.00 \\
0.00 \\
0.00\end{array}$ \\
\hline $\begin{array}{l}2000 \\
2005 \\
2010 \\
2015 \\
2020\end{array}$ & $\begin{array}{l}23.3 \\
23.3 \\
23.3 \\
23.1 \\
23.1\end{array}$ & $\begin{array}{l}0.00 \\
0.01 \\
0.00 \\
0.00 \\
0.00\end{array}$ & $\begin{array}{l}0120 \\
0125 \\
0130 \\
0135 \\
0140\end{array}$ & $\begin{array}{l}16.3 \\
16.1 \\
16.1 \\
15.9 \\
15.9\end{array}$ & $\begin{array}{l}0.00 \\
0.00 \\
0.00 \\
0.00 \\
0.00\end{array}$ & $\begin{array}{l}0645 \\
0650 \\
0655 \\
0700 \\
0705\end{array}$ & $\begin{array}{l}11.6 \\
11.6 \\
11.6 \\
11.6 \\
11.6\end{array}$ & $\begin{array}{l}0.00 \\
0.00 \\
0.00 \\
0.00 \\
0.00\end{array}$ \\
\hline $\begin{array}{l}2025 \\
2030 \\
2035 \\
2040 \\
2045\end{array}$ & $\begin{array}{l}22.8 \\
23.1 \\
22.8 \\
22.6 \\
22.6\end{array}$ & $\begin{array}{l}0.00 \\
0.01 \\
0.00 \\
0.00 \\
0.00\end{array}$ & $\begin{array}{l}0145 \\
0150 \\
0155 \\
0200 \\
0205\end{array}$ & $\begin{array}{l}15.9 \\
15.7 \\
15.5 \\
15.5 \\
15.3\end{array}$ & $\begin{array}{l}0.00 \\
0.00 \\
0.00 \\
0.00 \\
0.00\end{array}$ & $\begin{array}{l}0710 \\
0715 \\
0720 \\
0725 \\
0730\end{array}$ & $\begin{array}{l}11.4 \\
11.4 \\
11.3 \\
11.3 \\
11.3\end{array}$ & $\begin{array}{l}0.00 \\
0.00 \\
0.00 \\
0.00 \\
0.00\end{array}$ \\
\hline $\begin{array}{l}2050 \\
2055 \\
2100 \\
2105 \\
2110\end{array}$ & $\begin{array}{l}22.6 \\
22.6 \\
22.6 \\
22.4 \\
22.4\end{array}$ & $\begin{array}{l}0.00 \\
0.00 \\
0.00 \\
0.00 \\
0.00\end{array}$ & $\begin{array}{l}0210 \\
0215 \\
0220 \\
0225 \\
0230\end{array}$ & $\begin{array}{l}15.3 \\
15.3 \\
15.3 \\
15.3 \\
14.9\end{array}$ & $\begin{array}{l}0.00 \\
0.00 \\
0.00 \\
0.00 \\
0.00\end{array}$ & $\begin{array}{l}0735 \\
0740 \\
0745 \\
0750 \\
0755\end{array}$ & $\begin{array}{l}11.1 \\
11.1 \\
11.1 \\
11.1 \\
11.3\end{array}$ & $\begin{array}{l}0.00 \\
0.00 \\
0.00 \\
0.00 \\
0.00\end{array}$ \\
\hline $\begin{array}{l}2115 \\
2120 \\
2125 \\
2130 \\
2135\end{array}$ & $\begin{array}{l}22.2 \\
21.9 \\
21.9 \\
21.7 \\
21.9\end{array}$ & $\begin{array}{l}0.00 \\
0.00 \\
0.00 \\
0.00 \\
0.00\end{array}$ & $\begin{array}{l}0235 \\
0240 \\
0245 \\
0250 \\
0255\end{array}$ & $\begin{array}{l}15.1 \\
14.7 \\
14.7 \\
14.7 \\
14.5\end{array}$ & $\begin{array}{l}0.00 \\
0.00 \\
0.00 \\
0.00 \\
0.00\end{array}$ & $\begin{array}{l}0800 \\
0805 \\
0810 \\
0815 \\
0820\end{array}$ & $\begin{array}{l}11.1 \\
11.1 \\
10.9 \\
10.9 \\
10.9\end{array}$ & $\begin{array}{l}0.00 \\
0.00 \\
0.00 \\
0.00 \\
0.00\end{array}$ \\
\hline
\end{tabular}


Table 146 . - - Streamflow and rainfall at station 02176380 , Coosawhatchie River tributary at Allendale, September 9-11, 1988--Continued

\begin{tabular}{|c|c|c|c|c|c|c|c|c|}
\hline $\begin{array}{l}\text { Time } \\
\text { (hours) }\end{array}$ & $\begin{array}{l}\text { Streamflow } \\
\text { (cubic feet } \\
\text { per second) }\end{array}$ & $\begin{array}{l}\text { Rain- } \\
\text { fall } \\
\text { (inches) }\end{array}$ & $\begin{array}{l}\text { Time } \\
\text { (hours) }\end{array}$ & $\begin{array}{l}\text { Streamflow } \\
\text { (cubic feet } \\
\text { per second) }\end{array}$ & $\begin{array}{l}\text { Rain- } \\
\text { fall } \\
\text { (inches) }\end{array}$ & $\begin{array}{l}\text { Time } \\
\text { (hours) }\end{array}$ & $\begin{array}{l}\text { Streamflow } \\
\text { (cubic feet } \\
\text { per second) }\end{array}$ & $\begin{array}{l}\text { Rain- } \\
\text { fall } \\
\text { (inchos) }\end{array}$ \\
\hline $\begin{array}{l}0825 \\
0830 \\
0835 \\
0840 \\
0845\end{array}$ & $\begin{array}{l}10.9 \\
10.9 \\
10.7 \\
10.6 \\
10.7\end{array}$ & $\begin{array}{l}0.00 \\
0.00 \\
0.00 \\
0.00 \\
0.00\end{array}$ & $\begin{array}{l}1350 \\
1355 \\
1400 \\
1405 \\
1410\end{array}$ & $\begin{array}{l}9.3 \\
9.1 \\
9.0 \\
9.0 \\
9.0\end{array}$ & $\begin{array}{l}0.00 \\
0.00 \\
0.00 \\
0.00 \\
0.00\end{array}$ & $\begin{array}{l}1915 \\
1920 \\
1925 \\
1930 \\
1935\end{array}$ & $\begin{array}{l}7.5 \\
7.5 \\
7.5 \\
7.5 \\
7.5\end{array}$ & $\begin{array}{l}0.00 \\
0.00 \\
0.00 \\
0.00 \\
0.00\end{array}$ \\
\hline $\begin{array}{l}0850 \\
0855 \\
0900 \\
0905 \\
0910\end{array}$ & $\begin{array}{l}10.7 \\
10.7 \\
10.6 \\
10.6 \\
10.4\end{array}$ & $\begin{array}{l}0.00 \\
0.00 \\
0.00 \\
0.00 \\
0.00\end{array}$ & $\begin{array}{l}1415 \\
1420 \\
1425 \\
1430 \\
1435\end{array}$ & $\begin{array}{l}9.0 \\
9.0 \\
9.0 \\
8.8 \\
8.8\end{array}$ & $\begin{array}{l}0.00 \\
0.00 \\
0.00 \\
0.00 \\
0.00\end{array}$ & $\begin{array}{l}1940 \\
1945 \\
1950 \\
1955 \\
2000\end{array}$ & $\begin{array}{l}7.5 \\
7.3 \\
7.3 \\
7.3 \\
7.3\end{array}$ & $\begin{array}{l}0.00 \\
0.00 \\
0.00 \\
0.00 \\
0.00\end{array}$ \\
\hline $\begin{array}{l}0915 \\
0920 \\
0925 \\
0930 \\
0935\end{array}$ & $\begin{array}{l}10.4 \\
10.4 \\
10.4 \\
10.2 \\
10.2\end{array}$ & $\begin{array}{l}0.00 \\
0.00 \\
0.00 \\
0.00 \\
0.00\end{array}$ & $\begin{array}{l}1440 \\
1445 \\
1450 \\
1455 \\
1500\end{array}$ & $\begin{array}{l}8.8 \\
8.8 \\
8.8 \\
8.7 \\
8.7\end{array}$ & $\begin{array}{l}0.00 \\
0.00 \\
0.00 \\
0.00 \\
0.00\end{array}$ & $\begin{array}{l}2005 \\
2010 \\
2015 \\
2020 \\
2025\end{array}$ & $\begin{array}{l}7.3 \\
7.2 \\
7.2 \\
7.2 \\
7.2\end{array}$ & $\begin{array}{l}0.00 \\
0.11 \\
0.03 \\
0.01 \\
0.00\end{array}$ \\
\hline $\begin{array}{l}0940 \\
0945 \\
0950 \\
0955 \\
1000\end{array}$ & $\begin{array}{l}10.4 \\
10.2 \\
10.4 \\
10.4 \\
10.4\end{array}$ & $\begin{array}{l}0.00 \\
0.00 \\
0.00 \\
0.00 \\
0.00\end{array}$ & $\begin{array}{l}1505 \\
1510 \\
1515 \\
1520 \\
1525\end{array}$ & $\begin{array}{l}8.8 \\
8.7 \\
8.7 \\
8.7 \\
8.7\end{array}$ & $\begin{array}{l}0.00 \\
0.00 \\
0.00 \\
0.00 \\
0.00\end{array}$ & $\begin{array}{l}2030 \\
2035 \\
2040 \\
2045 \\
2050\end{array}$ & $\begin{array}{l}7.2 \\
7.2 \\
7.0 \\
7.0 \\
7.0\end{array}$ & $\begin{array}{l}0.01 \\
0.00 \\
0.00 \\
0.00 \\
0.00\end{array}$ \\
\hline $\begin{array}{l}1005 \\
1010 \\
1015 \\
1020 \\
1025\end{array}$ & $\begin{array}{l}10.2 \\
10.2 \\
10.2 \\
10.2 \\
10.2\end{array}$ & $\begin{array}{l}0.00 \\
0.00 \\
0.00 \\
0.00 \\
0.00\end{array}$ & $\begin{array}{l}1530 \\
1535 \\
1540 \\
1545 \\
1550\end{array}$ & $\begin{array}{l}8.7 \\
8.7 \\
8.5 \\
8.7 \\
8.5\end{array}$ & $\begin{array}{l}0.00 \\
0.00 \\
0.00 \\
0.00 \\
0.00\end{array}$ & $\begin{array}{l}2055 \\
2100 \\
2105 \\
2110 \\
2115\end{array}$ & $\begin{array}{l}7.0 \\
7.0 \\
7.6 \\
8.5 \\
9.1\end{array}$ & $\begin{array}{l}0.00 \\
0.00 \\
0.00 \\
0.00 \\
0.00\end{array}$ \\
\hline $\begin{array}{l}1030 \\
1035 \\
1040 \\
1045 \\
1050\end{array}$ & $\begin{array}{r}10.1 \\
10.1 \\
10.1 \\
9.9 \\
10.1\end{array}$ & $\begin{array}{l}0.00 \\
0.00 \\
0.00 \\
0.00 \\
0.00\end{array}$ & $\begin{array}{l}1555 \\
1600 \\
1605 \\
1610 \\
1615\end{array}$ & $\begin{array}{l}8.5 \\
8.4 \\
8.4 \\
8.5 \\
8.4\end{array}$ & $\begin{array}{l}0.00 \\
0.00 \\
0.00 \\
0.00 \\
0.00\end{array}$ & $\begin{array}{l}2120 \\
2125 \\
2130 \\
2135 \\
2140\end{array}$ & $\begin{array}{l}9.3 \\
9.3 \\
9.3 \\
9.3 \\
9.3\end{array}$ & $\begin{array}{l}0.00 \\
0.00 \\
0.00 \\
0.00 \\
0.00\end{array}$ \\
\hline $\begin{array}{l}1055 \\
1100 \\
1105 \\
1110 \\
1115\end{array}$ & $\begin{array}{r}10.1 \\
9.9 \\
9.9 \\
9.9 \\
9.9\end{array}$ & $\begin{array}{l}0.00 \\
0.00 \\
0.00 \\
0.00 \\
0.00\end{array}$ & $\begin{array}{l}1620 \\
1625 \\
1630 \\
1635 \\
1640\end{array}$ & $\begin{array}{l}8.4 \\
8.4 \\
8.4 \\
8.2 \\
8.2\end{array}$ & $\begin{array}{l}0.00 \\
0.00 \\
0.00 \\
0.00 \\
0.00\end{array}$ & $\begin{array}{l}2145 \\
2150 \\
2155 \\
2200 \\
2205\end{array}$ & $\begin{array}{l}9.3 \\
9.3 \\
9.3 \\
9.1 \\
9.1\end{array}$ & $\begin{array}{l}0.00 \\
0.00 \\
0.00 \\
0.00 \\
0.00\end{array}$ \\
\hline $\begin{array}{l}1120 \\
1125 \\
1130 \\
1135 \\
1140\end{array}$ & $\begin{array}{l}10.1 \\
10.1 \\
10.1 \\
10.1 \\
10.1\end{array}$ & $\begin{array}{l}0.00 \\
0.00 \\
0.00 \\
0.00 \\
0.00\end{array}$ & $\begin{array}{l}1645 \\
1650 \\
1655 \\
1700 \\
1705\end{array}$ & $\begin{array}{l}8.2 \\
8.1 \\
8.2 \\
8.1 \\
8.1\end{array}$ & $\begin{array}{l}0.00 \\
0.00 \\
0.00 \\
0.00 \\
0.00\end{array}$ & $\begin{array}{l}2210 \\
2215 \\
2220 \\
2225 \\
2230\end{array}$ & $\begin{array}{l}9.0 \\
9.0 \\
9.0 \\
8.8 \\
8.7\end{array}$ & $\begin{array}{l}0.00 \\
0.00 \\
0.00 \\
0.00 \\
0.00\end{array}$ \\
\hline $\begin{array}{l}1145 \\
1150 \\
1155 \\
1200 \\
1205\end{array}$ & $\begin{array}{l}9.9 \\
9.9 \\
9.9 \\
9.9 \\
9.8\end{array}$ & $\begin{array}{l}0.00 \\
0.00 \\
0.00 \\
0.00 \\
0.00\end{array}$ & $\begin{array}{l}1710 \\
1715 \\
1720 \\
1725 \\
1730\end{array}$ & $\begin{array}{l}8.1 \\
8.1 \\
8.1 \\
7.9 \\
7.9\end{array}$ & $\begin{array}{l}0.00 \\
0.00 \\
0.00 \\
0.00 \\
0.00\end{array}$ & $\begin{array}{l}2235 \\
2240 \\
2245 \\
2250 \\
2255\end{array}$ & $\begin{array}{l}8.7 \\
8.7 \\
8.7 \\
8.7 \\
8.7\end{array}$ & $\begin{array}{l}0.00 \\
0.00 \\
0.00 \\
0.00 \\
0.00\end{array}$ \\
\hline $\begin{array}{l}1210 \\
1215 \\
1220 \\
1225 \\
1230\end{array}$ & $\begin{array}{l}9.8 \\
9.8 \\
9.8 \\
9.8 \\
9.8\end{array}$ & $\begin{array}{l}0.00 \\
0.00 \\
0.00 \\
0.00 \\
0.00\end{array}$ & $\begin{array}{l}1735 \\
1740 \\
1745 \\
1750 \\
1755\end{array}$ & $\begin{array}{l}7.9 \\
7.8 \\
7.9 \\
7.8 \\
7.8\end{array}$ & $\begin{array}{l}0.00 \\
0.00 \\
0.00 \\
0.00 \\
0.00\end{array}$ & $\begin{array}{l}2300 \\
2305 \\
2310 \\
2315 \\
2320\end{array}$ & $\begin{array}{l}8.5 \\
8.5 \\
8.5 \\
8.5 \\
8.5\end{array}$ & $\begin{array}{l}0.00 \\
0.00 \\
0.00 \\
0.00 \\
0.00\end{array}$ \\
\hline $\begin{array}{l}1235 \\
1240 \\
1245 \\
1250 \\
1255\end{array}$ & $\begin{array}{l}9.6 \\
9.6 \\
9.5 \\
9.6 \\
9.5\end{array}$ & $\begin{array}{l}0.00 \\
0.00 \\
0.00 \\
0.00 \\
0.00\end{array}$ & $\begin{array}{l}1800 \\
1805 \\
1810 \\
1815 \\
1820\end{array}$ & $\begin{array}{l}7.8 \\
7.8 \\
7.8 \\
7.8 \\
7.8\end{array}$ & $\begin{array}{l}0.00 \\
0.00 \\
0.00 \\
0.00 \\
0.00\end{array}$ & $\begin{array}{l}2325 \\
2330 \\
2335 \\
2340 \\
2345\end{array}$ & $\begin{array}{l}8.5 \\
8.5 \\
8.4 \\
8.4 \\
8.4\end{array}$ & $\begin{array}{l}0.00 \\
0.00 \\
0.00 \\
0.00 \\
0.00\end{array}$ \\
\hline $\begin{array}{l}1300 \\
1305 \\
1310 \\
1315 \\
1320\end{array}$ & $\begin{array}{l}9.5 \\
9.3 \\
9.3 \\
9.3 \\
9.1\end{array}$ & $\begin{array}{l}0.00 \\
0.00 \\
0.00 \\
0.00 \\
0.00\end{array}$ & $\begin{array}{l}1825 \\
1830 \\
1835 \\
1840 \\
1845\end{array}$ & $\begin{array}{l}7.6 \\
7.8 \\
7.6 \\
7.6 \\
7.6\end{array}$ & $\begin{array}{l}0.00 \\
0.00 \\
0.00 \\
0.00 \\
0.00\end{array}$ & $\begin{array}{l}2350 \\
2355 \\
\text { Sept ember } \\
0000 \\
0005\end{array}$ & $\begin{aligned} & 8.4 \\
& 8.4 \\
& 111, 1988 \\
& 8.4 \\
& 8.2\end{aligned}$ & $\begin{array}{l}0.00 \\
0.00 \\
0.00 \\
0.00\end{array}$ \\
\hline $\begin{array}{l}1325 \\
1330 \\
1335 \\
1340 \\
1345\end{array}$ & $\begin{array}{l}9.3 \\
5.1 \\
9.1 \\
9.3 \\
9.1\end{array}$ & $\begin{array}{l}0.00 \\
0.01 \\
0.00 \\
0.00 \\
0.00\end{array}$ & $\begin{array}{l}1850 \\
1855 \\
1900 \\
1905 \\
1910\end{array}$ & $\begin{array}{l}7.6 \\
7.6 \\
7.6 \\
7.6 \\
7.6\end{array}$ & $\begin{array}{l}0.00 \\
0.00 \\
0.00 \\
0.00 \\
0.00\end{array}$ & $\begin{array}{l}0010 \\
0015 \\
0020 \\
0025 \\
0030\end{array}$ & $\begin{array}{l}8.2 \\
8.2 \\
8.2 \\
8.1 \\
8.1\end{array}$ & $\begin{array}{l}0.00 \\
0.00 \\
0.00 \\
0.00 \\
0.00\end{array}$ \\
\hline
\end{tabular}


Table 146.--Streamflow and rainfall at station 02176380, Coosawhatchie River tributary at Allendale, September 9-11,1988--Continued

\begin{tabular}{|c|c|c|c|c|c|c|c|c|}
\hline $\begin{array}{l}\text { Time } \\
\text { (hours) }\end{array}$ & $\begin{array}{l}\text { Streamflow } \\
\text { (cubic feet } \\
\text { per second) }\end{array}$ & $\begin{array}{l}\text { Rain- } \\
\text { fall } \\
\text { (inches) }\end{array}$ & $\begin{array}{l}\text { Time } \\
\text { (hours) }\end{array}$ & $\begin{array}{l}\text { Streamflow } \\
\text { (cubic feet } \\
\text { per second) }\end{array}$ & $\begin{array}{l}\text { Rain- } \\
\text { fall } \\
\text { (inches) }\end{array}$ & $\begin{array}{l}\text { Time } \\
\text { (hours) }\end{array}$ & $\begin{array}{l}\text { Streamflow } \\
\text { (cubic feet } \\
\text { per second) }\end{array}$ & $\begin{array}{l}\text { Rain- } \\
\text { fall } \\
\text { (inches) }\end{array}$ \\
\hline $\begin{array}{l}0035 \\
0040 \\
0045 \\
0050 \\
0055\end{array}$ & $\begin{array}{l}7.9 \\
7.9 \\
7.9 \\
7.9 \\
7.9\end{array}$ & $\begin{array}{l}0.00 \\
0.00 \\
0.00 \\
0.00 \\
0.00\end{array}$ & $\begin{array}{l}0600 \\
0605 \\
0610 \\
0615 \\
0620\end{array}$ & $\begin{array}{l}6.5 \\
6.5 \\
6.5 \\
6.5 \\
6.5\end{array}$ & $\begin{array}{l}0.00 \\
0.00 \\
0.00 \\
0.00 \\
0.00\end{array}$ & $\begin{array}{l}1125 \\
1130 \\
1135 \\
1140 \\
1145\end{array}$ & $\begin{array}{l}5.9 \\
5.9 \\
5.9 \\
5.9 \\
5.9\end{array}$ & $\begin{array}{l}0.00 \\
0.00 \\
0.00 \\
0.00 \\
0.00\end{array}$ \\
\hline $\begin{array}{l}0100 \\
0105 \\
0110 \\
0115 \\
0120\end{array}$ & $\begin{array}{l}7.8 \\
7.8 \\
7.8 \\
7.8 \\
7.8\end{array}$ & $\begin{array}{l}0.00 \\
0.00 \\
0.00 \\
0.00 \\
0.00\end{array}$ & $\begin{array}{l}0625 \\
0630 \\
0635 \\
0640 \\
0645\end{array}$ & $\begin{array}{l}6.3 \\
6.3 \\
6.3 \\
6.5 \\
6.5\end{array}$ & $\begin{array}{l}0.00 \\
0.00 \\
0.00 \\
0.00 \\
0.00\end{array}$ & $\begin{array}{l}1150 \\
1155 \\
1200 \\
1205 \\
1210\end{array}$ & $\begin{array}{l}5.9 \\
5.9 \\
5.9 \\
5.9 \\
5.9\end{array}$ & $\begin{array}{l}0.00 \\
0.00 \\
0.01 \\
0.00 \\
0.00\end{array}$ \\
\hline $\begin{array}{l}0125 \\
0130 \\
0135 \\
0140 \\
0145\end{array}$ & $\begin{array}{l}7.6 \\
7.6 \\
7.6 \\
7.6 \\
7.5\end{array}$ & $\begin{array}{l}0.00 \\
0.00 \\
0.00 \\
0.00 \\
0.00\end{array}$ & $\begin{array}{l}0650 \\
0655 \\
0700 \\
0705 \\
0710\end{array}$ & $\begin{array}{l}6.5 \\
6.5 \\
6.5 \\
6.5 \\
6.5\end{array}$ & $\begin{array}{l}0.00 \\
0.00 \\
0.00 \\
0.00 \\
0.00\end{array}$ & $\begin{array}{l}1215 \\
1220 \\
1225 \\
1230 \\
1235\end{array}$ & $\begin{array}{l}5.9 \\
5.9 \\
5.9 \\
5.8 \\
5.8\end{array}$ & $\begin{array}{l}0.00 \\
0.00 \\
0.00 \\
0.00 \\
0.00\end{array}$ \\
\hline $\begin{array}{l}0150 \\
0155 \\
0200 \\
0205 \\
0210\end{array}$ & $\begin{array}{l}7.5 \\
7.5 \\
7.5 \\
7.5 \\
7.3\end{array}$ & $\begin{array}{l}0.00 \\
0.00 \\
0.00 \\
0.00 \\
0.00\end{array}$ & $\begin{array}{l}0715 \\
0720 \\
0725 \\
0730 \\
0735\end{array}$ & $\begin{array}{l}6.3 \\
6.3 \\
6.3 \\
6.3 \\
6.3\end{array}$ & $\begin{array}{l}0.00 \\
0.00 \\
0.00 \\
0.00 \\
0.00\end{array}$ & $\begin{array}{l}1240 \\
1245 \\
1250 \\
1255 \\
1300\end{array}$ & $\begin{array}{l}5.8 \\
5.8 \\
5.8 \\
5.8 \\
5.8\end{array}$ & $\begin{array}{l}0.00 \\
0.00 \\
0.00 \\
0.00 \\
0.00\end{array}$ \\
\hline $\begin{array}{l}0215 \\
0220 \\
0225 \\
0230 \\
0235\end{array}$ & $\begin{array}{l}7.3 \\
7.3 \\
7.3 \\
7.3 \\
7.3\end{array}$ & $\begin{array}{l}0.00 \\
0.00 \\
0.00 \\
0.00 \\
0.00\end{array}$ & $\begin{array}{l}0740 \\
0745 \\
0750 \\
0755 \\
0800\end{array}$ & $\begin{array}{l}6.3 \\
6.3 \\
6.3 \\
6.3 \\
6.2\end{array}$ & $\begin{array}{l}0.00 \\
0.00 \\
0.00 \\
0.00 \\
0.00\end{array}$ & $\begin{array}{l}1305 \\
1310 \\
1315 \\
1320 \\
1325\end{array}$ & $\begin{array}{l}5.8 \\
5.8 \\
5.8 \\
5.8 \\
5.8\end{array}$ & $\begin{array}{l}0.00 \\
0.00 \\
0.00 \\
0.00 \\
0.00\end{array}$ \\
\hline $\begin{array}{l}0240 \\
0245 \\
0250 \\
0255 \\
0300\end{array}$ & $\begin{array}{l}7.3 \\
7.2 \\
7.2 \\
7.2 \\
7.2\end{array}$ & $\begin{array}{l}0.00 \\
0.00 \\
0.00 \\
0.00 \\
0.00\end{array}$ & $\begin{array}{l}0805 \\
0810 \\
0815 \\
0820 \\
0825\end{array}$ & $\begin{array}{l}6.2 \\
6.2 \\
6.2 \\
6.2 \\
6.2\end{array}$ & $\begin{array}{l}0.00 \\
0.00 \\
0.00 \\
0.00 \\
0.00\end{array}$ & $\begin{array}{l}1330 \\
1335 \\
1340 \\
1345 \\
1350\end{array}$ & $\begin{array}{l}5.6 \\
5.6 \\
5.6 \\
5.6 \\
5.6\end{array}$ & $\begin{array}{l}0.00 \\
0.00 \\
0.00 \\
0.00 \\
0.00\end{array}$ \\
\hline $\begin{array}{l}0305 \\
0310 \\
0315 \\
0320 \\
0325\end{array}$ & $\begin{array}{l}7.2 \\
7.2 \\
7.0 \\
7.0 \\
7.0\end{array}$ & $\begin{array}{l}0.00 \\
0.00 \\
0.00 \\
0.00 \\
0.00\end{array}$ & $\begin{array}{l}0830 \\
0835 \\
0840 \\
0845 \\
0850\end{array}$ & $\begin{array}{l}6.2 \\
6.2 \\
6.1 \\
6.1 \\
6.1\end{array}$ & $\begin{array}{l}0.00 \\
0.00 \\
0.00 \\
0.00 \\
0.00\end{array}$ & $\begin{array}{l}1355 \\
1400 \\
1405 \\
1410 \\
1415\end{array}$ & $\begin{array}{l}5.6 \\
5.6 \\
5.6 \\
5.6 \\
5.6\end{array}$ & $\begin{array}{l}0.00 \\
0.00 \\
0.00 \\
0.00 \\
0.00\end{array}$ \\
\hline $\begin{array}{l}0330 \\
0335 \\
0340 \\
0345 \\
0350\end{array}$ & $\begin{array}{l}7.0 \\
7.0 \\
6.9 \\
6.9 \\
6.9\end{array}$ & $\begin{array}{l}0.00 \\
0.00 \\
0.00 \\
0.00 \\
0.00\end{array}$ & $\begin{array}{l}0855 \\
0900 \\
0905 \\
0910 \\
0915\end{array}$ & $\begin{array}{l}6.1 \\
6.1 \\
6.1 \\
6.1 \\
6.1\end{array}$ & $\begin{array}{l}0.00 \\
0.00 \\
0.00 \\
0.00 \\
0.00\end{array}$ & $\begin{array}{l}1420 \\
1425 \\
1430 \\
1435 \\
1440\end{array}$ & $\begin{array}{l}5.5 \\
5.5 \\
5.5 \\
5.5 \\
5.5\end{array}$ & $\begin{array}{l}0.00 \\
0.00 \\
0.00 \\
0.00 \\
0.00\end{array}$ \\
\hline $\begin{array}{l}0355 \\
0400 \\
0405 \\
0410 \\
0415\end{array}$ & $\begin{array}{l}6.9 \\
6.9 \\
6.9 \\
6.9 \\
6.9\end{array}$ & $\begin{array}{l}0.00 \\
0.00 \\
0.00 \\
0.00 \\
0.00\end{array}$ & $\begin{array}{l}0920 \\
0925 \\
0930 \\
0935 \\
0940\end{array}$ & $\begin{array}{l}6.1 \\
6.1 \\
6.1 \\
6.1 \\
6.1\end{array}$ & $\begin{array}{l}0.00 \\
0.00 \\
0.00 \\
0.00 \\
0.00\end{array}$ & $\begin{array}{l}1445 \\
1450 \\
1455 \\
1500 \\
1505\end{array}$ & $\begin{array}{l}5.5 \\
5.5 \\
5.5 \\
5.5 \\
5.5\end{array}$ & $\begin{array}{l}0.00 \\
0.00 \\
0.00 \\
0.00 \\
0.00\end{array}$ \\
\hline $\begin{array}{l}0420 \\
0425 \\
0430 \\
0435 \\
0440\end{array}$ & $\begin{array}{l}6.9 \\
6.7 \\
6.7 \\
6.7 \\
6.7\end{array}$ & $\begin{array}{l}0.00 \\
0.00 \\
0.00 \\
0.00 \\
0.00\end{array}$ & $\begin{array}{l}0945 \\
0950 \\
0955 \\
1000 \\
1005\end{array}$ & $\begin{array}{l}6.1 \\
5.9 \\
6.1 \\
5.9 \\
5.9\end{array}$ & $\begin{array}{l}0.00 \\
0.00 \\
0.00 \\
0.00 \\
0.00\end{array}$ & $\begin{array}{l}1510 \\
1515 \\
1520 \\
1525 \\
1530\end{array}$ & $\begin{array}{l}5.5 \\
5.4 \\
5.4 \\
5.4 \\
5.4\end{array}$ & $\begin{array}{l}0.00 \\
0.00 \\
0.00 \\
0.00 \\
0.00\end{array}$ \\
\hline $\begin{array}{l}0445 \\
0450 \\
0455 \\
0500 \\
0505\end{array}$ & $\begin{array}{l}6.7 \\
6.7 \\
6.7 \\
6.7 \\
6.7\end{array}$ & $\begin{array}{l}0.00 \\
0.00 \\
0.00 \\
0.00 \\
0.00\end{array}$ & $\begin{array}{l}1010 \\
1015 \\
1020 \\
1025 \\
1030\end{array}$ & $\begin{array}{l}5.9 \\
6.1 \\
6.1 \\
6.1 \\
6.1\end{array}$ & $\begin{array}{l}0.00 \\
0.00 \\
0.00 \\
0.00 \\
0.00\end{array}$ & $\begin{array}{l}1535 \\
1540 \\
1545 \\
1550 \\
1555\end{array}$ & $\begin{array}{l}5.4 \\
5.4 \\
5.4 \\
5.4 \\
5.4\end{array}$ & $\begin{array}{l}0.00 \\
0.00 \\
0.00 \\
0.00 \\
0.00\end{array}$ \\
\hline $\begin{array}{l}0510 \\
0515 \\
0520 \\
0525 \\
0530\end{array}$ & $\begin{array}{l}6.7 \\
6.7 \\
6.6 \\
6.6 \\
6.6\end{array}$ & $\begin{array}{l}0.00 \\
0.00 \\
0.00 \\
0.00 \\
0.00\end{array}$ & $\begin{array}{l}1035 \\
1040 \\
1045 \\
1050 \\
1055\end{array}$ & $\begin{array}{l}6.1 \\
6.1 \\
6.1 \\
6.1 \\
5.9\end{array}$ & $\begin{array}{l}0.00 \\
0.00 \\
0.00 \\
0.00 \\
0.00\end{array}$ & $\begin{array}{l}1600 \\
1605 \\
1610 \\
1615 \\
1620\end{array}$ & $\begin{array}{l}5.3 \\
5.3 \\
5.3 \\
5.3 \\
5.3\end{array}$ & $\begin{array}{l}0.00 \\
0.00 \\
0.00 \\
0.01 \\
0.00\end{array}$ \\
\hline $\begin{array}{l}0535 \\
0540 \\
0545 \\
0550 \\
0555\end{array}$ & $\begin{array}{l}6.6 \\
6.6 \\
6.6 \\
6.6 \\
6.5\end{array}$ & $\begin{array}{l}0.00 \\
0.00 \\
0.00 \\
0.00 \\
0.00\end{array}$ & $\begin{array}{l}1100 \\
1105 \\
1110 \\
1115 \\
1120\end{array}$ & $\begin{array}{l}5.9 \\
5.9 \\
5.9 \\
5.9 \\
5.9\end{array}$ & $\begin{array}{l}0.00 \\
0.00 \\
0.00 \\
0.00 \\
0.00\end{array}$ & $\begin{array}{l}1625 \\
1630 \\
1635 \\
1640 \\
1645\end{array}$ & $\begin{array}{l}5.3 \\
5.3 \\
5.1 \\
5.1 \\
5.1\end{array}$ & $\begin{array}{l}0.00 \\
0.00 \\
0.00 \\
0.00 \\
0.00\end{array}$ \\
\hline 1650 & 5.1 & 0.00 & 1655 & 5.1 & 0.00 & 1700 & 5.1 & 0.00 \\
\hline
\end{tabular}




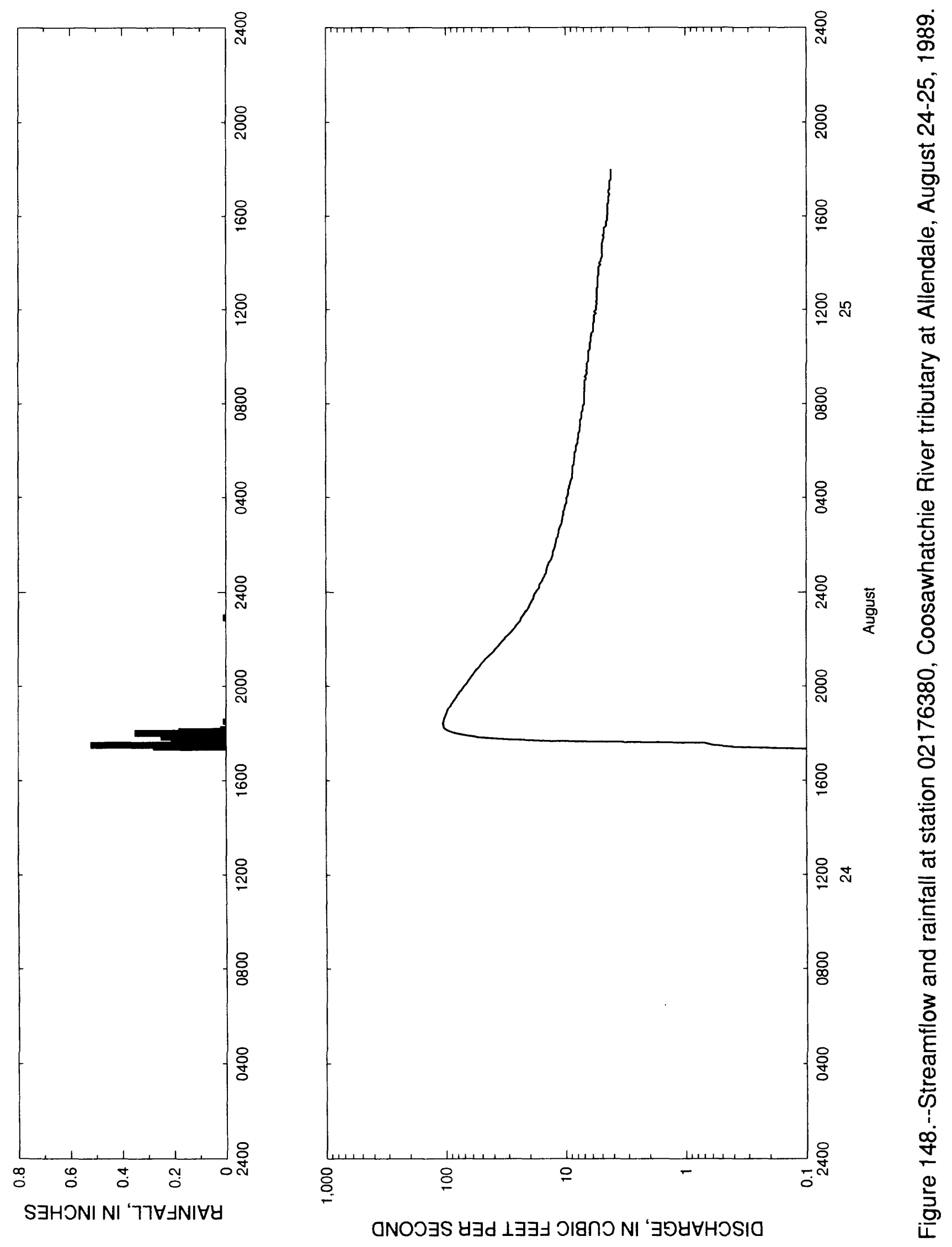



August $24-25,1989$

\begin{tabular}{|c|c|c|c|c|c|c|c|c|}
\hline $\begin{array}{l}\text { Time } \\
\text { (hours) }\end{array}$ & $\begin{array}{l}\text { Streamflow } \\
\text { (cubic feet } \\
\text { per second) }\end{array}$ & $\begin{array}{l}\text { Rain- } \\
\text { fall } \\
\text { (inches) }\end{array}$ & $\begin{array}{l}\text { Time } \\
\text { (hours) }\end{array}$ & $\begin{array}{l}\text { Streamflow } \\
\text { (cubic feet } \\
\text { per second) }\end{array}$ & $\begin{array}{l}\text { Rain- } \\
\text { fall } \\
\text { (inches) }\end{array}$ & $\begin{array}{l}\text { Time } \\
\text { (hours) }\end{array}$ & $\begin{array}{l}\text { Streamflow } \\
\text { (cubic feet } \\
\text { per second) }\end{array}$ & $\begin{array}{l}\text { Rain- } \\
\text { fall } \\
\text { (inches) }\end{array}$ \\
\hline $\begin{array}{c}\text { August } \\
1720 \\
1725 \\
1730 \\
1735\end{array}$ & $\begin{array}{r}1989 \\
0.1 \\
0.4 \\
0.6 \\
0.7\end{array}$ & $\begin{array}{l}0.00 \\
0.28 \\
0.52 \\
0.15\end{array}$ & $\begin{array}{l}2240 \\
2245 \\
2250 \\
2255 \\
2300\end{array}$ & $\begin{array}{l}25.1 \\
24.2 \\
23.8 \\
23.5 \\
22.8\end{array}$ & $\begin{array}{l}0.00 \\
0.00 \\
0.00 \\
0.01 \\
0.00\end{array}$ & $\begin{array}{l}0400 \\
0405 \\
0410 \\
0415 \\
0420\end{array}$ & $\begin{array}{l}9.8 \\
9.6 \\
9.5 \\
9.5 \\
9.5\end{array}$ & $\begin{array}{l}0.00 \\
0.00 \\
0.00 \\
0.00 \\
0.00\end{array}$ \\
\hline $\begin{array}{l}1740 \\
1745 \\
1750 \\
1755 \\
1800\end{array}$ & $\begin{array}{l}13.6 \\
32.2 \\
53.2 \\
68.9 \\
82.8\end{array}$ & $\begin{array}{l}0.17 \\
0.21 \\
0.25 \\
0.18 \\
0.35\end{array}$ & $\begin{array}{l}2305 \\
2310 \\
2315 \\
2320 \\
2325\end{array}$ & $\begin{array}{l}22.2 \\
21.7 \\
21.0 \\
20.6 \\
20.2\end{array}$ & $\begin{array}{l}0.00 \\
0.00 \\
0.00 \\
0.00 \\
0.00\end{array}$ & $\begin{array}{l}0425 \\
0430 \\
0435 \\
0440 \\
0445\end{array}$ & $\begin{array}{l}9.3 \\
9.3 \\
9.1 \\
9.1 \\
9.0\end{array}$ & $\begin{array}{l}0.00 \\
0.00 \\
0.00 \\
0.00 \\
0.00\end{array}$ \\
\hline $\begin{array}{l}1805 \\
1810 \\
1815 \\
1820 \\
1825\end{array}$ & $\begin{array}{r}93.4 \\
100.0 \\
105.0 \\
105.0 \\
106.0\end{array}$ & $\begin{array}{l}0.18 \\
0.02 \\
0.00 \\
0.00 \\
0.00\end{array}$ & $\begin{array}{l}2330 \\
2335 \\
2340 \\
2345 \\
2350\end{array}$ & $\begin{array}{l}20.0 \\
19.5 \\
19.1 \\
18.7 \\
18.5\end{array}$ & $\begin{array}{l}0.00 \\
0.00 \\
0.00 \\
0.00 \\
0.00\end{array}$ & $\begin{array}{l}0450 \\
0455 \\
0500 \\
0505 \\
0510\end{array}$ & $\begin{array}{l}8.8 \\
8.8 \\
8.8 \\
8.7 \\
8.7\end{array}$ & $\begin{array}{l}0.00 \\
0.00 \\
0.00 \\
0.00 \\
0.00\end{array}$ \\
\hline $\begin{array}{l}1830 \\
1835 \\
1840 \\
1845 \\
1850\end{array}$ & $\begin{array}{r}105.0 \\
104.0 \\
103.0 \\
101.0 \\
99.6\end{array}$ & $\begin{array}{l}0.01 \\
0.00 \\
0.00 \\
0.00 \\
0.00\end{array}$ & $\begin{array}{c}2355 \\
\text { August } \\
0000 \\
0005 \\
0010\end{array}$ & $\begin{array}{r}18.3 \\
25,1989 \\
17.8 \\
17.4 \\
16.8\end{array}$ & $\begin{array}{l}0.00 \\
0.00 \\
0.00 \\
0.00\end{array}$ & $\begin{array}{l}0515 \\
0520 \\
0525 \\
0530 \\
0535\end{array}$ & $\begin{array}{l}8.7 \\
8.7 \\
8.5 \\
8.5 \\
8.5\end{array}$ & $\begin{array}{l}0.00 \\
0.00 \\
0.00 \\
0.00 \\
0.00\end{array}$ \\
\hline $\begin{array}{l}1855 \\
1900 \\
1905 \\
1910 \\
1915\end{array}$ & $\begin{array}{l}97.8 \\
96.9 \\
94.4 \\
91.7 \\
89.8\end{array}$ & $\begin{array}{l}0.00 \\
0.00 \\
0.00 \\
0.00 \\
0.00\end{array}$ & $\begin{array}{l}0015 \\
0020 \\
0025 \\
0030 \\
0035\end{array}$ & $\begin{array}{l}16.6 \\
16.6 \\
16.1 \\
15.7 \\
15.5\end{array}$ & $\begin{array}{l}0.00 \\
0.00 \\
0.00 \\
0.00 \\
0.00\end{array}$ & $\begin{array}{l}0540 \\
0545 \\
0550 \\
0555 \\
0500\end{array}$ & $\begin{array}{l}8.5 \\
8.4 \\
8.4 \\
8.4 \\
8.2\end{array}$ & $\begin{array}{l}0.00 \\
0.00 \\
0.00 \\
0.00 \\
0.00\end{array}$ \\
\hline $\begin{array}{l}1920 \\
1925 \\
1930 \\
1935 \\
1940\end{array}$ & $\begin{array}{l}87.5 \\
85.3 \\
82.8 \\
81.2 \\
79.0\end{array}$ & $\begin{array}{l}0.00 \\
0.00 \\
0.00 \\
0.00 \\
0.00\end{array}$ & $\begin{array}{l}0040 \\
0045 \\
0050 \\
0055 \\
0100\end{array}$ & $\begin{array}{l}15.1 \\
14.9 \\
14.5 \\
14.5 \\
14.4\end{array}$ & $\begin{array}{l}0.00 \\
0.00 \\
0.00 \\
0.00 \\
0.00\end{array}$ & $\begin{array}{l}0605 \\
0610 \\
0615 \\
0620 \\
0625\end{array}$ & $\begin{array}{l}8.2 \\
8.2 \\
8.1 \\
7.9 \\
7.9\end{array}$ & $\begin{array}{l}0.00 \\
0.00 \\
0.00 \\
0.00 \\
0.00\end{array}$ \\
\hline $\begin{array}{l}1945 \\
1950 \\
1955 \\
2000 \\
2005\end{array}$ & $\begin{array}{l}77.0 \\
74.3 \\
72.1 \\
70.5 \\
67.9\end{array}$ & $\begin{array}{l}0.00 \\
0.00 \\
0.00 \\
0.00 \\
0.00\end{array}$ & $\begin{array}{l}0105 \\
0110 \\
0115 \\
0120 \\
0125\end{array}$ & $\begin{array}{l}14.2 \\
14.0 \\
13.8 \\
13.4 \\
13.2\end{array}$ & $\begin{array}{l}0.00 \\
0.00 \\
0.00 \\
0.00 \\
0.00\end{array}$ & $\begin{array}{l}0630 \\
0635 \\
0640 \\
0645 \\
0650\end{array}$ & $\begin{array}{l}7.9 \\
7.8 \\
7.8 \\
7.8 \\
7.6\end{array}$ & $\begin{array}{l}0.00 \\
0.00 \\
0.00 \\
0.00 \\
0.00\end{array}$ \\
\hline $\begin{array}{l}2010 \\
2015 \\
2020 \\
2025 \\
2030\end{array}$ & $\begin{array}{l}66.1 \\
64.8 \\
62.7 \\
61.2 \\
59.4\end{array}$ & $\begin{array}{l}0.00 \\
0.00 \\
0.00 \\
0.00 \\
0.00\end{array}$ & $\begin{array}{l}0130 \\
0135 \\
0140 \\
0145 \\
0150\end{array}$ & $\begin{array}{l}13.0 \\
12.9 \\
12.9 \\
12.7 \\
12.5\end{array}$ & $\begin{array}{l}0.00 \\
0.00 \\
0.00 \\
0.00 \\
0.00\end{array}$ & $\begin{array}{l}0655 \\
0700 \\
0705 \\
0710 \\
0715\end{array}$ & $\begin{array}{l}7.6 \\
7.6 \\
7.5 \\
7.5 \\
7.5\end{array}$ & $\begin{array}{l}0.00 \\
0.00 \\
0.00 \\
0.00 \\
0.00\end{array}$ \\
\hline $\begin{array}{l}2035 \\
2040 \\
2045 \\
2050 \\
2055\end{array}$ & $\begin{array}{l}57.9 \\
56.4 \\
54.7 \\
52.6 \\
51.5\end{array}$ & $\begin{array}{l}0.00 \\
0.00 \\
0.00 \\
0.00 \\
0.00\end{array}$ & $\begin{array}{l}0155 \\
0200 \\
0205 \\
0210 \\
0215\end{array}$ & $\begin{array}{l}12.3 \\
12.3 \\
12.1 \\
12.0 \\
12.0\end{array}$ & $\begin{array}{l}0.00 \\
0.00 \\
0.00 \\
0.00 \\
0.00\end{array}$ & $\begin{array}{l}0720 \\
0725 \\
0730 \\
0735 \\
0740\end{array}$ & $\begin{array}{l}7.5 \\
7.3 \\
7.3 \\
7.3 \\
7.3\end{array}$ & $\begin{array}{l}0.00 \\
0.00 \\
0.00 \\
0.00 \\
0.00\end{array}$ \\
\hline $\begin{array}{l}2100 \\
2105 \\
2110 \\
2115 \\
2120\end{array}$ & $\begin{array}{l}50.0 \\
48.0 \\
46.7 \\
45.0 \\
43.1\end{array}$ & $\begin{array}{l}0.00 \\
0.00 \\
0.00 \\
0.00 \\
0.00\end{array}$ & $\begin{array}{l}0220 \\
0225 \\
0230 \\
0235 \\
0240\end{array}$ & $\begin{array}{l}11.6 \\
11.6 \\
11.4 \\
11.4 \\
11.3\end{array}$ & $\begin{array}{l}0.00 \\
0.00 \\
0.00 \\
0.00 \\
0.00\end{array}$ & $\begin{array}{l}0745 \\
0750 \\
0755 \\
0800 \\
0805\end{array}$ & $\begin{array}{l}7.2 \\
7.2 \\
7.2 \\
7.0 \\
7.0\end{array}$ & $\begin{array}{l}0.00 \\
0.00 \\
0.00 \\
0.00 \\
0.00\end{array}$ \\
\hline $\begin{array}{l}2125 \\
2130 \\
2135 \\
2140 \\
2145\end{array}$ & $\begin{array}{l}41.3 \\
39.9 \\
38.9 \\
37.4 \\
36.1\end{array}$ & $\begin{array}{l}0.00 \\
0.00 \\
0.00 \\
0.00 \\
0.00\end{array}$ & $\begin{array}{l}0245 \\
0250 \\
0255 \\
0300 \\
0305\end{array}$ & $\begin{array}{l}11.1 \\
10.9 \\
10.7 \\
10.7 \\
10.6\end{array}$ & $\begin{array}{l}0.00 \\
0.00 \\
0.00 \\
0.00 \\
0.00\end{array}$ & $\begin{array}{l}0810 \\
0815 \\
0820 \\
0825 \\
0830\end{array}$ & $\begin{array}{l}7.0 \\
7.0 \\
7.0 \\
7.0 \\
7.0\end{array}$ & $\begin{array}{l}0.00 \\
0.00 \\
0.00 \\
0.00 \\
0.00\end{array}$ \\
\hline $\begin{array}{l}2150 \\
2155 \\
2200 \\
2205 \\
2210\end{array}$ & $\begin{array}{l}35.1 \\
33.9 \\
32.7 \\
31.9 \\
30.5\end{array}$ & $\begin{array}{l}0.00 \\
0.00 \\
0.00 \\
0.00 \\
0.00\end{array}$ & $\begin{array}{l}0310 \\
0315 \\
0320 \\
0325 \\
0330\end{array}$ & $\begin{array}{l}10.6 \\
10.4 \\
10.4 \\
10.4 \\
10.2\end{array}$ & $\begin{array}{l}0.00 \\
0.00 \\
0.00 \\
0.00 \\
0.00\end{array}$ & $\begin{array}{l}0835 \\
084 C \\
0845 \\
0850 \\
0855\end{array}$ & $\begin{array}{l}5.9 \\
7.0 \\
6.9 \\
5.9 \\
6.9\end{array}$ & $\begin{array}{l}0.00 \\
0.00 \\
0.00 \\
0.00 \\
0.00\end{array}$ \\
\hline $\begin{array}{l}2215 \\
2220 \\
2225 \\
2230 \\
2235\end{array}$ & $\begin{array}{l}29.3 \\
28.3 \\
27.4 \\
26.5 \\
26.0\end{array}$ & $\begin{array}{l}0.00 \\
0.00 \\
0.00 \\
0.00 \\
0.00\end{array}$ & $\begin{array}{l}0335 \\
0340 \\
0345 \\
0350 \\
0355\end{array}$ & $\begin{array}{r}10.2 \\
10.1 \\
9.9 \\
9.8 \\
9.8\end{array}$ & $\begin{array}{l}0.00 \\
0.00 \\
0.00 \\
0.00 \\
0.00\end{array}$ & $\begin{array}{l}0900 \\
0905 \\
0910 \\
0915 \\
0920\end{array}$ & $\begin{array}{l}6.9 \\
6.7 \\
6.9 \\
5.7 \\
6.6\end{array}$ & $\begin{array}{l}0.00 \\
0.00 \\
0.00 \\
0.00 \\
0.00\end{array}$ \\
\hline
\end{tabular}


Table 147.--Streamflow and rainfall at station 02176380, Coosawhatchie River tributary at Allendale, August 24-25, 1989--Continued

\begin{tabular}{|c|c|c|c|c|c|c|c|c|}
\hline $\begin{array}{l}\text { Time } \\
\text { (hours) }\end{array}$ & $\begin{array}{l}\text { Streamflow } \\
\text { (cubic feet } \\
\text { per second) }\end{array}$ & $\begin{array}{l}\text { Rain- } \\
\text { fall } \\
\text { (inches) }\end{array}$ & $\begin{array}{l}\text { Time } \\
\text { (hours) }\end{array}$ & $\begin{array}{l}\text { Streamflow } \\
\text { (cubic feet } \\
\text { per second) }\end{array}$ & $\begin{array}{l}\text { Rain- } \\
\text { fal1 } \\
\text { (inches) }\end{array}$ & $\begin{array}{l}\text { Time } \\
\text { (hours) }\end{array}$ & $\begin{array}{l}\text { Streamflow } \\
\text { (cubic feet } \\
\text { per second) }\end{array}$ & $\begin{array}{l}\text { Rain- } \\
\text { fall } \\
\text { (inches) }\end{array}$ \\
\hline $\begin{array}{l}0925 \\
0930 \\
0935 \\
0940 \\
0945\end{array}$ & $\begin{array}{l}6.7 \\
6.6 \\
6.6 \\
6.6 \\
6.6\end{array}$ & $\begin{array}{l}0.00 \\
0.00 \\
0.00 \\
0.00 \\
0.00\end{array}$ & $\begin{array}{l}1220 \\
1225 \\
1230 \\
1235 \\
1240\end{array}$ & $\begin{array}{l}5.6 \\
5.5 \\
5.5 \\
5.5 \\
5.5\end{array}$ & $\begin{array}{l}0.00 \\
0.00 \\
0.00 \\
0.00 \\
0.00\end{array}$ & $\begin{array}{l}1515 \\
1520 \\
1525 \\
1530 \\
1535\end{array}$ & $\begin{array}{l}4.8 \\
4.8 \\
4.8 \\
4.8 \\
4.6\end{array}$ & $\begin{array}{l}0.00 \\
0.00 \\
0.00 \\
0.00 \\
0.00\end{array}$ \\
\hline $\begin{array}{l}0950 \\
0955 \\
1000 \\
1005 \\
1010\end{array}$ & $\begin{array}{l}6.5 \\
6.5 \\
6.5 \\
6.5 \\
6.5\end{array}$ & $\begin{array}{l}0.00 \\
0.00 \\
0.00 \\
0.00 \\
0.00\end{array}$ & $\begin{array}{l}1245 \\
1250 \\
1255 \\
1300 \\
1305\end{array}$ & $\begin{array}{l}5.5 \\
5.5 \\
5.5 \\
5.4 \\
5.4\end{array}$ & $\begin{array}{l}0.00 \\
0.00 \\
0.00 \\
0.00 \\
0.00\end{array}$ & $\begin{array}{l}1540 \\
1545 \\
1550 \\
1555 \\
1600\end{array}$ & $\begin{array}{l}4.6 \\
4.6 \\
4.5 \\
4.5 \\
4.5\end{array}$ & $\begin{array}{l}0.00 \\
0.00 \\
0.00 \\
0.00 \\
0.00\end{array}$ \\
\hline $\begin{array}{l}1015 \\
1020 \\
1025 \\
1030 \\
1035\end{array}$ & $\begin{array}{l}6.5 \\
6.3 \\
6.3 \\
6.3 \\
6.3\end{array}$ & $\begin{array}{l}0.00 \\
0.00 \\
0.00 \\
0.00 \\
0.00\end{array}$ & $\begin{array}{l}1310 \\
1315 \\
1320 \\
1325 \\
1330\end{array}$ & $\begin{array}{l}5.4 \\
5.4 \\
5.4 \\
5.4 \\
5.3\end{array}$ & $\begin{array}{l}0.00 \\
0.00 \\
0.00 \\
0.00 \\
0.00\end{array}$ & $\begin{array}{l}1605 \\
1610 \\
1615 \\
1620 \\
1625\end{array}$ & $\begin{array}{l}4.5 \\
4.5 \\
4.5 \\
4.5 \\
4.5\end{array}$ & $\begin{array}{l}0.00 \\
0.00 \\
0.00 \\
0.00 \\
0.00\end{array}$ \\
\hline $\begin{array}{l}1040 \\
1045 \\
1050 \\
1055 \\
1100\end{array}$ & $\begin{array}{l}6.2 \\
6.2 \\
6.2 \\
6.1 \\
6.1\end{array}$ & $\begin{array}{l}0.00 \\
0.00 \\
0.00 \\
0.00 \\
0.00\end{array}$ & $\begin{array}{l}1335 \\
1340 \\
1345 \\
1350 \\
1355\end{array}$ & $\begin{array}{l}5.3 \\
5.3 \\
5.3 \\
5.3 \\
5.1\end{array}$ & $\begin{array}{l}0.00 \\
0.00 \\
0.00 \\
0.00 \\
0.00\end{array}$ & $\begin{array}{l}1630 \\
1635 \\
1640 \\
1645 \\
1650\end{array}$ & $\begin{array}{l}4.5 \\
4.4 \\
4.4 \\
4.4 \\
4.4\end{array}$ & $\begin{array}{l}0.00 \\
0.00 \\
0.00 \\
0.00 \\
0.00\end{array}$ \\
\hline $\begin{array}{l}1105 \\
1110 \\
1115 \\
1120 \\
1125\end{array}$ & $\begin{array}{l}5.9 \\
5.9 \\
5.9 \\
5.9 \\
5.9\end{array}$ & $\begin{array}{l}0.00 \\
0.00 \\
0.00 \\
0.00 \\
0.00\end{array}$ & $\begin{array}{l}1400 \\
1405 \\
1410 \\
1415 \\
1420\end{array}$ & $\begin{array}{l}5.3 \\
5.1 \\
5.1 \\
5.0 \\
5.0\end{array}$ & $\begin{array}{l}0.00 \\
0.00 \\
0.00 \\
0.00 \\
0.00\end{array}$ & $\begin{array}{l}1655 \\
1700 \\
1705 \\
1710 \\
1715\end{array}$ & $\begin{array}{l}4.3 \\
4.4 \\
4.4 \\
4.3 \\
4.3\end{array}$ & $\begin{array}{l}0.00 \\
0.00 \\
0.00 \\
0.00 \\
0.00\end{array}$ \\
\hline $\begin{array}{l}1130 \\
1135 \\
1140 \\
1145 \\
1150\end{array}$ & $\begin{array}{l}5.8 \\
5.8 \\
5.8 \\
5.8 \\
5.6\end{array}$ & $\begin{array}{l}0.00 \\
0.00 \\
0.00 \\
0.00 \\
0.00\end{array}$ & $\begin{array}{l}1425 \\
1430 \\
1435 \\
1440 \\
1445\end{array}$ & $\begin{array}{l}5.0 \\
5.0 \\
5.0 \\
5.0 \\
5.0\end{array}$ & $\begin{array}{l}0.00 \\
0.00 \\
0.00 \\
0.00 \\
0.00\end{array}$ & $\begin{array}{l}1720 \\
1725 \\
1730 \\
1735 \\
1740\end{array}$ & $\begin{array}{l}4.3 \\
4.3 \\
4.3 \\
4.2 \\
4.2\end{array}$ & $\begin{array}{l}0.00 \\
0.00 \\
0.00 \\
0.00 \\
0.00\end{array}$ \\
\hline $\begin{array}{l}1155 \\
1200 \\
1205 \\
1210 \\
1215\end{array}$ & $\begin{array}{l}5.8 \\
5.6 \\
5.6 \\
5.6 \\
5.5\end{array}$ & $\begin{array}{l}0.00 \\
0.00 \\
0.00 \\
0.00 \\
0.00\end{array}$ & $\begin{array}{l}1450 \\
1455 \\
1500 \\
1505 \\
1510\end{array}$ & $\begin{array}{l}5.0 \\
4.9 \\
4.9 \\
4.8 \\
4.9\end{array}$ & $\begin{array}{l}0.00 \\
0.00 \\
0.00 \\
0.00 \\
0.00\end{array}$ & $\begin{array}{l}1745 \\
1750 \\
1755 \\
1800\end{array}$ & $\begin{array}{l}4.2 \\
4.2 \\
4.2 \\
4.2\end{array}$ & $\begin{array}{l}0.00 \\
0.00 \\
0.00 \\
0.00\end{array}$ \\
\hline
\end{tabular}




\section{Station 02187260, Whitner Creek at Anderson, S.C.}

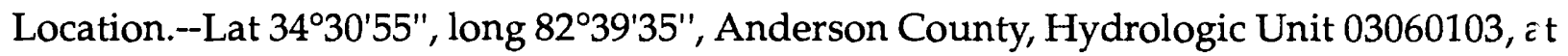
culvert on Lee Street (State secondary road 622), 1.1 mi northwest of Anderson City Hall, and $2.1 \mathrm{mi}$ upstream from the mouth at Big Generostee Creek.

Period of record.-- December 18, 1985 to October 20, 1989.

Gage.--Digital stage recorder with 5-minute punch interval. The recorder is housed in a metal shelter atop a stilling well attached to the upstream headwall. A sealed intake pipe extends $18 \mathrm{ft}$ upstream from the triple 5.9 - $\mathrm{ft}$ reinforced concrete pipe culvert headwall. The gage is not capable of recording stages less than $0.25 \mathrm{ft}$ above the concrete-lined channel bottom. A single crest-stage indicator is attached to the downstream headwall.

Rating.--The stage-streamflow relation is defined by current meter measurements up tc $8.8 \mathrm{ft}^{3} / \mathrm{s}$. The stage-streamflow relation was extended to $900 \mathrm{ft}^{3} / \mathrm{s}$ using theoretical step-backwater computational methods.

Rain gage and location.--Station 343055082393200, lat 34 $30^{\prime} 55^{\prime \prime}$, long $82^{\circ} 39^{\prime} 32^{\prime \prime}$. A shelter containing a digital cumulative rainfall recorder with a 5-minute punch interval attached to the downstream headwall at the Lee Street (State secondary road 622) crossing of Whitner Creek, 1.1 mi northwest of Anderson City Hall.

Selected basin characteristics.--

Drainage area $-0.77 \mathrm{mi}^{2}$

Physiographic province -- Piedmont

Channel slope -- $79.4 \mathrm{ft} / \mathrm{mi}$

Channel length $-1.30 \mathrm{mi}$

Total impervious area -- 32.0 percent

Basin development factor -- 12

2-year, 2-hour rainfall amount -- 2.15 in.

Flood frequency data: $\mathrm{UQ}_{2}$

$687 \mathrm{ft}^{3} / \mathrm{s}$

$\mathrm{UQ}_{5} \quad 1,060 \mathrm{ft}^{3} / \mathrm{s}$

$\mathrm{UQ}_{10} \quad 1,290 \mathrm{ft}^{3} / \mathrm{s}$

$\mathrm{UQ}_{25} \quad 1,580 \mathrm{ft}^{3} / \mathrm{s}$

$\mathrm{UQ}_{50} \quad 1,780 \mathrm{ft}^{3} / \mathrm{s}$

$\mathrm{UQ}_{100} \quad 1,970 \mathrm{ft}^{3} / \mathrm{s}$

$\mathrm{UQ}_{500} \quad 2,390 \mathrm{ft}^{3} / \mathrm{s}$ 


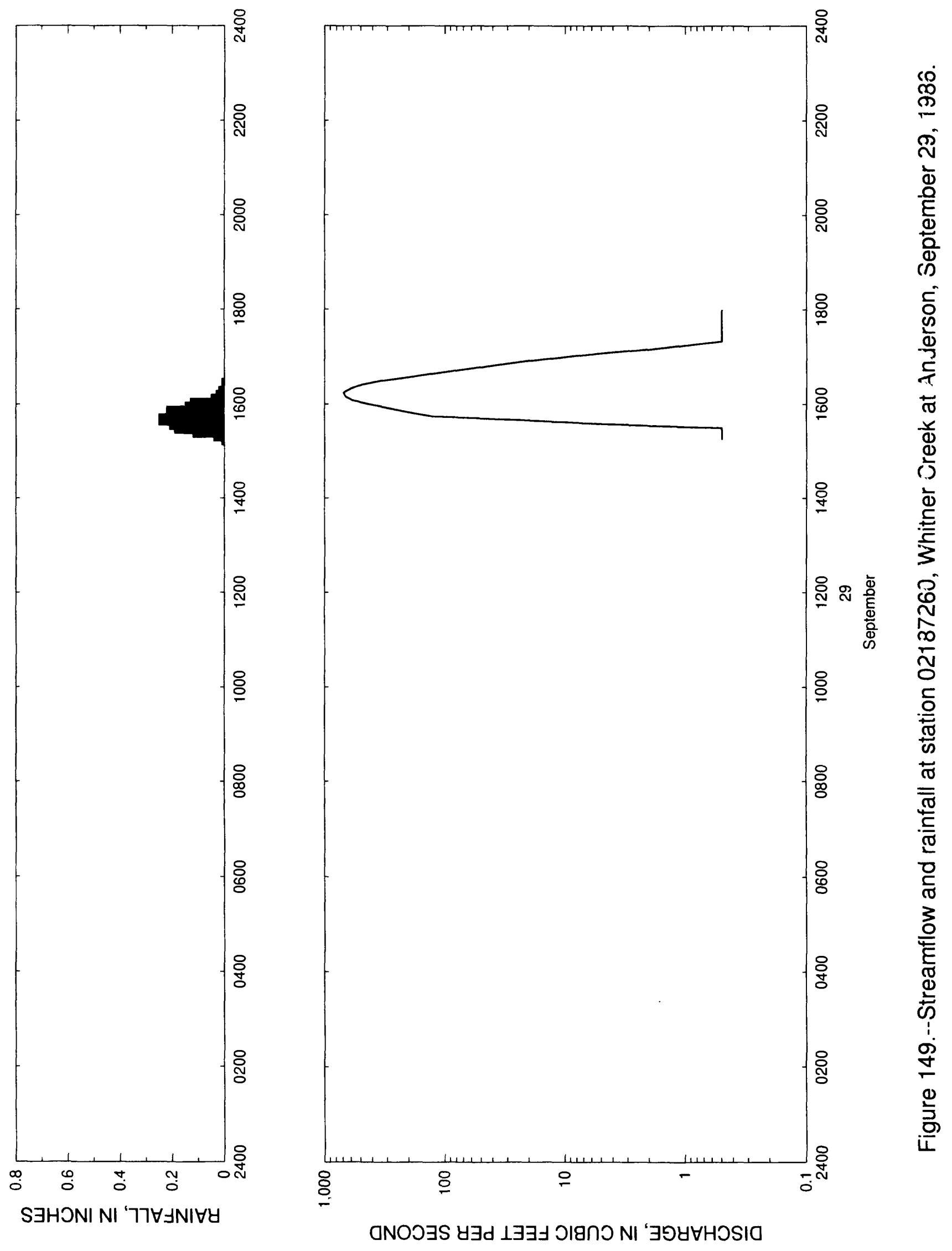


Table 148.--Streamflow and rainfall at station 02187260, Whitner Creek at Anderson, September 29, 1986

\begin{tabular}{|c|c|c|c|c|c|c|c|c|}
\hline $\begin{array}{l}\text { Time } \\
\text { (hours) }\end{array}$ & $\begin{array}{l}\text { Streamflow } \\
\text { (cubic feet } \\
\text { per second) }\end{array}$ & $\begin{array}{l}\text { Rain- } \\
\text { fall } \\
\text { (inches) }\end{array}$ & $\begin{array}{l}\text { Time } \\
\text { (hours) }\end{array}$ & $\begin{array}{l}\text { Streamflow } \\
\text { (cubic feet } \\
\text { per second) }\end{array}$ & $\begin{array}{l}\text { Rain- } \\
\text { fall } \\
\text { (inches) }\end{array}$ & $\begin{array}{l}\text { Time } \\
\text { (hours) }\end{array}$ & $\begin{array}{l}\text { Streamflow } \\
\text { (cubic feet } \\
\text { per second) }\end{array}$ & $\begin{array}{l}\text { Rain- } \\
\text { fall } \\
\text { (inches) }\end{array}$ \\
\hline $\begin{array}{l}\text { September } \\
1515 \\
1520 \\
1525 \\
1530\end{array}$ & $\begin{aligned} & 19, 1986 \\
& 0.5 \\
& 0.5 \\
& 0.5 \\
& 0.5\end{aligned}$ & $\begin{array}{l}0.01 \\
0.04 \\
0.12 \\
0.19\end{array}$ & $\begin{array}{l}1610 \\
1615 \\
1620 \\
1625 \\
1630\end{array}$ & $\begin{array}{l}669.0 \\
696.0 \\
599.0 \\
489.0 \\
334.0\end{array}$ & $\begin{array}{l}0.03 \\
0.02 \\
0.01 \\
0.01 \\
0.00\end{array}$ & $\begin{array}{l}1710 \\
1715 \\
1720 \\
1725 \\
1730\end{array}$ & $\begin{array}{l}2.0 \\
1.0 \\
0.5 \\
0.5 \\
0.5\end{array}$ & $\begin{array}{l}0.07 \\
0.07 \\
0.07 \\
0.07 \\
0.07\end{array}$ \\
\hline $\begin{array}{l}1535 \\
1540 \\
1545 \\
1550 \\
1555\end{array}$ & $\begin{array}{r}5.0 \\
23.7 \\
134.0 \\
200.0 \\
284.0\end{array}$ & $\begin{array}{l}0.21 \\
0.25 \\
0.21 \\
0.22 \\
0.15\end{array}$ & $\begin{array}{l}1635 \\
1640 \\
1645 \\
1650 \\
1655\end{array}$ & $\begin{array}{r}188.0 \\
112.0 \\
65.0 \\
37.9 \\
20.5\end{array}$ & $\begin{array}{l}0.00 \\
0.00 \\
0.00 \\
0.00 \\
0.00\end{array}$ & $\begin{array}{l}1735 \\
1740 \\
1745 \\
1750 \\
1755\end{array}$ & $\begin{array}{l}0.5 \\
0.5 \\
0.5 \\
0.5 \\
0.5\end{array}$ & $\begin{array}{l}0.07 \\
0.07 \\
0.00 \\
0.07 \\
0.07\end{array}$ \\
\hline $\begin{array}{l}1600 \\
1605\end{array}$ & $\begin{array}{l}422.0 \\
587.0\end{array}$ & $\begin{array}{l}0.13 \\
0.05\end{array}$ & $\begin{array}{l}1700 \\
1705\end{array}$ & $\begin{array}{r}10.0 \\
5.0\end{array}$ & $\begin{array}{l}0.00 \\
0.00\end{array}$ & 1800 & 0.5 & 0.07 \\
\hline
\end{tabular}




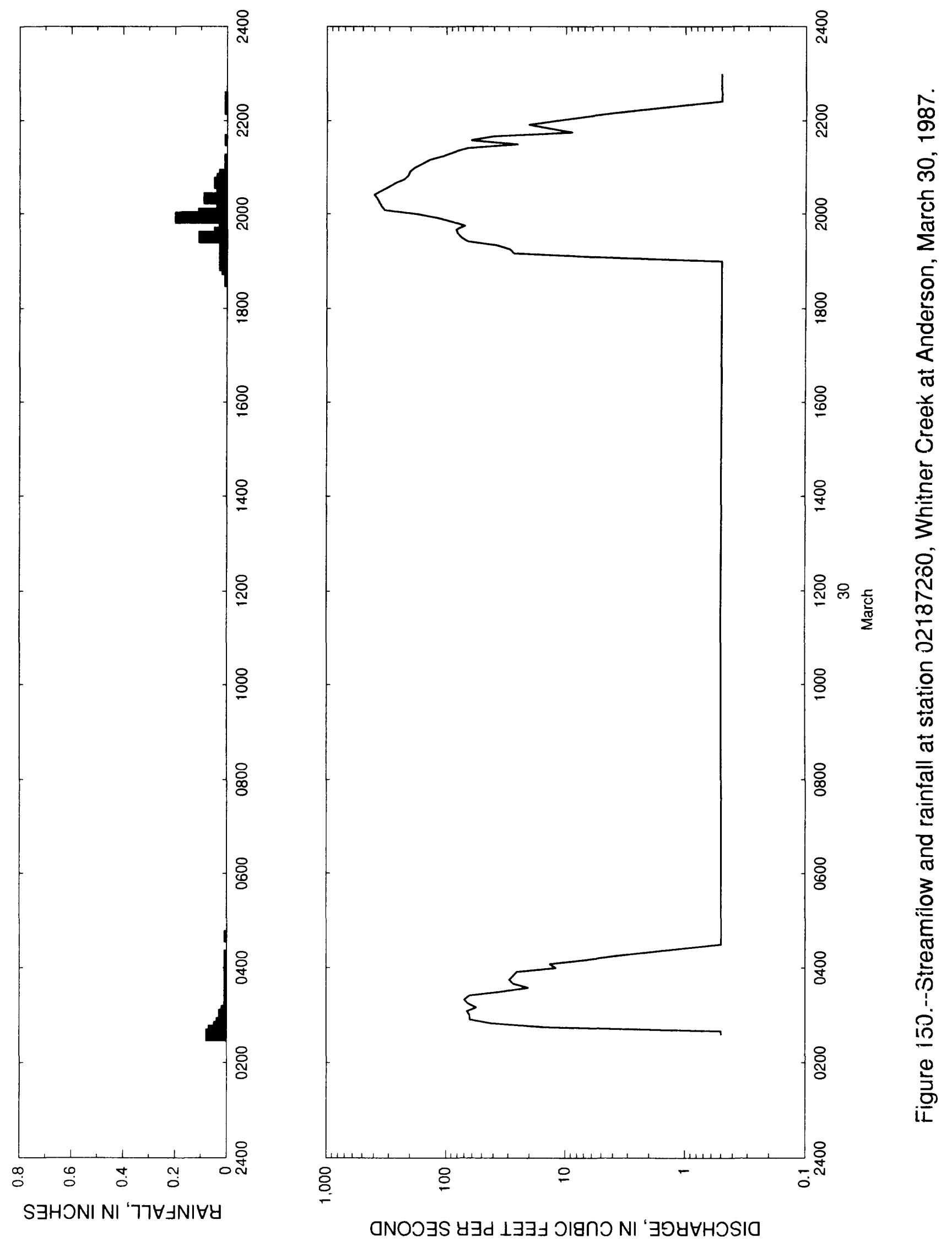


Table 149. - Streamflow and rainfall at station 02187260, Whitner Creek at Anderson.

March 30,1987

\begin{tabular}{|c|c|c|c|c|c|c|c|c|}
\hline $\begin{array}{l}\text { Time } \\
\text { (hours) }\end{array}$ & $\begin{array}{l}\text { Streamflow } \\
\text { (cubic feet } \\
\text { per second) }\end{array}$ & $\begin{array}{l}\text { Rain- } \\
\text { fall } \\
\text { (inches) }\end{array}$ & $\begin{array}{l}\text { Time } \\
\text { (hours) }\end{array}$ & $\begin{array}{l}\text { Streamflow } \\
\text { (cubic feet } \\
\text { per second) }\end{array}$ & $\begin{array}{l}\text { Rain- } \\
\text { fall } \\
\text { (inches) }\end{array}$ & $\begin{array}{l}\text { Time } \\
\text { (hours) }\end{array}$ & $\begin{array}{l}\text { Streamflow } \\
\text { (cubic feet } \\
\text { per second) }\end{array}$ & $\begin{array}{l}\text { Rain- } \\
\text { fall } \\
\text { (inches) }\end{array}$ \\
\hline $\begin{array}{r}\text { March } 30, \\
0235 \\
0240 \\
0245 \\
0250\end{array}$ & $\begin{array}{r}1987 \\
0.5 \\
0.5 \\
15.0 \\
41.7\end{array}$ & $\begin{array}{l}0.08 \\
0.07 \\
0.05 \\
0.04\end{array}$ & $\begin{array}{l}0755 \\
0800 \\
0805 \\
0810 \\
0815\end{array}$ & $\begin{array}{l}0.5 \\
0.5 \\
0.5 \\
0.5 \\
0.5\end{array}$ & $\begin{array}{l}0.00 \\
0.00 \\
0.00 \\
0.00 \\
0.00\end{array}$ & $\begin{array}{l}1320 \\
1325 \\
1330 \\
1335 \\
1340\end{array}$ & $\begin{array}{l}0.5 \\
0.5 \\
0.5 \\
0.5 \\
0.5\end{array}$ & $\begin{array}{l}0.00 \\
0.00 \\
0.00 \\
0.00 \\
0.00\end{array}$ \\
\hline $\begin{array}{l}0255 \\
0300 \\
0305 \\
0310 \\
0315\end{array}$ & $\begin{array}{l}63.0 \\
63.0 \\
66.7 \\
55.5 \\
65.0\end{array}$ & $\begin{array}{l}0.03 \\
0.03 \\
0.02 \\
0.01 \\
0.01\end{array}$ & $\begin{array}{l}0820 \\
0825 \\
0830 \\
0835 \\
0840\end{array}$ & $\begin{array}{l}0.5 \\
0.5 \\
0.5 \\
0.5 \\
0.5\end{array}$ & $\begin{array}{l}0.00 \\
0.00 \\
0.00 \\
0.00 \\
0.00\end{array}$ & $\begin{array}{l}1345 \\
1350 \\
1355 \\
1400 \\
1405\end{array}$ & $\begin{array}{l}0.5 \\
0.5 \\
0.5 \\
0.5 \\
0.5\end{array}$ & $\begin{array}{l}0.00 \\
0.00 \\
0.00 \\
0.00 \\
0.00\end{array}$ \\
\hline $\begin{array}{l}0320 \\
0325 \\
0330 \\
0335 \\
0340\end{array}$ & $\begin{array}{l}70.1 \\
63.0 \\
34.0 \\
20.5 \\
27.4\end{array}$ & $\begin{array}{l}0.00 \\
0.01 \\
0.00 \\
0.01 \\
0.01\end{array}$ & $\begin{array}{l}0845 \\
0850 \\
0855 \\
0900 \\
0905\end{array}$ & $\begin{array}{l}0.5 \\
0.5 \\
0.5 \\
0.5 \\
0.5\end{array}$ & $\begin{array}{l}0.00 \\
0.00 \\
0.00 \\
0.00 \\
0.00\end{array}$ & $\begin{array}{l}1410 \\
1415 \\
1420 \\
1425 \\
1430\end{array}$ & $\begin{array}{l}0.5 \\
0.5 \\
0.5 \\
0.5 \\
0.5\end{array}$ & $\begin{array}{l}0.00 \\
0.00 \\
0.00 \\
0.00 \\
0.00\end{array}$ \\
\hline $\begin{array}{l}0345 \\
0350 \\
0355 \\
0400 \\
0405\end{array}$ & $\begin{array}{l}29.5 \\
27.4 \\
25.5 \\
12.0 \\
13.6\end{array}$ & $\begin{array}{l}0.00 \\
0.01 \\
0.00 \\
0.01 \\
0.00\end{array}$ & $\begin{array}{l}0910 \\
0915 \\
0920 \\
0925 \\
0930\end{array}$ & $\begin{array}{l}0.5 \\
0.5 \\
0.5 \\
0.5 \\
0.5\end{array}$ & $\begin{array}{l}0.00 \\
0.00 \\
0.00 \\
0.00 \\
0.00\end{array}$ & $\begin{array}{l}1435 \\
1440 \\
1445 \\
1450 \\
1455\end{array}$ & $\begin{array}{l}0.5 \\
0.5 \\
0.5 \\
0.5 \\
0.5\end{array}$ & $\begin{array}{l}0.00 \\
0.00 \\
0.00 \\
0.00 \\
0.00\end{array}$ \\
\hline $\begin{array}{l}0410 \\
0415 \\
0420 \\
0425 \\
0430\end{array}$ & $\begin{array}{l}7.0 \\
4.0 \\
2.0 \\
1.0 \\
0.5\end{array}$ & $\begin{array}{l}0.00 \\
0.01 \\
0.00 \\
0.00 \\
0.00\end{array}$ & $\begin{array}{l}0935 \\
0940 \\
0945 \\
0950 \\
0955\end{array}$ & $\begin{array}{l}0.5 \\
0.5 \\
0.5 \\
0.5 \\
0.5\end{array}$ & $\begin{array}{l}0.00 \\
0.00 \\
0.00 \\
0.00 \\
0.00\end{array}$ & $\begin{array}{l}1500 \\
1505 \\
1510 \\
1515 \\
1520\end{array}$ & $\begin{array}{l}0.5 \\
0.5 \\
0.5 \\
0.5 \\
0.5\end{array}$ & $\begin{array}{l}0.00 \\
0.00 \\
0.00 \\
0.00 \\
0.00\end{array}$ \\
\hline $\begin{array}{l}0435 \\
0440 \\
0445 \\
0450 \\
0455\end{array}$ & $\begin{array}{l}0.5 \\
0.5 \\
0.5 \\
0.5 \\
0.5\end{array}$ & $\begin{array}{l}0.00 \\
0.01 \\
0.00 \\
0.00 \\
0.00\end{array}$ & $\begin{array}{l}1000 \\
1005 \\
1010 \\
1015 \\
1020\end{array}$ & $\begin{array}{l}0.5 \\
0.5 \\
0.5 \\
0.5 \\
0.5\end{array}$ & $\begin{array}{l}0.00 \\
0.00 \\
0.00 \\
0.00 \\
0.00\end{array}$ & $\begin{array}{l}1525 \\
1530 \\
1535 \\
1540 \\
1545\end{array}$ & $\begin{array}{l}0.5 \\
0.5 \\
0.5 \\
0.5 \\
0.5\end{array}$ & $\begin{array}{l}0.00 \\
0.00 \\
0.00 \\
0.00 \\
0.00\end{array}$ \\
\hline $\begin{array}{l}0500 \\
0505 \\
0510 \\
0515 \\
0520\end{array}$ & $\begin{array}{l}0.5 \\
0.5 \\
0.5 \\
0.5 \\
0.5\end{array}$ & $\begin{array}{l}0.00 \\
0.00 \\
0.00 \\
0.00 \\
0.00\end{array}$ & $\begin{array}{l}1025 \\
1030 \\
1035 \\
1040 \\
1045\end{array}$ & $\begin{array}{l}0.5 \\
0.5 \\
0.5 \\
0.5 \\
0.5\end{array}$ & $\begin{array}{l}0.00 \\
0.00 \\
0.00 \\
0.00 \\
0.00\end{array}$ & $\begin{array}{l}1550 \\
1555 \\
1600 \\
1605 \\
1610\end{array}$ & $\begin{array}{l}0.5 \\
0.5 \\
0.5 \\
0.5 \\
0.5\end{array}$ & $\begin{array}{l}0.00 \\
0.00 \\
0.00 \\
0.00 \\
0.00\end{array}$ \\
\hline $\begin{array}{l}0525 \\
0530 \\
0535 \\
0540 \\
0545\end{array}$ & $\begin{array}{l}0.5 \\
0.5 \\
0.5 \\
0.5 \\
0.5\end{array}$ & $\begin{array}{l}0.00 \\
0.00 \\
0.00 \\
0.00 \\
0.00\end{array}$ & $\begin{array}{l}1050 \\
1055 \\
1100 \\
1105 \\
1110\end{array}$ & $\begin{array}{l}0.5 \\
0.5 \\
0.5 \\
0.5 \\
0.5\end{array}$ & $\begin{array}{l}0.00 \\
0.00 \\
0.00 \\
0.00 \\
0.00\end{array}$ & $\begin{array}{l}1615 \\
1620 \\
1625 \\
1630 \\
1635\end{array}$ & $\begin{array}{l}0.5 \\
0.5 \\
0.5 \\
0.5 \\
0.5\end{array}$ & $\begin{array}{l}0.00 \\
0.00 \\
0.00 \\
0.00 \\
0.00\end{array}$ \\
\hline $\begin{array}{l}0550 \\
0555 \\
0600 \\
0605 \\
0610\end{array}$ & $\begin{array}{l}0.5 \\
0.5 \\
0.5 \\
0.5 \\
0.5\end{array}$ & $\begin{array}{l}0.00 \\
0.00 \\
0.00 \\
0.00 \\
0.00\end{array}$ & $\begin{array}{l}1115 \\
1120 \\
1125 \\
1130 \\
1135\end{array}$ & $\begin{array}{l}0.5 \\
0.5 \\
0.5 \\
0.5 \\
0.5\end{array}$ & $\begin{array}{l}0.00 \\
0.00 \\
0.00 \\
0.00 \\
0.00\end{array}$ & $\begin{array}{l}1640 \\
1645 \\
1650 \\
1655 \\
1700\end{array}$ & $\begin{array}{l}0.5 \\
0.5 \\
0.5 \\
0.5 \\
0.5\end{array}$ & $\begin{array}{l}0.00 \\
0.00 \\
0.00 \\
0.00 \\
0.00\end{array}$ \\
\hline $\begin{array}{l}0615 \\
0620 \\
0625 \\
0630 \\
0635\end{array}$ & $\begin{array}{l}0.5 \\
0.5 \\
0.5 \\
0.5 \\
0.5\end{array}$ & $\begin{array}{l}0.00 \\
0.00 \\
0.00 \\
0.00 \\
0.00\end{array}$ & $\begin{array}{l}1140 \\
1145 \\
1150 \\
1155 \\
1200\end{array}$ & $\begin{array}{l}0.5 \\
0.5 \\
0.5 \\
0.5 \\
0.5\end{array}$ & $\begin{array}{l}0.00 \\
0.00 \\
0.00 \\
0.00 \\
0.00\end{array}$ & $\begin{array}{l}1705 \\
1710 \\
1715 \\
1720 \\
1725\end{array}$ & $\begin{array}{l}0.5 \\
0.5 \\
0.5 \\
0.5 \\
0.5\end{array}$ & $\begin{array}{l}0.00 \\
0.00 \\
0.00 \\
0.00 \\
0.00\end{array}$ \\
\hline $\begin{array}{l}0640 \\
0645 \\
0650 \\
0655 \\
0700\end{array}$ & $\begin{array}{l}0.5 \\
0.5 \\
0.5 \\
0.5 \\
0.5\end{array}$ & $\begin{array}{l}0.00 \\
0.00 \\
0.00 \\
0.00 \\
0.00\end{array}$ & $\begin{array}{l}1205 \\
1210 \\
1215 \\
1220 \\
1225\end{array}$ & $\begin{array}{l}0.5 \\
0.5 \\
0.5 \\
0.5 \\
0.5\end{array}$ & $\begin{array}{l}0.00 \\
0.00 \\
0.00 \\
0.00 \\
0.00\end{array}$ & $\begin{array}{l}1730 \\
1735 \\
1740 \\
1745 \\
1750\end{array}$ & $\begin{array}{l}0.5 \\
0.5 \\
0.5 \\
0.5 \\
0.5\end{array}$ & $\begin{array}{l}0.00 \\
0.00 \\
0.00 \\
0.00 \\
0.00\end{array}$ \\
\hline $\begin{array}{l}0705 \\
0710 \\
0715 \\
0720 \\
0725\end{array}$ & $\begin{array}{l}0.5 \\
0.5 \\
0.5 \\
0.5 \\
0.5\end{array}$ & $\begin{array}{l}0.00 \\
0.00 \\
0.00 \\
0.00 \\
0.00\end{array}$ & $\begin{array}{l}1230 \\
1235 \\
1240 \\
1245 \\
1250\end{array}$ & $\begin{array}{l}0.5 \\
0.5 \\
0.5 \\
0.5 \\
0.5\end{array}$ & $\begin{array}{l}0.00 \\
0.00 \\
0.00 \\
0.00 \\
0.00\end{array}$ & $\begin{array}{l}1755 \\
1800 \\
1805 \\
1810 \\
1815\end{array}$ & $\begin{array}{l}0.5 \\
0.5 \\
0.5 \\
0.5 \\
0.5\end{array}$ & $\begin{array}{l}0.00 \\
0.00 \\
0.00 \\
0.00 \\
0.00\end{array}$ \\
\hline $\begin{array}{l}0730 \\
0735 \\
0740 \\
0745 \\
0750\end{array}$ & $\begin{array}{l}0.5 \\
0.5 \\
0.5 \\
0.5 \\
0.5\end{array}$ & $\begin{array}{l}0.00 \\
0.00 \\
0.00 \\
0.00 \\
0.00\end{array}$ & $\begin{array}{l}1255 \\
1300 \\
1305 \\
1310 \\
1315\end{array}$ & $\begin{array}{l}0.5 \\
0.5 \\
0.5 \\
0.5 \\
0.5\end{array}$ & $\begin{array}{l}0.00 \\
0.00 \\
0.00 \\
0.00 \\
0.00\end{array}$ & $\begin{array}{l}1820 \\
1825 \\
1830 \\
1835 \\
1840\end{array}$ & $\begin{array}{l}0.5 \\
0.5 \\
0.5 \\
0.5 \\
0.5\end{array}$ & $\begin{array}{l}0.00 \\
0.00 \\
0.00 \\
0.01 \\
0.01\end{array}$ \\
\hline
\end{tabular}


Table 149. - Streamflow and rainfall at station 02187260, Whitner Creek at Anderson, March 30,1987--Continued

\begin{tabular}{|c|c|c|c|c|c|c|c|c|}
\hline $\begin{array}{l}\text { Time } \\
\text { (hours) }\end{array}$ & $\begin{array}{l}\text { Streamflow } \\
\text { (cubic feet } \\
\text { per second) }\end{array}$ & $\begin{array}{l}\text { Rain- } \\
\text { fall } \\
\text { (inches) }\end{array}$ & $\begin{array}{l}\text { Time } \\
\text { (hours) }\end{array}$ & $\begin{array}{l}\text { Streamflow } \\
\text { (cubic feet } \\
\text { per second) }\end{array}$ & $\begin{array}{l}\text { Rain- } \\
\text { fall } \\
\text { (inches) }\end{array}$ & $\begin{array}{l}\text { Time } \\
\text { (hours) }\end{array}$ & $\begin{array}{l}\text { Streamflow } \\
\text { (cubic feet } \\
\text { per second) }\end{array}$ & $\begin{array}{l}\text { Rain- } \\
\text { fall } \\
\text { (inches) }\end{array}$ \\
\hline $\begin{array}{l}1845 \\
1850 \\
1855 \\
1900 \\
1905\end{array}$ & $\begin{array}{l}0.5 \\
0.5 \\
0.5 \\
0.5 \\
5.0\end{array}$ & $\begin{array}{l}0.01 \\
0.02 \\
0.03 \\
0.03 \\
0.03\end{array}$ & $\begin{array}{l}2015 \\
2020 \\
2025 \\
2030 \\
2035\end{array}$ & $\begin{array}{l}364.0 \\
379.0 \\
402.0 \\
351.0 \\
305.0\end{array}$ & $\begin{array}{l}0.04 \\
0.09 \\
0.04 \\
0.02 \\
0.03\end{array}$ & $\begin{array}{l}2145 \\
2150 \\
2155 \\
2200 \\
2205\end{array}$ & $\begin{array}{r}8.8 \\
13.6 \\
20.5 \\
12.0 \\
7.0\end{array}$ & $\begin{array}{l}0.00 \\
0.00 \\
0.00 \\
0.00 \\
0.00\end{array}$ \\
\hline $\begin{array}{l}1910 \\
1915 \\
1920 \\
1925 \\
1930\end{array}$ & $\begin{array}{l}27.4 \\
29.5 \\
37.9 \\
66.7 \\
75.4\end{array}$ & $\begin{array}{l}0.02 \\
0.02 \\
0.03 \\
0.02 \\
0.11\end{array}$ & $\begin{array}{l}2040 \\
2045 \\
2050 \\
2055 \\
2100\end{array}$ & $\begin{array}{l}268.0 \\
224.0 \\
209.0 \\
202.0 \\
185.0\end{array}$ & $\begin{array}{l}0.05 \\
0.04 \\
0.03 \\
0.01 \\
0.01\end{array}$ & $\begin{array}{l}2210 \\
2215 \\
2220 \\
2225 \\
2230\end{array}$ & $\begin{array}{l}4.0 \\
2.0 \\
1.0 \\
0.5 \\
0.5\end{array}$ & $\begin{array}{l}0.00 \\
0.01 \\
0.00 \\
0.00 \\
0.01\end{array}$ \\
\hline $\begin{array}{l}1935 \\
1940 \\
1945 \\
1950 \\
1955\end{array}$ & $\begin{array}{r}81.0 \\
83.0 \\
70.1 \\
88.9 \\
118.0\end{array}$ & $\begin{array}{l}0.05 \\
0.02 \\
0.02 \\
0.03 \\
0.20\end{array}$ & $\begin{array}{l}2105 \\
2110 \\
2115 \\
2120 \\
2125\end{array}$ & $\begin{array}{r}160.0 \\
139.0 \\
106.0 \\
85.9 \\
66.7\end{array}$ & $\begin{array}{l}0.00 \\
0.01 \\
0.00 \\
0.00 \\
0.00\end{array}$ & $\begin{array}{l}2235 \\
2240 \\
2245 \\
2250 \\
2255\end{array}$ & $\begin{array}{l}0.5 \\
0.5 \\
0.5 \\
0.5 \\
0.5\end{array}$ & $\begin{array}{l}0.00 \\
0.00 \\
0.00 \\
0.00 \\
0.00\end{array}$ \\
\hline $\begin{array}{l}2000 \\
2005 \\
2010\end{array}$ & $\begin{array}{l}175.0 \\
328.0 \\
348.0\end{array}$ & $\begin{array}{l}0.11 \\
0.02 \\
0.04\end{array}$ & $\begin{array}{l}2130 \\
2135 \\
2140\end{array}$ & $\begin{array}{l}25.5 \\
63.0 \\
40.0\end{array}$ & $\begin{array}{l}0.00 \\
0.01 \\
0.00\end{array}$ & 2300 & 0.5 & 0.00 \\
\hline
\end{tabular}




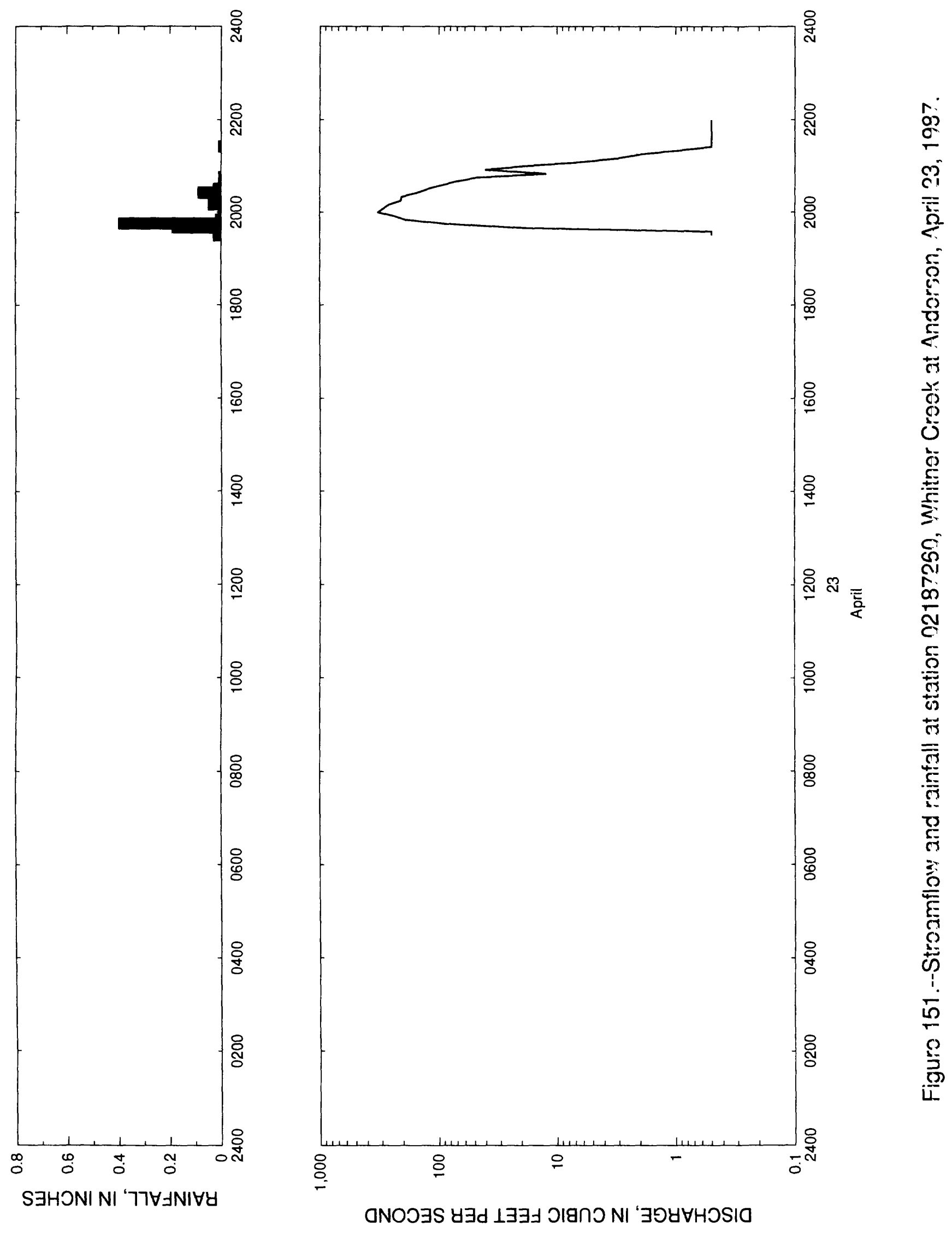


Table 150.--Streamflow and rainfall at station 02187260, Whitner Creek at Anderson, April $2 \overline{3,1987}$

\begin{tabular}{|c|c|c|c|c|c|c|c|c|}
\hline $\begin{array}{l}\text { Time } \\
\text { (hours) }\end{array}$ & $\begin{array}{l}\text { Streamflow } \\
\text { (cubic feet } \\
\text { per second) }\end{array}$ & $\begin{array}{l}\text { Rain- } \\
\text { fall } \\
\text { (inches) }\end{array}$ & $\begin{array}{l}\text { Time } \\
\text { (hours) }\end{array}$ & $\begin{array}{l}\text { Streamflow } \\
\text { (cubic feet } \\
\text { per second) }\end{array}$ & $\begin{array}{l}\text { Rain- } \\
\text { fal1 } \\
\text { (inches) }\end{array}$ & $\begin{array}{l}\text { Time } \\
\text { (hours) }\end{array}$ & $\begin{array}{l}\text { Streamflow } \\
\text { (cubic feet } \\
\text { per second) }\end{array}$ & $\begin{array}{l}\text { Rain- } \\
\text { fa11 } \\
\text { (inches) }\end{array}$ \\
\hline $\begin{array}{l}\text { Apri1 23, } \\
1930 \\
1935 \\
1940 \\
1945 \\
1950\end{array}$ & $\begin{array}{r}1987 \\
0.5 \\
0.5 \\
20.0 \\
85.9 \\
188.0\end{array}$ & $\begin{array}{l}0.03 \\
0.03 \\
0.19 \\
0.40 \\
0.02\end{array}$ & $\begin{array}{l}2020 \\
2025 \\
2030 \\
2035 \\
2040 \\
2045\end{array}$ & $\begin{array}{r}206.0 \\
154.0 \\
124.0 \\
95.2 \\
71.8 \\
47.0\end{array}$ & $\begin{array}{l}0.01 \\
0.09 \\
0.03 \\
0.01 \\
0.00 \\
0.01\end{array}$ & $\begin{array}{l}2115 \\
2120 \\
2125 \\
2130 \\
2135 \\
2140\end{array}$ & $\begin{array}{l}2.0 \\
1.0 \\
0.5 \\
0.5 \\
0.5 \\
0.5\end{array}$ & $\begin{array}{l}0.00 \\
0.00 \\
0.01 \\
0.00 \\
0.00 \\
0.00\end{array}$ \\
\hline $\begin{array}{l}1955 \\
2000 \\
2005 \\
2010\end{array}$ & $\begin{array}{l}236.0 \\
325.0 \\
292.0 \\
260.0\end{array}$ & $\begin{array}{l}0.00 \\
0.01 \\
0.01 \\
0.05\end{array}$ & $\begin{array}{l}2050 \\
2055 \\
2100 \\
2105\end{array}$ & $\begin{array}{r}12.0 \\
40.0 \\
18.7 \\
6.3\end{array}$ & $\begin{array}{l}0.00 \\
0.00 \\
0.00 \\
0.00\end{array}$ & $\begin{array}{l}2145 \\
2150 \\
2155 \\
2200\end{array}$ & $\begin{array}{l}0.5 \\
0.5 \\
0.5 \\
0.5\end{array}$ & $\begin{array}{l}0.00 \\
0.00 \\
0.00 \\
0.00\end{array}$ \\
\hline 2015 & 209.0 & 0.02 & 2110 & 3.0 & 0.00 & & & \\
\hline
\end{tabular}




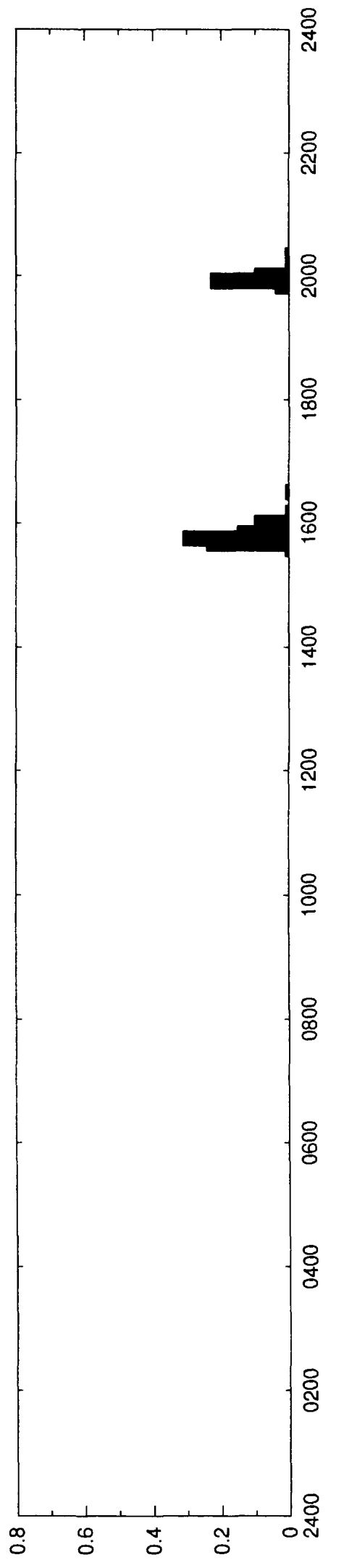

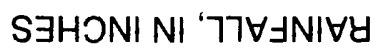

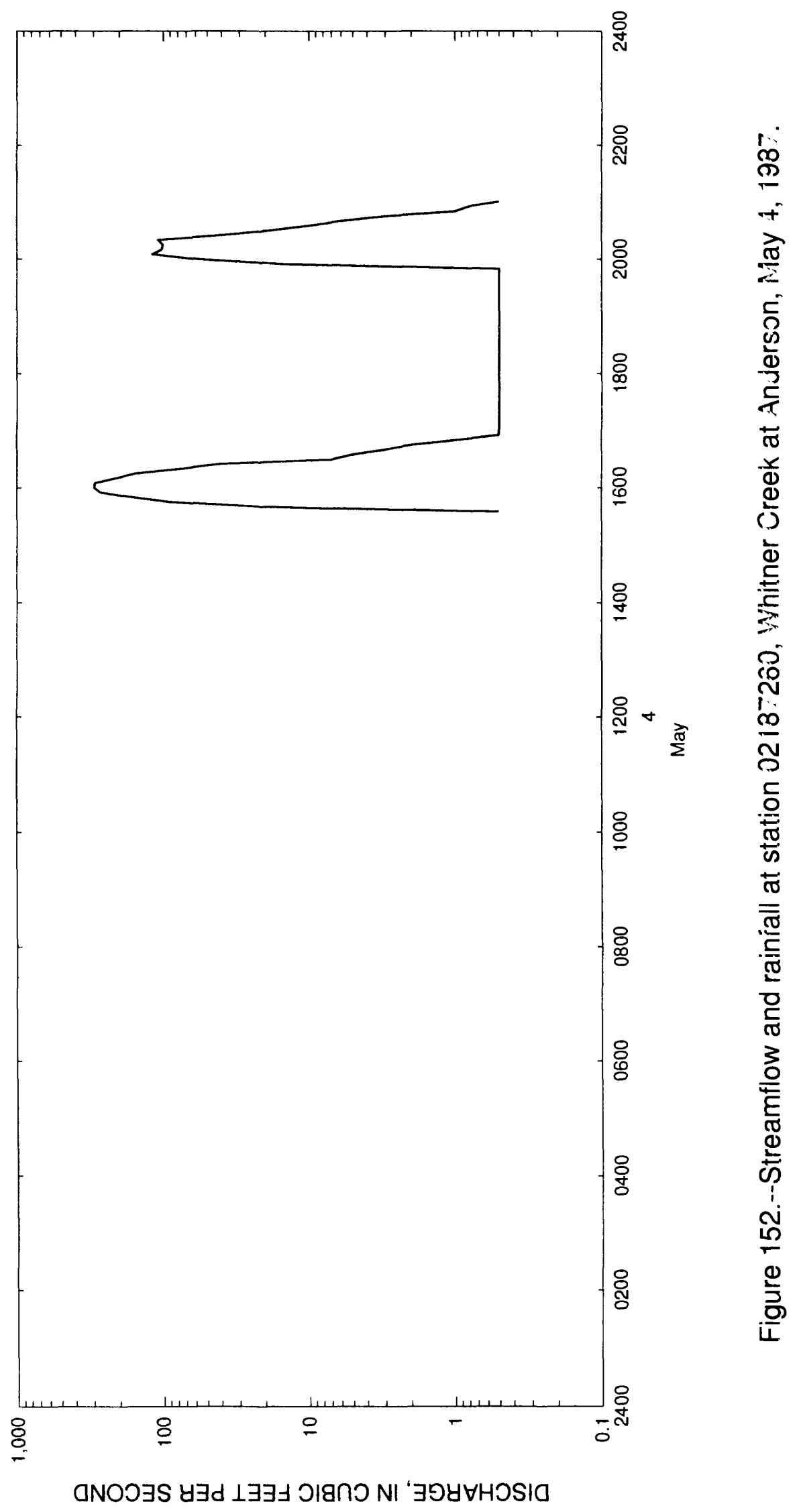


Table 151.- - Streamflow and rainfall at station 02187260, Whitner Creek at Anderson, May $4, \overline{1987}$

\begin{tabular}{|c|c|c|c|c|c|c|c|c|}
\hline $\begin{array}{l}\text { Time } \\
\text { (hours) }\end{array}$ & $\begin{array}{l}\text { Streamflow } \\
\text { (cubic feet } \\
\text { per second) }\end{array}$ & $\begin{array}{l}\text { Rain- } \\
\text { fall } \\
\text { (inches) }\end{array}$ & $\begin{array}{l}\text { Time } \\
\text { (hours) }\end{array}$ & $\begin{array}{l}\text { Streamflow } \\
\text { (cubic feet } \\
\text { per second) }\end{array}$ & $\begin{array}{l}\text { Rain- } \\
\text { fall } \\
\text { (inches) }\end{array}$ & $\begin{array}{l}\text { Time } \\
\text { (hours) }\end{array}$ & $\begin{array}{l}\text { Streamflow } \\
\text { (cubic feet } \\
\text { per second) }\end{array}$ & $\begin{array}{l}\text { Rain- } \\
\text { fall } \\
\text { (inches) }\end{array}$ \\
\hline $\begin{array}{c}\text { May 4, } 1 \\
1535 \\
1540 \\
1545 \\
1550\end{array}$ & $\begin{array}{r}1987 \quad 0.5 \\
20.0 \\
88.9 \\
162.0\end{array}$ & $\begin{array}{l}0.01 \\
0.24 \\
0.31 \\
0.15\end{array}$ & $\begin{array}{l}1725 \\
1730 \\
1735 \\
1740 \\
1745\end{array}$ & $\begin{array}{l}0.5 \\
0.5 \\
0.5 \\
0.5 \\
0.5\end{array}$ & $\begin{array}{l}0.00 \\
0.00 \\
0.00 \\
0.00 \\
0.00\end{array}$ & $\begin{array}{l}1920 \\
1925 \\
1930 \\
1935 \\
1940\end{array}$ & $\begin{array}{l}0.5 \\
0.5 \\
0.5 \\
0.5 \\
0.5\end{array}$ & $\begin{array}{l}0.00 \\
0.00 \\
0.00 \\
0.00 \\
0.00\end{array}$ \\
\hline $\begin{array}{l}1555 \\
1600 \\
1605 \\
1610 \\
1615\end{array}$ & $\begin{array}{l}268.0 \\
297.0 \\
292.0 \\
213.0 \\
154.0\end{array}$ & $\begin{array}{l}0.04 \\
0.10 \\
0.00 \\
0.01 \\
0.00\end{array}$ & $\begin{array}{l}1750 \\
1755 \\
1800 \\
1805 \\
1810\end{array}$ & $\begin{array}{l}0.5 \\
0.5 \\
0.5 \\
0.5 \\
0.5\end{array}$ & $\begin{array}{l}0.00 \\
0.00 \\
0.00 \\
0.00 \\
0.00\end{array}$ & $\begin{array}{l}1945 \\
1950 \\
1955 \\
2000 \\
2005\end{array}$ & $\begin{array}{r}0.5 \\
0.5 \\
15.0 \\
59.2 \\
119.0\end{array}$ & $\begin{array}{l}0.00 \\
0.04 \\
0.23 \\
0.10 \\
0.01\end{array}$ \\
\hline $\begin{array}{l}1620 \\
1625 \\
1630 \\
1635 \\
1640\end{array}$ & $\begin{array}{r}75.4 \\
40.0 \\
7.0 \\
5.0 \\
3.0\end{array}$ & $\begin{array}{l}0.00 \\
0.00 \\
0.01 \\
0.00 \\
0.00\end{array}$ & $\begin{array}{l}1815 \\
1820 \\
1825 \\
1830 \\
1835\end{array}$ & $\begin{array}{l}0.5 \\
0.5 \\
0.5 \\
0.5 \\
0.5\end{array}$ & $\begin{array}{l}0.00 \\
0.00 \\
0.00 \\
0.00 \\
0.00\end{array}$ & $\begin{array}{l}2010 \\
2015 \\
2020 \\
2025 \\
2030\end{array}$ & $\begin{array}{r}103.0 \\
101.0 \\
109.0 \\
40.0 \\
18.7\end{array}$ & $\begin{array}{l}0.00 \\
0.00 \\
0.01 \\
0.00 \\
0.00\end{array}$ \\
\hline $\begin{array}{l}1645 \\
1650 \\
1655 \\
1700 \\
1705\end{array}$ & $\begin{array}{l}2.0 \\
1.0 \\
0.5 \\
0.5 \\
0.5\end{array}$ & $\begin{array}{l}0.00 \\
0.00 \\
0.00 \\
0.00 \\
0.00\end{array}$ & $\begin{array}{l}1840 \\
1845 \\
1850 \\
1855 \\
1900\end{array}$ & $\begin{array}{l}0.5 \\
0.5 \\
0.5 \\
0.5 \\
0.5\end{array}$ & $\begin{array}{l}0.00 \\
0.00 \\
0.00 \\
0.00 \\
0.00\end{array}$ & $\begin{array}{l}2035 \\
2040 \\
2045 \\
2050 \\
2055\end{array}$ & $\begin{array}{r}10.0 \\
6.0 \\
3.0 \\
1.0 \\
0.8\end{array}$ & $\begin{array}{l}0.00 \\
0.00 \\
0.00 \\
0.00 \\
0.00\end{array}$ \\
\hline $\begin{array}{l}1710 \\
1715 \\
1720\end{array}$ & $\begin{array}{l}0.5 \\
0.5 \\
0.5\end{array}$ & $\begin{array}{l}0.00 \\
0.00 \\
0.00\end{array}$ & $\begin{array}{l}1905 \\
1910 \\
1915\end{array}$ & $\begin{array}{l}0.5 \\
0.5 \\
0.5\end{array}$ & $\begin{array}{l}0.00 \\
0.00 \\
0.00\end{array}$ & 2100 & 0.5 & 0.00 \\
\hline
\end{tabular}




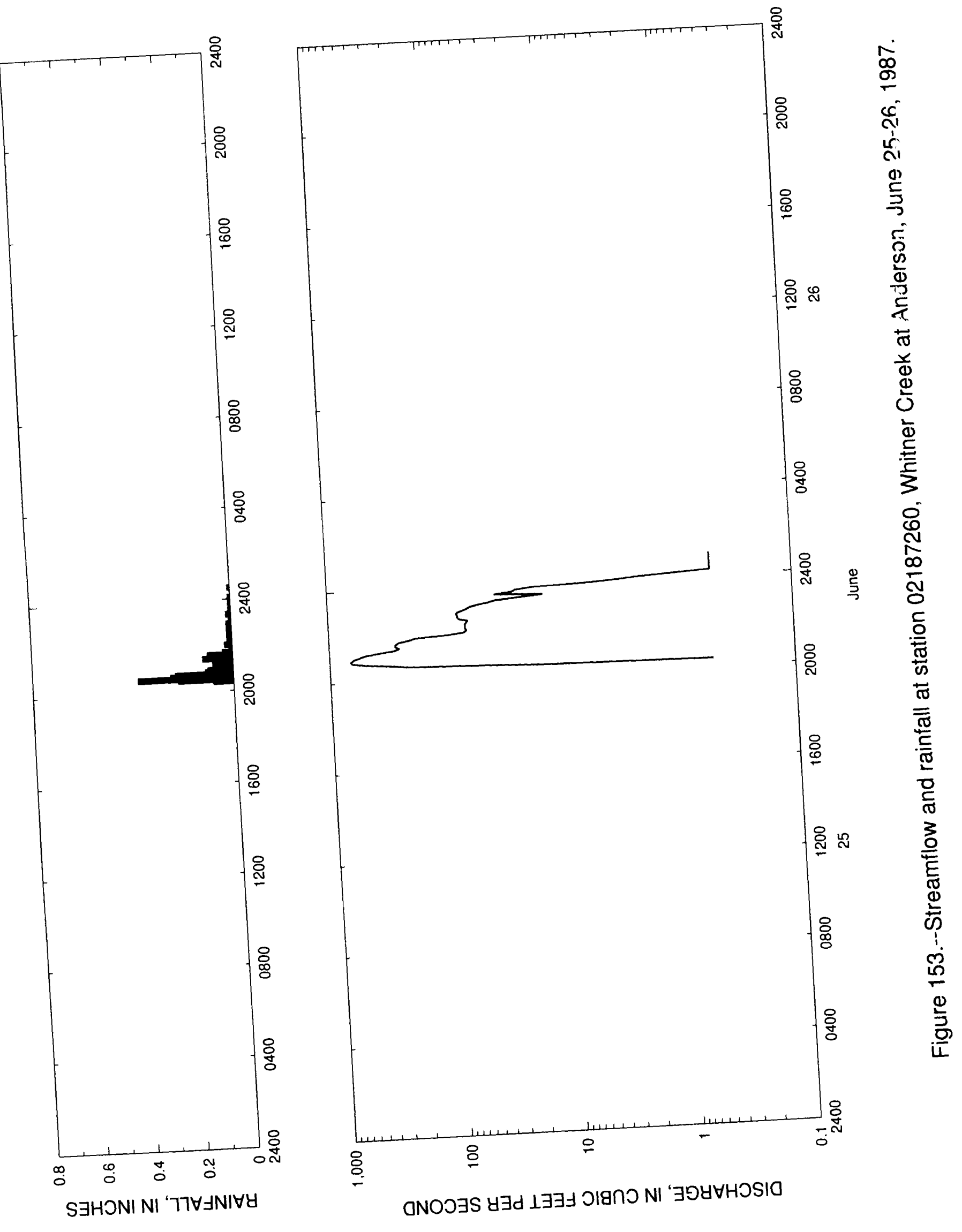


Table 152. - Streamflow and rainfall at station 02187260, Whitner Creek at Anderson, June $25-26,1987$

\begin{tabular}{|c|c|c|c|c|c|c|c|c|}
\hline $\begin{array}{l}\text { Time } \\
\text { (hours) }\end{array}$ & $\begin{array}{l}\text { Streamflow } \\
\text { (cubic feet } \\
\text { per second) }\end{array}$ & $\begin{array}{l}\text { Rain- } \\
\text { fall } \\
\text { (1nches) }\end{array}$ & $\begin{array}{l}\text { Time } \\
\text { (hours) }\end{array}$ & $\begin{array}{l}\text { Streamflow } \\
\text { (cubic feet } \\
\text { per second) }\end{array}$ & $\begin{array}{l}\text { Rain- } \\
\text { fall } \\
\text { (inches) }\end{array}$ & $\begin{array}{l}\text { Time } \\
\text { (hours) }\end{array}$ & $\begin{array}{l}\text { Streamflow } \\
\text { (cubic feet } \\
\text { per second) }\end{array}$ & $\begin{array}{l}\text { Rain- } \\
\text { fal1 } \\
\text { (inches) }\end{array}$ \\
\hline $\begin{array}{l}\text { June } 25, \\
2020 \\
2025 \\
2030 \\
2035\end{array}$ & $\begin{array}{r}1987 \\
0.5 \\
15.0 \\
41.7 \\
209.0\end{array}$ & $\begin{array}{l}0.00 \\
0.08 \\
0.22 \\
0.38\end{array}$ & $\begin{array}{l}2155 \\
2200 \\
2205 \\
2210 \\
2215\end{array}$ & $\begin{array}{l}93.6 \\
68.3 \\
65.0 \\
66.7 \\
66.7\end{array}$ & $\begin{array}{l}0.01 \\
0.03 \\
0.02 \\
0.02 \\
0.02\end{array}$ & $\begin{array}{l}2335 \\
2340 \\
2345 \\
2350 \\
2355\end{array}$ & $\begin{array}{r}35.9 \\
25.5 \\
23.7 \\
17.0 \\
5.6\end{array}$ & $\begin{array}{l}0 . C 0 \\
0 . C 1 \\
0 . C 0 \\
0 . C 1 \\
0 . C 0\end{array}$ \\
\hline $\begin{array}{l}2040 \\
2045 \\
2050 \\
2055 \\
2100\end{array}$ & $\begin{array}{l}294.0 \\
496.0 \\
646.0 \\
660.0 \\
625.0\end{array}$ & $\begin{array}{l}0.25 \\
0.23 \\
0.11 \\
0.10 \\
0.08\end{array}$ & $\begin{array}{l}2220 \\
2225 \\
2230 \\
2235 \\
2240\end{array}$ & $\begin{array}{l}66.7 \\
65.0 \\
63.0 \\
75.4 \\
77.2\end{array}$ & $\begin{array}{l}0.02 \\
0.02 \\
0.02 \\
0.02 \\
0.02\end{array}$ & $\begin{array}{l}\text { June } 26 \text {, } \\
0000 \\
0005 \\
0010 \\
0015\end{array}$ & $\begin{array}{r}1987 \\
3.0 \\
2.0 \\
1.0 \\
0.5\end{array}$ & $\begin{array}{l}0.00 \\
0.01 \\
0.00 \\
0.00\end{array}$ \\
\hline $\begin{array}{l}2105 \\
2110 \\
2115 \\
2120 \\
2125\end{array}$ & $\begin{array}{l}558.0 \\
500.0 \\
376.0 \\
276.0 \\
250.0\end{array}$ & $\begin{array}{l}0.05 \\
0.03 \\
0.08 \\
0.05 \\
0.12\end{array}$ & $\begin{array}{l}2245 \\
2250 \\
2255 \\
2300 \\
2305\end{array}$ & $\begin{array}{l}77.2 \\
79.1 \\
73.6 \\
65.0 \\
61.1\end{array}$ & $\begin{array}{l}0.01 \\
0.01 \\
0.02 \\
0.01 \\
0.01\end{array}$ & $\begin{array}{l}0020 \\
0025 \\
0030 \\
0035 \\
0040\end{array}$ & $\begin{array}{l}0.5 \\
0.5 \\
0.5 \\
0.5 \\
0.5\end{array}$ & $\begin{array}{l}0.00 \\
0.00 \\
0.01 \\
0.00 \\
0.00\end{array}$ \\
\hline $\begin{array}{l}2130 \\
2135 \\
2140 \\
2145 \\
2150\end{array}$ & $\begin{array}{l}270.0 \\
270.0 \\
253.0 \\
206.0 \\
179.0\end{array}$ & $\begin{array}{l}0.10 \\
0.10 \\
0.04 \\
0.01 \\
0.01\end{array}$ & $\begin{array}{l}2310 \\
2315 \\
2320 \\
2325 \\
2330\end{array}$ & $\begin{array}{l}52.0 \\
41.7 \\
35.9 \\
22.1 \\
13.6\end{array}$ & $\begin{array}{l}0.01 \\
0.01 \\
0.02 \\
0.01 \\
0.01\end{array}$ & $\begin{array}{l}0045 \\
0050 \\
0055 \\
0100\end{array}$ & $\begin{array}{l}0.5 \\
0.5 \\
0.5 \\
0.5\end{array}$ & $\begin{array}{l}0.00 \\
0.00 \\
0.00 \\
0.00\end{array}$ \\
\hline
\end{tabular}




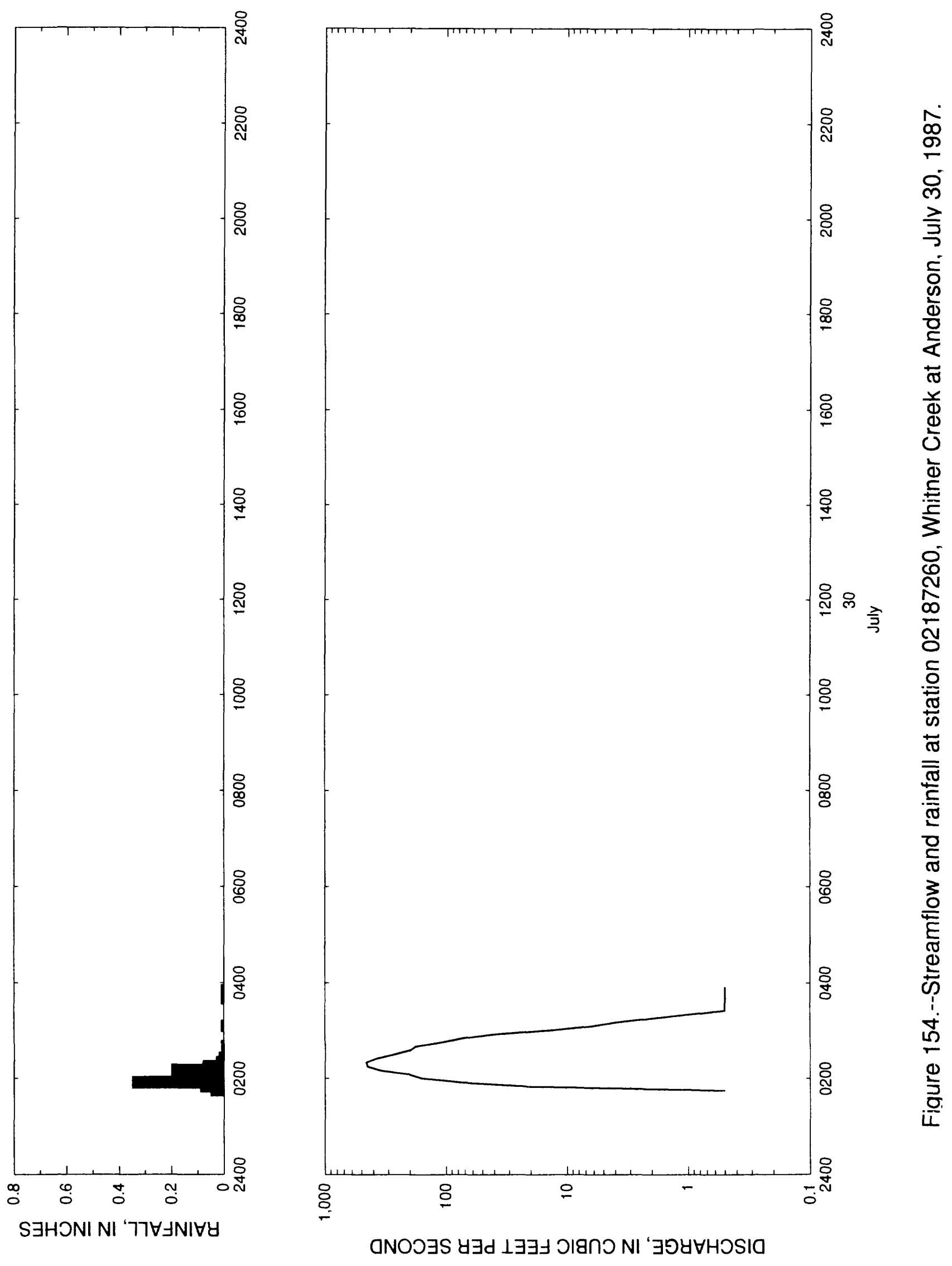


Table 153. - Streamflow and rainfall at station 02187260, Whitner Creek at Anderson, July 30,1987

\begin{tabular}{|c|c|c|c|c|c|c|c|c|}
\hline $\begin{array}{l}\text { Time } \\
\text { (hours) }\end{array}$ & $\begin{array}{l}\text { Streamflow } \\
\text { (cubic feet } \\
\text { per second) }\end{array}$ & $\begin{array}{l}\text { Rain- } \\
\text { fall } \\
\text { (inches) }\end{array}$ & $\begin{array}{l}\text { Time } \\
\text { (hours) }\end{array}$ & $\begin{array}{l}\text { Streamflow } \\
\text { (cubic feet } \\
\text { per second) }\end{array}$ & $\begin{array}{l}\text { Rain- } \\
\text { fall } \\
\text { (inches) }\end{array}$ & $\begin{array}{l}\text { Time } \\
\text { (hours) }\end{array}$ & $\begin{array}{l}\text { Streamflow } \\
\text { (cubic feet } \\
\text { per second) }\end{array}$ & $\begin{array}{l}\text { Rain- } \\
\text { fall } \\
\text { (inches) }\end{array}$ \\
\hline $\begin{array}{l}\text { July } 30, \\
0145 \\
0150 \\
0155 \\
0200\end{array}$ & $\begin{array}{r}1987 \\
0.5 \\
20.0 \\
75.4 \\
158.0\end{array}$ & $\begin{array}{l}0.05 \\
0.09 \\
0.35 \\
0.16\end{array}$ & $\begin{array}{l}0230 \\
0235 \\
0240 \\
0245 \\
0250\end{array}$ & $\begin{array}{r}273.0 \\
200.0 \\
181.0 \\
110.0 \\
73.6\end{array}$ & $\begin{array}{l}0.01 \\
0.00 \\
0.01 \\
0.00 \\
0.00\end{array}$ & $\begin{array}{l}0320 \\
0325 \\
0330 \\
0335 \\
0340\end{array}$ & $\begin{array}{l}1.0 \\
0.5 \\
0.5 \\
0.5 \\
0.5\end{array}$ & $\begin{array}{l}0.07 \\
0.07 \\
0.00 \\
0.00 \\
0.01\end{array}$ \\
\hline $\begin{array}{l}0205 \\
0210 \\
0215 \\
0220 \\
0225\end{array}$ & $\begin{array}{l}202.0 \\
351.0 \\
446.0 \\
456.0 \\
379.0\end{array}$ & $\begin{array}{l}0.19 \\
0.20 \\
0.08 \\
0.03 \\
0.02\end{array}$ & $\begin{array}{l}0255 \\
0300 \\
0305 \\
0310 \\
0315\end{array}$ & $\begin{array}{r}40.0 \\
13.6 \\
6.3 \\
4.0 \\
2.0\end{array}$ & $\begin{array}{l}0.00 \\
0.00 \\
0.01 \\
0.00 \\
0.00\end{array}$ & $\begin{array}{l}0345 \\
0350 \\
0355 \\
0400\end{array}$ & $\begin{array}{l}0.5 \\
0.5 \\
0.5 \\
0.5\end{array}$ & $\begin{array}{l}0 . C 1 \\
0 . C 1 \\
0 . C 0 \\
0 . C 1\end{array}$ \\
\hline
\end{tabular}




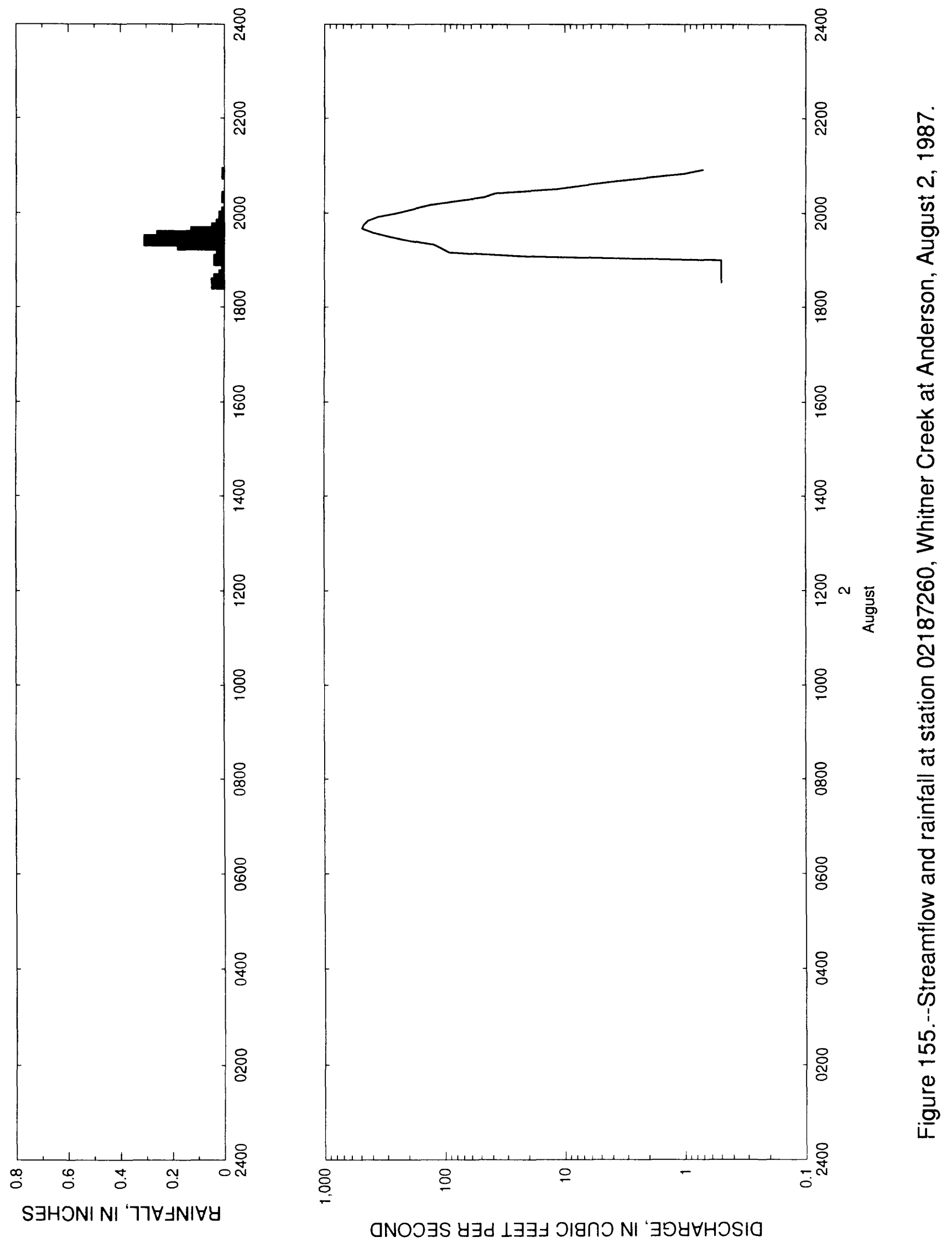


Table 154. - Streamflow and rainfall at station 02187260, Whitner Creek at Anderson, August 2,1987

\begin{tabular}{|c|c|c|c|c|c|c|c|c|}
\hline $\begin{array}{l}\text { Time } \\
\text { (hours) }\end{array}$ & $\begin{array}{l}\text { Streamflow } \\
\text { (cubic feet } \\
\text { per second) }\end{array}$ & $\begin{array}{l}\text { Rain- } \\
\text { fall } \\
\text { (inches) }\end{array}$ & $\begin{array}{l}\text { Time } \\
\text { (hours) }\end{array}$ & $\begin{array}{l}\text { Streamflow } \\
\text { (cubic feet } \\
\text { per second) }\end{array}$ & $\begin{array}{l}\text { Rain- } \\
\text { fall } \\
\text { (inches) }\end{array}$ & $\begin{array}{l}\text { Time } \\
\text { (hours) }\end{array}$ & $\begin{array}{l}\text { Streamflow } \\
\text { (cubic feet } \\
\text { per second) }\end{array}$ & $\begin{array}{l}\text { Rain- } \\
\text { fall } \\
\text { (inches) }\end{array}$ \\
\hline $\begin{array}{c}\text { August } 2 \\
1830 \\
1835 \\
1840 \\
1845\end{array}$ & $\begin{array}{r}1987 \\
0.5 \\
0.5 \\
0.5 \\
0.5\end{array}$ & $\begin{array}{l}0.05 \\
0.04 \\
0.02 \\
0.01\end{array}$ & $\begin{array}{l}1920 \\
1925 \\
1930 \\
1935 \\
1940\end{array}$ & $\begin{array}{l}124.0 \\
202.0 \\
292.0 \\
398.0 \\
489.0\end{array}$ & $\begin{array}{l}0.18 \\
0.31 \\
0.26 \\
0.13 \\
0.05\end{array}$ & $\begin{array}{l}2015 \\
2020 \\
2025 \\
2030 \\
2035\end{array}$ & $\begin{array}{r}81.0 \\
47.0 \\
37.9 \\
12.0 \\
7.0\end{array}$ & $\begin{array}{l}0.00 \\
0.01 \\
0.00 \\
0.00 \\
0.00\end{array}$ \\
\hline $\begin{array}{l}1850 \\
1855 \\
1900 \\
1905 \\
1910\end{array}$ & $\begin{array}{r}0.5 \\
0.5 \\
0.5 \\
20.0 \\
92.0\end{array}$ & $\begin{array}{l}0.01 \\
0.00 \\
0.04 \\
0.03 \\
0.01\end{array}$ & $\begin{array}{l}1945 \\
1950 \\
1955 \\
2000 \\
2005\end{array}$ & $\begin{array}{l}474.0 \\
435.0 \\
361.0 \\
248.0 \\
183.0\end{array}$ & $\begin{array}{l}0.03 \\
0.02 \\
0.02 \\
0.01 \\
0.00\end{array}$ & $\begin{array}{l}2040 \\
2045 \\
2050 \\
2055 \\
2100\end{array}$ & $\begin{array}{l}4.0 \\
2.0 \\
1.0 \\
0.7 \\
0.5\end{array}$ & $\begin{array}{l}0.00 \\
0.00 \\
0.01 \\
0.00 \\
0.00\end{array}$ \\
\hline 1915 & 106.0 & 0.03 & 2010 & 134.0 & 0.00 & & & \\
\hline
\end{tabular}




\section{Station 02187268, Dye Creek at Anderson, S.C.}

Location.-Lat $34^{\circ} 30^{\prime} 01^{\prime \prime}$, long 82 40'13", Anderson County Hydrologic Unit 03060103, at culvert on Market Street (State secondary road 22), $1.2 \mathrm{mi}$ west of Anderson City Hall, and $0.5 \mathrm{mi}$ upstream from the mouth at Generostee Creek.

Period of record.-- January 30, 1986 to November 1, 1990.

Gage.--Digital stage recorder with 5-minute punch interval. The recorder is housed in a metal shelter atop a stilling well attached to the right upstream webwall of a triple barrel $10.1 \mathrm{ft}$ by $7.6 \mathrm{ft}$ concrete box culvert. A sealed intake pipe extends $40 \mathrm{ft}$ upstream to a separate stilling basin (sand trap) with a removable lid. One creststage indicator is located on the right downstream wingwall. A second crest-stage indicator is located on the left bank $40 \mathrm{ft}$ upstream from the culvert.

Rating.--The stage-streamflow relation is defined by current meter measurements up to $266 \mathrm{ft}^{3} / \mathrm{s}$. The stage-streamflow relation was extended to $810 \mathrm{ft}^{3} / \mathrm{s}$ using indirect computational methods.

Rain gage and location.--Station 343001082401300 , lat $34^{\circ} 30^{\prime} 01^{\prime \prime}$, long $82^{\circ} 40^{\prime} 13^{\prime \prime}$. A shelter containing a digital cumulative rainfall recorder with a 5-minute punch interval attached to the right downstream wingwall of the culvert at Market Street (State secondary road 22), approximately $1.2 \mathrm{mi}$ west of Anderson City Hall, and $0.5 \mathrm{mi}$ upstream from the mouth at Generostee Creek.

Selected basin characteristics.--

Drainage area $-2.85 \mathrm{mi}^{2}$

Physiographic province -- Piedmont

Channel slope -- $43.8 \mathrm{ft} / \mathrm{mi}$

Channel length $-2.77 \mathrm{mi}$

Total impervious area -- 20.0 percent

Basin development factor -- 3

2-year, 2-hour rainfall amount -- 2.15 in.

Flood frequency data: $\mathrm{UQ}_{2} \quad 616 \mathrm{ft}^{3} / \mathrm{s}$

$\mathrm{UQ}_{5} \quad 952 \mathrm{ft}^{3} / \mathrm{s}$

$\mathrm{UQ}_{10} \quad 1,210 \mathrm{ft}^{3} / \mathrm{s}$

$\mathrm{UQ}_{25} \quad 1,560 \mathrm{ft}^{3} / \mathrm{s}$

$\mathrm{UQ}_{50} \quad 1,850 \mathrm{ft}^{3} / \mathrm{s}$

$\mathrm{UQ}_{100} \quad 2,170 \mathrm{ft}^{3} / \mathrm{s}$

$\mathrm{UQ}_{500} \quad 2,990 \mathrm{ft}^{3} / \mathrm{s}$ 


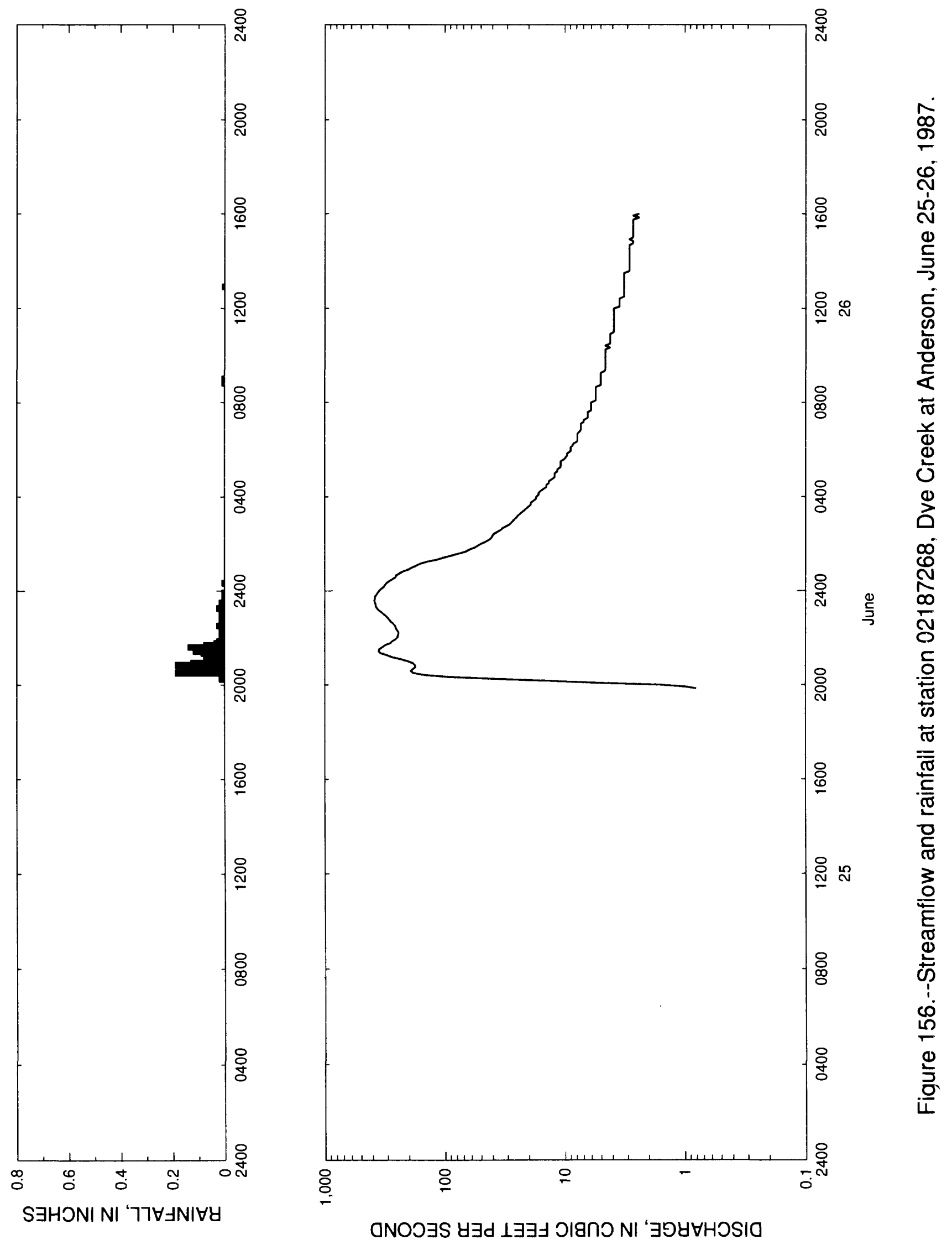


Table 155. - Streamflow and rainfall at station 02187268, Dye Creek at Anderson, June 25-26, 1987

\begin{tabular}{|c|c|c|c|c|c|c|c|c|}
\hline $\begin{array}{l}\text { Time } \\
\text { (hours) }\end{array}$ & $\begin{array}{l}\text { Streamflow } \\
\text { (cubic feet } \\
\text { per second) }\end{array}$ & $\begin{array}{l}\text { Rain- } \\
\text { fall } \\
\text { (inches) }\end{array}$ & $\begin{array}{l}\text { Time } \\
\text { (hours) }\end{array}$ & $\begin{array}{l}\text { Streamflow } \\
\text { (cubic feet } \\
\text { per second) }\end{array}$ & $\begin{array}{l}\text { Rain- } \\
\text { fall } \\
\text { (inches) }\end{array}$ & $\begin{array}{l}\text { Time } \\
\text { (hours) }\end{array}$ & $\begin{array}{l}\text { Streamflow } \\
\text { (cubic feet } \\
\text { per second) }\end{array}$ & $\begin{array}{l}\text { Rain- } \\
\text { fall } \\
\text { (inches) }\end{array}$ \\
\hline $\begin{array}{l}\text { June } 25 \\
1950 \\
1955 \\
2000 \\
2005\end{array}$ & $\begin{array}{r}1987 \\
0.8 \\
1.0 \\
1.6 \\
5.5\end{array}$ & $\begin{array}{l}0.00 \\
0.00 \\
0.00 \\
0.00\end{array}$ & $\begin{array}{l}0105 \\
0110 \\
0115 \\
0120 \\
0125\end{array}$ & $\begin{array}{l}171.0 \\
159.0 \\
139.0 \\
115.0 \\
103.0\end{array}$ & $\begin{array}{l}0.00 \\
0.00 \\
0.00 \\
0.00 \\
0.00\end{array}$ & $\begin{array}{l}0630 \\
0635 \\
0640 \\
0645 \\
0650\end{array}$ & $\begin{array}{l}7.8 \\
7.8 \\
7.8 \\
7.5 \\
7.3\end{array}$ & $\begin{array}{l}0.00 \\
0.00 \\
0.00 \\
0.00 \\
0.00\end{array}$ \\
\hline $\begin{array}{l}2010 \\
2015 \\
2020 \\
2025 \\
2030\end{array}$ & $\begin{array}{r}12.1 \\
34.8 \\
93.7 \\
151.0 \\
184.0\end{array}$ & $\begin{array}{l}0.00 \\
0.02 \\
0.01 \\
0.02 \\
0.19\end{array}$ & $\begin{array}{l}0130 \\
0135 \\
0140 \\
0145 \\
0150\end{array}$ & $\begin{array}{l}89.2 \\
77.8 \\
67.4 \\
62.4 \\
56.5\end{array}$ & $\begin{array}{l}0.00 \\
0.00 \\
0.00 \\
0.00 \\
0.00\end{array}$ & $\begin{array}{l}0655 \\
0700 \\
0705 \\
0710 \\
0715\end{array}$ & $\begin{array}{l}7.3 \\
7.3 \\
7.3 \\
6.9 \\
6.9\end{array}$ & $\begin{array}{l}0.00 \\
0.00 \\
0.00 \\
0.00 \\
0.00\end{array}$ \\
\hline $\begin{array}{l}2035 \\
2040 \\
2045 \\
2050 \\
2055\end{array}$ & $\begin{array}{l}192.0 \\
185.0 \\
175.0 \\
177.0 \\
184.0\end{array}$ & $\begin{array}{l}0.15 \\
0.15 \\
0.14 \\
0.19 \\
0.13\end{array}$ & $\begin{array}{l}0155 \\
0200 \\
0205 \\
0210 \\
0215\end{array}$ & $\begin{array}{l}53.2 \\
50.0 \\
45.9 \\
42.9 \\
40.9\end{array}$ & $\begin{array}{l}0.00 \\
0.00 \\
0.00 \\
0.00 \\
0.00\end{array}$ & $\begin{array}{l}0720 \\
0725 \\
0730 \\
0735 \\
0740\end{array}$ & $\begin{array}{l}6.4 \\
6.4 \\
6.4 \\
6.4 \\
6.0\end{array}$ & $\begin{array}{l}0.00 \\
0.00 \\
0.00 \\
0.00 \\
0.00\end{array}$ \\
\hline $\begin{array}{l}2100 \\
2105 \\
2110 \\
2115 \\
2120\end{array}$ & $\begin{array}{l}204.0 \\
232.0 \\
274.0 \\
304.0 \\
344.0\end{array}$ & $\begin{array}{l}0.08 \\
0.03 \\
0.05 \\
0.08 \\
0.09\end{array}$ & $\begin{array}{l}0220 \\
0225 \\
0230 \\
0235 \\
0240\end{array}$ & $\begin{array}{l}40.0 \\
39.1 \\
36.5 \\
34.0 \\
32.9\end{array}$ & $\begin{array}{l}0.00 \\
0.00 \\
0.00 \\
0.00 \\
0.00\end{array}$ & $\begin{array}{l}0745 \\
0750 \\
0755 \\
0800 \\
0805\end{array}$ & $\begin{array}{l}6.0 \\
6.0 \\
6.0 \\
6.0 \\
5.5\end{array}$ & $\begin{array}{l}0.00 \\
0.00 \\
0.00 \\
0.00 \\
0.00\end{array}$ \\
\hline $\begin{array}{l}2125 \\
2130 \\
2135 \\
2140 \\
2145\end{array}$ & $\begin{array}{l}356.0 \\
350.0 \\
332.0 \\
314.0 \\
284.0\end{array}$ & $\begin{array}{l}0.12 \\
0.11 \\
0.14 \\
0.08 \\
0.04\end{array}$ & $\begin{array}{l}0245 \\
0250 \\
0255 \\
0300 \\
0305\end{array}$ & $\begin{array}{l}30.7 \\
28.7 \\
27.7 \\
26.7 \\
25.8\end{array}$ & $\begin{array}{l}0.00 \\
0.00 \\
0.00 \\
0.00 \\
0.00\end{array}$ & $\begin{array}{l}0810 \\
0815 \\
0820 \\
0825 \\
0830\end{array}$ & $\begin{array}{l}5.5 \\
5.5 \\
5.5 \\
5.5 \\
5.5\end{array}$ & $\begin{array}{l}0.00 \\
0.00 \\
0.00 \\
0.00 \\
0.00\end{array}$ \\
\hline $\begin{array}{l}2150 \\
2155 \\
2200 \\
2205 \\
2210\end{array}$ & $\begin{array}{l}274.0 \\
256.0 \\
247.0 \\
245.0 \\
242.0\end{array}$ & $\begin{array}{l}0.03 \\
0.02 \\
0.01 \\
0.02 \\
0.01\end{array}$ & $\begin{array}{l}0310 \\
0315 \\
0320 \\
0325 \\
0330\end{array}$ & $\begin{array}{l}24.9 \\
24.0 \\
22.9 \\
21.9 \\
20.9\end{array}$ & $\begin{array}{l}0.00 \\
0.00 \\
0.00 \\
0.00 \\
0.00\end{array}$ & $\begin{array}{l}0835 \\
0840 \\
0845 \\
0850 \\
0855\end{array}$ & $\begin{array}{l}5.5 \\
5.5 \\
5.0 \\
5.0 \\
5.0\end{array}$ & $\begin{array}{l}0.00 \\
0.00 \\
0.00 \\
0.01 \\
0.00\end{array}$ \\
\hline $\begin{array}{l}2215 \\
2220 \\
2225 \\
2230 \\
2235\end{array}$ & $\begin{array}{l}244.0 \\
251.0 \\
256.0 \\
259.0 \\
268.0\end{array}$ & $\begin{array}{l}0.02 \\
0.01 \\
0.02 \\
0.03 \\
0.02\end{array}$ & $\begin{array}{l}0335 \\
0340 \\
0345 \\
0350 \\
0355\end{array}$ & $\begin{array}{l}20.0 \\
19.1 \\
19.1 \\
18.2 \\
17.3\end{array}$ & $\begin{array}{l}0.00 \\
0.00 \\
0.00 \\
0.00 \\
0.00\end{array}$ & $\begin{array}{l}0900 \\
0905 \\
0910 \\
0915 \\
0920\end{array}$ & $\begin{array}{l}5.0 \\
5.0 \\
5.0 \\
5.0 \\
4.6\end{array}$ & $\begin{array}{l}0.01 \\
0.00 \\
0.00 \\
0.00 \\
0.00\end{array}$ \\
\hline $\begin{array}{l}2240 \\
2245 \\
2250 \\
2255 \\
2300\end{array}$ & $\begin{array}{l}280.0 \\
289.0 \\
298.0 \\
309.0 \\
324.0\end{array}$ & $\begin{array}{l}0.02 \\
0.02 \\
0.01 \\
0.02 \\
0.01\end{array}$ & $\begin{array}{l}0400 \\
0405 \\
0410 \\
0415 \\
0420\end{array}$ & $\begin{array}{l}17.3 \\
16.5 \\
16.5 \\
15.8 \\
15.0\end{array}$ & $\begin{array}{l}0.00 \\
0.00 \\
0.00 \\
0.00 \\
0.00\end{array}$ & $\begin{array}{l}0925 \\
0930 \\
0935 \\
0940 \\
0945\end{array}$ & $\begin{array}{l}4.6 \\
4.6 \\
4.6 \\
4.6 \\
4.6\end{array}$ & $\begin{array}{l}0.00 \\
0.00 \\
0.00 \\
0.00 \\
0.00\end{array}$ \\
\hline $\begin{array}{l}2305 \\
2310 \\
2315 \\
2320 \\
2325\end{array}$ & $\begin{array}{l}338.0 \\
356.0 \\
367.0 \\
375.0 \\
376.0\end{array}$ & $\begin{array}{l}0.02 \\
0.02 \\
0.03 \\
0.01 \\
0.02\end{array}$ & $\begin{array}{l}0425 \\
0430 \\
0435 \\
0440 \\
0445\end{array}$ & $\begin{array}{l}14.2 \\
14.2 \\
13.5 \\
13.5 \\
12.8\end{array}$ & $\begin{array}{l}0.00 \\
0.00 \\
0.00 \\
0.00 \\
0.00\end{array}$ & $\begin{array}{l}0950 \\
0955 \\
1000 \\
1005 \\
1010\end{array}$ & $\begin{array}{l}4.6 \\
4.6 \\
4.6 \\
4.6 \\
4.6\end{array}$ & $\begin{array}{l}0.00 \\
0.00 \\
0.00 \\
0.00 \\
0.00\end{array}$ \\
\hline $\begin{array}{l}2330 \\
2335 \\
2340 \\
2345 \\
2350\end{array}$ & $\begin{array}{l}381.0 \\
385.0 \\
381.0 \\
381.0 \\
370.0\end{array}$ & $\begin{array}{l}0.02 \\
0.01 \\
0.01 \\
0.00 \\
0.00\end{array}$ & $\begin{array}{l}0450 \\
0455 \\
0500 \\
0505 \\
0510\end{array}$ & $\begin{array}{l}12.1 \\
12.1 \\
12.1 \\
11.5 \\
11.5\end{array}$ & $\begin{array}{l}0.00 \\
0.00 \\
0.00 \\
0.00 \\
0.00\end{array}$ & $\begin{array}{l}1015 \\
1020 \\
1025 \\
1030 \\
1035\end{array}$ & $\begin{array}{l}4.6 \\
4.2 \\
4.6 \\
4.2 \\
4.2\end{array}$ & $\begin{array}{l}0.00 \\
0.00 \\
0.00 \\
0.00 \\
0.00\end{array}$ \\
\hline $\begin{array}{l}2355 \\
\text { June } 26 \\
0000 \\
0005 \\
0010\end{array}$ & $\begin{array}{l}361.0 \\
1987 \\
350.0 \\
339.0 \\
322.0\end{array}$ & $\begin{array}{l}0.01 \\
0.00 \\
0.00 \\
0.00\end{array}$ & $\begin{array}{l}0515 \\
0520 \\
0525 \\
0530 \\
0535\end{array}$ & $\begin{array}{l}10.8 \\
10.8 \\
10.8 \\
10.8 \\
10.1\end{array}$ & $\begin{array}{l}0.00 \\
0.00 \\
0.00 \\
0.00 \\
0.00\end{array}$ & $\begin{array}{l}1040 \\
1045 \\
1050 \\
1055 \\
1100\end{array}$ & $\begin{array}{l}4.2 \\
4.2 \\
4.2 \\
4.2 \\
3.9\end{array}$ & $\begin{array}{l}0.00 \\
0.00 \\
0.00 \\
0.00 \\
0.00\end{array}$ \\
\hline $\begin{array}{l}0015 \\
0020 \\
0025 \\
0030 \\
0035\end{array}$ & $\begin{array}{l}315.0 \\
304.0 \\
289.0 \\
272.0 \\
256.0\end{array}$ & $\begin{array}{l}0.00 \\
0.01 \\
0.00 \\
0.00 \\
0.00\end{array}$ & $\begin{array}{l}0540 \\
0545 \\
0550 \\
0555 \\
0600\end{array}$ & $\begin{array}{l}9.8 \\
9.5 \\
9.5 \\
8.9 \\
8.9\end{array}$ & $\begin{array}{l}0.00 \\
0.00 \\
0.00 \\
0.00 \\
0.00\end{array}$ & $\begin{array}{l}1105 \\
1110 \\
1115 \\
1120 \\
1125\end{array}$ & $\begin{array}{l}3.9 \\
3.9 \\
3.9 \\
3.9 \\
3.9\end{array}$ & $\begin{array}{l}0.00 \\
0.00 \\
0.00 \\
0.00 \\
0.00\end{array}$ \\
\hline $\begin{array}{l}0040 \\
3045 \\
0050 \\
0055 \\
0100\end{array}$ & $\begin{array}{ll}254 & 0 \\
238 & 0 \\
221.0 \\
200 & 0 \\
187 & 0\end{array}$ & $\begin{array}{l}0.00 \\
0.00 \\
0.00 \\
0.00 \\
0.00\end{array}$ & $\begin{array}{l}0605 \\
0610 \\
0615 \\
0620 \\
0625\end{array}$ & $\begin{array}{l}8.9 \\
8.6 \\
8.4 \\
7.8 \\
7.8\end{array}$ & $\begin{array}{l}0.00 \\
0.00 \\
0.00 \\
0.00 \\
0.00\end{array}$ & $\begin{array}{l}1130 \\
1135 \\
1140 \\
1145 \\
1150\end{array}$ & $\begin{array}{l}3.9 \\
3.9 \\
3.9 \\
3.9 \\
3.9\end{array}$ & $\begin{array}{l}0.00 \\
0.00 \\
0.00 \\
0.00 \\
0.00\end{array}$ \\
\hline
\end{tabular}


Table 155.--Streamflow and rainfal1 at station 02187268, Dye Creek at Anderson, June $25-26,1987^{--C o n t i n u e d}$

\begin{tabular}{|c|c|c|c|c|c|c|c|c|}
\hline $\begin{array}{l}\text { Time } \\
\text { (hours) }\end{array}$ & $\begin{array}{l}\text { Streamflow } \\
\text { (cubic feet } \\
\text { per second) }\end{array}$ & $\begin{array}{l}\text { Rain- } \\
\text { fall } \\
\text { (inches) }\end{array}$ & $\begin{array}{l}\text { Time } \\
\text { (hours) }\end{array}$ & $\begin{array}{l}\text { Streamflow } \\
\text { (cubic feet } \\
\text { per second) }\end{array}$ & $\begin{array}{l}\text { Rain- } \\
\text { fall } \\
\text { (inches) }\end{array}$ & $\begin{array}{l}\text { Time } \\
\text { (hours) }\end{array}$ & $\begin{array}{l}\text { Streamflow } \\
\text { (cubic feet } \\
\text { per second) }\end{array}$ & $\begin{array}{l}\text { Rair- } \\
\text { fall } \\
\text { (inctes) }\end{array}$ \\
\hline $\begin{array}{l}1155 \\
1200 \\
1205 \\
1210 \\
1215\end{array}$ & $\begin{array}{l}3.9 \\
3.9 \\
3.5 \\
3.5 \\
3.5\end{array}$ & $\begin{array}{l}0.00 \\
0.00 \\
0.00 \\
0.00 \\
0.00\end{array}$ & $\begin{array}{l}1320 \\
1325 \\
1330 \\
1335 \\
1340\end{array}$ & $\begin{array}{l}3.2 \\
3.2 \\
3.2 \\
2.9 \\
2.9\end{array}$ & $\begin{array}{l}0.00 \\
0.00 \\
0.00 \\
0.00 \\
0.00\end{array}$ & $\begin{array}{l}1445 \\
1450 \\
1455 \\
1500 \\
1505\end{array}$ & $\begin{array}{l}2.7 \\
2.7 \\
2.9 \\
2.7 \\
2.7\end{array}$ & $\begin{array}{l}0.0 \mathrm{C} \\
0.0 \mathrm{C} \\
0.0 \mathrm{C} \\
0.0 \mathrm{C} \\
0.0 \mathrm{C}\end{array}$ \\
\hline $\begin{array}{l}1220 \\
1225 \\
1230 \\
1235 \\
1240\end{array}$ & $\begin{array}{l}3.5 \\
3.5 \\
3.2 \\
3.2 \\
3.2\end{array}$ & $\begin{array}{l}0.00 \\
0.00 \\
0.00 \\
0.00 \\
0.00\end{array}$ & $\begin{array}{l}1345 \\
1350 \\
1355 \\
1400 \\
1405\end{array}$ & $\begin{array}{l}2.9 \\
2.9 \\
2.9 \\
2.9 \\
2.9\end{array}$ & $\begin{array}{l}0.00 \\
0.00 \\
0.00 \\
0.00 \\
0.00\end{array}$ & $\begin{array}{l}1510 \\
1515 \\
1520 \\
1525 \\
1530\end{array}$ & $\begin{array}{l}2.7 \\
2.7 \\
2.7 \\
2.7 \\
2.7\end{array}$ & $\begin{array}{l}0.0 \mathrm{C} \\
0.0 \mathrm{C} \\
0.0 \mathrm{C} \\
0.0 \mathrm{C} \\
0.0 \mathrm{C}\end{array}$ \\
\hline $\begin{array}{l}1245 \\
1250 \\
1255 \\
1300 \\
1305\end{array}$ & $\begin{array}{l}3.2 \\
3.2 \\
3.2 \\
3.2 \\
3.2\end{array}$ & $\begin{array}{l}0.00 \\
0.00 \\
0.01 \\
0.00 \\
0.00\end{array}$ & $\begin{array}{l}1410 \\
1415 \\
1420 \\
1425 \\
1430\end{array}$ & $\begin{array}{l}2.9 \\
2.9 \\
2.9 \\
2.9 \\
2.9\end{array}$ & $\begin{array}{l}0.00 \\
0.00 \\
0.00 \\
0.00 \\
0.00\end{array}$ & $\begin{array}{l}1535 \\
1540 \\
1545 \\
1550 \\
1555\end{array}$ & $\begin{array}{l}2.7 \\
2.7 \\
2.7 \\
2.4 \\
2.7\end{array}$ & $\begin{array}{l}0.0 C \\
0.0 C \\
0.0 C \\
0.0 C \\
0.0 C\end{array}$ \\
\hline $\begin{array}{l}1310 \\
1315\end{array}$ & $\begin{array}{l}3.2 \\
3.2\end{array}$ & $\begin{array}{l}0.00 \\
0.00\end{array}$ & $\begin{array}{l}1435 \\
1440\end{array}$ & $\begin{array}{l}2.9 \\
2.9\end{array}$ & $\begin{array}{l}0.00 \\
0.00\end{array}$ & 1600 & 2.4 & $0.0 \mathrm{C}$ \\
\hline
\end{tabular}




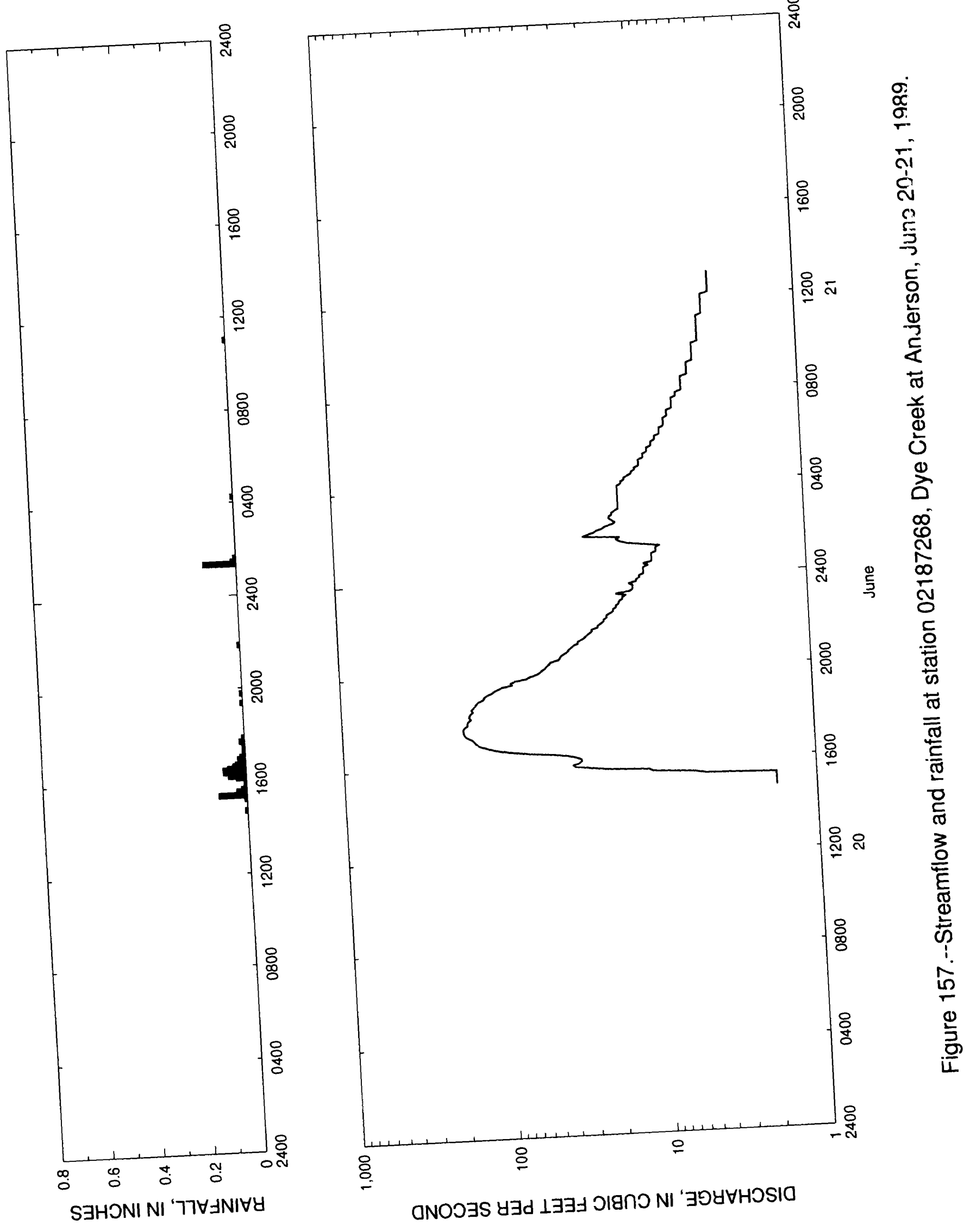




\begin{tabular}{|c|c|c|c|c|c|c|c|c|}
\hline $\begin{array}{l}\text { Time } \\
\text { (hours) }\end{array}$ & $\begin{array}{l}\text { Streamflow } \\
\text { (cubic feet } \\
\text { per second) }\end{array}$ & $\begin{array}{l}\text { Rain- } \\
\text { fall } \\
\text { (inches) }\end{array}$ & $\begin{array}{l}\text { Time } \\
\text { (hours) }\end{array}$ & $\begin{array}{l}\text { Streamflow } \\
\text { (cubic feet } \\
\text { per second) }\end{array}$ & $\begin{array}{l}\text { Rain- } \\
\text { fall } \\
\text { (inches) }\end{array}$ & $\begin{array}{l}\text { Time } \\
\text { (hours) }\end{array}$ & $\begin{array}{l}\text { Streamflow } \\
\text { (cubic feet } \\
\text { per second) }\end{array}$ & $\begin{array}{l}\text { Rain- } \\
\text { fall } \\
\text { (inches) }\end{array}$ \\
\hline $\begin{array}{l}\text { June } 20, \\
1440 \\
1445 \\
1450 \\
1455\end{array}$ & $\begin{array}{r}1989 \\
1.8 \\
1.8 \\
1.8 \\
1.8\end{array}$ & $\begin{array}{l}0.01 \\
0.00 \\
0.00 \\
0.00\end{array}$ & $\begin{array}{l}2000 \\
2005 \\
2010 \\
2015 \\
2020\end{array}$ & $\begin{array}{l}53.2 \\
51.1 \\
49.0 \\
48.0 \\
45.9\end{array}$ & $\begin{array}{l}0.00 \\
0.00 \\
0.00 \\
0.00 \\
0.00\end{array}$ & $\begin{array}{l}0120 \\
0125 \\
0130 \\
0135 \\
0140\end{array}$ & $\begin{array}{l}10.8 \\
13.5 \\
15.0 \\
15.8 \\
15.0\end{array}$ & $\begin{array}{l}0.13 \\
0.02 \\
0.00 \\
0.01 \\
0.00\end{array}$ \\
\hline $\begin{array}{l}1500 \\
1505 \\
1510 \\
1515 \\
1520\end{array}$ & $\begin{array}{l}1.8 \\
1.8 \\
1.8 \\
1.8 \\
5.0\end{array}$ & $\begin{array}{l}0.00 \\
0.00 \\
0.01 \\
0.01 \\
0.11\end{array}$ & $\begin{array}{l}2025 \\
2030 \\
2035 \\
2040 \\
2045\end{array}$ & $\begin{array}{l}44.9 \\
40.0 \\
39.1 \\
38.2 \\
36.5\end{array}$ & $\begin{array}{l}0.00 \\
0.00 \\
0.00 \\
0.00 \\
0.00\end{array}$ & $\begin{array}{l}0145 \\
0150 \\
0155 \\
0200 \\
0205\end{array}$ & $\begin{array}{l}25.8 \\
24.0 \\
21.9 \\
20.9 \\
19.1\end{array}$ & $\begin{array}{l}0.00 \\
0.00 \\
0.00 \\
0.00 \\
0.00\end{array}$ \\
\hline $\begin{array}{l}1525 \\
1530 \\
1535 \\
1540 \\
1545\end{array}$ & $\begin{array}{r}6.0 \\
10.8 \\
11.5 \\
20.9 \\
26.7\end{array}$ & $\begin{array}{l}0.02 \\
0.04 \\
0.02 \\
0.00 \\
0.00\end{array}$ & $\begin{array}{l}2050 \\
2055 \\
2100 \\
2105 \\
2110\end{array}$ & $\begin{array}{l}34.8 \\
34.0 \\
32.9 \\
31.8 \\
29.7\end{array}$ & $\begin{array}{l}0.00 \\
0.00 \\
0.00 \\
0.00 \\
0.00\end{array}$ & $\begin{array}{l}0210 \\
0215 \\
0220 \\
0225 \\
0230\end{array}$ & $\begin{array}{l}18.2 \\
16.5 \\
15.8 \\
16.5 \\
17.3\end{array}$ & $\begin{array}{l}0.00 \\
0.00 \\
0.00 \\
0.00 \\
0.00\end{array}$ \\
\hline $\begin{array}{l}1550 \\
1555 \\
1600 \\
1605 \\
1610\end{array}$ & $\begin{array}{l}34.0 \\
34.8 \\
31.8 \\
30.7 \\
30.7\end{array}$ & $\begin{array}{l}0.01 \\
0.00 \\
0.01 \\
0.04 \\
0.07\end{array}$ & $\begin{array}{l}2115 \\
2120 \\
2125 \\
2130 \\
2135\end{array}$ & $\begin{array}{l}29.7 \\
27.7 \\
26.7 \\
25.8 \\
24.9\end{array}$ & $\begin{array}{l}0.00 \\
0.00 \\
0.00 \\
0.00 \\
0.00\end{array}$ & $\begin{array}{l}0235 \\
0240 \\
0245 \\
0250 \\
0255\end{array}$ & $\begin{array}{l}17.3 \\
16.5 \\
16.5 \\
15.8 \\
15.0\end{array}$ & $\begin{array}{l}0.00 \\
0.00 \\
0.00 \\
0.00 \\
0.00\end{array}$ \\
\hline $\begin{array}{l}1615 \\
1620 \\
1625 \\
1630 \\
1635\end{array}$ & $\begin{array}{l}32.9 \\
37.3 \\
45.9 \\
64.9 \\
83.4\end{array}$ & $\begin{array}{l}0.04 \\
0.09 \\
0.09 \\
0.07 \\
0.05\end{array}$ & $\begin{array}{l}2140 \\
2145 \\
2150 \\
2155 \\
2200\end{array}$ & $\begin{array}{l}24.0 \\
24.0 \\
21.9 \\
21.9 \\
20.9\end{array}$ & $\begin{array}{l}0.00 \\
0.00 \\
0.01 \\
0.00 \\
0.00\end{array}$ & $\begin{array}{l}0300 \\
0305 \\
0310 \\
0315 \\
0320\end{array}$ & $\begin{array}{l}15.0 \\
15.0 \\
15.0 \\
15.0 \\
15.0\end{array}$ & $\begin{array}{l}0.00 \\
0.00 \\
0.00 \\
0.00 \\
0.00\end{array}$ \\
\hline $\begin{array}{l}1640 \\
1645 \\
1650 \\
1655 \\
1700\end{array}$ & $\begin{array}{l}101.0 \\
115.0 \\
126.0 \\
137.0 \\
141.0\end{array}$ & $\begin{array}{l}0.04 \\
0.03 \\
0.00 \\
0.03 \\
0.02\end{array}$ & $\begin{array}{l}2205 \\
2210 \\
2215 \\
2220 \\
2225\end{array}$ & $\begin{array}{l}20.0 \\
20.0 \\
19.1 \\
19.1 \\
18.2\end{array}$ & $\begin{array}{l}0.00 \\
0.00 \\
0.00 \\
0.00 \\
0.00\end{array}$ & $\begin{array}{l}0325 \\
0330 \\
0335 \\
0340 \\
0345\end{array}$ & $\begin{array}{l}15.0 \\
15.0 \\
15.0 \\
15.0 \\
15.0\end{array}$ & $\begin{array}{l}0.00 \\
0.00 \\
0.00 \\
0.00 \\
0.00\end{array}$ \\
\hline $\begin{array}{l}1705 \\
1710 \\
1715 \\
1720 \\
1725\end{array}$ & $\begin{array}{l}145.0 \\
149.0 \\
156.0 \\
164.0 \\
168.0\end{array}$ & $\begin{array}{l}0.01 \\
0.01 \\
0.01 \\
0.00 \\
0.00\end{array}$ & $\begin{array}{l}2230 \\
2235 \\
2240 \\
2245 \\
2250\end{array}$ & $\begin{array}{l}17.3 \\
17.3 \\
16.5 \\
16.5 \\
15.8\end{array}$ & $\begin{array}{l}0.00 \\
0.00 \\
0.00 \\
0.00 \\
0.00\end{array}$ & $\begin{array}{l}0350 \\
0355 \\
0400 \\
0405 \\
0410\end{array}$ & $\begin{array}{l}15.0 \\
15.0 \\
14.2 \\
14.2 \\
13.5\end{array}$ & $\begin{array}{l}0.00 \\
0.00 \\
0.00 \\
0.00 \\
0.00\end{array}$ \\
\hline $\begin{array}{l}1730 \\
1735 \\
1740 \\
1745 \\
1750\end{array}$ & $\begin{array}{l}170.0 \\
170.0 \\
170.0 \\
167.0 \\
160.0\end{array}$ & $\begin{array}{l}0.01 \\
0.00 \\
0.02 \\
0.01 \\
0.01\end{array}$ & $\begin{array}{l}2255 \\
2300 \\
2305 \\
2310 \\
2315\end{array}$ & $\begin{array}{l}15.8 \\
15.0 \\
15.0 \\
14.2 \\
16.5\end{array}$ & $\begin{array}{l}0.00 \\
0.00 \\
0.00 \\
0.00 \\
0.00\end{array}$ & $\begin{array}{l}0415 \\
0420 \\
0425 \\
0430 \\
0435\end{array}$ & $\begin{array}{l}13.5 \\
12.8 \\
12.1 \\
12.1 \\
11.5\end{array}$ & $\begin{array}{l}0.01 \\
0.00 \\
0.00 \\
0.00 \\
0.00\end{array}$ \\
\hline $\begin{array}{l}1755 \\
1800 \\
1805 \\
1810 \\
1815\end{array}$ & $\begin{array}{l}160.0 \\
158.0 \\
151.0 \\
155.0 \\
154.0\end{array}$ & $\begin{array}{l}0.00 \\
0.00 \\
0.00 \\
0.00 \\
0.00\end{array}$ & $\begin{array}{l}2320 \\
2325 \\
2330 \\
2335 \\
2340\end{array}$ & $\begin{array}{l}13.5 \\
12.8 \\
12.8 \\
12.8 \\
13.5\end{array}$ & $\begin{array}{l}0.00 \\
0.00 \\
0.00 \\
0.00 \\
0.00\end{array}$ & $\begin{array}{l}0440 \\
0445 \\
0450 \\
0455 \\
0500\end{array}$ & $\begin{array}{l}11.5 \\
10.8 \\
10.8 \\
10.8 \\
10.8\end{array}$ & $\begin{array}{l}0.00 \\
0.00 \\
0.00 \\
0.00 \\
0.00\end{array}$ \\
\hline $\begin{array}{l}1820 \\
1825 \\
1830 \\
1835 \\
1840\end{array}$ & $\begin{array}{l}151.0 \\
146.0 \\
149.0 \\
145.0 \\
141.0\end{array}$ & $\begin{array}{l}0.00 \\
0.00 \\
0.00 \\
0.00 \\
0.00\end{array}$ & $\begin{array}{l}2345 \\
2350 \\
2355 \\
\text { June } 21 . \\
0000\end{array}$ & $\begin{array}{r}12.1 \\
12.1 \\
11.5 \\
1989 \\
11.5\end{array}$ & $\begin{array}{l}0.00 \\
0.00 \\
0.00 \\
0.00\end{array}$ & $\begin{array}{l}0505 \\
0510 \\
0515 \\
0520 \\
0525\end{array}$ & $\begin{array}{r}10.1 \\
10.1 \\
10.1 \\
9.5 \\
9.5\end{array}$ & $\begin{array}{l}0.00 \\
0.00 \\
0.00 \\
0.00 \\
0.00\end{array}$ \\
\hline $\begin{array}{l}1845 \\
1850 \\
1855 \\
1900 \\
1905\end{array}$ & $\begin{array}{l}138.0 \\
134.0 \\
124.0 \\
122.0 \\
118.0\end{array}$ & $\begin{array}{l}0.00 \\
0.00 \\
0.00 \\
0.00 \\
0.00\end{array}$ & $\begin{array}{l}0005 \\
0010 \\
0015 \\
0020 \\
0025\end{array}$ & $\begin{array}{l}10.8 \\
10.8 \\
10.8 \\
10.8 \\
10.1\end{array}$ & $\begin{array}{l}0.00 \\
0.00 \\
0.00 \\
0.00 \\
0.00\end{array}$ & $\begin{array}{l}0530 \\
0535 \\
0540 \\
0545 \\
0550\end{array}$ & $\begin{array}{l}9.5 \\
8.9 \\
8.9 \\
8.9 \\
8.4\end{array}$ & $\begin{array}{l}0.00 \\
0.00 \\
0.00 \\
0.00 \\
0.00\end{array}$ \\
\hline $\begin{array}{l}1910 \\
1915 \\
1920 \\
1925 \\
1930\end{array}$ & $\begin{array}{r}110.0 \\
106.0 \\
100.0 \\
93.7 \\
80.6\end{array}$ & $\begin{array}{l}0.00 \\
0.00 \\
0.01 \\
0.00 \\
0.00\end{array}$ & $\begin{array}{l}0030 \\
0035 \\
0040 \\
0045 \\
0050\end{array}$ & $\begin{array}{r}10.8 \\
9.5 \\
9.5 \\
9.5 \\
9.5\end{array}$ & $\begin{array}{l}0.00 \\
0.00 \\
0.00 \\
0.00 \\
0.00\end{array}$ & $\begin{array}{l}0555 \\
0600 \\
0605 \\
0610 \\
0615\end{array}$ & $\begin{array}{l}8.4 \\
8.4 \\
7.8 \\
7.8 \\
7.8\end{array}$ & $\begin{array}{l}0.00 \\
0.00 \\
0.00 \\
0.00 \\
0.00\end{array}$ \\
\hline $\begin{array}{l}: 935 \\
1940 \\
1945 \\
1950 \\
1955\end{array}$ & $\begin{array}{l}82.0 \\
76.5 \\
64.9 \\
6 i .2 \\
55.4\end{array}$ & $\begin{array}{l}3.00 \\
0.00 \\
0.01 \\
0.00 \\
0.00\end{array}$ & $\begin{array}{l}0055 \\
0100 \\
0105 \\
0110 \\
0115\end{array}$ & $\begin{array}{l}9.5 \\
8.9 \\
8.9 \\
8.9 \\
8.4\end{array}$ & $\begin{array}{l}0.00 \\
0.00 \\
0.00 \\
0.00 \\
0.00\end{array}$ & $\begin{array}{l}0620 \\
0625 \\
0630 \\
0635 \\
0640\end{array}$ & $\begin{array}{l}7.8 \\
7.3 \\
7.3 \\
7.3 \\
7.3\end{array}$ & $\begin{array}{l}0.00 \\
0.00 \\
0.00 \\
0.00 \\
0.00\end{array}$ \\
\hline
\end{tabular}


Table 156. - - Streamflow and rainfal1 at station 02187268, Dye Creek at Anderson, June $20-21,1989--$ Cont inued

\begin{tabular}{|c|c|c|c|c|c|c|c|c|}
\hline $\begin{array}{l}\text { Time } \\
\text { (hours) }\end{array}$ & $\begin{array}{l}\text { Streamflow } \\
\text { (cubic feet } \\
\text { per second) }\end{array}$ & $\begin{array}{l}\text { Rain- } \\
\text { fall } \\
\text { (inches) }\end{array}$ & $\begin{array}{l}\text { Time } \\
\text { (hours) }\end{array}$ & $\begin{array}{l}\text { Streamflow } \\
\text { (cubic feet } \\
\text { per second) }\end{array}$ & $\begin{array}{l}\text { Rain- } \\
\text { fall } \\
\text { (inches) }\end{array}$ & $\begin{array}{l}\text { Time } \\
\text { (hours) }\end{array}$ & $\begin{array}{l}\text { Streamflow } \\
\text { (cubic feet } \\
\text { per second) }\end{array}$ & $\begin{array}{l}\text { Rain- } \\
\text { fall } \\
\text { (inches) }\end{array}$ \\
\hline $\begin{array}{l}0645 \\
0650 \\
0555 \\
0700 \\
0705\end{array}$ & $\begin{array}{l}7.3 \\
6.9 \\
6.9 \\
6.9 \\
6.9\end{array}$ & $\begin{array}{l}0.00 \\
0.00 \\
0.00 \\
0.00 \\
0.00\end{array}$ & $\begin{array}{l}0855 \\
0900 \\
0905 \\
0910 \\
0915\end{array}$ & $\begin{array}{l}5.0 \\
5.0 \\
5.0 \\
4.6 \\
4.6\end{array}$ & $\begin{array}{l}0.00 \\
0.00 \\
0.00 \\
0.00 \\
0.00\end{array}$ & $\begin{array}{l}1105 \\
1110 \\
1115 \\
1120 \\
1125\end{array}$ & $\begin{array}{l}4.2 \\
3.9 \\
3.9 \\
3.9 \\
3.9\end{array}$ & $\begin{array}{l}0.00 \\
0.00 \\
0.00 \\
0.00 \\
0.00\end{array}$ \\
\hline $\begin{array}{l}0710 \\
0715 \\
0720 \\
0725 \\
0730\end{array}$ & $\begin{array}{l}6.4 \\
6.4 \\
6.4 \\
6.4 \\
6.4\end{array}$ & $\begin{array}{l}0.00 \\
0.00 \\
0.00 \\
0.00 \\
0.00\end{array}$ & $\begin{array}{l}0920 \\
0925 \\
0930 \\
0935 \\
0940\end{array}$ & $\begin{array}{l}4.6 \\
4.6 \\
4.6 \\
4.6 \\
4.6\end{array}$ & $\begin{array}{l}0.00 \\
0.00 \\
0.00 \\
0.00 \\
0.00\end{array}$ & $\begin{array}{l}1130 \\
1135 \\
1140 \\
1145 \\
1150\end{array}$ & $\begin{array}{l}3.9 \\
3.9 \\
3.9 \\
3.9 \\
3.9\end{array}$ & $\begin{array}{l}0.00 \\
0.00 \\
0.00 \\
0.00 \\
0.00\end{array}$ \\
\hline $\begin{array}{l}0735 \\
0740 \\
0745 \\
0750 \\
0755\end{array}$ & $\begin{array}{l}6.4 \\
6.0 \\
6.0 \\
6.0 \\
5.5\end{array}$ & $\begin{array}{l}0.00 \\
0.00 \\
0.00 \\
0.00 \\
0.00\end{array}$ & $\begin{array}{l}0945 \\
0950 \\
0955 \\
1000 \\
1005\end{array}$ & $\begin{array}{l}4.6 \\
4.6 \\
4.6 \\
4.2 \\
4.2\end{array}$ & $\begin{array}{l}0.00 \\
0.00 \\
0.00 \\
0.00 \\
0.00\end{array}$ & $\begin{array}{l}1155 \\
1200 \\
1205 \\
1210 \\
1215\end{array}$ & $\begin{array}{l}3.9 \\
3.9 \\
3.5 \\
3.5 \\
3.5\end{array}$ & $\begin{array}{l}0.00 \\
0.00 \\
0.00 \\
0.00 \\
0.00\end{array}$ \\
\hline $\begin{array}{l}0800 \\
0805 \\
0810 \\
0815 \\
0820\end{array}$ & $\begin{array}{l}5.5 \\
5.5 \\
5.5 \\
5.5 \\
5.5\end{array}$ & $\begin{array}{l}0.00 \\
0.00 \\
0.00 \\
0.00 \\
0.00\end{array}$ & $\begin{array}{l}1010 \\
1015 \\
1020 \\
1025 \\
1030\end{array}$ & $\begin{array}{l}4.2 \\
4.2 \\
4.2 \\
4.2 \\
4.2\end{array}$ & $\begin{array}{l}0.00 \\
0.00 \\
0.00 \\
0.00 \\
0.00\end{array}$ & $\begin{array}{l}1220 \\
1225 \\
1230 \\
1235 \\
1240\end{array}$ & $\begin{array}{l}3.5 \\
3.5 \\
3.5 \\
3.5 \\
3.5\end{array}$ & $\begin{array}{l}0.00 \\
0.00 \\
0.00 \\
0.00 \\
0.00\end{array}$ \\
\hline $\begin{array}{l}0825 \\
0830 \\
0835 \\
0840 \\
0845\end{array}$ & $\begin{array}{l}5.5 \\
5.5 \\
5.0 \\
5.0 \\
5.0\end{array}$ & $\begin{array}{l}0.00 \\
0.00 \\
0.00 \\
0.00 \\
0.00\end{array}$ & $\begin{array}{l}1035 \\
1040 \\
1045 \\
1050 \\
1055\end{array}$ & $\begin{array}{l}4.2 \\
4.2 \\
4.2 \\
4.2 \\
4.2\end{array}$ & $\begin{array}{l}0.00 \\
0.00 \\
0.00 \\
0.00 \\
0.00\end{array}$ & $\begin{array}{l}1245 \\
1250 \\
1255 \\
1300\end{array}$ & $\begin{array}{l}3.5 \\
3.5 \\
3.5 \\
3.5\end{array}$ & $\begin{array}{l}0.00 \\
0.00 \\
0.00 \\
0.00\end{array}$ \\
\hline 0850 & 5.0 & 0.00 & 1100 & 4.2 & 0.01 & & & \\
\hline
\end{tabular}




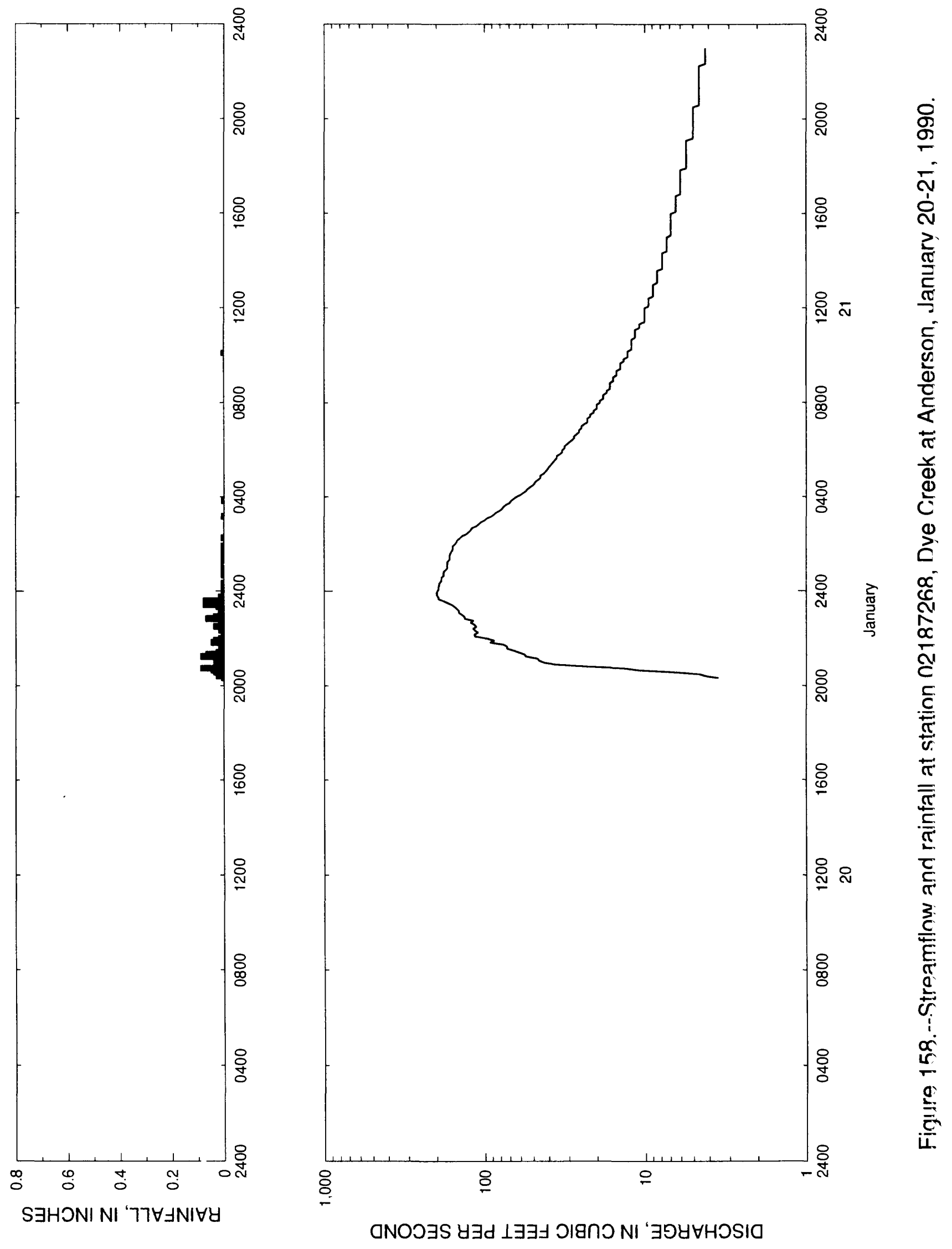


Table 157. - Streamflow and rainfall at station 02187268, Dye Creek at Anderson, January $20-21,1990$

\begin{tabular}{|c|c|c|c|c|c|c|c|c|c|}
\hline $\begin{array}{l}\text { Time } \\
\text { (hours) }\end{array}$ & $\begin{array}{l}\text { St } \\
\text { (cu } \\
\text { per }\end{array}$ & $\begin{array}{l}\text { reamflow } \\
\text { dbic feet } \\
\text { second) }\end{array}$ & $\begin{array}{l}\text { Rain- } \\
\text { fall } \\
\text { (inches) }\end{array}$ & $\begin{array}{l}\text { Time } \\
\text { (hours) }\end{array}$ & $\begin{array}{l}\text { Streamflow } \\
\text { (cubic feet } \\
\text { per second) }\end{array}$ & $\begin{array}{l}\text { Rain- } \\
\text { fall } \\
\text { (inches) }\end{array}$ & $\begin{array}{l}\text { Time } \\
\text { (hours) }\end{array}$ & $\begin{array}{l}\text { Streamflow } \\
\text { (cubic feet } \\
\text { per second) }\end{array}$ & $\begin{array}{l}\text { Rain- } \\
\text { fall } \\
\text { (inches) }\end{array}$ \\
\hline $\begin{array}{l}\text { January } \\
2020 \\
2025 \\
2030 \\
2035\end{array}$ & 20 & $\begin{array}{r}1990 \\
3.5 \\
4.2 \\
4.6 \\
6.4\end{array}$ & $\begin{array}{l}0.01 \\
0.03 \\
0.02 \\
0.04\end{array}$ & $\begin{array}{l}0135 \\
0140 \\
0145 \\
0150 \\
0155\end{array}$ & $\begin{array}{l}164.0 \\
162.0 \\
159.0 \\
158.0 \\
158.0\end{array}$ & $\begin{array}{l}0.01 \\
0.00 \\
0.01 \\
0.01 \\
0.01\end{array}$ & $\begin{array}{l}0700 \\
0705 \\
0710 \\
0715 \\
0720\end{array}$ & $\begin{array}{l}24.9 \\
24.0 \\
22.9 \\
22.9 \\
22.9\end{array}$ & $\begin{array}{l}0.00 \\
0.00 \\
0.00 \\
0.00 \\
0.00\end{array}$ \\
\hline $\begin{array}{l}2040 \\
2045 \\
2050 \\
2055 \\
2100\end{array}$ & & $\begin{array}{l}10.8 \\
13.5 \\
24.0 \\
36.5 \\
42.9\end{array}$ & $\begin{array}{l}0.05 \\
0.09 \\
0.04 \\
0.04 \\
0.04\end{array}$ & $\begin{array}{l}0200 \\
0205 \\
0210 \\
0215 \\
0220\end{array}$ & $\begin{array}{l}153.0 \\
150.0 \\
148.0 \\
142.0 \\
138.0\end{array}$ & $\begin{array}{l}0.00 \\
0.00 \\
0.00 \\
0.01 \\
0.00\end{array}$ & $\begin{array}{l}0725 \\
0730 \\
0735 \\
0740 \\
0745\end{array}$ & $\begin{array}{l}21.9 \\
21.9 \\
20.9 \\
20.9 \\
20.0\end{array}$ & $\begin{array}{l}0.00 \\
0.00 \\
0.00 \\
0.00 \\
0.00\end{array}$ \\
\hline $\begin{array}{l}2105 \\
2110 \\
2115 \\
2120 \\
2125\end{array}$ & & $\begin{array}{l}45.9 \\
46.9 \\
55.4 \\
56.5 \\
61.2\end{array}$ & $\begin{array}{l}0.03 \\
0.01 \\
0.09 \\
0.07 \\
0.03\end{array}$ & $\begin{array}{l}0225 \\
0230 \\
0235 \\
0240 \\
0245\end{array}$ & $\begin{array}{l}130.0 \\
126.0 \\
122.0 \\
120.0 \\
113.0\end{array}$ & $\begin{array}{l}0.00 \\
0.00 \\
0.00 \\
0.00 \\
0.00\end{array}$ & $\begin{array}{l}0750 \\
0755 \\
0800 \\
0805 \\
0810\end{array}$ & $\begin{array}{l}20.0 \\
20.0 \\
19.1 \\
19.1 \\
18.2\end{array}$ & $\begin{array}{l}0.00 \\
0.00 \\
0.00 \\
0.00 \\
0.00\end{array}$ \\
\hline $\begin{array}{l}2130 \\
2135 \\
2140 \\
2145 \\
2150\end{array}$ & & $\begin{array}{l}66.1 \\
72.6 \\
72.6 \\
76.5 \\
92.2\end{array}$ & $\begin{array}{l}0.02 \\
0.02 \\
0.01 \\
0.02 \\
0.05\end{array}$ & $\begin{array}{l}0250 \\
0255 \\
0300 \\
0305 \\
0310\end{array}$ & $\begin{array}{r}109.0 \\
106.0 \\
100.0 \\
96.8 \\
90.7\end{array}$ & $\begin{array}{l}0.00 \\
0.00 \\
0.00 \\
0.00 \\
0.01\end{array}$ & $\begin{array}{l}0815 \\
0820 \\
0825 \\
0830 \\
0835\end{array}$ & $\begin{array}{l}18.2 \\
18.2 \\
17.3 \\
17.3 \\
16.5\end{array}$ & $\begin{array}{l}0.00 \\
0.00 \\
0.00 \\
0.00 \\
0.00\end{array}$ \\
\hline $\begin{array}{l}2155 \\
2200 \\
2205 \\
2210 \\
2215\end{array}$ & & $\begin{array}{r}87.7 \\
96.8 \\
115.0 \\
116.0 \\
110.0\end{array}$ & $\begin{array}{l}0.04 \\
0.02 \\
0.01 \\
0.01 \\
0.01\end{array}$ & $\begin{array}{l}0315 \\
0320 \\
0325 \\
0330 \\
0335\end{array}$ & $\begin{array}{l}87.7 \\
84.8 \\
80.6 \\
77.8 \\
76.5\end{array}$ & $\begin{array}{l}0.00 \\
0.00 \\
0.00 \\
0.00 \\
0.00\end{array}$ & $\begin{array}{l}0840 \\
0845 \\
0850 \\
0855 \\
0900\end{array}$ & $\begin{array}{l}16.5 \\
16.5 \\
16.5 \\
15.8 \\
15.8\end{array}$ & $\begin{array}{l}0.00 \\
0.00 \\
0.00 \\
0.00 \\
0.00\end{array}$ \\
\hline $\begin{array}{l}2220 \\
2225 \\
2230 \\
2235 \\
2240\end{array}$ & & $\begin{array}{l}115.0 \\
118.0 \\
113.0 \\
116.0 \\
122.0\end{array}$ & $\begin{array}{l}0.02 \\
0.02 \\
0.04 \\
0.02 \\
0.02\end{array}$ & $\begin{array}{l}0340 \\
0345 \\
0350 \\
0355 \\
0400\end{array}$ & $\begin{array}{l}73.9 \\
70.0 \\
68.7 \\
66.1 \\
63.6\end{array}$ & $\begin{array}{l}0.00 \\
0.00 \\
0.01 \\
0.00 \\
0.00\end{array}$ & $\begin{array}{l}0905 \\
0910 \\
0915 \\
0920 \\
0925\end{array}$ & $\begin{array}{l}15.8 \\
15.0 \\
15.0 \\
15.0 \\
14.2\end{array}$ & $\begin{array}{l}0.00 \\
0.00 \\
0.00 \\
0.00 \\
0.00\end{array}$ \\
\hline $\begin{array}{l}2245 \\
2250 \\
2255 \\
2300 \\
2305\end{array}$ & & $\begin{array}{l}118.0 \\
133.0 \\
134.0 \\
139.0 \\
145.0\end{array}$ & $\begin{array}{l}0.01 \\
0.07 \\
0.04 \\
0.01 \\
0.00\end{array}$ & $\begin{array}{l}0405 \\
0410 \\
0415 \\
0420 \\
0425\end{array}$ & $\begin{array}{l}60.0 \\
57.7 \\
55.4 \\
54.3 \\
52.2\end{array}$ & $\begin{array}{l}0.00 \\
0.00 \\
0.00 \\
0.00 \\
0.00\end{array}$ & $\begin{array}{l}0930 \\
0935 \\
0940 \\
0945 \\
0950\end{array}$ & $\begin{array}{l}14.2 \\
14.2 \\
14.2 \\
13.5 \\
13.5\end{array}$ & $\begin{array}{l}0.00 \\
0.00 \\
0.00 \\
0.00 \\
0.00\end{array}$ \\
\hline $\begin{array}{l}2310 \\
2315 \\
2320 \\
2325 \\
2330\end{array}$ & & $\begin{array}{l}145.0 \\
149.0 \\
154.0 \\
160.0 \\
170.0\end{array}$ & $\begin{array}{l}0.02 \\
0.02 \\
0.03 \\
0.08 \\
0.04\end{array}$ & $\begin{array}{l}0430 \\
0435 \\
0440 \\
0445 \\
0450\end{array}$ & $\begin{array}{l}50.0 \\
49.0 \\
48.0 \\
45.9 \\
44.9\end{array}$ & $\begin{array}{l}0.00 \\
0.00 \\
0.00 \\
0.00 \\
0.00\end{array}$ & $\begin{array}{l}0955 \\
1000 \\
1005 \\
1010 \\
1015\end{array}$ & $\begin{array}{l}12.8 \\
12.8 \\
12.8 \\
12.8 \\
12.1\end{array}$ & $\begin{array}{l}0.00 \\
0.00 \\
0.01 \\
0.00 \\
0.00\end{array}$ \\
\hline $\begin{array}{l}2335 \\
2340 \\
2345 \\
2350 \\
2355\end{array}$ & & $\begin{array}{l}181.0 \\
194.0 \\
195.0 \\
199.0 \\
200.0\end{array}$ & $\begin{array}{l}0.08 \\
0.02 \\
0.02 \\
0.00 \\
0.01\end{array}$ & $\begin{array}{l}0455 \\
0500 \\
0505 \\
0510 \\
0515\end{array}$ & $\begin{array}{l}44.9 \\
42.9 \\
41.9 \\
40.9 \\
40.0\end{array}$ & $\begin{array}{l}0.00 \\
0.00 \\
0.00 \\
0.00 \\
0.00\end{array}$ & $\begin{array}{l}1020 \\
1025 \\
1030 \\
1035 \\
1040\end{array}$ & $\begin{array}{l}12.1 \\
12.1 \\
12.1 \\
12.1 \\
12.1\end{array}$ & $\begin{array}{l}0.00 \\
0.00 \\
0.00 \\
0.00 \\
0.00\end{array}$ \\
\hline $\begin{array}{l}\text { January } \\
0000 \\
0005 \\
0010 \\
0015\end{array}$ & 21 & $\begin{array}{l}1990 \\
197.0 \\
194.0 \\
195.0 \\
192.0\end{array}$ & $\begin{array}{l}0.00 \\
0.01 \\
0.00 \\
0.01\end{array}$ & $\begin{array}{l}0520 \\
0525 \\
0530 \\
0535 \\
0540\end{array}$ & $\begin{array}{l}39.1 \\
38.2 \\
37.3 \\
36.5 \\
35.6\end{array}$ & $\begin{array}{l}0.00 \\
0.00 \\
0.00 \\
0.00 \\
0.00\end{array}$ & $\begin{array}{l}1045 \\
1050 \\
1055 \\
1100 \\
1105\end{array}$ & $\begin{array}{l}11.5 \\
11.5 \\
11.5 \\
11.5 \\
11.5\end{array}$ & $\begin{array}{l}0.00 \\
0.00 \\
0.00 \\
0.00 \\
0.00\end{array}$ \\
\hline $\begin{array}{l}0020 \\
0025 \\
0030 \\
0035 \\
0040\end{array}$ & & $\begin{array}{l}192.0 \\
187.0 \\
186.0 \\
186.0 \\
180.0\end{array}$ & $\begin{array}{l}0.01 \\
0.00 \\
0.00 \\
0.00 \\
0.01\end{array}$ & $\begin{array}{l}0545 \\
0550 \\
0555 \\
0600 \\
0505\end{array}$ & $\begin{array}{l}35.6 \\
34.0 \\
32.9 \\
32.9 \\
31.8\end{array}$ & $\begin{array}{l}0.00 \\
0.00 \\
0.00 \\
0.00 \\
0.00\end{array}$ & $\begin{array}{l}1110 \\
1115 \\
1120 \\
1125 \\
1130\end{array}$ & $\begin{array}{l}10.8 \\
10.8 \\
10.8 \\
10.1 \\
10.1\end{array}$ & $\begin{array}{l}0.00 \\
0.00 \\
0.00 \\
0.00 \\
0.00\end{array}$ \\
\hline $\begin{array}{l}0045 \\
0050 \\
0055 \\
0100 \\
0105\end{array}$ & & $\begin{array}{l}181.0 \\
180.0 \\
174.0 \\
171.0 \\
172.0\end{array}$ & $\begin{array}{l}0.01 \\
0.00 \\
0.01 \\
0.00 \\
0.01\end{array}$ & $\begin{array}{l}0610 \\
0615 \\
0520 \\
0625 \\
0530\end{array}$ & $\begin{array}{l}31.8 \\
30.7 \\
29.7 \\
28.7 \\
27.7\end{array}$ & $\begin{array}{l}0.00 \\
0.00 \\
0.00 \\
0.00 \\
0.00\end{array}$ & $\begin{array}{l}1135 \\
1140 \\
1145 \\
1150 \\
1155\end{array}$ & $\begin{array}{l}10.1 \\
10.1 \\
10.1 \\
10.1 \\
10.1\end{array}$ & $\begin{array}{l}0.00 \\
0.00 \\
0.00 \\
0.00 \\
0.00\end{array}$ \\
\hline $\begin{array}{l}0110 \\
0115 \\
0120 \\
0125 \\
0130\end{array}$ & & $\begin{array}{l}171.0 \\
171.0 \\
166.0 \\
166.0 \\
166.0\end{array}$ & $\begin{array}{l}0.00 \\
0.01 \\
0.00 \\
0.01 \\
0.00\end{array}$ & $\begin{array}{l}0635 \\
0640 \\
0645 \\
0650 \\
0655\end{array}$ & $\begin{array}{l}27.7 \\
26.7 \\
25.8 \\
25.8 \\
24.9\end{array}$ & $\begin{array}{l}0.00 \\
0.00 \\
0.00 \\
0.00 \\
0.00\end{array}$ & $\begin{array}{l}1200 \\
1205 \\
1210 \\
1215 \\
1220\end{array}$ & $\begin{array}{r}10.1 \\
9.5 \\
9.5 \\
9.5 \\
9.5\end{array}$ & $\begin{array}{l}0.00 \\
0.00 \\
0.00 \\
0.00 \\
0.00\end{array}$ \\
\hline
\end{tabular}


Table 157.--Streamflow and rainfall at station 02187268, Dye Creek at Anderson, January $20-21,1990--C o n t i n u e d$

\begin{tabular}{|c|c|c|c|c|c|c|c|c|}
\hline $\begin{array}{l}\text { Time } \\
\text { (hours) }\end{array}$ & $\begin{array}{l}\text { Streamflow } \\
\text { (cubic feet } \\
\text { per second) }\end{array}$ & $\begin{array}{l}\text { Rain- } \\
\text { fall } \\
\text { (inches) }\end{array}$ & $\begin{array}{l}\text { Time } \\
\text { (hours) }\end{array}$ & $\begin{array}{l}\text { Streamflow } \\
\text { (cubic feet } \\
\text { per second) }\end{array}$ & $\begin{array}{l}\text { Rain- } \\
\text { fall } \\
\text { (inches) }\end{array}$ & $\begin{array}{l}\text { Time } \\
\text { (hours) }\end{array}$ & $\begin{array}{l}\text { Streamflow } \\
\text { (cubic feet } \\
\text { per second) }\end{array}$ & $\begin{array}{l}\text { Rain- } \\
\text { fall } \\
\text { (inches) }\end{array}$ \\
\hline $\begin{array}{l}1225 \\
1230 \\
1235 \\
1240 \\
1245\end{array}$ & $\begin{array}{l}9.5 \\
8.9 \\
8.9 \\
8.9 \\
8.9\end{array}$ & $\begin{array}{l}0.00 \\
0.00 \\
0.00 \\
0.00 \\
0.00\end{array}$ & $\begin{array}{l}1600 \\
1605 \\
1610 \\
1615 \\
1620\end{array}$ & $\begin{array}{l}6.9 \\
6.4 \\
6.4 \\
6.4 \\
6.4\end{array}$ & $\begin{array}{l}0.00 \\
0.00 \\
0.00 \\
0.00 \\
0.00\end{array}$ & $\begin{array}{l}1935 \\
1940 \\
1945 \\
1950 \\
1955\end{array}$ & $\begin{array}{l}5.0 \\
5.0 \\
5.0 \\
5.0 \\
5.0\end{array}$ & $\begin{array}{l}0.00 \\
0.00 \\
0.00 \\
0.00 \\
0.00\end{array}$ \\
\hline $\begin{array}{l}1250 \\
1255 \\
1300 \\
1305 \\
1310\end{array}$ & $\begin{array}{l}8.9 \\
8.9 \\
8.9 \\
8.4 \\
8.4\end{array}$ & $\begin{array}{l}0.00 \\
0.00 \\
0.00 \\
0.00 \\
0.00\end{array}$ & $\begin{array}{l}1625 \\
1630 \\
1635 \\
1640 \\
1645\end{array}$ & $\begin{array}{l}6.4 \\
6.4 \\
6.4 \\
6.4 \\
6.4\end{array}$ & $\begin{array}{l}0.00 \\
0.00 \\
0.00 \\
0.00 \\
0.00\end{array}$ & $\begin{array}{l}2000 \\
2005 \\
2010 \\
2015 \\
2020\end{array}$ & $\begin{array}{l}5.0 \\
5.0 \\
5.0 \\
5.0 \\
5.0\end{array}$ & $\begin{array}{l}0.00 \\
0.00 \\
0.00 \\
0.00 \\
0.00\end{array}$ \\
\hline $\begin{array}{l}1315 \\
1320 \\
1325 \\
1330 \\
1335\end{array}$ & $\begin{array}{l}8.4 \\
8.4 \\
8.4 \\
8.4 \\
8.4\end{array}$ & $\begin{array}{l}0.00 \\
0.00 \\
0.00 \\
0.00 \\
0.00\end{array}$ & $\begin{array}{l}1650 \\
1655 \\
1700 \\
1705 \\
1710\end{array}$ & $\begin{array}{l}6.0 \\
6.0 \\
6.0 \\
6.0 \\
6.0\end{array}$ & $\begin{array}{l}0.00 \\
0.00 \\
0.00 \\
0.00 \\
0.00\end{array}$ & $\begin{array}{l}2025 \\
2030 \\
2035 \\
2040 \\
2045\end{array}$ & $\begin{array}{l}5.0 \\
5.0 \\
4.6 \\
4.6 \\
4.6\end{array}$ & $\begin{array}{l}0.00 \\
0.00 \\
0.00 \\
0.00 \\
0.00\end{array}$ \\
\hline $\begin{array}{l}1340 \\
1345 \\
1350 \\
1355 \\
1400\end{array}$ & $\begin{array}{l}7.8 \\
7.8 \\
7.8 \\
7.8 \\
7.8\end{array}$ & $\begin{array}{l}0.00 \\
0.00 \\
0.00 \\
0.00 \\
0.00\end{array}$ & $\begin{array}{l}1715 \\
1720 \\
1725 \\
1730 \\
1735\end{array}$ & $\begin{array}{l}6.0 \\
6.0 \\
6.0 \\
6.0 \\
6.0\end{array}$ & $\begin{array}{l}0.00 \\
0.00 \\
0.00 \\
0.00 \\
0.00\end{array}$ & $\begin{array}{l}2050 \\
2055 \\
2100 \\
2105 \\
2110\end{array}$ & $\begin{array}{l}4.6 \\
4.6 \\
4.6 \\
4.6 \\
4.6\end{array}$ & $\begin{array}{l}0.00 \\
0.00 \\
0.0 C \\
0.0 C \\
0.0 C\end{array}$ \\
\hline $\begin{array}{l}1405 \\
1410 \\
1415 \\
1420 \\
1425\end{array}$ & $\begin{array}{l}7.8 \\
7.8 \\
7.8 \\
7.8 \\
7.3\end{array}$ & $\begin{array}{l}0.00 \\
0.00 \\
0.00 \\
0.00 \\
0.00\end{array}$ & $\begin{array}{l}1740 \\
1745 \\
1750 \\
1755 \\
1800\end{array}$ & $\begin{array}{l}6.0 \\
6.0 \\
6.0 \\
5.5 \\
5.5\end{array}$ & $\begin{array}{l}0.00 \\
0.00 \\
0.00 \\
0.00 \\
0.00\end{array}$ & $\begin{array}{l}2115 \\
2120 \\
2125 \\
2130 \\
2135\end{array}$ & $\begin{array}{l}4.6 \\
4.6 \\
4.6 \\
4.6 \\
4.6\end{array}$ & $\begin{array}{l}0.0 C \\
0.0 C \\
0.0 C \\
0.00 \\
0.00\end{array}$ \\
\hline $\begin{array}{l}1430 \\
1435 \\
1440 \\
1445 \\
1450\end{array}$ & $\begin{array}{l}7.3 \\
7.3 \\
7.3 \\
7.3 \\
7.3\end{array}$ & $\begin{array}{l}0.00 \\
0.00 \\
0.00 \\
0.00 \\
0.00\end{array}$ & $\begin{array}{l}1805 \\
1810 \\
1815 \\
1820 \\
1825\end{array}$ & $\begin{array}{l}5.5 \\
5.5 \\
5.5 \\
5.5 \\
5.5\end{array}$ & $\begin{array}{l}0.00 \\
0.00 \\
0.00 \\
0.00 \\
0.00\end{array}$ & $\begin{array}{l}2140 \\
2145 \\
2150 \\
2155 \\
2200\end{array}$ & $\begin{array}{l}4.6 \\
4.6 \\
4.6 \\
4.6 \\
4.6\end{array}$ & $\begin{array}{l}0.00 \\
0.00 \\
0.00 \\
0.00 \\
0.00\end{array}$ \\
\hline $\begin{array}{l}1455 \\
1500 \\
1505 \\
1510 \\
1515\end{array}$ & $\begin{array}{l}7.3 \\
7.3 \\
6.9 \\
6.9 \\
6.9\end{array}$ & $\begin{array}{l}0.00 \\
0.00 \\
0.00 \\
0.00 \\
0.00\end{array}$ & $\begin{array}{l}1830 \\
1835 \\
1840 \\
1845 \\
1850\end{array}$ & $\begin{array}{l}5.5 \\
5.5 \\
5.5 \\
5.5 \\
5.5\end{array}$ & $\begin{array}{l}0.00 \\
0.00 \\
0.00 \\
0.00 \\
0.00\end{array}$ & $\begin{array}{l}2205 \\
2210 \\
2215 \\
2220 \\
2225\end{array}$ & $\begin{array}{l}4.6 \\
4.6 \\
4.6 \\
4.2 \\
4.2\end{array}$ & $\begin{array}{l}0.00 \\
0.00 \\
0.00 \\
0.00 \\
0.00\end{array}$ \\
\hline $\begin{array}{l}1520 \\
1525 \\
1530 \\
1535 \\
1540\end{array}$ & $\begin{array}{l}6.9 \\
6.9 \\
6.9 \\
6.9 \\
6.9\end{array}$ & $\begin{array}{l}0.00 \\
0.00 \\
0.00 \\
0.00 \\
0.00\end{array}$ & $\begin{array}{l}1855 \\
1900 \\
1905 \\
1910 \\
1915\end{array}$ & $\begin{array}{l}5.5 \\
5.5 \\
5.5 \\
5.0 \\
5.0\end{array}$ & $\begin{array}{l}0.00 \\
0.00 \\
0.00 \\
0.00 \\
0.00\end{array}$ & $\begin{array}{l}2230 \\
2235 \\
2240 \\
2245 \\
2250\end{array}$ & $\begin{array}{l}4.2 \\
4.2 \\
4.2 \\
4.2 \\
4.2\end{array}$ & $\begin{array}{l}0.00 \\
0.00 \\
0.00 \\
0.00 \\
0.00\end{array}$ \\
\hline $\begin{array}{l}1545 \\
1550 \\
1555\end{array}$ & $\begin{array}{l}6.9 \\
6.9 \\
6.9\end{array}$ & $\begin{array}{l}0.00 \\
0.00 \\
0.00\end{array}$ & $\begin{array}{l}1920 \\
1925 \\
1930\end{array}$ & $\begin{array}{l}5.0 \\
5.0 \\
5.0\end{array}$ & $\begin{array}{l}0.00 \\
0.00 \\
0.00\end{array}$ & $\begin{array}{l}2255 \\
2300\end{array}$ & $\begin{array}{l}4.2 \\
4.2\end{array}$ & $\begin{array}{l}0.00 \\
0.00\end{array}$ \\
\hline
\end{tabular}



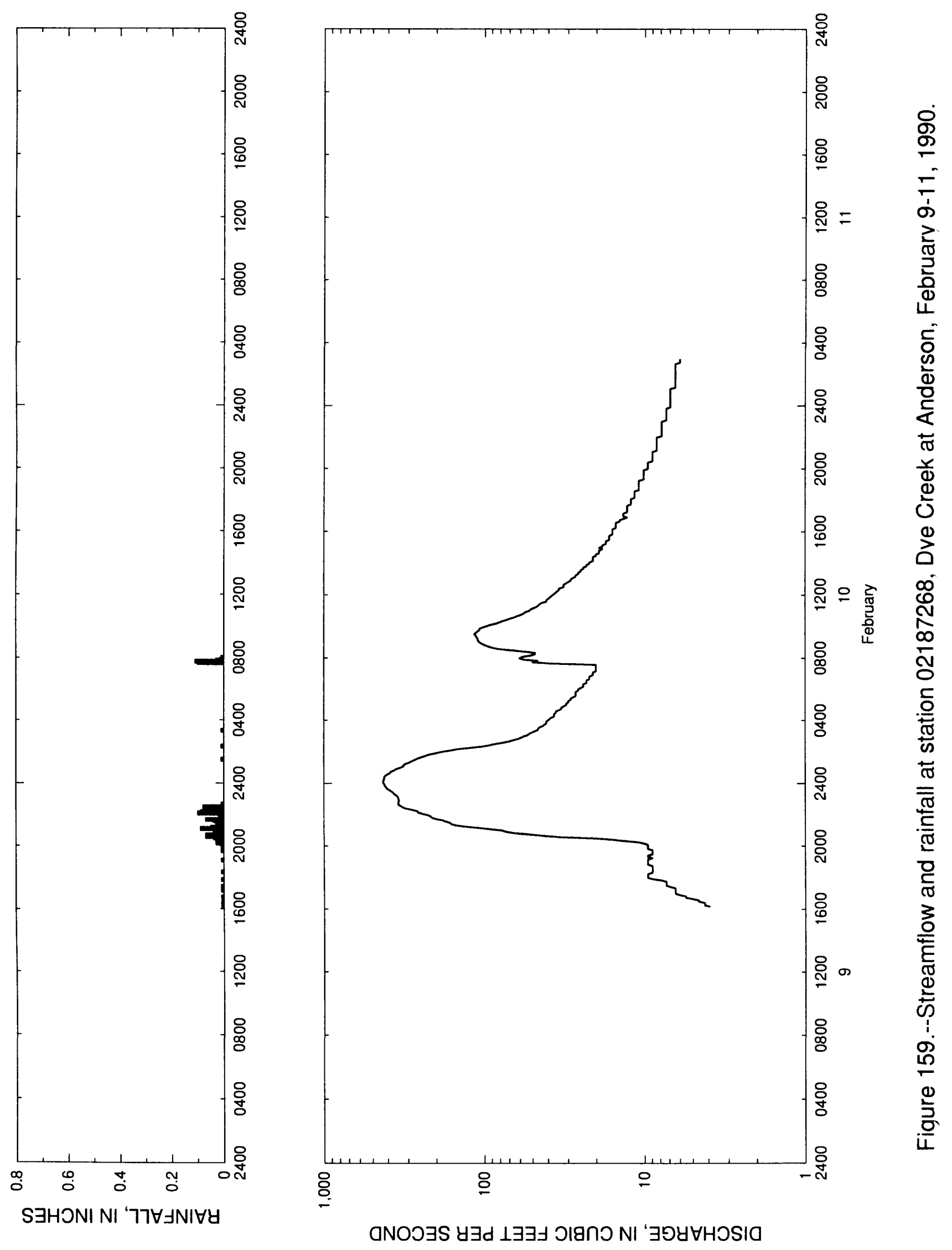
Table 158.--Streamflow and rainfall at station 02187268, Dye Creek at Anderson, February 9-11, 1990

\begin{tabular}{|c|c|c|c|c|c|c|c|c|}
\hline $\begin{array}{l}\text { Time } \\
\text { (hours) }\end{array}$ & $\begin{array}{l}\text { Streamflow } \\
\text { (cubic feet } \\
\text { per second) }\end{array}$ & $\begin{array}{l}\text { Rain- } \\
\text { fall } \\
\text { (inches) }\end{array}$ & $\begin{array}{l}\text { Time } \\
\text { (hours) }\end{array}$ & $\begin{array}{l}\text { Streamflow } \\
\text { (cubic feet } \\
\text { per second) }\end{array}$ & $\begin{array}{l}\text { Rain- } \\
\text { fall } \\
\text { (inches) }\end{array}$ & $\begin{array}{l}\text { Time } \\
\text { (hours) }\end{array}$ & $\begin{array}{l}\text { Streamflow } \\
\text { (cubic feet } \\
\text { per second) }\end{array}$ & $\begin{array}{l}\text { Rain- } \\
\text { fall } \\
\text { (inches) }\end{array}$ \\
\hline $\begin{array}{c}\text { February } \\
1610 \\
1615 \\
1620 \\
1625\end{array}$ & $\begin{array}{r}09,1990 \\
3.9 \\
4.2 \\
4.2 \\
4.2\end{array}$ & $\begin{array}{l}0.01 \\
0.00 \\
0.01 \\
0.01\end{array}$ & $\begin{array}{l}2130 \\
2135 \\
2140 \\
2145 \\
2150\end{array}$ & $\begin{array}{l}164.0 \\
176.0 \\
184.0 \\
203.0 \\
213.0\end{array}$ & $\begin{array}{l}0.01 \\
0.04 \\
0.07 \\
0.02 \\
0.01\end{array}$ & $\begin{array}{l}0250 \\
0255 \\
0300 \\
0305 \\
0310\end{array}$ & $\begin{array}{l}61.2 \\
58.8 \\
56.5 \\
53.2 \\
52.2\end{array}$ & $\begin{array}{l}0.00 \\
0.00 \\
0.00 \\
0.00 \\
0.00\end{array}$ \\
\hline $\begin{array}{l}1630 \\
1635 \\
1640 \\
1645 \\
1650\end{array}$ & $\begin{array}{l}4.6 \\
4.6 \\
5.0 \\
5.5 \\
5.5\end{array}$ & $\begin{array}{l}0.00 \\
0.00 \\
0.00 \\
0.01 \\
0.00\end{array}$ & $\begin{array}{l}2155 \\
2200 \\
2205 \\
2210 \\
2215\end{array}$ & $\begin{array}{l}217.0 \\
226.0 \\
244.0 \\
259.0 \\
262.0\end{array}$ & $\begin{array}{l}0.01 \\
0.02 \\
0.10 \\
0.09 \\
0.03\end{array}$ & $\begin{array}{l}0315 \\
0320 \\
0325 \\
0330 \\
0335\end{array}$ & $\begin{array}{l}50.0 \\
48.0 \\
45.9 \\
45.9 \\
44.9\end{array}$ & $\begin{array}{l}0.00 \\
0.01 \\
0.00 \\
0.00 \\
0.00\end{array}$ \\
\hline $\begin{array}{l}1655 \\
1700 \\
1705 \\
1710 \\
1715\end{array}$ & $\begin{array}{l}6.0 \\
6.4 \\
6.4 \\
6.4 \\
6.4\end{array}$ & $\begin{array}{l}0.00 \\
0.00 \\
0.00 \\
0.01 \\
0.01\end{array}$ & $\begin{array}{l}2220 \\
2225 \\
2230 \\
2235 \\
2240\end{array}$ & $\begin{array}{l}284.0 \\
311.0 \\
325.0 \\
334.0 \\
345.0\end{array}$ & $\begin{array}{l}0.04 \\
0.03 \\
0.08 \\
0.01 \\
0.01\end{array}$ & $\begin{array}{l}0340 \\
0345 \\
0350 \\
0355 \\
0400\end{array}$ & $\begin{array}{l}42.9 \\
41.9 \\
40.9 \\
40.9 \\
40.0\end{array}$ & $\begin{array}{l}0.00 \\
0.00 \\
0.00 \\
0.00 \\
0.00\end{array}$ \\
\hline $\begin{array}{l}1720 \\
1725 \\
1730 \\
1735 \\
1740\end{array}$ & $\begin{array}{l}6.4 \\
6.9 \\
7.3 \\
7.3 \\
7.3\end{array}$ & $\begin{array}{l}0.01 \\
0.01 \\
0.00 \\
0.00 \\
0.00\end{array}$ & $\begin{array}{l}2245 \\
2250 \\
2255 \\
2300 \\
2305\end{array}$ & $\begin{array}{l}344.0 \\
344.0 \\
341.0 \\
344.0 \\
345.0\end{array}$ & $\begin{array}{l}0.00 \\
0.00 \\
0.00 \\
0.00 \\
0.00\end{array}$ & $\begin{array}{l}0405 \\
0410 \\
0415 \\
0420 \\
0425\end{array}$ & $\begin{array}{l}39.1 \\
38.2 \\
36.5 \\
36.5 \\
36.5\end{array}$ & $\begin{array}{l}0.00 \\
0.00 \\
0.00 \\
0.00 \\
0.00\end{array}$ \\
\hline $\begin{array}{l}1745 \\
1750 \\
1755 \\
1800 \\
1805\end{array}$ & $\begin{array}{l}7.3 \\
7.8 \\
8.9 \\
9.5 \\
9.5\end{array}$ & $\begin{array}{l}0.00 \\
0.01 \\
0.00 \\
0.00 \\
0.00\end{array}$ & $\begin{array}{l}2310 \\
2315 \\
2320 \\
2325 \\
2330\end{array}$ & $\begin{array}{l}348.0 \\
356.0 \\
366.0 \\
372.0 \\
381.0\end{array}$ & $\begin{array}{l}0.00 \\
0.00 \\
0.00 \\
0.00 \\
0.00\end{array}$ & $\begin{array}{l}0430 \\
0435 \\
0440 \\
0445 \\
0450\end{array}$ & $\begin{array}{l}35.6 \\
35.6 \\
34.0 \\
32.9 \\
32.9\end{array}$ & $\begin{array}{l}0.00 \\
0.00 \\
0.00 \\
0.00 \\
0.00\end{array}$ \\
\hline $\begin{array}{l}1810 \\
1815 \\
1820 \\
1825 \\
1830\end{array}$ & $\begin{array}{l}9.5 \\
9.5 \\
8.9 \\
8.9 \\
8.9\end{array}$ & $\begin{array}{l}0.00 \\
0.00 \\
0.01 \\
0.00 \\
0.00\end{array}$ & $\begin{array}{l}2335 \\
2340 \\
2345 \\
2350 \\
2355\end{array}$ & $\begin{array}{l}393.0 \\
405.0 \\
410.0 \\
417.0 \\
420.0\end{array}$ & $\begin{array}{l}0.00 \\
0.00 \\
0.00 \\
0.00 \\
0.00\end{array}$ & $\begin{array}{l}0455 \\
0500 \\
0505 \\
0510 \\
0515\end{array}$ & $\begin{array}{l}31.8 \\
30.7 \\
30.7 \\
29.7 \\
29.7\end{array}$ & $\begin{array}{l}0.00 \\
0.00 \\
0.00 \\
0.00 \\
0.00\end{array}$ \\
\hline $\begin{array}{l}1835 \\
1840 \\
1845 \\
1850 \\
1855\end{array}$ & $\begin{array}{l}8.9 \\
8.9 \\
8.9 \\
9.5 \\
9.5\end{array}$ & $\begin{array}{l}0.00 \\
0.00 \\
0.00 \\
0.00 \\
0.00\end{array}$ & $\begin{array}{c}\text { February } \\
0000 \\
0005 \\
0010 \\
0015\end{array}$ & $\begin{array}{r}1990 \\
425.0 \\
429.0 \\
425.0 \\
425.0\end{array}$ & $\begin{array}{l}0.00 \\
0.00 \\
0.00 \\
0.00\end{array}$ & $\begin{array}{l}0520 \\
0525 \\
0530 \\
0535 \\
0540\end{array}$ & $\begin{array}{l}28.7 \\
28.7 \\
27.7 \\
26.7 \\
26.7\end{array}$ & $\begin{array}{l}0.00 \\
0.00 \\
0.00 \\
0.00 \\
0.00\end{array}$ \\
\hline $\begin{array}{l}1900 \\
1905 \\
1910 \\
1915 \\
1920\end{array}$ & $\begin{array}{l}9.5 \\
9.5 \\
9.5 \\
8.9 \\
9.5\end{array}$ & $\begin{array}{l}0.00 \\
0.01 \\
0.00 \\
0.00 \\
0.00\end{array}$ & $\begin{array}{l}0020 \\
0025 \\
0030 \\
0035 \\
0040\end{array}$ & $\begin{array}{l}419.0 \\
423.0 \\
414.0 \\
402.0 \\
388.0\end{array}$ & $\begin{array}{l}0.00 \\
0.00 \\
0.00 \\
0.00 \\
0.00\end{array}$ & $\begin{array}{l}0545 \\
0550 \\
0555 \\
0600 \\
0605\end{array}$ & $\begin{array}{l}26.7 \\
26.7 \\
25.8 \\
25.8 \\
24.9\end{array}$ & $\begin{array}{l}0.00 \\
0.00 \\
0.00 \\
0.00 \\
0.00\end{array}$ \\
\hline $\begin{array}{l}1925 \\
1930 \\
1935 \\
1940 \\
1945\end{array}$ & $\begin{array}{l}9.5 \\
8.9 \\
8.9 \\
8.9 \\
8.9\end{array}$ & $\begin{array}{l}0.00 \\
0.00 \\
0.00 \\
0.01 \\
0.00\end{array}$ & $\begin{array}{l}0045 \\
0050 \\
0055 \\
0100 \\
0105\end{array}$ & $\begin{array}{l}384.0 \\
366.0 \\
357.0 \\
338.0 \\
321.0\end{array}$ & $\begin{array}{l}0.00 \\
0.00 \\
0.00 \\
0.00 \\
0.00\end{array}$ & $\begin{array}{l}0610 \\
0615 \\
0620 \\
0625 \\
0630\end{array}$ & $\begin{array}{l}24.0 \\
24.0 \\
24.0 \\
22.9 \\
22.9\end{array}$ & $\begin{array}{l}0.00 \\
0.00 \\
0.00 \\
0.00 \\
0.00\end{array}$ \\
\hline $\begin{array}{l}1950 \\
1955 \\
2000 \\
2005 \\
2010\end{array}$ & $\begin{array}{r}9.5 \\
9.5 \\
9.5 \\
9.5 \\
10.1\end{array}$ & $\begin{array}{l}0.01 \\
0.00 \\
0.00 \\
0.01 \\
0.03\end{array}$ & $\begin{array}{l}0110 \\
0115 \\
0120 \\
0125 \\
0130\end{array}$ & $\begin{array}{l}319.0 \\
309.0 \\
294.0 \\
283.0 \\
272.0\end{array}$ & $\begin{array}{l}0.00 \\
0.00 \\
0.00 \\
0.00 \\
0.01\end{array}$ & $\begin{array}{l}0635 \\
0640 \\
0645 \\
0650 \\
0655\end{array}$ & $\begin{array}{l}22.9 \\
21.9 \\
21.9 \\
21.9 \\
20.9\end{array}$ & $\begin{array}{l}0.00 \\
0.00 \\
0.00 \\
0.00 \\
0.00\end{array}$ \\
\hline $\begin{array}{l}2015 \\
2020 \\
2025 \\
2030 \\
2035\end{array}$ & $\begin{array}{l}10.8 \\
13.5 \\
15.8 \\
20.0 \\
32.9\end{array}$ & $\begin{array}{l}0.02 \\
0.01 \\
0.02 \\
0.04 \\
0.07\end{array}$ & $\begin{array}{l}0135 \\
0140 \\
0145 \\
0150 \\
0155\end{array}$ & $\begin{array}{l}261.0 \\
248.0 \\
233.0 \\
220.0 \\
201.0\end{array}$ & $\begin{array}{l}0.00 \\
0.00 \\
0.00 \\
0.00 \\
0.00\end{array}$ & $\begin{array}{l}0700 \\
0705 \\
0710 \\
0715 \\
0720\end{array}$ & $\begin{array}{l}20.9 \\
20.9 \\
20.0 \\
20.0 \\
20.0\end{array}$ & $\begin{array}{l}0.00 \\
0.00 \\
0.00 \\
0.00 \\
0.00\end{array}$ \\
\hline $\begin{array}{l}2040 \\
2045 \\
2050 \\
2055 \\
2100\end{array}$ & $\begin{array}{l}41.9 \\
51.1 \\
64.9 \\
72.6 \\
77.8\end{array}$ & $\begin{array}{l}0.07 \\
0.03 \\
0.03 \\
0.04 \\
0.04\end{array}$ & $\begin{array}{l}0200 \\
0205 \\
0210 \\
0215 \\
0220\end{array}$ & $\begin{array}{l}184.0 \\
164.0 \\
148.0 \\
124.0 \\
104.0\end{array}$ & $\begin{array}{l}0.00 \\
0.00 \\
0.00 \\
0.00 \\
0.01\end{array}$ & $\begin{array}{l}0725 \\
0730 \\
0735 \\
0740 \\
0745\end{array}$ & $\begin{array}{l}20.0 \\
20.0 \\
20.0 \\
37.3 \\
50.0\end{array}$ & $\begin{array}{l}0.00 \\
0.00 \\
0.00 \\
0.10 \\
0.11\end{array}$ \\
\hline $\begin{array}{l}2105 \\
2110 \\
2115 \\
2120 \\
2125\end{array}$ & $\begin{array}{r}92.2 \\
105.0 \\
133.0 \\
151.0 \\
162.0\end{array}$ & $\begin{array}{l}0.09 \\
0.05 \\
0.01 \\
0.01 \\
0.03\end{array}$ & $\begin{array}{l}0225 \\
0230 \\
0235 \\
0240 \\
0245\end{array}$ & $\begin{array}{l}93.7 \\
86.3 \\
77.8 \\
70.0 \\
66.1\end{array}$ & $\begin{array}{l}0.00 \\
0.00 \\
0.00 \\
0.00 \\
0.00\end{array}$ & $\begin{array}{l}0750 \\
0755 \\
0800 \\
0805 \\
0810\end{array}$ & $\begin{array}{l}45.9 \\
56.5 \\
60.0 \\
57.7 \\
51.1\end{array}$ & $\begin{array}{l}0.03 \\
0.01 \\
0.01 \\
0.00 \\
0.00\end{array}$ \\
\hline
\end{tabular}


Table 158. - - Streamflow and rainfall at station 02187268 , Dye Creek at Anderson, February $9-11,1990--$ Continued

\begin{tabular}{|c|c|c|c|c|c|c|c|c|}
\hline $\begin{array}{l}\text { Time } \\
\text { (hours) }\end{array}$ & $\begin{array}{l}\text { Streamflow } \\
\text { (cubic feet } \\
\text { per second) }\end{array}$ & $\begin{array}{l}\text { Rain- } \\
\text { fall } \\
\text { (inches) }\end{array}$ & $\begin{array}{l}\text { Time } \\
\text { (hours) }\end{array}$ & $\begin{array}{l}\text { Streamflow } \\
\text { (cubic feet } \\
\text { per second) }\end{array}$ & $\begin{array}{l}\text { Rain- } \\
\text { fall } \\
\text { (inches) }\end{array}$ & $\begin{array}{l}\text { Time } \\
\text { (hours) }\end{array}$ & $\begin{array}{l}\text { Streamflow } \\
\text { (cubic feet } \\
\text { per second) }\end{array}$ & $\begin{array}{l}\text { Rain- } \\
\text { fall } \\
\text { (inches) }\end{array}$ \\
\hline $\begin{array}{l}0815 \\
0820 \\
0825 \\
0830 \\
0835\end{array}$ & $\begin{array}{l}48.0 \\
48.0 \\
55.4 \\
68.7 \\
82.0\end{array}$ & $\begin{array}{l}0.00 \\
0.00 \\
0.00 \\
0.00 \\
0.00\end{array}$ & $\begin{array}{l}1340 \\
1345 \\
1350 \\
1355 \\
1400\end{array}$ & $\begin{array}{l}24.0 \\
24.0 \\
22.9 \\
22.9 \\
21.9\end{array}$ & $\begin{array}{l}0.00 \\
0.00 \\
0.00 \\
0.00 \\
0.00\end{array}$ & $\begin{array}{l}1905 \\
1910 \\
1915 \\
1920 \\
1925\end{array}$ & $\begin{array}{l}10.8 \\
10.8 \\
10.8 \\
10.1 \\
10.1\end{array}$ & $\begin{array}{l}0.00 \\
0.00 \\
0.00 \\
0.00 \\
0.00\end{array}$ \\
\hline $\begin{array}{l}0840 \\
0845 \\
0850 \\
0855 \\
0900\end{array}$ & $\begin{array}{r}89.2 \\
95.3 \\
100.0 \\
104.0 \\
107.0\end{array}$ & $\begin{array}{l}0.00 \\
0.00 \\
0.00 \\
0.00 \\
0.00\end{array}$ & $\begin{array}{l}1405 \\
1410 \\
1415 \\
1420 \\
1425\end{array}$ & $\begin{array}{l}21.9 \\
20.9 \\
20.9 \\
20.9 \\
20.9\end{array}$ & $\begin{array}{l}0.00 \\
0.00 \\
0.00 \\
0.00 \\
0.00\end{array}$ & $\begin{array}{l}1930 \\
1935 \\
1940 \\
1945 \\
1950\end{array}$ & $\begin{array}{l}10.1 \\
10.1 \\
10.1 \\
10.1 \\
10.1\end{array}$ & $\begin{array}{l}0.00 \\
0.00 \\
0.00 \\
0.00 \\
0.00\end{array}$ \\
\hline $\begin{array}{l}0905 \\
0910 \\
0915 \\
0920 \\
0925\end{array}$ & $\begin{array}{l}109.0 \\
110.0 \\
110.0 \\
112.0 \\
113.0\end{array}$ & $\begin{array}{l}0.00 \\
0.00 \\
0.00 \\
0.00 \\
0.00\end{array}$ & $\begin{array}{l}1430 \\
1435 \\
1440 \\
1445 \\
1450\end{array}$ & $\begin{array}{l}20.0 \\
20.0 \\
19.1 \\
19.1 \\
19.1\end{array}$ & $\begin{array}{l}0.00 \\
0.00 \\
0.00 \\
0.00 \\
0.00\end{array}$ & $\begin{array}{l}1955 \\
2000 \\
2005 \\
2010 \\
2015\end{array}$ & $\begin{array}{r}10.1 \\
9.5 \\
9.5 \\
9.5 \\
9.5\end{array}$ & $\begin{array}{l}0.00 \\
0.00 \\
0.00 \\
0.00 \\
0.00\end{array}$ \\
\hline $\begin{array}{l}0930 \\
0935 \\
0940 \\
0945 \\
0950\end{array}$ & $\begin{array}{l}115.0 \\
112.0 \\
110.0 \\
107.0 \\
107.0\end{array}$ & $\begin{array}{l}0.00 \\
0.00 \\
0.00 \\
0.00 \\
0.00\end{array}$ & $\begin{array}{l}1455 \\
1500 \\
1505 \\
1510 \\
1515\end{array}$ & $\begin{array}{l}18.2 \\
19.1 \\
18.2 \\
18.2 \\
17.3\end{array}$ & $\begin{array}{l}0.00 \\
0.00 \\
0.00 \\
0.00 \\
0.00\end{array}$ & $\begin{array}{l}2020 \\
2025 \\
2030 \\
2035 \\
2040\end{array}$ & $\begin{array}{l}9.5 \\
9.5 \\
8.9 \\
8.9 \\
8.9\end{array}$ & $\begin{array}{l}0.00 \\
0.00 \\
0.00 \\
0.00 \\
0.00\end{array}$ \\
\hline $\begin{array}{l}0955 \\
1000 \\
1005 \\
1010 \\
1015\end{array}$ & $\begin{array}{r}103.0 \\
96.8 \\
92.2 \\
84.8 \\
80.6\end{array}$ & $\begin{array}{l}0.00 \\
0.00 \\
0.00 \\
0.00 \\
0.00\end{array}$ & $\begin{array}{l}1520 \\
1525 \\
1530 \\
1535 \\
1540\end{array}$ & $\begin{array}{l}17.3 \\
17.3 \\
16.5 \\
16.5 \\
16.5\end{array}$ & $\begin{array}{l}0.00 \\
0.00 \\
0.00 \\
0.00 \\
0.00\end{array}$ & $\begin{array}{l}2045 \\
2050 \\
2055 \\
2100 \\
2105\end{array}$ & $\begin{array}{l}8.9 \\
8.9 \\
8.9 \\
8.9 \\
8.9\end{array}$ & $\begin{array}{l}0.00 \\
0.00 \\
0.00 \\
0.00 \\
0.00\end{array}$ \\
\hline $\begin{array}{l}1020 \\
1025 \\
1030 \\
1035 \\
1040\end{array}$ & $\begin{array}{l}76.5 \\
72.6 \\
68.7 \\
64.9 \\
62.4\end{array}$ & $\begin{array}{l}0.00 \\
0.00 \\
0.00 \\
0.00 \\
0.00\end{array}$ & $\begin{array}{l}1545 \\
1550 \\
1555 \\
1600 \\
1605\end{array}$ & $\begin{array}{l}16.5 \\
15.8 \\
15.8 \\
15.8 \\
15.8\end{array}$ & $\begin{array}{l}0.00 \\
0.00 \\
0.00 \\
0.00 \\
0.00\end{array}$ & $\begin{array}{l}2110 \\
2115 \\
2120 \\
2125 \\
2130\end{array}$ & $\begin{array}{l}8.4 \\
8.4 \\
8.4 \\
8.4 \\
8.4\end{array}$ & $\begin{array}{l}0.00 \\
0.00 \\
0.00 \\
0.00 \\
0.00\end{array}$ \\
\hline $\begin{array}{l}1045 \\
1050 \\
1055 \\
1100 \\
1105\end{array}$ & $\begin{array}{l}58.8 \\
56.5 \\
55.4 \\
52.2 \\
51.1\end{array}$ & $\begin{array}{l}0.00 \\
0.00 \\
0.00 \\
0.00 \\
0.00\end{array}$ & $\begin{array}{l}1610 \\
1615 \\
1620 \\
1625 \\
1630\end{array}$ & $\begin{array}{l}15.8 \\
15.0 \\
15.0 \\
15.0 \\
15.0\end{array}$ & $\begin{array}{l}0.00 \\
0.00 \\
0.00 \\
0.00 \\
0.00\end{array}$ & $\begin{array}{l}2135 \\
2140 \\
2145 \\
2150 \\
2155\end{array}$ & $\begin{array}{l}8.4 \\
8.4 \\
8.4 \\
8.4 \\
8.4\end{array}$ & $\begin{array}{l}0.00 \\
0.00 \\
0.00 \\
0.00 \\
0.00\end{array}$ \\
\hline $\begin{array}{l}1110 \\
1115 \\
1120 \\
1125 \\
1130\end{array}$ & $\begin{array}{l}49.0 \\
46.9 \\
45.9 \\
44.9 \\
43.9\end{array}$ & $\begin{array}{l}0.00 \\
0.00 \\
0.00 \\
0.00 \\
0.00\end{array}$ & $\begin{array}{l}1635 \\
1640 \\
1645 \\
1650 \\
1655\end{array}$ & $\begin{array}{l}15.0 \\
14.2 \\
14.2 \\
13.5 \\
12.8\end{array}$ & $\begin{array}{l}0.00 \\
0.00 \\
0.00 \\
0.00 \\
0.00\end{array}$ & $\begin{array}{l}2200 \\
2205 \\
2210 \\
2215 \\
2220\end{array}$ & $\begin{array}{l}8.4 \\
7.8 \\
7.8 \\
7.8 \\
7.8\end{array}$ & $\begin{array}{l}0.00 \\
0.00 \\
0.00 \\
0.00 \\
0.00\end{array}$ \\
\hline $\begin{array}{l}1135 \\
1140 \\
1145 \\
1150 \\
1155\end{array}$ & $\begin{array}{l}40.9 \\
40.9 \\
40.0 \\
39.1 \\
38.2\end{array}$ & $\begin{array}{l}0.00 \\
0.00 \\
0.00 \\
0.00 \\
0.00\end{array}$ & $\begin{array}{l}1700 \\
1705 \\
1710 \\
1715 \\
1720\end{array}$ & $\begin{array}{l}13.5 \\
13.5 \\
13.5 \\
12.8 \\
12.8\end{array}$ & $\begin{array}{l}0.00 \\
0.00 \\
0.00 \\
0.00 \\
0.00\end{array}$ & $\begin{array}{l}2225 \\
2230 \\
2235 \\
2240 \\
2245\end{array}$ & $\begin{array}{l}7.8 \\
7.8 \\
7.8 \\
7.8 \\
7.8\end{array}$ & $\begin{array}{l}0.00 \\
0.00 \\
0.00 \\
0.00 \\
0.00\end{array}$ \\
\hline $\begin{array}{l}1200 \\
1205 \\
1210 \\
1215 \\
1220\end{array}$ & $\begin{array}{l}37.3 \\
36.5 \\
35.6 \\
34.8 \\
34.0\end{array}$ & $\begin{array}{l}0.00 \\
0.00 \\
0.00 \\
0.00 \\
0.00\end{array}$ & $\begin{array}{l}1725 \\
1730 \\
1735 \\
1740 \\
1745\end{array}$ & $\begin{array}{l}12.8 \\
12.8 \\
12.8 \\
12.8 \\
12.1\end{array}$ & $\begin{array}{l}0.00 \\
0.00 \\
0.00 \\
0.00 \\
0.00\end{array}$ & $\begin{array}{l}2250 \\
2255 \\
2300 \\
2305 \\
2310\end{array}$ & $\begin{array}{l}7.8 \\
7.8 \\
7.8 \\
7.3 \\
7.3\end{array}$ & $\begin{array}{l}0.00 \\
0.00 \\
0.00 \\
0.00 \\
0.00\end{array}$ \\
\hline $\begin{array}{l}1225 \\
1230 \\
1235 \\
1240 \\
1245\end{array}$ & $\begin{array}{l}34.0 \\
31.8 \\
31.8 \\
31.8 \\
30.7\end{array}$ & $\begin{array}{l}0.00 \\
0.00 \\
0.00 \\
0.00 \\
0.00\end{array}$ & $\begin{array}{l}1750 \\
1755 \\
1800 \\
1805 \\
1810\end{array}$ & $\begin{array}{l}12.1 \\
12.1 \\
12.1 \\
12.1 \\
11.5\end{array}$ & $\begin{array}{l}0.00 \\
0.00 \\
0.00 \\
0.00 \\
0.00\end{array}$ & $\begin{array}{l}2315 \\
2320 \\
2325 \\
2330 \\
2335\end{array}$ & $\begin{array}{l}7.3 \\
7.3 \\
7.3 \\
7.3 \\
7.3\end{array}$ & $\begin{array}{l}0.00 \\
0.00 \\
0.00 \\
0.00 \\
0.00\end{array}$ \\
\hline $\begin{array}{l}1250 \\
1255 \\
1300 \\
1305 \\
1310\end{array}$ & $\begin{array}{l}29.7 \\
28.7 \\
28.7 \\
27.7 \\
26.7\end{array}$ & $\begin{array}{l}0.00 \\
0.00 \\
0.00 \\
0.00 \\
0.00\end{array}$ & $\begin{array}{l}1815 \\
1820 \\
1825 \\
1830 \\
1835\end{array}$ & $\begin{array}{l}11.5 \\
11.5 \\
11.5 \\
11.5 \\
11.5\end{array}$ & $\begin{array}{l}0.00 \\
0.00 \\
0.00 \\
0.00 \\
0.00\end{array}$ & $\begin{array}{c}2340 \\
2345 \\
2350 \\
2355 \\
\text { February }\end{array}$ & $\begin{array}{r}7.3 \\
7.3 \\
7.3 \\
6.9 \\
11.1990\end{array}$ & $\begin{array}{l}0.00 \\
0.00 \\
0.00 \\
0.00\end{array}$ \\
\hline $\begin{array}{l}1315 \\
1320 \\
1325 \\
1330 \\
1335\end{array}$ & $\begin{array}{l}26.7 \\
25.8 \\
25.8 \\
24.9 \\
24.9\end{array}$ & $\begin{array}{l}0.00 \\
0.00 \\
0.00 \\
0.00 \\
0.00\end{array}$ & $\begin{array}{l}1840 \\
1845 \\
1850 \\
1855 \\
1900\end{array}$ & $\begin{array}{l}10.8 \\
10.8 \\
10.8 \\
10.8 \\
10.8\end{array}$ & $\begin{array}{l}0.00 \\
0.00 \\
0.00 \\
0.00 \\
0.00\end{array}$ & $\begin{array}{l}0000 \\
0005 \\
0010 \\
0015 \\
0020\end{array}$ & $\begin{array}{l}6.9 \\
6.9 \\
6.9 \\
6.9 \\
6.9\end{array}$ & $\begin{array}{l}0.00 \\
0.00 \\
0.00 \\
0.00 \\
0.00\end{array}$ \\
\hline
\end{tabular}


Table 158.--Streamflow and rainfall at station 02187268, Dye Creek at Anderson, February $9-11,1990--$ Continued

\begin{tabular}{|c|c|c|c|c|c|c|c|c|}
\hline $\begin{array}{l}\text { Time } \\
\text { (hours) }\end{array}$ & $\begin{array}{l}\text { Streamflow } \\
\text { (cubic feet } \\
\text { per second) }\end{array}$ & $\begin{array}{l}\text { Rain- } \\
\text { fall } \\
\text { (inches) }\end{array}$ & $\begin{array}{l}\text { Time } \\
\text { (hours) }\end{array}$ & $\begin{array}{l}\text { Streamflow } \\
\text { (cubic feet } \\
\text { per second) }\end{array}$ & $\begin{array}{l}\text { Rain- } \\
\text { fall } \\
\text { (inches) }\end{array}$ & $\begin{array}{l}\text { Time } \\
\text { (hours) }\end{array}$ & $\begin{array}{l}\text { Streamflow } \\
\text { (cubic feet } \\
\text { per second) }\end{array}$ & $\begin{array}{l}\text { Rain- } \\
\text { fall } \\
\text { (inches) }\end{array}$ \\
\hline $\begin{array}{l}0025 \\
0030 \\
0035 \\
0040 \\
0045\end{array}$ & $\begin{array}{l}6.9 \\
6.9 \\
6.9 \\
6.9 \\
6.9\end{array}$ & $\begin{array}{l}0.00 \\
0.00 \\
0.00 \\
0.00 \\
0.00\end{array}$ & $\begin{array}{l}0120 \\
0125 \\
0130 \\
0135 \\
0140\end{array}$ & $\begin{array}{l}6.4 \\
6.4 \\
6.4 \\
6.4 \\
6.4\end{array}$ & $\begin{array}{l}0.00 \\
0.00 \\
0.00 \\
0.00 \\
0.00\end{array}$ & $\begin{array}{l}0215 \\
0220 \\
0225 \\
0230 \\
0235\end{array}$ & $\begin{array}{l}6.4 \\
6.4 \\
6.4 \\
6.4 \\
6.4\end{array}$ & $\begin{array}{l}0.00 \\
0.00 \\
0.00 \\
0.00 \\
0.00\end{array}$ \\
\hline $\begin{array}{l}0050 \\
0055 \\
0100 \\
0105 \\
0110\end{array}$ & $\begin{array}{l}6.9 \\
6.9 \\
6.9 \\
6.9 \\
6.4\end{array}$ & $\begin{array}{l}0.00 \\
0.00 \\
0.00 \\
0.00 \\
0.00\end{array}$ & $\begin{array}{l}0145 \\
0150 \\
0155 \\
0200 \\
0205\end{array}$ & $\begin{array}{l}6.4 \\
6.4 \\
6.4 \\
6.4 \\
6.4\end{array}$ & $\begin{array}{l}0.00 \\
0.00 \\
0.00 \\
0.00 \\
0.00\end{array}$ & $\begin{array}{l}0240 \\
0245 \\
0250 \\
0255 \\
0300\end{array}$ & $\begin{array}{l}6.4 \\
6.0 \\
6.0 \\
6.0 \\
6.0\end{array}$ & $\begin{array}{l}0.00 \\
0.00 \\
0.00 \\
0.00 \\
0.00\end{array}$ \\
\hline 0115 & 6.4 & 0.00 & 0210 & 6.4 & 0.00 & & & \\
\hline
\end{tabular}




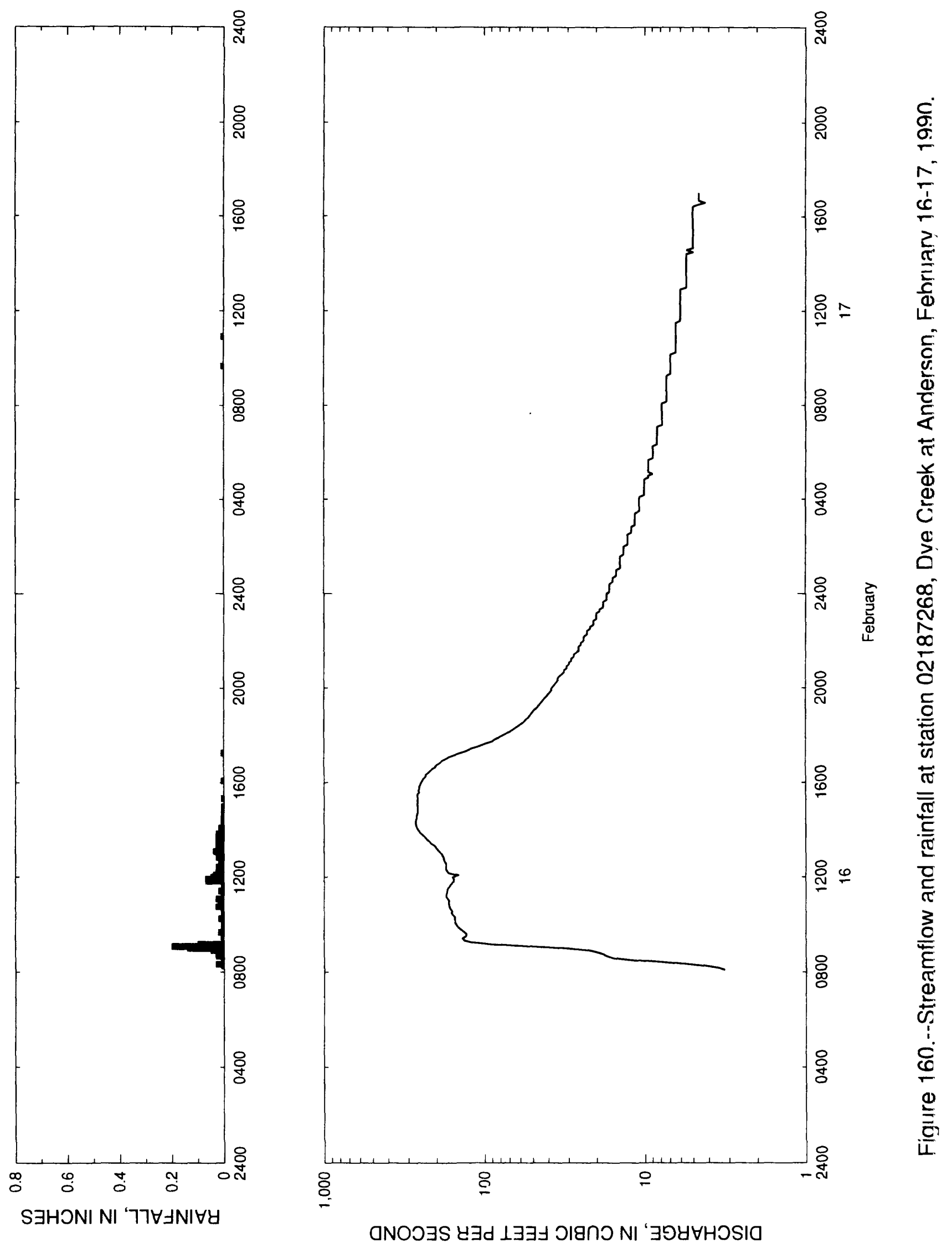


Table 159. - - Streamflow and rainfal1 at station 02187268. Dye Creek at Anderson, February $16-17,1990$

\begin{tabular}{|c|c|c|c|c|c|c|c|c|}
\hline $\begin{array}{l}\text { Time } \\
\text { (hours) }\end{array}$ & $\begin{array}{l}\text { Streamflow } \\
\text { (cubic feet } \\
\text { per second) }\end{array}$ & $\begin{array}{l}\text { Rain- } \\
\text { fall } \\
\text { (inches) }\end{array}$ & $\begin{array}{l}\text { Time } \\
\text { (hours) }\end{array}$ & $\begin{array}{l}\text { Streamflow } \\
\text { (cubic feet } \\
\text { per second) }\end{array}$ & $\begin{array}{l}\text { Rain- } \\
\text { fall } \\
\text { (inches) }\end{array}$ & $\begin{array}{l}\text { Time } \\
\text { (hours) }\end{array}$ & $\begin{array}{l}\text { Streamflow } \\
\text { (cubic feet } \\
\text { per second) }\end{array}$ & $\begin{array}{l}\text { Rain- } \\
\text { fall } \\
\text { (inches) }\end{array}$ \\
\hline $\begin{array}{c}\text { February } \\
0805 \\
0810 \\
0815 \\
0820\end{array}$ & $\begin{array}{r}16, \quad 1990 \\
3.2 \\
3.5 \\
4.2 \\
5.5\end{array}$ & $\begin{array}{l}0.00 \\
0.00 \\
0.01 \\
0.03\end{array}$ & $\begin{array}{l}1325 \\
1330 \\
1335 \\
1340 \\
1345\end{array}$ & $\begin{array}{l}216.0 \\
220.0 \\
228.0 \\
234.0 \\
240.0\end{array}$ & $\begin{array}{l}0.03 \\
0.03 \\
0.02 \\
0.03 \\
0.01\end{array}$ & $\begin{array}{l}1850 \\
1855 \\
1900 \\
1905 \\
1910\end{array}$ & $\begin{array}{l}52.2 \\
51.1 \\
50.0 \\
49.0 \\
46.9\end{array}$ & $\begin{array}{l}0.00 \\
0.00 \\
0.00 \\
0.00 \\
0.00\end{array}$ \\
\hline $\begin{array}{l}0825 \\
0830 \\
0835 \\
0840 \\
0845\end{array}$ & $\begin{array}{r}7.8 \\
12.1 \\
15.8 \\
17.3 \\
18.2\end{array}$ & $\begin{array}{l}0.01 \\
0.01 \\
0.01 \\
0.03 \\
0.03\end{array}$ & $\begin{array}{l}1350 \\
1355 \\
1400 \\
1405 \\
1410\end{array}$ & $\begin{array}{l}248.0 \\
255.0 \\
261.0 \\
265.0 \\
269.0\end{array}$ & $\begin{array}{l}0.03 \\
0.02 \\
0.01 \\
0.02 \\
0.01\end{array}$ & $\begin{array}{l}1915 \\
1920 \\
1925 \\
1930 \\
1935\end{array}$ & $\begin{array}{l}45.9 \\
44.9 \\
43.9 \\
42.9 \\
41.9\end{array}$ & $\begin{array}{l}0 . C 0 \\
0 . C 0 \\
0 . C 0 \\
0 . C 0 \\
0.100\end{array}$ \\
\hline $\begin{array}{l}0850 \\
0855 \\
0900 \\
0905 \\
0910\end{array}$ & $\begin{array}{l}20.0 \\
22.9 \\
30.7 \\
54.3 \\
90.7\end{array}$ & $\begin{array}{l}0.02 \\
0.05 \\
0.14 \\
0.20 \\
0.10\end{array}$ & $\begin{array}{l}1415 \\
1420 \\
1425 \\
1430 \\
1435\end{array}$ & $\begin{array}{l}268.0 \\
269.0 \\
268.0 \\
265.0 \\
265.0\end{array}$ & $\begin{array}{l}0.00 \\
0.01 \\
0.00 \\
0.00 \\
0.01\end{array}$ & $\begin{array}{l}1940 \\
1945 \\
1950 \\
1955 \\
2000\end{array}$ & $\begin{array}{l}40.9 \\
40.0 \\
39.1 \\
38.2 \\
38.2\end{array}$ & $\begin{array}{l}0 . c 0 \\
0 . C 0 \\
0 . C 0 \\
0 . C 0 \\
0 . C 0\end{array}$ \\
\hline $\begin{array}{l}0915 \\
0920 \\
0925 \\
0930 \\
0935\end{array}$ & $\begin{array}{l}120.0 \\
135.0 \\
138.0 \\
131.0 \\
130.0\end{array}$ & $\begin{array}{l}0.01 \\
0.01 \\
0.01 \\
0.01 \\
0.00\end{array}$ & $\begin{array}{l}1440 \\
1445 \\
1450 \\
1455 \\
1500\end{array}$ & $\begin{array}{l}264.0 \\
261.0 \\
262.0 \\
262.0 \\
262.0\end{array}$ & $\begin{array}{l}0.00 \\
0.00 \\
0.01 \\
0.00 \\
0.01\end{array}$ & $\begin{array}{l}2005 \\
2010 \\
2015 \\
2020 \\
2025\end{array}$ & $\begin{array}{l}37.3 \\
36.5 \\
35.6 \\
34.8 \\
34.8\end{array}$ & $\begin{array}{l}0 . C 0 \\
0 . C 0 \\
0 . C 0 \\
0 . C 0 \\
0 . C 0\end{array}$ \\
\hline $\begin{array}{l}0940 \\
0945 \\
0950 \\
0955 \\
1000\end{array}$ & $\begin{array}{l}134.0 \\
139.0 \\
144.0 \\
149.0 \\
151.0\end{array}$ & $\begin{array}{l}0.02 \\
0.00 \\
0.01 \\
0.01 \\
0.00\end{array}$ & $\begin{array}{l}1505 \\
1510 \\
1515 \\
1520 \\
1525\end{array}$ & $\begin{array}{l}264.0 \\
262.0 \\
264.0 \\
262.0 \\
264.0\end{array}$ & $\begin{array}{l}0.00 \\
0.00 \\
0.00 \\
0.01 \\
0.00\end{array}$ & $\begin{array}{l}2030 \\
2035 \\
2040 \\
2045 \\
2050\end{array}$ & $\begin{array}{l}34.0 \\
32.9 \\
31.8 \\
31.8 \\
30.7\end{array}$ & $\begin{array}{l}0.00 \\
0.00 \\
0.00 \\
0.00 \\
0.00\end{array}$ \\
\hline $\begin{array}{l}1005 \\
1010 \\
1015 \\
1020 \\
1025\end{array}$ & $\begin{array}{l}154.0 \\
153.0 \\
155.0 \\
154.0 \\
159.0\end{array}$ & $\begin{array}{l}0.00 \\
0.01 \\
0.02 \\
0.01 \\
0.00\end{array}$ & $\begin{array}{l}1530 \\
1535 \\
1540 \\
1545 \\
1550\end{array}$ & $\begin{array}{l}262.0 \\
256.0 \\
259.0 \\
255.0 \\
256.0\end{array}$ & $\begin{array}{l}0.00 \\
0.00 \\
0.00 \\
0.00 \\
0.00\end{array}$ & $\begin{array}{l}2055 \\
2100 \\
2105 \\
2110 \\
2115\end{array}$ & $\begin{array}{l}30.7 \\
29.7 \\
29.7 \\
28.7 \\
28.7\end{array}$ & $\begin{array}{l}0.00 \\
0.00 \\
0.00 \\
0.00 \\
0.00\end{array}$ \\
\hline $\begin{array}{l}1030 \\
1035 \\
1040 \\
1045 \\
1050\end{array}$ & $\begin{array}{l}162.0 \\
160.0 \\
164.0 \\
166.0 \\
167.0\end{array}$ & $\begin{array}{l}0.01 \\
0.00 \\
0.01 \\
0.03 \\
0.01\end{array}$ & $\begin{array}{l}1555 \\
1600 \\
1605 \\
1610 \\
1615\end{array}$ & $\begin{array}{l}252.0 \\
249.0 \\
245.0 \\
241.0 \\
234.0\end{array}$ & $\begin{array}{l}0.00 \\
0.00 \\
0.01 \\
0.00 \\
0.00\end{array}$ & $\begin{array}{l}2120 \\
2125 \\
2130 \\
2135 \\
2140\end{array}$ & $\begin{array}{l}27.7 \\
27.7 \\
26.7 \\
25.8 \\
25.8\end{array}$ & $\begin{array}{l}0.00 \\
0.00 \\
0.00 \\
0.00 \\
0.00\end{array}$ \\
\hline $\begin{array}{l}1055 \\
1100 \\
1105 \\
1110 \\
1115\end{array}$ & $\begin{array}{l}168.0 \\
167.0 \\
170.0 \\
174.0 \\
174.0\end{array}$ & $\begin{array}{l}0.00 \\
0.02 \\
0.03 \\
0.01 \\
0.01\end{array}$ & $\begin{array}{l}1620 \\
1625 \\
1630 \\
1635 \\
1640\end{array}$ & $\begin{array}{l}233.0 \\
225.0 \\
218.0 \\
212.0 \\
203.0\end{array}$ & $\begin{array}{l}0.00 \\
0.00 \\
0.00 \\
0.00 \\
0.00\end{array}$ & $\begin{array}{l}2145 \\
2150 \\
2155 \\
2200 \\
2205\end{array}$ & $\begin{array}{l}25.8 \\
24.9 \\
24.9 \\
24.0 \\
24.0\end{array}$ & $\begin{array}{l}0.00 \\
0.00 \\
0.00 \\
0.00 \\
0.00\end{array}$ \\
\hline $\begin{array}{l}1120 \\
1125 \\
1130 \\
1135 \\
1140\end{array}$ & $\begin{array}{l}172.0 \\
172.0 \\
171.0 \\
167.0 \\
164.0\end{array}$ & $\begin{array}{l}0.01 \\
0.02 \\
0.01 \\
0.01 \\
0.01\end{array}$ & $\begin{array}{l}1645 \\
1650 \\
1655 \\
1700 \\
1705\end{array}$ & $\begin{array}{l}199.0 \\
190.0 \\
184.0 \\
174.0 \\
167.0\end{array}$ & $\begin{array}{l}0.00 \\
0.00 \\
0.00 \\
0.00 \\
0.00\end{array}$ & $\begin{array}{l}2210 \\
2215 \\
2220 \\
2225 \\
2230\end{array}$ & $\begin{array}{l}24.0 \\
22.9 \\
22.9 \\
22.9 \\
21.9\end{array}$ & $\begin{array}{l}0.00 \\
0.00 \\
0.00 \\
0.00 \\
0.00\end{array}$ \\
\hline $\begin{array}{l}1145 \\
1150 \\
1155 \\
1200 \\
1205\end{array}$ & $\begin{array}{l}160.0 \\
156.0 \\
156.0 \\
159.0 \\
146.0\end{array}$ & $\begin{array}{l}0.00 \\
0.07 \\
0.07 \\
0.05 \\
0.04\end{array}$ & $\begin{array}{l}1710 \\
1715 \\
1720 \\
1725 \\
1730\end{array}$ & $\begin{array}{l}154.0 \\
142.0 \\
131.0 \\
122.0 \\
112.0\end{array}$ & $\begin{array}{l}0.00 \\
0.01 \\
0.00 \\
0.00 \\
0.00\end{array}$ & $\begin{array}{l}2235 \\
2240 \\
2245 \\
2250 \\
2255\end{array}$ & $\begin{array}{l}21.9 \\
20.9 \\
20.9 \\
20.9 \\
20.0\end{array}$ & $\begin{array}{l}0.00 \\
0.00 \\
0.00 \\
0.00 \\
0.00\end{array}$ \\
\hline $\begin{array}{r}1210 \\
1215 \\
, 1220 \\
1225 \\
1230\end{array}$ & $\begin{array}{l}168.0 \\
172.0 \\
175.0 \\
174.0 \\
174.0\end{array}$ & $\begin{array}{l}0.03 \\
0.02 \\
0.02 \\
0.03 \\
0.02\end{array}$ & $\begin{array}{l}1735 \\
1740 \\
1745 \\
1750 \\
1755\end{array}$ & $\begin{array}{r}104.0 \\
96.8 \\
89.2 \\
86.3 \\
80.6\end{array}$ & $\begin{array}{l}0.00 \\
0.00 \\
0.00 \\
0.00 \\
0.00\end{array}$ & $\begin{array}{l}2300 \\
2305 \\
2310 \\
2315 \\
2320\end{array}$ & $\begin{array}{l}20.0 \\
20.0 \\
20.0 \\
19.1 \\
19.1\end{array}$ & $\begin{array}{l}0.00 \\
0.00 \\
0.00 \\
0.00 \\
0.00\end{array}$ \\
\hline $\begin{array}{l}1235 \\
1240 \\
1245 \\
1250 \\
2255\end{array}$ & $\begin{array}{l}175.0 \\
179.0 \\
180.0 \\
181.0 \\
184 .\end{array}$ & $\begin{array}{l}0.02 \\
0.01 \\
0.02 \\
0.03 \\
0.02\end{array}$ & $\begin{array}{l}1800 \\
1805 \\
1810 \\
1815 \\
1820\end{array}$ & $\begin{array}{l}76.5 \\
72.6 \\
68.7 \\
66.1 \\
63.6\end{array}$ & $\begin{array}{l}0.00 \\
0.00 \\
0.00 \\
0.00 \\
0.00\end{array}$ & $\begin{array}{l}2325 \\
2330 \\
2335 \\
2340 \\
2345\end{array}$ & $\begin{array}{l}18.2 \\
18.2 \\
18.2 \\
18.2 \\
17.3\end{array}$ & $\begin{array}{l}0.00 \\
0.00 \\
0.00 \\
0.00 \\
0.00\end{array}$ \\
\hline $\begin{array}{l}: 300 \\
: 30= \\
1310 \\
1315 \\
-320\end{array}$ & $\begin{array}{l}185 . i \\
1910 \\
195, i \\
2010 \\
2050\end{array}$ & $\begin{array}{ll}j & 02 \\
0 & 04 \\
0.02 \\
0 & 03 \\
0 & 02\end{array}$ & $\begin{array}{l}1825 \\
1830 \\
1835 \\
1840 \\
1845\end{array}$ & $\begin{array}{l}61.2 \\
58.8 \\
56.5 \\
55.4 \\
53.2\end{array}$ & $\begin{array}{l}0.00 \\
0.00 \\
0.00 \\
0.00 \\
0.00\end{array}$ & $\begin{array}{l}2350 \\
2355 \\
\text { September } \\
0000 \\
0005\end{array}$ & $\begin{array}{c}17.3 \\
17.3 \\
1990 \\
17.3 \\
16.5\end{array}$ & $\begin{array}{l}0.00 \\
0.00\end{array}$ \\
\hline
\end{tabular}


Table 159.--Streamflow and rainfall at station 02187268, Dye Creek at Anderson,

February 16-17, 1990--Continued

\begin{tabular}{|c|c|c|c|c|c|c|c|c|}
\hline $\begin{array}{l}\text { Time } \\
\text { (hours) }\end{array}$ & $\begin{array}{l}\text { Streamflow } \\
\text { (cubic feet } \\
\text { per second) }\end{array}$ & $\begin{array}{l}\text { Rain- } \\
\text { fall } \\
\text { (inches) }\end{array}$ & $\begin{array}{l}\text { Time } \\
\text { (hours) }\end{array}$ & $\begin{array}{l}\text { Streamflow } \\
\text { (cubic feet } \\
\text { per second) }\end{array}$ & $\begin{array}{l}\text { Rain- } \\
\text { fall } \\
\text { (inches) }\end{array}$ & $\begin{array}{l}\text { Time } \\
\text { (hours) }\end{array}$ & $\begin{array}{l}\text { Streamflow } \\
\text { (cubic feet } \\
\text { per second) }\end{array}$ & $\begin{array}{l}\text { Rain- } \\
\text { fall } \\
\text { (inches) }\end{array}$ \\
\hline $\begin{array}{l}0010 \\
0015 \\
0020 \\
0025 \\
0030\end{array}$ & $\begin{array}{l}16.5 \\
16.5 \\
16.5 \\
16.5 \\
15.8\end{array}$ & $\begin{array}{l}0.00 \\
0.00 \\
0.00 \\
0.00 \\
0.00\end{array}$ & $\begin{array}{l}0535 \\
0540 \\
0545 \\
0550 \\
0555\end{array}$ & $\begin{array}{l}9.5 \\
9.5 \\
8.9 \\
8.9 \\
8.9\end{array}$ & $\begin{array}{l}0.00 \\
0.00 \\
0.00 \\
0.00 \\
0.00\end{array}$ & $\begin{array}{l}1100 \\
1105 \\
1110 \\
1115 \\
1120\end{array}$ & $\begin{array}{l}6.4 \\
6.4 \\
6.4 \\
6.4 \\
6.4\end{array}$ & $\begin{array}{l}0.00 \\
0.00 \\
0.00 \\
0.00 \\
0.00\end{array}$ \\
\hline $\begin{array}{l}0035 \\
0040 \\
0045 \\
0050 \\
0055\end{array}$ & $\begin{array}{l}15.8 \\
15.8 \\
15.0 \\
15.0 \\
15.0\end{array}$ & $\begin{array}{l}0.00 \\
0.00 \\
0.00 \\
0.00 \\
0.00\end{array}$ & $\begin{array}{l}0600 \\
0605 \\
0610 \\
0615 \\
0620\end{array}$ & $\begin{array}{l}8.9 \\
8.9 \\
8.9 \\
8.9 \\
8.4\end{array}$ & $\begin{array}{l}0.00 \\
0.00 \\
0.00 \\
0.00 \\
0.00\end{array}$ & $\begin{array}{l}1125 \\
1130 \\
1135 \\
1140 \\
1145\end{array}$ & $\begin{array}{l}6.4 \\
6.4 \\
6.0 \\
6.0 \\
6.0\end{array}$ & $\begin{array}{l}0.00 \\
0.00 \\
0.00 \\
0.00 \\
0.00\end{array}$ \\
\hline $\begin{array}{l}0100 \\
0105 \\
0110 \\
0115 \\
0120\end{array}$ & $\begin{array}{l}15.0 \\
14.2 \\
14.2 \\
14.2 \\
14.2\end{array}$ & $\begin{array}{l}0.00 \\
0.00 \\
0.00 \\
0.00 \\
0.00\end{array}$ & $\begin{array}{l}0625 \\
0630 \\
0635 \\
0640 \\
0645\end{array}$ & $\begin{array}{l}8.4 \\
8.4 \\
8.4 \\
8.4 \\
8.4\end{array}$ & $\begin{array}{l}0.00 \\
0.00 \\
0.00 \\
0.00 \\
0.00\end{array}$ & $\begin{array}{l}1150 \\
1155 \\
1200 \\
1205 \\
1210\end{array}$ & $\begin{array}{l}6.0 \\
6.0 \\
6.0 \\
6.0 \\
6.0\end{array}$ & $\begin{array}{l}0.00 \\
0.00 \\
0.00 \\
0.00 \\
0.00\end{array}$ \\
\hline $\begin{array}{l}0125 \\
0130 \\
0135 \\
0140 \\
0145\end{array}$ & $\begin{array}{l}14.2 \\
14.2 \\
14.2 \\
13.5 \\
13.5\end{array}$ & $\begin{array}{l}0.00 \\
0.00 \\
0.00 \\
0.00 \\
0.00\end{array}$ & $\begin{array}{l}0650 \\
0655 \\
0700 \\
0705 \\
0710\end{array}$ & $\begin{array}{l}8.4 \\
8.4 \\
8.4 \\
8.4 \\
7.8\end{array}$ & $\begin{array}{l}0.00 \\
0.00 \\
0.00 \\
0.00 \\
0.00\end{array}$ & $\begin{array}{l}1215 \\
1220 \\
1225 \\
1230 \\
1235\end{array}$ & $\begin{array}{l}6.0 \\
6.0 \\
6.0 \\
6.0 \\
6.0\end{array}$ & $\begin{array}{l}0.00 \\
0.00 \\
0.00 \\
0.00 \\
0.00\end{array}$ \\
\hline $\begin{array}{l}0150 \\
0155 \\
0200 \\
0205 \\
0210\end{array}$ & $\begin{array}{l}13.5 \\
13.5 \\
13.5 \\
12.8 \\
12.8\end{array}$ & $\begin{array}{l}0.00 \\
0.00 \\
0.00 \\
0.00 \\
0.00\end{array}$ & $\begin{array}{l}0715 \\
0720 \\
0725 \\
0730 \\
0735\end{array}$ & $\begin{array}{l}7.8 \\
7.8 \\
7.8 \\
7.8 \\
7.8\end{array}$ & $\begin{array}{l}0.00 \\
0.00 \\
0.00 \\
0.00 \\
0.00\end{array}$ & $\begin{array}{l}1240 \\
1245 \\
1250 \\
1255 \\
1300\end{array}$ & $\begin{array}{l}6.0 \\
6.0 \\
6.0 \\
6.0 \\
5.5\end{array}$ & $\begin{array}{l}0.00 \\
0.00 \\
0.00 \\
0.00 \\
0.00\end{array}$ \\
\hline $\begin{array}{l}0215 \\
0220 \\
0225 \\
0230 \\
0235\end{array}$ & $\begin{array}{l}12.8 \\
12.8 \\
12.8 \\
12.8 \\
12.1\end{array}$ & $\begin{array}{l}0.00 \\
0.00 \\
0.00 \\
0.00 \\
0.00\end{array}$ & $\begin{array}{l}0740 \\
0745 \\
0750 \\
0755 \\
0800\end{array}$ & $\begin{array}{l}7.8 \\
7.8 \\
7.8 \\
7.8 \\
7.8\end{array}$ & $\begin{array}{l}0.00 \\
0.00 \\
0.00 \\
0.00 \\
0.00\end{array}$ & $\begin{array}{l}1305 \\
1310 \\
1315 \\
1320 \\
1325\end{array}$ & $\begin{array}{l}5.5 \\
5.5 \\
5.5 \\
5.5 \\
5.5\end{array}$ & $\begin{array}{l}0.00 \\
0.00 \\
0.00 \\
0.00 \\
0.00\end{array}$ \\
\hline $\begin{array}{l}0240 \\
0245 \\
0250 \\
0255 \\
0300\end{array}$ & $\begin{array}{l}12.1 \\
12.1 \\
12.1 \\
11.5 \\
11.5\end{array}$ & $\begin{array}{l}0.00 \\
0.00 \\
0.00 \\
0.00 \\
0.00\end{array}$ & $\begin{array}{l}0805 \\
0810 \\
0815 \\
0820 \\
0825\end{array}$ & $\begin{array}{l}7.8 \\
7.3 \\
7.3 \\
7.3 \\
7.3\end{array}$ & $\begin{array}{l}0.00 \\
0.00 \\
0.00 \\
0.00 \\
0.00\end{array}$ & $\begin{array}{l}1330 \\
1335 \\
1340 \\
1345 \\
1350\end{array}$ & $\begin{array}{l}5.5 \\
5.5 \\
5.5 \\
5.5 \\
5.5\end{array}$ & $\begin{array}{l}0.00 \\
0.00 \\
0.00 \\
0.00 \\
0.00\end{array}$ \\
\hline $\begin{array}{l}0305 \\
0310 \\
0315 \\
0320 \\
0325\end{array}$ & $\begin{array}{l}11.5 \\
11.5 \\
11.5 \\
11.5 \\
11.5\end{array}$ & $\begin{array}{l}0.00 \\
0.00 \\
0.00 \\
0.00 \\
0.00\end{array}$ & $\begin{array}{l}0830 \\
0835 \\
0840 \\
0845 \\
0850\end{array}$ & $\begin{array}{l}7.3 \\
7.3 \\
7.3 \\
7.3 \\
7.3\end{array}$ & $\begin{array}{l}0.00 \\
0.00 \\
0.00 \\
0.00 \\
0.00\end{array}$ & $\begin{array}{l}1355 \\
1400 \\
1405 \\
1410 \\
1415\end{array}$ & $\begin{array}{l}5.5 \\
5.5 \\
5.5 \\
5.5 \\
5.5\end{array}$ & $\begin{array}{l}0.00 \\
0.00 \\
0.00 \\
0.00 \\
0.00\end{array}$ \\
\hline $\begin{array}{l}0330 \\
0335 \\
0340 \\
0345 \\
0350\end{array}$ & $\begin{array}{l}10.8 \\
10.8 \\
10.8 \\
10.8 \\
10.8\end{array}$ & $\begin{array}{l}0.00 \\
0.00 \\
0.00 \\
0.00 \\
0.00\end{array}$ & $\begin{array}{l}0855 \\
0900 \\
0905 \\
0910 \\
0915\end{array}$ & $\begin{array}{l}7.3 \\
7.3 \\
7.3 \\
7.3 \\
7.3\end{array}$ & $\begin{array}{l}0.00 \\
0.00 \\
0.00 \\
0.00 \\
0.00\end{array}$ & $\begin{array}{l}1420 \\
1425 \\
1430 \\
1435 \\
1440\end{array}$ & $\begin{array}{l}5.5 \\
5.5 \\
5.0 \\
5.5 \\
5.0\end{array}$ & $\begin{array}{l}0.00 \\
0.00 \\
0.00 \\
0.00 \\
0.00\end{array}$ \\
\hline $\begin{array}{l}0355 \\
0400 \\
0405 \\
0410 \\
0415\end{array}$ & $\begin{array}{l}10.8 \\
10.8 \\
10.8 \\
10.1 \\
10.1\end{array}$ & $\begin{array}{l}0.00 \\
0.00 \\
0.00 \\
0.00 \\
0.00\end{array}$ & $\begin{array}{l}0920 \\
0925 \\
0930 \\
0935 \\
0940\end{array}$ & $\begin{array}{l}6.9 \\
6.9 \\
6.9 \\
6.9 \\
6.9\end{array}$ & $\begin{array}{l}0.00 \\
0.00 \\
0.00 \\
0.00 \\
0.01\end{array}$ & $\begin{array}{l}1445 \\
1450 \\
1455 \\
1500 \\
1505\end{array}$ & $\begin{array}{l}5.0 \\
5.0 \\
5.0 \\
5.0 \\
5.0\end{array}$ & $\begin{array}{l}0.00 \\
0.00 \\
0.00 \\
0.00 \\
0.00\end{array}$ \\
\hline $\begin{array}{l}0420 \\
0425 \\
0430 \\
0435 \\
0440\end{array}$ & $\begin{array}{l}10.1 \\
10.1 \\
10.1 \\
10.1 \\
10.1\end{array}$ & $\begin{array}{l}0.00 \\
0.00 \\
0.00 \\
0.00 \\
0.00\end{array}$ & $\begin{array}{l}0945 \\
0950 \\
0955 \\
1000 \\
1005\end{array}$ & $\begin{array}{l}6.9 \\
6.9 \\
6.9 \\
6.9 \\
6.9\end{array}$ & $\begin{array}{l}0.00 \\
0.00 \\
0.00 \\
0.00 \\
0.00\end{array}$ & $\begin{array}{l}1510 \\
1515 \\
1520 \\
1525 \\
1530\end{array}$ & $\begin{array}{l}5.0 \\
5.0 \\
5.0 \\
5.0 \\
5.0\end{array}$ & $\begin{array}{l}0.00 \\
0.00 \\
0.00 \\
0.00 \\
0.00\end{array}$ \\
\hline $\begin{array}{l}0445 \\
0450 \\
0455 \\
0500 \\
0505\end{array}$ & $\begin{array}{r}10.1 \\
10.1 \\
9.5 \\
9.5 \\
8.9\end{array}$ & $\begin{array}{l}0.00 \\
0.00 \\
0.00 \\
0.00 \\
0.00\end{array}$ & $\begin{array}{l}1010 \\
1015 \\
1020 \\
1025 \\
1030\end{array}$ & $\begin{array}{l}6.9 \\
6.4 \\
6.4 \\
6.4 \\
6.4\end{array}$ & $\begin{array}{l}0.00 \\
0.00 \\
0.00 \\
0.00 \\
0.00\end{array}$ & $\begin{array}{l}1535 \\
1540 \\
1545 \\
1550 \\
1555\end{array}$ & $\begin{array}{l}5.0 \\
5.0 \\
5.0 \\
5.0 \\
5.0\end{array}$ & $\begin{array}{l}0.00 \\
0.00 \\
0.00 \\
0.00 \\
0.00\end{array}$ \\
\hline $\begin{array}{l}0510 \\
0515 \\
0520 \\
0525 \\
0530\end{array}$ & $\begin{array}{l}9.5 \\
9.5 \\
9.5 \\
9.5 \\
9.5\end{array}$ & $\begin{array}{l}0.00 \\
0.00 \\
0.00 \\
0.00 \\
0.00\end{array}$ & $\begin{array}{l}1035 \\
1040 \\
1045 \\
1050 \\
1055\end{array}$ & $\begin{array}{l}6.4 \\
6.4 \\
6.4 \\
6.4 \\
6.4\end{array}$ & $\begin{array}{l}0.00 \\
0.00 \\
0.00 \\
0.00 \\
0.01\end{array}$ & $\begin{array}{l}1600 \\
1605 \\
1610 \\
1615 \\
1620\end{array}$ & $\begin{array}{l}5.0 \\
5.0 \\
5.0 \\
5.0 \\
5.0\end{array}$ & $\begin{array}{l}0.00 \\
0.00 \\
0.00 \\
0.00 \\
0.00\end{array}$ \\
\hline $\begin{array}{l}1625 \\
1630 \\
1635\end{array}$ & $\begin{array}{l}5.0 \\
4.6 \\
4.2\end{array}$ & $\begin{array}{l}0.00 \\
0.00 \\
0.00\end{array}$ & $\begin{array}{l}1640 \\
1645 \\
1650\end{array}$ & $\begin{array}{l}4.6 \\
4.6 \\
4.6\end{array}$ & $\begin{array}{l}0.00 \\
0.00 \\
0.00\end{array}$ & $\begin{array}{l}1655 \\
1700\end{array}$ & $\begin{array}{l}4.6 \\
4.6\end{array}$ & $\begin{array}{l}0.00 \\
0.00\end{array}$ \\
\hline
\end{tabular}



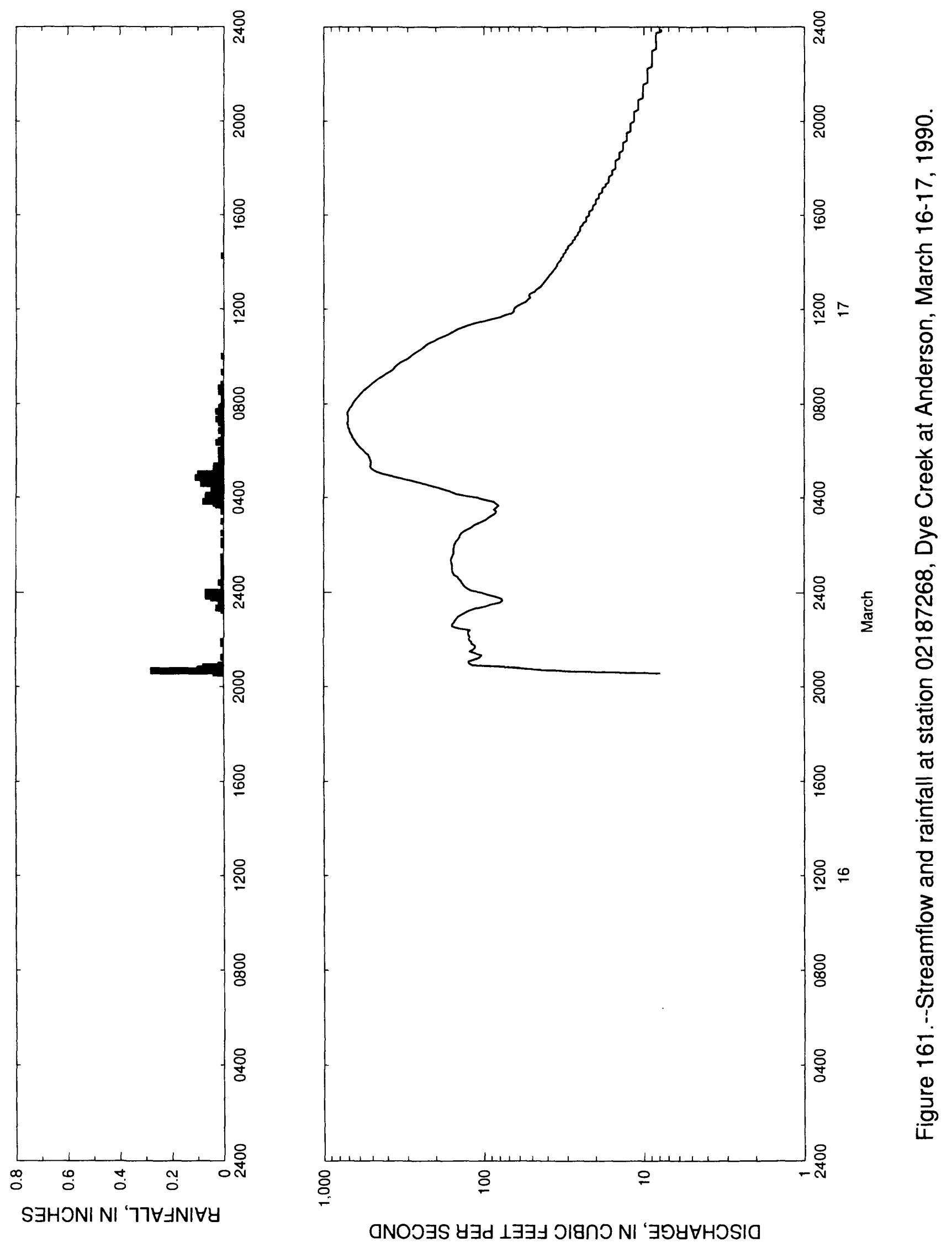


\begin{tabular}{|c|c|c|c|c|c|c|c|c|}
\hline $\begin{array}{l}\text { Time } \\
\text { (hours) }\end{array}$ & $\begin{array}{l}\text { Streamflow } \\
\text { (cubic feet } \\
\text { per second) }\end{array}$ & $\begin{array}{l}\text { Rain- } \\
\text { fall } \\
\text { (inches) }\end{array}$ & $\begin{array}{l}\text { Time } \\
\text { (hours) }\end{array}$ & $\begin{array}{l}\text { Streamflow } \\
\text { (cubic feet } \\
\text { per second) }\end{array}$ & $\begin{array}{l}\text { Rain- } \\
\text { fall } \\
\text { (inches) }\end{array}$ & $\begin{array}{l}\text { Time } \\
\text { (hours) }\end{array}$ & $\begin{array}{l}\text { Streamflow } \\
\text { (cubic feet } \\
\text { per second) }\end{array}$ & $\begin{array}{l}\text { Rain- } \\
\text { fall } \\
\text { (inches) }\end{array}$ \\
\hline $\begin{array}{r}\text { March } 16, \\
2035 \\
2040 \\
2045 \\
2050\end{array}$ & $\begin{array}{r}1990 \\
7.8 \\
26.7 \\
50.0 \\
67.4\end{array}$ & $\begin{array}{l}0.04 \\
0.28 \\
0.10 \\
0.08\end{array}$ & $\begin{array}{l}0150 \\
0155 \\
0200 \\
0205 \\
0210\end{array}$ & $\begin{array}{l}155.0 \\
154.0 \\
153.0 \\
151.0 \\
149.0\end{array}$ & $\begin{array}{l}0.00 \\
0.00 \\
0.01 \\
0.00 \\
0.01\end{array}$ & $\begin{array}{l}0715 \\
0720 \\
0725 \\
0730 \\
0735\end{array}$ & $\begin{array}{l}706.0 \\
706.0 \\
703.0 \\
705.0 \\
711.0\end{array}$ & $\begin{array}{l}0.01 \\
0.03 \\
0.02 \\
0.02 \\
0.02\end{array}$ \\
\hline $\begin{array}{l}2055 \\
2100 \\
2105 \\
2110 \\
2115\end{array}$ & $\begin{array}{l}118.0 \\
124.0 \\
124.0 \\
113.0 \\
106.0\end{array}$ & $\begin{array}{l}0.02 \\
0.00 \\
0.00 \\
0.00 \\
0.01\end{array}$ & $\begin{array}{l}0215 \\
0220 \\
0225 \\
0230 \\
0235\end{array}$ & $\begin{array}{l}145.0 \\
142.0 \\
141.0 \\
138.0 \\
133.0\end{array}$ & $\begin{array}{l}0.00 \\
0.00 \\
0.00 \\
0.01 \\
0.00\end{array}$ & $\begin{array}{l}0740 \\
0745 \\
0750 \\
0755 \\
0800\end{array}$ & $\begin{array}{l}706.0 \\
693.0 \\
686.0 \\
669.0 \\
661.0\end{array}$ & $\begin{array}{l}0.03 \\
0.01 \\
0.02 \\
0.01 \\
0.01\end{array}$ \\
\hline $\begin{array}{l}2120 \\
2125 \\
2130 \\
2135 \\
2140\end{array}$ & $\begin{array}{l}103.0 \\
113.0 \\
122.0 \\
116.0 \\
113.0\end{array}$ & $\begin{array}{l}0.00 \\
0.00 \\
0.00 \\
0.00 \\
0.00\end{array}$ & $\begin{array}{l}0240 \\
0245 \\
0250 \\
0255 \\
0300\end{array}$ & $\begin{array}{l}126.0 \\
119.0 \\
115.0 \\
109.0 \\
103.0\end{array}$ & $\begin{array}{l}0.00 \\
0.00 \\
0.00 \\
0.00 \\
0.01\end{array}$ & $\begin{array}{l}0805 \\
0810 \\
0815 \\
0820 \\
0825\end{array}$ & $\begin{array}{l}648.0 \\
635.0 \\
620.0 \\
604.0 \\
588.0\end{array}$ & $\begin{array}{l}0.00 \\
0.01 \\
0.01 \\
0.00 \\
0.01\end{array}$ \\
\hline $\begin{array}{l}2145 \\
2150 \\
2155 \\
2200 \\
2205\end{array}$ & $\begin{array}{l}113.0 \\
119.0 \\
119.0 \\
123.0 \\
123.0\end{array}$ & $\begin{array}{l}0.00 \\
0.01 \\
0.01 \\
0.00 \\
0.00\end{array}$ & $\begin{array}{l}0305 \\
0310 \\
0315 \\
0320 \\
0325\end{array}$ & $\begin{array}{l}96.8 \\
93.7 \\
89.2 \\
84.8 \\
83.4\end{array}$ & $\begin{array}{l}0.00 \\
0.00 \\
0.00 \\
0.00 \\
0.01\end{array}$ & $\begin{array}{l}0830 \\
0835 \\
0840 \\
0845 \\
0850\end{array}$ & $\begin{array}{l}572.0 \\
556.0 \\
539.0 \\
520.0 \\
503.0\end{array}$ & $\begin{array}{l}0.02 \\
0.01 \\
0.02 \\
0.00 \\
0.01\end{array}$ \\
\hline $\begin{array}{l}2210 \\
2215 \\
2220 \\
2225 \\
2230\end{array}$ & $\begin{array}{l}124.0 \\
126.0 \\
126.0 \\
122.0 \\
144.0\end{array}$ & $\begin{array}{l}0.00 \\
0.00 \\
0.00 \\
0.00 \\
0.00\end{array}$ & $\begin{array}{l}0330 \\
0335 \\
0340 \\
0345 \\
0350\end{array}$ & $\begin{array}{l}86.3 \\
83.4 \\
80.6 \\
83.4 \\
86.3\end{array}$ & $\begin{array}{l}0.01 \\
0.01 \\
0.03 \\
0.04 \\
0.08\end{array}$ & $\begin{array}{l}0855 \\
0900 \\
0905 \\
0910 \\
0915\end{array}$ & $\begin{array}{l}486.0 \\
467.0 \\
451.0 \\
429.0 \\
412.0\end{array}$ & $\begin{array}{l}0.00 \\
0.00 \\
0.00 \\
0.00 \\
0.00\end{array}$ \\
\hline $\begin{array}{l}2235 \\
2240 \\
2245 \\
2250 \\
2255\end{array}$ & $\begin{array}{l}158.0 \\
158.0 \\
154.0 \\
151.0 \\
148.0\end{array}$ & $\begin{array}{l}0.00 \\
0.00 \\
0.00 \\
0.00 \\
0.00\end{array}$ & $\begin{array}{l}0355 \\
0400 \\
0405 \\
0410 \\
0415\end{array}$ & $\begin{array}{r}98.4 \\
110.0 \\
130.0 \\
149.0 \\
160.0\end{array}$ & $\begin{array}{l}0.04 \\
0.03 \\
0.07 \\
0.04 \\
0.05\end{array}$ & $\begin{array}{l}0920 \\
0925 \\
0930 \\
0935 \\
0940\end{array}$ & $\begin{array}{l}392.0 \\
373.0 \\
364.0 \\
357.0 \\
345.0\end{array}$ & $\begin{array}{l}0.01 \\
0.00 \\
0.00 \\
0.00 \\
0.00\end{array}$ \\
\hline $\begin{array}{l}2300 \\
2305 \\
2310 \\
2315 \\
2320\end{array}$ & $\begin{array}{l}144.0 \\
137.0 \\
130.0 \\
123.0 \\
113.0\end{array}$ & $\begin{array}{l}0.00 \\
0.00 \\
0.00 \\
0.01 \\
0.03\end{array}$ & $\begin{array}{l}0420 \\
0425 \\
0430 \\
0435 \\
0440\end{array}$ & $\begin{array}{l}176.0 \\
192.0 \\
213.0 \\
233.0 \\
264.0\end{array}$ & $\begin{array}{l}0.02 \\
0.05 \\
0.04 \\
0.09 \\
0.04\end{array}$ & $\begin{array}{l}0945 \\
0950 \\
0955 \\
1000 \\
1005\end{array}$ & $\begin{array}{l}332.0 \\
318.0 \\
301.0 \\
289.0 \\
279.0\end{array}$ & $\begin{array}{l}0.00 \\
0.00 \\
0.00 \\
0.01 \\
0.00\end{array}$ \\
\hline $\begin{array}{l}2325 \\
2330 \\
2335 \\
2340 \\
2345\end{array}$ & $\begin{array}{l}98.4 \\
90.7 \\
79.2 \\
76.5 \\
77.8\end{array}$ & $\begin{array}{l}0.01 \\
0.02 \\
0.02 \\
0.00 \\
0.05\end{array}$ & $\begin{array}{l}0445 \\
0450 \\
0455 \\
0500 \\
0505\end{array}$ & $\begin{array}{l}293.0 \\
336.0 \\
381.0 \\
429.0 \\
465.0\end{array}$ & $\begin{array}{l}0.05 \\
0.11 \\
0.10 \\
0.10 \\
0.02\end{array}$ & $\begin{array}{l}1010 \\
1015 \\
1020 \\
1025 \\
1030\end{array}$ & $\begin{array}{l}268.0 \\
256.0 \\
245.0 \\
237.0 \\
230.0\end{array}$ & $\begin{array}{l}0.00 \\
0.00 \\
0.00 \\
0.00 \\
0.00\end{array}$ \\
\hline $\begin{array}{r}2350 \\
2355 \\
\text { March } 17, \\
0000 \\
0005\end{array}$ & $\begin{array}{r}84.8 \\
95.3 \\
1990 \\
103.0 \\
119.0\end{array}$ & $\begin{array}{l}0.07 \\
0.03 \\
0.07 \\
0.00\end{array}$ & $\begin{array}{l}0510 \\
0515 \\
0520 \\
0525 \\
0530\end{array}$ & $\begin{array}{l}488.0 \\
508.0 \\
511.0 \\
512.0 \\
509.0\end{array}$ & $\begin{array}{l}0.03 \\
0.04 \\
0.04 \\
0.01 \\
0.02\end{array}$ & $\begin{array}{l}1035 \\
1040 \\
1045 \\
1050 \\
1055\end{array}$ & $\begin{array}{l}220.0 \\
204.0 \\
195.0 \\
182.0 \\
170.0\end{array}$ & $\begin{array}{l}0.00 \\
0.00 \\
0.00 \\
0.00 \\
0.00\end{array}$ \\
\hline $\begin{array}{l}0010 \\
0015 \\
0020 \\
0025 \\
0030\end{array}$ & $\begin{array}{l}126.0 \\
131.0 \\
134.0 \\
137.0 \\
139.0\end{array}$ & $\begin{array}{l}0.01 \\
0.01 \\
0.01 \\
0.02 \\
0.01\end{array}$ & $\begin{array}{l}0535 \\
0540 \\
0545 \\
0550 \\
0555\end{array}$ & $\begin{array}{l}512.0 \\
516.0 \\
522.0 \\
529.0 \\
550.0\end{array}$ & $\begin{array}{l}0.02 \\
0.02 \\
0.02 \\
0.02 \\
0.02\end{array}$ & $\begin{array}{l}1100 \\
1105 \\
1110 \\
1115 \\
1120\end{array}$ & $\begin{array}{l}160.0 \\
153.0 \\
145.0 \\
134.0 \\
123.0\end{array}$ & $\begin{array}{l}0.00 \\
0.00 \\
0.00 \\
0.00 \\
0.00\end{array}$ \\
\hline $\begin{array}{l}0035 \\
0040 \\
0045 \\
0050 \\
0055\end{array}$ & $\begin{array}{l}144.0 \\
146.0 \\
154.0 \\
156.0 \\
158.0\end{array}$ & $\begin{array}{l}0.01 \\
0.00 \\
0.00 \\
0.01 \\
0.00\end{array}$ & $\begin{array}{l}0600 \\
0605 \\
0610 \\
0615 \\
0620\end{array}$ & $\begin{array}{l}564.0 \\
584.0 \\
600.0 \\
615.0 \\
628.0\end{array}$ & $\begin{array}{l}0.02 \\
0.01 \\
0.01 \\
0.01 \\
0.03\end{array}$ & $\begin{array}{l}1125 \\
1130 \\
1135 \\
1140 \\
1145\end{array}$ & $\begin{array}{r}112.0 \\
100.0 \\
89.2 \\
79.2 \\
73.9\end{array}$ & $\begin{array}{l}0.00 \\
0.00 \\
0.00 \\
0.00 \\
0.00\end{array}$ \\
\hline $\begin{array}{l}0100 \\
0105 \\
0110 \\
0115 \\
0120\end{array}$ & $\begin{array}{l}158.0 \\
158.0 \\
158.0 \\
159.0 \\
160.0\end{array}$ & $\begin{array}{l}0.01 \\
0.00 \\
0.00 \\
0.01 \\
0.00\end{array}$ & $\begin{array}{l}0625 \\
0630 \\
0635 \\
0640 \\
0645\end{array}$ & $\begin{array}{l}636.0 \\
649.0 \\
663.0 \\
671.0 \\
683.0\end{array}$ & $\begin{array}{l}0.02 \\
0.01 \\
0.01 \\
0.01 \\
0.01\end{array}$ & $\begin{array}{l}1150 \\
1155 \\
1200 \\
1205 \\
1210\end{array}$ & $\begin{array}{l}67.4 \\
64.9 \\
64.9 \\
63.6 \\
61.2\end{array}$ & $\begin{array}{l}0.00 \\
0.00 \\
0.00 \\
0.00 \\
0.00\end{array}$ \\
\hline $\begin{array}{l}0125 \\
0130 \\
0135 \\
0140 \\
0145\end{array}$ & $\begin{array}{l}160.0 \\
158.0 \\
156.0 \\
154.0 \\
155.0\end{array}$ & $\begin{array}{l}3.00 \\
0.01 \\
0.00 \\
0.00 \\
0.00\end{array}$ & $\begin{array}{l}0650 \\
0655 \\
0700 \\
0705 \\
0710\end{array}$ & $\begin{array}{l}691.0 \\
693.0 \\
705.0 \\
705.0 \\
713.0\end{array}$ & $\begin{array}{l}0.02 \\
0.01 \\
0.01 \\
0.01 \\
0.02\end{array}$ & $\begin{array}{l}1215 \\
1220 \\
1225 \\
1230 \\
1235\end{array}$ & $\begin{array}{l}57.7 \\
54.3 \\
53.2 \\
51.1 \\
52.2\end{array}$ & $\begin{array}{l}0.00 \\
0.00 \\
0.00 \\
0.00 \\
0.00\end{array}$ \\
\hline
\end{tabular}


Table 160.--Streamflow and rainfal1 at station 02187268, Dye Creek at Anderson, March 16-17, 1990--Continued

\begin{tabular}{|c|c|c|c|c|c|c|c|c|}
\hline $\begin{array}{l}\text { Time } \\
\text { (hours) }\end{array}$ & $\begin{array}{l}\text { Streamflow } \\
\text { (cubic feet } \\
\text { per second) }\end{array}$ & $\begin{array}{l}\text { Rain- } \\
\text { fall } \\
\text { (inches) }\end{array}$ & $\begin{array}{l}\text { Time } \\
\text { (hours) }\end{array}$ & $\begin{array}{l}\text { Streamflow } \\
\text { (cubic feet } \\
\text { per second) }\end{array}$ & $\begin{array}{l}\text { Rain- } \\
\text { fall } \\
\text { (inches) }\end{array}$ & $\begin{array}{l}\text { Time } \\
\text { (hours) }\end{array}$ & $\begin{array}{l}\text { Streamflow } \\
\text { (cubic feet } \\
\text { per second) }\end{array}$ & $\begin{array}{l}\text { Rain- } \\
\text { fall } \\
\text { (inches) }\end{array}$ \\
\hline $\begin{array}{l}1240 \\
1245 \\
1250 \\
1255 \\
1300\end{array}$ & $\begin{array}{l}51.1 \\
48.0 \\
46.9 \\
44.9 \\
43.9\end{array}$ & $\begin{array}{l}0.00 \\
0.00 \\
0.00 \\
0.00 \\
0.00\end{array}$ & $\begin{array}{l}1630 \\
1635 \\
1640 \\
1645 \\
1650\end{array}$ & $\begin{array}{l}20.0 \\
20.0 \\
20.0 \\
19.1 \\
19.1\end{array}$ & $\begin{array}{l}0.00 \\
0.00 \\
0.00 \\
0.00 \\
0.00\end{array}$ & $\begin{array}{l}2020 \\
2025 \\
2030 \\
2035 \\
2040\end{array}$ & $\begin{array}{l}11.5 \\
11.5 \\
10.8 \\
10.8 \\
10.8\end{array}$ & $\begin{array}{l}0.00 \\
0.00 \\
0.00 \\
0.00 \\
0.00\end{array}$ \\
\hline $\begin{array}{l}1305 \\
1310 \\
1315 \\
1320 \\
1325\end{array}$ & $\begin{array}{l}42.9 \\
41.9 \\
40.9 \\
40.0 \\
39.1\end{array}$ & $\begin{array}{l}0.00 \\
0.00 \\
0.00 \\
0.00 \\
0.00\end{array}$ & $\begin{array}{l}1655 \\
1700 \\
1705 \\
1710 \\
1715\end{array}$ & $\begin{array}{l}19.1 \\
18.2 \\
18.2 \\
18.2 \\
17.3\end{array}$ & $\begin{array}{l}0.00 \\
0.00 \\
0.00 \\
0.00 \\
0.00\end{array}$ & $\begin{array}{l}2045 \\
2050 \\
2055 \\
2100 \\
2105\end{array}$ & $\begin{array}{l}10.8 \\
10.8 \\
10.8 \\
10.1 \\
10.1\end{array}$ & $\begin{array}{l}0.00 \\
0.00 \\
0.00 \\
0.00 \\
0.00\end{array}$ \\
\hline $\begin{array}{l}1330 \\
1335 \\
1340 \\
1345 \\
1350\end{array}$ & $\begin{array}{l}38.2 \\
37.3 \\
36.5 \\
35.6 \\
34.8\end{array}$ & $\begin{array}{l}0.00 \\
0.00 \\
0.00 \\
0.00 \\
0.00\end{array}$ & $\begin{array}{l}1720 \\
1725 \\
1730 \\
1735 \\
1740\end{array}$ & $\begin{array}{l}17.3 \\
16.5 \\
16.5 \\
16.5 \\
16.5\end{array}$ & $\begin{array}{l}0.00 \\
0.00 \\
0.00 \\
0.00 \\
0.00\end{array}$ & $\begin{array}{l}2110 \\
2115 \\
2120 \\
2125 \\
2130\end{array}$ & $\begin{array}{l}10.1 \\
10.1 \\
10.1 \\
10.1 \\
10.1\end{array}$ & $\begin{array}{l}0.00 \\
0.00 \\
0.00 \\
0.07 \\
0.07\end{array}$ \\
\hline $\begin{array}{l}1355 \\
1400 \\
1405 \\
1410 \\
1415\end{array}$ & $\begin{array}{l}34.8 \\
34.0 \\
32.9 \\
32.9 \\
31.8\end{array}$ & $\begin{array}{l}0.00 \\
0.00 \\
0.00 \\
0.00 \\
0.01\end{array}$ & $\begin{array}{l}1745 \\
1750 \\
1755 \\
1800 \\
1805\end{array}$ & $\begin{array}{l}15.8 \\
15.8 \\
15.8 \\
15.0 \\
15.0\end{array}$ & $\begin{array}{l}0.00 \\
0.00 \\
0.00 \\
0.00 \\
0.00\end{array}$ & $\begin{array}{l}2135 \\
2140 \\
2145 \\
2150 \\
2155\end{array}$ & $\begin{array}{r}10.1 \\
9.5 \\
9.5 \\
9.5 \\
9.5\end{array}$ & $\begin{array}{l}0.00 \\
0.00 \\
0.00 \\
0.07 \\
0.07\end{array}$ \\
\hline $\begin{array}{l}1420 \\
1425 \\
1430 \\
1435 \\
1440\end{array}$ & $\begin{array}{l}31.8 \\
30.7 \\
30.7 \\
29.7 \\
29.7\end{array}$ & $\begin{array}{l}0.00 \\
0.00 \\
0.00 \\
0.00 \\
0.00\end{array}$ & $\begin{array}{l}1810 \\
1815 \\
1820 \\
1825 \\
1830\end{array}$ & $\begin{array}{l}15.0 \\
15.0 \\
15.0 \\
14.2 \\
14.2\end{array}$ & $\begin{array}{l}0.00 \\
0.00 \\
0.00 \\
0.00 \\
0.00\end{array}$ & $\begin{array}{l}2200 \\
2205 \\
2210 \\
2215 \\
2220\end{array}$ & $\begin{array}{l}9.5 \\
9.5 \\
9.5 \\
9.5 \\
8.9\end{array}$ & $\begin{array}{l}0.07 \\
0.07 \\
0.0 ? \\
0.0 ? \\
0.0 ?\end{array}$ \\
\hline $\begin{array}{l}1445 \\
1450 \\
1455 \\
1500 \\
1505\end{array}$ & $\begin{array}{l}28.7 \\
27.7 \\
27.7 \\
26.7 \\
26.7\end{array}$ & $\begin{array}{l}0.00 \\
0.00 \\
0.00 \\
0.00 \\
0.00\end{array}$ & $\begin{array}{l}1835 \\
1840 \\
1845 \\
1850 \\
1855\end{array}$ & $\begin{array}{l}14.2 \\
14.2 \\
13.5 \\
13.5 \\
13.5\end{array}$ & $\begin{array}{l}0.00 \\
0.00 \\
0.00 \\
0.00 \\
0.00\end{array}$ & $\begin{array}{l}2225 \\
2230 \\
2235 \\
2240 \\
2245\end{array}$ & $\begin{array}{l}8.9 \\
8.9 \\
8.9 \\
8.9 \\
8.9\end{array}$ & $\begin{array}{l}0.0 ? \\
0.0 ? \\
0.0 ? \\
0.0 ? \\
0.0 ?\end{array}$ \\
\hline $\begin{array}{l}1510 \\
1515 \\
1520 \\
1525 \\
1530\end{array}$ & $\begin{array}{l}25.8 \\
25.8 \\
24.9 \\
24.9 \\
24.9\end{array}$ & $\begin{array}{l}0.00 \\
0.00 \\
0.00 \\
0.00 \\
0.00\end{array}$ & $\begin{array}{l}1900 \\
1905 \\
1910 \\
1915 \\
1920\end{array}$ & $\begin{array}{l}13.5 \\
13.5 \\
12.8 \\
12.8 \\
12.8\end{array}$ & $\begin{array}{l}0.00 \\
0.00 \\
0.00 \\
0.00 \\
0.00\end{array}$ & $\begin{array}{l}2250 \\
2255 \\
2300 \\
2305 \\
2310\end{array}$ & $\begin{array}{l}8.9 \\
8.9 \\
8.9 \\
8.4 \\
8.4\end{array}$ & $\begin{array}{l}0.0 ? \\
0.0 ? \\
0.00 \\
0.0 ? \\
0.0 ?\end{array}$ \\
\hline $\begin{array}{l}1535 \\
1540 \\
1545 \\
1550 \\
1555\end{array}$ & $\begin{array}{l}24.0 \\
24.0 \\
22.9 \\
22.9 \\
22.9\end{array}$ & $\begin{array}{l}0.00 \\
0.00 \\
0.00 \\
0.00 \\
0.00\end{array}$ & $\begin{array}{l}1925 \\
1930 \\
1935 \\
1940 \\
1945\end{array}$ & $\begin{array}{l}12.8 \\
12.8 \\
12.1 \\
12.1 \\
12.1\end{array}$ & $\begin{array}{l}0.00 \\
0.00 \\
0.00 \\
0.00 \\
0.00\end{array}$ & $\begin{array}{l}2315 \\
2320 \\
2325 \\
2330 \\
2335\end{array}$ & $\begin{array}{l}8.4 \\
8.4 \\
8.4 \\
8.4 \\
8.4\end{array}$ & $\begin{array}{l}0.0 ? \\
0.0 ? \\
0.0 ? \\
0.0 ? \\
0.0 ?\end{array}$ \\
\hline $\begin{array}{l}1600 \\
1605 \\
1610 \\
1615 \\
1620\end{array}$ & $\begin{array}{l}21.9 \\
21.9 \\
21.9 \\
20.9 \\
20.9\end{array}$ & $\begin{array}{l}0.00 \\
0.00 \\
0.00 \\
0.00 \\
0.00\end{array}$ & $\begin{array}{l}1950 \\
1955 \\
2000 \\
2005 \\
2010\end{array}$ & $\begin{array}{l}12.1 \\
12.1 \\
11.5 \\
11.5 \\
11.5\end{array}$ & $\begin{array}{l}0.00 \\
0.00 \\
0.00 \\
0.00 \\
0.00\end{array}$ & $\begin{array}{l}2340 \\
2345 \\
2350 \\
2355\end{array}$ & $\begin{array}{l}8.4 \\
8.4 \\
7.8 \\
7.8\end{array}$ & $\begin{array}{l}0.07 \\
0.00 \\
0.00 \\
0.00\end{array}$ \\
\hline 1625 & 20.9 & 0.00 & 2015 & 11.5 & 0.00 & & & \\
\hline
\end{tabular}




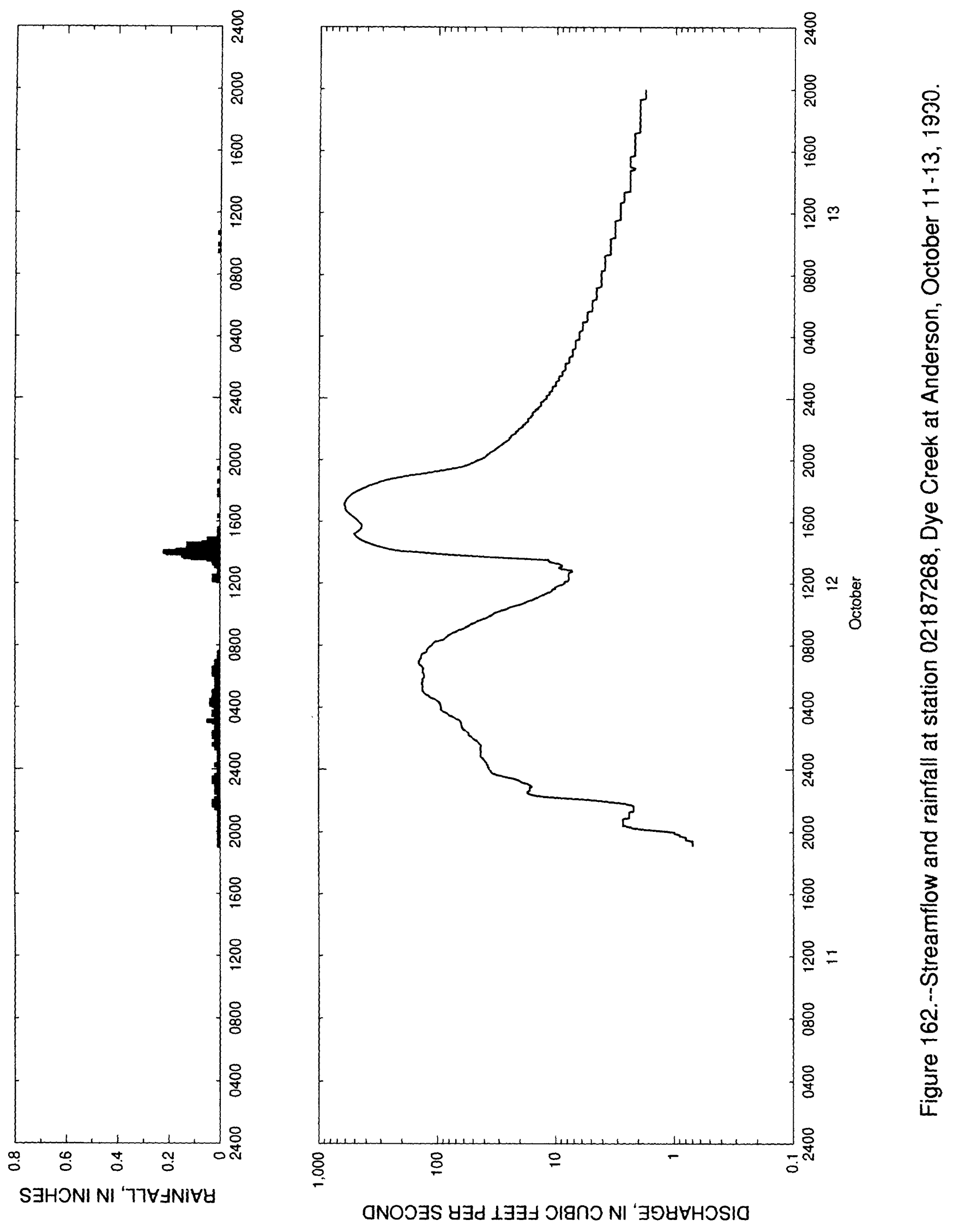


Table 161. - Streamflow and rainfall at station 02187268, Dye Creek at Anderson, October $11-13,1990$

\begin{tabular}{|c|c|c|c|c|c|c|c|c|}
\hline $\begin{array}{l}\text { Time } \\
\text { (hours) }\end{array}$ & $\begin{array}{l}\text { Streamflow } \\
\text { (cubic feet } \\
\text { per second) }\end{array}$ & $\begin{array}{l}\text { Rain- } \\
\text { fall } \\
\text { (inches) }\end{array}$ & $\begin{array}{l}\text { Time } \\
\text { (hours) }\end{array}$ & $\begin{array}{l}\text { Streamflow } \\
\text { (cubic feet } \\
\text { per second) }\end{array}$ & $\begin{array}{l}\text { Rain- } \\
\text { fall } \\
\text { (inches) }\end{array}$ & $\begin{array}{l}\text { Time } \\
\text { (hours) }\end{array}$ & $\begin{array}{l}\text { Streamflow } \\
\text { (cubic feet } \\
\text { per second) }\end{array}$ & $\begin{array}{l}\text { Rain- } \\
\text { fall } \\
\text { (inches) }\end{array}$ \\
\hline $\begin{array}{l}\text { October } \\
1905 \\
1910 \\
1915 \\
1920\end{array}$ & $\begin{array}{r}11,1990 \\
0.7 \\
0.7 \\
0.7 \\
0.7\end{array}$ & $\begin{array}{l}0.01 \\
0.01 \\
0.01 \\
0.01\end{array}$ & $\begin{array}{l}0020 \\
0025 \\
0030 \\
0035 \\
0040\end{array}$ & $\begin{array}{l}38.2 \\
38.2 \\
39.1 \\
40.0 \\
40.9\end{array}$ & $\begin{array}{l}0.01 \\
0.01 \\
0.01 \\
0.01 \\
0.00\end{array}$ & $\begin{array}{l}0545 \\
0550 \\
0555 \\
0600 \\
0605\end{array}$ & $\begin{array}{l}134.0 \\
133.0 \\
130.0 \\
129.0 \\
130.0\end{array}$ & $\begin{array}{l}0.01 \\
0.02 \\
0.02 \\
0.02 \\
0.03\end{array}$ \\
\hline $\begin{array}{l}1925 \\
1930 \\
1935 \\
1940 \\
1945\end{array}$ & $\begin{array}{l}0.7 \\
0.8 \\
0.8 \\
0.8 \\
0.9\end{array}$ & $\begin{array}{l}0.01 \\
0.00 \\
0.01 \\
0.01 \\
0.00\end{array}$ & $\begin{array}{l}0045 \\
0050 \\
0055 \\
0100 \\
0105\end{array}$ & $\begin{array}{l}41.9 \\
42.9 \\
42.9 \\
42.9 \\
42.9\end{array}$ & $\begin{array}{l}0.01 \\
0.01 \\
0.01 \\
0.01 \\
0.01\end{array}$ & $\begin{array}{l}0610 \\
0615 \\
0620 \\
0625 \\
0630\end{array}$ & $\begin{array}{l}130.0 \\
133.0 \\
133.0 \\
133.0 \\
131.0\end{array}$ & $\begin{array}{l}0.01 \\
0.03 \\
0.02 \\
0.03 \\
0.03\end{array}$ \\
\hline $\begin{array}{l}1950 \\
1955 \\
2000 \\
2005 \\
2010\end{array}$ & $\begin{array}{l}0.9 \\
1.0 \\
1.0 \\
1.3 \\
1.8\end{array}$ & $\begin{array}{l}0.01 \\
0.00 \\
0.00 \\
0.00 \\
0.01\end{array}$ & $\begin{array}{l}0110 \\
0115 \\
0120 \\
0125 \\
0130\end{array}$ & $\begin{array}{l}42.9 \\
42.9 \\
42.9 \\
42.9 \\
42.9\end{array}$ & $\begin{array}{l}0.01 \\
0.01 \\
0.02 \\
0.02 \\
0.02\end{array}$ & $\begin{array}{l}0635 \\
0640 \\
0645 \\
0650 \\
0655\end{array}$ & $\begin{array}{l}134.0 \\
137.0 \\
141.0 \\
144.0 \\
144.0\end{array}$ & $\begin{array}{l}0.02 \\
0.02 \\
0.01 \\
0.02 \\
0.02\end{array}$ \\
\hline $\begin{array}{l}2015 \\
2020 \\
2025 \\
2030 \\
2035\end{array}$ & $\begin{array}{l}2.2 \\
2.4 \\
2.7 \\
2.7 \\
2.7\end{array}$ & $\begin{array}{l}0.00 \\
0.00 \\
0.01 \\
0.00 \\
0.01\end{array}$ & $\begin{array}{l}0135 \\
0140 \\
0145 \\
0150 \\
0155\end{array}$ & $\begin{array}{l}42.9 \\
43.9 \\
44.9 \\
45.9 \\
48.0\end{array}$ & $\begin{array}{l}0.03 \\
0.02 \\
0.02 \\
0.02 \\
0.02\end{array}$ & $\begin{array}{l}0700 \\
0705 \\
0710 \\
0715 \\
0720\end{array}$ & $\begin{array}{l}142.0 \\
141.0 \\
137.0 \\
138.0 \\
137.0\end{array}$ & $\begin{array}{l}0.01 \\
0.01 \\
0.01 \\
0.01 \\
0.00\end{array}$ \\
\hline $\begin{array}{l}2040 \\
2045 \\
2050 \\
2055 \\
2100\end{array}$ & $\begin{array}{l}2.7 \\
2.7 \\
2.7 \\
2.4 \\
2.4\end{array}$ & $\begin{array}{l}0.01 \\
0.00 \\
0.00 \\
0.01 \\
0.00\end{array}$ & $\begin{array}{l}0200 \\
0205 \\
0210 \\
0215 \\
0220\end{array}$ & $\begin{array}{l}50.0 \\
51.1 \\
53.2 \\
54.3 \\
54.3\end{array}$ & $\begin{array}{l}0.02 \\
0.03 \\
0.03 \\
0.02 \\
0.03\end{array}$ & $\begin{array}{l}0725 \\
0730 \\
0735 \\
0740 \\
0745\end{array}$ & $\begin{array}{l}135.0 \\
129.0 \\
123.0 \\
123.0 \\
122.0\end{array}$ & $\begin{array}{l}0.01 \\
0.01 \\
0.00 \\
0.00 \\
0.00\end{array}$ \\
\hline $\begin{array}{l}2105 \\
2110 \\
2115 \\
2120 \\
2125\end{array}$ & $\begin{array}{l}2.4 \\
2.4 \\
2.4 \\
2.2 \\
2.2\end{array}$ & $\begin{array}{l}0.00 \\
0.01 \\
0.00 \\
0.01 \\
0.00\end{array}$ & $\begin{array}{l}0225 \\
0230 \\
0235 \\
0240 \\
0245\end{array}$ & $\begin{array}{l}55.4 \\
57.7 \\
60.0 \\
61.2 \\
62.4\end{array}$ & $\begin{array}{l}0.02 \\
0.02 \\
0.02 \\
0.00 \\
0.01\end{array}$ & $\begin{array}{l}0750 \\
0755 \\
0800 \\
0805 \\
0810\end{array}$ & $\begin{array}{l}119.0 \\
116.0 \\
112.0 \\
110.0 \\
107.0\end{array}$ & $\begin{array}{l}0.00 \\
0.00 \\
0.00 \\
0.00 \\
0.00\end{array}$ \\
\hline $\begin{array}{l}2130 \\
2135 \\
2140 \\
2145 \\
2150\end{array}$ & $\begin{array}{l}2.2 \\
2.2 \\
2.2 \\
2.4 \\
2.7\end{array}$ & $\begin{array}{l}0.02 \\
0.01 \\
0.03 \\
0.02 \\
0.02\end{array}$ & $\begin{array}{l}0250 \\
0255 \\
0300 \\
0305 \\
0310\end{array}$ & $\begin{array}{l}62.4 \\
62.4 \\
62.4 \\
63.6 \\
64.9\end{array}$ & $\begin{array}{l}0.01 \\
0.02 \\
0.03 \\
0.05 \\
0.02\end{array}$ & $\begin{array}{l}0815 \\
0820 \\
0825 \\
0830 \\
0835\end{array}$ & $\begin{array}{r}103.0 \\
90.7 \\
87.7 \\
84.8 \\
82.0\end{array}$ & $\begin{array}{l}0.00 \\
0.00 \\
0.00 \\
0.00 \\
0.00\end{array}$ \\
\hline $\begin{array}{l}2155 \\
2200 \\
2205 \\
2210 \\
2215\end{array}$ & $\begin{array}{r}3.5 \\
4.2 \\
5.5 \\
8.4 \\
12.1\end{array}$ & $\begin{array}{l}0.03 \\
0.02 \\
0.02 \\
0.01 \\
0.00\end{array}$ & $\begin{array}{l}0315 \\
0320 \\
0325 \\
0330 \\
0335\end{array}$ & $\begin{array}{l}68.7 \\
71.3 \\
75.2 \\
79.2 \\
82.0\end{array}$ & $\begin{array}{l}0.02 \\
0.02 \\
0.01 \\
0.03 \\
0.03\end{array}$ & $\begin{array}{l}0840 \\
0845 \\
0850 \\
0855 \\
0900\end{array}$ & $\begin{array}{l}80.6 \\
76.5 \\
72.6 \\
68.7 \\
64.9\end{array}$ & $\begin{array}{l}0.00 \\
0.00 \\
0.00 \\
0.00 \\
0.00\end{array}$ \\
\hline $\begin{array}{l}2220 \\
2225 \\
2230 \\
2235 \\
2240\end{array}$ & $\begin{array}{l}15.0 \\
16.5 \\
17.3 \\
17.3 \\
16.5\end{array}$ & $\begin{array}{l}0.01 \\
0.01 \\
0.02 \\
0.02 \\
0.01\end{array}$ & $\begin{array}{l}0340 \\
0345 \\
0350 \\
0355 \\
0400\end{array}$ & $\begin{array}{l}84.8 \\
89.2 \\
92.2 \\
93.7 \\
93.7\end{array}$ & $\begin{array}{l}0.03 \\
0.02 \\
0.02 \\
0.02 \\
0.02\end{array}$ & $\begin{array}{l}0905 \\
0910 \\
0915 \\
0920 \\
0925\end{array}$ & $\begin{array}{l}60.0 \\
57.7 \\
54.3 \\
52.2 \\
49.0\end{array}$ & $\begin{array}{l}0.00 \\
0.00 \\
0.00 \\
0.00 \\
0.00\end{array}$ \\
\hline $\begin{array}{l}2245 \\
2250 \\
2255 \\
2300 \\
2305\end{array}$ & $\begin{array}{l}16.5 \\
16.5 \\
15.8 \\
16.5 \\
17.3\end{array}$ & $\begin{array}{l}0.01 \\
0.01 \\
0.02 \\
0.02 \\
0.01\end{array}$ & $\begin{array}{l}0405 \\
0410 \\
0415 \\
0420 \\
0425\end{array}$ & $\begin{array}{r}93.7 \\
93.7 \\
95.3 \\
96.8 \\
100.0\end{array}$ & $\begin{array}{l}0.03 \\
0.04 \\
0.03 \\
0.04 \\
0.04\end{array}$ & $\begin{array}{l}0930 \\
0935 \\
0940 \\
0945 \\
0950\end{array}$ & $\begin{array}{l}46.9 \\
44.9 \\
41.9 \\
39.1 \\
37.3\end{array}$ & $\begin{array}{l}0.00 \\
0.00 \\
0.00 \\
0.00 \\
0.00\end{array}$ \\
\hline $\begin{array}{l}2310 \\
2315 \\
2320 \\
2325 \\
2330\end{array}$ & $\begin{array}{l}19.1 \\
20.0 \\
20.9 \\
22.9 \\
25.8\end{array}$ & $\begin{array}{l}0.03 \\
0.01 \\
0.02 \\
0.03 \\
0.01\end{array}$ & $\begin{array}{l}0430 \\
0435 \\
0440 \\
0445 \\
0450\end{array}$ & $\begin{array}{l}104.0 \\
109.0 \\
116.0 \\
119.0 \\
124.0\end{array}$ & $\begin{array}{l}0.03 \\
0.02 \\
0.03 \\
0.02 \\
0.02\end{array}$ & $\begin{array}{l}0955 \\
1000 \\
1005 \\
1010 \\
1015\end{array}$ & $\begin{array}{l}35.6 \\
34.0 \\
32.9 \\
30.7 \\
28.7\end{array}$ & $\begin{array}{l}0.00 \\
0.00 \\
0.00 \\
0.00 \\
0.00\end{array}$ \\
\hline $\begin{array}{l}2335 \\
2340 \\
2345 \\
2350 \\
2355\end{array}$ & $\begin{array}{l}28.7 \\
31.8 \\
34.0 \\
34.8 \\
35.6\end{array}$ & $\begin{array}{l}0.02 \\
0.01 \\
0.01 \\
0.01 \\
0.01\end{array}$ & $\begin{array}{l}0455 \\
0500 \\
0505 \\
0510 \\
0515\end{array}$ & $\begin{array}{l}129.0 \\
131.0 \\
133.0 \\
134.0 \\
134.0\end{array}$ & $\begin{array}{l}0.02 \\
0.03 \\
0.02 \\
0.01 \\
0.02\end{array}$ & $\begin{array}{l}1020 \\
1025 \\
1030 \\
1035 \\
1040\end{array}$ & $\begin{array}{l}25.8 \\
24.9 \\
22.9 \\
20.9 \\
19.1\end{array}$ & $\begin{array}{l}0.00 \\
0.00 \\
0.00 \\
0.00 \\
0.00\end{array}$ \\
\hline $\begin{array}{l}0000 \\
0005 \\
0010 \\
0015\end{array}$ & $\begin{array}{c}\text { October } \\
365 \\
36.5 \\
373 \\
373\end{array}$ & 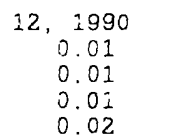 & $\begin{array}{l}0520 \\
0525 \\
0530 \\
0535 \\
0540\end{array}$ & $\begin{array}{l}133.0 \\
133.0 \\
135.0 \\
135.0 \\
133.0\end{array}$ & $\begin{array}{l}0.01 \\
0.01 \\
0.01 \\
0.02 \\
0.02\end{array}$ & $\begin{array}{l}1045 \\
1050 \\
1055 \\
1100 \\
1105\end{array}$ & $\begin{array}{l}18.2 \\
17.3 \\
15.8 \\
15.0 \\
14.2\end{array}$ & $\begin{array}{l}0.00 \\
0.00 \\
0.00 \\
0.00 \\
0.00\end{array}$ \\
\hline
\end{tabular}




\begin{tabular}{|c|c|c|c|c|c|c|c|c|}
\hline $\begin{array}{l}\text { Time } \\
\text { (hours) }\end{array}$ & $\begin{array}{l}\text { Streamflow } \\
\text { (cubic feet } \\
\text { per second) }\end{array}$ & $\begin{array}{l}\text { Rain- } \\
\text { fall } \\
\text { (inches) }\end{array}$ & $\begin{array}{l}\text { Time } \\
\text { (hours) }\end{array}$ & $\begin{array}{l}\text { Streamflow } \\
\text { (cubic feet } \\
\text { per second) }\end{array}$ & $\begin{array}{l}\text { Rain- } \\
\text { fall } \\
\text { (inches) }\end{array}$ & $\begin{array}{l}\text { Time } \\
\text { (hours) }\end{array}$ & $\begin{array}{l}\text { Streamflow } \\
\text { (cubic feet } \\
\text { per second) }\end{array}$ & $\begin{array}{l}\text { Rain- } \\
\text { fall } \\
\text { (inches) }\end{array}$ \\
\hline $\begin{array}{l}1110 \\
1115 \\
1120 \\
1125 \\
1130\end{array}$ & $\begin{array}{l}13.5 \\
12.8 \\
12.1 \\
11.5 \\
10.8\end{array}$ & $\begin{array}{l}0.00 \\
0.00 \\
0.00 \\
0.00 \\
0.00\end{array}$ & $\begin{array}{l}1635 \\
1640 \\
1645 \\
1650 \\
1655\end{array}$ & $\begin{array}{l}576.0 \\
589.0 \\
599.0 \\
600.0 \\
600.0\end{array}$ & $\begin{array}{l}0.00 \\
0.00 \\
0.00 \\
0.00 \\
0.00\end{array}$ & $\begin{array}{l}2200 \\
2205 \\
2210 \\
2215 \\
2220\end{array}$ & $\begin{array}{l}20.9 \\
20.0 \\
19.1 \\
19.1 \\
18.2\end{array}$ & $\begin{array}{l}0.00 \\
0.00 \\
0.00 \\
0.00 \\
0.00\end{array}$ \\
\hline $\begin{array}{l}1135 \\
1140 \\
1145 \\
1150 \\
1155\end{array}$ & $\begin{array}{r}10.8 \\
10.1 \\
10.1 \\
9.5 \\
8.9\end{array}$ & $\begin{array}{l}0.00 \\
0.00 \\
0.00 \\
0.00 \\
0.00\end{array}$ & $\begin{array}{l}1700 \\
1705 \\
1710 \\
1715 \\
1720\end{array}$ & $\begin{array}{l}610.0 \\
614.0 \\
609.0 \\
602.0 \\
599.0\end{array}$ & $\begin{array}{l}0.00 \\
0.00 \\
0.00 \\
0.00 \\
0.00\end{array}$ & $\begin{array}{l}2225 \\
2230 \\
2235 \\
2240 \\
2245\end{array}$ & $\begin{array}{l}18.2 \\
17.3 \\
17.3 \\
17.3 \\
16.5\end{array}$ & $\begin{array}{l}0.00 \\
0.00 \\
0.00 \\
0.00 \\
0.00\end{array}$ \\
\hline $\begin{array}{l}1200 \\
1205 \\
1210 \\
1215 \\
1220\end{array}$ & $\begin{array}{l}8.4 \\
8.4 \\
7.8 \\
7.8 \\
7.8\end{array}$ & $\begin{array}{l}0.00 \\
0.00 \\
0.03 \\
0.01 \\
0.01\end{array}$ & $\begin{array}{l}1725 \\
1730 \\
1735 \\
1740 \\
1745\end{array}$ & $\begin{array}{l}588.0 \\
578.0 \\
564.0 \\
551.0 \\
537.0\end{array}$ & $\begin{array}{l}0.00 \\
0.00 \\
0.00 \\
0.01 \\
0.00\end{array}$ & $\begin{array}{l}2250 \\
2255 \\
2300 \\
2305 \\
2310\end{array}$ & $\begin{array}{l}16.5 \\
15.8 \\
15.8 \\
15.8 \\
15.0\end{array}$ & $\begin{array}{l}0.00 \\
0.00 \\
0.00 \\
0.00 \\
0.00\end{array}$ \\
\hline $\begin{array}{l}1225 \\
1230 \\
1235 \\
1240 \\
1245\end{array}$ & $\begin{array}{l}7.8 \\
7.8 \\
7.8 \\
7.8 \\
7.3\end{array}$ & $\begin{array}{l}0.03 \\
0.00 \\
0.00 \\
0.01 \\
0.00\end{array}$ & $\begin{array}{l}1750 \\
1755 \\
1800 \\
1805 \\
1810\end{array}$ & $\begin{array}{l}517.0 \\
494.0 \\
472.0 \\
446.0 \\
422.0\end{array}$ & $\begin{array}{l}0.00 \\
0.00 \\
0.01 \\
0.00 \\
0.00\end{array}$ & $\begin{array}{l}2315 \\
2320 \\
2325 \\
2330 \\
2335\end{array}$ & $\begin{array}{l}15.0 \\
14.2 \\
14.2 \\
13.5 \\
13.5\end{array}$ & $\begin{array}{l}0.00 \\
0.00 \\
0.00 \\
0.00 \\
0.00\end{array}$ \\
\hline $\begin{array}{l}1250 \\
1255 \\
1300 \\
1305 \\
1310\end{array}$ & $\begin{array}{l}7.3 \\
8.9 \\
9.5 \\
8.9 \\
8.9\end{array}$ & $\begin{array}{l}0.00 \\
0.01 \\
0.01 \\
0.02 \\
0.02\end{array}$ & $\begin{array}{l}1815 \\
1820 \\
1825 \\
1830 \\
1835\end{array}$ & $\begin{array}{l}396.0 \\
376.0 \\
351.0 \\
325.0 \\
305.0\end{array}$ & $\begin{array}{l}0.00 \\
0.00 \\
0.00 \\
0.00 \\
0.01\end{array}$ & $\begin{array}{c}2340 \\
2345 \\
2350 \\
2355 \\
\text { October }\end{array}$ & $\begin{array}{r}13.5 \\
13.5 \\
12.8 \\
12.8 \\
13,1990\end{array}$ & $\begin{array}{l}0.00 \\
0.00 \\
0.00 \\
0.00\end{array}$ \\
\hline $\begin{array}{l}1315 \\
1320 \\
1325 \\
1330 \\
1335\end{array}$ & $\begin{array}{r}9.5 \\
10.8 \\
11.5 \\
11.5 \\
18.2\end{array}$ & $\begin{array}{l}0.03 \\
0.02 \\
0.02 \\
0.05 \\
0.11\end{array}$ & $\begin{array}{l}1840 \\
1845 \\
1850 \\
1855 \\
1900\end{array}$ & $\begin{array}{l}279.0 \\
251.0 \\
220.0 \\
194.0 \\
170.0\end{array}$ & $\begin{array}{l}0.00 \\
0.00 \\
0.00 \\
0.00 \\
0.00\end{array}$ & $\begin{array}{l}0000 \\
0005 \\
0010 \\
0015 \\
0020\end{array}$ & $\begin{array}{l}12.1 \\
12.1 \\
12.1 \\
11.5 \\
11.5\end{array}$ & $\begin{array}{l}0.00 \\
0.00 \\
0.00 \\
0.00 \\
0.00\end{array}$ \\
\hline $\begin{array}{l}1340 \\
1345 \\
1350 \\
1355 \\
1400\end{array}$ & $\begin{array}{r}31.8 \\
46.9 \\
75.2 \\
106.0 \\
144.0\end{array}$ & $\begin{array}{l}0.14 \\
0.15 \\
0.13 \\
0.21 \\
0.22\end{array}$ & $\begin{array}{l}1905 \\
1910 \\
1915 \\
1920 \\
1925\end{array}$ & $\begin{array}{r}139.0 \\
120.0 \\
104.0 \\
89.2 \\
76.5\end{array}$ & $\begin{array}{l}0.00 \\
0.00 \\
0.00 \\
0.00 \\
0.01\end{array}$ & $\begin{array}{l}0025 \\
0030 \\
0035 \\
0040 \\
0045\end{array}$ & $\begin{array}{l}11.5 \\
10.8 \\
10.8 \\
10.8 \\
10.8\end{array}$ & $\begin{array}{l}0.00 \\
0.00 \\
0.00 \\
0.00 \\
0.00\end{array}$ \\
\hline $\begin{array}{l}1405 \\
1410 \\
1415 \\
1420 \\
1425\end{array}$ & $\begin{array}{l}208.0 \\
245.0 \\
272.0 \\
301.0 \\
328.0\end{array}$ & $\begin{array}{l}0.17 \\
0.11 \\
0.04 \\
0.13 \\
0.11\end{array}$ & $\begin{array}{l}1930 \\
1935 \\
1940 \\
1945 \\
1950\end{array}$ & $\begin{array}{l}67.4 \\
61.2 \\
56.5 \\
53.2 \\
50.0\end{array}$ & $\begin{array}{l}0.00 \\
0.00 \\
0.00 \\
0.00 \\
0.00\end{array}$ & $\begin{array}{l}0050 \\
0055 \\
0100 \\
0105 \\
0110\end{array}$ & $\begin{array}{r}10.1 \\
10.1 \\
10.1 \\
10.1 \\
9.5\end{array}$ & $\begin{array}{l}0.00 \\
0.00 \\
0.00 \\
0.00 \\
0.00\end{array}$ \\
\hline $\begin{array}{l}1430 \\
1435 \\
1440 \\
1445 \\
1450\end{array}$ & $\begin{array}{l}352.0 \\
378.0 \\
404.0 \\
428.0 \\
450.0\end{array}$ & $\begin{array}{l}0.13 \\
0.07 \\
0.04 \\
0.03 \\
0.05\end{array}$ & $\begin{array}{l}1955 \\
2000 \\
2005 \\
2010 \\
2015\end{array}$ & $\begin{array}{l}48.0 \\
44.9 \\
41.9 \\
40.0 \\
39.1\end{array}$ & $\begin{array}{l}0.00 \\
0.00 \\
0.00 \\
0.00 \\
0.00\end{array}$ & $\begin{array}{l}0115 \\
0120 \\
0125 \\
0130 \\
0135\end{array}$ & $\begin{array}{l}9.5 \\
9.5 \\
9.5 \\
8.9 \\
8.9\end{array}$ & $\begin{array}{l}0.00 \\
0.00 \\
0.00 \\
0.00 \\
0.00\end{array}$ \\
\hline $\begin{array}{l}1455 \\
1500 \\
1505 \\
1510 \\
1515\end{array}$ & $\begin{array}{l}468.0 \\
484.0 \\
496.0 \\
508.0 \\
490.0\end{array}$ & $\begin{array}{l}0.01 \\
0.01 \\
0.01 \\
0.01 \\
0.01\end{array}$ & $\begin{array}{l}2020 \\
2025 \\
2030 \\
2035 \\
2040\end{array}$ & $\begin{array}{l}38.2 \\
36.5 \\
35.6 \\
34.0 \\
32.9\end{array}$ & $\begin{array}{l}0.00 \\
0.00 \\
0.00 \\
0.00 \\
0.00\end{array}$ & $\begin{array}{l}0140 \\
0145 \\
0150 \\
0155 \\
0200\end{array}$ & $\begin{array}{l}8.9 \\
8.9 \\
8.4 \\
8.4 \\
8.4\end{array}$ & $\begin{array}{l}0.00 \\
0.00 \\
0.00 \\
0.00 \\
0.00\end{array}$ \\
\hline $\begin{array}{l}1520 \\
1525 \\
1530 \\
1535 \\
1540\end{array}$ & $\begin{array}{l}474.0 \\
459.0 \\
446.0 \\
439.0 \\
437.0\end{array}$ & $\begin{array}{l}0.00 \\
0.00 \\
0.01 \\
0.00 \\
0.00\end{array}$ & $\begin{array}{l}2045 \\
2050 \\
2055 \\
2100 \\
2105\end{array}$ & $\begin{array}{l}31.8 \\
30.7 \\
29.7 \\
28.7 \\
27.7\end{array}$ & $\begin{array}{l}0.00 \\
0.00 \\
0.00 \\
0.00 \\
0.00\end{array}$ & $\begin{array}{l}0205 \\
0210 \\
0215 \\
0220 \\
0225\end{array}$ & $\begin{array}{l}8.4 \\
8.4 \\
8.4 \\
7.8 \\
7.8\end{array}$ & $\begin{array}{l}0.00 \\
0.00 \\
0.00 \\
0.00 \\
0.00\end{array}$ \\
\hline $\begin{array}{l}1545 \\
1550 \\
1555 \\
1600 \\
1605\end{array}$ & $\begin{array}{l}436.0 \\
442.0 \\
454.0 \\
467.0 \\
478.0\end{array}$ & $\begin{array}{l}0.00 \\
0.00 \\
0.00 \\
0.00 \\
0.00\end{array}$ & $\begin{array}{l}2110 \\
2115 \\
2120 \\
2125 \\
2130\end{array}$ & $\begin{array}{l}26.7 \\
25.8 \\
24.9 \\
24.9 \\
24.0\end{array}$ & $\begin{array}{l}0.00 \\
0.00 \\
0.00 \\
0.00 \\
0.00\end{array}$ & $\begin{array}{l}0230 \\
0235 \\
0240 \\
0245 \\
0250\end{array}$ & $\begin{array}{l}7.8 \\
7.8 \\
7.8 \\
7.3 \\
7.3\end{array}$ & $\begin{array}{l}0.00 \\
0.00 \\
0.00 \\
0.00 \\
0.00\end{array}$ \\
\hline $\begin{array}{l}1610 \\
1615 \\
1620 \\
1625 \\
1630\end{array}$ & $\begin{array}{l}493.0 \\
508.0 \\
525.0 \\
540.0 \\
558.0\end{array}$ & $\begin{array}{l}0.00 \\
0.00 \\
0.01 \\
0.00 \\
0.00\end{array}$ & $\begin{array}{l}2135 \\
2140 \\
2145 \\
2150 \\
2155\end{array}$ & $\begin{array}{l}24.0 \\
22.9 \\
21.9 \\
21.9 \\
20.9\end{array}$ & $\begin{array}{l}0.00 \\
0.00 \\
0.00 \\
0.00 \\
0.00\end{array}$ & $\begin{array}{l}0255 \\
0300 \\
0305 \\
0310 \\
0315\end{array}$ & $\begin{array}{l}7.3 \\
7.3 \\
7.3 \\
7.3 \\
6.9\end{array}$ & $\begin{array}{l}0.00 \\
0.00 \\
0.00 \\
0.00 \\
0.00\end{array}$ \\
\hline
\end{tabular}


Table 161.--Streamflow and rainfal1 at station 02187268, Dye Creek at Anderson, October 11-13,1990--Continued

\begin{tabular}{|c|c|c|c|c|c|c|c|c|}
\hline $\begin{array}{l}\text { Time } \\
\text { (hours) }\end{array}$ & $\begin{array}{l}\text { Streamflow } \\
\text { (cubic feet } \\
\text { per second) }\end{array}$ & $\begin{array}{l}\text { Rain- } \\
\text { fall } \\
\text { (inches) }\end{array}$ & $\begin{array}{l}\text { Time } \\
\text { (hours) }\end{array}$ & $\begin{array}{l}\text { Streamflow } \\
\text { (cubic feet } \\
\text { per second) }\end{array}$ & $\begin{array}{l}\text { Rain- } \\
\text { fall } \\
\text { (inches) }\end{array}$ & $\begin{array}{l}\text { Time } \\
\text { (hours) }\end{array}$ & $\begin{array}{l}\text { Streamflow } \\
\text { (cubic feet } \\
\text { per second) }\end{array}$ & $\begin{array}{l}\text { Rain- } \\
\text { fall } \\
\text { (inches) }\end{array}$ \\
\hline $\begin{array}{l}0320 \\
0325 \\
0330 \\
0335 \\
0340\end{array}$ & $\begin{array}{l}6.9 \\
6.9 \\
6.9 \\
6.9 \\
6.9\end{array}$ & $\begin{array}{l}0.00 \\
0.00 \\
0.00 \\
0.00 \\
0.00\end{array}$ & $\begin{array}{l}0845 \\
0850 \\
0855 \\
0900 \\
0905\end{array}$ & $\begin{array}{l}3.9 \\
3.9 \\
3.9 \\
3.9 \\
3.9\end{array}$ & $\begin{array}{l}0.00 \\
0.00 \\
0.00 \\
0.00 \\
0.00\end{array}$ & $\begin{array}{l}1410 \\
1415 \\
1420 \\
1425 \\
1430\end{array}$ & $\begin{array}{l}2.4 \\
2.4 \\
2.4 \\
2.4 \\
2.4\end{array}$ & $\begin{array}{l}0 . n 0 \\
0 . n 0 \\
0 . n 0 \\
0 . n 0 \\
0 . n 0\end{array}$ \\
\hline $\begin{array}{l}0345 \\
0350 \\
0355 \\
0400 \\
0405\end{array}$ & $\begin{array}{l}6.9 \\
6.4 \\
6.4 \\
6.4 \\
6.4\end{array}$ & $\begin{array}{l}0.00 \\
0.00 \\
0.00 \\
0.00 \\
0.00\end{array}$ & $\begin{array}{l}0910 \\
0915 \\
0920 \\
0925 \\
0930\end{array}$ & $\begin{array}{l}3.9 \\
3.9 \\
3.5 \\
3.5 \\
3.5\end{array}$ & $\begin{array}{l}0.00 \\
0.00 \\
0.00 \\
0.00 \\
0.01\end{array}$ & $\begin{array}{l}1435 \\
1440 \\
1445 \\
1450 \\
1455\end{array}$ & $\begin{array}{l}2.4 \\
2.4 \\
2.4 \\
2.2 \\
2.2\end{array}$ & $\begin{array}{l}0.00 \\
0.00 \\
0.00 \\
0.00 \\
0.00\end{array}$ \\
\hline $\begin{array}{l}0410 \\
0415 \\
0420 \\
0425 \\
0430\end{array}$ & $\begin{array}{l}6.4 \\
6.4 \\
6.4 \\
6.0 \\
6.0\end{array}$ & $\begin{array}{l}0.00 \\
0.00 \\
0.00 \\
0.00 \\
0.00\end{array}$ & $\begin{array}{l}0935 \\
0940 \\
0945 \\
0950 \\
0955\end{array}$ & $\begin{array}{l}3.5 \\
3.5 \\
3.5 \\
3.5 \\
3.5\end{array}$ & $\begin{array}{l}0.00 \\
0.00 \\
0.00 \\
0.00 \\
0.01\end{array}$ & $\begin{array}{l}1500 \\
1505 \\
1510 \\
1515 \\
1520\end{array}$ & $\begin{array}{l}2.4 \\
2.4 \\
2.4 \\
2.4 \\
2.4\end{array}$ & $\begin{array}{l}0.00 \\
0.00 \\
0 . n 0 \\
0.00 \\
0.00\end{array}$ \\
\hline $\begin{array}{l}0435 \\
0440 \\
0445 \\
0450 \\
0455\end{array}$ & $\begin{array}{l}6.0 \\
6.0 \\
6.0 \\
6.0 \\
6.0\end{array}$ & $\begin{array}{l}0.00 \\
0.00 \\
0.00 \\
0.00 \\
0.00\end{array}$ & $\begin{array}{l}1000 \\
1005 \\
1010 \\
1015 \\
1020\end{array}$ & $\begin{array}{l}3.5 \\
3.5 \\
3.5 \\
3.5 \\
3.5\end{array}$ & $\begin{array}{l}0.00 \\
0.00 \\
0.00 \\
0.00 \\
0.00\end{array}$ & $\begin{array}{l}1525 \\
1530 \\
1535 \\
1540 \\
1545\end{array}$ & $\begin{array}{l}2.4 \\
2.4 \\
2.4 \\
2.4 \\
2.2\end{array}$ & $\begin{array}{l}0.00 \\
0.00 \\
0.00 \\
0.00 \\
0.00\end{array}$ \\
\hline $\begin{array}{l}0500 \\
0505 \\
0510 \\
0515 \\
0520\end{array}$ & $\begin{array}{l}5.5 \\
5.5 \\
5.5 \\
5.5 \\
5.5\end{array}$ & $\begin{array}{l}0.00 \\
0.00 \\
0.00 \\
0.00 \\
0.00\end{array}$ & $\begin{array}{l}1025 \\
1030 \\
1035 \\
1040 \\
1045\end{array}$ & $\begin{array}{l}3.2 \\
3.2 \\
3.2 \\
3.2 \\
3.2\end{array}$ & $\begin{array}{l}0.00 \\
0.00 \\
0.00 \\
0.01 \\
0.00\end{array}$ & $\begin{array}{l}1550 \\
1555 \\
1600 \\
1605 \\
1610\end{array}$ & $\begin{array}{l}2.2 \\
2.2 \\
2.2 \\
2.2 \\
2.2\end{array}$ & $\begin{array}{l}0 . c 0 \\
0 . c 0 \\
0 . c 0 \\
0 . c 0 \\
0 . c 0\end{array}$ \\
\hline $\begin{array}{l}0525 \\
0530 \\
0535 \\
0540 \\
0545\end{array}$ & $\begin{array}{l}5.5 \\
5.5 \\
5.5 \\
5.0 \\
5.0\end{array}$ & $\begin{array}{l}0.00 \\
0.00 \\
0.00 \\
0.00 \\
0.00\end{array}$ & $\begin{array}{l}1050 \\
1055 \\
1100 \\
1105 \\
1110\end{array}$ & $\begin{array}{l}3.2 \\
3.2 \\
3.2 \\
3.2 \\
3.2\end{array}$ & $\begin{array}{l}0.00 \\
0.00 \\
0.00 \\
0.00 \\
0.00\end{array}$ & $\begin{array}{l}1615 \\
1620 \\
1625 \\
1630 \\
1635\end{array}$ & $\begin{array}{l}2.2 \\
2.2 \\
2.2 \\
2.2 \\
2.2\end{array}$ & $\begin{array}{l}0 . C 0 \\
0 . C 0 \\
0 . C 0 \\
0 . C 0 \\
0 . C 0\end{array}$ \\
\hline $\begin{array}{l}0550 \\
0555 \\
0600 \\
0605 \\
0610\end{array}$ & $\begin{array}{l}5.0 \\
5.0 \\
5.0 \\
5.0 \\
5.0\end{array}$ & $\begin{array}{l}0.00 \\
0.00 \\
0.00 \\
0.00 \\
0.00\end{array}$ & $\begin{array}{l}1115 \\
1120 \\
1125 \\
1130 \\
1135\end{array}$ & $\begin{array}{l}3.2 \\
3.2 \\
3.2 \\
3.2 \\
2.9\end{array}$ & $\begin{array}{l}0.00 \\
0.00 \\
0.00 \\
0.00 \\
0.00\end{array}$ & $\begin{array}{l}1640 \\
1645 \\
1650 \\
1655 \\
1700\end{array}$ & $\begin{array}{l}2.2 \\
2.2 \\
2.2 \\
2.2 \\
2.2\end{array}$ & $\begin{array}{l}0 . C 0 \\
0 . C 0 \\
0 . C 0 \\
0 . C 0 \\
0 . C 0\end{array}$ \\
\hline $\begin{array}{l}0615 \\
0620 \\
0625 \\
0630 \\
0635\end{array}$ & $\begin{array}{l}5.0 \\
5.0 \\
4.6 \\
4.6 \\
4.6\end{array}$ & $\begin{array}{l}0.00 \\
0.00 \\
0.00 \\
0.00 \\
0.00\end{array}$ & $\begin{array}{l}1140 \\
1145 \\
1150 \\
1155 \\
1200\end{array}$ & $\begin{array}{l}2.9 \\
2.9 \\
2.9 \\
2.9 \\
2.9\end{array}$ & $\begin{array}{l}0.00 \\
0.00 \\
0.00 \\
0.00 \\
0.00\end{array}$ & $\begin{array}{l}1705 \\
1710 \\
1715 \\
1720 \\
1725\end{array}$ & $\begin{array}{l}2.2 \\
2.2 \\
2.0 \\
2.0 \\
2.0\end{array}$ & $\begin{array}{l}0 . C 0 \\
0 . C 0 \\
0 . C 0 \\
0 . C 0 \\
0 . C 0\end{array}$ \\
\hline $\begin{array}{l}0640 \\
0645 \\
0650 \\
0655 \\
0700\end{array}$ & $\begin{array}{l}4.6 \\
4.6 \\
4.6 \\
4.6 \\
4.6\end{array}$ & $\begin{array}{l}0.00 \\
0.00 \\
0.00 \\
0.00 \\
0.00\end{array}$ & $\begin{array}{l}1205 \\
1210 \\
1215 \\
1220 \\
1225\end{array}$ & $\begin{array}{l}2.9 \\
2.9 \\
2.9 \\
2.9 \\
2.9\end{array}$ & $\begin{array}{l}0.00 \\
0.00 \\
0.00 \\
0.00 \\
0.00\end{array}$ & $\begin{array}{l}1730 \\
1735 \\
1740 \\
1745 \\
1750\end{array}$ & $\begin{array}{l}2.0 \\
2.0 \\
2.0 \\
2.0 \\
2.0\end{array}$ & $\begin{array}{l}0 . C 0 \\
0 . C 0 \\
0 . C 0 \\
0 . C 0 \\
0 . C 0\end{array}$ \\
\hline $\begin{array}{l}0705 \\
0710 \\
0715 \\
0720 \\
0725\end{array}$ & $\begin{array}{l}4.6 \\
4.6 \\
4.2 \\
4.2 \\
4.2\end{array}$ & $\begin{array}{l}0.00 \\
0.00 \\
0.00 \\
0.00 \\
0.00\end{array}$ & $\begin{array}{l}1230 \\
1235 \\
1240 \\
1245 \\
1250\end{array}$ & $\begin{array}{l}2.9 \\
2.9 \\
2.9 \\
2.7 \\
2.7\end{array}$ & $\begin{array}{l}0.00 \\
0.00 \\
0.00 \\
0.00 \\
0.00\end{array}$ & $\begin{array}{l}1755 \\
1800 \\
1805 \\
1810 \\
1815\end{array}$ & $\begin{array}{l}2.0 \\
2.0 \\
2.0 \\
2.0 \\
2.0\end{array}$ & $\begin{array}{l}0 . C 0 \\
0 . C 0 \\
0 . C 0 \\
0 . C 0 \\
0 . C 0\end{array}$ \\
\hline $\begin{array}{l}0730 \\
0735 \\
0740 \\
0745 \\
0750\end{array}$ & $\begin{array}{l}4.2 \\
4.2 \\
4.2 \\
4.2 \\
4.2\end{array}$ & $\begin{array}{l}0.00 \\
0.00 \\
0.00 \\
0.00 \\
0.00\end{array}$ & $\begin{array}{l}1255 \\
1300 \\
1305 \\
1310 \\
1315\end{array}$ & $\begin{array}{l}2.7 \\
2.7 \\
2.7 \\
2.7 \\
2.7\end{array}$ & $\begin{array}{l}0.00 \\
0.00 \\
0.00 \\
0.00 \\
0.00\end{array}$ & $\begin{array}{l}1820 \\
1825 \\
1830 \\
1835 \\
1840\end{array}$ & $\begin{array}{l}2.0 \\
2.0 \\
2.0 \\
2.0 \\
2.0\end{array}$ & $\begin{array}{l}0 . C 0 \\
0 . C 0 \\
0 . C 0 \\
0 . C 0 \\
0 . C 0\end{array}$ \\
\hline $\begin{array}{l}0755 \\
0800 \\
0805 \\
0810 \\
0815\end{array}$ & $\begin{array}{l}4.2 \\
4.2 \\
4.2 \\
4.2 \\
4.2\end{array}$ & $\begin{array}{l}0.00 \\
0.00 \\
0.00 \\
0.00 \\
0.00\end{array}$ & $\begin{array}{l}1320 \\
1325 \\
1330 \\
1335 \\
1340\end{array}$ & $\begin{array}{l}2.7 \\
2.4 \\
2.4 \\
2.4 \\
2.4\end{array}$ & $\begin{array}{l}0.00 \\
0.00 \\
0.00 \\
0.00 \\
0.00\end{array}$ & $\begin{array}{l}1845 \\
1850 \\
1855 \\
1900 \\
1905\end{array}$ & $\begin{array}{l}2.0 \\
2.0 \\
2.0 \\
2.0 \\
2.0\end{array}$ & $\begin{array}{l}0 . C 0 \\
0 . C 0 \\
0 . C 0 \\
0 . C 0 \\
0 . C 0\end{array}$ \\
\hline $\begin{array}{l}0820 \\
0825 \\
0830 \\
0835 \\
0840\end{array}$ & $\begin{array}{l}3.9 \\
3.9 \\
3.9 \\
3.9 \\
3.9\end{array}$ & $\begin{array}{l}0.00 \\
0.00 \\
0.00 \\
0.00 \\
0.00\end{array}$ & $\begin{array}{l}1345 \\
1350 \\
1355 \\
1400 \\
1405\end{array}$ & $\begin{array}{l}2.4 \\
2.4 \\
2.4 \\
2.4 \\
2.4\end{array}$ & $\begin{array}{l}0.00 \\
0.00 \\
0.00 \\
0.00 \\
0.00\end{array}$ & $\begin{array}{l}1910 \\
1915 \\
1920 \\
1925 \\
1930\end{array}$ & $\begin{array}{l}2.0 \\
2.0 \\
2.0 \\
1.8 \\
1.8\end{array}$ & $\begin{array}{l}0 .<0 \\
0 . C 0 \\
0 . C 0 \\
0 . C 0 \\
0 . C 0\end{array}$ \\
\hline $\begin{array}{l}1935 \\
1940\end{array}$ & $\begin{array}{l}1.8 \\
1.8\end{array}$ & $\begin{array}{l}0.00 \\
0.00\end{array}$ & $\begin{array}{l}1945 \\
1950\end{array}$ & $\begin{array}{l}1.8 \\
1.8\end{array}$ & $\begin{array}{l}0.00 \\
0.00\end{array}$ & $\begin{array}{l}1955 \\
2000\end{array}$ & $\begin{array}{l}1.8 \\
1.8\end{array}$ & $\begin{array}{l}0 . c 0 \\
0.80\end{array}$ \\
\hline
\end{tabular}




\section{REFERENCES}

Bodhaine, G.L., 1968, Measurement of peak discharge at culverts by indirect methods: U.S. Geological Survey Techniques of Water-Resources Investigations, book 3, chap. A3, 60 p.

Bohman, L.R., 1992, Determination of flood hydrographs for streams in South Carolina; Volume 2. Estimation of peak discharge frequency, run-off volumes, and flood hydrographs for urban watersheds: U.S. Geological Survey Water-Resc urces Investigations Report 92-4040, 100 p.

Cochran, W.G., 1963, Sampling techniques: New York, John Wiley, p. 71-86.

U.S. Weather Bureau, 1961, Rainfall-frequency atlas of the United States: U.S. Weather Bureau Technical Paper 40, 115 p.

Sauer, V.B., Thomas, W.O., Stricker, V.A., and Wilson, K.V., 1983, Flood characteristics of urban watersheds in the United States: U.S. Geological Survey Water-Supply Paper 2207, $63 \mathrm{p}$. 